\title{
Geology and Mineral Deposits of the Venezuelan Guayana Shield
}

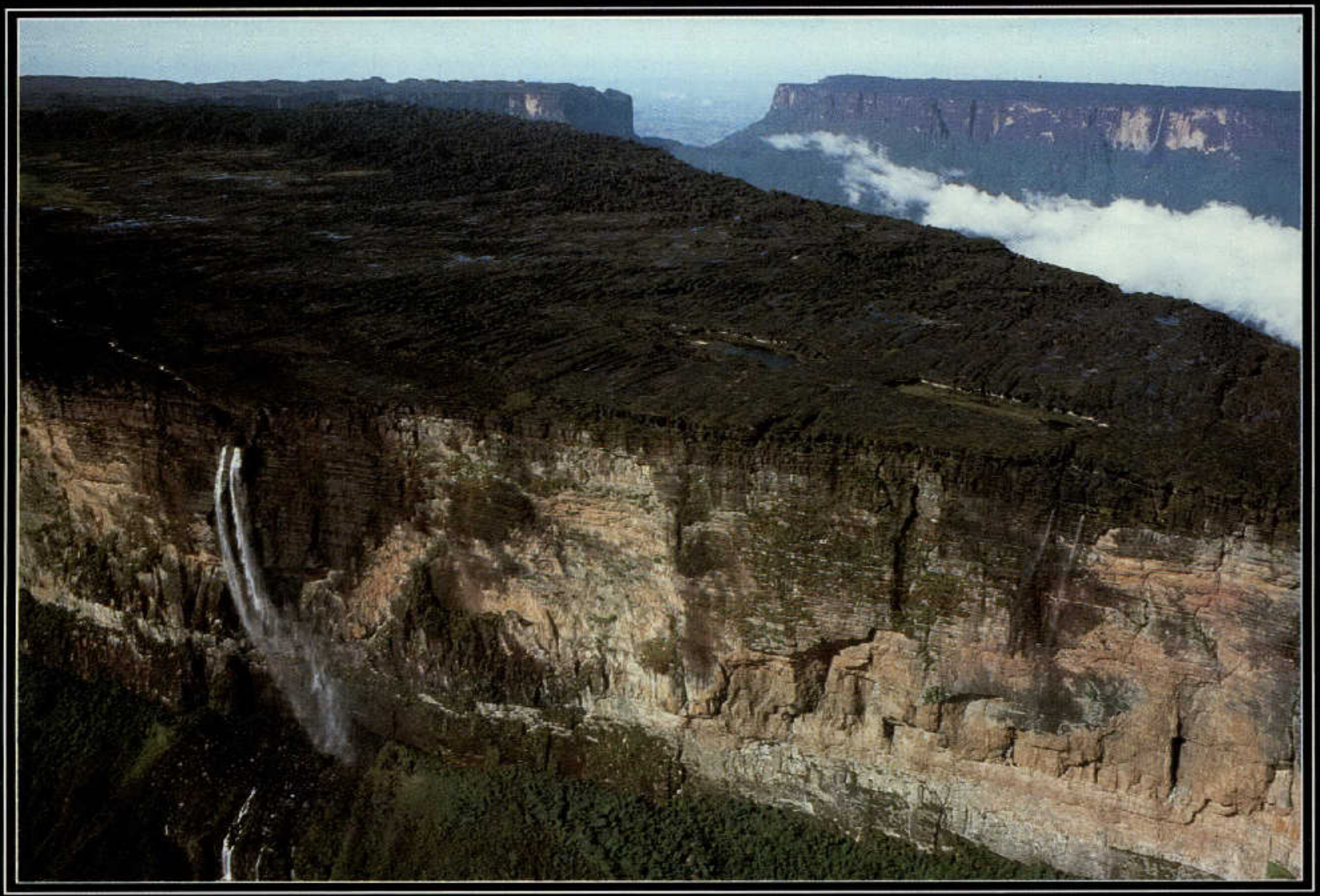

metadc958055

U.S. GEOLOGICAL SURVEY BULLETIN 2124 
Cover. Detail of pseudokarst labyrinth on summit platform of Cerro Roraima, Venezuela. The pervasively cross stratified quartzose of the Matauí Formation that forms the summit platform has been deeply etched by orographically intensified rainfall estimated at about $5 \mathrm{~m}$ per year. High-angle-oblique aerial view from a height of about $300 \mathrm{~m}$. Photograph by John Dohrenwend. 


\section{Geology and Mineral Deposits of the Venezuelan Guayana Shield}

Edited by Gary B. Sidder, Andrés E. García, and Judith W. Stoeser

\section{U.S. GEOLOGICAL SURVEY BULLETIN 2124}

Prepared as part of a cooperative project with the

Corporación Venezolana de Guayana, Técnica Minera, C.A.

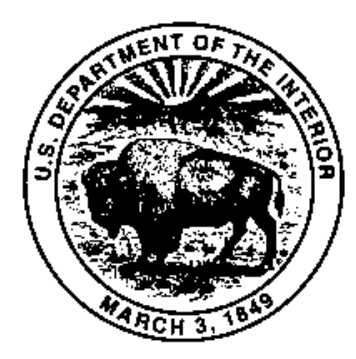




\title{
U.S. DEPARTMENT OF THE INTERIOR BRUCE BABBITT, Secretary
}

\author{
U.S. GEOLOGICAL SURVEY \\ Gordon P. Eaton, Director
}

\begin{abstract}
Published in the Central Region, Denver, Colorado
Manuscript approved for publication January 12, 1995

Edited by Judith Stoeser

Cartography by Wayne Hawkins

Photocomposition by Wayne Hawkins

Cover designed by Carol Quesenberty

Spanish abstracts prepared by Andrés E. García G.
\end{abstract}

For sale by U.S. Geological Survey, Information Services

Box 25286, Federal Center

Denver, CO 80225

Any use of trade, product, or firm names in this publication is for descriptive purposes only and does not imply endorsement by the U.S. Government

Library of Congress Cataloging-in-Publication Data

Geology and mineral deposits of the Venezuelan Guayana Shield / edited by

Gary B. Sidder, Andrés E. García G., and Judith W. Stoeser.

p. cm-(U.S. Geological Survey bulletin : 2124)

"Prepared as part of a cooperative project with the Corporación Venezolana de

Guayana, Técnica Minera, C.A."

Includes bibliographical references.

Supt. of Docs. no. : I 19.3:2124

1. Geology-Venezuela. 2. Minerals-Venezuela. 3. Guayana Shield.

I. Sidder, Gary B. II. Garcia G., Andrés E. III. Stoeser, J.W. IV. Series.

QE75.B9 no. 2124

$557.3 \mathrm{~s}-\mathrm{dc} 20$

[558.7] 


\section{CONTENTS}

[Letters designate chapters]

A. The Cooperative Project Between the U.S. Geological Survey and the Corporación Venezolana de Guayana, Técnica Minera, C.A., in the Venezuelan Guayana Shield, Estado Bolívar and Estado Amazonas, Venezuela

By Jeffrey C. Wynn, Gary B. Sidder, Floyd Gray, Norman J Page, and Vicente Mendoza S.

B. Geology of the Venezuelan Guayana Shield and its Relation to the Geology of the Entire Guayana Shield

By Gary B. Sidder and Vicente Mendoza S.

C. Analysis of Aeromagnetic Data to Improve Geologic Maps of the Bochinche Mining District, Estado Bolívar, Venezuela

By Jeffrey C. Wynn, Anne E. McCafferty, and Edixon Salazar

D. Exploración Geofísica en el Area de Bochinchito, Estado Bolívar, Venezuela (Geophysical Exploration in the Bochinchito Area, Estado Bolívar, Venezuela)

By Alí R. Fernández P.

E. Geology of the Lo Increible Mining District and U-Pb Age of the Early Proterozoic Yuruari Formation of the Pastora Supergroup,

Guayana Shield, Venezuela

By Warren C. Day, Richard M. Tosdal, E.L. Acosta, J.C. Aruspon, L. Carvajal, E. Cedeño, Glenda Lowry, L.F. Martinez, J.A. Noriega, Femando J. Nuñez, J. Rojas, and $\mathrm{F}$. Prieto

F. Geology and Geophysics of the Sierra Verdún-Cerro Piedra del Supamo Area, Estado Bolívar, Venezuela

By Floyd Gray, Fernando J. Nuñez, Jeffrey C. Wynn, Gary B. Sidder, Freddy Davila, and Angel Baez

G. Gold Prospecting in the Cerro Arrendajo Study Area, Estado Bolívar, Venezuela

By William E. Brooks, Acenk Guerra, and Fernando J. Nuñez

H. Gold Resources of the Río Chivao Study Area, Estado Bolívar, Venezuela

By William E. Brooks, Acenk Guerra, and Fernando J. Nuñez

I. Estratigrafía del Grupo Roraima e Interpretación Petrológica en la Región del Noreste del Parque Nacional Canaima, Estado Bolívar, Venezuela (Stratigraphy of the Roraima Group and Petrologic Interpretation in the Northeast Region of Canaima National Park, Estado Bolívar, Venezuela)

By Margarita Alberdi and Gloria Contreras

J. Geology, Geochemistry, and Geophysics of Gold-Quartz Veins in the Pistonn de Uroy Area, Estado Bolívar, Venezuela

By Jeffrey C. Wynn, Norman J Page, Gloria Contreras, R.J. Quesada, Barry C. Moring, and Robert L. Oscarson 
K. Cenozoic Landscape Evolution of the Southern Part of the Gran Sabana, Southeastern Venezuela-Implications for the Occurrence of Gold and Diamond Placers

By John C. Dohrenwend, Galo Yánez P., and Glenda Lowry

L. Gold and Diamond Resources of the Icabarú Sur Study Area, Estado Bolívar, Venezuela

By William E. Brooks, Richard M. Tosdal, and Fernando J. Nuñez

M. Bauxita en Superficie de Planación de la Guayana Venezolana

(Bauxite on a Planation Surface in Venezuelan Guayana)

By Galo Yánez P.

N. Geochemistry of Six Gold-Bearing Quartz-Carbonate-Tourmaline Vein Systems, Estado Bolívar, Venezuela

By Sherman P. Marsh, Herbert A. Pierce, Henry Sanchez, and Norman J Page

o. Mineral Deposits of the Venezuelan Guayana Shield

By Gary B. Sidder 
The Cooperative Project Between the

U.S. Geological Survey and the

Corporación Venezolana de Guayana, Técnica Minera, C.A., in the Venezuelan Guayana Shield,

Estado Bolívar and Estado Amazonas, Venezuela

By Jeffrey C. Wynn, Gary B. Sidder, Floyd Gray, Norman J Page, and

Vicente Mendoza S.

GEOLOGY AND MINERAL DEPOSITS OF THE VENEZUELAN GUAYANA SHIELD

U.S. GEOLOGICAL SURVEY BULLETIN 2124-A

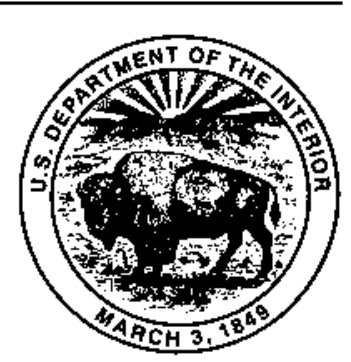

UNITED STATES GOVERNMENT PRINTING OFFICE, WASHINGTON : 1995 


\section{CONTENTS}

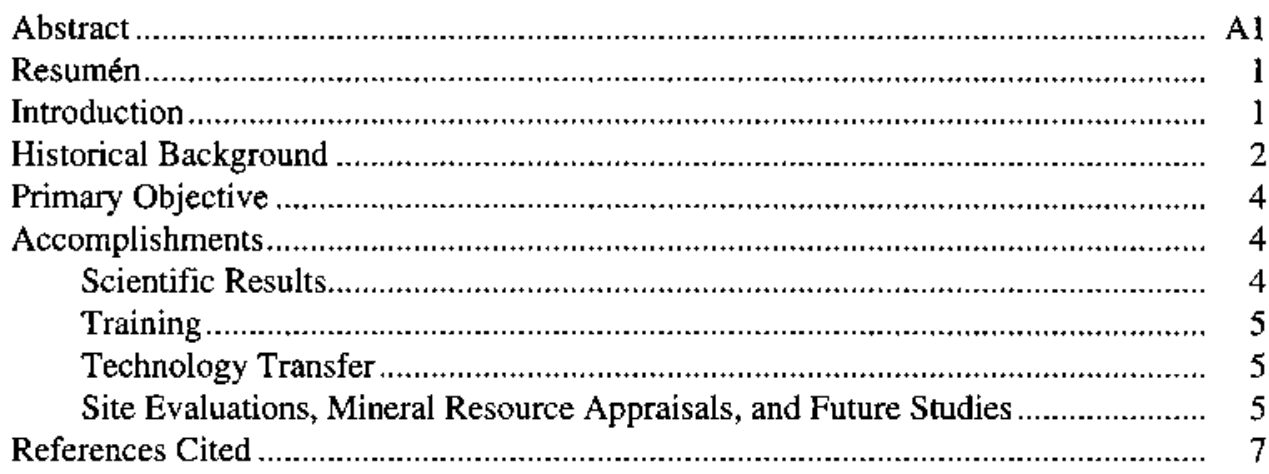

\section{PLATE}

[Plate is in pocket]

1. Map showing selected geographic features of the Venezuelan Guayana Shield.

\section{FIGURES}

1. Map showing location of Guayana Shield in northern South America.

2. Map showing geographic features, Venezuelan Guayana Shield, and areas worked jointly by USGS and TECMIN geologists.

\section{TABLE}

1. Area and site evaluations by scientists of the U.S. Geological Survey, 1986-1990. 


\title{
The Cooperative Project Between the U.S. Geological Survey and the Corporación Venezolana de Guayana, Técnica Minera, C.A., in the Venezuelan Guayana Shield, Estado Bolívar and Estado Amazonas, Venezuela
}

\author{
By Jeffrey C. Wynn, ${ }^{1}$ Gary B. Sidder, ${ }^{2}$ Floyd Gray, ${ }^{3}$ Norman J Page, ${ }^{3}$ and \\ Vicente Mendoza $\mathrm{S} .^{4}$
}

\begin{abstract}
The U.S. Geological Survey and the Corporación Venezolana de Guayana, Técnica Minera, C.A., conducted a cooperative mapping, exploration, and mineral resource estimation study in Venezuela from 1987 to 1992 . The work was conducted in the Venezuelan Guayana Shield, an Archean to Early and Middle Proterozoic craton in southern and eastern Venezuela of almost $415,000 \mathrm{~km}^{2}$ that is mostly covered by jungle and savanna. Results obtained from this project contribute a new understanding of the geology and evolution of the Venezuelan Guayana Shield and the nature of its mineral occurrences. Personnel from Técnica Minera, C.A., were trained both in the field and in the office to conduct modern mineral exploration and geologic mapping and research programs. This five-year project was supported financially by the Corporación Venezolana de Guayana.
\end{abstract}

\section{RESUMEN}

El Servicio Geológico de Los Estados Unidos conjuntamente con la Corporación Venezolana de Guayana y su filial Técnica Minera, C.A., llevaron a cabo un estudio de exploración, cartografía geológica y estimación del potencial minerai en Venezuela. El trabajo fue conducido en la porción

'U.S. Geological Survey, Unit 62101, APO AE 09811-2101, USA.

${ }^{2}$ U.S. Geological Survey, Denver Federal Center, MS905, Denver, Colorado 80225.

${ }^{3}$ U.S. Geological Survey, Corbett Building, 210 E. 7th Street, Tucson, Arizona 85705.

${ }^{4}$ Corporación Venezolana de Guayana, Técnica Minera, C.A., C.C. Chilemex, Piso 1, Puerto Ordaz, Venezuela.
Venezolana del Escudo de Guayana el cual está situado en el sureste de Venezuela y que tiene una edad Arqueozoica a Proterozoico Temprano a Medio. El área del escudo es aproximadamente $415,000 \mathrm{~km}^{2}$ y está cubierto principalmente por selva tropical y vegetación de sabana. Los resultados obtenidos de este proyecto han contribuido a un nuevo entendimiento de la geología y evolución del Escudo de Guayana en Venezuela así como también sobre la naturaleza de sus recursos minerales. El personal de Técnica Minera, C.A., fue entrenado en técnicas modernas para la exploración, cartografía geológica y programas de investigación. El proyecto que tuvó una duración de 5 años fue apoyado financieramente por la Corporación Venezolana de Guayana.

\section{INTRODUCTION}

In September 1987 the U.S. Geological Survey (USGS) established an office in Puerto Ordaz, Venezuela, as part of a cooperative project with the Corporación Venezolana de Guayana (CVG), Técnica Minera, C.A. (TECMIN). The goals of this project were to map the relatively unknown and unexplored jungle-covered Precambrian Guayana Shield and to assess its potential mineral wealth. To accomplish these goals, teams of geologists, geochemists, and geophysicists were sent to numerous areas to conduct both detailed and reconnaissance geologic mapping and mineral exploration. Many of the results from the project are presented in the chapters of this volume.

These joint studies of the Venezuelan Guayana Shield have advanced the understanding of the evolution of the shield and the nature of its mineral occurrences. Among the results included herein are (1) the first recognition of platinum-bearing rocks in the Guayana Shield (in the Píston 


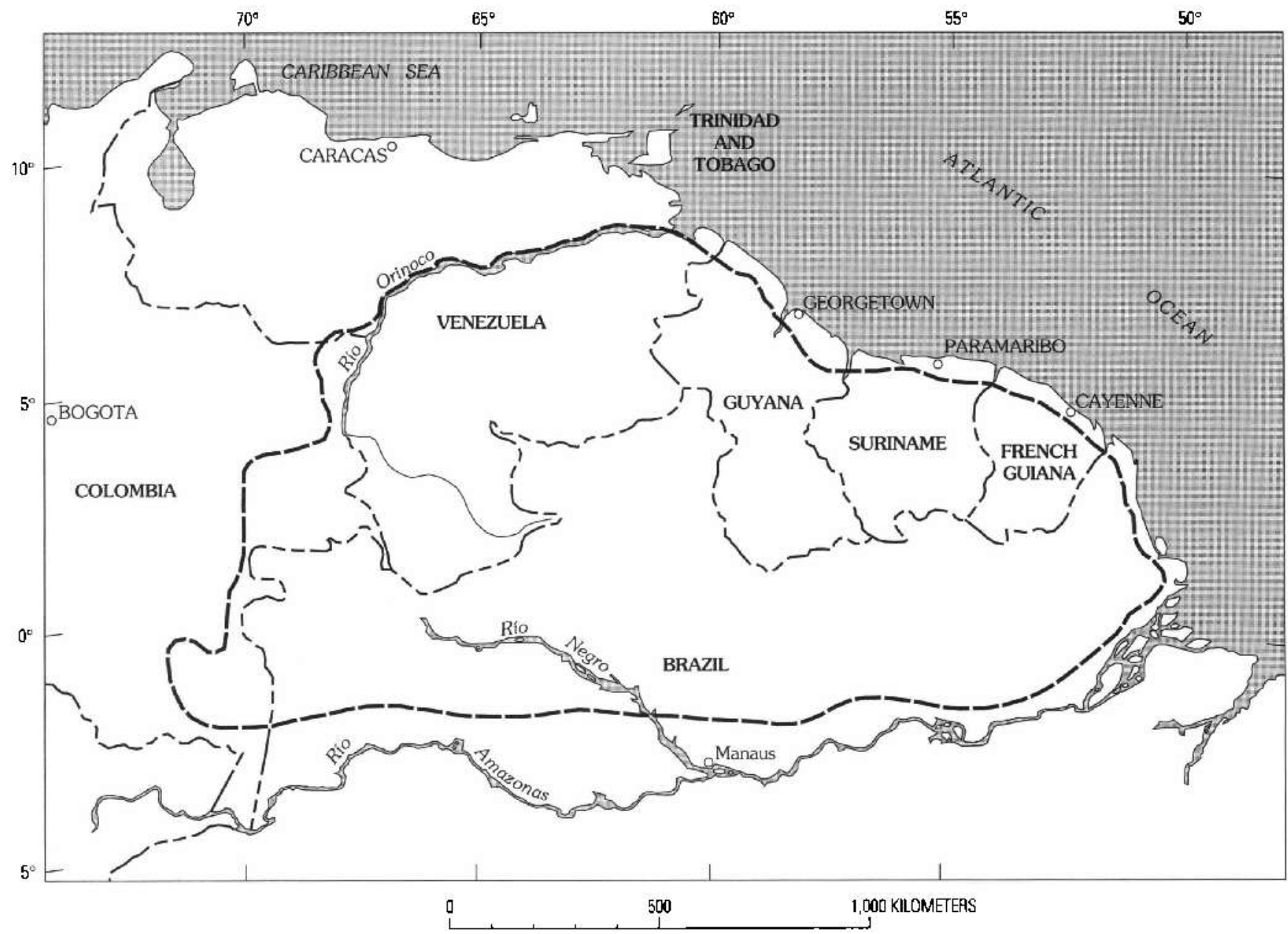

Figure 1. Location of Guayana Shield (dashed line) in northern South America. Modified from Derry (1980) and Gibbs and Barron (1983, 1993).

de Uroy and La Flor-Carapo areas); (2) the relation between shear zones and gold deposits, such as in the Lo Increible district; (3) the timing and character of the several magmatic and orogenic events that led to the formation of the shield; and (4) a catalog of known mineral deposits and prospects in the Venezuelan Guayana Shield classified by mineral deposit type.

The Guayana Shield is an Archean and Early to Middle Proterozoic craton. Figure 1 shows the location of the Guayana Shield of northern South America. Figure 2 illustrates the major physical features of the study area and areas discussed herein where USGS and TECMIN geoscientists worked together. Plate 1 shows numerous geographic features of the Venezuelan Guyana Shield and was originally published as plate 2 of U.S. Geological Survey-Corporación Venezolana de Guayana, Técnica Minera, C.A. (1993).

Acknowledgements.-Many individuals contributed professionaily to the work described in this chapter and elsewhere in this volume. In addition to the authors of the chapters herein, these include, from TECMIN, Nestor Angulo, Cruz Briceño, Juan Candelaria, Luis Guzman,
Glenda Lowry, Felix Martínez, Miguel Martínez, Jorge Penott, Enot Quintana, Haydee Rincon, Ivan Rivero, Yasmin Estanga de Sánchez, Gustavo Sardi, and Femando Susach. From the USGS, they include William Bagby, Jerry Consul, Dennis Cox, Robert Eahart, Darrell Herd, Richard Krushensky, Stephen Ludington, W. David Menzie, Stephen Olmore, Paul Schruben, and Gary Selner. Wayne Hawkins created the figures and plates of this book from the pen-scratchings of the many authors.

\section{HISTORICAL BACKGROUND}

In 1985, representatives of CVG-Ferrominera Orinoco, C.A., proposed a cooperative project between CVG and the USGS. Representatives of the USGS made an initial visit to Venezuela in January 1986, and in February 1987 a formal agreement was signed by the Venezuelan Ambassador to the United States, Hernandez-Valentín, and the Associate Director of the USGS, Doyle Frederick, in the Venezuelan Embassy in Washington, D.C. In September 1987, the USGS established an advisory group to work in Venezuela with the 


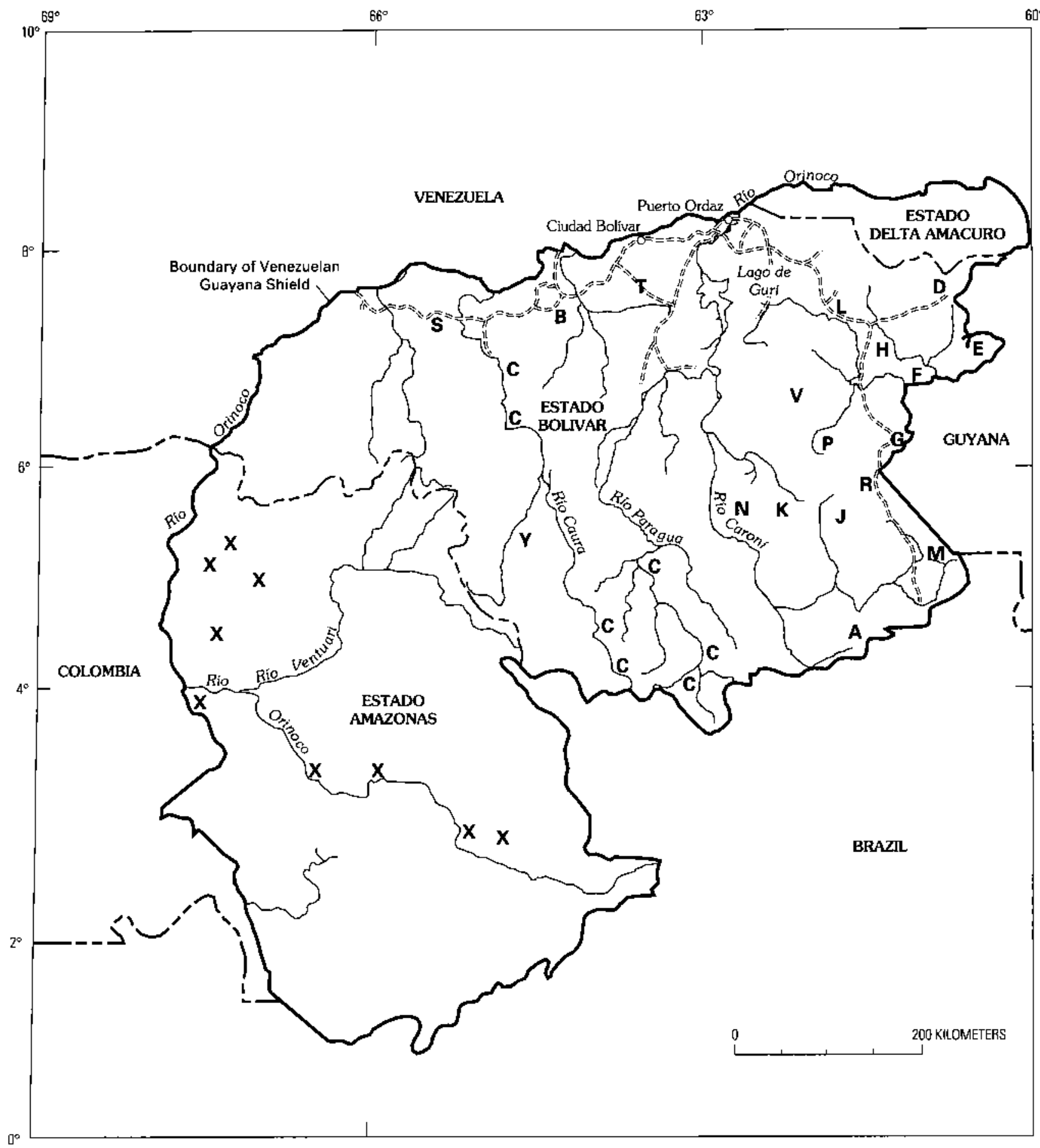

Figure 2. Areas in the Venezuelan Guayana Shield worked jointly by geologists of the U.S. Geological Survey and Corporación Venezolana de Guayana, Técnica Minera, C.A. A, Santa Elena de Uairén-Chiricayen-Icabarú; B, La Flor-Carapo; C, numerous sites in Río Caura and Río Paragua field areas; D, Bochinche concession; E, Marwani area; F, Anacoco area; G, Venamo prospect; H, Las Flores prospecting zone; J, Kavanayen; K, Kamarata; L, El Callao-Lo Increible mining districts; M, Mount Roraima; N, Auyantepuy (Angel Falls); P, Píston de Uroy-Río Chivao-Cerro Arrendajo prospecting areas; R, Kilometer 88-Las Cristinas; S, Santa Rosalía area; T, Cerro Bolívar-San Isidro mines; V, Sierra Verdún prospecting site; X, numerous heliports and camps in Estado Amazonas (upper Río Orinoco and Río Ventuari areas); Y, Cácaro dike area. Table 1 lists these areas and the scientists who worked at each and indicates when studies were conducted. Double-dashed lines indicate paved roads. 
CVG. The group initially consisted of two resident scientists, later three, and then one, headquartered in Puerto Ordaz and Ciudad Bolívar, Venezuela; as many as 10 visiting scientists per year worked in Venezuela with the CVG during the project.

The Venezuelan host agency, TECMIN, was formally organized in 1986 as an outgrowth of the original CVGFerrominera Orinoco mineral exploration and development group (Yacimientos). CVG is a government-owned corporation (and government ministry) established by presidential decree in 1972 and given charge over the regional economic development of the southern half of Venezuela. The area of responsibility includes Estado Bolívar, Estado Delta Amacuro, and Estado Amazonas. TECMIN is a mineral exploration company wholly owned by the CVG.

The USGS was established in 1879 to conduct scientific investigations on the geology and mineral resources of the United States. Since the 1940's, the USGS has participated in large cooperative-assistance projects in foreign countries including Saudi Arabia, Brazil, Liberia, Indonesia, Colombia, Puerto Rico, Costa Rica, and Pakistan. In addition, USGS scientists have worked on smaller projects throughout the world.

\section{PRIMARY OBJECTIVE}

The primary objective of the USGS-TECMIN cooperative project was to gain a better understanding of the geology of the Guayana Shield by using modern scientific methods. This integration of field geologic mapping, geochemical sampling, and geophysical surveying, in addition to modern laboratory and data analysis, resulted in training of TECMIN staff, transfer of technology, evaluation of specific mining concessions held by TECMIN, and mineral resource appraisals of these and other areas.

Technical and professional staff of TECMIN were trained in methods for regional mapping, mineral resource evaluation, and exploration. Regional geologic mapping was done in cooperation with the Inventory Group (Grupo de Inventario), and mineral exploration was carried out within the Exploration Group (Grupo de Prospección), the two major operational units of TECMIN. Training was conducted by means of formal short courses (six in the first three years of the project), each lasting one to three wecks and taught in Spanish at several sites in Venezuela. Less formal training of individuals and groups was performed by resident USGS scientists in the field and in the office.

Technology transfer included purchase of new computers, upgrade of existing computer equipment, installation of the latest specialized instrumentation and software for chemical analysis, mineral exploration, and natural-resources inventory, and training in the use of instrumentation and software. A sample preparation laborastory and a chemical analysis laboratory were designed by the USGS and built in Tumeremo, Estado Bolivar.

Site-evaluation studies were conducted by USGS scientists at sites selected by TECMIN geologists and management with input by the resident USGS staff. Recommendations from these efforts are being used by TECMIN to determine which areas warrant additional exploration. These site-evaluation studies were in Estado Bolívar and Estado Amazonas (fig. 2). Estado Delta Amacuro is mostly covered by Quaternary sediments, and TECMIN conducted only regional mapping and limited reconnaissance mineral exploration there.

Mineral resource appraisals were accomplished by USGS scientists in cooperation with TECMIN geologists. These appraisals arc evaluations of large regions, typically $1^{\circ} \times 1 \mathrm{a}^{\circ}$ or larger in size, and include domain maps that identify areas permissive for the occurrence of various mineral deposit types. The domain maps are based on descriptive mineral deposit models developed by the USGS (Cox and Singer, 1986). The number of undiscovered deposits and their metal contents were estimated by using mineral deposit density and grade and tonnage curves established for each deposit type based on data from known deposits worldwide. In addition, Monte Carlo-type computer simulations were used to estimate the quantity of metal remaining in place (Bliss and others, 1987). Wynn and Sidder (1991) and U.S. Geological Survey-Corporación Venezolana de Guayana, Técnica Minera, C.A. (1993) are examples of published mineral resource assessments for part and all, respectively, of the Venezuelan Guayana Shield.

\section{ACCOMPLISHMENTS}

\section{SCIENTIFIC RESULTS}

The chapters in this volume describe the entire spectrum of work conducted under the umbrella of the CVG-USGS cooperative project, exclusive of the resource appraisals described above. Sidder and Mendoza present a new, comprehensive overview of the geology of the Venezuelan Guayana Shield and its relation to the entire Guayana Shield and the West African craton that incorporates findings of the cooperative project. Wynn and others combine geologic mapping and geophysical modeling to produce a bedrock geologic map of the Bochinche area, and they identify a number of new targets for gold exploration. Fernández presents an application of geophysical methods to help map and interpret the geology in the Bochinchito district, which hosts gold deposits that are currently being mined. Day and others provide the first complete description of Lo Increible, an active gold mining district north of El Callao, and they show the importance of shear zones in the formation of the gold deposits. Gray and others report on the Sierra Verdún-Cerro Piedra del Supamo area, where 
greenstone-belt rocks and granitic rocks of the Eariy Proterozoic Supamo Complex are intruded by a mafic-ultramafic complex. Brooks and others studied two areas of greenstone-belt rocks, Cerro Arrendajo and Río Chivao, that are cut by gold-bearing quartz veins. Alberdi and Contreras mapped a previously undescribed area of the Early to Middlc Proterozoic Roraima Group and its underlying rocks in Canaima National Park.

Wynn and others combine geophysical, geochemical, and geologic mapping to define a large gold-bearing quartz vein system as wide as $8 \mathrm{~m}$ at Pistón de Uroy. This vein system was discovered during mapping of the northern margin of the Gran Sabana. Dohrenwend describes the geomorphology of the southern Gran Sabana and its relation to the source of diamonds and gold produced in that area. Brooks, Tosdal, and Nuñez mapped an area near Icabarú that contains rhyolitic tuff of the Early Proterozoic Cuchivero Group and sandstone of the Early to Middle Proterozoic Roraima Group. Diamonds are mined from placer deposits in streams that drain the area. Yánez describes the geomorphological framework underlying the discovery of the Los Pijiguaos bauxite deposit in the western part of the shield. Marsh and others describe the results of geochemical sampling of six gold-bearing quartz-carbonate-tourmaline vein systems in the El Callao, Lo Increible, Bochinche, and Marwani areas, all of which contain low-sulfide gold-quartz vein-type deposits. Sidder's compilation of mineral deposits and prospects in the Venezuelan Guayana Shield includes a comprehensive map of known deposits and prospects in Venezuela south of the Río Orinoco.

\section{TRAINING}

The USGS conducted training in the form of formal, one- to three-week-long short courses on mineral deposit models, mineral resource estimation, digital geologic mapping, data analysis and statistics, field geologic mapping, geochemical sampling, and environmental hazard mitigation. In addition, resident and visiting scientists spent many man-months on individual and small-group training in computer usage, geologic mapping, laboratory methods, field geochemistry, petrography, geophysical methods, hydrothermal alteration, igneous petrology, and econonic geology. This training extended beyond the professionals within TECMIN to include, by invitation of TECMIN management, representatives of other CVG entities (Minería de Venezuela (MINERVEN), Bauxita Venezolana (BAUXIVEN), and Ferrominera Orinoco) and other Venezuelan government agencies (Ministerio de Energía y Minas and Ministerio de Ambiente), as well as geologists from several universities (Universidad Central de Venezuela, Universidad Simón Bolívar, and Universidad de Oriente). One geologist from Guatemala participated in the field geology course.

\section{TECHNOLOGY TRANSFER}

The USGS installed sufficient laboratory equipment to bring to operational status a modern sample preparation laboratory in Tumeremo. In August 1992, an emission spectrograph and required ancillary equipment was installed in the new USGS-TECMIN-designed chemical analysis facility in Tumeremo. Nine computers were delivered and set up in Puerto Ordaz and Ciudad Bolívar, together with peripheral devices, software (both commercial and USGS-developed), plotters, and digitizers.

\section{SITE EVALUATIONS, MINERAL RESOURCE APPRAISALS, AND FUTURE STUDIES}

Sixteen USGS scientists worked with TECMIN geologists at more than 60 mines, concessions, and mineral prospects in 28 areas in Venezuela. These sites were identified initially by noting activity of local prospectors, by looking for extensions of known mineral deposits, and during geologic mapping by the Inventory Group. The major areas visited are listed in table 1.

The mineral resource appraisal of Venezuela was carried out on several different levels. Each visiting USGS scientist provided an evaluation of the sites visited and studied. On a larger scale, a prototype mineral resource assessment was carried out for the NB-20-4 quadrangle (fig. 2) in eastem Estado Bolívar (Wynn and Sidder, 1991). This evaluation provides geologic and geophysical information, a compilation of mineral production and current mining activity, and a map of areas interpreted to be permissive for different types of mineral deposits. In the case of the NB-20-4 quadrangle, few geochemical data are available. Nevertheless, sufficient geologic information was available to permit the estimation (using Monte Carlo simulation) of undiscovered gold resources. This estimation was made using calcuIations of the size of the known (mapped) greenstone belts, augmented by aeromagnetic data that show additional areas probably underlain by greenstone belts. Using a mineral deposit density model (Bliss and others, 1987) for the low-sulfide gold-quartz vein type of deposit and grade and tonnage cumulative-frequency curves (Bliss and Jones, 1988), it was estimated that between 16 and 27 deposits of the low-sulfide gold-quartz vein type are present within the quadrangle, of which only two deposits are currently being mined. A total of 8-36 metric tons of gold remains in place, using the 90-percent confidence level of a Monte Carlo simulation (Wynn and Sidder, 1991). A shieldwide mineral resource assessment was conducted at the end of the cooperative project (U.S. Geological Survey-Corporación Venezolana de Guayana, Técnica Minera, C.A., 1993); geographic, geologic, side-looking radar, mineral occurrence, and mineral assessment maps, all at 1:1,000,000 scale, are included in the assessment report. 
Table 1. Area and site evaluations by scientists of the U.S. Geological Survey, 1986-1990. [Shown by letter in figure 2]

\begin{tabular}{|c|c|c|}
\hline Site & Scientists & Date. \\
\hline Alto Río Caura (C) & Sidder & March 1988-April 1988 \\
\hline Alto Río Paragua (C) & Sidder & March 1988 \\
\hline Anacoco $(\mathrm{F})$ & $\begin{array}{l}\text { Day } \\
\text { Wynn }\end{array}$ & $\begin{array}{l}\text { April } 1988 \\
\text { June } 1989\end{array}$ \\
\hline Auyantepuy $(\mathrm{N})$ & Day, Wynn & July 1989 \\
\hline Bajo Rso Caura (C) & Sidder & May 1988 \\
\hline Bochinche (D) & $\begin{array}{l}\text { Page, Raines, Krushensky } \\
\text { Page, Bliss, Krushensky, Wynn, Sidder } \\
\text { Cox, Sidder, Wynn } \\
\text { Page } \\
\text { Marsh } \\
\text { Earhart } \\
\text { Page, Wynn } \\
\text { Wynn }\end{array}$ & $\begin{array}{l}\text { January } 1986 \\
\text { July } 1987 \\
\text { November } 1987 \\
\text { Febnary } 1988 \\
\text { March } 1988 \\
\text { April } 1988 \\
\text { Novenber } 1988 \\
\text { May } 1989\end{array}$ \\
\hline Cacaro dike area (Y) & Page, Olmore & February 1989 \\
\hline Cerro Arrendajo (P) & Brooks, Wynn & March 1988 \\
\hline Cerro Bolívar-San Isidro (T) & Cox, Sidder, Wynn & November 1987 \\
\hline Chiticayen (A) & $\begin{array}{l}\text { Page, Herd, Sidder, Marsh, Wynn } \\
\text { Dohrenwend, Wynn }\end{array}$ & $\begin{array}{l}\text { September } 1988 \\
\text { October } 1989\end{array}$ \\
\hline Icabarú-Los Caribes (A) & $\begin{array}{l}\text { Page } \\
\text { Brooks } \\
\text { Dohrenwend, Wynn }\end{array}$ & $\begin{array}{l}\text { March } 1988 \\
\text { April 1988 } \\
\text { October } 1989\end{array}$ \\
\hline Kamarata (K) & $\begin{array}{l}\text { Page, Sidder } \\
\text { Page. Wynn }\end{array}$ & $\begin{array}{l}\text { July } 1987 \\
\text { September } 1988\end{array}$ \\
\hline Kavanayen (J) & Page, Wynn & September 1988 \\
\hline Kilometer $88(\mathrm{R})$ & $\begin{array}{l}\text { Bagby, Menzie } \\
\text { Marsh }\end{array}$ & $\begin{array}{l}\text { January } 1988 \\
\text { April } 1988\end{array}$ \\
\hline La Flor-Carapo (B) & $\begin{array}{l}\text { Sidder } \\
\text { Sidder, Olmore } \\
\text { Sidder, Wynn } \\
\text { Day, Sidder } \\
\text { Day } \\
\text { Gray, Marsh }\end{array}$ & $\begin{array}{l}\text { March } 1989-\text { May } 1989 \\
\text { March } 1989 \\
\text { April } 1989 \\
\text { June } 1989 \\
\text { July } 1989 \\
\text { November } 1990\end{array}$ \\
\hline Las Cristinas (R) & $\begin{array}{l}\text { Cox } \\
\text { Bagby, Menzie } \\
\text { Marsh }\end{array}$ & $\begin{array}{l}\text { November } 1987 \\
\text { January } 1988 \\
\text { April } 1988\end{array}$ \\
\hline Las Flores $(\mathbf{H})$ & $\begin{array}{l}\text { Page, Krushensky, Raines } \\
\text { Wynn, Gray }\end{array}$ & $\begin{array}{l}\text { January } 1986 \\
\text { September } 1989\end{array}$ \\
\hline Lo Increíble (L) & $\begin{array}{l}\text { Cox, Sidder, Wynn } \\
\text { Day, Wynn }\end{array}$ & $\begin{array}{l}\text { November } 1987 \\
\text { June } 1989\end{array}$ \\
\hline
\end{tabular}

The information used to make mineral resource appraisals normally includes (1) reliable tectonic and geologic maps, (2) stream-sediment geochemical data, (3) regional geophysical data, and (4) locations of mineral deposits and prospects. In the case of the Guayana Shield, few regional geochemical data are available; however, reasonably good quality aeromagnetic data exist for at least half of the area. Using these data, available geologic maps, maps 
Table 1. Area and site evaluations by scientists of the U.S. Geological Survey-Continued.

\begin{tabular}{|c|c|c|}
\hline Site & Scientists & Date \\
\hline Marwani (E) & $\begin{array}{l}\text { Sidder, Wynn } \\
\text { Wynn } \\
\text { Marsh } \\
\text { Earhart }\end{array}$ & $\begin{array}{l}\text { July } 1987 \\
\text { October } 1987 \\
\text { February } 1988 \\
\text { April } 1988\end{array}$ \\
\hline Medio Río Paragua (C) & Sidder & April 1988 \\
\hline Mina Colombia (El Callao district) (L) & $\begin{array}{l}\text { Cox, Sidder, Wynl } \\
\text { Marsh } \\
\text { Page, Gray }\end{array}$ & $\begin{array}{l}\text { November } 1987 \\
\text { April } 1988 \\
\text { July } 1990\end{array}$ \\
\hline Mt. Roraima (M) & $\begin{array}{l}\text { Wynn } \\
\text { Dohrenwend, Wynn }\end{array}$ & $\begin{array}{l}\text { September } 1988 \\
\text { October } 1989\end{array}$ \\
\hline Pistón de Uroy (P) & $\begin{array}{l}\text { Page } \\
\text { Page, Wynn } \\
\text { Wyon }\end{array}$ & $\begin{array}{l}\text { March } 1988 \\
\text { January } 1989 \\
\text { May } 1989\end{array}$ \\
\hline Río Chivao (P) & Brooks & March 1988 \\
\hline Río Ventuari (X) & $\begin{array}{l}\text { Olmore } \\
\text { Olmore, Wynn }\end{array}$ & $\begin{array}{l}\text { April } 1989 \\
\text { February } 1990\end{array}$ \\
\hline Santa Rosalía (\$) & Sidder & February 1988 \\
\hline Sierra Verdún (V) & $\begin{array}{l}\text { Gray, Wynn } \\
\text { Gray }\end{array}$ & $\begin{array}{l}\text { March } 1990 \\
\text { May } 1990\end{array}$ \\
\hline Upper Río Orinoco (X) & $\begin{array}{l}\text { Olmore, Wynn } \\
\text { Olmore } \\
\text { Olmore } \\
\text { Olmore }\end{array}$ & $\begin{array}{l}\text { February } 1990 \\
\text { April } 1990 \\
\text { May } 1990 \\
\text { October } 1990\end{array}$ \\
\hline Venamo $(G)$ & Ludington & February 1988 \\
\hline
\end{tabular}

of mines and prospects, and field reconnaissance data collected during the cooperative study, a new tectonic and geologic map series of the Venezuelan Guayana Shield is being assembled. By incorporating geophysical data, it has been possible to map terrane boundaries in areas covered almost completely with alluvial and eluvial deposits and extensive jungle. This tectonic and geologic framework map series, compiled on $121: 500,000$-scale quadrangles, is the foundation on which future mineral resource appraisals of the Venezuelan Guayana Shield will be made.

\section{REFERENCES CITED}

Bliss, J.D., and Jones, G.M., 1988, Mineralogical and grade-tonnage information on low-sulfide Au-quartz veins: U.S. Geological Survey Open-File Report 88-229, 99 p.

Bliss, J.D., Menzie, W.D., Orris, G.J., and Page, N.J, 1987, Mineral deposit density-A useful tool for mineral-resource assess- ment, in Sachs, J.S., ed., U.S. Geological Survey Research on Mineral Resources-1987 Program and Abstracts: U.S. Geological Survey Circular 995, p. 6.

Cox, D.P., and Singer, D.A., eds., 1986, Mineral deposit models: U.S. Geological Survey Bulletin 1693, 379 p.

Derry, D.R., 1980, A concise world atlas of geology and mineral deposits: New York, John Wiley and Sons, 110 p.

Gibbs, A.K., and Barron, C.N., 1983, The Guiana Shield reviewed: Episodes, v. 1983, no. 2, p. 7-14.

1993, The geology of the Guiana Shield: New York, Oxford University Press, Oxford Monographs on Geology and Geophysics 22, $246 \mathrm{p}$.

U.S. Geological Survey-Corporación Venezolana de Guayana, Técnica Minera, C.A., 1993, Geology and mineral resource assessment of the Venezuelan Guayana Shield: U.S. Geological Survey Bulletin 2062, $121 \mathrm{p}$.

Wynn, J.C., and Sidder, G.B., 1991, Mineral resource potential of the NB-20-4 quadrangle, eastern Guayana Shield, Bolivar State, Venezuela: U.S. Geological Survey Bulletin 1960, 16 p. 

Geology of the Venezuelan Guayana Shield and Its Relation to the Geology of the Entire Guayana Shield

By Gary B. Sidder and Vicente Mendoza S.

GEOLOGY AND MINERAL DEPOSITS OF THE VENEZUELAN GUAYANA SHIELD

U.S. GEOLOGICAL SURVEY BULLETIN 2124-B

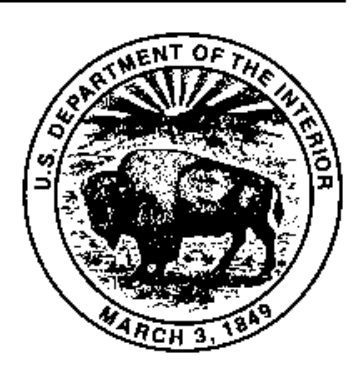

UNITED STATES GOVERNMENT PRINTING OFFICE, WASHINGTON : 1995 



\section{CONTENTS}

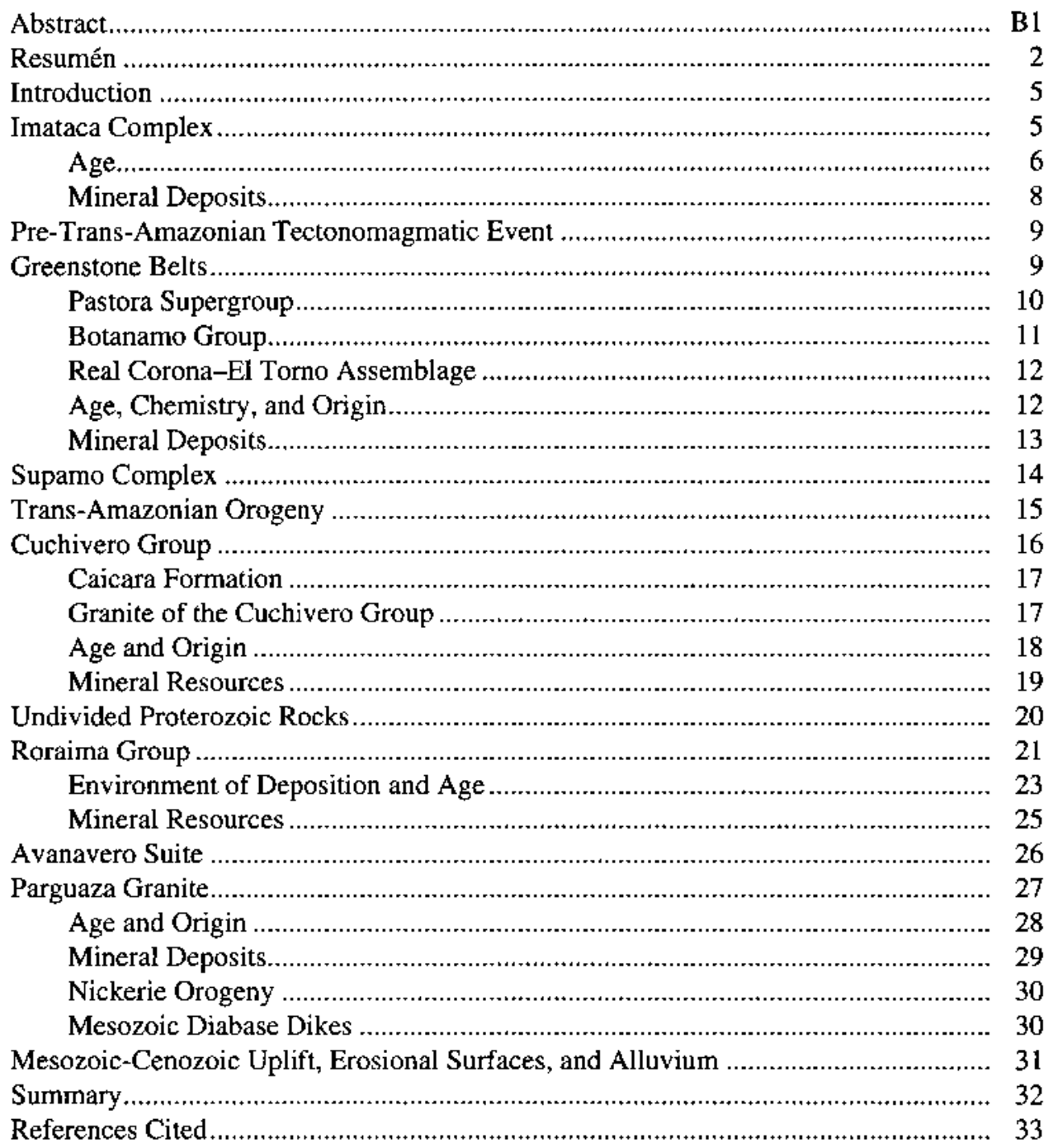

\section{FIGURES}

\section{1, 2. Maps showing:}

1. Major geographic features, northeastem South America .................................................................. B4

2. Geologic provinces, Venezuelan Guayana Shield ............................................................................... 7

3-6. Diagrams showing:

3. Rubidium versus yttrium+niobium, Cuchivero Group, Guayana Shield .................................................. 19

4. Potassium-argon dates, Proterozoic diabase, Guayana Shield .......................................................... 25

5. Potassium-argon dates, Phanerozoic diabase, Guayana Shield ................................................................. 31

6. Chronology of Venezuelan Guayana Shield..................................................................................... 32 


\section{CONTENTS}

\section{TABLES}

1. Rock units and tectonic events of the Guayana Shield of Venezuela .......................................................... B6

2-5. Rubidium-strontium whole-rock isochron dates for:

2. Volcanic and plutonic rocks of the Cuchivero Group and its equivalents ............................................... 19

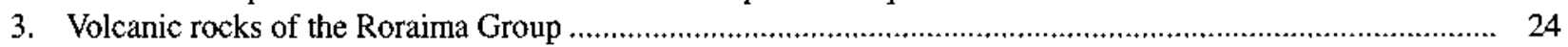

4. Diabase of the Avanavero Suite and homfels formed from its intrusion into the Roraima Group ................... 24

5 Granitic rocks of the Parguaza province and their equivalents ............................................................... 29 


\title{
Geology of the Venezuelan Guayana Shield and Its Relation to the Geology of the Entire Guayana Shield
}

\author{
By Gary B. Sidder ${ }^{1}$ and Vicente Mendoza S. ${ }^{2}$
}

\begin{abstract}
The Guayana Shield in Venezuela is composed of five lithotectonic provinces: (1) an Archean amphibolite- to granulite-facies gneiss terrane, (2) an Early Proterozoic greenstone-granite terrane(s), (3) an Early Proterozoic metamorphosed volcanic-plutonic complex, (4) Early to Middle Proterozoic continental sedimentary rocks, and (5) Middle Proterozoic anorogenic rapikivi-type granite. Early Proterozoic rocks in Estado Amazonas of western Venezuela are undivided, and their relation to other rocks of the Venezuelan Guayana Shield is uncertain. Early to Middle Proterozoic continental-type tholeiitic dikes, sills, and small iregular intrusive bodies and Mesozoic dikes emplaced during the opening of the Atlantic Ocean cut all of the lithotectonic provinces. Major mineral deposits of the Venezuelan Guayana Shield include gold, iron, bauxite, and diamonds.

The Archean Imataca Complex, the oldest unit of the shield, consists of gneiss and granulite and minor dolomite and banded iron formation. Large isoclinal folds that have been refolded into relatively open folds are common. Metamorphic grade ranges from granulite facies in the northeast part of the belt to amphibolite facies in the southwest. Deposits of enriched banded iron formation in the Imataca Complex contain more than 2 billion metric tons of iron ore. During the pre-Trans-Amazonian tectonomagmatic event, about 2,800-2,700 Ma, granitic rocks intruded the Imataca Complex, and injection gneiss and migmatite were developed.

The Early Protcrozoic grecnstone belts, which formed about 2,250-2,100 Ma, consist of a submarine sequence of tholeiitic mafic volcanic rocks, a sequence of tholeiitic to calc-alkaline basalt to rhyolite, and a sequence of turbiditic graywacke, volcaniclastic rocks, and chemical sedimentary

'U.S. Geological Survey, Denver Federal Center, MS905, Denver, Colorado 80225.

${ }^{2}$ Corporación Venezolana de Guayana, Técnica Minera, C.A., C.C. Chilemex, Piso 1, Puerto Ordaz, Venezuela.

rocks that characterize the basal, middle, and upper parts, respectively. Layered mafic complexes also are present in the greenstone belts. Metamorphic grade ranges from greenschist to amphibolite facies. Shear zones that cut the greenstone-belt rocks host numerous deposits of low-sulfide gold-quartz veins.

Granitic domes of the Supamo Complex intruded the greenstone-belt rocks about 2,230-2,050 Ma, dividing the greenstone-belt rocks into branching synclinoria between intrusions. The Trans-Amazonian orogeny was a period of continental accretion, deformation, and magmatism between about 2,150 and 1,960 Ma, during which the Imatata and the greenstone-granite terranes were deformed and metamorphosed.

Volcanic, subvolcanic, and plutonic rocks of the Cuchivero Group represent postcollisional, postTrans-Amazonian magmatism in the Guyanan Shield about 1,930-1,790 Ma. Silicic rocks (rhyolite and granite to granodiorite) dominate; intermediate to mafic dikes and lava flows are less abundant. Mining has not occurred in rocks of the Cuchivero Group, although precious-metal, tin, and molybdenum prospects are present, and Olympic Dam-type iron-copper-uranium-gold-rare earth element deposits are permissive. The only known diamond-bearing kimberlite deposit in the Guayana Shield is in the Quebrada Grande area. This deposit and the carbonatite at Cerro Impacto are within the outcrop area of the Cuchivero Group. The kimberlite was emplaced about $1,732 \pm 82 \mathrm{Ma}$; however, the carbonatite is not dated. Possible periods of intrusion are about 1.7 $\mathrm{Ga}$ or during the Mesozoic after the opening of the Atlantic Ocean.

Undivided Proterozoic rocks in Estado Amazonas of western Venezuela include granitic rocks, gneiss, and migmatite. Metamorphism and magmatism were most intense in this area about $1,860-1,730 \mathrm{Ma}$.

Unmetamorphosed, posttectonic sedimentary rocks including quartzaronite, conglomerate, arkose, siltstone, and shale of the Roraima Group were deposited in fluvial,
\end{abstract}


deltaic, shallow-marine, and lacustrine or epicontinental environments. Some rocks of the Roraima Group are at least 1,670 Ma in age, and others are possibly as old as about $1,900 \mathrm{Ma}$ and as young as about 1,500 $\mathrm{Ma}$ or younger. Paleoplacer deposits of gold and diamonds in the lower part of the Roraima Group are the source for modern placers.

Continental-type tholeiitic dikes, sills, and iregular intrusive bodies of the Avanavero Suite cut all older rocks of the Guayana Shield. These intrusions are about 1,650 Ma in age and may be as old as about 1,850 Ma.

Middle Proterozoic (about $1.55 \mathrm{Ga}$ ) undeformed granite having rapikivi texture is characteristic of the Parguaza province. Quartz veins, pegmatite, and greisen in the Parguaza Granite have moderate potential for tin deposits. Similarities in age, composition, and tectonic environment indicate that Olympic Dam-type iron-copper-uranium-gold-rare earth element deposits may be present in the Parguaza Granite and its associated volcanic rocks.

Continental collision in the westernmost part of the Guayana Shield during the Nickerie orogeny reset many potassium-argon and rubidium-strontium mineral ages of Archean and Early Proterozoic rocks in the central and eastern parts of the shield to about 1,200 Ma. Tholeitic diabase dikes intruded the Guayana Shield during the opening of the Atlantic Ocean from about 210 to $200 \mathrm{Ma}$. Variable lithologic resistance to weathering and erosion of a thick sequence of flat-lying to very gently dipping sedimentary strata in the Roraima Group have produced at least six planation surfaces in the Guayana Shield at distinct elevations between about 2,900 and $50 \mathrm{~m}$ above sea level.

Tropical weathering of the diverse rock types of the Guayana Shield has formed many deposits of bauxite and lateritic bauxite. The largest bauxite deposit is Los Pijiguaos, which developed on the Parguaza Granite. Deposits of bauxite and enriched banded iron formation formed on the Imataca-Nuria erosional surface. Placer diamond and gold deposits are mined in modem channels of the major rivers and in colluvial-alluvial deposits in low-order drainages.

Rocks, mineral deposits, and tectonic events in the Venezuelan Guayana Shield are generally correlative with those elsewhere in the Guayana Shield and (or) in the West African craton. Although Archean rocks are not known elsewhere in the Guayana Shield, Archean rocks similar to those in the Imataca Complex and coeval Archean tectonic events are present in the West African craton. Rocks in the Early Proterozoic greenstone belts in Venezuela are comparable in age and lithology to greenstone-belt rocks throughout the Guayana Shield and in the West African craton. The Trans-Amazonian orogeny in northem South America and the Eburnean orogeny in West Africa are the major Early Proterozoic tectonic event. Differences in the types of late Early Proterozoic and Middle Proterozoic rocks in the Guayana Shield and the West African craton are significant. For example, granite and rhyolite similar to the
Cuchivero Group are present throughout the Guayana Shield, but are only locally present in the West African Shield. Also, rocks comparable to the Roraima Group and the Parguaza Granite, although widespread in the Guayana Shield, are rare or absent in West Africa.

\section{RESUMEN}

El Escudo de Guayana en Venezuela está compuesto por 5 provincias litotectónicas: (1) un terrano Arqueano con metamorfiamo de la facie de la anfibolita a la granulita, (2) un terrano granítico-cinturones de rocas verdes de edad Proterozoio Temprano, (3) un complete volcánico-plutónico sin metamorfismo, de edad Proterozoico Temprano, (4) rocas continentales de edad Proterozoico Temprano, y (5) granito rapakivi anorogénico de edad Proterozoico Medio. Las rocas del Proterozoico Temprano en el Estado Amazonas no han sido diferenciadas, por consiguiente, su relación con otras rocas del Escudo de Guayana en Venezuela no ha sido definida. Los diques, sills y cuerpos intrusivos pequeños e iregulares, de composición toleítica y origen continental de edad Proterozoico Temprano a Medio, y diques de edad Mesozoico que fueron emplazados durante la apertura del Oceano Atlántico, cortan las rocas de todas las provincias litotectónicas. Los principales yacimientos minerales son de oro, hierro, bauxita y diamantes.

El Complejo de Imataca de edad Arqueano es la unidad más antigua del escudo, consiste de gneises y granulita con cantidades menores de formación bandeada de hierro y dolomita. El estilo estructural consiste de grandes pliegues isoclinales los cuales han sido replegados formando pliegues relativamente más abiertos. El grado metamórfico varía desde la facie de la granulita, en la parte noreste del cinturón, a la facie de la anfibolita en la parte suroeste. Los depósitos de hierro en formaciones bandeadas de hierro enriquecidas contienen aproximadamente 2 billones de toneladas métricas de mineral de hierro. El Complejo de Imataca fue afectado durante el evento tectono-magmático pre-Trans-Amazónico, entre 2,800 y $2,700 \mathrm{Ma}$, cuando se formaron gneis de injección y migmatitas.

Los cinturones de rocas verdes del Proterozoico Temprano se formaron aproximadamente entre 2,250 y 2,100 Ma. Estos consisten de una secuencia submarina de rocas volcánicas máficas toleíticas, una secuencia toleítica a calco-alcalina de basalto a riolita y una secuencia de grauwacas turbidíticas, rocas volcaniclásticas y rocas sedimentarias de origen químico las cuales caracterizan la base, parte media y partes superiores respectivamente. También se encuentran complejos estratificados maficos-ultramáficos. El grado metamórfico varía entre las facies del esquisto verde y anfibolita. Las zonas de cizalla que cortan los cinturones de rocas verdes contienen numerosos depósitos de oro en vetas de cuarzo con bajo contenido de sulfuros. 
Los cinturones de rocas verdes fueron intrusionados por domos graníticos del Complejo de Supamo aproximadamente entre 2,230 y 2,050 Ma. Los domos graníticos dividieron los cinturones de rocas verdes en sinclinorios los cuales, en vista en mapa, presentan ramificaciones. La orogenesis Trans-Amazónica fue un período de colisión y crecimiento continental, deformación y magmatismo entre 2,150 y 1,960 Ma durante el cual las rocas del Complejo de Imataca y la provincia granítico-rocas verdes fueron deformados y metamorfizados.

Las rocas volcánicas, subvolcánicas y plutónicas del Grupo Cuchivero representan un período de magmatismo entre 1,930 y 1,790 Ma después de la colisión Trans-Amazónica. Predominan rocas silícicas (riolita y granito a granodiorita); diques y lavas intermedias a máficas son menos abundantes. Aunque existen prospectos de minerales preciosos, estaño y molibdeno, y prospectos del tipo Olympic Dam cobre-uranio-oro estan permisivo, hasta la fecha no hay operaciones mineras eл rocas del Grupo Cuchivero. La única kimberlita diamantífera conocida en el Escudo de Guayana está localizada en el área de la Quebrada Grande. Este depósito, y la carbonatita del Cerro Impacto están localizados dentro de la región del Grupo Cuchivero. La kimberlita fue intrusionada aproximadamente hace $1,732 \pm 82 \mathrm{Ma}$. Aunque la edad de la carbonatita no ha sido definida, las edades posibles de intrusión son acerca de 1.7 Ma o durante el Mesozoico después de la apertura del Océano Atlántico.

Las rocas de edad Proterozoico en el Estado Amazonas no han sido divididas, pero incluyen rocas graníticas, gneis y migmatita. En esta área, el magmatismo y metamorfismo fueron más intensos aproximadamente entre 1,860 y 1,730 Ma.

Las rocas sedimentarias del Grupo Roraima fueron depositadas después del tectonismo Trans-Amazónico en ambientes fluviales, deltáicos, marino somero y lacustrino o epicontinentales. Estas rocas no están metamorfizadas e incluyen cuarzo-arenita, conglomerado, arcosa, limolita y lutita. Algunas de las rocas del Grupo Roraima tienen una edad de al menos 1,670 Ma, otras posiblemente tienen una edad de 1,900 Ma y otras pueden ser tan jovenes como 1,500 Ma. Los depósitos de oro y diamantes en paleoplaceres en la parte inferior del Grupo Roraima son la fuente para depósitos de placer modernos.

La Suite Avanavero, la cual comprende diques, sills y cuerpos intrusivos irregulares de composición toleítica continental, cortan todas las unidades más antiguas del Escudo de Guayana. Estas intrusiones probablemente se formaron aproximadaments hace 1,650 Ma, y quizás hace 1,850 Ma.

El granito rapakivi, no deformado, de edad Proterozoico Medio (aproximadamente 1,545 Ma), conforma la Provincia de Parguaza. El granito de Parguaza presenta vetas de cuarzo, y greisen conteniendo un potencial moderado para depósitos de estaño. La similitud en edad, composición y ambiente tectónico del granito de Parguaza con las rocas que contienen el depósito Olympic Dam de hierro, cobre, uranio, oro y elementos tierras raras, indican que este granito y rocas volcánicas asociadas tienen potencial para esos minerales.

La colisión continental en el extremo occidental del Escudo de Guayana, ocurrida durante la orogenesis Nickerie aproximadamente hace 1,200 Ma, re-estableció las edades isotópicas de los sistemas potasio-argón y rubidio-stroncio de las rocas Arquenas y Proterozoico presentes en la parte central y oriental del escudo. Durante la apertura del Océano Atlántico, entre 210 y $200 \mathrm{Ma}$, diques de diabasa toleítica intrusionaron el Escudo de Guayana. El levantamiento y erosión del los terrenos Precámbricos durante las Eras Mesozoica y Cenozoica produjeron al menos seis superficies de erosión en el Escudo de Guayana a distintas elevaciones entre 2,900 y 50 m.s.n.m.

La meteorización en clima tropical, de los distintos tipos de rocas del Escudo de Guayana, ha formado muchos depósitos de bauxita y bauxita laterítica. El depósito más grande es Los Pijiguaos, el cual se formó sobre el Granito de Parguaza. También se formaron depósitos de bauxita y hierro enriquecido a partir de formación bandeada de hiero en la superficie de erosión Imataca-Nuria. Diamantes y oro en depósitos de tipo placer son actualmente minados en canales activos de los ríos mayores y también en depósitos coluvio-aluviales en drenajes de orden menor.

Las rocas, depositos minerales y eventos tectónicos en el Escudo de Guayana en Venezuela son generalmente correlacionables con esos en otras partes del Escudo de Guayana y/o en el Craton de Africa Occidental. Aunque no se conocen rocas Arqueanas en otras partes del Escudo de Guayana, las rocas y eventos tectónicos en Africa Occidental de edad Arqueana son similares a las del Complejo de Imataca. Las rocas Proterozoicas de los cinturones de rocas verdes "greenstones" en Venezuela son comparables en edad y litología al resto de las rocas en los cinturones de rocas verdes a traves del Escudo de Guayana y en el Craton de Africa Occidental. La orogenia Trans-Amazónica ocurrida en la parte norte de Suramerica, y la orogenia Eburneana en Africa Occidental es el evento tectónico más importante durante el Proterozoico Temprano. En contraste a la similitud entre rocas Arqueanas y del Proterozoico Temprano entre Suramerica y Africa, existen diferencias significativas entre los tipos de rocas del Proterozoico Temprano tardío y Proterozoico Medio entre las mencionadas regiones. Por ejemplo, a traves del Escudo de Guayana hay granitos y riolitas similares a aquellos del Grupo Cuchivero, mientras que en el Escudo de Africa Occidental estas rocas están presentes solo localmente. Lo mismo sucede con las rocas del Grupo Roraima y el granito de Parguaza, las cuales afloran a traves del Escudo de Guayana pero no así en Africa Occidental donde raramente afloran o están ausentes. 

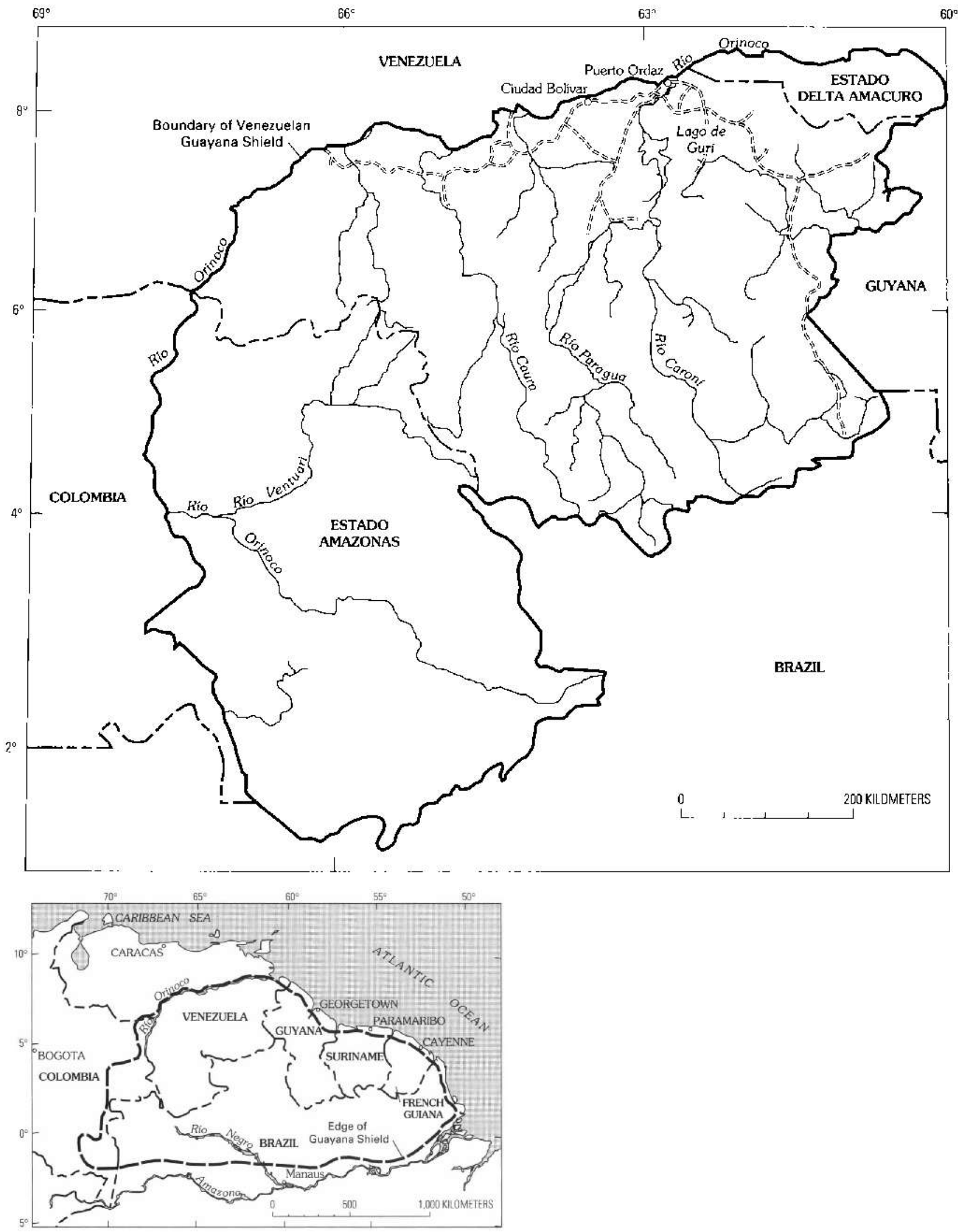

Figure 1. Major geographic features of the Venezuelan Guayana Shield. Snaller map shows outline of Guayana Shield of northeastern South America (modified from Gibbs and Barron, 1983). 


\section{INTRODUCTION}

The U.S. Geological Survey assisted the Corporacion Venezolana de Guayana, Técnica Minera, C.A. (CVG-TEC MIN, or TECMIN) between 1987 and 1992 in its assessment of and exploration for new mineral deposits in the Precambrian Guayana Shield of Venezuela (Wynn, Sidder, and others, this volume). The Guayana Shield, in the northem part of the Amazonian craton of South America, measures about $1,100 \mathrm{~km}$ north to south and $2,100 \mathrm{~km}$ east to west, covering an area of about $2,310,000 \mathrm{~km}^{2}$ (fig. 1). Shield rocks crop out in Colombia, Venezuela, Guyana, Brazil, Suriname, and French Guiana. The Guaporé or western Central Brazil Shield, south of the Amazon River Basin, forms the southem part of the Amazonian craton (Gibbs and Barron, 1983; Teixeira and others, 1989; Goodwin, 1991). Although now separated by the Atlantic Ocean, the geologic histories of the Guayana Shield and the West African craton indicate that Archean and Early Proterozoic rocks of both areas were deposited in similar environments and were affected by coeval tectonic and metamorphic events.

The Guayana Shield in Venezuela consists of five lithotectonic provinces: (1) Archean amphibolite- to two-pyroxene granulite-facies gneiss terrane, (2) Early Proterozoic greenstone-granite terrane(s), (3) Early Proterozoic unmetamorphosed volcanic-plutonic complex, (4) Early to Middle Proterozoic continental sedimentary rocks, and (5) Middle Proterozoic anorogenic rapakivi-type granite (Gibbs and Barron, 1983; Teixeira and others, 1989). Early Proterozoic and possibly Archean rocks in Estado Amazonas of western Venezuela are undivided, and their relation to other rocks of the Venezuelan Guayana Shield is uncertain. Early to Middle Proterozoic continental-type tholeiitic dikes, sills, and small irregular intrusive bodies and Mesozoic dikes emplaced during the opening of the Atlantic Ocean are present in all of the lithotectonic provinces. Table 1 is a simplified stratigraphic chart of the rock units and tectonic events of the Guayana Shield of Venezuela, and figure 2 is a simplified geologic province map. Geologic and geographic maps of the Guayana Shield of Venezuela are presented in U.S. Geological Survey and Corporación Venezolana de Guayana, Técnica Minera, C.A. (1993), and mineral deposits mentioned herein are shown on plate 1 of Sidder (this volume).

In this paper, we present an overview of the geology of the Venezuelan Guayana Shield and discuss its relation to the geology of the entire Guayana Shield. The discussion of the evolution of the shield includes recently published uranium-lead and samarium-neodymium isotopic data. Geochronological data have been standardized by recalculation with one set of constants as recommended by the Subcommission on Geochronology of the International Union of Geological Sciences ${ }^{3}$ (Steiger and Jäger, 1977); errors in all dates are given at the 1-sigma level. Such standardization helps to define more narrowly the ranges of specific magmatic or tectonic events. For example, a single tectonic epi- sode such as the Trans-Amazonian orogeny, which previously had been reported to span 400 m.y., is herein constrained to a much shorter interval of 190 m.y. Similarly, the formation of the Supamo Complex (granite and gneiss associated with the greenstone-belt rocks), which reportedly occurred between 2,700 and $2,100 \mathrm{Ma}$, is herein restricted to $2,230-2,050 \mathrm{Ma}$. These recalculated dates of the major geologic events in the Venezuelan Guayana Shield allow its history to be interpreted more realistically (table 1, fig. 2).

\section{IMATACA COMPLEX}

The Archean Imataca Complex is a northeast-trending belt of amphibolite- to granulite-facies metasedimentary and metaigneous rocks. This belt is at least $510 \mathrm{~km}$ long and $65-130 \mathrm{~km}$ wide, and it forms the northernmost margin of the Venezuelan Guayana Shield (fig. 2). Rocks of the Pliocene and Pleistocene Mesa Formation (not shown in fig. 2) and alluvium from the floodplain of the Río Orinoco cover the Imataca Complex along its northern margin, and the Guri shear zone separates the Imataca Complex from the Early Proterozoic greenstone-granite terrane to the south. The Imataca Complex abuts against plutonic and volcanic rocks of the Early Proterozoic Cuchivero Group along the Río Caura in the west. The nature of the contact is unknown because it is obscured by thick overburden and alluvium along the Rio Caura (Kalliokoski, 1965; Ascanio, 1975; Mendoza, 1977a).

The Imataca Complex includes more than 80 percent quartzofeldspathic orthogneiss, paragneiss, and felsic granulite, $10-15$ percent intermediate to mafic orthogneiss, granulite, and charnockite, 1 percent metamorphosed banded iron formation, and minor manganiferous metasedimentary rocks, dolomitic marble, and anorthosite. The protolith of the Imataca Complex consisted of clastic and chemical sedimentary rocks, silicic calc-alkaline subaerial volcanic rocks, and lesser plutonic rocks (Kalliokoski, 1965; Dougan, 1977; Gibbs and Wirth, 1986).

The grade of metamorphism in the Imataca Complex varies from two-pyroxene granulite facies in that part of the belt generally northeast of the Lago de Guri area to

\footnotetext{
${ }^{3}$ All rubidium-strontium isochron dates reported here have been recalculated with the decay constants and isotopic abundances recommended by Stciger and Jäger $(1977):{ }^{87} \mathrm{Rb}$ decay constant $=1.42 \times 10^{-1} \mathrm{yr}^{-1}$; atomic ratio ${ }^{85} \mathrm{Rb} /{ }^{87} \mathrm{Rb}=2.59265$; atomic ratio ${ }^{86} \mathrm{Sr} /{ }^{88} \mathrm{Sr}=0.1194$; atomic ratio ${ }^{84} \mathrm{Sr}^{86}{ }^{8} \mathrm{~S} r=0.056584$. A best-fit line has been calculated by the method of York (1969). Dates reported arc those from model 3 of York, which assumes that the scatter of data is due to a combination of the assigned analytical error and a nomally distributed variation in the initial ${ }^{87} \mathrm{~S}{ }^{866} \mathrm{Sr}$. All potassium-argon dates have been recalculated (where sufficient data are available) using the decay constants and isotopic abundances recommended by Steiger and Jäger (1977): $\quad \lambda^{40} \mathrm{~K}_{\mathrm{e}}+\lambda^{40} \mathrm{~K}_{\mathrm{e}}=0.581 \times 10^{-10} / \mathrm{yr}$; ${ }^{40} \mathrm{~K}_{\beta}=4.962 \times 10^{-10} \mathrm{yr}^{-1} ;{ }^{40} \mathrm{~K}=0.01167$ atomic percent $\left(1.167 \times 10^{-4} \mathrm{~mol} / \mathrm{mol}\right)$; or by conversion with the critical table for conversion of K-AI ages from old western constants to new IUGS constants (Dalrymple, 1979).
} 
Table 1. Rock units and tectonic events of the Guayana Shield of Venezuela.

[Rock unit designations as used in figure 2]

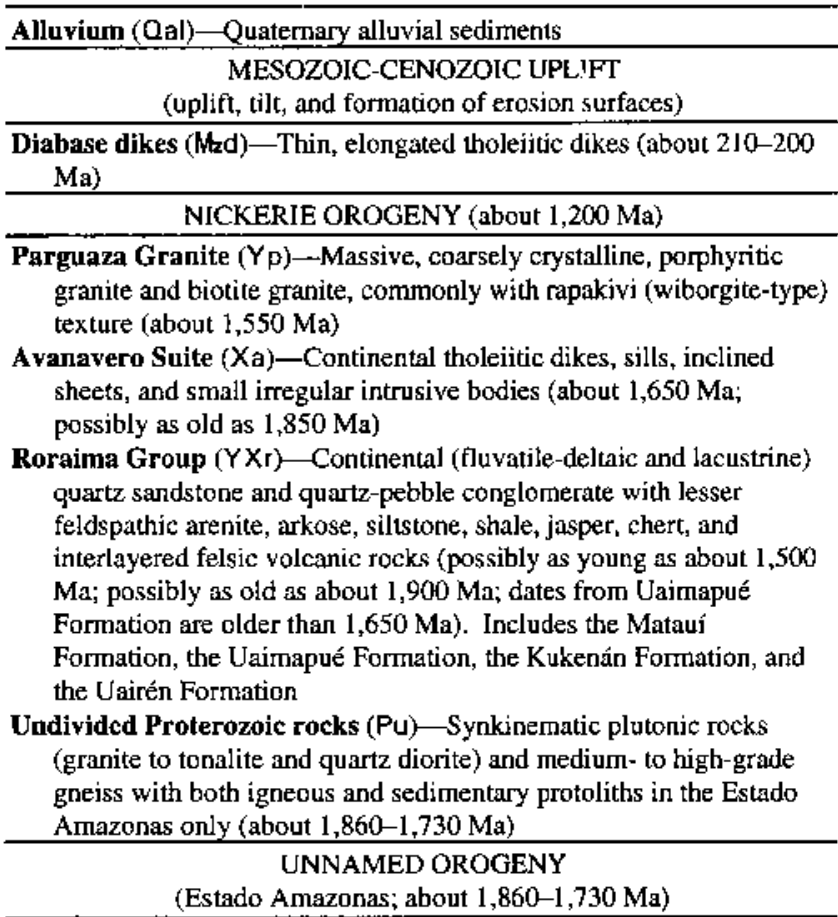

Cuchivero Group (Xc)-Thick sequence of unmetamorphosed felsic to intermediate subaerial volcanic rocks and their associated granitic rocks (about 1,930-1,790 Ma). Includes the granite of Guaniamito, the granites of San Pedro and Santa Rosalia (including the granite of Las Trincheras), and the Caicara Formation

\section{TRANS-AMAZONIAN OROGENY}

(about 2,150-1,960 Ma)

Supamo Complex (Xs)-Gneiss, schist, migmatite, and granitic rocks such as trondhjemite (sodic granite), tonatite, granodiorite, and quartz monzonite associated with the greenstone-belt terrane $(2,230$ $2,050 \mathrm{Ma}$ )

Greenstone-belt rocks $(\mathrm{Xg})$-Sequences as thick as $11,000 \mathrm{~m}$ of metamorphosed tholeiitic basalt and gabbro with interflow chemical sedimentary rocks in the lower part of the sequence; interstratified, porphyritic, tholeiitic and calc-alkalic basaltic to rhyolitic lava flows and tuffs in the middle part; and tuffaceous, volcaniclastic, turbiditic, pelitic, and chemical sedimentary rocks in the upper part. About 2,250-2,100 Ma. Includes the Los Caribes and Caballape Formations of the Botanamo Group; the Yuruari Formation and the Cicapra and El Callao Formations of the Pastora Supergroup; and the Real Corona-El Torno assemblage

PRE-TRANS-AMAZONIAN TECTONOMAGMATIC EVENT (about 2,800-2,700 Ma)

Imataca Complex (Ai)-Amphibolite- to granulite-facies quartzofeldspathic orthogneiss, paragneiss, and felsic granulite, intermediate to mafic orthogneiss, granulite, and chamockite, metamorphosed banded iron formation, and minor manganiferous metasedimentary rocks, dolomitic marble, and anorthosite $(>2,800$ Ma; protolith possibly $3,700-3,400 \mathrm{Ma}$ )

amphibolite facies southwest of the area. The gneiss is commonly migmatitic and consists of quartz-potassium feldspar-plagioclase \pm biotite \pm hornblende \pm orthopyroxene \pm clinopyroxene \pm garnet \pm sillimanite \pm cordierite \pm muscovite. Estimates of peak metamorphic conditions in granu- lite-facies rocks indicate that temperature was between about $750^{\circ} \mathrm{C}$ and $800^{\circ} \mathrm{C}$ and pressure was between about 8.0 and $8.5 \mathrm{~kb}$ (Short and Steenken, 1962; Swapp and Onstott, 1989); in the amphibolite-facies rocks, temperature was between about $625^{\circ} \mathrm{C}$ and $700^{\circ} \mathrm{C}$, and pressure was between 4 and $7 \mathrm{~kb}$ (Dougan, 1974, 1977).

Rocks of the Imataca Complex are strongly deformed. The entire stratigraphic sequence of the complex was folded into large isoclinal folds that were refolded by relatively open folds (Ruckmick, 1963; Onstott and others, 1989). In the northern part of the Imataca Complex, the isoclinal fold axes strike generally northwest, whereas in the southem part they strike east-west. Fold axes are deflected to the northeast close to the Guri shear zone (fig. 2), which can be traced in the field for a distance of more than $400 \mathrm{~km}$ (Onstott and others, 1989). This shear zone, from several hundred meters to $1 \mathrm{~km}$ in width, is marked by alternating bands of mylonite, pseudotachylite, and strongly sheared gneiss and amphibolite. Crushed rock is visible in thin sections of samples collected as far away as $2 \mathrm{~km}$ on either side of this shear zone (Short and Steenken, 1962). The deflection of structural trends and mineral lineations adjacent to the Guri fault indicates that major movement on the fault was left-slip, possibly with later vertical displacement. The rocks of the Imataca Complex are also cut by north-verging low-angle thrust faults that are associated with the Guri shear zone and in part caused the folding (Ascanio, 1975). High-grade mylonite zones, such as the El Pao and the Río Claro fault zones, also cut the Imataca Complex (Short and Steenken, 1962; Onstott and others, 1989; Swapp and Onstott, 1989). These faults may have been reactivated one or more times in the Proterozoic and Phanerozoic during the Nickerie and Caribbean orogenies (Gibbs and Barron, 1993; Olmore and others, 1993). For example, faults that cut the Imataca Complex and are subparallel to the Guri fault zone show evidence of postuplift, Cenozoic, right-lateral and normal displacement (Olmore and others, 1993).

\section{AGE}

Most of the radiometric dates of rocks in the Imataca Complex record regional metamorphic and magmatic events. Metasedimentary protoliths for some gneissic rocks of the Imataca Complex have been dated at 3,700-3,400 Ma by whole-rock rubidium-strontium isochron and lead-lead methods (Montgomery, 1979); it is possible that these dates reflect an inherited detrital Archean component rather than a primary age of deposition (R.M. Tosdal, U.S. Geological Survey, oral commun., 1990). Rocks of the Imataca Complex were deformed, intruded, and regionally metamorphosed about 2,800-2,700 Ma. During the TransAmazonian orogeny, about $2,150-1,960 \mathrm{Ma}$, they underwent upper amphibolite- to granulite-facies metamorphism and granitic intrusion (Hurley and others, 1976; Onstott and 


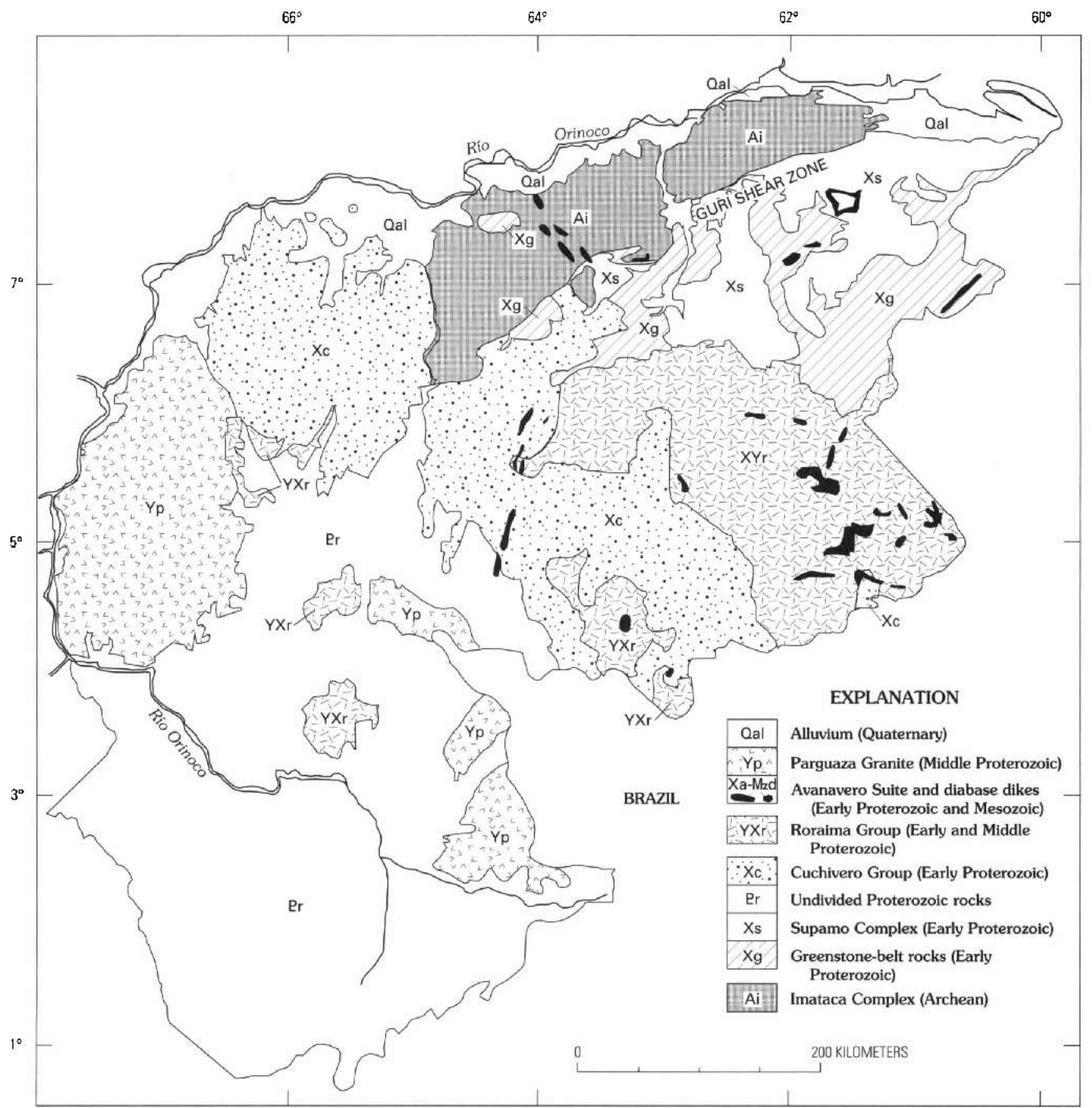

Figure 2. Simplified geologic provinces of the Venezuelan Guayana Shield, Rock units are described in table 1. Modified from Rodriguez and others (1976).

others, 1989). A sensitive high mass-resolution ion microprobe (SHRIMP) study of the uranium-lead ages of zircons collected from sand in the Río Orinoco west of Ciudad Bolivar identified a small, discrete population of zircons that have an age of about $2,800 \mathrm{Ma}$ in addition to a larger population having an age of about 2,100-2,000 Ma (Goldstein and Arndt, 1988). The scarcity of zircon grains of Archean age demonstrates that Archean rocks form only a minor pro- portion of the Venezuelan Guayana Shield (Goldstein and Amdt, 1988).

Rocks correlative in age to the Imataca Complex are not known elsewhere in the Guayana Shield; however, amphibolite- to granulite-facies rocks, including banded iron formation, in the Kenema-Man domain of the Leo Shield and in the western Reguibat Shield of the West African craton may be correlative with rocks of the Imataca Complex (Cahen and 
others, 1984; Cohen and Gibbs, 1989; Rocci and others, 1991). In the Archean terrane of West Africa, quartzofeldspathic gneiss, migmatite, and granite are ubiquitous, and layered and massive gabbro and ultramafic rocks, amphibolite, banded iron formation, anorthosite, and calc-silicate or marble beds are common (Williams, 1988; Rocci and others, 1991). The peak temperature of metamorphism for these West African shield rocks was about $750^{\circ} \mathrm{C}-850^{\circ} \mathrm{C}$, and pressure estimates of $7-10 \mathrm{~kb}$ indicate a depth of equilibration of about 21-30 km (Williams, 1988; Rocci and others, 1991). Paleomagnetic reconstructions and geochronological data indicate that the Guri shear zone in the Venezuelan Guayana Shield is aligned with the Sassandra-Trou Mountain fault zone in the Leo Shield of the West African craton, which may also be equivalent to the Zednes fault in the Reguibat Shield. The latter two faults also separate Archean high-grade metamorphic rocks from Early Proterozoic, lower grade greenstone-granite terranes (Onstott and Hargraves, 1981; Caen-Vachette, 1988; Cohen and Gibbs, 1989; Rocci and others, 1991; Boher and others, 1992).

Several high-grade metamorphic terranes in the Guayana Shield and the West African craton have been considered to be Archean in age because of their intense deformation and high-grade metamorphism. For example, granulite and chamockite in the Apiaú Complex, Brazil, the Kanuku Complex, Guyana, and the Falawatra Group in the Bakhuis Mountains, Suriname, are part of the central Guyana granulite belt (Gibbs and Wirth, 1986; Gibbs and Barron, 1993). Although these rocks and the L'Ile de Cayenne Complex in French Guiana have structural, stratigraphic, and petrographic similarities to the Imataca Complex, they have apparent protolith ages of about 2,300-2,200 $\mathrm{Ma}$, and peak metamorphism in these rocks is related to the Trans-Amazonian orogeny at about $2,000 \mathrm{Ma}$ (Priem and others, 1978; Ben Othman and others, 1984; Teixeira and others, 1984; Gibbs and Wirth, 1986; Rowley and Pindell, 1989; Teixeira and others, 1989; Gibbs and Barron, 1993). Uranium-lead and rubidium-strontium isotopic evidence for an age older than $2,400 \mathrm{Ma}$ does not exist for these rocks (Priem and others, 1978; Gibbs and Barron, 1993). Two quasicratonic nuclei, the Pakaraima nucleus in Estado Amazonas of Venezuela and the Xingu nucleus of northern Brazil, that consist of granitoid gneiss, migmatite, amphibolite, quartzite, and schist are assumed to be Archean in age because of their upper amphibolite- to granulite-facies metamorphic grade (Cordani and Brito Neves, 1982; Goodwin, 1991); however, only a few radiometric dates have been reported for these areas (Cordani and Brito Neves, 1982; Goodwin, 1991), and the age of these granitic and gneissic rocks is still unknown. Similar high-grade metaigneous and metasedimentary gneisses in the West African craton have precise isotopic ages of formation of about 2.19-2.14 Ga, and metamorphism occurred about 2.15-2.14 Ga (Boher and others, 1992). Tonalitic and trondhjemitic rocks associated with granulitic rocks in the Cupixi area, Amapa Federal Ter- ritory, northeastern Brazil, may be Late Archean in age (De Vletter and Kroonenberg, 1984; Teixeira and others, 1989).

\section{MINERAL DEPOSITS}

Iron is the predominant metal produced from the Imataca Complex. Several deposits of enriched banded iron formation in the Imataca Complex, such as Cerro Bolivar and San Isidro (Sidder, this volume, pl. 1), rank among the world's largest (Gruss, 1973; Sidder, this volume). Reserves of iron ore are greater than 1,855 million metric tons at a grade of about 63 percent iron and about 11,700 million metric tons at a grade of about 44 percent (Rodriguez, 1986, 1987; Doan, 1994). Banded iron formation protore consisted of an oxide facies assemblage in which magnetite and hematite were the dominant iron minerals. Enriched banded iron formation ore, composed predominantly of goethite and limonite, generally is in the limbs and centers of synclines. The iron-rich beds are intimately interbedded with layers of silica, present as quartz, and iron-bearing metamorphic minerals such as greenalite, grunerite, cummingtonite, crossite-magnesioriebeckite, acmite, and chlorite (Ruckmick, 1963; Gruss, 1973; Ascanio, 1985; Moreno and Bertani, 1985a). These deposits are most similar to Superior-type banded iron formation, although some Algoma-type banded iron formation may also be present (Sidder, this volume). The precious-metal content of these deposits is apparently low (Engineering and Mining Journal, 1987).

Small deposits and prospects of manganese and bauxite are present in the Upata-El Palmar-Guacuripia area (Sidder, this volume, pl. 1). Beds of secondarily enriched manganese ore are interstratified with gneiss, migmatite, amphibolite, and granulite of the Imataca Complex (Drovenik and others, 1967). These rocks are part of a stratigraphic sequence of gondite, quartz-biotite schist, amphibole schist, and dolomitic marble that is less than $500 \mathrm{~m}$ thick. The individual manganiferous beds are generally less than $10 \mathrm{~m}$ thick and have strike lengths of as much as $20 \mathrm{~km}$ or more (Drovenik and others, 1967). Drovenik and others concluded that the sedimentary-nonvolcanogenic manganese deposit model best represents the protore deposits of manganese in the Imataca Complex; however, the association with felsic to intermediate volcanic rocks in some areas (Dougan, 1977) rather than with a sedimentary protolith suggests that the sedimentary-volcanogenic manganese model (Sidder, 1991) may also characterize some of the manganese deposits. Bauxite in the Upata district is locally associated with weathered gabbro, amphibolite, and possibly granitic gneiss of the Imataca Complex (Candiales, 1961). A large-tonnage, low-grade high-silica bauxite deposit was recently discovered north of El Palmar on the Palsapa Plateau. Volcanogenic massive sulfide deposits have not been discovered in the Imataca Complex or elsewhere in the Guayana Shield (Gibbs and Barron, 1983, 1993). 


\section{PRE-TRANS-AMAZONIAN TECTONOMAGMATIC EVENT}

Intrusion of homogeneous granitic rocks and injection gneiss and the development of migmatite characterize the pre-Trans-Amazonian tectonomagmatic event about 2,800-2,700 Ma in the Guayana Shield. The Cerro La Ceiba migmatite in the Imataca Complex is representative of rocks formed at this time (Hurley and others, 1976).

This event is correlative with the Liberian tectonothermal event in the Leo and Reguibat Shields of the West African craton, during which Archean rocks were metamorphosed and intruded by plutonic rocks between about 2,780 and 2,750 Ma (Hedge and others, 1975; Rollinson and Cliff, 1982; Tysdal and Thorman, 1983; Cahen and others, 1984). This event is also known as the Aroense in Venezuela, the Guriense in Guyana, and the Jequié in Brazil (Singh, 1974; Schobbenhaus and others, 1984).

\section{GREENSTONE BELTS}

Early Proterozoic greenstone-granite terranes in the central and eastern parts of the Venezuelan Guayana Shield (fig. 2) comprise an area of about $360 \mathrm{~km}$ by $250 \mathrm{~km}$. Felsic to intermediate volcanic rocks of the Cuchivero Group and clastic sedimentary rocks of the Roraima Group overlie rocks of the greenstone-granite terranes to the west and south. Rocks of the greenstone-granite terranes are continuous with those identified in Guyana to the east. The contact between the greenstone-granite terranes and the Imataca Complex to the north is along the Guri shear zone (Gibbs and Olszewski, 1982; Onstott and others, 1989).

Rocks of the greenstone belts in Venezuela have a total thickness of $11,000 \mathrm{~m}$ or more. Named stratigraphic units of the Venezuelan greenstone belts include the Pastora Supergroup and the Botanamo Group (table 1). The Pastora Supergroup, which consists of the Carichapo Group (El Callao and Cicapra Formations) and the Yuruari Formation, is discordantly overlain by the Botanamo Group, which consists of the Caballape and Los Caribes Formations. Granitic plutons and domelike batholiths, gneiss, and migmatite of the Supamo Complex divide these metasedimentary and metaigneous rocks of the greenstone belts into branching synclinoria (Menendez, 1968, 1972; Benaim, 1972, 1974; Cox, Gray, and others, 1993). Metasedimentary and metavolcanic rocks of the Real Corona-El Torno assemblage to the west of the Río Aro (fig. 2) are tentatively correlated with those of the Pastora Supergroup (Kalliokoski, 1965). Rocks of the Pastora-Botanamo greenstone belts are correlative with those of the Barama-Mazaruni Supergroup in Guyana, the Marowijne Group in Suriname, the Paramaca Series (Orapu and Bonidoro Groups) in French Guiana, and the Vila Nova Group in Brazil (Bosma and others, 1983; Gibbs and Barron,
1983, 1993; Schobbenhaus and others, 1984; Teixeira and others, 1984, 1989; Gruau and others, 1985). All of these metaigneous and metasedimentary rocks form part of the Maroni-Itacaiunas province, a so-called mobile belt or greenstone belt that makes up a large part of the supracrustal rocks of the Amazonian craton (Cordani and Brito Neves, 1982; Teixeira and others, 1989; Goodwin, 1991).

Early Proterozoic greenstone belts of the Guayana Shield are comparable in age and lithology to Birimian greenstone belts of the West African craton (Black, 1980; Kesse, 1985; Cohen and Gibbs, 1989; Boher and others, 1992; Sylvester and Attoh, 1992). Rocks of these greenstone belts have been correlated on the basis of grossly similar lithostratigraphy, chemistry, age, structure, and intensity of metamorphism. The rocks of the Guayana Shield and the West African craton probably represent several penecontemporaneous greenstone belts, not one continuous belt.

Rocks of the greenstone belts of the Guayana Shield were deposited predominantly in a submarine environment. Basalt containing pillow structures and chemical and mineralogical alteration characteristic of submarine spilitization dominates the lower parts of the greenstone-belt sequence. The middle part of the sequence has a higher proportion of porphyritic andesite, dacite, and rhyolite submarine and possibly subaerial lava flows and siliceous and tuffaceous interflow sediments. Turbiditic graywacke, pelite, tuff, chemical sedimentary rocks, and volcaniclastic rocks are dominant in the uppermost part of the greenstone-belt sequence. The transition from volcanic to sedimentary rocks is locally conformable (Menendez, 1972; Bosma and others, 1983; Gibbs and others, 1984; Gibbs and Wirth, 1986; Gibbs, 1987; Day and others, 1989). In the greenstone belt of western Guyana, which is continuous into Venezuela, basalt and gabbro (some representing slow-cooled interiors of thick flows and sills) make up about 75 percent of the igneous rocks, basaltic andesite and andesite flow rocks about 17 percent, and rhyolite flow and pyroclastic rocks about 8 percent (Renner and Gibbs, 1987). Both tholeitic and calc-alkaline chemical trends are present in the volcanic rocks of the greenstone belts (Renner and Gibbs, 1987; Day and others, 1989).

Ultramafic rocks make up about 1-2 percent of the igneous rocks in the greenstone belts of the Guayana Shield (Gibbs, 1987). Komatiite has been tentatively identified in two isolated areas of the Guayana Shield in Venezuela on the basis of high magnesian content (22 weight percent $\mathrm{MgO}$ or more) (Tosiani and Sifontes, 1989); however, reported relic spinifex texture (Tosiani and Sifontes, 1989) is actually rosettes of amphibole after pyroxene in contact metamorphic aureoles of gabbroic intrusive rocks (Gray and others, this volume). Spinifex textures have not been reported elsewhere in the Guayana Shield (Gibbs, 1987), although peridotitic komatiite has been identified in central French Guiana on the basis of whole-rock chemistry (Gruau and others, 1985).

Mafic-ultramafic intrusive rocks are present throughout the stratigraphic sequence of the greenstone belts of the 
Guayana Shield. They commonly form layered complexes that include cumulate rocks such as pyroxenite ${ }^{4}$ and peridotite associated with gabbro and lesser anorthosite and diorite. These intrusive complexes are present both as strongly metamorphosed and deformed bodies and as relatively unmetamorphosed and undeformed bodies. In a few cases, the lower grade of metamorphism and less intense deformation are only in the interior parts of massive gabbroic bodies; the outer parts of these bodies are strongly deformed and metamorphosed. Some gabbroic rocks are relatively fresh and undeformed and therefore are apparently younger than the Trans-Amazonian orogeny (table 1); these gabbroic rocks may be associated with the Early to Middle Proterozoic Avanavero Suite (Benaim, 1972; Menendez, 1972, 1974; De Roever and Bosma, 1975; Gibbs, 1986; Gibbs and Barron, 1993). Wynn, Page, and others (this volume) describe a mafic-ultramafic layered complex at Pistón de Uroy, and Gray and others (this volume) describe similar rocks in the Sierra Verdún-Cerro Piedra del Supamo area.

Mafic and ultramafic rocks in the Venezuelan Guayana Shield form belts of small bodies of serpentinite and amphibole-talc-serpentine-carbonate rocks. Some of these gabbroic complexes apparently were preferentially intruded into the upper part of the EI Callao Formation, where they are parallel to subparallel with basaltic lava flows of this formation. The maximum thickness of these gabbroic bodies is about $500 \mathrm{~m}$ (Menendez, 1972). Possibly some gabbro represents the slowly cooled interior of thick lava flows.

\section{PASTORA SUPERGROUP}

The Pastora Supergroup consists of the Carichapo Group (El Callao and Cicapra Formations) and the Yuruari Formation (table 1). The El Callao Formation is the oldest unit of the Pastora Supergroup. Its basal contact is everywhere intruded by granitic rocks of the Supamo Complex, and its upper contact is transitional with the Cicapra Formation or concordant with the Yuruari Formation. The El Callao Formation was originally described in the El Callao area by Korol (1965) and Menendez (1968). Rocks called El Callao Formation in other areas do not necessarily conform to the description of the unit from the type section. This is also true for other units of the greenstone belts; that is, descriptions outside of the area of the type section may not agree with those of the type section. Thus, it is possible, or even likely, that more than one greenstone belt is present in the Venezuelan Guayana Shield, even though present strati-

${ }^{4}$ For simplicity, the metaigneous and metasedimentary rocks in the greenstone belts are referrcd to by their precursor rock type name; that is, pyroxenite rather than metapyroxenite, basalt instead of metabasalt, graywacke instead of metagraywacke. graphic nomenclature implies that only one belt exists. Recent compilations of the geology of the Venezuelan Guayana Shield (Cox, Gray, and others, 1993; Cox, Wynn, and others, 1993) retain formation names only in the El Callao area. In other areas, rocks are divided on a lithologic basis into units such as mafic to intermediate rocks containing abundant chlorite and actinolite, felsic metavolcanic rocks containing abundant quartz and white mica, gabbro, peridotite, and mica schist and phyllite (Cox, Gray, and others, 1993; Cox, Wynn, and others, 1993).

The El Callao Formation, as thick as $3,000 \mathrm{~m}$, consists almost exclusively of metamorphosed low-potassium basaltic to andesitic lava flows that commonly contain pillow structures and have amygdular and brecciated flow tops (Menendez, 1968, 1972; Benaim, 1972). Minor ferruginous quartzite and ferruginous and manganiferous chert (metamorphosed banded iron formation?) and talc schist lenses are present in several areas. Rocks of the El Callao Formation have been metamorphosed to the greenschist facies and locally to the almandine-amphibolite subfacies of the amphibolite facies. Greenschist-facies rocks typically are biotite-chlorite-albite-epidote \pm actinolite schist. Close to granitic intrusions of the Supamo Complex, the rocks are amphibolite containing blue-green homblende and plagioclase (albite to andesine). A metamorphic and color zonation has been identified in pillow lavas as far as $6 \mathrm{~km}$ from the intrusive rocks (Menendez, 1968). The light-green greenschist-facies lavas are darker, grayish-green to greenish-black, amphibolite-facies rocks toward the intrusive bodies. Amphibolite is also abundant within $30 \mathrm{~km}$ of the Guri fault (Cox, Wynn, and others, 1993).

Hills having irregular crests typify the topographic expression of the El Callao Formation. They are $300-800 \mathrm{~m}$ in elevation, about $100-500 \mathrm{~m}$ above the surrounding terrain. In contrast, gabbro in mafic complexes forms slightly higher and smoother crested hills. Red soil on the El Callao Formation supports a dense forest (Menendez, 1968).

The Cicapra Formation overlies the El Callao Formation and includes a sequence as thick as $2,000 \mathrm{~m}$ of rhythmically bedded submarine andesitic tuff, turbiditic graywacke, and siltstone in packets about $10 \mathrm{~m}$ thick. Lithic tuff, tuff breccia, volcanic agglomerate, and, in the uppermost part of the formation, manganiferous hematitic chert are minor components of the Cicapra Formation (Menendez, 1972). These rocks are greenschist-facies, porphyroblastic, quartz-poor actinolite-biotite-epidote-albite schist. Amphibolite developed locally in this formation near granitic rocks does not contain biotite or porphyroblasts of amphibole. Schistosity, oblique to parallel to stratification, is generally poorly developed; in areas near granitic intrusive rocks, it is better developed. Rocks of the Cicapra Formation form a completely flat topography covered by a clayey soil the color of red wine. This unit wedges out and disappears southeast of El Callao, at which point the Yuruari Formation rests on the El Callao Formation (Menendez, 1968). 
The basal contact between the Yuruari and the Cicapra Formations is gradational and that between the Yuruari and El Callao Formations is both depositional and faulted. The Yuruari Formation consists of mica schist, phyllite, and felsic metatuff possibly derived from epiclastic and turbiditic rocks; rhythmically bedded packets of feldspathic sandstone, siltstone, and black shale are as thick as $50 \mathrm{~m}$. Locally, tuffaceous breccia, manganiferous phylite, and intercalated dacitic to basaltic tuff, breccia, and lava flows, and chert are also present (Menendez, 1968, 1972; Benaim, 1972). Some phyllite and schist in the Yuruari Formation classified previously as metasedimentary rocks commonly contain relict phenocrysts of subhedral feldspar and rounded, embayed quartz, that indicates some phyllite and schist originated as felsic volcanic rocks (Cox, Gray, and others, 1993). The overall thickness of this formation is about $1,000 \mathrm{~m}$ (Menendez, 1968, 1972; Benaim, 1972; Day and others, this volume). Rocks of the Yuruari Formation are typically greenschist-facies chlorite-sericite \pm calcite schist. Only locally are rocks of the Yuruari Formation intruded by granite of the Supamo Complex. In aureoles of granitic intrusions, homblende-homfels and pyroxene-hornfels facies containing biotite, sillimanite or andalusite, chloritoid, tourmaline, and garnet developed. The upper contact does not crop out, but the contact with the overfying Caballape Formation is apparently an angular unconformity and (or) a tectonic disconformity (Menendez, 1968). Low hills and plains exhibiting a rectangular drainage pattern and a varicolored (light to dark yellow, reddish yellow, and several shades of red) clayey residual soil have developed on the Yuruari Formation. Savanna-type vegetation is characteristic (Benaim, 1972; Menendez, 1972).

Rocks of the greenstone belts of the Pastora Supergroup are strongly deformed and record at least two episodes of deformation. Recumbent isoclinal folds with folded axial planes are characteristic, and the axjal planes are commonly parallel to subparallel with the borders of the granitic intrusions of the Supamo Complex (Menendez, 1972). Thus, the rocks of the Pastora Supergroup typically fonn synforms that wrap around granitic domes of the Supamo Complex. Foliation is commonly developed in rocks of the greenstone belt and is parallel to subparallel with the primary stratification. Foliation is best developed close to the contacts with the Supamo Complex. Cleavage parallel with the axial plane of the folds is also well developed in these rocks. Major shear zones as wide as $1 \mathrm{~km}$ and as long as $35 \mathrm{~km}$ cut the rocks of the Pastora Supergroup (Menendez, 1972, 1974).

\section{BOTANAMO GROUP}

Rocks in the Caballape and Los Caribes Formations of the Botanamo Group discordantly overlie the Pastora Supergroup. The Caballape Formation includes mafic to felsic lava and pyroclastic flows and breccia interbedded with epi- clastic and turbiditic sedimentary rocks. Menendez (1968) estimated that graywacke, conglomerate, and siltstone make up 80 percent of the unit in the El Callao-Guasipati area, the remainder being andesitic to rhyodacitic pyroclastic tuff and breccia. Benaim (1972) noted, however, that only the basal part of the formation crops out in this area. Day and others (1989) determined that in the Anacoco area the Caballape Formation consists of about 80 percent basaltic to dacitic volcanic flows (some with pillow lavas) and associated pyroclastic rocks and about 20 percent volcanic breccia and graywacke and thin ( $1-5 \mathrm{~cm}$ thick) horizons of shale. Use of the name Caballape Formation should be restricted to those rocks in the type section area near El Callao. The basal contact of the Caballape Formation is discordant to unconformable with the Pastora Supergroup, and the upper contact is reportedly concordant with the Los Caribes Formation (Benaim, 1972). The minimum thickness of this formation is about $5,000 \mathrm{~m}$ (Menendez, 1968). Granite of the Supamo Complex apparently does not intrude rocks of the Caballape Formation, and thus amphibolite is not present in this formation, in contrast to the Pastora Supergroup (Cox, Wynn, and others, 1993). The Caballape Formation consists only of greenschist-facies schist containing chlorite, epidote, sericite, quartz, calcite, biotite, and opaque oxide minerals; the schist is only moderately folded into broad synforms. The terrain underlain by this formation is flat; low hills are elongate parallel with the trend of the beds, and the drainage pattern is rectangular or dendritic. The rocks weather to form a bleached soil (Benaim, 1972; Menendez, 1972).

The Los Caribes Formation consists of intercalated red phyllite and sandstone, polymict conglomerate, and siltstone and minor felsic tuff. Some authors excluded this unit from the greenstone-belt sequence and referred to it as pre-Roraima metasedimentary rocks or pre-Roraima foliated sandstone (Ghosh, 1985). It is likely that rocks of both pre-Cuchivero and post-Cuchivero age have been included within the Los Caribes Formation because some rocks mapped as Los Caribes Formation contain fragments of unmetamorphosed felsic tuff typical of the Caicara Formation of the Cuchivero Group, not greenschist-facies metavolcanic rocks (Cox, Wynn, and others, 1993). Thus, use of the name Los Caribes Formation should be restricted to that area near the type section in the Río Cuyuni where the contact between the Caballape and Los Caribes Formations has been mapped as concordant and interdigitated (Benaim, 1972).

Sedimentary rocks of the Los Caribes Formation are metamorphosed to the greenschist facies, whereas sedimentary rocks of the Roraima Group are unmetamorphosed or only weakly thermally metamorphosed as shown by the presence of pyrophyllite and andalusite (Ghosh, 1985). Minerals such as chlorite, muscovite, epidote, chloritoid, and recrystallized sheared quartz in the Los Caribes Formation are representative of the greenschist facies. Also, in contrast to rocks of the Roraima Group, folds in conglomerate, sandstone, and phyllitic shale of the Los Caribes Formation are 
isoclinal or chevron in shape, and the rocks are foliated and have a fracture cleavage at a high angle to bedding (Benaim, 1972; Ghosh, 1985; Lira and others, 1985). Some conglomeratic units are as thick as $60 \mathrm{~m}$; however, the total thickness of this formation has not been determined. The Los Caribes Formation probably represents environments transitional from marine to continental.

Rocks of the Los Caribes Formation are chronologically correlative with those of the Cinaruco Formation in Estado Amazonas and with those of the Muruwa, Rosebel, and Orapu Formations in Guyana, Suriname, and French Guiana, respectively (Ghosh, 1985). These rocks also resemble a gold-bearing sequence known as the Tarkwaian Series in the eastern West African craton (Black, 1980; Bonhomme and Bertrand-Sarfati, 1982; Kesse, 1985; Cohen and Gibbs, 1989; Vinchon, 1989; Ledru and others, 1994). The Tarkwaian Series consists of Early Proterozoic clastic metasedimentary rocks about $2,500-6,700 \mathrm{~m}$ thick that are folded within the Birimian greenstone-belt rocks (Ntiamoah-Agyakwa, 1979; Black, 1980; Kesse, 1985; Norman and Appiah, 1989; Eisenlohr and Hirdes, 1992; Watkins and others, 1993).

\section{REAL CORONA-EL TORNO ASSEMBLAGE}

Supracrustal rocks, including basal feldspathic quartzite and conglomerate, tholeiitic basalt, gabbro, and thin beds of shale, chert, and ferruginous quartzite, form an east-trending structural basin about $100 \mathrm{~km}$ southwest of Ciudad Bolívar (fig. 2). The basin, or syncline, is about $45 \mathrm{~km}$ long and $16 \mathrm{~km}$ wide and is underlain both on the north and south by a gneissic basement about 2,240 Ma in age (Kalliokoski, 1965; Sidder, Day, and others, 1991). The basal quartzite is in depositional contact with the basement of granitic gneiss. The quartzite is as thick as $150 \mathrm{~m}$; thicknesses of the other units are not known. These rocks have been penetratively deformed; they exhibit well-developed foliation, mineral lineation, and mylonitic fabric and are metamorphosed to the amphibolite facies. Hills underlain by quartzite and chert are as much as $200 \mathrm{~m}$ above the generally flat gneissic terrain. Vegetation in the area is savannalike.

\section{AGE, CHEMISTRY, AND ORIGIN}

Greenstone belts of the Guayana Shield formed during the Early Proterozoic and closely resemble in structure, lithostratigraphy, and composition of their metavolcanic and metasedimentary rocks and in areal extent greenstone belts of Early Proterozoic age such as those associated with the West African Shield and the Penokean orogen in the Superior province of the Canadian Shield, as well as many greenstone belts of Archean age (Sims and others, 1989; Sylvester and Attoh, 1992). Geochronological data, including uranium-lead zircon and whole-rock samarium-neodymium and rubidium-strontium isochron dates, document that the metavolcanic greenstone-belt rocks and associated granitic rocks were emplaced throughout the Guayana Shield between about 2,250 and 2,100 Ma (Gibbs and Olszewski, 1982; Gruau and others, 1985). These ages are the same as those obtained from the most detailed geochronological study of rocks of the greenstone belts of Venezuela, which determined a conservative age range of less than 2,300 to about $2,050 \mathrm{Ma}$, and a narrower range of 2,165 to $2,080 \mathrm{Ma}$, for emplacement of the metavolcanic-metasedimentary greenstone-belt sequence and crystalkization of granite of the Supamo Complex (Klar, 1979). A sample of dacitic tuff from the Yuruari Formation in the Lo Increible mining district has a uranium-lead zircon age of $2,131 \pm 10 \mathrm{Ma}$ (Day and others, this volume), which coincides with the published ages of rocks of the greenstone belts. Voluminous magmatism in the Birimian greenstone belts of the Reguibat and Leo Shields of the West African craton has been dated by uranium-lead zircon and samarium-neodymium and lead-lead whole-rock dating methods as about $2.18-2.07 \mathrm{Ga}$; the maximum interval of 2.3-2.0 Ga includes scattered, less well constrained dates (Cahen and others, 1984; Boher and others, 1992; Hirdes and others, 1992; Taylor and others, 1992).

The chemistry of rocks of the greenstone belts in the Guayana Shield has not been systematically studied. Those investigators who have conducted geochemical studies on these rocks noted that the original chemical composition of the igneous rocks has been altered by weathering, hydrothermal alteration (spilitization and potassium metasomatism), and greenschist- and amphibolite-facies regional metamorphism. Recent studies by Gibbs (1987) and Renner and Gibbs (1987) in Guyana and by Day and others (1989) in Venezuela provide data for representative areas of the Guayana Shield. Both tholeiitic and calc-alkaline differentiation trends are common in the volcanic rocks. Low-potassium subalkaline tholeiitic basalt and basaltic andesite are the dominant rock types; lesser subequal proportions of calc-alkaline andesite, dacite, and rhyolite are also present (Gibbs, 1987). Few rocks in the lower part of the greenstone belts from throughout the Guayana Shield have silica contents in the range from 63 to 68 weight percent, and the overall distribution of silica may be considered bimodal (Gibbs, 1987); however, rocks of the Caballape Formation in the Anacoco area of Venezuela have a compositional continuum with a systematic variation in the major and trace elements that forms a cogenetic mafic to felsic calc-alkaline magmatic series (Day and others, 1989). The Birimian greenstone belts of the West African craton also include tholeitic basalt overlain by calc-alkaline intermediate to felsic tuff and lava (Boher and others, 1992; Sylvester and Attoh, 1992; Vidal and Alric, 1994).

Early Proterozoic magmatism in the Guayana Shield (and in its associated West African craton) represents a major period of rapid crustal growth from mantle-derived 
melts; however, discriminant diagrams used to define the tectonic setting of volcanic rocks are not consistent in specifying the tectonic environment of deposition of the greenstone-belt rocks of the Guayana Shield (Gibbs, 1987). The volcanic rocks were erupted predominantly in a submarine environment, and they have chemical characteristics of modern ocean floor basalts, island arc rocks, and continental arc rocks. Initial ${ }^{87} \mathrm{Sr} /{ }^{86} \mathrm{Sr}$ and ${ }^{143} \mathrm{Nd} /{ }^{144} \mathrm{Nd}$ ratios of 0.7019 and 0.51002 , respectively, as well as an $\varepsilon_{\mathrm{Nd}}$ value of 2.1 (Gruau and others, 1985), indicate that the volcanic rocks are derivatives of mantle melts and do not contain any component of Archean continental crust. Similarly, the Birimian volcanic and granitic rocks contain a negligible component, if any, of Archean crust (Rocci and others, 1991; Boher and others, 1992; Sylvester and Attoh, 1992; Taylor and others, 1992). Ambiguous geochemical signatures in the volcanic rocks of the Guayana Shield (and West African craton) may reflect an evolutionary history from young, immature, oceanic istand arc to back-arc marginal basin and mature (thickened) island arc environments. The Trans-Amazonian orogeny (Eburnean orogeny in West Africa) resulted in the accretion of these new crustal components (Choudhuri, 1980; Bosma and others, 1983; Gibbs, 1987; Renner and Gibbs, 1987; Teixeira and others, 1989; Liégeois and others, 1991; Rocci and others, 1991; Boher and others, 1992).

Supracrustal rocks of the Real Corona-El Torno assemblage were deposited in a submarine environment within or marginal to the craton, possibly as a back-arc marginal basin inboard from the Pastora island arc or during an early cratonic rifting phase associated with the Trans-Amazonian orogeny. Closure of the basin and regional compressive tectonism associated with the later phases of the Trans-Amazonian orogeny produced penetrative deformation and metamorphism and variably thrust the basaltic rocks over the basal quartzite. The age of the basement gneiss places a maximum age on the rifting of 2,240 Ma (Sidder, Day, and others, 1991).

\section{MINERAL DEPOSITS}

Rocks of the greenstone belts of the Guayana Shield contain deposits of shear-zone-hosted, low-sulfide gold-quartz veins (Berger, 1986). Several deposits in Venezuela are currently being mined, including those in the $\mathrm{El}$ Callao, Lo Increíble, and Botanamo districts (Sidder, this volume). Mafic metavolcanic rocks of the El Callao Formation are the most common ore host in the El Callao district, which is the largest gold-producing district in Venezuela and has total production of about 200 metric tons of gold; however, all rock types in the greenstone belts throughout the shield, except those in the Los Caribes Formation, are known to host low-sulfide gold-quartz veins (Korol, 1961; Carter and Femandes, 1969; Menendez, 1972; Dahlberg, 1975; Blanc and others, 1980; Barnard, 1990). Ore in the green- stone belts is localized by faults and shear zones (Menendez, 1972; Day and others, this volume). Quartz veins range in thickness from $2 \mathrm{~cm}$ to more than $10 \mathrm{~m}$. Quartz is milky white to gray and locally banded. Native gold, minor to trace amounts of pyrite, and lesser amounts of tetrahedrite, chalcopyrite, bornite, molybdenite, scheelite, and sphalerite are the most typical metallic minerals in the quartz veins. Carbonate (commonly ankerite) in the quartz veins and carbonate alteration as much as $30 \mathrm{~m}$ into the wallrocks are common in some districts such as El Callao. In addition to carbonate alteration, the wallrocks are intensely silicified, sericitized, and propylitized (with epidote and chlorite) as much as several tens of meters from the veins, and tourmaline and mariposite (chrome mica) are variably present in the alteration assemblage (Macdonald, 1968; Banerjee and Moorhead, 1970; Barron, 1973; Menendez, 1974). These shear-zone-hosted, Iow-sulfide gold-quartz vein deposits are similar to Early Proterozoic gold deposits in Ghana and elsewhere in West Africa (Milési and others, 1992; Dzigbodi-Adjimah, 1993; Petersen, 1993). The quartzvein-hosted and other gold deposits in Early Proterozoic rocks of the greenstone belts of West Africa, excluding the Tarkwaian gold-bearing conglomerates, have produced more than 1,000 metric tons of gold at grades between 2 and 30 grams per metric ton, and reserves of more than 350 metric tons are present (Milési and others, 1989, 1992; Dzigbodi-Adjimah, 1993).

Vuelvan Caras and Payapal are the only gold-bearing vein deposits in the Venezuelan Guayana Shield known to be present in granitic rocks (Graterol, 1974; Wynn and Sidder, 1991). They are similar to gold deposits in Guyana, such as those at Omai, Peters' Mine, and Eagle Mountain, that are in stockwork veins within and at the periphery of granitic plutons that range in age from about 2,100 to $1,800 \mathrm{Ma}$ as dated by whole-rock rubidium-strontium isochrons (Macdonald, 1968; Barron, 1969; Carter and Fernandes, 1969; Berrange, 1977; Elliot, 1986; Barnard, 1990; Gibbs and Barron, 1993). Although in Venezuela the association of granitic intrusive rocks and gold-bearing quartz veins is not well documented, several authors have noted that gold deposits in greenstone-belt rocks in Guyana, Suriname, and French Guiana are spatially associated with, if not genetically related to, granitic intrusive rocks (Carter and Fernandes, 1969; Banerjee and Moorhead, 1970; Dahlberg, 1975, Blanc and others, 1980; Gibbs and Barron, 1993). Some gold deposits within the Birimian greenstone belts of Ghana in West Africa show a spatial association with granitic intrusive rocks (Leube and others, 1990). Early Proterozoic granitic rocks associated with the Birimian greenstone belts throughout West Africa contain gold reserves of less than 50 metric tons, which is a minor proportion (about 3 percent) of the total gold reserves in Early Proterozoic rockss (Milési and others, 1992).

Metals other than gold have not been produced in any significant quantity from rocks of the greenstone belts of the Guayana Shield. Small prospects of manganese in Venezu- 
ela, such as San Cristobal and La Esperanza, and iron prospects in banded iron formation have not been systematically worked or evaluated. The manganese prospects in Venezuela are similar to sedimentary-volcanogenic deposits at Matthews Ridge in Guyana, Serra do Navio in Amapa Federal Territory, Brazil, and Nsuta in Ghana, Tambao in Burkina Faso, and Ziémougoula, Ivory Coast, of West Africa. Matthews Ridge produced about 1.3 million metric tons with a grade of about 39.3 percent manganese from 1961 to 1968 and has ore reserves of about 288,500 metric tons of 37 percent manganese (Barron, 1973). Prospects in the San Cristobal area may be extensions of manganiferous strata from the Matthews Ridge area (Gibbs and Barron, 1993). Serro do Navio has measured reserves of 15.7 million metric tons at 39.3 percent $\mathrm{MnO}_{2}$, and total reserves of 20.1 million metric tons (Nagell, 1962; Damasceno, 1982; Lima, 1984; Schobbenhaus and others, 1984). Production from Nsuta between 1954 and 1983 totalled about 12.8 million metric tons of manganese (Kesse, 1985). Reserves are estimated to be about 5 million metric tons of high-grade oxide ore ( 48.9 percent manganese) and 2 million metric tons of low-grade oxide ore (34.3 percent manganese) and about 28 million metric tons of carbonate ore (26.9 percent manganese) (Kesse, 1985). Some of the manganese horizons in Ghana have a spatial relation with gold deposits (Leube and others, 1990; Milesi and others, 1992). The manganese deposits are on the flanks of the volcanic belts and in the transition zone from volcanic rocks to basinal sedimentary rocks. These transition zones, or breaks, are characterized by chemical sedimentary rocks such as chert, iron-magnesium carbonate rocks, and carbon-rich argillite and are the foci for the gold deposits (Leube and others, 1990; Milési and others, 1992).

Undiscovered deposits such as those of Algoma-type banded iron formation and Homestake-type gold may be present in the Early Proterozoic metavolcanic and metasedimentary rocks of the greenstone beits of the Venezuelan Guayana Shield. Banded iron formation is generally absent in the Guayana and West African Shields; however, manganese-rich exhalative rocks are common (Holtrop, 1965; Leube and others, 1990; Milési and others, 1992). As discussed previously, manganese-rich rocks and other chemical sedimentary rocks are important exploration guides for gold deposits in the Early Proterozoic rocks of the greenstone belts in Ghana (Ntiamoah-Agyakwa, 1979; Leube and others, 1990).

Volcanogenic massive sulfide deposits have not been discovered in the Guayana Shield, although the tectonic and volcanosedimentary environments are favorable for volcanic-hosted kuroko-type massive sulfide deposits. Prospects in Guyana such as Groete Creek, near Aremu, and in the middle Puruni River area contain anomalous copper, zinc, and gold in metavolcanic and metasedimentary sequences (Barron, 1973; Gibbs and Barron, 1993). Polymetallic volcanogenic massive sulfide deposits are also uncommon in the West African craton (Milési and others, 1992). The only known Early Proterozoic volcanogenic massive sulfide deposit in West Africa is Perkoa in Burkina Faso. It is a zinc-silver deposit dated at 2,120 $\pm 41 \mathrm{Ma}$ (Marcoux and others, 1988); reserves are estimated to be 4.5 million metric tons at 17 percent zinc and about 60 grams silver per metric ton (Milési and others, 1989, 1992). Although bands or layers of sulfide-rich rocks are rare in the West African Shicld, disseminated pyrite and arsenopyrite are common in gold-bearing carbonate within the sequence of chemical sedimentary rocks in the transition zone from volcanic rocks to basinal sedimentary rocks (Leube and others, 1990).

Platinum-group elements, chromium, and nickel-copper deposits may be associated with mafic-ultramafic complexes in the greenstone belts. Anomalous amounts of platinum-group elements are present in mafic rocks at Pistón de Uroy and in the Real Corona-El Torno assemblage (Sidder, this volume; Wynn, Page, and others, this volume). Platinum-group elements are also present in gold lode and placer deposits (Dahlberg, 1975; Sidder, this volume).

\section{SUPAMO COMPLEX}

The Supamo Complex includes paragneiss, schist, migmatite, and granitic rocks such as trondhjemite, tonalite, and granodiorite (Moreno and Mendoza, 1975). Quartz monzonite and granite that intrude trondhjemite, tonalite, and granodiorite and the greenstone-belt rocks of the Pastora Supergroup have also been included within the Supamo Complex by some authors (Menendez, 1972). Plutonic rocks of the Supamo Complex are massive to foliated and generally form domes; metamorphic grade in the country rocks increases from greenschist to amphibolite facies within about $6 \mathrm{~km}$ of the intrusive bodies. The marginal facies of the intrusive bodies are generally concordant with the supracrustal host rocks. The granitic rocks generally underlie a savanna that has small, rounded, isolated hills and a dendritic drainage pattern. The soil is sandy with minor clay and has a bleached or whitish color (Menendez, 1972, 1974; Benaim, 1974). Rocks of the Supamo Complex are not known to host any mineral deposits.

The age of the Supamo Complex is commonly described as ranging from 2,700 to $2,100 \mathrm{Ma}$; the younger rocks are said to be "remobilized Supamo." Recent uranium-lead isotopic data for zircons indicate that trondhjemite of the Supamo Complex crystallized between about 2,200 and 2,050 Ma (Klar, 1979). The age of emplacement of quartz monzonite plutons into the greenstone-granite terrane and the Imataca Complex also ranges from about 2,200 to 2,050 Ma, on the basis of uranium-lead zircon dates (Klar, 1979), and possibly to $1,958 \mathrm{Ma}$, as indicated by rubidium-strontium data for biotite (Onstott, Hargraves, York, and Hall, 1984). The reinterpreted age of gneissic rocks in the Supamo Complex is about 2,230 Ma, consistent with an age of $2,227 \mathrm{Ma}$ for the apparently correlative Bar- 
tica Gneiss in Guyana (Gibbs and Olszewski, 1982). The maximum age for gneiss in the Supamo Complex is about $2,300 \mathrm{Ma}(\mathrm{Klar}, 1979)$. Granite and high-grade gneiss associated with the greenstone belts of the West African craton also range in age from about 2,220 to about $2,070 \mathrm{Ma}$ (Rocci and others, 1991; Boher and others, 1992; Taylor and others, 1992). Trondhjemitic intrusive rocks and more potassium rich granite and granodiorite of the West African craton have similar ages (Boher and others, 1992), as is true in the Venezuelan Guayana Shield. Sodic granitoid rocks associated with the Nangodi greenstone belt in Ghana have high $\mathrm{Sr} / \mathrm{Nd}$ and $\mathrm{Tb} / \mathrm{Dy}$ ratios relative to normal mid-ocean ridge basalt that indicate the granitic rocks may have formed by melting of relatively hot, subducted slab material ("amphibolite") (Sylvester and others, 1993). Essentially contemporaneous potassic-rich granitic rocks, therefore, may have had less of a slab component and incorporated more sialic crustal material. Gneiss and migmatite in Ghana are coeval and cogenetic with the granitic rocks (Opare-Addo and others, 1993). Differences in structural and textural features between the metamorphic and granitic rocks, such as foliation, homogeneity, and grain size, are due to emplacement at different depths; the migmatites were generated at deeper crustal levels than the granitic rocks (Opare-Addo and others, 1993).

\section{TRANS-AMAZONIAN OROGENY}

The Trans-Amazonian orogeny was a major cycle of greenschist- to upper amphibolite- and granulite-facies metamorphism, deformation, and magmatic activity in the Guayana Shield during the Early Proterozoic. It was a period of continental collision and accretion of assorted Archean and Early Proterozoic terranes into the Amazonian craton, the subsequent common deformation of these accreted terranes, and the first development of continental environments on much of the craton. Paleomagnetic and ${ }^{40} \mathrm{Ar} /{ }^{39} \mathrm{Ar}$ data indicate that the Guayana and Guaporé Shields and possibly the West African craton were combined as a single tectonic plate during the Trans-Amazonian orogeny (Gibbs and Wirth, 1986; Renne and others, 1988; Teixeira and others, 1989; Rocci and others, 1991; Boher and others, 1992). The Imataca Complex was thrust over the Pastora-Supamo greenstone-granite terrane during the Trans-Amazonian orogeny, and oblique compression between these two terranes resulted in left slip along major fault zones such as the Guri shear zone (Swapp and Onstott, 1989). The Guri fault zone, and its inferred continuation in the West African craton, the Sassandra-Trou Mountain fault zone (Caen-Vachette, 1988; Cohen and Gibbs, 1989), is a suture between Archean rocks (the Imataca Complex in Venezuela) and Early Proterozoic greenstone-belt rocks.

The Trans-Amazonian orogeny in the Guayana Shield occurred between about 2,150 and $1,960 \mathrm{Ma}$ and possibly continued to about $1,730 \mathrm{Ma}$. The wide range in ages may be the result of tectonic activity that was time transgressive across the shield from northeast to southwest (Gaudette and Olszewski, 1985). Alternatively, the range in ages may span two distinct orogenic episodes, a predominantly collisional and metamorphic event accompanied by intrusive magmatic activity throughout the shield from about 2,150 to $1,960 \mathrm{Ma}$, and a period of intense metamorphism, deformation, and intrusion between about 1,860 and 1,730 Ma in the westernmost part of the shield in Estado Amazonas of Venezuela (Klar, 1979; Gibbs, 1980; Bosma and others, 1983; Teixeira and others, 1984; Gaudette and Olszewski, 1985). Postorogenic and (or) anorogenic magmatic activity from about 1,930 to about $1,790 \mathrm{Ma}$ that emplaced rocks of the Cuchivero Group and its equivalents and was accompanied by minor uplift but little or no deformation or metamorphism is not considered here to be part of the Trans-Amazonian orogeny.

Rocks of the Imataca Complex reveal a history of prograde metamorphism and retrograde cooling and uplift associated with the Trans-Amazonian orogeny. Detailed rubidium-strontium isotopic studies of the age of granulite-facies metamorphism in the Imataca Complex indicate an age of $2,022 \pm 67 \mathrm{Ma}$ for the Trans-Amazonian orogeny (Montgomery and Hurley, 1978). This age apparently predates the peak pressure associated with the orogeny and postdates the peak temperature (Swapp and Onstott, 1989). Plateau dates from ${ }^{40} \mathrm{Ar} /{ }^{39} \mathrm{Ar}$ analyses of hornblende and biotite in the Imataca Complex range from about 2,044 to $1,760 \mathrm{Ma}$ and are interpreted to record decompression, uplift, and cooling following peak metamorphism of the Trans-Amazonian orogeny (Onstott and others, 1989; Swapp and Onstott, 1989). The Imataca Complex was uplifted from a depth of about $32 \mathrm{~km}$ to about $16 \mathrm{~km}$ during southward thrusting of the Imataca terrane over the greenstone belts within about $30 \mathrm{~m} . \mathrm{y}$. after initiation of uplift and after reaching peak pressure conditions (Swapp and Onstott, 1989). Extremely slow cooling rates implied by plateau dates of biotite, potassium feldspar, and plagioclase from granulite-facies rocks in the core of the Imataca Complex indicate that uplift of the Imataca Complex had mostly ceased by about 1,962 Ma and that rocks in the complex cooled isobarically at intermediate crustal levels of about 15 $\mathrm{km}$ until about 1,100 Ma (Onstott and others, 1989; Swapp and Onstott, 1989). All argon-bearing mineral systems were closed by $1,100 \mathrm{Ma}$, perhaps as a result of renewed uplift associated with the Nickerie or K'Mudku episode (table 1) (Onstott and others, 1989). In contrast, metamorphic rocks in the Carajas region, Brazil, of the Guaporé Shield cooled rapidly and attained stable magnetization by about $1,910 \mathrm{Ma}$ (Renne and others, 1988). Paleomagnetic and ${ }^{40} \mathrm{Ar} /{ }^{99} \mathrm{Ar}$ data preclude the possibility of any regional metamorphism in the Guapore Shield to even the lowest greenschist facies after the Trans-Amazonian orogeny (Renne and others, 1988).

The Trans-Amazonian orogeny in the Guayana Shield is defined here to consist of deformation, metamorphism, 
and magmatic activity between about 2,150 and $1,960 \mathrm{Ma}$. Rocks of the Pastora Supergroup were deformed in two pulses or episodes of tectonic activity within this interval, whereas rocks of the Botanamo Group were affected only by the second pulse of deformation.

The Eburnean orogeny in the West African craton was a period of igneous and metamorphic activity and deformation about 2,200-1,980 Ma, possibly between only 2,112 and 2,073 Ma (Hedge and others, 1975; Onstott and Dorbor, 1987; Cohen and Gibbs, 1989; Feybesse and others, 1989; Liégeois and others, 1991), coincident with the Trans-Amazonian orogeny in the Guayana Shield. Deformation associated with the Ebumean orogeny in the West African craton has been subdivided into two phases; the lower group of Birimian rocks (Birimian I) was affected by both phases, and the upper group (Birimian II) was folded just once (Rocci and others, 1991; Milési and others, 1992). Recent work suggests, however, that the distribution of deformation features is spatially controlled by shear zones and is not temporally restricted to particular stratigraphic units (Mortimer, 1992; Watkins and others, 1993). Hence, all Birimian and Tarkwaian units have been affected by all phases of the Eburnean orogeny (Mortimer, 1992: Watkins and others, 1993). Deformation D1 is represented by thrust faults (Feybesse and Milési, 1994), foliation S1 that is subparallel with bedding ( $\mathrm{SO}$ ), lineation $\mathrm{L} 1$ defined by the intersection of bedding and foliation $\mathrm{S} 1$, isoclinal folds $\mathrm{P} 1$, and low- to medium-grade metamorphism; it is referred to as a tangential (S1 parallel to S0) deformation event (Feybesse and others, 1989; Milési and others, 1989, 1992; Liégeois and others, 1991; Eisenlohr and Hirdes, 1992). Deformation D1 is attributed to collision tectonics. Calc-alkaline volcanism and deposition of volcaniclastic and turbiditic material in the upper Birimian, as well as deposition of the Tarkwaian sediments (equivalent to the Caballape and Los Caribes Formations in the El Callao area and the so-called eugeosynclinal metavolcanic rocks in the Botanamo and Anacoco areas [Cox, Wynn, and others, 1993]), followed deformation D1. Deformation D2 was a sinistral transcurrent shear event characterized by left-lateral strike-slip faults that are locally associated with thrust zones, large, regional upright folds $\mathrm{P} 2$, a crenulation cleavage $\mathrm{S} 2$ that crenulates foliation $\mathrm{S} 1$, stretching lineation $\mathrm{L} 2$, and low- to medium-grade metamorphism (Feybesse and others, 1989; Liégeois and others, 1991; Eisenlohr and Hirdes, 1992; Milési and others, 1992; Vidal and Alric, 1994). This second deformation was also a period of compressive transcurrent tectonics. Uranium-lead, samarium-neodymium, and rubidium-strontium dates determined for D1 and D2 in West Africa indicate that these deformations associated with the Eburnean orogeny took place between about 2,112 and 2,073 Ma (Feybesse and others, 1989; Liégeois and others, 1991). In the eastern part of the West African shield, deformation D3 produced dextral shear zones, folds $\mathrm{P} 3$, foliation and crenulation cleavage $\mathrm{S}$, a stretching lineation $\mathrm{L} 3$, and reactivation and local offset of
D2 faults (Milési and others, 1989, 1992; Liégeois and others, 1991; Watkins and others, 1993). Event D3 accompanied low-grade metamorphism at about 2,073 Ma (Milési and others, 1989). A late or post-Ebumean tectonic shortening event characterized by a crenulation cleavage and a transcurrent shear zone, but unaccompanied by igneous or metarnorphic activity, may have occurred as many as $90 \mathrm{~m}$.y. after deformation D3 at about 1,980 Ma (Milési and others, 1989; Liégeois and others, 1991; Vidal and Alric, 1994).

The Cuchivero Group, about $1,930-1,790 \mathrm{Ma}$, is regarded here to be post-Trans-Amazonian in age. Postcollisional magmatism following collision and amalgamation of the island-arc greenstone belts with the Imataca Complex resulted in the eruption and intrusion of the Cuchivero Group and its equivalents. Rocks of the Cuchivero Group are generally unmetamorphosed and relatively undeformed, and their character is sufficiently different from that of rocks of the greenstone belts that they should be considered part of an unnamed thermomagmatic event. This post-Trans-Amazonian, postcollisional magmatic activity continued until about 1,790 Ma. Similar, but less voluminous, posttectonic magmatism in the Reguibat Shield of the West African craton took place between about 1,970 and 1,750 Ma (Cahen and others, 1984; Rocci and others, 1991).

Metamorphism, deformation, and magmatic activity about 1,860-1,730 Ma in Estado Amazonas must be considered as part of a separate orogenic event (see discussion of undivided Proterozoic rocks). Gaudette and Olszewski (1985) correlated this younger orogenic episode in Estado Amazonas with the older Trans-Amazonian event $(2,150-1,960 \mathrm{Ma})$; however, the age of $1,900 \pm 200 \mathrm{Ma}$ reported for the Trans-Amazonian orogeny (Moreno and others, 1977; Gaudette and Olszewski, 1985), which is based on potassium-argon and whole-rock rubidium-strontium dates for an intrusion in the Imataca Complex and for rocks of the Cuchivero Group, is not compatible with the recent and more accurate uranium-lead and argon-argon dates for metamorphism and deformation of the Trans-Amazonian orogeny. As noted in the discussion on undivided Proterozoic rocks in Estado Amazonas, geologic mapping, geochemical sampling, and geochronologic dating are insufficient for a rigorous interpretation of the geology in this area.

\section{CUCHIVERO GROUP}

Early to Middle Proterozoic supracrustal rocks were emplaced in and deposited on the older greenstone-granite terrane in the southern, central, and western parts of the Venezuelan Guayana Shield (fig. 2). They include a thick pile (greater than $3 \mathrm{~km}$ thick) of mostly felsic to lesser intermediate and mafic volcanic, subvolcanic, and plutonic rocks and associated volcanogenic sedimentary rocks of the Cuchivero Group; sandstone and conglomerate and lesser siltstone, 
shale, chert, and interlayered felsic volcanic rocks (jasper) of the Roraima Group; continental tholeiitic dikes, sills, inclined sheets, and small irregular intrusive bodies of the Avanavero Suite; and rapakivi granite of the Parguaza Granite (Rios, 1972; Mendoza and others, 1975; Ghosh, 1985; Gibbs, 1986; Sidder and Martinez, 1990).

The Cuchivero Group includes the relatively older volcanic rocks of the Caicara Formation and the younger granites of Guaniamito, San Pedro, and Santa Rosalía (Rios, 1972; Mendoza and others, 1975). Mesozoic and (or) Cenozoic tilting of the shield and subsequent erosion have exposed the deeper level granitic rocks in the northem part of the Cuchivero terrane, whereas high-level volcanic rocks of the Caicara Formation predominate in the southern part. Broad, open folds are common, and structures such as faults and lineaments generally strike northwest to north-northwest and north-northeast. The El Viejo Formation, the volcanic suite of the Parucito Valley, and other relatively unmetamorphosed volcanic and plutonic rocks in Estado Amazonas, the Uatumã Supergroup (including the Surumu and Iricoumé Formations and the granodiorite of Serra do Mel) in northern Brazil, the Kuyuwini and Burro-burro Groups in Guyana, and the Dalbana Formation in Suriname all correlate with the Cuchivero Group (Mendoza and others, 1975; Montalvao, 1975; Talukdar and Colvee, 1975, 1977; Berrange, 1977; Mendoza and others, 1977; Tepedino, 1985; Gibbs, 1987; Sidder and Martinez, 1990; Machado and others, 1991; Gibbs and Barron, 1993; Dall'Agnol and others, 1994). Minor amounts of rocks equivalent to the Cuchivero Group are present in French Guiana and the West African craton (Cahen and others, 1984; Gibbs, 1987; Rocci and others, 1991).

\section{CAICARA FORMATION}

The Caicara Formation consists of subaerially deposited pyroclastic rocks including variably welded ash-flow and air-fall tuff and breccia and minor lava flows and domes and intercalated volcaniclastic rocks. The rocks are aphyric to porphyritic, and both crystal-rich and crystal- and lithic-rich varieties are present. Vitroclastic and eutaxitic textures including devitrified glass shards and collapsed pumice fragments are common (Rios, 1972; Mendoza, 1977b; Sidder and Martinez, 1990). The Caicara Formation is made up of rhyolite, subordinate rhyodacite and dacite, and minor proportions of andesite, basaltic andesite, and basalt. On a total alkali-silica diagram, some rocks of the Caicara Formation are classified as trachyte and trachydacite. Silicic rocks are mainly tuff, whereas andesitic and basaltic rocks are lava flows and dikes. These rocks are metaluminous to peraluminous, subalkalic to alkalic, and together form an apparent comagmatic calc-alkaline series (Talukdar and Colvée, 1975, 1977; Mendoza, 1977b; Sidder and Martinez, 1990). Felsic to intermediate volcanic and vol- caniclastic rocks near Ichún Tepuy (fig. 1) named the Ichún Formation are interpreted to be part of the Roraima Group (Briceño and others, 1989); however, these rocks are chemically and lithologically similar to rocks of the Caicara Formation to the north and south along the Río Paragua and have the same stratigraphic position. Moreover, the basal conglomerate and overlying sandstone of the Roraima Group near Ichún Tepuy conformably overlie the volcanic rocks (Sidder, unpublished data, 1988). A similar conformable contact has been mapped between rocks of the Caicara Formation and the overlying Roraima Group in Estado Amazonas (Stephen D. Olmore, U.S. Geological Survey, oral commun., 1990), and intercalations of volcanic tuff of the Surumu Formation are common near the base of the Roraima Group in Brazil within $80 \mathrm{~km}$ south of the Brazil-Venezuela-Guyana junction (Amaral and Halpern, 1975).

\section{GRANITE OF THE CUCHIVERO GROUP}

Granite associated spatially and temporally with the volcanic rocks of the Caicara Formation includes the granites of San Pedro, Santa Rosalía (including the granite of Las Trincheras), and Guaniamito. These granitic bodies comprise hypabyssal biotite granite, quartz monzonite, and granodiorite (Rios, 1972; Mendoza, 1974; Tepedino, 1985) and are in intrusive and fault contact with the volcanic rocks. The rocks are generally equigranular to porphyritic and medium to coarse grained. The granite of San Pedro is dominantly a fine-grained leucocratic granite that has been interpreted as a marginal border phase of the coarser grained biotite granite of Santa Rosalía (Mendoza, 1974). The granite of Guaniamito is a porphyritic, medium to coarsely crystalline, biotite \pm hornblende granite. All of these granites are generally massive in texture but locally are foliated, especially near the intrusive contact of granite with the volcanic rocks of the Caicara Formation (Rios, 1972). Primary minerals include potassium feldspar (orthoclase and microcline, 20-60 modal percent), quartz (10-40 percent), plagioclase (albite-oligoclase, $5-40$ percent), biotite $(<1-10$ percent), and accessory sphene, apatite, zircon, muscovite, homblende, allanite, and iron-titanium-oxide minerals (magnetite and lesser ilmenite). Secondary alteration minerals are epidote, clinozoisite, and white mica in plagioclase and potassium feldspar, chlorite after biotite, and hematite after magnetite. Aplite dikes and barren quartz veins commonly cut the granitic bodies (Rios, 1972; Mendoza, 1974; Tepedino, 1985; Sidder, unpublished data, 1988). Hypabyssal biotite granite and leucogranite in Suriname that are associated with and intrude rhyolitic volcanic rocks of the Dalbana Formation (De Roever and Bosma, 1975; Bosma and others, 1983) are considered to be comagmatic equivalents of the volcanic rocks (Mendoza, 1977b; Bosma and others, 1983). 
Granitic and volcanic rocks of the Cuchivero Group and their equivalents throughout the Guayana Shield are generally unmetamorphosed. Reports of lower greenschist facies metamorphism apparently refer to local contact metamorphic aureoles in volcanic and volcaniclastic rocks close to intrusions. For example, field and petrographic evidence of metamorphism is not present in samples of volcanic rocks from the upper Río Caura or Río Paragua areas (Sidder, unpublished data, 1990; Sidder and Martinez, 1990). Indeed, as noted previously, vitroclastic and eutaxitic textures are abundant. Minor alteration in the volcanic and granitic rocks, such as partial replacement of feldspar by fine-grained sericite and epidote, chlorite alteration of biotite, and thin veinlets of quartz or epidote+chlorite, is indicative of deuteric and local hydrothermal alteration. Rios (1972) recognized that the volcanic rocks of the Caicara Formation are thermally metamorphosed in restricted zones close to intrusions. It is significant to note that Rios called primary flow bands developed during the extrusion and emplacement of the volcanic rocks "foliación," or foliation. He did not recognize any effects of regional metamorphism. Other authors have, however, referred to the Caicara Formation as a sequence of metavolcanic rocks (Tepedino, 1985), and still others have called the rocks metavolcanic but have noted that the rocks have undergone contact metamorphism ("thermal-regional" or "plutono-metamorphism") only due to intrusion of the granitic batholith of the Cuchivero Group (Mendoza, 1977b). Similarly, Bosma and others (1983) referred to rhyolitic rocks of the Dalbana Formation in Suriname as metavolcanic but noted (p. 247) that "Distinctly recrystallized metavolcanics*** form broad marginal zones along the granites***The recrystallization, without significant foliation or folding, is spatially related to granite intrusions and probably took place at shallow depth under homblende-hornfels facies conditions." Thus, the volcanic rocks of the Caicara Formation and granitic rocks of the Cuchivero Group and similar rocks throughout the Guayana Shield are not regionally metamorphosed, but they are contact metamorphosed or hydrothermally altered in proximity to intrusions, faults, dikes, and veins (De Roever and Bosma, 1975; Sidder and Martinez, 1990).

\section{AGE AND ORIGIN}

Whole-rock rubidium-strontium dates for rocks of the Cuchivero Group and its equivalents throughout the Guayana Shield range from 1,930 to $1,640 \mathrm{Ma}$, and the majority are between 1,930 and 1,790 Ma (table 2) (Hurley and others, 1977; Moreno and others, 1977; Bosma and others, 1983; Schobbenhaus and others, 1984; Teixeira and others, 1989; Machado and others, 1991). Initial ${ }^{87} \mathrm{Sr} /{ }^{86} \mathrm{Sr}$ ratios range from 0.698 for the granites of Guaniamito, San Pedro, and Santa Rosalía to 0.721 for volcanic rocks of the Sunumu Formation in Brazil (table 2). The former initial ratio is not geologically reasonable because basaltic achondrite meteorites have an initial ratio of 0.69897 (Faure, 1986). The latter ratio is extremely high due to scatter of the data; the mean squares weighted deviation (MSWD) is 60.9 , and the 1 -sigma error in the calculated initial ratio is 0.017 . Most of the initial ratios for rocks of the Cuchivero Group and its equivalents are between about 0.705 and 0.707 , values between initial ratios inferred for Proterozoic crust $(>0.708)$ and mantle-derived magmas (<0.7045) (Priem, 1987; Riciputi and others, 1990), and are a further indication of some contribution of continental crust in the generation of the magmas. Those initial ratios as high as 0.712 may reflect melts derived directly from crustal material.

Rocks of the Cuchivero Group and their equivalents have been considered both as orogenic, related to the Trans-Amazonian collision and deformation, and as anorogenic (De Vletter and Kroonenberg, 1984). Supporters of the orogenic interpretation suggest that the contact between the felsic volcanic rocks and rocks of the underlying greenstone belt is conformable, and therefore they include the Cuchivero Group and its equivalents as a second, dominantly magmatic, stage of the Trans-Amazonian orogeny between about 2,000 and 1,870 Ma (Bosma and others, 1983; De Vletter and Kroonenberg, 1984; Teixeira and others, 1984). As noted above, however, characteristics of deformation and metamorphism in the Cuchivero Group are significantly different from those in rocks of the greenstone belts, and therefore a conformable contact is extremely unlikely. Those who suggest that the predominantly felsic igneous rocks of the Cuchivero Group and its equivalents are anorogenic have noted that the contact with rocks of the greenstone belts is a profound angular unconformity and that crustal extension, as evidenced by widespread intrusion of mafic dikes and sills of the Avanavero Suite, was penecontemporaneous with deposition of the volcanic rocks (Montalvao, 1975; Gibbs, 1980, 1986; Gibbs and Olszewski, 1982). As discussed following, however, the Avanavero Suite (about 1,650 Ma) is younger than the Cuchivero Group, and these units are not coeval.

The volcanic and plutonic rocks of the Cuchivero Group are referred to here as postcollisional, post-Trans-Amazonian because they do not have a clear association with any orogenic belt, they are not regionally metamorphosed, and they are weakly deformed and lack a pervasive penetrative fabric. Any deformation that they underwent may be attributed to younger post-Trans-Amazonian events, and low-grade contact metamorphism in the volcanic rocks is related to granitic intrusions. Granites formed in postcollisional tectonic settings commonly postdate the collisional event by about 25-75 m.y. (Sylvester, 1989), which is the approximate amount of time between termination of uplift of the Imataca Complex (collision with rocks of the greenstone belts) and magmatism in the Cuchivero Group. Limited geochemical data suggest that the tectonic environment of the granite of Santa Rosalía and the volcanic rocks of the Caicara Formation is transitional; the 
Table 2. Rubidium-strontium whole-rock isochron dates for volcanic and plutonic rocks of the Cuchivero Group and its equivalents, Guayana Shield.

[Number of samples on which age is based is given in parentheses after age. MSWD is mean squares weighted deviation]

\begin{tabular}{llcccc}
\hline Country & \multicolumn{1}{c}{ Unit } & Age $(\mathrm{Ma})$ & $\left(^{87} \mathrm{St} f^{86} \mathrm{Sr}\right)_{0}$ & MSWD & Reference \\
\hline Venezuela & Caicara Formation & $1,700 \pm 220(n=3)$ & 0.709 & 1.72 & Gaudette and others (1978). \\
Venezuela & Granites of Santa Rosalía and San Pedro & $1,880 \pm 88(n=7)$ & 0.698 & 24.3 & Gaudette and others (1978). \\
Guyana & Kuyuwini Group & $1,800 \pm 420(n=4)$ & 0.705 & 20.9 & Berrange (1977). \\
Suriname & Felsic volcanic rocks (Dalbana Formation) & $1,930 \pm 48(n=18)$ & 0.705 & 2.25 & Priem and others (1971). \\
Suriname & Granitoid rocks & $1,850 \pm 40(n=14)$ & 0.707 & 2.58 & Priem and others (1971). \\
Suriname & Granitic and volcanic rocks together & $1,880 \pm 31(n=32)$ & 0.706 & 2.64 & Priem and others (1971). \\
Brazil & Surumu Formation & $1,800 \pm 94(n=6)$ & 0.721 & 60.9 & Basei and Teixeira (1975). \\
Brazil & Surumu Formation & $1,640 \pm 55(n=6)$ & 0.714 & 18.2 & Amaral and Halpern (1975). \\
Brazil & Surumu Formation & $1,820 \pm 55(n=10)$ & 0.712 & 45.7 & Basei and Teixeira (1975). \\
Brazil & Granite of Serra do Mel & $1,790 \pm 62(n=4)$ & 0.706 & 4.63 & Basei and Teixeira (1975). \\
\hline
\end{tabular}

'As reported by Priem and others(1971).

${ }^{2}$ Includes four samples analyzed by Amaral and Halperm (1975) as reported by Basei and Teixeira (1975).

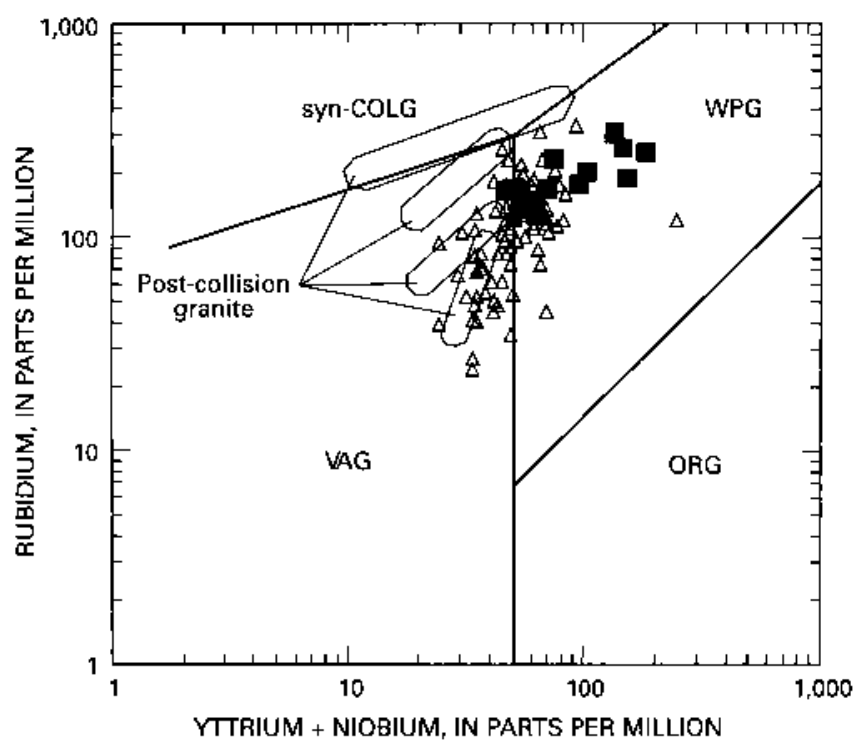

Figure 3. Rubidium versus yttrium+niobium for granite and volcanic rocks of the Early Proterozoic Cuchivero Group of the Guayana Shield. Fields of postcollision granite from Pearce and others (1984); solid squares, granite; open triangles, volcanic rocks; VAG, volcanic-arc granite; ORG, ocean-ridge granite; WPG, within-plate granite; syn-COLG, syncollision granite. Data from Sidder and Martinez (1990) and Sidder (unpublished data, 1990).

granitic and volcanic rocks plot between within-plate (anorogenic) granite and volcanic-arc granite on several discriminant diagrams and approximately in the field of postcollision granite on the rubidium versus yttrium+ niobium diagram (fig. 3) (Pearce and others, 1984; Sylvester, 1989; Sidder, unpublished data, 1990). The variously indicated tectonic settings may result from transitional mantle and crustal sources; postcollision, within-plate crustal magmatism may have been followed by renewed subduction and mantle-derived continental arc magmatism. Post-Eburnean granitoid rocks in the West African craton are posttectonic or anorogenic rocks that were intruded at shallow levels and plot in the field of within-plate granite (Rocci and others, 1991).

\section{MINERAL RESOURCES}

Major mineral deposits have not yet been discovered in the Cuchivero Group. Quartz veins containing silver and gold are present locally in volcanic rocks of the Caicara Formation, and isolated areas of rhyolite contain trace amounts of disseminated cassiterite (Sidder and Martinez, 1990; Sidder, Brooks, and others, 1991; Sidder, this volume). Although epithermal and bonanza-type precious-metal vein deposits are uncommon in Precambrian rocks (Hutchinson, 1987), the felsic to intermediate composition and pyroclastic character of the volcanic rocks of the Cuchivero Group, as well as geochemical anomalies of silver, bismuth, and molybdenum in some quartz-sulfide veins and gold in panned concentrates, are suggestive of epithermal precious-metal deposits (Sidder and Martinez, 1990; Sidder, Brooks, and others, 1991). Mineralized epithermal systems in volcanic rocks of the Cuchivero Group may have been preserved by burial shortly after deposition by sedimentary rocks of the Roraima Group, as exhibited by locally conformable contacts.

Field and geochemical evidence indicates that shallow porphyritic granitic intrusive rocks in volcanic rocks of the Caicara Formation in western Estado Bolívar and Estado Amazonas and possibly equivalent rocks in Brazil have moderate potential for associated porphyry molybdenum-type deposits. Molybdenite is relatively common in contact zones between felsic volcanic rocks of the Caicara Formation and biotite granite of the Cuchivero Group in Venezuela (Mendoza and others, 1977). In northern Brazil, molybdenite is disseminated in biotite granite and in small quartz veins at the faulted contact between granite and volcanic rocks of the Surumu Formation (Montalvao and 
others, 1975; Berrange, 1977; Schobbenhaus and others, 1984).

Cassiterite and wood tin are sparsely disseminated in some samples of high-silica rhyolite in the Caicara Formation and its equivalent rocks of the Iricoume Formation in Brazil (Jones and others, 1986; Sidder, this volume). Cassiterite is also present in panned concentrates such as those from creeks that drain into the upper Río Paragua near the Brazil-Venezuela border (Sidder, this volume, pl. 1). These occurrences of cassiterite disseminated in rhyolite and in panned concentrates are typical of rhyolite-hosted tin deposits (Duffield and others, 1990); however, occurrences of economic significance are not yet known. In Brazil, granitic rocks, such as alaskite, granite, granodiorite, and quartz diorite, of the Uatumã Supergroup that are associated with volcanic rocks equivalent to the Caicara Formation host stockwork veins and disseminations of cassiterite (Damasceno, 1988). The granitic rocks are commonly greisenized to an assemblage of muscovite, fluorite, topaz, and tourmaline (Damasceno, 1988).

The carbonatite at Cerro Impacto (within the Cuchivero terrane) (Sidder, this volume, pl. 1) near the intersection of large northeast- and northwest-striking fractures is enriched in niobium, thorium, barium, cerium, and other metals and rare earth elements (Aarden and others, 1978; Premoli and Kroonenberg, 1981). The northwest-striking fractures may be coextensive with those along which kimberlite was emplaced in the Quebrada Grande area, and they are parallel with large regional fractures that apparently controlled emplacement of pegmatitic dikes into the Parguaza Granite. These fractures extend throughout the western part of the Guayana Shield in Estado Bolívar, Estado Amazonas, and into Brazil. Mendoza and others (1977) suggested that the carbonatitic complex intruded plutonic rocks of the Cuchivero Group during the Mesozoic between 150 and $80 \mathrm{Ma}$; however, a rubidium-strontium whole-rock isochron date of about $1,732 \pm 82$ Ma for leached kimberlitic rocks in the Quebrada Grande area (Nixon and others, 1992) indicates that the carbonatite at Cerro Impacto may be much older than Mesozoic. The carbonatite at Cerro Impacto may be Early Proterozoic, or about the same age as kimberlite in the Quebrada Grande area. The date for kimberlite in the Quebrada Grande area is similar to carbonatite emplaced elsewhere in the world between about 1,800 and 1,650 Ma (Meyer, 1988). Additional work is required to date more precisely the age of intrusion of both carbonatite and kimberlite in the Guayana Shield.

The similarity in age, composition, and tectonic environment between the Early Proterozoic Cuchivero Group in Venezuela and the granite-rhyolite terranes of the St. Francois Mountains and the Olympic Dam area suggests that Olympic Dam-type deposits are a possible exploration target in the Venezuelan Guayana Shield (Sidder, this volume). Olympic Dam-type iron-copper-uranium-gold-rare earth element magmatic-hydrothermal deposits are genetically related to magmas, especially those of intermediate to mafic composition, that formed the host granite-rhyolite terrane (Sidder and Day, 1993; Sidder and others, 1993).

\section{UNDIVIDED PROTEROZOIC ROCKS}

Many Proterozoic and possibly Archean rocks in Estado Amazonas either have not been studied or have been examined only in reconnaissance fashion and thus are herein included as an undivided group of rocks (fig. 2). These rocks are predominantly granitic and associated volcanic rocks, mafic and alkaline intrusive rocks, and medium- to high-grade gneiss of both igneous and sedimentary protoliths (Mendoza and others, 1977; Gaudette and Olszewski, 1985; Cox, Wynn, and others, 1993). Cordani and Brito Neves (1982) and Goodwin (1991) referred to the granite and high-grade gneiss terrane as basement rocks of the Pakaraima nucleus and considered this nucleus to be an Archean crustal remnant. Mendoza and others (1977) and Gaudette and Olszewski (1985) informally named some of these rocks after the area where they were mapped, such as the Minicia gneiss or migmatite, the Macabana augen gneiss, the granites of Atabapo, San Carlos, Sipapo, and so on. Barrios and others (1985) grouped these locally named units into two provinces, the Ventuari and Casiquiare dominions (fig. 2), on the basis of similar structural, petrologic, and geochronologic characteristics. The Ventuari dominion, primarily north and east of the Río Orinoco in Estado Amazonas, consists of volcanic and plutonic rocks similar to the Cuchivero Group, the Parguaza Granite, sedimentary rocks of the Roraima Group, isolated metasedimentary sequences, and massive alkaline and mafic intrusions. Topographic relief in the Ventuari dominion is high, and elevations are as much as $2,000 \mathrm{~m}$ above sea level on the tops of some vertically cliffed plateaus or table mountains, which are called tepuis. The Casiquiare dominion, generally south of the Río Orinoco in Estado Amazonas (fig. 2), includes granite, gneiss, migmatite, and scarce outcrops of the Roraima Group; volcanic rocks and alkaline or mafic intrusive bodies are not present. Elevations rarely are more than $500 \mathrm{~m}$ above sea level in this dominion (Barrios and others, 1985). Similar granitic and metamorphic rocks in southeastern Colombia near the Colombia-Venezuela border were named "Complejo migmatítico de Mitú" (Mitú migmatitic complex) (Priem and others, 1982). Notably, all of these authors commented on the complexity of the relations between the rocks, the poor exposures in the jungle, and the intense weathering of the rocks. Most of the mapped and sampled outcrops form discontinuous and isolated exposures along rivers.

The undivided Proterozoic and possibly Archean intrusive rocks in Estado Amazonas range in composition from biotite granite to tonalite and diorite. They are generally medium to coarse grained, equigranular to porphyritic, and 
weakly foliated. The plutonic rocks have been moderately deformed by small-scale faults and shears, and cataclastic textures are common. Aplite dikes of more than one intrusive episode cut the plutonic rocks (Mendoza and others, 1977; Priem and others, 1982; Gaudette and Olszewski, 1985). Granitic rocks of the Ventuari dominion, such as the granite of Padamo and unnamed plutonic rocks along the Ríos Orinoco, Ventuari, and Paru, are similar to the granite of Santa Rosalía. Associated volcanic rocks of the El Viejo Formation, the volcanic suite of the Parucito Valley, and similar locally named units such as the felsic to intermediate volcanic rocks of Yaví, Asita, Autana, and others in the Ventuari dominion are probably equivalent to the Caicara Formation or to volcanic rocks associated with the Parguaza Granite (Talukdar and Colvée, 1975, 1977; Mendoza and others, 1977; Gaudette and Olszewski, 1985). Some granitic rocks in the Casiquiare dominion are similar to the Parguaza Granite (Barrios and others, 1985; Gaudette and Olszewski, 1985).

The undivided Proterozoic metamorphic rocks range from poorly foliated and mildly tectonized gneiss to well-foliated gneiss and migmatite having cataclastic texture. Phyllite and quartzite are weakly metamorphosed sedimentary rocks. Granitic gneiss, or metamorphosed plutonic rocks, ranges in composition from granite to granodiorite, tonalite, and diorite. The intensity of metamorphism is as high as the greenschist and amphibolite facies with assemblages of chlorite \pm muscovite \pm epidote \pm chloritoid and plagioclase-homblende \pm gamet, respectively (Mendoza and others, 1977; Gaudette and Olszewski, 1985).

Geochronological data indicate that peak metamorphism and magmatism of the undivided Proterozoic and possibly Archean rocks in Estado Amazonas occurred between about 1,860 and 1,730 Ma. Gaudette and Olszewski (1985) correlated this metamorphic and magmatic activity with the Trans-Amazonian orogeny, but it is probably part of a younger unnamed event, as discussed previously. Low initial ${ }^{87} \mathrm{Sr} /{ }^{86} \mathrm{Sr}$ ratios of about 0.703 for paragneiss imply that the protolith of the metasedimentary rocks was not considerably older. Strongly deformed and metamorphosed plutonic rocks of about $1,860 \mathrm{Ma}$, in addition to moderately to weakly deformed plutonic rocks of about $1,730 \mathrm{Ma},{ }^{5}$ indicate that plutonism and metamorphism may have been synchronous from about 1,860 to $1,730 \mathrm{Ma}$. Unmetamorphosed, undeformed granitic rocks of about 1,600 Ma represent postorogenic plutonic activity in Estado Amazonas, and the Parguaza rapakivi granite (fig. 2) typifies magmatic activity at about 1,545 Ma. In general, dates for granitic rocks in the

\footnotetext{
${ }^{5}$ This date is recalculated from the original published data. The same decay constant, atomic ratios, and experimental errors were used. The results determined here are $1,730 \pm 71 \mathrm{Ma}$, initial ratio $=0.705$, and MSWD=73.3; however, the data in the publication (Gaudette and Olszews$\mathrm{ki}$, 1985) were reported as $1,793 \pm 79 \mathrm{Ma}$, initial ratio $=0.704$, and MSWD $=18.4$.
}

Ventuari dominion are older than for those for rocks to the southwest in the Casiquiare dominion (Barrios and others, 1985; Gaudette and Olszewski, 1985; Gibbs and Wirth, 1986).

Geochronological data from the Amazon Territory of Brazil and the Amazonas region of southeastern Colombia demonstrate ages of metarrorphic and magmatic activity similar to those for the Casiquiare dominion of Estado Amazonas of Venezuela. Tassinari (1984) utilized whole-rock rubidium-strontium and lead-lead dating methods to date granitic to granodioritic gneiss and migmatite of the Río Negro-Juruena province that truncates the MaroniItacaiunas belt (and the Ventuari dominion) in Estado Amazonas and southeastem Colombia (Cordani and Brito Neves, 1982; Teixeira and others, 1989). He determined that a magmatic arc and new continental crust formed in this province between about 1,750 and 1,600 Ma from magma generated in the upper mantle (initial ${ }^{87} \mathrm{Sr} /{ }^{86} \mathrm{Sr}$ ratio 0.7030 ).

Priem and others (1982) used whole-rock rubidium-strontium and uranium-lead zircon data to conclude that the granite gneiss basement of the Amazonas region of southeasten Colombia has a minimum age of about 1,850 Ma. A maximum age of about 1,450 Ma was established for the high-grade metamorphism and resetting of the isotopic systems. The Complejo migmatítico de Mitú formed about 1,560-1,450 Ma by large-scale granitic plutonism during the Parguaza episode and metamorphic reconstitution of rocks having a minimum age of about 1,850 Ma (Priem and others, 1982).

Based on the previously discussed radiometric data, Gaudette and Olszewski (1985) suggested that a tectonic zone or boundary is present along the Río Orinoco south of about lat $4^{\circ} 00^{\prime} \mathrm{N}$. This zone marks the contact between the Ventuari and Casiquiare dominions and the MaroniItacaiunas and the Río Negro-Juruena mobile belts (Barrios and others, 1985; Teixeira and others, 1989). The evolution of a northeast-facing subduction zone between about 1,900 and 1,450 Ma and a change from compressional horizontal tectonics to tensional vertical tectonics at the end of subduction may account for the geologic relations in the undivided Proterozoic rocks of the Amazon region of Venezuela, Colombia, and Brazil (Priem and others, 1982; Barrios and others, 1985; Gaudette and Olszewski, 1985).

\section{RORAIMA GROUP}

The Roraima Group is a generally flat lying (dipping less than $20^{\circ}$ ) suite of sedimentary rocks deposited in fluvial, deltaic, shallow-marine, and lacustrine or epicontinental environments. It originally covered an area of at least $250,000 \mathrm{~km}^{2}$, possibly as much as $1,200,000 \mathrm{~km}^{2}$, that extended about $1,500 \mathrm{~km}$ east to west from Suriname to Brazil and Estado Amazonas of Venezuela; rocks equivalent to the Roraima Group are apparently not present in French 
Guiana and the West African craton (Gansser, 1954; Ghosh, 1985; Cahen and others, 1984; Gibbs and Barron, 1993). The original northern extent of rocks of the Roraima Group is not known. The north-facing frontal scarp of the Roraima Group is apparently erosional, although some structural control is possible. Quartzarenite is the predominant rock type; feldspathic arenite, conglomerate, quartzite, arkose, argillaceous siltstone, shale, jasper, and chert are also present. This suite of rocks is generally $700-1,000 \mathrm{~m}$ thick and in some areas is more than 3,000 $\mathrm{m}$ thick (Ghosh, 1985; Dohrenwend and others, this volume). The basal contact is not exposed in all places; however, the Roraima Group has been reported to overlie unconformably the Early Proterozoic greenstonegranite terrane, the Caicara Formation, the Parguaza Granite, and undivided Proterozoic rocks in Estado Amazonas (De Loczy, 1973; Ghosh, 1985; Gibbs and Barron, 1993). As noted previously, rocks of the Roraima Group locally lie conformably on volcanic rocks of the Caicara Formation. Rocks that overlie the Roraima Group are not common. Fluvial sedimentary rocks about $30 \mathrm{~m}$ thick, possibly Miocene to Pliocene in age, overlie the Roraima Group in parts of Guyana and Brazil (De Loczy, 1973); however, Late Proterozoic or Phanerozoic sedimentary rocks are not known to overlie the Roraima Group in Venezuela (Ghosh, 1985; George, 1989).

Rocks of the Roraima Group in Venezuela form startling, vertically cliffed tepuis that rise $1,000 \mathrm{~m}$ or more above the surrounding jungle. The tops of the tepuis are commonly saucer shaped and dip about $20^{\circ}-45^{\circ}$ toward the center of the tepuis (Gansser, 1974; Ghosh, 1985). This topography has been attributed to (1) inverted topography in which the tepuis are on the axes of synclines, (2) isostatic depression, (3) buckling related to vertical basement tectonics, and (4) faults along the hinge zones between the marginal rims and the central plateaus that formed central graben and marginal horst blocks (Gansser, 1974; Ghosh, 1985). Briceño and others (1990) concluded that the tepuis resulted from topographic inversion and are remnants of doubly plunging synclines, the low, eroded areas around the tepuis corresponding to the dismantled anticlines. Karst features such as large caves, shafts, underground streams, karren, and dolines are locally developed on the tops of some tepuis (Szczerban and Urbani, 1974), and several species of plants are native only to the tops of individual tepuis (George, 1989).

Structural features in the Roraima Group generally are broad, open folds and block faults that strike northeast and north-northeast to north-northwest throughout Venezuela and the Guayana Shield (Gansser, 1954; Ghosh, 1985; Briceño and others, 1990). Numerous joint sets cut the Roraima Group; however, joint trends measured in outcrop do not coincide with those measured from aerial photographs or side-looking airborne radar (SLAR) images (Sidder, 1988, unpublished data; Briceño and others, 1990). Dohrenwend and others (this volume) recognized a deformational gradient from south to north in the Gran Sabana area of southeastern Venezuela: relatively tight folds and conspicuous axial planar foliation are present in the lower part of the Roraima Group in the south, and relatively undisturbed, gently dipping to horizontal, unfoliated strata are present in the north. The axial planar foliation imposes a conspicuous ridge and valley topography in the south, whereas in the north less deformed and undeformed rocks underlie the high plateaus (Dohrenwend and others, this volume).

Rocks of the Roraima Group generally are unmetamorphosed; most samples do not show any textural or mineralogical evidence of metamorphism (Ghosh, 1985). Pyrophyllite and andalusite in some rocks are interpreted as metamorphic minerals that formed from very low grade burial metamorphism (Urbani, 1977; Briceño and others, 1990); however, these minerals are also in localized contact metamorphic aureoles around diabasic and gabbroic intrusions of the Avanavero Suite or of the Mesozoic dike swarms (Gansser, 1974; Urbani, 1977; Ghosh, 1985; Gibbs, 1986). Rocks interpreted, on the basis of the presence of pyrophyllite or andalusite, to have been affected by burial metamorphism may in fact have been metamorphosed by an unexposed intrusion. Alternatively, an unknown thickness of rocks, but presumably at least $3 \mathrm{~km}$ or more to cause burial metamorphism, may have been completely eroded from the top of the Roraima Group. The matrix of some rocks has been recrystallized to interstitial quartz, fine-grained white mica, and hematite (Gibbs and Barron, 1993).

Reid (1974a) divided the Roraima Group in the Gran Sabana area of Venezuela into four formations, in ascending order, the Uairén, Kukenán, Uaimapué, and Matuaí Formations. Elsewhere in the Guayana Shield, the Roraima Group has been subdivided into lower (generally equivalent to the Uairén Formation), middle (the Kukenán and Uaimapué Formations), and upper (Matuaí Formation) members (Gansser, 1954; Buteson, 1966; Priem and others, 1973; Ghosh, 1985; Gibbs and Barron, 1993). The stratigraphy of the Roraima Group is complex, although it may appear simple in some areas. Units are not continuous - rather they appear to grade both daterally and vertically - and few marker beds have been established for regional correlation in the shield. For example, conglomerate, arkose, and jasperoid tuffaceous rocks, which are distinctive in the Gran Sabana area of Venezuela, Brazil, and Guyana, are not present in tepuis in Estado Amazonas (Ghosh, 1985). Moreover, the stratigraphic sequences in several tepuis of Estado Amazonas do not correlate with each other. The rocks in Estado Amazonas are included in the Roraima Group because of their abundant thick sequences of crossbedded, fine- to medium-grained quartzarenite and feldspathic arenite and lesser interbedded layers of shale. Possibly these rocks are time transgressive with those of the Roraima Group in the Gran Sabana area (Ghosh, 1985).

Alberdi and Contreras (this volume) describe a 128-m-thick sequence of graywacke, siltstone, and shale that underlies the basal sandstone and conglomerate of the 
Uairén Formation north of the Gran Sabana area. They suggest that these rocks be included in the Roraima Group as the Urico Formation. In northern Brazil and Guyana, the Urico Formation is apparently correlative with the Wailan Formation, which is composed of silty to sandy shate and argillaceous sandstone and is transgressed by conglomerate of the Roraima Group (Gansser, 1954); however, Gansser (1954) considered the Wailan Formation to be equivalent to the Haimarakka Formation, which is correlative with the Caicara Formation rather than with part of the Roraima Group.

The Uairén Formation consists of about $800-900 \mathrm{~m}$ of quartzitic sandstone, conglomerate, and minor shaly siltstone. Thin lenses and beds (from less than $50 \mathrm{~cm}$ to about $10 \mathrm{~m}$ in thickness) of quartz-pebble and polymict conglomerate and thin beds and laminae of shaly siltstone are intercalated with the sandstone (Reid, 1974a; Reid and Bisque, 1975). Dohrenwend and others (this volume) subdivide the Uairén Formation into a lower member about $600 \mathrm{~m}$ thick and an upper member about $100-300 \mathrm{~m}$ thick. The former consists of well-sorted, coarse- to medium-grained quartz sandstone that is cross-stratified with trough and festoon crossbeds and is intercalated with conglomerate and shaly siltstone; the latter includes medium-grained sandstone that contains abundant trough cross-stratification and intercalated channel gravels (Reid, 1974a; Reid and Bisque, 1975; Dohrenwend and others, this volume). The lower member is moderately bedded to massive and underlies high cliffs and extensive dip slopes of several cuestas along the southern margin of the Gran Sabana. The upper member forms conspicuously benched scarp slopes and irregular ridges (Dohrenwend and others, this volume).

The Kukenán (also spelled Cuquenán) Formation is composed of sandstone interbedded with siltstone, claystone, and shale. The sandstone is well bedded to massive and fine to medium grained, and the siltstone, claystone, and shale are medium to thin bedded, laminated, and variegated. The formation has a maximum thickness of about $100 \mathrm{~m}$ in the Gran Sabana area (Reid, 1974a; Reid and Bisque, 1975; Dohrenwend and others, this volume).

The lower part of the Uaimapué Formation is similar to the Uairén Formation in that it consists of sandstone and conglomerate and interbedded siltstone and mudstone; however, abundant beds of jasper, chert, and arkose characterize the upper part of the formation (Gansser, 1954; Reid, 1974a; Reid and Bisque, 1975; Dohrenwend and others, this volume). The total thickness of the Uaimapue Formation in the Gran Sabana area is about $250 \mathrm{~m}$. Sandstone in the lower part of the formation is fine to coarse grained and pervasively channelled with trough cross-stratification. Clasts in the conglomerate are predominantly quartz pebbles. Red arkose, green and red jasper, and green, red, and gray chert are interbedded in the upper part of the formation (Reid, 1974a; Reid and Bisque, 1975). The arkose contains pyroclastic material, and the jasper contains distinct shards of devitrified volcanic glass (Gansser, 1974; Reid, 1976; Ascanio and others, 1985).
The jasper beds, which are about $20 \mathrm{~cm}$ thick and are interbedded with siltstone and sandstone forming sequences about $10 \mathrm{~m}$ thick, are interpreted as volcaniclastic tuff (Ascanio and others, 1985); they are marker beds for correlation throughout the Guayana Shield and have been radiometrically dated.

The Mataui Formation, the youngest unit of the Roraima Group, forms the vertical cliffs of some tepuis and is dominantly crossbedded, ripple-marked, and massive quartz sandstone and quartzite (Reid, 1974a; Reid and Bisque, 1975). Sandstone in the uppermost part of the formation, as on the tops of the tepuis, is less well cemented, friable, and thinner bedded and contains sandy shale horizons. The total thickness of the unit is $1,000 \mathrm{~m}$ or more (Gansser, 1954; Reid, 1974a; Reid and Bisque, 1975).

The Roraima Group in Estado Amazonas, which is best observed in tepuis, includes quartzarenite, feldspathic arenite, and shale and generally is made up of three members; however, the stratigraphic sequence cannot be correlated from one tepui to another (Ghosh, 1977, 1985). The lower member, about $300-500 \mathrm{~m}$ thick, consists of thinly graded beds of fine- to coarse-grained, cross-stratified, ripple-marked, laminated quartzarenite, minor quartz wacke, and thin conglomeratic beds (Ghosh, 1977, 1985; Mendoza and others, 1977). The middle member, about $100-200 \mathrm{~m}$ thick, includes medium-grained, crossbedded quartzarenite, feldspathic arenite, and argillaceous quartzarenite. Dark-gray to black shale units as thick as $50 \mathrm{~m}$ are typical of the middle member. The upper member, which forms prominent cliffs, is composed of $500-700 \mathrm{~m}$ of medium- to coarse-grained quartzarenite and lesser feldspathic arenite and lenticular clay beds that have thin carbonate-rich laminations (Ghosh, 1977, 1985; Mendoza and others, 1977). Major units of conglomerate, arkose, or jasper have not been observed in Estado Amazonas (Ghosh, 1977, 1985).

\section{ENVIRONMENT OF DEPOSITION AND AGE}

Rocks of the Roraima Group were deposited in fluvial, deltaic, shallow coastal marine, and lacustrine or epicontinental environments such as low-sinuosity river channels and their floodplains, delta distributaries above tranquil interdeltaic lakes, coastal lagoons to interdeltaic bays, nonbarred beaches, and intertidal mud flats (Ghosh, 1985; Briceño and Schubert, 1990). The lateral and vertical distribution of the lithologic units depicts an alluvial-deltaic complex near a wave-dominated, high-energy coastline that had abundant beaches, sandy flats, and subtidal bars and less common mudflats and coastal lagoons (Ghosh, 1985). Cross-stratification, ripple marks, and pebble orientation indicate that the sediments were transported from a source to the northeast, east, and southeast (Gansser, 1954; Keats, 1974; Reid and Bisque, 1975; Ghosh, 1985; Gibbs and Bar- 
Table 3. Rubidium-strontium whole-rock isochron dates for volcanic rocks of the Roraima Group, Guayana Shield. [Number of samples on which age is based is given in parentheses after age. MSWD is mean squares weighted deviation]

\begin{tabular}{llcccc}
\hline Country & \multicolumn{1}{c}{ Unit } & Age (Ma) & $\left.{ }^{87} \mathrm{Sr}^{86}{ }^{86}\right)_{\psi}$ & MSWD & Reference \\
\hline Venezuela & Canaima & $1,730 \pm 120(n=8)^{1}$ & 0.708 & 11.2 & Gaudette and Olszewski (1985). \\
Venezuela & Santa Elena de Uairén & $1,570 \pm 83(n=16)^{2}$ & 0.721 & 79.8 & Pringle and Teggin (1985). \\
Suriname & Tafelberg & $1,660 \pm 27(n=14)$ & 0.708 & 1.84 & Priem and others (1973). \\
\hline
\end{tabular}

${ }^{1}$ These dates are recalculated from the original published data. The same decay constant, atomic ratios, and experimental erors were used; however, the data in the publication were reported as $1,747 \pm 49 \mathrm{Ma}$, initial ratio=0.708, MSWD $=2.84$.

${ }^{2}$ These dates are recalculated from the original published data. The same decay constant, atomic ratios, and experimental errors were used; however, the data in the publication were reported as $1,579 \pm 18 \mathrm{Ma}$, initial ratio $=0.720, \mathrm{MSWD}=19.95$.

Table 4. Rubidium-strontium whole-rock isochron dates for diabase of the Avanavero Suite and homfels formed from its intrusion into the Roraima Group, Guayana Shield.

[Number of samples on which age is based is given in parentheses after age. MSWD is mean squares weighted deviation. N.A. indicates not available]

\begin{tabular}{llllll}
\hline Country & \multicolumn{1}{c}{ Unit } & Age (Ma) & $\left.{ }^{87} \mathrm{Sr}^{\beta 6} \mathrm{Sr}\right)_{\circ}$ & MSWD & Reference \\
\hline Suriname & Dolerite of Avanavero Suite & $1,670 \pm 18(n=22)$ & 0.704 & 4.24 & Hebeda and others (1973). \\
Guyana & Dolerite of Roraima intrusive suite & $1,640 \pm 58(n=8)$ & 0.704 & 11.9 & McDougall and others (1963). \\
Brazil & Hornfelsed sandstone of the Roraima Group next to a diabase dike & $1,990 \pm 170(n=3)^{1}$ & 0.696 & 0.078 & Basei and Teixeira (1975). \\
Guyana & Hornfelsed shale of the Roraima Group overlying a diabase sill & $1,600 \pm 44(n=2)$ & 0.856 & N.A. & Snclling and McConnell (1969). \\
\hline
\end{tabular}

'These ages are calculated using Model 1 of York (1969), which assumes that the only cause for scatter from a straight line ane the assigned errors; however, the errors for ${ }^{87} \mathrm{Rb}{ }^{86} \mathrm{Sr}$ and ${ }^{87} \mathrm{Sr} /{ }^{86} \mathrm{Sr}$ were not cited in the original references. Values of 2.0 percent and 0.1 percent, respectively, were used for the calculations.

ron, 1993). Rocks of the Roraima Group may have been deposited in several basins (fault-block basins?) separated by basement highs (Ghosh, 1985).

The Roraima Group may be as old as about $1,900 \mathrm{Ma}$ and as young as about 1,500 Ma or younger (Ghosh, 1985). Correlation of the Roraima Group throughout the shield is problematic because radiometric dating of felsic pyroclastic rocks interbedded with sandstone of the middie part of the Roraima Group (Uaimapué Formation and its equivalents) and diabase dikes and sills that intrude the Roraima Group yields erratic dates. For example, felsic volcanic rocks have whole-rock rubidium-strontium isochron dates of about $1,730,1,660$, and $1,570 \mathrm{Ma}$ (table 3) near Canaima in the northern Gran Sabana area, in Suriname, and near Santa Elena de Uairén in the southern Gran Sabana area, respectively (Gaudette and Olszewski, 1985; Priem and others, 1973; Pringle and Teggin, 1985, respectively). These dates are analytically indistinguishable $(1,650 \mathrm{Ma})$, given the eror and MSWD associated with each date (table 3). Diabase dikes that cut rocks of the Roraima Group throughout the central and eastern parts of the Guayana Shield have been dated by ${ }^{40} \mathrm{Ar} /{ }^{39} \mathrm{Ar}$ and whole-rock and mineral rubidium-strontium and potassium-argon methods. Mineral and whole-rock rubidium-strontium isochrons for doleritic ${ }^{6}$ sills that intrude the Roraima Group in Guyana and Suriname yield dates of about 1,640 Ma and 1,670 Ma, respectively

${ }^{6}$ Dolerite is a British term for diabase. The two terms are used synonymously herein; the mafic intrusive rocks in Guyana and Suriname are generally referred to as dolerite (the original usage) and those in Venezuela and Brazil as diabase. (table 4). The potassium-argon method does not give accurate ages for the diabase intrusive rocks (fig. 4) (McDougall, 1968 ), and ${ }^{40} \mathrm{Ar} /{ }^{39} \mathrm{Ar}$ analyses of biotite and plagioclase from one sample of diabase gave dates of about 1,800 and 1,470 Ma, respectively (Onstott, Hargraves, and York, 1984). Direct dating of the Roraima Group yields an age of about 1,650 Ma for the middle member (Uaimapué Fornation), which rests on as much as $1,200 \mathrm{~m}$ of quartzarenite, and indirect dating of diabase dikes and sills indicates an age not younger than 1,670-1,640 Ma for the lower and middle parts of the Roraima Group (McDougall and others, 1963; Hebeda and others, 1973).

Both discordant and concordant contacts have been mapped between rocks of the Roraima Group and the Caicara Formation, which was deposited between about 1,930 and 1,790 Ma (table 2) (Reid and Bisque, 1975; Amaral and Halpern, 1975; Sidder, unpublished data, 1988). In addition, the contact between the Roraima Group and the Parguaza Granite (1,545 Ma) has been identified as an angular unconformity (Mendoza, 1974; Mendoza and others, 1977). In support of this interpretation, Ghosh $(1985$, p. 48$)$ noted that "contact metamorphic minerals are conspicuous by their absence in the Roraimas overlying the Parguaza Rapakivi granite." In contrast, other Proterozoic units, such as the Cinaruco Formation in Estado Amazonas (equivalent to the Los Caribes Formation), contain andalusite in a contact aureole as much as $0.5 \mathrm{~km}$ from the intrusive contact (Ghosh, 1985). These geologic relations bracket the age of the Roraima Group as being as old as about 1,900 Ma in southeastern Venezuela and as young as about 1,500 $\mathrm{Ma}$ or younger in Estado Amazonas. 


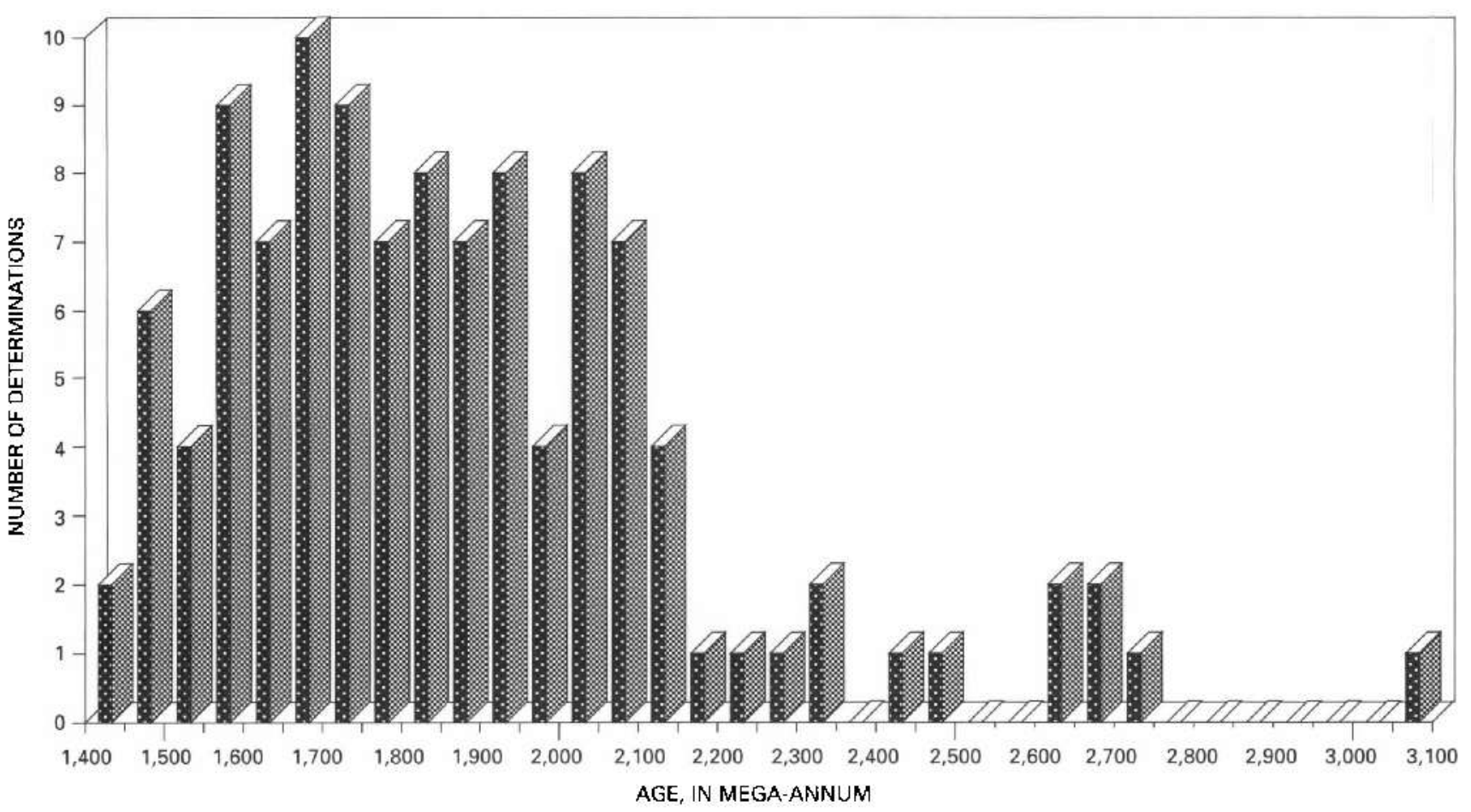

Figure 4. Potassium-argon dates for Proterozoic diabase of the Guayana Shield. Data from McDougall and others (1963), Snelling (1963), Sneling and McConnell (1969), Hebeda and others (1973), Frick and Steiger (1974), Basei and Teixeira (1975), and Teggin and others (1985).

Sedimentary rocks of the Roraima Group apparently record a long period of sedimentation on a relatively stable crust. It has been proposcd that the present crustal thickness of shields was not attained at the time of "stabilization," or the cessation of deformation and magmatisn (end of the Trans-Amazonian orogeny), but rather that continued passive underplating of the crust (intrusion of part of the Cuchivero Group and its equivalents) and subsequent subsidence and sedimentation may have extended for several hundred million years after initial stabilization (Rogers and others, 1984). The sandstones throughout the Guayana Shield presently correlated with the Roraima Group apparently record a long period of subsidence and continental-nearshore sedimentation that perhaps migrated successively westward in multiple basins on a stable craton possibly from as early as 1,900 to at least $1,545 \mathrm{Ma}$.

\section{MINERAL RESOURCES}

Modern and paleoplacer deposits of gold and diamonds have been mined extensively in the Venezuelan Guayana Shield (Mendoza, 1985; Sidder, this volume). Recent field work (Dohrenwend and others, this volume) in the southern Gran Sabana area identifies three types of placer occurrences: (1) diamond placers within modern channels of major rivers, (2) gold and diamond placers in colluvialalluvial deposits of low-order drainages, and (3) gold and diamond paleoplacers associated with conglomeratic lenses and beds within the lower $500-600 \mathrm{~m}$ of the Uairén Formation. These paleoplacer deposits are the source of gold for modern placer and colluvial-alluvial gravel deposits (Reid and Bisque, 1975; Mendoza, 1985; Dohrenwend and others, this volume). Paleoplacer gold-bearing units in quartzpebble conglomerate and quartzarenite in the lower part of a fluvatile-deltaic sequence of conglomerate, arenite, quartzite, and intercalated graphitic phyllite in Colombia (Rodriguez and Warden, 1993) are similar to those in the Roraima Group.

Conglomerates in the lower part of the Roraima Group have been proposed as the source of diamonds by many investigators (Gansser, 1954; Pollard and others, 1957; De Loczy, 1973; Briceño, 1984; Mendoza, 1985). Reid (1974b) suggested that kimberlite, possibly in Brazil or even West Africa, was the source for the paleoplacer deposits in the Roraima Group. Studies at San Salvador de Paúl (Briceño, 1984) and elsewhere along the Río Caroní and in the Gran Sabana area document that conglomerates of the Uairén Formation are the source of alluvial diamonds (Reid, 1974b; Reid and Bisque, 1975; Dohrenwend and others, this volume). Briceño (1984) stated that the conglomerates in the Uairén Formation are themselves paleoplacers and were the source for diamond-bearing gravels deposited about 8,000 years ago at San Salvador de Paúl. These Holocene paleoplacers may be the source of diamonds in some deposits now being mined in active drainages (Gansser, 1954; Briceño, 1984). 
Kimberlite, a common source of diamonds, and its indicator minerals such as chrome pyrope and magnesian ilmenite have been identified in Venezuela only in the Quebrada Grande area (Baptista and Svisero, 1978; Meyer and McCallum, 1993). More than a dozen diamond-bearing kimberlitic dikes and sills containing chrome pyrope, titanium-rich phlogopite, chromite, and yimengite $\left(\mathrm{K}(\mathrm{Cr}, \mathrm{Ti}, \mathrm{Fe}, \mathrm{Mg})_{12} \mathrm{O}_{19}\right)$, a rare alteration product of chromite previously recognized only in kimberlite from China, have been located (Nixon, 1988; Nixon and Condliffe, 1989; Nixon and others, 1989, 1992). A rubidium-strontium whole-rock isochron date of leached kimberlitic samples indicates that the dikes and sills were emplaced at about 1,732 $182 \mathrm{Ma}$ (Nixon and others, 1992). Mendoza and others (1977) suggested that the Cerro Impacto carbonatite and possibly associated kimberlite were intruded during the Mesozoic between about 150 and $80 \mathrm{Ma}$. Although neither kimberlite nor its indicator minerals have been identified elsewhere in Venezuela, it is possible that other Proterozoic diamond-bearing kimberlites were emplaced along the north-northwest-striking fractures that extend throughout the western part of the Guayana Shield in Estado Bolívar, Estado Amazonas, and into Brazil. Sediments of the Roraima Group may have incorporated diamonds from these older Proterozoic kimberlites during their transport and deposition. Numerous diamond-bearing kimberlite intrusions were emplaced in the West African craton during the Mesozoic, particularly about $100 \mathrm{Ma}$ (Williams and Williams, 1977; Morel, 1979). Proterozoic kimberlite intrusions in West Africa are less well documented; however, the Kanangono kimberlite in the Leo Shield of the Ivory Coast is dated as about 1,480 Ma (Onstott and Dorbor, 1987). Alluvial diamonds mined in Ghana and elsewhere in West Africa are presumed to have a source in rocks of the Early Proterozoic Birimian greenstone belts such as tuffaceous graywacke or associated with ultramafic rocks, such as within the Birim diamond field in Ghana (Kesse, 1985; Milési and others, 1992; McKitrick and others, 1993). Neither kimberlite nor kimberlitic indicator minerals has been identified in these rocks.

Radiometric anomalies have been measured in rocks of the Roraima Group on the south end of the Gran Sabana between Santa Elena de Uairén and Icabarú. The apparent similarity of the basal conglomerate of the Roraima Group and gold-uranium-bearing conglomerates of the Witwatersrand, South Africa, Jacobina, Brazil, and Blind River, Canada (De Loczy, 1973; Bellizzia and others, 1981) and the reported occurrence of authigenic pyrite (Gallagher, 1976) have led to the proposal that the basal conglomerates of the Roraima Group are a viable exploration target for uranium deposits, as well as for gold deposits (De Loczy, 1973; Mendoza, 1985; Brooks and Nuñez, 1991). Rocks of the Roraima Group are significantly younger (about $1,900-1,500 \mathrm{Ma}$ ), however, than the Early Proterozoic and Archean $(3,100-2,200 \mathrm{Ma})$ gold-uranium deposits and were depos- ited under a more oxygenated atmosphere. The uranium potential in the Roraima Group is low.

\section{AVANAVERO SUITE}

Unmetamorphosed mafic intrusive rocks of the Avanavero Suite (formerly known as the Roraima Intrusive Suite) are present throughout the Guayana Shield as dikes, sills, inclined sheets, and small irregular intrusive bodies such as laccoliths. These rocks are present from western Venezuela to Suriname and Brazil; the age of unmetamorphosed mafic dikes in French Guiana that are cut by Mesozoic diabase dikes is not known (Gibbs, 1986; Gibbs and Barron, 1993). Intrusion of a dense network of mafic dikes at about 1,600 Ma in the Reguibat Shield also indicates a period of contemporaneous crustal extension in the West African craton (Cahen and others, 1984; Rocci and others, 1991). Dikes of the Guayana Shield generally strike north, within $15^{\circ}$, or almost east; they are as thick as $1,000 \mathrm{~m}$ and have strike lengths of as much as $150 \mathrm{~km}$ (Bosma and others, 1983; Gibbs, 1986). Sills in the Guayana Shield are restricted to the Roraima and Cuchivero Groups, and they were fed by dikes and irregular intrusive bodies in the underlying basement rocks (Hawkes, 1966a; Gibbs, 1986). The sills are commonly intruded along the unconformity between the greenstone-granite terrane and the Roraima Group, as well as throughout the lower and middle members of the Roraima Group (Hawkes, 1966b). The stratigraphically highest sill was previously thought to be at the base of the upper member (Matauí Formation) (Bateson, 1966). On Mount Roraima, at the junction between Venezuela, Guyana, and Brazil, a large gabbroic body forms the boundary between the middle and upper members (Gansser, 1954). Briceno and others (1990) reported, however, that tholeiitic diabase stocks and sills are intrusive into the Matauí Formation in several tepuis of the Chimantá massif in southeastern Venezuela.

Diabasic rocks of the Guayana Shield range from gabbro and norite to granophyre. They are typically medium to coarse grained and massive; chilled margins are developed locally (Hawkes, 1966a; Sial and others, 1986). Subophitic to ophitic textures are common, and the finer grained rocks are commonly porphyritic. Cumulate textures and rhythmic layering are present in the Tumatumari-Kopinang dike and sill complex in Guyana (Hawkes, 1966b). Plagioclase $\left(\mathrm{An}_{35}-\mathrm{An}_{70}\right)$, hypersthene, bronzite, augite, and inverted pigeonite are the primary minerals; accessory amounts of biotite, magnetite, ilmenite, corona-textured olivine, hornblende, and graphic intergrowths of quartz and potassium feldspar (micropegmatite) and trace amounts of apatite, zircon, pyrite, and chalcopyrite are also present (Hawkes, 1966a, b; Hebeda and others, 1973; Gibbs, 1986; Sial and others, 1986; Briceño and others, 1990). The accessory minerals range in abundance from about 2 to as much as 15 
modal percent. Minor amounts of secondary minerals such as hornblende and uralite replacing pyroxene, serpentine pseudomorphs of olivine, chlorite after biotite and hornblende, and sericitic and saussuritic alteration of plagioclase are also present. Evidence of metamorphism has not been observed (Hawkes, 1966a, b; Hebeda and others, 1973; Sial and others, 1986). Chemical weathering products of diabase throughout the shield are similar, even at different elevations and on different planation surfaces. Diabase weathers directly to an assemblage of goethite and gibbsite, without intermediate clayey phases (Briceño and others, 1990).

The chemistry of diabase throughout the Guayana Shield is similar to that of continental tholeiite. All samples of dikes and irregular bodies in the basement rocks and sills in the Roraima Group are tholeiitic, and major element concentrations are similar, although trace element abundances of rubidium, barium, yttrium, strontium, and chromium may vary (Hawkes, 1966a, b; Teggin and others, 1985). Gabbroic rocks contain about 51-54 weight percent silica and granophyric rocks about 58-65 weight percent silica (Hawkes, 1966a; Teggin and others, 1985). Diabase analyses plot in the tholeiitic field on several discriminant diagrams such as total alkali-silica, AFM $\left(\mathrm{Na}_{2} \mathrm{O}+\mathrm{K}_{2} \mathrm{O}-\mathrm{FeO}{ }^{*}-\mathrm{MgO}\right)$, and Jensen (cation percent $\left(\mathrm{FeO}+\mathrm{Fe}_{2} \mathrm{O}_{3}+\mathrm{TiO}_{2}\right)-\mathrm{Al}_{2} \mathrm{O}_{3}-\mathrm{MgO}$ ) plots (Teggin and others, 1985; Sial and others, 1986). Quartz and hypersthene are common normative minerals (Hawkes, 1966b; Teggin and others, 1985). Samples of Proterozoic diabase contain less total iron, titanium, zirconium, vanadium, volatile content (water, carbon dioxide, fluorine, and chlorine as measured by loss on ignition), and possibly copper than samples of the Mesozoic diabase suite (Teggin and others, 1985; Sial and others, 1986). It has been suggested, on the basis of these and other chemical differences between the Proterozoic and Mesozoic diabases, that the Proterozoic rocks represent differentiates of parent magmas that underwent pre-intrusive, shallow-level (crustal) differentiation (Choudhuri, 1978) or that were derived from a shallower region in the mantle (Sial and others, 1986). In contrast, the Mesozoic dike swarms represent magmas derived directly from the mantle, possibly related to a hot spot or mantle plume, during the breakup of Gondwanaland and the formation of the Atlantic Ocean (Choudhuri, 1978; Sial and others, 1986).

Dating rocks of the Avanavero Suite is difficult. As noted previously, diabase from throughout the Guayana Shield has been dated by argon-argon and whole-rock and mineral rubidium-strontium and potassium-argon methods. Potassium-argon dates range from about 3,095 to $1,418 \mathrm{Ma}$ (fig. 4), whereas two mineral and whole-rock rubidium-strontium isochrons yield dates of about 1,670 and $1,640 \mathrm{Ma}$ (table 4). The ${ }^{40} \mathrm{Ar} /{ }^{39} \mathrm{Ar}$ integrated age dates for biotite and plagioclase in a diabase sill in Guyana are 1,798 and 1,468 Ma, respectively (Onstott, Hargraves, and York, 1984). The last 10 percent of ${ }^{39} \mathrm{Ar}_{\mathrm{K}}$ released from plagioclase indicates an age of $1,823 \mathrm{Ma}$; the last 40 percent of
${ }^{39} \mathrm{Ar}_{\mathrm{K}}$ released from biotite defines a plateau at $1,810 \mathrm{Ma}$, and individual fractions indicate an age of about 1,850 Ma. The dates for biotite are, however, suspect because of the high percentage of atmospheric argon ( $>29$ percent and as much as 91 percent in the fraction at $1,150^{\circ} \mathrm{C}$ ) in 16 of 17 fractions of the biotite analysis. The ${ }^{40} \mathrm{Ar} /{ }^{39} \mathrm{Ar}$ data for plagioclase support the conclusion that younger dates for the diabase are caused by argon loss (McDougall, 1968; Onstott, Hargraves, and York, 1984).

The lack of a well-defined peak on the histogram of potassium-argon dates for 114 analyses of diabase (fig. 4) indicates that this method has not adequately distinguished the age of the diabasic intrusive rocks of the Guayana Shield. Detailed studies of the distribution of radiogenic argon in samples of diabase prove that the argon is inhomogeneously distributed throughout the rocks and minerals both by excess argon contamination (Hebeda and others, 1973) and by loss of argon (McDougall, 1968) after crystallization of the diabase. These changes are attributed to a tectonothermal event known as the Nickerie or K'Mudku episode at about 1,200 Ma that affected the entire Guayana Shield (Snelling and McConnell, 1969; Hebeda and others, 1973; Bosma and others, 1983). As stated by McDougall (1968, p. 144), "The spread in ages determined by the K-Ar method on the Roraima dolerites shows that little is to be gained by undertaking further measurements by this technique on these rocks. The question as to the age or ages of emplacement of the dolerites probably will only be resolved by detailed and precise Rb-Sr whole-rock measurements on many samples."

Rubidium-strontium isochrons for samples of homfelsed sandstone and shale collected adjacent to diabase intrusive rocks yield disparate results (table 4). The initial ${ }^{87} \mathrm{Sr} /{ }^{86} \mathrm{Sr}$ ratio determined for these samples (table 4 ) indicates that these isochrons may not be representative of the true age of emplacement. The small number of analyses precludes a rigorous interpretation of these data.

Paleomagnetic analyses of Proterozoic diabase from Venezuela, Guyana, and Suriname define at least two groups having remanence orientations approximately opposite in declination (Hargraves, 1968; Veldkamp and others, 1971; Onstott, Hargraves, and York, 1984); however, the radiometric age determinations do not distinguish separate periods of diabase intrusion (table 4, fig. 4) (Gibbs, 1986). At present, the age of diabase intrusion in the Guayana Shield can only be estimated to be about $1,650 \mathrm{Ma}$, and it may be as old as about 1,850 Ma.

\section{PARGUAZA GRANITE}

The Parguaza Granite constitutes a batholith of at least $10,000 \mathrm{~km}^{2}$, and possibly as much as $30,000 \mathrm{~km}^{2}$, in Estado Amazonas (fig. 2). These granitic rocks were emplaced predominantly in the Ventuari dominion into rocks equivalent to those of the Cuchivero Group. Granite of similar compo- 
sition and age is present to the south and southeast into Brazil and westward into Colombia (Mendoza, 1975; Kovach and others, 1976; Gaudette and others, 1978; Priem and others, 1982); these intrusive bodies include the Agua Boa and Madeira plutons, which host the world-class tin deposit at Pitinga, as well as the Surucucus, Mucajai, Abonari, Velho Guilherme, and other intrusive suites in Brazil (Dall'Agnol and others, 1975, 1987, 1994; Dall'Agnol, 1982; Schobbenhaus and others, 1984; Jones and others, 1986; Issler and Lima, 1987; Gibbs and Barron, 1993). Volcanic rocks such as the rhyodacite of Guayapo are associated with the Parguaza Granite (Mendoza and others, 1977). Some felsic to intermediate tuffs in Estado Amazonas identified as correlative with the Caicara Formation may also be related to the Parguaza Granite.

Rocks of the Parguaza Granite include massive, coarsely crystalline, porphyritic granite and biotite granite, commonly having rapakivi (wiborgite-type) texture. They contain quartz (5-34 modal percent), potassium feldspar (microcline perthite, 25-55 percent), plagioclase (oligoclase, 15-31 percent), biotite (3-17 percent), and hornblende (1-24 percent) and accessory clinopyroxene, apatite, sphene, zircon, ilmenite, and magnetite (Mendoza, 1974, 1975; Gaudette and others, 1978). Rapakivi and, less commonly, antirapakivi textures, with ovoids of potassium feldspar mantled by plagioclase and plagioclase mantled by microcline, respectively, are characteristic of these granitic rocks. The Parguaza Granite is relatively unmetamorphosed and unaltered. Epidote is rarely present as a secondary mineral in plagioclase, and chlorite is not present, in contrast to the granitic rocks of Santa Rosalía (Mendoza, 1974; Gaudette and others, 1978).

Rocks of the Parguaza Granite are metaluminous to slightly peraluminous and have a tholeiitic affinity, as indicated by high $\mathrm{FeO} /(\mathrm{FeO}+\mathrm{MgO})$ ratios. Silica ranges from about 66 to 74 weight percent; amounts of $\mathrm{Na}_{2} \mathrm{O}$ and $\mathrm{MgO}$ are low to moderate, 2.9-3.9 weight percent and 0.2-0.7 weight percent, respectively; and concentrations of total iron as $\mathrm{Fe}_{2} \mathrm{O}_{3}, \mathrm{TiO}_{2}$, and $\mathrm{CaO}$ are relatively high, 2.6-7.2, $0.4-0.9$, and 1.0-3.1 weight percent, respectively (Mendoza, 1975). Major- and trace-element contents of the Parguaza Granite are similar to those of other A-type granites such as granophyre from the Duluth and Skaergaard Complexes, Nigerian chamockite, rapakivi granite in Finland, and Middle Proterozoic ( $1.48-1.35 \mathrm{Ga}$ ) granite in the granite-rhyolite terranes of the Midcontinent of the United States (Mendoza, 1975; Gaudette and others, 1978; Sims and others, 1987).

\section{AGE AND ORIGIN}

The Parguaza Granite was intruded about $1.55 \mathrm{Ga}$ in the Ventuari dominion of Estado Amazonas (Gaudette and others, 1978). Other granitic rocks in the westernmost part of the Guayana Shield and southward beneath alluvial cover of the upper Amazon Basin are similiar in age and composition (table 5). Together, these granites have been interpreted to represent widespread anorogenic magmatism at about 1.55 $\mathrm{Ga}$ (Dall'Agnol and others, 1975, 1994; Kovach and others, 1976; Gaudette and others, 1978; Priem and others, 1982; Gibbs and Barron, 1983; Teixeira and others, 1989). Anorogenic granite magmatism to the east and southeast in the Central Amazonian Province of Brazil is generally older, having a uranium-lead zircon age of about $1.88 \mathrm{Ga}$ and rubidium-strontium isochron ages of 1.8-1.6 Ga (Dall' Agnol and others, 1994). These older ages suggest that anorogenic granite magmatism in the eastern area was a separate, independent event from that in the west.

The generation of the Parguaza granitic magmas has been characterized as a rift-related event (Gaudette and others, 1978; Gaudette and Olszewski, 1985; Jones and others, 1986; Dall'Agnol and others, 1994). A tectonic environment represented by within-plate crustal extension accompanied by a high thermal gradient due to intrusion of mantle-derived basaltic magmas may explain the origin of the Parguaza Granite. The Parguaza Granite is similar in age, composition, and tectonic setting to the Middle Proterozoic (1,480-1,450 Ma) granite-rhyolite terrane of the St. Francois Mountains in southeastern Missouri of the United States (Kisvarsanyi and Kisvarsanyi, 1989). The formation of rocks in the St. Francois terrane has been explained as a failed cratonic rift or an anorogenic extensional tectonic setting at a passive continental margin (Kisvarsanyi, 1975; Windley, 1989) or, possibly, as the result of shallow subduction, delamination of continental lithosphere, or orogenic-accretionary processes related to the early stages of the adjoining Grenville orogen (Patchett and Ruiz, 1989; Van Schmus, 1993; Storey and others, 1994). The lack of (1) alluvial sediment fill, (2) minor to major quantities of basalt, and (3) basalt erupted peripherally to the rift indicates that the St. Francois granite-rhyolite terrane did not form in a classic rift environment (Patchett and Ruiz, 1989). A similar argument may be made against a rift setting for the Parguaza Granite. Indeed, the Parguaza Granite may be related to shallow subduction or early orogenic-accretionary processes associated with the 1,200-Ma Garzón-Santa Marta granulite belt in Colombia, which has been correlated with the Grenville orogenic belt (Kroonenberg, 1982; Priem and others, 1989).

Ratios such as $\mathrm{Na} / \mathrm{K}, \mathrm{Ba} / \mathrm{Sr}$, and $\mathrm{K} / \mathrm{Rb}$ indicate that fractional crystallization was an important process during the formation of the Parguaza rapakivi granite (Mendoza, $1974,1975)$. The low initial ratio of ${ }^{87} \mathrm{Sr} /{ }^{86} \mathrm{Sr}(0.701$, table 5 ), neodymium isotopic data $\left({ }^{143} \mathrm{Nd} /{ }^{144} \mathrm{Nd}=0.51160\right)$, and high average content of nickel (about $12 \mathrm{ppm}$, as high as 710 ppm) all suggest that the granitic magmas may have been derived from lower crustal material of trondhjemitic or charnockitic composition and a component of undifferentiated mantle material (Mendoza, 1974, 1975; Gaudette and others, 1978; Allègre and Ben Othman, 1980). Initial ratios of ${ }^{87} \mathrm{Sr} /{ }^{86} \mathrm{Sr}$ between 0.704 and 0.716 and uranium-lead inher- 
Table 5. Rubidium-strontium whole-rock isochron dates for granitic rocks of the Parguaza province and their equivalents, Guayana Shield.

[Number of samples on which age is based is given in parentheses after age. MSWD is mean squares weighted deviation. N.A. indicates not available]

\begin{tabular}{|c|c|c|c|c|c|}
\hline Country & Unit & Age (Ma) & $\left({ }^{87} \mathrm{Sr} /{ }^{86} \mathrm{Sr}\right)_{0}$ & MSWD & Reference \\
\hline Venezuela & Parguaza Granite & $1,490 \pm 120(n=4)^{1}$ & $0.70 !$ & 2.09 & Gaudette and ot \\
\hline Venezuela & Granite of San Carlos de Río Negro (Casiquiare dominion) & $567 \pm 25(n=4)$ & 0.704 & 0.93 & ski (1985). \\
\hline olombia & Granites of the Río Inirida and Río Guaviare (Ventuari' & 1,48 & 0.706 & 1.6 & 982. \\
\hline Brazil & Surucucus granite & $40(n=6)^{1}$ & 0.696 & 22.2 & $\begin{array}{l}\text { Basei and Teixeira (1975), } \\
\text { Dall'Agnol and others (1975). }\end{array}$ \\
\hline 421 & Grar & & 0.706 & 0.29 & \\
\hline Brazil & Agua Boa-Madeira plutons, Pitinga area & $1,700 \pm 34(n=9)^{3}$ & 0.701 & 5.98 & \\
\hline \multicolumn{6}{|c|}{$\begin{array}{l}{ }^{1} \text { The errors for }{ }^{87} \mathrm{Rb} b^{86} \mathrm{Sr} \text { and }{ }^{87} \mathrm{Sr}{ }^{86} \mathrm{Sr} \text { were not cited in the original references. Values of } 1.5 \text { and } 0.085 \text { percent (H.E. Gaudette, University of New } \\
\text { Hampshire, oral commun., 1990) and } 2.0 \text { and } 0.1 \text { percent, respectively, were used for the calculations of the dates of the Parguaza and the Surucucus } \\
\text { granites, respectively. The Parguaza Granite has a uranium-lead zircon age of } 1,545 \pm 20 \mathrm{Ma} \text { (Gaudette and others, 1978). Dall'Agnol and others (1993) } \\
\text { reported a reference isochron age of } 1,583 \mathrm{Ma} \text { at an initial ratio of } 0.708 \text { for the Surucucus granite. } \\
{ }^{2} \text { These three samples are several hundred kilometers from one another and may not be comagmatic. Their model ages, assuming an initial ratio of } \\
0.706 \text {, are } 1,541,1,536 \text {, and } 1,528 \mathrm{Ma} \text {. } \\
{ }^{3} \text { This date is recalculated from the original published data. The same decay constant and atomic ratios were used; however, the date in the publication }\end{array}$} \\
\hline
\end{tabular}

itance patterns in zircon in similar anorogenic granite from other parts of the shield indicate a crustal source or an important contribution of continental crust to the magmas that generated these rocks (Pimentel and others, 1991; Dall'Agnol and others, 1994).

\section{MINERAL DEPOSITS}

Placer, eluvial, and lode occurrences of tin in Estado Amazonas and Estado Bolívar are spatially associated with the Parguaza Granite. Cassiterite in lodes is associated with quartz veins that cut the granite, and anomalous values of tantalum, niobium, zirconium, and titanium, contained in tantalum-rich rutile or struverite, tantalum-niobiumiron-manganese-bearing rutile, tantalite-columbite, stanniferous tantalite or ixiolite, and zircon (Aarden and Davidson, 1977), are present in pegmatite associated with the granite (Rodriguez and Perez, 1982; Perez and others, 1985). The best known tin prospect is that near Caño Aguamena (Sidder, this volume, pl. 1).

The Parguaza Granite is equivalent in composition and origin and approximately equal in age (table 5) to granite in the Agua Boa and Madeira plutons, which host the Pitinga deposit in Brazil. Pitinga is one of the world's largest tin deposits and produces about 12 percent of the western world's tin (Thorman and Drew, 1988). As of 1984, it had measured reserves of about 203,000 metric tons of tin, of which about 30 percent was in alluvial deposits (Daoud and Antonietto, 1988). Measured, indicated, and inferred reserves totaled about 269,000 metric tons of tin; alluvial reserves accounted for about 64 percent (Daoud and Antonietto, 1988). Greisenized granite, locally called apogranite, hosts the primary tin ore and is the source of the alluvial deposits (Jones and others, 1986; Macambira and others, 1987; Daoud and Antonietto, 1988; Thorman and Drew, 1988). In the Surucucus area of northernmost Brazil, alkaline granite having rapakivi texture is about $1.5-1.6 \mathrm{Ga}$ and has potential reserves of 20,000 metric tons of tin (Dall'Agnol and others, 1975, 1994; Schobbenhaus and others, 1984; Jones and others, 1986). Thus, the Parguaza Granite has high potential for identification of undiscovered tin deposits.

The similarity in age, composition, and tectonic environment between the Parguaza Granite and the granite-rhyolite terrane of the St. Francois Mountains suggests that Olympic Dam-type iron-copper-uranium-gold-rare earth element deposits are a favorable exploration target in the Parguaza terrane (Sims, 1988; Sidder and Day, 1993; Sidder and others, 1993). Aeromagnetic and radiometric data could help locate potential prospects. A highly magnetic area and a superimposed uranium anomaly detected in aeromagnetic and aeroradiometric data over the Parguaza Granite in the westernmost part of Estado Bolívar (lat $5^{\circ} 10^{\prime} \mathrm{N}$., long $64^{\circ} 20^{\prime}$ W.) (Wynn, 1993) is a good area to explore further.

The bauxite deposit at the Los Pijiguaos mine formed from the Parguaza rapakivi granite (Moreno and Bertani, $1985 \mathrm{~b}$ ). The richest ore is at an erosional level (known as the Imataca-Nuria erosion surface) at elevations between 620 and $690 \mathrm{~m}$, and it formed during an intense weathering cycle in the Late Cretaceous and early Tertiary (Short and Steenken, 1962; Menendez and Sarmentero, 1985; Schubert and others, 1986). Bauxita Venezolana C.A. (BAUXIVEN) produced about 245,157 metric tons of ore in 1987 during its first year of operation at Los Pijiguaos, almost 2 million metric tons in 1991, and a reported 1.05 million metric tons in 1992 (Ensminger, 1992; Doan, 1994). Initial measured and indicated reserves of bauxite were 201.8 million metric tons with a grade of 48.7 percent $\mathrm{Al}_{2} \mathrm{O}_{3}$ and 10.9 percent $\mathrm{SiO}_{2}$, which included reserves of 70.1 million metric tons with 51.8 percent $\mathrm{Al}_{2} \mathrm{O}_{3}$ and 6.4 percent $\mathrm{SiO}_{2}$ (Menendez and Sarmentero, 1985). Newman (1989) reported that proven (200 million metric tons) and probable (500 million metric tons) reserves of 700 million metric tons are present in the Los Pijiguaos area. Three new bauxite deposits in the Par- 
guaza terrane were discovered in 1989 between the Los Pijiguaos mine and Puerto Ayacucho on the Río Orinoco (Ensminger, 1992).

\section{NICKERIE OROGENY}

Potassium-argon, argon-argon, and rubidium-strontium dates of about 1,350-1,100 Ma for mica and feldspar from Archean and Early Proterozoic rocks of the Guayana Shield are indicative of partial resetting and overprinting due to the Nickerie metamorphic episode (Priem and others, 1968; Kroonenberg, 1982; Onstott and others, 1989), Loss of argon and strontium due to recrystallization resulted in the abnormally young Middle Proterozoic dates for Early Proterozoic and Archean rocks, and increase of argon in diabase of the Avanavero Suite caused the aberrantly old dates (fig. 4). Rocks affected by this episode extend from western Surinarne through Guyana to Venezuela, Colombia, and northern Brazil. The eastern boundary of reset mica ages is in central Suriname (Priem and others, 1971; De Vletter and Kroonenberg, 1984). East of this boundary, Early Proterozoic rocks show Trans-Amazonian, not Nickerie, mineral ages. In Venezueia the Nickerie orogeny is also called the Orinoquean orogenesis (Mendoza, 1977a; Moreno and others, 1977); in Guyana it is named the K'Mudku mylonite episode (Barron, 1969; Singh, 1974); and in Brazil it is known as the Jari-Falsino event (Kroonenberg, 1982). The Nickerie orogeny is equivalent to the Grenville orogeny in North America and Antarctica (Moores, 1991; Storey and others, 1994).

Reactivation of east-northeast-striking faults, such as the Guri shear zone, and minor uplift throughout the central and western parts of the Guayana Shield characterize the Nickerie episode. Cataclastic textures and locally mylonite zones and pseudotachylite developed along some faults (Short and Steenken, 1962; Priem and others, 1968; Barron, 1969; Gibbs and Barron, 1993). Minor aplite and pegmatite dikes may have been emplaced coincident with faulting (Mendoza, 1977a). Extremely low grade to medium-grade metamorphism due to cataclasis and mylonitization in the central Guayana Shield during the Nickerie episode produced minerals such as pumpellyite, prehnite, epidote, albite, muscovite, chlorite, biotite, stilpnomelane, sphene, actinolite, and garnet (De Roever and Bosma, 1975). In the western part of the shield, high-grade metamorphism generated charnockitic and enderbitic granulite, mafic granulite, amphibolite, and augen gneiss (Priem and others, 1989).

The Nickerie metamorphic episode commonly has been described as a regional tectonothermal event (Priem and others, 1968; Barron, 1969; De Roever and Bosma, 1975; Mendoza, 1977a), but a cause for the tectonism or increased heat flow has not been identified. Recent geochronological studies of the Garzón massif in the Andes of Colombia indicate that a quartzofeldspathic, calc-alkaline (continental arc) sequence of rocks along the westem margin of the Guayana
Shield was metamorphosed to granulite facies about 1,172 Ma (Priem and others, 1989). This metamorphism and associated deformation are attributed to continental collision (Kroonenberg, 1982; Priem and others, 1989; Park, 1992). This collision resulted in an early Neoproterozoic supercontinent during the 1.3-1.0-Ga Grenvillian (-Nickerie) orogeny (Dalziel, 1992; Storey, 1993). The reset mineral ages in rocks of the Guayana Shield are herein interpreted to be the result of thermal and tectonic effects in the hinterland of this proposed collision during the Nickerie orogeny.

\section{MESOZOIC DIABASE DIKES}

Narrow $(<200 \mathrm{~m})$, thin $(<50 \mathrm{~m})$, long (as much as 250 $\mathrm{km})$ unmetamorphosed diabase dikes that trend approximately east-northeast in Venezuela and north-northwest in the eastern part of the Guayana Shield are related to the opening of the Atlantic Ocean (MacDonald and Opdyke, 1974; Gibbs, 1986). They have been called the Apatoe dike suite in Guyana (Gibbs and Barron, 1993). These dikes are generally thinner and straighter than dikes of the Avanavero Suite, possibly due to a more rigid crust at the time of their emplacement (Gibbs and Barron, 1993); however, because the field appearance and chemistry of these diabase suites are similar, the Mesozoic dikes are grouped with those of the Avanavero Suite (unit $\mathrm{Xa}$ ) in figure 2 . The dike rocks are fine to medium grained, have subophitic to ophitic texture (Hargraves, 1978), and contain plagioclase (commonly labradorite) and augite, minor pigeonite, relict olivine cores in pyroxene, biotite, green amphibole, apatite, opaque minerals such as titaniferous magnetite, ilmenite, and rare chalcopyrite and pyrrhotite, and minor interstitial granophyric intergrowths of quartz and microcline microperthite (Hawkes, 1966a; Hargraves, 1978; Choudhuri and others, 1984). These rocks are quartz-saturated tholeiite that has a continental basalt affinity (Choudhuri and others, 1984), and they generally contain more titanium, total iron, zirconium, vanadium, volatile content (water, carbon dioxide, fluorine, and chlorine as measured by loss on ignition), and possibly copper than does diabase of the Avanavero Suite (Choudhuri, 1978; Teggin and others, 1985). The chemistry of the Mesozoic rocks suggests that the dike swarms were derived directly from an undepleted mantle source, possibly related to a mantle plume and hot spot, during the breakup of Gondwanaland and the separation of South America from Africa (Choudhuri and others, 1984).

The age of these younger diabase dikes, which are present throughout the Guayana Shield, has not been determined precisely. As shown in the histogram in figure 5, potassium-argon dates for 59 samples of diabase range from about 550 to $130 \mathrm{Ma}$. The majority of dates are between about 230 and $170 \mathrm{Ma}$, and many are about $210 \mathrm{Ma}$ (fig. 5). Dikes that have different potassium-argon dates have similar magnetic poles that are poles characteristic of Permian- 


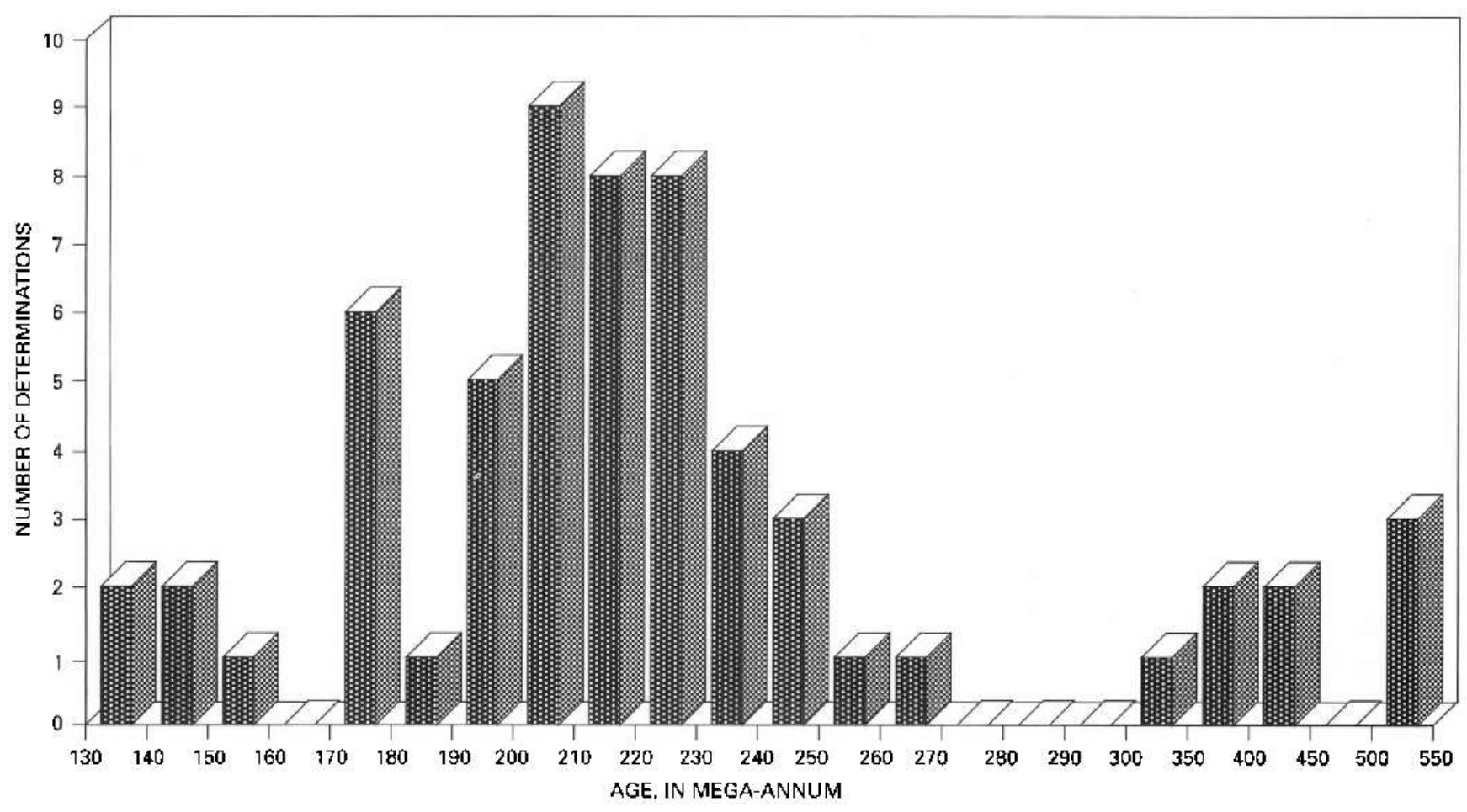

Figure 5. Potassium-argon dates for Phanerozoic diabase of the Guayana Shield. Data from Priem and others (1968), Frick and Steiger (1974), MacDonald and Opdyke (1974), Schobbenhaus and others (1984), and Teggin and others (1985).

Triassic rocks (Veldkamp and others, 1971; Hargraves, 1978); however, scatter of the paleomagnetic pole positions does not allow the age of the dikes to be distinguished more accurately. Dates for diabase dikes in Liberia, West Africa, that intruded Proterozoic basement rocks range from about 1,222 to $177 \mathrm{Ma}$. These dikes contain large and variable amounts of excess ${ }^{40} \mathrm{Ar}$ that resulted in anomalously old dates (Dalrymple and others, 1975; Mauche and others, 1989). Dates for diabase dikes that intruded Paleozoic sandstone range, however, from about 201 to $177 \mathrm{Ma}$. Dikes that cut sandstone may also contain small amounts of extraneous ${ }^{40} \mathrm{Ar}$ (Dalrymple and others, 1975; Mauche and others, 1989). Thus, dates for diabase dikes in the Guayana Shield, all of which intrude Proterozoic or Archean rocks, may not be representative of the time of dike emplacement and crystallization. All of the dikes are probably latest Triassic to earliest Jurassic, about $210-200 \mathrm{Ma}$, in age. It is not known whether emplacement of the dikes marked the initiation of or predated the separation of South America and Africa and the opening of the Atlantic Ocean.

\section{MESOZOIC-CENOZOIC UPLIFT, EROSIONAL SURFACES, AND ALLUVIUM}

Uplift and southward tilt of the Imataca Complex and other rocks in the northem Guayana Shield of Venezuela occurred just prior to or during the separation of South America from Africa (Onstott and others, 1989). Additional uplift and tilt may also have been associated with mid-Cenozoic orogeny in the Caribbean area (Short and Steenken, 1962; Olmore and Estanga, 1989; Olmore and García-Gerdes, 1990; Olmore and others, 1993). These uplifts caused erosion of the Guayana Shield and subsequent deposition in a basin north of the Río Orinoco (Schubert and others, 1986; Olmore and García-Gerdes, 1990; Olmore and others, 1993). Geomorphic and geologic evidence of Cenozoic tectonism has not been observed in the Gran Sabana area; however, slow, broad regional upwarping may not have generated a recognizable geomorphic expression (Dohrenwend and others, this volume).

At least six planar geomorphic surfaces, marked by distinct elevations, have been identified in the Venezueian Guayana Shield. They are, from oldest to youngest, (1) Auyantepui $(2,000-2,900 \mathrm{~m}), \quad$ (2) Wonken or Kamarata-Pakaraima (900-1,200 m), (3) Imataca-Nuria $(600-700 \mathrm{~m})$, (4) Caroní-Aro $(200-450 \mathrm{~m})$, (5) Llanos $(80-150 \mathrm{~m}$ ), and (6) Orinoco floodplain $(0-50 \mathrm{~m})$ (Short and Steenken, 1962; Menendez and Sarmentero, 1985; Schubert and others, 1986, 1989; Briceño and Schubert, 1990; Gibbs and Barron, 1993; Dohrenwend and others, this volume). The ages of the oldest two surfaces are not well known; Schubert and others (1986) speculated that they are Mesozoic. The other surfaces range in age from early Tertiary to Holocene (Schubert and others, 1986; Briceño and Schubert, 


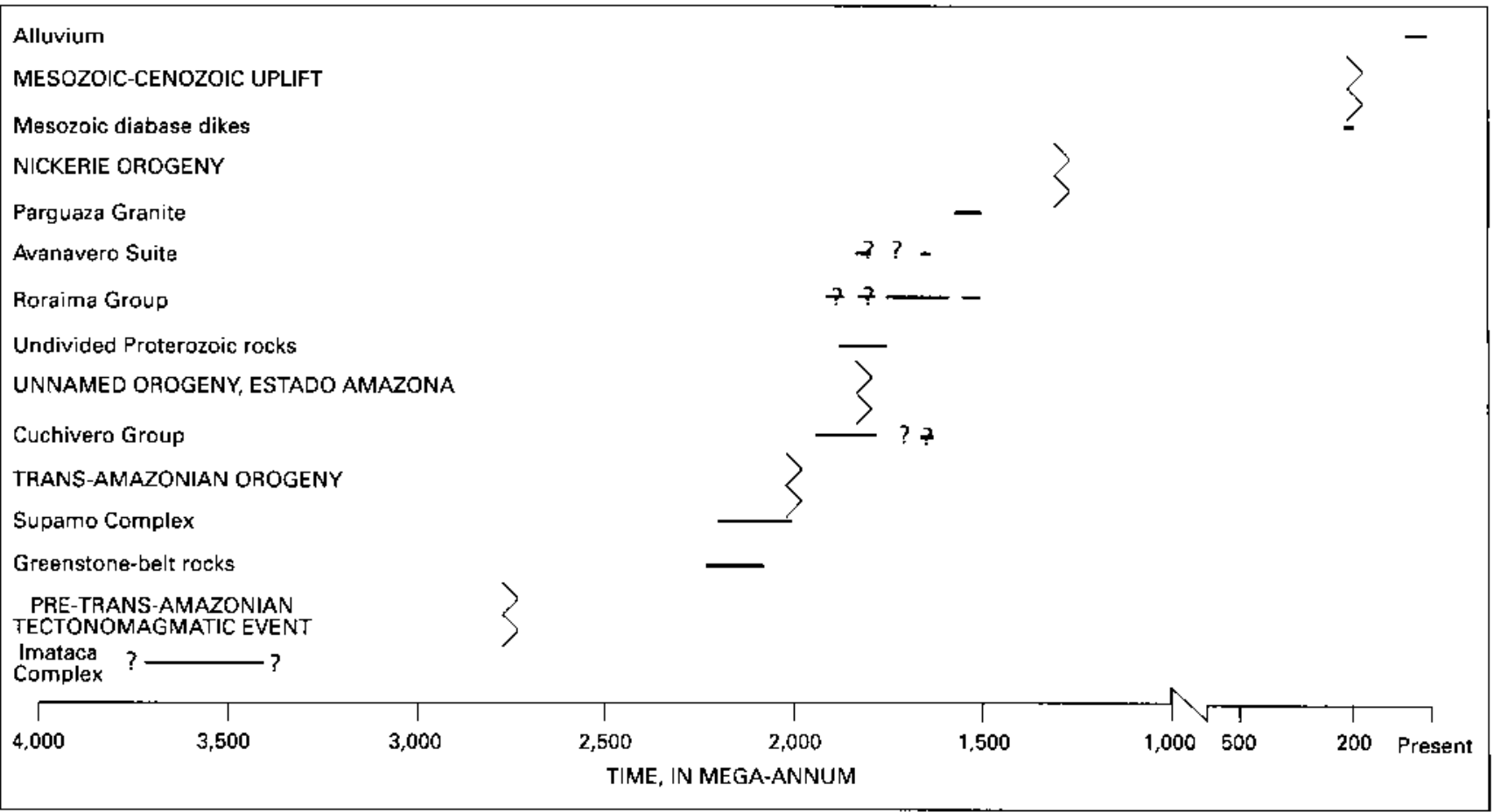

Figure 6. Chronology of the Venezuelan Guayana Shield. Rock units described in table. 1

1990). The Eocene-Oligocene Imataca-Nuria surface is important economically because bauxite and enriched deposits of banded iron formation are developed on it (Menendez and Sarmentero, 1985; Schubert and others, 1986). All of the planation surfaces have been correlated with similar surfaces in Brazil, Guyana, Suriname, and (or) French Guiana, as well as in West Africa and India (Short and Steenken, 1962; Prasad, 1983; Schubert and others, 1986; Briceño and Schubert, 1990; Gibbs and Barron, 1993).

Episodic periods of tectonic uplift, landscape dissection in response to uplift, and parallel slope retreat during succeeding intervals of stability are considered to be the cause of formation of these planation surfaces. Many of the surfaces coincide, however, with lithologic units, and the steps that separate them commonly coincide with lithologic discontinuities (Kroonenberg and Melitz, 1983). Furthermore, within the southern part of the Gran Sabana, ferricrete-capped remnants of a middle(?) Tertiary geomorphic surface cut across several of the regional planation surface levels and extend almost continuously from dissected strath terraces lying less than $10 \mathrm{~m}$ above modem streams to high, structurally controlled ridges rising more than $200 \mathrm{~m}$ above the floors of the larger valleys (Dohrenwend and others, this volume). Thus, present-day relief within the Guayana Shield is mostly a function of lithologic resistance. At least some of these so-called planation surfaces are a manifestation of lithologic control in a relatively stable landscape that is developed on a thick sequence of flat-lying to very gently dipping sedimentary strata.
Tertiary-Quaternary paleoplacer deposits and the lower Roraima Group are the source of diamonds and gold in Holocene alluvium (Briceño, 1984; Dohrenwend and others, this volume).

\section{SUMMARY}

The Guayana Shield of Venezuela consists predominantly of Archean and Early to Middle Proterozoic rocks (fig. 6). Archean rocks are not known eisewhere in the Guayana Shield, but similar Archean rocks and tectonic events are present in the West African Shield. Early Proterozoic greenstone-belt rocks and orogenic events in the rest of the Guayana Shield and in the West African Shield are comparable to those in the Venezuelan Guayana Shield. Differences in the types of late Early Proterozoic and Middle Proterozoic rocks in the two shields are notable. For example, granite and rhyolite equivalent to the Cuchivero Group are present throughout the Guayana Shield but are only locally present in the West African Shield. Also, rocks equivalent to the Roraima Group and the Parguaza Granite, although widespread in the Guayana Shield, are absent or rare in West Africa.

The only confirmed Archean rocks in the Guayana Shield are in the Imataca Complex. The Imataca Complex includes gneiss, granulite, amphibolite, dolomite, manganiferous rocks, and banded iron formation. Amphibolite- to granulite-facies metamorphism and refolded isoclinal folds are characteristic of the Imataca Complex. 
The Early Proterozoic greenstone belts in Venezuela comprise submarine sequences of mafic volcanic rocks at the base, a middle section of basalt to rhyolite, and an upper section of turbiditic graywacke, volcaniclastic rocks, and chemical sedimentary rocks. Tholeiitic and calc-alkaline differentiation trends are common in the volcanic rocks. Layered mafic complexes are also present in the greenstone belts. Rocks of the greenstone belts formed between about 2,250 and 2,100 Ma. They were metamorphosed to the greenschist facies and locally the amphibolite facies near granitic domes of the Supamo Complex, which intruded the greenstone belts between about 2,230 and 2,050 Ma. Major deposits of low-sulfide gold-quartz veins are hosted by rocks of the greenstone belts in shear zones. The Imataca Complex and the greenstone-granite terranes were deformed and metamorphosed during the Trans-Amazonian orogeny, which represents a period of continental collision between about 2,150 and 1,960 Ma. Postcollisional, post-TransAmazonian magmatism between about 1,930 and 1,790 Ma produced volcanic and plutonic rocks of the Cuchivero Group. Kimberlite in the Quebrada Grande area (and possibly carbonatite in the Cerro Impacto area) was intruded about 1,730 Ma. Undivided Proterozoic and possibly Archean(?) rocks in Estado Amazonas include granitic rocks, gneiss, and migmatite. Peak metamorphism and intrusion of these rocks occurred between about 1,860 and 1,730 Ma.

Unmetamorphosed rocks of the Roraima Group were deposited in fluvial, deltaic, shallow coastal marine, and lacustrine or epicontinental environments. The Roraima Group is possibly as old as about $1,900 \mathrm{Ma}$ and as young as about 1,500 Ma. Conglomeratic lenses and beds in the lower $500-600 \mathrm{~m}$ of the Roraima Group contain paleoplacers, some of which are the source of diamonds and gold in modern placer deposits. Mafic dikes, sills, and irregular intrusive bodies of the Avanavero Suite cut all earlier rocks of the Guayana Shield. These continental tholeiitic intrusions are about 1,650 Ma in age and possibly as old as about $1,850 \mathrm{Ma}$. Middle Proterozoic, 1.55-Ga rapakivi granite of the Parguaza terrane hosts occurrences of tin in quartz veins. Major deposits of bauxite are developed on the Parguaza Granite. Continental collision during the Nickerie orogeny in the westernmost part of the Guayana Shield reset mineral ages in Archean and Early Proterozoic rocks of the central and eastern parts of the shield to about $1,200 \mathrm{Ma}$. The Nickerie orogeny is equivalent to the Grenville orogeny in North America.

Diabase dikes intruded the Guayana Shield during the opening of the Atlantic Ocean about 210-200 Ma. Kimberlite and carbonatite may have been intruded during the Mesozoic. Six planar geomorphic surfaces developed at distinct elevations in the Guayana Shield during the Mesozoic and Cenozoic eras. Deposits of bauxite and enriched banded iron formation formed on the early Tertiary Imataca-Nuria surface. Gold and diamond placers are present in modern major river channels and in colluvial-alluvial deposits of low-order drainages.

\section{REFERENCES CITED}

Aarden, H.M., and Davidson, M.T., 1977, Minerales de estaño, niobio, tántalo y titanio en la zona del Caño Aguamena, Estado Bolívar, analizades con microsonda de electrones: Congreso Geológico Venezolano, 5th, Caracas, 1977, Memoria, v. 3, p. $919-940$.

Aarden, H.M., Iturralde de Arozena, J.M., Navarro, Jorge, Moticska, Peter, Pasquali Z., Jean, and Sifontes, R.S., 1978, Geología del área del Cerro Impacto [abs.]: Congreso Latinoamericano de Geología, 2nd, Caracas, 1973, Memoria, Publicación Especial 7, v. 5, p. 3897-3898.

Allègre, C.J., and Ben Othman, Dalila, 1980, Nd-Sr isotopic relationship in granitoid rocks and continental crust development-A chemical approach to orogenesis: Nature, v. 286, p. 335-342.

Amaral, Gilberto, and Halpern, Martin, 1975, K-Ar and Rb-Sr age studies on the extensive Precambrian volcanism of the Brazilian Amazon region: Conferencia Geológica Interguianas, 10th, Belém, Brazil, 1975, Memoria, p. 474-487.

Ascanio T., Gustavo, 1975, El Complejo de Imataca en los alrededores de Cerro Bolívar, Estado Bolívar, Venezuela: Conferencia Geológica Interguianas, 10th, Belém, Brazil, 1975, Memoria, p. 181-197.

1985, Yacimientos de mineral de hierro del Precámbrico de Venezuela: Simposium Amazonico, 1st, Caracas, 1985, Publicación Especial 10, p. $464-473$.

Ascanio T., Gustavo, Mendoza, Vicente, Candelaria, Juan, and García, Andrés, 1985, Sección geológica de La Escalera-Santa Elena, Estado Bolívar, Venezuela: Congreso Geológico Venezolano, 6th, Caracas, 1985, Memoria, v. 3, p. 1409-1431.

Banerjee, A.K., and Moorhead, G.A., 1970, Gold and sulphide mineralisation in the Guiana Shield: Inter-Guiana Geological Conference, 8th, Georgetown, 1969, Proceedings, Paper 7, 24 p.

Baptista G., J., and Svisero, D.P., 1978, Geología de los depositos diamantíferos de la parte noroccidental de la Guayana Venezolana: Venezuela, Ministerio de Energía y Minas, Dirección General Sectorial de Minas y Geología, Boletín de Geología, v, 13 , no. 24 , p. 3-46.

Bamard, Fred, 1990, Gold rush arrives in Guiana Shield: Engineering and Mining Journal, v. 191, p. 57-63.

Barrios, Fernando, Cordani, Umberto, and Kawashita, Koji, 1985 , Caracterización geocronologica del Territorio Federal Amazonas, Venezuela: Congreso Geológico Venezolano, 6th, Caracas, 1985, Memoria, v. 3, p. 1432-1480.

Barron, C.N., 1969, Notes on the stratigraphy of Guyana: Guiana Geological Conference, 7th, Paramaribo, Suriname, 1966, Proceedings, Geological Survey of Guyana Records, v. 6, Paper 21-1, p. 1-28.

1973, A further guide to mineral exploration in Guyana forming a supplement to Bulletin 38: Geological Survey of Guyana Bulletin $38 \mathrm{a}, 39 \mathrm{p}$.

Basei, M.A.S., and Teixeira, Wilson, 1975, Geocronologia do Território de Roraima: Conferencia Geológica Interguianas, 10th, Belém, Brazil, 1975, Memoria, p. 453-473. 
Bateson, J.H., 1966, Some aspects of the geology of the Roraima Formation in British Guiana: Caribbean Geological Conference, 3rd, Kingston, Jamaica, 1962, Transactions, p. 144-150.

Bellizzia G., Alirjo, Pimentel de Bellizzia, Nelly, and Rodriguez, S.E., 1981, Recursos minerales de Venezuela y su relación a la metalogenesis: Venezuela, Ministerio de Energia y Minas, Publicación Especial 8, p. 6-77.

Ben Othman, Dalila, Polvé, Mireille, and Allègre, C.J., 1984, Nd-Sr isotopic composition of granulites and constraints on the evolution of the lower continental crust: Nature, v. 307, p. 510-515.

Benaim, Nesin, 1972, Geología de la region de Botanamo, Edo. Bolívar: Congreso Geológico Venezolano, 4th, Caracas, 1971, Memoria, Publicación Especial 5, v. 3, p. 1291-1314.

-1974, Geología de la región El Dorado-AnacocoBotanamo, Estado Bolívar: Conferencia Geológica Inter-Guayanas, 9th, Ciudad Guayana, Venezuela, 1972, Memoria, Publicación Especial 6, p. 198-206.

Berger, B.R., 1986, Descriptive model of low-sulfide Au-quartz veins, in Cox, D.P., and Singer, D.A., eds., Mineral deposit models: U.S. Geological Survey Bulletin 1693, p. 239.

Berrange, J.P., 1977, The geology of southern Guyana, South America: Institute of Geological Sciences, London, Overseas Division Memoir, v. 4, 112 p.

Black, Russell, 1980, Precambrian of West Africa: Episodes, v. 1980 , no. 4 , p. 3-8.

Blanc, C., Mesnier, H.P., Plat, R., and Zeegers, Hubert, 1980, Datos nuevos sobre los yacimientos de oro primario en Guyana Francesa y su prospección: Caribbean Geological Conference, 9th, Sarto Domingo, Dominican Republic, 1980, Transactions, p. 273-276.

Boher, Muriel, Abouchami, Wafa, Michard, Annie, Albarede, Francis, and Andt, N.T., 1992, Crustal growth in West Africa at $2.1 \mathrm{Ga}$ : Journal of Geophysical Research, v. 97, no. B1, p. $345-369$.

Bonhomme, M.G., and Bertrand-Sarfati, Janine, 1982, Correlation of Proterozoic sediments of western and central Africa and South America based upon radiochronological and palacontological data: Precambrian Research, v. 18, p. 171-194.

Bosma, W., Kroonenberg, S.B., Maas, K., and De Roever, E.W.F., 1983, Igneous and metamorphic complexes of the Guiana Shield in Suriname: Geologie en Mijnbouw, v. 62, p. 241-254.

Briceño M., H.O., 1984, Genesis de yacimientos minerales Venezolanos II-Placeres diamantíferos de San Salvador de Paúl: Acta Cientifica Venezolana, v. 36, p. 154-158.

Briceño, H.O., and Schubert, Carlos, 1990, Geomorphology of the Gran Sabana, Guayana Shield, southeastem Venezuela: Geomorphology, v. 3, p. 125-141.

Briceño, H.O., Schubert, Carlos, and Paolini, J., 1990, Table-mountain geology and surficial geochemistry-Chimantá Massif, Venezuelan Guayana Shield: Journal of South American Earth Sciences, v. 3, p. 179-194.

Briceño, H.O., Tapia, Jhonny, and Estanga, Jazmin, 1989, Formación Ichún, volćanismo acido del Grupo Roraima: Congreso Geológico Venezolano, 7th, Barquisimeto, Venezuela, 1989, Memoria, v. 1, p. 58-81.

Brooks, W.E., and Nuñez, Femando, 1991, Road reconnaissance of anomalous radioactivity in the Early Proterozoic Roraima Group near Santa Elena de Uairen, Estado Bolivar, Venezuela: U.S. Geological Survey Open-File Report 91-632, 10 p.
Caen-Vachette, Michelle, 1988, Le crat on ouest-africain et le bouclier guyanais-Un seul craton au Protérozoĭque inférieur?: Journal of African Earth Sciences, v. 7, p. 479-488.

Cahen, Lucien, Snelling, N.J., Delhal, Jacques, and Vail, J.R., 1984, The geochronology and evolution of Africa: Oxford, Clarendon Press, 512 p.

Candiales, L.J., 1961, Descubrimiento y exploración de bauxita en Venezuela: Congreso Geológico Venezolano, 3rd, Caracas, 1959 , v. 4, p. 1661-1680.

Carter, J.W., and Fernandes, L.L., 1969, The stratigraphical, lithological and structural controls to mineralization within the Barama-Mazanuni Assemblage: Geological Survey of Guyana, Records, v. 6, Paper 12-1, p. 12-1-12-22.

Choudhuri, Asit, 1978, Geochemical trends in tholeiite dykes of different ages from Guiana: Chemical Geology, v. 22, p. $79-85$.

1980, The Early Proterozoic greenstone belt of the northern Guiana Shield, South America: Precambrian Research, v. 13, p. 363-374,

Choudhuri, Asit, Iyer, S.S., and Vasconcellos, M.B.A., 1984, U, Th, and rare earth elements in Mesozoic tholeiite dykes from the northern Guiana Shield: Symposium Amazonico, 2nd, Manaus, Brazil, 1984, Anais, p. 171-177.

Cohen, H.A., and Gibbs, A.K., 1989, Is the equatorial Atlantic discordant?: Precambrian Research, v. 42, p. 353-369.

Cordani, U.G., and Brito Neves, B.B. de, 1982, The geologic evolution of South America during the Archaean and Early Proterozoic: Revista Brasileira de Geociêncjas, v. 12, no, 1-3, p. $78-88$.

Cox, D.P., Gray, Floyd, Acosta, Juan, Stewart, J.H., Arespón, Jesús, Brooks, W.E., Franco, Luis, Salazar, Edixon, and Lopez, Yolanda, 1993, Geologic map of the Guri and southern part of the Tucupita $2^{\circ} \times 3^{\circ}$ quadrangles, Bolívar State, Venezuela: U.S. Geological Survey Miscellaneous Field Studies Map MF-2242, scale 1:500,000.

Cox, D.P., Wynn, J.C., Sidder, G.B., and Page, N.J, 1993, Geology of the Venezuelan Guayana Shield, in U.S. Geological Survey and Corporación Venezolana de Guayana, Técrica Minera, C.A., Geology and mineral resource assessment of the Venezuelan Guayana Shield: U.S. Geological Survey Bulletin 2062, p. $9-15$.

Dahlberg, E.H., 1975, The metallogenic map of Suriname: Conferencia Geológica Interguianas, 10th, Belém, Brazil, 1975, Memoria, p. 706-714.

Dall'Agnol, Roberto, 1982, Os granitos anorogenicos da Amazonia Brasileira-Suas analogias com os "Younger Granites" do oeste da Africa: Congreso Latinoamericano de Geología, 5th, Buenos Aires, 1982, Actas, v. 2, p. 113-131.

Dall'Agnol, Roberto, Bettencourt, J.S., Jorge-João, X.S., Medeiros, Hamilton de, Costi, H.T., and Macambira, M.J.B., 1987, Granitogenesis in northern Brazilian region-A review: Revista Brasileira de Geociências, v. 17, p. 382-403.

Dall'Agnol, Roberto, Dreher, A.M., Araujo, J.F.V., and Abreu, A.S., 1975, Granito Surucucu: Conferencia Geológica Interguianas, 10th, Belém, Brazil, 1975, Memoria, p. 340-388.

Dall'Agnol, Roberto, Lafon, J.-M., and Macambira, M.J.B., 1994, Proterozoic anorogenic magmatism in the Central Amazonian Province, Amazonian Craton-Geochronological, petrological and geochemical aspects: Mineralogy and Petrology, v. 50, p. 113-138. 
Dalrymple, G.B., 1979, Critical tables for conversion of K-Ar ages from old to new constants: Geology, v. 7, p. 558-560.

Dalrymple, G.B., Grommé, C.S., and White, R.W., 1975, Potassium-argon age and paleomagnetism of diabase dikes in Liberia-Initiation of central Atlantic rifting: Geological Society of America Bulletin, v. 86, p. 399-411.

Dalziel, I.W.D., 1992, On the organization of American plates in the Neoproterozoic and the breakout of Laurentia: GSA Today, v. 2 , no. 11 , p. $237,240-241$.

Damasceno, E.C., 1982, Archean and Early Proterozoic mineral deposits in Brazil: Revista Brasileira de Geociencias, International Symposium on Archean and Early Proterozoic Geologic Evolution and Metallogenesis, Salvador, Bahia, Brazil, 1982, v. 12 , no. 1-3, p. 426-436.

1988, Geologia do estanho, in Schobbenhaus, Carlos, and Coelho, C.E.S., coordinators, Principais depósitos minerais do Brasil: Brasília, Departamento Nacional da Produção Mineral, v. 3, Metais básicos não-ferrosos, ouro e alumínio, p. 181-199.

Daoud, W.E.K., and Antonietto, Aldo, Jr,, 1988, Mina de estanho de Pitinga, Amazonas, in Schobbenhaus, Carlos, and Coelho, C.E.S., coordinators, Principais depósitos minerais do Brasil; Brasília, Departamento Nacional da Produção Mineral, v. 3, Metais básicos não-ferrosos, ouro e alumínio, p. 201-211.

Day, W.C., Franco, Luis, and Quintana, Enot, 1989, Bedrock geology and geochemistry of the Anacoco Sur II area, Bolívar State, Venezuela: U.S. Geological Survey Open-File Report 89-305, 14 p.

De Loczy, Louis, 1973, Some problems of the tectonic framework of the Guiana Shield with special regard for the Roraima Formation: Geologische Rundschau, v. 62, p. 318-342.

De Roever, E.W.F., and Bosma, W., 1975, Precambrian magmatism and regional metamorphism in Suriname: Conferencia Geológica Interguianas, 10th, Belém, Brazil, 1975, Memoria, p. 123-163.

De Vletter, D.R., and Kroonenberg, S.B., 1984, Review of some outstanding problems in the Precambrian geology of Surjname: Symposium Amazonico, 2nd, Manaus, Brazil, 1984, Anais, p. 163-170.

Doan, D.B., 1994, The mineral industry of Venezuela, in U.S. Department of the Interior, Bureau of Mines, Mineral industries of Latin America and Canada: Minerals Yearbook, 1992 International Review, v. 3, 9 p.

Dougan, T.W., 1974, Cordierite gneisses and associated lithologies of the Guri area, northwest Guayana Shield, Venezuela: Contributions to Mineralogy and Petrology, v. 46, p. 169-188.

1977, The Imataca Complex near Cerro Bolívar, Venezuela; a calc-alkaline Archean protolith: Precambrian Research, v. 4, no. 3, p. 237-268.

Drovenik, F., Kruk, Z., Tajder, M., and Talic, S., 1967, Menas manganesíferas de la región de Upata: Venezuela, Ministerio de Minas e Hidrocarburos, Boletín de Geología, v. 8, no. 17, p. 3-163.

Duffield, W.A., Reed, B.L., and Richter, D.H., 1990, Origin of rhyolite-hosted tin mineralization-Evidence from the Taylor Creek Rhyolite, New Mexico: Economic Geology, v. 85, p. 392-398.

Dzigoodi-Adjimah, Komla, 1993, Geology and geochemical pattems of the Birimian gold deposits, Ghana, West Africa: Journal of Geochemical Exploration, v, 47, p. 305-320.
Eisenlohr, B.N., and Hirdes, Wolfgang, 1992, The structural development of the early Proterozoic Birimian and Tarkwaian rocks of southwest Ghana, West Africa: Joumal of African Earth Sciences, v. 14, p. 313-325.

Elliot, R.G., 1986, The nature and distribution of primary gold in the oxidized zone of the Omai and Kaburi goldfields, central Guyana: Newsletter of International Liaison Group on Gold Mineralization, October 1986, no. 3, p. 56-57.

Engineering and Mining Joumal, 1987, Gold could be a key to Venezuela's economic future: Engineering and Mining Journal, October 1987, v. 118, p. 16G-16K.

Ensminger, H.R., 1992, Venezuela, in Bureau of Mines minerals yearbook, 1990 international review: Washington, U.S. Department of the Interior, v. 3, p. 313-324.

Faure, Gunter, 1986, Principles of isotope geology (2nd ed.): New York, John Wiley and Sons, 589 p.

Feybesse, J.-L., and Milési, J.-P., 1994, The Archaean/Proterozoic contact zone in West Africa-A mountain belt of décollement thrusting and folding on a continental margin related to $2.1 \mathrm{Ga}$ convergence of Archaean cratons?: Precambrian Reserach, v. 69 , p. 199-227.

Feybesse, J.-L., Milési, J.-P., Johan, Véra, Dommanget, Alain, Calvez, J.-Y., Boher, Muriel, and Abouchami, Wafa, 1989, La limite Archéen/Protérozoïque inférieur d'Afrique de l'Ouest-Une zone de chevauchement majeure antérieure à l'accident de Sassandra; l'exemple des régions d'Odiénné et de Touba (Côte-d'Ivoire): Comptes Rendus de l'Académie des Sciences, France, v. 309, p. 1847-1853.

Frick, U., and Steiger, R.H., 1974, K-Ar dating of some Guyana Shield dyke rocks, appendix in Gansser, August, The Roraima problem (South America), in Jung, Peter, ed., Contributions to the geology and paleobiology of the Caribbean and adjacent areas: Verhandlungen der Naturforschenden Gesellschaft in Basel, v. 84 , no. 1, p. $98-100$.

Gallagher, M.J., 1976, Recommendations for an initial five-year programme of uranium exploration in Venezuela: International Atomic Energy Agency/TA Report 1173, 30 p.

Gansser, August, 1954, The Guiana Shield (S. America): Eclogae Geologicae Helvetiae, v. 47, p. 77-112.

1974, The Roraima problem (South America), in Jung, Peter, ed., Contributions to the geology and paleobiology of the Caribbean and adjacent areas: Verhandlungen der Naturforschenden Gesellschaft in Basel, v. 84, no. 1, p. 80-97.

Gaudette, H.E., Mendoza, Vicente, Hurley, P.M., and Fairbairn, H.W. 1978, Geology and age of the Parguaza rapakivi granite, Venezuela: Geological Society of America Bulletin, v. 89, p. 1335-1340.

Gaudette, H.E., and Olszewski, W.J., Jr., 1985, Geochronology of the basement rocks, Amazonas Territory, Venezuela and the tectonic evolution of the western Guiana Shield: Geologie en Mijnbouw, v. 64, p. 131-143.

George, Uwe, 1989, Venezuela's islands in time: National Geographic, v. 175 , p. 526-561.

Ghosh, S.K., 1977, Geología del Grupo Roraima en Territorio Federal Amazonas: Congreso Geológico Venezolano, 5th, Caracas, 1977, Memoria, v. 1, p. 167-193.

1985, Geology of the Roraima Group and its implications: Simposium Amazonico, 1st, Caracas, 1981, Publicación Especial 10, p. 31-50. 
Gibbs, A.K., 1980, Geology of the Barama-Mazaruni Supergroup of Guyana: Cambridge, Massachusetts, Harvard University, Ph.D. thesis, $385 \mathrm{p}$.

1986, Contrasting styles of continental mafic intrusions in the Guiana Shield, in Halls, H.C., and Fahrig, W.F., eds., Mafic dyke swarms: Geological Association of Canada Special Paper 34, p. 457-465.

___ 1987, Proterozoic volcanic rocks of the northern Guiana Shield, South America, in Pharoah, T.C., Beckinsale, R.D., and Rickard, D., eds., Geochemistry and mineralization of Proterozoic volcanic suites: Geological Society of London Special Publication 33, p. 275-288.

Gibbs, A.K., and Barron, C.N., 1983, The Guiana Shield reviewed: Episodes, v. 1983, no. 2, p. 7-14.

1993, The geology of the Guiana Shield: New York, Oxford University Press, Oxford Monographs on Geology and Geophysics 22, 246 p.

Gibbs, A.K., O'Day, P.A., and Renner, Rebecca, 1984, Recent work on the Barama-Mazaruni Supergroup of Guyana: Symposium Amazonico, 2nd, Manaus, Brazil, 1984, Anais, p. $39-52$.

Gibbs, A.K., and Olszewski, W.J., Jr., 1982, Zircon U-Pb ages of Guyana greenstone-gneiss terrane: Precambrian Research, v. 17 , p. $199-214$.

Gibbs, A.K., and Wirth, K.R., 1986, Origin and evolution of the Amazonian Craton, in Ashwal, L.D., ed., Workshop on early crustal genesis; world's oldest rocks: Godthab, Greenland, July 21-30, 1985, LPI Technical Report, v. 86-04, p. 46-50.

Goldstein, S.L., and Amdt, N.T., 1988, History of a continent from a sample of river sand [abs.]: Chemical Geology, v. 70, p. 68.

Goodwin, A.M., 1991, Precambrian geology-The dynamic evolution of the continental crust: New York, Academic Press, 655 p.

Graterol, Victor, 1974, Resultados de la prospección geofísica en las zonas de Vuelvan Caras y Botanamo, Edo. Bolívar: Conferencia Geológica Inter-Guayanas, Ciudad Guayana, Venezuela, 1972, Memoria, Publicación Especial 6, p. 529-549.

Gruau, Gerard, Martin, Herve, Leveque, Bernard, Capdevila, Raymond, and Marot, Alain, 1985, Rb-Sr and Sm-Nd geochronology of Lower Proterozoic granite-greenstone terrains in French Guiana, South America: Precambrian Research, v. 30 , p. $63-80$.

Gruss, H., 1973, Itabirite iron ores of the Liberia and Guyana shields, in Genesis of Precambrian iron and manganese deposits: Kiev Symposium, August 1970, Proceedings; Earth Sciences, v. 9, p. $335-359$.

Hargraves, R.B., 1968, Paleomagnetism of the Roraima dolerites: Geophysical Journal of the Royal Astronomical Society, v. 16, p. 147-160.

1978, Problems in palaeomagnetic synthesis illustrated by results from Permo-Triassic dolerites in Guyana: Physics of the Earth and Planetary Interiors, v. 16, p. 277-284.

Hawkes, D.D., 1966a, The petrology of the Guiana dolerites: Geological Magazine, v. 103, p. 320-335.

$1966 \mathrm{~b}$, Differentiation of the Tumatumari-Kopinang dolerite intmsion, British Guiana: Geological Society of America Builetin, v. 77, p. 1131-1158.

Hebeda, E.H., Boelrijk, N.A.I.M., Priem, H.N.A., Verdurmen, E.A.Th., and Verschure, R.H., 1973, Excess radiogenic argon in the Precambrian Avanavero dolerite in western Suriname
(South America): Earth and Planetary Science Letters, v, 20, p. 189-200.

Hedge, C.E., Marvin, R.F., and Naeser, C.W, 1975, Age provinces in the basement rocks of Liberia: U.S. Geological Survey Journal of Research, v. 3, p. 425-429.

Hirdes, Wolfgang, Davis, D.W., and Eisenlohr, B.N., 1992, Reassessment of Proterozoic granitoid ages in Ghana on the basis of $\mathrm{U} / \mathrm{Pb}$ zircon and monazite dating: Precambrian Research, v. 56, p. $89-96$.

Holtrop, J.F., 1965, The manganese deposits of the Guiana Shield: Economic Geology, v. 60, p. $1185-1212$.

Hurley, P.M., Fairbaim, H.W., and Gaudette, H.E., 1976, Progress report on Early Archean rocks in Liberia, Sierra Leone and Guayana, and their general stratigraphic setting, in Windley, B.F., ed., The early history of the Earth: New York, John Wiley and Sons, p. 51 1-52l.

Hurley, P.M., Fairbairn, H.W., Gaudette, H.E., Mendoza, Vicente, Martin, Cecilia, and Espejo, Anibal, 1977, Progress report on $\mathrm{Rb}-\mathrm{Sr}$ age dating in the northem Guayana Shield: Congreso Latinoamericano de Geología, 2nd, Caracas, 1973, Memoria, Publicación Especial 7, v. 4, p. 3035-3044.

Hutchinson, R.W., 1987, Metallogeny of Precambrian gold deposits-Space and time relationships: Economic Geology, v. 82, p. 1993-2007.

Issler, R.S., and Lima, M.I.C. de, 1987, Amazonic craton (Brazil) granitogenesis and its relation to geotectonic units: Revista Brasileira de Geociências, v. 17, p. 426-441.

Jones, J.P., Yamada, E.H., Marques, C.G.M., Yokoi, O.Y., and Yamamoto, M.F., 1986, Some aspects of the geology of the newly discovered tin deposits of Brazil: Mining Latin Amenca/Minería Latinoamericana Conference, Santiago, Chile, 1986, Institution of Mining and Metallurgy, London, p. 165-182.

Kalliokoski, Joseph, 1965, Geology of north-central Guayana Shield, Venezuela: Geological Society of America Bulletin, v. 76, p. $1027-1050$.

Keats, W., 1974, The Roraima Formation in Guyana: Congreso Latinoamericano de Geología, 2nd, Caracas, 1973, Memoria, Publicaciôn Especial 7, v. 2, p. 901-940.

Kesse, G.O., 1985, The mineral and rock resources of Ghana: Boston, A.A. Balkema, 610 p.

Kisvarsanyi, E.B., and Kisvarsanyi, Geza, 1989, Alkaline granite ring complexes and metallogeny in the Middle Proterozoic St. Francois terrane, southeastern Missouri, U.S.A., in Gower,

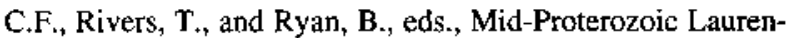
tia-Baltica: Geological Association of Canada Special Paper $38,14 \mathrm{p}$.

Kisvarsanyi, Geza, 1975, Genesis of the Precambrian St. Francois terrane, midcontinent, U.S.A., in Lowell, G.R., ed., A field guide to the Precambrian geology of the St. Francois Mountains, Missouri: Cape Girardeau, Southeast Missouri State University, p. 49-54.

Klar, Giampaolo, 1979, Geochronology of the El Manteco-Guri and Guasipati areas, Venezuelan Guiana Shield: Cleveland, Case Western Reserve University, Ph.D. dissertation, 163 p. (Dissertation Abstracts Intemational, Sec. B, Sciences and Engineering, v. 39, p. 5284-B.)

Korol, Bohdan, 1961, Genesis de los yacimientos auríferos en las rocas verdes de la Serie Pastora: Congreso Geológico Venezolano, 3rd, Caracas, 1959, v. 4, p. 1881-1889. 
1965, Estratigrafía de la Serie Pastora, región Guasipati-El Dorado: Ministerio de Minas e Hidrocarburos, Boletín de Geología, v. 7, no. 13, p. 3-18.

Kovach, Adam, Fairbairn, H.W., Hurley, P.M., Basei, M.A.S., and Cordani, U.G., 1976, Reconnaissance geochronology of basement rocks from the Amazonas and Maranhão Basins in Brazil: Precambrian Research, v. 3, p. $471-480$.

Kroonenberg, S.B., 1982, A Grenvillian granulite belt in the Colombian Andes and its relation to the Guiana Shield: Geologie en Mijnbouw, v. 61, p. 325-333.

Kroonenberg, S.B., and Melitz, P.J., 1983, Summit levels, bedrock control, and the etchplain concept in the basement of Surinam: Geologie en Mijnbouw, v. 62, p. 389-399.

Ledru, Patrick, Johan, Véra, Milési, J.P., and Tegyey, Monique, 1994, Markers of the last stages of the Palaeoproterozoic collision-Evidence for a $2 \mathrm{Ga}$ continent involving circum-South Atlantic provinces: Precambrian Research, v. 69, p. 169-191.

Leube, Alfred, Hirdes, Wolfgang, Mauer, Rudolf, and Kesse, G.O., 1990, The Early Proterozoic Birimian Supergroup of Ghana and some aspects of its associated gold mineralization: Precambrian Research, v. 46, p. 139-165.

Liégeois, J.P., Claessens, W., Camara, D., and Klerkx, J., 1991, Short-lived Eburnian orogeny in southern Malj-Geology, tectonics, U-Pb and Rb-Sr geochronology: Precambrian Research, v. 50, p. 111-136.

Lima, M.I.C. de, 1984, Provincias geológicas do craton Amazônico em Território Brasileiro: Symposium Amazonico, 2nd, Manaus, Brazil, 1984, Arais, p. 9-23.

Lira, Pedro, Martínez, Jesús, Rodríguez, Baltazar, and Sosa, César, 1985, Reconocimiento geológico de la zona Botanamo-Akarabisí, Estado Bolívar: Congreso Geológico Venezolano, 6th, Caracas, 1985, Memoria, v. 3, p. 1758-1782.

Macambira, M.J.B., Teixeira, J.T., Daoud, W.E.K., and Costi, H.T., 1987, Geochemistry, mineralizations and age of tin-bearing granites from Pitinga, northwestern Brazil: Revista Brasileira de Geociências, v. 17 , no. 4 , p. $562-570$.

Macdonald, J.R., 1968, A guide to mineral exploration in Guyana: Geological Survey of Guyana Bulletin 38, 91 p.

MacDonald, W.D., and Opdyke, N.D., 1974, Triassic paleomagnetism of northern South America: American Association of Petroleum Geologists Bulletin, v. 58, p. 208-215.

Machado, N., Lindenmayer, Z.G., Krogh, T.E., and Lindenmayer, D., 1991, U-Pb geochronology of Archean magmatism and basement reactivation in the Carajás area, Amazon shield, Brazil: Precambrian Research, v. 49, p. 329-354.

Marcoux, Eric, Ouedraogo, M.-F., Feybesse, J.-L., Milési, J.-P., and Prost, André, 1988, Géochimie et géochronologie isotopiques-Age $\mathrm{Pb} / \mathrm{Pb}$ à 2 I $20 \pm 41$ Ma des corps sulfurés massifs à Zn-Ag de Perkoa (Burkina Faso): Comptes Rendus de l'Académie des Sciences, France, v. 306, p. 589-595.

Mauche, Renée, Faure, Gunter, Jones, L.M., and Hoefs, Jochen, 1989, Anomalous isotopic compositions of $\mathrm{Sr}, \mathrm{Ar}$ and $\mathrm{O}$ in the Mesozoic diabase dikes of Liberia, West Africa: Contributions to Mineralogy and Petrology, v, 101, p. 12-18.

McDougall, Ian, 1968, Isotopic dating of the Roraima dolerites: Geophysical Journal of the Royal Astronomical Society, v. 16, p. 141-145.

McDougall, Ian, Compston, W, and Hawkes, D.D., 1963, Leakage of radiogenic argon and strontium from minerals in Proterozoic dolerites from British Guiana: Nature, v. 198, p. 564-567.
McKitrick, S.A., Norman, D.I., and Appiah, Henry, 1993, Proterozoic Ghanian metakimberlites [abs.]: EOS, Transactions, American Geophysical Union, v. 74, no. 43, p. 679.

Mendoza S., Vicente, 1974, Geology of the Suapure River area, NW Guiana Shield, Venezueja: Binghamton, New York, State University of New York, Ph.D. dissertation, $230 \mathrm{p}$.

1975, Estudios geoquímicos del no-tectonizado granito rapakivi del Parguaza, noroeste Guyana Venezolana: Conferencia Geológica Interguianas, 10th, Belém, Brazil, 1975, Memoria, p. 628-656.

1977a, Evolución tectónica del Escudo de Guayana: Congreso Latinoamericano de Geología, 2nd, Caracas, 1973, Memoria, Publicación Especial 7, v. 3, p. 2237-2270.

$1977 \mathrm{~b}$, Petrogénesis de rocas volcánicas (-piroclásticas) precámbricas del noroeste del Escudo de Guayana, Venezuela: Congreso Geológico Venezolano, 5th, Caracas, 1977 , Memoria, v. 2, p. 555-589.

1985, Potencial aurífero de Guayana; trabajo en progreso: Congreso Geológico Venezolano, 6th, Caracas, 1985 , Memoria, v. 6, p. 4038-4068.

Mendoza, Vicente, Moreno, L.A., Bartios, Fernando, Rivas, Duggar, Martínez, Jesús, Lira, Pedro, Sardi, Gustavo, and Ghosh, S.K., 1977, Geología de la parte norte del Territorio Federal Amazonas, Venezuela (informe en progreso): Congreso Geológico Venezolano, 5th, Caracas, 1977, Memoria, v. 1, p. 363-404.

Mendoza, Vicente, Rios, J.H., Moreno, L.A., Benaim, Nesin, and Tepedino, Victor, 1975, Evolución geoquímica de rocas graníticas de la Guayana Venezolana: Conferencia Geológica Interguianas, 10th, Belém, Brazil, 1975, Memoria, p. 558-575.

Menendez V. de V., Alfredo, 1968, Revisión de la estratigrafía de la Provincia de Pastora según el estudio de la región de Guasipati, Guayana Venezolana: Ministerio de Minas e Hidrocarburos, Boletín de Geología, v. 10, no. 19, p. 309-338.

1972, Geología de la región Guasipati, Guayana Venezolana: Congreso Geológico Venezolano, 4th, Caracas, 1971, Memoria, Publicación Especial 5, v. 4, p. 2001-2046.

1974, Guia de la excursión geológica Guasipati-El Callao-Canaima: Conferencia Geológica Inter-Guayanas, 9th, Ciudad Guayana, Venezuela, 1972, Memoria, Publicación Especial 6, p. 49-67.

Menendez V. de V., Alfredo, and Sarmentero, Alberto, 1985, Exploración de bauxita en la Guayana Venezolana con particular referencia a la Serranía de Los Pijiguaos: Simposium Amazonico, 1st, Caracas, 1981, Publicación Especial 10, p. 571-586.

Meyer, Charles, 1988, Proterozoic ore-forming habitats-Tectonic and chemical transitions, in Kisvarsanyi, Geza, and Grant, S.K., eds., North American Conference on Tectonic Control of Ore Deposits and the Vertical and Horizontal Extent of Ore Systems: University of Missouri-Rolla, Proceedings, p. 217-235.

Meyer, H.O.A., and McCallum, M.E., 1993, Diamonds and their sources in the Venezuelan portion of the Guyana Shield: Economic Geology, v. 88, p. 989-998.

Milési, J.-P., Feybesse, J.-L., Ledru, Patrick, Dommanget, Alain, Ouedraogo, M.F., Marcoux, Eric, Prost, André, Vinchon, Charlotte, Sylvain, J.-P., Johan, Vera, Tegyey, Monique, Calvez, J.-Y., and Lagny, Philippe, 1989, West African gold 
deposits in their Lower Proterozoic lithostructural setting: Chronique d€ la Recherche Minière, no. 497, p. 3-98.

Milési, J.-P., Ledru, Patrick, Feybesse, J.-L., Dommanget, Alain, and Marcoux, Eric, 1992, Early Proterozoic ore deposits and tectonics of the Brrimian orogenic beit, West Africa: Precambrian Research, v. 58, p. 305-344.

Montalvao, R.M.G. de, 1975, Grupo Uatuma do Craton Guianes: Conferencia Geológica Intergujanas, 10th, Belém, Brazil, 1975, Memoria, p. 286-339.

Montalvao, R.M.G. de, Muniz, M. de. B., Issler, R.S., Dall' Agnol, Roberto, Lima, M.I.C. de, Fernandes, P.E.C.A., and da Silva, G.G., 1975, Folha NA.20 Boa Vista e parte das Folhas NA.21 Tumucumaque, NB.20 Roraima e NB.21, Parte 1-Geologia: Rio de Janeiro, Levantamento de Recursos Naturais, Ministério das Minas e Energia, Departamento Nacional da Produção Mineral, Projecto RADAMBRASIL, v. 8, p. 13-136.

Montgomery, C.W., 1979, Uranium-lead geochronology of the Archean Imataca Series, Venezuelan Guayana Shield: Contributions to Mineralogy and Petrology, v. 69, p. 167-176.

Montgomery, C.W., and Hurley, P.M., 1978, Total-rock U-Pb and Rb-Sr systematics in the Imataca Series, Guayana Shield, Venezuela: Earth and Planetary Science Letters, v. 39, p. 281-290.

Moores, E.M., 1991, Southwest U.S.-East Antarctica (SWEAT) connection-A hypothesis: Geology, v. 19, p. 425-428.

Morel, S.W., 1979, Geology and mineral resources of Sierra Leone: Economic Geology, v. 74, p. 1563-1576.

Moreno, L.A., and Bertanj, César, 1985a, Mineralogía de algunas menas del Cerro San Isidro y sus implicaciones geneticas: Congreso Geológico Venezolano, 6th, Caracas, 1985 Memoria, v. 6, p. 4133-4156.

-1985b, Caracterización química del yacimiento de bauxita de Los Pijiguaos e influencia de las estructuras y morfología en el enriquecimiento de las menas, con enfasis en el bloque 3 de dicho yacimiento: Congreso Geológico Venezolano, 6th, Caracas, 1985, Memoria, v. 6, p. 4069-4132.

Moreno, L.A., Lira, Pedro, Mendoza, Vicente, and Rios, J.H., 1977, Análisis de edades radiometricas en la parte oriental de la Guayana Venezolana y eventos tectónicos-termales registrados: Congreso Geológico Venezolano, 5th, Caracas, 1977, Memoria, v. 2, p. 509-518.

Moreno, L.A., and Mendoza, Vicente, 1975, Petroquimica de rocas graníticas del alto Supamo SE Guayana Venezolana (en progreso): Conferencia Geológica Interguianas, 10th, Belém, Brazil, 1975, Memoria, p. 430-452.

Mortimer, J., 1992, Lithostratigraphy of the early Proterozoic Toumodi Volcanic Group in Central Côte d'Ivoire-Implications for Birrimian stratigraphic models: Joumal of African Earth Sciences, v. 14, p. 81-91.

Newman, H.R., 1989, The mineral industry of Venezuela: U.S. Bureau of Mines Minerals Yearbook 1987, p. 945-951.

Nixon, P.H., 1988, Diamond source rocks from Venezuela: Industrial Diamond Quarterly, no. 51, 1988/3, p. 23-29.

Nixon, P.H., and Condliffe, Eric, 1989, Yimengite of K-Ti metasomatic origin in kimberlitic rocks from Venezuela: Mineralogical Magazine, v. 53, p. 305-309.

Nixon, P.H., Davies, G.R, Condliffe, Eric, Baker, N.R., and Baxter Brown, R., 1989, Discovery of ancient source rocks of Venezuela diamonds [abs.]: Intemational Geological Congress, 28th, Washington, D.C., 1989, Workshop on Diamonds, p. $73-75$.
Nixon, P.H., Davies, G.R., Rex, D.C., and Gray, Alan, 1992, Venezuela kimberlites: Journal of Volcanology and Geothermal Research, v. 50, p. 101-115.

Norman, D.I, and Appiah, Henry, 1989, The Tarkwa paleoplacer gold deposit, Ghana: Geological Society of America Abstracts with Programs, v. 21, no. 6, p. A293-A294.

Ntiamoah-Agyakwa, Y., 1979, Relationship between gold and manganese mineralizations in the Birimian of Ghana, West Africa: Geological Magazine, v. 116, p. 345-352.

Olmore, S.D., and Estanga, Yasmin, 1989, Reconnaissance observations of a Tertiary(?) graben near Pie de Salto on the Caura River, Guayana Shield, Venezuela: Congreso Geológico Venezolano, 7th, Barquisimeto, Venezuela, 1989, Memoria, v. 1, p. $114-123$.

Olmore, S.D., and García Gerdes, Andrés, 1990, Cenozoic tectonic evolution of the northern margin of the Guiana Shjeld, Bolívar State, Venezuela: Geological Society of America Abstracts with Programs, v. 22, no. 7, p. A337.

Olmore, S.D., García, Andrés, and Antonio, S.C., 1993, Cenozoic uplift of the northern margin of the Guayana Shield, Venezuela, and its influence on the distribution of mineral deposits [abs.]: American Association of Petroleum Geologists-Sociedad Venezolana de Geólogos International Congress and Exhibition, Caracas, March 1993, p. 61.

Onstott, T.C., and Dorbor, Jenkins, $1987,{ }^{40} \mathrm{Ar} /{ }^{39} \mathrm{Ar}$ and paleomagnetic results from Liberia and the Precambrian APW data base for the West African Shiejd: Journal of African Earth Sciences, v. 6, p. $537-552$.

Onstott, T.C., Hall, C.M., and York, Derek, $1989,{ }^{40} \mathrm{Ar} /{ }^{39} \mathrm{Ar}$ thermochronometry of the Imataca Complex, Venezuela: Precambrian Research, v. 42 , p. $255-291$.

Onstott, T.C., and Hargraves, R.B., 1981, Proterozoic transcurrent tectonics-Palaeomagnetic evidence from Venezuela and Africa: Nature, v. 289, p. 131-136.

Onstott, T.C., Hargraves, R.B., and York, Derek, 1984, Dating of Precambrian diabase dikes of Venezuela using paleomagnetic and ${ }^{40} \mathrm{Ar} /{ }^{39} \mathrm{Ar}$ methods: Symposium Amazonico, 2nd, Manaus, Brazil, 1984, Anais, p. 513-518.

Onstott, T.C., Hargraves, R.B., York, Derek, and Hall, Chris, 1984, Constraints on the motions of South American and African Shields during the Proterozoic-I, ${ }^{40} \mathrm{Ar} /{ }^{39} \mathrm{Ar}$ and paleomagnetic correlations between Venezuela and Liberia: Geological Society of America Bulletin, v. 95, p. 1045-1054.

Opare-Addo, E., Browning, P., and John, B.E., 1993, Pressure-temperature constraints on the evolution of an Early Proterozoic plutonic suite in southern Ghana, West Africa: Joumal of African Earth Sciences, v. 17, p. 13-22.

Park, R.G., 1992, Plate kinematic history of Baltica during the Middle to Late Proterozoic-A model: Geology, v. 20, p. 725-728.

Patchett, J.P., and Ruiz, Joaquin, 1989, Nd isotopes and the origin of Grenville-age rocks in Texas-Implications for Proterozoic evolution of the United States mid-continent region: Journal of Geology, v. 97, p. 685-695.

Pearce, J.A., Harris, N.B.W., and Tindle, A.G., 1984, Trace element discrimination diagrams for the tectonic interpretation of granitic rocks: Joumal of Petrology, v. 25, p. 956-983.

Pérez, H.G., Salazar, Rolando, Peñaloza, Alberto, and Rodríguez, S.E., 1985, Evaluación geoeconómica de los aluviones que presentan minerales de $\mathrm{Ti}, \mathrm{Sn}, \mathrm{Nb}$ y $\mathrm{Ta}$ en el área de Boquerones y Aguamena, Distrito Cedeño del Estado Bolívar 
y Territorio Federal Amazonas: Simposium Amazonico, 1st, Caracas, 1981, Publicación Especial 10, p. 587-602.

Petersen, J.S., 1993, Exploration in tropical rain forest terrain-The Dabokrom gold project, westem region, Ghana, in Romberger, S.B., ed., Extended abstracts of technical presentations: Society of Economic Geologists, Integrated Methods in Exploration and Discovery, Denver, April 17-20, 1993, p. AB-85-AB-86.

Pimentel, M.M., Heaman, Larry, Fuck, R.A., and Marini, O.J., 1991, U-Pb zircon geochronology of Precambrian tin-bearing continental-type acid magmatism in central Brazil: Precambrian Research, v. 52, p. 321-335.

Pollard, E.R., Dixon, C.G., and Dujardin, R.A., 1957, Diamond resources of British Guiana: British Guiana Geological Survey Bulletin 28, 45 p.

Prasad, Gisela, 1983, A review of the early Tertiary bauxite event in South America, Africa, and India: Joumal of African Earth Sciences, v. 1, p. 305-313.

Premoli, C., and Kroonenberg, S.B., 1981, Radioactive mineral potential of carbonatites in western parts of the South American shields, in Geology and metallogenesis of uranium deposits of South America: Proceedings of a Working Group Meeting, San Luis, Argentina, 1981, Panel Proceedings Series, International Atomic Energy Agency STU/PUB/641, g. 245-268.

Priem, H.N.A., 1987, Isotopic tales of ancient continents: Geologie en Mijnbouw, v. 66, p. 275-292.

Priem, H.N.A., Andriessen, P.A.M., Boelrijk, N.A.I.M., de Boorder, H., Hebeda, E.H., Huguett, A., Verdurmen, E.A. Th., and Verschure, R.H., 1982, Geochronology of the Precambrian in the Amazonas region of southeastern Colombia (western Guiana Shield): Geologie en Mijnbouw, v, 61, p. 229-242.

Priem, H,N.A., Boelrijk, N.A.I.M., Hebeda, E.H., Kuijper, R.P., De Roever, E.W.F., Verdurmen, E.A. Th., Verschure, R.H., and Wielens, J.B.W., 1978, How old are the supposedly Archean charnockitic granulites in the Guiana Shield basement of western Suriname (South America)?, in Zartman, R.E., ed., Short papers of the Fourth International Conference, Geochronology, Cosmochronology, Isotope Geology, Snowmass-at-Aspen, Colorado, 1978: U.S. Geological Survey Open-File Report $78-701$, p. 341-343.

Priem, H.N.A., Boelrijk, N.A.I.M., Hebeda, E.M., Verdurmen, E.A. Th., and Verschure, R.H., 1973, Age of the Precambrian Roraima Formation in northeastem South America-Evidence from isotopic dating of Roraima pyroclastic volcanic rocks in Suriname: Geological Society of America Bulletin, v. 84, p. $1677-1684$.

Priem, H.N.A., Boelrijk, N.A.I.M., Hebeda, E.M., Verschure, R.H., and Verdurmen, E.A., 1971, Isotopic ages of the Trans-Amazonian acidic magmatism and the Nickerie metamorphic episode in the Precambrian basement of Suriname, South America: Geological Society of America Bulletin, v. 82, p. $1667-1680$.

Priem, H.N.A., Hebeda, E.H., Boelrijk, N.A.I.M., and Verschure, R.H., 1968, Isotopic age determinations on Surinam rocks, 3-Proterozoic and Permo-Triassic basalt magmatism in the Guiana Shield: Geologie en Mijnbouw, v. 47, p. 17-20.

Priem, H.N.A., Kroonenberg, S.B., Boelrijk, N.A.I.M., and Hebeda, E.H., 1989, Rb-Sr and K-Ar evidence for the presence of a $1.6 \mathrm{Ga}$ basement underlying the $1.2 \mathrm{Ga}$ Garzón-Santa Marta granulite belt in the Colombian Andes: Precambrian Research, v. 42, p. $315-324$.

Pringle, I.R., and Teggin, David, 1985, La edad de rocas piroclásticas intercaladas en el Grupo Roraima: Congreso Geológico Venezolano, 6th, Caracas, 1985, Memoria, v. 3, p. 1995-2008.

Reid, A.R., 1974a, Stratigraphy of the type area of the Roraima Group, Venezuela: Conferencia Geológica Inter-Guayanas, Ciudad Guayana, Venezuela, 1972, Memoria, Publicación Especial 6, p. 343-353.

1974b, Proposed origin for Guianian diamonds: Geology, v. 2 , no. 2 , p. $67-68$.

1976, An attempt to localize kimberlite source areas for Venezuelan diamonds from stratigraphy and analysis of diamond mineral inclusions: Golden, Colorado School of Mines, Ph.D. dissertation, 142 p.

Reid, A.R., and Bisque, R.E., 1975, Stratigraphy of the diamond-bearing Roraima Group, Estado Bolívar, Venezuela: Quarterly Bulletin of the Colorado School of Mines, v. 70, no. 1, p. 61-82.

Renne, P.R., Onstott, T.C., and Joao, S. da S.J., 1988, ${ }^{40} \mathrm{Ar} /{ }^{39} \mathrm{Ar}$ and paleomagnetic results from the Guapore Shield-Further implications for the nature of Middle-Late Proterozoic mobile belts of Gondwanaland: Congresso Latinoamericano de Geologia, 7th, Belém, Brazil, 1988, Anais, v. 1, p. 348-362.

Renner, Rebecca, and Gibbs, A.K., 1987, Geochemistry and petrology of metavolcanic rocks of the early Proterozoic Mazanuni greenstone belt, northem Guyana, in Pharoah, T.C., Beckinsale, R.D., and Rickard, D., eds., Geochemistry and mineralization of Proterozoic volcanic suites: Geological Society of London Special Publication 33, p. 289-309.

Riciputi, L.R., Johnson, C.M., Sawyer, D.A., and Lipman, P.W., $1990, \mathrm{Nd}, \mathrm{Sr}$, and $\mathrm{Pb}$ isotope evidence for crust/mantle interaction during silicic magmatism in the central San Juan caldera cluster, CO: Geological Society of America Abstracts with Programs, v. 22, no. 7, p. A256.

Rios, J.H., 1972, Geología de la región de Caicara, Estado Bolívar: Congreso Geológico Venezolano, 4th, Caracas, 1971, Memoria, Publicación Especial 5, v. 3, p. 1759-1782.

Rocci, Georges, Bronner, Georges, and Deschamps, M., 1991, Crystalline basement of the West African craton, in Dallmeyer, R.D., and Lécorché, J.P., eds., The West African orogens and circum-Atlantic correlatives: New York, Springer-Verlag, p. 29-61.

Rodríguez C., C.J., and Warden, A.J., 1993, Overview of some Colombian gold deposits and their development potential: Mineralium Deposita, v. 28, p. 47-57.

Rodríguez M., S.E., 1986, Recursos minerales de Venezuela; Caracas, Ministerio de Energía y Minas, Dirección General Sectorial de Minas y Geología, Boletín de Geología, v. 15, no. 27,228 p.

1987, Venezuela: Mining International, August 1987, p. $165-167$.

Rodíguez, S.E., Moya, E., Baptista G., J., Vasquez, J.C., Martin F., Cecilia, Vasquez, E., Marcano, F., and Vogel, S., 1976, Mapa metalogerico de Venezuela: Ministerio de Minas e Hidrocarburos, scale $1: 1,000,000$.

Rodríguez, S.E., and Pérez, H.G., 1982, Nb, Ta, and Sn mineralization related to granitic magmatism in western Bolívar State, Venezuela: International Association on the Genesis of Ore Deposits Symposium, 6th, Tbilisi, U.S.S.R., 1982, 10 p. 
Rogers, J.J., Dabbagh, M.E., Olszewski, W.J., Jr., Gaudette, H.E., Greenberg, J.K., and Brown, B.A., 1984, Early poststabilization sedimentation and later growth of shields: Geology, v. 12, p. 607-609.

Rollinson, H.R., and Cliff, R.A., 1982, New Rb-Sr age determinations on the Archaean basement of eastern Sierra Leone: Precambrian Research, v. 17, p. 63-72.

Rowley, D.B., and Pindell, J.L., 1989, End Paleozoic-Early Mesozoic western Pangean reconstruction and its implications for the distribution of Precambrian and Paleozoic rocks around Meso-America: Precambrian Research, v. 42, p. 411-444.

Ruckmick, J.C., 1963, The iron ores of Cerro Bolívar, Venezuela: Economic Geology, v. 58, p. 218-236.

Schobbenhaus, Carlos, Campos, D. de A., Derze, G.R., and Asmus, H.E., coordinators, 1984, Geologia do Brasil-Texto explicativo do mapa geológico do Brasil e da área oceânica adjacente incluindo depósitos minerais, escala 1:2,500,000: Brasflia, Departamento Nacional da Produção Mineral, 419 p.

Schubert, Carlos, Briceño, H.O., and Fritz, Peter, 1986, Paleoenvironmental aspects of the Caroni-Paragua River basin (southeastern Venezuela): Interciencia, v. 1 1, p. 278-289.

Schubert, Carlos, Fritz, Peter, and Aravena, Ramón, 1989, Investigaciones paleoambientales en el Macizo de Chimantá, Escudo de Guayana: Congreso Geologico Venezolano, 7th, Barquisimeto, Venezuela, 1989, Memoria, v. 3, p. 1320-1342

Short, K.C., and Steenken, W.F., 1962, A reconnaissance of the Guayana Shield from Guasipati to the Río Aro, Venezuela: Asociación Venezolana de Geología, Minería y Petroleo, Boletín Informativo, v. 5, no. 7, p. 189-221.

Sial, A.N., Oliveira, E.P., and Choudhuri, Asit, 1986, Mafic dyke swarms of Brazil, in Halls, H.C., and Fahrig, W.F., eds., Mafic dyke swanms: Geological Association of Canada Special Paper 34, p. $467-481$.

Sidder, G.B., 1991, Iron and manganese, in Gluskoter, H.J., Rice, D.D., and Taylor, R.B., eds., Economic geology, U.S.; Boulder, Colorado, Geological Socjety of America, The Geology of North America, v. P-2, p. 63-86.

Sidder, G.B., Brooks, W.E., Estanga, Yasmin, Nuñez, Fernando, and García, Andres, 1991, Early to Middle Proterozoic supracrustal rocks and mineralization of the southern Guayana Shield, Venezuela, in Good, E.E., Slack, J.F., and Kotra, R.K., eds., USGS Research on Mineral Resources-1991 Program and Abstracts: U.S. Geological Survey Circular 1062, p. 69.

Sidder, G.B., and Day, W.C., 1993, Fe-Cu-REE deposits in Middle Proterozoic rocks of the Midcontinent region of the United States-Are they Olympic Dam-type deposits: The Gangue, Geological Association of Canada, Mineral Deposits Division Newsletter, issue 42, p. 1-5.

Sidder, G.B., Day, W.C., Nuelle, L.M., Seeger, C.M., and Kisvarsanyi, E.B., 1993, Mineralogic and fluid-inclusion studies of the Pea Ridge iron-rare-earth-element deposit, southeast Missouri, in Scott, R.W., Jr., Detra, P.S., and Berger, B.R., eds., Advances related to United States and international mineral resources-Developing frameworks and exploration technologies: U.S. Geological Survey Bulletin 2039, p. 205-216.

Sidder, G.B., Day, W.C., Tosdal, R.M., Olmore, S.D., Guzman, Luis, and Prieto, Freddy, 1991, Evolution of an Early Proterozoic rift basin in the La Esmeralda area, Guayana Shield, Venezuela, in Good, E.E., Slack, J.F., and Kotra, R.K., eds.,
USGS Research on Mineral Resources-1991 Program and Abstracts: U.S. Geological Survey Circular 1062, p. 69-70.

Sidder, G.B., and Martinez, Felix, 1990, Geology, geochemistry, and mineral resources of the upper Caura River area, Bolívar State, Venezuela: U.S. Geological Survey Open-File Report 90-231, 29 p.

Sims, P.K., 1988, The Precambrian basement of the northern midcontinent, U.S.A.-A major frontier for mineral exploration, in Kisvarsanyi, Geza, and Grant, S.K., eds., North American Conference on Tectonic Control of Ore Deposits and the Vertical and Horizontal Extent of Ore Systems: University of Missouri-Rolla, Proceedings, p. 236-244.

Sims, P.K., Kisvarsanyi, E.B., and Morey, G.B., 1987, Geology and metallogeny of Archean and Proterozoic basement terranes in the northem midcontinent, U.S.A.-An overview: U.S. Geological Survey Bulletin 1815, $51 \mathrm{p}$.

Sims, P.K., Van Schmus, W.R., Schulz, K.J., and Peterman, Z.E., 1989, Tectono-stratigraphic evolution of the Early Proterozoic Wisconsin magmatic terranes of the Penokean Orogen: Canadian Journal of Earth Sciences, v. 26, p. 2145-2158.

Singh, Sobharam, 1974, The tectonic evolution of that portion of the Guiana Shield represented in Guyana-An evaluation of the present status of investigations and correlations across the Guiana Shield: Revista Brasileirà de Geociências, v, 4, p. $41-49$.

Snelling, N.J., 1963, Age of the Roraima Formation, British Gujana: Nature, v. 198, p. 1079-1080.

Snelling, N.J., and McConnell, R.B., 1969, The geochronology of Guyana: Geologie en Mijnbouw, v. 48, p. 201-213.

Stciger, R.H., and Jäger, Emilie, 1977, Subcommission on geochronology - Convention on the use of decay constants in geo- and cosmochronology: Earth and Planetary Science Letters, v. 36, p. $359-362$.

Storey, B.C., 1993, The changing face of late Precambrian and early Palaeozoic reconstructions: Journal of the Geological Society, London, v. 150, p. 665-668.

Storey, B.C., Pankhurst, R.J, and Johnson, A.C., 1994, The Grenville Province within Antarctica-A test of the SWEAT hypothesis: Journal of the Geological Society, London, v. 151, p. $1-4$.

Swapp, S.M., and Onstott, T.C., 1989, P-T-time characterization of the Trans-Amazonian orogeny in the Imataca Complex, Venezuela: Precambrian Research, v. 42, p. 293-314.

Sylvester, P.J., 1989, Post-collisional alkaline granites: Journal of Geology, v. 97, p. 261-280.

Sylvester, P.J., and Attoh, Kodjopa, 1992, Lithostratigraphy and composition of 2.1 Ga greenstone belts of the West African craton and their bearing on crustal evolution and the Archean-Proterozoic boundary: Journal of Geology, v. 100 , p. 377-393.

Sylvester, P.J., Attoh, Kodjopa, and Schulz, K.J., 1993, 2.1 Ga granitoids from the West African craton and their derivation by slab melting in an unusually hot Early Proterozoic mantle [abs.]: American Geophysical Union Spring Mceting, Supplement to EOS, Transactions, v. 74, no. 16, p. 346.

Szczerban, Eugenio, and Urbani, Franco, 1974, Carsos de Venezuela-Parte 4, Formas carsicas en areniscas Precámbricas del Temitorio Federal Amazonas y Estado Bolívar: Sociedad Venezolana de Espeleologia, Boletín, v. 5, no. 1, p. 27-54. 
Talukdar, S.C., and Colvée G., Pablo, 1975, Nuevos datos petrológicos sobre las rocas volcánicas Precámbricas de la Meseta de El Viejo, Territorio Federal Amazonas, Venezuela: Boletín Informativo, Asociación Venezolana de Geología, Minería, y Petroleo, v. 18, p. 201-220.

1977. Implicaciones del estudio petrológico de las rocas volcánicas del valle del Parucito, T.F. Amazonas: Congreso Geológico Venezolano, 5th, Caracas, 1977, Memoria, v. 2, p. $591-610$.

Tassinari, C.C.G., 1984, A porção ocidental do craton Amazônico-Evidências isotópicas de acreção continental no Proterozóico médio: Symposium Amazonico, 2nd, Manaus, Brazil, 1984, Anais, p. 439-446.

Taylor, P.N., Moorbath, Stephen, Leube, Alfred, and Hirdes, Wolfgang, 1992, Early Proterozoic crustal evolution in the Birimian of Ghana-Constraints from geochronology and isotope geochemistry: Precambrian Research, v, 56, p. 97-111.

Teggin, D.E., Martínez, Manuela, and Palacios, Gladys, 1985, Un estudio preliminar de las diabasas del Estado Bolívar, Venezuela: Congreso Geológico Venezolano, 6th, Caracas, 1985, Memoria, v. 4, p. 2159-2206.

Teixeira, Wilson, Ojima, S.K., and Kawashita, Koji, 1984, A evolução geocronológica de rochas metamórficas e igneas da faixa movel Maroni-Itacaiunas, na Guiana Francesa: Symposium Amazonico, 2nd, Manaus, Brazil, 1984, Anais, p. 75-85.

Teixeira, Wilson, Tassinari, C.C.G., Cordani, U.G., and Kawashita, Koji, 1989, A review of the geochronology of the Amazonian craton-Tectonic implications: Precambrian Research, v. 42, p. 213-227.

Tepedino B., Victor, 1985, Geología de la región del bajo Caura, Estado Bolívar: Simposium Amazonico, 1st, Caracas, 1981, Publicación Especial 10, p. 151-162.

Thorman, C.H., and Drew, L.J., 1988, A report on site visits to some of the largest tin deposits in Brazil, March 11-25, 1988: U.S. Geological Survey Open-File Report 88-0594, 19 p.

Tosiani D., Tommaso, and Sifontes G., Ramón, 1989, Asociación de rocas máficas-ultramáficas en la región del Cerro Piedra del Supamo, sur de El Callao, Estado Bolívar, Venezuela: Congreso Geológico Venezolano, 7th, Barquisimeto, Venezuela, 1989, Memoria, v. 1, p. 163-174.

Tysdal, R.G., and Thorman, C.H., 1983, Geologic map of Liberia: U.S. Geological Survey Miscellaneous Investigations Series Map I-1480, scale 1:1,000,000.

Urbani P., Franco, 1977, Metamorfismo de las rocas del Grupo Roraima, Estado Bolívar y Territorio Federal Amazonas: Congreso Geológico Venezolano, 5th, Caracas, 1977, Memoria, v. 2 , p. $623-641$.

U.S. Geological Survey and Corporación Venezolana de Guayana, Técnica Minera, C.A., 1993, Geology and mineral resource assessment of the Venezuelan Guayana Shield: U.S. Geological Survey Bulletin 2062, $121 \mathrm{p}$.

Van Schmus, W.R., 1993, Re-examination of models for the origin of granite-rhyolite provinces in the midcontinent region, USA: Geological Society of America, Abstracts with Program, v. 25, no. 3, p. 87 .

Veldkamp, J.F., Mulder, F.G., and Zijderveld, J.D.A., 1971, Palaeornagnetism of Suriname dolerites: Physics of the Earth and Planetary Interiors, v. 4, p. 370-380.

Vidal, M., and Alric, Gilles, 1994, The Palaeoproterozoic (Birimian) of Haute-Comoé in the West African craton, Ivory Coast-A transtensional back-arc basin: Precambrian Research, v. 65, p. 207-229.

Vinchon, Charlotte, 1989, Nouvelles hypothèses sur les contrôles sédimentologiques des gîtes aurifêres dans les séries gréso-conglomératiques du Witwatersrand (Afrique du Sud), du Tarkwaïen (Afrique el l'Ouest) et de l'Orapu (Guyane française): Chronique de la Recherche Minière, no. 497, p. 115-129.

Watkins, A.P., Iliffe, J.E., and Sharp, W.E., 1993, The effects of extensional and transpressional tectonics upon the development of Birimian sedimentary facies in Ghana, $W$. Africa-Evidence from the Bomfa/Beposo District, near Konongo: Journal of African Earth Sciences, v, 17, p. $457-478$.

Williams, H.R., 1988, The Archaean Kasila Group of western Sierra Leone-Geology and relations with adjacent granite-greenstone terrane: Precambrian Research, v, 38, p. 201-213.

Williams, H.R., and Williams, R.A., 1977, Kimberlites and plate-tectonics in West Africa: Nature, v. 270, p. 507-508.

Windley, B.F., 1989, Anorogenic magmatism and the Grenvillian orogeny: Canadian Journal of Earth Sciences, v. 26, p. $479-489$.

Wynn, J.C., 1993, Geophysics of the Venezuelan Guayana Shield, in U.S. Geological Survey and Corporación Venezolana de Guayana, Técnica Minera, C.A., Geology and mineral resource assessment of the Venezuelan Guayana Shield: U.S. Geological Survey Bulletin 2062, p. 17-27.

Wynn, J.C., and Sidder, G.B., 1991, Mineral resource potential of the NB-20-4 quadrangle, eastern Guayana Shield, Bolívar State, Venezuela: U.S. Geological Survey Bulletin 1960, 16 p.

York, Derek, 1969, Least squares fitting of a straight line with correlated errors: Earth and Planetary Science Letters, v. 5, p. $320-324$. 

Analysis of Aeromagnetic Data to Improve Geologic Maps of the Bochinche Mining District, Estado Bolívar, Venezuela

By Jeffrey C. Wynn, Anne E. McCafferty, and Edixon Salazar

GEOLOGY AND MINERAL DEPOSITS OF THE VENEZUELAN GUAYANA SHIELD

U.S. GEOLOGICAL SURVEY BULLETIN 2124-C

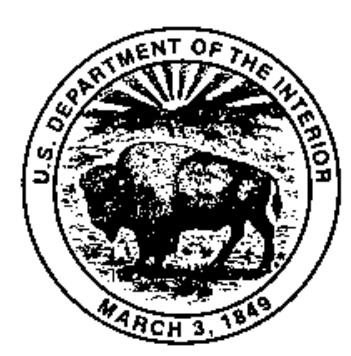

UNITED STATES GOVERNMENT PRINTING OFFICE, WASHINGTON : 1995 


\section{CONTENTS}

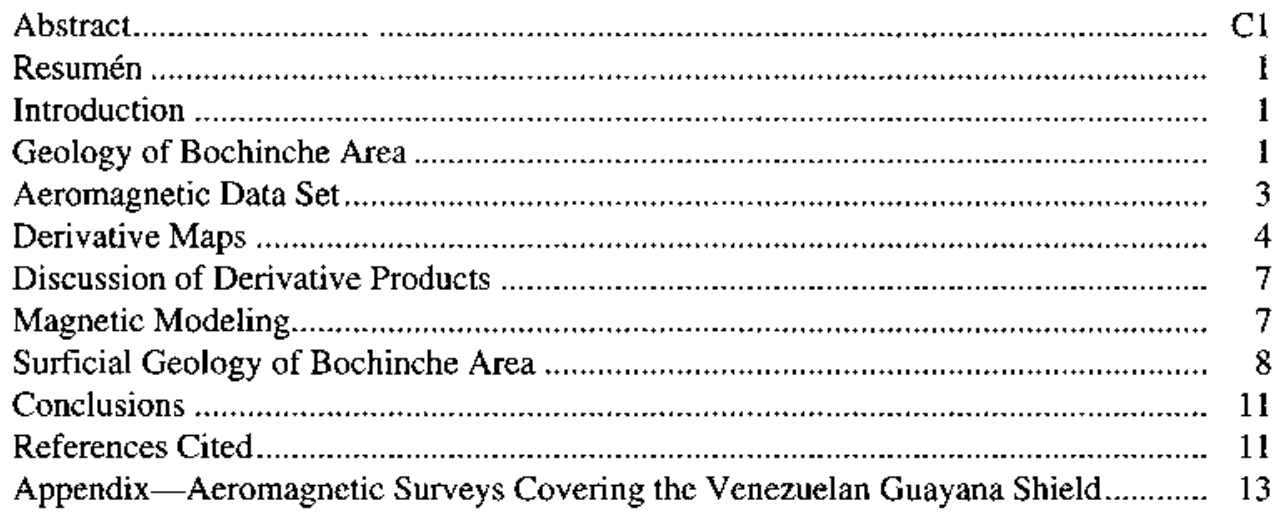

\section{FIGURES}

1. Map showing location of Bochinche 1:50,000-scale quadrangle and aeromagnetic surveys covering the Venezuelan Guayana Shield

2. Aeromagnetic map for part of Bochinche quadrangle

3. Shaded relief map of reduced-to-the-pole aeromagnetic data for part of Bochinche quadrangle .............................. 4

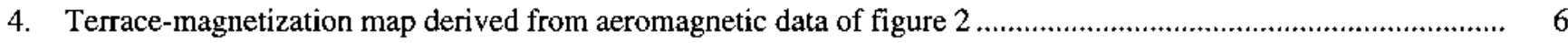

5. Two-and-one-half-dimensional model of magnetic data from profile crossing Laguna dike complex, Bochinche mining district.

6. Map showing surficial geology of part of Bochinche area...

7. Map showing bedrock geology of Bochinche quadrangle . 


\title{
Analysis of Aeromagnetic Data to Improve Geologic Maps of the Bochinche Mining District, Estado Bolívar, Venezuela
}

\author{
By Jeffrey C. Wynn, ${ }^{1}$ Anne E. McCafferty, ${ }^{2}$ and Edixon Salazar ${ }^{3}$
}

\begin{abstract}
A $1: 50,000$-scale aeromagnetic contour map for the Bochinche area of the northeastem Venezuelan Guayana Shield was manually digitized along flight line-contour line intersections. Several derivative products including horizontal gradient of pseudogravity, reduced-to-the-pole, and terrace-magnetization maps were developed from the original data. These products, and interpretations of them, were combined with available geologic information to create a bedrock geologic map that indicates several new areas for gold exploration in the Bochinche area. This type of analysis is applicable to many other areas of the Guayana Shield.
\end{abstract}

\section{RESUMEN}

Un mapa de isolineas aeromagnéticas a escala 1:50,000 del área de Bochinche, el cual está ubicado at noreste del Escudo de Guayana en Venezuela, fue digitizado manualmente a lo largo de las intersecciones de las lineas de vuelo con las isolineas acromagnéticas. A partir de los datos originales se derivaron y desarrollaron varios productos tales como el gradiente horizontal de pseudogravedad, reducción al polo y mapas de magnetización en terraza. Estos productos, e interpretaciones fueron, combinados con información geológica disponible para crear un mapa del basamento cristalino. En este mapa se indican varias áreas para exploración aurífera en el área de Bochinche. Este tipo de análisis es aplicable a muchas áreas del Escudo de Guayana.

\section{INTRODUCTION}

The Venezuelan Guayana Shield encompasses large areas of greenstone belts and associated plutonic rocks. The

${ }^{1}$ U.S. Geological Survey, Unit 62101, APO AE 0981 1-2101, USA.

${ }^{2}$ U.S. Geological Survey, Denver Federal Center, MS964, Denver, Colorado 80225 .

${ }^{3}$ Corporación Venezolana de Guayana, Técnica Minera, C.A., C.C. Chilemex, Piso 1, Puerto Ordaz, Venezuela. area of the greenstone belts has been a gold-producing region for at least a century, but it is extremely difficult to map geologically because of dense jungle cover and intensely weathered soils. Few outcrops are present, and these few are not only difficult to find, but the rocks are also difficult to classify because of changes due to weathering, metamorphism, and deformation. Little geomorphological expression of the geologic features exists; relief is generally low throughout the region.

The Bochinche 15-minute quadrangle in the northeastem part of the Venezuelan Guayana Shield (fig. 1) provides an excellent setting in which to test the feasibility of using available aeromagnetic data to map in heavily forested terrane. The intensely weathered, deformed, and metamorphosed Early Proterozoic greenstone-belt rocks that underlie this area are characteristic of the region. Although aeromagnetic surveys have been flown over most of the region (fig. 1 , appendix), the Bochinche area presents an unusual opportunity because attempts have been made to map it geologically.

The geology of the area was mapped during two separate field efforts (Salazar, 1988; Salazar and Franco, 1988), primarily using inferences from soil colors and information from rare outcrops. An aeromagnetic survey (survey $C$, appendix), with flight lines spaced $500 \mathrm{~m}$ apart draping the topography at about $150 \mathrm{~m}$, also covers the quadrangle. Although the original data were acquired in analog form, digitization of the published 1:50,000-scale aeromagnetic map provided sufficient detail to distinguish different geologic units based on their distinctive magnetic signatures.

\section{GEOLOGY OF BOCHINCHE AREA}

Most of the rocks in the Bochinche area are Early Proterozoic, the notable exception being a series of diabase dikes that nay be as young as Mesozoic (Bellizzia and others, 1976, 1981; Sidder and Mendoza, this volume). Although Archean rocks arc present north of the Bochinche area, the oldest rocks in the Bochinche area are volcanic, 


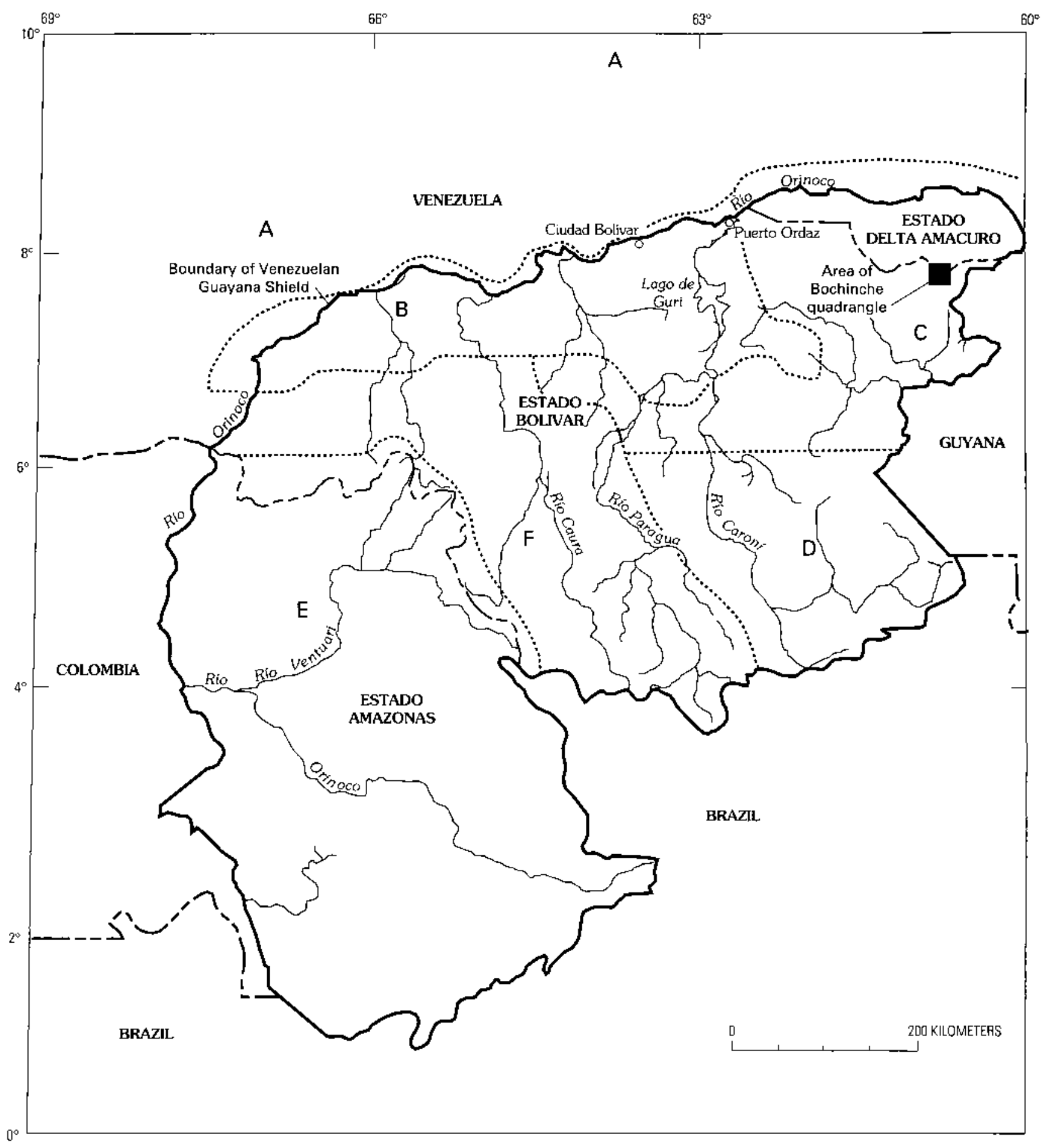

Figure 1. Location of Bochinche 1:50,000-scale quadrangle, Estado Bolívar, Venezuela. Letters and dotted lines indicate various aeromagnetic surveys conducted over the Venezuelan Guayana Shield described in the appendix.

volcaniclastic, and turbiditic rocks of greenschist facies, dated between 2,250 and 2,100 Ma (Wynn and Sidder, 1991). These are intermediate to mafic lavas and tuff of the Carichapo Group and overlying quartzite, pyroclastic, and sedimentary rocks of the Yuruari Formation, all of which are part of the Pastora Supergroup. These greenstone-belt rocks were later intruded and deformed by granitic to granodioritic and trondhjemitic rocks of the Supamo Complex about 2,230-2,050 Ma (Klar, 1979). In areas of contact with Supamo intrusive rocks, the greenstone-belt rocks are locally 


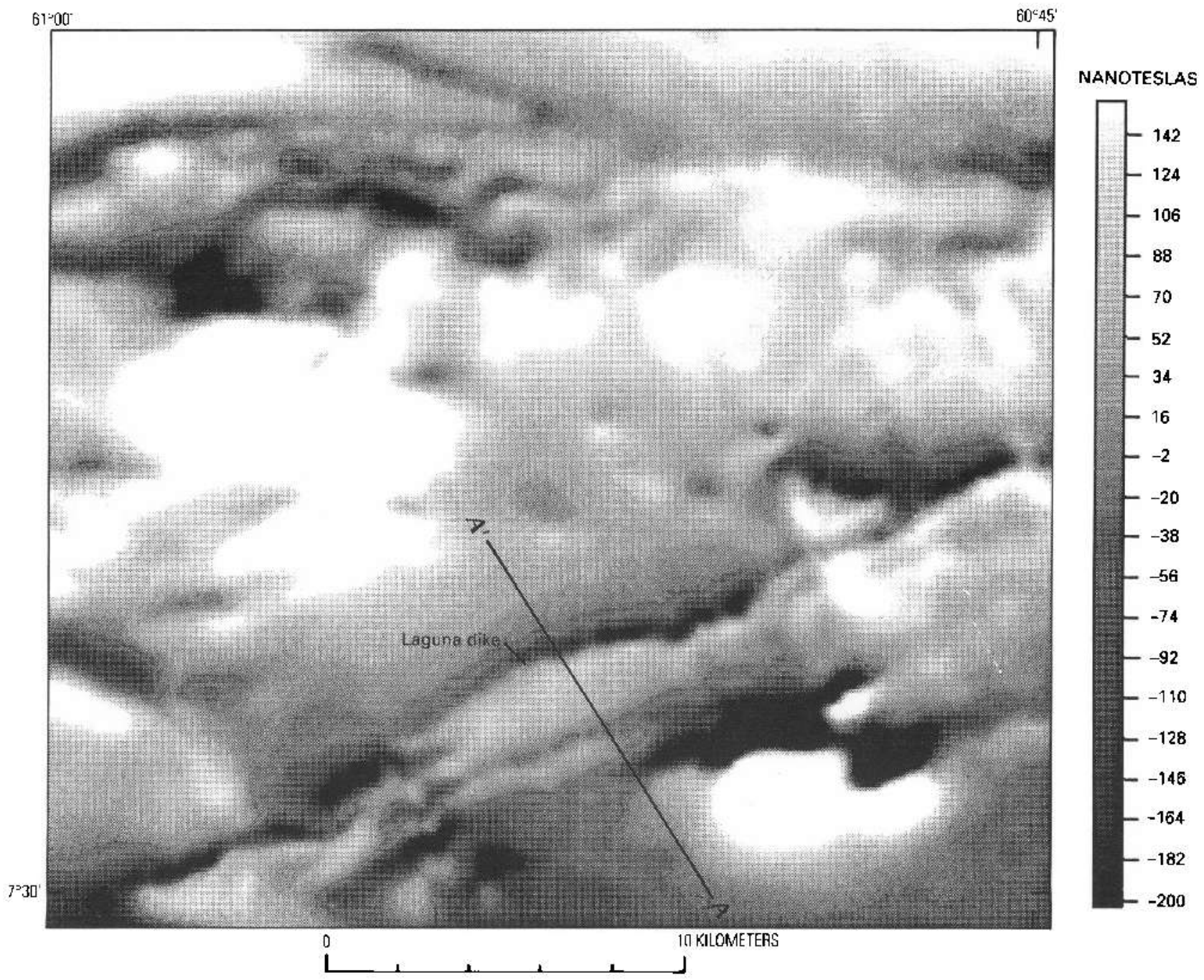

Figure 2. Aeromagnetic map for part of Bochinche 15-minute quadrangle, eastern Estado Bolívar, Venezuela. Total-field aeromagnetic data were acquired in 1961 ; contour interval $18 \mathrm{nT}$, flight-line spacing $500 \mathrm{~m}$, flown at 150 -m barometric altitude bearing N. $22^{\circ}$ W. Line of profile $A-A^{\prime}$ (fig. 5) is shown.

metamorphosed to amphibolite facies (Menende7, 1968; Wynn and Sidder, 1991).

About 2,150-2,000 Ma a major orogenic cycle of metamorphism, deformation, and plutonism, the Trans-Amazonian orogeny, deformed and metamorphosed rocks of the Pastora Supergroup and the Supamo Complex. This orogeny is recognized throughout cratonic northem South America (Gibbs and Barron, 1983, 1993). Mafic to granitic intrusive rocks are associated with this orogeny, and several mafic bodies in the Bochinche arca apparently date from this event.

Numerous elongate tholeitic dikes and sills, generally oriented east-northeast, formed in the Guayana Shield during the opening of the Atlantic Ocean about $200 \mathrm{Ma}$. The Laguna dike discussed following may be a combination of two different diabase dikes, coincidentally parallel, but injected during different events as part of the late Early Proterozoic Avanavero Suite and the Mesozoic dike swarms.
Deposition of Tertiary and Quaternary alluvial, colluvial, and eluvial sediments in the Bochinche area, together with extensive tropical weathering, has left few outcrops to map. Structural and lithologic infornation from the rare outcrops was supplemented during recent mapping with data from drill holes, trenches, and roadcuts (Salazar, 1988; Salazar and Franco, 1988).

\section{AEROMAGNETIC DATA SET}

Most of the gold discovered in the Venezuelan Guayana Shield is associated with rocks of the greenstone belts. Aeromagnetic contour maps from survey C (fig. 1 , appendix) were examined for a block of data that would be amenable to modern potential-field data processing methods. Initially, an area of greenstone terrane that had 


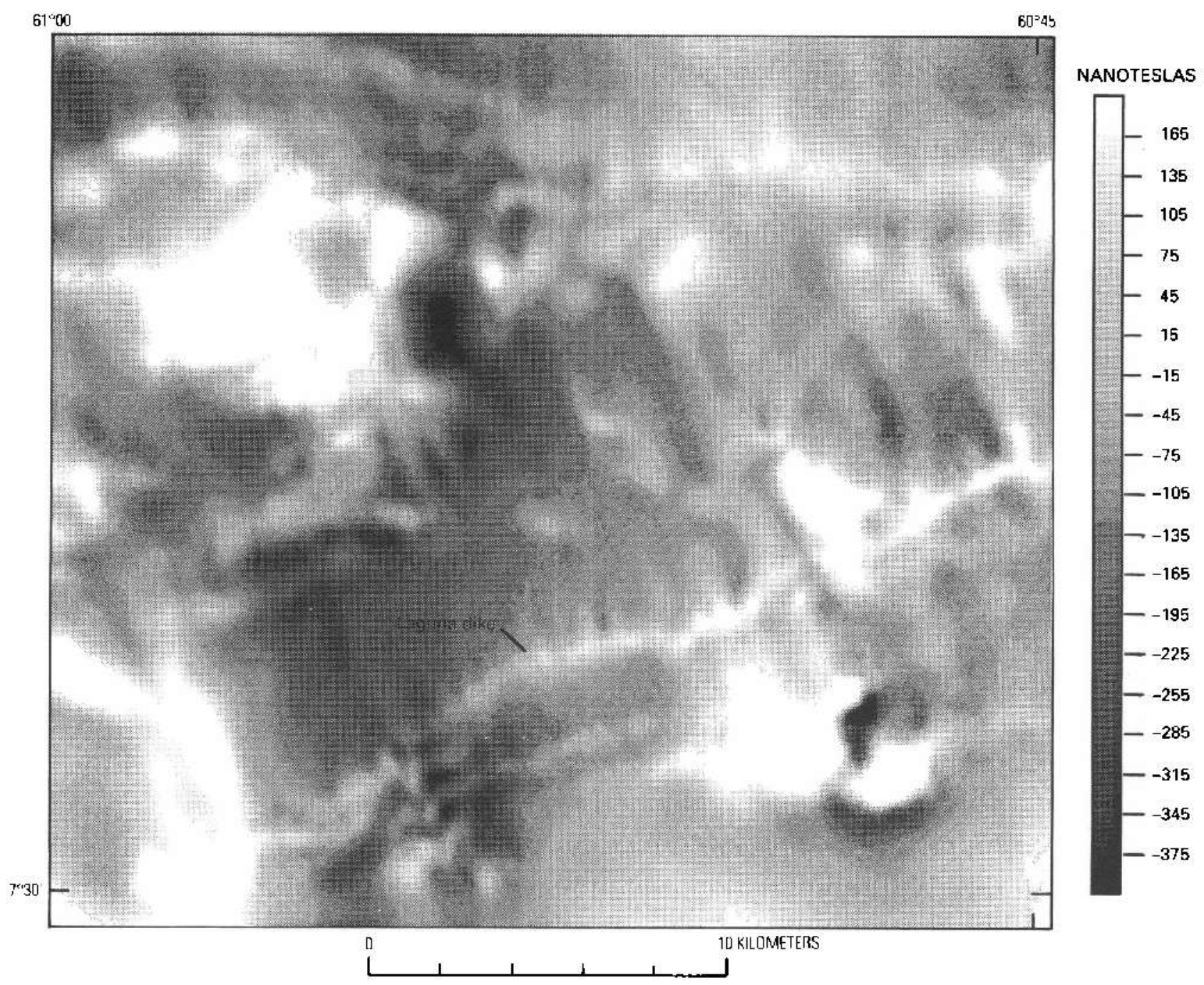

Figure 3. Reduced-to-the pole magnetic field map for part of Bochinche 15-minute quadrangle, eastern Estado Bolivar, Venezuela, calculated from aeromagnetic data of figure 2 . In some cases, anomalies (depending on depth to source) may be shifted northward by several kilometers.

been mapped in detail was sought. The Bochinche area in eastern Estado Bolívar had the most detailed geologic maps available, but, because outcrops are rare, the geology had been mostly mapped by changes in soil color. The objective of the present study was to develop a more detailed and precise bedrock geologic map of the Bochinche mining district. Due to economic restrictions, this was accomplished without acquisition of additional aeromagnetic data.

The Bochinche mining district is within survey $\mathrm{C}$ (fig. 1), approximately $225 \mathrm{~km}$ east-southeast of Puerto Ordaz and adjacent to the frontier with Guyana. The aeromagnetic data were available only in hand-contoured map form. To digitally process the aeromagnetic data for the 1:50,000-scale Bochinche 15-minute quadrangle (lat $7^{\circ} 30^{\prime}-7^{\circ} 45^{\prime}$ N., long $60^{\circ} 45^{\prime}-61^{\circ} 00^{\prime}$ W.), maps were digitized manually along the flight lines at the contour-line intersections. The data were subsequently processed using public-domain software developed by the U.S. Geological Survey (1989).

Figure 2 is an aeromagnetic map in image form obtained from the digitized data of part of the Bochinche $1: 50,000$-scale map. It is presented as a gray-shaded-relief map with an illumination direction of N. $30^{\circ} \mathrm{W}$. The line of profile $A-A^{\prime}$ was modeled and is discussed in a later section.

\section{DERIVATIVE MAPS}

Maps derived by applying analytical techniques to the digitized acromagnetic data provide considerable new information. This information is present in the original aeromagnetic data but is generally not apparent to the eye in con- 
tour form. Several analytical filters were applied to the aeromagnetic data to extract additional information about rock types and structures in the greenstone terrane and to determine how these features might relate to the known mineral deposits (especially gold) within the study area. The derivative products include reduced-to-the-pole, terrace-magnetization (subsequently called "terrace"), and horizontal gradient of pseudogravity maps.

The reduced-to-the-pole map (fig. 3) shows the magnetic data in a form equivalent to a vertically incident magnetic field (Hildenbrand, 1983). In this region near the Equator, the Earth's magnetic field has a shallow inclination $\left(31^{\circ}\right)$ that produces markedly dipolar magnetic anomalies that do not overlie their sources. The reduction program recalculates the field using a multiplicative filter in the frequency domain and requires the inclination and declination of Earth's fjeld in the area of interest. An inclination $\left(31^{\circ}\right)$ and declination $\left(-12^{\circ}\right)$ of the magnetic field at the midpoint of the data set for the year and month that the survey was flown were selected. The northward shift of the magnetic highs, which can be viewed as replacement of lows with highs and vice versa, between figures 2 and 3 is substantial but nevertheless typical for Venezuela.

The magnetic field measured over crustal rocks is influenced by many physicochemical phenomena. These include induction in the Earth's present magnetic field, remanent magnetization acquired when igneous rocks cooled in an ancient magnetic field, isothermal remanent magnetization, and chemical remanent magnetization. The modern magnetic field measured over the Venezuelan Guayana Shield could be influenced by a combination of some or all of the above. Because isothermal remanent magnetization is a soft magnetization that tracks the Earth's field through time, it can be treated for calculation purposes as part of the induced magnetization. Chemical remanent magnetization can be combined with other fixed-polarity contributions into remanent magnetization for the same purposes. For lack of evidence to the contrary (such as dipolar anomalies aligned in directions different from the local declination direction of N. $11^{\circ} \mathrm{W}$.), it was assumed that most of the magnetic sources in the Bochinche aeromagnetic data have magnetization vectors parallel with the Earth's present magnetic field. This is a reasonable assumption because the anomalies in the study area are caused by ancient rocks, and any remanent magnetization component has likely been attenuated by long-term decay and modification over time by subsequent tectonothermal events. Application of the reduced-to-the-pole filter results in a plot of the magnetic field that centers anomalies over their causative sources.

Where the magnetic latitude is very low, as in the Bochinche area, uncorrected magnetic anomalies are generally dipolar and centered, with the positive side south and the negative side north, over their source bodies. Note that at very low latitudes, a reduction-to-the-pole recalculation can generate artificial anomalies if there is considerable noise in the data and can produce unacceptable artifacts in the resulting map (see Hansen and Pawlowski, 1989, for a study of a seamount at a magnetic latitude of $17^{\circ}$ ). This was a minor problem in the study area and is shown by the elongate northwest-trending artifacts. Although some minor artifacts remain in the data, the reduction-to-pole filter was successful in producing an interpretable map.

A data processing technique called terracing (Cordell and McCafferty, 1989) was applied to the gridded aeromagnetic data to produce a map of inferred magnetization called a terrace-magnetization, or terrace, map (fig. 4). Some of the inferred magnetization domains and their edges coincide with known geologic features such as faults, contacts, or igneous bodies. Therefore, a terrace-magnetization map is a geologiclike map that, together with field geologic ground checks, can aid geologic mapping in areas where rocks are scarce in outcrop or buried. The terrace technique in this study was used to define magnetization domains and (or) geologic structures within the Venezuelan Guayana Shield and to infer rock types based on magnetization values within domain boundaries.

The terrace technique is relatively new, and the steps followed to produce the terrace map are briefly summarized. For a complete description of the theory and technique see Cordell and McCafferty (1989) and Phillips (1992). The first step involves a mathematical calculation to remove a second-order polynomial surface from the gridded data (Cordell and others, 1992), thus producing a second-order residual magnetic field. Removal of the regional field is necessary in order to decrease the dynamic range of the data without degrading the short-wavelength features. This step improves the resolution of the shallow crustal sources represented by the short-wavelength anomalies. The second-order residual magnetic anomalies are then transformed to pseudogravity anomalies (Hildenbrand, 1983). The positions of magnetic anomalies depend on the geomagnetic latitude of the source and the dipolar nature of the bodies causing the anomalies; the actual positions of the anomalies are displaced from their correct locations. The pseudogravity transformation, similar to a reduction-to-pole filter, corrects for this shift.

The gridded pseudogravity data are then terraced; that is, the smoothly varying anomalies are transformed into steplike functions in which the vertical segments of the steps mark the steepest parts (or the inflection points) of the anomalies. At this point in the process, the amplitude range of the terrace function is identical to the range of the input anomalies. A more complicated aspect of the terracing procedure involves converting units on the terrace map to units of magnetization within each domain. This is done by referring the terrace function to a model represented by a slab of rock having a constant thickness and flat top. The top of the slab for this model is defined to be the topographic surface; topographic relief is only about $60 \mathrm{~m}$ in the Bochinche 


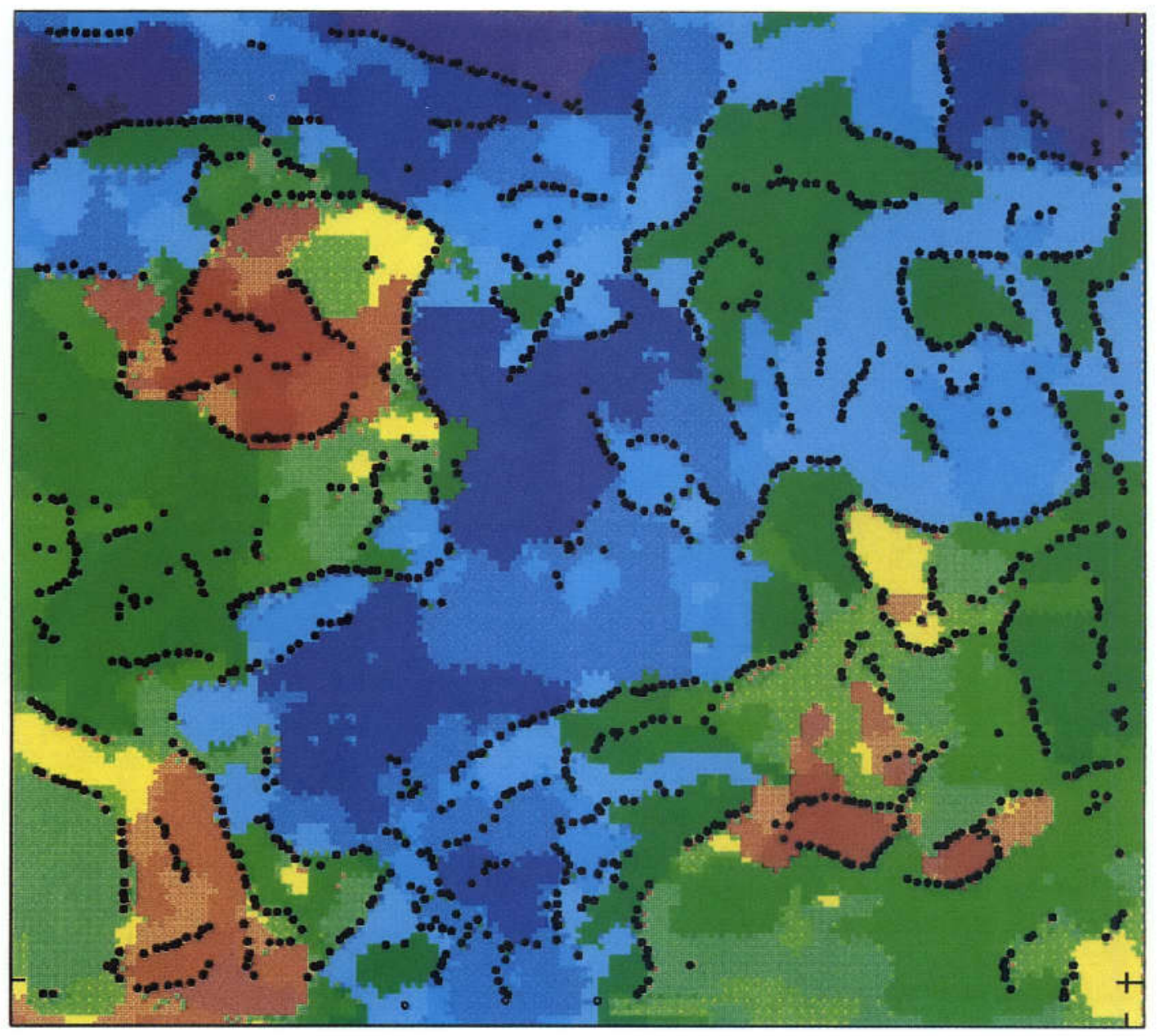

Figure 4. Terrace-magnetization map derived from the aeromagnetic data of figure 2, Maxima of the horizontal-gradient-of-pseudogravity (circles) are superimposed on the terrace map and mark probable lithologic boundaries. Color scale is in electromagnetic units per cubic centimeter.

area, and therefore a flat surface is used in the forward calculation as an average estimate for the top of the slab.

A slab thickness is chosen for the model that yields a best fit between the second-order residual magnetic field and the forward-calculated field (not shown), as well as plausible magnetization values. The thickness of the slab is allowed to vary until best-fit conditions are attained. For this data set, a slab $3 \mathrm{~km}$ thick best served to determine the magnetization values of individual domains.

The terrace-magnetization domains can be visualized as jigsaw pieces, each $3 \mathrm{~km}$ thick, having a flat top and bottom and vertical sides. The magnetization within each domain is constant in the vertical dimension but varies laterally from domain to domain.

The values shown on the color scale in figure 4 represent inferred magnetization values in electromagnetic units (emu) per cubic centimeter. Determining an acceptable background magnetization value against which to contrast the calculated values is difficult without measured samples. Because such samples were not available, the magnetization of the rocks was assumed to be entirely induced in the direction of the present-day magnetic field and was then contrasted with the values against a magnetization of $0.00 \mathrm{emu} / \mathrm{cm}^{3}$. This datum is arbitrary, and 
negative magnetization related either to relatively weak magnetization or to predominantly remanent magnetization is admissible, although unlikely for reasons discussed previously.

To emphasize further the magnetization boundaries, the locations (marked as circles in figure 4) tracking horizontal gradient maxima of the pseudogravity data are superimposed on the terrace image. As discussed by Cordell and Grauch (1985), the maxima delimit abrupt lateral changes in the magnetic field and, by inference, are interpreted to be steep or almost vertical lithologic contacts. The positions of the maxima are offset downdip if the contact is gradational or does not dip steeply. Location of the contact may also be inexact if data sampling is insufficient or if a number of sources are spatially close together (Grauch and Cordell, 1987), Several sources are spatially close together in the northeastern part of the Bochinche quadrangle (figs. 2,3 ), just beyond the area of mapped geology.

\section{DISCUSSION OF DERIVATIVE PRODUCTS}

In the aeromagnetic map of figure 2 , beginning at the southwesternmost corner and continuing east-northeast across most of the map area, the magnetic signature of the Laguna dike is evident. The Laguna diabase dike cuts the $\mathrm{El}$ Callao gold district more than $100 \mathrm{~km}$ to the west of the Bochinche area and has been mapped geologically almost continuously from west-southwest of El Callao eastward to Bochinche and beyond. An intense elliptical magnetic anomaly in the southeastem comer of the Bochinche map area is caused by ultramafic rocks, the weathered relics of which have been observed on the surface in some places.

Several discrete structures are visible in the terrace map (fig. 4), and their boundaries are more precise than in the gray image of figure 2 . The Bochinche area can be divided roughly into three magnetic terranes: a strongly magnetic western-southwestern part, a less magnetic southeastem part, and a weakly magnetic central and northern part. The latter two parts are connected by a linear feature (faintly visible in fig. 2, more clearly visible on the original $1: 50,000$-scale contoured map) that correlates with the Laguna dike. The high magnetization in the southeastem and southwestern parts of the area is apparently caused by mafic volcanic and volcaniclastic rocks. The generally low magnetization in the northern part of the map area is coincident with extensive tracts of quartzite of the Yuruari Formation. Terrace maps do not provide information on depths of discrete bodies (Cordell and McCafferty, 1989), and thus several individual magnetic anomalies were modeled.

\section{MAGNETIC MODELING}

Figure 5 shows a two-dimensional model calculated to fit discrete data points from the original aeromagnetic map in the area of the Laguna dike complex. The modeled profile trends $\mathrm{N}, 22^{\circ} \mathrm{W}$. (along the flight-line direction), starting from a point at lat $7^{\circ} 30^{\prime} \mathrm{N}$., Jong $60^{\circ} 50^{\prime} 50^{\prime \prime} \mathrm{W}$., on the southern margin of the Bochinche quadrangle. In the lower center of the map area of figure 2, two discrete linear anomalies are coincident with two known manifestations of tholeiitic dikes, called here the northern and southern extensions of the Laguna dike. In an earlier unpublished map (Edixon Salazar), these two dikes were classified differently-the northern dike was called a gabbro and the southem a diabase - mainly to distinguish their different grain size (the rocks were analyzed chemically only for gold).

The dikes were mapped in two trenches, and their approximate widths are thus known near the model profile. Using these widths, the model suggests that the Laguna dike is actually two tabular bodies having different susceptibilities. The southern body is only about $800 \mathrm{~m}$ deep and probably dips north, whereas the northern dike has almost 10 times the magnetic susceptibility of the southern dike, is at least $5 \mathrm{~km}$ deep, and dips south. Estimates of the dips of the dikes are derived from the model because the trenches sampled only the tops of the dikes. Both dikes extend almost to the surface (within 3 and $30 \mathrm{~m}$, southern dike and northern dike, respectively) in the model; effects of weathering extend 10-18 $\mathrm{m}$ below the surface, as indicated by drill-hole data. Louis Guilloux (Bureau de Recherches Géologiques et Minières, oral commun., 1989) inferred from stnuctural measurements in the trenches that the two dikes are subvertical and may dip steeply to the north or south. Although the model presented in figure 5 is not a unique solution, it is a reasonable estimate of the geometry and susceptibility of the dikes.

The magnetic susceptibility of the narrower, northern extension of the dike is $0.0048 \mathrm{emu} / \mathrm{cm}^{3}$, almost nine times that of the wider southem extension $\left(0.000525 \mathrm{emu} / \mathrm{cm}^{3}\right)$. This difference in magnetic susceptibility supports the inference that these two features represent different geologic units. In comparison, a sample of diabase from the Gran Sabana, about $200 \mathrm{~km}$ to the south, has a magnetic susceptibility of $0.0016 \mathrm{emu} / \mathrm{cm}^{3}$, and a sample of diabase from the Marwani area, about $80 \mathrm{~km}$ to the south-southeast of Bochinche, has a magnetic susceptibility of 0.000008 emu/ $\mathrm{cm}^{3}$, significantly less than susceptibilities of samples from Bochinche. Although the model presented in figure 5 is not a unique solution, it is a reasonable estimate of the dike's geometry and susceptibility. In the terrace map, the northem dike dominates the image because of its much greater magnetic susceptibility, but, because the two features are so close together, both contribute to form a single band.

A broad magnetic low about $3.0 \mathrm{~km}$ along the profile shown in figure 5 was not modeled because it is caused by sideswipe; that is, it is a contribution from a source some distance off line. The source, in fact, is the ultramafic body that is manifested as a strong anomaly in the southeastem comer of the map area of figures 2 and 3 . 

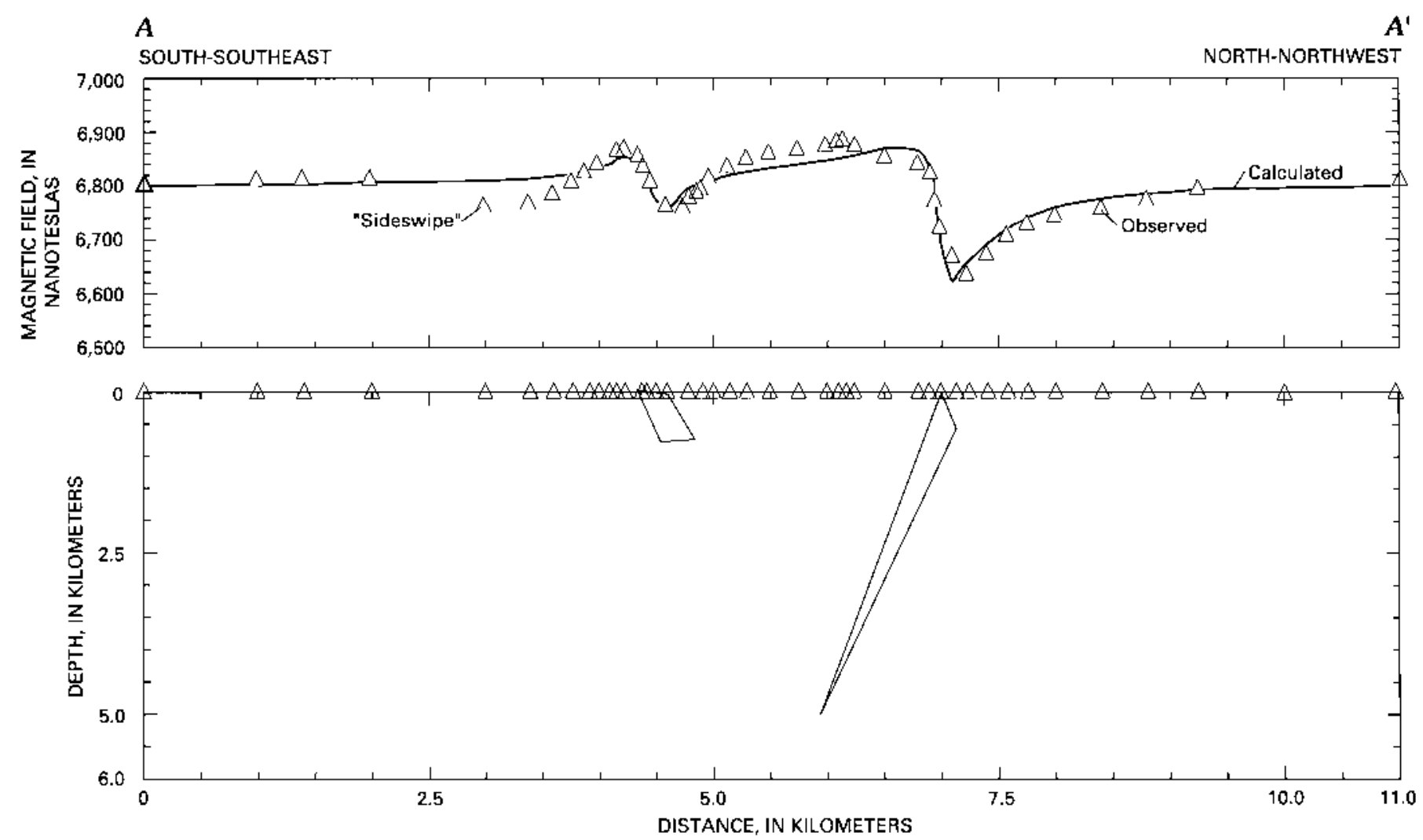

Figure 5. Two-and-one-half-dimensional model of magnetic data from a profile crossing the Laguna dike complex, Bochinche mining district. Data are from the aeromagnetic map (fig. 2) and are represented by triangles. The profile extends $\mathrm{N}$. $22^{\circ} \mathrm{W}$. from a zero point at lat $7^{\circ} 30^{\prime} \mathrm{N}$., long $60^{\circ} 50^{\prime} 50^{\prime \prime} \mathrm{W}$. The southem dike has an observed minimum depth (in trenches) of about 3 m and a magnetic susceptibility of $0.000525 \mathrm{emu} / \mathrm{cm}^{3}$. The northen dike has a depth of $30 \mathrm{~m}$ or more (from nearby drill holes; possibly somewhat shallower) and a modeled magnetic susceptibility of $0.0048 \mathrm{emu} / \mathrm{cm}^{3}$. Sideswipe refers to an effect from an off-line anomaly (see discussion in the text). Line of profile is shown in figures 2 and 7.

\section{SURFICIAL GEOLOGY OF BOCHINCHE AREA}

Figure 6 is a compilation of two geologic maps prepared during separate mapping surveys in 1985-1987 in the southern and western parts of the Bochinche quadrangle (Salazar, 1988; Salazar and Franco, 1988). Detailed geologic mapping was not carried out in the northern part of the quadrangle because of logistical limitations; less than a fraction of a percent of this area has outcrop, and most of the mapping was done by inference from soil color. The two geologic maps were digitized at their original scale of $1: 25,000$, then combined and reduced in size. The stratigraphy of these maps follows that described by Menendez (1968) and Mendoza (1977) and modified by Wynn and Sidder (1991). The lithostratigraphy is described briefly herein; a more complete description is given in Sidder and Mendoza (this volume). The surficial geologic map (fig. 6) is located only approximately because base maps for the area do not have geodetic control; the location of the main Bochinche road and the two reference points extracted from a third informal index map used by Corporación Venezolana de Guayana, Técnica Minera, C.A. (CVG-TECMIN) are shown; the original geologic maps used slightly different locations of this road for reference.

The map was compiled, and units assigned, before adding data for the quartz veins. When the field-mapped quartz veins were plotted, their locations proved to correlate closely with the new, geophysically inferred contacts between intrusive rocks and mafic lavas of the Carichapo Group. This correlation is consistent with the deposit model for low-sulfide gold-quartz veins (Berger, 1986; Bliss and Jones, 1988; Wynn and Sidder, 1991). This deposit model (also see Colvine and others, 1988) allows (1) the presence of mafic and ultramafic rocks as a source of gold, (2) an intrusive event to provide heat for hydrothenmal cells, and (3) highly fractured rocks such as volcanic rocks and turbidite sequences to host the gold. The new bedrock geologic map of figure 7 thus provides new target areas for gold exploration, especially in the southeastern quarter of the Bochinche quadrangle. 


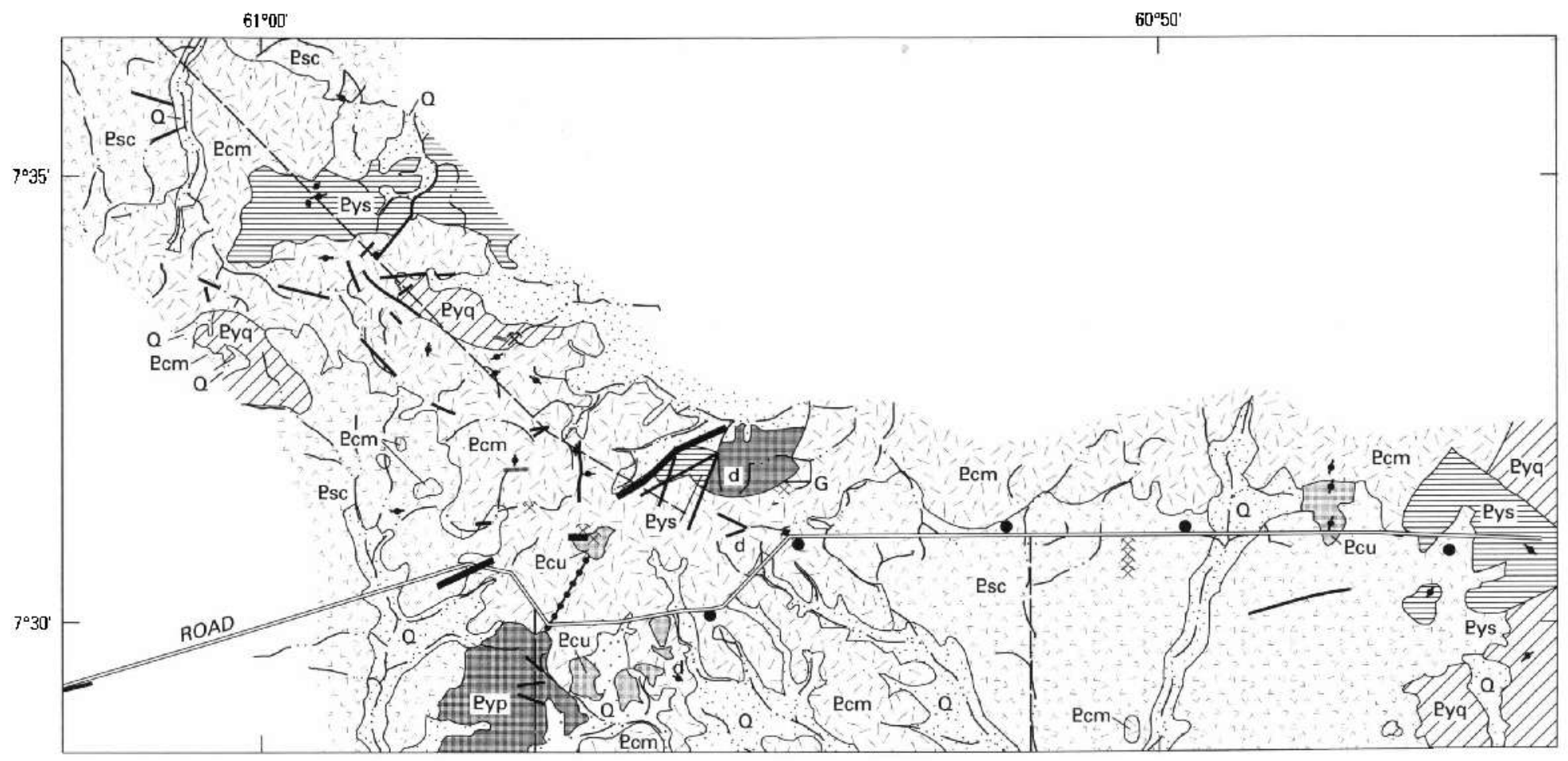

0 5 KILOMETERS

\begin{tabular}{|c|c|}
\hline Q & Quatemary alluvium \\
\hline Psc & Supamo Complex (granite-monzonite) \\
\hline Eyp & Yuruat Formation (pyroclastic rocks) \\
\hline Eys $\equiv$ & Yuruarl Formation (schist) \\
\hline Eyq & Yuruari Formation (quartzite) \\
\hline $\mathrm{Ecm}$ & Carichapo Group (mafic lavas) \\
\hline
\end{tabular}

EXPLANATION

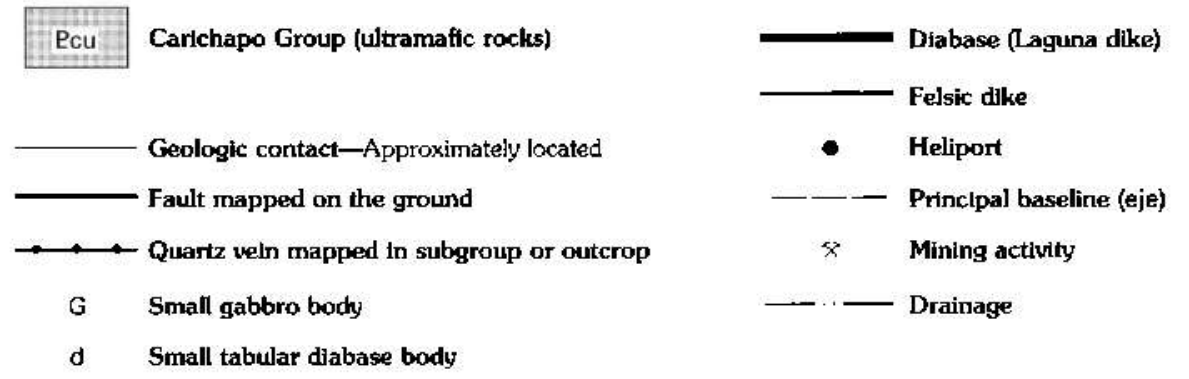

Figure 6. Surficial geology of part of the Bochinche area, Venezuela, compiled from two surficial geologic maps of the Bochinche area (Salazar, 1988; Salazar and Franco, 1988). 


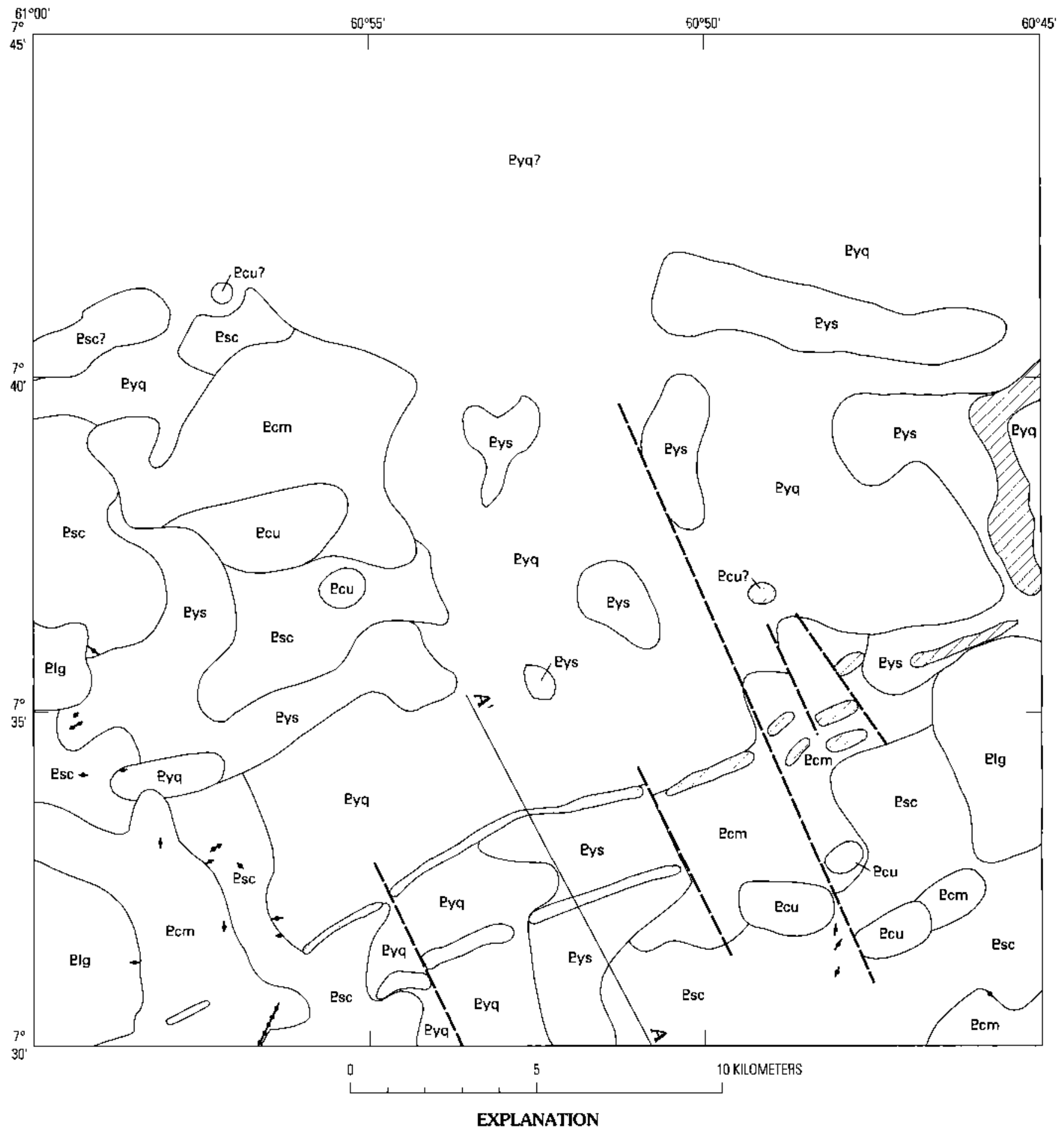

\begin{tabular}{|c|c|}
\hline $\mathrm{Elg}$ & Late-stage granite intrusive rocks \\
\hline Esc & Supamo Complex (granite-monzonite) \\
\hline Eys & Yuruari Formation (schist) \\
\hline Evq & Yuruari Formation (quartzite) \\
\hline Ecm & Carichapo Group (mafic lava) \\
\hline
\end{tabular}

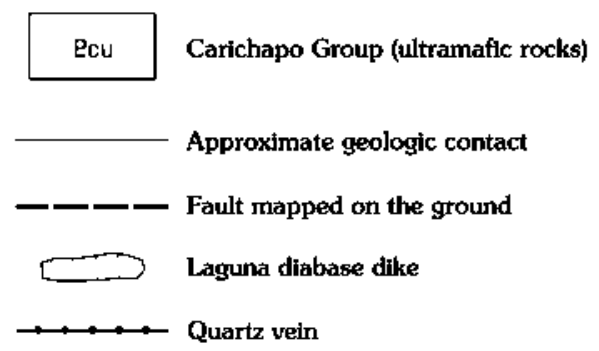


Figure 7 (facing page). Bedrock geology of the Bochinche 15-minute quadrangle, Venezuela. This map was compiled using the surficial geologic map of figure 6 , the terrace map of figure 4 (including lines showing maximum horizontal gradient of pseudogravity), additional information from modeling of discrete magnetic anomalies (including fig. 5), and limited anecdotal information from several geologists who have worked in the area. The diagonal-lined areas represent what is thought to be the location of the eastern extension of the Laguna dike. Unit Plg (Early Proterozoic late granite intrusive rocks) is similar to rocks north and west of the Bochinche quadrangle (Wynn and Sidder, 1991) (see text for discussion). Line of profile $A-A^{\prime}$ (fig. 5) is also shown.

On the geologic map, the Laguna dike is indicated by the generally narrow, diagonal-lined bodies. The dike splits into two entities, but exactly where this split takes place is not clear from the airborne magnetic data. Ground magnetic data (Fernández, this volume) also clearly show two extensions of the Laguna dike. These higher resolution, but limited extent, ground data suggest that the southem extension is the continuation of the dike from farther to the west and that the northern extension (which is more apparent in both the ground-magnetic and the aeromagnetic maps) is a different rock unit, probably of a different age because it has been described as a different rock in its weathered form (Salazar and Franco, 1988). In the east-central part of the map, the Laguna dike is apparently offset or folded along a probable fault that also splits the southeastem ultramafic bodies into discrete parts. It is possible that the mafic-ultramafic bodies were intruded at the same time as, or after, emplacement of the dikes and caused their displacement.

The Bochinche district was originally selected for exploration by CVG-TECMIN because it is along strike of the Laguna dike from the well-known and highly productive El Callao gold district. Experienced geologists working in eastern Venezuela have subsequently concluded that the El Callao deposits are not genetically related to the Laguna dike and that the spatial correlation is fortuitous (Vicente Mendoza, CVG-TECMIN, oral commun., 1987).

Louis Guilloux (oral commun., 1989) asserted that most of the gold-bearing quartz veins are related to structures that strike about N. $20^{\circ} \mathrm{W}$. Although some of these structures are clearly visible in the strike of the quartz veins in figures 6 and 7, unfortunately the aeromagnetic survey was designed to cross the Laguna dike perpendicularly and was flown on a strike of N. $22^{\circ}-25^{\circ} \mathrm{W}$. This direction minjmizes the usefulness of these data in locating gold-bearing structures. Despite this fact, the faults that are shown in figure 7 are manifested strongly in the magnetic data and are logical areas for further gold exploration.

\section{CONCLUSIONS}

Digital processing of aeromagnetic data, especially horizontal gradient of pseudogravity and terracing, can prove useful to geologists mapping in areas of deeply weathered rock covered by dense tropical forest. With the geologic control provided by this study in the Bochinche area of the Venezuelan Guayana Shield, the aeromagnetic data were used to extend and refine our knowledge of the geology in the surrounding region at minimal expense. Digital processing of aeromagnetic data to produce a refined bedrock geology map, as described in this study, may also be useful in mineral exploration of the Venezuelan Guayana Shield.

\section{REFERENCES CITED}

Bellizzia, Alirio, Pimentel, Nelly, and Bajo de Osuna, R., 1976, Mapa geológico estructural de Venezuela: Caracas, Ministerio de Minas e Hidrocarburos, escala 1:500,000.

Bellizzia G., Alirio, Pimentel de Bellizzia, Nelly, and Muñoz M., M.I., 1981, Geology and tectonics of northem South America: Caracas, Ministerio de Energía y Minas, Geodynamics Bulletin 3, Boletín de Geología, Publicación Especial 9, p. 7-88.

Berger, B.R., 1986, Descriptive model of low-sulfide Au-quartz veins, in Cox, D.P., and Singer, D.A., eds., Mineral deposit models: U.S. Geological Survey Bulletin 1693, p. 239.

Bliss, J.D., and Jones, G.M., 1988, Mineralogical and grade-tonrage information on low-sulfide Au-quartz veins: U.S. Geological Survey Open-File Report 88-229, 99 p.

Colvine, A.C., Fyon, J.A., Heather, K.B., Marmont, Soussan, Smith, P.M., and Troop, D.G., 1988, Archean lode gold deposits in Ontario: Ontario Geological Survey Miscellaneous Paper $139,136 \mathrm{p}$

Cordell, Lindrith, and Grauch, V.J.S., 1985, Mapping basement magnetization zones from aeromagnetic data in the San Juan basin, New Mexico, in Hinze, W.J., ed., The utility of regional gravity and magnetic anomaly maps: Tulsa, Oklahoma, Society of Exploration Geophysicists, p. 181-197.

Cordell, Lindrith, and McCafferty, A.E., 1989, A terracing operator for physical property mapping with potential field data: Geophysics, v. 54, p. 621-634.

Cordell, Lindrith, Phillips, J.D., and Godson, R.H., 1992, U.S. Geological Survey potential-field software version 2.0: U.S. Geological Survey Open-File Report 92-18A-G, 6 diskettes.

Day, W.C., 1989, Report on the bedrock geology and geochemistry of the Anacoco Sur II area, Bolívar State, Venezuela: U.S. Geological Survey Open-File Report 89-305, 14 p.

Gibbs, A.K., and Barron, C.N., 1983, The Guiana Shield reviewed: Episodes, v. 1983, no. 2, p. 7-14.

1993, The geology of the Guiana Shield: New York, Oxford University Press, Oxford Monographs on Geology and Geophysics 22, 246 p.

Graterol, Victor, 1974, Resultados de la prospección geofísica en las zonas de Vuelvan Caras y Botanamo, Estado Bolívar: 
Novena Conferencia Geológica Inter-Guayanas, Ciudad Guayana, Venezuela, 1972, Memoria, Publicación Especial 6, p. 529-549.

Grauch, V.J.S., and Cordell, Lindrith, 1987, Limitations of determining density or magnetic boundaries from the horizontal gradient of gravity or pseudogravity data: Geophysics, v, 52, p. 118-121.

Hansen, R.O., and Pawlowski, R.S., 1989, Reduction to the pole at low latitudes by Wiener filtering: Geophysics, v. 54, p. 1607-1613.

Herrero, Emilio, and Navarro, J., 1989, Mapa de anomalías magnéticas de Venezuela: Caracas, Ministerio de Energía y Minas, folio of 1:500,000-scale sheets.

Hildenbrand, T.G., 1983, FFTFIL-A filtering program based on two-dimensional Fourier analysis of geophysical data: U.S. Geological Survey Open-File Report 83-237.

Klar, Giampaolo, 1979, Geochronology of the El Manteco-Guri and Guasipati areas, Venezuelan Guiana Shielo: Cleveland, Case Western Reserve University, Ph.D. dissertation, 163 p. (Dissertation Abstracts International, Sec. B, Sciences and Engineering, v. 39, p. 5284-B.)

Mendoza S., Vicente, 1977, Evolución tectónica del Escudo de Guayana: Congreso Latinoamericano de Geología, 2nd, Caracas 1973, Memoria, Publicación Especial 7, v. 3, p. $2237-2270$.

Menendez, Alfredo, 1968, Revisión de la estratigrafía de la Provincia de Pastora, según el estudio de la región de Guasipati,
Guayana Venezolana: Caracas, Boletín de Geología, v. 10, p. 309-338.

Phillips, J.D., 1992, TERRACE-A terracing procedure for gridded data, with FORTRAN programs and VAX command procedure and Unix C-shell implementations: U.S. Geological Survey Open-File Report 92-5A-B, 18 p.

Salazar, Edixon, 1988, Mapa geológico estructural de la zona la Esperanza, Distrito Roscio, Estado Bolívar, 1:25,000 scale: Internal report of the Gerencia de Proyectos Especiales, Corporación Venezolana de Guayana, Técnica Minera, C.A., Puerto Ordaz, Venezuela.

Salazar, Edixon, and Franco, Luis, 1988, Mapa geológico estructural de la zona de Bochinchito, Distrito Roscio, Estado Bolívar, 1:25,000 scale: Intemal report of the Gerencia de Proyectos Especiales, Corporación Venezolana de Guayana, Técnica Minera, C.A., Puerto Ordaz, Venezuela.

U.S. Geological Survey, 1989, Potential-field geophysical programs for VAX $7 \times x$ computers: U.S. Geological Survey Open-File Report 89-115A-D.

Wynn, J.C., McCafferty, A.E., and Salazar, Edixon, 1989, Geologic information derived from digital aeromagnetic data: Simposio Sudamerica de COGEODATA, 5th, Caracas 1989, Resumen de los Trabajos, p. 32-33.

Wynn, J.C., and Sidder, G.B., 1991, Mineral resource potential of the NB-20-4 quadrangle, eastem Guayana Shield, Estado Bolívar, Venezuela: U.S. Geological Survey Bulletin 1960, $16 \mathrm{p}$. 


\section{APPENDIX \\ AEROMAGNETIC SURVEYS COVERING THE VENEZUELAN GUAYANA SHIELD}

Five aeromagnetic surveys have been flown over parts of the Venezuelan Guayana Shield (text fig. 1, appendix table 1). These surveys have flight-line spacings of from 500 $\mathrm{m}$ (considered good to excellent for mineral exploration) to $6 \mathrm{~km}$ (useful for regional mapping only). Data from Estado Amazonas, making up as much as 40 percent of the aeromagnetic data available for the shield, could be converted to digital form if flight-line records were released by the Ministerio de Energía y Minas of Venezuela. The Amazonas geophysical data set also includes radiometric information, and thus it may be the most useful survey carried out in the shield. The remaining aeromagnetic data range from published contoured maps (without digital data) to analog strip-chart records (neither contoured maps nor digital data). Much, but not all, of these data have been published in a photoreduced form at 1:500,000 scale (Herrero and Navarro, 1989; Emilio Herrero, Ministerio de Energía y Minas de Venezuela, oral commun., 1987-1990).

Survey $A$ is available in digital form; however, it covers only a fraction of the northern margin of the Venezuelan Shield because it was acquired as part of a study of the Cuenca Oriental petroleum province north of the Río Orinoco. The area of survey B, flown in 1959 , is bounded by the Río Orinoco on the north, has an irregular southern boundary generally between lat $6^{\circ} 30^{\prime}$ and $7^{\circ} 00^{\prime} \mathrm{N}$., and extends as far east as the El Callao mining district at about long $62^{\circ} \mathrm{W}$. This was the first survey flown in Venezuela; unfortunately, it has such severe registration problems (fiducial points picked during data acquisition and compilation can be shown to be displaced from true location by as much as $7 \mathrm{~km}$ ) that it is unusable and was not included in the magnetic map of Herrero and Navarro (1989).

The area of survey C, flown in 1961, is bounded by survey $B$ on the west, with a little overlap in places, by the Guyana frontier on the east, and by Estado Delta Amacuro on the north. The southern boundary is irregular but in places is near lat $6^{\circ} \mathrm{N}$. The data are in the form of contour maps (some with flight lines indicated) at a scale of 1:50,000.

The western and northern boundaries of survey $\mathrm{D}$ are not published and are only imperfectly known to us; Brazil and Guyana bound the survey area to the south and east. The survey was flown in the late 1970's to cover the Gran Sabana region of Venezuela and is only in the form of analog strip-chart records; it was not compiled into a contour map, and it is not included in the map of Herrero and Navarro (1989).

The area of survey E was flown in 1972 and covers most of Estado Amazonas. This survey makes up as much as 40 percent of the aeromagnetic data available for the shield and could be converted to digital form if flight-line records were released for public use. The digital data are not presently usable because the digital tapes use a nonstandard location coding requiring use of the pilot's flight-path strips to recover. These flight-path strips are currently held by the Ministerio de Energía y Minas (Jeffrey C. Wynn, U.S. Geological Survey, written commun., September 1989). This survey includes radiometric information (uranium, thorium, potassium, and total-count) and may be the most useful survey carried out in the shield. A number of areas of topographically higher elevation, generally underlain by rocks of the Roraima Group and covered by clouds almost the whole year, were not flown.

The area of survey $\mathbf{F}$, in Estado Bolívar south of lat $6^{\circ} \mathrm{N}$. and bounded on the south by the Brazilian border, on the east by Estado Amazonas, and on the west by approximately the Río Caura and Río Paragua, has apparently not been flown (Emilio Herrero, oral commun., 1988).

Appendix table 1. Aeromagnetic surveys flown over Venezuelan Guayana Shield.

\begin{tabular}{|c|c|c|c|c|c|c|}
\hline Survey name & Date flown & Area & Type & Spacing & Height & Direction \\
\hline A. Orinoco & $1981-82$ & North of Orinoco River & Digital; contour map & $3,000 \mathrm{~m}$ & $500 \mathrm{~m}$ & North-south \\
\hline B. Northwest Shield & 1959 & Northwest Estado Bolívar & Analog; contour map & $500 \mathrm{~m}$ & $150 \mathrm{~m}$ & N. $22^{\circ} \mathrm{W}$. \\
\hline C. Northeast Shield & 1961 & Northeast Estado Bolivar & Analog; contour map & $500 \mathrm{~m}$ & $150 \mathrm{~m}$ & N. $22^{\circ} \mathrm{W}$ \\
\hline D. Gran Sabana & Late 1970 's? & Southeast Estado Bolivar & Analog; no maps & $6,000 \mathrm{~m}$ & Not known & North-south \\
\hline E. Amazonas & $1972-1975$ & Estado Amazonas & Digital; magnetic, and radjometric & $1,000 \mathrm{~m}$ & $150 \mathrm{~m}, 300 \mathrm{~m}$ & $1,000-2,000 \mathrm{~m} ?$ \\
\hline
\end{tabular}



Exploración Geofísica en el Area de Bochinchito, Estado Bolívar, Venezuela

(Geophysical Exploration in the Bochinchito Area, Estado Bolívar, Venezuela)

By Alí R. Fernández P.

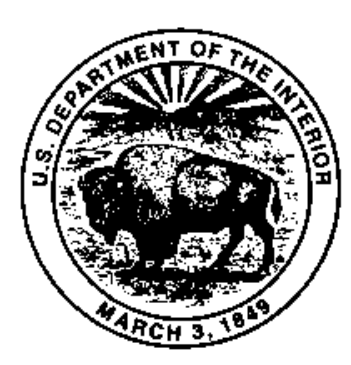




\section{CONTENIDOS}

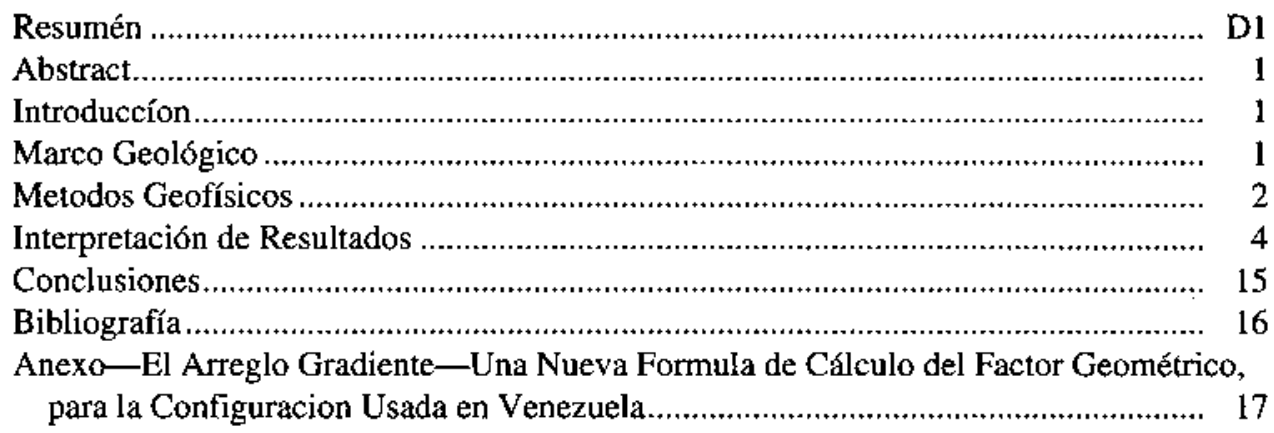

\section{FIGURAS}

1, 2. Mapas de:

1. Ubicación relativa del área de Bochinchito I y II............................................................................ D2

2. Geología local de Bochinchito I y II ............................................................................................ 3

3. Diagrama del levantamiento eléctrico y magnético, Bochinchito I y II .......................................................... 4

4, 5. Mapas de:

4. Contornos del campo magnético total, Bochinchito I y II ...................................................................... 5

5. Perfiles magnéticos de la zona Bochinchito I y II ................................................................................. 6

6, 7. Perfiles de resistividad aparente sobre las picas en el área de:

6. Bochinchito I donde se observaron las anomalías más fuertes ................................................................ 7

7. Bochinchito II donde se observaron anomalías más fuertes ................................................................... 9

8-10. Mapas de:

8. Contornos de isovalores de resistividad aparente , Bochinchito I y II ................................................. 10

9. Interpretación magnético-estructural, Bochinchito I y II .................................................................. 11

10. Interpretación eléctrico estructural, Bochinchito I y II .................................................................... 12

11-13. Modelaje geológico-geofísico del área de la:

11. Pica 12, Bochinchito I .......................................................................................................

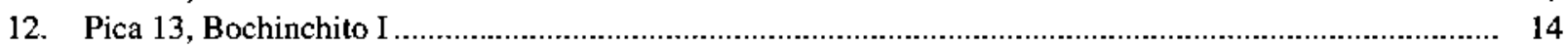

13. Pica 4 (izquierda) y pica 5 (derecha), Bochinchito II................................................................. 15

\section{TABLA}

1. Resumén de resultados del modelaje magnético 


\title{
Exploración Geofísica en el Area de Bochinchito, Estado Bolívar, Venezuela (Geophysical Exploration in the Bochinchito Area, Estado Bolívar, Venezuela)
}

\author{
By Alí R. Fernández P. ${ }^{1}$
}

\begin{abstract}
RESUMEN
La zona de Bochinchito es considerada de interés geoeconómico por la ocurrencia de vetas de cuarzo con posible mineralización de oro. Esta área es similar al prospecto de Bochinche, Estado Bolívar, estudiada por Corporación Venezolana de Guayana-Técnica Minera, C.A., durante los años 1986 a 1988. Los objetivos de la prospección geofísica en la zona fueron la delimitación de contactos y estructuras principales ademas de la ubicación de vetas de cuarzo.

Los resultados muestran la ocurrencia de anomalías magnéticas debido a : (1) cuerpos máficos y ultramáficos de rumbo NE a NE-E de forma tabular, y largos (más de 4.0 $\mathrm{km}$ ), poco profundos. Estos intrusivos están comunmente fallados perpendicularmente. Asociados a estos pequeños intrusivos existen cuerpos resistivos (más de 15,000 $\Omega \mathrm{m}$ ) de rumbo NE-N, compuestos por metasedimentos cuarcíferos, vetas de cuarzo y(o) diques félsicos, localizados cercanos entre si dentro de una zona sinclinal asimétrica. (2) Zonas de contacto litológico entre metasedimentos cuarcíferos o cuerpos graníticos y lavas andesíticas. Se recomienda que los horizontes resistivos, donde se han verificado carbonatos, sulfuros y oro, sean estudiadas en detalle con metodos de polarización inducida y sondeos electricos verticales.
\end{abstract}

\section{ABSTRACT}

The Bochinchito area in eastem Estado Bolívar is considered important economically because of its proximity to the Bochinche mining district, an area of known gold mineralization associated with quartz veins. Geophysical studies were conducted in an attempt to identify geologic contacts

\footnotetext{
${ }^{\mathrm{I}}$ Corporación Venezolana de Guayana, Técnica Minera, C.A., C.C. Chilemex, Piso 1, Puerto Ordaz, Venezuela.
}

and locate quartz veins in an area almost completely devoid of outcrop.

The results demonstrate substantial geophysical anomalies due to (1) ultramafic bodies and (2) important lithologic contacts. Geophysical evidence indicates that the ultramafic bodies are large, tabular, as long as $4 \mathrm{~km}$, generally shallow, and east-northeast striking. They are associated with small, highly resistive (more than $15,000 \Omega \mathrm{m}$ ) metasedimentary rocks, quartz veins, and (or) felsic dikes, all of which are within an asymmetric synform. Distinct lithologic contacts can be recognized between quartz-rich metasedimentary rocks (or granitic bodies) and andesitic flow rocks.

Further work is recommended. Induced polarization and vertical electric soundings might delimit the ultramafic bodies and fault structures believed to control the quartz-vein system and its associated gold deposits. The gold deposits have already been verified in isolated outcrops that contain secondary carbonate, sulfide minerals, and gold.

\section{INTRODUCCION}

Las áreas de estudio están aproximadamente a $65 \mathrm{~km}$ al este de la población de Tumeremo, y a $14 \mathrm{~km}$ al oeste del caserío La Esperanza. Las coordenadas geograficas de la zona de estudio (fig. 1) son lat $7^{\circ} 32^{\prime} 02^{\prime \prime}$ N. a $7^{\circ} 28^{\prime} 35^{\prime \prime}$ N. y Iong $60^{\circ} 57^{\prime} 10^{\prime \prime} \mathrm{O}$. a $60^{\circ} 54^{\prime} 45^{\prime \prime} \mathrm{O}$.

\section{MARCO GEOLOGICO}

La zona de Bochinchito es parte de la provincia geológica de Pastora (Menéndez, 1968, 1972), donde afloran rocas del Grupo Carichapo (mas antigua) y alla Formación Yuruari (mas joven) los cuales componen el Supergrupo Pastora (figura 1). Se encuentran cuerpos graníticos del 

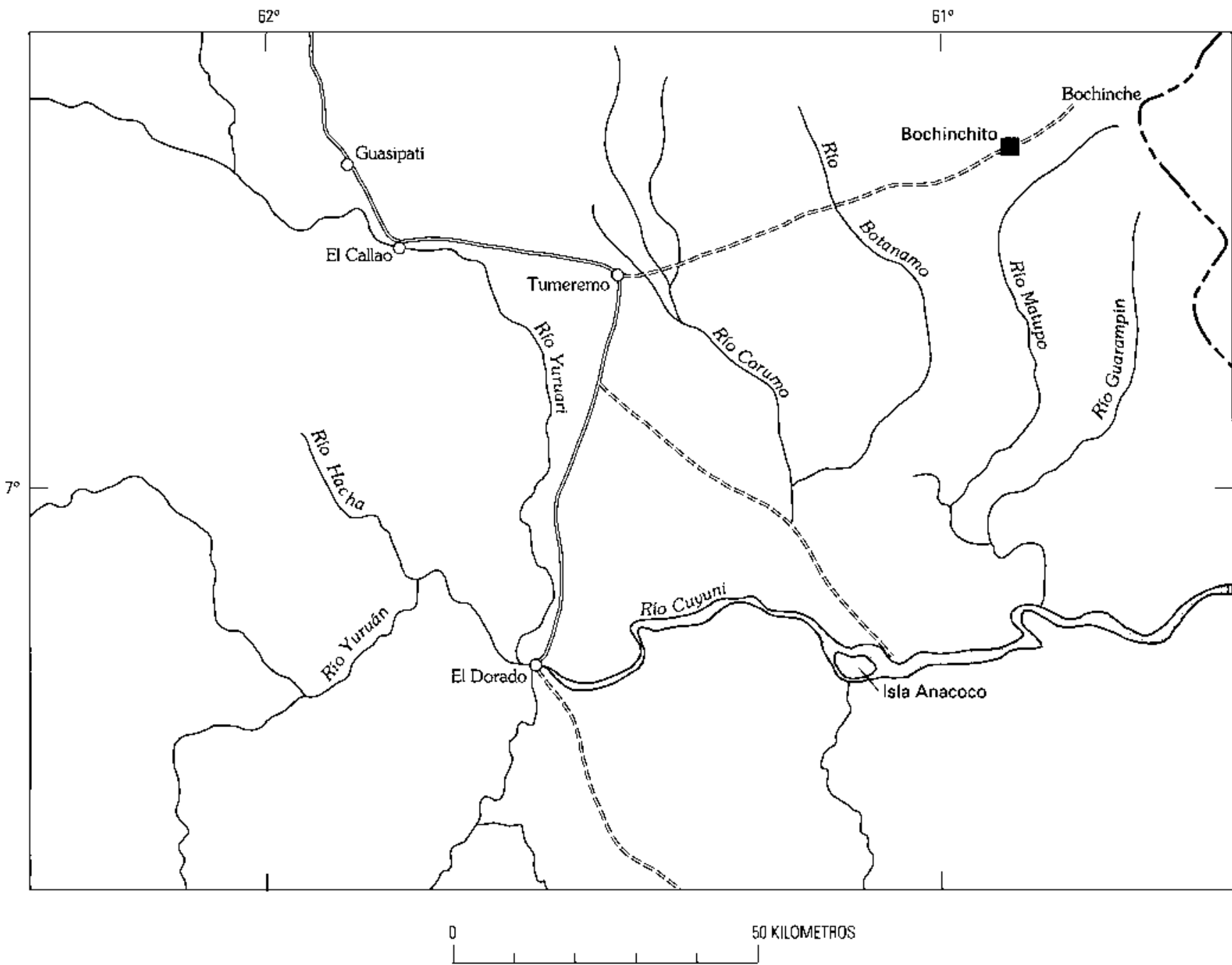

Figura 1. Ubicación relativa del área de Bochinchito I y II.

Complejo de Supamo que intrusionan al Supergrupo Pastora.

Existen tres unidades geológicas importantes en la zona de Bochinchito (Edixon Salazar, Corporación Venezolana de Guayana-Técnica Minera, C.A. (CVG-TECMIN), 1988, comunicación escrita). Estas son (1) unidad de lavas máficas a intermedias (Grupo Carichapo sin diferenciar), (2) asociación de rocas piroclásticas de composición intermediaácida, esquistos cuarzo sericíticos, y cuarcitas ferruginosas; estas rocas están mineralizadas con sulfuros y forman parte de la Formación Yunuari, y (3) unidad de rocas félsicas graníticas del Complejo de Supamo.

Además, existen otros cuerpos intrusivos tabulares, zonas aluvionales derivadas de las unidades félsicas, y gran cantidad de vetas asociadas. La tendencia estructural regional es noroeste con lineamientos $\mathrm{y}(\mathrm{o})$ fallas de rumbo noreste y noroeste y vetas de orientación preferencial noreste $\mathrm{y}$ otras pocas de rumbo noroeste. El modelo del posible yacimiento aurífero consiste de vetas de cuarzo con bajo contenido de sulfuros (Berger, 1986).

\section{METODOS GEOFISICOS}

Los métodos geofísicos empleados fueron el magnético y el eléctrico con el objetivo de ayudar a la ubicación de vetas de cuarzo, establecer relaciones estructurales, y verificar la posibilidad de mineralizaciones en estas. $\mathbf{L a}$ figura 3 muestra la cobertura de los metodos empleados sobre toda la zona.

El levantamiento magnético se ejecuto sobre picas separadas cada $250 \mathrm{~m}$ con numbos de $50^{\circ}-40^{\circ}$ noreste para Bochinchito I, y de $0^{\circ}-16^{\circ}$ noroeste para Bochinchito II. Se tomaron lecturas cada $25 \mathrm{~m}$, cubriéndose un área de $32 \mathrm{~km}^{2}$ y más de $150 \mathrm{~km}$ lineales. Se utilizaron magnetómetros convencionales de precesión de protones.

El procesamiento de los datos magnéticos se dividió en dos fases: procesamiento basico y procesamiento analítico. El procesamiento basico corrige la deriva temporal diurna, crea el banco de datos con ubicación geográfica, topográfica, y del campo magnético, y elabora un mapa de contornos del campo magnetico total (fig. 4) y perfiles magnéticos (fig. 5). 

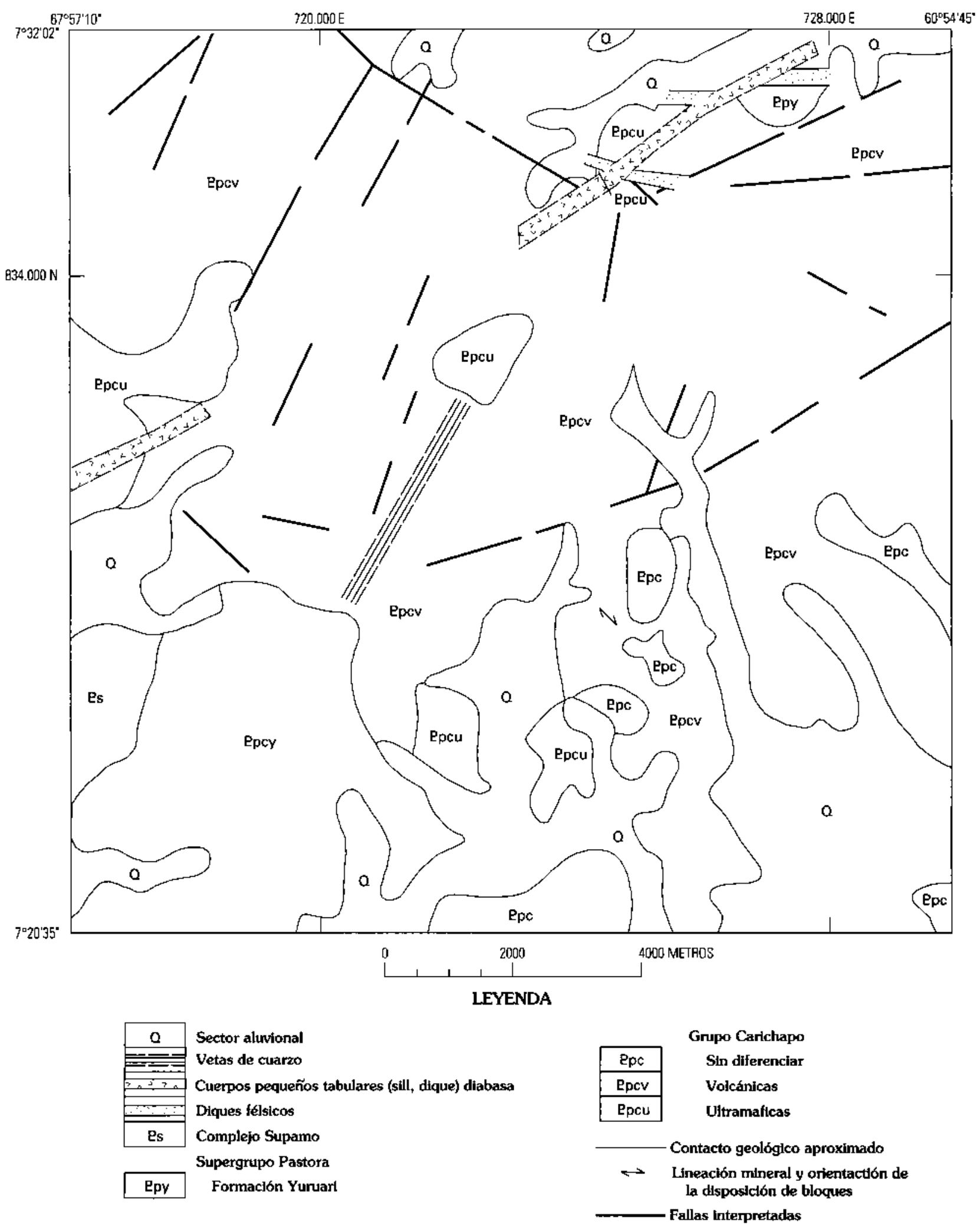

Figura 2. Geología local de Bochinchito I y II. Tomado de Edixon Salazar (comunicación escrita, 1988).

El procesamiento analítico de los datos magnéticos incluye filtros espectrales y modelaje matemático de anomalías magnéticas.
El levantamiento eléctrico consistió en la medición de las resistividades aparentes con el arreglo gradiente, con $\mathrm{MN}=50$ y $100 \mathrm{~m}$, entre las picas $\mathrm{P} 7$ a P20 de Bochinchito I, 


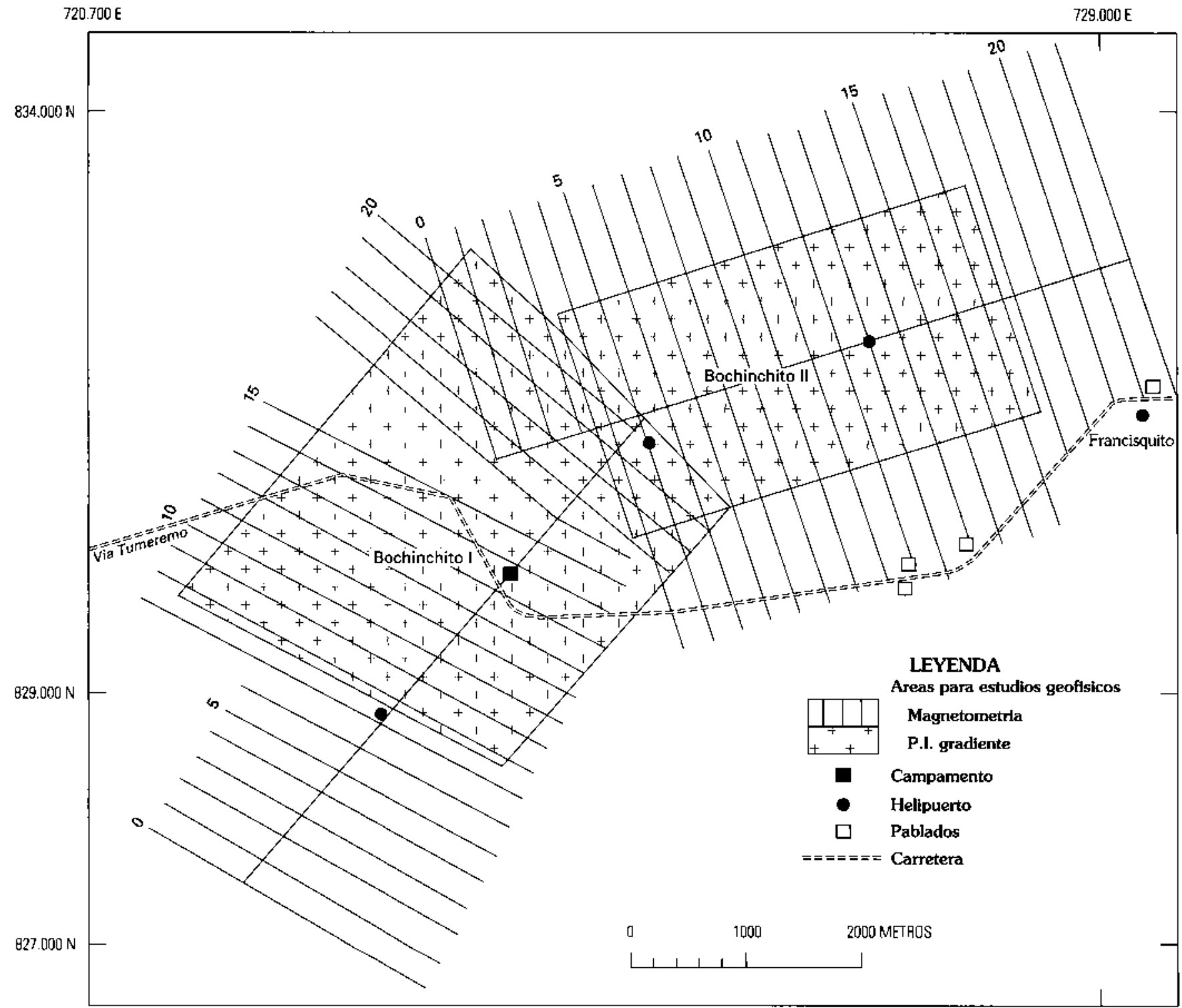

Figura 3. Diagrama del levantamiento eléctrico y magnético, Bochinchito I y II.

y las picas P4 a P13 de Bochinchito II. Estas líneas se escogieron porque cubrían el área de mayor complejidad geológica. Se utilizo equipo convencional de polarización inducida (PI), usándose como receptor, un microvoltímetro; no se midieron valores de cargabilidad. El método cubrió un área de $14 \mathrm{~km}^{2}$ y una longitud de $60.5 \mathrm{~km}$ lineales.

El procesamiento de los datos eléctricos es similar al de los datos magnéticos. El procesamiento básico crea un banco de datos de ubicación y topografía, cálcula la resistividad aparente (ver anexo), elabora perfiles de resistividad (figs. 6 y 7) y un mapa de contomos de resistividad aparente (fig. 8). El procesamiento analítico utiliza un filtro de frecuencias para una longitud de onda de 0.5 en el ancho de la ventana para reducir el ruido geológico y obtener el valor de fondo y residual de las resistividades. El método permite el modelaje e interpretación de la forma, tamaño, y profundidad de los cuerpos resistivos.

\section{INTERPRETACION DE RESULTADOS}

La interpretación de los datos magnéticos (fig. 4) permite establecer tendencias estructurales regionales noreste-este. Las fallas son de tipo sinestral y presentan rumbo noroeste-oeste.

De los mapas de contomos (figs. 4 y 8 ) del campo magnético total y de resistividad aparente, se diferencian cuatro subzonas magnéticas (fig. 9) y cuatro zonas geoeléctricas (fig. 10) importantes: 


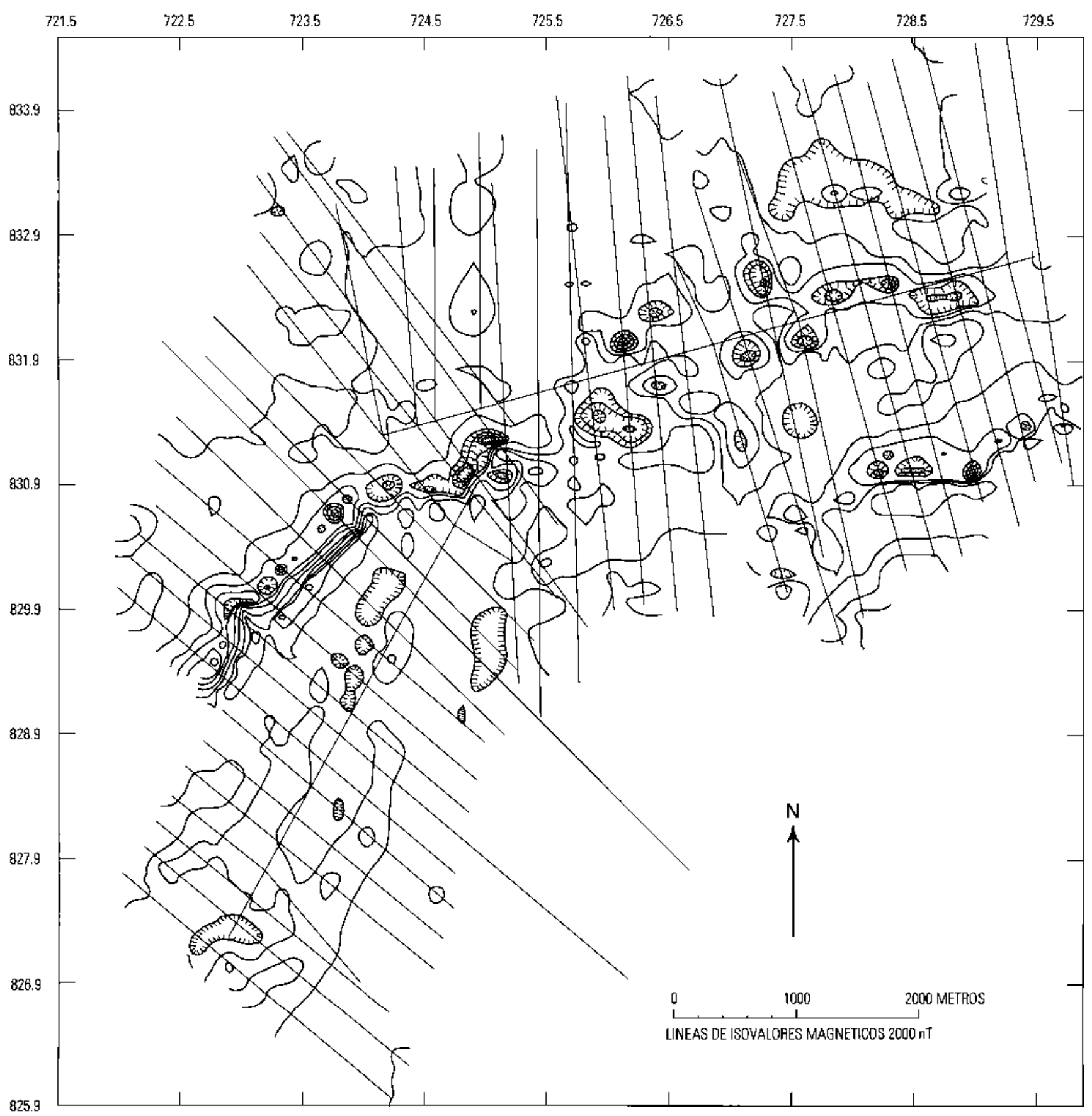

Figura 4. Mapa de contornos del campo magnético total, Bochinchito I y II. Contornos a intervalos de 2,000 nT.

I. Zona de susceptibilidad magnética y gradiente del campo magnético bajo y de baja resistividad, entre $0-4,000$ $\Omega \mathrm{m}$. No presenta anomalías magnéticas importantes. Probablemente sea una zona granítica, correlacionable con el Complejo de Supamo. Esta zona se subdivide en dos subzonas geoeléctricas concéntricas, una de ellas denominada $Q A$, con resistividades menores a $2,000 \Omega \mathrm{m}$, otra denominada $\mathrm{QB}$, con resistividades entre $2,000-4,000 \Omega \mathrm{m}$. Estas coinciden con áreas donde se encuentran quebradas de primer o segundo orden, y están asociadas a litologías aluvionales.
También, aparecen en bajos topograficos al sur y sureste del área.

II. Zona de alta susceptibilidad magnética y alta resistividad, entre 10,000 y $15,000 \Omega \mathrm{m}$. Presenta anomalías magnéticas fuertes, pero de bajo gradiente. Se ubica al sur del área de Bochinchito I, alrededor del eje del sistema de picas. Se asocian con rocas ferruginosas como metasedimentos cuarcíferos, esquistos $y(0)$ rocas piroclásticas típicos de la Formación Yuruari, y tambien a intrusivos félsicos. Esta zona se relaciona a un alto estructural con rumbo norte- 


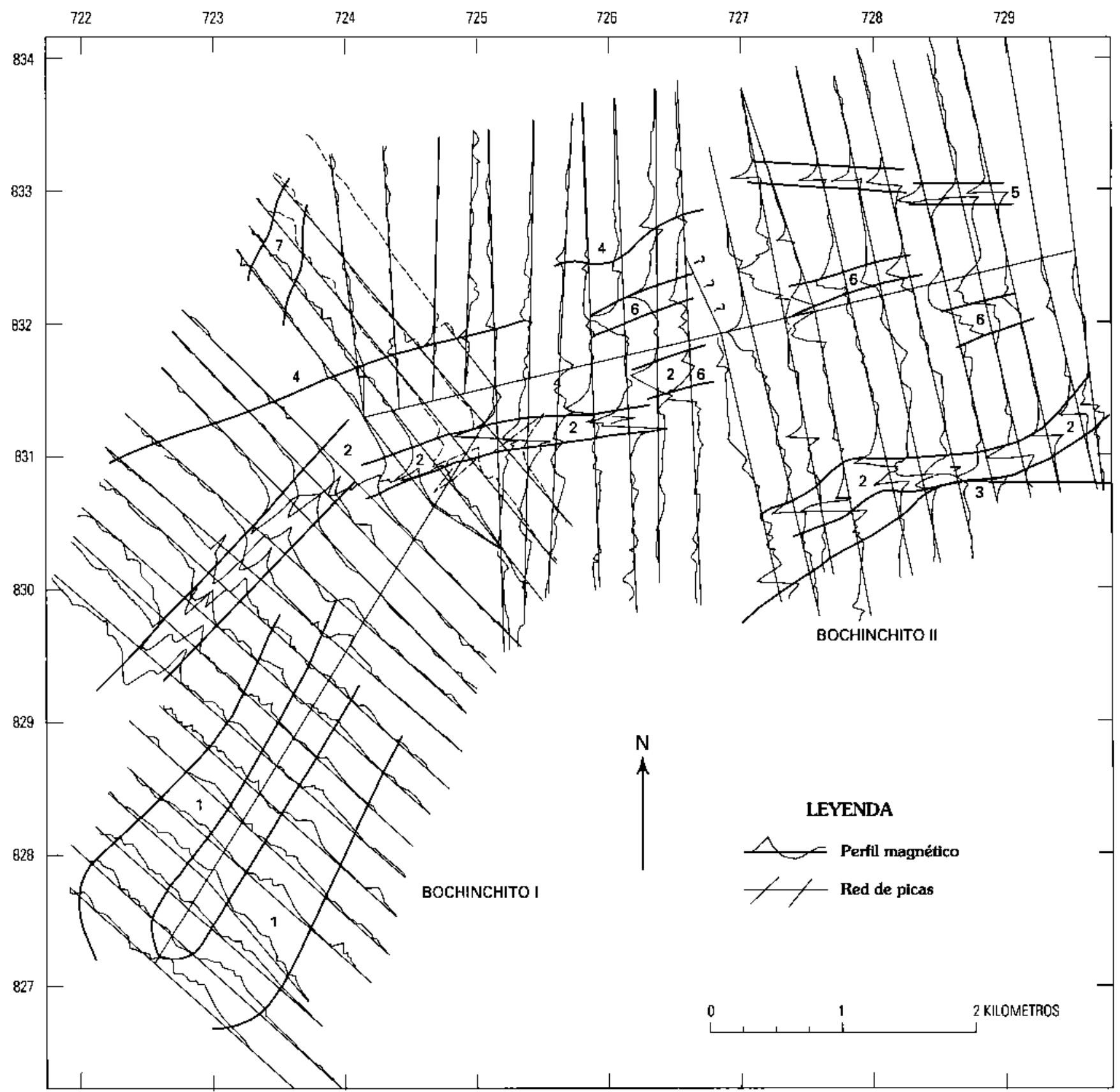

Figura 5. Perfiles magnéticos de la zona Bochinchito I y II. Interpretación y numeración referida al texto.

noreste. Es posible la existencia de vetas de cuarzo de interés prospectivo en esta zona.

III. Zona de alto gradiente del campo magnético y de resistividad intermedia, entre 4,000 y $10,000 \Omega \mathrm{m}$. Comprende los valores de fondo de resistividad de la zona. Esta zona presenta anomalías magneticas intensas, pero de susceptibilidad intermedia a alta. Se asocia a lava máfica a intermedia, gabro, diques de diabasa, y andesita. Se ubica en una franja central desde Bochinchito I a Bochinchito II. Probablemente correspondan a eventos volcánicos del Grupo Carichapo y menos probable can lavas de la Formatión Yuruari.
IV. Zona de gradiente intermedio y susceptibilidad alta. Consiste de cuerpos magnéticos anchos pero poco extensos de forma elipsoidal. Se relacionan con cuerpos ultramáficos del Grupo Carichapo.

Figura 6. Perfiles de resistividad aparente sobre las picas en el área de Bochinchito I donde se observaron las anomalías más fuertes. Se representan filtros de frecuencia (LOWESS, W=0.5) que determina el "regional" filtro de cinco puntos $(\mathrm{a} 1=\mathrm{a} 2=\mathrm{a} 4=\mathrm{a} 5=1 / 8 \mathrm{a} 3=1 / 2)$ que produce un registro eléctrico menos ruidoso. El "residual" es producto de la diferencia entre el perfil observado (ROA1) y el filtrado "regional." 


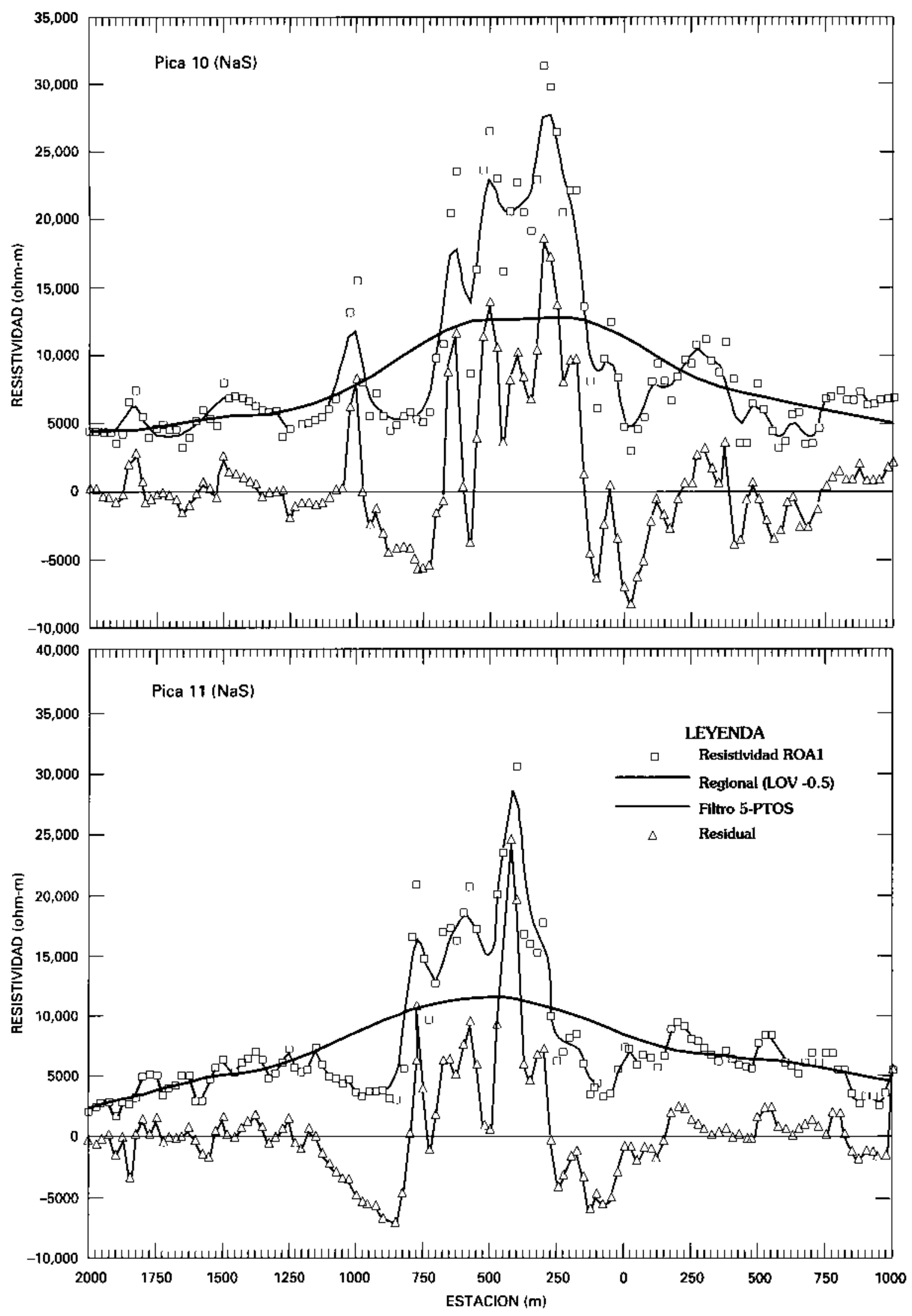


V. Zonas con valores de resistividad mayores a $15,000 \Omega \mathrm{m}$. Se vinculan a cuerpos pequeños resistivos $\mathrm{y}$ locales, de forna tabular y delgados, posiblemente sean diques felsicos o vetas de cuarzo. Esta zona es exclusiva del sistema Bochinchito I (parte centro-suroeste).

El procesamiento espectral de los datos magnéticos indica lo siguiente:

1. Reducción al polo. La intensidad del campo magnético que varia hacia el norte-noroeste de la zona es mas fuerte a los $100 \mathrm{~m}$ y mas debil hacia $350 \mathrm{~m}$.

2. Filtrado pasa banda. Se filtraron longitudes de onda entre 100 y $1,000 \mathrm{~m}$. Las anomalías resultantes presentan variaciones entre $-1,500$ y 1,500 gamma las cuales pueden clasificarse según su amplitud, de la siguiente forma:

Fuertes Entre -800 y 600 gamma, asociada a cuerpos máficos tipo dique

Intermedias Entre -500 y 300 gamma relacionadas a cuerpos ultramáficos

Bajas Entre -200 y 300 gamma correspondendientes a cuarcitas ferruginosas

Débiles Entre -200 y 100 gamma vinculadas a contactos entre rocas félsicas y lavas de composición intermedia

3. Segunda derivada vertical. Se distingue la ubicación de los principales contactos, los cuales son descritos por las anomalías magneticas mayores (tabla 1).

4. Continuación hacia arriba del campo $(100 \mathrm{~m})$. La continuación logra filtrar casi todas las anomalías residuales y se deduce la profundidad del tope de los cuerpos anómalos.

$\mathrm{El}$ análisis de los perfiles eléctricos (figs. 6 y 7 ) indica que el valor promedio de resistividad de la zona está sobre $\operatorname{los} 4,000 \Omega \mathrm{m}$. En el sistema Bochinchito I, destaca la presencia de una superposición de tres anomalías de alta resistividad.

El "residual"2 muestra tres anomalías de $10,000-15,000 \Omega \mathrm{m}$ con una anchura no mayor a los $50 \mathrm{~m}$ que tiende a superponer, hasta formar una sola anomalía en la dirección noreste. Estas anomalías parecen estar dentro de una unidad de resistividad alta, rodeada de otra de resistividad más baja. En el sistema Bochinchito II, las anomalías son de menor intensidad (15,000 $\Omega \mathrm{m}$ ) están escalonadas, dispersas y son más amplias que las del sistema Bochinchito I.

La anomalía 1 está al suroeste de la zona. Se debe a sedimentos ferruginosos con alta susceptibilidad, tiene rumbo noreste a este, y se divide en dos ramales.

La anomalía 2 está en el centro de la zona. Se debe a cuerpos locales delgados (entre 50 y $100 \mathrm{~m}$ ) tipo dique de diabasa, extensos (más de $4.0 \mathrm{~km}$ de largo). Presenta dos apófisis (basalto-diabasa) de rumbo noreste a este. La

\footnotetext{
${ }^{2}$ El término "regional" conno el términ "residual" no tiene el mismo significado usado en métodos potenciales como la magnetometría. En este caso solo se usan para describir la idea de fondo promedio de resistividad y de resistividades de los cuerpos anómalos locales, respectivamente.
} 

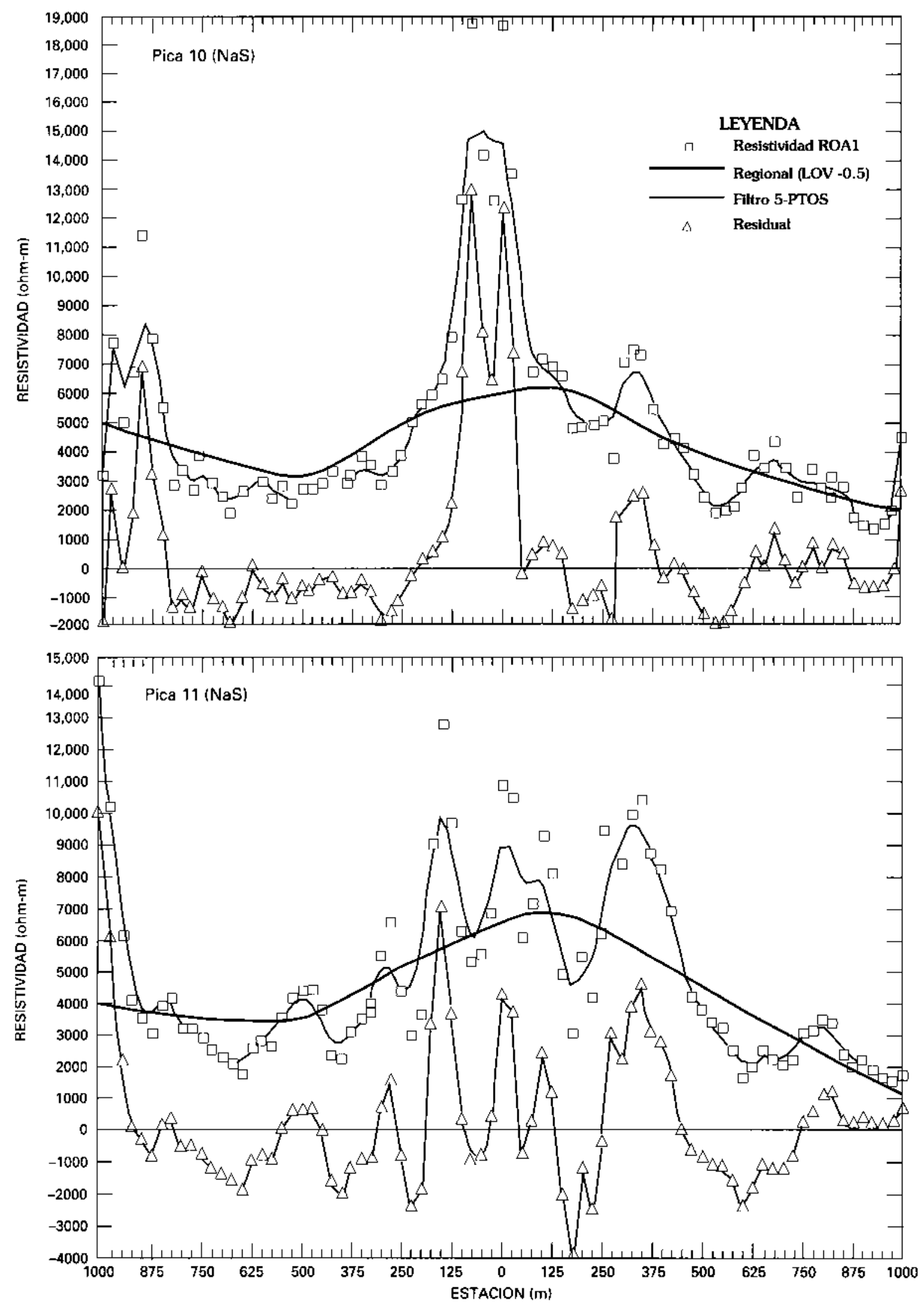

Figura 7. Perfiles de restividad aparente sobre las picas en el área de Bochinchito II donde se observaron anomalías más fuertes. Se representan los datos de campo y otros perfiles, al igual que los descritos en la leyenda de la figura 6. 


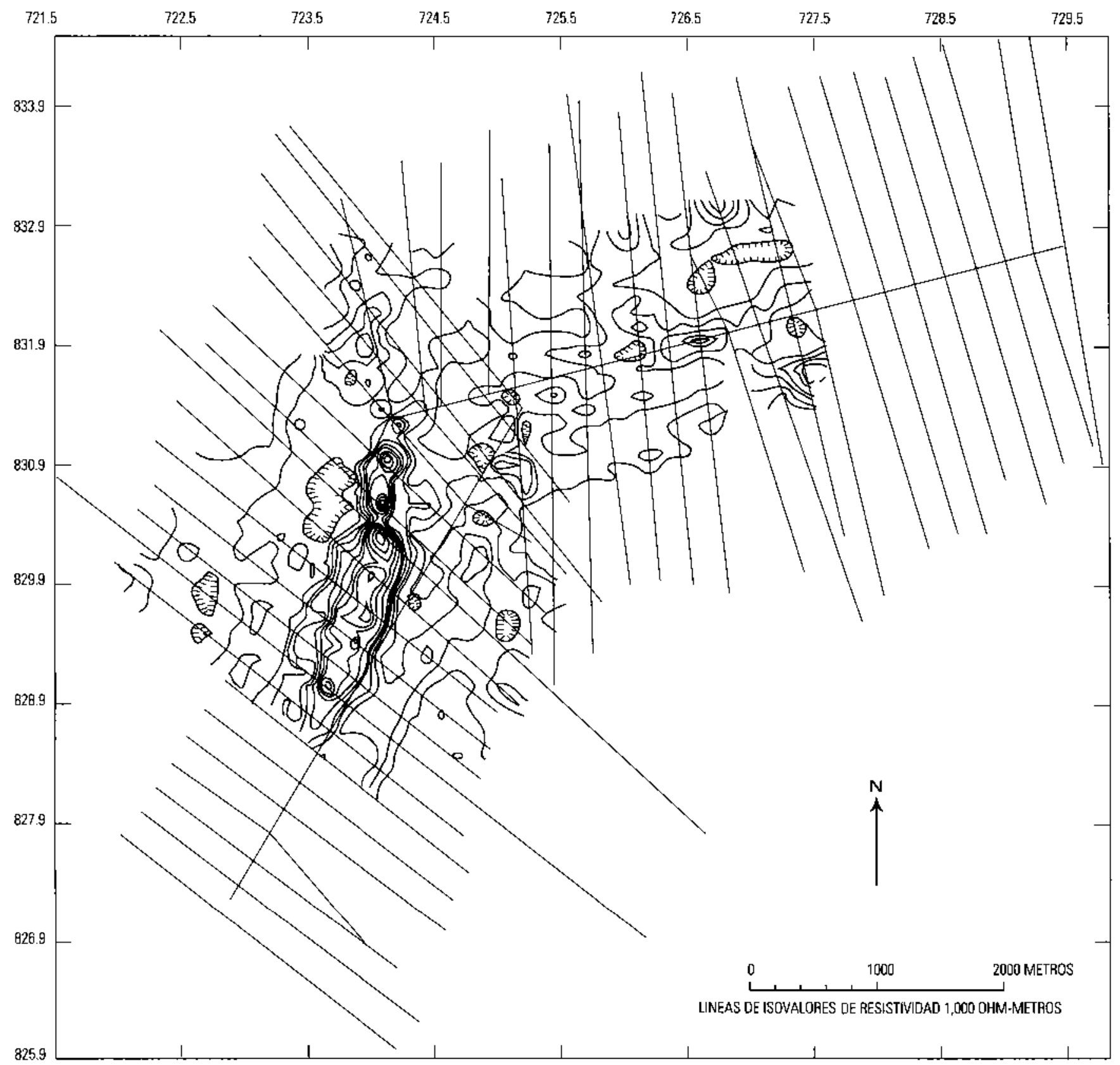

Figura 8. Mapa de contornos de isovalores de resistividad aparente (MN=100 m), Bochinchito I y II.

anomalía está desplazada por fallamiento o fracturas ortogonal esa su rumbo, reapareciendo entre las picas P4 y P8 del sistema Bochinchito II. El mismo cuerpo o uno similar aparece al sur entre P11 a P22 de Bochinchito II con posible continuidad al este, como expresión extrema del dique de diabasa Laguna el cual aflora en la zona de Bochinche y que se relaciona con las principales anomalías de oro de este prospecto.

La anomalía 3 representa el contacto entre rocas de susceptibilidad mayor y menor. Su lado sureste se puede superponer con la anomalía 2.
La anomalía 4 marca el contacto de rumbo noreste a este entre formaciones diferentes, al norte rocas graníticas y al sur lavas máficas a intermedias, o posiblemente se trate de un cuerpo máfico delgado, tipo dique.

La anomalía 5 está representada por un dique al noreste de la zona, el cual identifica con la anomalía 4 por correlación lateral al oeste.

La anomalía 6 está compuesta de pequeñas e intensas anomalías de rocas ultramáficas elipsoidales con rumbo este.

La anomalía 7 incluye una pequeña anomalía estructural al noreste, entre las picas P18 a P19 del sistema 


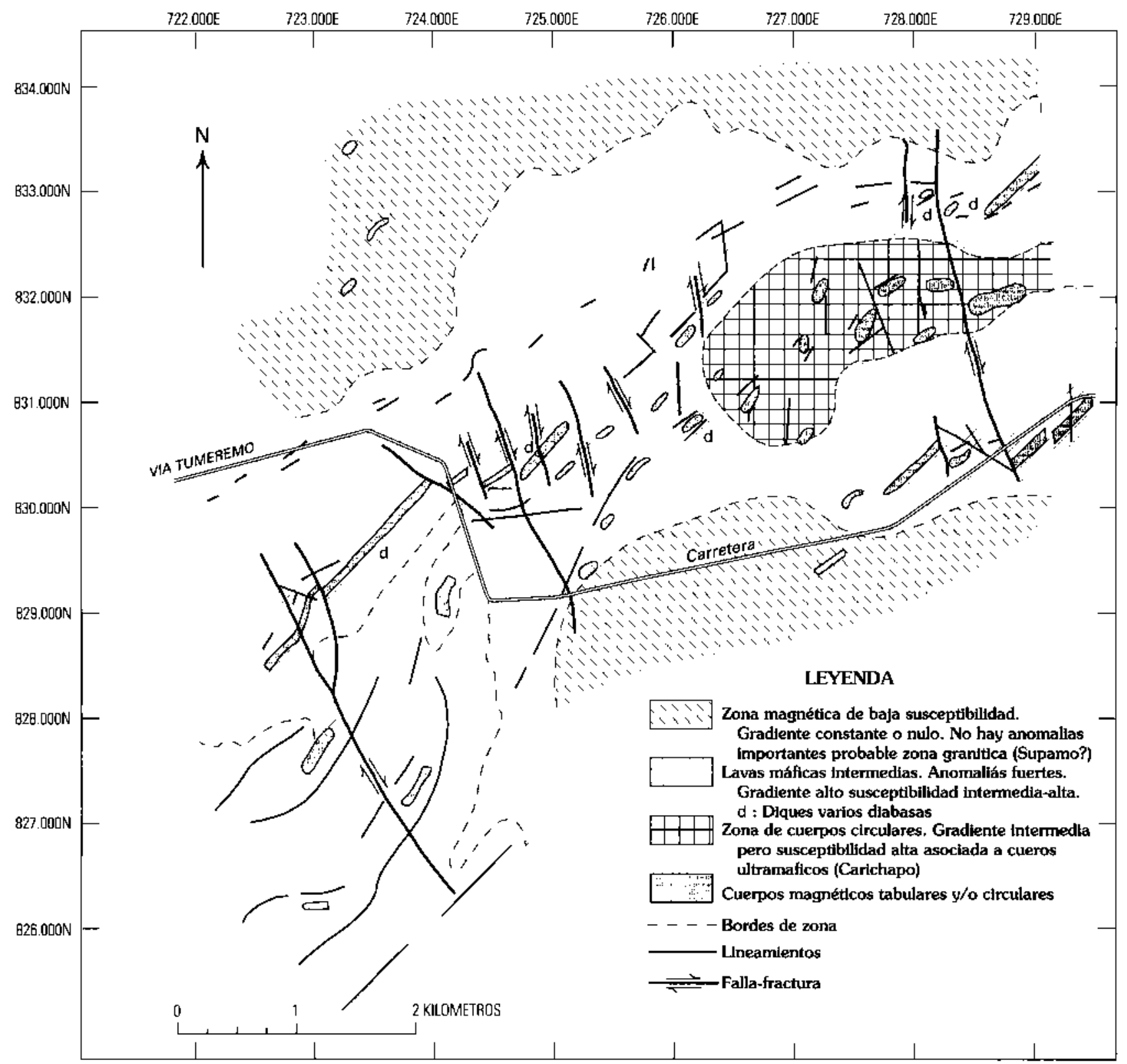

Figura 9. Interpretación magnético-estructural, Bochinchito I y II.

Bochinchito I, probablemente se deba al contacto entre rocas félsicas con diferentes susceptibilidades.

A partir de los perfiles, se efectúa el modelaje matemático de las anomalías magnéticas más importantes (figs. 11, 12, y 13). El modelaje magnético se realizo mediante el uso de programas de computación, basados en el algoritmo de Talwani y Heirtzler (1964). El modelaje eléctrico se realizo mediante un programa de computación de "solución inversa" (Asch, 1989).

El modelaje eléctrico permitió diferenciar tres unidades importantes: una unidad exterior de 5,000-7,000 $\Omega \mathrm{m}$ de resistividad (probablemente de granitos o lavas); seguida por otra unidad interior de más baja resistividad, entre 2,000 y
$4,000 \Omega \mathrm{m}$, probablemente aluvional; y finalmente el contacto intrusivo entre diques de diabasa y rocas más resistivas ( $>15,000 \Omega \mathrm{m}$ ) tales como cuarcitas y rocas piroclásticas. La estructura general se asemeja a un cuerpo sinclinal asimétrico con el flanco sur menos inclinado que el flanco norte y cuyo eje está centrado en un entorno a la progresiva 0+500 noroeste del sistema Bochinchito I. Es de esperar, fracturas o fallas radiales, desde la superficie al punto por donde pasa el eje del sinclinal. Las vetas se ubican en la zona central del sinclinal, con buzamiento alto hacia el noroeste. La profundidad de los cuerpos resistivos y su extensión son inciertos en el modelo realizado, pero se asume la superfi- 


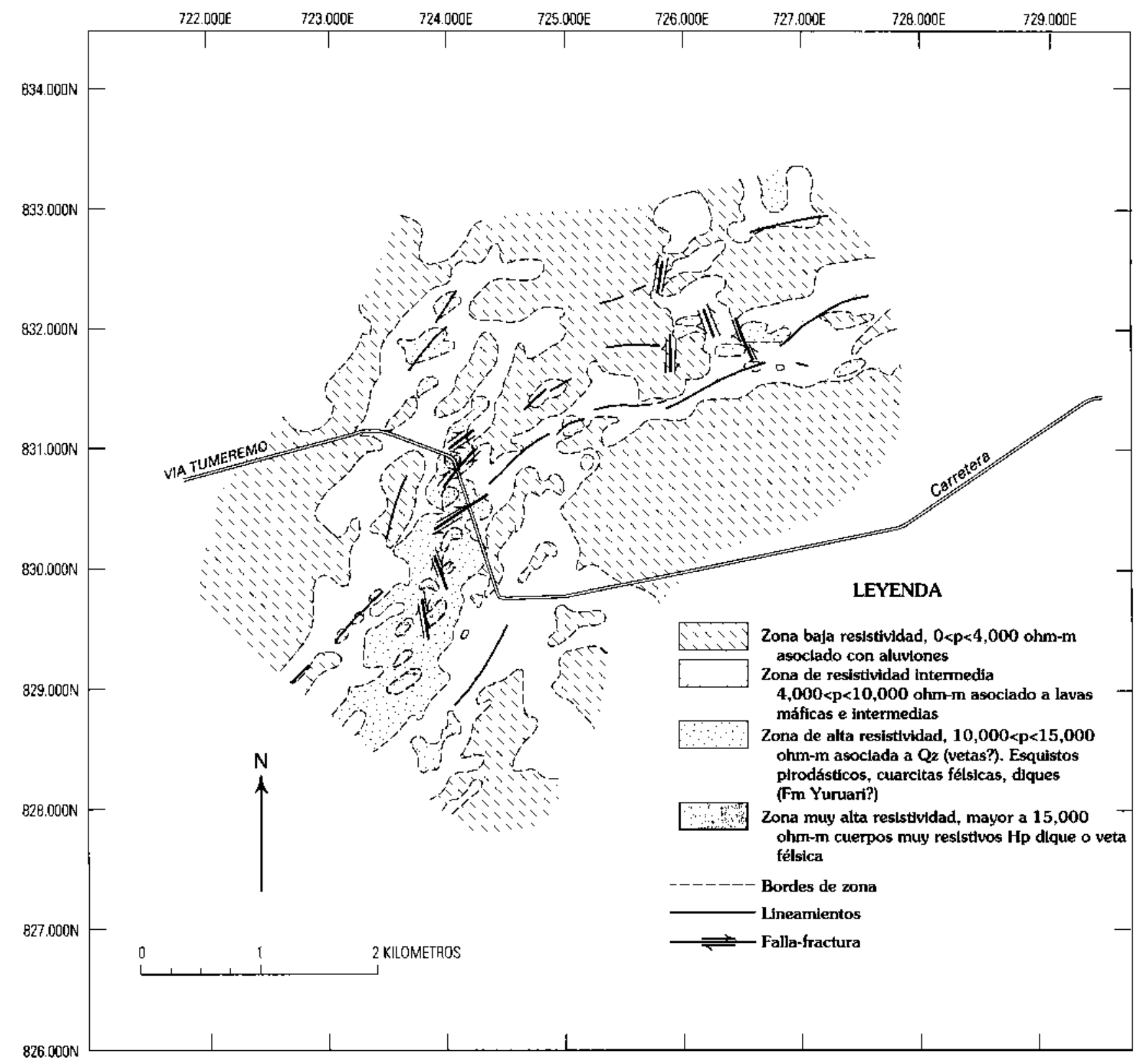

Figura 10. Interpretación eléctrico-estructural, Bochinchito I y II.

cialidad de estos (menos de $10 \mathrm{~m}$ de profundidad), dado el fuerte contraste de resistividad entre la parte central del perfil y los extremos.

El espesor de la capa de meteorización conductora es delgada. Los valores de resistividad ${ }^{3}$ de estos cuerpos son variables, pero superiores a $15,000 \Omega \mathrm{m}$. Se caracterizan por su alta frecuencia en el registro eléctrico y se supone que se

${ }^{3}$ El programa ha demostrado baja resolución en la pseudoseccion en profundidad, puesto que se necesitan variaciones de 5-10 veces el valor de la resistividad de la "roca caja," para producir un registro con una anomalía significativa. La profundización de un cuerpo de resistividades menores puede no ser notada en el registro eléctrico. ubican en un entorno de radio de $20 \mathrm{~m}$ al pico o máximo local. Su espesor no debe ser mayor a los $20 \mathrm{~m}$. En el sistema Bochinchito II, las zonas de alta resistividad asociadas con vetas de cuarzo se distribuyen esparcidamente y tienen buzamientos ligeramente al sureste. La geometría sinclinal está preservada y está relacionada con los altos topográficos estructurales a ambos lados del eje del sinclinal.

Las estructuras modeladas (tabla 1) se disponen en tres categorías: (1) al norte, son angostas y de buzamiento medio-alto $\left(40^{\circ}-80^{\circ}\right)$ hacia el sur; (2) al sur, son más amplias y de buzamientos altos $\left(80^{\circ}\right)$ al norte; y (3) las estructuras centrales son grandes, amplias y extensas lateralmente. Todas las anomalías se orientan con rumbo N. $80^{\circ} \mathrm{O}$. hasta N. $40^{\circ}$ E. Las estructuras son superficiales. La mayoría de las 

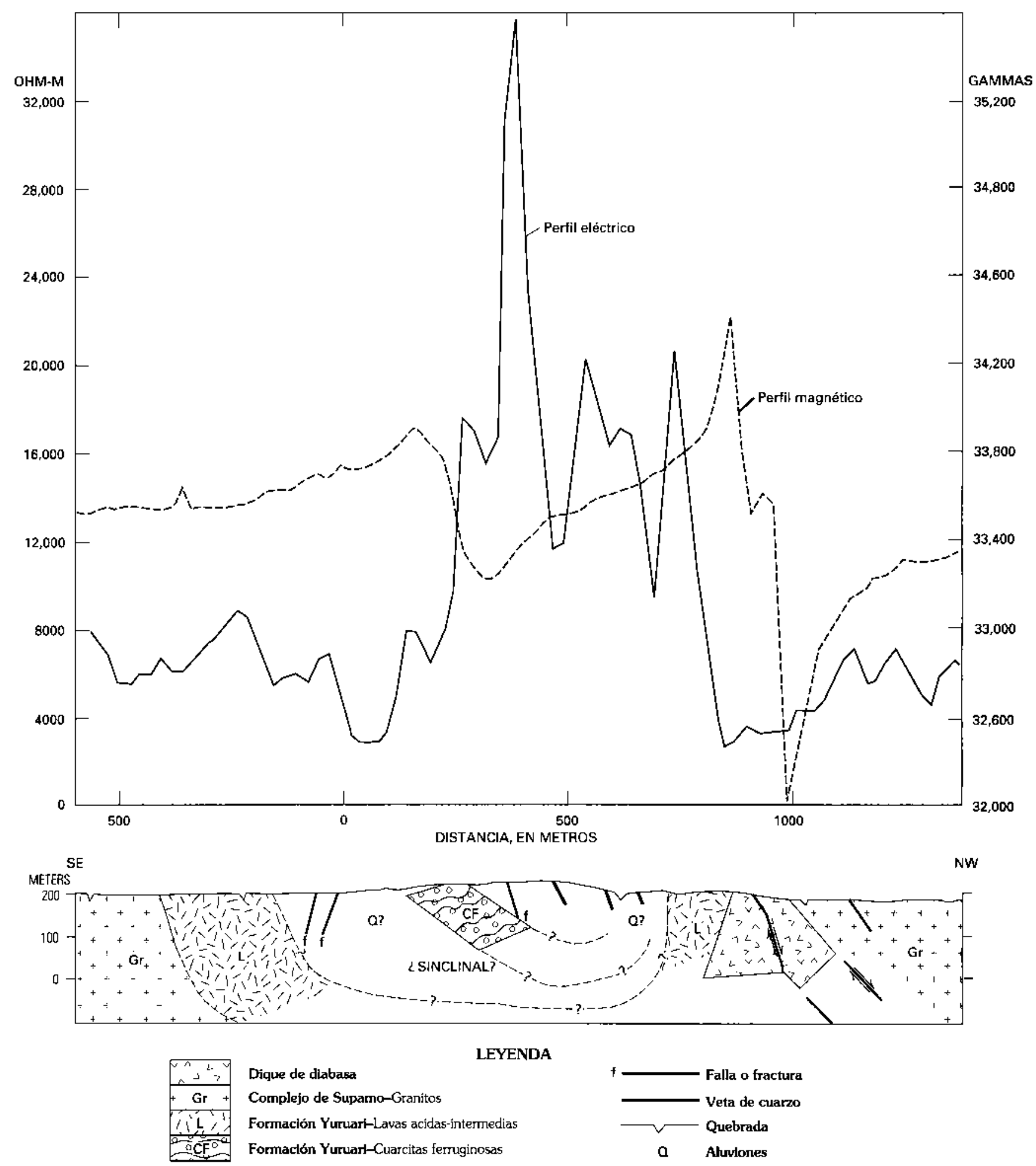

Figura 11. Modelaje geológico-geofísico del área de la pica 12, Bochinchito I. Perfil electrico MN=50 m. 


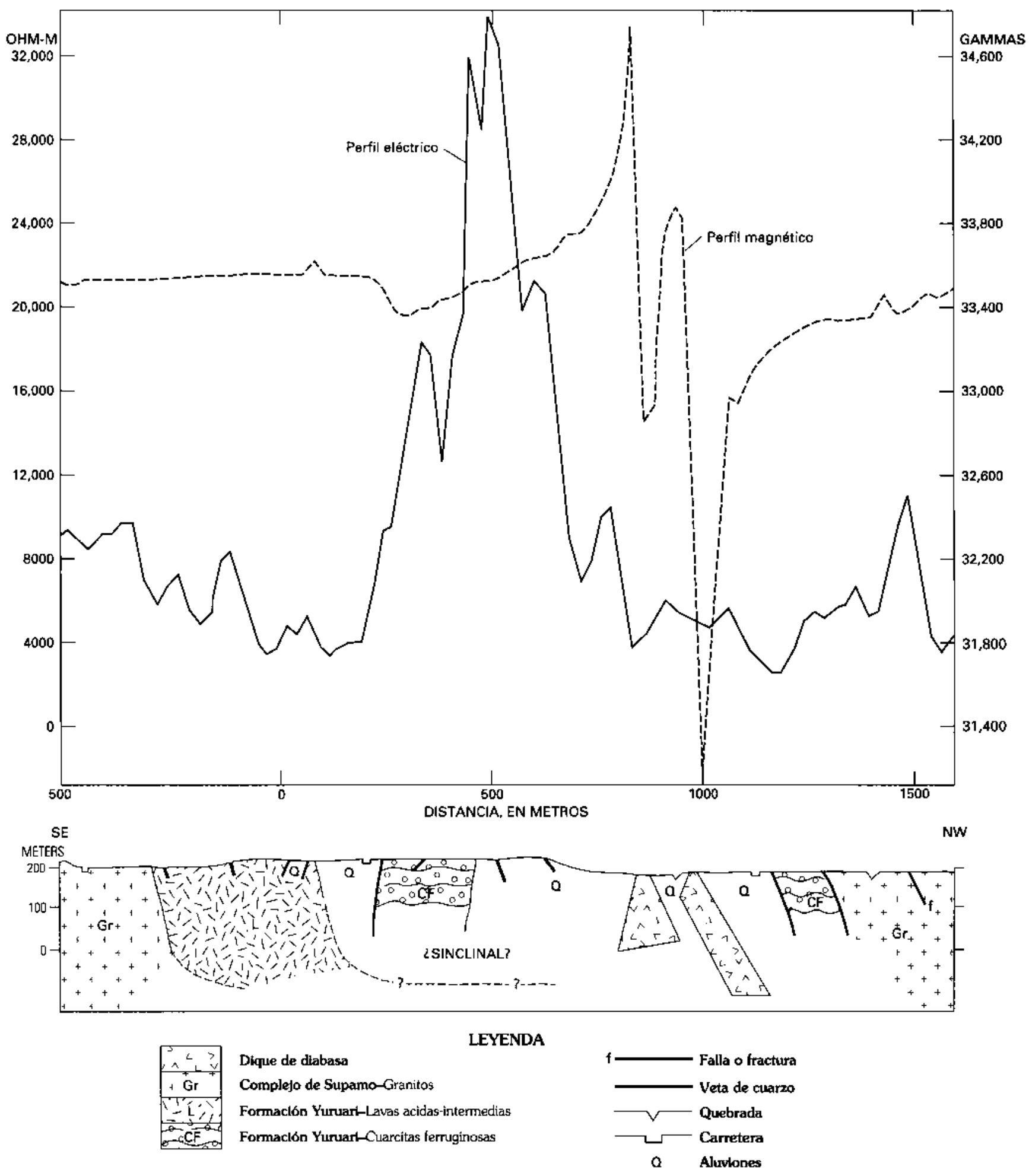

Figura 12. Modelaje geológico-geofísico del área de la pica 13, Bochinchito I. Perfil eléctrico MN=50 m. 


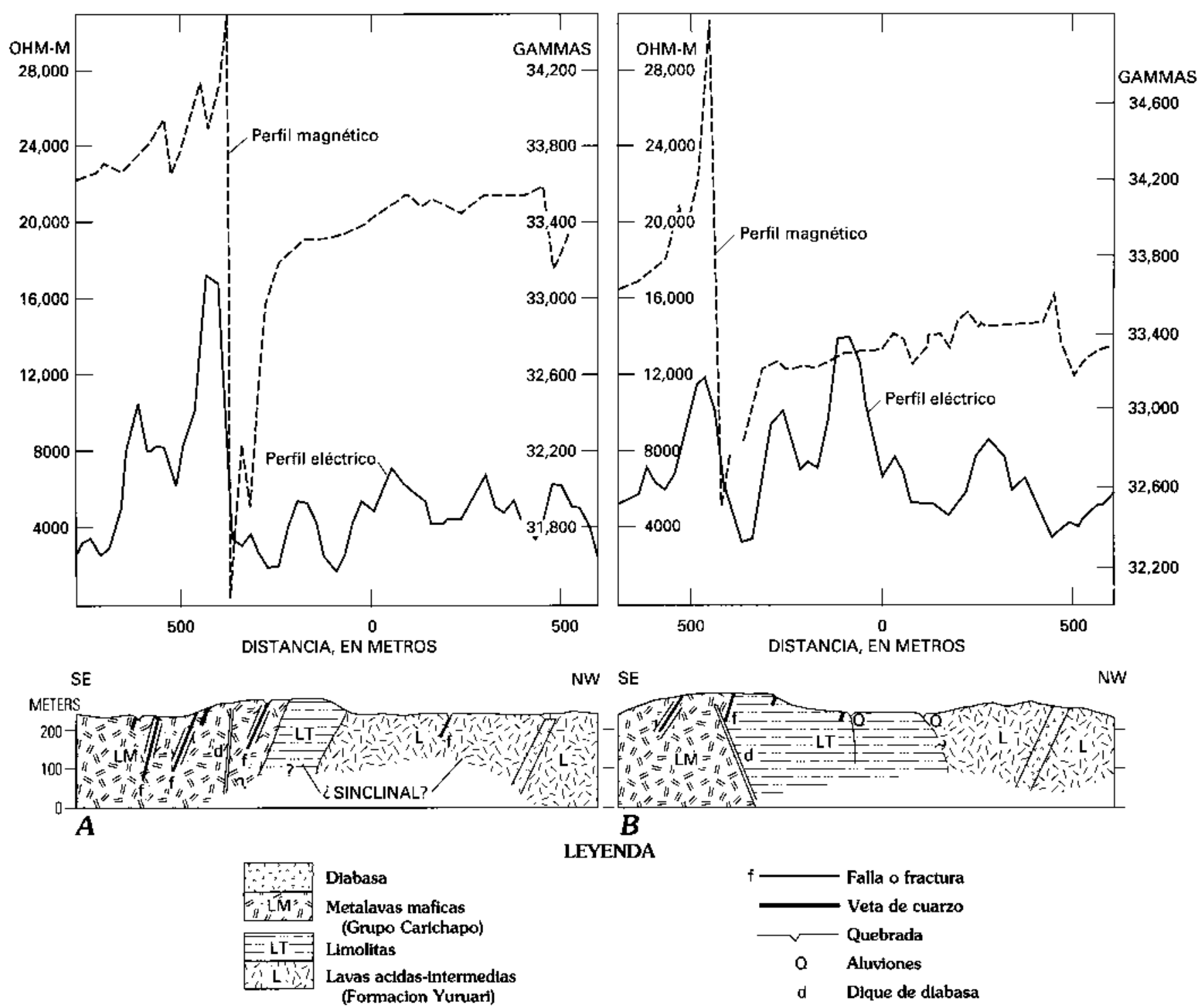

Figura 13. Modelaje geológico-geofísico del área de la pica 4 (izquierda) y pica 5 (derecha), Bochinchito II. $A$, Arreglo gradiente simétrico. $B$, Arreglo gradiente general.

anomalías se hacen mas amplias en la dirección este. Las susceptibilidades varían hasta 10 veces el valor promedio, to cual indica heterogeneidad de concentraciones de minerales magnéticos en las rocas de la zona.

\section{CONCLUSIONES}

El estudio de las anomalías magnéticas determinó la presencia de cuerpos magnéticos con tendencias regionales. Su numbo es noreste a este, y buzamiento es entre $40^{\circ}-80^{\circ} \mathrm{S}$. para cuerpos al norte de la zona y aproximadamente $80^{\circ} \mathrm{N}$. para los cuerpos al sur. Se determinó la superficialidad del tope de los cuerpos magnéticos principales, fallas sinestrales de rumbo norte-noroeste, y espesor entre 5-140 m en cuerpos tipo dique y hasta $500 \mathrm{~m}$ en cuerpos tabulares mayores. Se identificó la tendencia al aumento del espesor en la dirección este, una extensión lateral de varios kilómetros, y una variación de susceptibilidad amplia, que indica heterogeneidad de la concentracione de minerales magnéticos.

El estudio de las anomalías eléctricas ha permitido diferenciar 3 o 4 unidades geoeléctricas mayores. La morfología de las estructuras modeladas muestran una configuración geométrica sinclinal en la cual se encuentran cuerpos resistivos delgados, poco profundos o aflorando, 
con buzamiento alto al noroeste. El espesor de las vetas se asume menor a $20 \mathrm{~m}$. La correlación lateral de las zonas resistivas se extiende en varios cientos de metros aunque la continuidad de una misma veta es dudosa debido a fallas o fracturas de rumbo NO-N. La ocurrencia de un sistema de pequeñas vetas de numbo norte-noreste es mas probable. La complejidad estructural, aunado a la asociación de rocas máficas y rocas sedimentarías ferruginosas, muestra las condiciones necesarias para la mineralización de oro en las vetas de cuarzo, haciendo de la zona de Bochinchito un buen prospecto minero.

Agradecimientos.-A los técnicos Henry Brito, Freddy Rodriguez y Jhonny Villarroel (CVG-TECMIN) por su colaboración en la adquisición de datos de campo. Al Geofísico Antonio Ferrero (CVG-TECMIN) por su aporte en la elaboración del anexo así como su ayuda en el levantamiento de campo, y al Geofísico Jorge Penott por sus certeros comentarios sobre este trabajo. Al Dr. Jeffrey Wynn (U.S. Geological Survey) por su valiosisima ayuda en la asesoría técnica de este trabajo.

\section{BIBLIOGRAFIA}

Asch, $T_{,}, 1989$, Users manual for the program "RESIS2D" on the IBM AT: U.S. Geological Survey Order 012814-89, 33 p.

Berger, B.R., 1986, Descriptive model of low-sulfide Au-quartz veins, in Cox, D.P., and Singer, D.A., eds., Mineral deposit models: U.S. Geological Survey Bulletin 1693, p. 239.

Menendez V. de V., Alfredo, 1968, Revisión de la estratigrafía de la Provincia de Pastora según el estudio de la región de Guasipati, Guayana Venezolana: Boletín de Geología, Caracas, v. 10 , no. 19 , p. $309-338$

1972, Geología de la región Guasipati, Guayana Venezolana: Congreso Geológico Venezolano, 4th, Caracas, 1971, Memoria, Publicación Especial 5, v. 4, p. 2001-2046.

Talwani, Manik, and Heirtzler, J.R., 1964, Computation of magnetic anomalies caused by two dimensional structures of arbitrary shape, in Computers in the mineral industries, part I: Palo Alto, Stanford University Publications, Geological Sciences, v. 9, p. $464-480$. 


\section{ANEXO-EL ARREGLO GRADIENTE-UNA NUEVA FORMULA DE CALCULO DEL FACTOR GEOMETRICO, PARA LA CONFIGURACION USADA EN VENEZUELA}

El arreglo o dispositivo gradiente es una configuración geométrica de electrodos de potencial y de corriente que permite medir la resistividad aparente en un punto bajo la superficie. En general, para las mediciones de resistividad aparente, la validez de la ley de Ohm determina que:

$$
R o=(V / I) \times K
$$

donde $R o$ es la función de resistividad aparente puntual, puesto que la constante $K$ no es fija, sino depende del punto de ubicación dentro del arreglo, para una medición determinada. En un sistema de cuatro electrodos, esta constante $K$ depende de cuatro radio vectores entre cada electrodo y el punto de medición, de modo que :

$$
K=2 \pi\{1 /(1 / A N-1 / A M-1 / B N+1 / B M)\}
$$

donde $A N, A M, B N$, y $B M$ son los radios vectores mencionados.

El arreglo gradiente tradicionalmente usado por su simplicidad geométrica es aquel cuya simetría especular, permite el cálculo de los radio vectores mediante la solución de triángulos rectángulos sencillos (fig. A). De este modo, el arreglo gradiente tradicional se calculaba con :

$$
\begin{aligned}
& A N=\sqrt{ }\left\{(L-d-n \times c)^{2}+(m \times b)^{2}\right\} \\
& A M=\sqrt{ }\left\{(d+n \times c)^{2}+(m \times b)^{2}\right\} \\
& B N=\sqrt{ }\left\{(d+n \times c+a)^{2}+(m \times b)^{2}\right\} \\
& B M=\sqrt{ }\left\{(L-d-n \times c-a)^{2}+(m \times b)^{2}\right\}
\end{aligned}
$$

donde $n$ es entero y $c$ es la separación entre estaciones. Este arreglo exige que las líneas (o picas) sean paralelas entre si y perpendiculares al eje de simetría. Sin embargo, estas condiciones no se cumplen o son difíciles de controlar, en la etapa de adquisición de datos de campo. Dadas estas circumstancias, se desea usar un nuevo factor geométrico más general y arbitrario, dentro del contexto del arreglo gradiente, que no exija requerimientos especiales.

La figura B muestra las condiciones generales que pueden presentarse en casos de sistemas de picas o de líneas más reales. En este caso, los factores geométricos vienen dados por :

$$
\begin{aligned}
A N= & \sqrt{ }\left[\left\{L / 2-(n \times c+a / 2+E-F \times \cos \beta)^{*} \cos \alpha\right\}^{2}+\{F \times \operatorname{sen} \beta+\right. \\
& \left.\left.\left(n^{*} c+a / 2\right)^{*} \operatorname{sen} \alpha\right\}^{2}\right] \\
A M= & \sqrt{ }\left[\left(L / 2-(n \times c-a / 2+E-F \times \cos \beta)^{*} \cos \alpha\right\}^{2}+\{F \times \operatorname{sen} \beta+\right. \\
& \left.\left.\quad\left(n^{*} c-a / 2\right)^{*} \operatorname{sen} \alpha\right\}^{2}\right] \\
B N= & \sqrt{2}\left\{L / 2+(n \times c+a / 2+E-F \times \cos \beta)^{*} \cos \alpha\right\}^{2}+\{F \times \operatorname{sen} \beta+ \\
& \left.\left.\quad\left(n^{*} c-a / 2\right)^{*} \operatorname{sen} \alpha\right\}^{2}\right] \\
B M= & \sqrt{ }\left[\left(L / 2+(n \times c-a / 2+E-F \times \cos \beta)^{*} \cos \alpha\right\}^{2}+\{F \times \operatorname{sen} \beta+\right. \\
& \left.\left.\left(n^{*} c+a / 2\right)^{*} \operatorname{sen} \alpha\right\}^{2}\right]
\end{aligned}
$$

A pesar de la mayor complejidad de la ecuación, este nuevo factor geométrico permite poder trabajar con sistemas de líneas o picas arbitrarias, sin condicionamientos especiales sobre el arreglo. La fórmula tradicional, del arreglo gradiente simétrico, es reproducible con esta fórmula, bajo las condiciones siguientes: $\alpha=0^{\circ}, \beta=90^{\circ}, E=0$, y $F=m \times b(m$ entero).

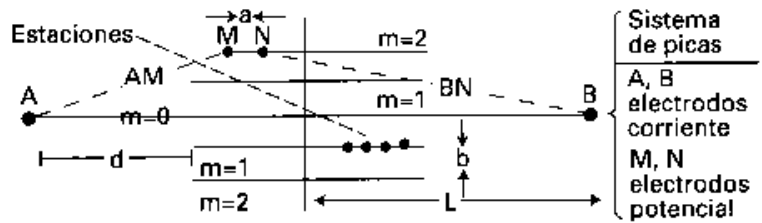

Figura A. Arreglo gradiente simétrico.

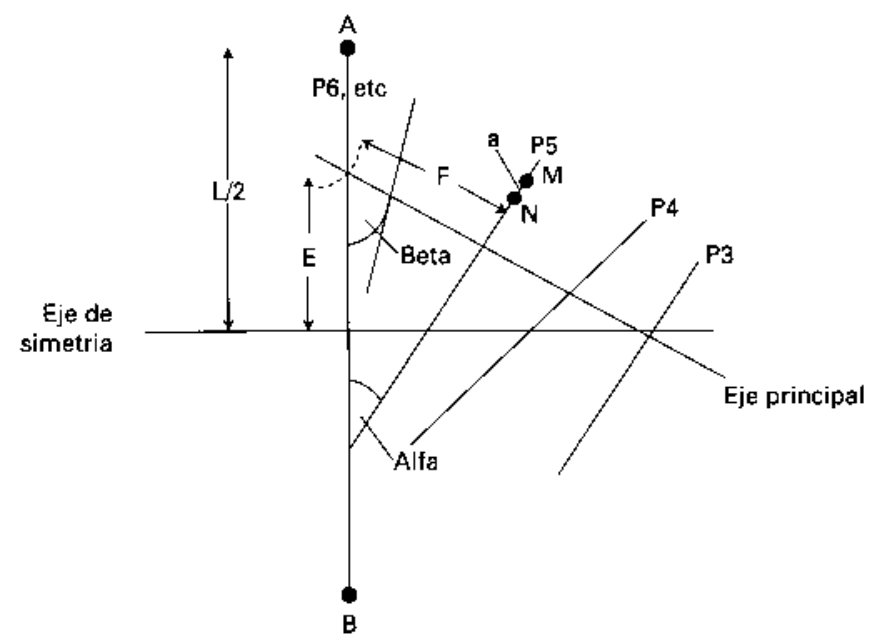

Figura B. Arreglo gradiente general. 

Geology of the Lo Increíble Mining District and

$\mathrm{U}-\mathrm{Pb}$ Age of the Early Proterozoic

Yuruari Formation of the Pastora Supergroup,

Guayana Shield, Venezuela

By Warren C. Day, Richard M. Tosdal, E.L. Acosta, J.C. Aruspon,

L. Carvajal, E. Cedeño, Glenda Lowry, L.F. Martinez, J.A. Noriega, Fernando J. Nuñez, J. Rojas, and F. Prieto

GEOLOGY AND MINERAL DEPOSITS OF THE VENEZUELAN GUAYANA SHIELD

U.S. GEOLOGICAL SURVEY BULLETIN 2024-E

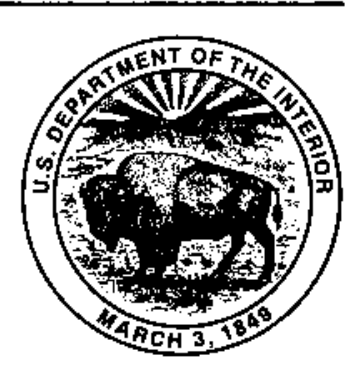

UNITED STATES GOVERNMENT PRINTING OFFICE, WASHINGTON : 1995 


\section{CONTENTS}

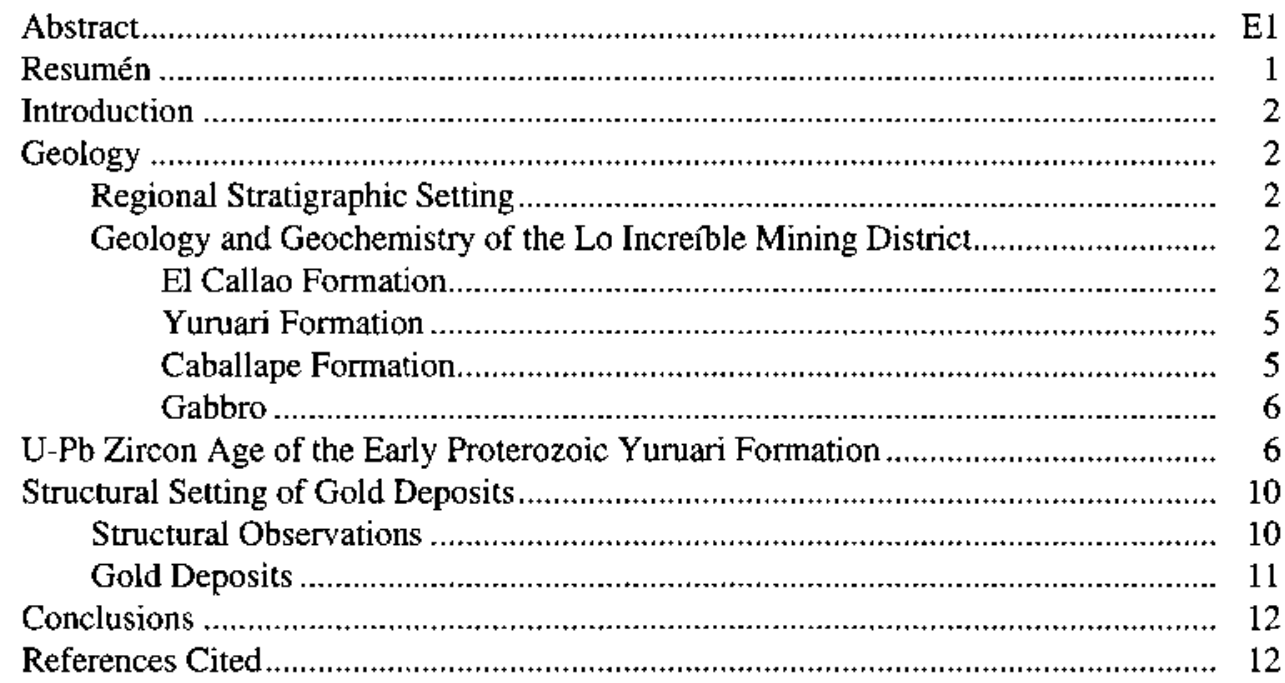

\section{FIGURES}

1. Map showing location of Lo Increible study area

2. Geologic map of Lo Increible mining district.

3. Ternary plots showing chemical characteristics of samples from Lo Increible mining district........................ 6

4. Chondrite-normalized rare earth element diagrams for rocks of Lo Increible mining district................................. 8

5 Spider diagrams for rocks of Lo Increible mining district ................................................................................

6. U-Pb concordia diagram showing U-Pb isotopic data for zircon from metadacite tuff in Yuruari Formation of the Pastora Supergroup, Lo Increíble mining district.

\section{TABLES}

1. Major- and trace-element abundances for rocks of the Lo Increfble mining district

2. U-Pb geochronologic data (zircon) for dacite from the Yuruari Formation of the Pastora Supergroup.............

3. Gold and trace element abundances for rocks of the Lo Increíble mining district. 


\title{
Geology of the Lo Increíble Mining District and $\mathrm{U}-\mathrm{Pb}$ Age of the Early Proterozoic Yuruari Formation of the Pastora Supergroup, Guayana Shield, Venezuela
}

\author{
By Warren C. Day, ${ }^{1}$ Richard M. Tosdal, ${ }^{2}$ E.L. Acosta, ${ }^{3}$ J.C. Aruspon, ${ }^{3}$ L. Carvajal, ${ }^{3}$ E. Cedeño, ${ }^{4}$ \\ Glenda Lowry, ${ }^{3}$ L.F. Martinez, ${ }^{3}$ J.A. Noriega, ${ }^{5}$ Fernando J. Nuñez, ${ }^{3}$ J. Rojas, ${ }^{3}$ and F. Prieto ${ }^{3}$
}

\begin{abstract}
Results of new mapping combined with geochemical and $\mathrm{U}-\mathrm{Pb}$ isotopic data provide a framework for the geology, age, and origin of gold deposits in the Lo Increible mining district of the Guayana Shield of eastern Venezuela. Gold deposits within the district are shear-zone-hosted lode deposits restricted to a major ductile transpressive shear zone that has developed a strong S-C mylonitic fabric, sigmoidal boudinage, and small-scale folds. Dextral oblique slip thrust (or reverse movement) in the shear zone has placed older tholeiitic metabasalt of the El Callao Formation over younger quartz-biotite-muscovite schist of the Yuruari Formation, both of the Early Proterozoic Pastora Supergroup. The gold deposits formed as discontinuous quartz veins parallel with the tectonic foliation within the zone.

Zircon mineral separates from the Yuruari Formation, which forms the upper unit of the Pastora Supergroup, yield a U-Pb age of 2,13I $\pm 10 \mathrm{Ma}$. This is the first published U-Pb zircon date of the Pastora Supergroup in Venezuela and confirms the Early Proterozoic age for greenstone-belt rocks of the Guayana Shield.

Major- and trace-element geochemical data for quartz-normative tholeitic pillow lavas of the Early Protero-

${ }^{1}$ U.S. Geological Survey, Denver Federal Center, MS905, Denver, Colorado 80225.

${ }^{2}$ U.S. Geological Survey, 345 Middlefield Road, MS90I, Menlo Park, California 94025 .

${ }^{3}$ CVG-Técnica Minera, C.A., C.C. Chilemex, Piso 1, Puerto Ordaz, Venezuela.

${ }^{4}$ Mineros de Venezuela, Mina Colombia, El Callao, Venezuela.

${ }^{5}$ Ministerio de Energía y Minas, Ciudad San Cristobal, Guatemala.
\end{abstract}

zoic El Callao Formation have affinity with modern low-potassium island arc tholeiite. Calc-alkaline basalt from the younger Early Proterozoic Caballape Formation has a composition similar to that of low-potassium calc-alkaline basalt and basaltic andesite typical of island arc sequences. We suggest that the rocks in the region formed in an immature intraoceanic island arc setting that underwent subsequent oblique dextral thrusting along a northwest-oriented axis of tectonic compression.

\section{RESUMEN}

Los resultados de la cartografía geológica reciente y datos geoquímicos isotópicos por el método U-Pb proporcionan un marco de referencia para la geología, edad y origen de los depósitos minerales en el Distrito Minero Lo Increible en el Escudo de Guayana. Los depósitos de oro en este distrito son del tipo de veta y diseminaciones encajados en zonas de falla restringidas a extensas zonas de cizallas dúctiles con movimiento transpresivo el cual ha originado una fuerte estructura milonítica del tipo $\mathrm{S}-\mathrm{C}$, budinage sigmoidal y pequeños pliegues. Corrimientos oblicuos dextrales (o movimiento inverso) en la zona de cizalla ha puesto basaltos toleíticos (más viejos) de la Formación El Callao sobre esquistos quarzo-biotítico-muscovítico (más joven) de la Formación Yuruari. Ambas formaciones pertenecen al Supergrupo Pastora de edad Proterozoico Temprano. Los depeositos de oro se formaron en vetas discontinuas de cuarzo paralelas a la foliación tectónica de la zona.

Los análisis isotópicos en zircones separados de la Formación Yuruari, la cual forma la unidad superior del Supergnupo Pastora, arrojan una edad por el metodo U-Pb de 
$2,131 \pm 10 \mathrm{Ma}$. Esta es la primera edad isotópica obtenida en zircones por el metodo U-Pb para el Supergrupo Pastora en Venezuela, la misma confirma la edad Proterozoico Temprano para rocas verdes (greenstones) en el Escudo de Guayana.

Datos geoquímicos de elementos mayores y elementos traza obtenidos de lavas toléticas almohadilladas con cuarzo normativo de la Formación El Callao, la cual tiene una edad Proterozoica Temprana, tienen afinidad con toleitas bajas en potasio originadas en un ambiente de arco de islas. Los basaltos calco-alcalinos de la Formación Caballape (más joven) tienen una composición similar a basaltos calco-alcalinos bajos en potasio y andesitas basálticas típicas en sequencias de arcos de islas. Las rocas de la región estudiada se formaron probablemente en un arco de islas inmaduro intraoceánico el cual fue deformado por corrimiento oblicuo dextral a to largo de un eje de compresión tectónica orientado en sentido noreste.

\section{INTRODUCTION}

The Lo Increible mining district provides a unique opportunity to unravel the structural setting of Precambrian lode gold deposits of the Guayana Shield of Venezuela and to date the Early Proterozoic Yuruari Formation of the Pastora Supergroup (fig. 1). Although Gibbs and Olszewski (1982) dated rocks equivalent to the Pastora Supergroup in Guyana to the east, this study provides the first published $\mathrm{U}-\mathrm{Pb}$ date on zircon from a sample of the Pastora Supergroup in Venezuela. The mapping described herein was a part of a joint U.S. Geological Survey-Corporación Venezolana de Guayana, Técnica Minera, C.A. (CVG-TECMIN) geologic field mapping course taught by W.C. Day in June 1989. R.M. Tosdal provided the U-Pb date on zircon from a sample of the Early Proterozoic Yuruari Formation. The remaining co-authors participated in the field course.

The Lo Increíble mining district is in the eastem part of Estado Bolívar, approximately $150 \mathrm{~km}$ southeast of Puerto Ordaz and $10 \mathrm{~km}$ northeast of the El Callao mining district. The study area is covered by a thick weathered profile and dense tropical jungle vegetation, and thus our observations were limited to linear traverses cut through the jungle and sites along roads and mines and creek bottoms.

\section{GEOLOGY}

\section{REGIONAL STRATIGRAPHIC SETTING}

Rocks of the Lo Increible mining district are Early Proterozoic volcanic, plutonic, and sedimentary rocks generally metamorphosed to low grade (middle to upper greenschist facies) and to a lesser extent medium grade (lower amphibolite facies). Regional mapping studies by
Menendez (1968, 1972, 1974) established the stratigraphic framework for the area. The oldest rocks in the study area belong to the Early Proterozoic Pastora Supergroup. Menendez recognized that the oldest part of the Pastora Supergroup is made up of the Carichapo Group, which consists of pillow lavas of the El Callao Formation and amphibole-biotite schist of the Cicapra Formation; however, rocks of the Cicapra Formation are not present in the study area. Sedimentary rocks of the Early Proterozoic Yuruari Formation, which forms the youngest unit within the Pastora Supergroup, structurally overlie the Carichapo Group (Menendez, 1968, 1972, 1974). Our mapping confirms that the contact between the two formations is faulted. Volcanogenic sedimentary rocks of the Early Proterozoic Caballape Formation overlie rocks of the Pastora Supergroup (Menendez, 1972). Rocks of the Pastora Supergroup and the Caballape Formation were regionally intruded by diabasic to gabbroic sills and (or) dikes.

\section{GEOLOGY AND GEOCHEMISTRY OF THE LO INCREIBLE MINING DISTRICT}

The northern part of the study area is underlain by rocks of the Early Proterozoic Yuruari Formation (fig. 2). Rocks of the Yunari Formation are poorly exposed, except in mine workings near the shear zone that separates the Yuruari and the El Callao Formations in the central part of the study area. The southern part of the study area is dominated by a large gabbro sill that forms a prominent ridge. The gabbroic sill is enfolded within the Caballape Formation.

\section{EL CALLAO FORMATION}

The oldest rocks in the study area are basalts of the Early Proterozoic El Callao Formation, which forms the basal unit in the Pastora Supergroup. This formation is characterized by tholeiitic basaltic pillow lava flows (unit Xec, fig. 2) and interlayered flow breccia (unit Xecb). The shape and orientation of the pillow structures, which are well exposed along the highway in the western part of the study area (fig. 2), indicate that the unit is upward facing and youngs stratigraphically to the southeast in the study area. The formation weathers light brown and in many places is recognized only by light-brown colluvial soil and float. Although regionally the unit is of low metamorphic grade, within and immediately adjacent to the shear zone $(<250 \mathrm{~m})$ in the central part of the study area the El Callao Formation has been recrystallized to hornblende-biotite schist of medium metamorphic grade.

Two sheets of basaltic breccia lie within the El Callao Formation (unit Xecb, fig. 2). These sheets are each about $50 \mathrm{~m}$ thick and contain angular basaltic clasts as much as 15 $\mathrm{cm}$ in diameter in a volcaniclastic basaltic matrix. The brec- 


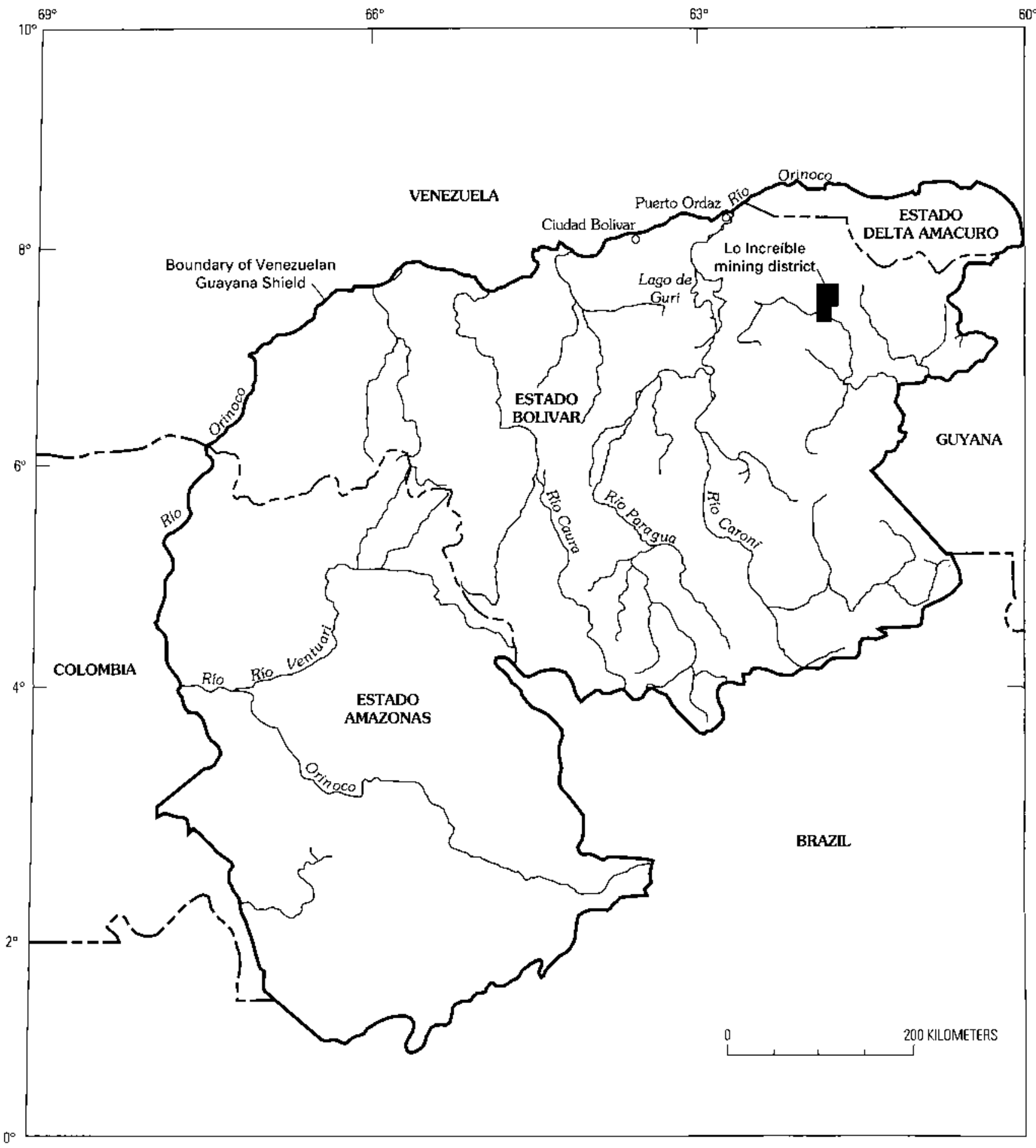

Figure 1. Location of the Lo Increible study area, Estado Bolívar, Venezuela.

cia sheets formed as interflow breccias within the basaltic flows of the El Callao Formation.

Rocks of the El Callao Formation are metaluminous, quartz-normative, Iow-potassium tholeiitic basalt. Plotted on a Jensen (1976) diagram, our samples of the El Callao Formation range from high-iron to high-magnesian tholeiite (fig. 3A). The $\mathrm{Mg}$-numbers are from about 47 to 63 (table 1), typical of tholeiitic basalt (Basaltic Volcanism Study Project, 1981, p. 132-192). The rare earth element patterns (fig. $4 \mathrm{~A}$ ) are relatively flat and are about 10 times chondrite in abundance. All of these characteristics are similar to modern mid-ocean ridge, low-potassium island arc, and back-arc 

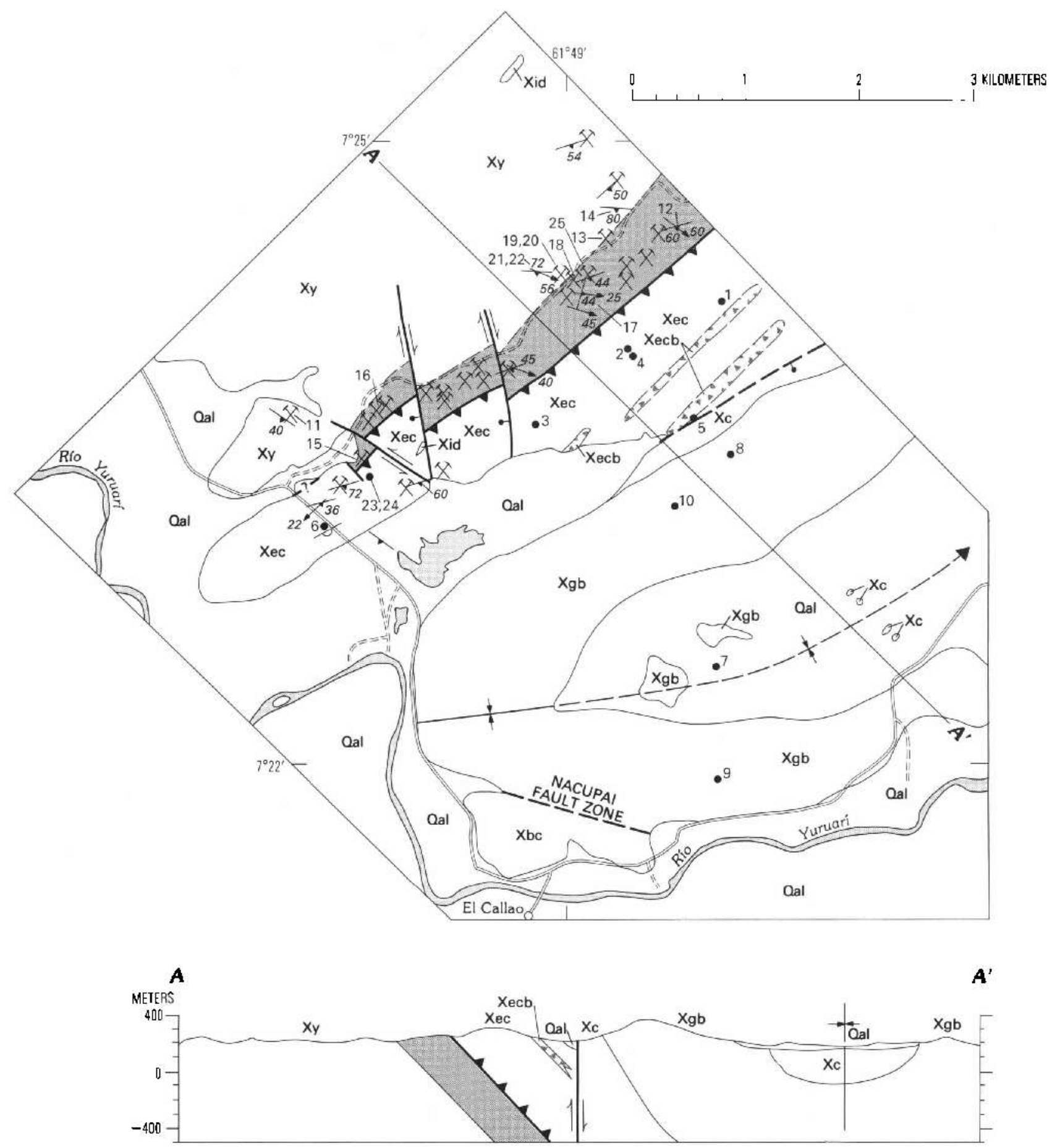

Figure 2 (above and facing column). Geologic map of the Lo Increible mining district, north of El Callao, Estado Bolívar, Venezuela. Numbered solid circles are sample localities.

basalts (see Jakes and Gill, 1970, p. 19). The proportions of $\mathrm{MnO}, \mathrm{TiO}_{2}$, and $\mathrm{P}_{2} \mathrm{O}_{5}$ are similar to those of modern island arc tholeiite (fig. 3B). Rocks of the El Callao Formation contain less $\mathrm{TiO}_{2}$ than tholeiite formed in mid-ocean ridge environments.
In order to characterize the environment of formation, the trace element geochemistry for samples of the El Callao Formation is compared with that for island arc low-potassium basalt and normal (or N-type) mid-ocean ridge basalt (MORB), which may have formed in similar tectonic 


\section{EXPLANATION}

\begin{tabular}{|c|}
\hline aal \\
\hline$X b c$ \\
\hline$X_{\mathfrak{g b}}$ \\
\hline$X_{i d}$ \\
\hline$X_{c}$ \\
\hline$X_{y}$ \\
\hline$X_{e c}$ \\
\hline$x_{e c b}$ \\
\hline
\end{tabular}

Alluvium

Tectonic breccla

Gabbro

Diabase

Pastora Supergroup-Dlvided into:

Caballape Formation

Yuruari Formation

El Callao Formation of the Carichapo Group-Includes volcanic breccia (unit Xecb)

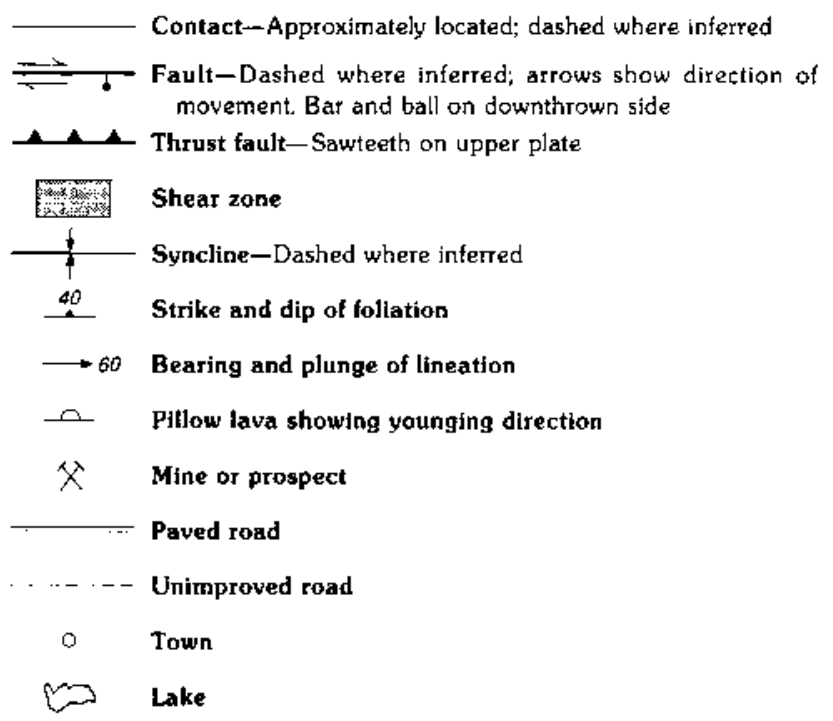

environments (fig. $5 A$ ). The data are normalized to an average composition for island arc low-potassium tholeiite formed near Benioff zones (Holm, 1985, p. 311). A sample with a trace element composition identical to that of the average island arc low-potassium tholeiite will have a ratio of unity, a sample having lower elemental abundances will plot below the unity line, and, conversely, a sample having higher abundances will plot above.

Tholeiite of the El Callao Formation is relatively depleted in the large-ion lithophile elements $\mathrm{K}, \mathrm{Sr}$, and $\mathrm{Ce}$ but has abundances of the high field strength elements $\mathrm{P}, \mathrm{Zr}$, $\mathrm{T}, \mathrm{Y}$, and $\mathrm{Yb}$ comparable to those of island arc low-potassium tholeiite (fig. $5 A$ ). The rubidium concentration of $\mathrm{El}$ Callao tholeiite is similar to that of island arc tholeiite. By comparison, normal mid-ocean ridge basalt (Pearce, 1982, p. 527 ) is also relatively depleted in large-ion lithophile elements but has higher high field strength element abundances than the El Callao Formation or island arc low-potassium tholeiite.

\section{YURUARI FORMATION}

The Yuruari Formation is a quartz-biotite-muscovite schist containing white quartz pods and veinlets that are parallel with the foliation. The unit is highly susceptible to weathering and forms low-lying topography. Outcrops are rare except near mines. The formation has a characteristic bright orange to red soil that contains residual pods of white quartz. The schist has been metamorphosed to medium grade (amphibolite facies), but ubiquitous alteration of primary biotite to chlorite indicates retrograde to low-grade (greenschist facies) metamorphism. Less weathered exposures within the shear zone show that the protolith was dacite and felsic volcaniclastic graywacke and locally interlayered basalt.

The intensely weathered nature of the Yuruari Formation limits geochemical sampling to determine the composition of the protolith. One sample of the Yuruari Formation, although weathered, is listed in table 1 (sample 11). The sample plots as calc-alkaline dacite on the Jensen diagram (fig. $3 \mathrm{~A}$ ) but has rhyolitic $\mathrm{SiO}_{2}$ content (75.6 weight percent). The relatively higher $\mathrm{SiO}_{2}$ may reflect the effects of weathering in which other constituents are leached. The rare earth element data also suggest similar leaching effects. Assuming that the composition of the protolith was generally similar to typical shale or graywacke (Menendez, 1972), approximately an order of magnitude loss has occurred in the abundance of the light rare earth elements (fig. 4B).

\section{CABALLAPE FORMATION}

The Caballape Formation consists of calc-alkaline andesite, dacite, and rhyolite tuff and felsic volcaniclastic sedimentary rocks that have been metamorphosed to low grade (greenschist facies). The formation is poorly exposed in the study area; outcrops are in the creek bed adjacent to the high-angle normal fault north of the gabbroic sill and at isolated locations in the core of the east-plunging syncline in the central and southern parts of the study area (fig. 2).

One sample from the core of the syncline in the study area is low-potassium calc-alkaline basalt (sample 7, table 1, fig. $3 A$ ). In the Anacoco area, approximately $100 \mathrm{~km}$ southeast of this study area, the Caballape Formation ranges in composition from calc-alkaline basalt through dacite (Day and others, 1989). In both the Anacoco and Lo Increible areas, the major-, minor-, and trace-element content of the unit is similar to that of calc-alkaline low-potassium basalt and basaltic andesite typical of island arc sequences (figs. $3 B, 4 C$ ). 


\section{GABBRO}

A large gabbroic body (unit Xgb, fig. 2) was intruded as a sill and then infolded with the Caballape Formation to form an eastward-plunging syncline in the central and southem part of the study area (fig. 2). Fresh surfaces are dark green to black. The texture of the gabbro grades from fine-grained diabasic margins inward to a medium- to coarse-grained interior. The gabbro has undergone regional greenschist facies metamorphism. It is relatively resistant to weathering and forms outcrops along the prominent ridge in the southern part of the study area.

The gabbro is younger than supracnustal rocks of the Pastora Supergroup. Several smaller diabasic sills (or dikes) are present within the El Callao and Yuruari Fomations (unit Xid, fig. 2). The relative ages of the main gabbro and the diabase sills are not established; however, the units are considered coeval.

The gabbro is quartz normative, metaluminous, and tholeiitic in composition (samples 8-10, table 1). The $\mathrm{Mg}$-numbers are relatively high (less evolved), ranging from approximately 65 to 69 (table 1). The gabbro is distinctly different from the El Callao Formation in that it has higher $\mathrm{Mg}$-numbers and greater abundances of the light rare earth (figs. $4 A, 4 D$ ) and large-ion lithophile (fig. $5 B$ ) elements. Although the major element contents of the gabbro are similar to komatiitic compositions (fig. $3 A$ ), the light rarc carth element contents and higher $\mathrm{MnO}$ abundances (fig. $3 B$ ) show that the gabbro has affinities with calc-alkaline basaltic magmas. The calc-alkaline affinity of the trace elements may imply that the gabbro evolved during the same calc-alkaline magmatic episode as the Caballape Formation, which it intrudes.

\section{U-PB ZIRCON AGE OF THE EARLY PROTEROZOIC YURUARI FORMATION}

Zircon extracted from a metadacite tuff within the Yuruari Formation (sample location 25, fig. 2) provides a reliable radiometric date for the formation and, therefore, for the upper part of the Pastora Supergroup. Although the Yuruari Formation is highly weathered, reliable age data can be extracted from zircon in units that have undergone extreme tropical weathering (Gibbs and Olszewski, 1982).

Five zircon fractions analyzed from the sample metadacite tuff of the Yuruari Formation have discordant ${ }^{206} \mathrm{~Pb} /{ }^{238} \mathrm{U}$ and ${ }^{207} \mathrm{~Pb} /{ }^{235} \mathrm{U}$ ages (table 2). All the fractions define a chord on a concordia diagram (mean square weighted deviation $=0.3$ ) (Ludwig, 1983) with an upper intercept of $2,131 \pm 10 \mathrm{Ma}$ and a lower intercept that is cssentially present-day (fig. 6). This pattern of discordance in the

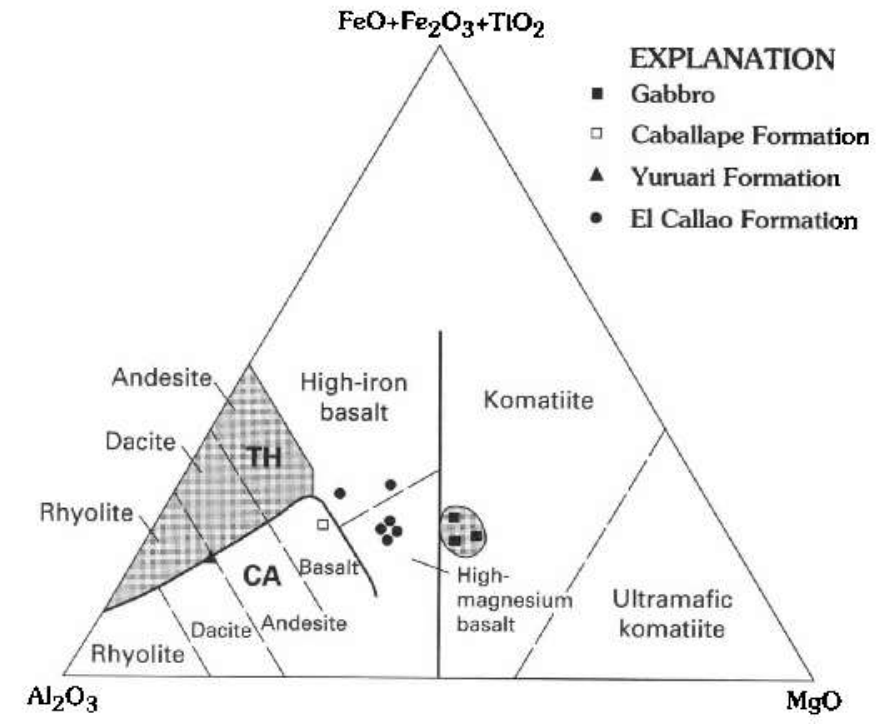

A

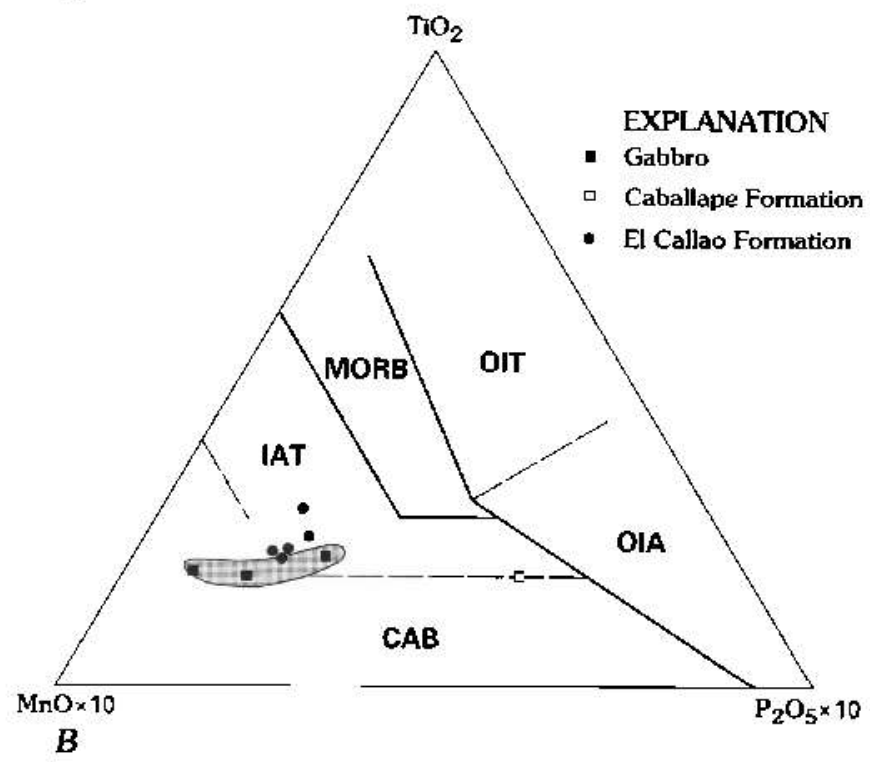

Figure 3. Ternary plots showing chemical characteristics of samples from the Lo Increible mining district, Estado Bolívar, Venezuela. $A$, Jensen diagram. Modified from Jensen (1976). $B$, $\mathrm{MnO} / \mathrm{TiO}_{2} / \mathrm{P}_{2} \mathrm{O}_{5}$ discriminant diagram for basalt and basaltic andesite. Fields: CAB, island arc calc-alkaline basalt; IAT, island arc tholeiite; MORB, mid-ocean ridge and marginal basin basalt; OIT, ocean island tholciite; OIA, ocean island basalt (Mullen, 1983).

ages indicates that lead was lost from zircon during a subsequent event (Silver and Deutsch, 1963). The upper concordia intercept age of 2,131 $\pm 10 \mathrm{Ma}$ is interpreted to indicate an Early Proterozoic crystallization age for the dacitic tuff. This interpretation is confimmed by the good agreement between the ${ }^{207} \mathrm{~Pb} /{ }^{206} \mathrm{~Pb}$ ages of the individual zircon fractions and the upper intercept age on the concordia diagram. The lower 
Table 1. Major- and trace-element abundances for rocks of the Lo Increíble mining district, Estado Bolívar, Venezuela.

[Locations of samples shown by sample numbers in figure 2. All field numbers are prefixed by WDV. Major-element oxides in weight percent; trace elements in parts per million]

\begin{tabular}{|c|c|c|c|c|c|c|c|c|c|c|c|}
\hline $\begin{array}{l}\text { Rock type } \\
\text { Formation } \\
\text { Sample No. } \\
\text { Field No. }\end{array}$ & $\begin{array}{c}\text { Basalt } \\
\text { El Callao } \\
1 \\
89-019 \\
\end{array}$ & $\begin{array}{c}\text { Basalt } \\
\text { El Callao } \\
2 \\
89-030 \\
\end{array}$ & $\begin{array}{c}\text { Basalt } \\
\text { El Callao } \\
3 \\
89-055 \\
\end{array}$ & $\begin{array}{c}\text { Basalt } \\
\text { El Cailao } \\
4 \\
89-031 \\
\end{array}$ & $\begin{array}{c}\text { Basalt } \\
\text { El Callao } \\
5 \\
89-034 \\
\end{array}$ & $\begin{array}{c}\text { Basalt } \\
\text { El Callao } \\
6 \\
89-068 \\
\end{array}$ & $\begin{array}{c}\text { Andesite } \\
\text { Caballape } \\
7 \\
89-073 \\
\end{array}$ & $\begin{array}{c}\text { Gabbro } \\
8 \\
89-037 \\
\end{array}$ & $\begin{array}{c}\text { Gabbro } \\
9 \\
89-071 \\
\end{array}$ & $\begin{array}{c}10 \\
89-051 \\
\end{array}$ & $\begin{array}{c}\text { Schist } \\
\text { Yuruari } \\
11 \\
89-063 \\
\end{array}$ \\
\hline \multicolumn{12}{|c|}{ Major elements } \\
\hline $\mathrm{SiO}_{2}$ & 47.60 & 48.50 & 49.00 & 49.90 & 49.40 & 50.00 & 55.60 & 49.30 & 49.40 & 50.10 & 75.60 \\
\hline $\mathrm{Al}_{2} \mathrm{O}_{3}$ & 15.60 & 14.60 & 14.40 & 14,10 & 13.50 & 14.20 & 14.80 & 11.60 & 12.30 & 11.30 & 11.80 \\
\hline $\mathrm{Fe}_{2} \mathrm{O}_{3} \mathrm{t}$ & 13.90 & 11.50 & 11.40 & 10.50 & 14.90 & 10.60 & 10.00 & 12.20 & 11.00 & 11.40 & 4.76 \\
\hline $\mathrm{MgO}$ & 5.58 & 8.52 & 8.16 & 7.93 & 7.23 & 7.60 & 4.99 & 10.10 & 10.80 & 11.30 & 1.26 \\
\hline $\mathrm{CaO}$ & 13.00 & 12.50 & 11.90 & 12.70 & 8.63 & 12.70 & 7.08 & 11.60 & 12.30 & 12.30 & 0.02 \\
\hline $\mathrm{Na}_{2} \mathrm{O}$ & 0.85 & 1.38 & 2.03 & 2.31 & 2.09 & 2.26 & 2.98 & 1.69 & 1.11 & 1.00 & 0.76 \\
\hline $\mathrm{K}_{2} \mathrm{O}$ & 0.04 & 0.04 & 0.04 & 0.03 & 0.04 & 0.06 & 0.38 & 0.50 & 0.17 & 0.17 & 0.50 \\
\hline $\mathrm{TiO}_{2}$ & 0.89 & 0.66 & 0.67 & 0.63 & 1.01 & 0.64 & 0.78 & 0.74 & 0.49 & 0.54 & 0.52 \\
\hline $\mathrm{P}_{2} \mathrm{O}_{5}$ & 0.06 & 0.06 & 0.06 & 0.06 & 0.09 & 0.06 & 0.23 & 0.09 & $<0.05$ & 0.05 & $<0.05$ \\
\hline MnO & 0.17 & 0.19 & 0.19 & 0.18 & 0.23 & 0.17 & 0.13 & 0.19 & 0.19 & 0.20 & $<0.02$ \\
\hline $\mathrm{CO}_{2}$ & $<0.01$ & $<0.01$ & 0.01 & 0.09 & 0.13 & 0.02 & $<0.01$ & 0.09 & 0.01 & 0.01 & 0.01 \\
\hline LOI $900^{\circ} \mathrm{C}$ & 2.70 & 2.45 & 2.16 & 1.78 & 2.86 & 1.77 & 2.76 & 2.20 & 2.50 & 2.35 & 1.67 \\
\hline Total & 100.39 & 100.40 & 100.01 & 100.12 & 99.98 & 100.06 & 99.73 & 100.21 & 100.26 & 100.71 & 96.89 \\
\hline Mg-number' & 51.00 & 65.76 & 64.98 & 66.19 & 55.71 & 65.02 & 56.40 & 68.21 & 71.79 & 71.99 & 40.69 \\
\hline \multicolumn{12}{|c|}{ Trace elements } \\
\hline$\overline{\mathrm{Nb}}$ & $<10$ & $<10$ & $<10$ & $<10$ & $<10$ & $<10$ & $<10$ & 13 & $<10$ & 11 & $<10$ \\
\hline $\mathrm{Rb}$ & 7 & $<2$ & 7 & $<2$ & 6 & $<2$ & 17 & 11 & 5 & 7 & 12 \\
\hline $\mathrm{Sr}$ & 443 & 165 & 108 & 82 & 105 & 65 & 522 & 165 & 139 & 134 & 158 \\
\hline $\mathrm{Zr}$ & 46 & 38 & 45 & 39 & 60 & 42 & 130 & 73 & 44 & 51 & 91 \\
\hline Y & 19 & 10 & 18 & 11 & 28 & 17 & 18 & 17 & 12 & 14 & 12 \\
\hline $\mathrm{Ba}$ & 11 & 9 & 10 & 8 & 11 & 18 & 201 & 199 & 86 & 104 & 229 \\
\hline $\mathrm{Cu}$ & 61 & 120 & 108 & 111 & 117 & 82 & 2 & 71 & 142 & 150 & 40 \\
\hline $\mathrm{Ni}$ & 178 & 141 & 110 & 117 & 91 & 118 & 105 & 184 & 156 & 149 & 44 \\
\hline $\mathrm{Zn}$ & 87 & 76 & 79 & 68 & 107 & 78 & 60 & 83 & 68 & 64 & 80 \\
\hline $\mathrm{Cr}$ & 297 & 439 & 431 & 384 & 45 & 400 & 264 & 307 & 100 & 112 & 88 \\
\hline La & 3.6 & 2.0 & 2.2 & 1.7 & 2.7 & 1.7 & 28.0 & 12.0 & 4.8 & 6.6 & 2.5 \\
\hline $\mathrm{Ce}$ & 8.0 & 5.1 & 5.7 & 4.9 & 7.3 & 4.6 & 53.0 & 25.0 & 10.0 & 15.0 & 4.4 \\
\hline $\operatorname{Pr}$ & 1.2 & 0.8 & 0.9 & 0.7 & 1.1 & 0.7 & 6.2 & 2.8 & 1.3 & 1.8 & 0.5 \\
\hline Nd & 6.7 & 4.3 & 5.0 & 4.3 & 6.5 & 4.2 & 27.0 & 14.0 & 5.8 & 8.1 & 2.1 \\
\hline $\mathrm{sm}$ & 2.20 & 1.40 & 1.50 & 1.20 & 2.10 & 1.40 & 4.90 & 3.30 & 1.70 & 2.20 & 0.88 \\
\hline Eu & 0.93 & 0.60 & 0.67 & 0.60 & 0.91 & 0.54 & 1.40 & 1.00 & 0.56 & 0.69 & 0.37 \\
\hline Gd & 2.6 & 1.8 & 2.0 & 1.7 & 2.4 & 1.5 & 4.2 & 3.2 & 1.7 & 2.4 & 1.1 \\
\hline $\mathrm{Tb}$ & 0.73 & 0.31 & 0.36 & 0.34 & 0.51 & 0.30 & 0.64 & 0.59 & 0.32 & 0.41 & 0.25 \\
\hline Dy & 4.5 & 2.5 & 2.9 & 2.5 & 3.8 & 2.4 & 3.4 & 3.6 & 1.8 & 2.4 & 2.0 \\
\hline Ho & 0.87 & 0.52 & 0.54 & 0.59 & 0.80 & 0.52 & 0.62 & 0.69 & 0.41 & 0.54 & 0.42 \\
\hline Er & 2.6 & 1.5 & 1.6 & 1.5 & 2.4 & 1.4 & 1.7 & 2.2 & 1.1 & 1.4 & 1.4 \\
\hline $\operatorname{Tm}$ & 0.42 & 0.26 & 0.25 & $0.2 \mathrm{l}$ & 0.38 & 0.22 & 0.24 & 0.30 & 0.14 & 0.26 & 0.18 \\
\hline $\mathrm{Yb}$ & 2.9 & 1.4 & 1.6 & 1.6 & 2.2 & 1.4 & 1.6 & 1.8 & 0.9 & 1.1 & 1.1 \\
\hline
\end{tabular}



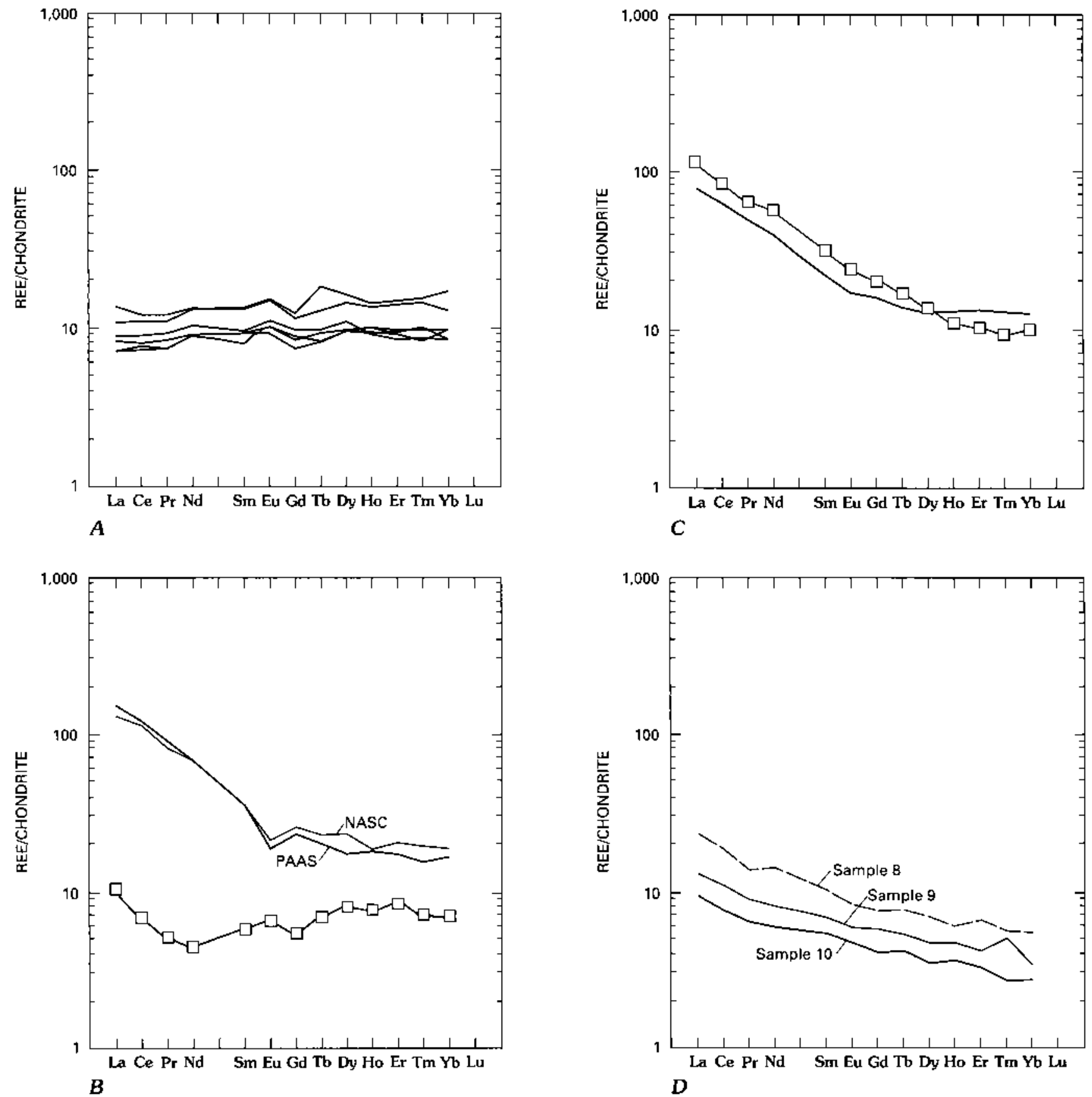

Figure 4. Chondrite-normalized rare earth element (REE) diagrams for rocks of the Lo Increíble mining district, Estado Bolívar, Venezuela. A, El Callao Formation. B, Weathered sample of the Early Proterozoic Yuruari Formation (open squares). Typical post-Archean Australia shale (PAAS; heavy line) and North America Shate Composite (NASC; light line) (Taylor and McLennan, 1985) are shown for comparison. $C$, Meta-andesite sample from the Caballape Formation (open squares). Typical calc-alkaline istand arc andesite (Gill, 1981) (heavy line) is shown for comparison. D, Samples from a gabbroic sill that intrudes the Caballape Formation.

intercept age is interpreted to indicate that the time of lead loss was recent. The lower intercept (70 $\pm 50 \mathrm{Ma}$ ) (fig. 6) probably reflects lead loss due to surficial weathering during the Cretaceous to Paleogene, similar to the lead loss described by Gibbs and Olszewski (1982) for rocks equivaenslent to the Pastora Supergroup in Guyana. The geomorphological development of the Venezuelan Guayana Shield and the effects of weathering on shield rocks in the Mesozoic and Tertiary are discussed by Briceño and Schubert (1990) and by references contained therein. 

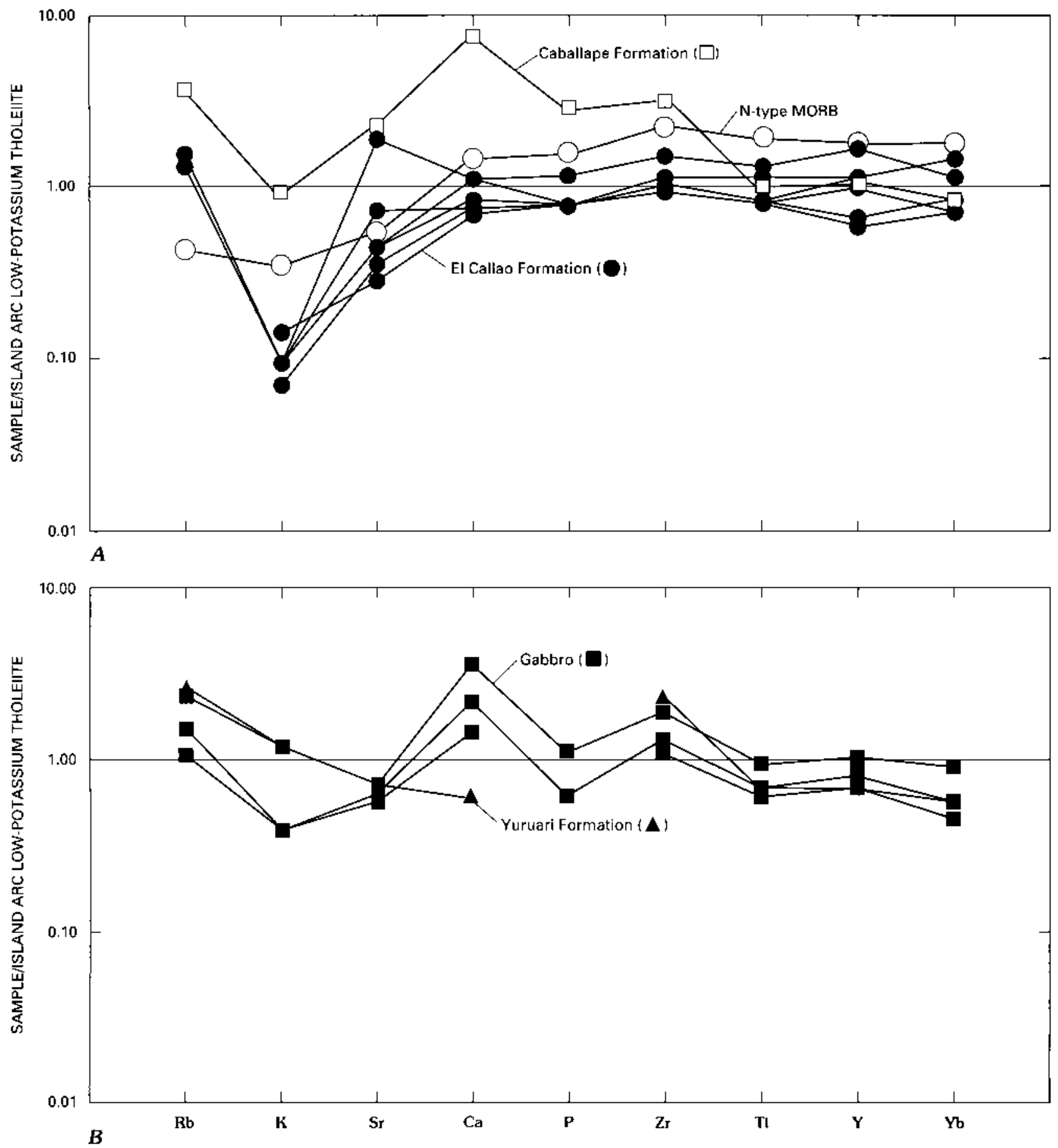

Figure 5. Spider diagrams for rocks of the Lo Increíble mining district, Estado Bolívar, Venezuela. Normalized to island arc lowpotassium tholeiite (Holm, 1985, p. 311). A, El Callao (circles) and Caballape Formations (squares). Normal mid-ocean ridge basalt (N-type MORB) (Pearce, 1982, p. 527) is also shown (diamonds). B. Yuruari Formation (triangles) and gabbro unit (squares) that intrudes the Caballape Formation.

Neither prograde medium-grade metamorphism within the shear zone nor subsequent retrograde (greenschist facies) metamorphism during the Trans-Amazonian orogeny (about 2.15-2.0 Ga) affected the U-Pb isotopic systematics in zircon from the sample of the Yuruari Formation. Lead loss during any younger event is enhanced by radiation damage to the zircon lattice that accumulates through geologic time. The low uranium content $\left(100-220 \mathrm{ppm}^{238} \mathrm{U}\right)$ of the zircon from the felsic tuff effectively precluded any extensive radiation damage to the zircon lattice due to the decay of 


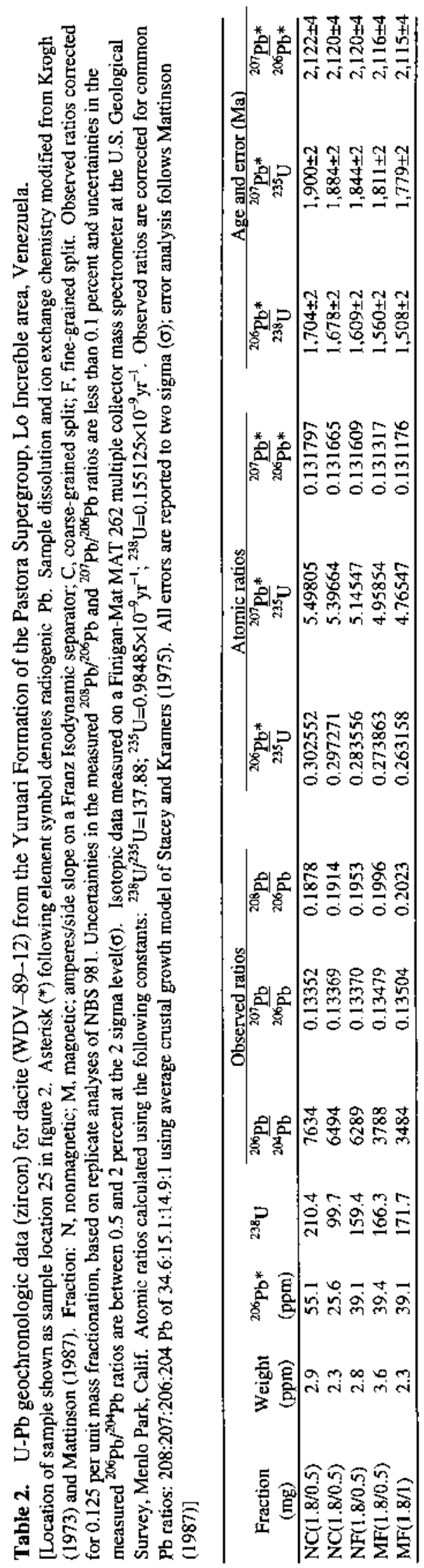

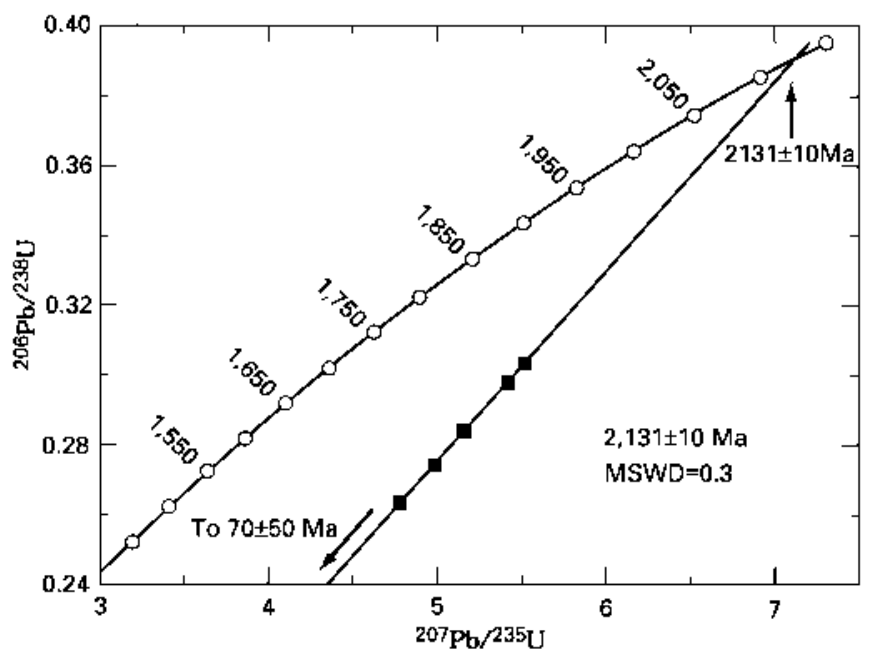

Figure 6. U-Pb concordia diagram showing $\mathrm{U}-\mathrm{Pb}$ isotopic data for zircon from a metadacite tuff in the Yuruari Formation of the Pastora Supergroup, Lo Increíble mining district, Estado Bolívar, Venezuela. Solid diamonds represent data points; analytical errors at the two-sigma $(2 \sigma)$ confidence level on each analysis are smaller than the square and are not shown. Solid chord is regression line through all five zircon fractions.

uranium and thorium in the period between the crystallization age of the tuff and its subsequent metamorphism and tectonic burial during the Trans-Amazonian orogeny.

\section{STRUCTURAL SETTING OF GOLD DEPOSITS}

\section{STRUCTURAL OBSERVATIONS}

The shear zone that separates the Yuruari and El Callao Formations in the study area is a northeast-striking zone of intense ductile deformation. Although rocks of the Yuruari Formation are dominant within the shear zone, locally rocks of the El Callao Formation are incorporated and have been recrystallized to amphibolite schist. The orientation of the shear zone is presumably parallel to the generally southeast dip of the tectonic foliation within the zone. Such an orientation indicates that the El Callao Formation south of the shear zone structurally overlies the Yuruari Formation to the north. Therefore, assuming the stratigraphy outlined by Menendez (1972), the shear zone has a component of thrusting, placing the older El Callao Formation over the younger Yuruari Formation.

Rocks within the shear zone are highly foliated and are locally deformed into small-scale folds of $\mathrm{S}$ and $\mathrm{Z}$ symmetry; the latter is the dominant geometry. An S-C mylonitic fabric is well developed within the shear zone. Two foliations characterize the $\mathrm{S}-\mathrm{C}$ mylonitic fabric. One foliation ( $\mathrm{C}$ surface) forms the dominant foliation and is the plane of strongly localized ductile shearing (see Lister and Snoke, 1984). The other foliation ( $\mathrm{S}$ surface) is developed oblique to 
the $\mathrm{C}$ surface and is characterized by elongation and flattening of mineral grains. Locally, the foliations are boudinaged parallel with the principal plane of ductile shearing ( $\mathrm{C}$ surface).

The intersection of the $S$ and $C$ surfaces forms an acute angle to the northeast, indicating a dextral sense of shear. In addition, sygmoidal-shaped boudins, as well as the predominance of small-scale folds having $\mathrm{Z}$ symmetry, confirm the dextral sense of lateral shear. These kinematic indicators, combined with the older-over-younger relation of the El Callao and Yuruari Formations (assuming the stratigraphy outlined by Menendez, 1972), indicate that the shear zone is a right-oblique slip-thrust (or reverse) fault zone. Therefore, rocks of the study area underwent a dextral oblique compression, or dextral transpression, along a northwest-oriented tectonic axis of maximum compression.

\section{GOLD DEPOSITS}

Gold deposits in the Lo Increíble mining district are low-sulfide shear-zone-hosted lode gold (or mesothermal) type. Native gold is within discontinuous quartz veins that are $0.5-20 \mathrm{~cm}$ wide and as long as $100 \mathrm{~m}$. The quartz veins pinch and swell within planes of shear foliation within the host schist and are both subparallel with and discordant to the tectonic foliation. The host schist is a tectonic melange of biotite-sericite schist of the Yuruari Formation and biotite-amphibole schist of recrystallized El Callao Formation. Therefore, the host samples listed in table 3 could have been derived originally from either formation, but were tectonically juxtaposed within the shear zone.

Two generations of quartz characterize the gold-bearing veins. An early dark-gray pyrite-bearing tourmaline-rich quartz is cut by later, white bull quartz veins. Alteration minerals associated with the gold deposits include tourmaline, sericite, chlorite, pyrite, quartz, and carbonate minerals.

Analyses of grab samples from quartz veins in surface deposits are listed in table 3 . Because weathering within the shear zone was intense, these analyses do not represent original protolith compositions. Sample 12, from a 5-10-m-deep prospect pit, is an unmineralized sample of schist. It is a weathered fine-grained mafic volcanic tuff that contains fine-grained feldspar phenocrysts and has a superimposed tectonic foljation. The protolith was probably fine-grained mafic tuff within the Yuruari Formation. Samples 13-16 are composite samples from several gold deposits in the district. Samples 17-22 are paired samples of host biotite-sericite schist and corresponding quartz-vein material (sample 17 with sample 18,19 with 20 , and 21 with 22). Protolith for the host biotite-sericite schist of the paired samples was probably volcaniclastic sedimentary rock of the Yuruari Formation.

In general, gold concentrations in these samples are as high as $18 \mathrm{ppm}$. Samples that have higher gold values also 
have elevated arsenic contents. The quartz veins are relatively enriched in gold, but they are depleted in most of the other elements analyzed.

The overall nature, mode of occurrence, and origin of the gold deposits are similar to those described by Berger and Bliss (1986) for low-sulfide gold-quartz veins and by Colvine (1989) for shear-zone-hosted lode-gold deposits in the Canadian Shield. The gold deposits are restricted to the quartz veins in or adjacent to the shear zone separating the Yuruari and El Callao Formations. Formation of alteration minerals in the host rock during deformation within the shear zone is indicated by the parallel foliation within the secondary micaceous minerals and the unmineralized host schist. Therefore, gold deposition accompanied deformation and alteration within the shear zone.

Historical grade and tonnage information for the gold deposits of the Lo Increible mining district is limited. Data for mines within the district (Locher, 1974) show that the district has produced at least $1,300 \mathrm{~kg}$ of gold at a grade of about 12 grams per metric ton $(53.3$ metric tons at 10.6 grams per metric tons for the Experiencia mine, 3.3 metric tons at 6.2 grams per metric ton for the Garrapata mine, 45.3 metric tons at 14.7 grams per metric ton for the Increíble mine, and 1.7 metric tons at 11.4 grams per metric ton for the Talisman mine). The limited production data are a result of the ad hoc mining within the district in dominantly hand dug surface trenches and primitive underground workings. Gold has been recovered primarily from mercury amalgamation of hand-cobbed quartz-vein material, and a quantitative assessment of the gold potential of the district would be speculative at best. The assay values reported in table 2 indicate, however, that high-grade veins are present in the district. High potential at a high degree of certainty is present for undiscovered shear-zone-hosted lode-gold deposits within and along the extension of the shear zone. Further exploration of the shear zone, especially to the east of the study area, should result in the discovery of additional gold deposits.

\section{CONCLUSIONS}

The paleotectonic environment of the Lo Increíble mining district of Estado Bolívar, Venezuela, and, by extension, the entire Pastora Supergroup, can be deciphered by integrating geologic and geochemical data from all of the units in the area. Major-, minor-, and trace element data for the El Callao Formation show an affinity of these rocks with modern low-potassium island arc tholeite. Metagraywacke of the Yuntari Formation may have formed along a convergent plate margin. Calc-alkaline basalt from the younger Early Proterozoic Caballape Formation is similar in composition to low-potassium calc-alkaline basalt and basaltic andesite typical of island arc sequences.

We suggest that the rocks in the Pastora Supergroup formed in an immature intraoceanic island are setting that underwent subsequent oblique dextral thrusting along a northwest-oriented axis of tectonic compression. Similar relationships are observed in the Early Proterozoic Birimian greenstone belts of West Africa (Sylvester and Attoh, 1992), which Sidder and Mendoza (1991, this volume) conelate with rocks of the Pastora Supergroup of Venezuela.

\section{REFERENCES CITED}

Basaltic Volcanism Study Project, 1981, Basaltic volcanism on the terrestrial planets: New York, Pergamon Press, 1286 p.

Berger, B.B., and Bliss, J.D., 1986, Descriptive model of low-sulfide Au-quartz veins, in Cox, D.P., and Singer, D.A., eds., Mineral deposit models: U.S. Geological Survey Bulletin 1693 , p. 239-243.

Briceño, H.O, and Schubert, Carlos, 1990, Geomorphology of the Gran Sabana, Guayana Shield, southeastem Venezuela: Geomorphology, v. 3, p. 125-141.

Colvine, A.C., 1989, An empirical model for the formation of Archean gold deposits-Products of final cratonization of the Superior Province, Canada, in Keays, R.R., Ramsay, W.R.H., and Groves, D.I., eds. The geology of gold deposits-The perspective in 1988: Economic Geology Monograph 6, p. 37-53.

Gibbs, A.K., and Olszewski, W.J., 1982, Zircon U-Pb age of Guyana greenstone belts: Precambrian Research, v. 17, p. 199-214.

Gill, J.B., 1981, Orogenic andesites and plate tectonics: Berlin, Springer-Verlag, $390 \mathrm{p}$.

Holm, P.E., 1985, The geochemical fingerprints of different tectonomagmatic environments using hygromagmatophile element abundances of tholeiitic basalts and basaltic andesites: Chemical Geology, v. 51, p. 303-323.

Jakes, P., and Gill, J. 1970, Rare earth elements and the island arc tholeiitic series: Earth and Planetary Science Letters, v. 9, p. $17-28$.

Jensen, L.S., 1976, A new cation plot for classifying subalkalic volcanic rocks: Ontario Ministry of Natural Resources Miscellaneous Paper 66, 22 p.

Krogh, T.E., 1973, A low contamination method for hydrothermal dissolution of zircons and extraction of $\mathrm{U}$ and $\mathrm{Pb}$ for isotopic age determinations: Geochimica et Cosmochimica Acta, v. 37 , p. $485-494$.

Lister, G.S., and Snoke, A.W., 1984, S-C mylonites: Journal of Stnuctural Geology, v. 6, p. 617-638.

Locher, Eugenio, 1974, Oro en Venezuela: Conferencia Geológica Inter-Guayanas, Ciudad Guayana, Venezuela, 1972, Memoria, Publicación Especial 6, p. 558-587.

Ludwig, K.R., 1983, Plotting and regression programs for isotope geochemists, for use with HP-86/87 microcomputers: U.S. Geological Survey Open-File Report 83-849, 94 p.

Mattinson, J.M., 1987, U-Pb ages of zircons-A basic examination of error propagation: Chemical Geology (Isotope Geoscience Section), v. 66, p. 151-162.

Menendez V. de V., Alfredo, 1968, Revisión de la estratigrafía de la Provincia de Pastora según el estudio de la región de Guasipati, Guayana Venezolana: Boletín de Geología, Caracas, v. 10 , no. 19 , p. $309-338$. 
1972, Geología de la región Guasipati, Guayana Venezolaла: Congreso Geológico Venezolano, 4th, Caracas, 1971, Memoria, Publicación Especial 5, v. 4, p. 2001-2046.

-1974, Guia de la excursión geológica Guasipati-El Callao-Canaima: Conferencia Geológica Inter-Guayanas, 9th, Ciudad Guayana, Venezuela, 1972, Memoria, Publicación Especial 6, p. 49-67.

Mullen, E.D., 1983, $\mathrm{MnO} / \mathrm{TiO}_{2} / \mathrm{P}_{2} \mathrm{O}_{5}-\mathrm{A}$ minor element discrimjnant for basaltic rocks of oceanic environments and its implications for petrogenesis: Earth and Planetary Science Letters, v. 62 , p. $53-62$.

Pearce, J.A., 1982, Trace element characteristics of lavas from destructive plate boundaries, in Thorpe, R.S., ed., Andesites: New York, John Wiley and Sons, p. 525-548.

Sidder, G.B., and Mendoza, Vicente, 1991, Geology of the Venezuelan Guayana Shield and its relation to the entire
Guayana Shield: U.S. Geological Survey Open-File Report 91-141, 59 p.

Silver, L.T., and Deutsch, S., 1963, Uranium-lead isotopic variations in zircons-A case study: Joumal of Geology, v. 71, p. $721-758$.

Stacey, J.S., and Kramers, J.D., 1975, Approximation of terrestrial lead isotope evolution by a two-stage model: Earth and Planetary Science Letters, v. 26, p. 207-221.

Sylvester, P.J., and Attoh, Kodjopa, 1992, Lithostratigraphy and composition of $2.1 \mathrm{Ga}$ greenstone belts of the West African craton and their bearing on crustal evolution and the Archean-Proterozoic boundary: Journal of Geology, v. 100 , p. $377-393$.

Taylor, S.R., and McLennan, S.M., 1985, The continental crust-Its composition and evolution: Oxford, England, Blackwell Scientific Publications, 312 p. 

Geology and Geophysics of the Sierra Verdún-Cerro Piedra del Supamo Area, Estado Bolívar, Venezuela

By Floyd Gray, Fernando J. Nuñez, Jeffrey C. Wynn, Gary B. Sidder, Freddy Davila, and Angel Baez

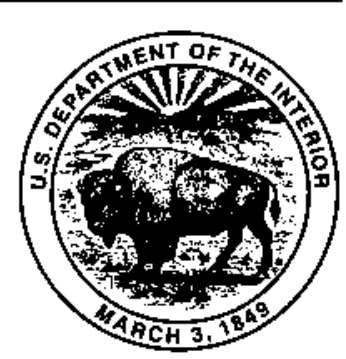




\section{CONTENTS}

\begin{tabular}{|c|c|}
\hline \\
\hline$\ldots$ & \\
\hline troduction .. & \\
\hline (1) & \\
\hline Regional Geologic Setting & \\
\hline Geology of the Study Area.. & \\
\hline (1) & \\
\hline 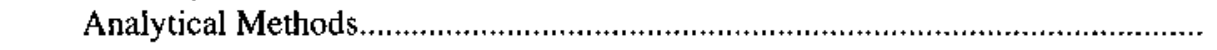 & \\
\hline 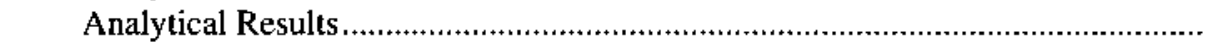 & \\
\hline Volcanic Rocks & \\
\hline 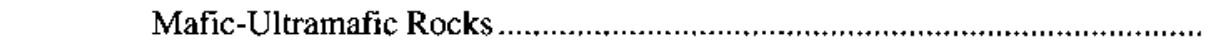 & \\
\hline netic Data & \\
\hline eposits & \\
\hline ons & \\
\hline & \\
\hline
\end{tabular}

\section{FIGURES}

1. Map showing location of Sierra Verdún-Cerro Piedra del Supamo study area .................................................. F2

2. Map showing geology of study area and adjacent region ............................................................................... 4

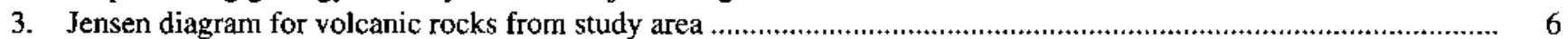

4. Diagrams showing geochemical characteristics of volcanic rocks from study area .............................................. 7

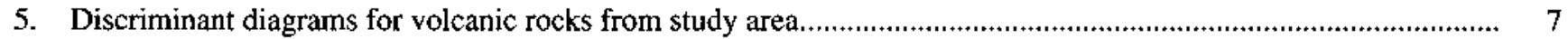

6. Magnesia-variation diagrams for volcanic rocks from study area ............................................................... 8

7. Jensen diagram for mafic-ultramafic rocks from study area ............................................................................ 10

8. AFM diagram showing geochemical characteristics of mafic-ultramafic rocks from study area........................... 10

9. Magnesia-variation diagrams for mafic-ultramafic rocks from study area ........................................................ 11

10. Aeromagnetic interpretation map of study area showing suggested boundaries of buried magnetic sources ........... 13

11. Profile of magnetic body that crosses and partially parallels Río Yuruán .......................................................... 15

12. Profile of magnetic body across east-trending body near Río Yuruán .................................................................. 16

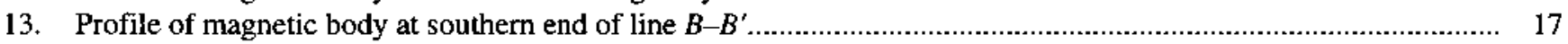

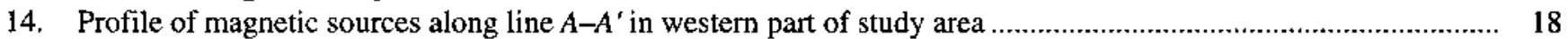




\title{
Geology and Geophysics of the Sierra Verdún-Cerro Piedra del Supamo Area, Estado Bolívar, Venezuela
}

\author{
By Floyd Gray, ${ }^{1}$ Fernando J. Nuñez, ${ }^{2}$ Jeffrey C. Wynn, ${ }^{3}$ Gary B. Sidder, ${ }^{4}$ \\ Freddy Davila, ${ }^{2}$ and Angel Baez ${ }^{2}$
}

\begin{abstract}
The Sierra Verdún-Cerro Piedra del Supamo area is in an Early Proterozoic greenstone-granite terrane in the Guayana Shield of southeastern Estado Bolívar, Venezuela. Rocks of the greenstone belts, mainly mafic flows and minor associated tuffaceous units, are strongly foliated and are metamorphosed to the greenschist facies. These rocks have been locally metamorphosed to the amphibolite facies, particularly near their contact with granite. A mafic-ultramafic complex was emplaced in older greenstone-belt rocks of basaltic andesite to basalt probably near the end of deformation of the greenstone belts. Historical and active placer and alluvial gold mining has stimulated recent interest in the area, which also has potential for deposits of shear-zone-hosted gold (low-sulfide gold-quartz veins), intrusion-related gold and precious-metals, chromite, placer and lode platinum-group elements, nickel-copper ore, and lateritic nickel.
\end{abstract}

\section{RESUMEN}

El área de Sierra Verdún-Piedra del Supamo está ubicado en un ambiente granito-rocas verdes de edad Proterozoico Temprano, el cual es parte del Escudo de Guayana en el Estado Bolívar, Venezuela. Las rocas del cinturón de rocas verdes, principalmente flujos máficos y unidades tobaceas menores, están fuertemente foliadas y metamorfizadas

${ }^{1}$ U.S. Geological Survey, Corbett Building., 210 E. 7th Street, Tucson, Arizona 85705

${ }^{2}$ Corporación Venezolana de Guayana, Técnica Minera, C.A., C.C. Chilemex, Piso 1, Puerto Ordaz, Venezuela.

${ }^{3}$ U.S. Geological Survey, Unit 62101, APO AE 09811-2101, USA.

${ }^{4}$ U.S. Geological Survey, Denver Federal Center, MS905, Denver, Colorado 80225 . a la facie del esquisto verde, y a la facie de la anfibolita cerca del contacto con rocas graníticas. Un complejo máfico-ultramáfico fue emplazado en rocas más antiguas del cinturon de rocas verdes, las cuales tienen una composición andesítica a basáltica. Este plutonismo máfico-ultramáfico probablemente ocurrió hacia el final de deformación de las rocas que conforman el cinturón de rocas verdes. Trabajos de mineria de oro, tanto antiguos como modernos, han estimulado el interes en el área, la cual también tiene potencial para yacimientos de oro formados en zonas de cizalla (vetas de cuarzo con oro y bajo contenido de sulfuros); metales preciosos y oro relacionados con intrusiones graníticas; depósitos de cromita; placeres y vetas con elementos del grupo del platino; mena de niquel-cobre, y lateritas niquelíferas.

\section{INTRODUCTION}

The Sierra Verdún-Cerro Piedra del Supamo study area covers an area of $544 \mathrm{~km}^{2}$ about $250 \mathrm{~km}$ south-southeast of Puerto Ordaz and about $60 \mathrm{~km}$ south of the town of Tumeremo in Estado Bolívar, Venezuela. The study area is centered near the confluence of the Río Supamo and the Río Yuruán and is between lat $6^{\circ} 36^{\prime}$ and $6^{\circ} 50^{\prime} \mathrm{N}$. and long $62^{\circ} 00^{\prime}$ and $61^{\circ} 47^{\prime} \mathrm{W}$. (fig. 1). It can be reached by helicopter; a poorly maintained logging road from El Callao or a 5-hour boat trip from El Dorado yields some limited, difficult access. The terrain is rugged and hilly and is characterized by a north-northwest-trending chain of mountains that has local relief of as much as $300 \mathrm{~m}$. Although excellent outcrops are present on ridge tops and in the rivers during the dry season, the area is generally heavily forested. Much of the fieldwork was conducted along traverses cut through the jungle at $2-\mathrm{km}$ intervals perpendicular to axes that are roughly parallel with the strike of structures and the trend of geologic units. 


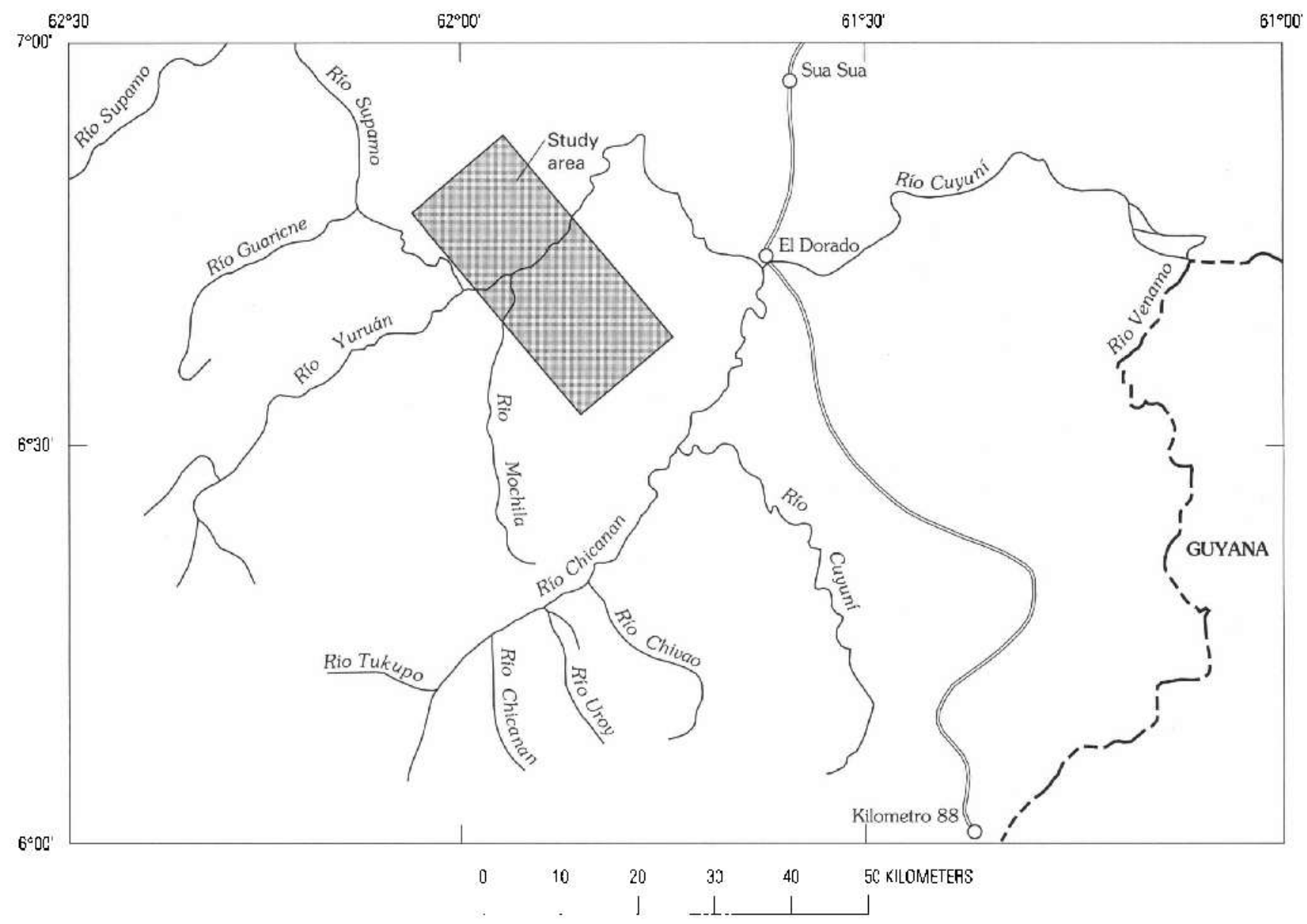

Figure 1. Location of the Sierra Verdún-Cerro Piedra del Supamo study area, Estado Bolívar, Venezuela.

The Sierra Verdún-Cerro Piedra del Supamo area was chosen for study for the following reasons:

1. Numerous gold placers and other surficial prospects, some of which are currently worked, are present in the area.

2. Radar images and reconnaissance mapping indicate that the area includes a diverse lithologic and stratigraphic section of greenstone belt.

3. A large mafic and ultramafic intrusive body within the greenstone belt, similar to rocks in other greenstone-belt areas in Venezuela, enables description of the nature of the contact relations for this particular suite of rocks and its mineral resource potential.

Geologic mapping was done in the area along and south of the Río Yuruán during March through July of 1990. Because much of the area is covered by forest and deeply weathered soil, detailed analysis of aeromagnetic data was used to better define the geology and structure.

\section{GEOLOGY \\ REGIONAL GEOLOGIC SETTING}

Early Proterozoic greenstone-granite terranes of the Pastora Supergroup and the Botanamo Group crop out in the central and eastern parts of the Venezuelan Guayana Shield (Sidder and Mendoza, this volume, fig. 2). They cover an area of about $360 \mathrm{~km}$ by $250 \mathrm{~km}$, or about $90,000 \mathrm{~km}^{2}$. The Pastora Supergroup consists of the El Callao and Cicapra Formations of the Carichapo Group and the Yuruari Formation. Rocks of the Botanamo Group, which contains the Caballape and Los Caribes Formations, lie discordantly on the Pastora Supergroup. Cox and others (1993) restricted the use of formation names to their type locations and considered the sequence of volcanic rocks in the Sierra Verdún-Cerro Piedra del Supamo area approximately age equivalent to other mafic greenstone sequences such as the El Callao Formation. 
Granitic plutons and domes of the Supamo Complex were intruded into the metasedimentary and meta-igneous rocks of the greenstone-granite terranes and separate the greenstone belts into branching synclinoria (Menendez, 1968, 1972; Benaim, 1972). Felsic to intermediate volcanic rocks of the Early Proterozoic Cuchivero Group and clastic sedimentary rocks of the Early to Middle Proterozoic Roraima Group overlie and cover rocks of the greenstone-granite terranes to the west and south of the study area. The contact between the greenstone-granite terranes and the Archean Imataca Complex to the north is the Guri shear zone (Gibbs and Olszewski, 1982; Onstott and others, 1989).

Mafic to ultramafic intrusive rocks are present in the stratigraphic sequence of the greenstone belts south of $\mathrm{El}$ Callao (Tosiani and Sifontes, 1989; Nuñez, unpublished data, 1990; Nuñez, Gray, and Davila, unpublished data, 1990; Wynn and others, this volume). The intrusive rocks commonly form layered complexes that include cumulate-textured rocks such as pyroxenite and peridotite associated with gabbroic cumulus and noncumulus rocks and lesser anorthosite and diorite. Country rocks of this intrusive sequence are basalt and basaltic andesite. The study area is part of an extensive north-striking ridge that originates in the El Callao area and continues southward to the Río Chicanán, interrupted by structures associated with the Río Yuruán.

\section{GEOLOGY OF THE STUDY AREA}

Within the study area, an Early Proterozoic supracrustal sequence of strongly deformed metavolcanic flows, tuffs, and hypabyssal mafic rocks forms the country rocks of an ultramafic-mafic complex (fig. 2). The supracrustal sequence is intruded and fragmented at its margins by granitic, monzonitic, and dioritic intrusive rocks of the Supamo Group. The westem margin of the intrusive rocks is exposed in the Río Yuruán near the mouth of the Río Mochila. The granitic rocks display a strong foliation parallel with the contact with rocks of the greenstone belt that trends $\mathrm{N}$. $43^{\circ}-55^{\circ} \mathrm{W}$. and dips steeply $60^{\circ}-80^{\circ} \mathrm{S}$. Basalt, minor gabbro, and interflow tuffs form xenolithic breccias and are extensively veined and stoped by a large granitic dome in a $0.5-\mathrm{km}$-wide zone.

In general, the southern part of the study area, including the area of the Río Yuruán, is characterized by low-lying volcanic rocks and the prominent north-northwest-striking Sierra Verdún ridge and its flank of curvilinear ridges. Northeastward (upsection) from the basal basalt are basaltic andesite and minor tuff and tuff breccia. The Sierra Verdún ridge consists of gabbroic rock; minor clinopyroxenite and feldspathic clinopyroxenite are in the eastern part of the ridge. The topography of the contact of the gabbro ridge at its northern limit suggests a fault contact with the volcanic rocks. The eastern margin of the greenstone belt is virtually identical to the westem margin in its fragmental intrusive character. East of the study area, outcrops of dacite, rhyolitic tuff, flow-banded rhyolite, cherty chemical sedimentary rocks, and minor lenses of intercalated arkosic rock in an adjacent body of greenstone-belt rocks (separated from greenstone-belt rocks in the study area by granite) are present.

Although ultramafic rocks probably account for 1-2 percent of the volume of igneous rocks in greenstone belts of the Guayana Shield in Guyana (Gibbs, 1987), the area near Cerro Piedra del Supamo contains a significantly greater volume of ultramafic-mafic intrusive rocks that are generally unfoliated and little affected by regional metamorphism as compared to volcanic country rocks. Sulfide-bearing, fine-grained homfels and recrystallized basaltic volcanic rocks that contain coarse acicular amphibole are in contact zones adjacent to gabbroic intrusive rocks. Medium-grained cumulate-textured rocks, sheared and mylonitized talc schist, and serpentinite are the most common rocks in the contact areas where hornfelsic rocks are found. Although neither spinifex textures nor features indicative of an extrusive origin for these rocks have been observed in the study area, komatiite was identified in the area on the basis of reported relic spinifex texture (Tosiani and Sifontes, 1989). The so-called spinifex texture is, however, rosettes of coarse acicular amphibole after pyroxene in contact metamorphic zones, and an origin other than komatiite is probable.

The ultramafic-mafic complex in the Sierra Verdún-Cerro Piedra del Supamo area is composed of crudely zoned, layered, cumulus dunite, wehrlite, olivine clinopyroxenite and minor feldspathic pyroxenite surrounded by locally foliated gabbroic rocks. The gabbroic rocks, which volumetrically are the most abundant rocks in the area, range from homogeneous textured gabbro to locally phase transitional pyroxene cumulate containing interstitial plagioclase and magnetite, plagioclase-pyroxene cumulate, and plagioclase cumulate containing oikocrysts of postcumulus pyroxene. The ultramafic rocks are cumulates composed of varying proportions of cumulus olivine, clinopyroxene, and orthopyroxene (?) and postcumulus plagioclase, orthopyroxene, brown hornblende, and magnetite. Layering and lamination strike variably north and dip between $20^{\circ}$ and $70^{\circ}$ to the west, although faults generally disrupt the orientation of the sequence. Textures are generally well preserved; however, locally, primary minerals are partly to totally altered to serpentine minerals, talc, amphibole, and magnetite. Large bodies of talc-serpentine schist are associated with fractures or shear zones within the ultramafic rocks. Pyrite, pyrrhotite, and chalcopyrite in amounts as much as $15-20$ percent form ubiquitous accessory minerals in the ultramafic rocks. 


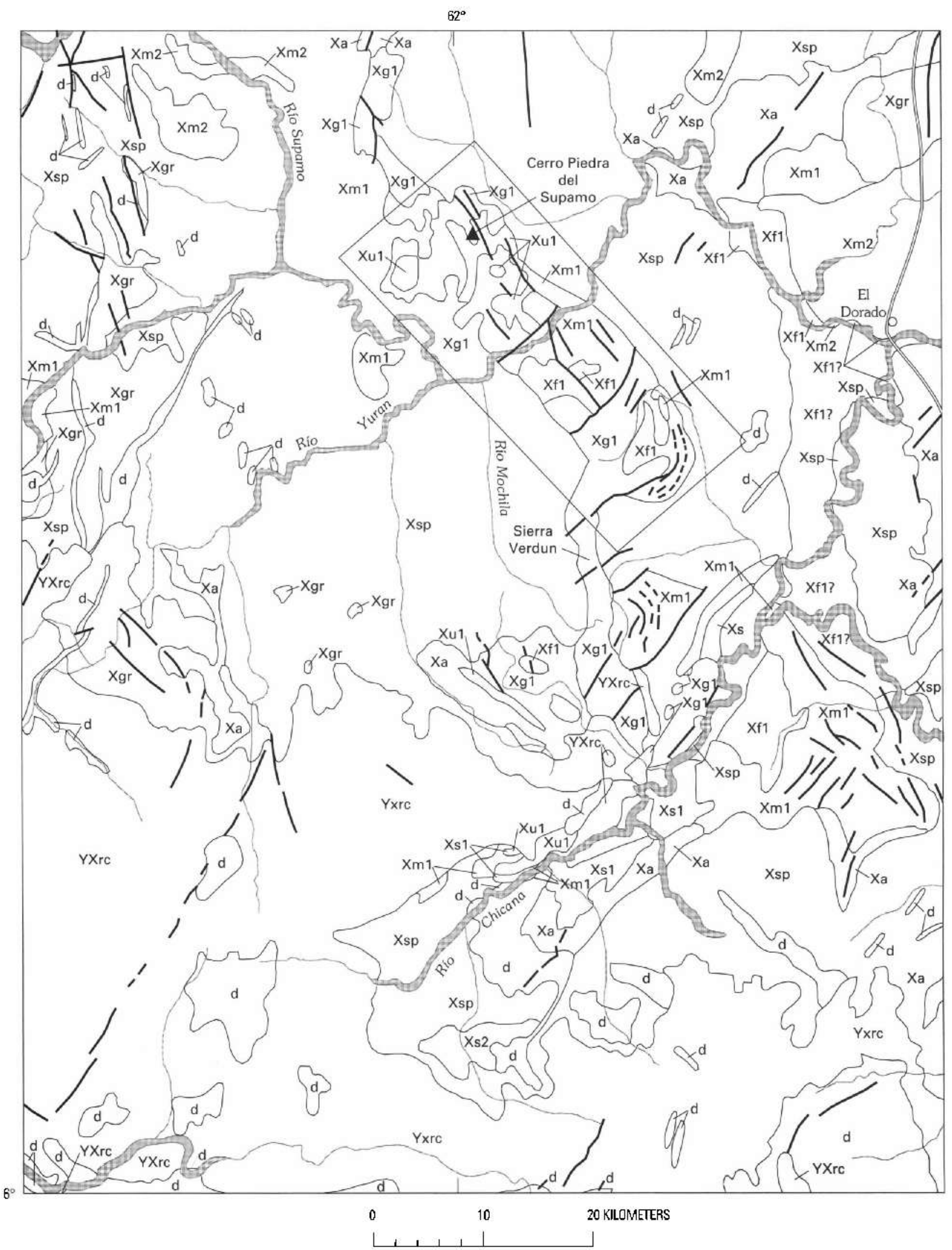




\section{EXPLANATION}

Diabase (Mesozoic and Early Proterozoic) - Dark-gray to greenish-gray, fine- to coarse-grained tholeitic intrusive rocks. Present as dikes, sills, and laccoliths. Includes rocks about 1,850-1,650 Ma and rocks about 270-219 Ma (Sidder and Mendoza, this volume!

RORAIMA GROUP (EARLY AND MIDDLE PROTEROZOIC)

YXrc

Canaima Formation of Yánez (1985)— Quartzarenite and arkose, conglomeratic arenite, conglomerate siltstone, and shale. Abundant cross-strata in arenite and arkose units. Weathers to form cliffs on resistant arenite, arkose, and conglomerate units and slopes on relatively nonresistant siltstone, shale, and silty arenite units. About 1,1000-2,000 m thick. Equivalent to Uairen and Cuquenán Formation, and lowemnost part of Uaimajué Formation, of Reid and Bisque (1975)

\section{GRANITC ROCKS (EARLY PROTEROZOIC)}

Granitic rocks-Mostly monzogranite and granite. Porphyritic medium to coarse grained, some inclusions of granodiorite Supamo Complex - Sadic granodiorite and trondhjemite, paragneiss, and migmatite; commonly in domeshaped intrusions. Sparse pegmatite. About 2,230 $2,050 \mathrm{Ma}$ [Sidder and Mendoza, this volume)

\section{EUGEOSYNCLINAL METAMORPHIC ROCKS} \{EARLY PROTEROZOIC

Mica schist and phyllite-Quartz + muscovite \pm chlorite \pm chloritoid \pm ankerite schist and phyllite and subordinate quartzite or metachert derived from sedimentary and felsic volcanic rocks. Ankeritic rocks weather to ferruginous schist and phyllite

Xm2 Mafic to intermediate metalava and metatuff-Chlorite \pm epidote \pm actinolite schist and phyllite and greenstone, commonly containing retict pyroxene phenocrysts. Relict textures suggest amygdaloidal flows and lithic- and crystal-rich tuff

\section{ROCKS OF THE GREENSTONE BELTS} (EARLY PROTEROZOIC)

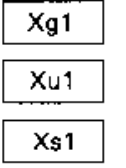

Metagabbro-Saussuritized and tocally amphibolitized. Locally has cumulus texture

Ultramafic rocks-Mainly metaperidotite, metapyroxenite, serpentinite, and talc schist

Mica schist and phyllite-Quartz+muscovite+chlorite+ ankerite schist and phyllite and subordinate quartzite or metachert derived from sedimentary and felsic volcanic rocks. Ankeritic rocks weather to ferruginous schist and phyllite

$x+1$ Felsic metatuff and flows-Quartz+muscovite+chlorite schist containing relict phenocrysts of partially resorbed quartz and broken feldspar

$\mathrm{Xm} 1$ Mafic to intermedlate metalava and metatuff-Chlorite+ albite+ epidote+actinolite schist and schistose greenstone, locally amygdaloidal. Subordinale albite-epidote amphibolite. Misor chert

$\mathrm{Xa}$

Amphibolite-Mainly highly deformed hornblende schist containing plagioclase (An 17). Locally shows outline of original phenocrysts replaced by homblende

\section{Contact}

Fault-Dashed where concealed

Figure 2 (above and facing page). Geology of the Sierra Verdún-Cerro Piedra del Supamo study area (outlined by box) and adjacent region, Estado Bolívar, Venezuela. Modified from $\mathrm{Cox}$ and others (1993).
Cumulus dunite, wehrlite, and olivine clinopyroxenite are volumetrically minor rock types in the ultramafic parts of the intrusive complex. Olivine cumulate generally consists of euhedral to subhedral olivine partly altered to serpentine and magnetite and postcumulus poikilitic clinopyroxene altered to talc, amphibole, and serpentine minerals. Sulfide minerals are present in interstitial, postcumulus areas. Olivine clinopyroxenite and wehrlite consist of euhedral to subhedral cumulus clinopyroxene, anhedral and locally network textured cumulus olivine, and postcumulus pyroxene, brown amphibole, and magnetite.

Clinopyroxene cumulate and feldspathic clinopyroxenite are the most abundant rock types in the ultramafic part of the intrusive complex. The transition between feldspathic clinopyroxenite and true gabbroic rocks (pyroxene cumulate, pyroxene-plagioclase cumulate, and homogenous textured gabbro) is difficult to define as a contact boundary. Initial mapping placed the contact between pyroxenite and gabbroic rocks generally at approximately 20 percent modal plagioclase (visual estimate); however, further systematic examination of hand specimens collected during traverses across the contact zone demonstrated that the rocks differ only slightly in modal abundance of interstitial postcumulus plagioclase and that the increase in abundance of plagioclase is irregular and gradual. Therefore, at least the more melanocratic varieties of gabbroic rock form part of a sequence consanguineous with pyroxenite. Clinopyroxene cumulate consists of medium- to coarse-grained, euhedral to subhedral clinopyroxene that is locally twinned, has iron-titanium oxide exsolution lamellae, and commonly contains interstitial plagioclase and less commonly magnetite and amphibole. Postcumulus plagioclase is altered to tremolite-actinolite, chlorite, and clay minerals. Fine-grained, disseminated sulfide minerals such as pymhotite, pyrite, and less abundant chalcopyrite occupy interstitial sites. Feldspathic clinopyroxenite consists of cumulus, euhedral to subhedral clinopyroxene, and varying amounts of interstitial plagioclase. Magnetite and amphibole are postcumulus phases.

The mafic part of the ultramafic-mafic complex is volumetrically more abundant. Mafic rocks are locally foliated and fine grained near the margins of the complex. They consist of clinopyroxene cumulate and plagioclase-clinopyroxene cumulate and lesser amounts of plagioclase cumulate, and they are locally laminated and modally layered. Plagioclase-clinopyroxene cumulate is composed of euhedral to subhedral, cumulus plagioclase and clinopyroxene; postcumulus clinopyroxene, magnetite, and brown hornblende fill interstitial spaces. Alteration is widespread, and secondary minerals include amphibole, chlorite, and epidote. 


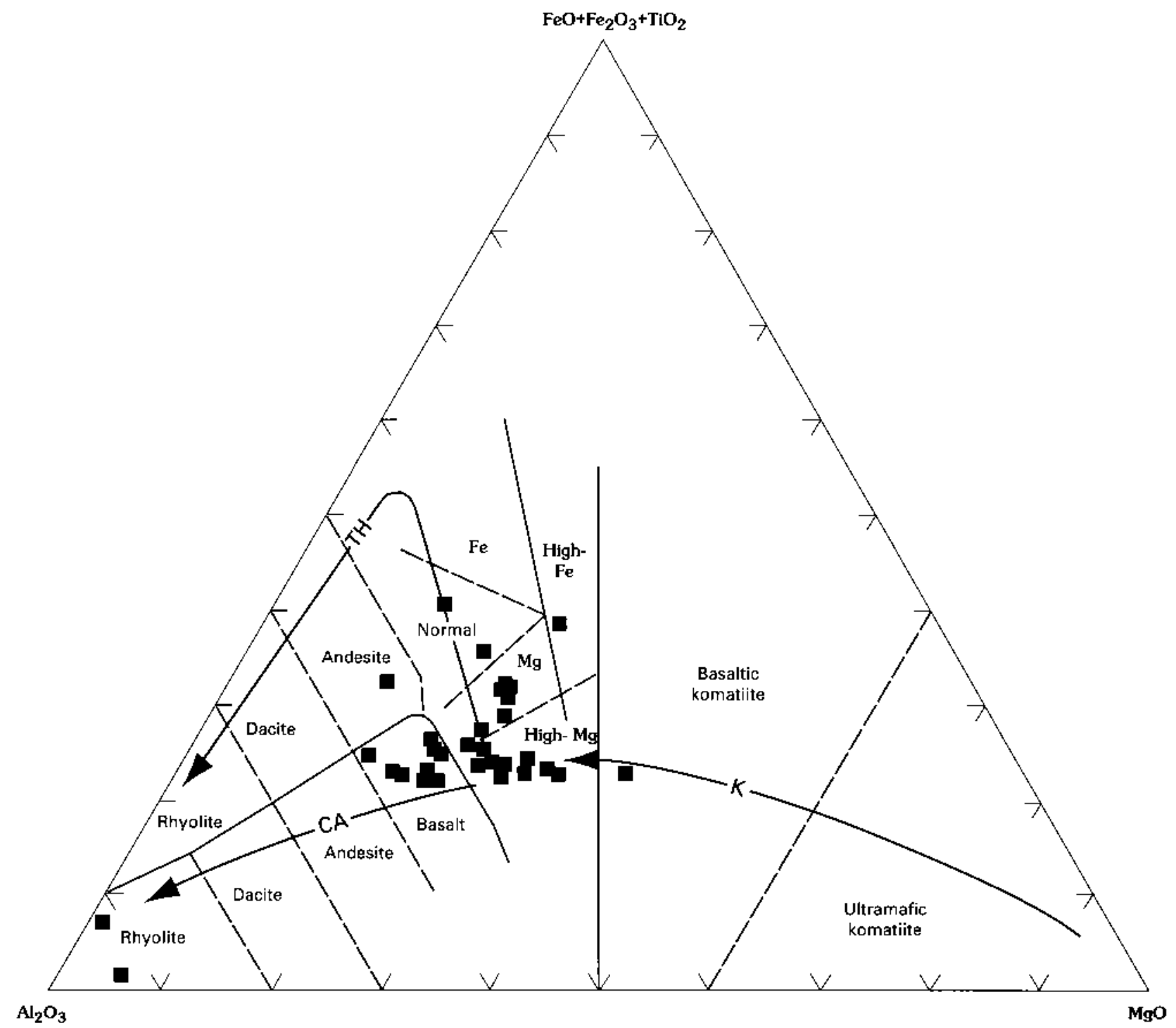

Figure 3. Jensen (1976) diagram for volcanic rocks from the Sierra Verdún-Cerro Piedra del Supamo study area showing their distribution relative to the cation percentages of $\mathrm{Al}_{2} \mathrm{O}_{3}, \mathrm{MgO}$, and $\left(\mathrm{FeO}+\mathrm{Fe}_{2} \mathrm{O}_{3}+\mathrm{TiO}_{2}\right)$.

\section{GEOCHEMISTRY}

\section{ANALYTICAL METHODS}

Rocks collected for chemical analysis in the Sierra Verdún-Cerro Piedra del Supamo study area vary in quality from fresh outcrops in and along the banks of the Río Yuruán and in the Cerro Piedra del Supamo to weathered float samples along ridges or sides of hills south of the Río Yuruán. The weathering rind on float samples was removed before chemical analysis. Each sample collected for geochemical analysis was $5-10 \mathrm{~kg}$ in size and was crushed and ground to -100 mesh powder. The major element oxides $\mathrm{Al}_{2} \mathrm{O}_{3}$, total $\mathrm{Fe}$ (reported as $\mathrm{FeTO}_{3}$ ), $\mathrm{MgO}, \mathrm{CaO}, \mathrm{Na}_{2} \mathrm{O}, \mathrm{K}_{2} \mathrm{O}, \mathrm{TiO}_{2}$, and $\mathrm{MnO}$ were analyzed by Marta García in the laboratories of Técnica Minera, C.A., by atomic absorption using a
Perkins-Elmer 5000 spectrograph, for $\mathrm{SiO}_{2}$ by the gravimetry, and for $\mathrm{P}_{2} \mathrm{O}_{5}$ and $\mathrm{TiO}_{2}$ by photocolorimetry. Abundance of the volatile elements $\mathrm{H}_{2} \mathrm{O}, \mathrm{CO}_{2}, \mathrm{~F}$, and $\mathrm{Cl}$ and the loss on ignition were not determined.

Figure 5 (facing page). Discriminant diagrams for volcanic rocks from the Sierra Verdún-Cerro Piedra del Supamo study area, Estado Bolívar, Venezuela, showing the chemical affinity of the rocks and their tectonic environment of deposition. $A, \mathrm{FeO}^{*} / \mathrm{MgO}$ versus $\mathrm{SiO}_{2}$. FeO* is total iron as $\mathrm{FeO}, B, \mathrm{SiO}_{2}$ versus $\left(\mathrm{FeO}+\mathrm{Fe}_{2} \mathrm{O}_{3}\right) / \mathrm{FeO}+\mathrm{Fe}_{2} \mathrm{O}_{3}+\mathrm{MgO} . C, \mathrm{TiO}_{2}$ versus $\mathrm{Mg}$-number. $D$, $\mathrm{MnO}(\times 10)-\mathrm{TiO}_{2}-\mathrm{P}_{2} \mathrm{O}_{5}(\times 10)$. Fielos: $\mathrm{CAB}$, island arc calc-alkaline basalt; IAT, island arc tholejite; MORB, mid-ocean ridge and marginal basin basalt; OIT, ocean island tholeiite; OIA, ocean island basalt (Mullen, 1983). 


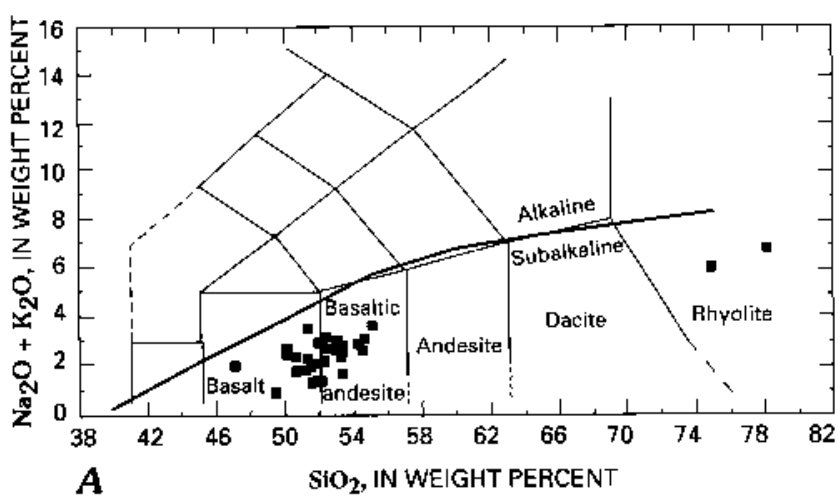

Figure 4. Diagrams showing geochemical characteristics of volcanic rocks from the Sierra Verdún-Cerro Piedra del Supamo study area, Estado Bolivar, Venezuela. A, Total alkalids $\left(\mathrm{Na}_{2} \mathrm{O}+\mathrm{K}_{2} \mathrm{O}\right)$ versus silica. $B, A F M\left(\mathrm{Na}_{2} \mathrm{O}+\mathrm{K}_{2} \mathrm{O}-\mathrm{FeO}{ }^{*}-\mathrm{MgO}\right)$. $\mathrm{FeO}^{*}$ is total iron as $\mathrm{FeO}$.

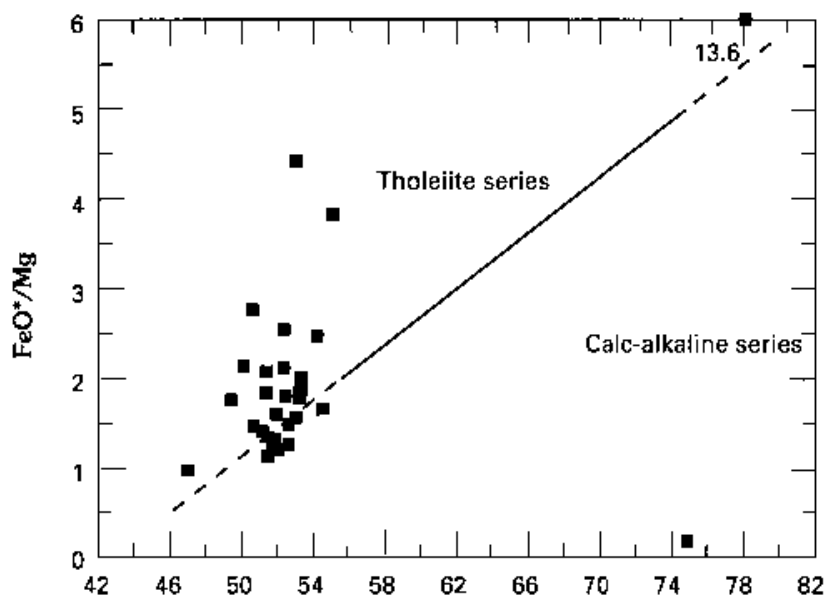

A

$\mathrm{SiO}_{2}$, IN WEIGHT PERCENT

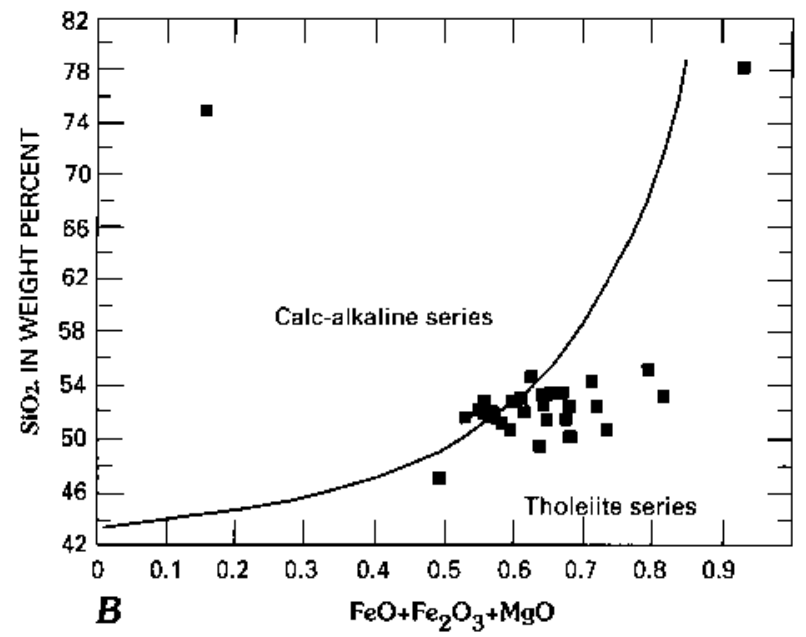

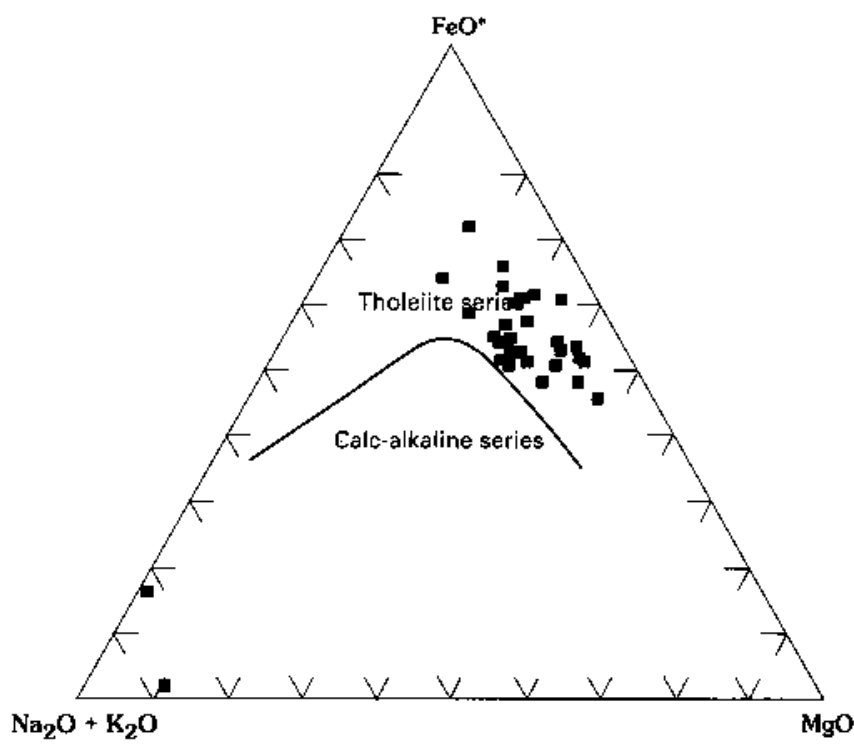

$B$
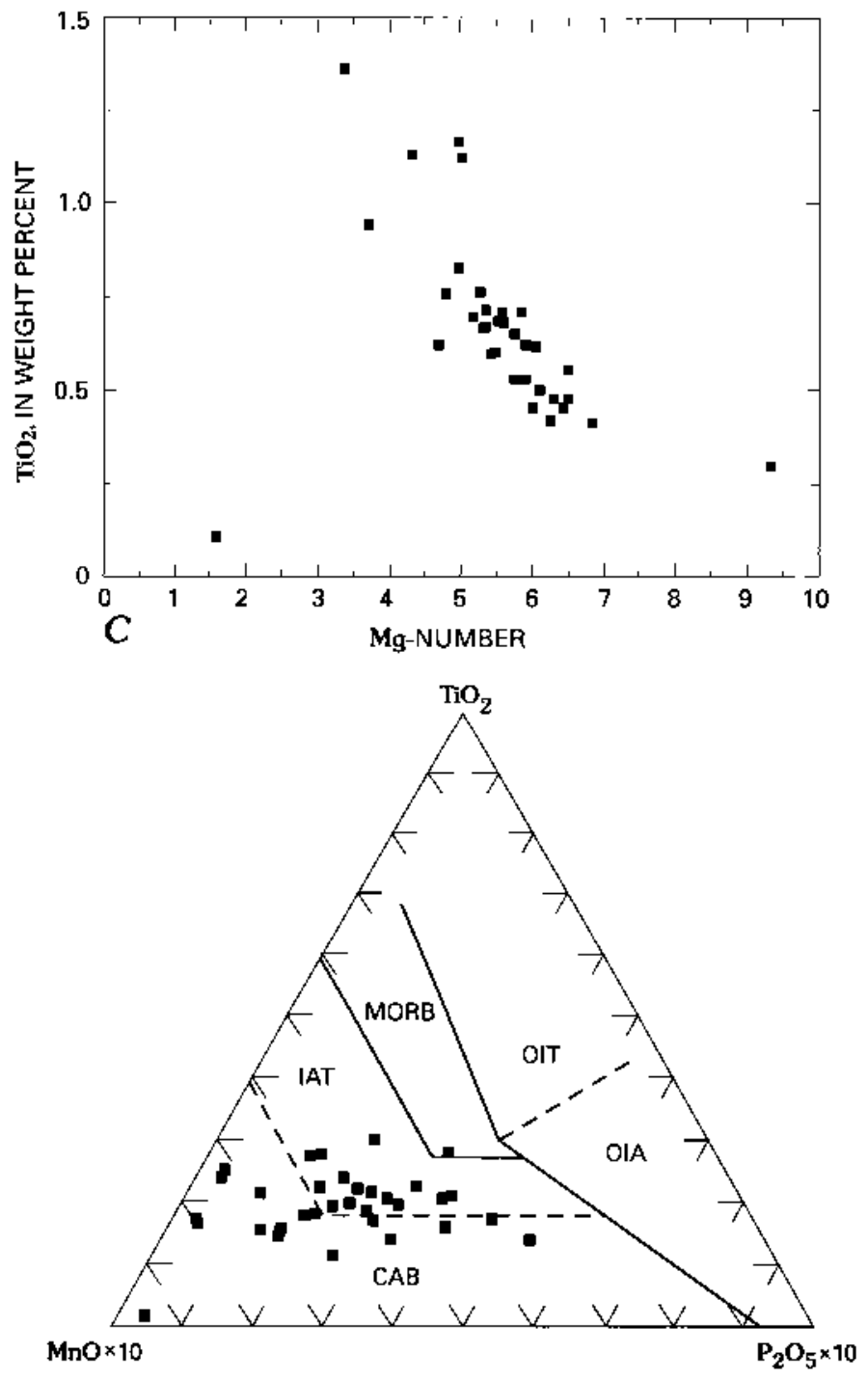

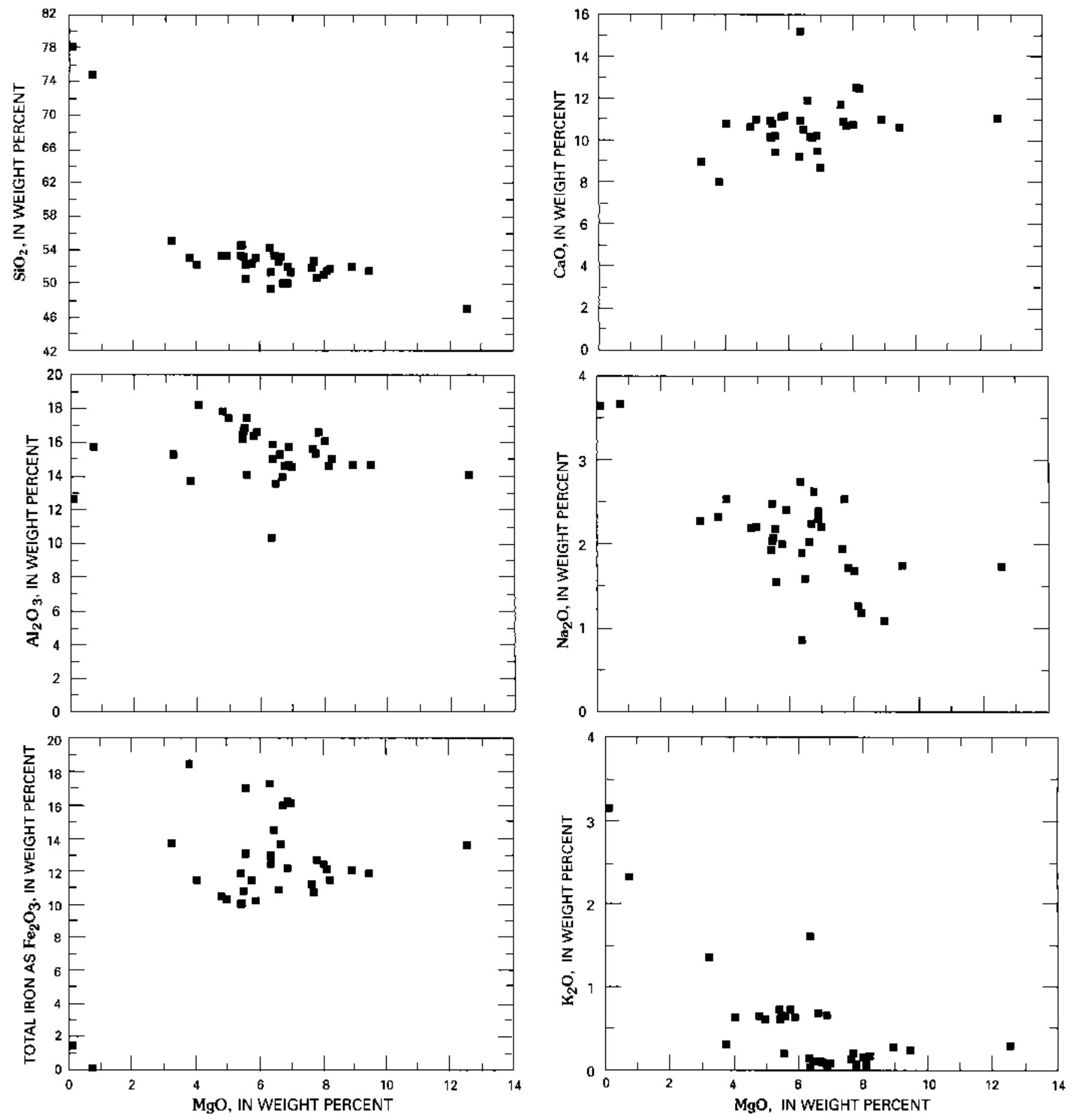

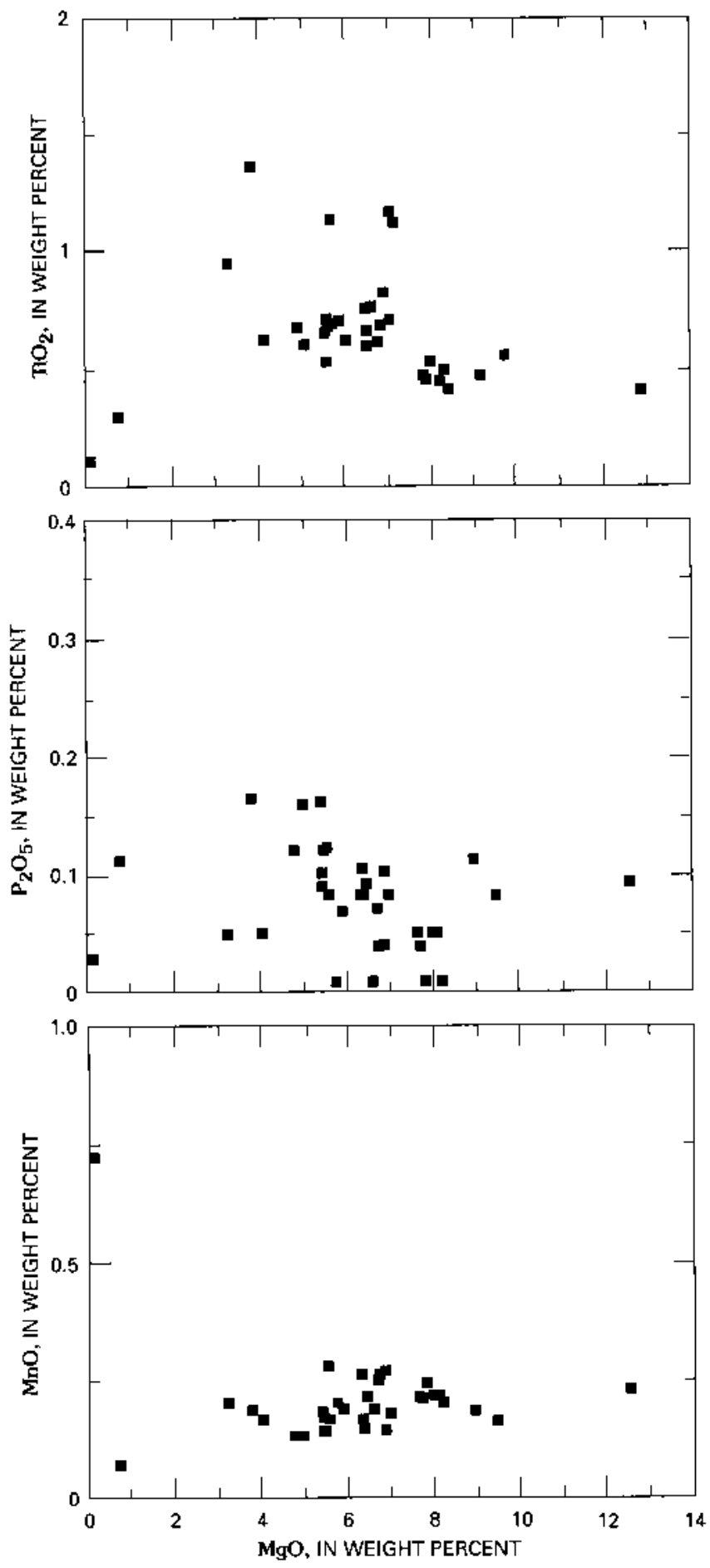

Figure 6 (above and facing page). Magnesia-variation diagrams for volcanic rocks from the Sierra Verdún-Cerro Piedra del Supamo study area, Estado Bolívar, Venezuela.

\section{ANALYTICAL RESULTS}

\section{VOLCANIC ROCKS}

In the Sierra Verdún-Cerro Piedra del Supamo area, all of the Early Proterozoic supracrustal rocks have been regionally metamorphosed to greenschist facies. The volcanic rocks were classified on a ternary plot that utilizes the cation percentages of $\mathrm{Al}$, ( $\mathrm{Fe}^{2++} \mathrm{Fe}^{3++} \mathrm{Ti}$ ), and $\mathrm{Mg}$ (fig. 3) (Jensen, 1976) and on a total alkalis-silica diagram (fig. 4A) (Le Bas and others, 1986, 1992; Le Bas and Streckeisen, 1991). Figures 3 and 4 show that proportions of basalt and basaltic andesite are subequal. The volcanic rocks are dominantly tholeiitic (figs, 4,5), and some samples plot as calc-alkalic basalt. Two samples that plot as rhyolite on the total alkali-silica diagram are altered granite or rhyolite dike. Suggested bimodality of the volcanic rocks in the greenstone belts of the Guayana Shield (Gibbs, 1987) could not be confirmed in this study because of the paucity of silicic samples.

The concentrations of the major oxides in these rocks are dominantly controlled by fractionation and by the compositional changes of plagioclase, pyroxene, and other mafic and iron-titanium oxide minerals during magma evolution. Magnesia-variation diagrams (fig. 6) show characteristic variations of the major-element oxides versus $\mathrm{MgO}$. Titania plotted versus $\mathrm{Mg}$-number shows a clear evolutionary trend (fig. $5 \mathrm{C}$ ). A ternary plot of the oxides of manganese, titanium, and phosphorous may indicate the tectonic environment of deposition of volcanic rocks (fig. 5D) (Mullen, 1983). The volcanic rocks of the Sierra Verdún-Cerro Piedra del Supamo area were probably deposited in an island arc setting.

\section{MAFIC-ULTRAMAFIC ROCKS}

Mafic intrusive rocks of the study area are clinopyroxene cumulate, plagioclase-clinopyroxene cumulate, and lesser amounts of plagioclase cumulate. Their whole-rock major-element-oxide chemical compositions reflect the dominant cumulus minerals. The composition of plagioclase-bearing rocks is similar to that of tholeiitic high-iron and high-magnesium basalt (fig. 7). On the Jensen cation plot (fig. 7), peridotitic rocks plot in the ultramafic komatiite field. Oxide abundances plotted on AFM (fig. 8) and $\mathrm{MgO}$-variation (fig. 9) diagrams show compositional gaps that may correspond to the occurrence of plagioclase on the liquidus. Basalt and basaltic andesite in the Sierra Verdún-Cerro Piedra del Supamo area probably are not consanguineous with these intrusive ultramafic-mafic rocks. 

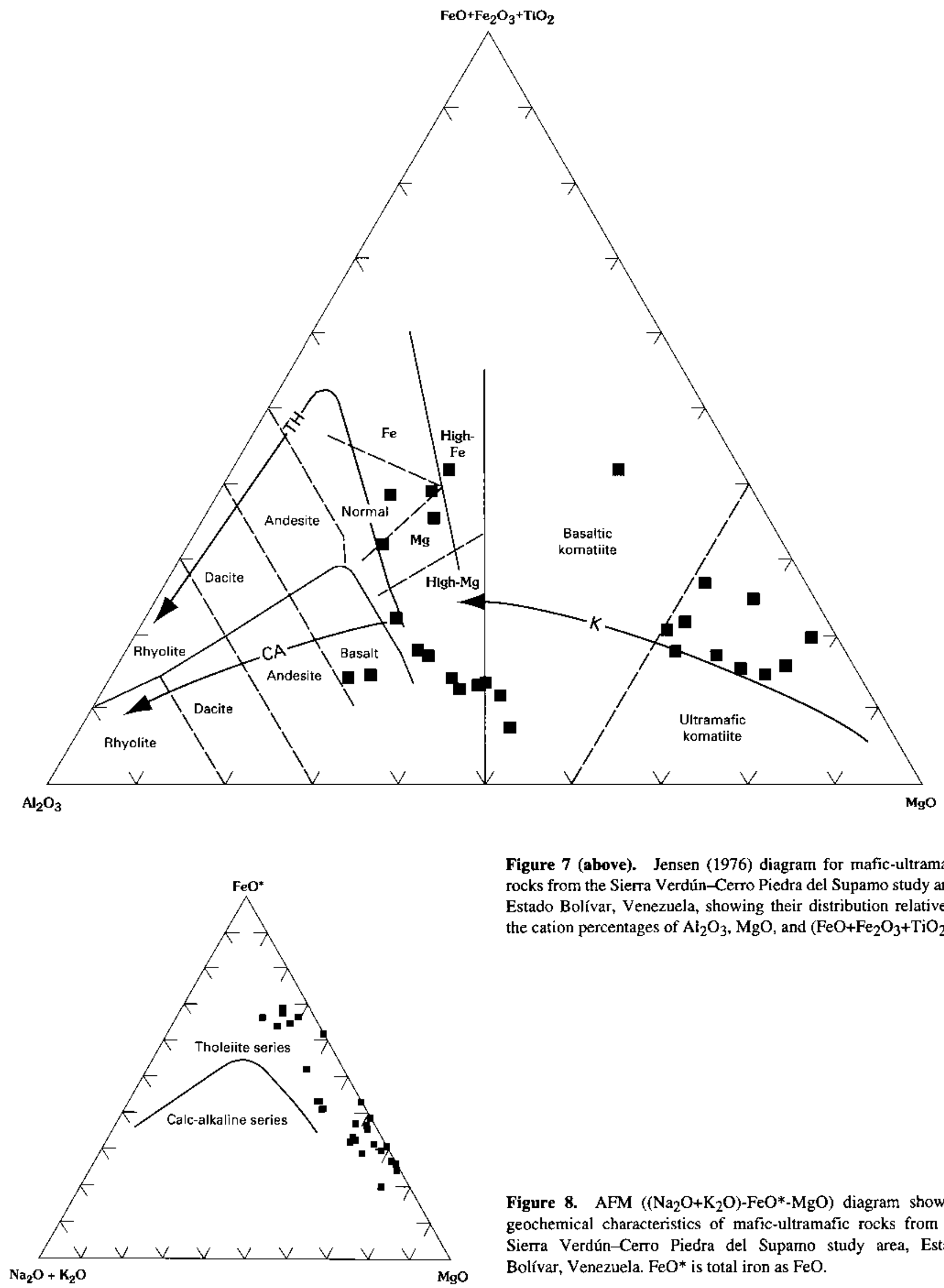

Figure 7 (above). Jensen (1976) diagram for mafic-ultramafic rocks from the Sierra Verdún-Cerro Piedra del Supamo study area, Estado Bolívar, Venezuela, showing their distribution relative to the cation percentages of $\mathrm{Ai}_{2} \mathrm{O}_{3}, \mathrm{MgO}$, and $\left(\mathrm{FeO}+\mathrm{Fe}_{2} \mathrm{O}_{3}+\mathrm{TiO}_{2}\right)$.

Figure 8. AFM $\left(\left(\mathrm{Na}_{2} \mathrm{O}+\mathrm{K}_{2} \mathrm{O}\right)-\mathrm{FeO}^{*}-\mathrm{MgO}\right)$ diagram showing geochemical characteristics of mafic-ultramafic rocks from the Siema Verdún-Cепто Piedra del Supamo study area, Estado Bolívar, Venezuela. FeO* is total iron as $\mathrm{FeO}$. 

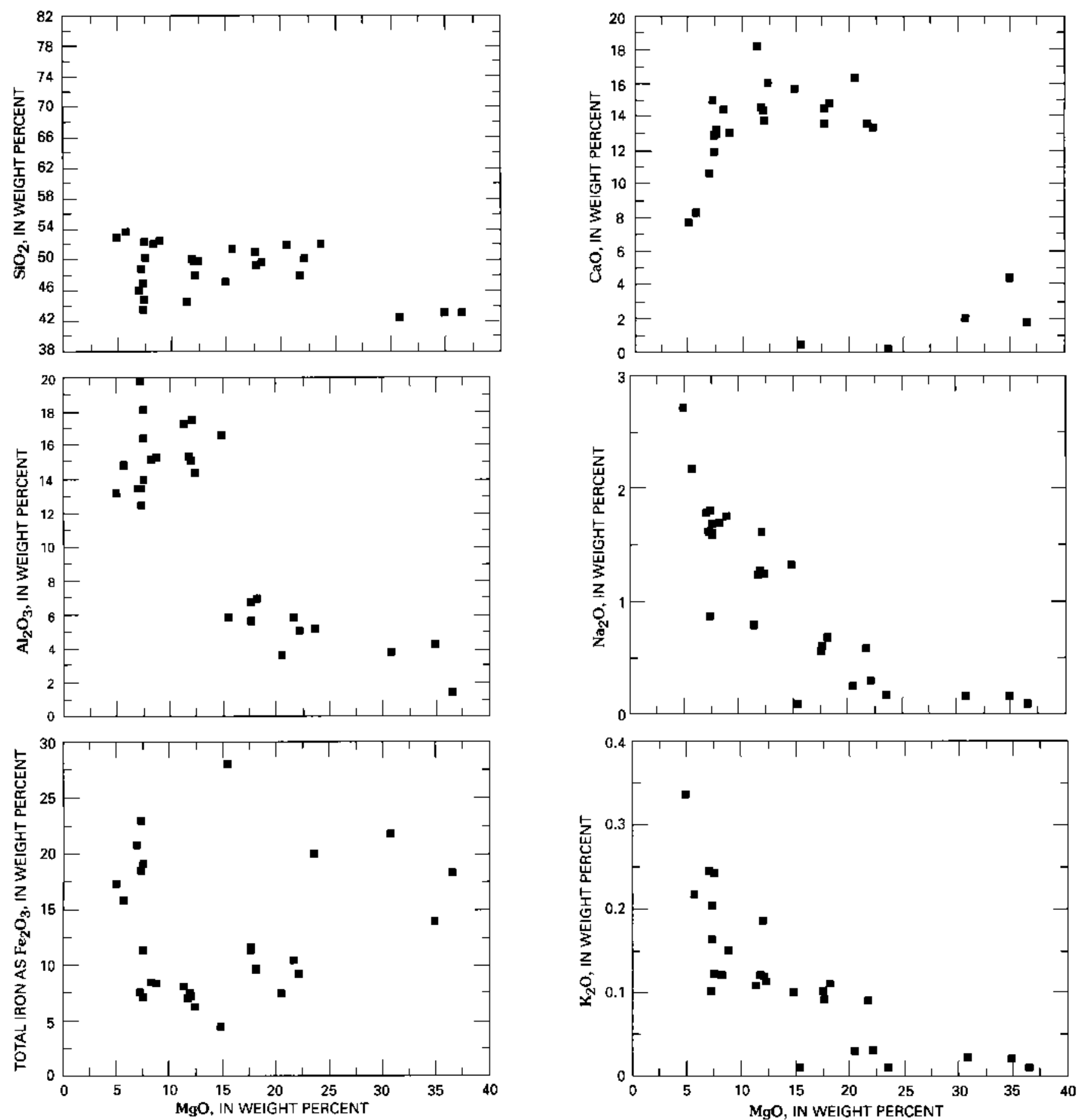

Figure 9 (above and following page). Magnesia-variation diagrams for mafic-ultramafic rocks from the Sierra Verdún-Cerro Piedra del Supamo study area, Estado Bolívar, Venezuela.

\section{AEROMAGNETIC DATA}

Aeromagnetic data for the Guri 1:500,000-scale quadrangle (lat $6^{\circ}-8^{\circ} \mathrm{N}$., long $60^{\circ}-63^{\circ} \mathrm{W}$.), including the area of the present study, were acquired in 1959 and 1961 by Hunting Surveys (Canada) for the Venezuelan Ministry of Energy and Mines through a contract with Goodyear Aeroservice (Aeroservicio de Venezuela, C.A.). Flight lines were spaced approximately $1 \mathrm{~km}$ apart and were flown at $152-\mathrm{m}$ mean terrain clearance in a N. $22^{\circ} \mathrm{W}$, direction that was chosen to cut across the strike of regional foliation. Internal evidence, such as poor correlation between surveys spaced two years apart, suggests that incorrect registration of fiducial marks may have led to errors in horizontal location of as much as $2.5 \mathrm{~km}$. A synoptic interpretive diagram (fig. 10) was manually derived using forward two-dimensional magnetic mod- 

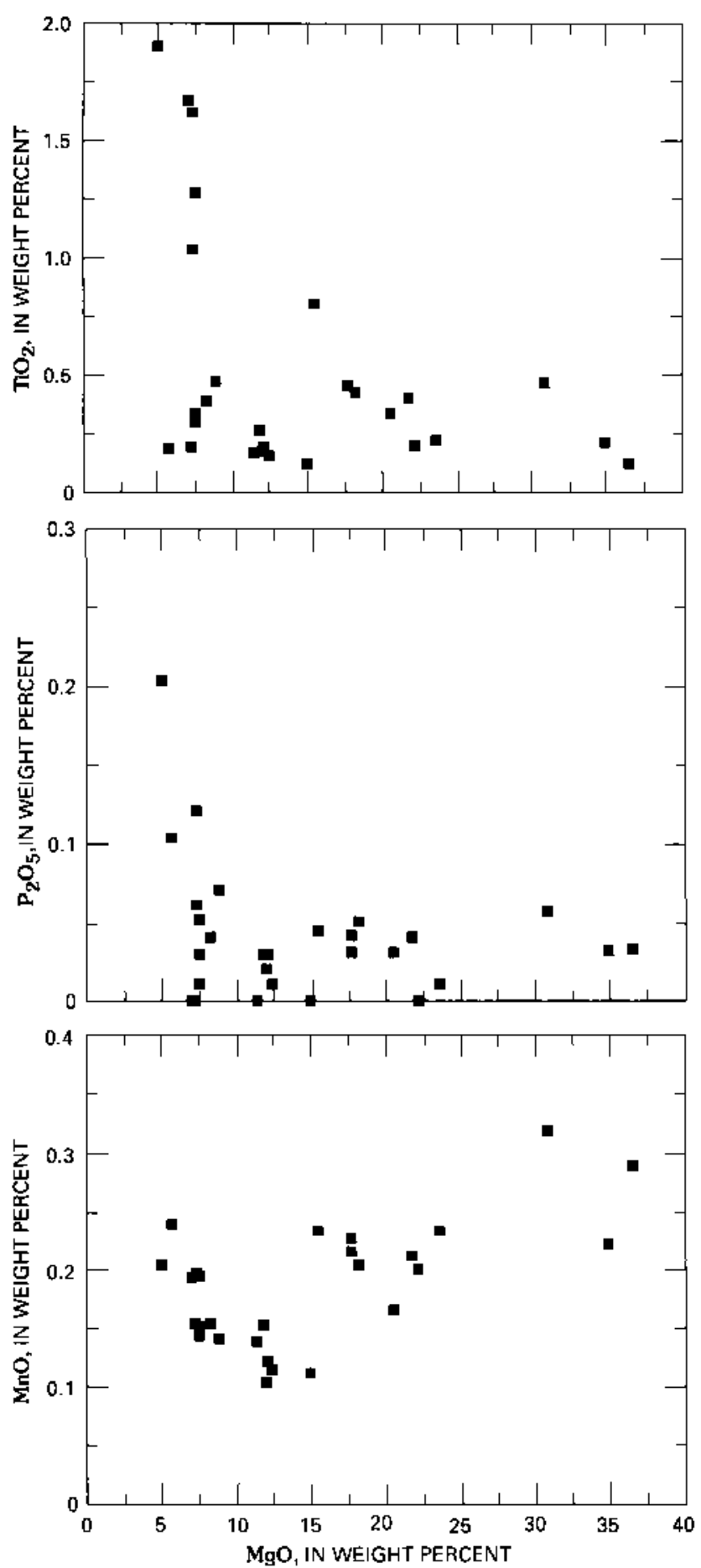

eling for control. The anomalies were classified using the steepest tangent method (Vacquier and others, 1951) into two rough depth ranges, from superficial (probably outcrop or rocks under only a thin veneer of saprolite) to $2.5 \mathrm{~km}$ depth. Data were reduced and specific areas modeled using Geosoft (1988), a magnetic data modeling software package.

Figure 10 shows the interpreted boundaries or buried contacts of the source bodies, probably granitic material, causing the anomalies derived from various 1:50,000-scale aeromagnetic contour maps. Areas of almost nonmagnetic basement complex (mafic to felsic metalavas and metatuffs and mafic-ultramafic intrusive rocks of the greenstone belt) were not interpreted. Surprisingly, these rocks exhibited only a weak to nondetectable magnetic signature. Preliminary examination of the magnetic susceptibility of samples collected in the field area yielded inconsistent results; basaltic rocks showed variations in magnetic susceptibility of almost two orders of magnitude, and granitic and gneissic rocks had susceptibilities that were 3-10 times greater than that of the basalt.

The interpretation presented herein fits in the context of a larger interpretation of the Guri 1:500,000-scale quadrangle (Wynn and Sidder, 1991; Cox and others, 1993). The crosshatched areas shown in figure 10 represent bodies whose magnetic signatures indicate that their tops are within $500 \mathrm{~m}$ of the surface. The enclosed areas without hatching represent the outlines of bodies $500 \mathrm{~m}$ or deeper. Smaller shallow bodies are commonly present within these deeper bodies; these are possible superficial expressions of deeper plutonic bodies such as apophyses of a deeper intrusion.

Figure $10 B$ shows a detailed geophysical interpretative anomaly map of part of the study area (area 1). The detailed map shows several lensoidal, west- and northwest-striking bodies near the Río Yuruán and a number of other bodies north of the river. Gold is found in placer, alluvial, and weathered bedrock workings associated with weathered quartz veins and quartz-vein float in the central part of the study area and across the Río Yuruán (see mine symbols). These occurrences are superimposed on the eastern half of a shallow west-striking feature (anomaly A). Intrusion-related gold deposits such as Vuelvan Caras and Omai are present in other parts of the Guayana Shield. Other plutonlike expressions in the study area are similar to that of anomaly A and may be exploration targets.

Figure 11 is the profile of the magnetic body anomaly $\mathrm{A}$. The source body may crop out locally, and it dips to the north. Figure 12 shows a geophysical model across the west-striking body (anomaly $\mathrm{B}$, fig. 10B) to the south of anomaly A. Because the edges of the anomaly are compromised by interference with adjacent anomalies, the model can only approximately define the source body. The model suggests a depth to source of about $500 \mathrm{~m}$. 


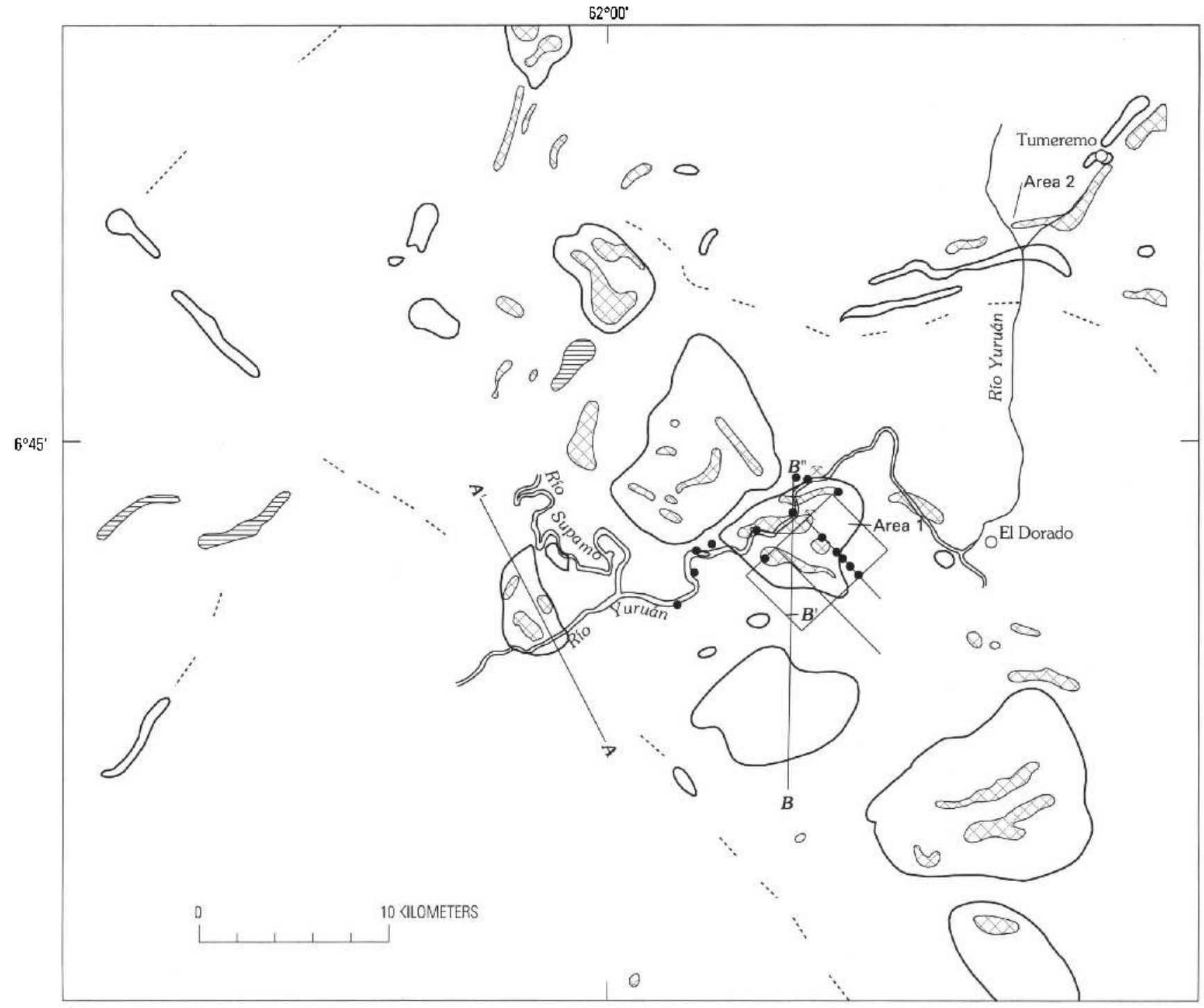

$\boldsymbol{A}$

\section{EXPLANATION}

- Picas (traverses)-Shown in figure $10 \mathrm{~B}$

Magnetic terrane boundary or extension of narrow dike

$\$$ Outline of shallow magnetc source-Top within $500 \mathrm{~m}$ of the surface

Outline of intermediate-depth magnetic source-Plutonic source $>500 \mathrm{~m}$ depth

$\rightleftharpoons$ Outline of reversely polarized magnetic body

- Station

$\times \quad$ Mine or prospect

Figure 10 (above and following page). Aeromagnetic interpretation maps of the Sierra Verdún-Cerro Piedra del Supama study area, Estado Bolívar, Venezuela, showing suggested boundaries of buried magnetic sources. $A$, Map of study area. $B$, Detail of area 1 shown in $A$. 


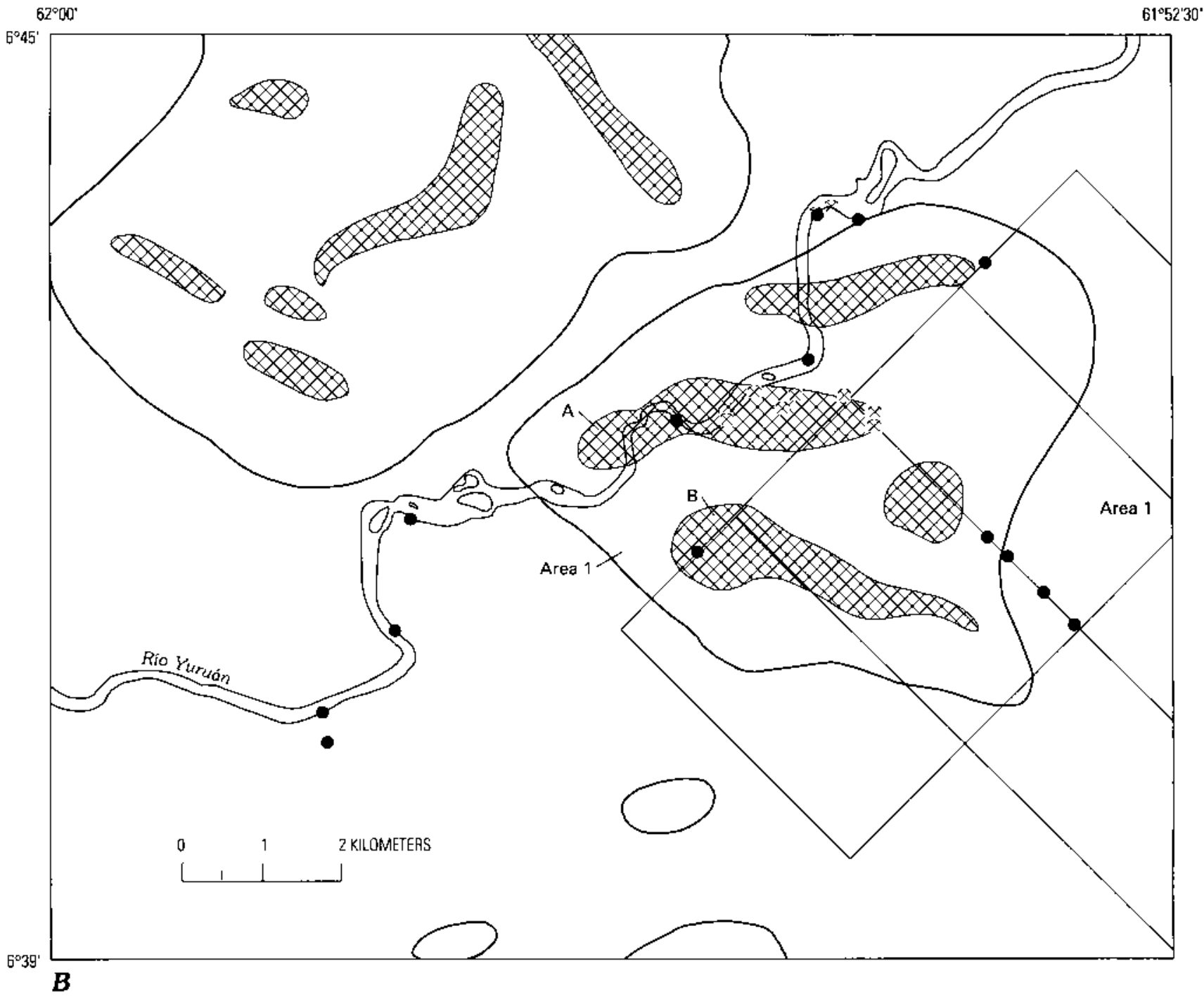

A large plutonic source without any shallow expressions is at the southem end of the line of profile $B-B^{\prime}$ (fig. 10A). The model of this source (fig. 13) suggests that the source is a plutonic body about $3 \mathrm{~km}$ wide (north-south) and buried at least $2 \mathrm{~km}$ deep. It is distinct from the plutonic bodies to the north and to the southeast.

Figure 14 shows an attempt to model as a single discrete body one of the complex, multilevel anomaly areas that has a deep source and superficial expressions along profile $A-A^{\prime}$ (fig. 10). Because the modeling program only used tabular bodies, the resulting model is approximate. Nevertheless, the model (fig. 14) suggests that the buried body probably has surface outcrops. This body is almost $5 \mathrm{~km}$ in maximum diameter and trends N. $22^{\circ} \mathrm{W}$; it may cross the Río Yuruán west of the Río Supamo intersection.

In the northeastem part of the study area (fig. 10A, area 2), two separate strings of long, tabular bodies strike east to northeast. The bodies in the southern set of these strings probably are deep; those of the northern set crop out on the northem bank of the Río Yuruán and may control its direction. The signatures of the anomalies indicate that both sets of tabular bodies comprise the same rock type. From previous experience in the Guayana Shield, it is possible to speculate that the source bodies are diabase dikes. 
A
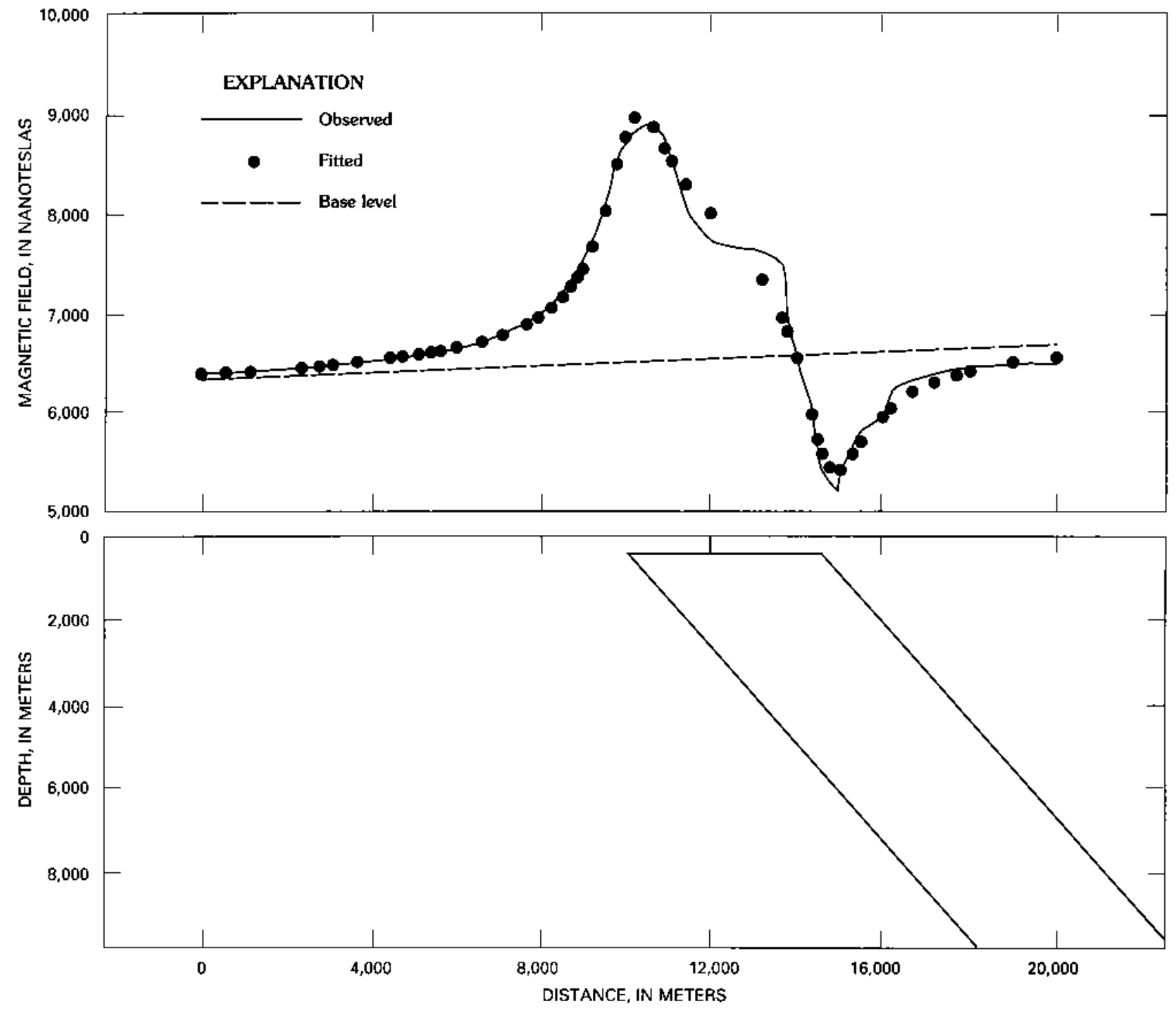

\begin{tabular}{|c|c|c|}
\hline \multicolumn{3}{|c|}{ MODEL PARAMETERS } \\
\hline Model type & & TABULAR 2 \\
\hline Depth & $\mathrm{x}$ & $393 \mathrm{~m}$ \\
\hline Half width & $\mathbf{F}$ & $2,275 \mathrm{~m}$ \\
\hline Length left & $\mathrm{x}$ & $1,200 \mathrm{~m}$ \\
\hline Length right & $x$ & $1,200 \mathrm{~m}$ \\
\hline Dip & $\mathbf{F}$ & $50^{\circ}$ \\
\hline Thickness & $\mathbf{F}$ & $17,203 \mathrm{~m}$ \\
\hline Susceptibility & $\mathrm{F}$ & $0.0282 \mathrm{emu}$ \\
\hline Remnance ratio & $x$ & $\alpha^{\circ}$ \\
\hline Remnance incl & $\mathrm{x}$ & $0^{\circ}$ \\
\hline Remnance decl & $\mathrm{x}$ & $0^{\circ}$ \\
\hline Position & $F$ & $12,386 \mathrm{~m}$ \\
\hline Base level & $\mathrm{F}$ & $6,558.0604 n T$ \\
\hline Base slope & $F$ & $0.0170704 \mathrm{nT} / \mathrm{m}$ \\
\hline
\end{tabular}

GEOMAGNETIC FIELD

Field strength $\quad 35,000 \mathrm{nT}$

Inclination $\quad 35^{\circ}$

Declination $\quad-11^{\text {D }}$

PLAN DIRECTIONS

Strike prep $\quad-22^{\circ}$

Line direction $\quad-22^{\circ}$

Sensor height $\quad 150 \mathrm{~m}$

Figure 11. Profile of magnetic body that crosses and is partially parallel with the Río Yuruán. Line of profile is shown in figure 10. 

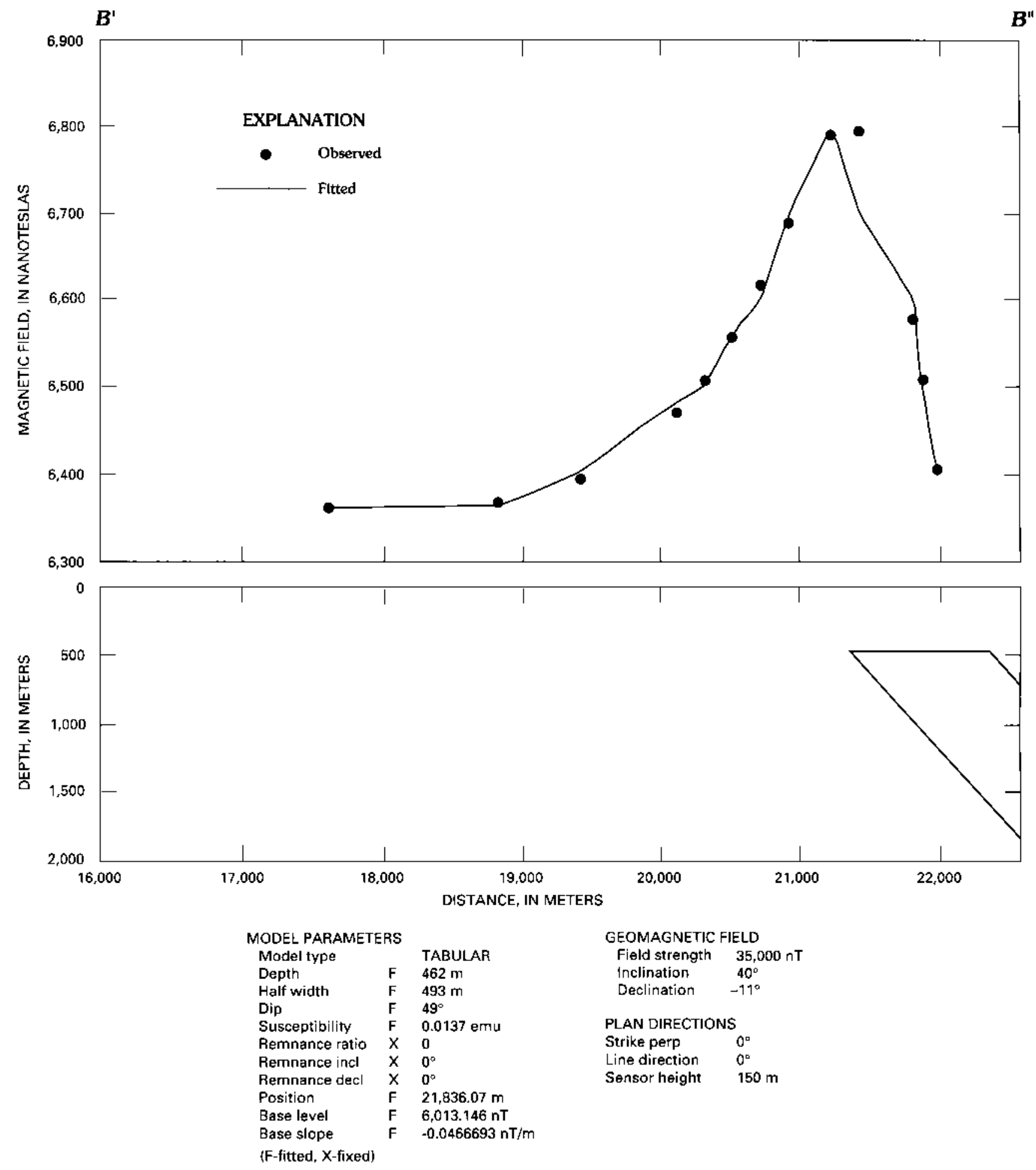

Figure 12. Profile of magnetic body across east-trending body near the Río Yuruán. Line of profile is shown in figure 10 . 

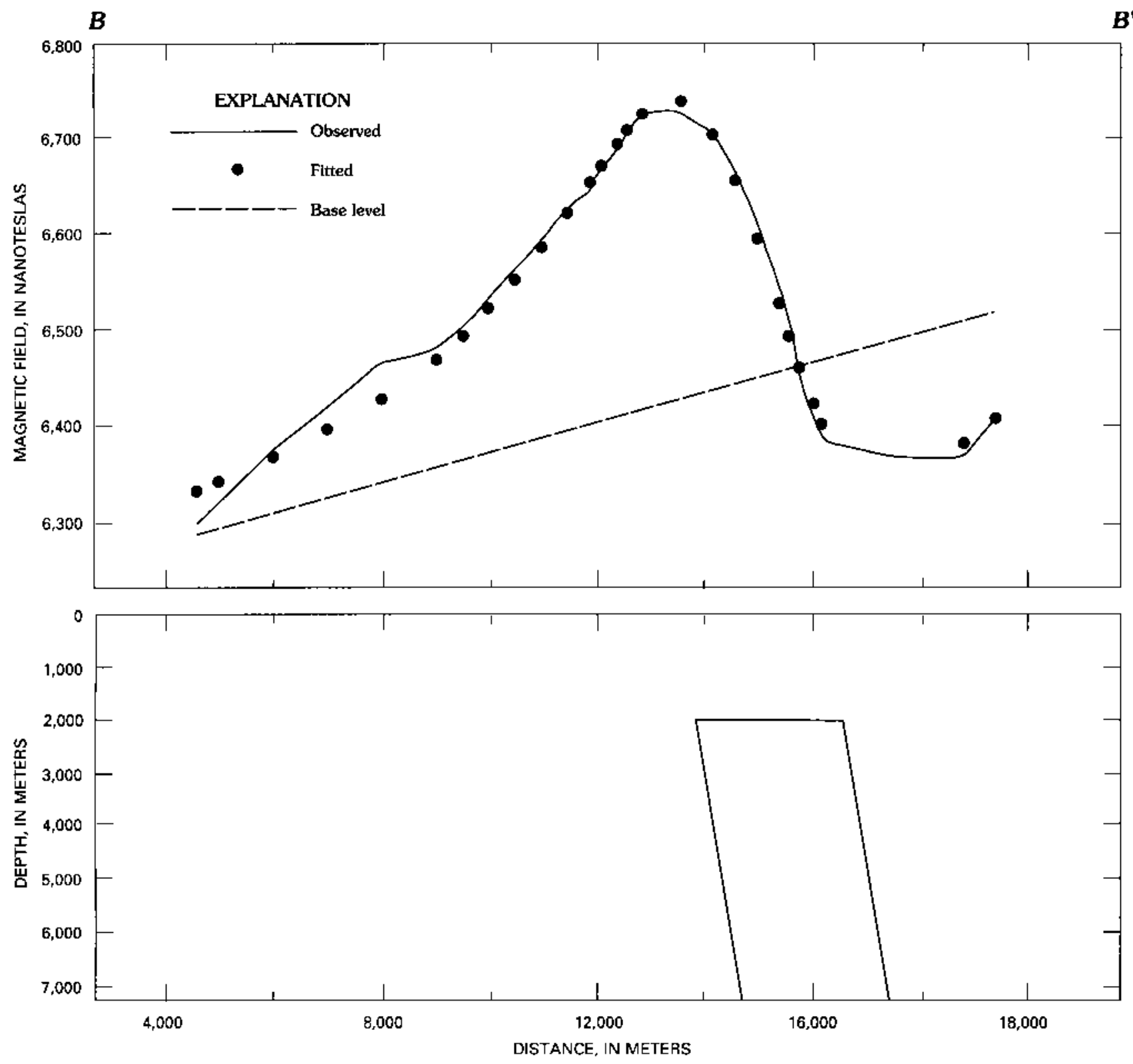

\begin{tabular}{|c|c|c|}
\hline & \multirow{3}{*}{$\begin{array}{l}\text { TABULAR } 2 \\
2,117 \mathrm{~m}\end{array}$} \\
\hline \multicolumn{2}{|c|}{$\begin{array}{l}\text { MODEL PARAMETERS } \\
\text { Model type }\end{array}$} & \\
\hline Depth & $\mathbf{F}$ & \\
\hline Half width & $\mathbf{F}$ & $1,368 \mathrm{~m}$ \\
\hline Length left & $x$ & $1,800 \mathrm{~m}$ \\
\hline Length right & $x$ & $1,800 \mathrm{~m}$ \\
\hline Dip & $\mathbf{F}$ & $82^{\circ}$ \\
\hline Thickness & $\mathbf{F}$ & $72,342 \mathrm{~m}$ \\
\hline Susceptibility & $\mathbf{F}$ & $0.0127 \mathrm{emu}$ \\
\hline Remnance ratio & $x$ & 0 \\
\hline Remnance incl & $\mathrm{x}$ & $0^{\circ}$ \\
\hline Remnance decl & $x$ & $0^{\circ}$ \\
\hline Position & $F$ & $15,222.54 \mathrm{~m}$ \\
\hline Base level & $\mathrm{F}$ & $6,447.996 \mathrm{nT}$ \\
\hline Base slope & $\mathrm{F}$ & $0.0150515 \mathrm{nT} / \mathrm{m}$ \\
\hline$(F$, -fitted, $X, f i$ & & \\
\hline
\end{tabular}

GEOMAGNETIC FIELD

Field strength $35,000 \mathrm{nT}$

Inclination $40^{\circ}$

Declination $-11^{\circ}$

PLAN DIRECTIONS

Strike perp $0^{\circ}$

Line direction $0^{\circ}$

Sensor height $150 \mathrm{~m}$

(F,-fitted, $X$, fixed)

Figure 13. Profile of magnetic body on the southem end of line $B-B^{\prime}$. Line of profile is shown in figure 10 . 

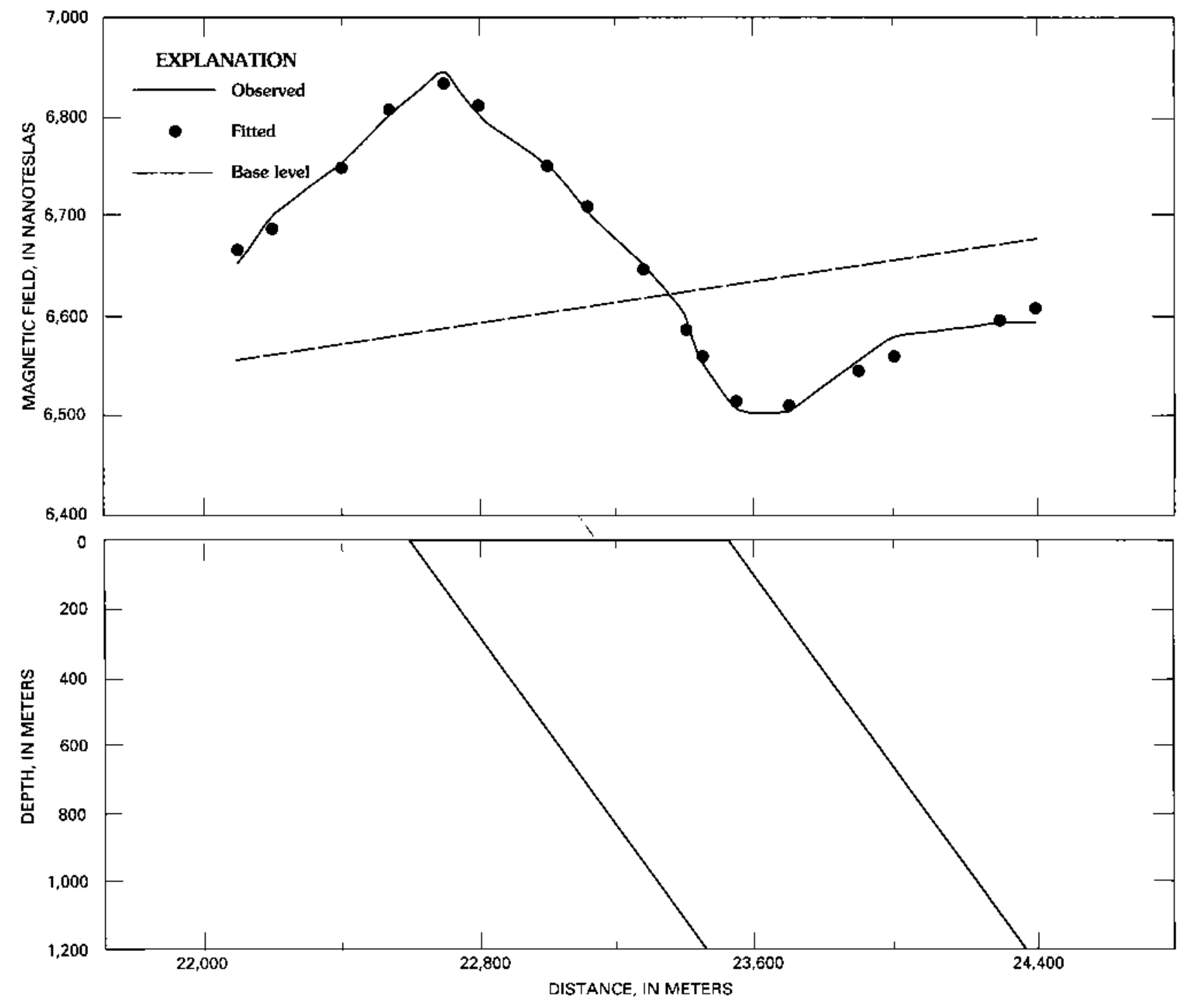

\begin{tabular}{|c|c|c|}
\hline \multicolumn{3}{|c|}{ MODEL PARAMETERS } \\
\hline Model type & & TABULAR \\
\hline Depth & L & $9.42 \mathrm{~m}$ \\
\hline Half width & $\mathbf{F}$ & $465 \mathrm{~m}$ \\
\hline Dip & $F$ & $55^{\circ}$ \\
\hline Susceptibility & $\mathbf{F}$ & $0.00400 \mathrm{emu}$ \\
\hline Remnance ratio & $x$ & 0 \\
\hline Remnance incl & $x$ & $0^{\mathrm{D}}$ \\
\hline Remnance decl & $x$ & $0^{\circ}$ \\
\hline Position & $F$ & $23,068.26 \mathrm{~m}$ \\
\hline Base level & $F$ & $6,406.858 \mathrm{nT}$ \\
\hline Base slope & $\mathbf{F}$ & $0.1016821 \mathrm{nT} / \mathrm{m}$ \\
\hline
\end{tabular}

GEOMAGNETIC FIELD

Field strength $\quad 35,000 \mathrm{nT}$

Inclination $\quad \mathbf{4} 0^{\circ}$

Declination $\quad-11^{\circ}$

PLAN DIRECTIONS

Strike perp $\quad 0^{\circ}$

Line direction $0^{\circ}$

Sensor height $150 \mathrm{~m}$

(F-fitted, X-fixed, L-limit)

Figure 14. Magnetic profite of a complex, multilevel anomaly area along line $A-A^{\prime}$ (left to right). Line of profile is shown in figure 10.

\section{MINERAL DEPOSITS}

Mining in the Sierra Verdún-Cerro Piedra del Supamo area has concentrated on saprolitic and placer alluvial gold deposits in the weathered horizon. Newly opened and abandoned prospect pits scattered in the area immediately south of the Río Yuruán in weathered saprolite overlying the greenstone-belt sequence may represent oxidized primary lode deposits. The greenstone belt may contain other types of mineral deposits common in Proterozoic greenstone belts elsewhere in the world.

A strong penetrative fabric was observed in the supracrustal rocks of the study area, and, although major ductile shear zones were not observed, they cannot be ruled out because of the general lack of outcrop. Several prominent lineaments observed in side-looking airborne radar 
images are interpreted as faults. Quartz-tourmaline veins and abundant quartz chips were observed as float immediately north of the Río Yuruán. The combination of quartz veins, panned free gold, active prospects, and shallowly buried intrusive rocks suggests that the area surrounding and immediately adjacent to the Río Yuruán, east of the Río Supamo-Río Yuruán confluence, is an excellent target for mineral exploration.

Mafic and ultramafic complexes associated with the greenstone belts may host minor deposits of chromite; they are sources of placer and lode platinum-group elements and are permissive for synorogenic-synvolcanic nickel-copper sulfide ore and nickel laterite. Several ultramafic samples in the Sierra Verdún-Cerro Piedra del Supamo area contain greater than accessory amounts of sulfide minerals, mainly pyrrhotite, as intercumulus grains. Altered shear zones that cut these bodies may be good targets for talc and serpentine.

\section{CONCLUSIONS}

Greenstone-belt rocks in the Sierra Verdún-Cerro Piedra del Supamo area of Estado Bolívar, Venezuela, correlate with other Early Proterozoic mafic rocks in the Guayana Shield and are age equivalent to the El Callao Formation. Mafic-ultramafic intrusive rocks in the area, by contrast, represent a younger regional magmatic event in the development of the Guayana Shield, an event slightly younger to contemporaneous with the granitic doming event. The intrusive rocks constitute a zoned, layered complex of cumulus dunite, wehrlite, olivine clinopyroxenite, and minor feldspathic pyroxenite enclosed in locally foliated gabbroic rocks. Low-lying volcanic rocks consist of intermixed basalt and basaltic andesite with minor tuff and tuff breccia. Granitic intrusive rocks are scattered throughout the greenstone belt.

A strong penetrative foliation in the greenstone-belt rocks of the study area is parallel with the regional contact with granitic domes. Although exposure in the jungle is poor, several prominent lineaments, schist-rich zones, and quartz-tourmaline vein float suggest buried shear zones.

Geochemical data indicate that mafic volcanic rocks in the study area are tholenitic basalt and basaltic andesite. The mafic-ultramafic intrusive rocks are not, however, related to the volcanic rocks.

Geophysical data suggest that shallow buried intrusive rocks are present in the study area. At least one magnetic anomaly near the Río Yuruán suggests an association between a magnetic polarizing body, quartz veins, and a gold prospect.

Economic concentrations of gold, platinum-group elements, nickel-copper sulfide, nickel laterite, serpentine, and talc may be present in the study area. The distribution and abundance of these commodities are speculative and merit more detailed study.

\section{REFERENCES CITED}

Benaim, Nesin, 1974, Geología de la región El Dorado-Anacoco-Botanamo, Estado Bolívar: Conferencia Geológica Inter-Guayanas, 9th, Ciudad Guayana, Venezuela, 1972, Memoria, Publicación Especial 6, p. 198-206.

Cordell, L.E., and McCafferty, A.E., 1989, Terracing operator for physical property mapping with potential field data: Geophysics, v. 54 , p. $621-634$.

Cox, D.P., Gray, Floyd, Acosta, Juan, Stewart, J.H., Arespón, Jesús, Brooks, W.E., Franco, Luis, Salazar, Edixon, and Lopez, Yolanda, 1993, Geologic map of the Guri and southern part of the Tucupita $2^{\circ} \times 3^{\circ}$ quadrangles, Bolívar State, Venezuela: U.S. Geological Survey Miscellaneous Field Studies Map MF-2242, scale 1:500,000.

Geosoft, Inc. 1988, MAGMOD3 magnetic data modeling software package: Suite 500, 204 Richmond Street West, Toronto, Canada.

Gibbs, A.K., 1987, Proterozoic volcanic rocks of the northern Guiana Shield, South America, in Pharoah, T.C., Beckinsale, R.D., and Rickard, D., eds., Geochemistry and mineralization of Proterozoic volcanic suites: Geological Society of London Special Publication 33, p. 275-288.

Gibbs, A.K., O'Day, P.A., and Renner, Rebecca, 1984, Recent work on the Barama-Mazaruni Supergroup of Guyana: Symposium Amazonico, 2nd, Manaus, Brazil, 1984, Anais, p. 39-52.

Gibbs, A.K., and Olszewski, W.J., Jr., 1982, Zircon U-Pb ages of Guyana greenstone-gneiss terrane: Precambrian Research, v. 17, p. 199-214.

Gray, Floyd, 1992, Report on reconnaissance look at the Las Cristinas deposit-Observations for a new deposit model: U.S. Geological Survey Administrative Report, 23 p.

Jensen, L.S., 1976, A new cation plot for classifying subalkalic volcanic rocks: Ontario Division of Mines Miscellaneous Paper 66, 22 p.

Le Bas, M.J., Le Maitre, R.W., Streckeisen, A.L., and Zanettin, Bruno, 1986, A chemical classification of volcanic rocks based on the total alkali-silica diagram: Journal of Petrology, v. 27, p 745-750.

Le Bas, M.J., Le Maitre, R.W., and Woolley, A.R., I992, The construction of the total alkali-silica chemical classification of volcanic rocks: Mineralogy and Petrology, v. 46, p. 1-22.

Le Bas, M.J., and Streckeisen, A.L., 1991, The IUGS systematics of igneous rocks: Journal of the Geological Society, London, v 148, p. 825-833.

Menendez V. de V., Alfredo, 1968, Revisión de la estratigrafía de la Provincia de Pastora según el estudio de la región de Guasipati, Guayana Venezolana: Boletín de Geología, Caracas, v. 10, no. 19 , p. 309-338.

1972, Geología de la región Guasipati, Guayana Venezolana: Congreso Geológico Venezolano, 4th, Caracas, 1971, Memoria, Publicación Especial 5, v. 4, p. 2001-2046.

Mullen, E.D., 1983, $\mathrm{MnO} / \mathrm{TiO}_{2} / \mathrm{P}_{2} \mathrm{O}_{5}-\mathrm{A}$ minor element discriminant for basaltic rocks of oceanic environments and its implications for petrogenesis: Earth and Planetary Science Letters, v. 62, p. 53-62. 
Onstott, T.C., Hall, C.M., and York, Derek, $1989,{ }^{40} \mathrm{Ar} /{ }^{39} \mathrm{Ar}$ thermochronometry of the Imataca Complex, Venezuela: Precambrian Research, v. 42, p. 255-291.

Reid, A.R., and Bisque, R.E., 1975, Stratigraphy of the diamond-bearing Roraima Group, Estado Bolívar, Venezucla: Colorado School of Mines Quarterly Bulletin, v. 70, no. 1, p. 61-82.

Sidder, G.B., Acosta, E., Brooks, W.E., Contreras, G., Day, W.C., Earhart, R.L., Estanga, Y., Franco, L., Garcia, A., Guerra, A., Ludington, S., Marcano, I., Marsh, S.P., Martinez, F., Nuñez, F., Page, N.J, Quintana, E., Rivero, I., Sanchez, H., and Wynn, J.C., 1988, Preliminary mineral resource evaluation of the Guayana Shield, Bolivar State, Venezuela: Geological Society of America, Abstracts with Programs, v. 20, no. 7, p. A277-A278.

Tosiani D., Tommaso, and Sifontes G., Ramón, 1989, Asociación de rocas máficas-ultramáficas en la región del Cerro Piedra del
Supamo, sur de El Callao: Congreso Geológico Venezolana, 7th, Barquisimeto, Venezuela, 1989, Memoria, v. 1, p. 163-174.

Vacquier, Victor, Steenland, N.C., and Henderson, R.G., 1951, Interpretation of aeromagnetic maps: Geological Society of America Memoir 47, $151 \mathrm{p}$.

Wynn, J.C., McCafferty, A.E., and Salazar, Edixon, 1989, Geologic information derived from digital aeromagnetic data: Simposium Sudamericano de COGEODATA, 5th, Caracas, Resumén de los Trabajos, p. 32-33.

Wynn, J.C., and Sidder, G.B., 1991, The mineral resource potential of the NB-20-4 quadrangle, Eastern Guayana Shield, Bolivar State, Venezuela: U.S. Geological Survey Bulletin 1960, 16 p. Yánez, Galo, 1985, Geología y geomofología del Grupo Roraima en el sureste de Venezuel: Congreso Geológico Venezolan, 6th, Caracas, Ministerio de Energía y Minas, v. 2, p. 1243-1306. 
Gold Prospecting in the Cerro Arrendajo Study Area, Estado Bolívar, Venezuela

By William E. Brooks, Acenk Guerra, and Fernando J. Nuñez

GEOLOGY AND MINERAL DEPOSITS OF THE VENEZUELAN GUAYANA SHIELD

U.S. GEOLOGICAL SURVEY BULLETIN 2124-G

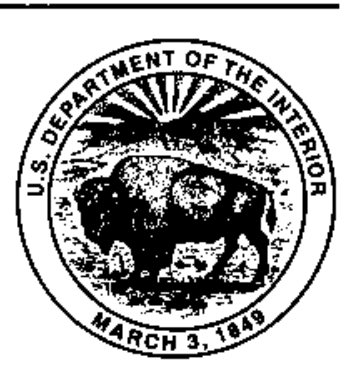

UNITED STATES GOVERNMENT PRINTING OFFICE, WASHINGTON : 1995 


\section{CONTENTS}

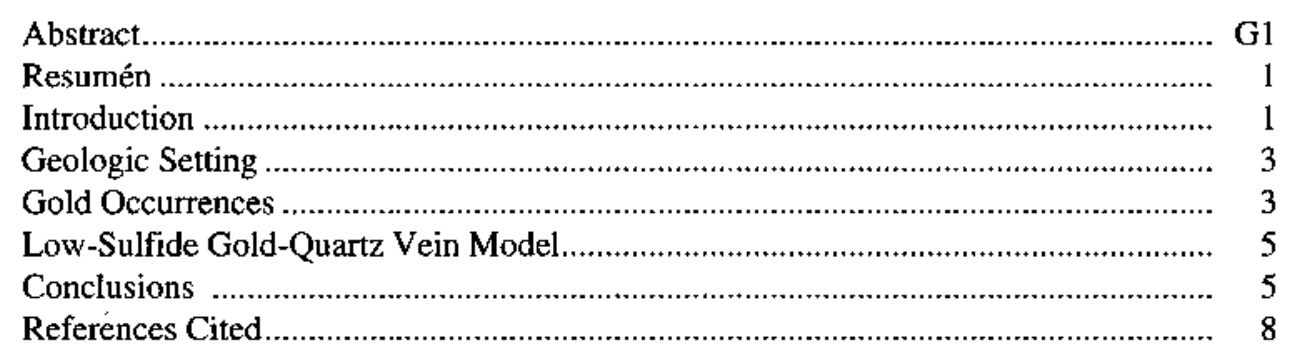

\section{FIGURES}

1. Map showing location of Cerro Arrendajo study area ........................................................................ G2

2. Geologic map of Cerro Arrendajo study area..............................................................................................

\section{TABLES}

1. Analytical results for rocks collected in the Cerro Arrendajo study area.

2. Analytical results for rocks collected in the Cепо Arrendajo study area. 


\title{
Gold Prospecting in the Cerro Arrendajo Study Area, Estado Bolívar, Venezuela
}

\author{
By William E. Brooks, ${ }^{1}$ Acenk Guerra, ${ }^{2}$ and Fernando J. Nuñez ${ }^{2}$
}

\begin{abstract}
The Cerro Arrendajo study area is in dense jungle in the eastern part of Estado Bolívar, Venezuela, approximately 75 $\mathrm{km}$ southwest of the mining town of El Dorado. Early Proterozoic greenstone of the study area comprises two lithologic terranes: mafic flows in the southern terrane and gabbro in the northern terrane. Small areas of granite crop out in both terranes. Quartz veins, with and without tourmaline, are present in rocks of the southem terrane. The grade of metamorphism of rocks in the study area is low, and the rocks are not sheared.

Gold prospecting is indicated in both terranes by the presence of numerous prospect pits and tailings. Visible gold is present only in the southern terrane, mainly in stream-sediment samples from a drainage downslope from a tourmaline-bearing quartz vein. The gold content of the mafic flows and the granite is as high as $9 \mathrm{ppb}$ and $16 \mathrm{ppb}$, respectively. A fine-grained silicic dike in the southern terrane contains $13 \mathrm{ppb}$ gold. Tourmaline-bearing quartz veins, and possibly granite, are the more promising exploration targets in the area.
\end{abstract}

\section{RESUMEN}

El área de estudio en el Cerro Arrendajo está localizada en selva densa en la parte oriental del Estado Bolívar, aproximadamente a $75 \mathrm{~km}$ al suroeste del pueblo minero de El Dorado. Las rocas verdes de edad Proterózoicó Tempranó del área comprenden dos terrenos litológicos: (1) flujos volcánicos máficos en la parte sur y (2) gabro en la parte norte. $\mathrm{La}$ rocas graníticas forman pequeños afloramientos en ambos terrenos. Vetas de cuarzo con o sin turmalina están presentes en rocas del terreno sur. El grado metamórfico de todas las rocas es bajo y no están cizalladas.

IU.S. Geological Survey, Denver Federal Center, MS905, Denver, Colorado 80225 .

${ }^{2}$ Corporactón Venezolana de Guayana, Técnica Minera, C.A., C.C. Chilemex, Piso 1, Puerto Ordaz, Venezuela.
La exploración aurífera en toda el área está indicada por la presencia de numerosos huecos de prospección y colas asociadas. El oro visible está presente solamente en el terreno sur, principalmente en muestras de sedimentos en una quebrada cuesta abajo de una veta de cuarzo con turmalina. El contenido de oro de los flujos máficos y del granito alcanza 9 ppb y $16 \mathrm{ppb}$ respectivamente. Un dique siliceo de grano fino en el terreno sur contiene $13 \mathrm{ppb}$ de oro. Las vetas de cuarzo con turmalina y posiblemente el granito son áreas con potencial mineral.

\section{INTRODUCTION}

The Cerro Arrendajo study area is in Estado Bolívar, Venezuela, in dense jungle $75 \mathrm{~km}$ southwest of El Dorado (fig. 1). Abandoned huts in the study area indicate seasonal occupation by indigenous people. Access to the $10-\mathrm{km}^{2}$ study area is by helicopter and trails. Río Chicanán is the major named geographic feature in the study area.

The study area is underlain by Early Proterozoic greenstone of the Guayana Shield, which forms the northem part of the Amazon platform (Gibbs and Barron, 1983). Gabbro and granite comprise the northern part of the study area, and mafic flows, granite, and quartz veins comprise the southern part (fig. 2).

During previous reconnaissance of the Cerro Arrendajo study area, Guerra and others (1987) found numerous flooded prospect pits and tailings in both the northern and southern areas that indicated recent gold prospecting. A summary of work in the Cerro Arrendajo study area was included in an overview of three auriferous zones near El Dorado by Alberdi and Contreras (1988). During our work in 1988, visible gold was found in stream-sediment samples taken from drainages within the approximately $10-\mathrm{km}^{2}$ area that was traversed (fig. 2). Because topographic maps have not been published, sample sites and contacts were compiled on a drainage base made from aerial photographs; due to dense jungle cover, locations of faults and contacts are inferred. 


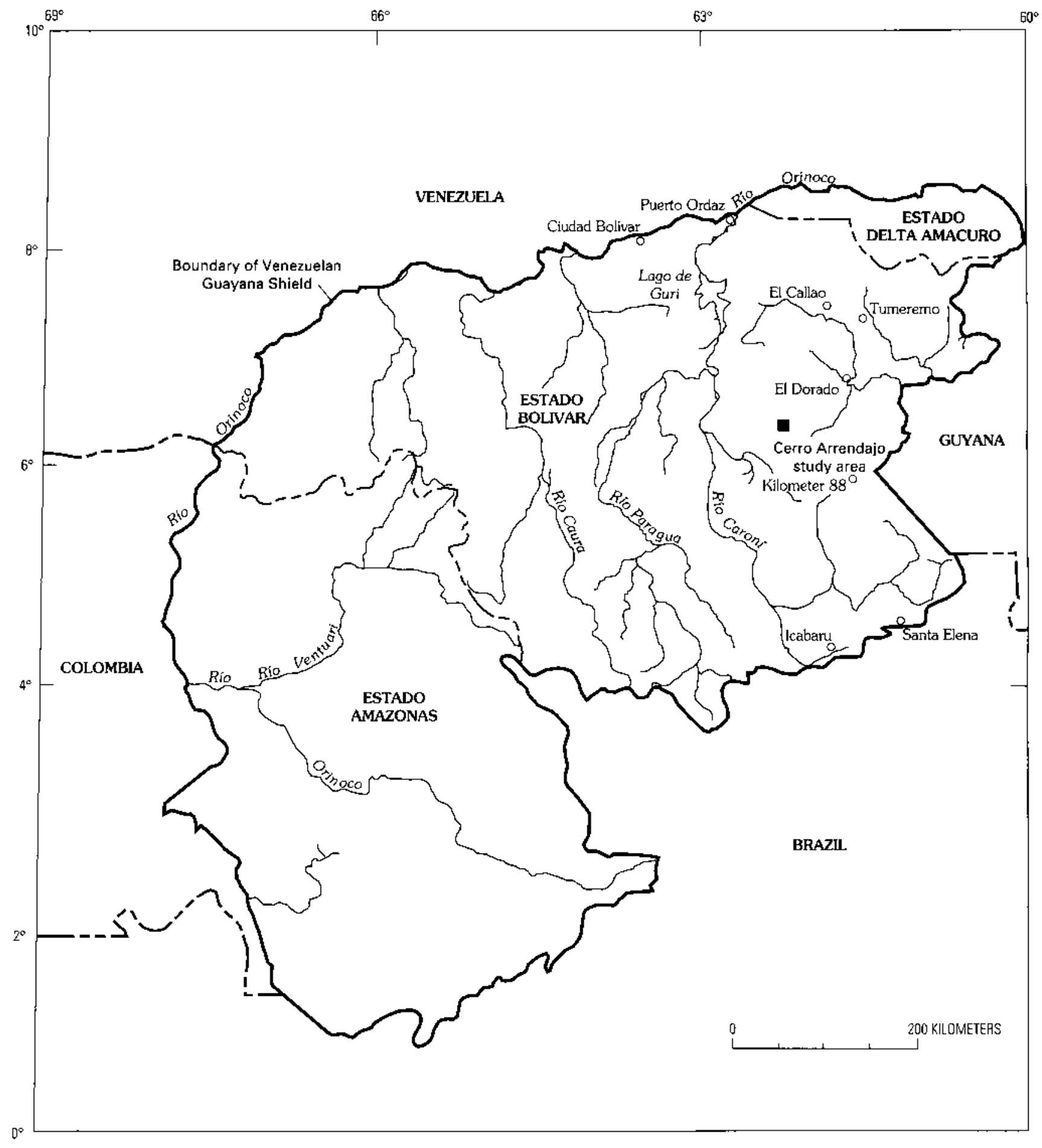

Figure 1. Location of Cerro Arrendajo study area, Estado Bolívar, Venezuela. 


\section{GEOLOGIC SETTING}

The Cerro Arrendajo study area is within an Early Proterozoic (2,250-2,100 Ma) greenstone terrane (Gibbs and Barron, 1983; Sidder and Mendoza, this volume) in the Venezuelan part of the Guayana Shield. It is approximately $150 \mathrm{~km}$ south of the El Callao and Lo Increíble mining districts. Gold ore at El Callao and Lo Increible is associated with metamorphosed Early Proterozoic basaltic to andesitic lavas of the El Callao Formation that host quartz veins containing tourmaline, native gold, pyrite, and calcite (Pasquali and Bisque, 1975; Vasquez, 1988; Day and others, this volume). The El Callao Formation has been regionally metamorphosed to greenschist facies, and the gold mines and prospects are spatially associated with quartz veins within shear zones (Day and others, this volume).

Greenstone of the study area comprises two lithologic terranes (fig. 2). The northem terrane, which is rarely exposed and is deeply weathered, is composed of greenish-gray, fine-grained gabbro. Quartz veinlets and mafic dikes a few centimeters thick cut the gabbro. The southern terrane is composed of weakly metamorphosed, foliated to nonfoliated, greenish-gray, mafic volcanic rocks. Lava flows are common, and subordinate flow breccias and pillow lavas are present in small areas in the headwaters of Quebrada Paranpin and in an unnamed stream approximately $1 \mathrm{~km}$ northeast of the heliport (fig. 2). Rocks of the southern terrane range from basalt to andesite in composition (47-56 weight percent $\mathrm{SiO}_{2}$ ).

The gabbro of the northern terrane and the mafic flows of the southern terrane contain small areas of biotite granodiorite to granite containing 69-77 weight percent $\mathrm{SiO}_{2}$ (table 1). These greenish-gray intrusive rocks are weakly metamorphosed and contain clots and phenocrysts of albitized feldspar. Several milky quartz veins and a tourmaline-bearing quartz vein in the southern terrane cut the mafic units.

In the southern terrane, an inclusion of mafic rock (approximately $1 \mathrm{~m}$ by $0.5 \mathrm{~m}$ ) in the southernmost granite outcrop (unit Xg, fig. 2) is interpreted to be a clast of the adjacent mafic country rock. This relation indicates that intrusion of the granite occurred after emplacement of the mafic flows. This outcrop was under a meter of water in a pool, and within the limited exposure in the stream juxtaposition of the rocks due to shearing was not apparent.

A northeast-striking inferred fault was mapped in the north-central part of the study area in Quebrada Arendajo.
Despite the intense weathering and thick jungle cover that obscure most geologic relations, inference of the fault is allowed based on the following field observations: outcrops of mafic flows are present in the streams east of the fault and are absent to the west; topography changes abruptly with hills to the east absent to the west; and mafic flows and quartz veins along the inferred fault are brecciated.

The contact between the gabbro (unit $\mathrm{Xgb}$ ) and the mafic flows (unit $\mathrm{Xm}$ ) is inferred to be along a drainage divide between Quebradas Paranpin and Arrendajo (fig. 2). The nature of the contact is unknown.

Numerous quartz veins, having apparently random orientation, cut the rocks of the southem terrane. The veins are commonly a few centimeters thick, but may be as much as a meter thick; they are milky white, unbrecciated, and unsheared. Neither calcite nor sulfide minerals were identified in the veins. One tourmaline-bearing quartz vein was mapped in the central part of the southem terrane. Stream-sediment samples taken downslope from the tourmaline-bearing quartz vein contained as many as 15 flakes of gold (sample CH402S, fig. 2).

Both rock and stream-sediment samples were taken in the study area. Rock samples were sent to U.S. Geological Survey laboratories in Denver for analytical work. Stream-sediment samples were panned in the field, the number of flakes of gold per sample was recorded, and the panned concentrates were retained by Corporación Venezolana de Guayana, Técnica Minera, C.A. Stream-sediment samples were taken at every stream crossing; however, only six contained flakes of gold. Locations of analyzed rock samples and the stream-sediment samples containing gold are shown in figure 2 .

\section{GOLD OCCURRENCES}

The northem and southem parts of the Cerro Arendajo study area differ in geology and gold potential. Alluvial gold was reported by Guerra and others (1987) in six stream-sediment concentrates from the study area; however, the number of flakes of gold per sample was not recorded. During this study, gold was not found in panned concentrates from the northern terrane. Physical evidence of alluvial prospecting was found downstream from a granite outcrop. Gold content of the granite is 1 and $14 \mathrm{ppb}$ (samples CH405R, CH404R, respectively; table 1). 


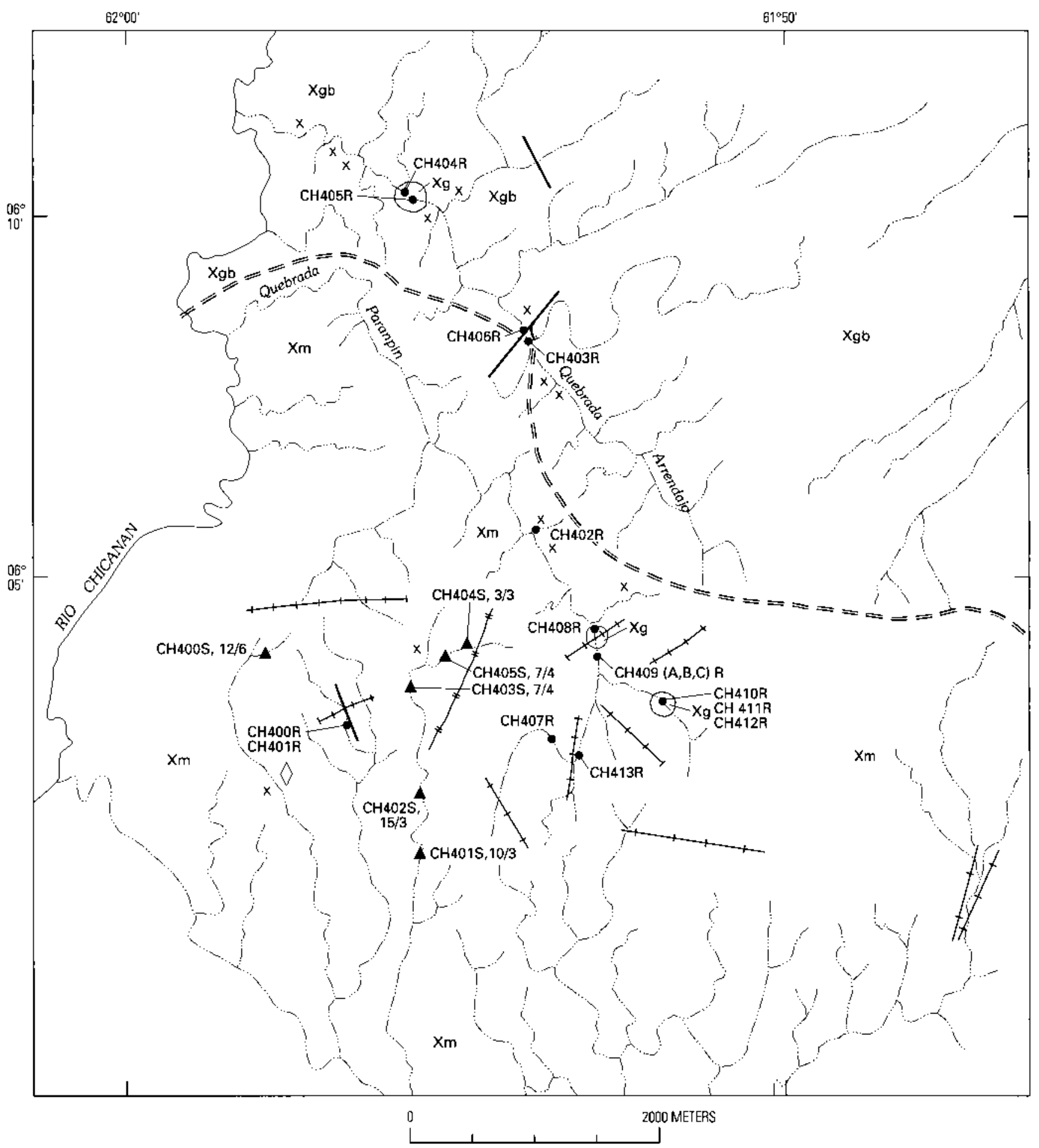

Figure 2. Geology of the Cerro Arrendajo study area, Estado Bolívar, Venezuela. Latitude and longitude are approximate. Drainage base by A. Guerra, taken from aerial photographs; misión 0501109 , fotos 1.105-1.108, escala 1:50,000, Proyecto Inventario, Recursos Naturales, Gerencia General, Desarrollo Regional, Corporación Venezolana de Guayana. 


\section{EXPLANATION}

\begin{tabular}{|c|c|}
\hline $\mathrm{Xg}$ & $\begin{array}{l}\text { Granite (Early Proterozoic)-Weakly metamorphosed, } \\
\text { grayish-green to white. Clots and phenocrysts of } \\
\text { albitized feldspar as much as } 3 \text { mm, quartz, biotite, } \\
\text { chlorite, and sparse zircon }\end{array}$ \\
\hline $\mathrm{Xgb}$ & $\begin{array}{l}\text { Gabbro (Early Proterozoic)_Grayish-green, fine-grained, } \\
\text { weakly metamorphosed equigranular gabbro containing } \\
\text { albitized feldspar, amphibole, and opaque minerals. Cut by } \\
\text { millimetet-sized quartz veinlets. Poorly exposed }\end{array}$ \\
\hline$X_{m}$ & $\begin{array}{l}\text { Mafic flows (Early Proterozoic)_Greenish-gray, fire-grained, } \\
\text { basaltic to andesitic flows, breccia, and pillow lavas. } \\
\text { Weakly metamorphosed, coritains chlorite and epidote, } \\
\text { foliated to nonfoliated. Sparse pyrite }\end{array}$ \\
\hline & Contact-Approximately located \\
\hline & Fault-Approximately located \\
\hline & Quartz vein \\
\hline 4 & Tourmaline-bearing quartz veln \\
\hline & Mafic dike \\
\hline$x$ & Prospect \\
\hline & Sample locality \\
\hline $\begin{array}{c}\mathrm{CH} 402 \mathrm{R} \\
\bullet \\
\mathrm{CH} 4035,\end{array}$ & $\begin{array}{l}\text { Analyzed rock sample and field number-Analytical } \\
\text { results shown in table } 1\end{array}$ \\
\hline$\stackrel{7 / 4}{\Delta}$ & $\begin{array}{l}\text { Stream-sediment sample containing flakes of gold- } \\
\text { Sample number, flakes of gold per number of } \\
\text { pans are also shown }\end{array}$ \\
\hline 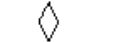 & Heliport (cleared for this study) \\
\hline
\end{tabular}

Alluvial gold is present in six stream-sediment samples only in the southern terrane (fig. 2). Flakes of gold were found primarily in stream-sediment samples taken downstream from tourmaline-bearing veins in the central part of the study area (fig. 2).

Flakes of gold were not found in stream-sediment samples taken near the granitic rocks; however, chemical analyses indicate that the gold content of the granite is $\sim 1$ and 16 $\mathrm{ppb}$ (samples $\mathrm{CH} 405 \mathrm{R}$ and $\mathrm{CH} 422 \mathrm{R}$, respectively, table 1). A fine-grained silicic dike contains $13 \mathrm{ppb}$ gold (sample CH408, table 2). Gold content of the mafic flows is low; however, the sample having the highest gold content $(9 \mathrm{ppb}$, sample CH409BR; table 1) was taken near the silicic dike that contains 13 ppb gold.

\section{LOW-SULFIDE GOLD-QUARTZ VEIN MODEL}

The presence of quartz veins in this greenstone terrane suggests that the low-sulfide gold-quartz vein deposit model (Berger, 1986) could serve as an exploration guide at Cerro Arrendajo, especially if the model is expanded to include the presence of tourmaline-bearing quartz veins. Low-sulfide gold-bearing quartz veins are present in greenstone belts as massive veins in regionally metamorphosed volcanic rocks and volcanic-derived sedimentary rocks. Quartz veins mapped from float on hill slopes and gold recovered from the quebradas (ravines) indicate that deposits of this model type are permissive in the study area; however, volcanic-derived sedimentary rocks were not found in the study area nor are sulfide minerals present in the quartz veins. The identification of tourmaline-bearing quartz veins, even though not strictly included in the model, is important in the origin of gold in the study area. Therefore, the presence of quartz veins, even without sulfide minerals, and gold in streams downslope from tourmaline-bearing quartz veins indicates low potential for low-sulfide gold-quartz veins in the study area.

\section{CONCLUSIONS}

Similarities between the Cerro Arrendajo study area and the El Callao mining district of Estado Bolívar, Venezuela, include possibly correlative mafic flows cut by quartz veins. In the Cerro Arrendajo study area, however, the degree of metarnorphism is less and the rocks are not sheared, two important factors in the genesis of gold at El Callao.

Tourmaline-bearing quartz veins may be the primary source of gold in the Cerro Arrendajo study area based on the quantity of flakes of gold collected downstream from these types of veins. The gold content of the granite and granitic dikes ( $1-16 \mathrm{ppb})$ indicates a possible secondary source of gold because gold was not found downstream from the granite outcrops. Reconnaissance mapping would be useful in finding more tourmaline-bearing quartz veins, granite outcrops, and, perhaps, shear zones. The low-sulfide gold-quartz vein model, if expanded to include the tourmaline-bearing quartz veins, is an important part of exploration strategy at Cerro Arendajo. 
Table 1. Analytical results for rocks collected in the Cerro Arrendajo study area, Estado Bolivar, Venezuela.

[Location of samples shown by field number in figure 2; rock units described in figure 2. Major element oxides (weight percent, uncorrected) were determined by X-ray spectroscopy; analysts; J.

Taggart, A. Bartel, and D. Siems; $\mathrm{FeTO}_{3}$ indicates total iron reported as $\mathrm{Fe}_{2} \mathrm{O}_{3}$. Trace elements (in parts per million) determined by an energy-dispersive analyzer $\mathrm{Cd}{ }^{109}$ source for $\mathrm{Rb}$, $\mathrm{Sr}$, $\mathrm{Y}$, $\mathrm{Zr}$, and $\mathrm{Nb}$ and an $\mathrm{Am}^{95}$ source for $\mathrm{Ba}$; analyst: E. Rivera; N, not detected at value listed; L, limit of determination. Spectrogtaphic analyses are reported in parts per million unless noted; analyst $\mathrm{R}$. Hopkins. Lower limit of detection is given in parentheses after element symbol; N, not detected at lower limit of determination shown; L, detected but below lower limit of determination shown. Atomic absorption analyses are reported in parts per million; analyst J. McHugh]

\begin{tabular}{|c|c|c|c|c|c|c|c|c|c|c|c|c|}
\hline \multirow[b]{2}{*}{$\begin{array}{l}\text { Lab No. } \\
\text { Field No. }\end{array}$} & \multicolumn{8}{|c|}{ Mafic flows (unit $\mathrm{Xm}$ ) } & \multicolumn{4}{|c|}{ Granite funit $X g$ ) } \\
\hline & $\begin{array}{c}\mathrm{D}-316942 \\
\mathrm{CH} 400 \mathrm{R}\end{array}$ & $\begin{array}{c}\text { D-316943 } \\
\text { CH402R }\end{array}$ & $\begin{array}{c}\text { D-316944 } \\
\text { CH403R }\end{array}$ & $\begin{array}{c}\mathrm{D}-316947 \\
\mathrm{CH} 406 \mathrm{R}\end{array}$ & $\begin{array}{c}\text { D-316948 } \\
\text { CH407R }\end{array}$ & $\begin{array}{l}\text { D-316951 } \\
\text { CH409BR }\end{array}$ & $\begin{array}{l}\text { D-316952 } \\
\text { CH409CR }\end{array}$ & $\begin{array}{c}D-316955 \\
C H 413 R\end{array}$ & $\begin{array}{c}\mathrm{D}-3 \mathrm{~J} 6945 \\
\mathrm{CH} 404 \mathrm{R}\end{array}$ & $\begin{array}{c}\text { D-316946 } \\
\text { CH405R }\end{array}$ & $\begin{array}{c}\text { D-316954 } \\
\text { CH411R }\end{array}$ & $\begin{array}{c}\text { D-316956 } \\
\text { CH412R }\end{array}$ \\
\hline \multicolumn{13}{|c|}{ Major elements } \\
\hline$\overline{\mathrm{SiO}_{2}}$ & 50.8 & 49.2 & 51.3 & 56.5 & 47.2 & 50.8 & 46.6 & 50.8 & 74.1 & 77.1 & 69.2 & 75.2 \\
\hline $\mathrm{AJ}_{2} \mathrm{O}_{3}$ & 13.6 & 14.8 & 14.4 & 15.1 & 14.9 & 14.3 & 16.3 & 13.4 & 13.2 & 12.2 & 15.2 & 12.8 \\
\hline $\mathrm{FeTO}_{3}$ & 16.7 & 11.3 & 12.4 & 10.0 & 12.9 & 11.1 & 11.7 & 12.1 & 1.97 & 1.67 & 2.69 & 1.21 \\
\hline $\mathrm{MgO}$ & 6.30 & 8.59 & 7.19 & 4.72 & 8.92 & 7.90 & 8.10 & 9.38 & 0.34 & 0.41 & 1.54 & 0.19 \\
\hline $\mathrm{CaO}$ & 7.43 & 13.9 & 9.99 & 6.37 & 11.5 & 12.4 & 12.8 & 10.2 & 1.45 & 1.79 & 2.42 & 0.73 \\
\hline $\mathrm{Na}_{2} \mathrm{O}$ & 2.46 & 1.29 & 1.85 & 2.29 & 1.22 & 2.19 & 1.17 & 2.06 & 2.87 & 3.39 & 4.81 & 2.82 \\
\hline $\mathrm{K}_{2} \mathrm{O}$ & 0.15 & 0.1 & 0.52 & 0.64 & 0.03 & 0.11 & 0.09 & 0.04 & 4.19 & 2.08 & 1.83 & 4.74 \\
\hline $\mathrm{TiO}_{2}$ & 1.34 & 0.63 & 0.92 & 0.78 & 0.67 & 0.63 & 0.55 & 0.69 & 0.18 & 0.10 & 0.32 & 0.11 \\
\hline $\mathrm{P}_{2} \mathrm{O}_{5}$ & 0.12 & 0.05 & 0.1 & 0.08 & $<0.05$ & 0.05 & $<0.05$ & 0.06 & $<0.05$ & $<0.05$ & 0.14 & $<0.05$ \\
\hline $\mathrm{MnO}$ & 0.25 & 0.18 & 0.20 & 0.14 & 0.22 & 0.19 & 0.17 & 0.22 & $<0.02$ & 0.03 & 0.04 & $<0.02$ \\
\hline LOI $900^{\circ} \mathrm{C}$ & 1.41 & 0.77 & 1.75 & 3.30 & 2.54 & 0.73 & 2.30 & 1.30 & 0.85 & 0.61 & 1.37 & 0.99 \\
\hline Total & 100.56 & 100.81 & 100.62 & 99.92 & 100.10 & 100.40 & 99.78 & 100.25 & 99.15 & 99.38 & 99.56 & 98.79 \\
\hline \multicolumn{13}{|c|}{ Trace elements } \\
\hline$\overline{\mathrm{Rb}}$ & 14 & 9 & 30 & 17 & $8 \mathrm{~L}$ & 12 & $8 \mathrm{~L}$ & $8 \mathrm{~L}$ & 108 & 71 & 56 & 119 \\
\hline $\mathrm{Sr}$ & 178 & 113 & 148 & 161 & 197 & 119 & 114 & 85 & 135 & 142 & 561 & 55 \\
\hline $\mathbf{Y}$ & 24 & 18 & 22 & 19 & 16 & 14 & 18 & 18 & 19 & 23 & 9 & 23 \\
\hline $\mathrm{Zr}$ & 76 & 31 & 89 & 204 & 39 & 39 & 37 & 38 & 143 & 103 & I 21 & 175 \\
\hline $\mathrm{Nb}$ & 7 & $6 \mathrm{~L}$ & 7 & 10 & $6 \mathrm{~L}$ & $6 \mathrm{~L}$ & $6 \mathrm{~L}$ & $6 \mathrm{~L}$ & 9 & 8 & 7 & 9 \\
\hline$\underline{\mathrm{Ba}}$ & $12 \mathrm{~L}$ & $12 \mathrm{~L}$ & 202 & 300 & 24 & 36 & 14 & 21 & 939 & 1,116 & 20,22 & 582 \\
\hline \multicolumn{13}{|c|}{ Spectrographic analyses } \\
\hline 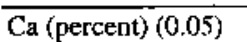 & 3 & 7 & 7 & 3 & 10 & $\overline{10}$ & 10 & 10 & 0.7 & 0.7 & 0.7 & 0.3 \\
\hline $\mathrm{Fe}$ (percent) $(0.05)$ & 7 & 7 & 7 & 5 & 10 & 7 & 5 & 7 & 2 & 2 & 3 & 1.5 \\
\hline $\mathrm{Mg}$ (percent)(0.02) & 3 & 3 & 3 & 1.5 & 3 & 3 & 3 & 7 & 0.5 & 0.5 & 1.5 & 0.3 \\
\hline $\mathrm{Na}$ (percent) $(0.2)$ & 1.5 & 1 & 1.5 & 2 & 1.5 & 1.5 & 1.5 & 2 & 2 & 2 & 2 & 2 \\
\hline $\mathrm{P}$ (percent) $(0.2)$ & N0.2 & No.2 & N0.2 & N0.2 & No.2 & No.2 & N0.2 & No.2 & No.2 & N0.2 & $<0.2$ & No.2 \\
\hline $\mathrm{Ti}$ (percent) $(0.002)$ & 0.3 & 0.3 & 0.5 & 0.3 & 0.3 & 0.3 & 0.15 & 0.3 & 0.1 & 0.07 & 0.2 & 0.1 \\
\hline $\mathrm{Ag}(0.5)$ & N0.5 & No.5 & $\mathrm{N} 0.5$ & N0.5 & N0.5 & No.5 & No.5 & No.5 & N0.5 & No.5 & N0.5 & N0.5 \\
\hline As $(200)$ & $\mathrm{N} 200$ & $\mathrm{~N} 200$ & $\mathrm{~N} 200$ & $\mathrm{~N} 200$ & $\mathrm{~N} 200$ & $\mathrm{~N} 200$ & $\mathrm{~N} 200$ & $\mathrm{~N} 200$ & $\mathrm{~N} 200$ & $\mathrm{~N} 200$ & $\mathrm{~N} 200$ & $\mathrm{~N} 200$ \\
\hline$A u(10)$ & N10 & $\mathrm{N} 10$ & N10 & N10 & N10 & N10 & N10 & N10 & N10 & N10 & N10 & N10 \\
\hline$B(10)$ & N10 & N10 & N10 & N10 & N10 & N10 & 10 & N10 & 10 & 10 & 10 & 10 \\
\hline $\mathrm{Ba}(20)$ & 30 & $\mathrm{~N} 20$ & 300 & 500 & 20 & 30 & 20 & 30 & 1,500 & 1,000 & 3,000 & 1,000 \\
\hline $\mathrm{Be}(1)$ & Nl & N1 & N1 & $<1$ & N1 & N] & N] & $\mathrm{N} 1$ & 2 & 2 & 1.5 & 1.5 \\
\hline Bi (10) & N10 & N10 & N10 & N10 & N10 & N10 & N10 & N10 & N10 & N10 & N10 & N10 \\
\hline $\mathrm{Cd}(20)$ & N20 & N2O & $\mathrm{N} 20$ & $\mathrm{~N} 20$ & $\mathrm{~N} 20$ & $\mathrm{~N} 20$ & $\mathrm{~N} 20$ & $\mathrm{~N} 20$ & N20 & $\mathrm{N} 20$ & $\mathrm{~N} 20$ & $\mathrm{~N} 20$ \\
\hline $\mathrm{Co}(10)$ & 50 & 70 & 50 & 30 & 100 & 70 & 30 & 70 & 10 & 10 & 20 & 10 \\
\hline
\end{tabular}




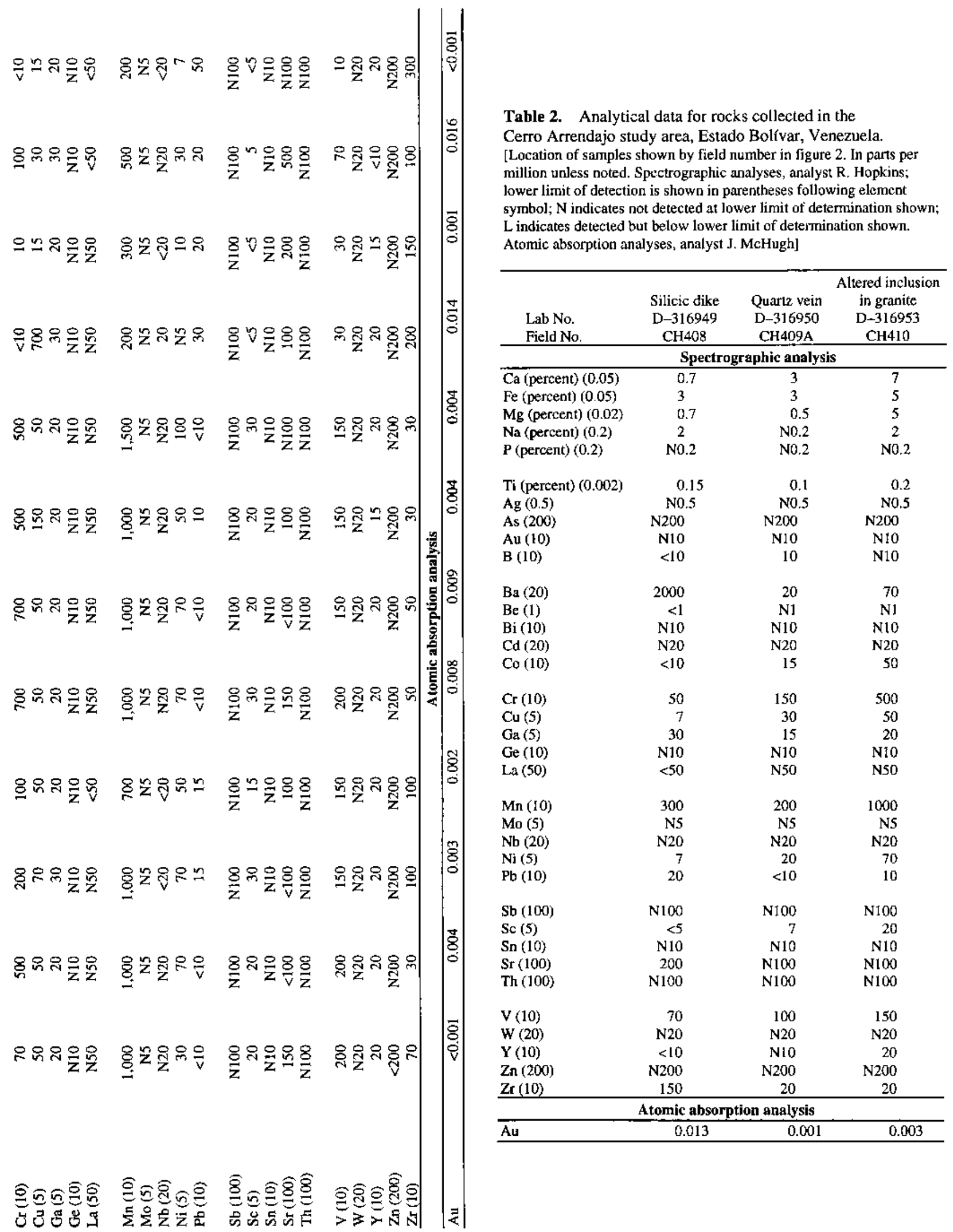




\section{REFERENCES CITED}

Alberdi, M., and Contreras, G., 1988, Tres prospectos auríferos en las cabeceras del Río Chicanán: El Pitón de Uroy, El Certo Arrendajo y El Hacha: Primer Símposio Internacional del Oro en Venezuela, Caracas, p. 336-352.

Berger, B.B., 1986, Descriptive model of low-sulfide Au-quartz veins (model 36a), in Cox, D.P., and Singer, D.A., eds., Mineral deposit models: U.S. Geological Survey Bulletin 1693, p. 239.

Gibbs, A.K., and Barron, C.N., 1983, The Guiana Shield reviewed: Episodes, v. 1983, no. 2, p. 7-14.
Guerra, Acenk, Franco, Luis, and Alberdi, Margarita, 1987, Trabajo de campo geológico-geoquímico en el area del Cerro Arrendajo: Corporación Venezolana de Guayana, Técnica Minera, C.A., Prospecciones Geológicas, Proyecto Canaima, Informe, $5 \mathrm{p}$.

Pasquali Z., Jean, and Bisque, R.E, 1975, Interpretation of soil geochemical expression of mineralization within EI Callao gold mining district, Venezuela: Quarterly of the Colorado School of Mines, v. 70, no. 1, p. 83-107.

Vasquez, J.C., 1988, E] Ministerio de Energía y Minas y la exploración aurífera: Primer Simposio Internacional del Oro en Venezuela, Caracas, p. 300-324. 
Gold Resources of the Río Chivao Study Area, Estado Bolívar, Venezuela

By William E. Brooks, Acenk Guerra, and Fernando J. Nuñez

GEOLOGY AND MINERAL DEPOSITS OF THE VENEZUELAN GUAYANA SHIELD

U.S. GEOLOGICAL SURVEY BULLETIN 2124-H

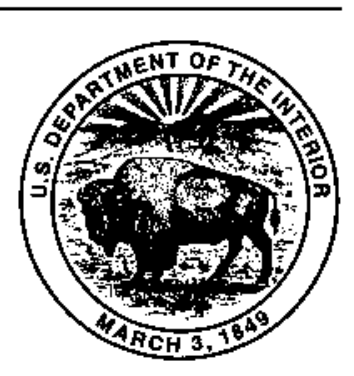

UNITED STATES GOVERNMENT PRINTING OFFICE, WASHINGTON : 1995 


\section{CONTENTS}

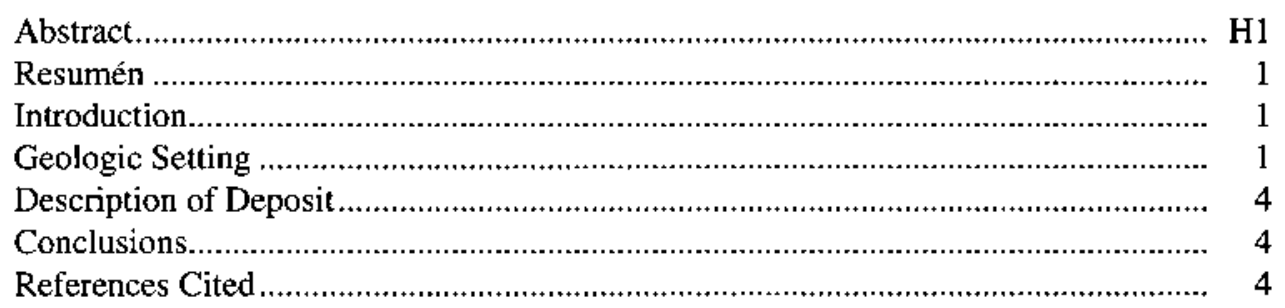

\section{FIGURES}

1. Map showing location of Río Chivao study area …................................................................................... H2

2. Outcrop and sample location map of Río Chivao study area ............................................................................

\section{TABLE}

1. Gold content of samples collected in the Río Chivao study area..... 


\title{
Gold Resources of the Río Chivao Study Area, Estado Bolívar, Venezuela
}

\author{
By William E. Brooks, ${ }^{1}$ Acenk Guerra, ${ }^{2}$ and Fernando J. Nuñez ${ }^{2}$
}

\begin{abstract}
The Río Chivao study area, about $20 \mathrm{~km}^{2}$, is in the eastem part of Estado Bolívar, Venezuela, in moderately dense jungle near the junction of Ríos Chicanán and Chivao. It is approximately $50 \mathrm{~km}$ southwest of the mining center of $\mathrm{El}$ Dorado.

In the Río Chivao study area, steeply dipping, highly altered quartz-mica schist that is cut by quartz veins is exposed in an irregularly shaped, 3-4- $\mathrm{km}^{2}$ open pit that consists of numerous individual excavations. These Early Proterozoic rocks contain as much as $34 \mathrm{ppm} \mathrm{Au}$, and visible gold was present in panned concentrates collected from drainages near the open pit. Other rock types in the area include pegmatite, indicated by sparse float, and mafic volcanic rocks.

Gold is mined by spraying the walls of the open pit with a strong stream of water, and the resulting slurry is pumped to a shaker table for recovery of the gold. Miners also pan gold directly from the mud using wooden gold pans.
\end{abstract}

\section{RESUMEN}

El área de estudio en el río Chivao es de $20 \mathrm{~km}^{2}$, está localizada en la parte oriental del Estado Bolívar cerca de la confluencia de los níos Chicanán y Chivao y está moderadamente cubierta por selva densa. El área está aproximadamente a $50 \mathrm{~km}$ al sur del centro minero de El Dorado.

En el área de estudio están expuestos esquistos cuarzo micaceos cortados por vetas de cuarzo en una excavación minera que consiste de numerosos buecos de prospección individuales en un área de 3 a $4 \mathrm{~km}^{2}$. Estas rocas de edad Proterozoico Temprano contienen hasta $34 \mathrm{ppm}$ de oro. Oro visible está presente en concentrados de batea colectados en

'U.S. Geological Survey, Denver Federal Center, MS905, Denver, Colorado 80225

${ }^{2}$ Corporación Venezolana de Guayana, Técrica Minera, C.A., C.C. Chilemex, Piso 1, Puerto Ordaz, Venezuela. drenajes cerca de los huecos mineros. El área incluye otros tipos litológicos tales como rocas volcánicas máficas y pegmatita, las cual es están indicada por fragmentos aislados.

$\mathrm{El}$ oro es minado aplicando un fuerte chorro de agua a las paredes de los huecos, el agua remueve el material aurífero el cual a su vez es bombeado a un cajón de recuperación (sluice box). El oro tambien es recuperado directamente del sedimento con bateas de madera.

\section{INTRODUCTION}

The Río Chivao study area is in Estado Bolívar, Venezuela, approximately $50 \mathrm{~km}$ southwest of El Dorado (fig. 1). Access is by helicopter from El Dorado or Kilometer 88 or by motorboat. The study area was described by Gutierrez (1987), and his reconnaissance of the $20-\mathrm{km}^{2}$ study area indicates an active open-pit gold mine and gold in nearby drainages (fig. 2). Existing mining trails and new trails cut for this study were followed in order to collect rock and stream-sediment samples from the open pit and adjacent areas.

\section{GEOLOGIC SETTING}

The Río Chivao study area is in a part of the Guayana Shield that contains undifferentiated Early Proterozoic granitic and metamorphic rocks (Gibbs and Barron, 1983). Rock types described in the study area by Gutierrez (1987) include schist of the Yuruari Formation, granite and pegmatite of the Supamo Complex, and unnamed mafic volcanic rocks.

During our traverses, quartz-mica schist (mainly in the open pit), pegmatite (float sample only), and mafic volcanic rocks were observed (fig. 2). The quartz-mica schist (unit $X s$ ) is steeply dipping, commonly weathered to clay, and usually red to yellow. This highly attered schist is gold bearing, has been flooded with quartz and minor sericite, and is cut by gold-bearing quartz veins. Millimeter-sized cubic vugs that may have hosted pyrite (?) are now filled with 


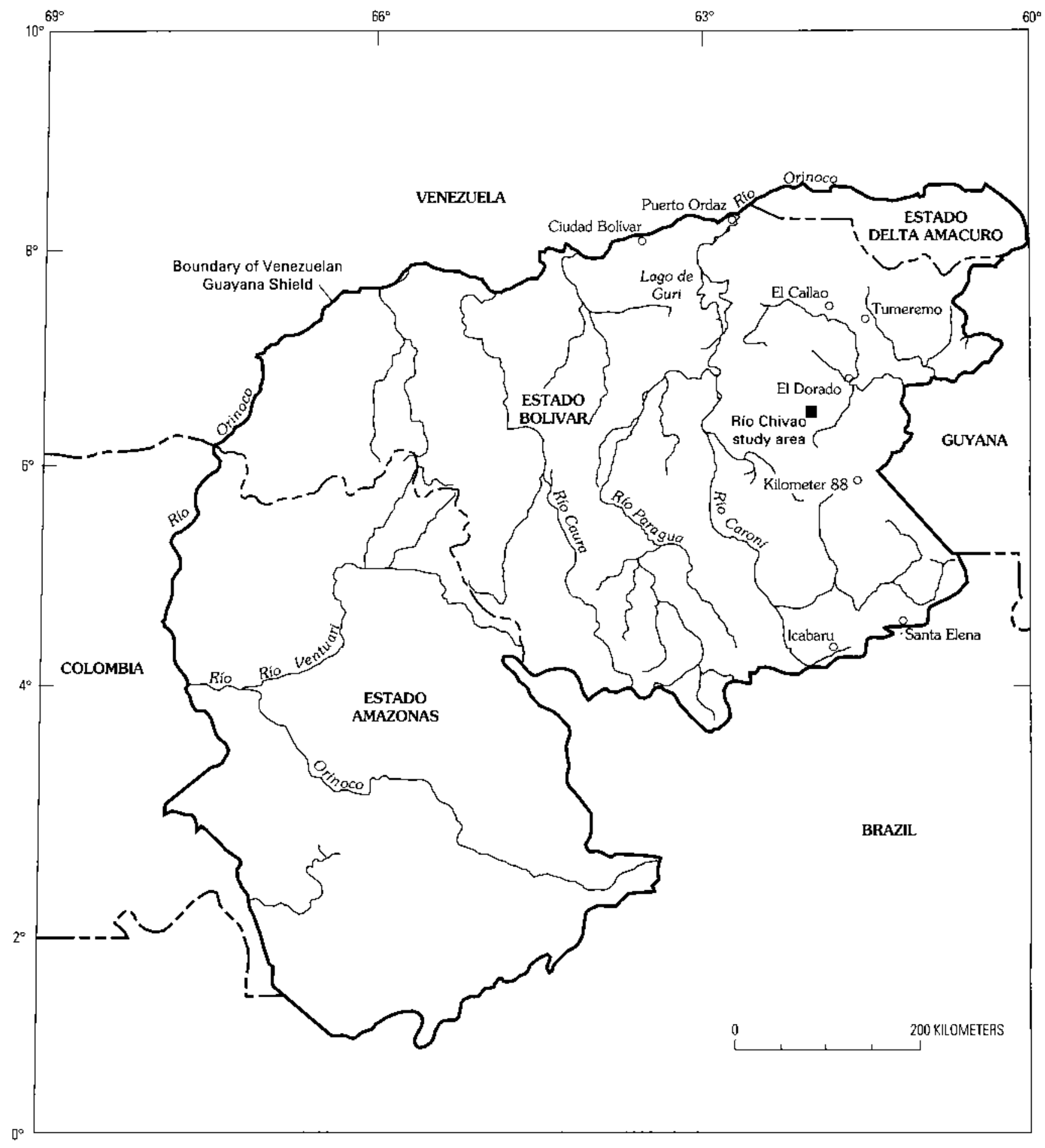

Figure 1. Map showing location of Río Chivao study area, Estado Bolívar, Venezuela. 


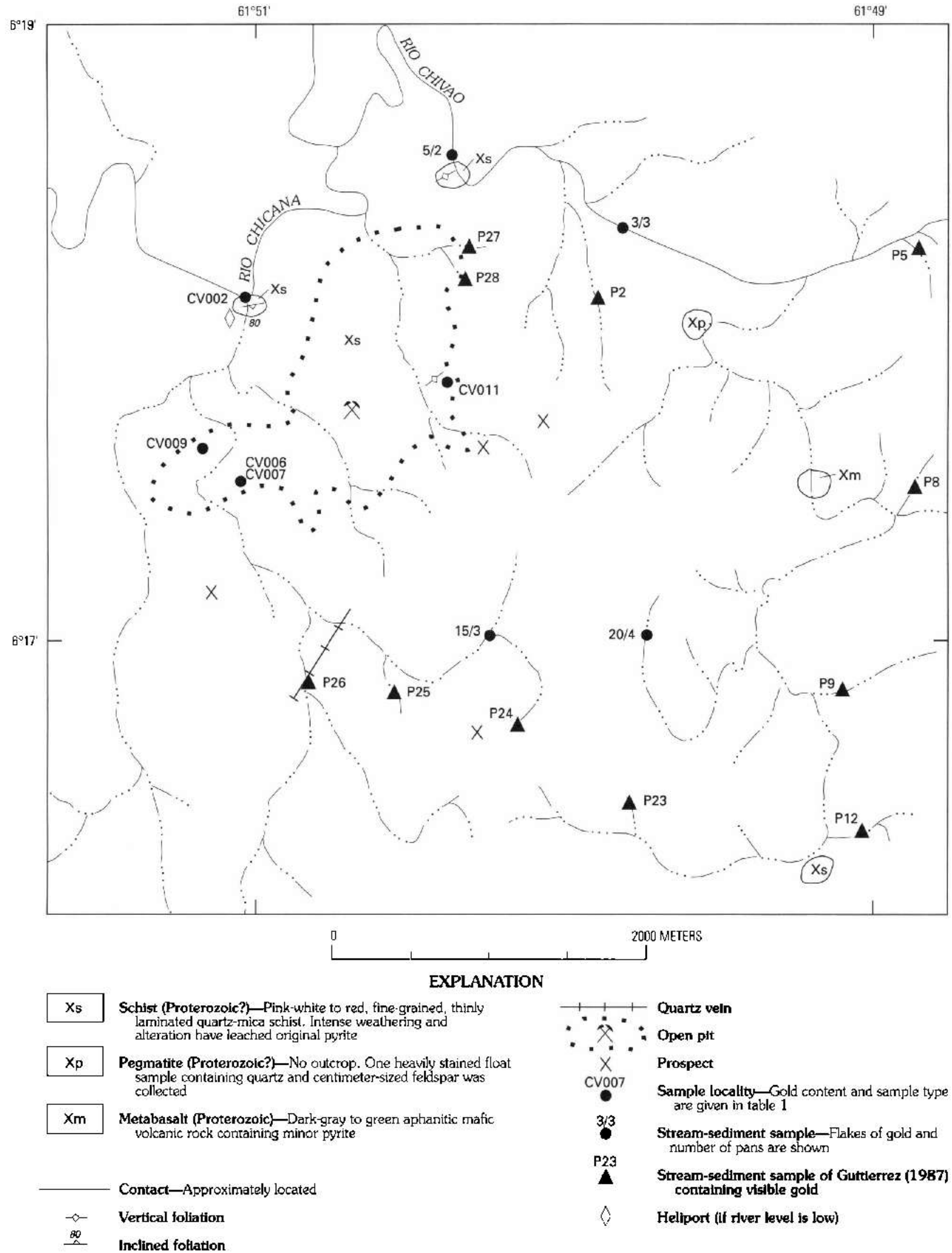

Figure 2. Outcrop and sample location map of the Río Chivao study area, Estado Bolívar, Venezuela. Drainage base from Catastro Minero Nacional, hoja 7834-IV-NE, escala 1:25,000. 
Table 1. Gold content of samples collected in the Río Chivao study area, Estado Bolívar, Venezucla.

[In parts per million. Locations shown by ficld number in figure 2 . Atomic absorption analysis by B. Roushey]

\begin{tabular}{lccc}
\hline Field No. & Lab No. & Gold & Sample description \\
\hline CV 002 & D316962 & 0.05 & Schist. \\
CV 006 & D316963 & 0.50 & Quartz vein. \\
CV 007 & D316964 & 2.70 & Schist. \\
CV 009 & D316965 & 0.80 & Schist. \\
CV 011 & D316966 & 34,0 & Quartz vein. \\
\hline
\end{tabular}

polycrystalline quartz. A piece of deeply weathered pegmatite float (unit Xp) $(8-10 \mathrm{~cm}$ long) containing a centimeter-size euhedral feldspar was found about $2 \mathrm{~km}$ east of the open pit. In the sands of Río Chivao, abundant muscovite ( $5 \mathrm{~mm}$ long), quartz, and feldspar grains indicate limited transport of detritus from a nearby coarse-grained silicic plutonic source, perhaps Supamo granite. During a river traverse, a small (about $25 \mathrm{~m}^{2}$ ) isolated outcrop of pyrite-bearing metabasalt (unit $\mathrm{Xm}$ ) was found approximately $2-3 \mathrm{~km}$ east of the active mine (fig. 2).

The nature and location of lithologic contacts in the study area are unknown because of the heavy jungle cover, sparse outcrops, and distance between outcrops, which may be as much as $2 \mathrm{~km}$. During this study, scintillometer readings taken during traverses were uniform and did not help to locate contacts or differences in radiation between rock units that might be used to infer a contact.

\section{DESCRIPTION OF DEPOSIT}

The center of mining activity is an irregularly shaped open pit, approximately $3-4 \mathrm{~km}^{2}$, that consists of numerous individual excavations (fig. 2). Discussions with the miners indicated that gold is present within the schist, along faults, and in the quartz veins. Gold values in the mine area are 0.8-2.7 ppm for schist and 0.5-34 ppm for quartz veins (table 1). The dark-gray to yellow quartz veins are called "piedra brava" (fierce or resistant rock) by the miners.

Individual excavations, some as deep as $15 \mathrm{~m}$, are dug, then the walls are sprayed with strong streams of water, and the sediments are pumped to a shaker table for recovery of the ore. Gold is panned directly from the mud washed down from the walls of the mine and from sediments derived from small outcrops of schist in Río Chicanán. A drop of mercury is usually added to the gold pan by the miners in order to amalgamate the gold. Gold-bearing sands and gravels in Río Chicanán and its tributaries in the study area result from eluvial decomposition of the underlying gold-bearing schist.

During traverses in the Río Chivao area, stream-sediment samples were washed and examined for visible gold. This method utilizes a conical wooden gold pan, called a batea, that is about $50 \mathrm{~cm}$ in diameter. Visible gold was found in panned concentrates taken at stream crossings north and south of the open pit (fig. 2). Gutierrez (1987) reported visible gold in several stream-sediment samples from drainages in the study area (fig. 2); however, the number of flakes of gold in each sample was not reported.

\section{CONCLUSIONS}

The regional geologic setting at Río Chivao, Estado Bolívar, Venezuela, is little known due to poorly exposed and sparse outcrops, distance between those outcrops, and the difficulty in detecting and defining contacts. For the Rio Chivao area, the high gold content of the quartz veins and schist in the mine and the presence of gold in stream-sediment samples outside of the mine area fits the descriptive model of low-sulfide gold-quartz veins (Berger, 1986). There is high potential for gold in the area of the mine but, too little is known of the geology outside the mine area to make a sound regional appraisal.

\section{REFERENCES CITED}

Berger, B.R., 1986, Descriptive model of low-sulfide Au-quartz veins (model 36a), in Cox, D.P., and Singer, D.A., eds., Mineral deposit models: U.S. Geological Survey Bulletin 1693, p. 239.

Gibbs, A.K., and Barron, C.N., 1983, The Guiana Shield reviewed: Episodes, v. 1983, no. 2, p. 7-14.

Gutiertez, José, 1987, Informe de avance sobre el trabajo de campo, efectuado en el Río Chivao desde el 29/10 al 05/11/87: Corporación Venezolana de Guayana, Técnica Minera, C.A., Informe, $5 \mathrm{p}$. 
Estratigrafía del Grupo Roraima Interpretación Petrológica en la Región Noreste del Parque Nacional Canaima, Estado Bolívar, Venezuela (Stratigraphy of the Roraima Group and Petrologic Interpretation in the Northeast Region of Canaima National Park, Estado Bolívar, Venezuela)

By Margarita Alberdi and Gloria Contreras

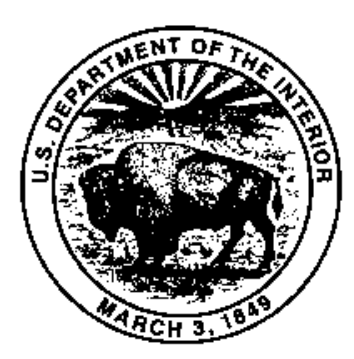




\section{CONTENIDOS}

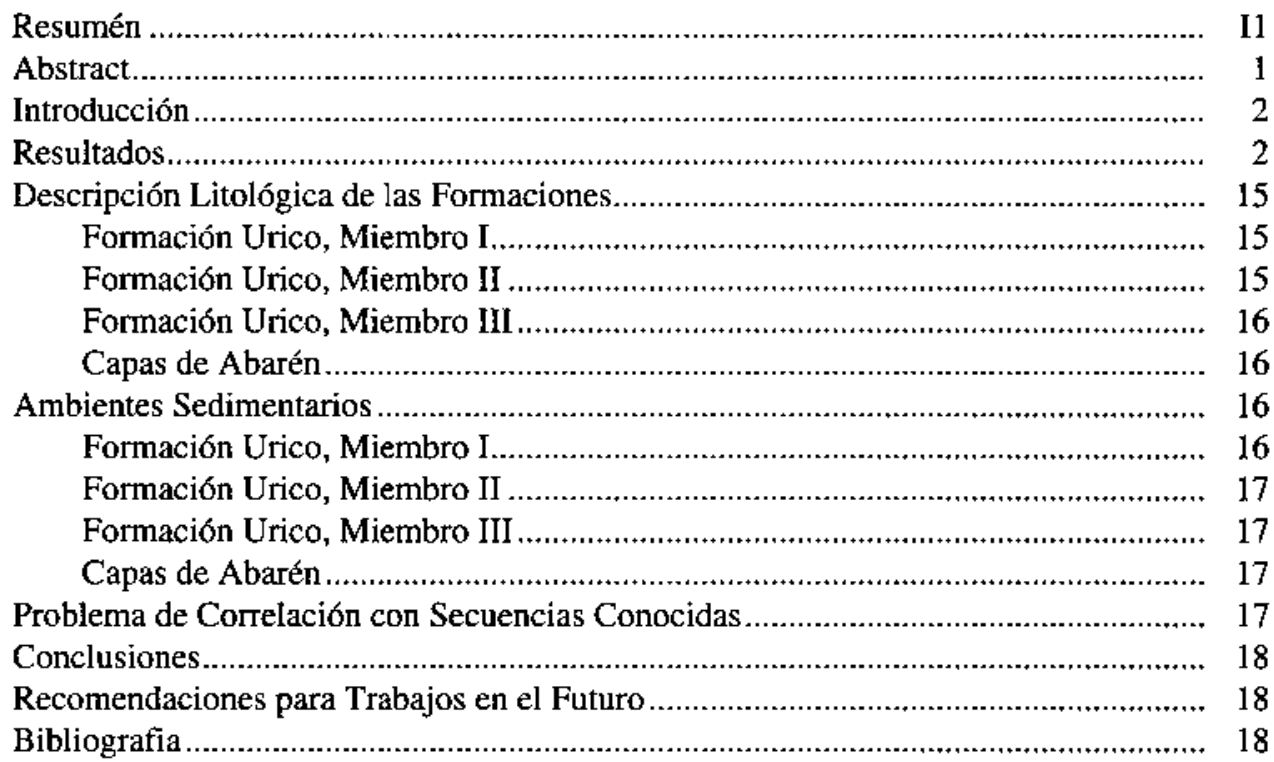

\section{FIGURAS}

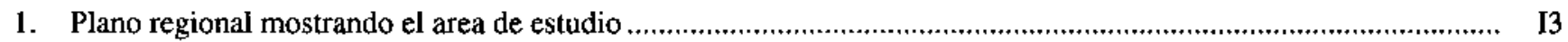

2. Plano mostrando las posiciones de las ocho secciónes estratigráficas .................................................................... 4

3. Columna estratigráfica de Río Urico-Occidental ............................................................................................. 5

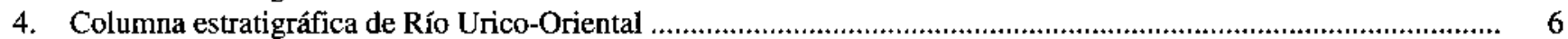

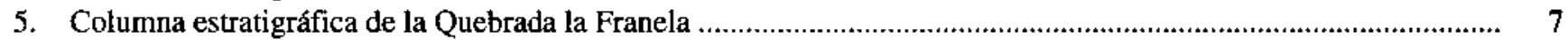

6. Columna estratigráfica de la Quebrada Abarén.....................................................................................

7. Columna estratigráfica del Río Uroy-Occidental ......................................................................................... 9

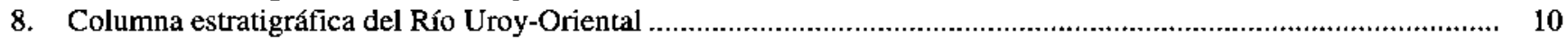

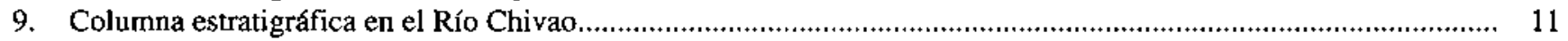

10. Columna estratigráfica en el Hacha-Serranía de Lema, Quebrada Hacha .......................................................... 12

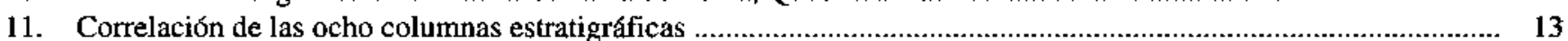

12. Columna estratigráfica generalizada reuniendo las observaciones de las ocho columnas a una general................... 14

13. Estructuras sedimentarias del miembro II en la sección Río Urico.................................................................. 15

14. Direcciones de paleocorrientes en la Quebrada Abarén que indica fuentes de aporte desde el noreste .................... 16 


\title{
Estratigrafía del Grupo Roraima Interpretación Petrológica en la Región Noreste del Parque Nacional Canaima, Estado Bolívar, Venezuela (Stratigraphy of the Roraima Group and Petrologic Interpretation in the Northeast Region of Canaima National Park, Estado Bolívar, Venezuela)
}

\author{
By Margarita Alberdi ${ }^{1}$ and Gloria Contreras ${ }^{2}$
}

\begin{abstract}
RESUMEN
Ocho secciones sedimentarias estudiadas a lo largo de la Serranía de Lema indican que el Grupo Roraima en esta región contiene una secuencia turbiditica. Se distinguieron dos secuencias sedimentarias disconformes con notorias diferencias petrológicas. Se propone el nombre de Formación Urico para la secuencia basal, la cual tiene su sección tipo en las cabeceras del Río Urico. El nombre de capas de Abarén se postula para la secuencia suprayacente, la cual tiene dos secciones de referencia en las Quebradas Franela y Abarén.

La Formación Urico está compuesta por tres miembros. El miembro I contiene grauwacas y brechas sedimentarias con abundantes clastos volcánicos. El miembro II suprayace en contacto disconforme y está compuesto por lutitas y limolitas de color gris oscuro, con pirita y alto contenido de carbonato. El miembro III tambien está en contacto disconforme y está caracterizado por un componente volcaniclastico. La base contiene areniscas cuarzosas interestratificadas con lutitas tobáceas verdes. La parte media son lutitas tobáceas verdes con laminación plano paralela y pirita. Por encima de la parte media, afloran, en contacto abrupto y concordante, limolitas tobáceas rojas de gran persistencia lateral. E1 miembro III se subdividió en 3 partes. La Formación Urico infrayace a una secuencia de areniscas cuarzosas y paraconglomerados polimícticos lá cual se denomina capas de Abarén. Las capas de Abarén presentan las
\end{abstract}

'Corporación Venezolana de Guayana, Técnica Minera, C.A., Puerto Ordaz, Venezuela.

${ }^{2}$ Voie de la Croix, 55000 Behonne, France; formerly Corporación Venezolana de Guayana, Técnica Minera, C.A., Puerto Ordaz, Venezuela. características sedimentológicas y petrológicas típicas del Grupo Roraima.

La Formación Urico se interpreta como depósitos de ambientes marinos, posiblemente de talud y quizás de plataforma. Las capas de Abarén se interpretan como sedimentos fluviales de ríos con canales entrelazados.

\section{ABSTRACT}

Eight stratigraphic sections of the Roraima Group were studied along the Lema Range in the northeastern part of the Gran Sabana of Venezuela. Two distinct sedimentary sequences that have markedly different lithology are present. The type section of the older, basal, turbiditic sequence, herein named the Urico Formation, is exposed in the headwaters of the Río Urico. Reference sections for an overlying, younger section, herein referred to as the Abarén beds, are along the Quebrada Abarén and Quebrada La Franela (Pistón de Uroy).

The Urico Formation consists of three informal members. The oldest, member I, consists of graywacke and sedimentary breccia that contain abundant volcanic clasts. The overlying member, member II, is in disconformable contact, consists of dark-gray shale and mudstone, and contains abundant pyrite and carbonate. Member III disconformably overlies member II and is characterized by a volcaniclastic component. The basal part of member III contains quartzarenite interstratified with green tuffaceous shale, and the middle part consists of green tuffaceous shale with planeparallel lamination. The upper part of member III rests on a sharp, but concordant, contact. It consists of laterally persistent red tuffaceous mudstone. Quartzitic and polymictic conglomerate and sandstone, herein called the Abarén beds, 
overlie the Urico Formation. The Abaren beds form a sequence of rocks typical of the Roraima Group.

The Urico Formation is interpreted to represent a marine environment of deposition, possibly continental slope and platform. The Abarén beds are fluvial sediments that were deposited in channels of anastomosing streams.

\section{INTRODUCCION}

Las unidades que forman el Grupo Roraima son extensas. En este trabajo, se estudió una pequeña región donde hay secciones estratigráficas bien desarrolladas con las cuáles se construyó una sección completa del Grupo Roraima. Además se evaluo el ambiente de deposición.

Las capas sedimentarias que afloran en el Monte Roraima y que ocupan un área de $450,000 \mathrm{~km}^{2}$ desde Tafelberg en Surinam hasta la Sierra de La Macarena en Colombia fueron denominadas por Dalton (1912) como "Serie Roraima." Aguerrevere et al (1939) elevaron la secuencia al rango de formación. Gansser (1954) y Yanez (1977) distinguieron tres miembros para la Formación Roraima. Por último, Reid (1973) y Ghosh (1977) le confirieron a la formación el rango de grupo. Los estudios geocronológicos de McDougall et al (1963), Snelling (1963), Priem et al (1973), y Basei y Teixeira (1975) determinaron una edad Proterozoico de 1,800 Ma.

Las rocas del Gnupo Roraima son conocidas en Surinam a través de los trabajos de Bisschops (1969) y en Brasil, principalmente, a través de los trabajos de De Loczy (1973) y Gansser (1954). Reid (1973), Simon et al (1985), Yanez (1985), y Ghosh (1977) realizaron descripciones estratigráficas en Venezuela, especificamente en el area del Monte Roraima, Canaima, y Estado Amazonas. No obstante, a pesar del número de trabajos dedicados a la geología del Grupo Roraima, existe un concenso general en cuanto a la falta de información estratigráfica detallada en grandes áreas inexploradas. Por lo cual, este trabajo contribuye al conocimiento del Grupo Roraima por describir macroscópicamente y microscópicamente rocas de ocho secciónes sedimentarias a lo largo de la Serranía de Lema. Se realiza una correlación de las ocho secciones, y se presenta una columna estratigráfica generalizada. Se presenta información y observaciones que permiten determinar los posibles ambientes sedimentariós y se postula una nueva formación con el nombre de Formación Urico, la cual infrayece sedimentos continentales correlacionables en términos generales con el Grupo Roraima. Estos sedimentos continentales se denominan "capas de Abarén."

Esta investigación está fundada en observaciones directas sobre los escarpes verticales de los tepuyes. La información estratigráfica se complementó con el estudio de 55 secciones finas y 20 análisis de difracción de rayos $\mathrm{X}$, lo que condujo, junto con los datos estratigráficos, a obtener una interpretación sedimentológica.

El trabajo se efectuó como parte del Proyecto Prospecciones Geológicas que la Corporación Venezolana de Guayana-Técnica Minera, C.A., desarrolló al norte del Parque Nacional Canaima. El área de trabajo está ubicado entre lat $6^{\circ} 00^{\prime}-6^{\circ} 45^{\prime} \mathrm{N}$. y long $61^{\circ} 45^{\prime}-62^{\circ} 15^{\prime} \mathrm{O}$. en el Distrito Sifontes del Estado Bolívar (fig. 1). Las secciones estratigráficas fueron estudiadas en las cabeceras del Río Urico (afluente del Yuruán), en la Quebrada La Franela (afluente del Río Chicanán), en las cabeceras de la Quebrada Hacha (afluente del Río Tukupö), en las cabeceras del Río Uroy, en las cabeceras del Río Chivao, y a lo largo de la Quebrada Abarén (figs. 1 y 2).

\section{RESULTADOS}

A lo largo de la Serranía de Lema, se estudiaron ocho secciones sedimentarias, seis de ellas son correlacionables por la presencia de dos capas tobáceas que sirvieron como capas guías. Para la mayoría de las secciones se pudo establecer correlaciones secundarias utilizando para ello las grauwacas más antiguas, los conglomerados polimícticos de matriz rosada, y las areniscas interestratificadas con limolitas rojas. Desafortunadamente, en la sección sedimentaria en la Quebrada Hacha no se observaron las capas guías y lo que se conoce hasta los momentos de su litología se presenta en este estudio hasta que trabajos mas detallados arrojen mas información.

Las figuras 3-10 son columnas estratigráficas y la figura 11 presenta una correlación entre las ocho secciones. La combinación de las secciónes estratigráficas correlacionables arroja la columna litoestratigráfica generalizada (fig. 12), en donde se muestra una secuencia sedimentaria en la base que se denominó Formación Urico y una secuencia superior llamada las capas de Abarén. Las capas de Abarén son correlacionables en forma general con las capas basales del Grupo Roraima en el área de Santa Elena de Uairen.

Los afloramientos de la Formación Urico se encuentran expuestos casi en su totalidad en la sección occidental levantada en las cabeceras del Río Urico, por lo que se postula a esta secuencia como la sección tipo de la Formación Urico. Sin embargo, también se observaron afloramientos parciales de ella en las secciónes sedimentarias de los Ríos Uroy, Chivao, y Quebrada La Franela. La capas de la Fornación Urico no presentan buzamientos aparentes, fallas o pliegues que indiquen tectonismo. Al igual que para el Grupo Roraima, estas capas no fueron deformadas por la Orogénesis Transamazónica propuesta por Mendoza (1977). 


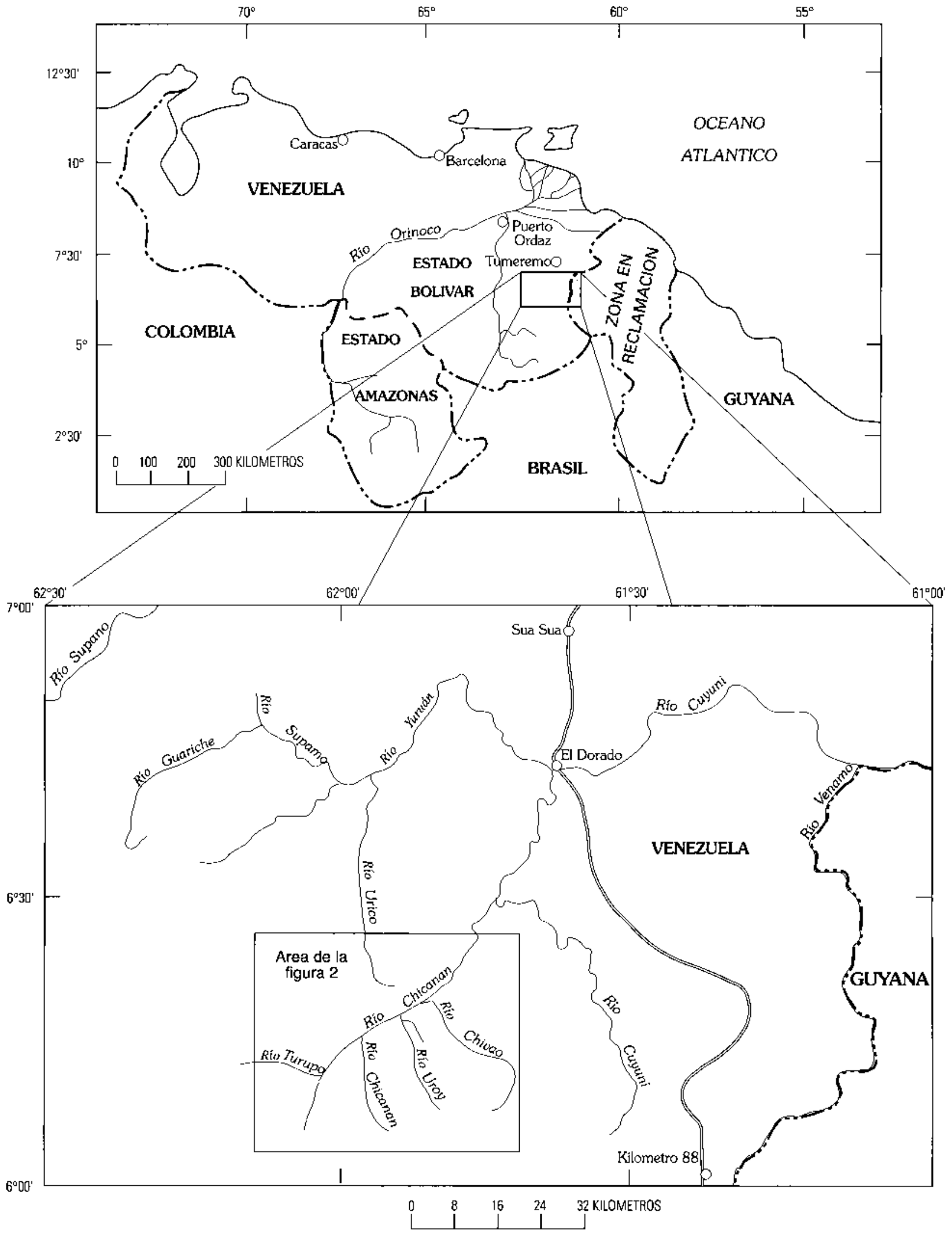

Figura 1. Plano regional mostrando el area de estudio. 


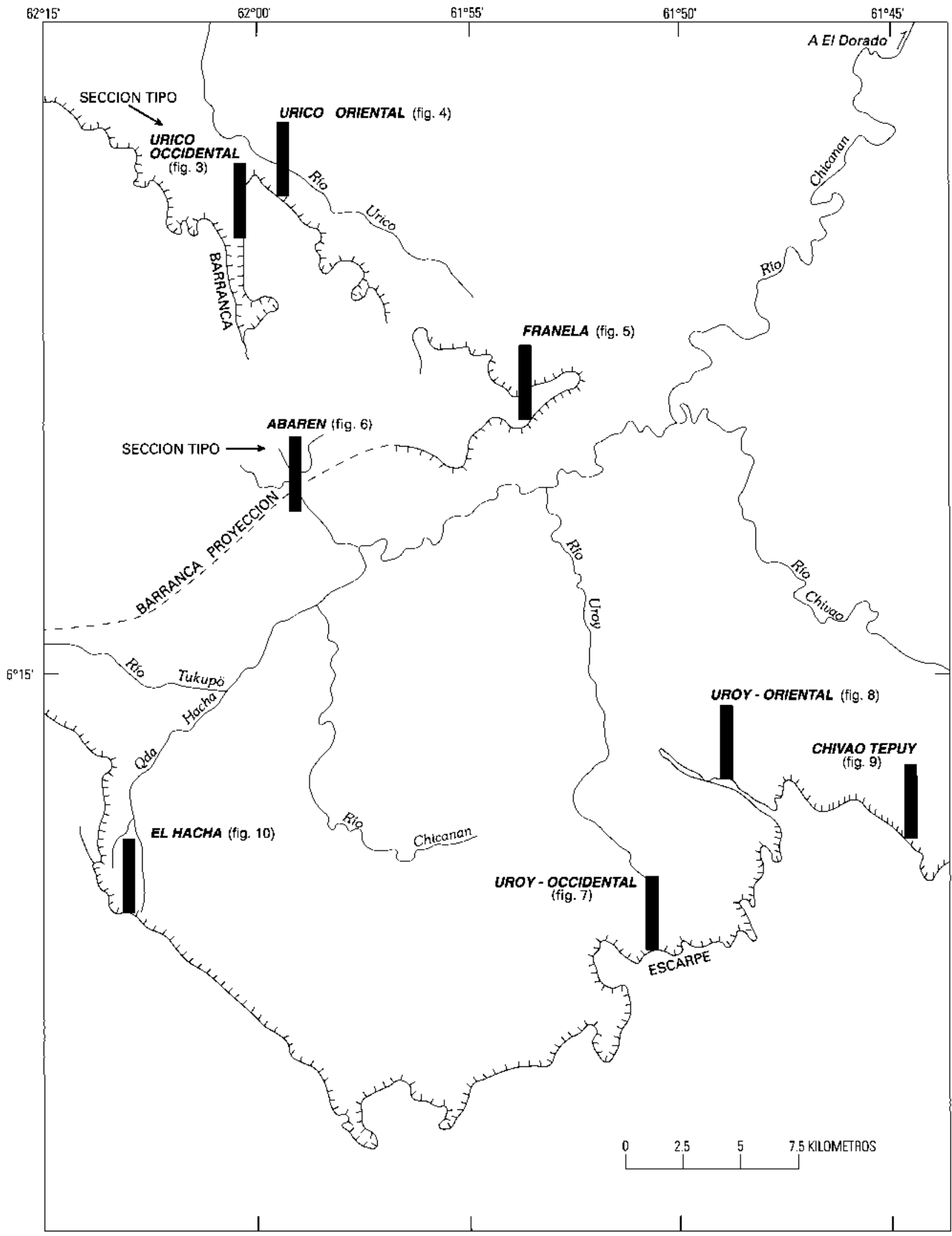

Figura 2. Plano mostrando las posiciones de las ocho secciónes estratigráficas. 


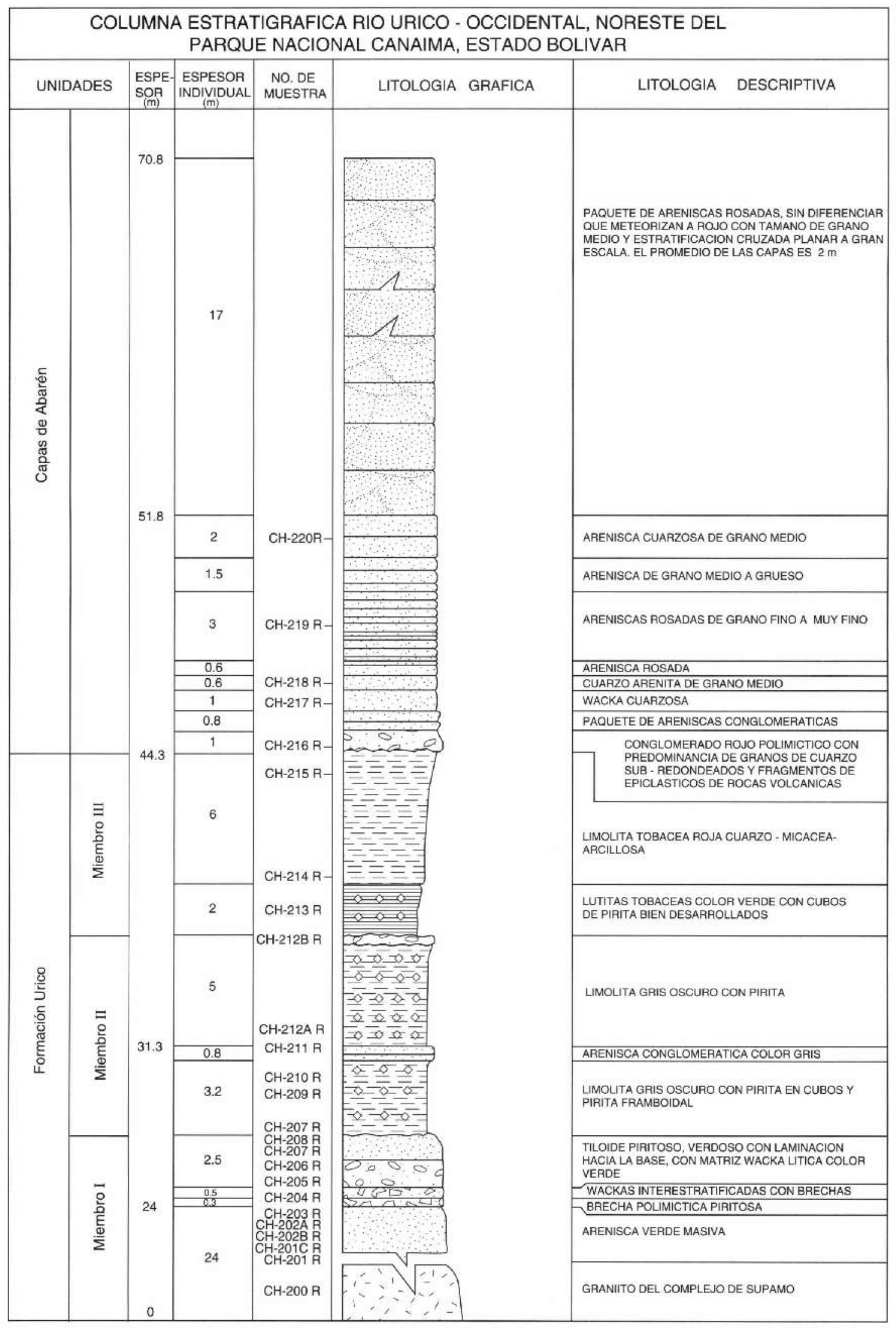

Figura 3. Columna estratigrafica de Río Urico-Occidental en el Parque Nacional Canaima, Estado Bolívar. 


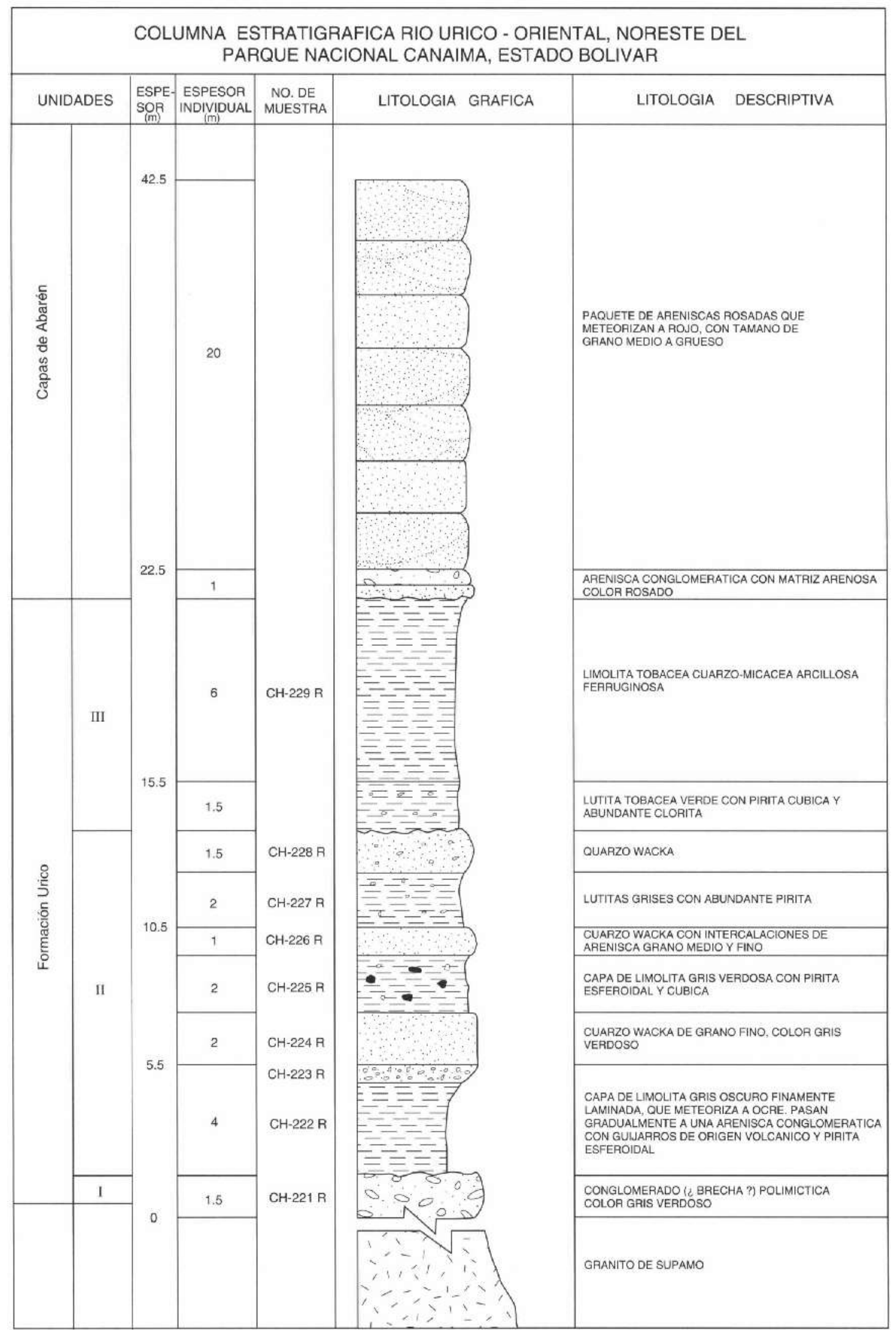

Figura 4. Columna estratigráfica de Río Unico-Oriental en el Parque Naciónal Canaima, Estado Bolívar. 


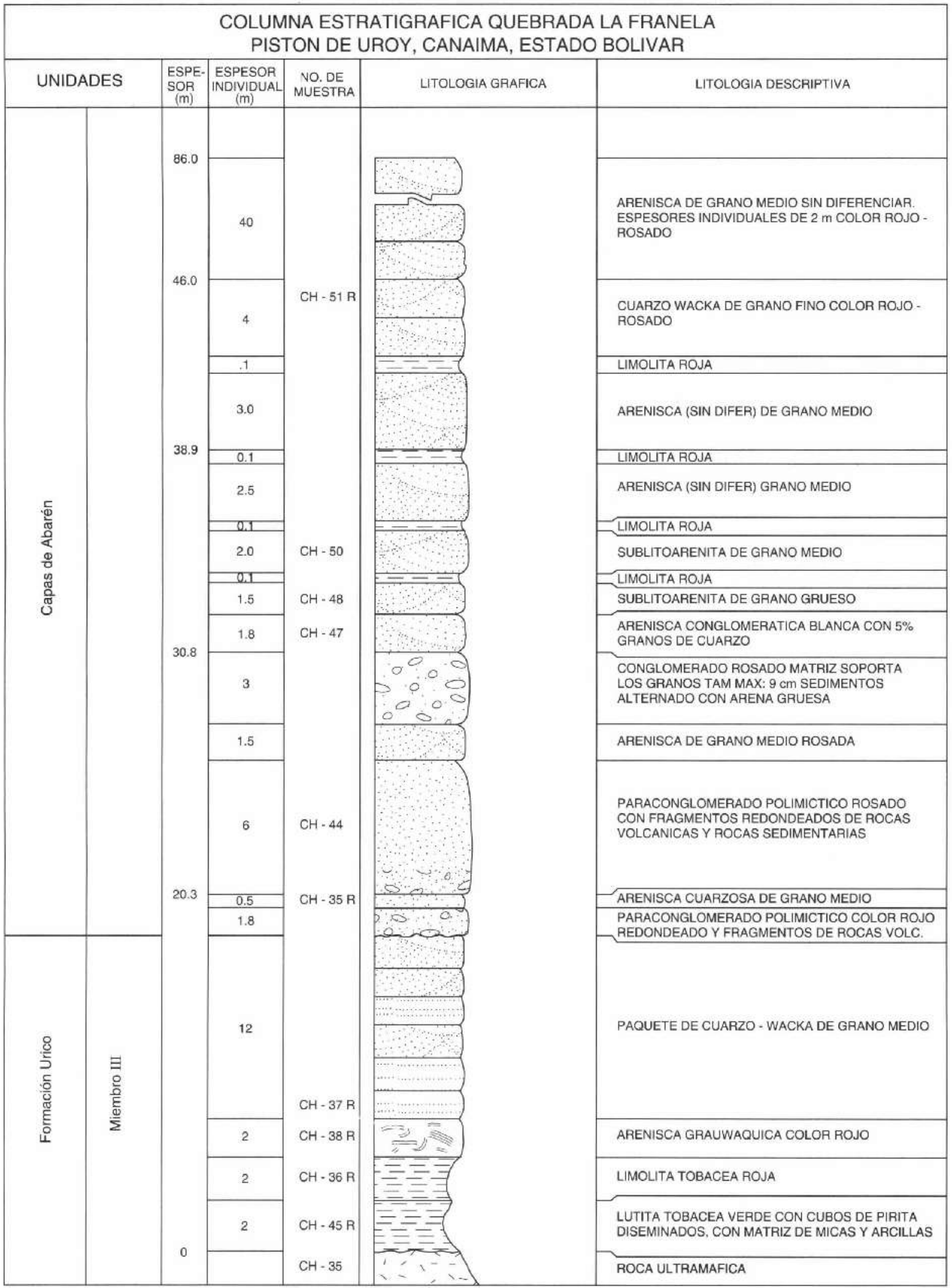

Figura 5. Columna estratigráfica de la Quebrada la Franela en el Parque Nacional Canaima, Pistón de Uroy, Estado Bolívar. 


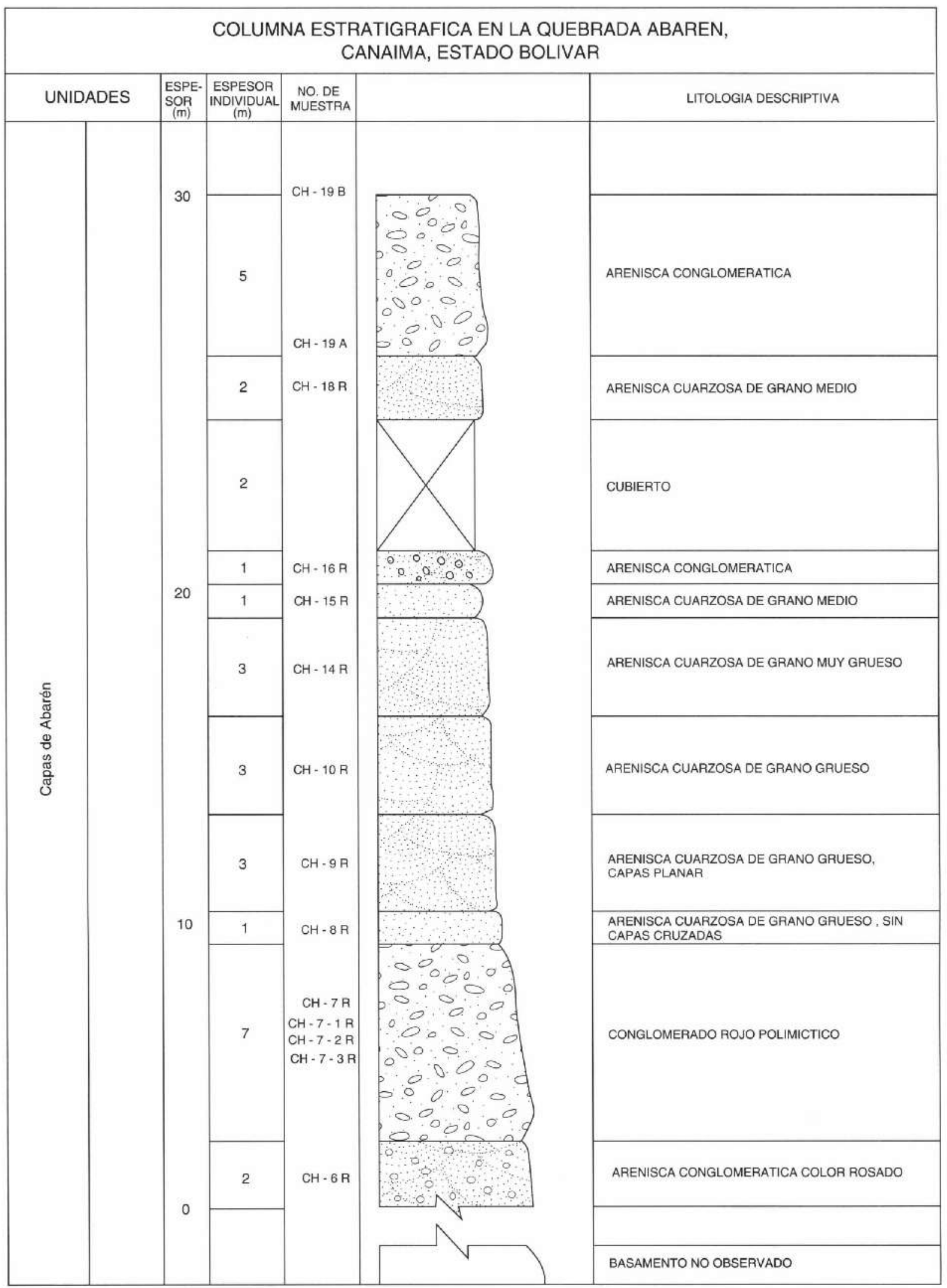

Figura 6. Columna estratigráfica de la Quebrada Abarén en el Parque Nacional Canaima, Estado Bolívar. 


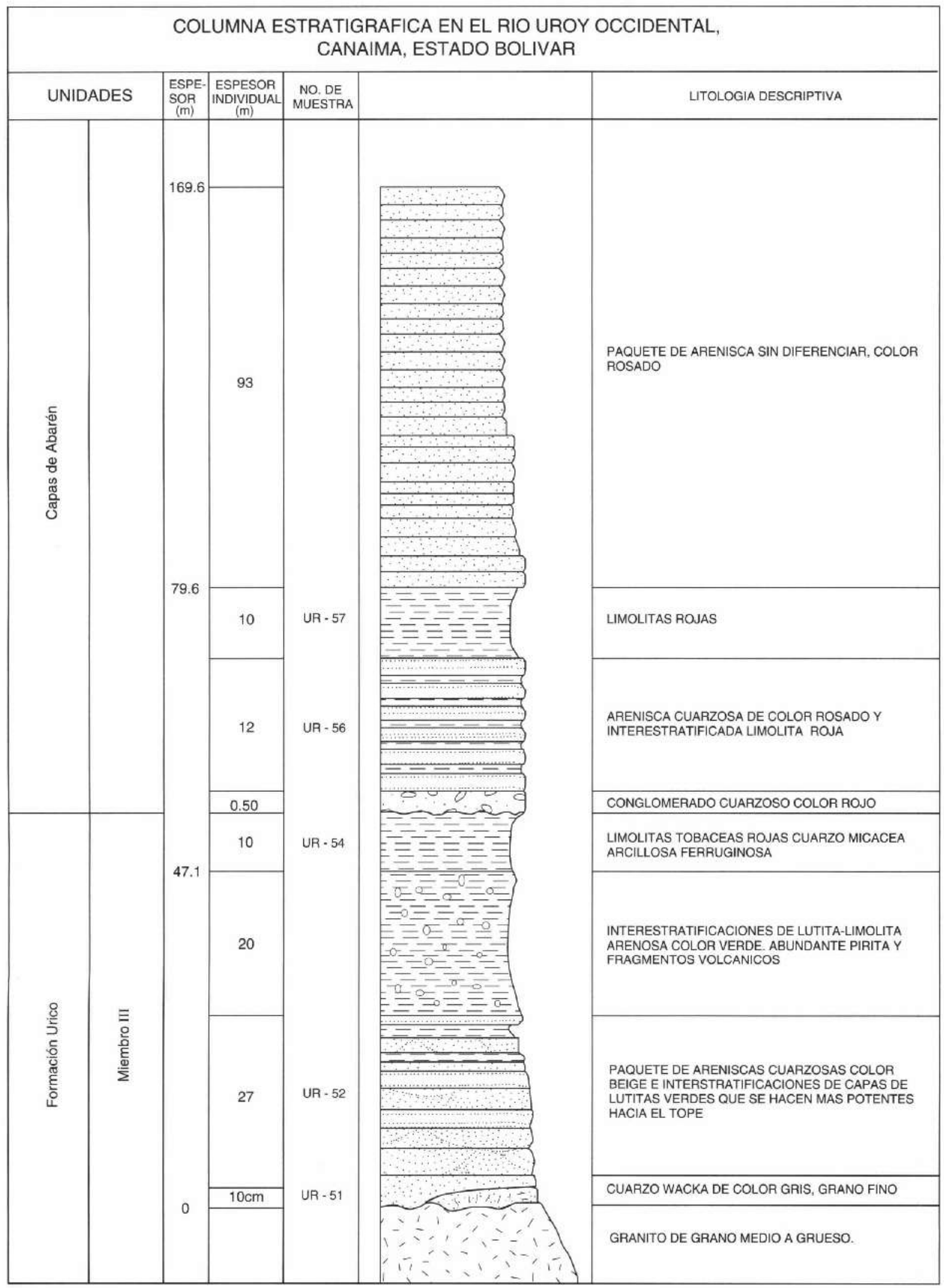

Figura 7. Columna estratigráfica del Río Uroy-Occidental en el Parque Nacional Canaima, Estado Bolívar. 


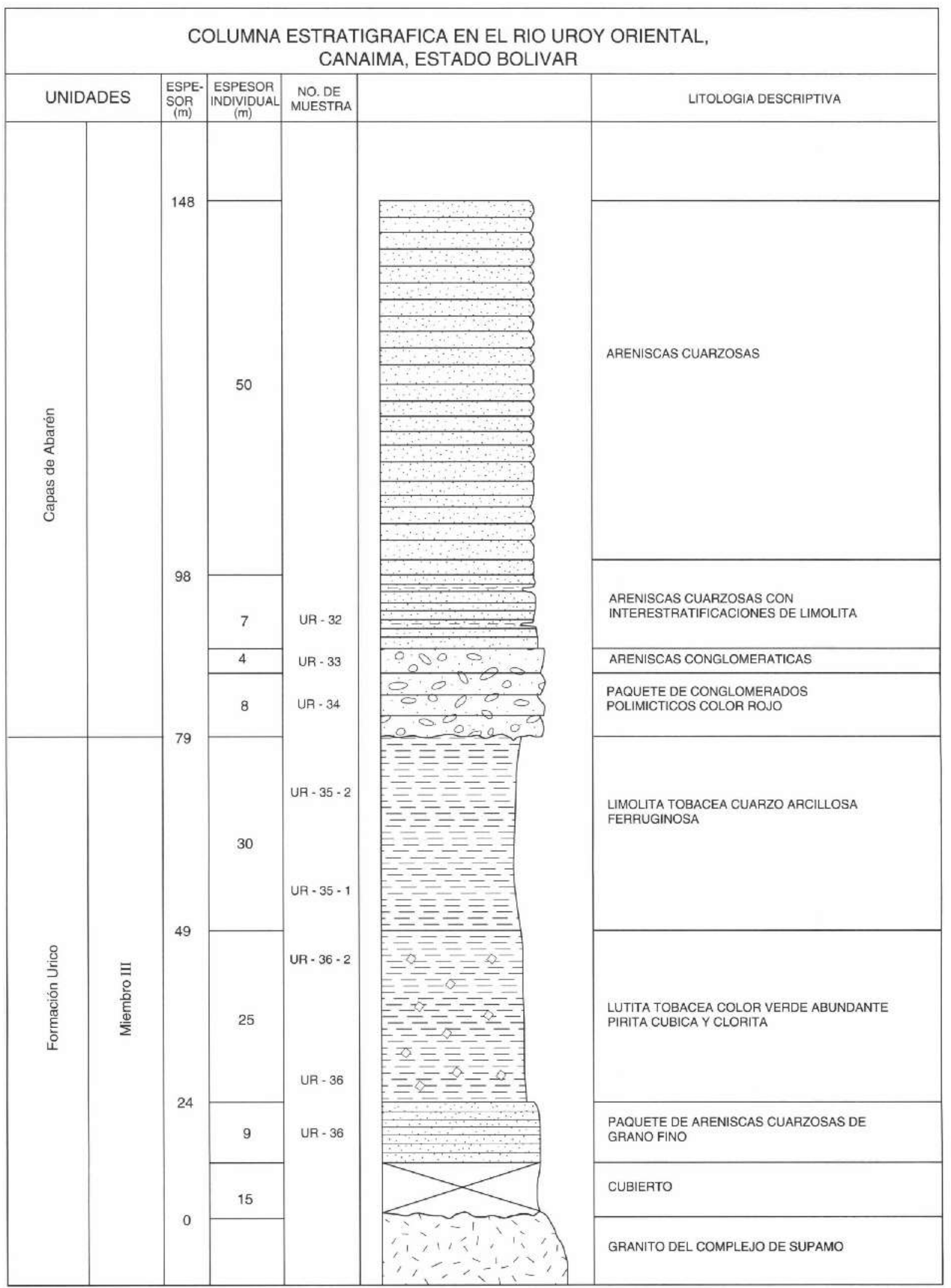

Figura 8. Columna estratigráfica del Río Uroy-Oriental en el Parque Nacional Canaima, Estado Bolívar. 


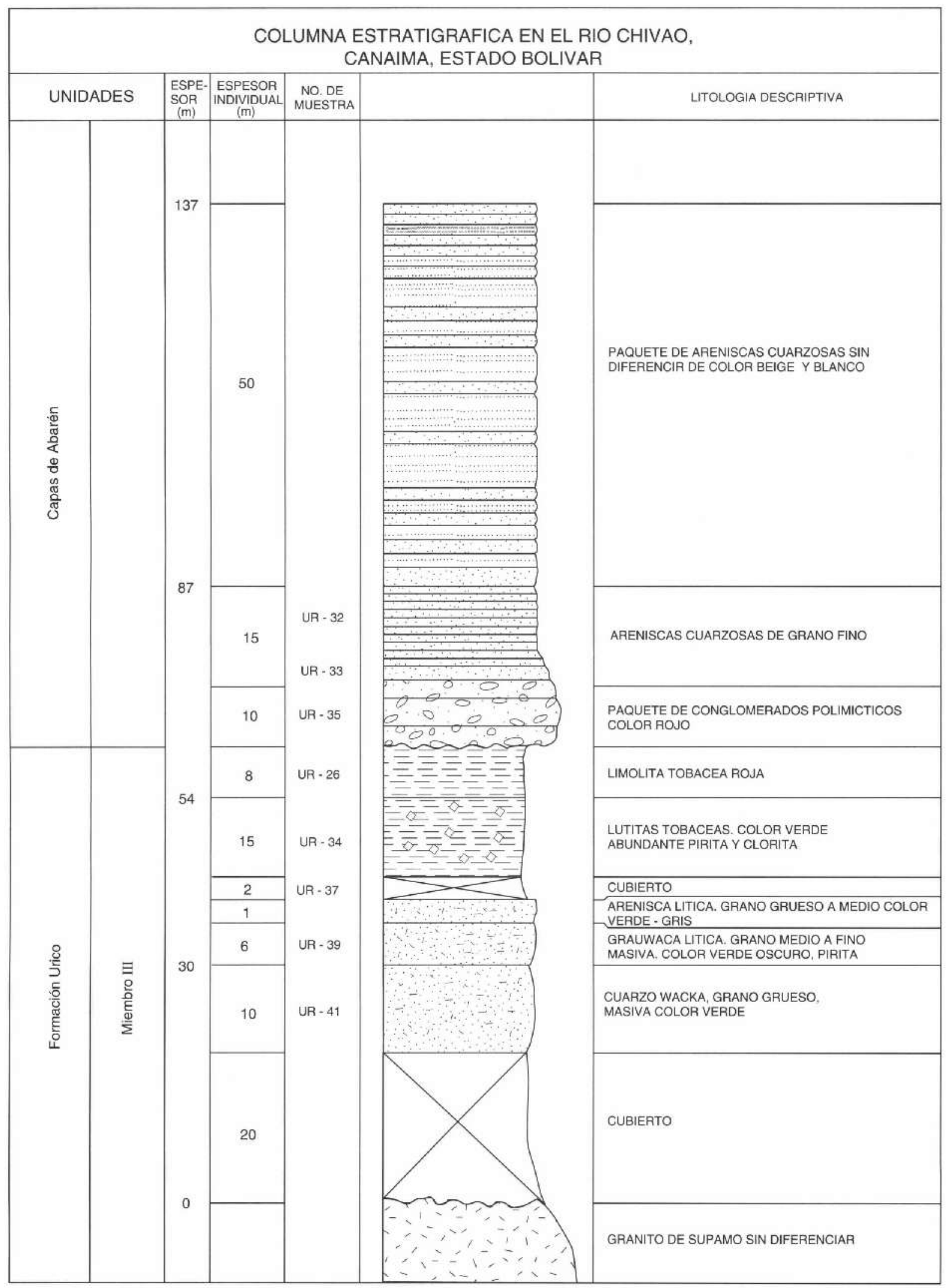

Figura 9. Columna estratigráfica en el Río Chivao en el Parque Nacional Canaima, Estado Bolívar. 


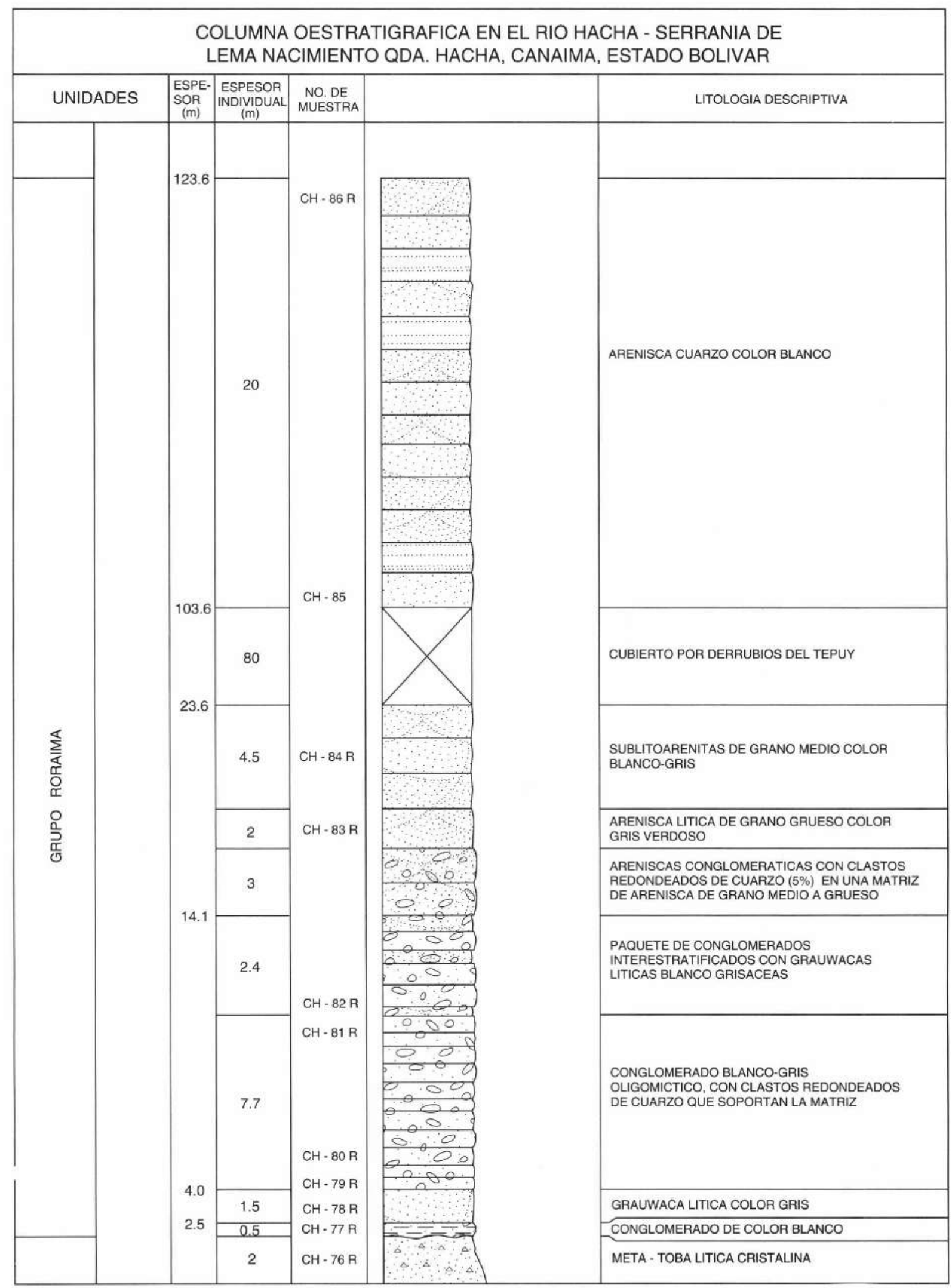

Figura 10. Columna estratigráfica en Quebrada Hacha-Serranía de Lema, Quebrada Hacha en Parque Nacional Canaima, Estado Bolívar. 


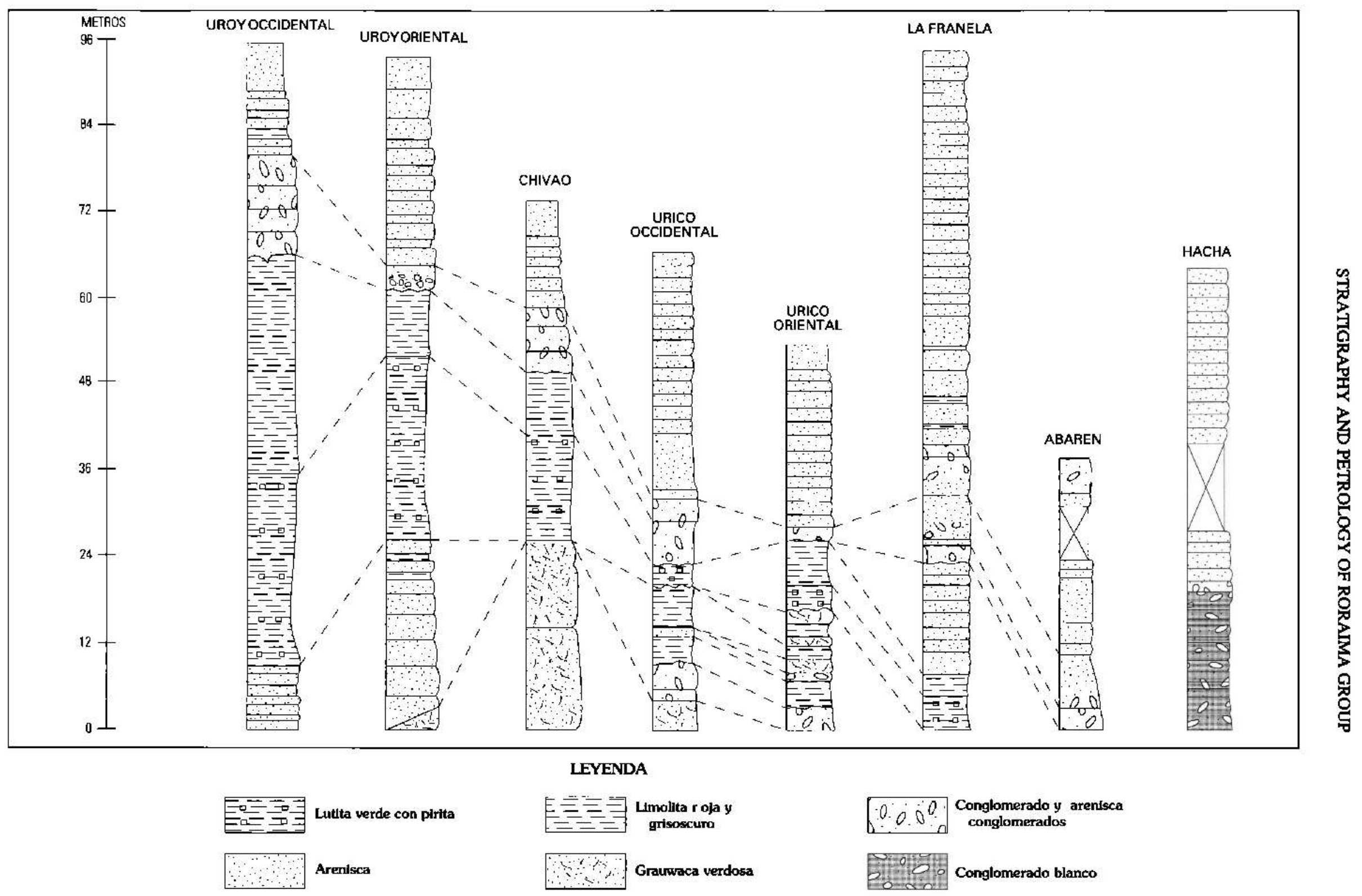

Figura 11. Correlación de las ocho columnas estratigráficas. Se indica la localidad de cada sección en figura 2. 


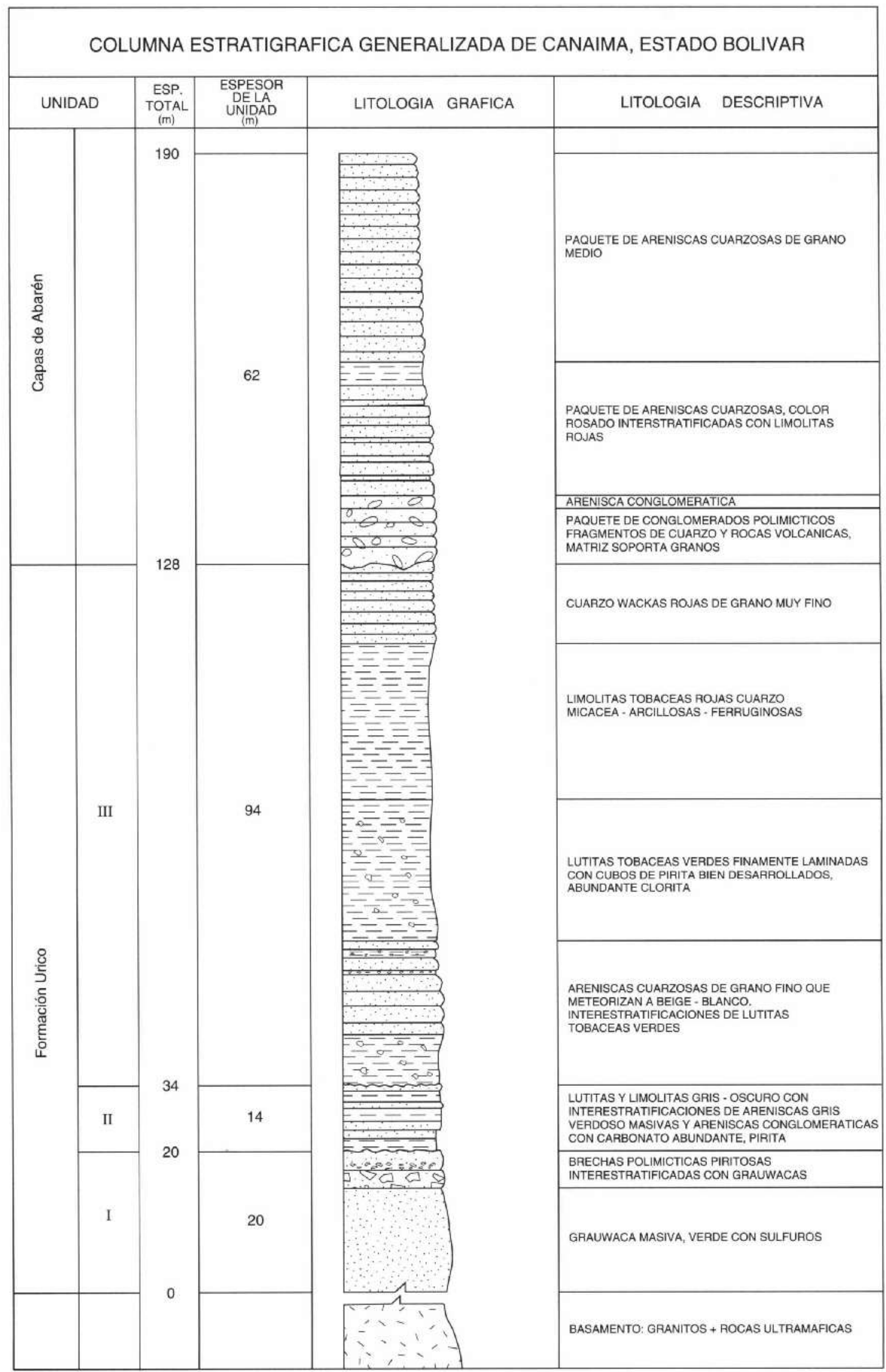

Figura 12. Columna estratigráfica generalizada reuniendo las observaciones de las ocho columnas a una general. 


\section{DESCRIPCION LITOLOGICA DE LAS FORMACIONES}

La Formación Urico yace sobre rocas graniticas del Complejo de Supamo y se dividió en tres miembros.

\section{FORMACION URICO, MIEMBRO I}

El miembro I fue observado en las secciones de los Ríos Urico y Chivao (figs. 3, 4, y 9). Rocas graniticas del Complejo de Supamo, las cuales afloran en la base de los tepuyes, infrayacen al mimebro I. El contacto no fue observado ya que está cubierto por derrubios.

El miembro I tiene $20 \mathrm{~m}$ de espesor y está formado por una secuencia que se inicia con cuarzo wackas de color verde, masivas de grano grueso a muy gnueso. Contiene aproximadamente $40-60$ por ciento de pirita diseminada, algunos granos tienen bordes corroidos. La matriz como epimatriz y ortomatriz (Dickinson, 1970) se compone de carbonatos, clorita, ilita-sericita, caolinita, pirofilita, feldespato, y cuarzo criptocristalino.

Las cuarzo-wackas pasan transicionalmente a grauwacas líticas, areniscas líticas en las cabeceras del Río Chivao (fig. 9), y a brechas polimícticas y conglomerados brechoides interestratificados con grauwacas en las cabeceras del Río Urico (fig. 3). Macroscopicamente, las brechas polimícticas contienen 45 por ciento de granos detriticos angulosos (tamaño maximo, $11 \mathrm{~cm}$; tamaño minimo, $0.5 \mathrm{~cm}$ ), 3-5 por ciento pirita, y $50-55$ por ciento matriz grauwáquica. La matriz está formada por epidota, carbonatos recristalizados, clorita, arcillas blancas, caolinita, feldespatos, y cuarzo criptocristalino y contiene como fracción gruesa fragmentos de roca volcánica, hornblenda basáltica, cuarzo mono-y policristalino, pirita, ilmenita-magnetita, y leucoxeno.

En la parte superior del miembro I se encuentra una capa de $2.5 \mathrm{~m}$ de espesor la cual está caracterizada por clastos máficos redondeados (dimensión maxima $15 \mathrm{~cm}$ ) y fragmentos de cuarzo anguloso embebido en una matriz piritosa. Petrográficamente, fué clasificada como wacka lítica. La matriz es laminada hacia la base y se hace masiva hacia el tope, petrograficamente se caracteriza por presentar cuarzo monocristalino, feldespatos, plagioclasa alterando completamente o parcialmente a carbonato, fragmentos de rocas volcánicas y sedimentarias, y minerales máficos sin diferenciar alterado completamente o parcialmente a clorita y calcita. Los clastos máficos de color gris oscuro están dispuestos paralelos a la estratificación, al igual que sus ejes mayores; la distancia aproximada entre clasto y clasto de $40 \mathrm{~cm}$.

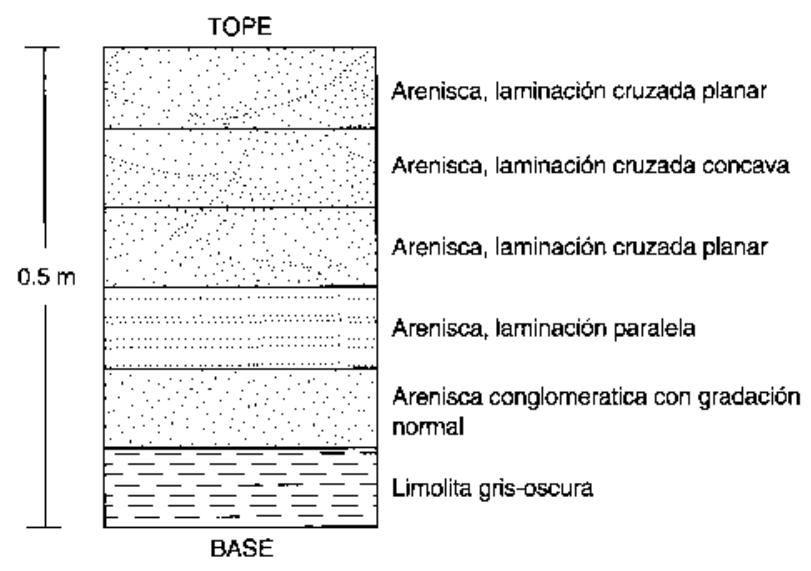

Figura 13. Estructuras sedimentarias del miembro II en la sección Río Urico en Parque Nacional Canaima, Estado Bolívar.

\section{FORMACION URICO, MIEMBRO II}

En las secciones sedimentarias que se cartografiaron en las cabeceras del Río Urico (fígs. 3 y 4), el miembro I infrayace disconforme al miembro II el cual consiste de estratos de lutitas color gris oscuro, laminadas, con un alto porcentaje de carbonatos y abundante pirita (framboidal y cúbica). Las lutitas gradan a limolitas. En la sección occidental del Río Urico (fig. 3), las limolitas gradan hacia el tope a areniscas y areniscas conglomeráticas (tamaño maximo, $5 \mathrm{~mm}$ ) que cierran dos ciclos de engrosamiento, y en la sección oriental del Río Urico (fig. 4), las limolitas se interestratifican con cuarzo wackas.

En la sección occidental del Río Urico, las areniscas del primer ciclo regresivo muestran progresivamente de base a tope estructuras de gradación normal, laminación paralela planar, cruzada planar, y cruzada concava (fig. 13). Petrográficamente, la arenisca conglomeratica está constituida por 45 por ciento de matriz, 25 por ciento de arcillas, y 30 por ciento de parches de carbonato. El carbonato se encuentra principalmente como pseudoespato, producto de la recristalización de un lodo micrítico original que paso progresivamente a microespato, y finalmente a pseudoespato. Dentro de los granos detríticos una matriz de cuarzo mono- y policristalino, fragmentos de rocas sedimentarias, fragmentos de rocas volcánicas, y trazas de leucoxeno, epidoto, biotita, y pirita. En esta misma sección sedimentaria, el segundo ciclo regresivo grada trancionalmente a una arenisca de grano fino con laminación convoluta. Las direcciones de paleocorrientes en la estratificación cruzada son suroeste indicando fuentes de aporte al noreste para esta parte de la Formación Urico. 


\section{FORMACION URICO, MIEMBRO III}

El miembro III se caracteriza por presentar una lutita tobácea, color verde, finamente laminada, con cubos de pirita bien desarrollados. Las lutitas afloran por distancias no menores de $50 \mathrm{~km}$ lineales sin cambios laterales de facies, y forma una capa guía. La lutita tobácea verde tiene fragmentos de pómez alterados, cuarzo retrabajado, clorita autigénica, muscovita, epidoto, trazas de carbonato, y fragmentos volcánicos. En sección fina, se observan a nivel micrométrico estructuras de deformación ("slumping").

En la sección sedimentaria en las cabeceras del Río Uroy (fig. 7), las lutitas verdes están interestratificadas en su base con areniscas de color beige-blanco de grano fino a medio y estratificación cruzada. Las areniscas en el tope alcanzan un espesor continuo de $25 \mathrm{~m}$ en las secciones del Ríos Uroy oriental (fig. 8) y Chivao (fig. 9). La lutita tobácea verde infrayace en contacto abrupto y concordante a una capa de limolitas tobáceas rojas, con laminación planar, gradación inversa y laminación paralela con clorita y feldespatos.

En la sección sedimentaria de La Franela (fig. 5), la limolita tobácea roja, infrayace un paquete de cuarzo wackas con abundante muscovita y minerales opacos. El tamaño de grano grada inversamente de muy fino a medio. Las areniscas presentan en la base rizaduras a pequeña escala y en el tope laminación cruzada concava a gran escala. Su posición estratigráfica y la concordancia con las limolitas tobáceas rojas infrayacentes sugiere la ubicación de este paquete dentro de la Formación Urico. El contacto entre la Formación Urico y las capas de Abarén es una disconformidad.

\section{CAPAS DE ABAREN}

Las capas de Abarén están por encima y en contacto discordante con la Formación Urico. Las capas se inician con un paquete de conglomerados polimicticos cuya matriz soporta los granos color de meteorización rosado; presentan estratificación gradada normal. Este conglomerado marca un intervalo de levantamiento y erosión. Los clastos son de diferentes litologías, principalmente granos de cuarzo y fragmentos de rocas volcánicas y sedimentarias. Los guijarros son redondeados a subredondeados, con dimensiones que alcanzan $13 \mathrm{~cm}$. Estan embebidos en una matriz que varia entre arenisca cuarzosa, sublitarenita, y arenisca lítica.

En la mayoría de las secciónes levantadas, el conglomerado pasa transicionalmente a una arenisca conglomerática con estratificación cruzada concava a gran escala, sin embargo, en la sección de Abarén, el conglomerado infrayace a un paquete de arenisca cuarzosa de grano grueso bien escogida, que presentan estratificación cruzada planar gruesa y hacia el tope estratificación cruzada concava. En Quebrada la Franela (fig. 5) y en las cabeceras del Río Uroy (fig. 7), se observó arenisca conglomerática sobre un paquete

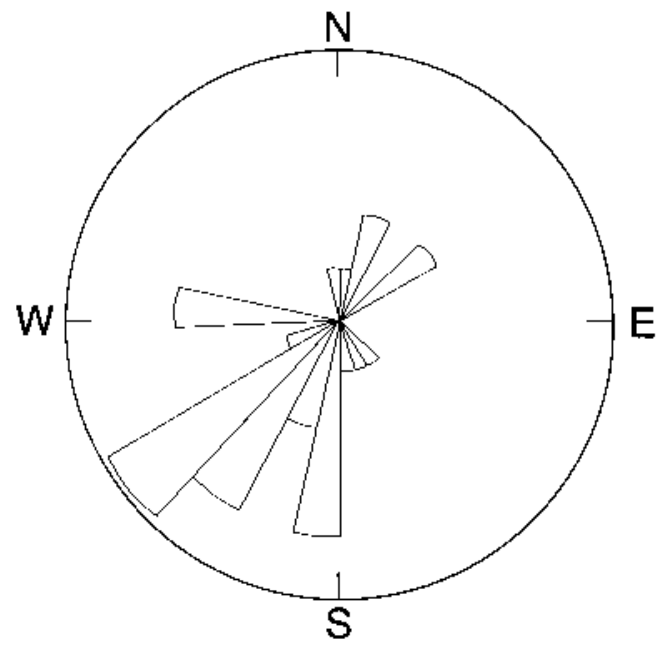

Figura 14. Dirrecciones de paleocorrientes en la Quebrada Abarén que indica fuentes de aporte desde el noreste.

de arenisca cuarzosa color rosado, interestratificadas con limolita roja.

Todas las secciones estratigráficas correlacionables terminan con un paquete de areniscas sin diferenciar de grano gneso, color rosado a blanco, con estratificación cruzada planar y concava que llega a alcanzar espesores totales de $90 \mathrm{~m}$ en las cabeceras del Río Uroy. Las direcciones de paleocorrientes indican, principalmente, fuentes de aporte desde el noreste similar a la Formación Unico. El estudio de paleocorrientes a lo largo de la Quebrada Abarén se muestra en la figura 14.

\section{AMBIENTES SEDIMENTARIOS}

\section{FORMACION URICO, MIEMBRO I}

La capa superior del miembro I (fig. 3) se caracteriza por clastos dispersos embebidos en una matriz grauwaquica, clastos de cuarzo anguloso, laminación paralela hacia la base, y clastos alineados con la estratificación y con los ejes mayores a la misma. El estudio de la petrografía textural y mineralógica de las grauwacas y su estratificación masiva indica un ambiente turbiditico con acción de corrientes marinas de turbidez como agentes de sedimentación. La estratigrafía sigue la secuencia de Bouma (Reading, 1986). En las cabeceras del Río Urico, la aparición de brechas polimícticas interestratificadas con grauwacas pone de manifiesto la incapacidad del medio sedimentario, para seleccionar los sedimentos transportados. Por otra parte, la pirita diseminada, apunta hacia un ambiente fisico-químico reductor. La recristalización de carbonato autigénico en la matriz sustenta la hipótesis de un ambiente marino por ser muy pocos los ambientes continentales capaces de precipitar carbonato (Flügel, 
1982) Ademas, la asociación litológica y estratigráfica observada en este trabajo no coincide con los escasos medios de sedimentación carbonática continental.

A la luz de los conocimientos de corrientes de turbidez y torrentes de barro asociados, es probable suponer que estas rocas resulten de corrientes subácuaticas de arena móvil. La capacidad de transportar clastos de gran tamaño por distancias considerables en estado semi-sólido es consistente con el propuesto para las brechas y grauwacas del miembro I de la Formación Urico las cusles fueron depositadas en un ambiente marino, quizás bajo la acción de corrientes de turbidez por encima de la capa de carbonato.

\section{FORMACION URICO, MIEMBRO II}

El miembro II fue depositado en un ambiente marino. El paso gradual de limolitas y lutitas en la base del miembro II hacia areniscas de grano medio-fino y conglomeráticas en el tope, junto con la secuencia de estructuras mostradas en la figura 14 y la aparición de la laminación convoluta, permiten postular pequeños ciclos regresivos, desde una sedimentación en aguas tranquilas hasta una sedimentación en aguas turbulentas. El ambiente marino se infiere a partir de la abundancia de carbonato en las lutitas y el alto porcentaje de pseudoespato en la arenisca conglomerática de la sección Río Urico occidental (fig. 3).

\section{FORMACION URICO, MIEMBRO III}

Las rocas volcaniclásticas del miembro III contienen un componente piroclástico procedente de un evento volcánico desconocido. Las estructuras sedimentarias (laminación paralela bien desarrollada y "flaser") a nivel macroscopico y estructuras de deformación a nivel microscopico, junto con la presencia de carbonato sugieren un ambiente de sedimentación subácuatico, posiblemente marino tanto para la lutita como para la limolita tobácea. Para la lutita tobácea, las condiciones reductoras en el ambiente sedimentario se manifiestan con el desarrollo conspicuo de pirita cúbica. $\mathrm{El}$ tope de este miembro está erosionado presentando un delgado "paleosol."

\section{CAPAS DE ABAREN}

La base de las capas de Abarén comienza con un paquete de conglomerados polimícticos que descansan en contacto disconforme sobre el miembro III de la Formación Urico. La abundancia de minerales estables en las areniscas, las superficies subredondeadas de los clastos, y el escogimiento de los granos junto con las siguientes observaciones de campo, permiten definir un ambiente fluvial de canales entrelazados. Evidencia para esto es presenta a continuación:

1. Los estratos presentan colores de meteorización rojizos y rosados, producto de un cemento hematítico temprano (observación petrográfica) que permite proponer un ambiente de sedimentación continental oxidante (Tucker, 1981; Reading, 1986).

2. Los conglomerados muestran un predominio de matriz sobre clastos, textura característica de alta a media energía en ríos de canales entrelazados (Cant, 1981). La marcada gradación normal es también propia de este ambiente (Nemec y Stell, 1984).

3. Se observan nueve ciclos "fining upward" o secuencias de disminución de tamaño de grano hacia arriba. Los ciclos comienzan con conglomerados en la base, los cuales corroboran la proposición del punto anterior en cuanto a la geomorfología del ambiente fluvial (William y Rust, 1969). Los ciclos "fining upward" a mediana escala (interestratificaciones de conglomerados y areniscas), parecen corresponder a ligereas fluctuaciones en la velocidad de la corriente (Harms et al, 1975). Los ciclos "fining upward" a gran escala se interpretaron como el proceso hidráulico de abandono de canales a largo plazo (Nemec y Stell, 1984; Walker y Cant, 1984).

4. En la Quebrada Abarén, se observaron estratos de arenisca cuarzosa con estratificación cruzada planar gruesa $(30 \mathrm{~cm}$ ) y con buzamientos de alto angulo, los cuales fueron interpretados como paleobarras de canales entrecruzados (Cant, 1981; Walker y Cant, 1984). Esta explicación se hizo extensiva a las potentes secuencias de areniscas con estratificación cruzada planar que conforman la parte superior de los tepuyes. En la mayoría de los casos, la estratificación cruzada cóncava se interpretó como depósitos de rizaduras linguoides que normalmente se desarrollan en la parte superior de los canales fluviales.

5. En la parte media de las capas de Abarén se cartografiaron capas centimétricas de limolitas rojas, que fueron interpretadas como paleo-llanuras de inundación según los modelos de facies (Walker y Cant, 1984; Reading, 1986).

Para finalizar, cabe recordar que en secuencias antiguas, las corrientes entrelazadas pueden ser confundidas con facilidad con meandros. Sin embargo, en las facies de canales meandricos, los espesores de limolitas son potentes y son escasos los conglomerados en la base. Se concluye que las capas de Abarén se sedimentaron en un medio fluvial de canales entrelazados.

\section{PROBLEMA DE CORRELACION CON SECUENCIAS CONOCIDAS}

La correlación de las secuencias levantadas en este estudio, con secciones conocidas en otras partes del escudo, es difícil. Las capas de Abarén están compuestas 
principalmente por areniscas cuarzosas con un porcentaje subordinado de wackas cuarzosas y sublitarenitas (figs. 3-9). Su madurez mineralógica y textural moderadamente altas e interestratificiones de paraconglomerados polimícticos y lentes de limolitas indican una sedimentación en un ambiente oxidante. Las fuentes de aporte principalmente son desde el noreste (fig. 14). Las capas de Abarén presentan similitudes con las descripciones hechas por Reid (1973) y Simón et al (1985) en la unidad basal del Grupo Roraima en las cercanías de Santa Elenea de Uairén.

La Formación Urico presenta una secuencia litológica no descrita anterionmente dentro del Grupo Roraima. Su ambiente sedimentario, aparentemente marino-reductor, junto con su importante componente volcanico, la presencia de carbonato y la baja madurez textural y mineralógica de los depósitos clásticos más antiguos soportan su diferenciación de las grandes secuencias continentales de ambiente próximo costeros que conforman al Grupo Roraima.

\section{CONCLUSIONES}

Este estudio presenta nueva información litológica, petrológica, y sedimentológica de ocho areas en el noreste del Parque Nacional Canaima. La estratigrafía de estas secuencias corresponden a dos grupos sedimentarios separadas por una disconformidad, y depositado en ambientes differentes. En la parte superior de la Serrania de Lema, los escarpes constituyen afloramientos de una secuencia sedimentaria compuesta por areniscas cuarzosas y conglomerados polimícticos con matriz de color rojo. Esta secuencia fue nombrada capas de Abarén, cuyas caracteristicas petrológicas, estructurales, y sedimentológicas son similares a las de la parte inferior del Grupo Roraima. Las capas descansan en contacto disconforme sobre otra secuencia, no tectonizada que se postula como la Formación Urico, cuyas características distintivas no permiten su correlación con el Grupo Roraima, tal y como ha sido definido en trabajos anteriores.

La Formación Urico tiene su sección tipo en las cabeceras del Río Urico y consiste de tres miembros. El más antiguo tiene brechas polimícticas y grauwacas con un componente volcánico importante. El segundo miembro suprayace en contacto discordante. Esta compuesto por lutitas y limolitas de color gris oscuro, con pirita framboidal y cúbica, laminación plano-paralela bien desarrollada, y una cantidad considerable de carbonato. El tercer miembro consiste de lutitas tobáceas verdes piritosas y limolitas tobáceas rojas de gran persistencia Iateral.

Las estructuras sedimentarias, las relaciones de campo, y las observaciones petrográficas permiten suponer que la Formación Urico representa depósitos marinos, posiblemente de talud o plataforma, mientras que las capas de Abarén representan paleocanales de ríos entrelazados.

\section{RECOMENDACIONES PARA TRABAJOS EN EL FUTURO}

1. Cartografiar lateralmente la Formación Urico y las capas de Abarén para relacionar su posición con otras partes del Grupo Roraima.

2. Analizar químicamente la secuencia sedimentaria en las cabeceras del Río Urico, con especial énfasis sobre las lutitas gris-piritosas cuyo ambiente sedimentario pudiese haber favorecido la precipitación o deposición de oro, uranio, y otros elementos de interés.

3. Determinar el ambiente tectónico de sedimentación para la Formación Urico y la transición a las capas de Abarén.

4. Estudiar las fuentes de aporte y concentrados pesados en las capas de Abarén y en la Formación Urico con el objeto de considerar las posibles correlaciones, fuentes para minerales, e interpretar el ambiente tectonico.

5. Realizar estudios geocronológicos para conocer la edad de la Formación Urico.

6. Explorar el contacto entre la Formación Urico y las capas de Abarén para posibles yacimientos económicos.

Agradecemos.-Este trabajo fue publicado parcialmente en la memoria del septimo Congreso Geológico Venezolano en 1989. El trabajo siguiente fué colaborado por la Corporación Venezolana de Guayana-Técnica Minera, C.A. (CVG-TECMIN), y el Servicio Geológico de los Estados Unidos. El honor de este trabajo va principalmente a los autores Alberdi y Contreras y se estima la colaboración del Sr. John-Mark Staude por la revisión. Nuestro más sincero agradecimiento al Dr. Vicente Mendoza, Dr. Santosh Ghosh, Dr. Jean Pasquali, Dra. María Lourdes de Gamero, Dr. Gary Sidder, Dr. Norman Page, Dr. Jeffrey Wynn, Ricardo Azuale, Dr. José Gutiérrez, Acenk Guerra, Ricardo Cedeño, Alexis Córdova, Jorge Penott, Luis Carlos Genolet, a la sección de cartografía de CVG-TECMIN y al dibujante Reinaldo Salazar, Bruce Galoob, y Patricia Covarrubias.

\section{BIBLIOGRAFIA}

Aguerrevere, S.E., López, V.M., Delgado, O.C., and Freeman, C.A., 1939, Exploración de la Gran Sabana: Revista de Fomento, año 3, no. 19, p. 501-542, 632-729.

Basei, M.A.S., and Teixeira, Wilson, 1975, Geocronología do Territorio de Roraima: Conferência Geológica Interguianas, 10th, Belém, Brazil, 1975, Memoria, p. 453-473.

Bisschops, J.H., 1969, The Roraima Formation in Suriname: Guiana Geological Conference, 7th, Paramaribo, Suriname, 1966, Proceedings; Verhandelingen van het Koninklijk Nederlands Geologisch Mijnbouwkundig Gerootschap, v. 27, p. 109-118.

Cant, D.J., 1982, Fluvial facies models and their application in sandstone depositional environments, in Scholle, P.A., and Spearing, Darwin, eds., Sandstone depositional environments: 
American Association of Petroleum Geologists Memoir 31, p. 139-178.

Dalton, L.V., 1912, On the geology of Venezuela: Geological Magazine, London, v. 9, p. 203-210.

De Loczy, Louis, 1973, Some problems of the tectonic framework of the Guiana Shield with special regard for the Roraima Formation: Geologische Rundschau, v. 62, p. 318-342.

Dickinson, D., 1970, Interpreting detrital modes of graywacke and arkose: Journal of Sedimentary Petrology, v. 40, p. 695-707.

Fliggel, Erik, 1982, Microfacies analysis of limestone: New York, Springer-Verlag, $633 \mathrm{p}$.

Gansser, August, 1954, The Guiana Shield (S. America): Eclogae Geologicae Helvetiae, v. 47, p. 77-1 12.

Ghosh, S.K., 1977, Geología del Grupo Roraima en Territorio Federal Amazonas: Congreso Geológico Venezolano, 5th, Caracas, 1977, Memoria, v. 1, p. 167-193.

Harms, J.C., Southard, J.B., Spearing, Darwin, and Walker, R.G., 1975, Depositional environments as interpreted from primary sedimentary structures and stratification sequences: Society of Paleontologists and Mineralogists Short Course 2, $161 \mathrm{p}$.

McDougall, Ian, Compston, W, and Hawkes, D.D., 1963, Leakage of radiogenic argon and strontium from minerals in Proterozoic dolerites from British Guiana: Nature, v. 198, p. 564-567.

Mendoza, Vicente, 1977, Evolución tectónica del escudo de Guayana: Congreso Latinoamericano de Geología, 2nd, Caracas, 1973, Memoria, Publicación Especial 7, v. 3, p. $2237-2270$.

Nemec, Wojciech, and Steel, R.J., 1984, Alluvial and coastal conglomerates-Their significant features and some comments on gravelly mass flow deposits, in Koster, E.H., and Steel, R.J., eds., Sedimentology of gravels and conglomerates: Canadian Society of Petroleum Geologists Memoir 10, p. 1-32.
Priem, H.N.A., Boelrijk, N.A.I.M., Hebeda, E.M., Verschure, R.H., and Verdurmen, E.A.Th., 1973, Age of the Precambrian Roraima Formation in northeastern South America-Evidence from isotopic dating of Roraima pyroclastic volcanic rocks in Suriname: Geological Society of America Bulletin, v. 84, p. $1677-1684$.

Reading, H.G., ed., 1986, Sedimentary environments and facies (2nd ed.): Oxford, Blackwell Scientific Publications, 615 p.

Reid, A.R., 1973, Stratigraphy of the type area of the Roraima Group, Venezuela: Conferencia Geológica Inter-Guayanas, 9th, Ciudad Guayana, Venezuela, 1972, Memoria, Publicación Especial 6, p. 343-353.

Simon, C., Castrillo, J.R., and Munoz, N., 1985, Sedimentología en zonas de Santa Elena de Uairén y Monte Roraima, Estado Bolívar, Venezuela: Congreso Geologico Venezolano, 6th, Caracas, 1985, Memoria, v. 2, p. 1135-1163.

Snelling, N.J., 1963, Age of the Roraima Formation, British Guiana: Nature, v. 198, p. 1079-1080.

Tucker, M.E., 1981, Sedimentary petrology-An introduction: Boston, Blackwell Scientific Publications, 252 p.

Walker, R.G., and Cant, D.J., 1984, Sandy fluvial systems, in Walker, R.G., ed., Facies models (2nd ed.): Geoscience Canada Reprint Series 1, p. 71-87.

William, P., and Rust, B., 1969, The sedimentology of braided rivers: Journal of Sedimentary Petrology, v. 39, p. 649-679.

Yánez, Galo, 1977, Provincia geológica de Roraima-Geología, estructural, y geomorfología de su parte suboriental: Congreso Geológico Venezolano, 5th, Caracas, 1977, v. 2, p. 845-854.

1985, Geología y geomorfología del Grupo Roraima en el sureste de Venezuela: Congreso Geologico Venezolano, 6th, Caracas, 1985, Memoria, v. 2, p. 1243-1306. 

Geology, Geochemistry, and Geophysics of Gold-Quartz Veins in the Pistón de Uroy Area, Estado Bolívar, Venezuela

By Jeffrey C. Wynn, Norman J Page, Gloria Contreras, R.J. Quesada, Barry C. Moring, and Robert L. Oscarson

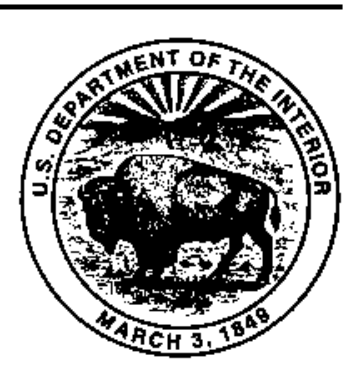




\section{CONTENTS}

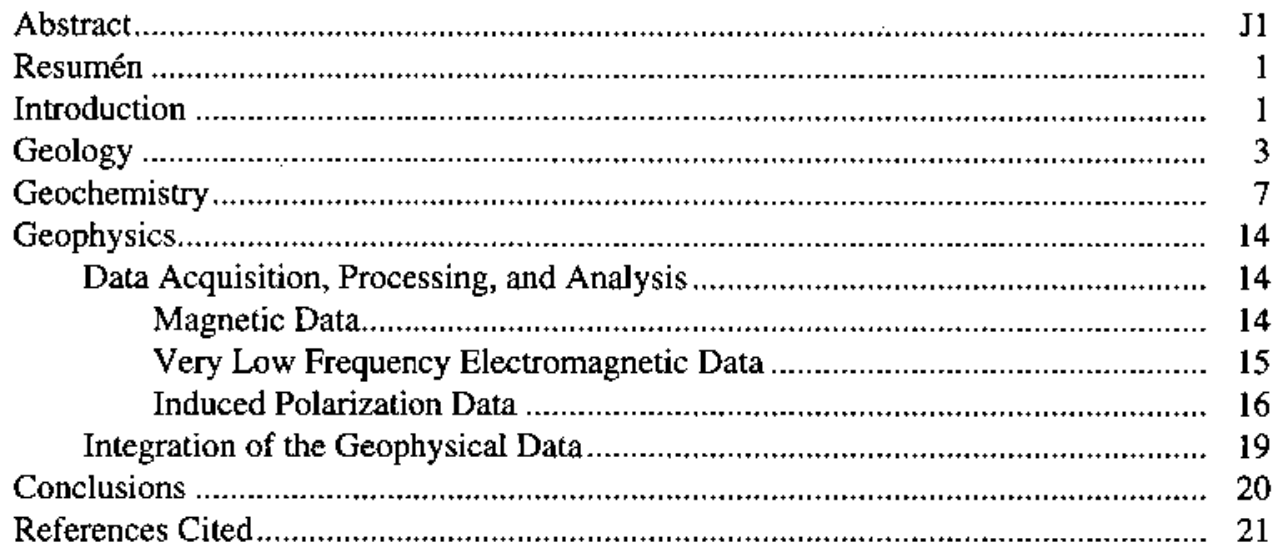

\section{PLATE}

[Plate is in pocket]

1. Schematic geologic map and cross sections, Pistón de Uroy area, Estado Bolívar, Venezuela.

\section{FIGURES}

\section{1, 2. Maps showing:}

1. Location of Pistón de Uroy area

2. Quartz-vein system, geologic grid, and geophysical grid, Pistón de Uroy study area

3. Scanning electron microprobe images and spectrum of sperrylite in composite grain of pyrite-chalcopyrite in altered clinopyroxenite.

4. Chondrite-normalized patterns for clinopyroxene, clinopyroxene-olivine, clinopyroxene-plagioclase, olivine-chromite, and olivine-clinopyroxene-chromite cumulates

5. Total-field magnetic map

6. Magnetic profile showing infered causative body, pica 11 ........................................................................ 15

7. Very low frequency electromagnetic profile along baseline of geologic grid ....................................................... 16

8,9. Maps showing contours of :

8. Gradient-array resistivity data from induced polarization survey acquired on geophysical grid.................... 18

9. Chargeability data from induced polarization survey .............................................................................. 18

10. Resistivity and chargeability profiles along pica 12 of geophysical grid ......................................................... 19

11. Map showing interpretation of magnetic, very low frequency electromagnetic, and induced polarization data and results of geological mapping of quartz-vein system.

\section{TABLES}

1. Trace-element and platinum-group-element analyses of unmineralized rocks from the Pistón de Uroy area .

2. Gold and trace-element analyses of rock and soil samples from quartz veins in the Pistón de Uroy area...

3. Statistical parameters for unqualified values of analyses of quartz-vein material. 


\title{
Geology, Geochemistry, and Geophysics of Gold-Quartz Veins in the Pistón de Uroy Area, Estado Bolívar, Venezuela
}

\author{
By Jeffrey C. Wynn, ${ }^{1}$ Norman J Page, ${ }^{2}$ Gloria Contreras, ${ }^{3}$ R.J. Quesada, ${ }^{4}$ \\ Barry C. Moring, ${ }^{5}$ and Robert L. Oscarson ${ }^{6}$
}

\begin{abstract}
Placer mining has been active in the Pistón de Uroy area of Estado Bolívar, Venezuela, on the middle Río Chicanán since the 1940's. A recently discovered mineralized quartz-vein system in the area is hosted by a mafic-ultramafic complex emplaced in older greenstone-belt rocks of andesitic to basaltic composition. North of the mineralized area, sandstone and quartz-pebble conglomerate of the Roraima Group overlie rocks of the Early Proterozoic greenstone belts. The vein is $1-8 \mathrm{~m}$ or more wide and as long as $3,000 \mathrm{~m}$, and it has a significant gold content, as demonstrated both by direct sampling and by the extensive placer mining activity downstream. In addition, sperrylite (a platinum-bearing mineral) is present in the ultramafic (pyroxenite) rocks. A magnetic survey shows that the pyroxenite dips moderately to the north, and very low frequency electromagnetic data were used to map faulted offsets in the quartz-vein system. Gradient-array resistivity data outline the western extension of the quartz-vein system; the vein system probably extends $700-800 \mathrm{~m}$ farther to the west than mapped on the surface.
\end{abstract}

\section{RESUMEN}

La minería de oro en placeres en la parte media del río Chicanán ha estado activa desde la década de 1940. Recientemente se ha descubierto un sistema mineralizado de

${ }^{1}$ U.S. Geological Survey, Unit 62101, APO AE 09811-2101, USA

${ }^{2}$ U.S. Geological Survey, Corbett Building., 210 E. 7th Street, Tucson, Arizona 85705.

${ }^{3}$ Voie de la Croix, 55000 Behonne, France; formerly Corporación Venezolana de Guayana, Técnica Minera, C.A., Puerto Ordaz, Venezuela.

${ }^{4}$ Urbanización Quebrada de Cariaco, Calle Llamo Adentro, No. 276, Municipio Vargas, Caracas, Venezuela; formerly Corporación Venezolana de Guayana, Técnica Minera, C.A., Puerto Ordaz, Venezuela.

${ }^{5}$ U.S. Geological Survey, 345 Middlefield Road, MS984, Menlo Park, California 94025 .

6U.S. Geological Survey, 345 Middlefield Road, MS916, Menlo Park, California 94025 . vetas de cuarzo, las cuales están encajadas en un complejo máfico-ultramáfico que a su vez está emplazado en rocas verdes (greenstones) más antiguas de composición basaltica a andesítica. Al norte de la zona mineralizada, areniscas y conglomerados de cantos redondeados de cuarzo yacen por encima de los cinturones de rocas verdes de edad Proterozoico Temprano. La veta principal tiene $1 \mathrm{~m}$ de ancho y puede llegar a medir al menos $8 \mathrm{~m}$ de ancho, se extiende hasta $3,000 \mathrm{~m}$ y tiene un contenido de oro significativo, lo cual está indicado por muestreo directo y por la cantidad de actividad minera en placeres aguas abajo. Ademas, el mineral sperrylita, el cual contiene platino, está presente en las rocas ultramáficas (pyroxenita). La prospección magnética muestra que la pyroxenita está buzando moderadamente hacia el norte. La prospección electromagnética de baja frequencia (VLF) fue usada para ubicar segmentos fallados en el sistema de vetas de cuarzo. "Gradient array resistivity data" revelan que el sistema de vetas de cuarzo se extiende entre 700 y $800 \mathrm{~m}$ más hacia el oeste que lo indicado en superficie.

\section{INTRODUCTION}

The Pistón de Uroy area is southwest of El Dorado in Estado Bolívar, north of the Río Chicanán between lat $6^{\circ} 15^{\prime}$ and $6^{\circ} 20^{\prime} \mathrm{N}$. and long $61^{\circ} 51^{\prime}$ and $61^{\circ} 56^{\prime} \mathrm{W}$. (fig. 1). Access to the area is either by air or river; roads to the area do not exist.

Placer deposits of gold have been exploited on the Río Chicanán and its tributaries near Pistón de Uroy since the 1940 's, thus indicating that the area might contain lode sources of gold. During regional reconnaissance, gold was identified in alluvial deposits in the La Franela stream channel and elsewhere in the Pistón de Uroy area, and a complex suite of mafic and ultramafic rocks was identified that is overlain unconformably by sedimentary rocks of the Early to Middle Proterozoic Roraima Group (Alberdi, 1988). Subsequently, in March and November 1988 and February and May 1989, N.J Page, G. Contreras, J.C. Wynn, D. Freitas, J. Quesada, and L. Guilloux conducted the fieldwork that 


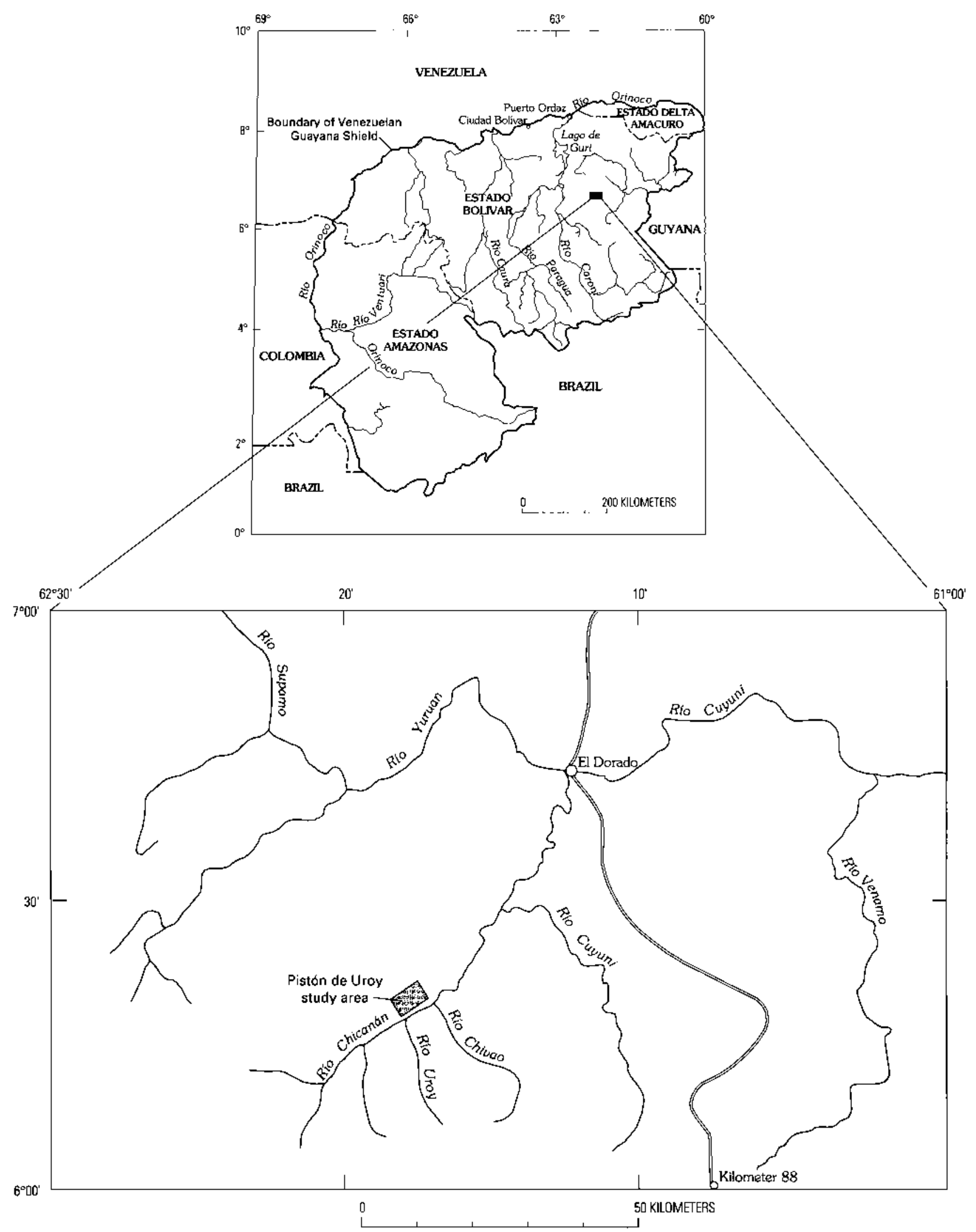

Figure 1. Maps showing location of the Pistón de Uroy study area, Estado Bolívar, Venezuela. 


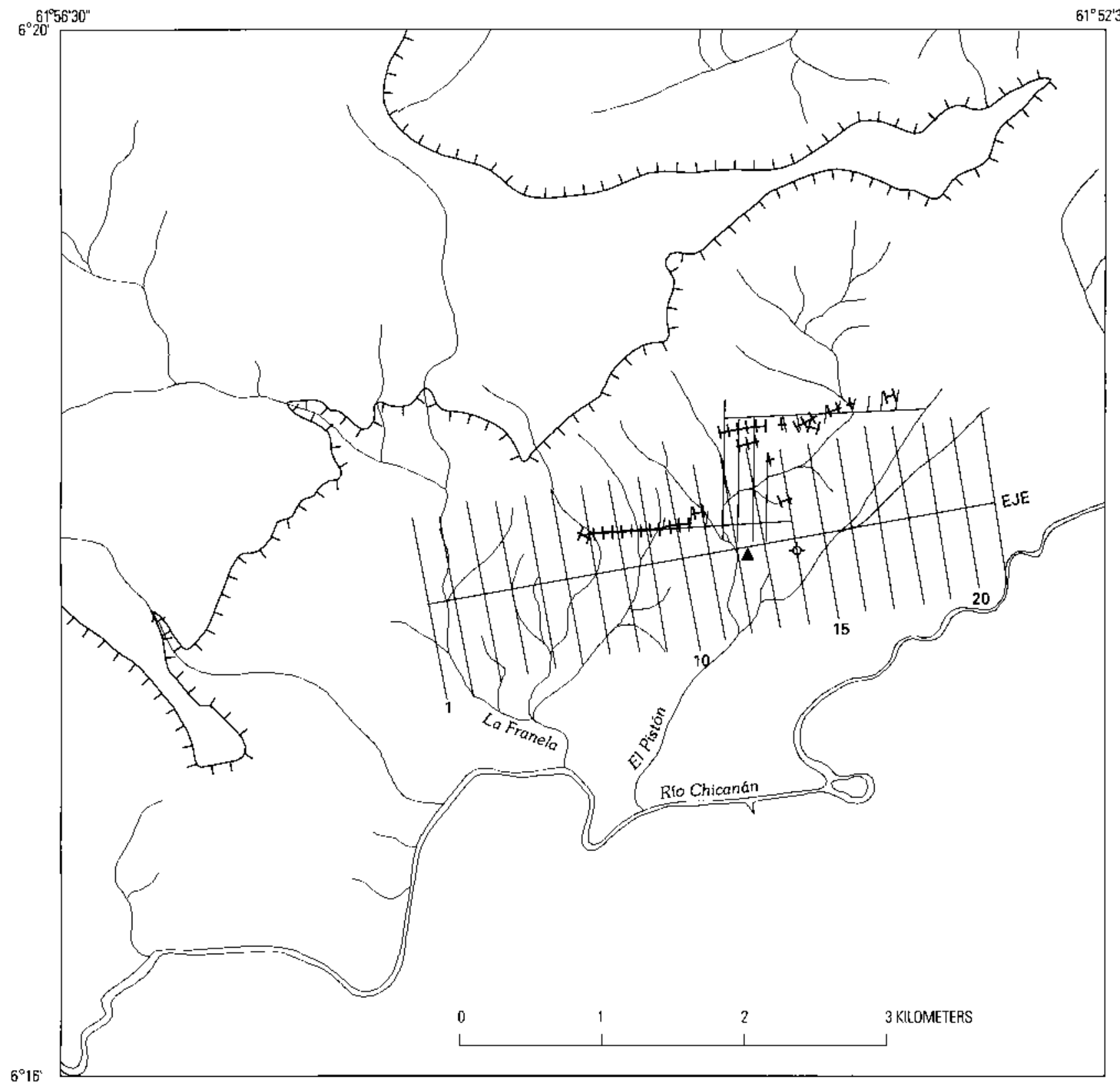

Figure 2. Map showing the quartz-vein system (railroad tracks), geologic grid (smaller, east-west grid parallel with the quartz-vein system), and geophysical grid (larger, regular grid with eje (baseline) trending N. $80^{\circ}$ E. and picas trending north-northwest and numbered from east to west), Pistón de Uroy area, Venezuela. The geophysical camp is shown by a triangle and the local heliport as a circle with four tick marks.

forms the basis for this report. Although some outcrops are present in the drainages and on ridges in the area, the area is heavily forested, and much of the study was conducted using cleared paths or profiles (called picas) at $100-\mathrm{m}$ intervals perpendicular to axes that are subparallel with the strike of the vein structure and the geologic units. The location of the geophysical and geological grids established in the study area and the location of the quartz-vein system are shown in figure 2. Within the context of the regional geology, which is not well known, the structure, lithology, petrology, and geochemistry of the gold-quartz veins and their host rocks in the Pistón de Uroy area are described. Because of the extensive soil and jungle coverage of the area, resistivity, magnetic, and very low frequency electromagnetic geophysical techniques were used to better define the geology.

\section{GEOLOGY}

The Piston de Uroy area forms part of an extensive greenstone belt in which rocks of the Pastora Supergroup 
and the younger Botanamo Group have been reported (Mendoza, 1977; Tosiani and Sifontes, 1989). To the north, between the Río Chicanán and the town of El Dorado, Tosiani and Sifontes (1989) identified gabbro, pyroxenite, and olivine cumulates. More recent work (Floyd Gray, U.S. Geological Survey, oral commun., 1990) confirms the existence of mafic and ultramafic cumulates in this area. This mafic-ultramafic complex was emplaced into andesitic and more siliceous volcanic rocks. Areas east and northeast of Pistón de Uroy are underlain by basaltic and andesitic volcanic rocks intruded by granitic rocks of the Supamo Complex. The greenstone-granite terrane is overlain by rocks of the Roraima Group (Alberdi and Contreras, this volume).

Folded flows, tuffs, and volcaniclastic rocks of andesitic to basaltic composition form the country rocks of a mafic-ultramafic complex that is host to the mineralized quartz-carbonate veins north of Río Chicanán (plate 1). Both groups of rocks are cut by diabase dikes; in addition, the mafic-ultramafic complex is cut by basaltic to andesitic brecciated and porphyritic dikes that are locally mineralized with pyrite and chalcopyrite. These volcanic and plutonic rocks underlie the relatively low (50-100 m relief), rounded hills north of the river. The steep escarpment farther to the north is formed by unconformably overlying rocks of the Roraima Group including sandstone, quartzite, conglomerate, and interlayered mudstone. Extensive colluvial and alluvial deposits cover much of the pre-Roraima Group bedrock, and close to the escarpment large blocks of quartzite, some as big as houses, form talus piles. Major structural features in the area include faults and east-striking quartz veins; the veins are cut by north-northwest-striking faults. On the southeast side of the mafic-ultramafic complex, veins and faults are cut by a northeast-striking fault filled by a diabase dike.

The mafic-ultramafic complex is composed of layered cumulus dunite, wehrlite, and clinopyroxenite and locally foliated, laminated, generally homogeneous gabbro. Layering and lamination strike northwest and dip to the north; modal-, phase-, and size-graded layering are present in the ultramafic rocks. Locally, the gabbro forms phase layers of two-pyroxene plagioclase cumulate and plagioclase cumulate containing oikocrysts of pyroxene. The ultramafic rocks are composed of varying proportions of cumulus olivine, chromite, and clinopyroxene and postcumulus plagioclase, orthopyroxene, and brown homblende. Textures are generally well preserved; however, the primary minerals are partly to totally altered to mixtures of serpentine minerals, talc, amphiboles, and magnetite. Accessory sulfide minerals include chalcopyrite, pyrrhotite, and pyrite; chalcopyrite is the most abundant sulfide mineral in clinopyroxene cumulates.

Olivine and olivine-chromite cumulates contain euhedral to subhedral olivine altered to serpentine minerals and magnetite, accessory amounts of pyrrhotite, chalcopyrite, and pyrite, and euhedral chromite that has secondary magnetite rims. Locally, oikocrysts of orthopyroxene are altered to talc, amphibole, and serpentine minerals. Most of the sulfide minerals are in interstitial spaces or at the margins of cumulus crystals, but rare inclusions of pyrrhotite and chalcopyrite in chromite are present.

Clinopyroxene cumulates consist of euhedral to subhedral, cumulus clinopyroxene that is locally twinned, has spinel exsolution lamellae, and is replaced to some degree by postcumulus brown amphibole. Interstitial postcumulus plagioclase is altered to tremolite-actinolite, chlorite, epidote, clay, and possible zeolite minerals. Some rocks contain oikocrysts of orthopyroxene altered to serpentine minerals and tremolite-actinolite. Primary brown hornblende is present interstitially. Euhedral to subhedral magnetite having exsolution lamellae of ilmenite (?) is also a primary magmatic mineral; both the magnetite and ilmenite are altered to secondary iron oxide minerals. One sample contained both interstitial biotite altered to chlorite and quartz associated with sulfide clots.

Secondary minerals in the clinopyroxene cumulates include green-brown to colorless amphibole that locally forms radiating clusters of crystals, as well as talc, chlorite, magnetite, epidote, and serpentine minerals. Sulfide minerals such as pyrrhotite, chalcopyrite, and pyrite are present as either single- or multi-phase grains and form inclusions in primary magnetite and clinopyroxene; they also are present in interstitial spaces. During the development of secondary amphiboles and other alteration minerals, the sulfide minerals were remobilized to varying degrees and formed intergrowths with the amphiboles. In the more altered rocks, pyrrhotite and chalcopyrite are replaced marginally and along fractures by magnetite. Sparse clusters of pyrite crystals, as much as $1 \mathrm{~mm}$ in diameter, are present. In these clusters, chalcopyrite and pyrrhotite are present both as inclusions in individual pyrite crystals and as interstitial material between pyrite crystals.

Clinopyroxene-olivine, clinopyroxene-orthopyroxene, and clinopyroxene-olivine-chromite cumulates are also present in the mafic-ultramafic complex. Primary and secondary minerals have the same cumulus and alteration textures as in the single-phase cumulates. The clinopyroxene-olivine-chromite cumulate contains only traces of pyrite, and the clinopyroxene-olivine cumulate contains only traces of pyrrhotite and chalcopyrite. These two latter types of cumulates are notably deficient in sulfide mincrals in comparison with other cumulates.

The mafic part of the complex consists of plagioclase-clinopyroxene cumulates and minor amounts of plagioclase-clinopyroxene-orthopyroxene and plagioclase cumulates; all three rock types are locally laminated and modally layered. The plagioclase-clinopyroxene cumulate is composed of euhedral to subhedral cumulus plagioclase and clinopyroxene; postcumulus brown homblende fills interstitial spaces and replaces clinopyroxene. Primary magnetite is also present. Secondary alteration minerals include variously colored amphiboles, chlorite, and epidote. Chalcopyrite, 
Table 1. Trace-element and platinum-group-element analyses of unmineralized rocks from the Pistón de Uroy area, Venezuela.

[Location of samples shown by number on plate 1 . Semiquantitative six-step emission spectrographic analyses are in parts per million except for Ti, which is in percent;

analyst, R. Hopkins. Fire-assay inductively coupled mass spectrometry analyses are in parts per biflion; analysts, P. Aruscavage and G. Riddle. Elements looked for but not detected at levels indicated given (in parts per million): $\mathrm{Ag}(0.5)$, $\mathrm{As}(200)$, $\mathrm{Au}(10), \mathrm{Be}(1), \mathrm{Bi}(10)$, Cd (20), Ge (10), La (50), Mo (5), Nb (20), $\mathrm{Sb}(200)$, Th (100), W (20), and Zn (200).

$\mathrm{N}$ indicates not detected at level shown]

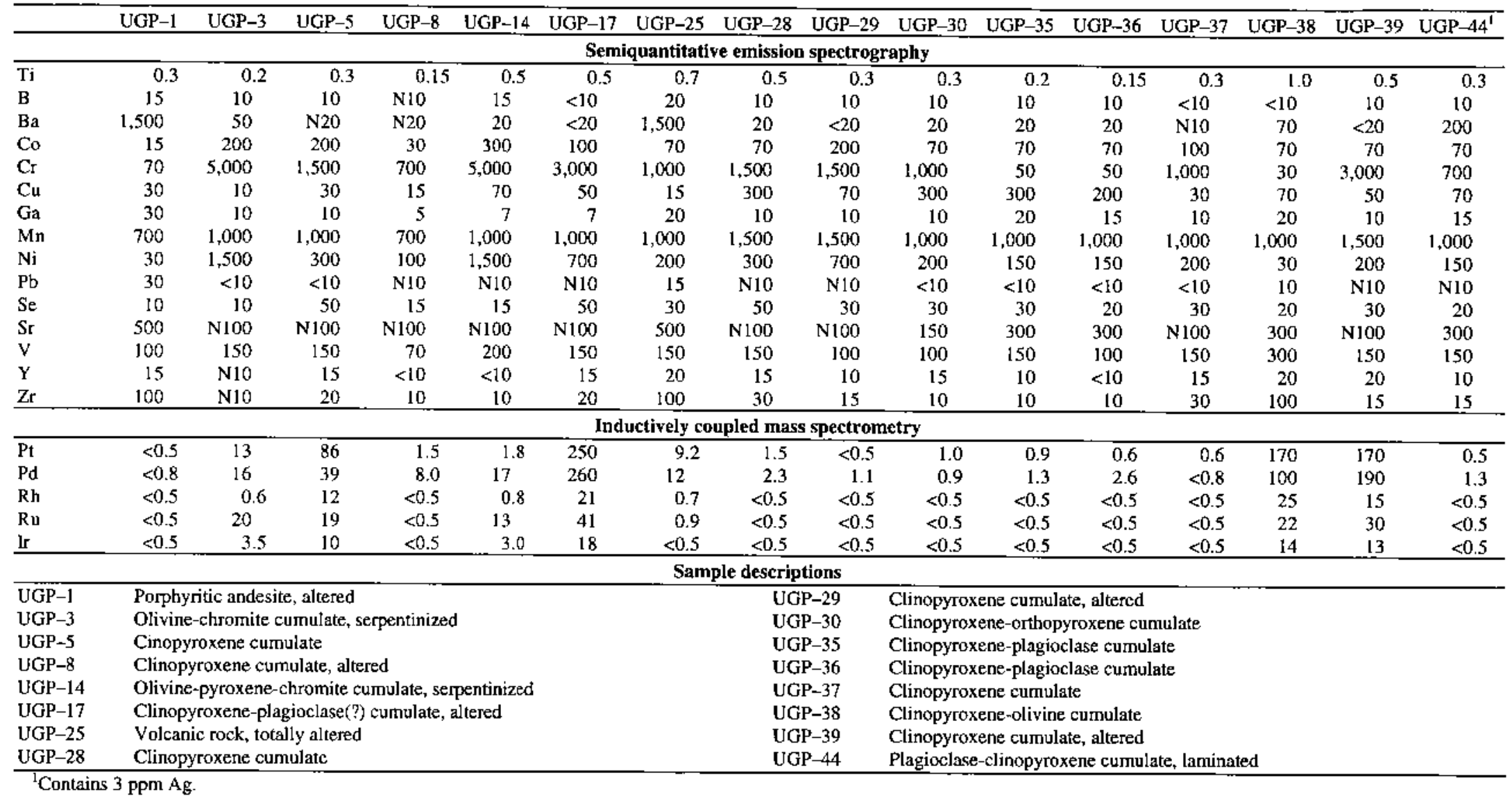


pyrrhotite, and pyritc are present interstitially, and their intergrowth with secondary amphiboles indicates some degree of remobilization of elements in the sulfide minerals during alteration. Locally, pyrite is present as sparsely distributed single crystals as much as $2 \mathrm{~mm}$ in size. In more altered rocks, both chalcopyrite and pyrrhotite are replaced by magnetite, and covellite and chalcocite locally replace chalcopyrite.

The quartz-vein system was mapped in detail between the EI Pistorn drainage and slightly west of the La Franela drainage (fig. 2, plate 1 ). The veins generally strike approximately east and dip steeply south or north. The veins and bands of altered country rock are $1-8 \mathrm{~m}$ wide. Outcrops are sparse in the area; the veins are marked only by blocks of quarz, rare outcrops, and, in places, extensive float. Where outcrop was sufficient, profiles perpendicular to the width of the vein were described, measured, and sampled by chipping across the profile over a measured thickness (plate 1). Elsewhere, chip samples from blocks were collected; sampling was biased toward the more oxide stained parts of the blocks. The contact between gabbro and ultramafic rocks was not observed but was mapped using geophysical information (Quesada and Wynn, 1990).

Quartz-vein material is present in four different geological settings (plate 1): (1) near the southern contact between gabbro and the ultramafic rocks; for example, from east of the La Franela drainage to $0+430 \mathrm{~W}$ on the southern eje; (2) near the northern contact between gabbro and ultramafic rocks; for example, between $0+150$ and $0+650 \mathrm{E}$ on the northern eje; (3) in gabbro; for example, between $1+100$ and $1+100 \mathrm{E}$ on southem eje; and (4) in ultramufic rocks; for example between $0+500$ and $1+000 \mathrm{E}$ on the northem eje. As shown in the cross sections (plate 1), the characteristics of the veins change along their strike and across their width. For example, in outcrops along the La Franela drainage (see profile, plate 1), the vein system consists of several thin (as thick as $20 \mathrm{~cm}$ ) quartz veins and quartz stockwork over a width of about $5 \mathrm{~m}$ in sheared and highly altered ultramafic rocks consisting of talc and serpentine, carbonate, and iron oxide minerals. East of La Franela, the vein is represented by 2-5-m-wide blocks of white quartz or quartz and oxidized material. In general, veins in ultramafic rocks contain less quartz by volume than veins in gabbroic rocks.

The vein material includes white, massive, barren quartz; quartz-carbonate; gray quartz; manganese-ironoxide-brecciated quartz; and vuggy quartz crystals. Alteration minerals consist of talc, amphiboles (?), chlorite, and serpentine, carbonate, and iron oxide minerals in highly sheared rock. All of the surface exposures are oxidized and apparently leached. Sulfide minerals were found only in vein material from a dump of an exploration adit at the eastern end of the vein system.

The veins formed in shear zones, near lithologic contacts or in faults, that strike approximately east. This early generation of structures is cut by faults that trend
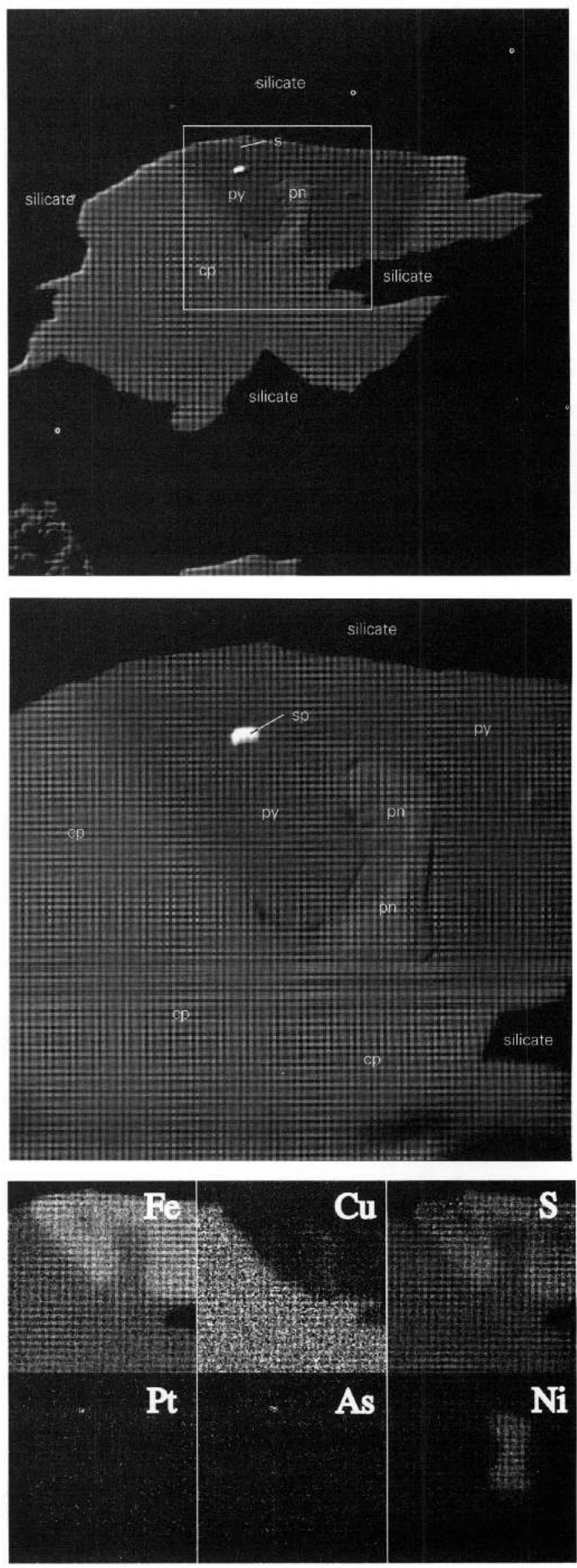


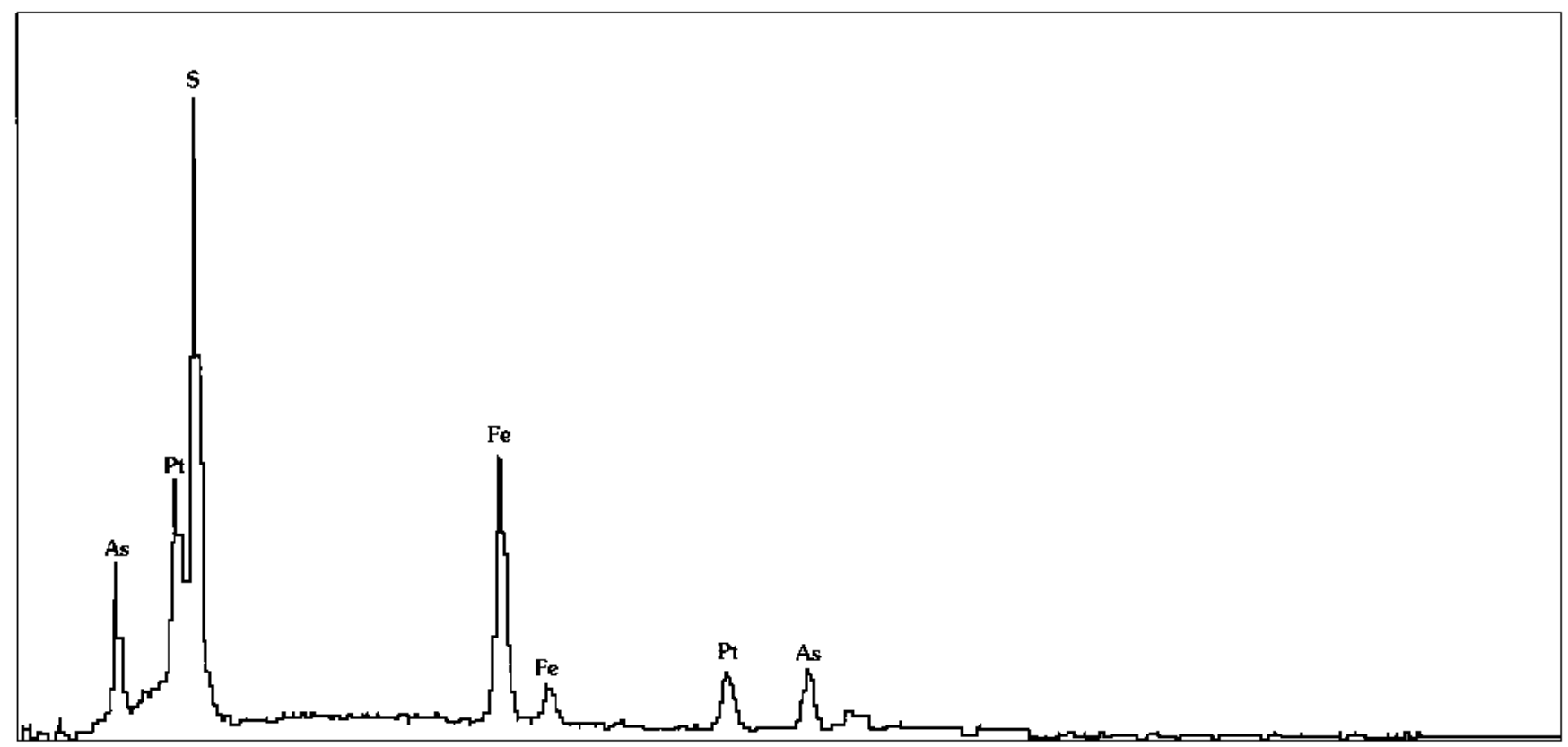

Figure 3 (above and facing column). Scanning electron microprobe images and spectrum of sperrylite in a composite grain of pyrite-chalcopyrite in altered clinopyroxenite, sample UGP-39, Pistón de Uroy area, Venezuela. $A-C$, Backscattered electron images. White area, sperrylite (s); light-gray areas, chalcopyrite (c) and pentlandite (pn); medium-gray area, pyrite (py); black area, silicate minerals. $B$ is an enlargement of the area in $A$ that is shown by the box. $C$, Images for iron, copper, sulfur, platinum, arsenic, and nickel. $D$, Spectrum from the sperrylite grain.

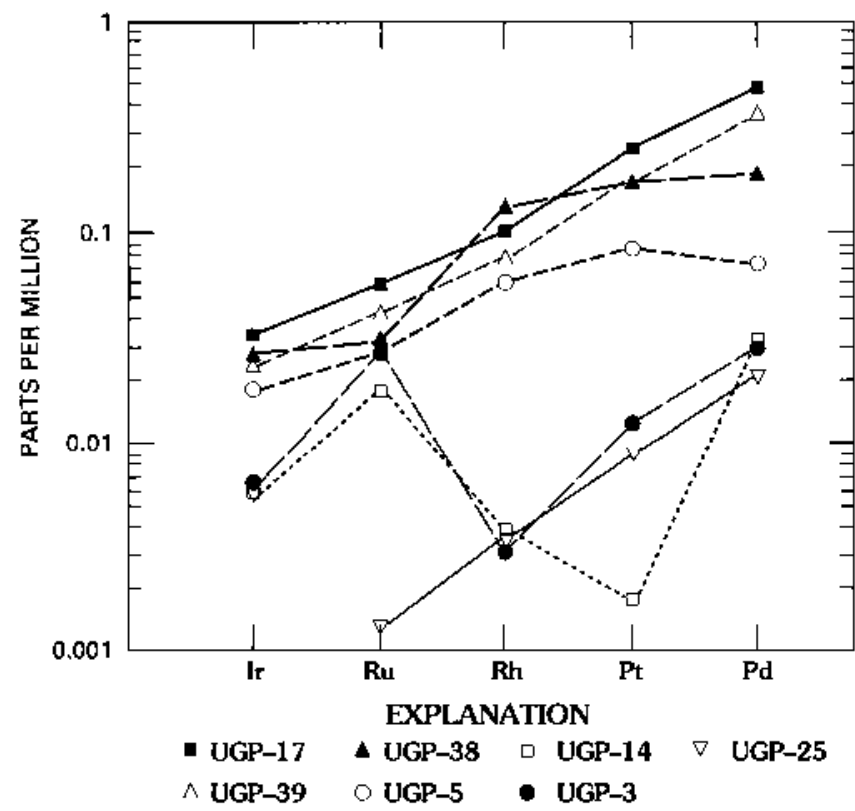

Figure 4. Chondrite-normalized pattens for clinopyroxene (UGP-39, UGP-5), clinopyroxene-olivine (UGP-38), clinopyroxene-plagioclase (UGP-17), olivine-chromite (UGP-3), and olivine-clinopyroxene-chromite (UGP-14) cumulates and a sample of volcanic rock (UGP-25), Pistón de Uroy area, Venezuela. Values used for normalization are from Naldrett (1981). north-northwest and offset the veins. These faults are cut by a third generation of structures that probably are major regional shear zones, such as the faults causing the El Pistón drainage, and are clearly visible in the very low frequency electromagnetic data (described later in this chapter).

\section{GEOCHEMISTRY}

A variety of materials was sampled during the course of the study. Panned concentrates were examined visually for gold (plate 1, VP-number series). In drainages that cross the vein system, samples collected below the veins contain gold. One hundred and nineteen samples of vein material, soil, and weathered adjacent rock were analyzed by semiquantitative six-step emission spectrography (Grimes and Marranzino, 1968) and for platinum-group elements by fire-assay inductively coupled plasma mass spectrometry (Meier and others, 1988). Vein materials and soils were analyzed for Se by hydride-generation atomic absorption, for $\mathrm{Te}$ and $\mathrm{Ti}$ by flameless atomic absorption, for $\mathrm{Hg}$ by cold-vapor atomic absorption, for $\mathrm{F}$ by specific-ion electrode, for $\mathrm{Au}$ by graphite-fumace atomic absorption, and for $\mathrm{As}, \mathrm{Bi}, \mathrm{Cd}, \mathrm{Sb}$, and $\mathrm{Zn}$ by inductively coupled plasma; methods are described by O'Leary and Meier (1986). Table 1 presents analytical results for unmineralized rocks and table 2 analytical results for vein material, soil, and weathered rock samples. 
Table 2. Gold and trace-element analyses of rock and soil samples from quartz veins in the Pistón de Uroy area, Venezuela.

[Location of samples shown by number on piate 1. In parts per million except for $\mathrm{Au}$, which is in parts per billion. $\mathrm{N}$ indicates not detected at level shown; leaders (--) indicate no data available.

Analysts: R. Hopkins, P. Hageman, E. Welsch, F. Tippih, J. Shankey, D. Fey]

\begin{tabular}{|c|c|c|c|c|c|c|c|c|c|c|c|c|c|}
\hline & $\mathrm{VI}$ & $\mathrm{V} 2$ & V3 & $\mathrm{V} 4$ & V5 & V6 & $\mathrm{V7}$ & V8 & V9 & $\mathrm{V} 10$ & $\mathrm{~V} 11 \mathrm{~A}$ & V!1B & $\mathrm{V} 12$ \\
\hline \multicolumn{14}{|c|}{ Gold and trace elements by various methods } \\
\hline$\overline{\mathrm{Au}}$ & 7 & 42 & $<2$ & $<2$ & 4,640 & 320 & 25 & $<2$ & $<2$ & $<2$ & $<2$ & 20 & 600 \\
\hline As & 100 & 1.0 & 0.4 & 4.8 & 5.5 & 170 & 1.8 & 18 & 0.2 & 35 & 1.3 & 4.1 & 54 \\
\hline Cd & -- & -- & -- & -- & -- & -- &.. & -- & -- & -- & -- & -. & -- \\
\hline $\mathrm{Hg}$ & $<0.02$ & $<0.02$ & $<0.02$ & $<0.02$ & $<0.02$ & $<0.02$ & $<0.02$ & $<0.02$ & 0.02 & $<0.02$ & $<0.02$ & 0.08 & 0.02 \\
\hline $\mathrm{Sb}$ & -- & -- & -- & - & $-\cdot$ & -- & -- & -- & -- & -. & .- & -- & -- \\
\hline $\mathrm{Se}$ & 0.3 & $<0.1$ & $<0.1$ & 0.1 & 0.2 & 0.4 & $<0.1$ & $<0.1$ & $<0.1$ & 0.2 & $<0.1$ & 0.1 & 0.3 \\
\hline $\mathrm{Te}$ & $<0.05$ & $<0.05$ & $<0.05$ & $<0.05$ & 0.05 & 0.05 & $<0.05$ & $<0.05$ & 0.15 & $<0.05$ & $<0.05$ & 1.3 & $<0.05$ \\
\hline $\mathrm{Tl}$ & $<0.05$ & $<0.05$ & $<0.05$ & $<0.05$ & 0.20 & 0.15 & $<0.05$ & $<0.05$ & $<0.05$ & $<0.05$ & $<0.05$ & 0.60 & $<0.05$ \\
\hline$\underline{Z_{n}}$ & $\because$ & 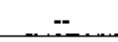 & - & -. & .- & -- & -- & -- & -- & $\ldots$ & -- & -- & -- \\
\hline \multicolumn{14}{|c|}{ Semiquantitative emission spectrography } \\
\hline$\overline{\mathrm{Ag}}$ & N0.5 & N0.5 & N0.5 & N0.5 & N0.5 & N0.5 & N0.5 & N0.5 & N0.5 & N0.5 & N0.5 & N0.5 & N0.5 \\
\hline $\mathrm{Ba}$ & 20 & 30 & 20 & $<20$ & 700 & 30 & 20 & $<20$ & 20 & $<20$ & $<20$ & 700 & $<20$ \\
\hline Co & 200 & N10 & N10 & N10 & 500 & 200 & $<10$ & 30 & N10 & 20 & N10 & 300 & 50 \\
\hline $\mathrm{Cr}$ & 1,000 & 15 & 30 & 30 & 20 & 1,000 & 70 & 700 & 20 & 100 & 20 & 700 & 1,000 \\
\hline $\mathrm{Cu}$ & 50 & $<5$ & N5 & 10 & 300 & 300 & 30 & 50 & 7 & 20 & 7 & 700 & 100 \\
\hline $\mathrm{Mn}$ & 1500 & 30 & 10 & 15 & $>5,000$ & 1,000 & 500 & 200 & 50 & 500 & 150 & $>5,000$ & 700 \\
\hline $\mathrm{Ni}$ & 2,000 & 7 & $<5$ & $<5$ & 150 & 150 & 7 & 100 & $<5$ & 50 & 5 & 300 & 50 \\
\hline $\mathrm{Pb}$ & 10 & N10 & N10 & N10 & $<10$ & 15 & N10 & N 10 & 20 & N10 & N10 & 10 & $<10$ \\
\hline $\mathrm{V}$ & 100 & $<10$ & 15 & 30 & 50 & 150 & 30 & 150 & 20 & 30 & 15 & 70 & 100 \\
\hline & $\mathrm{V} 13$ & V14 & $\mathrm{V} 15$ & V16 & V17 & UV-1-89 & UV $-2-89$ & UV-3-89 & UV-4-89 & UV $-5-89$ & UV $-6-89$ & WV $-7-89$ & UV-8-89 \\
\hline \multicolumn{14}{|c|}{ Gold and trace elements by various methods } \\
\hline Au & 60 & 1100 & 220 & $<2$ & $<2$ & 84 & 40 & $<2$ & 6 & 6 & $<2$ & $<2$ & 950 \\
\hline As & 87 & 430 & 210 & 4.6 & 8.2 & 1,310 & 170 & $<5$ & $<5$ & 12 & 13 & 77 & 161 \\
\hline $\mathrm{Cd}$ & -- & & -. & -- & -- & 0.7 & 0.4 & $<0.1$ & $<0.1$ & $<0.1$ & $<0.1$ & 0.9 & 1.0 \\
\hline $\mathrm{Hg}$ & $<0.02$ & $<0.02$ & $<0.02$ & $<0.02$ & $<0.02$ & 0.20 & 0.02 & N0.02 & No.02 & N0.02 & No.02 & 0.02 & 0.02 \\
\hline $\mathrm{Sb}$ & -- & -- & -- & -- & -- & 6.0 & 2 & $<2$ & 4 & $<2$ & $<2$ & $<2$ & $<2$ \\
\hline $\mathrm{Se}$ & 0.8 & 0.9 & 0.3 & 0.5 & 0.3 & 5.8 & 1.6 & $<0.2$ & $<0.02$ & 0.2 & $<0.02$ & 0.7 & 0.3 \\
\hline $\mathrm{Te}$ & $<0.05$ & 0.25 & $<0.05$ & $<0.05$ & $<0.05$ & 0.4 & 0.05 & $<0.05$ & 0.10 & $<0.05$ & $<0.05$ & 0.10 & 0.15 \\
\hline $\mathrm{Tl}$ & 0.60 & 0.15 & 0.15 & $<0.05$ & $<0.05$ & 0.15 & 0.10 & $<0.05$ & $<0.05$ & $<0.05$ & $<0.05$ & 0.20 & 0.15 \\
\hline $\mathrm{Zn}$ & -- &.- & -- & -. & -- & 40 & 40 & 7 & 53 & 11 & 16 & 101 & 35 \\
\hline \multicolumn{14}{|c|}{ Semiquantitative emission spectrography } \\
\hline$\overline{\mathrm{Ag}}$ & N0.5 & $\overline{\mathrm{N} 0.5}$ & N0.5 & N0.5 & N0.5 & N0.5 & N0.5 & N0.5 & N0.5 & N0.5 & N0.5 & N0.5 & N0.5 \\
\hline $\mathrm{Ba}$ & $<20$ & $<20$ & 70 & 30 & 20 & 70 & 50 & 100 & 300 & 70 & 100 & 300 & 300 \\
\hline Co & 20 & 70 & 150 & 30 & N10 & 50 & 50 & 50 & 300 & 30 & 30 & 300 & 500 \\
\hline $\mathrm{Cr}$ & 300 & 700 & 1,500 & 200 & 70 & 1,000 & 700 & 50 & 50 & 100 & 150 & 700 & 1,000 \\
\hline $\mathrm{Cu}$ & 50 & 50 & 100 & 15 & 15 & 70 & 70 & 30 & 700 & 50 & 50 & 700 & 700 \\
\hline Mn & 300 & 700 & 1,000 & 700 & 100 & 1,500 & 1,000 & 1,500 & $>5,000$ & 1,500 & 1,500 & $>5,000$ & $>5,000$ \\
\hline $\mathrm{Ni}$ & 100 & 500 & 500 & 30 & 7 & 300 & 200 & 70 & 700 & 50 & 100 & 300 & 200 \\
\hline $\mathrm{Pb}$ & $<10$ & 10 & 10 & $\mathrm{~N} 10$ & $<10$ & 15 & 20 & N10 & N10 & N10 & N10 & 15 & 15 \\
\hline v & 50 & 70 & 100 & 70 & 20 & 150 & 100 & 30 & 100 & 70 & 70 & 200 & 150 \\
\hline
\end{tabular}




\begin{tabular}{|c|c|c|c|c|c|c|c|c|c|c|c|c|c|}
\hline & UV-9-89. & UV-10-89 & UV-11-89 & UV-12-89 & UV-13-89 & UV-14-89 & UV-15-89 & UV-16-89 & UV-17-89 & UV-18-89 & UV-19-89 & UV-20-89 & UV-21-89 \\
\hline \multicolumn{14}{|c|}{ Gold and trace elements by various methods } \\
\hline$\overline{\mathrm{Au}}$ & 14 & 12 & 22 & 38 & 1,400 & 400 & 22 & 22 & 350 & 1,600 & 42 & 650 & 12 \\
\hline As & 15 & $<5$ & 7 & $<5$ & 9 & 33 & 21 & 57 & 43 & 19 & 51 & 44 & 20 \\
\hline $\mathrm{Cd}$ & $<0.1$ & $<0.1$ & $<0.1$ & $<0.1$ & 1.2 & 1.3 & 0.4 & 2.0 & 0.7 & 0.8 & 1.7 & 1 & 0.6 \\
\hline $\mathrm{Hg}$ & N0.02 & 0.02 & N0.20 & 0.02 & N0.20 & 1.7 & 0.04 & 0.04 & 0.06 & 0.02 & 0.04 & 0.08 & 0.08 \\
\hline $\mathrm{Sb}$ & $<2$ & $<2$ & $<2$ & $<2$ & $<2$ & $<2$ & $<2$ & $<2$ & $<2$ & $<2$ & $<2$ & $<2$ & $<2$ \\
\hline $\mathrm{Se}$ & $<0.02$ & $<0.02$ & $<0.02$ & $<0.02$ & $<0.02$ & 0.20 & 0.9 & 0.9 & 1.2 & $<0.2$ & 0.4 & 1.4 & 0.9 \\
\hline $\mathrm{Te}$ & $<0.05$ & $<0.05$ & $<0.05$ & $<0.05$ & $<0.05$ & 0.15 & 0.05 & 0.20 & 0.10 & 0.05 & 0.15 & 0.30 & 0.25 \\
\hline $\mathrm{Tl}$ & $<0.05$ & $<0.05$ & $<0.05$ & $<0.05$ & 0.30 & 0.40 & 0.25 & 0.10 & 0.20 & 0.05 & 0.20 & 0.10 & 0.10 \\
\hline$\underline{Z n}$ & 2 & $<2$ & 4. & 2 & 55 & 35 & $\underline{5}$ & 39 & 18 & 37 & 46 & 27 & 16 \\
\hline \multicolumn{14}{|c|}{ Semiquantitative emission spectrography } \\
\hline$\overline{\mathrm{Ag}}$ & N0.5 & N0.5 & 7 & N0.5 & $<0.5$ & 0.5 & N0.5 & No.5 & N0.5 & N0.5 & N0.5 & N0.5 & N0.5 \\
\hline Ba & 20 & 50 & 70 & 30 & 700 & 200 & 200 & 70 & 200 & 20 & 200 & 70 & 70 \\
\hline $\mathrm{Co}$ & $<10$ & 70 & 100 & 70 & 300 & 30 & $\mathrm{~N} 10$ & 70 & 30 & 30 & 50 & 30 & 15 \\
\hline $\mathrm{Cr}$ & 70 & 20 & 50 & 50 & 70 & 500 & 200 & 700 & 200 & 50 & 200 & 200 & 200 \\
\hline $\mathrm{Cu}$ & 30 & 30 & 70 & 30 & 300 & 200 & 100 & 300 & 150 & 150 & 200 & 100 & 100 \\
\hline Mn & 200 & 1,500 & 1,500 & 1,000 & $>5,000$ & 300 & 150 & 200 & 200 & 200 & 200 & 300 & 150 \\
\hline $\mathrm{Ni}$ & 10 & 30 & 30 & 20 & 100 & 50 & 70 & 70 & 70 & 50 & 100 & 50 & 50 \\
\hline $\mathrm{Pb}$ & N10 & $\mathrm{N} 10$ & N10 & N10 & N10 & 15 & 15 & 15 & 15 & 10 & 15 & 15 & 15 \\
\hline $\mathrm{V}$ & 30 & 30 & 30 & 30 & 50 & 150 & 150 & 150 & 150 & 70 & 100 & 150 & 150 \\
\hline & UV-22-89 & UV-23-89 & UV-24-89 & UV-25-89 & UV-26-89 & UV $-27-89$ & UV-28-89 & UV-29-89 & UV-30-89 & UV-31-89 & UV $-32-89$ & UV-33-89 & UV-34-89 \\
\hline \multicolumn{14}{|c|}{ Gold and trace elements by various methods } \\
\hline Au & 950 & 120 & 300 & $350^{\circ}$ & 4 & 42 & 200 & 4200 & 14 & 20 & 16 & 2 & 10 \\
\hline As & 20 & 26 & 20 & 32 & 24 & $<5$ & 366 & 46 & 140 & 84 & 123 & 44 & 99 \\
\hline Cd & 0.9 & 0.9 & 1.2 & 0.9 & $<0.1$ & $<0.1$ & 0.9 & 2.6 & 1.8 & 0.4 & 1.6 & 0.3 & 1.4 \\
\hline $\mathbf{H g}$ & 0.06 & 0.04 & 0.02 & 0.04 & 0.04 & No.02 & $\mathrm{N} 0.02$ & 0.04 & N0.02 & $\mathrm{N} 0.02$ & 0.02 & N0.02 & No.02 \\
\hline Sb & $<2$ & $<2$ & $<2$ & $<2$ & $<2$ & $<2$ & $<2$ & $<2$ & $<2$ & $<2$ & $<2$ & $<2$ & $<2$ \\
\hline $\mathrm{Se}$ & 1.2 & 0.8 & 0.2 & 0.7 & 0.8 & 0.3 & 1.5 & 1.0 & $<0.2$ & $<0.2$ & $<0.2$ & $<0.2$ & $<0.2$ \\
\hline $\mathrm{Te}$ & 0.20 & 0.10 & $<0.05$ & 0.10 & 0.05 & $<0.05$ & 0.20 & 0.35 & 0.05 & $<0.05$ & $<0.05$ & $<0.05$ & $<0.05$ \\
\hline $\mathrm{Tl}$ & 0.20 & 0.25 & 0.20 & 0.20 & 0.05 & 0.05 & 0.05 & 0.15 & $<0.05$ & $<0.05$ & 0.05 & $<0.05$ & 0.05 \\
\hline$\underline{\mathrm{Zn}}$ & 23 & 19 & 36 & 25 & 4 & $<2$ & 51 & 57 & 111 & 107 & 160 & 112 & 116 \\
\hline \multicolumn{14}{|c|}{ Semiquantitative emission spectrography } \\
\hline$\overline{\mathrm{Ag}}$ & N0.5 & N0.5 & N0.5 & N0.5 & N0.5 & N0.5 & N0.5 & N0.5 & N0.5 & N0.5 & N0.5 & N0.5 & N0.5 \\
\hline $\mathrm{Ba}$ & 150 & 200 & 200 & 200 & 70 & 30 & 30 & 100 & 150 & 200 & 500 & 50 & 300 \\
\hline $\mathrm{Co}$ & 30 & 30 & 70 & 50 & $<10$ & N10 & 30 & 70 & 100 & 100 & 150 & 50 & 150 \\
\hline $\mathrm{Cr}$ & 500 & 300 & 150 & 300 & 150 & 100 & 500 & 1,000 & 2,000 & 2,000 & 2,000 & 700 & 2000 \\
\hline $\mathrm{Cu}$ & 300 & 500 & 300 & 300 & 50 & 10 & 50 & 150 & 70 & 150 & 50 & 100 & 300 \\
\hline Mn & 300 & 300 & 200 & 500 & 300 & 150 & 700 & 1,500 & 1,500 & 1,500 & 1,500 & 700 & 1500 \\
\hline $\mathrm{Ni}$ & 70 & 70 & 100 & 100 & 50 & 7 & 150 & 300 & 500 & 500 & 700 & 300 & 700 \\
\hline $\mathrm{Pb}$ & 15 & 15 & 10 & 15 & $<10$ & $<10$ & 15 & 15 & 15 & $<10$ & $<10$ & $<10$ & $<10$ \\
\hline $\mathrm{v}$ & 200 & 200 & 150 & 200 & 100 & 70 & 100 & 150 & 150 & 150 & 150 & 100 & 150 \\
\hline
\end{tabular}


Table 2. Gold and trace-element analyses of rock and soil samples from quartz veins in the Pistón de Uroy area, Venezuela-Continued.

\begin{tabular}{|c|c|c|c|c|c|c|c|c|c|c|c|c|c|}
\hline & UV $-35-89$ & UV-36-89 & UV-37-89 & UV-38-89 & UV-39-89 & UV $-40-89$ & UV $-41-89$ & UV-42-89 & UV $-43-89$ & UV $-45-89$ & UV $-46-89$ & UV $-47-89$ & UV $-48-89$ \\
\hline \multicolumn{14}{|c|}{ Gold and trace elements by various methods } \\
\hline$\overline{\mathrm{Au}}$ & 10 & 4 & 8 & 10 & 2 & 8 & 2 & 300 & 16 & 28 & $<2$ & 10 & 10 \\
\hline As & 68 & 48 & 47 & 109 & 304 & 182 & $<5$ & 10 & 6 & 8 & 13 & 51 & 12 \\
\hline $\mathrm{Cd}$ & 1.4 & 1.9 & $<0.1$ & 1.2 & 0.7 & 0.5 & $<0.1$ & $<0.1$ & $<0.1$ & $<0.1$ & $<0.1$ & 1.4 & $<0.1$ \\
\hline $\mathrm{Hg}$ & N0.02 & N0.02 & No.02 & $\mathrm{N} 0.02$ & 0.02 & 0.02 & 0.02 & 0.04 & N0.02 & 0.02 & N0.02 & N0.02 & No.02 \\
\hline $\mathrm{sb}$ & $<2$ & $<2$ & $<2$ & $<2$ & 4 & $<2$ & $<2$ & $<2$ & $<2$ & $<2$ & $<2$ & $<2$ & $<2$ \\
\hline $\mathrm{Se}$ & $<0.2$ & $<0.2$ & $<0.2$ & $<0.2$ & 0.3 & 0.4 & 0.2 & 0.3 & $<0.2$ & 1.2 & $<0.2$ & 0.5 & $<0.2$ \\
\hline T] & $<0.05$ & $<0.05$ & $<0.05$ & $<0.05$ & 0.05 & 0.10 & $<0.05$ & 0.10 & $<0.05$ & 0.05 & $<0.05$ & 0.05 & $<0.05$ \\
\hline $\mathrm{Ti}$ & 0.10 & 0.05 & $<0.05$ & $<0.05$ & 0.15 & 0.05 & 0.05 & 0.10 & $<0.05$ & $<0.05$ & $<0.05$ & 0.75 & $<0.05$ \\
\hline$\underline{\mathrm{Zn}}$ & 92 & 116 & 25 & 73 & 58 & 40 & 2 & 2 & $<2$ & 31 & 7 & 196 & $<2$ \\
\hline \multicolumn{14}{|c|}{ Semiquantitative emission spectrography } \\
\hline$\overline{\mathrm{Ag}}$ & N0.5 & N0.5 & N0.5 & N0.5 & N0.5 & No.5 & N0.5 & 0.7 & N0.5 & N0.5 & N0.5 & 7 & N0.5 \\
\hline $\mathrm{Ba}$ & 300 & 500 & 100 & 150 & 200 & 20 & 30 & 30 & 70 & $<20$ & 20 & 5,000 & 70 \\
\hline $\mathrm{Co}$ & 100 & 150 & 70 & 200 & 100 & 30 & $<10$ & 30 & N10 & 70 & $<10$ & 1,000 & 15 \\
\hline $\mathrm{Cr}_{\mathrm{r}}$ & 2,000 & 3,000 & 2,000 & 5,000 & 700 & 700 & 100 & 500 & 70 & 1,500 & 150 & 150 & 100 \\
\hline $\mathrm{Cu}$ & 200 & 100 & 200 & 300 & 50 & 30 & 30 & 300 & 20 & 70 & 50 & 1000 & 30 \\
\hline $\mathrm{Mn}$ & 1,500 & 1,500 & 700 & 1,000 & 1,500 & 1,000 & 500 & 1,000 & 300 & 1,500 & 300 & $>5,000$ & 1,000 \\
\hline $\mathrm{Ni}$ & 700 & 700 & 500 & 1,000 & 150 & 100 & 30 & 150 & 7 & 200 & 30 & 300 & 7 \\
\hline $\mathrm{Pb}$ & $<10$ & $<10$ & $<10$ & $<10$ & 10 & $<10$ & $<10$ & NIO & N10 & N 10 & N10 & 15 & NIO \\
\hline \multirow[t]{2}{*}{$\underline{v}$} & 150 & 150 & 150 & 200 & 150 & 150 & 30 & 100 & 30 & 100 & 70 & 150 & 50 \\
\hline & UV $-49-89$ & UV-50-89 & UV-51-89' & UV $-52-89^{2}$ & UV $-53-89^{3}$ & UV $-54-89$ & UV $-55-89$ & UV $-56-89$ & UV $-57-89$ & UV $-58-89$ & UV $-59-89$ & UV $-60-89$ & UV $-61-89$ \\
\hline
\end{tabular}

\begin{tabular}{|c|c|c|c|c|c|c|c|c|c|c|c|c|c|}
\hline \multicolumn{14}{|c|}{ Gold and trace elements by various methods } \\
\hline$\overline{A u}$ & $<2$ & $<2$ & 2 & 10 & 68 & 22 & 30 & 6 & 14 & $<2$ & $<2$ & $<2$ & $<2$ \\
\hline As & 26 & 12 & 62 & 49 & 64 & 270 & 295 & 245 & 38 & 20 & 9 & 6 & $<5$ \\
\hline $\mathrm{Cd}$ & $<0.1$ & $<0.1$ & $<0.1$ & 0.1 & 0.2 & 0.2 & 0.2 & 0.2 & 0.1 & 0.4 & 0.7 & 0.6 & 0.2 \\
\hline $\mathrm{Hg}$ & No.02 & No.02 & 0.08 & 0.02 & 0.02 & No.02 & N0.02 & 0.02 & No.02 & 0.02 & 0.02 & 0.02 & 0.02 \\
\hline $\mathrm{Sb}$ & $<2$ & $<2$ & 2 & 3 & $<2$ & 3 & $<2$ & 3 & $<2$ & $<2$ & $<2$ & $<2$ & $<2$ \\
\hline $\mathrm{Se}$ & 0.6 & $<0.2$ & $<0.2$ & 0.3 & 0.3 & $<0.2$ & 0.3 & 0.6 & $<0.2$ & 0.7 & 0.5 & 0.4 & $<0.2$ \\
\hline $\mathrm{Tl}$ & 0.10 & $<0.05$ & 0.30 & 0.10 & 0.10 & 0.10 & 0.05 & 0.10 & 0.15 & $<0.05$ & $<0.05$ & $<0.05$ & $<0.5$ \\
\hline $\mathrm{Ti}$ & $<0.05$ & $<0.05$ & $<0.05$ & $<0.05$ & $<0.05$ & $<0.05$ & $<0.05$ & $<0.05$ & $<0.05$ & 0.05 & $<0.05$ & $<0.05$ & $<0.05$ \\
\hline Zn & $\leq 2$ & 2 & 29 & 18 & 21 & 80 & 70 & 90 & 50 & 20 & 41 & 47 & 35 \\
\hline \multicolumn{14}{|c|}{ Semiquantitative emission spectrography } \\
\hline$\overline{\mathrm{Ag}}$ & N0.5 & $\overline{\text { N0.5 }}$ & N0.5 & N0.5 & $\mathrm{N} 0.5$ & N0.5 & N0.5 & N.5 & N0.5 & N0.5 & N0.5 & No.5 & N0.5 \\
\hline $\mathrm{Ba}$ & 30 & 30 & $<20$ & 20 & 30 & 100 & 70 & 100 & 30 & 50 & 50 & 100 & 1,000 \\
\hline $\mathrm{Co}$ & $\mathrm{N} 10$ & 100 & 300 & 30 & 70 & 70 & 200 & 200 & 30 & 70 & 70 & 70 & 30 \\
\hline $\mathrm{C}_{\mathbf{r}}$ & 150 & 150 & 200 & 300 & 700 & 700 & 1,000 & 3,000 & 150 & 700 & 1,000 & 1,000 & 100 \\
\hline $\mathrm{Cu}$ & 30 & 20 & 50 & 30 & 70 & 100 & 150 & 150 & 50 & 50 & 50 & 50 & 100 \\
\hline $\mathrm{Mn}$ & 200 & 700 & 1,500 & 1,000 & 700 & 1,000 & 1,500 & 1,500 & 700 & 1500 & 2,000 & 2,000 & 200 \\
\hline $\mathrm{Ni}$ & 15 & 10 & 150 & 150 & 150 & 300 & 700 & 1,000 & 100 & 100 & 150 & 150 & 100 \\
\hline $\mathrm{Pb}$ & $<10$ & NIO & $<10$ & $<10$ & 15 & $<10$ & $<10$ & $<10$ & $<10$ & $<10$ & 10 & 10 & 10 \\
\hline $\mathrm{v}$ & 70 & 50 & 70 & 100 & 150 & 150 & 150 & 200 & 100 & 150 & 200 & 200 & 100 \\
\hline
\end{tabular}


\begin{tabular}{lllllllllllll} 
UV-62-89 & UV-63-89 & UV-64-89 & UV-65-89 & UV-66-89 & UV-67-89 & UV-81-89 & UV-82-89 & UV-83-89 & UV-84-89 & UV-85-89 & UV-86-89 & UV-87-89 \\
\hline
\end{tabular}

\begin{tabular}{|c|c|c|c|c|c|c|c|c|c|c|c|c|c|}
\hline \multicolumn{14}{|c|}{ Gold and trace elements by various methods } \\
\hline Au & $<2$ & $<2$ & $<2$ & $<2$ & $<2$ & $<2$ & $<2$ & $<2$ & $<2$ & 4 & $<2$ & $<2$ & $<2$ \\
\hline As & $<5$ & $<5$ & 17 & 5 & 151 & 11 & 375 & 39 & 29 & 427 & 13 & $<5$ & 46 \\
\hline $\mathrm{Cd}$ & 0.1 & 0.3 & 0.8 & $<0.1$ & 0.4 & $<0.1$ & 0.4 & $<0.1$ & $<0.1$ & 0.3 & $<0.1$ & $<0.1$ & $<0.1$ \\
\hline $\mathrm{Hg}$ & 0.02 & N0.02 & 0.04 & N0.02 & No.02 & N0.02 & $\mathrm{N} 0.02$ & N0.02 & N0.02 & $\mathrm{N} 0.02$ & N0.02 & N0.02 & N0.02 \\
\hline $\mathrm{Sb}$ & $<2$ & $<2$ & $<2$ & $<2$ & $<2$ & $<2$ & $<2$ & $<2$ & $<2$ & 5 & $<2$ & $<2$ & $<2$ \\
\hline Se & $<0.2$ & $<0.2$ & 0.6 & 0.3 & 0.3 & $<0.2$ & 0.9 & $<0.2$ & $<0.2$ & 1.0 & $<0.2$ & $<0.2$ & 0.3 \\
\hline $\mathrm{T} 2$ & 0.20 & 0.25 & 0.30 & $<0.05$ & $<0.5$ & $<0.05$ & 0.25 & $<0.05$ & $<0.05$ & $<0.05$ & $<0.05$ & $<0.05$ & $<0.05$ \\
\hline $\mathrm{Ti}$ & $<0.05$ & $<0.05$ & $<0.05$ & $<0.05$ & $<0.05$ & $<0.05$ & $<0.05$ & $<0.05$ & $<0.05$ & $<0.05$ & $<0.05$ & $<0.05$ & $<0.05$ \\
\hline$\underline{Z n}$ & 5 & 14 & 22 & 6 & 27 & $<2$ & 9 & 2 & 3 & 15 & 2 & $<2$ & 5 \\
\hline \multicolumn{14}{|c|}{ Semiquantitative emission spectrography } \\
\hline $\mathrm{Ag}$ & N0.5 & N0.5 & N0.5 & N0.5 & $\mathrm{N} 0.5$ & N0.5 & $\mathrm{N} 0.5$ & N0.5 & N0.5 & N0.5 & N0.5 & No.5 & N0.5 \\
\hline $\mathrm{Ba}$ & 300 & 50 & 300 & 100 & 200 & 30 & 20 & 20 & 30 & 100 & 30 & 50 & 20 \\
\hline Co & 15 & 20 & 70 & 200 & 100 & N10 & 10 & N10 & N10 & 70 & N10 & N10 & 20 \\
\hline $\mathrm{Cr}$ & 150 & 200 & 300 & 70 & 2,000 & 20 & 500 & 200 & 150 & 700 & 50 & 10 & 200 \\
\hline $\mathrm{Cu}$ & 30 & 30 & 200 & 70 & 100 & 5 & 70 & 30 & 15 & 50 & 30 & 7 & 50 \\
\hline $\mathrm{Mn}$ & 700 & 700 & 3,000 & 3,000 & 1,500 & 700 & 300 & 150 & 500 & 1,500 & 150 & 20 & 700 \\
\hline $\mathrm{Ni}$ & 70 & 100 & 150 & 100 & 500 & 5 & 100 & 30 & 15 & 300 & 20 & 5 & 70 \\
\hline $\mathrm{Pb}$ & $<10$ & $<10$ & 15 & $\mathrm{~N} 10$ & 10 & N10 & 10 & $<10$ & $<10$ & $<10$ & N10 & N10 & N10 \\
\hline $\mathrm{v}$ & 150 & 150 & 200 & 30 & 150 & 20 & 150 & 70 & 50 & 150 & 30 & $<10$ & 70 \\
\hline & UV-88-89 & UV-89-89 & UV-91-89 & UV-92-89 & UV-93-89 & UV-94-89 & UV-95-89 & UV-96-89 & UV-97-89 & UV-98-89 & UV-99-89 & UV-100-89 & \\
\hline \multicolumn{14}{|c|}{ Gold and trace elements by various methods } \\
\hline $\mathrm{Au}$ & 2 & 650 & 2 & 2 & 18 & 4 & 2 & $<2$ & $<2$ & 10 & $\mathrm{~N} 2$ & $\mathrm{~N} 2$ & \\
\hline As & 64 & 695 & 138 & 235 & 50 & 33 & 47 & 79 & 110 & 48 & 9 & $<5$ & \\
\hline Cd & $<0.1$ & 0.9 & $<0.1$ & $<0.1$ & $<0.1$ & $<0.1$ & $<0.1$ & $<0.1$ & $<0.1$ & $<0.1$ & $<0.1$ & $<0.1$ & \\
\hline $\mathrm{Hg}$ & N0.02 & N0.02 & N0.02 & N0.02 & N0.02 & No.02 & 0.04 & N0.02 & N0.02 & No.02 & N0.02 & No.02 & \\
\hline $\mathrm{Sb}$ & $<2$ & 6 & $<2$ & 2 & $<2$ & $<2$ & 5 & 4 & 3 & $<2$ & $<2$ & $<2$ & \\
\hline Se & 0.3 & 1.1 & 1.1 & 0.5 & $<0.2$ & $<0.2$ & 0.3 & 0.3 & 0.3 & 0.3 & 0.3 & $<0.2$ & \\
\hline $\mathrm{Tl}$ & $<0.05$ & 0.40 & 0.35 & 0.65 & $<0.05$ & $<0.05$ & N0.05 & N0.05 & N0.05 & N0.05 & N0.05 & N0.05 & \\
\hline $\mathrm{Ti}$ & $<0.05$ & $<0.05$ & $<0.05$ & $<0.05$ & $<0.05$ & $<0.05$ & N0.05 & N0.05 & No.05 & N0.05 & N0.05 & N0.05 & \\
\hline $\mathrm{Zn}$ & 3. & 32 & 4 & 7 & $<2$ & $<2$ & 4 & 4 & 4 & $<2$ & 4 & $<2$ & \\
\hline \multicolumn{14}{|c|}{ Semiquantitative emission spectrography } \\
\hline $\mathrm{Ag}$ & N0.5 & N0.5 & N0.5 & N0.5 & $\mathrm{N} 0.5$ & N0.5 & - & $\cdots$ & - & $\cdots$ & $\ddot{-\cdot}$ & $\cdots$ & \\
\hline $\mathrm{Ba}$ & 20 & 30 & 30 & 30 & 20 & 30 & -- & -- & -- & -- & -- & -- & \\
\hline Co & $<10$ & 30 & $<10$ & 15 & N10 & N10 & -- & -- & -- & -- & -- & -- & \\
\hline $\mathrm{Cr}$ & 150 & 700 & 200 & 200 & 100 & 150 & 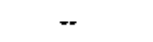 & -- & - & -- & -- & -- & \\
\hline $\mathrm{Cu}$ & 30 & 300 & 50 & 70 & 30 & 20 & -- & -- & -- & -- & -- & -- & \\
\hline Mn & 150 & 300 & 30 & 70 & 50 & 50 & -- & -. & -- & -. & -- & -- & \\
\hline $\mathrm{Ni}$ & 50 & 200 & 50 & 100 & 15 & 20 & -- & -- & -- & -- & $\ldots$ & .. & \\
\hline $\mathrm{Pb}$ & Nio & 15 & N10 & $<10$ & N10 & N10 & -- & -. & -- & -- & .. & -. & \\
\hline $\mathrm{v}$ & 70 & 100 & 70 & 70 & 30 & 50 & -. & -- & -- & -- & -. & .. & \\
\hline
\end{tabular}


Table 2. Gold and trace-element analyses of rock and soil samples from quartz veins in the Pistón de Uroy area, Venezuela—Continued.

\begin{tabular}{|c|c|c|c|c|c|}
\hline \multicolumn{6}{|c|}{ Sample descriptions } \\
\hline V1 & Chip sample of quartz vein & UV-10-89 & Chip sample of oxide-rich quartz, 1 m thick & UV-37-89 & Chip sample of altered, weathered rock \\
\hline v2 & Chip sample of quartz vein & UV-11-89 & $\begin{array}{l}\text { Chip sample of altered, oxide rich quartz vein, } \\
1 \mathrm{~m} \text { thick }\end{array}$ & UV-38-89 & Chip sample of altered rock, $30 \mathrm{~cm}$ thick \\
\hline v3 & Chip sample of quartz vein & UV-12-89 & $\begin{array}{l}\text { Chip sample of white quartz with limonite, } 3 \mathrm{~m} \\
\text { thick }\end{array}$ & UV-39-89 & $\begin{array}{l}\text { Chip sample from block of oxide altered quartz } \\
\text { vein }\end{array}$ \\
\hline V4 & Chip sample of quartz vein & UV-13-89 & Chip sample of foliated quartz blocks & UV $-42-89$ & $\begin{array}{l}\text { Grab sample of gray quartz with visible sulfide } \\
\text { munerals }\end{array}$ \\
\hline vs & Chip sample of quartz vein & UV-14-89 & $\begin{array}{l}\text { Yellow soil, channel sample across } 25-\mathrm{cm} \\
\text { interval }\end{array}$ & UV-43-89 & $\begin{array}{l}\text { Grab sample of vuggy quartz with terminated } \\
\text { quartz crystals }\end{array}$ \\
\hline v6 & Chip sample of quartz vein & UV-15-89 & $\begin{array}{l}\text { Red-brown soil, channel sample across } 50-\mathrm{cm} \\
\text { interval }\end{array}$ & UV $-45-89$ & Grab sample of oxide-rich quartz vein \\
\hline v7 & Chip sample of quartz vein & UV-16-89 & $\begin{array}{l}\text { Yellow soil, channel sample across } 30-\mathrm{cm} \\
\text { interval }\end{array}$ & UV $-46-89$ & $\begin{array}{l}\text { Grab sample of altered pyroxenite, vein country } \\
\text { rock }\end{array}$ \\
\hline v8 & Chip sample of quartz vein & UV-17-89 & $\begin{array}{l}\text { Red-brown soil, channel sample across } 35-\mathrm{cm} \\
\text { interval }\end{array}$ & UV $-47-89$ & Grab samplc of oxide-rich quartz yein \\
\hline v9 & Chip sample of quartz vein & UV-18-89 & $\begin{array}{l}\text { Oxidized quartz vein, channel sample across } \\
40-\mathrm{cm} \text { interval }\end{array}$ & UV $-48-89$ & Grab sample of quartz-vein float \\
\hline V10 & Chip sample of quartz vein & UV $-19-89$ & $\begin{array}{l}\text { Red-brown soil, charnel sample across } 40-\mathrm{cm} \\
\text { interval }\end{array}$ & UV $-49-89$ & Grab sample of quartz vein \\
\hline $\mathrm{V} 11 \mathrm{~A}$ & Chip sample of quartz vein & UV $-20-89$ & $\begin{array}{l}\text { Yellow soil, channel sample across } 20-\mathrm{cm} \\
\text { interval }\end{array}$ & UV $-50-89$ & Grab sample of gray quartz vein \\
\hline V11B & Chip sample of quartz vein & UV-21-89 & $\begin{array}{l}\text { Red-brown soil, channel sample across } 40-\mathrm{cm} \\
\text { interval }\end{array}$ & UV-51-89 & $\begin{array}{l}\text { Chip sample of quartz vein and altered rock, I m } \\
\text { thick }\end{array}$ \\
\hline $\mathrm{V} 12$ & Chip sample of quartz vein & UV $-22-89$ & $\begin{array}{l}\text { Red-brown soil, channel sample across } 20-\mathrm{cm} \\
\text { interval }\end{array}$ & UV-52-89 & $\begin{array}{l}\text { Chip sample of quartz vein and altered rock, } 1 \mathrm{~m} \\
\text { thick }\end{array}$ \\
\hline V13 & Chip sample of quartz vein & UV $-23-89$ & $\begin{array}{l}\text { Red-brown soil, channel sample across } 135 \text {-cm } \\
\text { interval }\end{array}$ & UV-53-89 & $\begin{array}{l}\text { Chip sample of quartz vein and altered rock, } 2.5 \\
\mathrm{~m} \text { thick }\end{array}$ \\
\hline V14 & Chip sample of quartz vein & UV-24-89 & $\begin{array}{l}\text { Red-brown soil, channel sample across } 30-\mathrm{cm} \\
\text { interval }\end{array}$ & UV-54-89 & Quartz stockwork in altered rock, $20 \mathrm{~cm}$ thick \\
\hline V15 & Chip sample of quartz vein & UV $-25-89$ & $\begin{array}{l}\text { Red-brown soil, channel sample across } 150 \text {-cm } \\
\text { interval }\end{array}$ & UV-55-89 & Quartz veinlets in altered rock, $20 \mathrm{~cm}$ thick \\
\hline V16 & Chip sample of quartz vein & UV-26-89 & $\begin{array}{l}\text { Red-brown soil, channel sample across } 150-\mathrm{cm} \\
\text { interval }\end{array}$ & UV-56-89 & Chip sample of quartz vein, $20 \mathrm{~cm}$ thick \\
\hline V17 & Chip sample of quartz vein & UV $-27-89$ & Chip sample from blocks of quartz vein & UV-57-89 & Chip sample of altered rock, $70 \mathrm{~cm}$ thick \\
\hline UV-1-89 & $\begin{array}{l}\text { Chip sample of white quartz vein, } \\
\text { approximately } 5 \mathrm{~m} \text { thick }\end{array}$ & UV-28-89 & $\begin{array}{l}\text { Chip sample from altered quartz-carbonate } \\
\text { boxwork, about } 5 \text { m thick }\end{array}$ & UV-58-89 & $\begin{array}{l}\text { Chip sample of quartz vein and altered rock, } 1.5 \\
\mathrm{~m} \text { thick }\end{array}$ \\
\hline UV-2-89 & $\begin{array}{l}\text { Chip sample of oxide material and quartz from } \\
\text { blocks }\end{array}$ & UV-29-89 & $\begin{array}{l}\text { Chip sample from quartz-carbonate boxwork, } 1 \\
\text { m thick }\end{array}$ & UV-59-89 & $\begin{array}{l}\text { Chip sample of quartz vein and altered rock, } 1.5 \\
m \text { thick }\end{array}$ \\
\hline UV-3-89 & Chip sample of white quartz, $0.5 \mathrm{~m}$ thick & UV-30-89 & $\begin{array}{l}\text { Chip sample from altered ultramafic rock, } 50 \\
\mathrm{~cm} \text { thick }\end{array}$ & UV-60-89 & $\begin{array}{l}\text { Chip sample of quartz vein and altered rock, } 1.5 \\
\text { m thick }\end{array}$ \\
\hline UV $-4-89$ & $\begin{array}{l}\text { Chip sample of gray brecciated quartz, } 2.5 \mathrm{~m} \\
\text { thick }\end{array}$ & UV $-31-89$ & Quartz-casbonate vein, $2 \mathrm{~cm}$ thick & UV-61-89 & Grab sample fragmental, altered volcanic rock \\
\hline UV-5-89 & Chip sample of foliated white quartz, $2 \mathrm{~cm}$ thick & UV-32-89 & Chip sample of altered rock, $50 \mathrm{~cm}$ thick & UV-62-89 & Chip sample of quartz vein, $1 \mathrm{~m}$ thick \\
\hline UV $-6-89$ & $\begin{array}{l}\text { Chip sample of altered, foliated quartz, } 30 \mathrm{~cm} \\
\text { thick }\end{array}$ & UV-33-89 & Quartz-carbonate vein, $2 \mathrm{~cm}$ thick & UV-63-89 & Chip sample of quartz vein, $1 \mathrm{~m}$ thick \\
\hline UV $-7-89$ & $\begin{array}{l}\text { Chip sample of altered ultamafic rock, } 2 \mathrm{~m} \\
\text { thick }\end{array}$ & UV $-34-89$ & Chip sample of altered rock, $120 \mathrm{~cm}$ thick & UV-64-89 & Chip sample from blocks of quartz vein \\
\hline UV-8-89 & Chip sample of foliated oxide quartz, $1 \mathrm{~m}$ thick & UV-35-89 & Quartz-carbonate vein, $2 \mathrm{~cm}$ thick & UV-65-89 & Grab sample oxide-rich quartz vein \\
\hline UV-9-89 & Chip sample of white quart2, $50 \mathrm{~cm}$ thick & $U V-36-89$ & Chip sample of altered rock, $47 \mathrm{~cm}$ thick & UV-66-89 & Chip sample from block of quartz vein \\
\hline
\end{tabular}



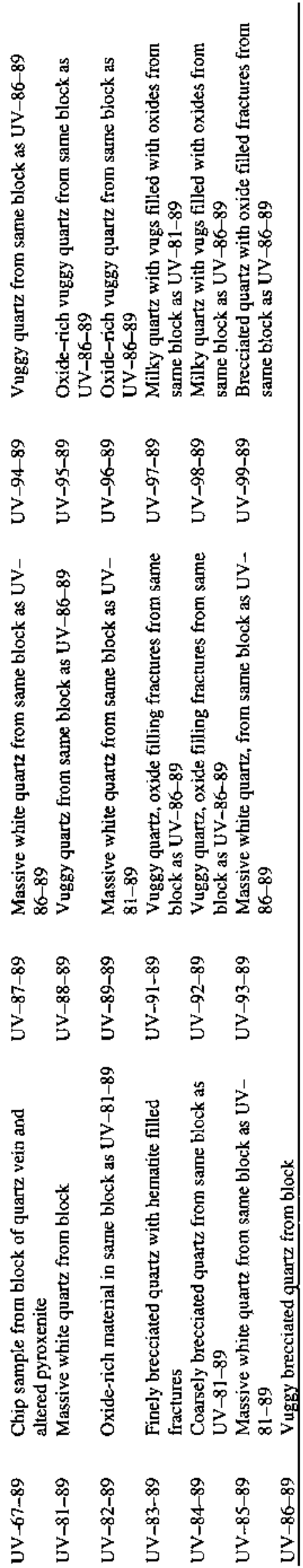

The trace-element content of the rocks is typical of that of ultramafic and mafic rocks. The copper content (table 1) correlates with the amount of chalcopyrite in polished sections and thus reflects well the amount of sulfide minerals in the rocks (table 2). The chromium content in the ultramafic rocks represents the amount of chromite. Some of the rock samples (UGP-5, UGP-17, UGP-38, UGP-39) contain anomalous amounts of platinum-group elements. Although a platinum-group mineral was not identified in the polished sections, sperrylite $\left(\mathrm{PtAs} \mathrm{s}_{2}\right)$ was identified in scanning electron microscope images (see fig. 3). Chondrite-normalized diagrams for the platinum-group elements show that cumulates containing cumulus chromite have a different type of pattern than those for the other types of cumulates, which show positive slopes reflecting the concentration of platinum-group elements by a process associated with sulfide mineral formation (fig. 4). The saw-toothed chondrite-normalized pattem for rocks that contain cumulus chromite may be the result of iridium, ruthenium, and rhodium concentration at the time of chromite precipitation and platinum and palladium concentration at the time of sulfide formation.

Samples UGP-5, UGP-17, UGP-38, and UGP-39 have the highest platinum-group element values and were examined for platinum-group minerals using the scanning electron microscope. Platinum-group minerals were not found in samples UGP-5 and UGP-17. Sample UGP-39 contained a grain of platinum and arsenic enclosed in a composite grain of chalcopyrite (fig. 3). The extremely small size of the grain precluded quantitative analysis; however, the qualitative data suggest that the mineral is sperrylite $\left(\mathrm{PtAs}_{2}\right)$. Sample UGP-38 also contained sperrylite, as well as a (Pt, Te, Ni, As) mineral (possibly moncheite), a (Pt, Fe, Ir) alloy, and a (Pt, Ir, Rh, As, S) mineral (possibly hollingworthite).

Gold in vein material and soil samples ranges from less than 2 to $4,640 \mathrm{ppb}$; the arithmetic mean of unqualified values is $292.6 \mathrm{ppb}$, and the geometric mean is $33.1 \mathrm{ppb}$ (table 2). Arithmetic and geometric means and standard deviation for the number of unqualified values for the analyses of vein material from table 2 are listed in table 3 . Large differences between the arithmetic and geometric means and the relatively large standard deviations indicate the skewed nature of the nomal distributions for most elements. Significant one-to-one correlations of lognormalized data exist between $\mathrm{Mn}, \mathrm{Co}, \mathrm{Cr}, \mathrm{Cu}$, and $\mathrm{Ni} ; \mathrm{Cr}, \mathrm{Mn}$, and $\mathrm{Ni}$; $\mathrm{Ni}$ and $\mathrm{Zn} ; \mathrm{As}, \mathrm{Ni}$ and $\mathrm{Se} ; \mathrm{Se}$ and $\mathrm{Tl} ; \mathrm{Tl}$ and $\mathrm{Hg} ; \mathrm{Ba}, \mathrm{Co}$, and $\mathrm{Cu}$; and $\mathrm{Au}$ and $\mathrm{Cd}$. The correlation with manganese reflects the development of manganese-iron oxide minerals and the absorption of other elements such as copper during weathering. The associations of arsenic, selenium, and tellurium probably reflect introduced materials related to mineralization.

In order to ascertain relations between metallic elements and elements other than gold, the data set in table 2 
Table 3. Statistical parameters for unqualified values of analyses of quartz-vein material given in table 2 .

[In parts per million except for gold, which is in parts per billion]

\begin{tabular}{lcccc}
\hline & Mean & $\begin{array}{c}\text { Standard } \\
\text { deviation }\end{array}$ & $\begin{array}{c}\text { Geometric } \\
\text { mean }\end{array}$ & $\begin{array}{c}\text { Number of } \\
\text { unqualified values }\end{array}$ \\
\hline $\mathrm{Au}$ & 292.6 & 793.6 & 33.1 & 69 \\
$\mathrm{As}$ & 103.8 & 189.8 & 35.5 & 93 \\
$\mathrm{Cd}$ & 0.83 & 0.58 & 0.63 & 47 \\
$\mathrm{Hg}$ & 0.08 & 0.26 & 0.03 & 42 \\
$\mathrm{Sb}$ & 4.1 & 1.5 & 3.8 & 14 \\
$\mathrm{Se}$ & 0.65 & 0.76 & 0.48 & 62 \\
$\mathrm{Te}$ & 0.19 & 0.21 & 0.14 & 46 \\
$\mathrm{Tl}$ & 0.18 & 0.17 & 0.13 & 37 \\
$\mathrm{Zn}$ & 37.1 & 39.7 & 19.2 & 75 \\
$\mathrm{Ag}$ & 3.8 & 3.7 & 2.0 & 4 \\
$\mathrm{Ba}$ & 188.0 & 548.2 & 75.4 & 88 \\
$\mathrm{Co}$ & 109.9 & 146.7 & 66.2 & 74 \\
$\mathrm{Cr}$ & 598.0 & 805.2 & 260.5 & 98 \\
$\mathrm{Cu}$ & 134.7 & 178.9 & 70.9 & 96 \\
$\mathrm{Mn}$ & $1,683.4$ & $1,262.5$ & 547.6 & 98 \\
$\mathrm{Ni}$ & 205.0 & 292.6 & 89.5 & 95 \\
$\mathrm{~Pb}$ & 13.6 & 2.8 & 13.3 & 36 \\
$\mathrm{~V}$ & 104.0 & 55.9 & 85.3 & 96 \\
\hline
\end{tabular}

was split into sets of groups. In one split, samples containing less than $2 \mathrm{ppb} \mathrm{Au}$ were separated from samples having unqualified values. Mean values for arsenic, copper, and zinc of these two sample groups are different at a 99 percent confidence level, and mean values for cadmium, chromium, mercury, and nickel are different at a 95 percent confidence level. In another split, samples whose gold content is above the mode of gold contents and below the mode were tested; only the means for cadmium, zinc, and copper showed significant differences between the two groups of samples. The significant differences in means of elements of the sample groups split on gold content may indicate that these elements were introduced to the vein system during mineralization. Copper and zinc probably are the best pathfinder elements for rocks that contain gold.

\section{GEOPHYSICS}

Soil and jungle cover is extensive in the Pistón de Uroy area, and several geophysical methods were used in order to obtain information on the buried rocks that host the quartz-vein system. Surveys were made using magnetic, induced polarization, and very low frequency electromagnetic methods. In addition, a group of students from Universidad de Simon Bolívar (Caracas) conducted a gravity survey at Pistón de Uroy (V.R. Graterol, written commun., 1989), but the data are not usable because local topography is steep, and topographic data were not collected for topographic corrections.
Following the initial geologic mapping, a grid was carefully surveyed and marked in anticipation of the geophysical surveys (plate 1 ). This grid is subsequently referred to as the geophysical grid to distinguish it from the original geologic (reconnaissance) grid (fig. 2). Traverse lines, called picas, were spaced $200 \mathrm{~m}$ apart along the 4-km-long baseline, called the eje. The eje is oriented N. $80^{\circ} \mathrm{E}$., and the picas are oriented perpendicular to the eje. In part because the topography is more nugged near the scarp of the Roraima Group to the north, all of the northem part of the quartz-vein system discovered during the geological mapping (see fig. 2) was not adequately sampled using the geophysical methods.

\section{DATA ACQUISITION, PROCESSING, AND ANALYSIS}

\section{MAGNETIC DATA}

Total-field magnetic data were acquired in January and May 1989 at 20 -m intervals along both the geological and geophysical grids using Geometrics model 816 and Scintrex model MP-2 magnetometers. A base station magnetometer was unavailable, but base stations were remeasured, on average, every one or two hours. The data were given UTM coordinates and reduced for drift (diurnal) correction using a computer program called SPDM3 (Alí Fernández, Corporación Venezolana de Guayana, Técnica Minera, C.A., written commun., 1989) and were gridded and plotted using a commercial software package called GDM developed by the Bureau de Recherches Géologique et Minières (fig. 5). The contoured data show a distinctive linear anomaly in the northern part of the geophysical grid caused by a strongly magnetic body trending roughly $\mathrm{N} .75^{\circ} \mathrm{E}$. This anomaly correlates closely with peridotite outcrops and may be caused by the ultramafic body mapped by Page and Contreras (written commun. from Norman J Page, U.S. Geological Survey, and Gloria Contreras, Técnica Minera, C.A., March 9, 1988, to Vicente Mendoza and César Gutiérrez, Técnica Minera, C.A., and February 16, 1989, to Vicente Mendoza, Fernando Susach, and Nestor Angulo, Técnica Minera, C.A.) (see also Contreras and Freites, 1989). The anomaly suggests that a larger continuous peridotite body is present in the subsurface.

A series of two-dimensional models was calculated along the picas using the MAGMOD3 software by Geosoft in an attempt to outline the surface trace of the peridotite body. This modeling is particularly important because the inclination of the Earth's magnetic field at Piston de Uroy of about $31^{\circ}$ leads to strong distortion and to lateral shifts of the anomalies from their source rocks. Figure 6 shows the magnetic data with the modeled causative body from pica 11 , approximately in the middle of the geophysical grid. When 


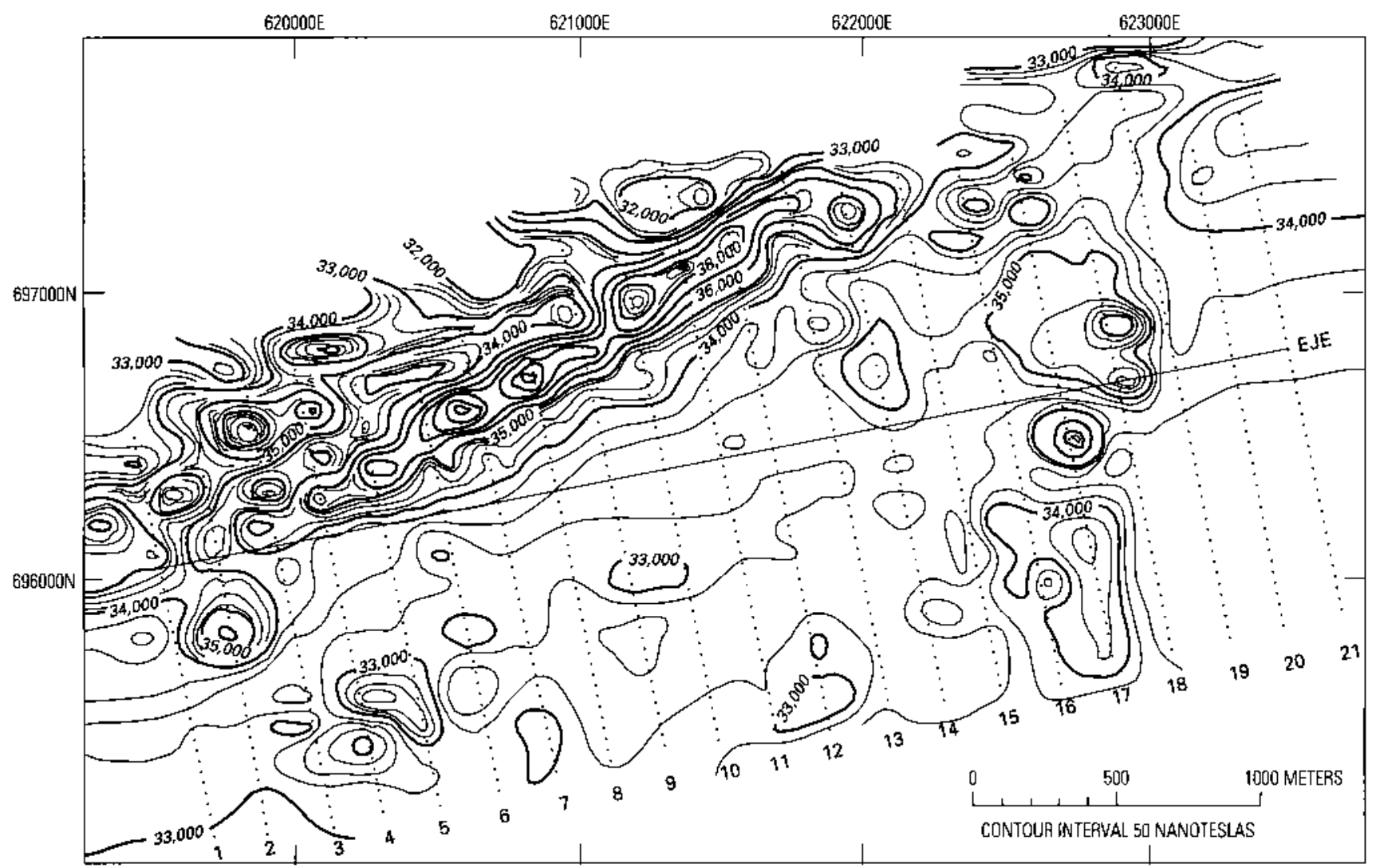

Figure 5. Total-field magnetic map for the Pistón de Uroy area, Venezuela. Geophysical grid is shown in figure 2 . Contour interval 50 nanoteslas (nT); dots show station locations along picas (traverse lines).

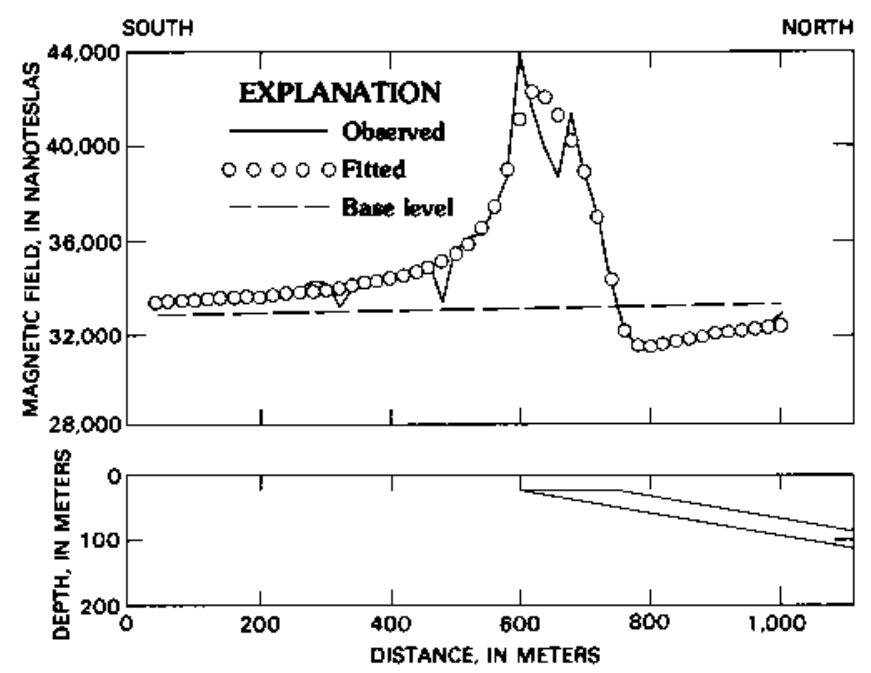

Figure 6. Magnetic model profile showing inferred causative body, pica 11 of geophysical grid shown in figure 2, Pistón de Uroy area, Venezuela. The best susceptibility fit uses a long, narrow body that is buried $24 \mathrm{~m}$ below the surface, dips $10^{\circ} \mathrm{N}$, and has a half-width of $72 \mathrm{~m}$. The modeled susceptibility is $0.358 \mathrm{emu}$. The Earth's field strength is taken to be $32,700 \mathrm{nT}$, field inclination $31^{\circ}$, and declination $-11^{\circ}$. See text for discussion. the model results were combined, it was possible to infer, in map view, the location, size, and dip of the peridotite body.

\section{VERY LOW FREQUENCY ELECTROMAGNETIC DATA}

Recognition of offsets and truncations of the quartz veins early in the geological mapping phase (Norman J Page and Gloria Contreras, written commun., March 9, 1988, to Vicente Mendoza and César Gutiérrez) led to speculation about a late-stage series of offsetting faults, apparently striking north. In an attempt to correlate probable offsets in two parts of the quartz-vein system, very low frequency electromagnetic measurements were made. Because the transmitting station was oriented almost due north, only the positive crossovers (that is, where dip angles of the very low frequency electromagnetic field are positive to the left, negative to the right) indicate the presence of a conductor (for instance, a water- and gouge-filled fault or narrow shear zone) at the midpoint (see fig. 7). The very low frequency electromagnetic method allows rapid reconnaissance (data can be acquired at almost the speed at which one can walk), but it is relatively limited in depth penetration (about 60-100 $m$ in resistivities such as those encountered at Pistón de 


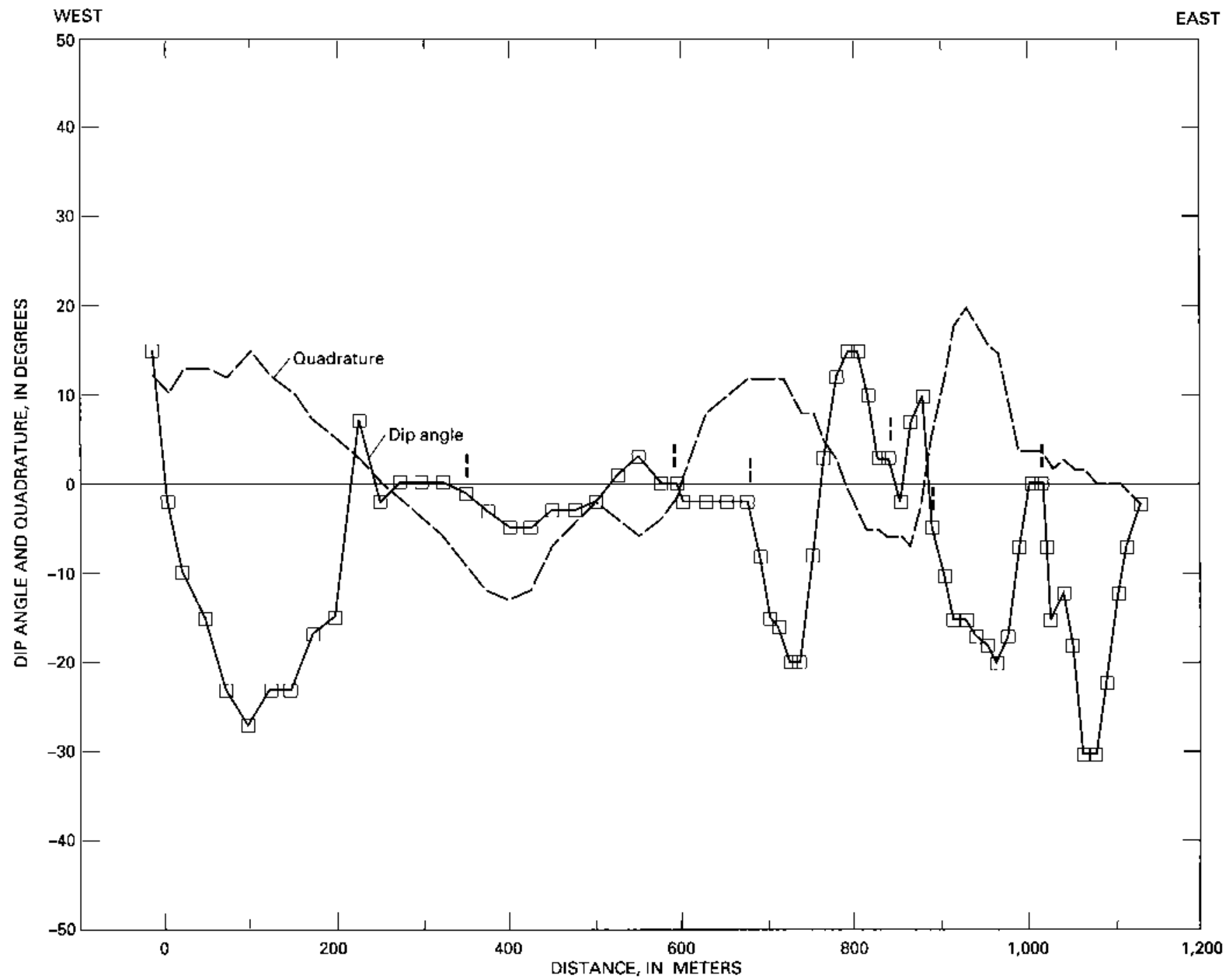

Figure 7. Very low frequency electromagnetic profile along the baseline (eje) of the geologic grid shown in figure 2, Pistón de Uroy area, Venezuela. The vertical dashed bars indicate probable water-filled faults that offset the quartz-vein system.

Uroy). The depth of penetration depends on the resistivity of the uppermost materials being measured.

Very low frequency electromagnetic data were acquired in January 1989 using a Geonics EM-16 system and were plotted (fig. 7) using conventions discussed in Fraser (1969). An insufficient number of parallel profiles were acquired to justify a derivative filter approach (Fraser, 1969). Two profiles were made, one along the geologic baseline or eje (fig. 2) and one parallel with it but $100 \mathrm{~m}$ to the north. Correlation of crossovers between these two parallel lines supports the possibility that a series of faults striking about $\mathrm{N} .10^{\circ} \mathrm{W}$. offsets the quartz-vein system in several places (shown by the vertical bars in fig. 7). In addition, large (as much as $30^{\circ}$ ) dip angles at $00 \mathrm{~m}$ and $1,000 \mathrm{~m}$ suggest that two major conductors (large, water-filled fault zones) are coincident with the La Franela and El Pistón stream channels (fig. 2).

\section{INDUCED POLARIZATION DATA}

Since World War II, the induced polarization (IP) method has been used successfully to detect disseminated sulfide minerals in rocks (Sumner, 1976). During the 1970's, it was determined that the induced polarization method could be used as a mapping tool by outlining systematic variations in clay and metallic sulfide mineral contents (Zonge and Wynn, 1975). In some cases, the induced polarization method can detect the presence of pyrite in amounts of less than 0.1 percent and thus is an ideal tool to assist in separating otherwise indistinguishable lithologies. The induced polarization effect is caused by frequency-dependent variations in resistivity; consequently, resistivity data are obtained during induced polarization measurements as additional information. Variations in resistivity normally correlate closely with porosity, at least in the absence of 
heterogeneities such as clay layers or metallic sulfide minerals. The more water present (for example, in a fault zone), the lower the apparent resistivity. Induced polarization data were collected in the Pistón de Uroy area to assist in mapping hidden fault zones and to delineate the buried rock units that may have controlled emplacement of the quartz veins.

Time-domain induced polarization data were collected over most of the geophysical grid in May 1989 using the gradient array configuration (Sumner, 1976; Alí Fernández, written commun., 1989) and a Scintrex TSQ series transmitter and IPR-10A time-domain receiver. A transmitter dipole $3,000 \mathrm{~m}$ long was set up along a pica, and smaller receiver dipoles were used both inline - that is, along the same pica, but only inside the center $2,000-\mathrm{m}$ zone of the transmitter-and as many as two picas ( $400 \mathrm{~m})$ away offline. Both $40-\mathrm{m}$ and $80-\mathrm{m}$ receiver dipole lengths were used, and receiver dipoles were moved $20 \mathrm{~m}$ between measurements. The 40-m receiver dipole data are not shown here because they are incomplete due to noise; commonly, the field operators did not record the values because the receiver would not stabilize. The 80-m data were given UTM coordinates and reduced to apparent resistivity values using a computer program called POLARIN (Alí Fernández, written commun., 1989). They were smoothed using a five-point low-pass filter and plotted using Lotus Symphony (for profiles) and SURFER4 (for plan maps).

Figure 8 represents a plan view of the resistivity data for 80-m dipoles acquired along the picas of the geophysical grid in the Pistón de Uroy area. The data show four anomalous (resistive) zones in a host-rock resistivity background of about $1,000 \mathrm{ohm}-\mathrm{m}$.

In the western half of the map area (fig. 8), north of the eje, a high-resistivity (as much as 4,000 ohm-m) linear anomaly strikes about N, $80^{\circ} \mathrm{E}$. and probably coincides with the eastern part of the western quartz-vein system. Mapping of the quartz-vein system in this area shows true widths of as much as $5 \mathrm{~m}$. The resistive anomaly is truncated toward the east at about pica 11 , in exactly the same manner as the mapped quartz vein, and probably extends westward at least as far as pica 2. This coincidence is remarkable for two reasons: one, it implies that the quartz-vein system has sufficient volume to be recognizable even with dilution of the resistivity by the surrounding rock, and, two, it signifies that the vein may extend at least $700-800 \mathrm{~m}$ farther to the west than is shown by surface mapping. This Iatter obscryation also implies that the vein is subparallel with, but eventually cuts, the peridotite body at an oblique angle, a relation that makes the quartz-vein system one of the youngest geological features in the area.

The unusual size or volume of the vein system contributes to its potentially economic importance. Note that with an $80-\mathrm{m}$ receiver dipole, the induced polarization system is sampling and averaging over a roughly hemispherical volume of rock centered around the dipole. Dilution of the resistivity by the surrounding rocks and soils to the resistivity contribution of a 2-5-m-wide quartz vein should therefore be substantial. Initially, it was expected that the induced polarization data would help in mapping rock types. A weak induced polarization anomaly over this part of the quartz-vein system is remarkable, which suggests that the total volume of the quartz-vein system is large.

Just south of the linear, so-called quartz-vein anomaly shown in figure 8 is a strong, discrete anomaly that is only expressed on picas 8 and 9 . Resistivity values are greater than $9,000 \mathrm{ohm}-\mathrm{m}$. The source body strikes N. $40^{\circ} \mathrm{E}$. and is as wide as $200 \mathrm{~m}$ and at least as long as $350 \mathrm{~m}$. The exact nature of the source is not clear, but it may be related to a gabbro inferred to be present from isolated float in the area of the anomaly. The source body may connect with another body to the east.

The third resistivity anomaly is an apparent eastern extension of the second. A profile across it is discussed following. In one place (pica 14), resistivity of more than 20,000 ohm-m suggests a dense, extremely low porosity, possibly silica-flooded rock. Although it is possible that current leakage caused this high apparent resistivity, it is unlikely because the high resistivity is coherent across several picas.

A fourth resistivity anomaly of as much as 9,000 ohm-m is parallel with the third anomaly but farther to the south. Comparison of the 40- and $80-\mathrm{m}$ receiver dipole data for this southeastern anomaly suggests that the source body may dip south-southeast. This interpretation is not as certain as the dip (calculated from magnetic models) of the peridotite body farther to the north, which dips north.

Figure 9 represents a plan view of the chargeability data from the induced polarization survey. Though filtered by the contouring package, the substantial amplitude of the noise nevertheless is evident; the noise is even greater in the $40-\mathrm{m}$ receiver dipole data. Two or three anomalies are clearly visible in figure 9. The westernmost anomaly is south of the eje, completely on pica 7 , and probably is unrelated to the resistivity anomaly on picas 8 and 9 . This anomaly has characteristics that suggest it is cultural in origin. Although a geologic origin cannot be completely excluded, the anomaly probably reflects buried debris left by miners working in the area.

The second most obvious chargeability anomaly shown in figure 9 is a linear feature about $100 \mathrm{~m}$ wide along profile, parallel with and about $150 \mathrm{~m}$ north of the eje, starting about pica 9 and extending at least $700 \mathrm{~m}$ through pica 12 . Chargeabilities are as high as $60 \mathrm{msec}$ on pica 10 and as high as 50 msec on pica 12 (see below). These relatively high values are probably due to disseminated pyrite (or possibly ilmenite), probably at least 2-3 percent by volume. This anomaly is close to, but not coincident with, the resistivity anomaly that is correlated with the western quartz-vein system. The area of the anomaly is a primary drill target.

Figure 10 shows a resistivity and chargeability profile along pica 12; these data are for an $80-\mathrm{m}$ receiver dipole length. The chargeability data are relatively noisy, primarily 


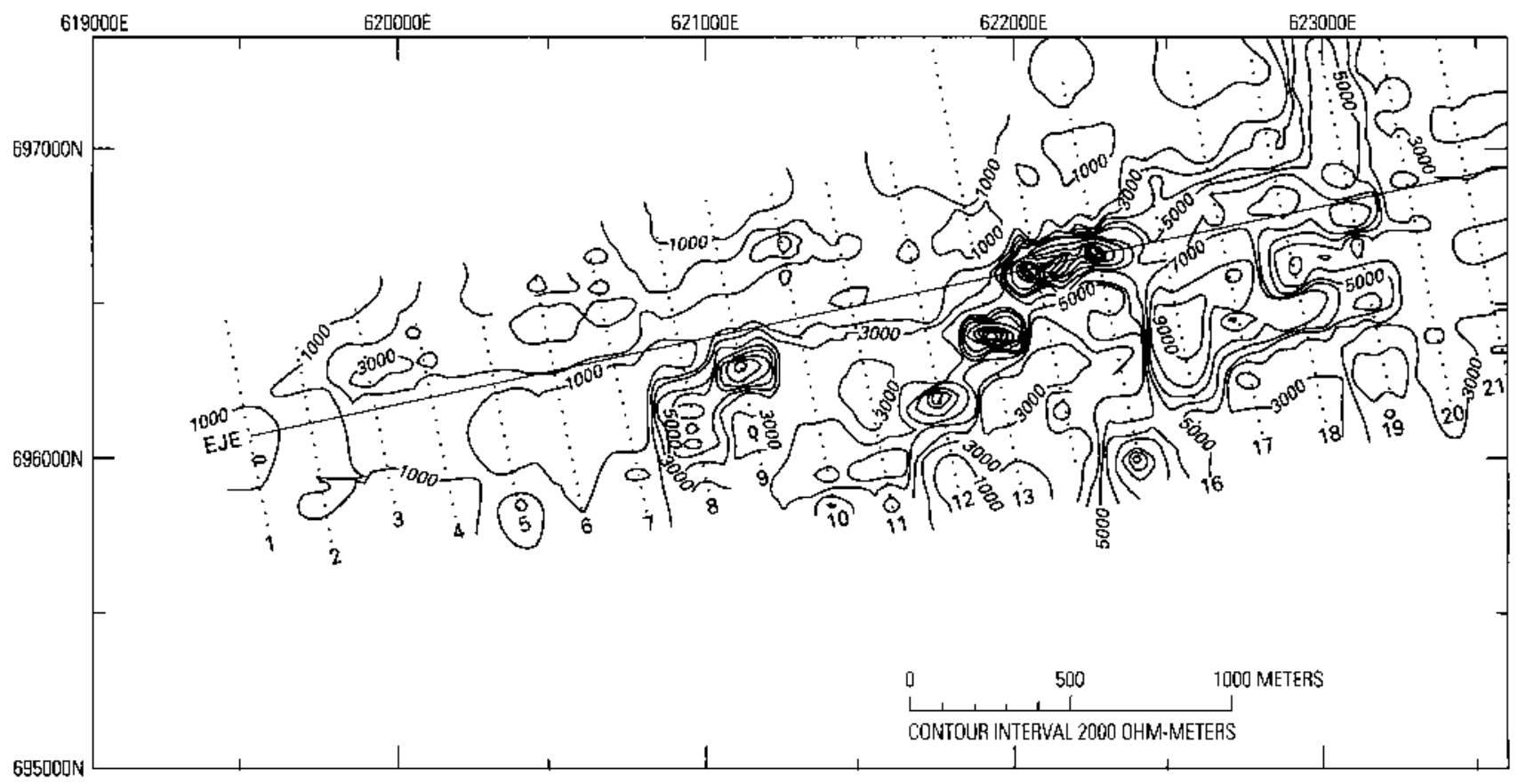

Figure 8. Map showing contours of gradient-array resistivity data (3,000-m transmitter dipole and 80-m receiver dipole) from the induced polarization survey acquired on the geophysical grid shown in figure 2, Pistón de Uroy area, Venezuela. This array is analogous to $\mathrm{AB}=3,000 \mathrm{~m}$ and $\mathrm{MN}=80 \mathrm{~m}$ in Schlumberger array resistivity surveys for the limiting case of the receiver dipole inline and centered in the middle of the transmitter dipole. Contour interval $2,000 \mathrm{ohm}-\mathrm{m}$. Dots indicate station locations along picas (traverse lines).

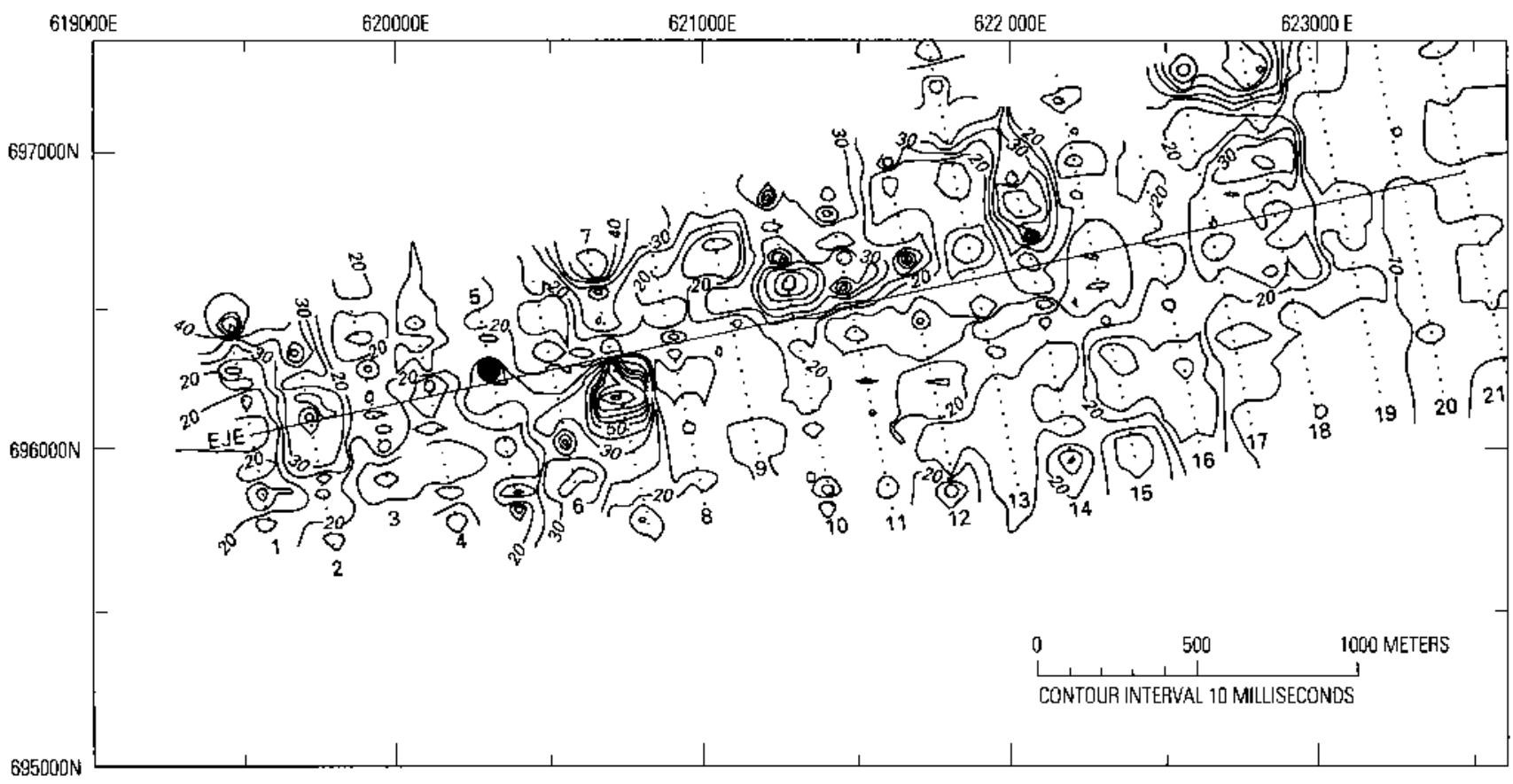

Figure 9. Map showing contours of chargeability data (polarization component) from the same induced polarization survey shown in figure 8 . Contour interval $10 \mathrm{msec}$.

because the field operators did not average sufficient readings at each station. The $40-\mathrm{m}$ receiver dipole chargeability data along this same profile, although providing better resolution, are in general too noisy to use except to roughly estimate dip direction of the polarized bodies at depth. A five-point digital filter (fig. 10, solid line) was applied to the 80 -m chargeability data in order to distinguish between rock types along the profile. The resistivity profile (fig. 10) 


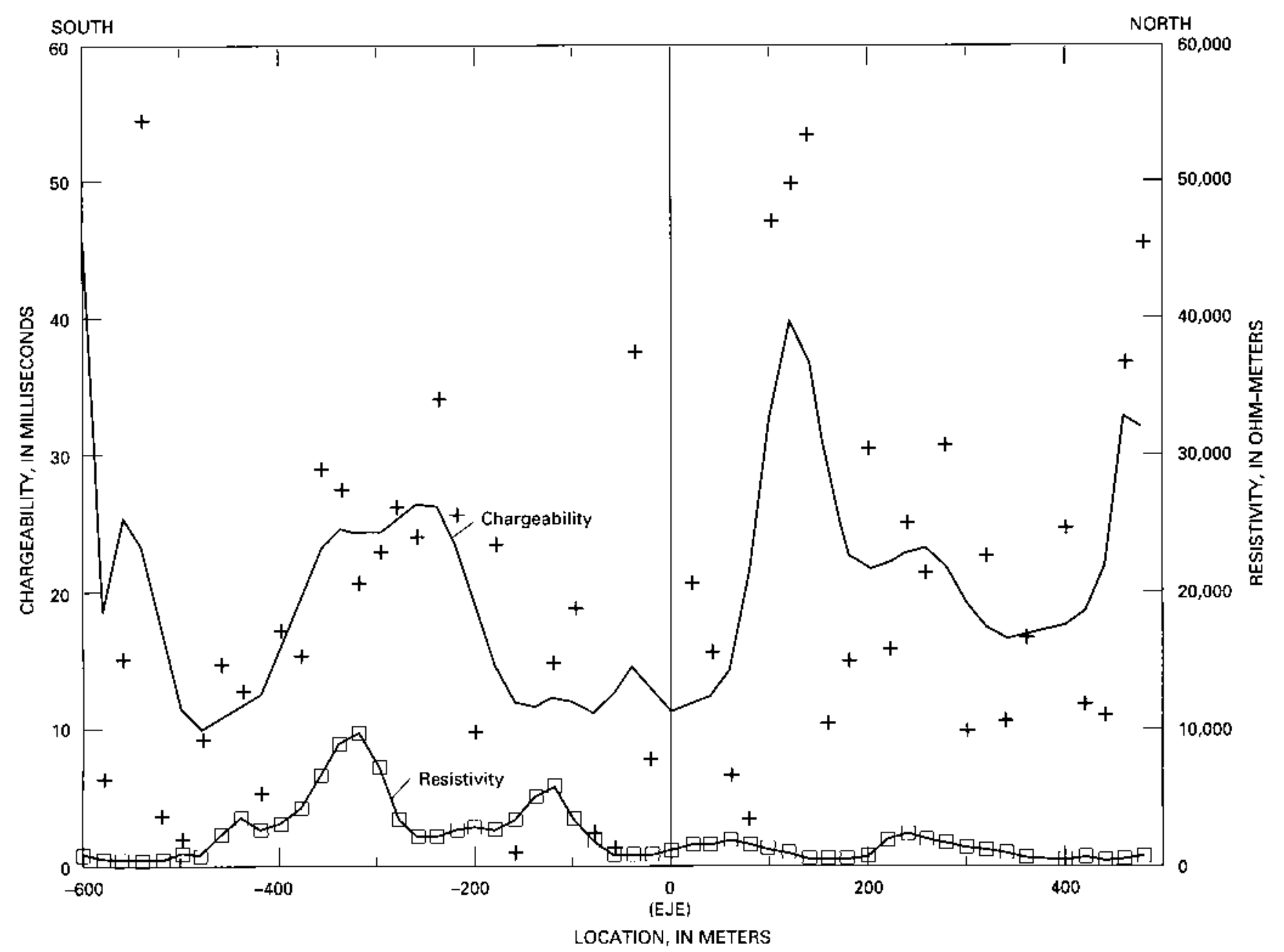

Figure 10. Resistivity (squares) and chargeability (pluses) profiles along pica 12 of the geophysical grid shown in figure 2 , Pistón de Uroy area, Venezuela. Data were acquired using an $80-\mathrm{m}$ receiver dipole spacing. Pluses represent original, noisy chargeability data, whereas the smooth curve represents a five-point (weighted) filtered version.

shows two distinct resistivity highs that probably represent silica-flooded (and therefore lower porosity) rocks. The southern high, centered about stations -300 and -400 , can be traced from profile to profile, and probably represents a distinct lithostratigraphic unit. The apparent resistivity of the unit is greater than $10,000 \mathrm{ohm}-\mathrm{m}$, a value that could reflect a true inherent resistivity as high as $30,000-50,000 \mathrm{ohm}-\mathrm{m}$. The southern high is associated with a significant chargeability anomaly of as much as $35 \mathrm{msec}$. The apparent resistivity and chargeability anomalies together indicate a $100-150-\mathrm{m}$-wide unit containing perhaps 2 percent pyrite and having much lower porosity (late-stage silica flooding or a relatively nontectonized intrusive rock) than the surrounding (volcanic?) rocks. The second resistivity high, around station -140 , is similar to the first but is lower in amplitude, both in resistivity and in chargeability. It probably represents similar rock but a narrower width.

On the north side of the eje, centered around station 120 (figs. 9, 10), is a chargeability anomaly; the resistivity is at or less than the background average of $1,000 \mathrm{ohm}-\mathrm{m}$. The anomaly is significant: three stations in sequence have chargeabilities of about $50 \mathrm{msec}$. The anomaly extends from pica 12 west to pica 9 and cannot be dismissed as mining debris. It is probably caused by a discrete geologic unit, only $50-100 \mathrm{~m}$ wide, containing several percent by volume of either clay (for instance, montmorillonite) or possibly sulfide minerals or ilmenite (but probably pyrite). It is significant that this anomaly is subparallel with the western quartz-vein system but extends several hundred meters beyond it to the east. The anomaly may represent a completely hidden mineralized body.

\section{INTEGRATION OF THE GEOPHYSICAL DATA}

Figure 11 combines the known (mapped) expressions of the quartz-vein system and an interpretation of the three geophysical data sets. The western quartz-vein system may 


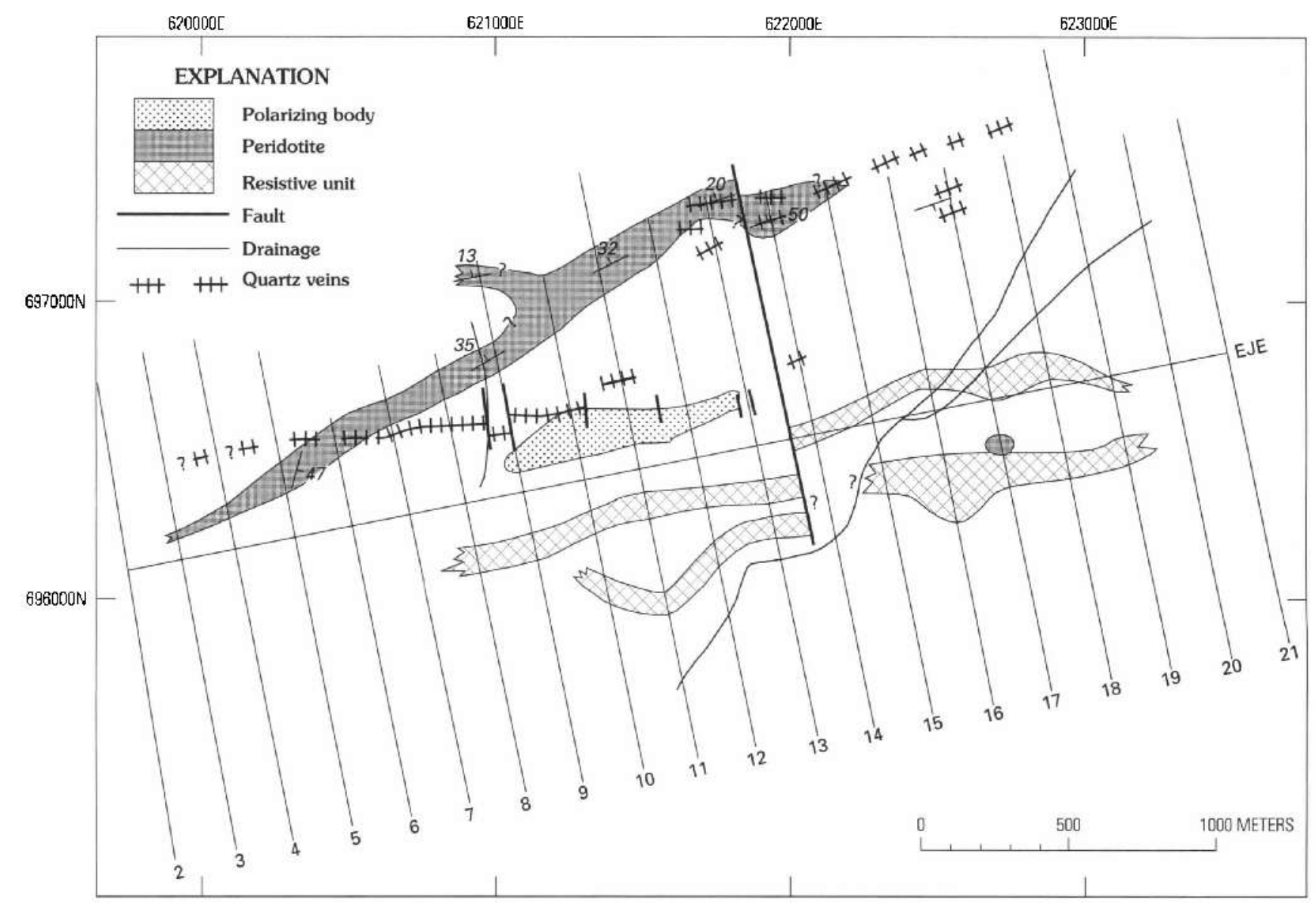

Figure 11. Map showing interpretation of magnetic, very low frequency electromagnetic, and induced polarization data and results of geological mapping of the quartz-vein system, Pistón de Uroy area, Venezuela. Geophysical grid is shown in figure 2.

extend $700-800 \mathrm{~m}$ farther to the west than mapped; however, it may or may not be offset $600 \mathrm{~m}$ by a left-lateral fault that is roughly parallel with, and between, picas 11 and 12 . In fact, the western quartz-vein system may be a separate entity. Nevertheless, a N. $10^{\circ}$ W.-striking conductor, probably a fault, is present at this point. Although the very low frequency electromagnetic data and field mapping show several short north-south offsets along the westem vein system, the presence of a large-displacement transcurrent fault between picas 11 and 12 is belied by the relative continuity of two different (roughly east trending) bodies mapped by the induced polarization survey and by the relatively continuous peridotite body inferred from the magnetic data. It is likely, therefore, that the eastem vein system has always been separate from the westem vein system.

The peridotite body on the north edge of the geophysical grid trends east-northeast, dips north for most of its length, and is more extensive in the subsurface. Magnetic susceptibility values for the peridotite (in outcrop) are about ten times those of the surrounding gabbro.

The highly polarized unit just north of the geophysical eje, between picas 9 and 12, is an enigma. It probably has a significant sulfide content and is subparallel with, and appar- ently related to, the eastem part of the western quartz-vein system.

The two parallel resistive units on and south of the geophysical eje in the central and eastern parts of the Pistón de Uroy area probably represent rocks that contain small amounts of sulfide minerals and have low porosity. This low porosity could be caused by silica flooding or by metamorphism; the source body could be a relatively dense volcanic rock without subsequent fractures due to tectonism. Although comparison of the $40-\mathrm{m}$ and $80-\mathrm{m}$ dipole data suggests some south-with-depth displacement of these resistive bodies, the strong noise in these data makes that interpretation far from certain.

\section{CONCLUSIONS}

In the Piston de Uroy area of Estado Bolívar, Venezuela, a quartz-vein system is subparallel with the strike of, and is hosted by, an ultramafic body. The cumulate ultramafic rocks and gabbro intrude an older greenstone belt that contains volcanic rocks of andesitic to basaltic character. Unconformably overlying these rocks is the basal section of 
sandstone and quartz-pebble conglomerate of the Early Proterozoic Roraima Group.

The gold-bearing quartz-vein system in the Pistón de Uroy area is roughly along the geologic baseline and north of the geophysical baseline. Although it appears that two segments of a single quartz-vein system are offset $600 \mathrm{~m}$ in a left-lateral direction, the continuity of adjacent subparallel units indicates that the eastern and western veins are probably distinct from each other. The quartz veins are unusually wide, $8 \mathrm{~m}$ or more at one location on the eastern vein, and, by virtue of their significant effect on the electrical resistivity data, they must constitute a large volume of rock. The overall length of both systems, including a probable $700-800 \mathrm{~m}$ extension of the western vein as suggested by the geophysical data, is at least $3,000 \mathrm{~m}$. Gold values are as high as $4,640 \mathrm{ppb}$ in the western vein system and as high as 220 $\mathrm{ppb}$ in the eastern vein system.

Both geologic mapping and geophysical data suggest that at least two sets of faults are present in the area. One set cuts the quartz-vein system and strikes approximately N. $10^{\circ} \mathrm{W}$., probably postdating the quartz veins, and has offsets typically less than $100 \mathrm{~m}$. The other set probably is part of a regional series of major shear zones that possibly follow older Precambrian structures. The shear zones are younger than the quartz veins because they are now highly conductive (water filled) and have not been recemented during metamorphism. The quartz-vein system has not been identified east of the El Pistón stream drainage. If the shear-zone system has had any significant movement since emplacement of the quartz veins at Pistón de Uroy, then movement has been greater than $1 \mathrm{~km}$, which is the size of the vein-free ground examined east of the shear zone. This is unlikely.

Geophysical data suggest the presence of additional lithologic units not mapped on the surface. A hidden, strongly polarizing body, nonmagnetic and probably silica rich, apparently extends for several hundred meters to the east of the western quartz-vein system. Several additional highly resistive, but nonpolarizing features, probably thick nontectonized, dikelike bodies or silica-flooded units, are in the central-southeastem part of the Pistón de Uroy area.

Without direct exploration such as trenching or drilling, the resource potential of the quartz-vein system of Pistón de Uroy is difficult to assess. The characteristics of the vein * system are similar to those of the low-sulfide gold-quartz vein model (Berger, 1986). A median grade for the low-sulfide gold-quartz vein model is 16 grams per metric ton, or $16 \mathrm{ppm}$ (Bliss, 1986), a value greater than any determined in the surface samples. Further direct exploration, such as more complete magnetic data and systematic dipole-dipole induced polarization surveys, is needed to more fully evaluate this prospect.

The probability of Jarge concentrations of chromite and nickel and base-metal sulfide minerals in the Pistón de Uroy area is low based on the lack of high concentrations of chromite or sulfide minerals in any samples collected to date or observed in the field. Some rock samples contain anomalous amounts of platinum-group elements, but the distribution and content of these elements have not been determined.

\section{REFERENCES CITED}

Alberdi, Margarita, 1988, Informe geológico-geoquímico de la zona El Pistón de Uroy-Abarén, in Corporación Venezolana de Guayana, Técnica Minera, C.A., Coordinación General de Prospecciones, Annual Report, 1987, v. 2: Available from Corporación Venezolana de Guayana, Técnica Minera, C.A., Calle Mexico cruce con Calle Estados Unidos, C.C. Chilemex, Piso 1, Puerto Ordaz, Venezuela.

Berger, B.R., 1986, Descriptive model of low-sulfide Au-quartz veins, in Cox, D.P., and Singer, D.A., eds., Mineral deposit models: U.S. Geological Survey Bulletin 1693, p. 239.

Bliss, J.D., 1986, Grade and tonnage of low-sulfide Au-quartz veins, in Cox, D.P., and Singer, D.A., eds., Mineral deposit models: U.S. Geological Survey Bulletin 1693, p. 239-243.

Contreras, Gloria, and Freites, Dennis, 1989, Informe geológico-geoquímico de las zonas de Canaima-Uroy-Chivao, Río Chicanán, Pistón de Uroy, y Río Cuyuní-Río Uey, in Corporación Venezolana de Guayana-Técnica Minera, C.A., Coordinación General de Prospecciones, Annual Report, 1987, v. 1, p. 282-455: Available from Corporación Venezolana de Guayana, Técnica Minera, C.A., Calle Mexico cruce con Calle Estados Unidos, C.C. Chilemex, Piso 1, Puerto Ordaz, Venezuela.

Fraser, D.C., 1969, Contouring of VLF-EM data: Geophysics, v. 34 , p. 958 .

Grimes, D.J., and Marranzino, A.P., 1968, Direct-current and spark emission spectrographic field methods for semiquantitative analysis of geologic materials: U.S. Geological Survey Circular 591, 6 p.

Meier, A.L., Carlson, R.R., Lichte, F.E., Aruscavage, P.J., and Riddle, G.O., 1988, Determination of the platinum-group elements by fire assay-inductively coupled plasma-mass spectrometry [abs]: The Geochemical Society, V.M. Goldschmidt Conference, Baltimore, May 11-13, 1988. 
Mendoza, Vicente, 1977, Evolución tectónica del Escudo de Guayana: Congreso Latinoamericano de Geología, 2nd, Caracas, 1973, Memoria, Publicación Especial 7, v. 3, p. 2237-2270.

Naldrett, A.J., 1981, Platinum-group element deposits, in Cabri, L.J., ed., Platinum-group elements--Mineralogy, geology, recovery: Canadian Institute of Mining and Metallurgy Special Volume 23, p. 197-232.

O'Leary, R.M., and Meier, A.L., 1986, Analytical methods used in geochemical exploration, 1984: U.S. Geological Survey Circular $948,48 \mathrm{p}$.

Quesada, R.J., and Wynn, J.C., 1990, Métodos geofísicos aplicados a sistemas de vetas de cuarzo aurífero en el Estado Bolívar,
Venezuela: Congreso Geofísico Venezolano, 5th, Caracas, $1990,6 \mathrm{p}$.

Sumner, J.S., 1976, Principles of induced polarization for geophysical exploration: New York, Elsevier, 277 p.

Tosiani D., Tommaso, and Sifontes G., Ram6n, 1989, Asociación de rocas máficas-ultramáficas en la región del Cerro Piedra del Supamo, al sur de El Callao, Estado Bolívar, Venezuela: Congreso Geológico Venezolano, 7th, Barquisimeto, 1989, Memoria, v. 1, p. 163-174.

Zonge, K.L., and Wynn, J.C., 1975, Recent advances and applications in complex resistivity measurements: Geophysics, v, 40, ло. 5, p. $851-864$. 
Cenozoic Landscape Evolution of the Southern Part of the Gran Sabana, Southeastern Venezuela-Implications for the Occurrence of Gold and Diamond Placers

By John C. Dohrenwend, Galo Yánez P., and Glenda Lowry

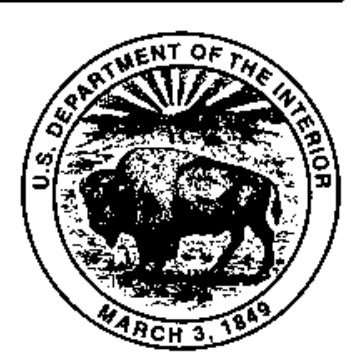




\section{CONTENTS}

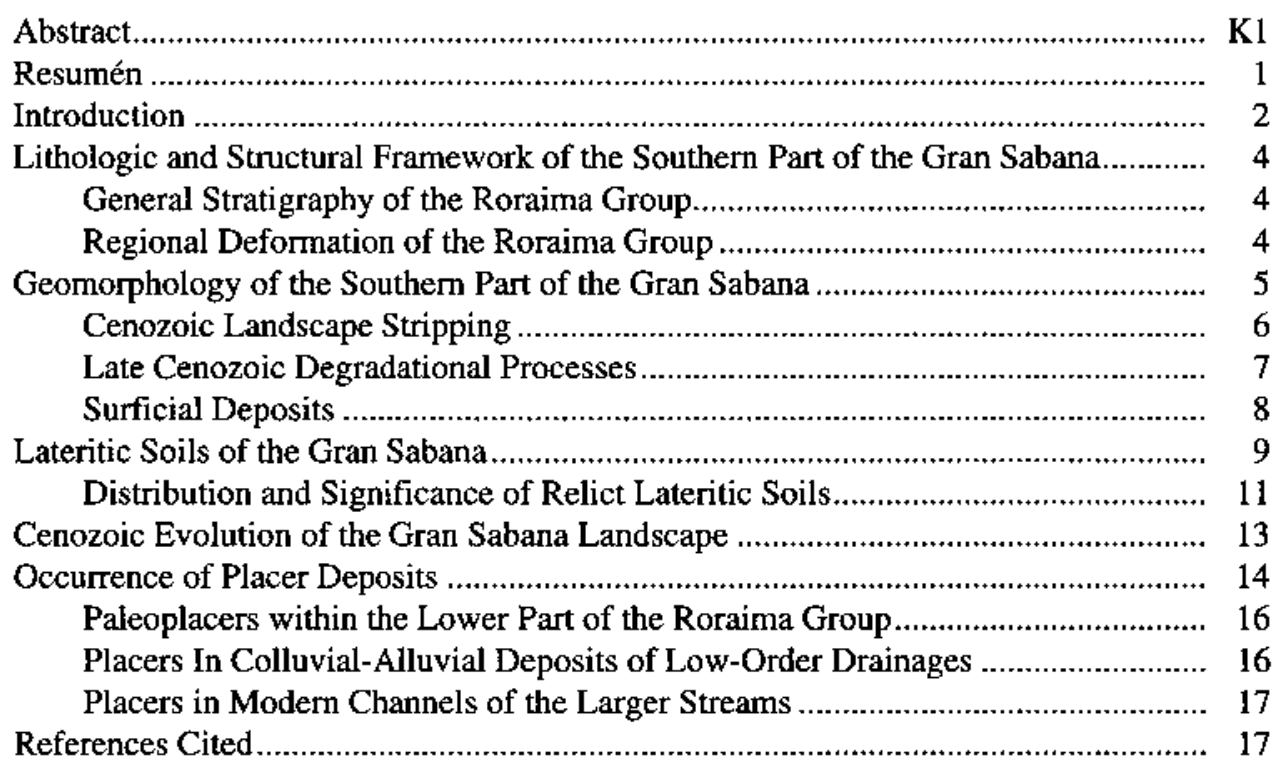

\section{FIGURES}

1. Map showing location of Gran Sabana .................................................................................................. K3

2-6. Photographs showing:

2. South-facing cuesta scarp developed on quartzose sandstone of lower part of Uairén Formation

near axis of broad northwest-plunging anticline at Chiricayen

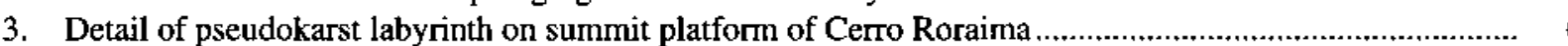

4. Prominent benches in almost flat lying strata of Uairén Formation ...................................................... 7

5. Flat, bedrock-floored channel of Quebrada de Jaspe cut into jasper beds of upper part of Uaimapué Formation

6. Valley of Río Cuquenán downstream from its confluence with Río Yuruaní ...............................................

7. Map showing distribution of laterite-capped paleosurface remnants within and adjacent to valley of

Río Cuquenán in vicinity of Cerro Chiricayen

8-13. Photographs showing:

8. Surface of relict lateritic soil capping cuesta ridge along southwestern flank of valley of Río Cuquenán ... 11

9. Typical lateritic soil roadcut exposure ..................................................................................... 12

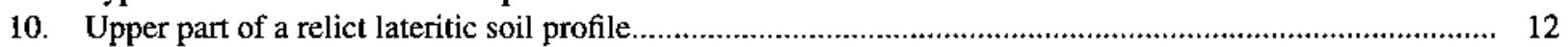

11. Detail of strongly developed nodular ferricrete crust ................................................................... 13

12. Surface of relict ferricrete crust capping series of low fluvial terrace remnants ................................... 14

13. Laterite-capped cuesta ridge developed on gently dipping strata of upper part of Uairén Formation .......... 15

14. Topographic profiles across valley of Río Cuquenán showing distribution of relict lateritic soils capping remnants of middle Tertiary paleolandscape 


\title{
Cenozoic Landscape Evolution of the Southern Part of the Gran Sabana, Southeastern Venezuela-Implications for the Occurrence of Gold and Diamond Placers
}

\author{
By John C. Dohrenwend, ${ }^{1}$ Galo Yánez P., ${ }^{2}$ and Glenda Lowry ${ }^{3}$
}

\begin{abstract}
The Gran Sabana of southeastern Venezuela is a degradational landscape that is well adjusted to the lithologic and structural variations of the underlying Early to Middle Proterozoic Roraima Group (fig. 1). The Roraima Group consists of a sequence of flat-lying to gently folded, generally unmetamorphosed, terrigenous to shallow coastal marine strata that is $2,000-3,000+m$ thick. Cuesta ridges and high mesalike tepuis (table mountains), having elevations as high as $2,800 \mathrm{~m}$, are underlain by silica-cemented quartz sandstone. The larger valleys, at elevations of $800-900 \mathrm{~m}$, are underlain by feldspathic sandstone, siltstone, claystone, and shale. Surficial deposits are generally limited to discontinuous colluvial-alluvial mantles, isolated colluvial aprons, thin (generally less than $2 \mathrm{~m}$ thick) fluvial terrace deposits, and somewhat thicker fluvial deposits within and adjacent to the channels of the largest rivers.

Within this degradational landscape, ferricrete-capped remnants of a middle (?) Tertiary geomorphic surface extend discontinuously from low strath terraces to high, structurally controlled ridges. The ferricrete remnants are particularly well developed on the finer grained and more feldspathic rocks that underlie the lower dip slopes, hills, and terraces within or adjacent to the larger valleys. These relict soils are characterized by a 1-3-m-thick, nodular to pisolitic ferricrete crust that contains abundant fragments of weathered bedrock and local concentrations of hematite and (or) gibbsite. This ferricrete crust is typically partly stripped and rubbled and is underlain by a deeply weathered, red- and yellow-mottled,

${ }^{1}$ U.S.Geological Survey, 345 Middlefield Road, MS905, Menlo Park, California 94025

${ }^{2}$ Corporación Venezolana de Guayana, Técnica Minera, C.A., Ciudad Bolívar, Venezuela.

${ }^{3}$ Corporación Venezolana de Guayana, Técnica Minera, C.A., Puerto Ordaz, Venezuela.
\end{abstract}

clay-enriched horizon as thick as $15 \mathrm{~m}$. In most respects, the middle Tertiary landscape defined by these ferricrete-capped remnants was as well adjusted to underlying lithology and structure as is the modern landscape and had an overall relief comparable to present-day relief. Thus, during middle and late Cenozoic time, landscape change in the Gran Sabana was limited to an undefined amount of upland dissection accompanied by less than $10 \mathrm{~m}$ of general lowering of the largest valleys. This scenario does not accord with previous geomorphic models, which emphasize cyclic planation as the principal mode of landscape evolution in northem South America.

Gold and diamond resources in the southern part of the Gran Sabana are primarily limited to areas underlain by or downstream from extensive exposures of the Uairén Formation, the oldest formation within the Roraima Group. Within these areas, geologic-geomorphic environments that host gold and diamonds include active channels and Holocene floodplains of the larger rivers, colluvial-alluvial placer deposits of small low-order drainage basins, and paleoplacer deposits associated with conglomeratic lenses and beds within the lower part (lower $500-600 \mathrm{~m}$ ) of the Uairén Formation. Additional gold and diamond resources may lie within or immediately beneath ferricrete crusts developed on surfaces underlain by the Uairén Formation. For the most part, these placer resources are limited in both grade and extent.

\section{RESUMEN}

La Gran Sabana al sur de Venezuela es un paisaje degradacional que está bien ajustado a las variaciones litológicas y estructurales de Grupo Roraima el cual infrayace la región. El Grupo Roraima, de edad Proterozoico Temprano a Medio, consiste de una secuencia de 2,000 a 3,000 m de espesor compuesta por estratos continentales y costeros 
marinos somerus. Los estratos están dispuestos horizontalmente o plegados suavemente. Areniscas cementadas con sílice forman las crestas de las cuestas e infrayacen las mesas (tepuis) los cuales alcanzan una elevación de $2,800 \mathrm{~m}$. Los valles más extensos, a una elevación de $800-900 \mathrm{~m}$, están formados sobre arenisca feldespática, limolita, arcillita, abanicos coluviales aislados, depósitos delgados (generalmente menos de $2 \mathrm{~m}$ de espesor) de terrazas fluviales y sobre depósitos fluviales algo más espesos dentro y adyacentes a los canales de los ríos de orden mayor.

Dentro de este paisaje degradacional, hay depósitos remanentes cubiertos por una laterita fernuginosa endurecida (ferricrete). Dichos remanentes son de una superficie geomórfica de edad Terciaria media (?). Estos se extienden discontinuamente desde las terrazas más antiguas localizadas en valles bajos hasta crestas controladas estructuramente.

Los remanentes ferruginosos están particularmente bien desarrollados sobre rocas feldespáticas de grano más fino las cuales infrayacen las partes bajas de las pendientes de buzamiento, colinas y terrazas dentro o adyacentes a los valles más grandes. Estos suelos relictos están caracterizados por una costra ferruginosa nodular a pisolítica la cual contiene abundantes fragmentos de roca infrayacente y concentraciones locales de hematita y/o gibbsita. Esta costra ferruginosa está típicamente desnuda y desmantelada, por debajo hay un horizonte enriquecido en arcilla, muy meteorizado, de color rojo moteado de amarillo, el cual puede alcanzar $15 \mathrm{~m}$ de espesor. En general, el paisaje durante el Terciario medio, definido por los remanentes con tope laterítico, estaba también ajustado a la litología infrayacente y a la estructura, generando una fisiografía comparable a la moderna. Así pues, durante el Cenozoico medio y tardío, el cambio del paisaje en la Gran Sabana estaba limitado por una cantidad no definida de disección en las áreas más altas acompañada por un rebajamiento general de $10 \mathrm{~m}$ en los valles más grandes. Este modelo no está de acuerdo con modelos geomórficos previos, los cuales enfatizan la planación cíclica como el modo principal de evolución del paisaje en la parte norte de América del Sur.

Los recursos de oro y diamantes en la parte sur de la Gran Sabana están primordialmente limitados a áreas que suprayacen la Formación Uairén o que están aguas abajo de dicha formación la cual es la más antigua del Grupo Roraima. Dentro de estas áreas se distinguen varios ambientes geológico-geomórficos que contienen oro y diamantes. Estos incluyen canales activos y planicies de inundación de ríos mayores de edad Holoceno, depósitos aluviales-coluviales de tipo placer en pequeñas cuencas de orden menor, y en depósitos de paleoplaceres asociados con lentes y capas conglomeráticas localizados en la base $(500-600 \mathrm{~m})$ de la Formación Uairén. Los recursos adicionales de oro y diamantes podrían estar presentes en o inmediatamente por debajo de las costras ferruginosas desarrolladas sobre superficies que a su vez suprayacen a la Formación Uairén. Los recursos de tipo placer, en su mayoría son limitados tanto en tenor como en extensión.

\section{INTRODUCTION}

The Gran Sabana of southeastern Venezuela is a degradational landscape that is well adjusted to the lithologic and structural variations of the underlying Early and Middle Proterozoic Roraima Group. This 2,000-3,000+-m-thick sequence of terrigenous to shallow coastal marine strata is flat lying to gently folded and generally unmetamorphosed. Cuesta ridges and high mesalike tepuis (table mountains), which are formed on silica-cemented quartz sandstone, have elevations of as much as $2,800 \mathrm{~m}$. In contrast, the floors of the larger valleys, which are underlain by interbedded feldspathic sandstone, siltstone, claystone, and shale, are at elevations between 800 and $900 \mathrm{~m}$. Benched hillsides and piedmonts are widespread, and numerous lithologically controlled waterfalls and rapids intermupt the otherwise gentle longitudinal profiles of most streams. Surficial deposits are mostly limited to discontinuous colluvial-alluvial mantles on hill slopes and piedmonts, isolated colluvial aprons preserved beneath residual gravel lags, 1-2-m-thick fluvial deposits overlying strath terraces in the larger valleys, and 5-10-m-thick channel deposits within the narrow late Quaternary floodplains of the largest rivers.

As many as six planar geomorphic surfaces, defined on the basis of regional correlations of similar elevations of summit levels and areas of low relief, have been recognized in the region of the Guayana Shield (James, 1959; McConnell, 1968; Zonneveld, 1985; Schubert and others, 1986; Briceño and Schubert, 1990). The formation of these surfaces is generally considered to be the result of alternating periods of tectonic uplift and stability, landscape dissection in response to the uplift, and parallel slope retreat during the succeeding interval of stability. The ages of these surfaces are generally thought to range from Mesozoic to Holocene; however, it has been pointed out that many of these surfaces coincide with lithologic units and that the steps which separate them commonly coincide with lithologic discontinuities (Kroonenberg and Melitz, 1983). Moreover, within the area of the southern part of the Gran Sabana, ferricrete-capped remnants of a middle (?) Tertiary geomorphic surface cut across several of these regional planation surface levels (extending almost continuously from dissected strath terraces lying less than $10 \mathrm{~m}$ above modern streams to high, structurally controlled ridges rising more than $200 \mathrm{~m}$ above the floors of the larger valleys). It is likely, therefore, that present-day relief within the Guayana Shield is mostly a function of lithologic resistance and that at least some of these so-called planation surfaces are primarily a manifestation of lithologic control in a relatively stable landscape that is developed on a thick sequence of very gently dipping to flat-lying sedimentary strata. 


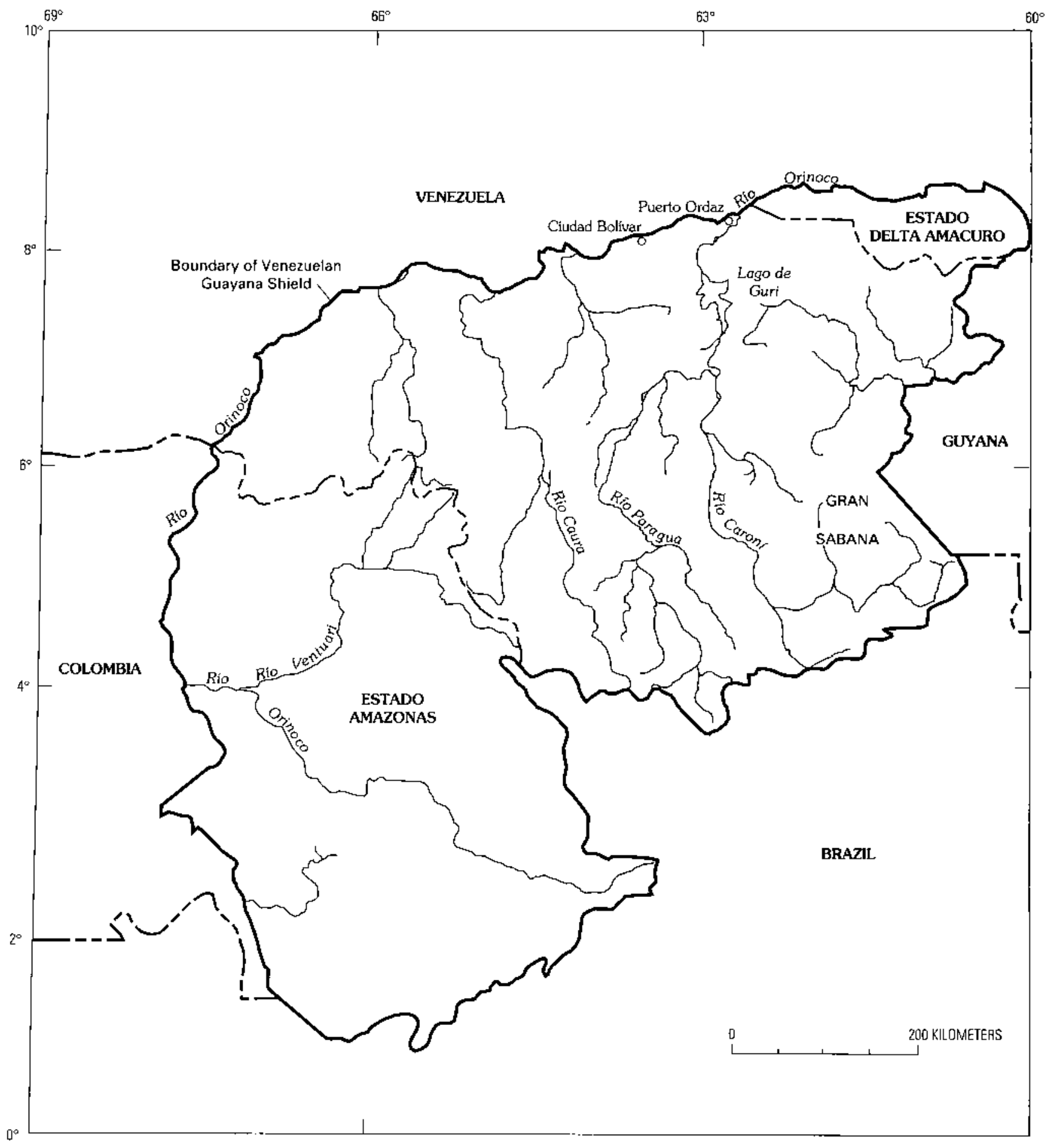

Figure 1. Location of the Gran Sabana, Estado Bolívar, Venezuela. Most of the geographic locations mentioned in the text are shown on plate 1 of Wynn, Sidder, and others (this volume). 


\section{LITHOLOGIC AND STRUCTURAL FRAMEWORK OF THE SOUTHERN PART OF THE GRAN SABANA}

\section{GENERAL STRATIGRAPHY OF THE RORAIMA GROUP}

The Roraima Group is a laterally extensive sequence of Early and Middle Proterozoic, fluvial to shallow coastal marine strata that mantle a large part of the Guayana Shield and underlie most of the Gran Sabana (Reid, 1974; Yanez, 1984; Sidder and Mendoza, this volume). These strata unconformably overlie an igneous and metamorphic basement complex of Early Proterozoic age, and they are intruded by about 1.65-Ga diabase dikes and sills. The Roraima Group is dominated by quartzose sandstone but also contains significant amounts of conglomerate, conglomeratic sandstone, pebbly quartz sandstone, arkosic to feldspathic sandstone, siltstone, mudstone, shale, and tuff. Cross stratification is common to abundant throughout the sequence. Within the Gran Sabana, deformation is limited to broad open folds; dips are generally less than $7^{\circ}$, although dips of as much as $15^{\circ}$ are present locally.

The stratigraphy and structure of the Roraima Group have been described in some detail by Reid (1974), Yánez (1984), and Ghosh (1985) and are summarized by Sidder and Mendoza (this volume). As defined by Reid (1974), the Roraima Group in the southern part of the Gran Sabana is divided into four units, the Uairén, Cuquenán, Uaimapué, and Matauí Formations.

The Uairén Formation can be usefully divided into upper and lower parts that are recognizable both geomorphically and lithologically throughout the southern part of the Gran Sabana. The lower part (Canaima Formation, Unit I of Yánez, 1984) is about $600 \mathrm{~m}$ thick and consists primarily of well-sorted, generally coarse to medium grained, moderately bedded to massive, cross-stratified quartzose sandstone and intercalated lenses and beds of polymictic and quartzose pebble conglomerate and minor thin beds and laminae of shaly siltstone. These rocks form the high cliffs and extensive dip slopes of Chiricayen, Cerro el Abismo, and other cuestas along the southern margin of the Gran Sabana. The upper part of the Uairén Formation (Canaima Formation, Unit II of Yanez, 1984) is 100-300 $\mathrm{m}$ thick and consists primarily of medium-grained sandstone with abundant trough cross-stratification and intercalated channel gravels. These rocks form benched scarp slopes and irregular ridges, particularly along the southern margin of the valley of the Río Cuquenán. A ferricrete-capped lateritic soil, interpreted by Reid (1974) as a Precambrian paleosol and used by him to define the top of the Uairén Formation, is in fact part of a deep weathering profile of middle (?) to late Tertiary age that mantles the middle part of the Roraima Group (from the upper part of the Uairen Formation to at least the middle of the Uaimapue Formation). This soil is highly significant to understanding the Cenozoic landscape evolution of the Gran Sabana and is described and discussed in some detail in a following section of this report.

The Uairén Formation is overlain by the Cuquenan Formation (Canaima Formation, Units III and IV of Yánez, 1984). Exposures of the Cuquenan Formation are limited, and it has not been comprehensively described. This unit underlies the valley of the Río Cuquenán from the vicinity of Moroc Meru to the confluence of the Río Cuquenán with the Río Aponguao. In this area, deeply weathered outcrops are present almost continuously along the Río Cuquenán wherever the modern channel is actively eroding the late Pleistocene strath surface, which underlies most of the valley floor. These outcrops reveal well-bedded to massive, fine- to medium-grained sandstone interbedded with medium- to thin-bedded and laminated siltstone, claystone, and shale.

The Uaimapue Formation, which overlies the Cuquenán Formation, can also be divided into two geomorphically distinct parts. The lower part (Canaima Formation, Unit V of Yánez, 1984) consists primarily of pervasively channelled and cross-stratified, fine- to coarse-grained sandstone and thin-bedded to laminated fine-grained sandstone, siltstone, and mudstone. The topography developed on these rocks is characterized by benched scarp slopes similar to the topography of the upper part of Uairén Formation. The upper part of the Uaimapué Formation (Guaiquinima Formation of Yánez, 1984) contains abundant beds and lenses of tuff and jasper that are interbedded with cross-stratified arkosic to quartzose sandstone. These resistant beds form conspicuous benches along hill slopes and numerous waterfalls and cascades along both major and tributary streams.

The Mataui Formation (Auyantepuy Formation of Yanez, 1984) consists primarily of pervasively cross stratified, fine- to medium-grained quartzarenite. This unit underlies the spectacular, vertical-walled high tepuis such as Cerro Roraima and Cuquenan Tepuy that dominate the landscape of the northem part of the Gran Sabana. It is not present within Gran Sabana Sur and therefore is not described in any detail in this report.

\section{REGIONAL DEFORMATION OF THE RORAIMA GROUP}

In the southern part of the Gran Sabana, the Roraima Group displays an apparent north-south deformational gradient ranging from relatively tight folds with conspicuous axial plane foliation in the south near the Brazilian border to very gently dipping to horizontal strata without foliation in the north in the vicinity of Chimata, Cuquenán, and Roraima tepuis. This deformational gradient is most conspicuous in the western part of the study area between the valley of the Río Icabarú and the Río Caroní, but it is also present in the 


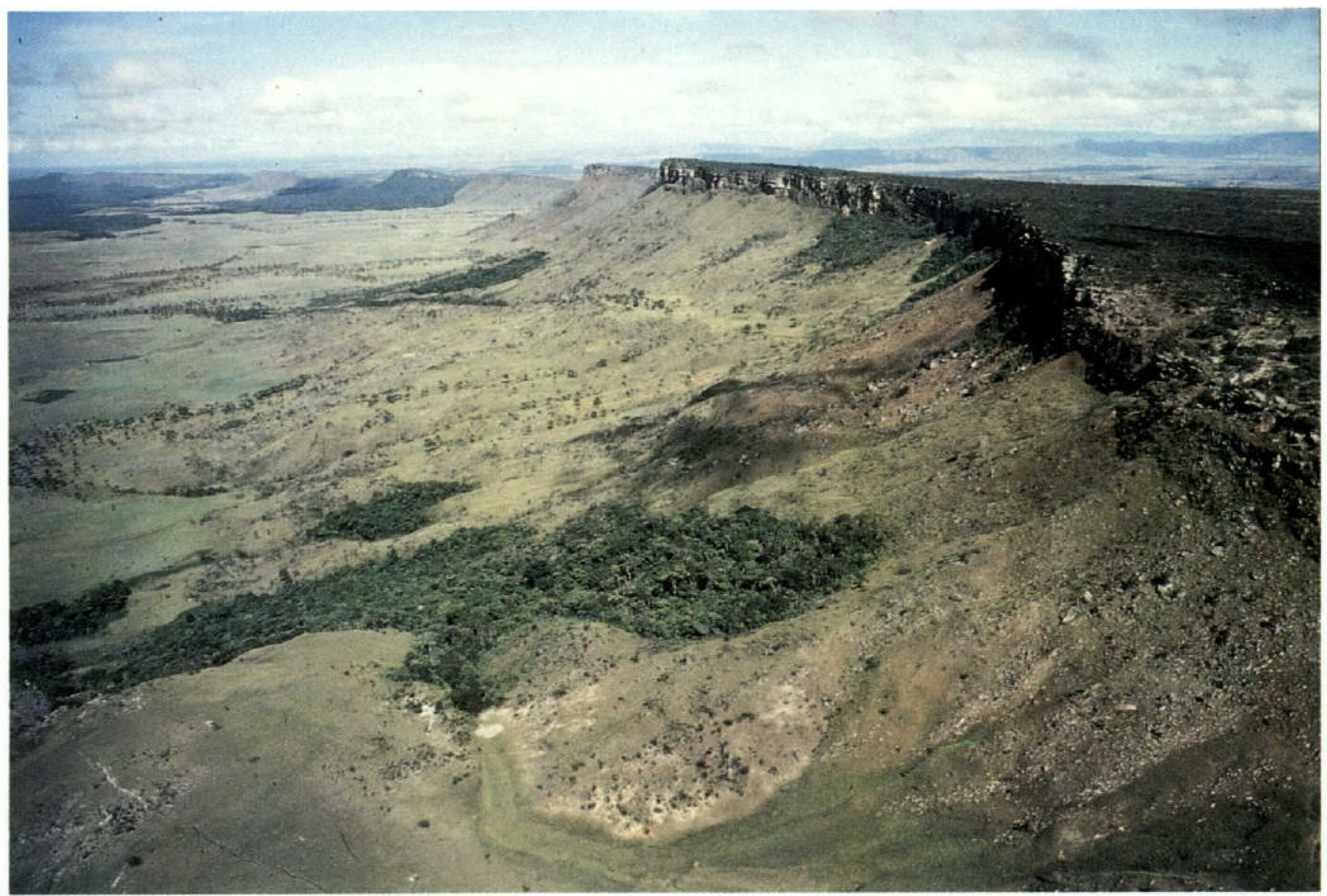

Figure 2. South-facing cuesta scarp developed on quartzose sandstone of the lower part of the Uairén Formation near the axis of a broad northwest-plunging anticline at Chiricayen, Venezuela (lat $4^{\circ} 50^{\prime} \mathrm{N}$. . long $61^{\circ} 15^{\prime} \mathrm{W}$.). Aerial view looking west.

castern part of the study area, east of Santa Elena de Uairén. In the Icabarú-EI Paují area, the axial plane foliation is sufficiently well developed to impose a conspicuous geomorphic overprint on the ridge and valley topography. It is likely that this north-south deformational gradient has been a significant factor in the geomorphic evolution of the region, facilitating the deep dissection and general stripping of the Roraima Group south from the Pacaraima Mountains into Brazil and the northward encroachment into the Gran Sabana by the southward-flowing drainages of the norhem Amazon basin.

\section{GEOMORPHOLOGY OF THE SOUTHERN PART OF THE GRAN SABANA}

The Gran Sabana is a degradational landscape that is mostly adjusted to the lithologic and structural variations of underlying bedrock (fig. 2). Indications of middle to late Cenozoic tectonism are not apparent within the region; however, it is unlikely that a broad regional upwarping of the present landscape would generate any readily recognizable geomorphic expression of tectonic activity. Indications of general landscape maturity are abundant.

1. General topographic features are well adjusted to lithology and structurc. Relatively resistant rock types underlic high tepuis and cuestas, whereas relatively nonresistant rock types underlie the larger valleys and adjacent low, rounded hills. In areas of folded, gently to moderately dipping rocks, ridges and valleys outline principal structures. Major streams are present as subsequent streams that are deflected around the noses of plunging folds. In the western part of the region between the Río Icabarí and the Rio Caroní, a classic ridge and valley topography has developed over the gently plunging, east-trending folds of the area.

2. Local geomorphic indicators of structural and lithologic control are common. Hillside and piedmont benching is widespread, particularly in areas underlain by either the Uairén or Uaimapué Formations. Lithologically controlled waterfalls and rapids are abundant along most lower order streams, and indeed such waterfalls are common 


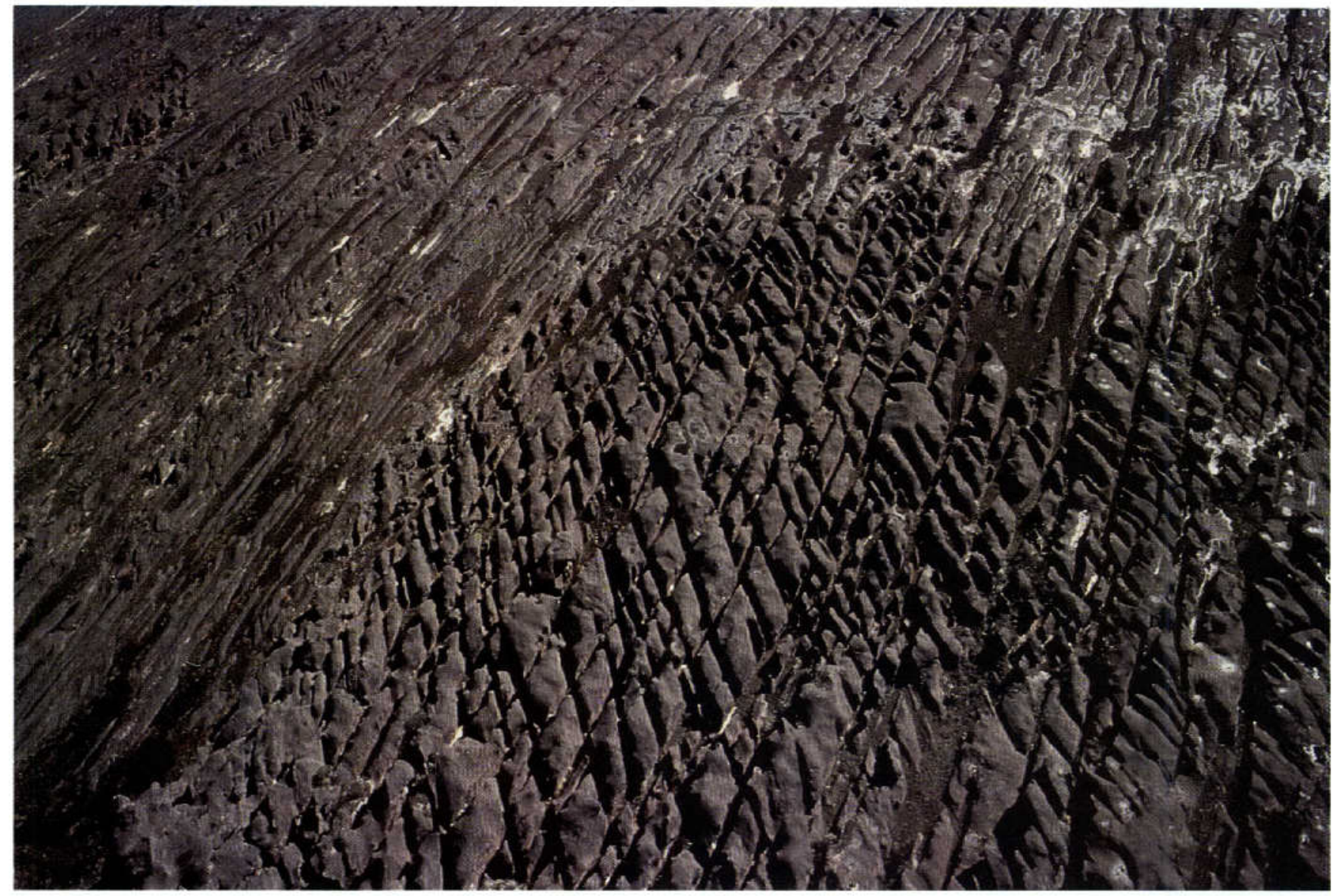

Figure 3. Detail of the pseudokarst labyrinth on the summit platform of Cerro Roraima, Venezuela. The pervasively cruss-stratified quartzose of the Matauí Formation that forms the summit platform has been deeply etched by orographically intensified rainfall estimated at about $5 \mathrm{~m}$ per year. High-angle-oblique acrial view from a height of about $300 \mathrm{~m}$.

even along some reaches of the principal drainages of the Río Cuquenán and Río Icabarú.

3. Paleosurface remnants are limited in abundance, extent, and state of preservation. In fact, the only indications of former geomorphic surfaces that remain in the present landscape are (1) possible paleosurface remnants defined by generally accordant ridge crests in broadly folded areas of ridge and valley topography; (2) laterite-capped hills, ridges, and low terraces that have survived only because of the pötection afforded by their resistant ferricrete caps; and (3) low, generally accordant, and completely rounded bedrock hills within the broad valleys of the principal streams at the general level of the laterite-capped terrace remnants.

\section{CENOZOIC IAANDSCAPE STRIPPING}

Ubiquitous geomorphic evidence indicates pervasive late Tertiary and Quatemary stripping of this landscape. These geomorphic features include:
1. Deep etching and almost continuous bedrock exposure on most tepuis and higher cuestas cover (cover, fig. 3)

2. Conspicuous, widespread bedrock outcrops and benching on most cuesta scarp slopes and extensive bedrock outcrops on many cuesta dip slopes (fig. 4)

3. Almost continuous bedrock exposure and numerous waterfalls and rapids along the channels of most tributary streams (fig. 5)

4. Almost continuous exposures of decply weathered bedrock along the channejs of the major rivers wherever these channels impinge upon pre-Holocene valley surfaces (fig. 6)

5. Extensive and widespread occurrences of rubbled ferricrete, lateritic lag gravels, and truncated deep weathering profiles developed directly on bedrock

6. A general lack of continuous surficial deposits (>1-2 $\mathrm{m}$ thick) in all areas of the landscape except local colluvial wedges on hill slopes armored by lateritic and (or) conglomeratic nubble and thin fluvial channel and overbank deposits within the modem floodplains of the largest rivers 


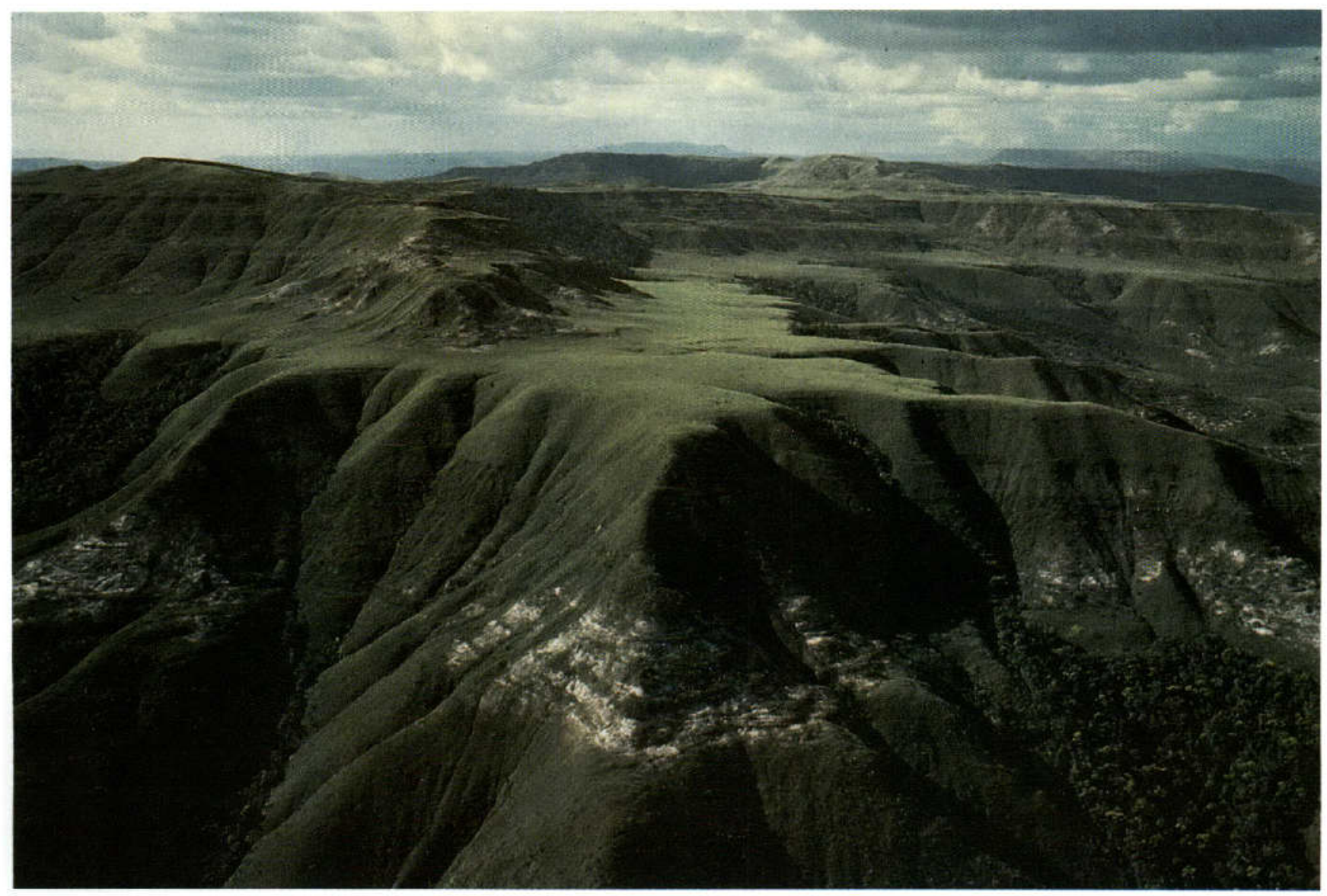

Figure 4. Prominent benches in almost flat lying strata of the Uairén Fommation. Surficial deposits in this area are limited to discontinuous colluvial aprons along the base of the bench scarps. Aerial view north along the Brazilian frontier approximately $35 \mathrm{~km}$ northeast of Santa Elena de Uairén, Venezuela

The principal reasons for this stripping are threefold:

1. The region is mostly underlain by weakly to moderately indurated, essentially unmetamorphosed, generally medium to very fine grained sedimentary rocks.

2. The humid-tropical conditions that likely dominated the middle to late Cenozoic climate of the region have decply leached and weathered these rocks such that when eroded they rapidly disaggregate into their constituent mincral grains or decompose into finer grained weathering products.

3. The wet-dry scasonality of the present-day climate, and of probable late Cenozoic paleoclimates, facilitates seasonal fiushing from the landscape of all available surficial materials.

\section{LATE CENOZOIC DEGRADATIONAL PROCESSES}

Middle to late Cenozoic degradation of the uplands of the Gran Sabana has been dominated by the following processes: (1) intense leaching and solutional etching of upland areas (particularly the tepuis and higher cuestas underlain by the quartzitic sandstone and conglomerate of the Mataui and lower part of the Uairén Formations); (2) solutional etching and rubbling of ferricrete crusts; (3) discontinuous slumping and sliding along laterite-capped hill slopes underlain by the upper part of the Uairén Formation and both laterite- and sandstone-capped scarp slopes underlain by the lower part of the Uaimapué Formation; and (4) basal sapping of hill slopes and cuesta dip slopes, particularly those underlain by interbedded sedimentary rocks of varying permeability and crosional resistance. The basal sapping is manifest on two distinct geomorphic scales: (1) conspicuous, locally intensive hillside and piedmont slope piping has formed narrow, almost vertical sided gullies and small box canyons as much as $30-40 \mathrm{~m}$ in width and $20 \mathrm{~m}$ in depth; and (2) more general large-scale basal sapping has cut large. stecp-sided, generally $\mathbf{U}$-shaped valleys into many of the larger cuestas and tepuis. These valleys and cuestas are strikingly similar, in both planimetric and cross-sectional form, to those canyons and cscarpments 


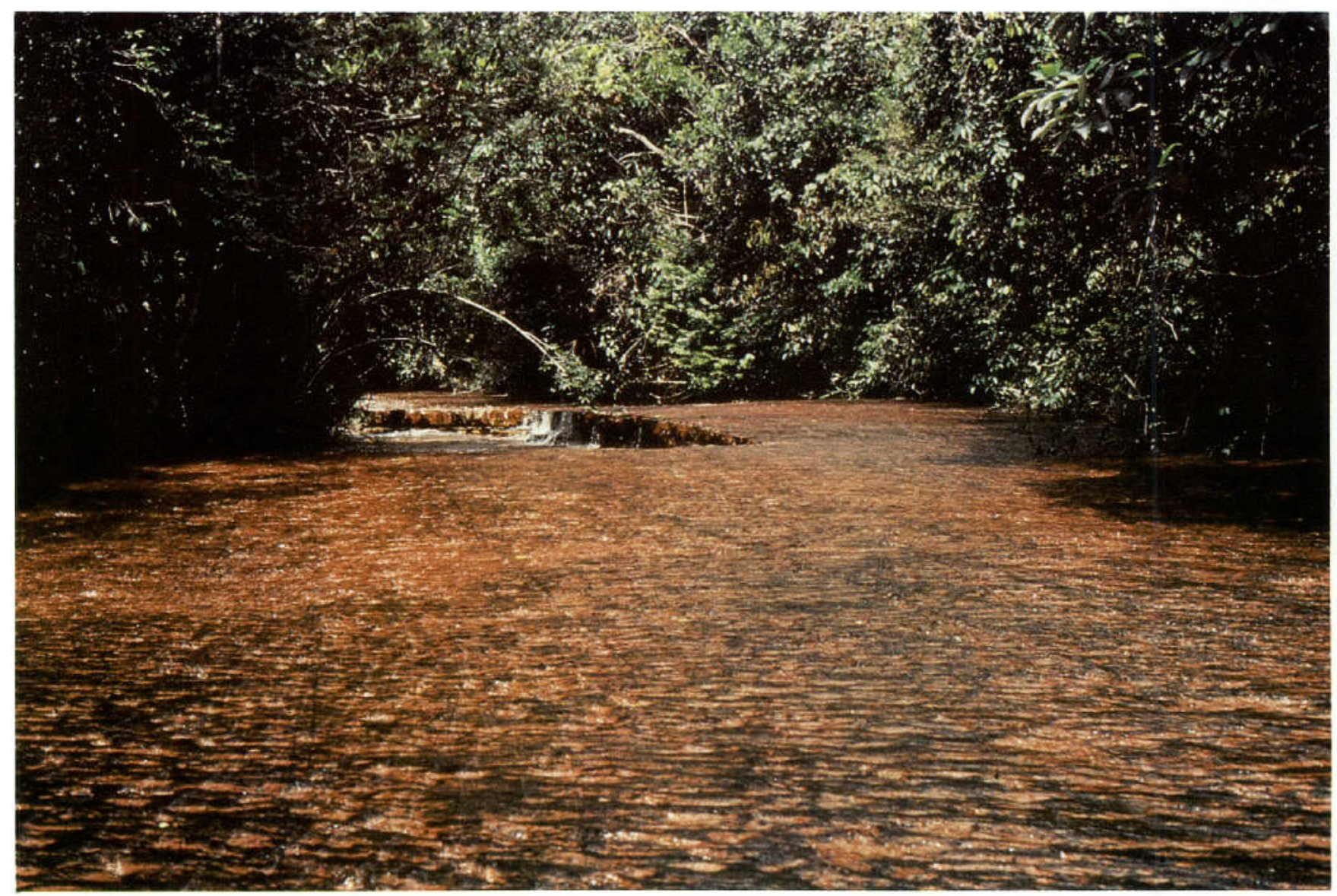

Figure 5. Detail of the flat, bedrock-floored channel of Quebrada de Jaspe cut into jasper beds of the upper part of the Uaimapue Formation.

of the Colorado ?lateau region where sapping erosion has been a principal degradational process (Laity and Malin, 1985; Howard, 1988). Many of the large, U-shaped valleys in the Gran Sabana are now beheaded, indicating that a significant amount of slope retreat has likely occurred along at least some of the cuesta scarps of the region and that basal sapping has been a significant valley-forming process during most of Cenozoic time. The relatively minor (generally less than $5-10 \mathrm{~m}$ ) general lowering of the larger valley floors has, most likely, been principally accomplished by high discharge stream flow during wet-season flooding.

\section{SURFICIAL DEPOSITS}

Surficial deposits of the Gran Sabana are mostly limited to a discontinuous veneer of colluvium and alluvium, generally less than 1-2 $\mathrm{m}$ thick, on most hillsides and piedmont slopes. Gray to dark-brown, weakly to moderately developed soils are on these deposits. In adjacent areas, ${ }^{14} \mathrm{C}$ age determinations made on similar surficial deposits indicate a Holocene age (Schubert and others, 1986). Locally, significant colluvial aprons have been preserved on hill slopes armored by pebble to cobble lags of weathered conglomerate or by cobble- to boulder-sized fragments derived from well-indurated sandstone or ferruginous lateritic crust; however, these oceurrences are limited to a small proportion of all hill slopes. Alluvial fans are not present within the study area; instead, piedmont surfaces are erosional straths discontinuously veneered by thin alluvial and colluvial deposits. Significant fluvial and valley bottom deposits are limited to the valleys of the largest tributaries and principal rivers, and even in the broadest valleys these deposits are generally thin, except within the modern floodplains of the larger rivers where they may be $5-10 \mathrm{~m}$ thick. Aerial observations and analysis of large-scale aerial photographs show that most tributary channels are developed in bedrock and contain little fluvial sediment, Waterfalls and rapids also are abundant along many of these lesser streams. Within the valley of the Río Cuquenán, between Moroc Meru and the Río Yuruaní, bedrock exposure is almost continuous along the modem channel and only 1-3 $\mathrm{m}$ of fluvial deposits lie beneath the surface of this 3-8-km-wide fluvial valley. 


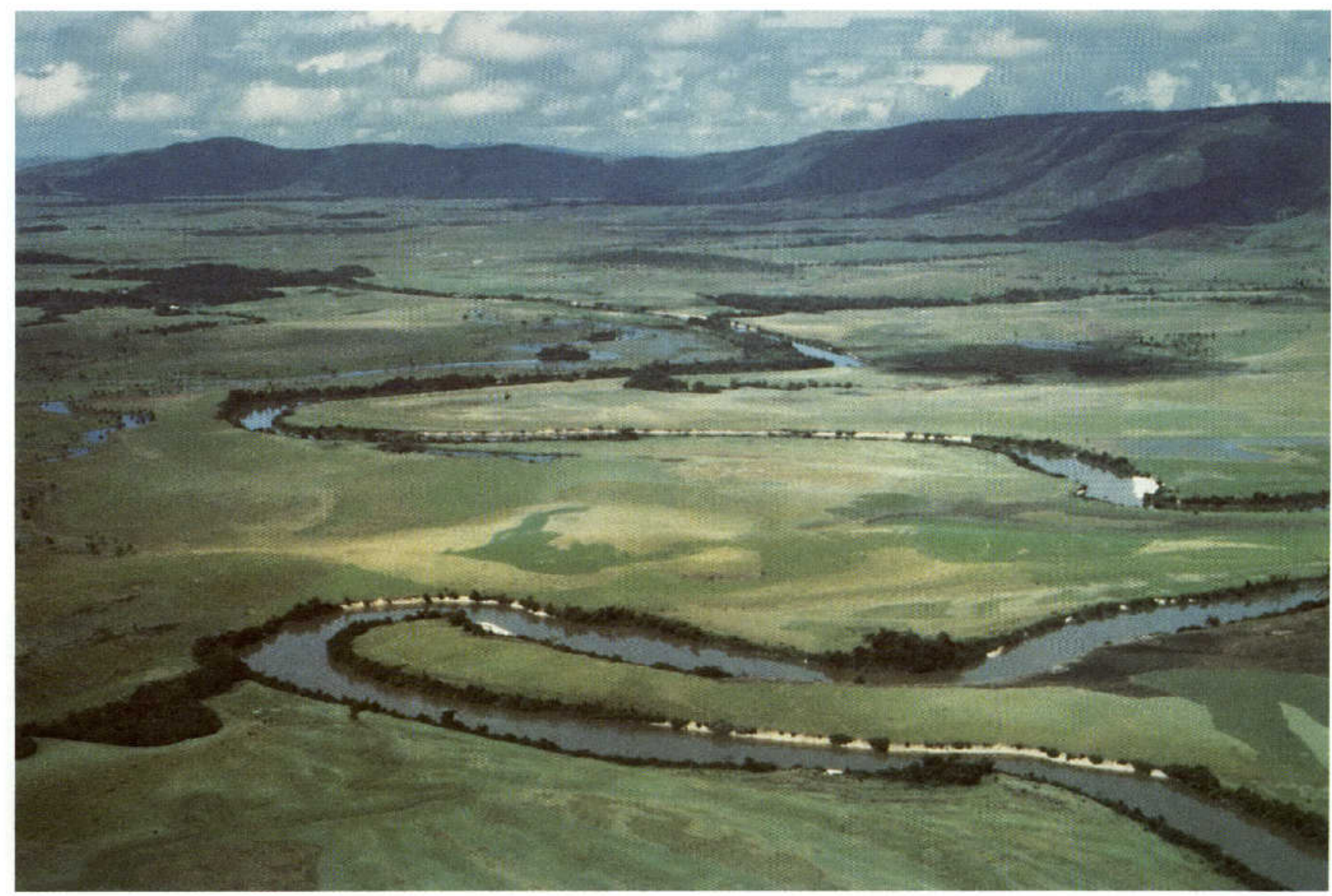

Figure 6. Valley of the Río Cuquenán downstream from its confluence with the Río Yuruani, Venezuela. This flat-floored strath valley, $7-8 \mathrm{~km}$ wide at this point, is the most extensive middle to late Cenozoic planation surface in the southerr part of the Gran Sabana.

\section{LATERITIC SOILS OF THE GRAN SABANA}

Relict lateritic soils cap numerous cuesta dip slopes, ridges, piedmont slopes, and strath terrace remnants within and adjacent to the valleys of the Rio Cuquenán, Río Aponguao, and Rio Yuruani (fig. 7). Laterite also is present as isolated remnants on cuesta dip slopes and other structurally controlled surfaces on high interfluve areas between the Río Cuquenán and the Río Yuruaní and on the high stripped structural surface west of the upper valley of the Rio Yuruaní. In most areas the well-indurated ferricrete crust that characterizes these relict soils has been at least partly stripped and nubled (fig. 8). These relations suggest periods of landscape stability and instability in the Gran Sabana.

The relict lateritic soils of the Gran Sabana are generally similar to lateritic soils described from other tropical and subtropical areas of the world (Nahon, 1986). In most areas of the southern part of the Gran Sabana, these soils are characterized by the following general profile from bedrock upward to the surface (layer designations from Nahon, 1986):

Layer $I$.-Weathered bedrock having preserved original structures

Layer 11 .-Highly irregular transitional zone between layer I and a pervasively mottled, clay-rich layer (layer III). This transitional zone may have as much as several meters of relief

Layer III.-Pervasively red and yellow mottled, clay-enriched zone wherein many preexisting rock structures have been destroyed. This layer locally is as thick 15 $\mathrm{m}$ or more (fig. 9)

Layer $I V$.-Transitional zone 0.5-2 m thick between the mottled layer (III) and the ferricrete crust (V)

Layer V.-Ferricrete layer having nodular and (or) pisolitic structure and containing numerous fragments of the underlying weathered bedrock. The upper part of this layer, commonly vesicular and weathered to dark brown or black, superficially resembles basic volcanic flow rocks. This layer is typically at least $1 \mathrm{~m}$ thick and Iocally may be as thick as 


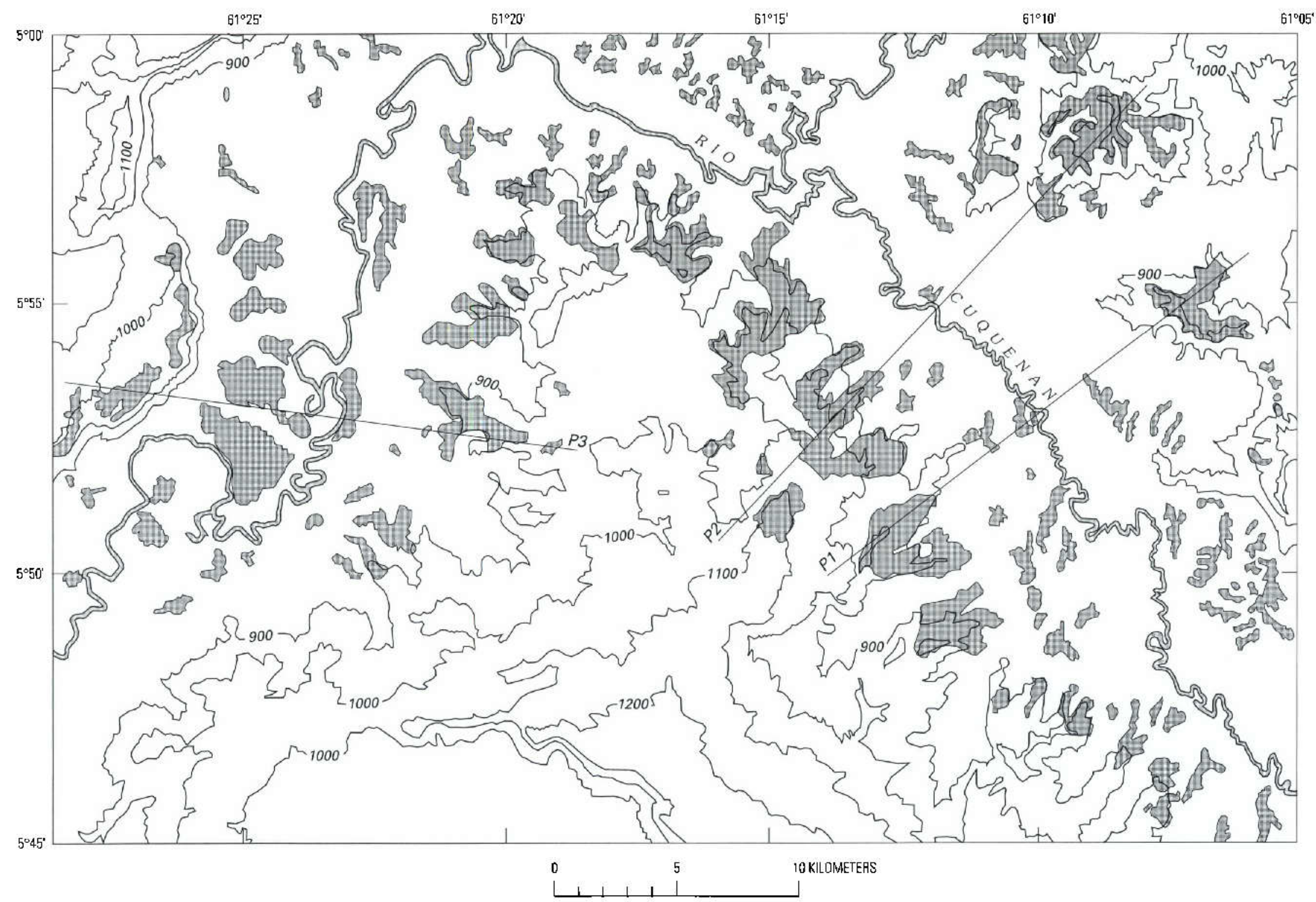

Figure 7. Map showing the distribution of laterite-capped paleosurface remnants (shaded) within and adjacent to the valley of the Río Cuquenán in the vicinity of Cerro Chiricayen, Venezuela. Topographic contour interval $100 \mathrm{~m}$. Lines of topographic profiles (fig. 14) are also shown (labeled P1, P2, and P3 to refer to profiles 1, 2, and 3, respectively). 


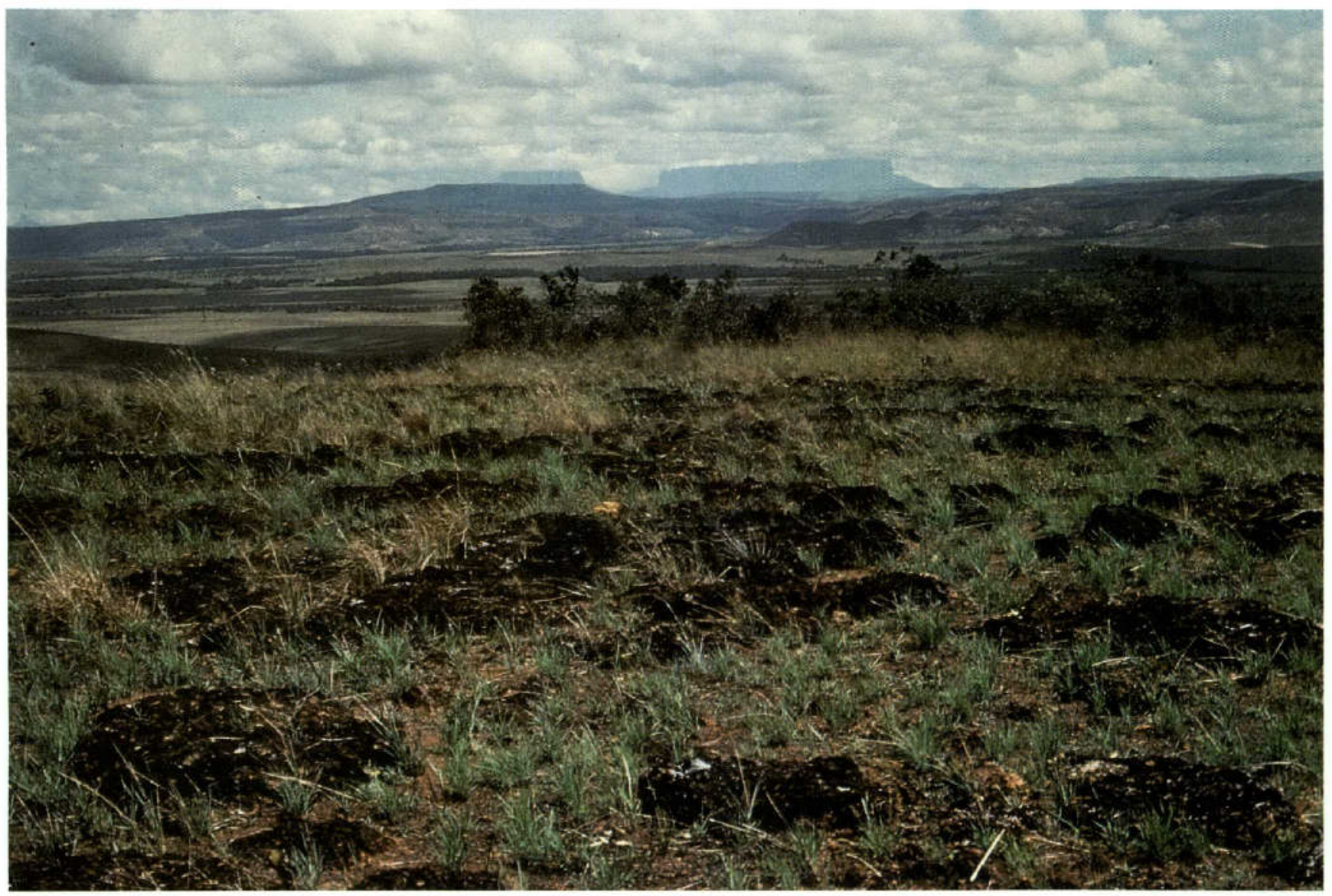

Figure 8. Surface of a relict laterite soil capping a cuesta ridge along the southwestem flank of the valley of the Río Cuquenán. These relict lateritic soils are typically degraded such that the upper part of the ferricrete crust is discontinuously exposed, etched, and partly rubbled to form a dark-red-brown to black, rough and irregular surface that is superficially reminiscent of the surface of a basaltic lava flow. View north toward Cerro Roraina (on skyline at center).

$3 \mathrm{~m}$. Locally, it contains conspicuous concentrations of hematite and gibbsite (figs. 10,11)

Layer VI. - Thin (generally $<10 \mathrm{~cm}$ thick) surface layer of ferruginous pebbles and other lateritic rubble generated by degradation of the underlying ferricrete crust

\section{DISTRIBUTION AND SIGNIFICANCE OF RELICT LATERITIC SOILS}

The present distribution of these relict ferricrete soils is apparently controlled by both stratigraphic (lithologic) and geomorphic factors. Lateritic soils are not present on the high cuestas and tepuis that are underlain by the deeply lcached and pervasively etched quartzitic sandstone and conglomerate of the lower parts of the Uairén and Matauí Fomations; however, they are particularly well developed in areas underlain by the finer grained and more feldspathic rocks of the upper part of the Uairén Formation, the
Cuquenán Formation, and the lower part of the Uaimapué Formation. They are present, but are generally somewhat less well developed, on strata of the upper part of the Uaimapué Formation.

Within and adjacent to the valley of the Río Cuquenán, a relict lateritic soil having a strongly indurated, 1-3-m-thick ferricrete crust mantles (1) dissected and rounded remnants of strath terraces of the Río Cuquenán that are within 5-10 $m$ of the level of the modern floodplain (fig. 12), (2) terrace remnants of tributary streams along the valley flanks and within some of the larger tributary valleys, and (3) dip slopes and cuesta ridges developed on the upper part of the Uairén Formation and on the lower part of the Uaimapué Formation (figs. 8, 13). Locally, these landscape relics range almost continuously over $200-300 \mathrm{~m}$ of elevation, from the level of the strath terraces along the Río Cuquenan to the crests of the cuesta ridges that form the valley sides (figs. 7,14 ).

The paleolandscape defined by these surface remnants was similar to the modem landscape. All of the major 


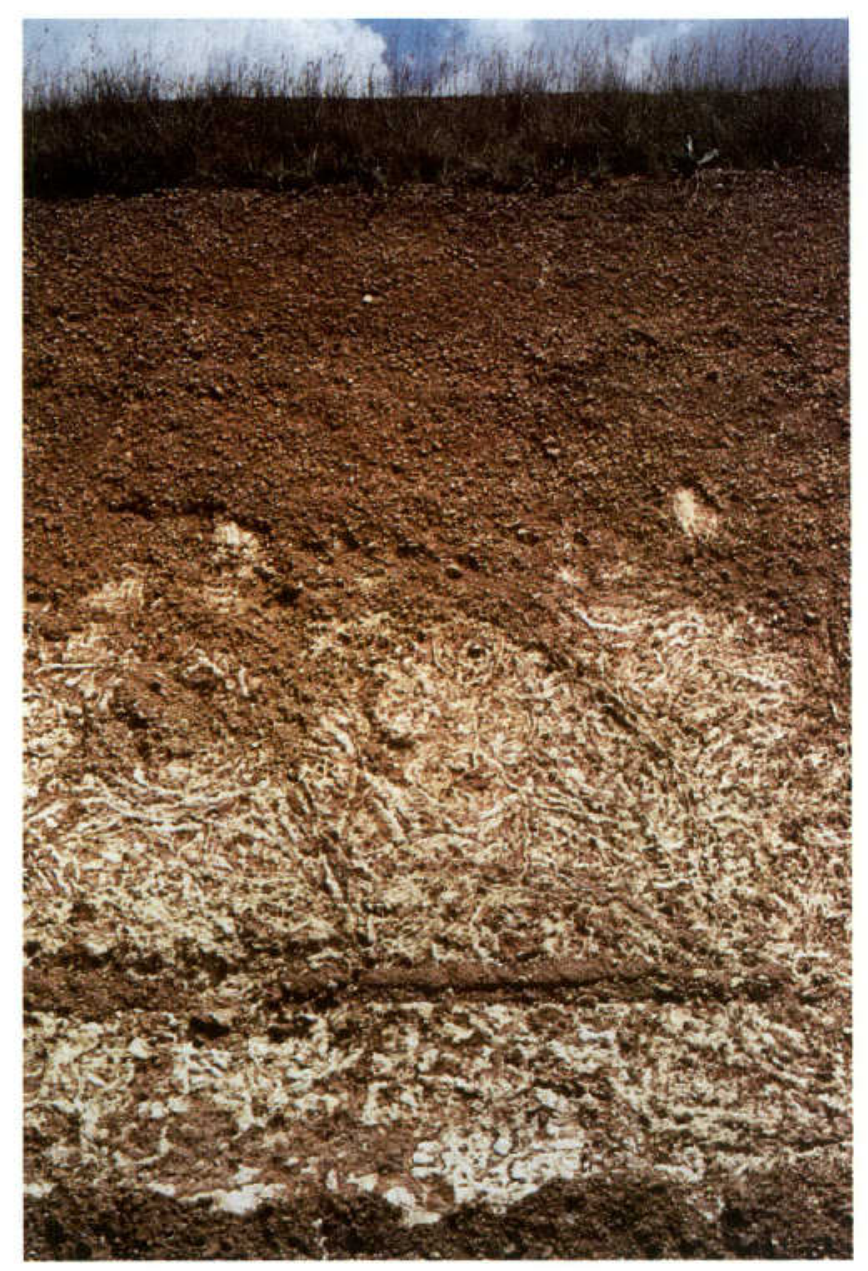

Figure 10. Typical lateritic soil roadcut exposure showing upper part of layer III (clay-enriched, red and yellow mottled zone), layer IV (ferricrete-mottled zone transition), and layer V (nodular ferricrete). Road cut is approximately $4 \mathrm{~m}$ high.

landscape components (such as stream valleys and cuesta ridges) occupied essentially the same relative and absolute positions as they do within the present landscape. Local relief between valley bottoms and ridge crests was about the same as now, and regional base level was within $10 \mathrm{~m}$ of modem base level. Upland dissection may have been somewhat less extensive than at present; however, geomorphic evidence to support this possibility is not preserved within the present landscape.

The age of this relict lateritic soil, and of the paleolandscape whose remnants it mantles, is not well constrained. Theoretical calculations suggest that a period of at least 1 m.y. would be required (under climatic conditions suitable for lateritic soil formation) to form a lateritic soil similar to

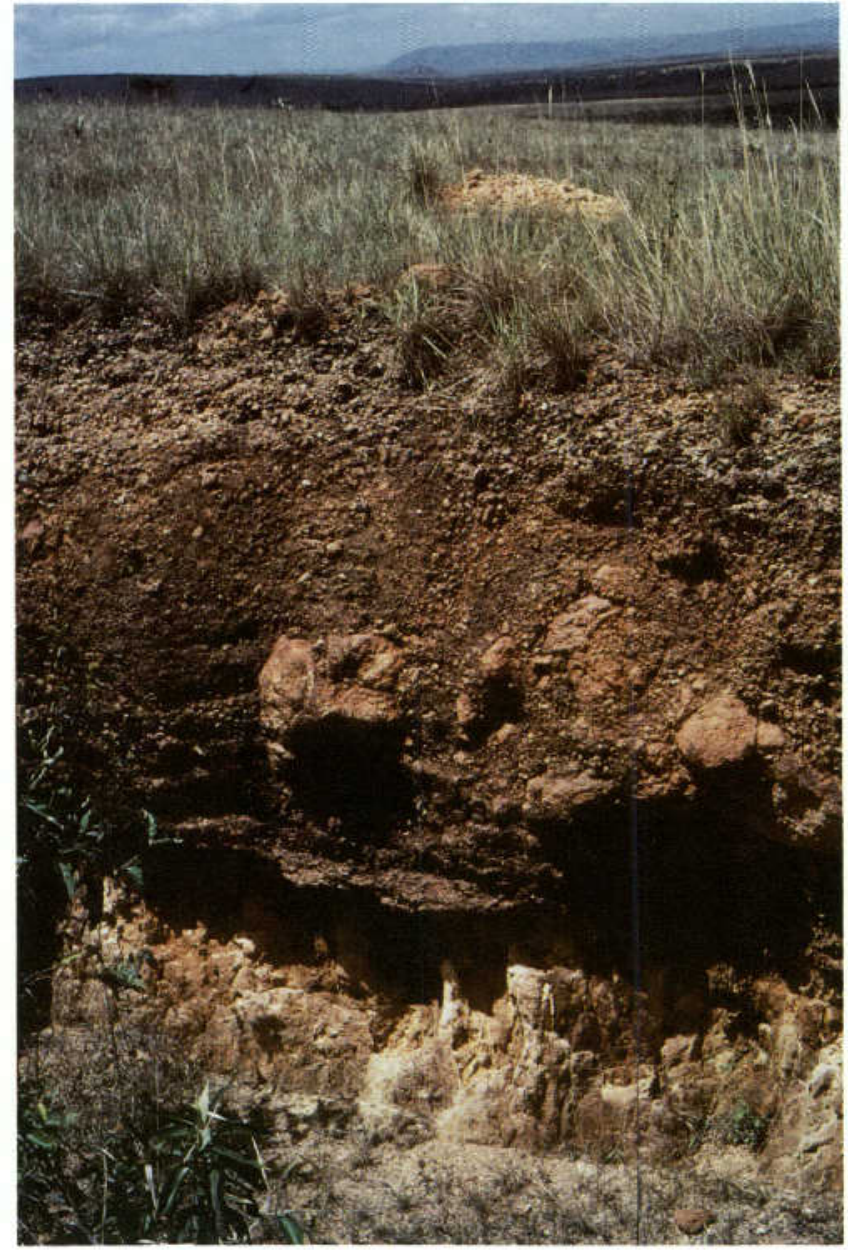

Figure 11. Upper part of a relict latcritic soil profile showing layer IV (ferricrete-mottled zone transition), layer V (nodular to pisolitic ferricrete crust; here about $2.5 \mathrm{~m}$ thick), and layer VI (disaggregated ferruginous pebble gravel lag). This relict soil profile is on the summit surface of Yuoromota tepuy at an elevation of about $1,000 \mathrm{~m}$, approximately $180 \mathrm{~m}$ above the level of the modem floodplain of the Río Cuquenán.

that mantling much of the landscape of the southem part of the Gran Sabana (Fritz, 1975). Field studies also suggest that development of ferricrete profiles requires a period of more than 1 m.y. of favorable climatic conditions (Nahon, 1986). For example, Nahon and Lappartient (1977) determined that formation of a ferricrete soil profile derived from basic volcanic rocks of the Senegalese-Mauritanian Basin occurred within 6 m.y.; however, ferricrete profile development on feldspathic to arkosic sedimentary rocks may take somewhat longer. Whatever the case, planation of the broad valley of the Río Cuquenán, development of a thick, strongly indurated ferricrete on that surface and on the surrounding hillsides and subsequent dissection of the valley sides and degradation of the ferricrete would probably require an 


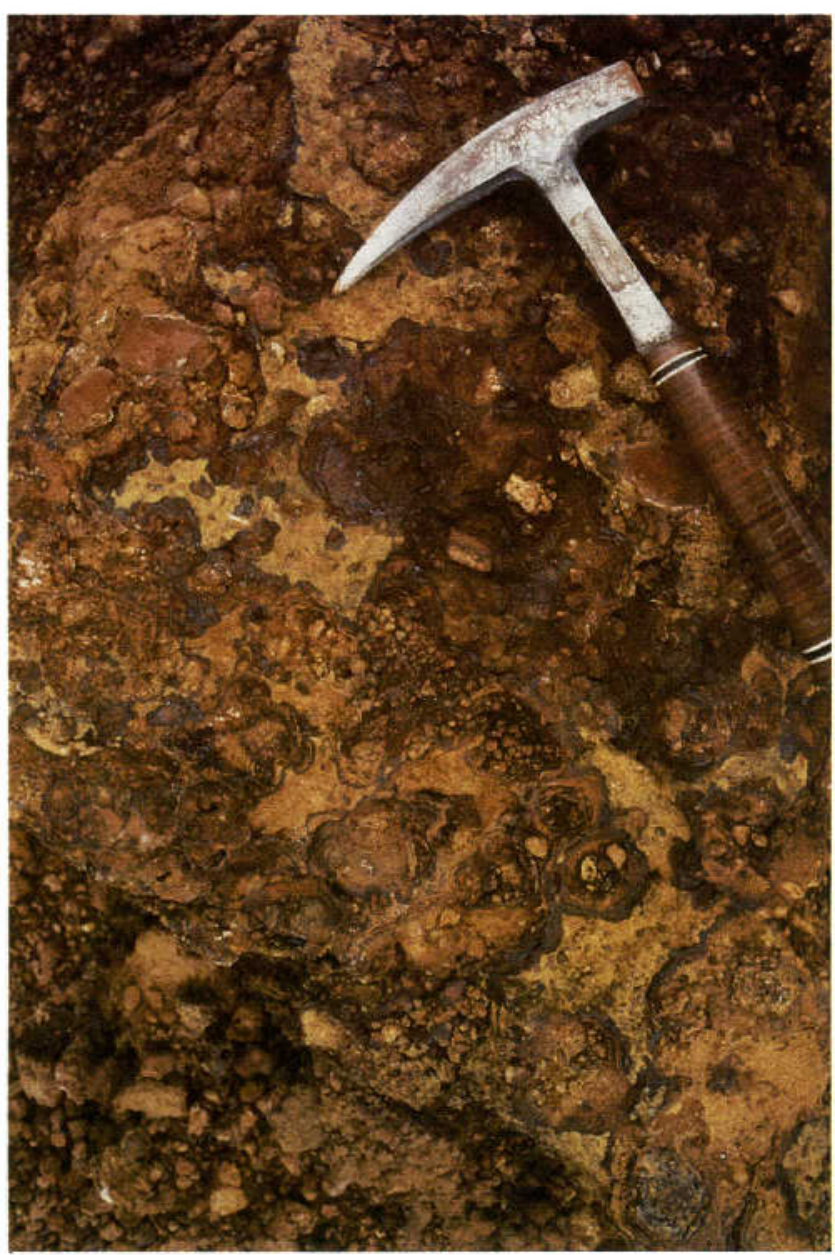

Figure 11. Detail of a strongly developed nodular ferricrete crust containing abundant rinds and nodules of hematite and lesser amounts of segregated gibbsite. Hammer is shown for scale.

aggregate period of several million years. Thus, the landscape remnants capped by this lateritic soil are likely to be at least as old as early Pliocene or late Miocene.

\section{CENOZOIC EVOLUTION OF THE GRAN SABANA LANDSCAPE}

As many as six planar geomorphic surfaces have been interpreted in the Guayana Shield (James, 1959; Short and Steenken, 1962; McConnell, 1968; Zonneveld, 1982; Schubert and others, 1986; Briceño and Schubert, 1990). These geomorphic surfaces have been defined on the basis of regional correlations of similar elevations of summit levels and areas of low relief. The surfaces are generally interpreted as remnants of a scries of regional planation surfaces that have been uplifted in the main shield area and downwarped along the coast and continental shelf (with a hinge line along the north coastal plain of the continent). Formation of multiple erosion surfaces is generally considered to be the result of altemating periods of tectonic uplift and stability, landscape dissection in response to the uplift, and parallel slope retreat during the succeeding interval of stability. The surfaces are generally thought to range from Mesozoic to Holocene in age; however, it has been pointed out by Kroonenberg and Melitz (1983) that many of these surfaces coincide with lithologic units and that the steps which separate them commonly coincide with lithologic discontinuities. Therefore, it is likely that present relief within the Guayana Shield is mostly a function of lithologic resistance and that at least some of these geomorphic surfaces are primarily a manifestation of lithologic control in a relatively stable landscape that is developed on a thick sequence of very gently dipping to flat-lying sedimentary strata.

Within the southern part of the Gran Sabana, the existence of an extensive laterite-capped paleolandscape that has $200-300 \mathrm{~m}$ of local relief and cuts across several of the regional planation surface levels hypothesized by previous workers argues strongly for a middle to late Cenozoic history wherein (1) vertical dissection, controlled at least in part by variations in lithologic resistance to weathering and erosion, has been the dominant mode of landscape evolution and (2) lateral planation was limited to the fornation of broad erosional floodplains along the major rivers. Indeed, landscape change in the Gran Sabana during middle and late Cenozoic time has been primarily, if not entirely, denudational. This denudational history has been marked by periods of general landscape dissection and stripping interrupted by intervals of relative landscape stability. The broad strath terraces that occupy the larger stream valleys most likely formed during the intervals of relative landscape stability. It is unlikely that any significant episodes of aggradation took place during most, if not all, of Cenozoic time.

In the mid-Tertiary, the landscape of the Gran Sabana was sufficiently stable to permit formation of broad strath floodplains, as wide as $7-8 \mathrm{~km}$, along major drainages of the region and widespread development of deep weathering profiles capped by thick, well-developed ferricrete crusts. In most other respects, however, this mid-Tertiary landscape was much like the landscape of today. The position and general morphology of the major landscape elements (tepuis, ridges, and major valleys) were essentially as they are today, and the overall landscape was well adjusted to underlying lithology and structure. Overall relief between ridge crests and valley bottoms may have been somewhat greater, however, than present-day relief.

Following this mid-Tertiary period of relative landscape stability and lateritic soil development, a probable long-term climatic change destabilized the landscape. Upland areas were dissected perhaps as much as $100-150 \mathrm{~m}$, and the lateritic soils were gradually stripped, etched, and rubbled; however, downwearing of the valley floors was 


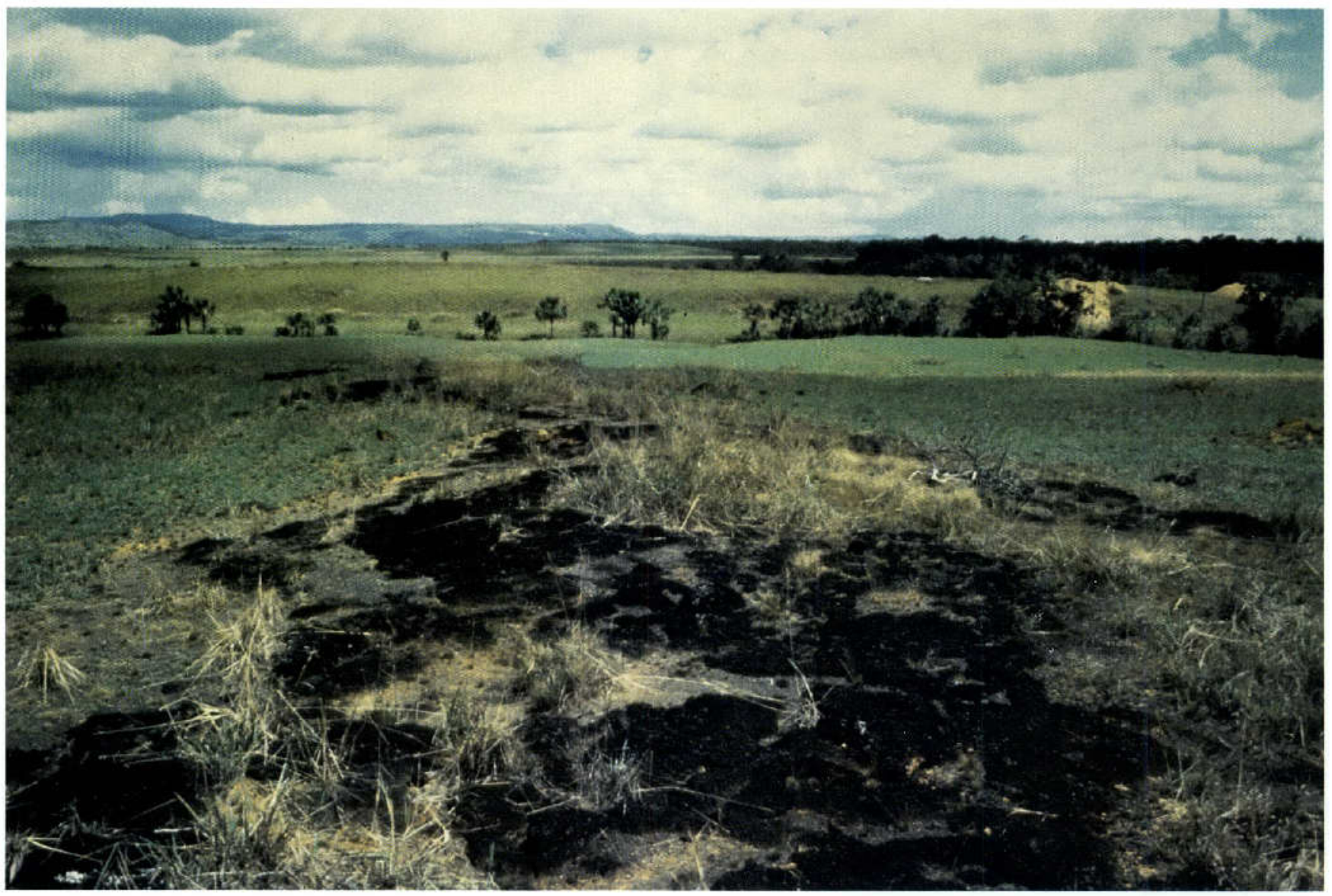

Figure 12. Surface of a relict ferricrete crust capping a series of low ( $5-10 \mathrm{~m}$ high) fluvial terrace remnants. This dissected broad valley surface can be traced almost continuously from this location, adjacent to the modem channel of the Río Cuquenán, to the crests of the low ridges along the valley margin on the left skyline (approximately $7-8 \mathrm{~km}$ distant and $200 \mathrm{~m}$ higher in elevation).

generally less than $5-10 \mathrm{~m}$. During the waning stages of this period of landscape destabilization and dissection, probably in late Tertiary or earliest Quatemary time, a shorter interval of relative landscape stability permitted formation of a 2-3-km-wide strath floodplain that is inset $5-10 \mathrm{~m}$ below the general level of the middle (?) Tertiary broad valley surface. General upland degradation likely slowed during this time, but available stream power was sufficient to rapidly transport essentially all available detrital material out of the local landscape system. This interval of renewed lateral stream planation was followed by renewed incision of the valley floors and a probable acceleration of upland stripping that apparently began during the late Quatemary, probably in response to a late Pleistocene-early Holocene climate change when an increase in mean annual temperature of as much as $5^{\circ} \mathrm{C}-7^{\circ} \mathrm{C}$ and a substantial increase in mean annual precipitation likely occurred in northem South America (Hammen, 1972; Liu and Colinvaux, 1985; Schubert and others, 1986). The net result of this Cenozoic degradational history is an erosional landscape, well adjusted to underlying lithology and structure, that is discontinuously mantled by generally less than $2 \mathrm{~m}$ of late Quaternary colluvial, alluvial, and fluvial deposits.

\section{OCCURRENCE OF PLACER DEPOSITS}

The presence of numerous paleosurface remnants developed on bedrock and mantled by thick ferricrete crusts and the almost complete absence of Tertiary or Quaternary deposits of any significant thickness indicate a lack of significant periods of sedimentary accumulation in the region of the southern part of the Gran Sabana during middle and late Cenozoic time. Surficial deposits in the Gran Sabana are limited to (1) generally less than 1-2 $\mathrm{m}$ of discontinuous colluvial-alluvial mantles on hill slopes and piedmonts, although somewhat thicker colluvial aprons are preserved locally beneath pebble to cobble lag gravels weathered from conglomerate Ienses and beds within the Roraima Group or beneath cobble- to small boulder-size rubble derived from degraded ferricrete crusts; (2) thin fluvial deposits in the 


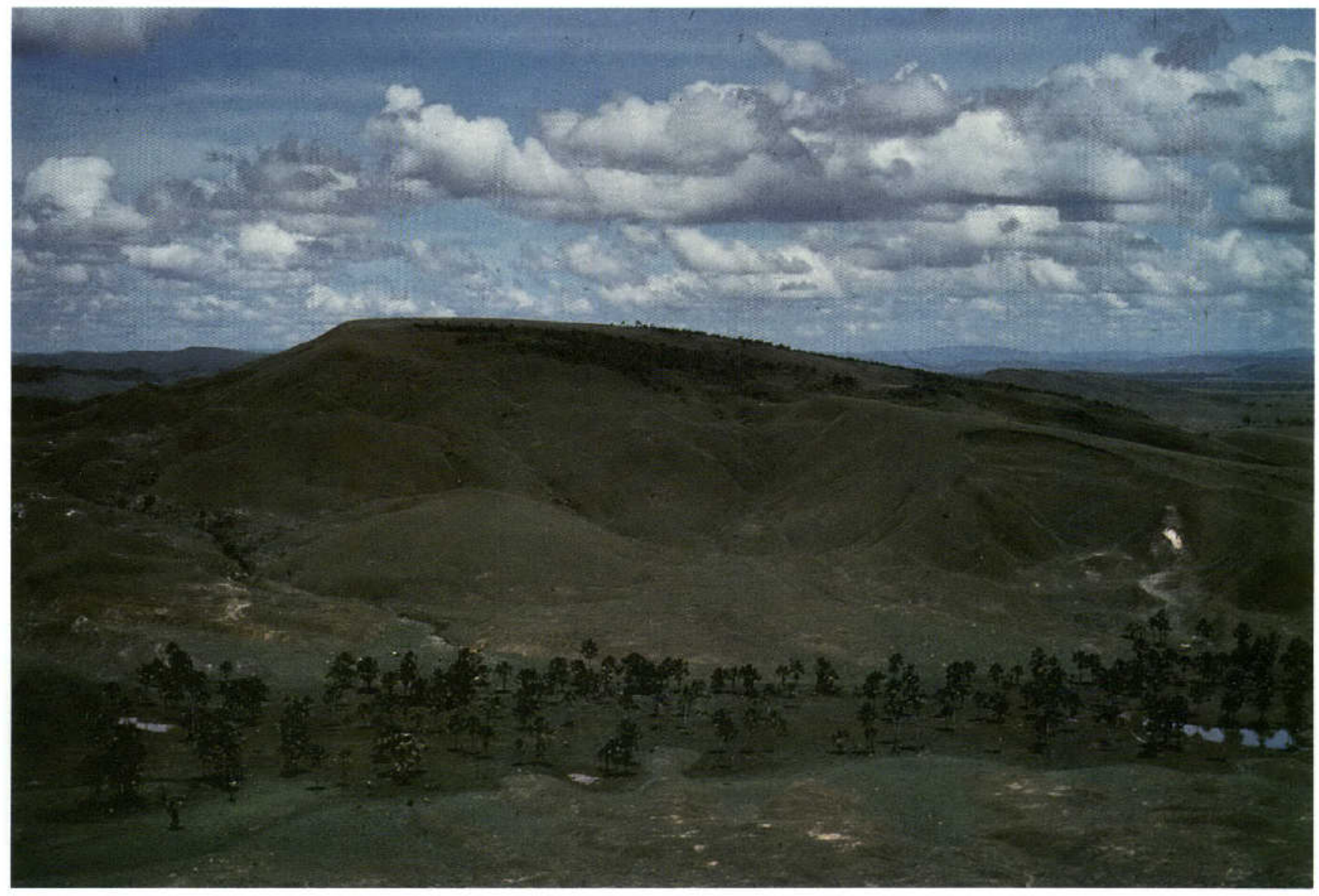

Figure 13. Laterite-capped cuesta ridge developed on gently dipping strata of the upper part of the Uairén Formation. A strongly developed ferrugenous crust, 2-4 m thick, caps the gently northeast sloping surface of this cuesta from the floor of the valley of the Río Cuquenán (out of view to the right) to the crest of the ridge. Local relief in this view, from the tree-covered floodplain of the small stream in the foreground to the cuesta summit, is about $160 \mathrm{~m}$.

larger valleys that are generally $1-2 \mathrm{~m}$ thick over Pleistocene (?) strath surfaces and 5-10 m thick within the narrow modern floodplains of the largest rivers; and (3) numerous, widely scattered landslide deposits, particularly in areas underlain by the upper part of the Uairén and the lower part of the Uaimapué Formations. Tertiary deposits have not been identified in the southern part of the Gran Sabana.

Consequently, gold and diamond resources in the southem part of the Gran Sabana are primarily restricted to three general geologic-geomorphic environments:

1. Placer deposits within the active channels and Holocene floodplains of the larger rivers downstream from extensive exposures of the Uairén Formation

2. Colluvial-alluvial placer deposits of small low-order drainage basins within or adjacent to exiensive exposures of the Uairen Formation. These placers typically are associated with pebble to cobble gravels lying on or within about $1 \mathrm{~m}$ of the basal colluvial-alluvial contact with the underlying bedrock
3. Paleoplacer deposits associated with conglomeratic lenses and beds within the lower $500-600 \mathrm{~m}$ of the Uairén Formation

These placer deposits have been mined in several locations where the conglomerates presently lie within a few meters of dip-slope surfaces. Additional gold and diamond resources might be present within or immediately beneath lateritic ferricrete crusts developed on surfaces underlain by the Uairén Formation. Gold concentrations beneath the iron crusts of lateritic soils have been reported from Western Australia (Mann, 1984), from the Mato Grosso area of Brazil (Michel, 1987), and from Dondo Mobi, Gabon (Colin and Viellard, 1991).

These gold and diamond resources are generally widely scattered and probably limited in both grade and tonnage, and cconomic exploitation of these resources is generally limited to surface mining techniques. Therefore, the resources are, for the most part, probably best suited for exploration and exploitation by small independent operators. 

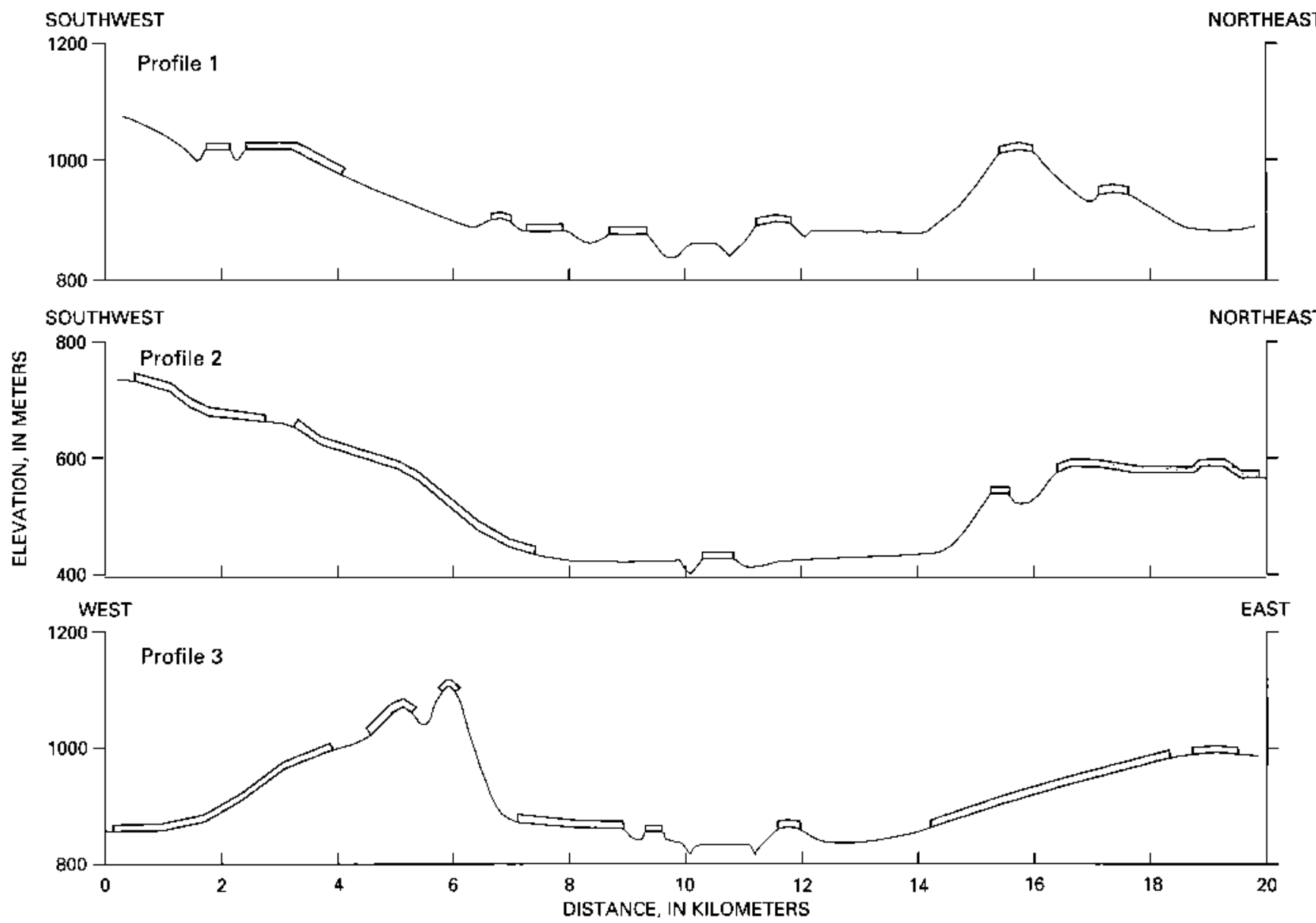

Figure 14. Topographic profiles across the valley of the Río Cuquenán showing the distribution of relict tateritic soils (shaded) capping the remnants of the middle Tertiary paleolandscape. Profile locations are shown in figure 7. Vertical exaggeration times 10.

\section{PALEOPLACERS WITHIN THE LOWER PART OF THE RORAIMA GROUP}

Gold and diamond paleoplacers are present at several different stratigraphic levels within the lower part of the Roraima Group. In northem Brazil, gold and diamonds are present within small conglomerate lenses approximately $160-210 \mathrm{~m}$ above the base of the local Roraima section near the summit of Serra Tepequem (approximately lat $3^{\circ} 47^{\prime} \mathrm{N}$., long $61^{\circ} 42^{\prime}$ W.) (Borges and D'Antona, 1988). In Venezuela, along the southern margin of the Gran Sabana, several mines are producing diamonds and (or) gold from conglomerate within the Uairén Formation. Four mines, apparently inactive at present, are between approximately 500 and 530 $m$ elevation on the gentle dip slopes of low cuestas that rim the inner valley of the Río Icabarú in the vicinity of the town of Icabaru. Production from these mines was probably mainly from gravel lenses and beds that are within the same general stratigraphic horizon immediately beneath this dip-slope surface. Moreover, at least two gold and diamond prospects are in conglomerate and associated deeply leached sandstone near the axis and on the east-dipping flank of the
Chiricayen anticline (near lat $4^{\circ} 50^{\prime} \mathrm{N}$., long $61^{\circ} 15^{\prime} \mathrm{W}$., and lat $4^{\circ} 42^{\prime}$ N., long $61^{\circ} 06^{\prime}$ W., respectively). At both prospects, the productive conglomeratic layers are at least $500-600 \mathrm{~m}$ above the base of the Uairen Fornation.

\section{PLACERS IN COLLUVIAL-ALLUVIAL DEPOSITS OF LOW-ORDER DRAINAGES}

Six active gold and diamond placer mines are within headwater areas of tributary drainages of the Río Icabarí and the Río Cuquenán. Three of these mines are immediately south of the north-dipping cuesta ridge, underlain by lower Roraima Group rocks, that bounds the southern margin of the strike valley of the Río Icabari (in the vicinity of lat $4^{\circ} 10^{\prime}$ N., long $61^{\circ} 12^{\prime}$ W.). The other three mines are in a similar geologic and geomorphic setting at the base of the scarp slope that defines the nose of the west-plunging syncline that underlies Paraitepuy (between lat $3^{\circ} 32^{\prime}$ and $3^{\circ} 39^{\prime}$ $\mathrm{N}$. and long $61^{\circ} 25^{\prime}$ and $61^{\circ} 28^{\prime}$ W.). These mines are all underlain by lower Roraima rocks, and they are all within a few kilometers of the headwaters of low-order streams drain- 
ing deeply dissected strata of the Uairén Formation. Production from these mines is derived from thin basal lenses of late Quatemary (Holocene?) pebble to cobble gravel that lie on or close to irregular bedrock surfaces. In addition, at least some production from two of these mines is derived from conglomerate lenses within the underlying, deeply weathered bedrock. Gold and diamond colluvial-alluvial prospects also occur near the axis of the north-northwest-plunging anticlinal nose of the Chiricayen anticline (within the drainage of Quebrada Nunque between lat $4^{\circ} 48^{\prime}$ and $4^{\circ} 52^{\prime} N$. and long $61^{\circ} 15^{\prime}$ and $61^{\circ} 20^{\prime} \mathrm{W}$.). The gold and diamonds in these prospects are in basal colluvial-alluvial gravels of probable late Quatemary age that were likely derived from local conglomerates several hundred meters above the base of the Uairén Formation.

\section{PLACERS IN MODERN CHANNELS OF THE LARGER STREAMS}

Approximately 40 chupadoras (pontoon-mounted air-lift pumps) were present during 1989 on the Río Icabarú between Los Caribes and the confluence of the Río Icabarú and the Río Caroní, a distance along the river channel of about $140 \mathrm{~km}$. These chupadoras are not uniformly distributed along the river channel; rather, they tend to be concentrated along limited reaches of the river. Most notably, about 60 percent were operating along a $30-\mathrm{km}$-long reach starting about $17 \mathrm{~km}$ downstream from Los Caribes and extending to the first major salto (waterfall), about 5.5 $\mathrm{km}$ downstream from the Río Hacha. About half of these were within $6 \mathrm{~km}$ of junctions with major tributaries. The reasons for this nonuniform distribution are not entirely clear. The distribution may indicate geologic and (or) fluvial geomorphic controls on the location of the richest channel placer or practical limitations of chupadora mining. It is probably significant, however, that almost all of these operations were within the region that is either underlain by or adjacent to uplands underlain by the lower part of the Roraima Group.

\section{REFERENCES CITED}

Borges, F.R., and D'Antona, R. de J.G., 1988, Geología e mineralizçoes da Serra Tepequém: Congreso Brasileiro de Geología, 35th, Belém, Pará, Brazil, Annals, v. 1, p. 155-163.

Briceño, H.O., and Schubert, Carlos, 1990, Geomorphology of the Gran Sabana, Guayana Shield, southeastern Venezuela: Geomorphology, v. 3, p. 125-141.

Colin, Fabrice, and Viellard, P., 1991, Behavior of gold in the lateritic equatorial environment-Weathering and surface dispersion of residual gold particles, at Dondo Mobi, Gabon: Applied Geochemistry, v. 6, p. 279-290.

Fritz, Bertrand, 1975, Etude thermodynamique et simulation des reactions entre mineraux et solutions, application a la geochimie des alterations et des eaux continentales: Universite de Strasbourg, Sciences Geologiques, Memoire, 41, $152 \mathrm{p}$.
Ghosh, S.K., 1985, Geology of the Roraima Group and its implications: Simposium Amazonico, 1st, Caracas, 1981, Publicación Especial 10, p. 31-50.

Hammen, Thomas van der, 1972, Changes in vegetation and climate in the Amazon Basin and surrounding areas during the Pleistocene: Geologie en Mijnbouw, v. 51, p. 641-643.

Howard, A.D., 1988, Introduction to cuesta landforms and sapping processes on the Colorado Plateau, in Howard, A.D., Kochel, R.C., and Holt, H.E., eds., Sapping features of the Colorado Plateau-A comparative planetary geology field guide: National Aeronautics and Space Administration Special Publication SP-491, p. 6-56.

James, P.E., 1959, The geomorphology of eastern Brazil as interpreted by Lester C. King: Geographical Reviews, v. 49, p. $240-246$.

Kroonenberg, S.B., and Melitz, P.J., 1983, Sumnit levels, bedrock control, and the etchplain concept in the basement of Surinam: Geologie en Mijnbouw, v. 62, p. 389-399.

Laity, J.E., and Malin, M.C., 1985, Sapping processes and the development of theater-headed networks in the Colorado Plateau: Geological Society of America Bulletin, v. 96, p. 203-217.

Liu, Kam-biu, and Colinvaux, P.A., 1985, Forest changes in the Amazon Basin during the last glacial maximum: Nature, v. 318 , p. $556-557$.

Mann, A.W., 1984, Mobility of gold and silver in lateritic weathering profiles-Some observations from Western Australia: Economic Geology, v. 79, p. 38-49.

McConnell, R.B., 1968, Planation surfaces in Guyana: Geographical Journal, v. 134, p. 506-520.

Michel, D., 1987, Concentration of gold in in-situ laterites from Mato Grosso: Mineralium Deposita, v. 22, p. 185-189.

Nahon, D.B., 1986, Evolution of iron crusts in tropical landscapes, in Colman, S.M., and Dethier, D.P., eds., Rates of chemical weathering in rocks and minerals: Orlando, Florida, Academic Press, 603 p.

Nahon, D.B., and Lappartient, J.R., 1977, Time factor and geochemistry in iron coust genesis: Catena, v. 4, p. 249-254.

Reid, A.R., 1974, Stratigraphy of the type area of the Roraima Group, Venezuela: Conferencia Geológica Inter-Guayanas, 9th, Ciudad Guayana, Venezuela, 1972, Memoria, Publicación Especial 6, p. 343-353.

Schubert, Carlos, Briceño, H.O., and Fritz, Peter, 1986, Paleoenvironmental aspects of the Caroni-Paragua River basin (southeastern Venezuela): Interciencia, v. 11, no. 6, p. 278-289.

Short, K.C., and Steenken, W.F., 1962, A reconnaissance of the Guayana Shield from Guasipati to the Río Aro, Venezuela: Asociación Venezolana de Geología, Minería y Petroleo, Boletín Informativo, v. 5 , no. 7, p. 189-221.

Yánez, Galo, 1984, Geology and geomorphology of the Roraima Group, southwestern Venezuela: West Lafayette, Indiana, Purdue University, Ph.D. dissertation, $145 \mathrm{p}$.

Zonneveld, J.I.S., 1982, Summit levels in Surinam: ITC Journal, 1982 , p. $237-242$.

1985, Geomorphological notes on the continental border in the Guyanas (N, South America): Zeitshrift fur Geomorphologie, N.F., supplement band 54, p. 71-83. 

Gold and Diamond Resources of the Icabarú Sur Study Area, Estado Bolívar, Venezuela

By William E. Brooks, Richard M. Tosdal, and Fernando J. Nuñez

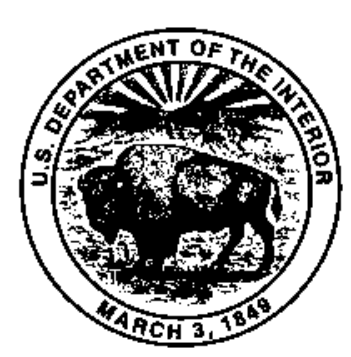




\section{CONTENTS}

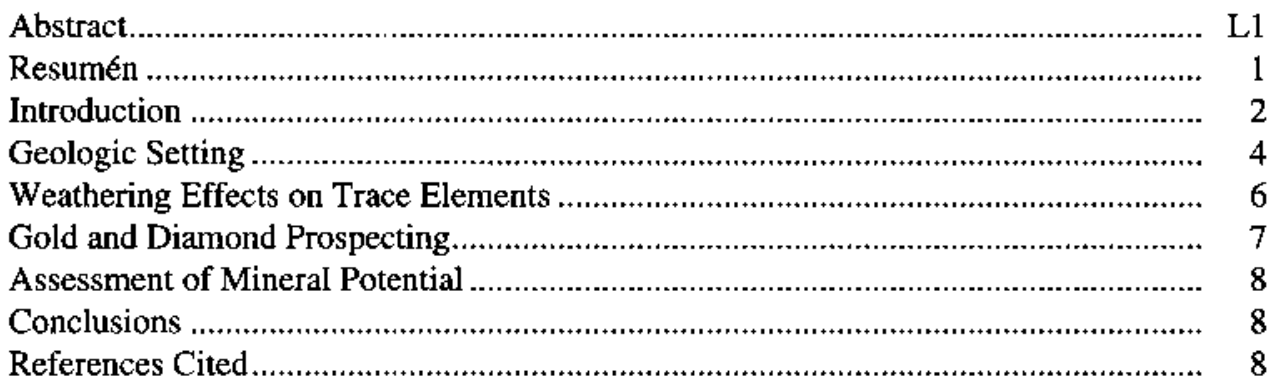

\section{FIGURES}

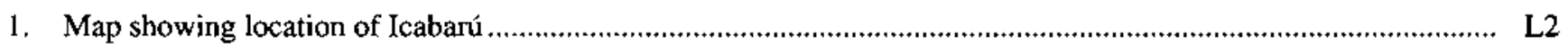

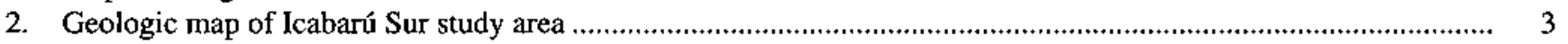

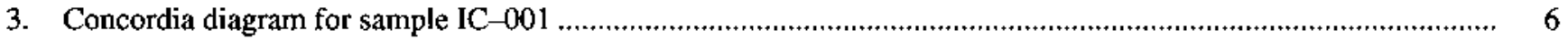

\section{TABLES}

1. Analytical data for rock samples of the Early Proterozoic Caicara Formation of the Cuchivero Group, Icabarú Sur study area....

2. U-Pb geochronologic data for felsic tuff (IC-001) from the Icabarú Sur study area...

3. Trace-element contents of unweathered and weathered sample pairs from the Early Proterozoic Caicara Formation of the Cuchivero Group, Icabaru Sur study area 


\title{
Gold and Diamond Resources of the Icabarú Sur Study Area, Estado Bolívar, Venezuela
}

\author{
By William E. Brooks, ${ }^{1}$ Richard M. Tosdal, ${ }^{2}$ and Fernando J. Nuñez ${ }^{3}$
}

\begin{abstract}
The Icabaru Sur study area is in the southern part of Estado Bolívar, Venezuela, in a transition zone between savanna and jungle. The study area is $15 \mathrm{~km}$ southwest of Icabarú, the supply town for miners in the area. Access to the $50-\mathrm{km}^{2}$ study area is by helicopter or by unimproved road from Santa Elena de Uairén, approximately $80 \mathrm{~km}$ to the east.

Exposed in the study area are Early Proterozoic rhyolitic ash-flow tuffs and a porphyritic rhyolite of the Cuchivero Group and sandstone of the Early to Middle Proterozoic Roraima Group. These rocks have not been affected by regional metamorphism; the ash-flow tuffs have well-preserved compaction foliation, shards, and pumice. Three zircon fractions from one pyrite-bearing sample of the Cuchivero Group have consistent U-Pb ages of about 1.98 $\mathrm{Ga}$. Northeast- to east-striking faults separate the Roraima Group to the north from the volcanic province to the south.

One diamond mine is active in the study area, and numerous small prospects dot streams. Diamonds are panned from gravels derived from the Roraima Group. The presence of placer diamonds suggests a kimberlitic source; however, diamonds were not found in stream-sediment samples from the study area, and minerals indicative of a kimberlitic source have not been identified in the study area or in the outcrop area of the Roraima Group elsewhere in the shield. The primary source of the diamonds remains undetermined.

The presence of silicic volcanic rocks in the study area suggests a potential for epithermal gold deposits. Minor pyrite, a fluorite veinlet in one sample, and small quartz

IU.S. Geological Survey, Denver Federal Center, MS905, Denver, Colorado 80225.

${ }^{2}$ U.S. Geological Survey, 345 Middlefield Road, MS901, Menlo Park, California 94025 .

${ }^{3}$ Corporación Venezolana de Guayana, Técnica Minera, C.A., C.C. Chilemex, Piso 1, Puerto Ordaz, Venezuela.
\end{abstract}

veins cutting the volcanic rocks are the only indications of mineralized rock.

\section{RESUMEN}

El área de estudio Icabarú Sur tiene $50 \mathrm{~km}^{2}$ de área, está localizada a $15 \mathrm{~km}$ al suroeste del poblado minero de Icabarú al sur del Estado Bolívar, Venezuela, y está ubicado en una zona transicional entre vegetación sabana y selva. El acceso se realiza desde Santa Elena de Uairén, a $80 \mathrm{~km}$ al este de Icabarú, ya sea por helicóptero o por carreteras para vehículos de doble tracción.

En el área de estudio están expuestas toba riolítica de flujo de ceniza y riolita porfirítica, ambas del Grupo Cuchivero, además aflora arenisca perteneciente al Grupo Roraima de edad Proterozoico Temprano a Medio. Estas rocas no han sido afectadas por metamorfismo regional; la toba riolítica de flujo de ceniza presenta foliación por compactación, esquirlas y fragmentos de pómez. Las tres fracciones de circón de una muestra que contiene pyrita arrojaron edades consistentes por el método U-Pb de aproximadamente $1.98 \mathrm{Ga}$. El Grupo Roraima, al norte, está separado de la provincia volcánica, al sur, por fallas que tienen un rumbo noreste a este.

Hay una mina de diamante activa en el área, y numerosos prospectos pequeños a lo largo de las quebradas. Los diamantes son extraidos con suruca (wire-mesh pan) a partir de grava derivada del Grupo Roraima. La presencia de diamante en depósitos tipo placer sugiere una fuente kimberlítica, sin embargo, no se encontraión diamantes en sedimentos de quebradas, además, no se han encontrado minerales indicativos de una fuente kimberlítica en el área de estudio o en rocas del Grupo Roraima a través del Escudo de Guayana. La fuente primaria de los diamantes permanece indeterminada.

La presencia de rocas volcánicas siliceas en Icabanú Sur sugiere un potencial de depósitos auríferos epitermales. La única indicación de mineralización en el área es trazas de pirita, una venilla de fluorita en una muestra y vetas pequeñas de cuarzo que invaden las rocas volcánicas. 


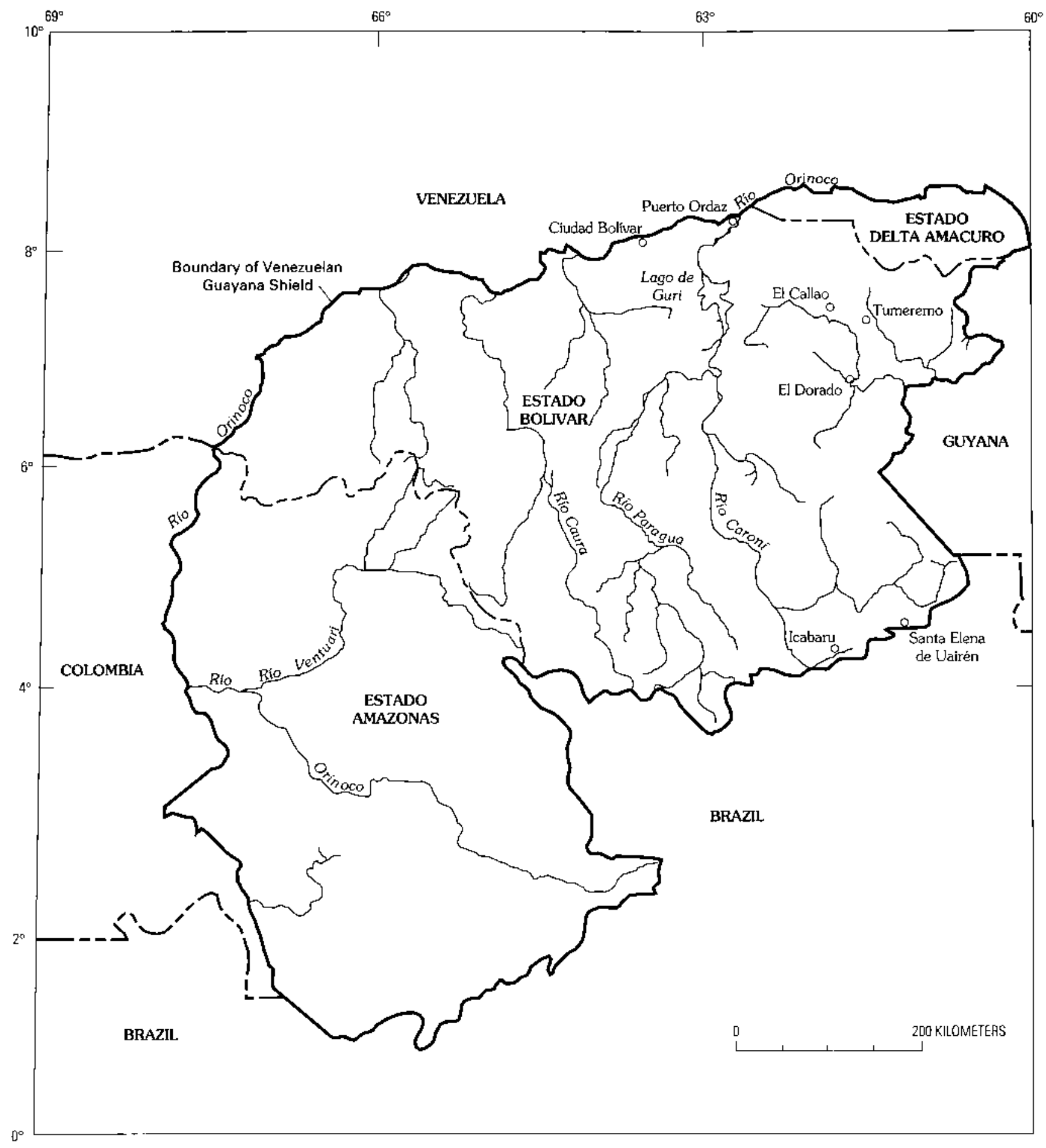

Figure 1. Location of Icabarú in southeastem Estado Bolívar, Venezuela. The Icabarú Sur study area is $15 \mathrm{~km}$ southwest of the town of Icabarú.

\section{INTRODUCTION}

The Icabarú Sur study area is in the southern part of Estado Bolívar, Venezuela (fig. 1). The study area is approximately $50 \mathrm{~km}^{2}$ in size and is $15 \mathrm{~km}$ southwest of Icabarú, a mining supply town for the region, in a transition zone between savanna in the north and dense jungle to the south. Access to the study area is by hard surface to unimproved road from Santa Elena de Uairén, approximately $80 \mathrm{~km}$ to the east, or by helicopter.

In this part of the Guayana Shield, Early Proterozoic rhyolitic ash-flow tuffs, thyolite of the Cuchivero Group, 
and sandstone of the Early to Middle Proterozoic Roraima Group (Gibbs and Barron, 1983; Sidder and Mendoza, this volume) are exposed. Rocks of the Roraima Group are commonly considered to be the source of placer gold and diamonds recovered from streams in the region. During a geologic reconnaissance of the area, Contreras and Page (1988) recommended additional field studies to investigate the potential of epithermal gold deposits in the region.

\section{GEOLOGIC SETTING}

The Icabaru Sur study area is within the central part of the Guayana Shield and contains volcanic rocks of the Early Proterozoic Uatuma Supergroup and sedimentary rocks of the Early to Middle Proterozoic Roraima Group (Gibbs and Barron, 1993) (fig. 2). Recent work by Sidder and Mendoza (this volume) indicates that the ash-flow tuff units and rhyolite are included in the Early Proterozoic Caicara Formation of the Cuchivero Group in Venezuela.

Silicic, relatively unmetamorphosed, volcanic rocks of the Caicara Formation of the Cuchivero Group crop out in the southern part of the study area. Three distinctive ash-flow tuffs and a porphyritic rhyolite are exposed. Compaction foliation visible in hand sample and outcrop indicates deposition as a subaerial ash-flow tuff. The silica content of these volcanic rocks ranges from 67.1 to 73.8 weight percent $\mathrm{SiO}_{2}$. Descriptions of the tuffs and the rhyolite are given in figure 2 , and analytical data are in table 1 . A source for these tuffs has not been identified.

Three fractions of a zircon concentrate from one of the ash-flows (IC-001, fig. 2) have consistent U-Pb ages that imply the rock is about $1.98 \mathrm{Ga}$ (fig. 3). The U-Pb geochronologic data are listed in table 2 . Abundant sulfide minerals, which if not removed can contribute lead to the analysis, and the very fine grain size of the zircon were problems in the analysis; however, the age is relatively accurate based on the transparent character of the zircons, which indicates that not much damage has occurred to the zircon crystal lattice, on the fact that the least discordant data point is close to concordia, and on comparison with other published ages (Sidder and Mendoza, this volume).

Red to orange, well-sorted sandstone of the Uairén Formation of the Roraima Group crops out in the northem part of the study area. Grains are subrounded, $0.3-0.5 \mathrm{~mm}$ in diameter, and cemented with hematite. Bedding is massive, and sedimentary structures are rare. The Roraima Group is a thick continental sedimentary sequence composed of four formations (Reid and Bisque, 1975) and is present in Venezuela, Guyana, Suriname, and northem Brazil. Regional thickness of the Roraima Group is estimated to be $2,600 \mathrm{~m}$ or more (Dalton in Reid and Bisque, 1975). Rocks mapped as the Roraima Group in southeastern Venezuela are at least
1,670 Ma in age; some are possibly as old as about $1,900 \mathrm{Ma}$ and others as young as about $1,500 \mathrm{Ma}$ or younger (Priem and others, 1973; Sidder and Mendoza, this volume). A study of heavy minerals in streams that flow through and over rocks of the Uairen Formation in the region near Icabarú (Del Ollo and others, 1989) indicates that the original source of the Roraima Group sediments was complex and included granitic, volcanic, alkaline, and metasedimentary rocks.

Sandstone of the Roraima Group is separated from the volcanic rocks to the south by northeast- to east-striking high-angle normal faults (Contreras and Page, 1988) that juxtapose rocks of the Roraima Group against the volcanic rocks of the older Caicara Formation. The amount of vertical displacement is unknown. Neither quartz veins, hydrothermal alteration, nor other physical evidence of mineralization is associated with these faults.

\section{WEATHERING EFFECTS ON TRACE ELEMENTS}

Exposures in the study area present an opportunity to study trace element variation between weathered and unweathered volcanic rocks in a tropical environment. The behavior of trace elements, especially zirconium, during weathering is not well known (Erlank and others, 1978). In chemical variation studies of metamorphic rocks in a tropical environment, Montero and others (1989) used zirconium content as an immobile reference element.

Five rock samples from the study area were collected and then sawed in order to separate the unweathered core from the weathered rind. These two splits were crushed, pulverized, and analyzed on an energy-dispersive analyzer that allows rapid analysis for $\mathrm{Zr}, \mathrm{Rb}, \mathrm{Sr}, \mathrm{Y}, \mathrm{Nb}$, and $\mathrm{Ba}$. Results of this study are presented in table 3 . The zirconium content of the weathered samples is dramatically higher than that of the unweathered samples. Weathering did not affect the niobium content in most of the samples, but the strontium content is lower in weathered samples. Changes in content of rubidium, yttrium, and barium with weathering are erratic.

Presumably, most of the zirconium in these silicic rocks is contained in zircon, a mineral that commonly is resistant to chemical weathering (Deer and others, 1982). Therefore, it is likely that zirconium is released during the weathering of minerals other than zircon or from minerals of which zirconium is a minor component (Erlank and others, 1978). Dennen and Anderson (1962) compared the compositions of various fresh rocks with their respective weathering rinds. The zirconium content was little changed or slightly enriched (as much as twofold) in most samples and was depleted in only one sample. 


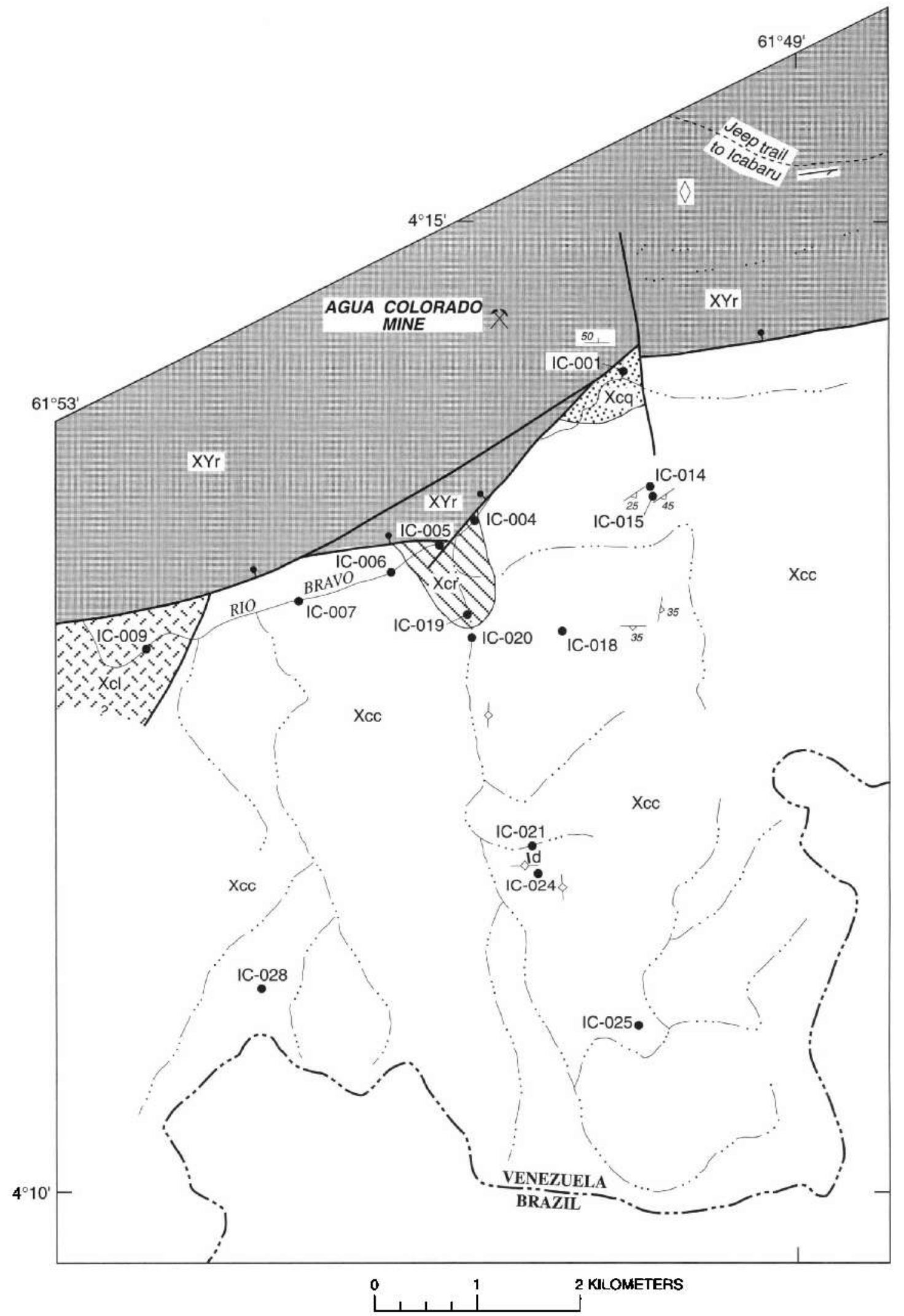

Figure 2. Geology of the Icabanú Sur study area, Estado Bolívar, Venezuela. Drainage base from Icabani Sur, 1985, hoja 7828. Geologic mapping by Brooks and Nuñez, 1988. 


\section{EXPLANATION}

$\mathrm{XYr}$-. Roraima Group (Early to Mlddle Proterozoic) —Red to orange, well-sorted ( $-0.3-0.5 \mathrm{~mm}$ diameter) quartz sandstone. Grains of subrounded quartz and polycrystalline quartz predominate; sparse subrounded zitcon, muscovite, and ppaque minerals are present; cement is hematite. Massive bedding. Neither metamorphic textures nor quartz overgrowths are present

Caicara Fomation of the Cuchivero Group (Early Proterozoic)

$\mathrm{Xcr} \quad$ Rhyolite (Early Proterozoic)-Green to gray porphyritic rhyolite. Phenocrysts and clots of sanidine gray porphynitic rhyolite. Phenocrysts ajs clots of sanidine contains opaque minerals and trace zircon

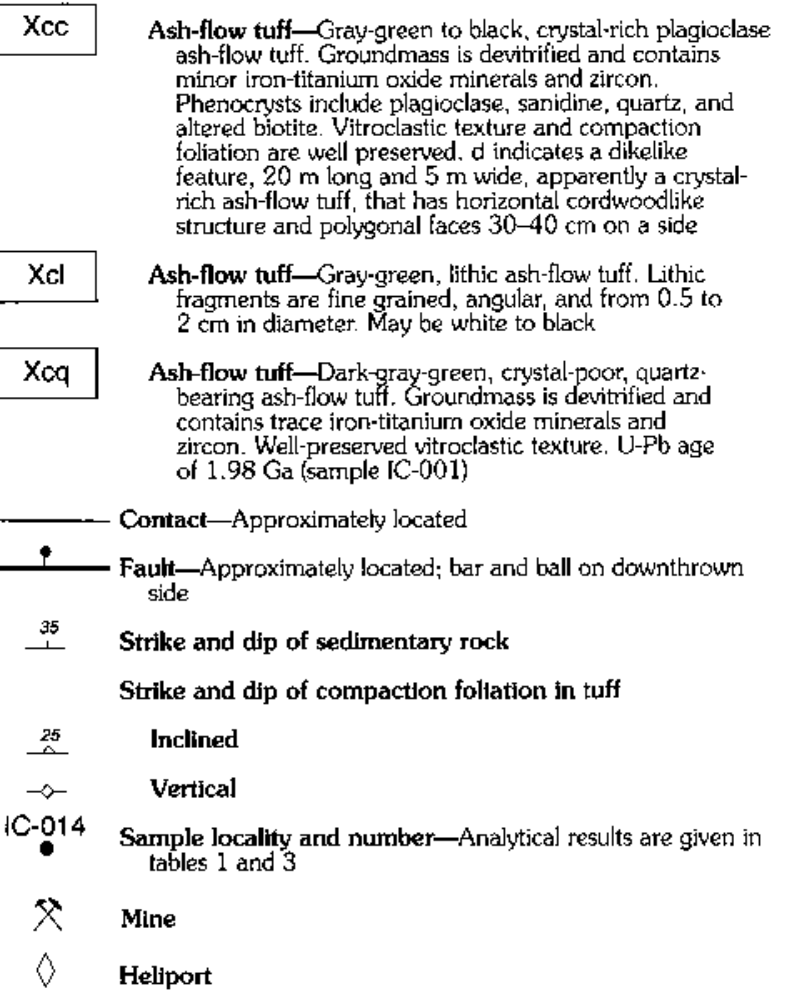

\section{GOLD AND DIAMOND PROSPECTING}

Gold and diamonds are recovered from alluvium down slope from conglomeratic horizons in the Uairén Formation of the Roraima Group (Reid and Bisque, 1975). Dohrenwend and others (this volume) indicate that the gold and diamond resources in the Gran Sabana are in the following geologic-geomorphologic environments: (1) placer deposits downstream from extensive exposures of the Uairén Formation; (2) colluvial-alluvial placer deposits adjacent to exposures of the Uairén Formation; and (3) paleoplacer deposits associated with conglomeratic lenses in the lower $500-600 \mathrm{~m}$ of the Uairén Formation.

The Roraima Group is commonly considered to be the immediate source of the modem placers and kimberlite in West Africa or possibly Brazil or Venezuela the initial primary source. Diamond placer deposits in Venezuela are the result of the following sequence of events, as proposed by Reid (1974): (1) intrusion of diamond-bearing kimberlite,

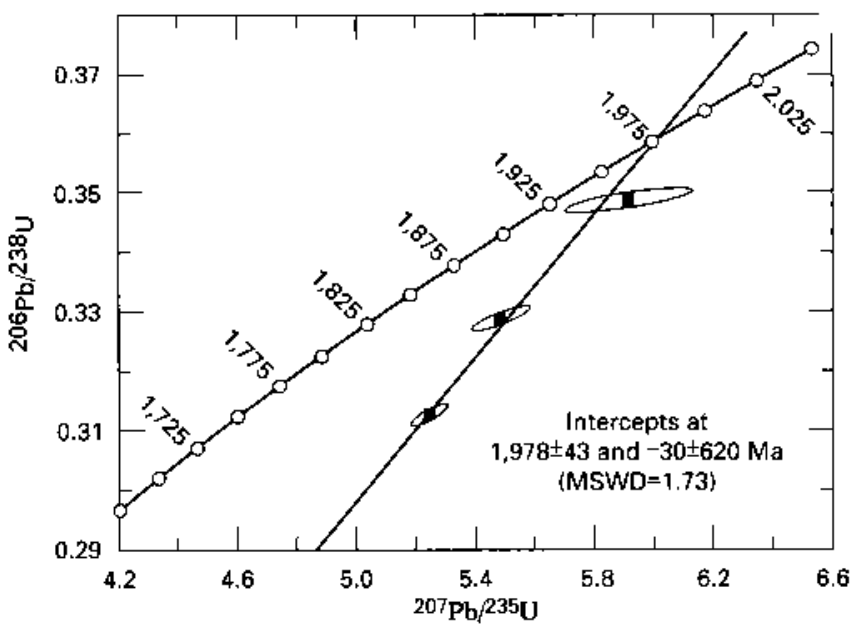

Figure 3. Concordia diagram for felsic tuff from the Icabarú Sur study area (sample IC-OOl), Estado Bolívar, Venezuela. Geochronologic data are given in table 2 .

possibly in West Africa; (2) uplift and erosion of the kimberlite and transport of the diamonds to an area in South America now known as Suriname before the separation of Africa and South America by rifting and continental drift; (3) erosion of the diamond-bearing rocks and redeposition as Roraima Group sediments; and (4) uplift and erosion of Roraima Group sediments and concentration of the diamonds in alluvium derived from the Roraima Group. In an overview discussion of diamonds in Venezuela, Nixon (1988) attributed the source of the diamonds to be recently discovered kimberlitic intrusions in the Quebrada Grande area in the northern part of the shield in Venezuela; however, sedimentological features such as cross-stratification, ripple marks, and pebble orientation indicate that sediments in the lower part of the Roraima Group were derived from an easterly, not a northwesterly, source (Keats, 1974; Reid and Bisque, 1975; Ghosh, 1985). Meyer and McCallum (1993) concluded, on the basis of both physical characteristics of the diamonds and their distribution, that the source for diamonds both in and derived from the Roraima Group is neither West Africa nor the Quebrada Grande area and that a primary source remains to be discovered.

Rock and stream-sediment samples were collected in the study area; however, only rock samples were returned to U.S. Geological Survey laboratories in Denver. The stream-sediment (panned concentrate) samples were kept by Corporación Venezolana de Guayana, Técnica Minera, C.A., in Tumeremo. Stream-sediment samples, which initially weighed $2-3 \mathrm{~kg}$, were collected from 29 localities in the study area. These samples were panned in the field; none of the panned concentrates contained visible gold, and only $I$ of the 29 samples contained a diamond. This milli- meter-size diamond was found at Agua Colorada, an active prospect in the northem part of the study area (fig. 3), when the prospector allowed us to sample his workings. 
Table 1. Analytical results for rock samples of the Early Proterozoic Caicara Formation of the Cuchivero Group, Icabaru Sur study area, Estado Bolívar, Venezuela.

[Location of samples shown in figure 2 by field number. Major-element oxides (weight percent, uncorrected) were determined by X-ray spectroscopy; analysts: J. Taggart, A. Bartel, and D. Siems;

$\mathrm{FeTO}_{3}$ indicates total iron reported as $\mathrm{Fe}_{2} \mathrm{O}_{3}$. Trace elements (in parts per million) determined by an energy-dispersive analyzer $\mathrm{Cd}{ }^{109}$ source for $\mathrm{Rb}, \mathrm{Sr}$, $\mathrm{Y}$, $\mathrm{Zr}$, and $\mathrm{Nb}$ and $\mathrm{Am}{ }^{95}$ source for $\mathrm{Ba}$; analyst:

E. Rivera; N, not detected at value listed; $\mathrm{L}$, limit of determination. Spectrographic analyses are in parts per million unless noted; analyst $\mathrm{R}$. Hopkins; lower limit of detection is given in parentheses after element symbol; $\mathrm{N}$, not detected at lower limit of determination shown; $\mathbf{L}$, detected but below lower limit of determination shown. Atomic absorption analyses are in parts per million; analyst J.

McHugh; $\mathbf{L}$, detected but below lower limit of determination shown]

\begin{tabular}{|c|c|c|c|c|c|c|c|c|c|c|c|c|}
\hline \multirow[b]{2}{*}{$\begin{array}{l}\text { Lab No. } \\
\text { Field No. }\end{array}$} & \multicolumn{2}{|c|}{ Rhyolite (unit Xcr) } & \multicolumn{8}{|c|}{ Crystal-rich ash-flow tuff $\left(\right.$ unil $\left.X_{c c}\right)$} & \multirow{2}{*}{$\begin{array}{c}\text { Lithic } \\
\text { ash-flow } \\
\text { tuff (unit Xol) } \\
\text { D-316933 } \\
\text { IC-009 }\end{array}$} & \multirow{2}{*}{$\begin{array}{c}\text { Crystal-poor } \\
\text { ash-flow tuff } \\
\text { (unit Xca) } \\
\text { D-316928 } \\
\text { IC-001 }\end{array}$} \\
\hline & $\begin{array}{c}D-316929 \\
\text { IC-004 }\end{array}$ & $\begin{array}{c}\text { D-316930 } \\
\text { IC- }-005\end{array}$ & $\begin{array}{c}\text { D-316931 } \\
\text { IC-006 }\end{array}$ & $\begin{array}{c}\text { D-316932 } \\
\text { IC }-007\end{array}$ & $\begin{array}{c}\text { D-316934 } \\
\text { IC-014 }\end{array}$ & $\begin{array}{c}\text { D-316935 } \\
\text { IC-018 }\end{array}$ & $\begin{array}{c}D-316937 \\
\text { IC }-021\end{array}$ & $\begin{array}{c}\text { D-316938 } \\
\text { IC- }-024\end{array}$ & $\begin{array}{c}D-316939 \\
\text { IC- }-025\end{array}$ & $\begin{array}{c}D-316940 \\
\text { IC-028 }\end{array}$ & & \\
\hline \multicolumn{13}{|c|}{ Major elements } \\
\hline$\overline{\mathrm{SiO}_{2}}$ & 71.7 & 69.9 & 71.9 & 70.2 & 73.8 & 73.0 & 72.9 & 72.4 & 70.4 & 72.3 & 67.1 & 74.9 \\
\hline $\mathrm{Al}_{2} \mathrm{O}_{3}$ & 14.1 & 14.9 & 14.7 & 13.5 & 13.3 & 13.3 & 13.6 & 13.7 & 14.4 & 13.8 & 15.1 & 12.8 \\
\hline $\mathrm{FeTO}_{3}$ & 2.19 & 3.00 & 1.86 & 3.34 & 1.63 & 1.70 & 1.79 & 1.91 & 2.26 & 2.01 & 4.68 & 1.71 \\
\hline $\mathrm{MgO}$ & 0.27 & 0.32 & 0.40 & 0.30 & 0.23 & 0.37 & 0.31 & 0.35 & 0.46 & 0.37 & 0.94 & 0.21 \\
\hline $\mathrm{CaO}$ & 0.45 & 0.13 & 0.09 & 0.78 & 0.52 & 0.82 & 0.62 & 0.71 & 1.10 & 0.77 & 0.35 & 0.68 \\
\hline $\mathrm{Na}_{2} \mathrm{O}$ & 3.62 & 3.80 & 2.83 & 3.65 & 3.48 & 3.82 & 4.35 & 3.99 & 4.14 & 3.94 & 3.46 & 1.28 \\
\hline $\mathrm{K}_{2} \mathrm{O}$ & 5.20 & 5.66 & 5.57 & 4.95 & 5.14 & 5.01 & 4.60 & 5.15 & 5.07 & 5.04 & 4.39 & 6.54 \\
\hline $\mathrm{TiO}_{2}$ & 0.41 & 0.49 & 0.44 & 0.48 & 0.34 & 0.33 & 0.34 & 0.39 & 0.46 & 0.38 & 0.60 & 0.26 \\
\hline $\mathbf{P}_{2} \mathrm{O}_{5}$ & 0.05 & 0.08 & 0.08 & 0.11 & $<0.05$ & 0.05 & 0.05 & $<0.05$ & 0.08 & 0.06 & 0.15 & $<0.05$ \\
\hline $\mathrm{MnO}$ & 0.09 & 0.12 & L0.02 & 0.12 & 0.04 & 0.06 & 0.08 & 0.06 & 0.07 & 0.07 & 0.34 & 0.06 \\
\hline LOI $900^{\circ} \mathrm{C}$ & 1.19 & 1.03 & 1.49 & 1.62 & 0.95 & 0.79 & 0.60 & 0.39 & 0.55 & 0.49 & 2.20 & 1.51 \\
\hline Total & 99.27 & 99.43 & 99.36 & 99.05 & 99.43. & 99.25 & 99.24 & 99.05 & 98.99 & 99.23 & 99.31 & 99.95 \\
\hline \multicolumn{13}{|c|}{ Trace elements } \\
\hline$\overline{\mathrm{Rb}}$ & 98 & 130 & 142 & 102 & 125 & 136 & 129 & 165 & 147 & 158 & 101 & 171 \\
\hline $\mathrm{Sr}$ & 123 & 84 & 106 & 187 & 94 & 86 & 96 & 120 & 179 & 108 & 241 & 96 \\
\hline $\mathbf{Y}$ & 57 & 44 & 42 & 40 & 28 & 37 & 36 & 36 & 36 & 32 & 34 & 53 \\
\hline $\mathbf{Z r}_{\mathbf{r}}$ & 595 & 662 & 354 & 391 & 316 & 293 & 297 & 347 & 416 & 339 & 292 & 373 \\
\hline $\mathrm{Nb}$ & 17 & 13 & 17 & 17 & 18 & 15 & 15 & 19 & 16 & 17 & 14 & 26 \\
\hline$\underline{\mathrm{Ba}}$ & 1,314 & 1,939 & 1,525 & 2,685 & 1,153 & 1,310 & 1,246 & 1,438 & 1,900 & 1,368 & 1,581 & 694 \\
\hline \multicolumn{13}{|c|}{ Spectrographic analyses } \\
\hline $\mathrm{Ca}$ (percent) (0.05) & 0.2 & 0.07 & 0.07 & 0.2 & 0.2 & 0.3 & 0.2 & 0.2 & 0.3 & 0.3 & 0.15 & 0.3 \\
\hline $\mathrm{Fe}$ (percent) $(0.05)$ & 2 & 2 & 2 & 2 & 2 & 2 & 2 & 2 & 2 & 1.5 & 3 & 2 \\
\hline $\mathrm{Mg}$ (percent) (0.02) & 0.2 & 0.2 & 0.3 & 0.2 & 0.2 & 0.5 & 0.3 & 0.3 & 0.3 & 0.3 & 0.7 & 0.1 \\
\hline $\mathrm{Na}$ (percent) $(0.2)$ & 3 & 3 & 2 & 2 & 2 & 3 & 2 & 2 & 2 & 3 & 2 & 2 \\
\hline$P$ (percent) $(0.2)$ & N0.2 & N0.2 & N0.2 & N0.2 & N0.2 & N0.2 & N0.2 & $\mathrm{N} 0.2$ & N0.2 & N0.2 & N0.2 & N0.2 \\
\hline Ti (percent) $(0.002)$ & 0.3 & 0.3 & 0.3 & 0.3 & 0.2 & 0.2 & 0.3 & 0.3 & 0.3 & 0.2 & 0.3 & 0.2 \\
\hline $\mathrm{Ag}(0.5)$ & N0.5 & N0.5 & N0.5 & N0.5 & N0.5 & N0.5 & N0.5 & N0.5 & N0.5 & N0.5 & N0.5 & N0.5 \\
\hline As $(200)$ & $\mathrm{N} 200$ & $\mathrm{~N} 200$ & $\mathrm{~N} 200$ & $\mathrm{~N} 200$ & $\mathrm{~N} 200$ & $\mathrm{~N} 200$ & $\mathrm{~N} 200$ & $\mathrm{~N} 200$ & $\mathrm{~N} 200$ & $\mathrm{~N} 200$ & $\mathrm{~N} 200$ & N200 \\
\hline $\mathrm{Au}(10)$ & N10 & N10 & N10 & N10 & N10 & N10 & N10 & N10 & N10 & N10 & N10 & N10 \\
\hline B (10) & L10 & N10 & N10 & N10 & N10 & N10 & N10 & N10 & N10 & N10 & N10 & L10 \\
\hline $\mathrm{Ba}(20)$ & 1,500 & 1,500 & 1,500 & 2,000 & 1,500 & 2,000 & 1,500 & 1,500 & 2,000 & 2,000 & 1,500 & 1,000 \\
\hline $\operatorname{Be}(1)$ & 3 & 2 & 3 & 3 & 2 & 3 & 3 & 3 & 3 & 3 & 3 & 3 \\
\hline $\mathrm{Bi}(10)$ & N10 & N10 & N10 & N10 & N10 & N10 & N10 & N10 & N10 & N10 & N10 & N10 \\
\hline $\mathrm{Cd}(20)$ & $\mathrm{N} 20$ & $\mathrm{~N} 20$ & $\mathrm{~N} 20$ & $\mathrm{~N} 20$ & $\mathrm{~N} 20$ & $\mathrm{~N} 20$ & $\mathrm{~N} 20$ & $\mathrm{~N} 20$ & $\mathrm{~N} 20$ & $\mathrm{~N} 20$ & $\mathrm{~N} 20$ & N20 \\
\hline $\operatorname{Co}(10)$ & N10 & L10 & N10 & 10 & N10 & N10 & N10 & N10 & N10 & N10 & 15 & N10 \\
\hline
\end{tabular}




\begin{tabular}{|c|c|c|c|c|c|c|c|c|c|c|c|c|}
\hline $\mathrm{Cr}(10)$ & L10 & L10 & L10 & 10 & L10 & L10 & N10 & L10 & L10 & LIO & 15 & 10 \\
\hline $\mathrm{Cu}(5)$ & L5 & 5 & L5 & 5 & 5 & L5 & 5 & L5 & 5 & L5 & 20 & 15 \\
\hline $\mathrm{Ga}(5)$ & 50 & 30 & 30 & 30 & 30 & 30 & 30 & 30 & 30 & 50 & 30 & 30 \\
\hline $\mathrm{Ge}(10)$ & N10 & N10 & N10 & N10 & N10 & N10 & $\mathrm{N} 10$ & N10 & N10 & N10 & N10 & N10 \\
\hline $\mathrm{La}(50)$ & 200 & 100 & 70 & 70 & 100 & 100 & 100 & 70 & 70 & 100 & 50 & 150 \\
\hline $\operatorname{Mn}(10)$ & 700 & 1000 & 300 & 1000 & 700 & 700 & 700 & 700 & 500 & 500 & 1500 & 700 \\
\hline Mo (5) & N5 & 50 & N5 & N5 & N5 & N5 & N5 & N5 & N5 & N5 & N5 & N5 \\
\hline $\mathrm{Nb}(20)$ & 20 & $\mathrm{~L} 20$ & $\mathrm{~L} 20$ & 20 & 20 & L20 & 20 & L20 & 20 & $\mathrm{~L} 20$ & $\mathrm{~L} 20$ & 20 \\
\hline $\mathrm{Ni}(5)$ & N5 & N5 & N5 & N5 & N5 & L5 & L5 & N5 & N5 & N5 & 5 & N5 \\
\hline $\mathrm{Pb}(10)$ & 30 & 50 & 50 & 50 & 30 & 30 & 30 & 50 & 50 & 30 & 30 & 30 \\
\hline Sb $(100)$ & N100 & $\mathrm{N} 100$ & $\mathrm{~N} 100$ & N100 & N100 & N100 & N100 & N100 & $\mathrm{N} 100$ & N100 & N100 & N100 \\
\hline Sc (5) & 7 & 10 & 7 & 7 & 7 & 7 & 7 & 7 & 7 & 7 & 10 & 7 \\
\hline Sn (10) & N10 & N10 & N10 & $\mathrm{N} 10$ & N10 & N10 & N10 & $\mathrm{N} 10$ & N10 & N10 & N10 & N10 \\
\hline $\operatorname{Sr}(100)$ & N100 & $\mathrm{N} 100$ & L100 & 150 & 100 & 100 & $\mathrm{~L} 100$ & L100 & 150 & 100 & 200 & 100 \\
\hline Th $(100)$ & N100 & $\mathrm{N} 100$ & N100 & N100 & N100 & N100 & N100 & NIOO & N100 & $\mathrm{N} 100$ & N100 & N100 \\
\hline$V(10)$ & 10 & 10 & 30 & 50 & 30 & 15 & 20 & 20 & 30 & 30 & 70 & L10 \\
\hline$W(20)$ & $\mathrm{N} 20$ & $\mathrm{~N} 20$ & $\mathrm{~N} 20$ & $\mathbf{N} 20$ & $\mathrm{~N} 20$ & $\mathrm{~N} 20$ & $\mathrm{~N} 20$ & $\mathrm{~N} 20$ & $\mathrm{~N} 20$ & $\mathrm{~N} 20$ & $\mathrm{~N} 20$ & $\mathrm{~N} 20$ \\
\hline$Y(10)$ & 50 & 30 & 30 & 30 & 30 & 30 & 30 & 30 & 20 & 30 & 20 & 50 \\
\hline $\mathrm{Zn}(200)$ & N200 & $\mathrm{N} 200$ & N200 & $\mathrm{N} 200$ & N200 & $\mathrm{N} 200$ & $\mathrm{~N} 200$ & $\mathrm{~N} 200$ & $\mathrm{~N} 200$ & N200 & $\mathrm{N} 200$ & L200 \\
\hline$\underline{\mathrm{Zr}}(10)$ & 700 & 1000 & 300 & 500 & 300 & 200 & 300 & 300 & 500 & 300 & 300 & 500 \\
\hline \multicolumn{13}{|c|}{ Atomic absorption analyses } \\
\hline$\overline{\mathrm{Au}}$ & L0.001 & 0.001 & 0.00 & 0.001 & 0.001 & L0.001 & 0.001 & 0.001 & 0.001 & 0.001 & 0.001 & Lo.001 \\
\hline
\end{tabular}

Table 2. U-Pb geochronologic data (zircon) for felsic tuff (IC-001) from the Icabarí Sur study area, Estado Bolívar, Venezuela.

[Location of sample shown in figure 2; major- and trace-element data for sample given in table 1. Asterisk (*) following element symbol denotes radiogenic Pb. Sample dissolution and ion-exchange chemistry modified from Krogh (1973) and Mattinson (1987). Fraction: N, nonmasnetic; M, magnetic; amperes/side slope on a Franz Isodynamic separator; 140 and 230 denote standard mesh size. Observed ratios corrected for 0.125 per unit mass fractionation, based on replicate analyses of NBS 981 . Uncertainties in the measured ${ }^{208} \mathrm{~Pb} /{ }^{206} \mathrm{~Pb}$ and ${ }^{207} \mathrm{~Pb} /{ }^{206} \mathrm{~Pb}$ ratios are less than 0.1 percent and uncertainties in the measured ${ }^{206} \mathrm{~Pb} /{ }^{204} \mathrm{~Pb}$ ratios are between 0.5 and 2 percent at the 2 sigma level $(\sigma)$. Isotopic data measured on a Finigan-Mat MAT 262 multiple collector mass spectrometer at the U.S. Geological Survey in Menlo Park. Atomic ratios calculated using the following constants: ${ }^{238} \mathrm{U}^{235} \mathrm{U}=137.88 ;{ }^{235} \mathrm{U}=0.98485 \times 10^{-9} \mathrm{yr} \mathrm{r}^{-1}$; ${ }^{238} \mathrm{U}=0.155125 \times 10^{-9} \mathrm{yr}^{-1}$. Observed ratios are corrected for common Pb ratios: 208:207:206:204 Pb of 34.6:15.1:14.9:1 using average crustal growth model of Stacey and Kramers (1975). All errors are reported to two-sigma (o); error analysis follows Mattinson (1987)]

\begin{tabular}{|c|c|c|c|c|c|c|c|c|c|c|c|c|}
\hline \multirow[b]{2}{*}{ Fraction } & \multirow[b]{2}{*}{$\begin{array}{l}\text { Weight } \\
\text { (mg) }\end{array}$} & \multirow[b]{2}{*}{$\begin{array}{l}{ }^{206} \mathrm{~Pb}^{*} \\
(\mathrm{ppm})\end{array}$} & \multirow[b]{2}{*}{$\begin{array}{c}{ }^{238} \mathrm{U} \\
\text { (ppm) }\end{array}$} & \multicolumn{3}{|c|}{ Observed ratios } & \multicolumn{3}{|c|}{ Atomic ratios } & \multicolumn{3}{|c|}{ Age and error (Ma) } \\
\hline & & & & ${ }^{2010} \mathrm{~Pb}$ & ${ }^{2007} \mathrm{~Pb}$ & ${ }^{2008} \mathrm{~Pb}$ & ${ }^{206} \frac{\mathrm{Pb}^{*}}{{ }^{235} \mathrm{U}^{*}}$ & ${ }^{207} \mathrm{~Pb}^{20}{ }^{*}{ }^{2}$ & $\begin{array}{l}{ }^{207}{ }^{207} \mathrm{~Pb}^{*} \\
\mathrm{~Pb}^{*}\end{array}$ & ${ }^{206} \mathrm{~Pb}^{* 38} \mathrm{U}$ & ${ }^{235} \mathrm{~Pb}^{206} \mathrm{U}$ & $\begin{array}{l}{ }^{207} \mathrm{~Pb}^{*} \\
{ }^{206} \mathrm{~Pb}^{*}\end{array}$ \\
\hline $\mathrm{N}(1,8 / 1,<140)$ & 1.7 & 43.7 & 142.8 & 104.7 & 0.2502 & 0.5774 & 0.348723 & 5.91752 & 0.123072 & $1,928 \pm 2$ & $1,963 \pm 25$ & $2,001 \pm 50$ \\
\hline $\mathrm{M}(1.8 / 1.5,>230)$ & 2.7 & 39.4 & 145.3 & 316.5 & 0.1637 & 0.3499 & 0.313032 & 5.25247 & 0.121696 & $1,756 \pm 2$ & $1,861 \pm 6$ & $1,981 \pm 10$ \\
\hline $\mathrm{M}(1.8 / 1.5,<230)$ & 4.1 & 75.6 & 266.0 & 183.8 & 0.1937 & 0.4276 & 0.328726 & 5.48515 & 0.121019 & $1,832 \pm 2$ & $1,898 \pm 10$ & $1,971 \pm 30$ \\
\hline
\end{tabular}


Table 3. Trace-element contents of unweathered and weathered sample pairs from the Early Proterozoic Caicara Formation of the Cuchivero Group, Icabarú Sur study area, Estado Bolívar, Venezuela.

[In parts per million. Location of samples shown in figure 2 by number; map unit symbols are defined in figure 2 . Determined by an energy-dispersive analyzer $\mathrm{Cd}^{109}$ source for $\mathrm{Rb}, \mathrm{Sr}, \mathrm{Y}, \mathrm{Zr}$, and $\mathrm{Nb}, \mathrm{Am}^{95}$ source for $\mathrm{Ba}$; analyst $\mathrm{E}$. Rivera. U indicates unweathered sample; W indicates weathered sample. More complete analytical data for samples ICU $-001,-004$, and -014 are given in table 1]

\begin{tabular}{|c|c|c|c|c|c|c|c|c|c|c|}
\hline \multirow{2}{*}{$\begin{array}{c}\text { Sample No. } \\
\text { Map unit } \\
\text { Sample type }\end{array}$} & \multicolumn{2}{|c|}{$\begin{array}{c}\mathrm{IC}-001 \\
\mathrm{XCq}\end{array}$} & \multicolumn{2}{|c|}{$\begin{array}{c}\mathrm{IC}-004 \\
\mathrm{Xcr}\end{array}$} & \multicolumn{2}{|c|}{$\begin{array}{c}\mathrm{IC}-014 \\
\mathrm{X} \in \mathrm{C}\end{array}$} & \multicolumn{2}{|c|}{$\begin{array}{c}\mathrm{IC}-015 \\
\mathrm{XCC}\end{array}$} & \multicolumn{2}{|c|}{$\begin{array}{c}\text { IC }-019 \\
X_{\text {Cr }}\end{array}$} \\
\hline & $\mathrm{U}$ & $W$ & $\mathrm{U}$ & $w$ & $\mathrm{U}$ & $W$ & $\mathrm{U}$ & $\mathrm{W}$ & $\mathrm{U}$ & W \\
\hline$\overline{\mathrm{Rb}}$ & 171 & 167 & 98 & 108 & 125 & 152 & 139 & 173 & 127 & 206 \\
\hline $\mathrm{Sr}$ & 96 & 20 & 123 & 70 & 94 & 73 & 144 & 90 & 81 & 60 \\
\hline $\mathrm{Y}$ & 53 & 40 & 57 & 40 & 28 & 34 & 36 & 24 & 45 & 48 \\
\hline $\mathrm{Zr}$ & 373 & 490 & 595 & 769 & 316 & 400 & 339 & 388 & 678 & 1,270 \\
\hline $\mathrm{Nb}$ & 26 & 26 & 17 & 16 & 18 & 23 & 19 & 21 & 20 & 36 \\
\hline $\mathrm{Ba}$ & 694 & 207 & 1,314 & 1,390 & 1,153 & 1,117 & 1,227 & 1,430 & 1,346 & 1,498 \\
\hline
\end{tabular}

The presence of silicic volcanic rocks, ash-flow tuff, and rhyolite of the Caicara Formation in the Icabarú Sur study area suggests a possible epithermal source for the gold (Contreras and Page, 1988). Quartz veins $(2-3 \mathrm{~mm})$ cut the ash-flow tuff, but alteration minerals such as alunite, sericite, montmorillonite, adularia, silica, tourmaline, and carbonate are not present in the veinlets or host rocks. Gold was not present in stream-sediment samples taken downstream from the veinlets. One sample of ash-flow tuff (IC-021, fig. 3) had a millimeter-thick veinlet of fluorite.

Ten rock samples and one quartz-vein sample were submitted for spectrographic and trace element (gold) analysis (table 1). Results for gold are uniformly low $(\sim 1 \mathrm{ppb})$, and neither arsenic nor silver were detected. One sample of porphyritic rhyolite (IC-005) contains $50 \mathrm{ppm}$ Mo. Anomalous concentrations of metals are not present in the sample that contains the fluorite veinlet.

\section{ASSESSMENT OF MINERAL POTENTIAL}

The geologic setting of the Icabani Sur study area permits consideration of the following deposit models: epithermal veins and diamond-bearing kimberlite pipes. The only feature common to both the Icabarú Sur study area and a generalized (Sado, Creede, Comstock) epithermal quartz-gold model is the presence of silicic volcanic rocks. Hypabyssal intrusive rocks are not present in the area, unless further mapping proves that the porphyritic rhyolite is intrusive. Similarly, neither faults and fractures related to doming nor ring-fracture zones associated with mineralized calderas have been identified (Mosier, Berger, and Singer, 1986; Mosier, Sato, and others, 1986; Mosier, Singer, and Berger, 1986). Therefore, the Icabarú Sur study area is assigned a low potential for an epithermal gold system; however, additional regional mapping, with attention to altered rock, intrusive rocks, quartz, and fluorite veins, would better define this assessment.
The presence of placer diamond production in the area of Icabaru is the strongest evidence for consideration of the descriptive model for diamond-bearing kimberlite pipes (Cox, 1986). Kimberlite is commonly highly fractured and deeply weathered, which typically produces topographic lows and which would be inconspicuous in such an environment (W.H. Raymond, U.S. Geological Survey, written commun., 1991). Therefore, the apparent absence of kimberlite pipes, perhaps unrecognized due to their small diameter and inconspicuous weathering style, might be due to the relatively small degree of coverage of the area by geologic mapping. Nonetheless, kimberlitic indicator minerals have not been identified from any of the alluvial diamond-bearing deposits associated with the Roraima Group (Briceño, 1984; Meyer and McCallum, 1993). Potential for diamond-bearing kimberlitic pipe deposits is, therefore, low.

\section{CONCLUSIONS}

In the Icabarú Sur study area of Venezuela, sandstones of the Early to Middle Proterozoic Roraima Group and ash-flow tuffs and rhyolite of the Early Proterozoic Caicara Formation of the Cuchivero Group are exposed. The absence of visible gold in stream-sediment samples and the minor amount of gold ( $\sim \mathrm{ppb})$ in analyses of rock samples eliminate the volcanic terrane as a possible source for the gold commonly found in placer deposits in the region. Therefore, conglomerates of the Uairén Formation of the Roraima Group remain the immediate source for gold and diamonds in the area. The geologic setting of the Icabarú region is generally favorable for mineral deposits, but the resource potential of the Icabaru Sur study area is apparently low.

\section{REFERENCES CITED}

Briceño M., H.O., 1984, Genesis de yacimientos minerales Venezolanos II-Placeres diamantíferos de San Salvador de Paúl: Acta Cientifica Venezolana, v. 36, p. 154-158. 
Contreras, Gloria, and Page, N.J, 1988, Informe sobre las actividades de campo realizadas en la zona de Paraytepuy-Icabarú-Los Caribes: Corporación Venezolana de Guayana, Técnica Minera, C.A., internal report, 4 p.

Cox, D.P., 1986, Descriptive model of diamond pipes (model 12), in Cox, D.P., and Singer, D.A., eds., Mineral deposit models: U.S. Geological Survey Bulletin 1693, p. 54.

Deer, W.A., Howie, R.A., and Zussman, J., 1982, Rock forming minerals—Orthosilicates (2nd ed.): London, Longman, v. 1A, $919 \mathrm{p}$.

Del Ollo, D., Tapia, Jhonny, Sifontes, Ramon, 1989, Estudio geológico-geoquímico en la región Hoyada-Icabarú, Gran Sabana, Estado Bolívar: Congreso Geológico Venezolano, 7th, v. 4 , p. $1788-1812$.

Dennen, W.H., and Anderson, P.J., 1962, Chemical changes in incipient rock weathering: Geological Society of America Bulletin, v. 73, p. 375-384.

Erlank, A.J., Smith, H.S., Marchant, J.W., Cardoso, M.P., and Ahrens, L.H., 1978, Zirconium (section 40-G), in Wedepohl, K.H., ed., Handbook of geochemistry: Bertin, Springer-Verlag, p. 40-A-1-40-0-16.

Ghosh, S.K., 1985, Geology of the Roraima Group and its implications: Simposium Amazonico, 1st, Caracas, 1981, Publicación Especial 10, p. 31-50.

Gibbs, A.K., and Barron, C.N. 1983, The Guiana Shield reviewed: Episodes, v. 1983, no. 2, p. 7-14.

1993, The geology of the Guiana Shield: New York, Oxford University Press, Oxford Monographs on Geology and Geophysics 22, $246 \mathrm{p}$.

Keats, W., 1974, The Roraima Formation in Guyana: Congreso Latinoamericano de Geología, 2nd, Caracas, 1973, Memoria, Publicación Especial 7, v. 2, p. 901-940.

Krogh, T.E., 1973, A low contamination method for hydrothermal dissolution of zircons and extraction of $\mathrm{U}$ and $\mathrm{Pb}$ for isotopic age determinations: Geochimica et Cosmochimica Acta, v. 37, p. $485-494$.

Mattinson, J.M., 1987, U-Pb ages of zircons-A basic examination of error propagation: Chemical Geology (Isotope Geoscience Section), v. 66, p. 151-162.
Meyer, H.O.A., and McCallum, M.E., 1993, Diamonds and their sources in the Venezuelan portion of the Guyana Shield: Economic Geology, v. 88, p. 989-998.

Montero, R.L., Yánez, Galo, and Lo Monaco, S., 1989, Estudio de las variaciones químicas y mineralógicas en la secuencia roca fresca-halo costra de meteorización en rocas félsicas y máficas en la cuenca del Río Paragua: Congreso Geológico Venezolano, 7th, v. 2, p. 892-911.

Mosier, D.L., Berger, B.R., and Singer, D.A., 1986, Descriptive model of Sado epithermal veins (model 25d), in Cox, D.P., and Singer, D.A., eds., Minera! deposit models: U.S. Geological Survey Bulletin 1693, p. 154.

Mosier, D.L., Sato, T., Page, N.J, Singer, D.A., and Berger, B.R, 1986. Descriptive model of Creede epithermal veins (model 25b), in Cox, D.P., and Singer, D.A., eds., Mineral deposit models: U.S. Geological Bulletin 1693, p. 145.

Mosier, D.L., Singer, D.A., and Berger, B.R., 1986, Descriptive model of Comstock epithermal veins (model $25 \mathrm{c}$ ), in Cox, D.P., and Singer, D.A., eds., Mineral deposit models: U.S. Geological Survey Bulletin 1693, p. 150.

Nixon, P.H., 1988, Diamond source rocks from Venezuela: Industrial Diamond Quarterly, no. 51, p. 23-29.

Priem, H.N.A., Boelrijk, N.A.I.M., Hebeda, E.H., Verdurmen, E.A.Th., and Verschure, R.H., 1973, Age of the Precambrian Roraima Formation in northeastern South America-Evidence from isotopic dating of Roraima pyroclastic volcanic rocks in Suriname: Geological Society of America Bulletin, v. 84, p $1677-1684$.

Reid, A.R., 1974, Proposed origin for Guianian diamonds: Geology, v. 2 , no. 2, p. $67-68$.

Reid, A.R., and Bisque, R.E., 1975, Stratigraphy of the diamond-bearing Roraima Group, Estado Bolívar, Venezuela: Quarterly of the Colorado School of Mines, v. 79, no. 1, p 61-82.

Stacey, J.S., and Kramers, J.D., 1975, Approximation of terrestrial lead isotope evolution by a two-stage model: Earth and Planetary Science Letters, v. 26, p. 207-221. 

Bauxita en Superficie de Planación de la

Guayana Venezolana

(Bauxite on a Planation Surface in

Venezuelan Guayana)

By Galo Yánez P.

GEOLOGY AND MINERAL DEPOSITS OF THE VENEZUELAN GUAYANA SHIELD

U.S. GEOLOGICAL SURVEY BULLETIN 2124-M

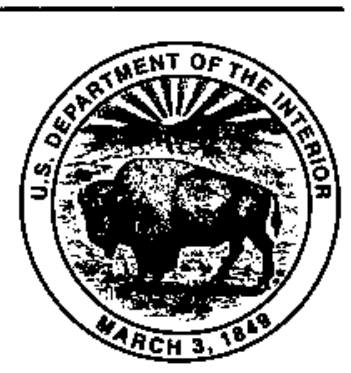

UNITED STATES GOVERNMENT PRINTING OFFICE, WASHINGTON : 1995 


\section{CONTENIDOS}

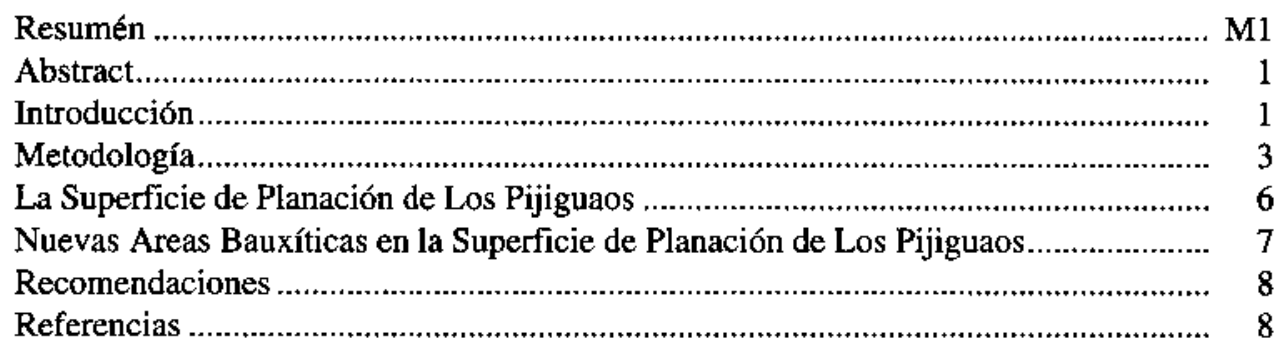

\section{FIGURAS}

\section{1-5. Mapas de:}

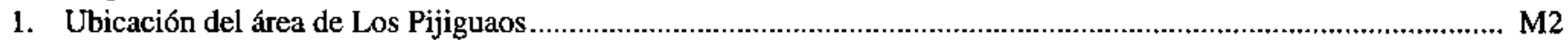

2. Areas de lateritas alumínicas y bauxita al este de Puerto Ayacucho ...................................................................... 3

3. Areas de lateritas alumínicas y bauxita al sur y este de Los Pijiguaos ..................................................................... 4

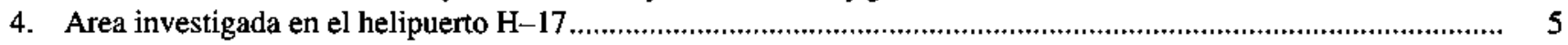

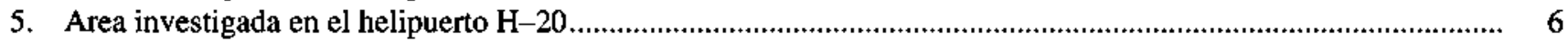

\section{TABLAS}

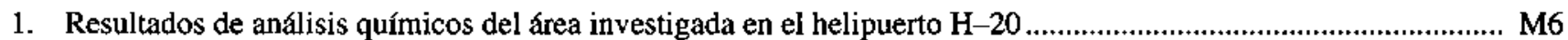

2. Resultados de análisis químicos del área investigada en el helipuerto $\mathrm{H}-17$ 


\title{
Bauxita en Superficie de Planación de la Guayana Venezolana (Bauxite on a Planation Surface in Venezuelan Guayana)
}

\author{
By Galo Yánez P. ${ }^{1}$
}

\begin{abstract}
RESUMEN
La investigación geomorfologica es parte de los trabajos que la Corporación Venezolana de Guayana, Técnica Minera, C.A., realiza para el inventario de los recursos naturales de la región Guayana en Venezuela. Para el caso del norte del Estado Amazonas y en el área del presente trabajo (entre lat $5^{\circ}-7^{\prime} \mathrm{N}$. y long $66^{\circ} 00^{\prime}-67^{\circ} 30^{\prime} \mathrm{O}$.) se ha determinado que la evolución del relieve ha estado mayormente controlada por un proceso de formación o destrucción de superficies de planación; debido en parte a la naturaleza predominantemente granítica del área y a la relativa estabilidad del escudo ígneo-metamórfico.

Se ha estudiado, con mayor detalle, el área de Los Pijiguaos, la cual ha desarrollado y preservado lateritas alumínicas y bauxita. Con este modelo geomorfológico, se han delimitado nuevas áreas de evolución geomorfológica semejante, de las cuales las dos más importantes fueron verificadas mediante la construcción de helipuertos, encontrándose abundante costra bauxítica de origen secundario, las cuales podrían triplicar el potencial ya conocido de Los Pijiguaos. Tales áreas se encuentran a $50 \mathrm{~km}$ hacia $\mathrm{S} .40^{\circ} \mathrm{E}$. de Los Pijiguaos y a $40 \mathrm{~km}$ hacia S. $75^{\circ}$ E. de Puerto Ayacucho. Se abrieron calicatas cercanas a los helipuertos, de las que se tomó muestras para análisis químicos y cuyos resultados se anexan. Tales resultados indican la presencia de un potencial bauxítico muy importante que debe ser investigado con mayor detalle.
\end{abstract}

'Corporación Venezolana de Guayana, Técnica Minera, C.A., Ciudad Bolivar, Venezuela.

\begin{abstract}
Geomorphological research is part of the inventory of natural resources that the Corporacion Venezolana de Guayana, Técnica Minera, C.A., is conducting in the Guayana Shield of Venezuela. In the northem part of Estado Amazonas, an area of relative tectonic stability between lat $5^{\circ}$ and $7^{\circ} \mathrm{N}$. and long $66^{\circ} 00^{\prime}$ and $67^{\circ} 30^{\prime} \mathrm{W}$., the evolution of geomorphological relief has been controlled chiefly by constructional and destructional processes associated with the development of planation surfaces on a substratum made up mostly of granitic rocks.

The Los Pijiguaos area was studied in more detail because of the economic value of its aluminous Jateritic cap. Application of the geomorphological model for this area to other areas in which a similar geomorphological evolution was identified allowed identification of new areas containing bauxitic caps of secondary origin. These new areas were later verified by helicopter-supported fieldwork. One area is about $50 \mathrm{~km} \mathrm{~S} .40^{\circ}$ E. of Los Pijiguaos, and the other is 40 $\mathrm{km} \mathrm{S} .75^{\circ}$ E. of Los Pijiguaos. Further investigation of mineralized rock in these areas may yield substantial reserves of aluminum, exceeding those of Los Pijiguaos.
\end{abstract}

\section{INTRODUCCION}

El presente trabajo se ha desarrollado en el marco de las investigaciones geomorfologicas que se hacen para el inventario de los recursos naturales de la región Guayana (Estado Bolívar, Estado Amazonas, y Estado Delta Amacuro) a escala 1:250,000. El área estudiada corresponde a las hojas de radar NB-19-8 y NB-19-12 a escala 1:250,000, situadas entre lat $5^{\circ} 00^{\prime}-7^{\circ} 00^{\prime} \mathrm{N}$. y long $66^{\circ} 00^{\prime}-67^{\circ} 30^{\prime} \mathrm{O}$. El mencionado inventario, desarrollado por la Corporación 


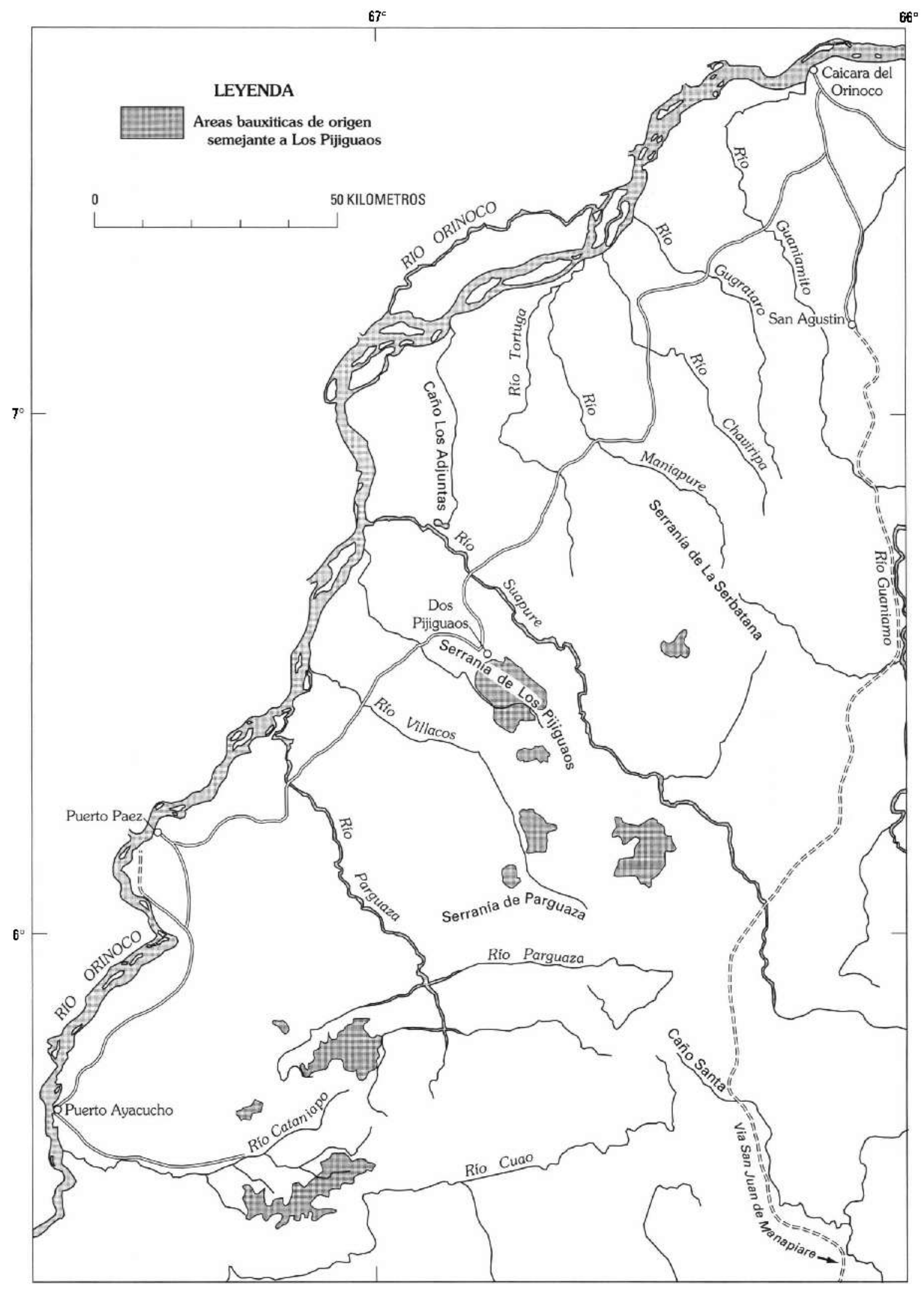

Figura 1. Mapa de ubicación del área de Los Pijiguaos. 


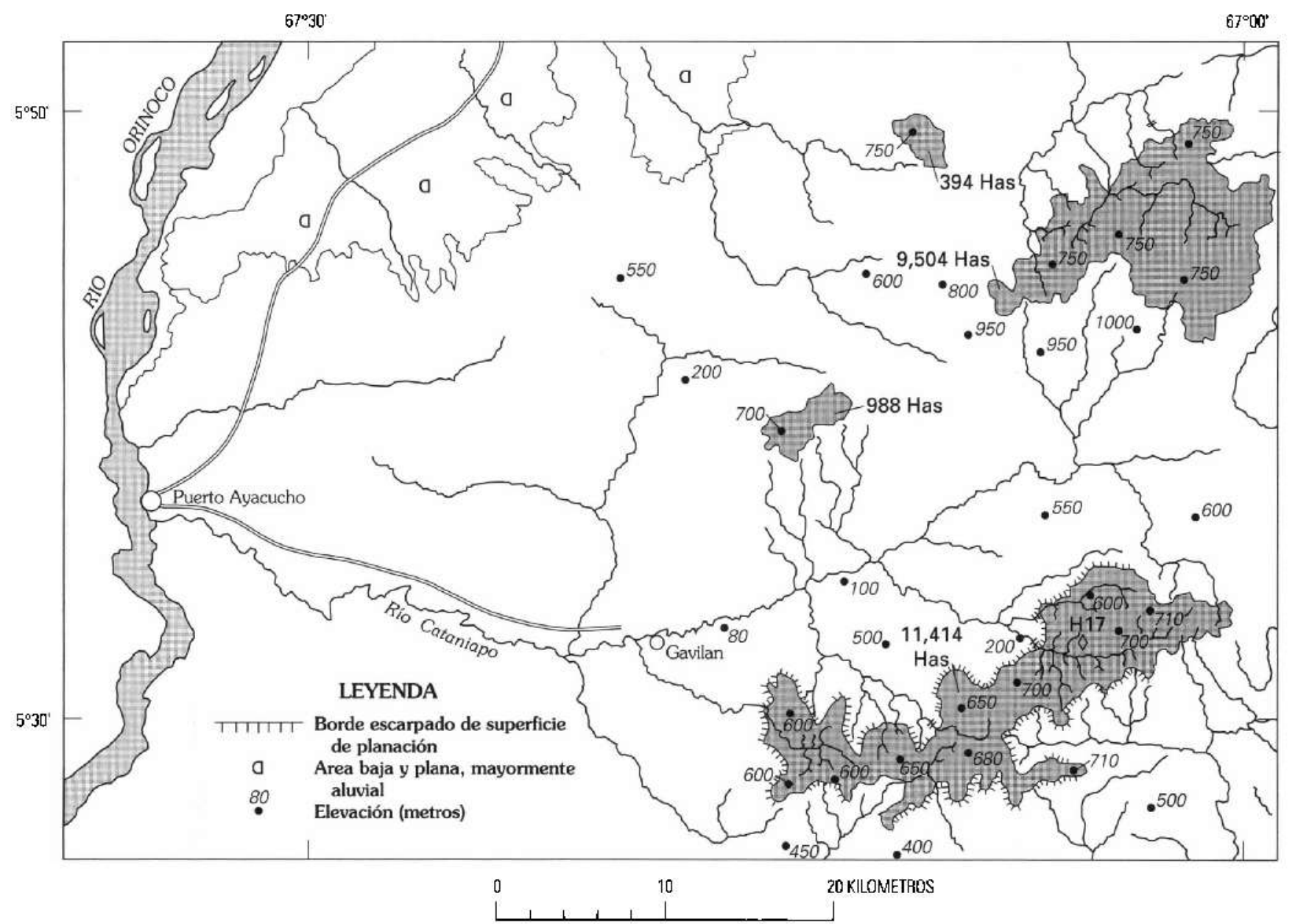

Flgura 2. Areas de lateritas alumínicas y bauxita al este de Puerto Ayacucho (zona A).

Venezolana de Guayana, Técnica Minera, C.A. (CVG-TECMIN o TECMIN), comenzó en 1985 en la frontera con Guyana y en la actualidad se está investigando el Estado Amazonas.

Entre los trabajos previos relativos al área estan Ríos (1969) y McCandless (1965) sobre la estratigrafía y petrología; Mendoza et al (1977) hace un estudio petrológico de la parte norte del Estado Amazonas; Menéndez et al (1985) y Menéndez y Sarmentero (1985) describen el marco geologico de la bauxita de Los Pijiguaos.

En lo que respecta a la naturaleza, origen y evolución de superficies de planación, King (1967) en su estudio "Morphology of the Earth" describió los fundamentos en que se basa el concepto de superficies de planación y paralelamente lanzó la hipótesis de la evolución del relieve por pedimentación, como un fenómeno generalizado e independiente del factor climático. King estableció varias superficies de planación en Africa, denominadas, de más antigua a más jôven, Gondwana (Jurásico), Post-Gondowana (Cretáceo antiguo a medio), Africana (Oligoceno), entre las más importantes; las mismas tienen sus equivalentes en Brasil, denominadas Gondwana, Post-Gondwana y Sur-Americana, respectivamente.

Por otra parte, los factores que pueden influir en el origen y evolución de las superficies de planación son analizados por Melhom y Dorland (1975). Los factores incluyen el factor tectónico, el factor eustático y el factor climático; así como también el significado de los registros sedimentarios resultantes de un sostenido proceso de denudación continental. En el Escudo Guayanés, varios autores han reconocido la existencia de superficies de planación, tales como McConnell (1969) en Guyana, Zonneveld (1969) en Surinam, Short y Steenken (1962) en Venezuela.

\section{METODOLOGIA}

En julio de 1988 se realizó una interpretación geológica y geomorfológica de las hojas de radar NB-19-8 y NB-19-12 a escala 1:250,000; luego, se hizo una interpret- 


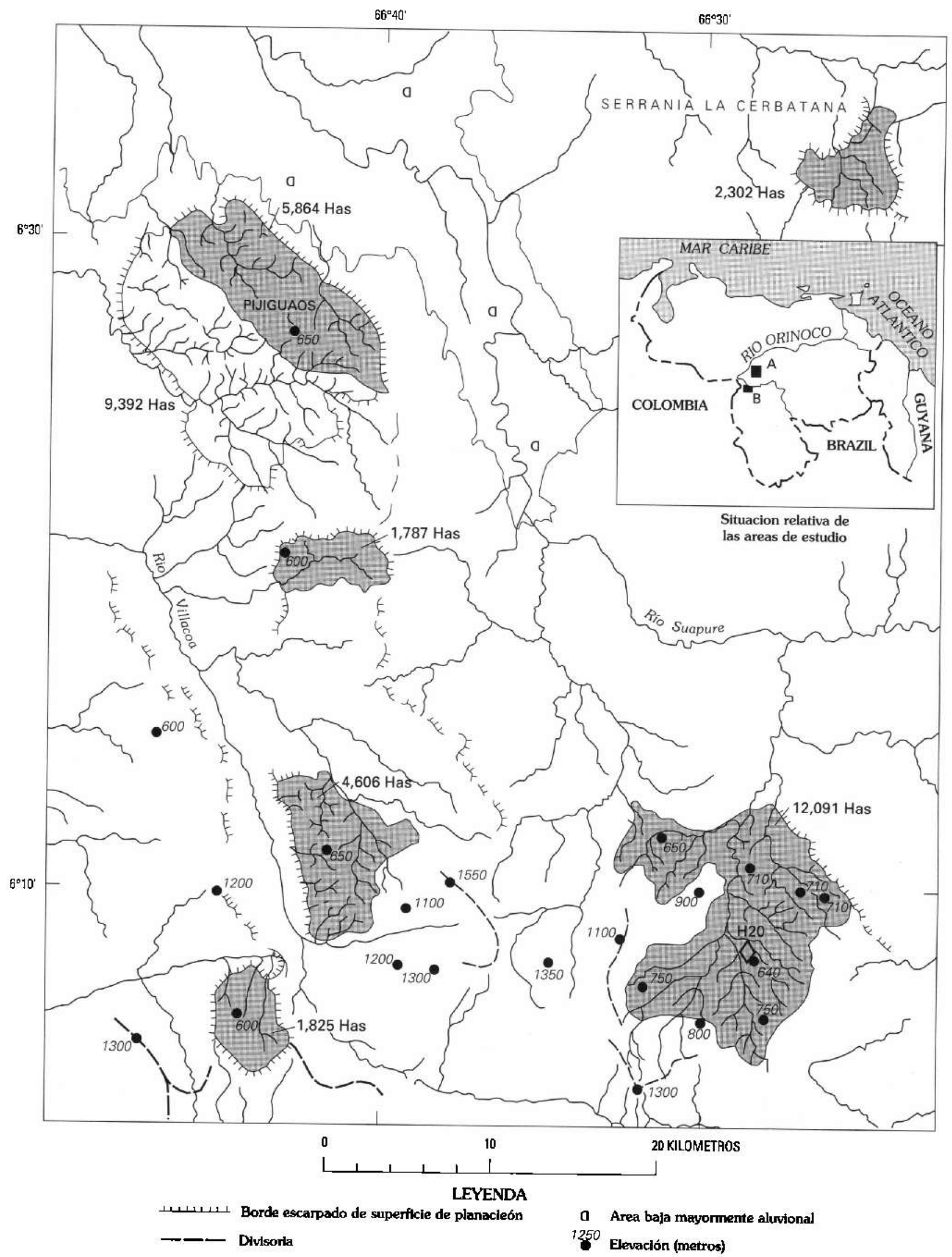

Figura 3. Areas de lateritas alumínicas y bauxita al sur y este de Los Pijiguaos (zona B). 


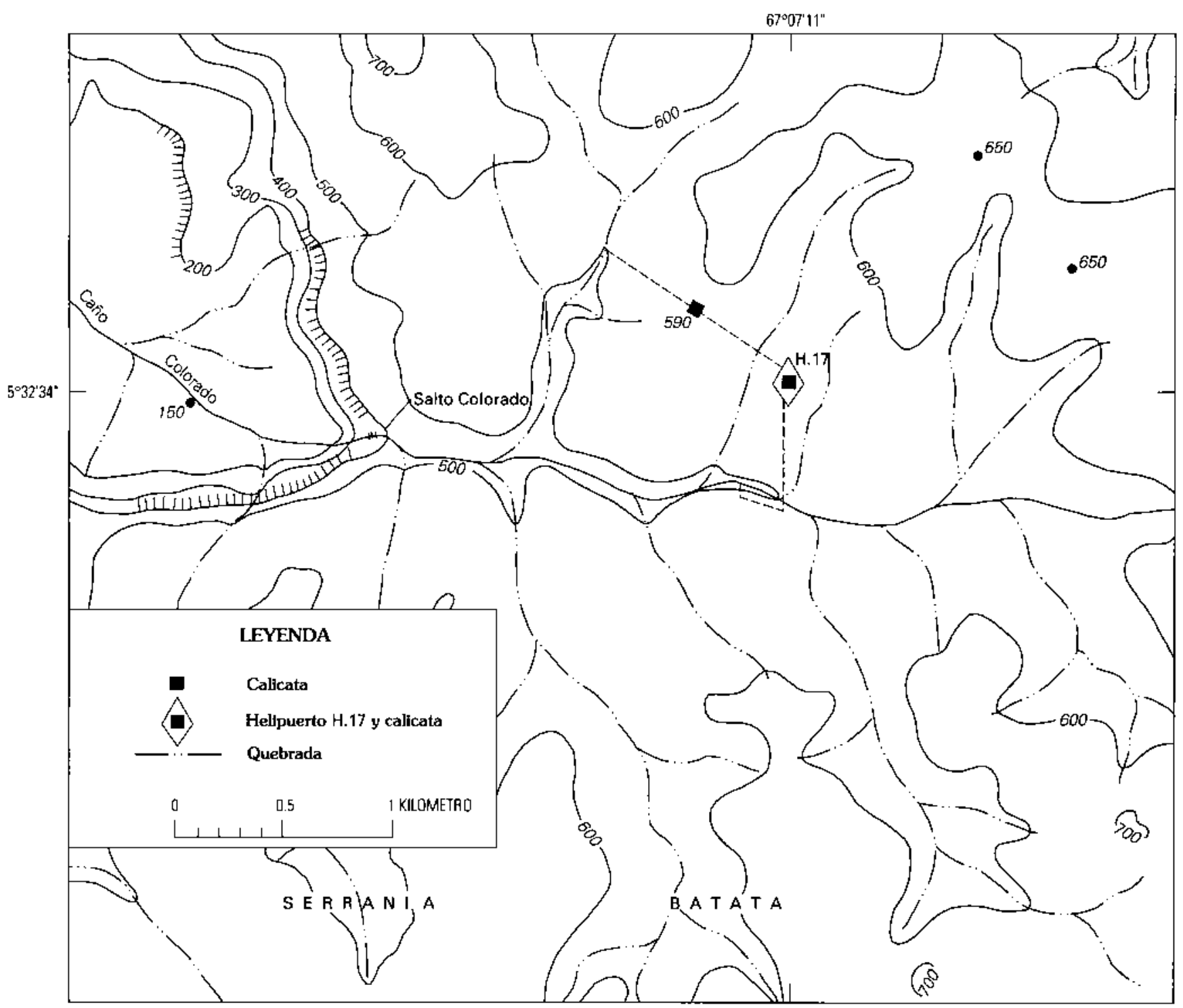

Figura 4. Area investigada en el helipuerto $\mathrm{H}-17$.

ación geológica y geomorfológica de fotografías aéreas a escala 1:50,000 del proyecto 172 y fotografías aéreas a escala 1:25,000 de la misión 050294 y la imágen de satélite CPDI 003-055 a escala 1:250,000. El area total interpreta da fué de $36,000 \mathrm{~km}^{2}$.

La información obtenida fue diseñada en transparencias sobre las hojas de radar. Paralelamente y mediante el empleo de mapas altimétricos del Catastro Minero Nacional, a escala $1: 25,000$ con lineas de nivel cada $20 \mathrm{~m}$ se establecieron las relaciones altimétricas de los distintos aspectos geologicos y geomorfologicos.

De esta manera, se determinó que en las extensas áreas de composición granítica que existen en el Estado Amazonas se ha desarrollado un modelo de evolución del relieve caracterizado por la formación y destrucción de superficies de planación, de las cuales, las más conspícuas por su mejor preservación se encuentran a los niveles $600-750 \mathrm{~m}$,
1,100-1,250 m y 1,500-1,600 m. Las más elevadas se sitúan escalonadamente hacia el sur. La influencia o el significado que estas superficies de planación pudieran tener en la naturaleza de los recursos naturales está en proceso de investigaciớn.

Sin embargo y tomando en consideración que la superficie de planación $600-750 \mathrm{~m}$ es un yacimiento de lateritas alumínicas y bauxita gibbsítica, en Los Pijiguaos, se realizo un estudio muy detallado, cualitativo y cuantitativo, en sus más variados parámetros. Luego, se procuró identificar áreas semejantes dentro de los $36,000 \mathrm{~km}^{2}$, consiguiéndose como resultado las áreas que se muestran en el mapa de la figura 1.

En marzo de 1989 y como parte del trabajo de campo, propio de las labores del inventario de los recursos naturales, TECMIN decidio la apertura de 20 helipuertos para obtener información de las áreas que por su inaccesibilidad no tenían información previa. De los 20 helipuertos, dos estaban local- 


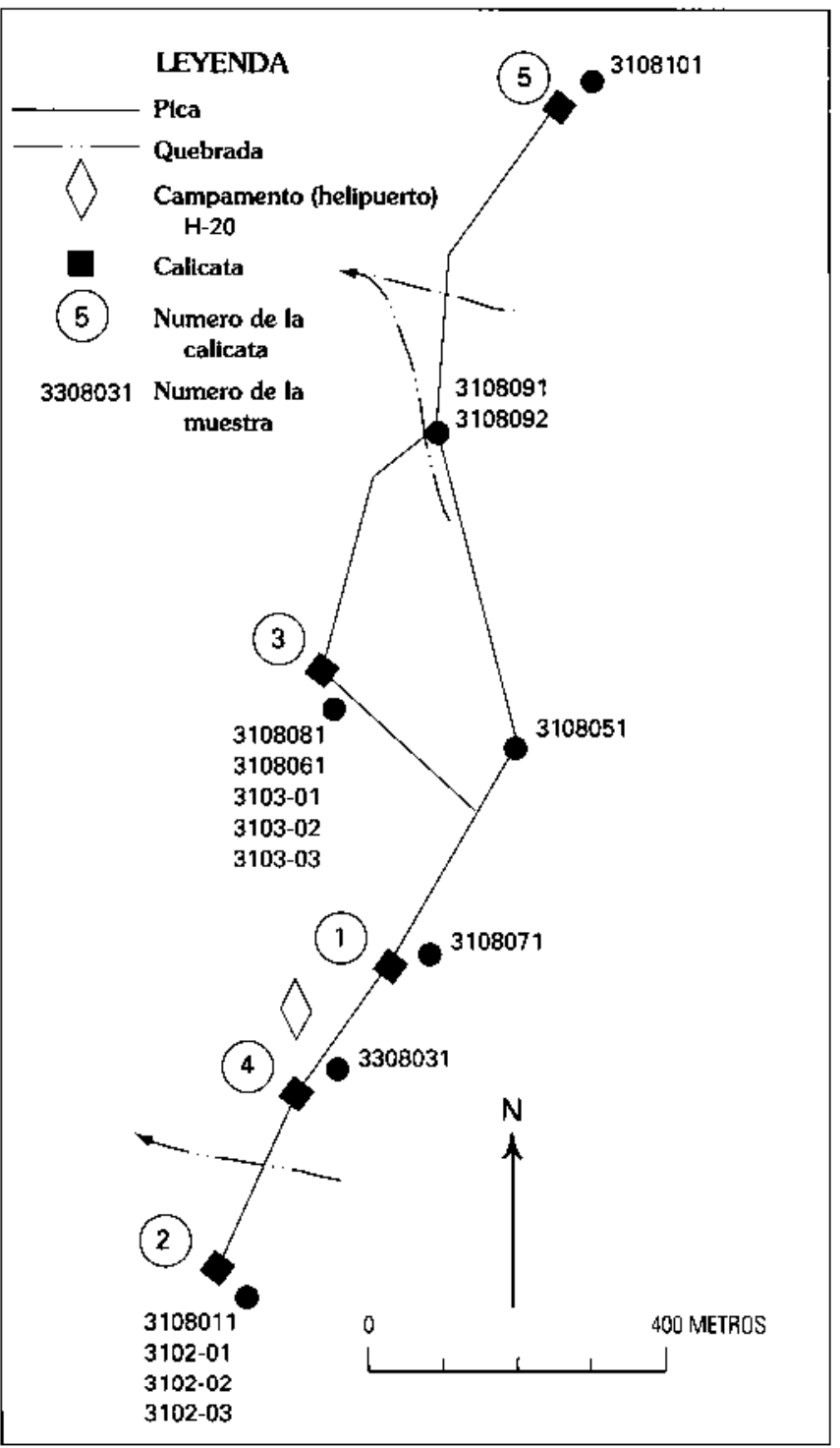

Figura 5. Area investigada en el helipuerto $\mathbf{H}-20$. izados en áreas interpretadas como lateritas aluminicas: $\mathrm{H}-17$ con coordenadas lat $5^{\circ} 32.2^{\prime} \mathrm{N}$., long $67^{\circ} 07.5^{\prime} \mathrm{O}$. (fig. 2), y H-20 con coordenadas lat $6^{\circ} 08.0^{\prime} \mathrm{N}$., long $66^{\circ} 28.0^{\prime} \mathrm{O}$. (fig. 3). Las coordenadas fueron tomadas instrumentalmente, del helicóptero, y no coinciden exactamente con las coordenadas aproximadas de las imágenes de radar, que presentan los mapas de las figuras 2 y 3 . En ambos helipuertos, bloques de coraza bauxútica en medio de la lateríta se encontraron.

En julio de 1989 se procedio a la apertura de calicatas que permitirian obtener muestras para su análisis químico. El trabajo de campo en el área del helipuerto $\mathrm{H}-20$ fué realizado por el Geólogo Andrés E. García Gerdes y en el helipuerto $\mathrm{H}-17$ por el Geólogo Frank Tovar. Se abrieron dos calicatas en $\mathrm{H}-17$ (fig. 4) y cinco calicatas en $\mathrm{H}-20$ (fig. 5) a diferentes profundidades, dependiendo de la dureza de la costra. En ambos casos, se tomaron muestras de bloques duros de bauxita y muestras de canal en laterita no consolidadas.

Los análisis químicos para determinar el porcentaje de los principales 6 xidos se realizaron tanto en el laboratorio de BAUXIVEN en Los Pijiguaos, como en el Laboratorio de Ferrominera del Orinoco en Puerto Ordaz. Los resultados de tales análises químicos se exponen en las tablas 1 y 2 .

\section{LA SUPERFICIE DE PLANACION DE LOS PLJIGUAOS}

El área de Los Pijiguaos de 5,864 has. (fig. 2) el cual es en la actualidad un yacimiento de bauxita gibbsítica y lateritas alumínicas en explotación, se ha originado de una superficie de planación en el granito de Parguaza con textura rapakivi (Mendoza, 1974). Esta superficie está considerada como parte de la denominada superficie Nuria (Short y Steenken, 1962) de Venezuela, llamada también superficie Imataca (Martín et al, 1975). A la superficie Nuria, se le atribuye una edad Cretácica Superior a Terciario Inferior por

Tabla 1. Resultados de análisis químicos del área investigada en el helipuerto $\mathbf{H}-20$.

\begin{tabular}{|c|c|c|c|c|c|c|c|}
\hline $\begin{array}{l}\text { No. de } \\
\text { muestra }\end{array}$ & $\begin{array}{l}\text { Tipo de } \\
\text { muestra }\end{array}$ & Profundidad & $\begin{array}{c}\mathrm{Al}_{2} \mathrm{O}_{3} \\
\text { (percentaje) }\end{array}$ & $\begin{array}{c}\mathrm{SiO}_{2} \\
\text { (percentaje) }\end{array}$ & $\begin{array}{c}\mathrm{Fe}_{2} \mathrm{O}_{3} \\
\text { (percentaje) }\end{array}$ & Laboratorio' & Ubicación \\
\hline 3108011 & Bloque & a $3 \mathrm{~m}$ & 49.61 & 5.75 & 15.16 & F.M.O. & Calicata 2 \\
\hline 3108081 & Bloque & a $2 \mathrm{~m}$ & 54.76 & 4.65 & 14.87 & F.M.O. & Calicata 3 \\
\hline 3108031 & Bloque & $\mathrm{a} 0 \mathrm{~m}$ & 50.48 & 10.26 & 8.29 & F.M.O. & Calicata 4 \\
\hline 3108101 & Bloque & a $1 \mathrm{~m}$ & 55.89 & 2.39 & 11.58 & F.M.O. & Calicata 5 \\
\hline 310201 & Canal & $0-1 \mathrm{~m}$ & 43.47 & 9.27 & 16.13 & F.M.O. & Calicata 2 \\
\hline 310202 & Canal & $1-2 m$ & 43.85 & 9.63 & 16.42 & F.M.O. & Calicata 2 \\
\hline 310203 & Canal & $2-3 \mathrm{~m}$ & 43.21 & 8.03 & 16.55 & F.M.O. & Calicata 2 \\
\hline 310301 & Canal & $0-1 \mathrm{~m}$ & 38.05 & 12.37 & 17.18 & F.M.O. & Calicata 3 \\
\hline 310302 & Canal & $1-2 \mathrm{~m}$ & 42.34 & 9.93 & 16.90 & F.M.O. & Calicata 3 \\
\hline 310303 & Canal & $2-3 \mathrm{~m}$ & 45.36 & 13.40 & 10.85 & F.M.O. & Calicata 3 \\
\hline
\end{tabular}

${ }^{1}$ Ferrominera del Orinoco, Puerto Ordaz. 
Tabla 2. Resultados de análisis químicos del área investigada en el helipuerto H-17.

\begin{tabular}{lcccccc}
\hline $\begin{array}{l}\text { Tipo de } \\
\text { muestra }\end{array}$ & Profundidad & $\begin{array}{c}\mathrm{Al}_{2} \mathrm{O}_{3} \\
\text { (percentaje) }\end{array}$ & $\begin{array}{c}\mathrm{SiO}_{2} \\
\text { (percentaje) }\end{array}$ & $\begin{array}{c}\mathrm{Fe}_{2} \mathrm{O}_{3} \\
\text { (percentaje) }\end{array}$ & Laboratorio' & Ubicación \\
\hline Bloque & $\mathrm{a} \mathrm{0} \mathrm{m}$ & 59.39 & 3.37 & 4.79 & BAUXIVEN & H-17 \\
Bloque & $\mathrm{a} 2 \mathrm{~m}$ & 50.57 & 14.90 & 6.88 & BAUXIVEN & H-17 \\
Bloque & $\mathrm{a} \mathrm{0} \mathrm{m}$ & 60.55 & 3.37 & 3.35 & BAUXIVEN & H-17 \\
Canal & $0-1 \mathrm{~m}$ & 42.21 & 13.80 & 14.11 & F.M.O. & Calicata 1 \\
Canal & $1-2 \mathrm{~m}$ & 46.62 & 10.07 & 14.30 & F.M.O. & Calicata 1 \\
Canal & $2-3 \mathrm{~m}$ & 46.36 & 8.60 & 13.58 & F.M.O. & Calicata 1 \\
Canal & $3-4 \mathrm{~m}$ & 43.22 & 10.20 & 16.84 & F.M.O. & Calicata 1 \\
Bloque & a $0 \mathrm{~m}$ & 59.29 & 2.29 & 2.63 & F.M.O. & H-17 \\
Bloque & a 2 m & 55.94 & 5.11 & 8.15 & F.M.O. & H-17 \\
\hline
\end{tabular}

'Bauxita de Venezuela, Los Pijiguaos; Ferrominera del Orinoco, Puerto Ordaz.

su semejanza con la superficie Kopinang de Guyana (McConnell, 1969). Tomando en cuenta el criterio de la altitud, se engloba con este nombre a todos los restos erosivos situados entre 600-700 m sin importar lo disímil que sea su naturaleza o el proceso evolutivo de su formación. En el presente trabajo se ha tratado de interpretar el modelo geomorfológico del área de Los Pijiguaos y delimitar otras áreas de evolución y naturaleza semejante, por esta razón se le denomina superficie de planación de Los Pijiguaos. Esta superficie contiene mena bauxítica de interés económico por meteorización del granito de Parguaza. La mena se fornó mediante un proceso de pedimentación con una elevación aproximada de 600 a $700 \mathrm{~m}$ y un desnivel abrupto de aproximadamente $500 \mathrm{~m}$.

El 85 por ciento de las bauxitas que ocurren en el mundo se encuentran sobre este tipo de superficies de planación que se desarrollan "in situ" sobre rocas magmáticas mediante procesos de meteorización de la roca original. El desarrollo de una superficie de planación implica un prolongado periodo de denudación continental en condiciones sub-aéreas y si las condiciones de clima lo permiten, pueden desarrollarse procesos de lateritización como paso previo al desarrollo de lateritas alumínicas y bauxita. El enriquecimiento en alúmina se produce por emigración del hierro en la forma de hidróxidos solubles y por lixiviación de la sílice. Se trata, pues, de un enriquecimiento "in situ" con mayores concentraciones de alúmina en los niveles superiores, tal como acontece en el caso de Los Pijiguaos.

Evidentemente, las condiciones estructurales de la roca parental son una condición inicial indispensable para que se desarrolle la meteorización profunda. En el caso de Los Pijiguaos, se lleva a efecto mediante diaclasas verticales y horizontales.

El desarrollo de un espeso manto de meteorización va a depender de las condiciones del clima, siendo favorables las condiciones de clima tropical-húmedo para una meteorización más profunda y más rápida de la roca original. En este aspecto, las condiciones topográficas juegan un papel decisivo para que en la relación entre la meteorización y la erosión prevalezca el ritmo de la meteorización dando como resultado el incremento de espesor de la zona meteorizada. El análisis de estas condiciones en el área de Los Pijiguaos exige una reconstrucción paleo-geográfica que apenas comienza a visualizarce.

El enriquecimiento en alúmina y la bauxitización requieren de excelentes condiciones de drenaje interno y altos niveles de precipitación pluvial. Aquí juega un papel estelar el levantamiento que ha experimentado la superficie de planación de Los Pijiguaos y el proceso que ha establecido un desnivel de $\mathbf{5 0 0}$ m entre la superficie de planación y los valles planos cercanos donde discurren los mayores ríos. El drenaje interno se facilita a través de las diaclasas verticales de la roca infrayacente. De hecho, las redes de drenaje sobre la superficie de planación de Los Pijiguaos es un paleo-drenaje controlado por el sistema de diaclasas, el mismo que ha sido capturado en muchos sitios por el sistema de drenaje que acompaña el proceso de pedimentación inferior. Los procesos de pedimentación son ampliamente discutidos por Twidale (1983).

En el caso de la superficie de planación de Los Pijiguaos, el levantamiento ha producido una profunda incisión de los cursos de agua a través de la capa de meteorización, lo que ha originado interfluvios planos y pendientes convexas y abruptas en los flancos de los cursos de agua. Cuando la incisión llega a la roca fresca aparece una superficie lateral lisa en el granito, como paso previo a la formación de domos graníticos.

\section{NUEVAS AREAS BAUXITICAS EN LA SUPERFICIE DE PLANACION DE LOS PIJIGUAOS}

Con las condiciones geomorfologicas anteriores se han delimitado nuevas áreas semejantes al área de Los Pijiguaos. Dichas áreas son remanentes erosionales de una superficie mayor la cual se ha denominada superficie de planación de Los Pijiguaos, debiendo aclararse que únicamente se han 
delimitado las áreas de mayor extensión y continuidad lateral que pudieran conformar un yacimiento bauxítico de interés económico (figs. 2 y 3). Desde el punto de vista geológico, todas las áreas que se han indicado se encuentran sobre el granito de Parguaza de textura rapakivi, con excepción del área sobre la serranía de La Cerbatana (fig. 2) que se ha desarrollado en el granito biotítico de Santa Rosalía (McCandless, 1965).

En el aspecto relativo a la altitud, todas tienen una altitud semejante, aún cuando una misma altitud de las formas del relieve no significa necesariamente contemporaneidad. Según el concepto de "equilibrio dinámico" (Hack, 1960), superficies de planación de igual altitud pueden tener edades distintas e, inversamente, superficies de planación de diferente altitud pueden desarrollarse simultáneamente.

En las áreas verificadas ( $\mathrm{H}-17$ y H-20), la forma de los interfluvios indica la presencia de una espesa zona de meteorización que ha sido preservada. El estado de desarrollo del relieve y, especialmente, su accesibilidad y condiciones topograficas semejantes a Los Pijiguaos, posibilitaría un sistema de explotación como el que se ha implementado en Los Pijiguaos. En el caso de Los Pijiguaos, la mena bauxítica superficial tiene un espesor de $7 \mathrm{~m}$ y debido a la incisión de las redes de drenaje el área de 5.804 has (fig. 2) se reduce a 1.600 has, en el tope de los interfluvios, lo que totaliza un potencial certificado de $200 \times 10^{6}$ toneladas métricas de bauxita.

Las dos áreas investigadas totalizan 23,505 has., en el caso de que estas áreas presenten una mineralización semejante a Los Pijiguaos, significarían $800 \times 10^{6}$ toneladas métricas de bauxita.

\section{RECOMENDACIONES}

Tomando en consideración que el origen y evolución de superficies de planación es un problema esencialmente geomorfológico (Aleva, 1981), el cual tiene influencia importante en los recursos naturales en general y en el origen de recursos minerales lateríticos, en particular, y que es un problema complejo que debe ser enfocado inter-disciplinariamente, tanto desde el campo geológico como desde el campo geografico, se recomienda formar un equipo de investigadores con el personal de los distintos entes públicos y privados que de una u otra forma estudian las superficies de planación en Venezuela. Es preciso continuar las exploraciones de éstas y otras superficies de planación, así como de los depósitos sedimentarios asociados, a fin de definir el modelo de evolución geomorfológica de la región Guayana y su significado en el origen de los recursos naturales del área.

\section{REFERENCIAS}

Aleva, G.J.J., 1981, Bauxitic and other duricrusts on the Guiana Shield, South America: A.A. Balkema-Rotterdam,
Proceedings of the International Seminar on Laterization Processes, p. 261-269.

Hack, J.T., 1960, Interpretation of erosional topography in humid temperate regions: American Journal of Science, v. 258-A, p. $80-97$.

King, L.C., 1967, Morphology of the Earth (2nd ed.): New York, Hafner Publishing Company, $726 \mathrm{p}$.

Martin Bellizzia, C., coordinator, and Ascanio, G., Candiales, L.J., Rios, J.H. and Luchsinger, S.E., guides, 1975, Excursión geológica No. 6, Puerto Ordaz-La Vergarena: Congreso Latinoamericano de Geología, 2nd, Caracas, 1973, Memoria, Publicación Especial 7, v. 1, p. 371-388.

McCandless, G.C., 1965, Reconocimiento geológico de la región Nor-Occidental del Estado Bolívar: Boletín de Geología, v. 7, no. 13 , p. 19-28.

McConnell, R.B., 1969, The succession of erosion bevels in Guyana: Interguiana Geological Conference, 8th, Georgetown 1969, Geological Survey of Guyana, Records, v. 6, Paper 8, Proceedings, p. 1-16.

Melhorn, N.M., and Dorland, E.E., 1975, The case for episodic continental-scale erosion surfaces- $\mathbf{A}$ tentative geodynamic model, in Theories of landform development: Binghamton, State University of New York, chapter 13, p. 243-276.

Mendoza, Vicente, 1974, Geología del área del Río Suapure, parte noroccidental del Escudo de Guayana, Estado Bolívar, Venezuela; informe de progreso: Conferencia Geológica Inter-Guayanas, 9th, Venezuela, Memoria, Publicación Especial 6, p. 306-338.

Mendoza, Vicente, Moreno, L.A., Barrios, Fernando, Rivas, Duggar, Martínez, Jesús, Lira, Pedro, Sardi, Gustavo, and Ghosh, S.K., 1977, Geología de la parte norte del Territorio Federal Amazonas, Venezuela (informe en progreso): Congreso Geológico Venezolano, 5th, Caracas, 1977, Memoria, v. 1, p. 363-404.

Menendez V. de V., Alfredo, Rios, J.H., Weingarten, B., and Ticona, I., 1985, Características geologicas de la parte noreste del yacimiento de bauxita de "Los Pijiguaos," Estado Bolívar, Venezuela: Simposium Amazonico, 1st, Caracas, 1981, Publicación Especial 10, p. 548-570.

Menendez V. de V., Alfredo, and Samentero, Alberto, 1985, Exploración de bauxita en la Guayana Venezolana con particular referencia a la Serranía de Los Pijiguaos: Simposium Amazonico, 1st, Caracas, 1981, Publicación Especial 10, p. 571-586.

Rios, J.H., 1972, Geología de la región de Caicara, Estado Bolívar: Congreso Geologico Venezolano, 4th, Caracas, 1971, Memoria, Publicación Especial 5, v. 3, p. 1759-1782.

Shor, K.C., and Steenken, W.F., 1962, A reconnaissance of the Guayana Shield from Guasipati to the Río Aro, Venezuela: Asociación Venezolana de Geología, Minería y Petroleo, Boletín Informativo, v. 5, no. 7, p. 189-221.

Twidale, C.R., 1983, Pediments, peneplaines and ultiplaines: Revue de Geomorphologie Dinamique, v. 32, no. I, p. 1-35.

Zonneveld, J.I.S., 1969, Preliminary remarks on summit levels and the evolution of the relief in Surinam (S. America): Proceedings, Guiana Geological Conference (Paramaribo, Suriname), 7th, 1966; Verhandelingen van het Koninklijk Nederlands Geologisch Mijnbouwkundig Genootschap, v. 27, p. $53-60$. 
Geochemistry of Six Gold-Bearing

Quartz-Carbonate-Tourmaline Vein Systems, Estado Bolívar, Venezuela

By Sherman P. Marsh, Herbert A. Pierce, Henry Sanchez, and Norman J Page

GEOLOGY AND MINERAL DEPOSITS OF THE VENEZUELAN GUAYANA SHIELD

U.S. GEOLOGICAL SURVEY BULLETIN 2124-N

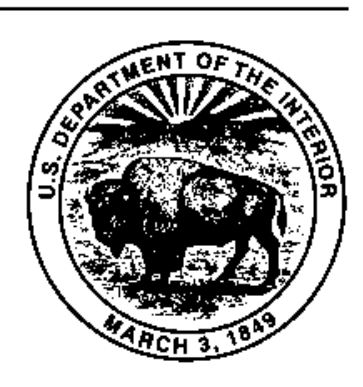

UNITED STATES GOVERNMENT PRINTING OFFICE, WASHINGTON : 1995 



\section{CONTENTS}

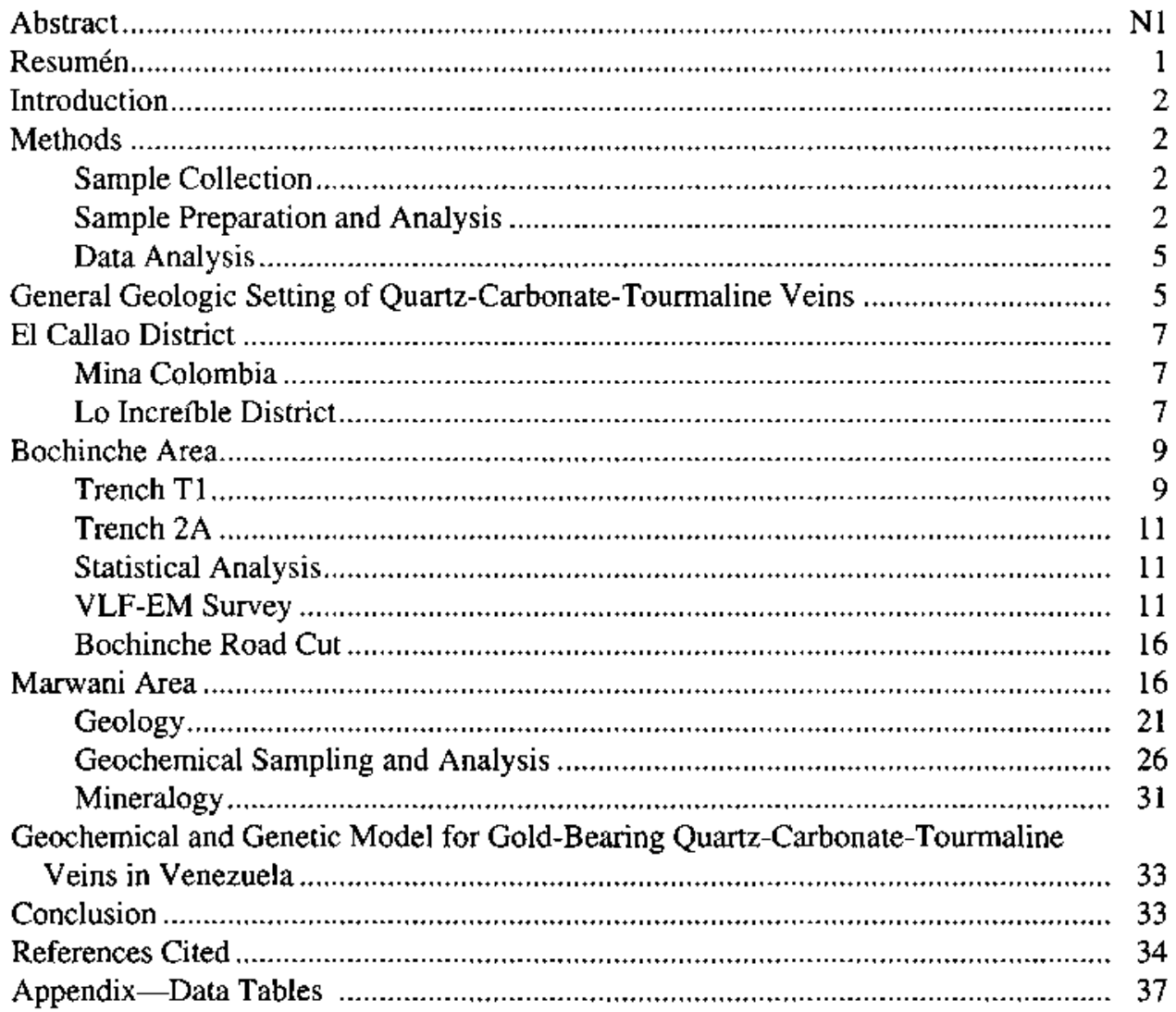

\section{FIGURES}

1. Map showing location of El Callao, Bochinche, and Marwani areas

2. Geologic map of Lo Increíble district showing locations of Mina-A, Mina Lapa, Mina Esperiencia, and Mina San Pedro.

3. Photograph of Mina-A open-pit mine, showing large gold-bearing quartz-carbonate-tourmaline vein boulder.

4. Photomicrograph of native gold from quartz-carbonate-tourmaline vein at Mina-A, .................................. 11

5. Plot of gold values for rock samples collected from trench in open-pit mine at Mina San Pedro ..................... 12

6. Map showing eastem Distrito Roscio and northwest part of Zone en Reclamación.......................................... 13

7-9. Photographs of Bochinche areas showing:

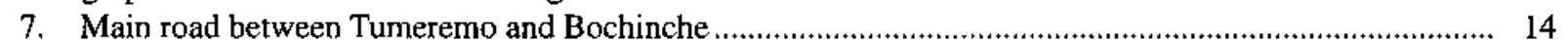

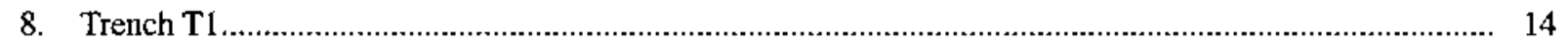

9. Main quartz-carbonate-tourmaline vein in trench T1 ........................................................................ 16

10. Plot of gold values for rock samples collected across quartz veins exposed in trench T1, Bochinche area ......... 17

11, 12. Photographs of Bochinche area showing:

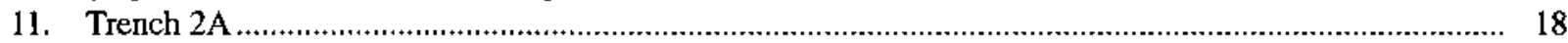

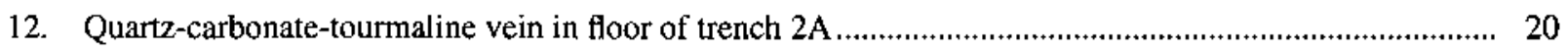

13. Plot of gold values for sample collected across vein system at trench $2 \mathrm{~A}$, Bochinche .....................................2. 23 


\section{CONTENTS}

14, 15. Profiles measured by VLF-EM receiver along trench $2 \mathrm{~A}$, Bochinche area, showing:

14. Resistivity.

15. Phase angle

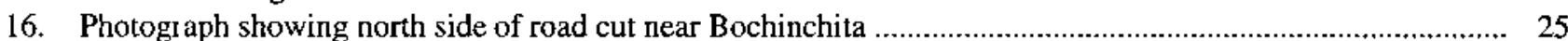

17. Plot of gold values across quartz veins exposed in road cut near Bochinchita .......................................... 27

18, 19. Maps of zone 4, Marwani concession, showing:

18. Schematic geology .

19. Rock sample locations

20. Photograph showing geology field camp near Esperanza along the main road between Tumeremo and Bochinche

21. Map showing panned-concentrate sample locations, zone 4, Marwani concession 32

\section{TABLES}

1,2. Limits of determination for semiquantitative emission spectrographic analysis of:

1. Rock samples N4

2. Panned concentrates from stream sediments..

3. Analytical methods used and limits of determination for inductively coupled plasma emission spectroscopy and flame atomic absorption spectrophotometry methods.

4. Univariate statistics for selvage and vein-rock samples, Mina Colombia 5

5. Cohen geometric means for host-rock samples and vien-rock samples, Mina Colombia ..

6. Univariate statistics for vein, host, and silicified rock samples, Mina San Pedro.

7. Comparison of Cohen geometric means of elemental values for vein and host-rock samples, Mina San Pedro

8. Univariate statistics for quartz-vein rock samples from trench $\mathrm{T} 1$, Bochinche 11

9. Correlation coefficients for quartz-vein samples from trench $\mathrm{T} 1$, Bochinche

10. Univariate statistics for host-rock samples from trench $\mathrm{T} 1$, Bochinche

11. Correlation coefficients for host-rock samples from trench $\mathrm{T} 1$, Bochinche .

12. Univariate statistics for quartz-vein rock samples from trench $2 \mathrm{~A}$, Bochinche.

13. Univariate statistics for host-rock samples from trench $2 \mathrm{~A}$, Bochinche...

14. Univariate statistics for silicified host-rock samples from trench $2 A$, Bochinche

15. Correlation coefficients for quartz-vein rock samples from trench $2 \mathrm{~A}$, Bochinche

16. Correlation coefficients for silicified host-rock samples from trench $2 \mathrm{~A}$, Bochinche

17. Correlation coefficients for host-rock samples from trench 2A, Bochinche.

18. Element associations for the six-factor, R-mode factor analysis for rock samples, trench $2 \mathrm{~A}$, Bochinche..........

19. Eigenvalues for the six-factor R-mode factor analysis for all rock samples, trench $2 \mathrm{~A}$, Bochinche ...................

20. Univariate statistics for host- and vein-rock samples from a road cut near Bochinche.....

21. Correlation coefficients for host- and vein-rock samples from a road cut near Bochinche

22. Univariate statistics for vein-rock samples from Marwani concession, zone 4 .

23. Correlation coefficients for vein-rock samples from Marwani concession, zone 4 . 


\title{
Geochemistry of Six Gold-Bearing Quartz-Carbonate-Tourmaline Vein Systems, Estado Bolívar, Venezuela
}

\author{
By Sherman P. Marsh, ${ }^{1}$ Herbert A. Pierce, ${ }^{2}$ Henry Sanchez, ${ }^{3}$ and Norman J Page ${ }^{2}$
}

\begin{abstract}
Rock samples collected from six vein systems and panned-concentrate samples collected from streams draining one of the vein systems were analyzed as part of a study of gold-bearing quartz-carbonate-tourmaline veins in the northeastern Guayana Shield of Venezuela. Samples are from Precambrian metavolcanic host rocks, mostly greenstone, and associated (and probably slightly younger) gold-bearing quartz-carbonate-tourmaline veins. All samples were analyzed by atomic absorption, atomic emission spectroscopy, and ion-specific electrode techniques. Field observations and analysis of samples suggest a deposit type consistent with low-sulfide gold-quartz veins. Analyzed rock samples from the surface, the near surface (3-15 m), and depth (300 m) show variations in gold concentrations from less than 0.002 to $10 \mathrm{ppm}$.

R-mode factor analysis on sample data from a trench in the Bochinche area identified four elemental associations: (1) a host-rock metavolcanic suite; (2) a mafic suite; (3) a tourmaline suite; and (4) a gold mineralization suite. The gold probably is in carbonate parts of the quartz veins, and carbonate fluids probably were the transport media.

A very low frequency geophysical survey parallel with the trench in the Bochinche area indicates that this electromagnetic technique can identify buried quartz veins (as deep as $10 \mathrm{~m}$ for veins about $1 \mathrm{~m}$ thick) in the deeply weathered tropical soils of Venezuela.
\end{abstract}

'U.S. Geological Survey, Denver Federal Center, MS973, Denver, Colorado 80225.

${ }^{2}$ U.S. Geological Survey, Corbett Building, 210 E. 7th Street, Tucson, Arizona 85705

${ }^{3}$ Corporación Venezolana de Guayana, Técnica Minera, C.A., C.C. Chilemex, Piso 1, Puerto Ordaz, Venezuela.

\section{RESUMEN}

Se analizaron un grupo de rocas colectadas en seis sistemas de vetas y concentrados pesados, los cuales provienen de quebradas que drenan uno de los sistemas de vetas. Estos análisis se llevaron a cabo como parte de un estudio sobre vetas de cuarzo con carbonato-turmalina-oro en la parte noreste del Escudo de Guayana en Venezuela. Las muestras incluyen (1) rocas metavolcánicas, principalmente rocas verdes "greenstones," las cuales forman la roca caja de edad Precambrico, y (2) vetas de cuarzo con carbonato-turmalina-oro, las cuales son probablemente un poco mas jovenes de las rocas verdes. Todas las muestras fueron analizadas por absorción atómica, espectroscopía de emisión atómica y técnicas con electrodos de iones específicos. Las observaciones de campo y análisis de muestras sugieren un depósito caracterizado por vetas de cuarzo con oro y bajo contenido de sulfuros. Las muestras de superficie, de baja profundidad (3-15 $\mathrm{m})$, y profundas $(300 \mathrm{~m}$ ) muestran una varición de $<0.002$ ppm a $10 \mathrm{ppm}$ de contenido de oro. La mayoría de las muestras contienen cantidades anómalas de oro, cinc, selenio, sílice y hierro.

El análisis factorial $\mathbf{R}$-modal, realizado en datos de muestras de la trinchera $2 \mathrm{~A}$ en el área de Bochinche, permitió identificar cuatro asociaciones de elementos que describen los siguientes rasgos geológicos: (1) rocas metavolcánicas (roca caja), (2) rocas máficas, (3) turmalina, y (4) mineralización de oro. El oro está probablemente en la fracciốn carbonatica de las vetas; además, fluidos ricos en carbonato fueron probablemente el medio de transporte del oro.

Un levantamiento geofísico de muy baja frecuencia (VLF), el cual fue realizado paralelo a la trinchera $2 \mathrm{~A}$, indica que este método electromagnético puede ser usado para identificar vetas de cuarzo que no afloran. Este método es efectivo para detectar vetas de $1 \mathrm{~m}$ de espesor hasta una profundidad de $10 \mathrm{~m}$ en suelos tropicales de Venezuela. 


\section{INTRODUCTION}

As part of the cooperative project between the U.S. Geological Survey (USGS) and the Corporación Venezolana de Guayana, Tecnica Minera, C.A. (CVG-TECMIN), gold-bearing low-sulfide quartz-carbonate-tourmaline veins in greenstone belts of the Guayana Shield of Venezuela were investigated during site visits in 1988 to determine their geochemical signature. Three types of vein occurrences were examined: surface exposures, near-surface exposures (3-15 $\mathrm{m}$ depth), and occurences at depth (300 m). Samples were collected and analyzed from six areas: Mina Colombia, Lo Increible, three areas near Bochinche, and zone 4 of the Marwani concession (fig. 1). Two of the studied areas are near the pueblo El Callao: the underground mine, Mina Colombia, $2.2 \mathrm{~km}$ south southeast of El Callao, and an open-pit operation, Mina San Pedro, in the Lo Increible district $15 \mathrm{~km}$ north of El Callao. Near Bochinche, two trenches, T1 and $2 \mathrm{~A}$, and a road cut between Esperanza and Bochinchita were studied. The sixth study area, zone 4 of the Marwani concession, is in the jungle near the Guyana border.

The gold-bearing low-sulfide quartz-carbonate-tourmaline veins are in volcanic and volcaniclastic rocks and graywacke in the eastern greenstone belts of the Guayana Shield. General geologic characteristics of the Guayana Shield are described by Sidder and Mendoza (this volume); a more detailed geologic and geophysical description of the Bochinche area is given by Wynn, McCafferty, and Salazar (this volume), and the Lo Increíble area is discussed by Day and others (this volume). The geology and geochemistry of zone 4 of the Marwani concession is discussed in this report, and the geology of Mina Colombia is described by Rodríguez (1986).

The Early Proterozoic greenstone belts of the Guayana Shield are composed of submarine sequences of tholeiitic to calc-alkalic basalt, rhyolite, turbiditic graywacke, volcaniclastic rocks, and chemical sedimentary rocks, in approximately this stratigraphic sequence from bottom to top. The belts also contain some ultramafic and mafic rocks, such as at Bochinche (Wynn, McCafferty, and Salazar, this volume). Metamorphism ranges from low-grade greenschist facies to high-grade amphibolite facies in the northem part of the shield near the Guri fault; shearing, folding, and faulting characterize postdepositional events in the greenstone belts. The beits formed between 2,250 and 2,100 Ma (Gibbs and Olszewski, 1982; Gnuau and others, 1985); granitic rocks ranging in age from about 2,230 to $2,050 \mathrm{Ma}$ have intruded the belts (Klar, 1979), and the granitic rocks and greenstone belts are crosscut by diabase dikes.

Acknowledgments. - We thank Michael Allen for his help with the statistics and intricacies of STATPAC and USGS analysts R. Hopkins and D. Fey. Without the help of CVG-TECMIN field camp crew Manuel Ramirez, Miguel Loreto, Armand Ledezma, Wilmer Maita, Carlos Maurera, and Javier Mendez the work in Marwani zone 4 would not have been possible. We express our appreciation to Jeffrey Wynn who added his insight to the Marwani zone 4 area from his interpretation of the aeromagnetics and for his contribution of the VLF-EM data for Bochinche trench 2A.

\section{METHODS}

\section{SAMPLE COLLECTION}

Samples were collected from the surface, from the near surface in trenches and a road cut, and from subsurface exposures in Mina Colombia. Most samples were taken from quartz-carbonate-tourmaline veins or their adjacent metavolcanic and metavolcaniclastic host rocks. Some surface rock samples were collected from float or colluvium where outcrops could not be found, and these may have been transported from their place of origin. Samples collected from many sites are single grab samples and may or may not be representative of their source materials on a larger scale. Some samples were collected because of the observed alteration and (or) mineralization (including visible gold) or because visible gold was identified in concentrate samples taken downstream from an outcrop. Some samples collected in trenches were composite chip samples, designed to be as representative as possible of the exposed rock unit, vein, or silicified zone. In general, host-rock samples were collected adjacent or in close proximity (usually within $10 \mathrm{~m}$ ) to the quartz-carbonate-tourmaline veins. This form of sampling was done to determine if gold mineralization extended into the host rocks and to study alteration (usually silicification) in the host rocks resulting from introduction of the veins. One hundred and forty-five rock samples were collected and analyzed (appendix tables 1-6).

In addition to rock samples, 86 panned-concentrate samples were collected from streams draining areas containing known or possible quartz-carbonate-tourmaline veins in zone 4 of the Marwani concession (appendix table 7). All panned concentrates were taken from active first-order streams. Concentrate samples were purposefully biased by collection in parts of streambeds favorable for concentration of heavy minerals by natural stream processes.

\section{SAMPLE PREPARATION AND ANALYSIS}

Rock samples were crushed, divided into splits of approximately $500 \mathrm{~g}$, and pulverized using a disk mill with ceramic plates to less than 100 mesh $(0.15 \mathrm{~mm})$. Panned-concentrate samples were reduced in the field to samples of $100-400 \mathrm{~g}$ and were further concentrated by floatation of the low-density minerals in bromoform (specific gravity 2.86 ). The remaining high-density fraction was separated into three fractions based on degree of magnetism. 


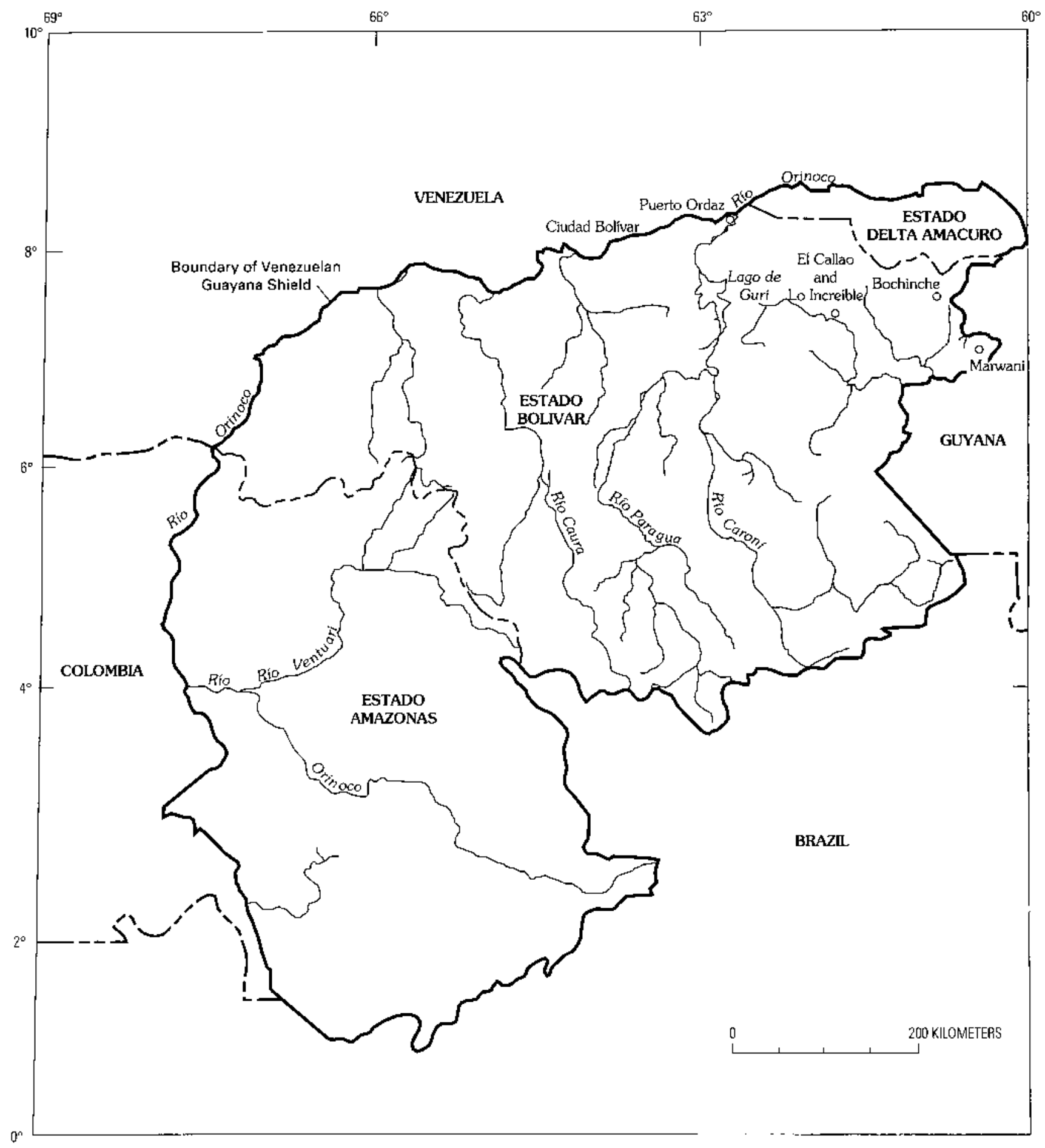

Figure 1. Map showing locstion of El Callao, Bochinche, and Marwani areas, Estado Bolívar, Venezuela.

After removal of a highly magnetic magnetite fraction with a hand magnet, the sample was split into magnetic and nonmagnetic fractions using a modified Franz isodynamic separator set at 2 amperes; the mineralogy of the resultant nonmagnetic heavy-mineral fraction was studied under a stereographic binocular microscope to identify the contained minerals. This nonmagnetic fraction was then ground to a powder for analysis.

All samples were analyzed for 35 elements using a semiquantitative direct-current arc emission spectrographic method (Grimes and Marranzino, 1968). Spectrographic results were obtained by visual comparison of spectra 
Table 1. Limits of determination for semiquantitative emission spectrographic analysis of rock samples, based on 10 -mg sample. [Values from Adrian in Arbogast (1990)]

\begin{tabular}{|c|c|c|c|c|c|}
\hline Element & $\begin{array}{c}\text { Lower limit } \\
\text { of determination }\end{array}$ & $\begin{array}{c}\text { Upper limit } \\
\text { of determination }\end{array}$ & Element & $\begin{array}{c}\text { Lower limit } \\
\text { of determination }\end{array}$ & $\begin{array}{c}\text { Upper limit } \\
\text { of determination }\end{array}$ \\
\hline \multicolumn{6}{|c|}{ Percent } \\
\hline Calcium (Ca) & 0.05 & 20 & Sodium (Na) & 0.2 & 5 \\
\hline Iron (Fe) & 0.05 & 20 & Phosphorus (P) & 0.2 & 10 \\
\hline Magnesium (Mg) & 0.02 & 10 & Titanium (Ti) & 0.002 & 1 \\
\hline \multicolumn{6}{|c|}{ Parts per million } \\
\hline Silver (Ag) & 0.5 & 5,000 & Molybdenum (Mo) & 5 & 2,000 \\
\hline Arsenic (As) & 200 & 10,000 & Niobium (Nb) & 20 & 2,000 \\
\hline Gold (Au) & 10 & 500 & Nickel (Ni) & 5 & 5,000 \\
\hline Boron (B) & 10 & 2,000 & Lead (Pb) & 10 & 20,000 \\
\hline Barium (Ba) & 20 & 5,000 & Antimony (Sb) & 100 & 10,000 \\
\hline Beryllium (Be) & 1 & 1,000 & Scandium (Sc) & 5 & 100 \\
\hline Bismuth (Bi) & 10 & 1,000 & $\operatorname{Tin}(S n)$ & 10 & 1,000 \\
\hline Cadrnium (Cd) & 20 & 500 & Strontium (Sr) & 100 & 5,000 \\
\hline Cobalt (Co) & 10 & 2,000 & Thorium (Th) & 100 & 2,000 \\
\hline Chromium (Cr) & 10 & 5,000 & Vanadium (V) & 10 & 10,000 \\
\hline Copper (Cu) & 5 & 20,000 & Tungsten (W) & 20 & 10,000 \\
\hline Gallium (Ga) & 5 & 100 & Yttrium (Y) & 10 & 2,000 \\
\hline Germanium (Ge) & 10 & 100 & Zinc (Zn) & 200 & 10,000 \\
\hline Lanthanum (La) & 50 & 1,000 & Zirconium $(\mathrm{Zr})$ & 10 & 1,000 \\
\hline Manganese (Mn) & 10 & 5,000 & & & \\
\hline
\end{tabular}

Table 2. Limits of determination for semiquantitative enission spectrographic analysis of panned concentrates from stream sediments. [Values from Adrian in Arbogast (1990)]

\begin{tabular}{|c|c|c|c|c|c|}
\hline Element & $\begin{array}{c}\text { Lower linit } \\
\text { of determination }\end{array}$ & $\begin{array}{c}\text { Upper limit } \\
\text { of determination }\end{array}$ & Element & $\begin{array}{c}\text { Lower limit } \\
\text { of determination }\end{array}$ & $\begin{array}{c}\text { Upper limit } \\
\text { of determination }\end{array}$ \\
\hline \multicolumn{6}{|c|}{ Percent } \\
\hline Calcium (Ca) & 0.1 & 50 & Sodium (Na) & 0.5 & 10 \\
\hline Iron $(\mathrm{Fe})$ & 0.1 & 50 & Phosphorus (P) & 0.5 & 20 \\
\hline Magnesium (Mg) & 0.05 & 20 & Tilanium (Ti) & 0.005 & 2 \\
\hline \multicolumn{6}{|c|}{ Parts per million } \\
\hline Silver (Ag) & 1 & 10,000 & Nickel (Ni) & 10 & 10,000 \\
\hline Arsenic (As) & 500 & 20,000 & Lead $(\mathrm{Pb})$ & 20 & 50,000 \\
\hline Gold (Au) & 20 & 1,000 & Palladium (Pd) & 5 & 1000 \\
\hline Boron (B) & 20 & 5,000 & Platinum (Pt) & 20 & 1000 \\
\hline Barium (Ba) & 50 & 10,000 & Antimony (Sb) & 200 & 20,000 \\
\hline Beryilium (Be) & 2 & 2,000 & Scandium (Sc) & 10 & 200 \\
\hline Bismuth (Bi) & 20 & 2,000 & $\operatorname{Tin}(S n)$ & 20 & 2,000 \\
\hline Cadmium (Cd) & 50 & 1,000 & Strontium (Sr) & 200 & 10,000 \\
\hline Cobalt (Co) & 10 & 5,000 & Vanadium (V) & 20 & 20,000 \\
\hline Chromium $(\mathrm{Cr})$ & 20 & 10,000 & Tungsten (W) & 100 & 20,000 \\
\hline Copper (Cu) & 10 & 50,000 & Yttrium (Y) & 20 & 5,000 \\
\hline Lanthanum (La) & 50 & 2,000 & Zinc $(\mathrm{Zn})$ & 500 & 20,000 \\
\hline Manganese (Mn) & 20 & 10,000 & Zisconium $(\mathrm{Zr})$ & 20 & 2,000 \\
\hline Molybdenum (Mo) & 10 & 5,000 & Thorium (Th) & 200 & 5,000 \\
\hline Niobium (Nb) & 50 & 5,000 & & & \\
\hline
\end{tabular}

derived from the sample with spectra obtained from standards made from pure oxides and carbonates. Standard concentrations are geometrically spaced over any given order of magnitude of concentration such that values reported for each sample are reported in the geometric sequence $10,15,20,30,50,70,100$, and so forth. The elements determined and their limits of determination are listed in table 1 . The precision of the method is plus or minus one reporting interval at 83 percent confidence or two reporting intervals at 96 percent confidence (Motooka and Grimes, 1976). Values determined for the major elements ( $\mathrm{Ca}, \mathrm{F}, \mathrm{Fe}$,
$\mathrm{Mg}, \mathrm{Na}, \mathrm{P}$, and $\mathrm{Ti}$ ) are given in weight percent; all other values are in parts per million. Analytical data from the spectrographic analyses are given in the appendix. Because the nonmagnetic heavy-mineral concentrate samples contain mineral species commonly high in iron, titanium, calcium, and zirconium, the sample weight used for analysis was reducéd by half and the resulting values from the observed spectra were doubled. This modification of the method was made to eliminate the special interferences produced by high concentrations of these elements. Similarly, the lower limits of detection were also doubled (table 2). 
Table 3. Analytical methods used and limits of determination for inductively coupled plasma emission spectroscopy (ICP) and flame atomic absorption spectrophotometry (AA) methods.

[In parts per million. Lower and upper limits of determination for the ICP method listed in this table are nominal and may be variable. The variability in limits of determination for an clement may be due to variable sample aliquot weight, dilution of an analytical aliquot, or instrumental interference correction]

\begin{tabular}{llrr}
\hline \multicolumn{1}{c}{ Element } & Analytical method & $\begin{array}{c}\text { Lower limit } \\
\text { of determination }\end{array}$ & $\begin{array}{c}\text { Upper limit } \\
\text { of deternination }\end{array}$ \\
\hline Silver (Ag) & ICP & 0.04 & 51,500 \\
Arsenic (As) & ICP & 0.6 & 3,000 \\
Gold (Au) & ICP & 0.15 & 2,400 \\
Bismuth (Bi) & ICP & 0.6 & 1,500 \\
Cadmium (Cd) & ICP & 0.03 & 500 \\
Copper (Cu) & ICP & 0.03 & 1,200 \\
Molybdenum (Mo) & ICP & 0.09 & 1,500 \\
Lead (Pb) & ICP & 0.6 & 12,000 \\
Antimony (Sb) & ICP & 0.6 & 800 \\
Zinc (Zn) & ICP & 0.03 & 500 \\
Tellurium (Te) & AA & 0.1 & 20 \\
Thallium (Tl) & AA & 0.2 & -- \\
Fluorine (F) & Ion-selective electrode & -- \\
Gold (Au) & AA (graphite furnace) & 0.01 & -- \\
\hline
\end{tabular}

Other methods of analyses used on samples from this study are summarized in table 3 . Gold analyses were done using atomic absorption spectrophotometry after hydrobromic acid digestion of a 10-g aliquot and an organic solvent extraction (O'Leary and Meier, 1984). Arsenic, bismuth, cadmium, antimony, and zinc were determined using an inductively coupled plasma-atomic emission spectroscopy method described by Crock and others $(1982,1983)$ and Lichte and others (1988). Mercury was determined using a modification of the atomic absorption method described by Wilson and others (1988). Fluorine was determined using an ion-selective electrode method described by Hopkins (1977). Tellurium and thallium were determined by the flame atomic absorption method (Hubert and Chao, 1985). Results of these analyses are given in the appendix.

\section{DATA ANALYSIS}

The analytical results were entered into a computer database that contains both descriptive geological information and analytical data. Information may be retrieved and converted to a binary form and then processed using the U.S. Geological Survey statistical package STATPAC for computerized analysis or publication (VanTrump and Miesch, 1976).

STATPAC programs were used to analyze data sets from the six areas. Variables (elements) that displayed values below the threshold of detection for more than 50 percent of the samples were removed from the data set and not used in the statistical analysis. The number of valid elements ranges from 23 to 28 depending on the data set. Basic univariate statistics were run on lognormalized data. These values can be compared using Cohen-estimated geometric means and deviations that account for qualified data where some values fall below the detection limit of the chemical analysis. Correlation matrices were constructed for most data sets to delineate various affinities (or disaffinities) between element pairs. In addition, one data set, Bochinche $2 \mathrm{~A}$, had enough samples to allow R-mode factor analysis to be performed.

\section{GENERAL GEOLOGIC SETTING OF QUARTZ-CARBONATE-TOURMALINE VEINS}

Gold-bearing quartz-carbonate-tourmaline veins are present in greenstone-belt rocks and slightly younger volcanic rocks in the Guayana Shield in the east-central part of Estado Bolívar, Venezuela. The greenstone belts form parts of two Precambrian rock groups, the Pastora Supergroup (Korol, 1965; Menéndez, 1968) and the structurally overlying volcanic rocks that crop out in the area of Río Botanamo. Volcanic rocks of the Pastora Supergroup are regionally metamorphised to greenschist facies and in the northem part of the shield, within $30 \mathrm{~km}$ of the Guri fault, to amphibolite facies. Localized zones of amphibolite schist are developed in mafic volcanic rocks near contacts within the Supamo Complex. Large parts of the volcanic areas can be described as greenstone belts because of their elongate form, greenschist facies metamorphism, and flanking granitic batholiths. In the El Callao area, the Pastora Supergroup was subdivided by Menéndez (1968) into the Carichapo Group and the overlying Yuruari Formation. The Carichapo Group comprises a lower pillow basalt containing local talc schist lenses and an upper andesitic metatuff. The Yuruari 
Table 4. Univariate statistics for selvage and vein-rock samples, Mina Colombia, El Callao district, Venezuela. [In parts per million unless otherwise noted. All analyses are by semiquantative spcctrographic method except for As, Cd, Zn, and Au, which were done by atomic absorption method. $L$, detected but below lower limit of determination; $N$, not detected at lower limit of determination]

\begin{tabular}{|c|c|c|c|c|c|c|c|c|c|}
\hline \multirow[b]{2}{*}{ Element } & \multicolumn{2}{|c|}{ Range } & \multicolumn{2}{|c|}{ Geometric } & \multicolumn{3}{|c|}{ Number of samples } & \multicolumn{2}{|c|}{ Cohen } \\
\hline & Minimum & Maximum & Mean & Deviation & Valid & $\mathrm{L}$ & $\mathrm{N}$ & Mean & Deviation \\
\hline $\mathrm{Fe} \%$ & 0.07 & 10 & 3.2 & 5.2 & 12 & 0 & 0 & 3.2 & 5.17 \\
\hline $\mathrm{Mg} \%$ & 0.07 & 1.5 & 0.7 & 2.3 & 12 & 0 & 0 & 0.7 & 2.34 \\
\hline $\mathrm{Ca} \%$ & 0.01 & 7 & 2.8 & 3.6 & 12 & 0 & 0 & 2.8 & 3.59 \\
\hline $\mathrm{Ti} \%$ & 0.007 & 1 & 0.3 & 4.9 & 12 & 0 & 0 & 0.3 & 4.9 \\
\hline Mn & 30 & 1,500 & 595.4 & 3.0 & 12 & 0 & 0 & 595 & 3.05 \\
\hline $\mathrm{Ag}$ & 1 & 7 & 2.0 & 2.4 & 4 & 0 & 8 & 0.2 & 6.89 \\
\hline B & 1 & 150 & 34.5 & 2.5 & 8 & 0 & 4 & 17.1 & 3.73 \\
\hline Ba & 20 & 70 & 28.9 & 1.7 & 7 & 0 & 1 & 20.1 & 1.89 \\
\hline Co & 30 & 100 & 47.3 & 1.7 & 9 & 0 & 3 & 27.8 & 2.90 \\
\hline $\mathrm{Cu}$ & 10 & 300 & 41.4 & 2.9 & 9 & 0 & 2 & 19.3 & 5.28 \\
\hline $\mathrm{Ni}$ & 7 & 50 & 18.0 & 2.5 & 4 & 0 & 4 & 2.3 & 6.48 \\
\hline $\mathrm{Pb}$ & 10 & 15 & 11.4 & 1.2 & 9 & 0 & 1 & 10.6 & 1.25 \\
\hline Sc & 7 & 30 & 22.9 & 1.6 & 10 & 0 & 2 & 16.7 & 2.30 \\
\hline $\mathrm{V}$ & 10 & 500 & 132.7 & 2.9 & 12 & 0 & 0 & 133 & 2.91 \\
\hline Y & 20 & 30 & 26.2 & 1.2 & 9 & 0 & 3 & 19.1 & 1.80 \\
\hline $\mathrm{Zr}$ & 20 & 70 & 47.7 & 1.5 & 9 & 0 & l & 28.4 & 2.70 \\
\hline $\mathrm{Na}$ & 0.2 & 5 & 1.9 & 2.5 & 10 & 0 & 2 & 1.2 & 4.03 \\
\hline Ga & 15 & 50 & 30.1 & 1.6 & 9 & 0 & 2 & 16.6 & 3.08 \\
\hline As & 5 & 87 & 18.9 & 2.7 & 7 & 0 & 0 & 6.8 & 4,63 \\
\hline $\mathrm{Cd}$ & 0.3 & 1.9 & 0.9 & 1.9 & 9 & 0 & 0 & 0.4 & 4.29 \\
\hline $\mathrm{Zn}$ & 20 & 110 & 72.9 & 1.8 & 10 & 0 & 0 & 35.6 & 5.50 \\
\hline $\mathrm{Te}$ & 0.25 & 0.8 & 0.47 & 1.6 & 4 & 0 & 0 & 0.02 & 15.3 \\
\hline Au & 0.003 & 10.0 & 0.56 & 14.0 & 10 & 0 & 0 & 0.16 & 42.2 \\
\hline
\end{tabular}

Table 5. Cohen geometric means for five host-rock samples and seven vein-rock samples, Mina Colombia, El Callao district, Venezuela.

[In parts per million unless otherwise noted. Elements too heavily qualified on either the upper or Jower detection limit to calculate a Cohen geometric mean are not included]

\begin{tabular}{|c|c|c|c|c|c|}
\hline Element & Vein & Host & Element & Vein & Host \\
\hline Fe\% & 1.7 & 7.5 & $\mathrm{~Pb}$ & 10.1 & 10.8 \\
\hline $\mathrm{Mg} \%$ & 0.5 & 1.0 & Sc & 10.9 & 27.7 \\
\hline $\mathrm{Ca} \%$ & 1.9 & 5.0 & $Y$ & 30.0 & 23.5 \\
\hline $\mathrm{Ti} \%$ & 0.4 & 0.7 & $\mathrm{Zr}$ & 17.7 & 43.0 \\
\hline$M n$ & 408 & 1,010 & $\mathrm{Na}$ & 0.6 & 2.7 \\
\hline $\mathrm{Ba}$ & 22 & 13 & Gà & 8.0 & 40.8 \\
\hline $\mathrm{Ni}$ & 1.2 & 3.5 & As & 14.4 & 4.5 \\
\hline Co & 16.5 & 42 & Cd & 0.2 & 1.3 \\
\hline $\mathrm{Cu}$ & 9.6 & 33.11 & $\mathrm{Zn}$ & 15.0 & 99.2 \\
\hline V & 96.6 & 207 & Au & 1.42 & 0.007 \\
\hline
\end{tabular}

Formation is an extensive unit of mica schist and phyllite and felsic metatuff. Similar types of rock are present in other greenstone areas, which are separated from El Callao by wide areas of granite, but in these belts topography is more subdued and jungle cover more dense, and stratigraphic relations between rock types are difficult to determine. It is likely that cycles of mafic and felsic volcanism of several different ages have contributed to the various greenstone belts in the northeastem part of the shield. In addition to volcanic rocks, extensive areas of gabbro and peridotite are present in the greenstone belt extending south from El Callao.

Metavolcanic and metasedimentary rocks in the Bochinche and Marwani areas may represent a volcanic environment distinctly different from that of other greenstone belts in the Guayana Shieid. The rocks are uniformly metamorphosed to greenschist facies and are strongly folded, judging from the steep dips of bedding and schistosity (Benaim, 1974) and the northeast-trending grain in the radar images (U.S. Geological Survey and Corporación 
Venezolana de Guayana, Técnica Minera, C.A., 1993, plate 3). The area of exposure is broad rather than beltlike, and limited petrochemical data from the Anacoco area (Day and others, 1989) indicate that the volcanic rocks belong to a calc-alkaline suite rather than to a bimodal assemblage such as described by Gibbs (1980) for more typical greenstone belts in adjacent areas of Guyana.

The Pastora Supergroup and overlying volcanic rocks are separated by a large northwest-trending shear zone that is interpreted to be a low-angle fault. The greenstone belts contain differentiated volcanic, pyroclastic, and related metavolcanic rocks that are metamorphosed to greenschist facies. In general, the quartz-carbonate-tourmaline veins cut across foliation at an oblique angle.

Many of the low-sulfide gold-quartz veins in the Guayana Shield are related either to dislocation zones within the greenstone belts (such as in the El Callao and Lo Increíble areas) or to inferred buried intermediate-composition plutons that intruded rocks of the greenstone belt.

\section{EL CALLAO DISTRICT}

The El Callao district contains a series of deposits from which the total production to date is about 180 metric tons of gold or roughly US\$1.8 trillion (1991 dollars). One mine in the district, Mina Colombia, was sampled for this study.

\section{MINA COLOMBIA}

Mina Colombia, an active underground gold mine operated by Compañia General de Minería de Venezuela, C.A. (Minerven), is south-southeast of the town of El Callao. Mina Colombia produces ore from a zone of quartz-carbonate-tourmaline veins that strike N. $60^{\circ}-70^{\circ}$ E. and dip $35^{\circ}-45^{\circ} \mathrm{S}$. Production is about 700 metric tons of ore per day with grades as high as 30 grams per metric ton and averaging about 9.9 grams per metric ton. The gold is present in pyrite (Ing. Fructuoso Rolando Salazar, oral commun.) and as free gold. The gold-bcaring quartz-carbonatc-tourmaline veins are in greenstone (metavolcanic and metavolcaniclastic rocks) that has been faulted and fractured. Two main veins-the America and the Colombia - currently are being mined on three levels. The veins are $2-5 \mathrm{~m}$ wide including adjacent fracture and breccia zones. The vein systems occupy fault structures and tension fractures in the greenstone; associated breccia zones and silicified areas are in both the veins and the host rocks. A zone of smaller secondary quartz veins normal to the primary veins extends approximately $10 \mathrm{~m}$ from the foot- and hanging-walls into the host rock. The secondary veins occupy fractures interpreted as result of tension and dilation of the primary America and Colombia veins. The secondary veins are deformed by folding and are also gold producing (appendix table 1). Host rocks adjacent to the veins contain abundant pyrite (cubes as large as $0.5 \mathrm{~cm}$ ) and tourmaline.

Twelve rock samples of vein and host material were collected and analyzed. Univariate statistics and Cohen-estimated geometric means and deviations are given in table 4 . Vein rocks collected from Mina Colombia are enriched in yttrium, barium, arsenic, and gold relative to the host rocks (table 5). Lead is the same for veins and host rocks, whereas other elements are depleted from 15 to 70 percent.

The enrichment of gold and arsenic is typical of the low-sulfide gold-quartz vein model (Bliss, 1986); however, measured levels of arsenic are low, 5-87 ppm (appendix table 1). The lack of an increase in iron probably indicates that most of the gold in this deposit is free gold and not chemically associated with the pyrite in the mine.

\section{LO INCREIBLE DISTRICT}

The Lo Increible district, $5-10 \mathrm{~km}$ northwest of El Callao (fig. 1), contains a series of small placers, open pits, and underground mines on and in a northeast-trending southeast-dipping shear zone (fig. 2). The shear zone contains many discontinuous quartz-carbonate-tourmaline veins, and it separates rocks of the Yurauri Formation and rocks of the El Callao Formation. The Yurauri Formation at Lo Increíble is composed of amphibolite-grade, medium-grained quartz-biotite-muscovite schist whose protolith ranges from felsic volcaniclastic tuff and tuff breccia to mafic volcanic rock. The El Callao Formation consists of magnesium-rich tholeiitic metabasalt that was deposited as subaqueous flows and has been locally strongly deformed and metamorphosed to chlorite-amphibolite schist near the shear zone. These flows are locally crossed by some northwest-trending fractures (Day and others, this volume).

Gold in the Lo Increible district is in the shear zone as native gold in discontinuous quartz-carbonate-tourmaline veins that pinch and swell along strike. The shear zone is mined along strike for a distance of several kilometers.

Mining operations in the Lo Increíble district use both underground (Mina Lapa) and open-pit methods (Mina-A and Mina San Pedro, figs. 2-4). Many of the open-pit mines in this area use bulldozers to break up surface exposures of the quartz veins, and commonly these mines occupy sites of former underground mines. Quartz boulders are as large as a meter or more in diameter, and gold is commonly visible on freshly broken surfaces. The deposit at Mina-A is extremely rich; at the time of sampling the mine had been in operation for about three months and had produced almost $45 \mathrm{~kg}$ of gold. Approximately two-thirds of the gold production at Mina-A is from outcrop, and one-third is from reworking tailings from previous mining. The mine currently produces about 350 metric tons of vein quartz per month at an average grade of 80 grams per metric ton ( $28 \mathrm{~kg}$ of gold per month). 


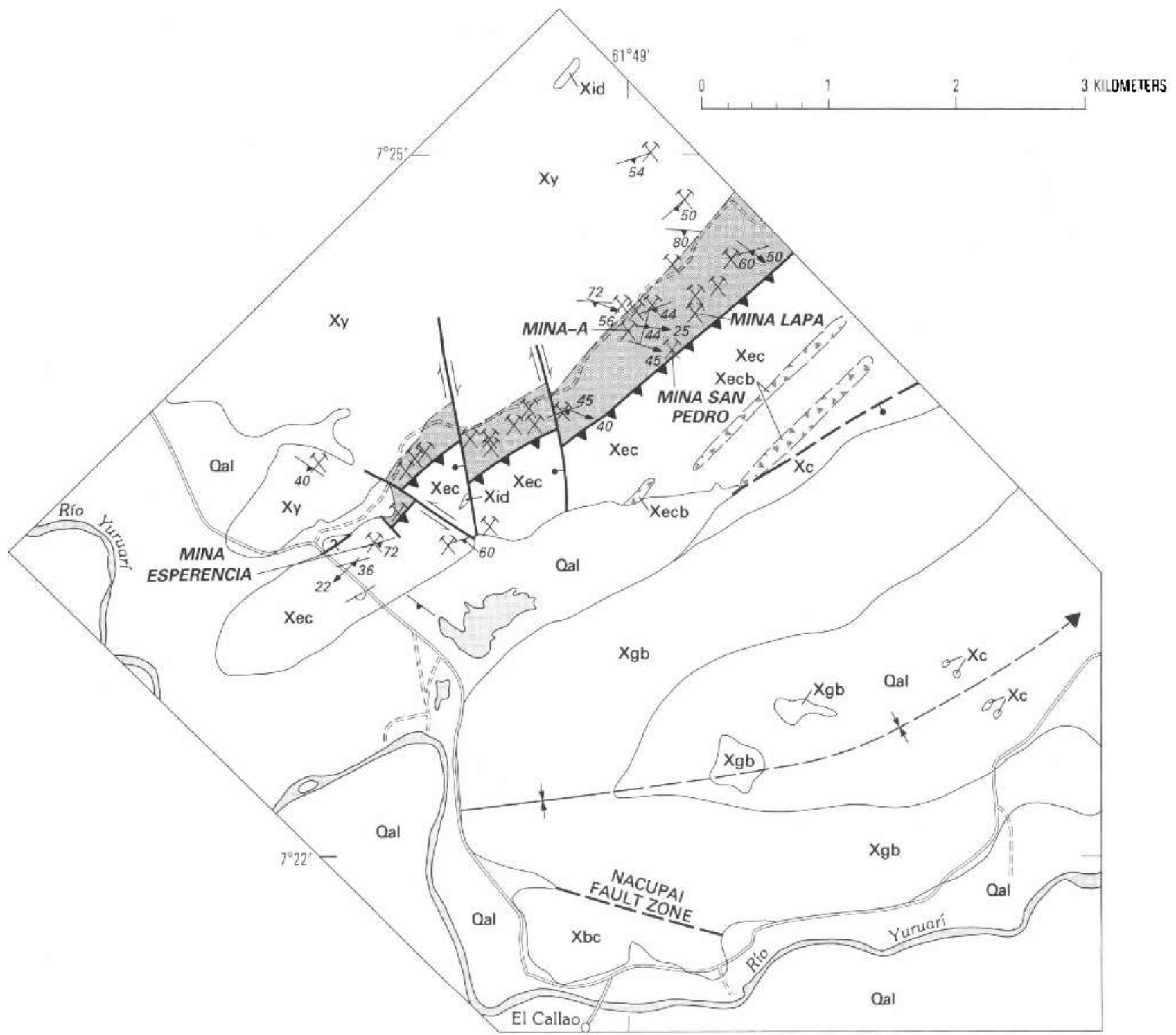

Figure 2. Geologic map of the Lo Increíble district, Estado Bolivar, Venczuela, showing locations of Mina-A, Mina Lapa, Mina Esperiencia, and Mina San Pedro. Modified from Day and others (this volume).

About $12 \mathrm{~kg}$ of gold per month is recovered from the tailings of the old underground mine.

Mina San Pedro is an east-trending open pit along a shear zone. A north-south trench, roughly $15 \mathrm{~m}$ below the natural grade at its deepest, crosses the trend of the vein-shear zone system. Nine samples collected from the trench wall reflect the altered bedrock lithology, quartz-carbonate-tourmaline veining, and silicified breccia zones. The sampled trench is roughly perpendicular to the trend of the quartz-carbonate-tourmaline veins, which strike east-west and dip $80^{\circ} \mathrm{S}$. The rocks in this area are brecciated, silicified, and altered to clays, sericite, and iron oxide minerals, and even the quart-carbonatc-tourmaline veins are brecciated and silicified. The veins contain pockets and holes where a carbonate mineral has apparently weathered out.

Analylical data for Mina San Pedro are given in appendix table 2. Univariate statistics and Cohen geometric corrections for qualified data for elements are given in table 6. A comparison of vein and host rock statistics using Cohen geometric means is given in table 7. At Mina San Pedro, only boron and gold are enriched in the veins relative to the host rock. Iron is unchanged between host and vein rocks, and the other elements are depleted in the veins relative to the host rock. Unlike Міла Colombia, arsenic, yttrium, and barium are not enriched in the veins. The lack of enrichment may reflect weathering in the near-surface environment. 


\section{EXPLANATION}

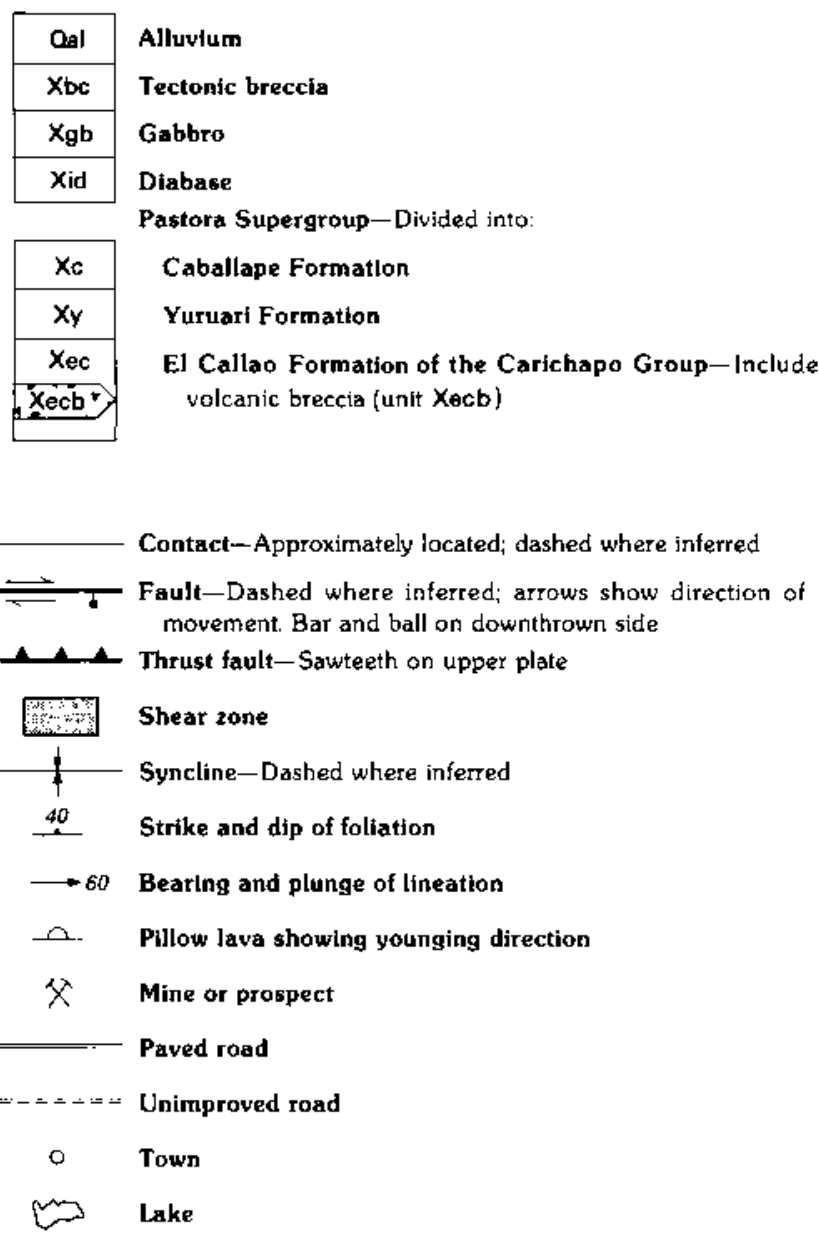

Figure 5 shows a plot of gold values in the Mina San Pedro trench. The irregular distribution of gold values in relation to the spatial distribution of the quartz veins and the secondary brecciation of the quartz veins suggest at least two episodes of silicification. The large quartz vein at $4 \mathrm{~m}$ shows low gold values, whereas the two relatively small quartz veins (at 1 and $2 \mathrm{~m}$ horizontal scale) show elevated gold values. The irregularity of gold values from the trench may be caused by an insufficient number of samples, sample collection bias, or a nugget effect.

\section{BOCHINCHE AREA}

Three locations in the Bochinche area were sampled: trench $\mathrm{T} 1$, trench $2 \mathrm{~A}$, and a quartz vein that crops out in a road cut along the main road between Esperanza and Bochinchita (figs. 6,7).

\section{TRENCH T1}

Trench $\mathrm{T} 1$ trends north-south, is about $70 \mathrm{~m}$ long, and at its deepest point is about $6 \mathrm{~m}$ below the natural grade (fig. 8). It exposes a main quartz-carbonate-tourmaline vein $2.5 \mathrm{~m}$ wide and smaller zones of quartz veining on either side. The main vein zone strikes $\mathrm{N}, 65^{\circ} \mathrm{E}$. and dips $75^{\circ} \mathrm{N}$., and the smaller veins adjacent to the large vein generally strike $\mathrm{N}$. $70^{\circ} \mathrm{E}$. and dip steeply $70^{\circ}-80^{\circ} \mathrm{N}$. Manganese oxide minerals commonly are developed on the margins of the smaller veins. Many small silicified zones pinch and swell along small fractures. These silicified zones begin with manganese oxide staining along a fracture, broaden out into small zones of silicification, and then pinch out entirely.

The veins contain abundant tourmaline, and the quartz in the veins contains small inclusions of tourmaline and pyrite. Other sulfide minerals are probably present in the inclusions but were not recognized in the field. The altered schistose wallrock is silicified, sericititzed, and very weathered, in places almost to clay, but the schistose texture is mostly preserved. Manganese oxide and iron oxide staining is evident on surfaces and margins of the veins.

Twenty-four samples of host schist, silicified host, and quartz-carbonate-tourmaline veins were collected. Data for the samples were divided into a host-rock group and a quartz-vein group. Because only three samples of silicified host were collected, statistics were not done for this group. Geochemical data are given in appendix table 3. Basic statistics, Cohen corrections, and correlation coefficients were calculated for both groups. Data for the quartz-vein group from trench $\mathrm{T} 1$ are given in tables 8 and 9 , and data for the host-rock group are given in tables 10 and 11 .

Cohen-corrected geometric means for the near-surface quartz-vein rock group from trench $\mathrm{Tl}$ show that barium, boron, nickel, and, marginally, zirconium concentrations are elevated as compared to those elements at Mina Colombia. This is similar to the elemental relations for Mina San Pedro with the exception that in trench $\mathbf{T} 1$ arsenic concentrations are about the same in host and vein rocks.

Cohen-corrected geometric means for the schist host-rock group and the quartz-carbonate-tourmaline vein group show that gold and manganese are elevated in the veins. Base metals, copper, and zinc are enriched twofold in the host rocks. The other elements are neither enriched nor depleted.

Samples of the quartz-carbonate-tourmaline veins (fig. 9) show correlations between iron, nickel, vanadium, copper, and zirconium that probably represent a pyrite or other sulfide mineral suite. Correlations for manganese, titanium, chromium, and cobalt probably represent the signature of a lithic group comprising metavolcanic host rocks. Significant correlations between gold, zinc, and nickel most likely represent the mineralizing suite.

Gold values are variable across the sampled trench in terms of geology, but they are relatively high for some 


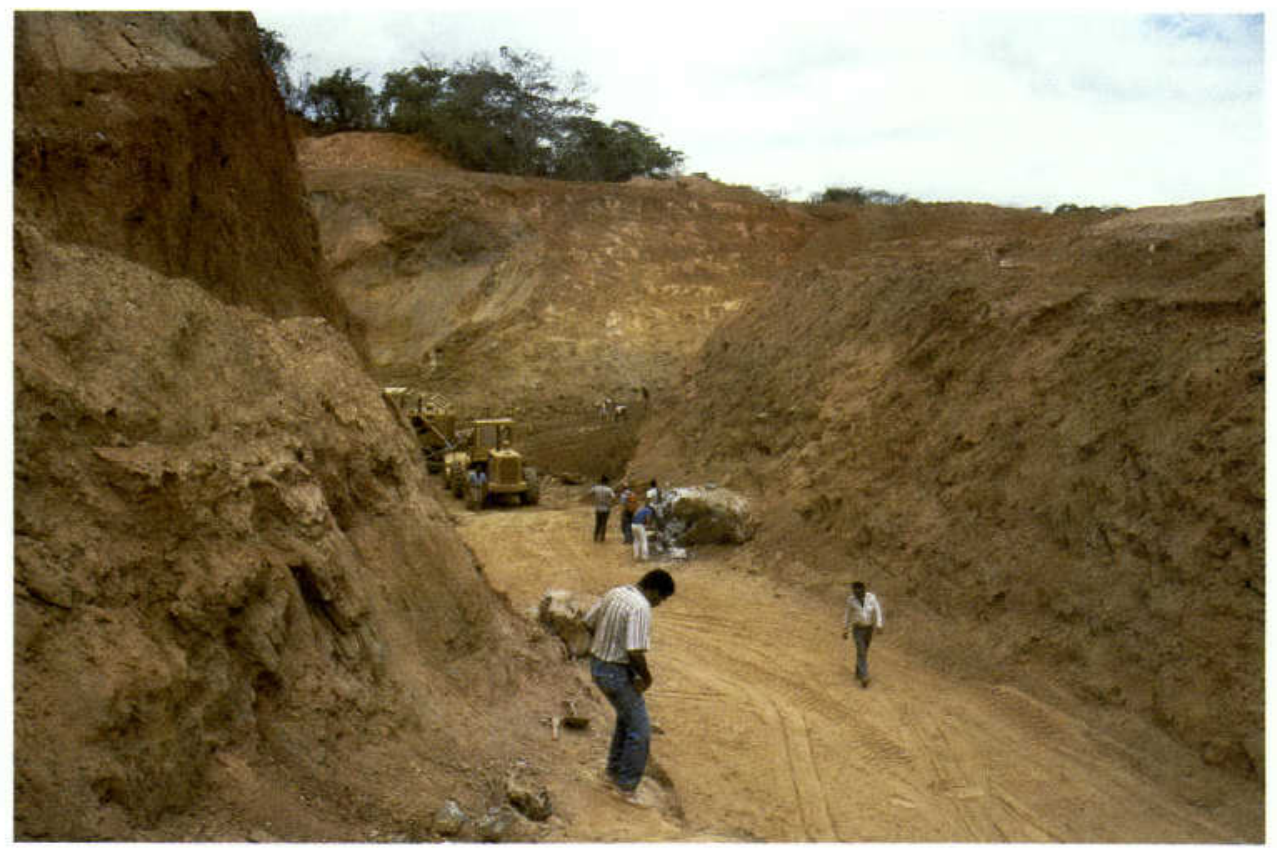

Figure 3. Mina-A open-pit mine, Lo Increíble district, Estado Bolívar, Venezuela; looking northeast. Large gold-bearing quartz-carbonate-toumaline vein boulder is in middle foreground.

Table 6. Univariate statistics for vein, host, and silicified rock samples, Mina San Pedro, Ei Callao district, Venezuela. [ln parts per million unless otherwise noted. All analyses are by semiquantative spectrographic method except for $\mathrm{As}, \mathrm{Cd}, \mathrm{Zn}$, Te, Tl, and $\mathrm{Au}$, which were done by atomic absorption method. L, detected but below lower limit of detemination: $\mathrm{N}$, not detected at lower limit of determination; $\mathrm{G}$, greater than upper limit of determination]

\begin{tabular}{|c|c|c|c|c|c|c|c|c|c|c|}
\hline \multirow[b]{2}{*}{ Elcment } & \multicolumn{2}{|c|}{ Range. } & \multicolumn{2}{|c|}{ Geometric } & \multicolumn{4}{|c|}{ Number of samples } & \multicolumn{2}{|c|}{ Cohen } \\
\hline & Minimum & Maximum & Merin & Deviation & Valid & L & $\mathrm{N}$ & $G$ & Mean & Deviation \\
\hline$\overline{\mathrm{Fe}} \%$ & 1.5 & 5.0 & 2.8 & 1.5 & 9 & 0 & 0 & 0 & 2.8 & 1.50 \\
\hline $\mathrm{Mg} \%$ & 0.1 & 1.0 & 0.3 & 2.2 & 9 & 0 & 0 & 0 & 0.3 & 2.2 \\
\hline $\mathrm{Ti} \%$ & 0.1 & 0.7 & 0.4 & 1.7 & 9 & 0 & 0 & 0 & 0.4 & 1.7 \\
\hline $\mathrm{Na} \%$ & 0.7 & 2 & 1.3 & 1.4 & 8 & 0 & I & 0 & 1.0 & 2.16 \\
\hline $\mathrm{Mn}$ & 30 & 200 & 92 & 2.1 & 9 & 0 & 0 & 0 & 91.6 & 2.11 \\
\hline $\mathrm{B}$ & 500 & 2,000 & 1,123 & 1.8 & 7 & 0 & 0 & 2 & 1,410 & 2.02 \\
\hline $\mathrm{Ba}$ & 150 & 1,500 & 553 & 2 & 9 & 0 & 0 & 0 & 553 & 2.03 \\
\hline $\mathrm{Co}$ & 10 & 20 & 12.6 & 1.5 & 3 & 3 & 3 & 0 & 7.5 & 1.70 \\
\hline $\mathrm{Cr}$ & 10 & 100 & 39.2 & 2.0 & 9 & 0 & 0 & 0 & 39.2 & 2.05 \\
\hline $\mathrm{Cu}$ & 7 & 50 & 28.9 & 1.8 & 9 & 0 & 0 & 0 & 28.9 & 1.85 \\
\hline $\mathrm{La}$ & 50 & 70 & 59.2 & 1.2 & 4 & 5 & 0 & 0 & 47.1 & 1.32 \\
\hline$\overline{\mathrm{Ni}}$ & 7 & 50 & 21 & 1.7 & 9 & 0 & 0 & 0 & 20.9 & 1.72 \\
\hline $\mathrm{Pb}$ & 10 & 20 & 15.6 & 1.4 & 8 & 1 & 0 & 0 & 14.6 & 1.42 \\
\hline Sc & 5 & 15 & 7.8 & 1.4 & 7 & 2 & 0 & 0 & 6.7 & 1.55 \\
\hline Sr & 200 & 700 & 389.1 & 1.6 & 8 & 0 & 1 & 0 & 324 & 1.98 \\
\hline V & 50 & 1,50 & 97.9 & 1.5 & 9 & 0 & 0 & 0 & 97.9 & 1.48 \\
\hline$Y$ & 10 & 20 & 16.2 & 1.3 & 6 & 3 & 0 & 0 & 12.5 & 1.56 \\
\hline $\mathrm{Zr}$ & 30 & 200 & 104.5 & 1.8 & 9 & 0 & 0 & 0 & 105 & 1.81 \\
\hline $\mathrm{Ga}$ & 15 & 50 & 23.9 & 1.5 & 8 & 1 & 0 & 0 & 19.6 & 1.97 \\
\hline $\mathrm{F}$ & 0.01 & 0.02 & 0.02 & 1.3 & 8 & 1 & 0 & 0 & 0.021 & 0.39 \\
\hline As & 21 & 95 & 49.4 & 1.7 & 9 & 0 & 0 & 0 & 49.4 & 1.73 \\
\hline Cd & 0.2 & 2.4 & 0.5 & 2.2 & 9 & 0 & 0 & 0 & 0.46 & 2.17 \\
\hline $\mathrm{Zn}$ & 6 & 31 & 15.6 & 1.8 & 9 & 0 & 0 & 0 & 15.6 & 1.82 \\
\hline $\mathrm{Hg}$ & 0.02 & 0.04 & 0.04 & 1.3 & 6 & 0 & 3 & 0 & 0.03 & 1.65 \\
\hline $\mathrm{Te}$ & 0.05 & 0.1 & 0.05 & 1.3 & 7 & 2 & 0 & 0 & 0.05 & 1.32 \\
\hline $\mathrm{TI}$ & 0.1 & 0.15 & 0.12 & 1.2 & 6 & 3 & 0 & 0 & 0.08 & 1.93 \\
\hline Au & 0.012 & 8.3 & 0.08 & 8.8 & 9 & 0 & 0 & 0 & 0.08 & 8.81 \\
\hline
\end{tabular}




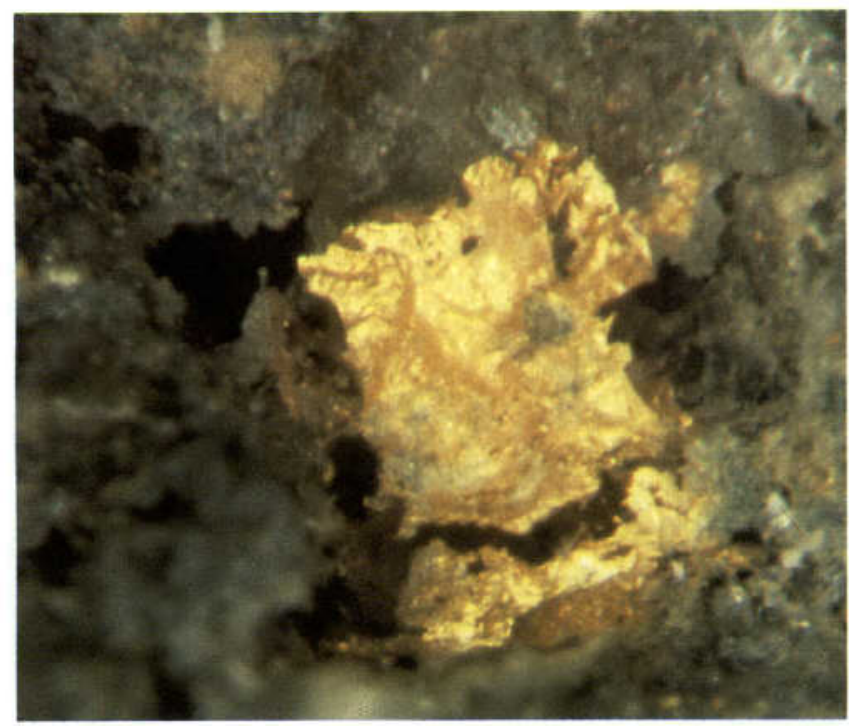

Figure 4. Photomicrograph of native gold from quartz-carbonate-tourmaline vein at Mina-A, Lo Increíble district, Estado Bolívar, Venezuela. Gold grain is about $0.5 \mathrm{~mm}$ square.

massive and small quartz veins (fig. 10). The apparently inconsistent values are probably due to the nugget effect, to variations in the weathering of the carbonate host rocks, or to small sample number bias. It is clear that the gold is related to the veins and that the schist has low gold values.

\section{TRENCH 2A}

Trench 2A trends north-south and is $120 \mathrm{~m}$ long and as deep as $15 \mathrm{~m}$ (figs. 11, 12). Exposed material in the trench is red, thinly bedded, micaceous, metavolcanic schistose rock containing abundant black layers and lenses. Schistosity strikes N. $75^{\circ}-80^{\circ}$ E. and dips $72^{\circ} \mathrm{N}$. Quartz-carbonate-tourmaline veins obliquely cut the host schist and generally strike N. $60^{\circ}-70^{\circ} \mathrm{W}$. and dip $65^{\circ}-70^{\circ} \mathrm{S}$. in the southern part of the trench. Northward along the trench these veins are more northcast trending, N. $45^{\circ}-55^{\circ}$ E., and also dip steeply to the south. Zones near the quartz-toumaline veins arc silicified, and the host rock in places is bleached.

Fifty-four samples of host schist, silicified host, and quartz-carbonate-tourmaline veins were taken, and the analytical data are shown in appendix table 4 . Basic statistics and Cohen-corected geometric means and deviations are given in tables 12-14, and corrclation coefficients are given in tables 15-17.

Comparison of Cohen-corrected geometric means for the quartz-carbonate-tourmaline veins and the host rocks shows an enrichment of cobalt, tellurium, and gold (fig. 13). All other clements are depleted or show tittle change.

\section{STATISTICAL ANALYSIS}

R-mode factor analysis on the entire data set for trench $2 \mathrm{~A}$ calculated the scores and loadings (table 18). An elemental suite of $\mathrm{Ga}, \mathrm{Na}, \mathrm{Ti}, \mathrm{Sc}, \mathrm{Zr}, \mathrm{Fe}, \mathrm{Sr}, \mathrm{Y}, \mathrm{V}, \mathrm{Tl}, \mathrm{Be}, \mathrm{Mn}, \mathrm{Ni}$, and $F$ (factor 1 ) probably reflects rock-forming minerals in the metavolcanic schistose host rocks. A second elemental suite consisting of cobalt, copper, (nickel), mercury, and selenium (factor 2) probably represents a mafic rock suite. A third element suite consisting of gold and zinc represents a mineralizing group (factor 3 ). The elements boron, magnesium, and (fluorine) (factor 4) probably represent the mineral tourmaline. Factors 5 and 6 do not casily fit into any group but arc probably part of the host rock group.

Table 19 lists eigenvalues for the six-factor varimax calculations. We chose the six-factor analysis because it resolved approximately 79 percent of the variance in the data. A seven-factor model, which created a single-element factor of selenium, only increased the amount of variance that could be resolved by 4 percent ( 1083 percent).

\section{VLF-EM SURVEY}

A very low frequency electromagnetic (VLF-EM) survey was performed along trench $2 \mathrm{~A}$ near Bochinche. The technique uses low-frequency $(18-24 \mathrm{kHz})$ radio signals

Table 7. Cohen geometric means for vein and host-rock samples, Mina San Pedro, Lo Increíble district, Venezuela.

[ln parts per million unless otherwise noted. Elenents too heavily qualified on either the upper or lower detection limit to calculate a Cohen geonetric mean arc not included]

\begin{tabular}{lcclrr}
\hline Element & Vein & Host & Element & Vein & Host \\
\hline Fe\% & 2.9 & 2.7 & $\mathrm{~Pb}$ & 12.4 & 17.3 \\
$\mathrm{~B}$ & 1.910 & $84 \mathrm{I}$ & $\mathrm{Sc}$ & $\mathrm{Y}$ & 7.3 \\
$\mathrm{Hg}$ & 0.02 & 0.03 & $\mathrm{Zr}$ & 10.8 & 14.9 \\
$\mathrm{Ti} \%$ & 0.38 & 0.45 & $\mathrm{Nat}$ & 86.1 & 133.0 \\
$\mathrm{Mn}$ & 87.3 & 97.4 & $\mathrm{Ga}$ & 0.7 & 1.6 \\
$\mathrm{Ba}$ & 367 & 926 & $\mathrm{As}$ & 14.5 & 27.8 \\
$\mathrm{Ni}$ & 18.0 & 25.1 & $\mathrm{Sr}$ & 41.1 & 62.1 \\
$\mathrm{Cr}$ & 37.6 & 41.4 & $\mathrm{Zn}$ & 231 & 479 \\
$\mathrm{Cu}$ & 22.9 & 38.7 & $\mathrm{Au}$ & 13.0 & 19.5 \\
$\mathrm{~V}$ & 94 & 103 & & 0.209 & 0.048 \\
\hline
\end{tabular}




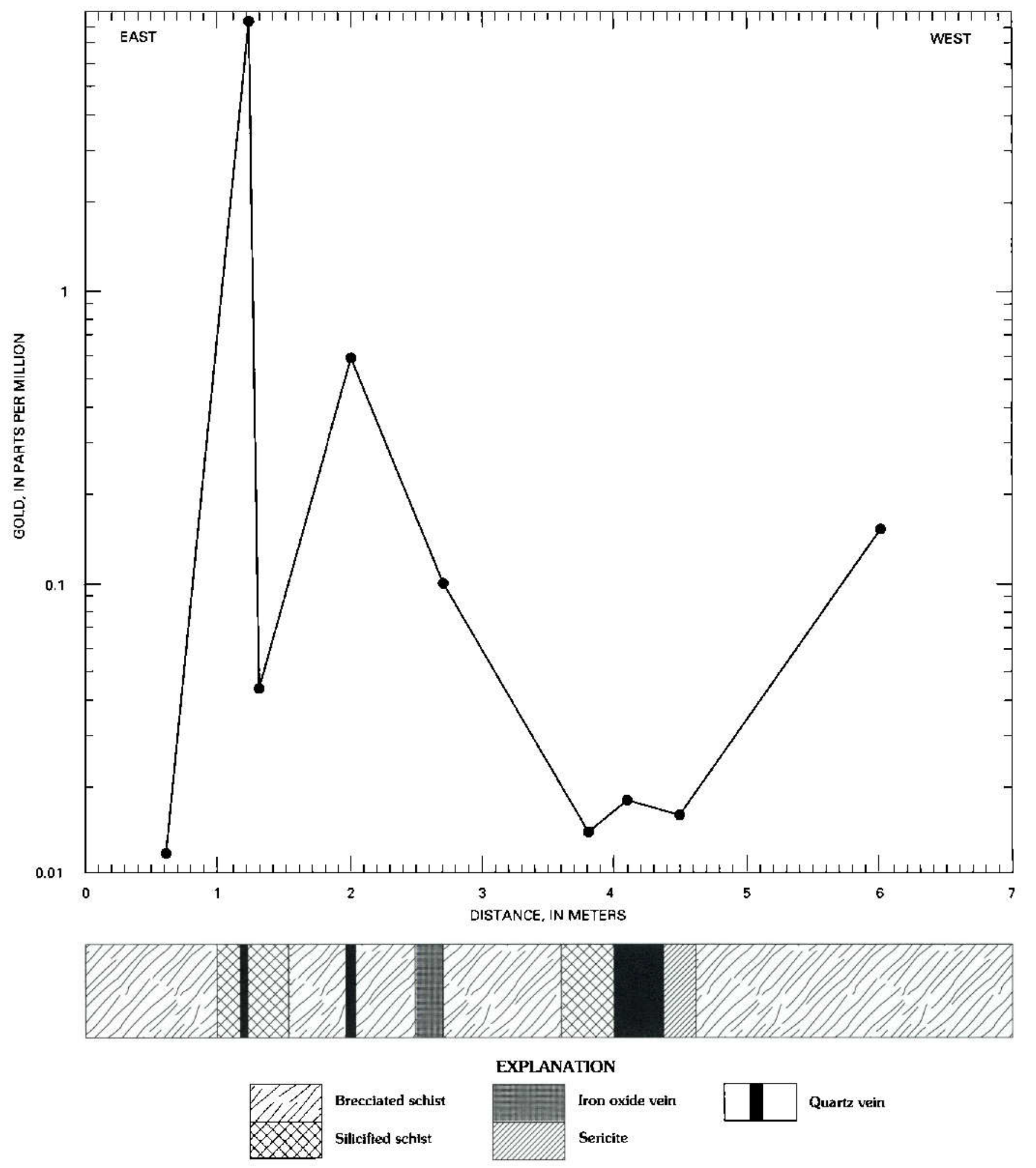

Figure 5. Plot of gold values for rock samples collected from a cross section in a trench in the open-pit mine at Mina San Pedro, Lo Increible district, Estado Bolívar, Venezuela. Generalized rock types for the sampled cross section are also shown. Data on which the plot is based are given in appendix table 2 . 


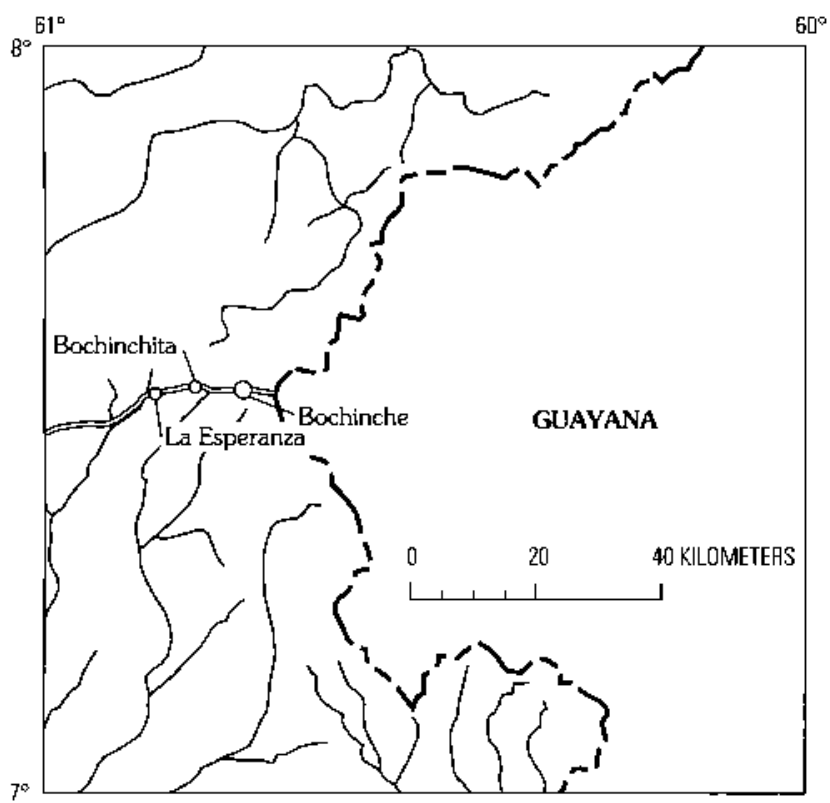

Figure 6. Map showing eastern Distrito Roscio, Estado Bolívar, Venezuela, and the northwest part of the Zona en Reclamación, Guayana. Trenches $\mathrm{T} 1$ and $2 \mathrm{~A}$ are just north of Bochinche, and the road cut is along the road between La Esperanza and Bochinchito.

Table 8. Univariate statistics for quartz-vein rock samples from trench T1, Bochinche, Venezuela, including all samples of vein, host, and silicified rocks.

[In parts per million unless otherwise noted. All analyses are by semiquantative spectrographic method except for $\mathrm{Cd}, \mathrm{Zn}, \mathrm{Te}, \mathrm{Tl}$, and $\mathrm{Au}$, which were done by atomic absorption method. L, detected but below lower limit of determination; N, not detected at lower limit of determination; $G$, greater than upper limit of determination]

\begin{tabular}{|c|c|c|c|c|c|c|c|c|c|c|}
\hline \multirow[b]{2}{*}{ Element } & \multicolumn{2}{|c|}{ Range } & \multicolumn{2}{|c|}{ Geometric } & \multicolumn{4}{|c|}{ Number of samples } & \multicolumn{2}{|c|}{ Cohen } \\
\hline & Minimum & Maximum & Mean & Deviation & Valid & $\mathbf{L}$ & $\mathrm{N}$ & $\mathrm{G}$ & Mean & Deviation \\
\hline $\mathrm{Fe} \%$ & 0.3 & 10 & 2.4 & 3.4 & 12 & 0 & 0 & 0 & 2.4 & 3.39 \\
\hline $\mathrm{Mg} \%$ & 0.02 & 0.5 & 0.1 & 2.2 & 12 & 0 & 0 & 0 & 0.1 & 2.2 \\
\hline $\mathrm{Ti} \%$ & 0.015 & 0.7 & 0.14 & 4.4 & 12 & 0 & 0 & 0 & 0.14 & 4.4 \\
\hline Mn & 50 & 2,000 & 764 & 2.9 & 11 & 0 & 0 & 1 & 937 & 3.40 \\
\hline B & 30 & 500 & 189 & 2.7 & 11 & 0 & 0 & 1 & 240 & 3.46 \\
\hline $\mathrm{Ba}$ & 50 & 1,500 & 366 & 2.8 & 12 & 0 & 0 & 0 & 366 & 2.76 \\
\hline $\mathrm{Be}$ & 1 & 1.5 & 1.1 & 1.2 & 5 & 1 & 6 & 0 & 1.1 & 1.20 \\
\hline Co & 10 & 300 & 55 & 2.5 & 10 & 0 & 2 & 0 & 38 & 3.45 \\
\hline $\mathrm{Cr}$ & 10 & 500 & 41 & 3.7 & 12 & 0 & 0 & 0 & 41 & 3.67 \\
\hline $\mathrm{Cu}$ & 5 & 100 & 29 & 2.6 & 12 & 0 & 0 & 0 & 29 & 2.61 \\
\hline $\mathrm{Ni}$ & 5 & 150 & 40 & 2.8 & 12 & 0 & 0 & 0 & 40 & 2.77 \\
\hline $\mathrm{Pb}$ & 10 & 20 & 14 & 1.4 & 6 & 6 & 0 & 0 & 9.5 & 1.60 \\
\hline Sc & 5 & 15 & 11 & 1.7 & 7 & 1 & 4 & 0 & 6.1 & 2.37 \\
\hline $\mathrm{Sr}$ & 100 & 200 & 144 & 1.4 & 3 & 2 & 7 & 0 & 64 & 1.91 \\
\hline V & 15 & 150 & 62 & 2,2 & 12 & 0 & 0 & 0 & 62 & 2.24 \\
\hline $\mathrm{Y}$ & 15 & 30 & 20 & 1.3 & 5 & 3 & 4 & 0 & 9 & 2.23 \\
\hline $\mathrm{Zr}$ & 10 & 200 & $\$ 6$ & 2.5 & 10 & 2 & 0 & 0 & 38 & 3.46 \\
\hline $\mathrm{Na} \%$ & 0.2 & 0.7 & 0.4 & 1.8 & 5 & 2 & 5 & 0 & 0.16 & 2.52 \\
\hline Ga & 5 & 50 & 17 & 2.1 & 6 & 2 & 4 & 0 & 5.3 & 4,03 \\
\hline $\mathrm{Cd}$ & 0.1 & 0.5 & 0.3 & 2.2 & 7 & 5 & 0 & 0 & 0.13 & 3.55 \\
\hline $\mathrm{Zn}$ & 3 & 100 & 24 & 2.8 & 11 & I & 0 & 0 & 19 & 3.63 \\
\hline Te & 0.05 & 0.65 & 0.2 & 2.6 & 7 & 5 & 0 & 0 & 0.08 & 5.34 \\
\hline $\mathrm{Tl}$ & 0.05 & 0.45 & 0.2 & 2.2 & 8 & 4 & 0 & 0 & 0.09 & 3.35 \\
\hline $\mathrm{Au}$ & 0.004 & 0.6 & 0.1 & 5.5 & 12 & 0 & 0 & 0 & 0.1 & 5.5 \\
\hline
\end{tabular}




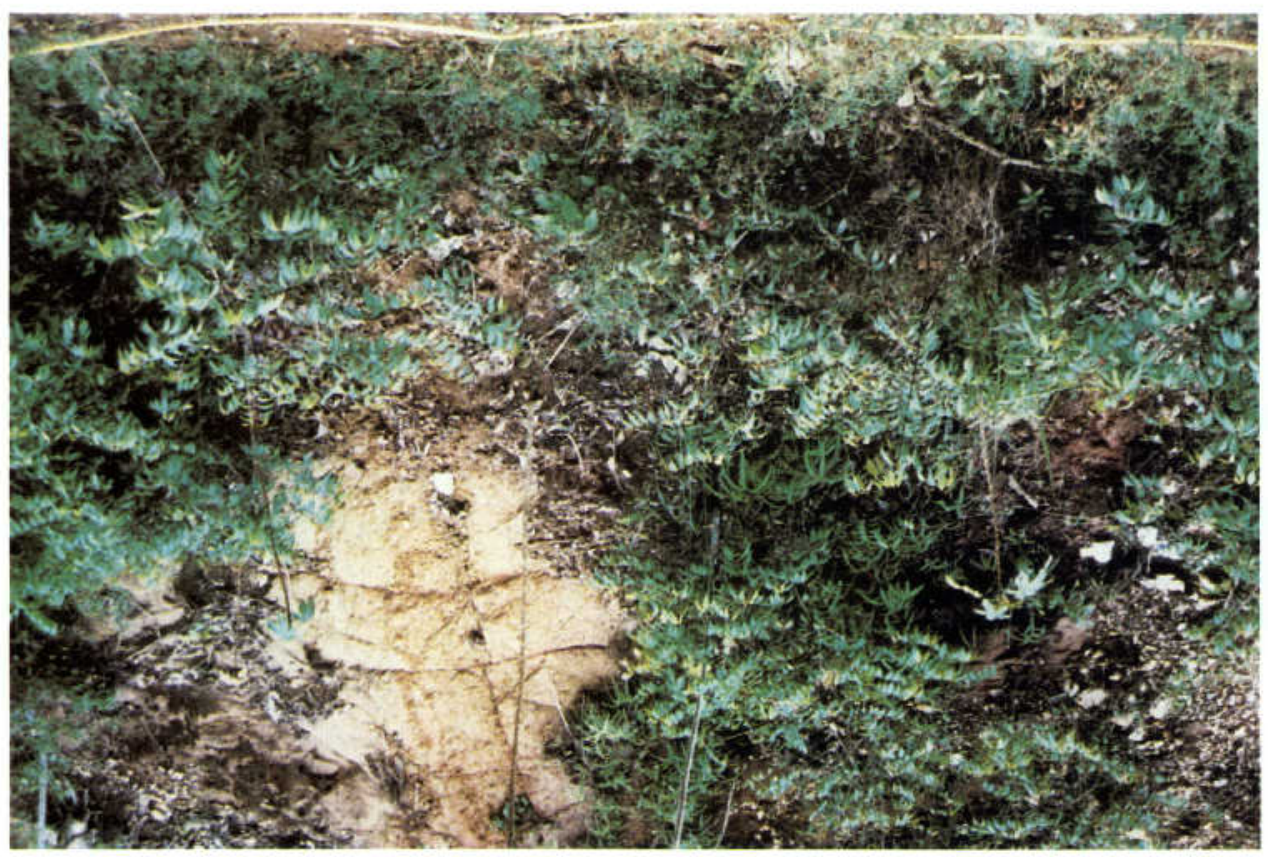

Figure 7. Along main road between Tumeremo and Bochinche, Fstado Bolívar, Venczucla. View looking east.

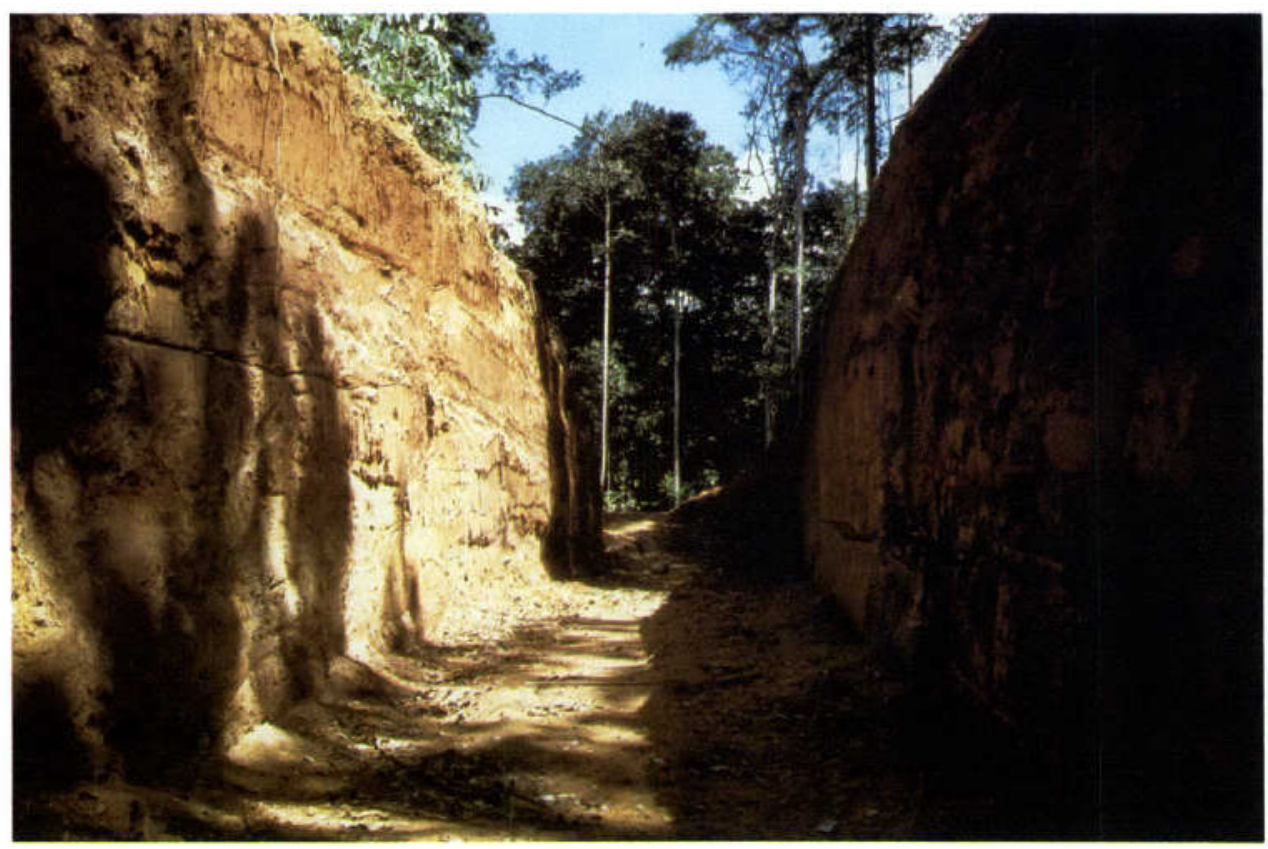

Figure 8. Trench T1, Bochinche area, Estado Bolívar, Venezuela. View looking north. 
Table 9. Correlation coefficients for quartz-vein rock samples, trench T1, Bochinche area, Venezuela. [Number of sample pairs used to calculate the correlation is shown in parentheses]

\begin{tabular}{|c|c|c|c|c|c|c|c|c|c|}
\hline & Ti & $\mathrm{Mn}$ & $\mathrm{Ni}$ & Co & $\mathrm{Cu}$ & $\mathrm{v}$ & $\mathrm{Zr}$ & $\mathrm{Zn}$ & $\mathrm{Au}$ \\
\hline $\mathrm{Ba}$ & $0.8705(12)$ & $0.8653(11)$ & $0.7822(12)$ & $0.8626(10)$ & $0.8150(12)$ & $0.8700(12)$ & & & \\
\hline $\mathrm{Fe}$ & & & $0.8016(12)$ & & $0.8911(12)$ & $0.7181(12)$ & $0.8394(11)$ & $0.9073(11)$ & \\
\hline $\mathrm{Ti}$ & & & & & & $0.9475(12)$ & & & \\
\hline $\mathrm{Ni}$ & & & & & & & & $0.9141(11)$ & $0.7854(12)$ \\
\hline $\mathrm{Cr}$ & & & & & & & $0.7837(11)$ & & \\
\hline $\mathrm{Cu}$ & & & & & & $0.8156(12)$ & $0.8887(10)$ & $0.8794(11)$ & \\
\hline $\mathrm{Zr}$ & & & & & & & & $0.9421(10)$ & \\
\hline$Z_{n}$ & & & & & & & & & $0.7521(10)$ \\
\hline
\end{tabular}

Table 10. Univariate statistics for host-rock samples from trench $\mathrm{T} 1$, Bochinche area, Venezuela.

[In parts per million unless otherwise noted. All analyses are by semiquantative spectrographic method except for $\mathrm{Cd}, \mathrm{Zn}, \mathrm{Te}, \mathrm{Tl}$, and $\mathrm{Au}$, which were done by atomic absorption method. L, detected but below lower limit of deternination; $\mathrm{N}$, not detected at lower limit of determination]

\begin{tabular}{|c|c|c|c|c|c|c|c|c|c|}
\hline \multirow[b]{2}{*}{ Element } & \multicolumn{2}{|c|}{ Range } & \multicolumn{2}{|c|}{ Geometric } & \multicolumn{3}{|c|}{ Number of samples } & \multicolumn{2}{|c|}{ Cohen } \\
\hline & Miлimum & Maximum & Mean & Deviation & Valid & $\mathbf{L}$ & $\mathrm{N}$ & Mean & Deviation \\
\hline $\bar{F}$ & 0.01 & 0.02 & 0.02 & 1.4 & 10 & 2 & 0 & 0.014 & 1.51 \\
\hline $\mathbf{B a}$ & 150 & 2,000 & 811 & 1.9 & 12 & 0 & 0 & 811 & 1.95 \\
\hline $\mathrm{Fe} \%$ & 3 & 15 & 6.8 & 1.5 & 12 & 0 & 0 & 6.77 & 1.47 \\
\hline $\mathrm{Mg} \%$ & 0.07 & 0.5 & 0.17 & 1.8 & 12 & 0 & 0 & 0.17 & 1.8 \\
\hline Ti\% & 0.3 & 1 & 0.61 & 1.4 & 12 & 0 & 0 & 0.61 & 1.4 \\
\hline $\mathrm{Mn}$ & 200 & 5,000 & 700 & 2.6 & 12 & 0 & 0 & 699 & 2.65 \\
\hline B & 20 & 1,500 & 302 & 5.4 & 11 & 0 & 1 & 211 & 7.44 \\
\hline $\mathrm{Ni}$ & 30 & 100 & 63 & 1.4 & 12 & 0 & 0 & 63.6 & 1.39 \\
\hline $\mathrm{Be}$ & 0.5 & 1.5 & 1.2 & 1.4 & 9 & 3 & 0 & 1.04 & 1.48 \\
\hline Co & 15 & 300 & 53 & 3.1 & 11 & 1 & 0 & 43.4 & 3.58 \\
\hline $\mathrm{Cr}$ & 50 & 500 & 153 & 2.0 & 12 & 0 & 0 & 153 & 1.95 \\
\hline $\mathrm{Cu}$ & 30 & 150 & 60 & 1.5 & 12 & 0 & 0 & 60.5 & 1.51 \\
\hline $\mathrm{V}$ & 70 & 200 & 138 & 1.4 & 12 & 0 & 0 & 138 & 1.35 \\
\hline $\mathrm{Pb}$ & 15 & 20 & 18 & 1.2 & 12 & 0 & 0 & 17.7 & 1.16 \\
\hline $\mathrm{Sc}$ & 7 & 20 & 15 & 1.4 & 12 & 0 & 0 & 14.8 & 1.41 \\
\hline Sr & 100 & 300 & 184 & 1.6 & 7 & 2 & 3 & 115 & 2.02 \\
\hline $\mathrm{Y}$ & 15 & 50 & 21 & 1.4 & 12 & 0 & 0 & 21.3 & 1.38 \\
\hline $\mathrm{Zr}_{r}$ & 70 & 200 & 133 & 1.4 & 12 & 0 & 0 & 133 & 1.37 \\
\hline $\mathrm{Na} \%$ & 0.3 & 2 & 0.9 & 1.8 & 11 & 0 & 1 & 0.800 & 2.16 \\
\hline $\mathrm{Ga}$ & 20 & 50 & 41 & 1.4 & 12 & 0 & 0 & 40.8 & 1.38 \\
\hline $\mathrm{Cd}$ & 0.1 & 1.4 & 0.4 & 2.2 & 11 & ] & 0 & 0.326 & 2.45 \\
\hline $\mathrm{Zn}$ & 18 & 72 & 37 & 1.7 & 12 & 0 & 0 & 37.4 & 1.68 \\
\hline $\mathrm{Te}$ & 0.05 & 1.5 & 0.3 & 4.4 & 10 & 2 & 0 & 0.164 & 5.49 \\
\hline $\mathrm{Tl}$ & 0.1 & 0.7 & 0.4 & 1.7 & 11 & 1 & 0 & 0.335 & 2.33 \\
\hline $\mathrm{Au}$ & 0.012 & $\mathrm{I}$ & 0.05 & 4.2 & 12 & 0 & 0 & 0.05 & 4.22 \\
\hline
\end{tabular}

Table 11. Correlation coefficients for host-rock samples from trench T1, Bochinche area, Venezuela.

[Note the lack of any significant correlation with gold]

\begin{tabular}{|c|c|c|c|c|c|c|c|c|}
\hline & $\mathrm{Mn}$ & $\mathrm{Co}$ & $\mathrm{V}$ & $\mathrm{Sc}$ & $Y$ & Cd & $\mathrm{Te}$ & $\mathrm{T1}$ \\
\hline $\mathrm{Ba}$ & $0.7047(12)$ & & & & & & & \\
\hline $\mathrm{Fe}$ & $0.8529(12)$ & & & & & $0.8824(11)$ & & \\
\hline $\mathrm{Mg}$ & & & & & $0.7508(12)$ & & & \\
\hline $\mathrm{Ti}$ & & & $0.9420(12)$ & & & & & \\
\hline B & & $0.7191(10)$ & & & & & & \\
\hline $\mathrm{Ni}$ & & & & & & & & $0.8964(11)$ \\
\hline $\mathrm{Co}$ & & & & & & & $0.8954(9)$ & \\
\hline V & & & & $0.744 I(I 2)$ & & & & \\
\hline
\end{tabular}




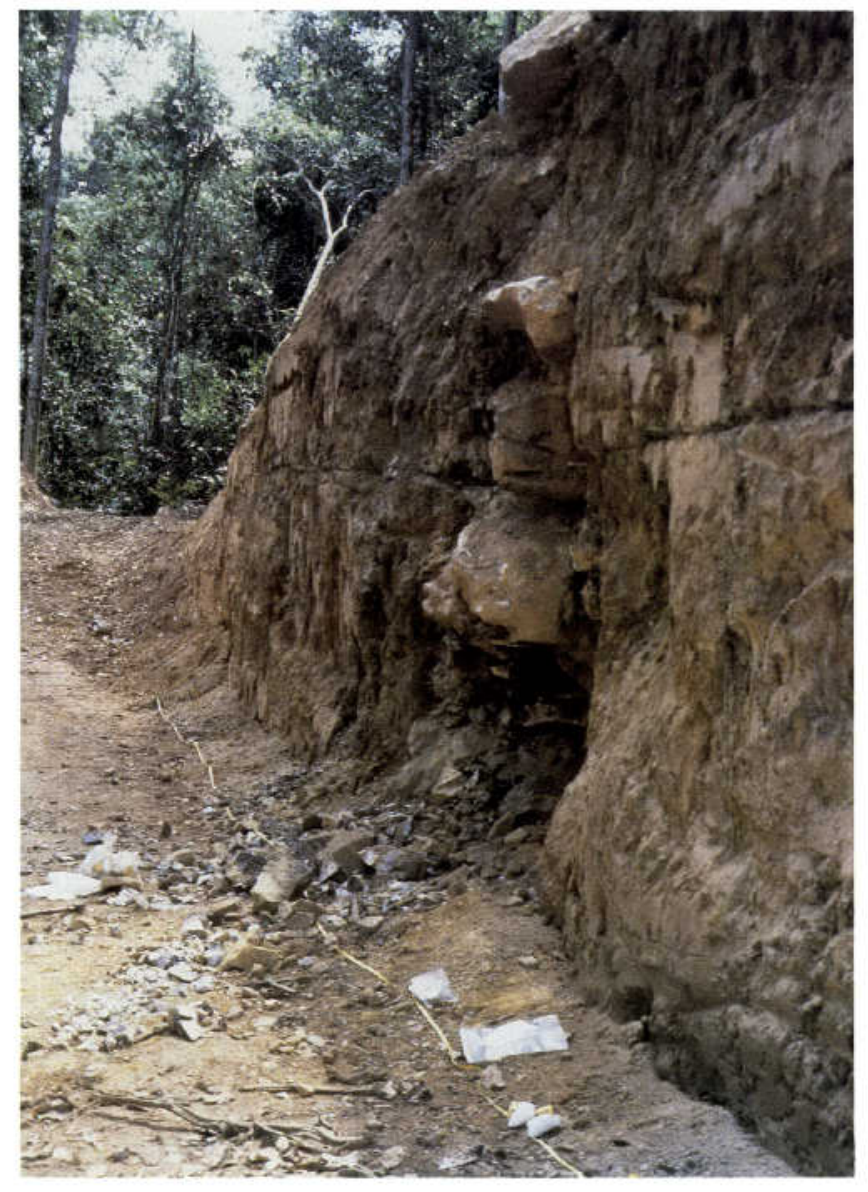

Figure 9. Main large quartz-carbonate-tourmaline vein in trench T1, Bochinche area, Estado Bolivar, Venezuela.

transmitted from several locations around the world. The instrument allows a calculation of resistivity and a direct reading of phase angle in the field. Figure 14 is a plot of distance versus resistivity and figure 15 a plot of distance versus phase angle. Both figures 14 and 15 also show the location of veins and the general rock types along the trench. The major quartz veins are shown in figure 14 as resistive highs. Background resistivity for the schist is about $500 \mathrm{ohm}-\mathrm{m}$. The low-sulfide quartz-carbonate-tourmaline gold-bearing veins have a resistivity of about $2,000-3,000 \mathrm{ohm}-\mathrm{m}$. It should be noted that only the larger veins or silicified zones can be identified using this technique. Many of the veins depicted in the lithology section below the plots are only 2-3 mm wide, not sufficiently wide to be resolved by this type of geophysical survey. The plots of resistivity and phase are slightly shifted in relation to the geology because the resistivity data were collected outside of the trench and the veins cut diagonally across the trench where the geochemical samples were collected and the geology was mapped.

The resistivity contrast of approximately five to one and the relatively high background resistivity values for lateritic clayey soil should lend themselves well to an airbome electromagnetic survey. A survey designed to use multiple frequencies such as $22,000,7,200$, and $900 \mathrm{~Hz}$ over areas suspected to contain large quartz-carbonate-tourmaline veins should easily map the extent and the trend of the veins and provide estimates of the depth to veins where the veins are covered by several meters of soil.

\section{BOCHINCHE ROAD CUT}

A large, vertical quartz-carbonate tourmaline vein that strikes N. $20^{\circ}$ E. and crops out in a road cut between Bochinchita and Esperanza was also sampled. The road cut is about $5 \mathrm{~km}$ southwest of Esperanza on the main road from Tumeremo to Bochinche (figs. 16,17). The vein is about $10 \mathrm{~m}$ wide and obliquely cuts host rocks of schist and fine-grained greenstone that have foliation striking N. $50^{\circ}$ E. and dipping $55^{\circ} \mathrm{S}$. Twelve rock samples of host schist and quartz-carbonate-tourmaline veins were collected, and the analytical data are given in appendix table 5. Cohen-corrected geometric means and deviations are given in table 20 , and correlations are given in table 21 .

The quartz-carbonate-tourmaline veins in the road cut are relatively barren, and only boron is elevated. The surrounding schist and greenstone host rocks contain little $\mathrm{B}$ but are enriched in $\mathrm{Cu}, \mathrm{Cr}, \mathrm{Fe}, \mathrm{Mg}, \mathrm{Ni}, \mathrm{Ti}, \mathrm{Zn}$, and $\mathrm{Cd}$ as compared to the veins (appendix table 5). Gold values for the veins are low, generally $0.002-0.030 \mathrm{ppm}$, generally lower than those of the host metavolcanic rocks. The lack of gold in this normally favorable environment of quartz-carbonate-toumaline veins perhaps can be explained by weathering or by the localized distribution of gold in this environment. Where gold was observed elsewhere in this type of vein, the gold distribution was irregular.

\section{MARWANI AREA}

The Marwani concession is a large rectangular arca that spans both sides of the Río Marwani in the extreme eastern part of Estado Bolivar. It extends northwest-southeast and is in inaccessible jungle $110 \mathrm{~km}$ east-southeast of Tumeremo and $60 \mathrm{kn}$ south-southeast of Bochinche (fig. 1). It borders the area in dispute between Venezuela and Guyana on the northeast and the Río Cuyuni on the south and southwest. Zone 4 of the concession is in the southwestern part of the concession and is the largest of the zones studied. The area is included on the 8036-1 NO and 8036-1 NE 1:25,000-scale topographic maps. Access to the Marwani concession is by helicopter to a number of heliports cut into the jungle: Further access to the area is by foot along handcut trails.

Zone 4 is an area of generally low relief and a northeast-trending chain of hills $180-200 \mathrm{~m}$ high. These hills form topographic linear features that are an expression of 

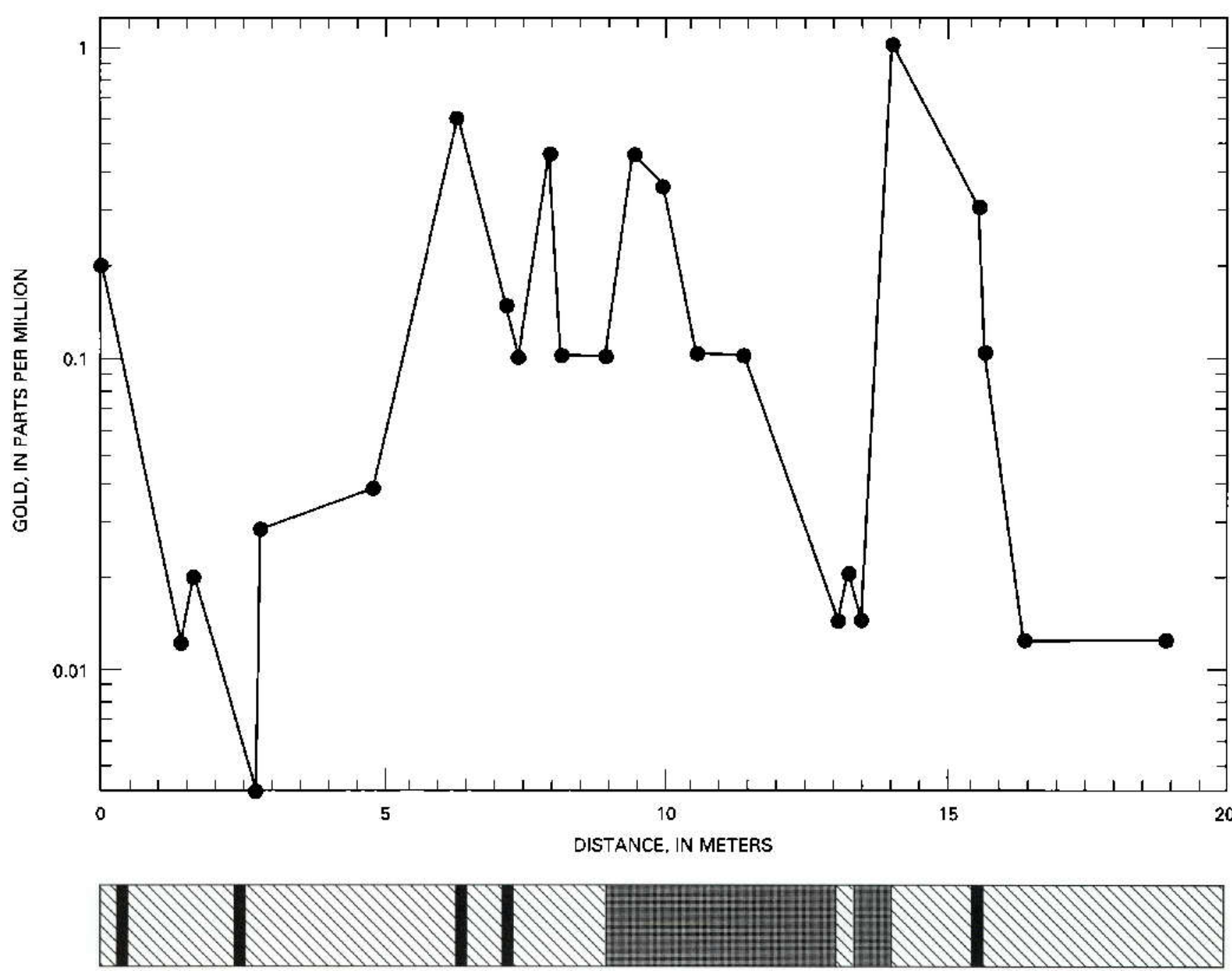

EXPLANATION
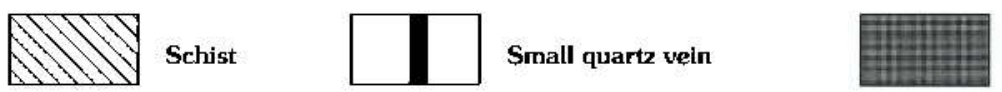

Massive quartz vein

Figure 10. Plot of gold values for rock samples collected across quartz veins exposed in trench T1, Bochinche area, Estado Bolívar, Venezuela. Data on which the plot is based are given in appendix table 3. Host rock and quartz veins are shown in a schematic cross section.

northeast-trending resistant formations, in many places quartz-carbonate-tourmaline veins.

Geologists from TECMIN spent more than a year working in zone 4, and the results of this work are discussed in Sanchez $(1986,1987)$ and Acosta (1987). Our decision to focus on zone 4 was made on the basis of this previous work, which indicated abundant gold in streams draining the area and the presence of quartz-carbonate-tourmaline veins (figs. $18,19)$. Maps of the area used for our study show topography, drainage, trails (picas and ejes), location of concentrate samples containing gold, and location of past mining activity and were generated from the previously cited works. An excellent interpretation of the aeromagnetic survey in the area of zone 4 was provided by Jeffrey Wynn (U.S. Geological Survey, oral commun., February 12, 1988). This interpretation delineates a north-northwest-trending pattern that corresponds to a topographic trend, indicates the possibility of several northwest-trending faults, and gave guidance to our fieldwork for locating the quartz-carbonate-tourmaline veins.

During the period February 14-25, 1988, fieldwork was conducted in zone 4. Personnel and equipment were transported by truck to Esperanza and from there by helicopter to heliport 10 (figs. 18, 20). The camp was $0.5 \mathrm{~km}$ northeast of the heliport. Operations were carried out from this camp for the first eight days of the ficld work. On the eighth day the 
Table 12. Univariate statistics for quartz-vein rock samples from trench $2 \mathrm{~A}$, Bochinche area, Venezuela. IIn parts per million unless otherwise noted. All analyses are by semiquantative spectrographic method except for $\mathrm{Cd}, \mathrm{Zn}, \mathrm{Hg}, \mathrm{Se}, \mathrm{Te}, \mathrm{TI}$, and Au, which were done by atomic absorption method. L, detected but below lower limit of detcrmination; N, not detected at lower limit of determination]

\begin{tabular}{|c|c|c|c|c|c|c|c|c|c|}
\hline \multirow[b]{2}{*}{ Element } & \multicolumn{2}{|c|}{ Range } & \multicolumn{2}{|c|}{ Geometric } & \multicolumn{3}{|c|}{ Number of samples } & \multicolumn{2}{|c|}{ Cohen } \\
\hline & Minimum & Maxinum & Mean & Deviation & Valid & L & $\mathrm{N}$ & Mean & Deviation \\
\hline $\bar{F}$ & 0.01 & 0.02 & 0.01 & 1.46 & 5 & 14 & 0 & 0.007 & 1.78 \\
\hline $\mathrm{Ba}$ & 30 & 1,500 & 249 & 3.71 & 19 & 0 & 0 & 249 & 3.71 \\
\hline $\mathrm{Fe} \%$ & 0.7 & 7 & 1.5 & 1.69 & 19 & 0 & 0 & 1.52 & 1.69 \\
\hline $\mathrm{Mg} \%$ & 0.02 & 0.7 & 0.16 & 2.72 & 19 & 0 & 0 & 0.16 & 2.72 \\
\hline Ti\% & 0.07 & 0.5 & 0.12 & 1.89 & 10 & 9 & 0 & 0.05 & 2.91 \\
\hline $\mathrm{Mn}$ & 0.03 & 1,000 & 0.27 & 3.06 & 12 & 0 & 0 & 67.5 & 3,310 \\
\hline B & 70 & 2,000 & 673 & 3.00 & 16 & 0 & 0 & 899 & 3.43 \\
\hline $\mathrm{Ni}$ & 5 & 500 & 14 & 3.35 & 18 & I & 0 & 12.9 & 3.48 \\
\hline $\mathrm{Be}$ & 1 & 1.5 & 1.1 & 1.22 & 4 & 13 & 2 & 0.78 & 1.32 \\
\hline Co & 10 & 2,000 & 71 & 4.61 & 15 & 4 & 0 & 37.2 & 6.69 \\
\hline $\mathrm{Cr}$ & 10 & 70 & 16.6 & 1.80 & 18 & 1 & 0 & 15.9 & 1.84 \\
\hline $\mathrm{Cu}$ & 10 & 700 & 42 & 2.83 & 19 & 0 & 0 & 42.0 & 2.83 \\
\hline V & 30 & 150 & 68 & 1.68 & 19 & 0 & 0 & 67.7 & 1.68 \\
\hline $\mathrm{Pb}$ & 10 & 1,000 & 75 & 4.67 & 18 & 1 & 0 & 64.7 & 5.13 \\
\hline $\mathrm{Sc}$ & 5 & 15 & 8.0 & 1.57 & 12 & 7 & 0 & 5.76 & 1.82 \\
\hline $\mathrm{Sr}$ & 100 & 200 & 168 & 1.41 & 4 & 1 & 14 & 50.5 & 2.37 \\
\hline $\mathrm{Y}$ & 10 & 30 & 16 & 1.58 & 4 & 8 & 7 & 4.87 & 2,42 \\
\hline $\mathrm{Zr}$ & 15 & 150 & 37 & 1.90 & 19 & 0 & 0 & 36.9 & 1.90 \\
\hline $\mathrm{Na} \%$ & 0.2 & 0.5 & 0.35 & I.65 & 5 & 6 & 8 & 0.109 & 2.57 \\
\hline Ga & 5 & 15 & 8.1 & 1.65 & 6 & 7 & 6 & 3.27 & 2.29 \\
\hline $\mathrm{Cd}$ & 0.1 & 4.6 & 0.43 & 4.30 & 13 & 6 & 0 & 0.181 & 6.28 \\
\hline$Z_{n}$ & 6 & 300 & 21 & 2.83 & 18 & I & 0 & 17.8 & 3.30 \\
\hline $\mathrm{Hg}$ & 0.02 & 170 & 0.19 & 44 & 8 & 0 & 11 & 0.004 & 125.00 \\
\hline $\mathrm{Sc}$ & 0.1 & 0.5 & 0.16 & 1.77 & 12 & 3 & 0 & 0.136 & 1.90 \\
\hline $\mathrm{Te}$ & 0.1 & 7.2 & 0.60 & 4.42 & 16 & 0 & 3 & 0.345 & 6.60 \\
\hline $\mathrm{Ti}$ & 0.05 & 0.25 & 0.10 & 1.79 & 10 & 4 & 5 & 0.05 & 2.50 \\
\hline Au & 0.002 & 1.0 & 0.02 & 5.84 & 19 & 0 & 0 & 0.02 & 5.82 \\
\hline
\end{tabular}

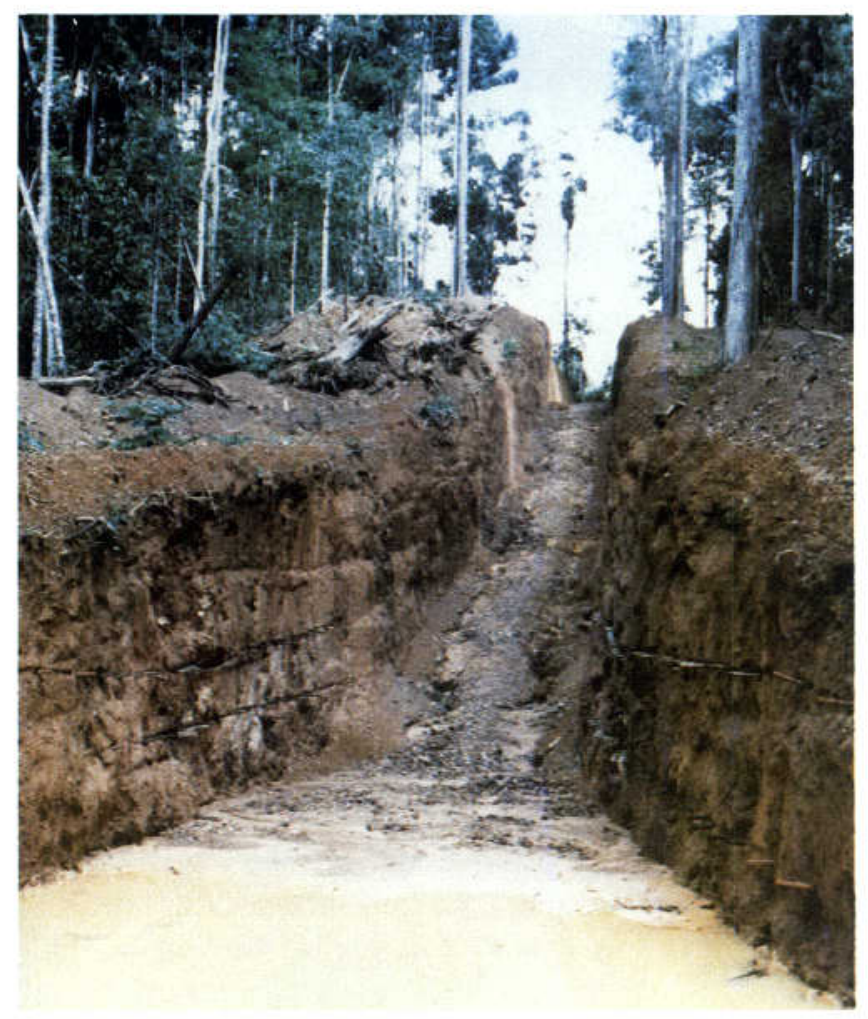

Figure 11. Trench 2A, Bochinche area, Estado Bolívar, Venezuela. View looking west. 
Table 13. Univariate statistics for host-rock samples from trench $2 \mathrm{~A}$, Bochinche, Venezuela.

¡In parts per million unless otherwise noted. All analyses are by semiquantative spectrographic method except for $\mathrm{Cd}, \mathrm{Zn}, \mathrm{Hg}, \mathrm{Se}, \mathrm{Te}, \mathrm{Tl}$, and Au, which were done by atomic absorption method. $\mathrm{L}$, detected but below lower limit of determination; N, not detected at lower limit of determination]

\begin{tabular}{|c|c|c|c|c|c|c|c|c|c|}
\hline \multirow[b]{2}{*}{ Element } & \multicolumn{2}{|c|}{ Range } & \multicolumn{2}{|c|}{ Geometric } & \multicolumn{3}{|c|}{ Number of samples } & \multicolumn{2}{|c|}{ Cohen } \\
\hline & Minimum & Maximum & Mean & Deviation & Valid & $L$ & $\mathrm{~N}$ & Mean & Deviation \\
\hline $\bar{F}$ & 0.01 & 0.02 & 0.01 & 1.42 & 3 & 3 & 0 & 0.01 & 1.46 \\
\hline $\mathrm{Ba}$ & 300 & 1,000 & 682 & 1.47 & 26 & 0 & 0 & 682 & 1.47 \\
\hline $\mathrm{Fe} \%$ & 2 & 10 & 5.2 & 1.38 & 26 & 0 & 0 & 5.22 & 1.38 \\
\hline $\mathrm{Mg} \%$ & 0.05 & 1.5 & 0.35 & 2.49 & 26 & 0 & 0 & 0.35 & 2.49 \\
\hline $\mathrm{Ti} \%$ & 0.15 & 1.0 & 0.52 & 1.44 & 26 & 0 & 0 & 0.52 & 1.44 \\
\hline Mn & 150 & 2,000 & 415 & 2.05 & 24 & 0 & 0 & 517 & 2.80 \\
\hline B & 20 & 2,000 & 421 & 4.21 & 17 & 0 & 0 & 1,150 & 6.71 \\
\hline $\mathrm{Ni}$ & 10 & 70 & 33 & 1.69 & 26 & 0 & 0 & 33.2 & 1.69 \\
\hline $\mathrm{Be}$ & 1.0 & 1.5 & 1.3 & 1.22 & 22 & 4 & 0 & 1.22 & 1.27 \\
\hline Co & 10 & 300 & 23 & 2,13 & 22 & 3 & 1 & 18.9 & 2.37 \\
\hline $\mathrm{Cr}$ & 10 & 200 & 105 & 1.86 & 26 & 0 & 0 & 105 & 1.86 \\
\hline $\mathrm{Cu}$ & 30 & 200 & 67 & 1.54 & 26 & 0 & 0 & 66.7 & 1.54 \\
\hline V & 70 & 200 & 126 & 1.34 & 26 & 0 & 0 & 126 & 1.34 \\
\hline $\mathrm{Pb}$ & 20 & 700 & 51 & 2.16 & 26 & 0 & 0 & 50.9 & 2.16 \\
\hline $\mathrm{Sc}$ & 7.0 & 20 & 17 & 1.34 & 26 & 0 & 0 & 17.2 & 1.34 \\
\hline Sr & 100 & 300 & 262 & 1.32 & 25 & 0 & 1 & 251 & 1.41 \\
\hline$Y$ & 15 & 50 & 24 & 1.41 & 25 & 1 & 0 & 23.5 & 1.48 \\
\hline $\mathrm{Zr}$ & 50 & 300 & 137 & 1.42 & 26 & 0 & 0 & 137 & 1.42 \\
\hline $\mathrm{Na} \%$ & 0.2 & 2.0 & 0.9 & 1.67 & 26 & 0 & 0 & 0.94 & 1.67 \\
\hline $\mathrm{Ga}$ & 5.0 & 50 & 39 & 1.62 & 26 & 0 & 0 & 39.1 & 1.62 \\
\hline $\mathrm{Cd}$ & 0.1 & 1.4 & 0.25 & 2,22 & 16 & 10 & 0 & 0.13 & 3.05 \\
\hline $\mathrm{Zn}$ & 3.0 & 150 & 46 & 2.13 & 25 & 1 & 0 & 40.2 & 2.69 \\
\hline $\mathrm{Hg}$ & 0.02 & 43 & 0.97 & 60 & 4 & 0 & 2 & 2.97 & 60.3 \\
\hline $\mathrm{Se}$ & 0.1 & 0.8 & 0.23 & 1.93 & 23 & 2 & 0 & 0.21 & 2.04 \\
\hline $\mathrm{Te}$ & 0.005 & 7.2 & 0.17 & 4.89 & 8 & 1 & 17 & 0.01 & 10.9 \\
\hline $\mathrm{Tl}$ & 0.1 & 0.35 & 0.18 & 1.46 & 26 & 0 & 0 & 0.17 & 4.89 \\
\hline $\mathrm{Au}$ & 0.002 & 0.05 & 0.005 & 2.48 & 24 & 2 & 0 & 0.005 & 2.64 \\
\hline
\end{tabular}

Table 14. Univariate statistics for silicified host-rock samples from trench $2 \mathrm{~A}$, Bochinche area, Venezuela. [In parts per million unless otherwise noted. All analyses are by semiquantative spectrographic method except for $\mathrm{Cd}, \mathrm{Zn}, \mathrm{Hg}, \mathrm{Se}, \mathrm{Te}, \mathrm{Tl}$ and Au, which were done by atomic absorption nethod. $\mathrm{L}$, detected but below lower limit of delermination; N, not detected at lower limit of determination]

\begin{tabular}{|c|c|c|c|c|c|c|c|c|c|}
\hline \multirow[b]{2}{*}{ Element } & \multicolumn{2}{|c|}{ Range } & \multicolumn{2}{|c|}{ Geometric } & \multicolumn{3}{|c|}{ Number of samples } & \multicolumn{2}{|c|}{ Cohen } \\
\hline & Minimum & Maximum & Mean & Deviation & Valid & $\mathrm{L}$. & $\mathrm{N}$ & Mean & Deviation \\
\hline$F$ & 0.01 & 0.03 & 0.001 & 0.008 & 8 & 2 & 0 & 0.01 & 1.76 \\
\hline Ba & 100 & 1,000 & 511 & 358 & 9 & 0 & 0 & 517 & 3.51 \\
\hline $\mathrm{Fe} \%$ & 1.5 & 7 & 3.9 & 1.7 & 10 & 0 & 0 & 3.59 & 1.62 \\
\hline $\mathrm{Mg} \%$ & 0.1 & 2 & 1.0 & 0.72 & 10 & 0 & 0 & 0.671 & 2.78 \\
\hline $\mathrm{Ti} \%$ & 0.07 & 0.7 & 0.4 & 0.23 & 8 & 2 & 0 & 0.169 & 3.45 \\
\hline $\mathrm{Mn}$ & 0.07 & 5,000 & 978 & 1789 & 9 & 0 & 0 & 61.9 & 98.4 \\
\hline B & 700 & 2,000 & 1.425 & 675 & 4 & 0 & 0 & 2,560 & 2.13 \\
\hline $\mathrm{Ni}$ & 7 & 150 & 52 & 43 & 10 & 0 & 0 & 38.5 & 2.34 \\
\hline $\mathrm{Be}$ & 1 & 1.5 & 1.4 & 0.24 & 10 & 0 & 0 & 1.33 & 1.22 \\
\hline $\mathrm{Co}$ & 10 & 2,000 & 394 & 650 & 9 & 1 & 0 & 79.5 & 7.32 \\
\hline $\mathrm{Cr}$ & 15 & 150 & 74 & 44 & 10 & 0 & 0 & 58.5 & 2.19 \\
\hline $\mathrm{Cu}$ & 30 & 700 & 160 & 205 & 10 & 0 & 0 & 98.1 & 2.59 \\
\hline V & 100 & 200 & 140 & 32 & 10 & 0 & 0 & 137 & 1.26 \\
\hline $\mathrm{Pb}$ & 20 & 700 & 129 & 218 & 10 & 0 & 0 & 56.9 & 3.21 \\
\hline Sc & 5 & 20 & 13 & 5.4 & 10 & 0 & 0 & 11.7 & 1.62 \\
\hline $\mathrm{Sr}$ & 200 & 500 & 311 & 78 & 9 & 1 & 0 & 268 & 1.55 \\
\hline$Y$ & 15 & 70 & 27 & 18 & 10 & 0 & 0 & 23.5 & 1.66 \\
\hline $\mathrm{Zr}$ & 50 & 300 & 157 & 69 & 10 & 0 & 0 & 141 & 1.68 \\
\hline $\mathrm{Na} \%$ & 0.2 & 1 & 0.7 & 0.25 & 9 & 1 & 0 & 0.590 & 1.93 \\
\hline $\mathrm{Ga}$ & 20 & 50 & 30 & 13 & 8 & 1 & 1 & 18.1 & 2.59 \\
\hline $\mathrm{Cd}$ & 0.1 & 6.8 & 1.6 & 2.37 & 7 & 3 & 0 & 0.242 & 7.65 \\
\hline $\mathrm{Zn}$ & 3 & 430 & 82 & 143 & 8 & 2 & 0 & 12.8 & 8.99 \\
\hline $\mathrm{Hg}$ & 0.02 & 130 & 36 & 49 & 6 & 0 & 4 & 0.08 & 336. \\
\hline Se & 0.1 & 0.5 & 0.26 & 0.17 & 7 & 0 & 0 & & \\
\hline $\mathrm{Te}$ & 0.1 & 0.75 & 0.32 & 0.3 & 4 & 0 & 6 & 0.03 & 7.30 \\
\hline $\mathrm{Tl}$ & 0.05 & 0.25 & 0.16 & 0.09 & 6 & 2 & 2 & 0.06 & 3.05 \\
\hline $\mathrm{Au}$ & 0.002 & 2.6 & 0.27 & 0.8 & 10 & 0 & 0 & 0.009 & 9.03 \\
\hline
\end{tabular}


Table 15. Correlation coefficients for quartz-vein rock samples from trench 2A, Bochinche area, Venezuela. [Matrix shows significant correlarions at or greater than the 95 percent confidence level. Number of sample pairs used to calculate the correlation is shown in parentheses]

\begin{tabular}{|c|c|c|c|c|c|c|c|c|}
\hline & $\mathrm{Fe}$ & $\mathrm{Ti}$ & B & $\mathrm{Ni}$ & $\mathrm{Co}$ & $\mathrm{Cr}$ & $\mathrm{Cu}$ & $\mathrm{V}$ \\
\hline \multicolumn{9}{|c|}{ F $\quad 0.7186(19)$} \\
\hline $\mathrm{Ba}$ & & & & & & & & $0.6588(19)$ \\
\hline $\mathrm{Fe}$ & & $0.8954(10)$ & & & & & & \\
\hline $\mathrm{Mg}$ & & & $0.7134(16)$ & $0.5621(18)$ & & $0.6366(19)$ & $0.6309(19)$ & $0.8757(19)$ \\
\hline $\mathbf{T i}_{\mathbf{i}}$ & & & & & & $0.8297(10)$ & & \\
\hline B & & & & & & & & $0.5309(16)$ \\
\hline $\mathrm{Ni}$ & & & & & $0.9743(15)$ & $0.9989(18)$ & & $0.7338(17)$ \\
\hline Co & & & & & & $0.9766(15)$ & & $0.6843(15)$ \\
\hline $\mathrm{Cr}$ & & & & & & & & $0.6286(18)$ \\
\hline $\mathrm{Cu}$ & & & & & & & & $0.5280(19)$ \\
\hline \multicolumn{9}{|l|}{ V } \\
\hline \multicolumn{9}{|l|}{$\mathrm{Pb}$} \\
\hline \multicolumn{9}{|l|}{$\mathrm{Se}$} \\
\hline \multicolumn{9}{|l|}{$\mathrm{Sr}$} \\
\hline \multicolumn{9}{|l|}{$\underline{Z}$} \\
\hline & $\mathrm{Pb}$ & $\mathrm{Sc}$ & $\mathrm{Zr}$ & $\mathrm{Cd}$ & $\mathrm{Zn}$ & $\mathrm{Hg}$ & $\mathrm{Se}$ & $\mathrm{Au}$ \\
\hline \multicolumn{9}{|l|}{$F$} \\
\hline $\mathrm{Ba}$ & $0.5855(18)$ & & & & & $0.7626(8)$ & & \\
\hline $\mathrm{Fe}$ & & $0.6822(12)$ & & & & & $0.8828(12)$ & $0.5156(19)$ \\
\hline $\mathbf{M g}$ & $0.7080(18)$ & & $0.6809(19)$ & & & $0.9750(8)$ & & \\
\hline $\mathrm{Ti}$ & & $0.7523(9)$ & $0.7578(10)$ & $0.8129(8)$ & $0.8864(9)$ & & & \\
\hline \multicolumn{9}{|c|}{ 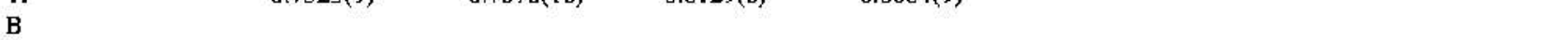 } \\
\hline $\mathrm{Ni}$ & & & & & & $0.9584(8)$ & & \\
\hline \multicolumn{9}{|l|}{ Co } \\
\hline $\mathrm{Cr}$ & & $0.7191(11)$ & $0.8974(18)$ & $0.7583(12)$ & $0.7997(17)$ & $0.7882(8)$ & & \\
\hline $\mathrm{Cu}$ & $0.7909(18)$ & & & & & $0.9598(8)$ & & \\
\hline $\mathrm{v}$ & $0.7065(18)$ & & $0.6723(19)$ & & & $0.9194(8)$ & & \\
\hline $\mathrm{Pb}$ & & & & & & $0.9163(7)$ & & \\
\hline $\mathrm{Sc}$ & & & $0.5646(18)$ & & & & & \\
\hline $\mathrm{Sr}$ & & & $0.6971(12)$ & & & & & \\
\hline $\mathrm{Zr}$ & & & & $0.7384(13)$ & $0.6767(18)$ & $0.7941(8)$ & & \\
\hline
\end{tabular}

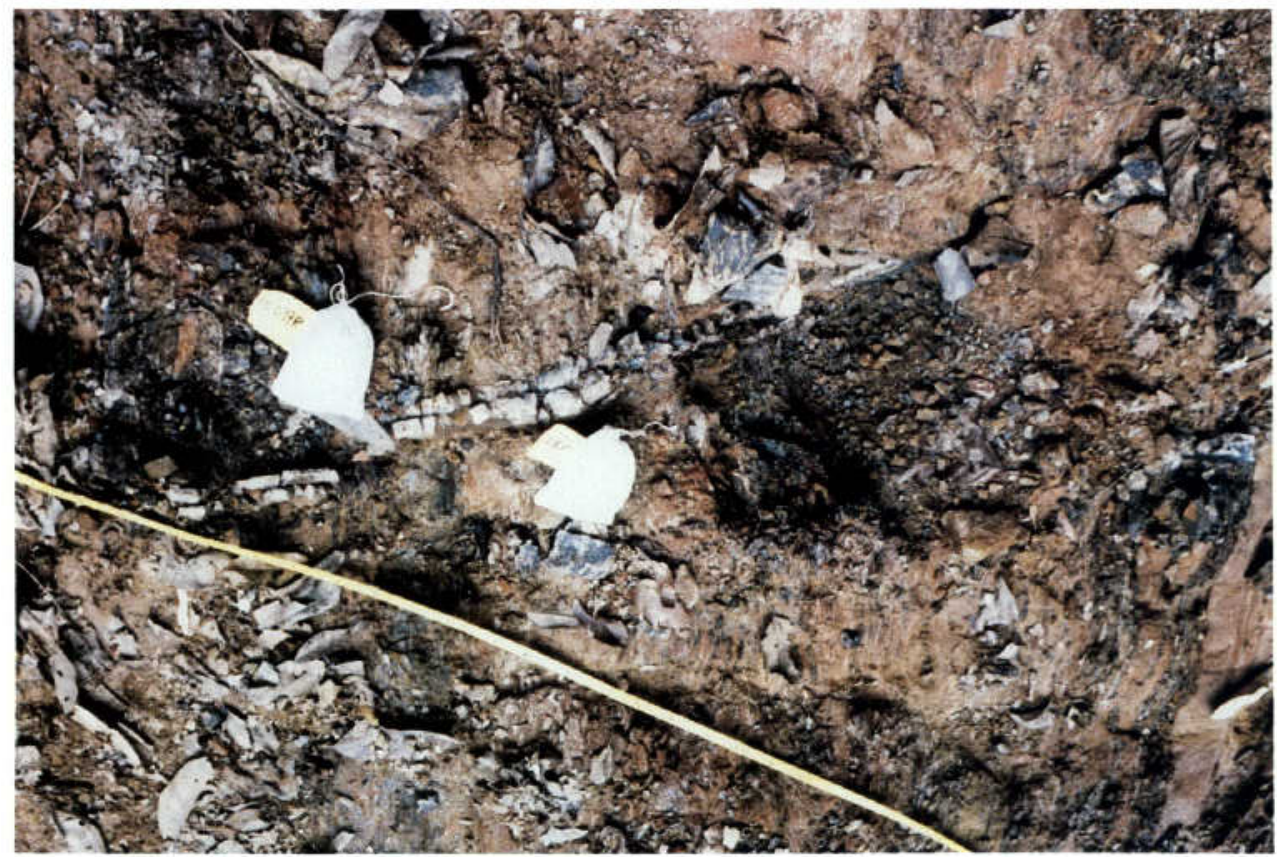

Figure 12. Small $(2-3 \mathrm{~cm})$ quartz-carbonate-tourmaline vein in floor of trench $2 \mathrm{~A}$, Bochinche area, Estado Bolívar, Venezuela. 
Table 16. Correlation coefficients for silicified host-rock samples from trench $2 \mathrm{~A}$, Bochinche area, Venezuela. [Matrix shows significant correlations at or greater than the 95 percent confidence level. Number of sample pairs used to calculate the correlation are shown in parentheses]

\begin{tabular}{|c|c|c|c|c|c|c|c|}
\hline & $\mathrm{Mg}$ & Co & $\mathrm{Cr}_{\mathrm{r}}$ & $\mathrm{Pb}$ & Sc & $\mathrm{Sr}$ & $\mathrm{Zr}$ \\
\hline $\mathrm{Fe}$ & $0.8768(10)$ & & $0.7390(10)$ & & $0.7640(10)$ & & $0.9030(10)$ \\
\hline $\mathrm{Mg}$ & & & $0.7676(10)$ & & $0.8419(10)$ & & $0.8259(10)$ \\
\hline $\mathrm{Mn}$ & & $0.7668(8)$ & & & & $0.8063(9)$ & \\
\hline \multirow{2}{*}{\multicolumn{8}{|c|}{$-0.8308(9)$}} \\
\hline & & & & & & & \\
\hline $\mathrm{Co}$ & & & & $0.9147(9)$ & & & \\
\hline $\mathrm{Cr}$ & & & & & $0.9109(10)$ & & \\
\hline $\mathrm{Cu}$ & & & & & & & \\
\hline $\mathrm{Ni}$ & & & & & & $0.7744(9)$ & \\
\hline \multicolumn{8}{|l|}{$\mathrm{Pb}$} \\
\hline \multicolumn{8}{|l|}{$\mathrm{Sr}$} \\
\hline \multicolumn{8}{|l|}{$\mathrm{v}$} \\
\hline \multicolumn{8}{|l|}{ Y } \\
\hline \multicolumn{8}{|l|}{$\mathrm{Zr}$} \\
\hline \multicolumn{8}{|l|}{$\mathrm{Na}$} \\
\hline \multirow{2}{*}{\multicolumn{8}{|c|}{$\mathrm{Zn}$}} \\
\hline$\underline{\mathrm{Te}}$ & & & & & & & \\
\hline & $\mathrm{Na}$ & $\mathrm{Ga}$ & $\mathrm{Cd}$ & $\mathrm{Zn}$ & $\mathrm{Hg}$ & $\mathrm{Tl}$ & $\mathrm{Au}$ \\
\hline \multirow{2}{*}{\multicolumn{8}{|c|}{$\overline{\mathrm{Fe}}$}} \\
\hline \multirow{2}{*}{\multicolumn{8}{|c|}{$\begin{array}{l}\mathrm{Mg} \\
\mathrm{Mn}\end{array}$}} \\
\hline & & & & & & & \\
\hline \multicolumn{8}{|l|}{$\mathrm{Ba}$} \\
\hline $\mathrm{Be}$ & & & & & & $0.9147(6)$ & \\
\hline \multirow{2}{*}{\multicolumn{8}{|c|}{$0.8559(6)$}} \\
\hline & & & & & & & \\
\hline $\mathrm{Cu}$ & & & $0.9756(6)$ & & & & \\
\hline \multicolumn{8}{|l|}{$\mathrm{Ni}$} \\
\hline $\mathrm{Pb}$ & & & & $0.8758(8)$ & & & $0.9213(10)$ \\
\hline $\mathrm{ST}_{\mathrm{T}}$ & & & $-.9803(6)$ & & & & \\
\hline $\mathrm{v}$ & $0.7011(9)$ & & & & & & \\
\hline Y & & & & & $0.8990(6)$ & & \\
\hline $\mathrm{Zr}$ & $0.7446(9)$ & & & & & & \\
\hline Na & & $0.8433(8)$ & & & & & \\
\hline $\mathrm{Zn}_{\mathrm{n}}$ & & & & & & & $0.9844(8)$ \\
\hline $\mathrm{Te}$ & & & & & & & $0.9230(7)$ \\
\hline
\end{tabular}

camp was moved to near heliport $11,3 \mathrm{~km}$ to the west, and the remainder of the fieldwork was done from this camp.

The central part of zone 4 was chosen for study on the basis of previous work consisting of geology, analysis of panned concentrates and soils, and examination of rocks from the area, all of which indicate the presence of quartz,-carbonate-tourmaline veins. Rock exposure, although not abundant, was sufficient, especially in the small streams, to provide an indication of rock types present in the area. The exposures of the quartz-carbonate-tourmaline veins were excellent because they are more resistant to weathering than the surrounding schistose host rocks.

The purpose of our study was to establish the presence of the quartz-carbonate-tourmaline veins, sample the veins and surrounding host rocks for chemical analysis, and prepare a geologic map of the central area showing structures and the location and extent of the quartz-carbonate-tourmaline veins. This study also helped to determine exploration techniques and methodology for gold-bearing quartz-carbonate-tourmaline veins in deeply weathered, highly vegetated tropical terranes.

\section{GEOLOGY}

Zone 4 is on the southwest side of a large northwest-trending structural zone that separates rocks of the Pastora Supergroup on the northeast from younger rocks of the Botanamo Group to the southwest (see Sidder and Mendoza, this volume). The rocks in zone 4 consist of metavolcanic and metasedimentary rocks intercalcalated with metalavas of intermediate composition. These rocks have been intruded by a large diabase-gabbro sill and many small diabase dikes (Acosta, 1987). In the central part of zone 4 is a layered schist-phyllite unit metamorphosed to upper greenschist facies. Quartz-carbonate-tourmaline veins cut the foliation of the host rocks at an oblique angle and are offset by at least one northwest-trending fault. Much of the geology is 
Table 17. Correlation coefficients for host-rock samples from trench 2A, Bochinche area, Venezuela.

[Matrix shows significant correlations at or greater than the 95 percent confidence level. Number of sample pairs used to calculate the correlation are shown in parentheses]

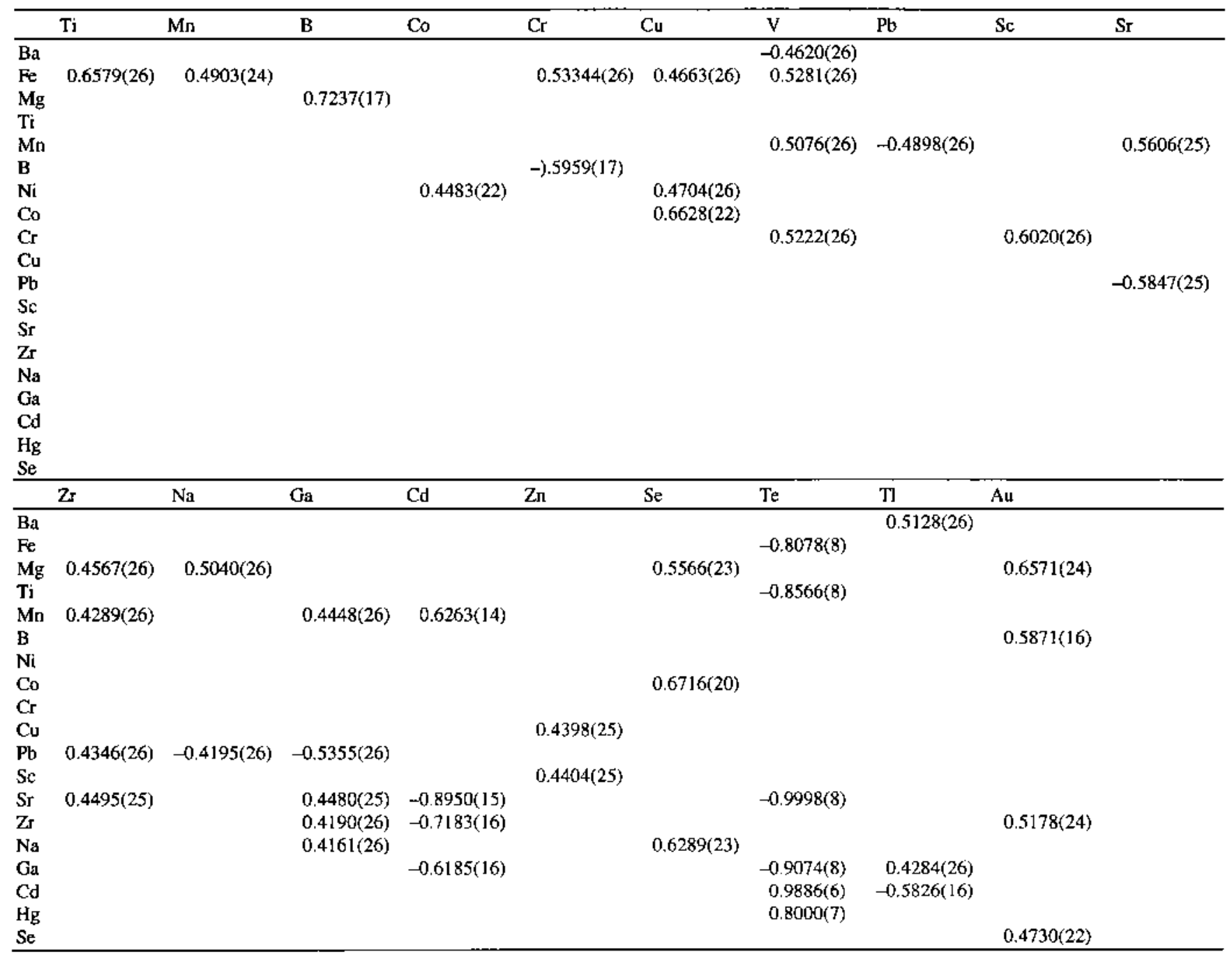

obscured by alluvial fill in the areas of low relief and by siliceous iron oxide material ("kanga") that forms over many of the higher hills. In this study we concentrated on the location and extent of the quartz-carbonate-tourmaline veins because these had the highest potential for gold mineralization.

There are numerous signs of past placer activity in the area, but by all indications the placer activity is more than 20 years old. In some places holes as much as $15 \mathrm{~m}$ in diameter and $2 \mathrm{~m}$ in depth go to bedrock; that is, to the interface between the zone of weathering and laterized host rock. Host rock for the quartz-tourmaline veins is a deeply weathered quartz-mica schist-phyllite of volcanic or volcaniclastic protolith that contains zones of oxidized pyrite and pods and stringers of massive white quartz, commonly with sericite on fracture surfaces. This quartz was barren where sampled and showed no visible sign of tourmaline nor any indication of gold. This quartz is interpreted to be part of the schist-phyllite, perhaps a metamorphic segregation, and not related to the younger, mineralized quartz-tourmaline veins.

Detailed mapping of the quartz-tourmaline veins established a strike length of more than $2 \mathrm{~km}$ and widths of as much as $10 \mathrm{~m}$ (fig. 18). The veins appear to be dipping steeply to the south. Field observations indicate that these veins are zoned, in some places for as much as $30 \mathrm{~m}$. This zonation consists of an outer zone of sugary textured quartzite and abundant small $(<1 \mathrm{~mm})$ magnetite crystals and common pyrite. Adjacent to the quartz-carbonate-tourmaline veins 

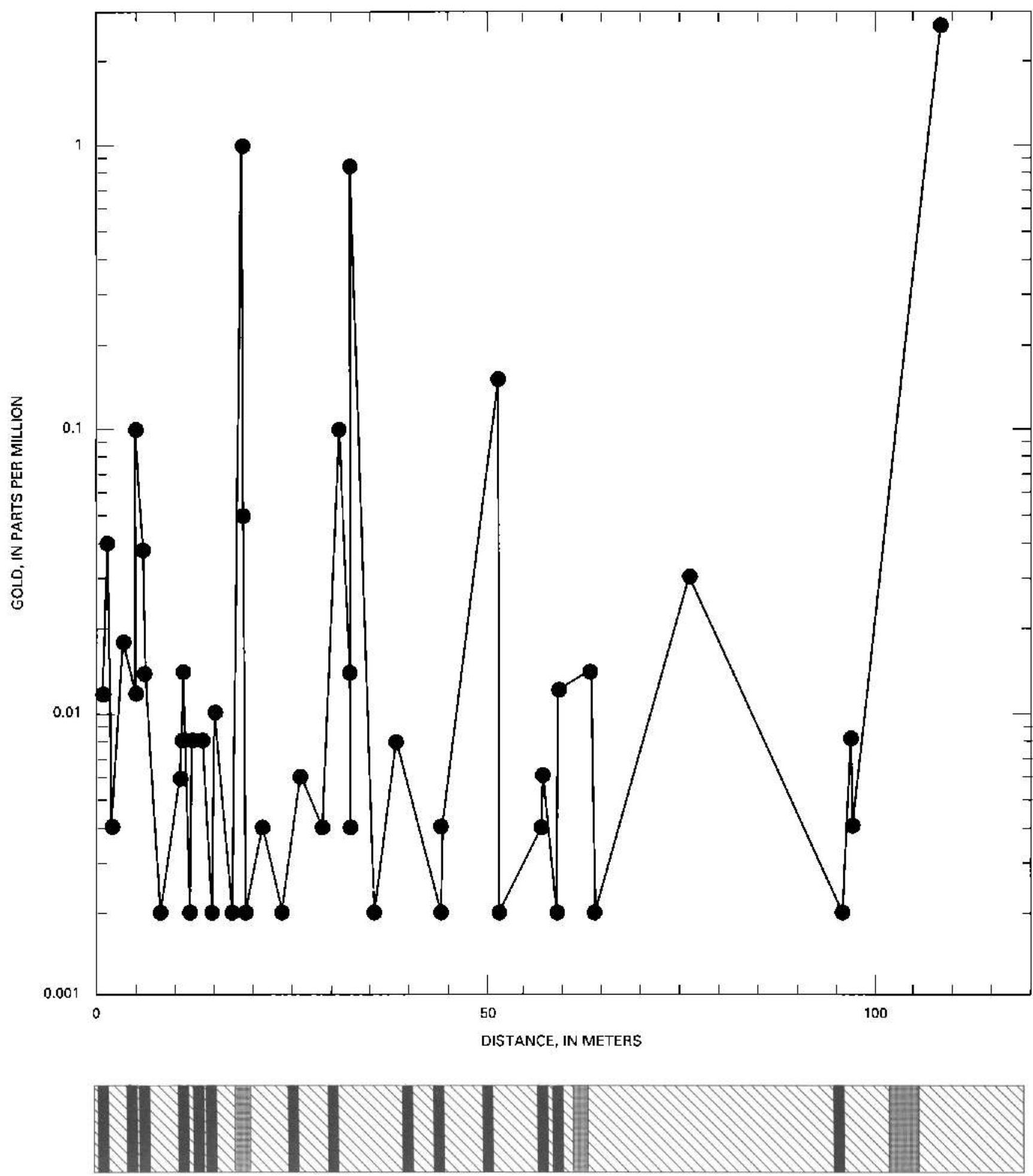

EXPLANATION

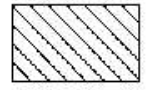

Silicified hast rock
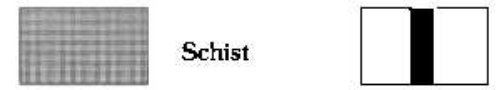

Quartz vein

Figure 13. Plot of gold values for sample collected across the vein system at trench $2 \mathrm{~A}$, Bochinche area, Estado Bolívar, Venezuela. Generalized geologic section is shown below the plot. 

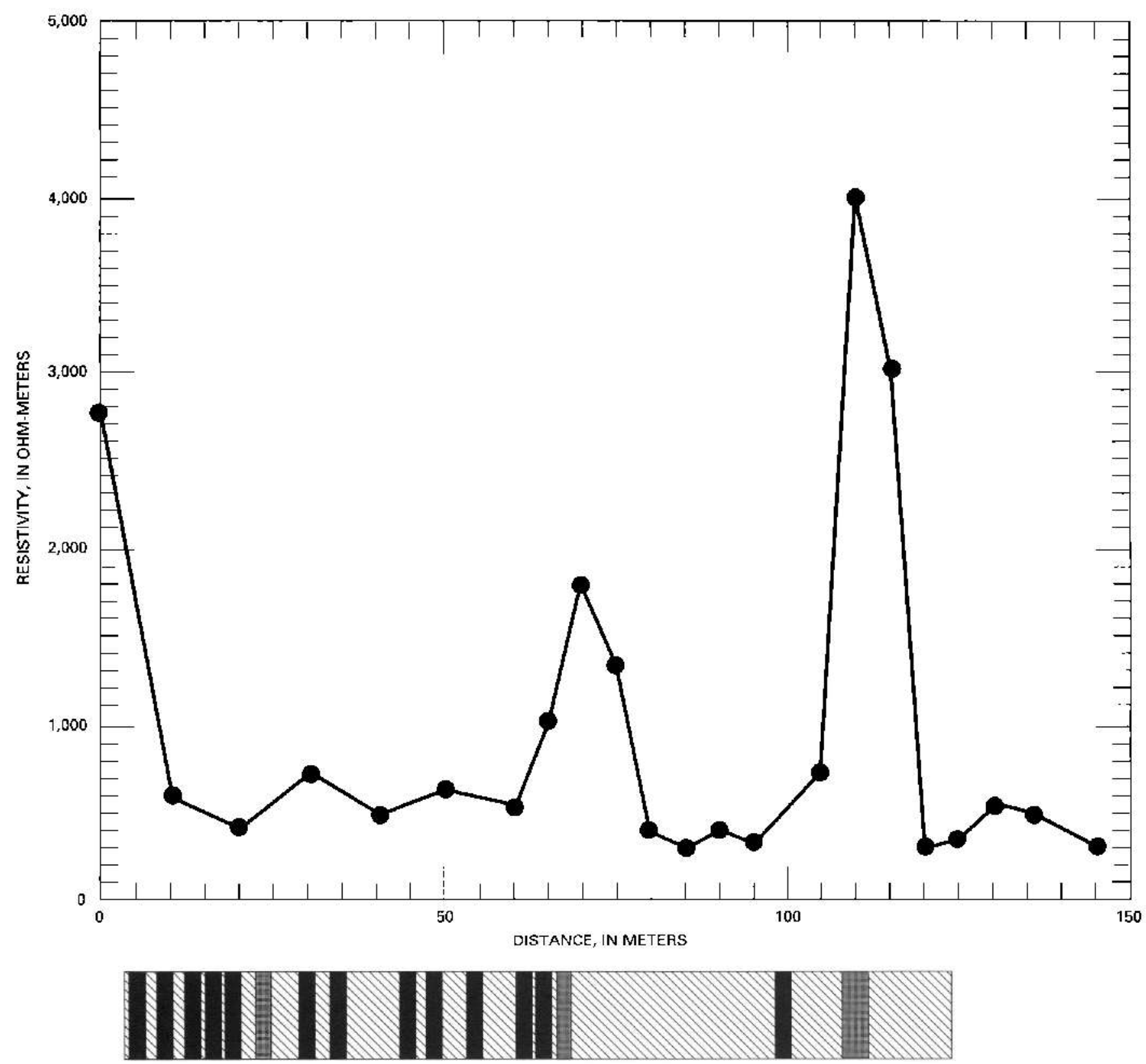

EXPLANATION

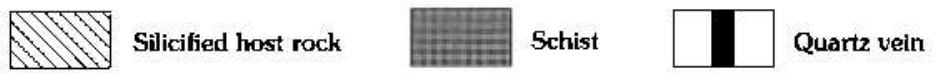

Figure 14. Resistivity measured by a VLF-EM receiver along trench 2A, Bochinche area, Estado Bolívar, Venezuela. Trench is approximately perpendicular to the strike of the gold-bearing quartz-carbonate-tourmaline veins.

this quartzite is microvesicular and dominated by boxwork quartz veins and some tourmaline. It is speculated that the microvesicular nature of the quartz veins is caused by dissolution of carbonate and (or) magnetite. These boxwork veins are as wide as $2-3 \mathrm{~cm}$ but more commonly are $3-5 \mathrm{~mm}$ wide. This quartzite may represent a silicified zone around the quartz-carbonate-tourmaline veins and may originally have been the schist-phyllite host rock. Observations from trench $\mathrm{T} \perp$ at Bochinche indicate that similar characteristics may be present on a much smaller scale next to quartz-carbonatc-tourmaline veins. Examination of drill core from Bochinche that cuts the quartz-carbonate-tourmaline veins indicates that at depth the veins contain carbonate minerals, but no carbonate minerals were observed in the surface 


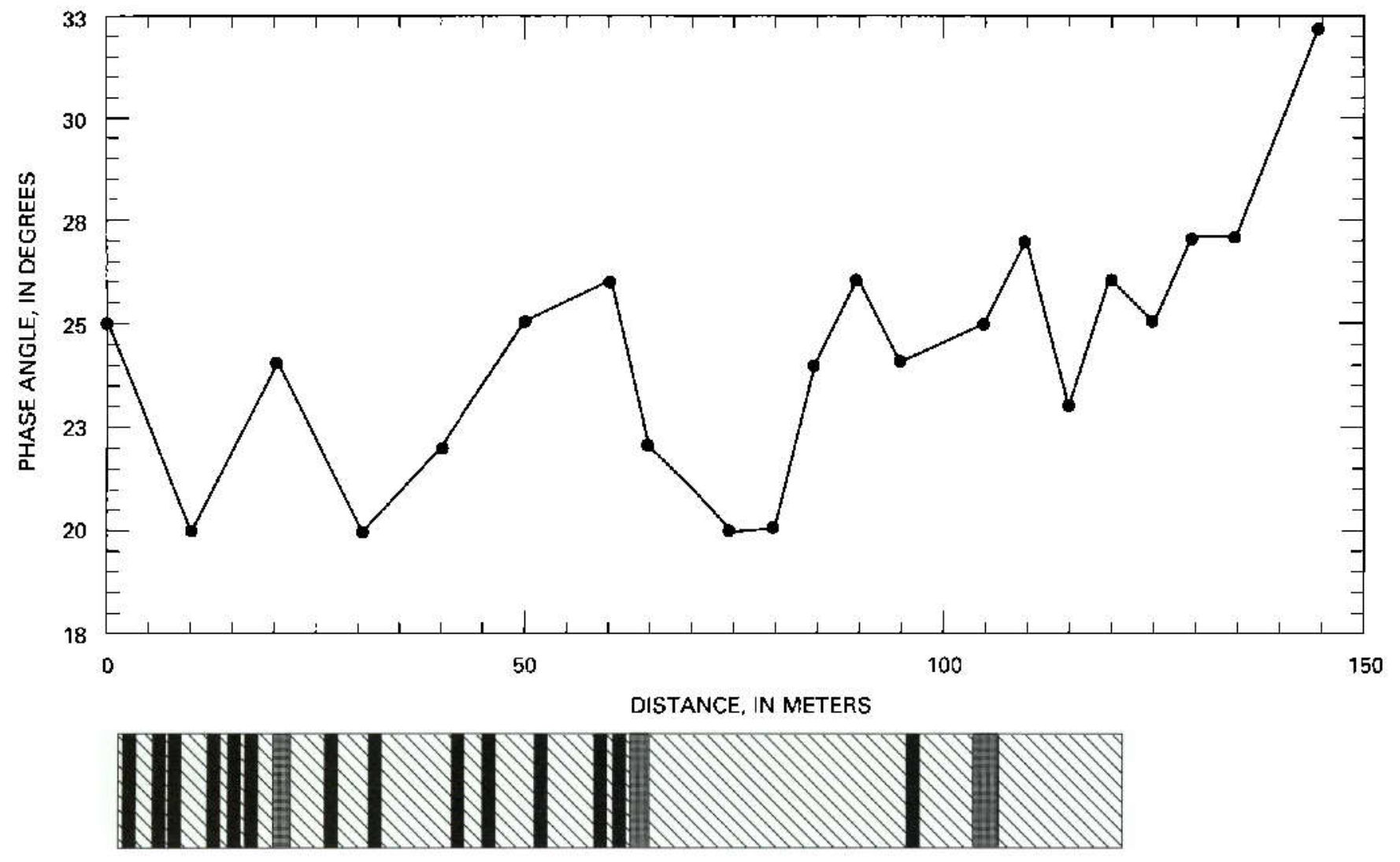

\section{EXPLANATION}
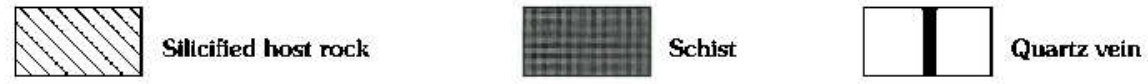

Figure 15. Phase angle measured by a VLF-EM receiver along trench $2 \mathrm{~A}$, Bochinche area, Estado Bolívar, Venezuela. Trench is approximately perpendicular to the strike of the gold-bearing quartz-carbonate-tourmaline veins.

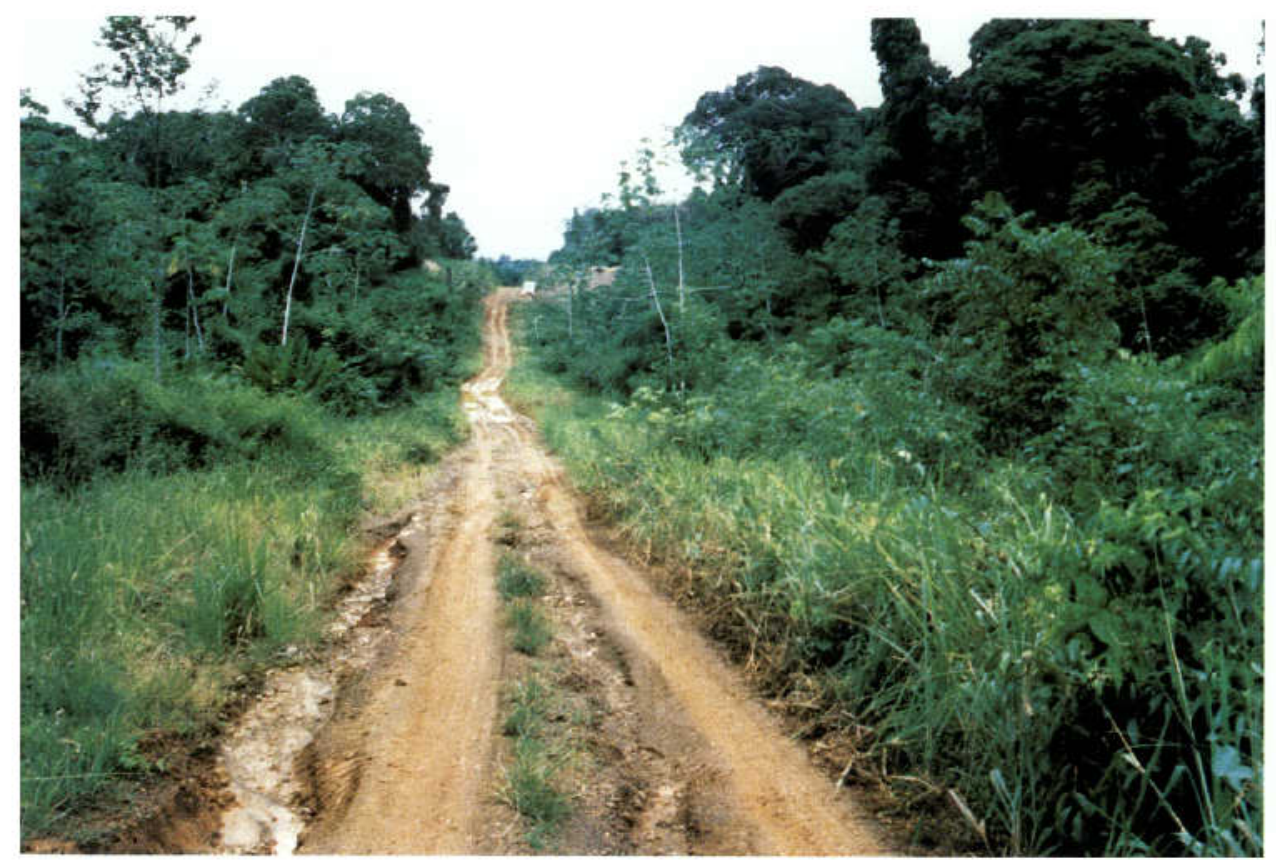

Figure 16. North side of road cut approximately $500 \mathrm{~m}$ northeast of Bochinchita, Estado Bolívar, Venezuela. Outcrop of schist and greenstone host rock is in right center of photograph. Small (3-4 cm) quartz-carbonate-tourmaline vein is near white sample bag. 
Table 18. Element associations for a six-factor R-mode factor analysis for rock samples from trench $2 \mathrm{~A}$, Bochinche area, Venezuela.

[In decreasing order of factor loadings. Parentheses indicate ]oadings that are not decreasing in order]

\begin{tabular}{|c|c|c|c|c|c|c|}
\hline & Factor 1 & Factor 2 & Factor 3 & Factor 4 & Factor 5 & Factor 6 \\
\hline $\mathrm{Ga}$ & 0.97 & & & & & \\
\hline $\mathrm{Na}$ & 0.93 & & & & & \\
\hline $\mathrm{Ti}$ & 0.92 & & & & & \\
\hline $\mathrm{Sc}$ & 0.92 & & & & & \\
\hline $\mathrm{Zr}$ & 0.89 & & & & & \\
\hline $\mathrm{Fe}$ & 0.88 & & & & & \\
\hline $\mathrm{S} r$ & 0.88 & & & & & \\
\hline Y & $0.8 \mathrm{t}$ & & & & & \\
\hline V & 0.75 & & & & & \\
\hline $\mathrm{Tl}$ & 0.69 & & & & & \\
\hline $\mathrm{Be}$ & 0.65 & & & & & \\
\hline Mn & 0.60 & & & & & \\
\hline $\mathrm{Ni}$ & 0.54 & $(0.71)$ & & & & \\
\hline $\mathbf{F}$ & 0.53 & & & $(0.46)$ & & \\
\hline Co & & 0.82 & & & & $(0.41)$ \\
\hline $\mathrm{Cl}$ & & 0.79 & & & & \\
\hline $\mathrm{Hg}$ & & 0.67 & & & & \\
\hline Se & & 0.54 & & & & \\
\hline $\mathrm{Au}$ & & & 0.89 & & & \\
\hline$Z_{n}$ & & & 0.82 & & & \\
\hline B & & & & 0.87 & & \\
\hline Mg & & & & 0.77 & & \\
\hline $\mathrm{Pb}$ & & & & & 0.79 & \\
\hline $\mathrm{Te}$ & & & & & 0.68 & \\
\hline $\mathrm{Cd}$ & & & & & & 0.83 \\
\hline $\mathrm{Ba}$ & & & & & & 0.67 \\
\hline (Cu) & & & & & & 0.41 \\
\hline
\end{tabular}

exposures of the veins at zone 4. This lack of carbonate minerals may be the result of deep weathering; inegular cavities observed in the quartz veins in many places may represent locations of former carbonate minerals. The quartzite and the boxwork quartz veins from zone 4 were also sampled.

\section{GEOCHEMICAL SAMPLING AND ANALYSIS}

During this study 33 rock and 7 panned-concentrate samples from streams draining the area were examined. In addition, 80 panned-concentrate samples that had been collected in previous TECMIN studies in zone 4 were analyzed (appendix tables 6, 7). Sample locations for rock and panned-concentrate samples are shown in figures 19 and 21 , respectively. Univariate statistics and Cohen-corrected geometric means and deviations for vein-rock samples are given in table 22, and correlations are given in table 23.

Although significant amounts of gold were not detected in the rock samples, gold was detected in each rock sample taken. Twenty-three of the rock samples were collected from quartz-carbonate-tourmaline veins; gold values ranged from less than 0.002 to $0.25 \mathrm{ppm}$. These results indicate that even at the surface of this deeply weathered terrane detectable gold remains in the quartz-carbonate-tourmaline veins.

Panned-concentrate samples were taken from small streams draining the Marwani zone 4 area (fig 21). Analytical results from the panned-concentrate samples are shown in appendix table 7.

Table 19. Eigenvalues for the six-factor R-mode factor analysis for all rock samples from trench $2 A$, Bochinche area, Venezuela.

[Six-factor element associations are given in table 18]

\begin{tabular}{|c|c|c|c|c|c|}
\hline $\begin{array}{l}\text { Number } \\
\text { of factors }\end{array}$ & Eigenvalue & $\begin{array}{c}\text { Cumulative } \\
\text { percent }\end{array}$ & $\begin{array}{c}\text { Number } \\
\text { of factors }\end{array}$ & Eigenvalue & $\begin{array}{c}\text { Cumulative } \\
\text { percent }\end{array}$ \\
\hline 1 & 11.5899 & 0.4293 & 11 & 0.4910 & 0.9261 \\
\hline 2 & 3.3407 & 0.5530 & 12 & 0.3797 & 0.9401 \\
\hline 3 & 2.2363 & 0.6358 & 13 & 0.3360 & 0.9526 \\
\hline 4 & 1.8977 & 0.7061 & 14 & 0.2428 & 0.9616 \\
\hline 5 & 1.2940 & 0.7540 & 15 & 0.2091 & 0.9693 \\
\hline 6 & 1.0465 & 0.7928 & 16 & 0.1586 & 0.9752 \\
\hline 7 & 0.9386 & 0.8275 & 17 & 0.1279 & 0.9799 \\
\hline 8 & 0.8201 & 0.8579 & 18 & 0.1054 & 0.9838 \\
\hline 9 & 0.7289 & 0.8849 & 19 & 0.0873 & 0.9871 \\
\hline 10 & 0.6204 & 0.9079 & 20 & 0.0789 & 0.9900 \\
\hline
\end{tabular}



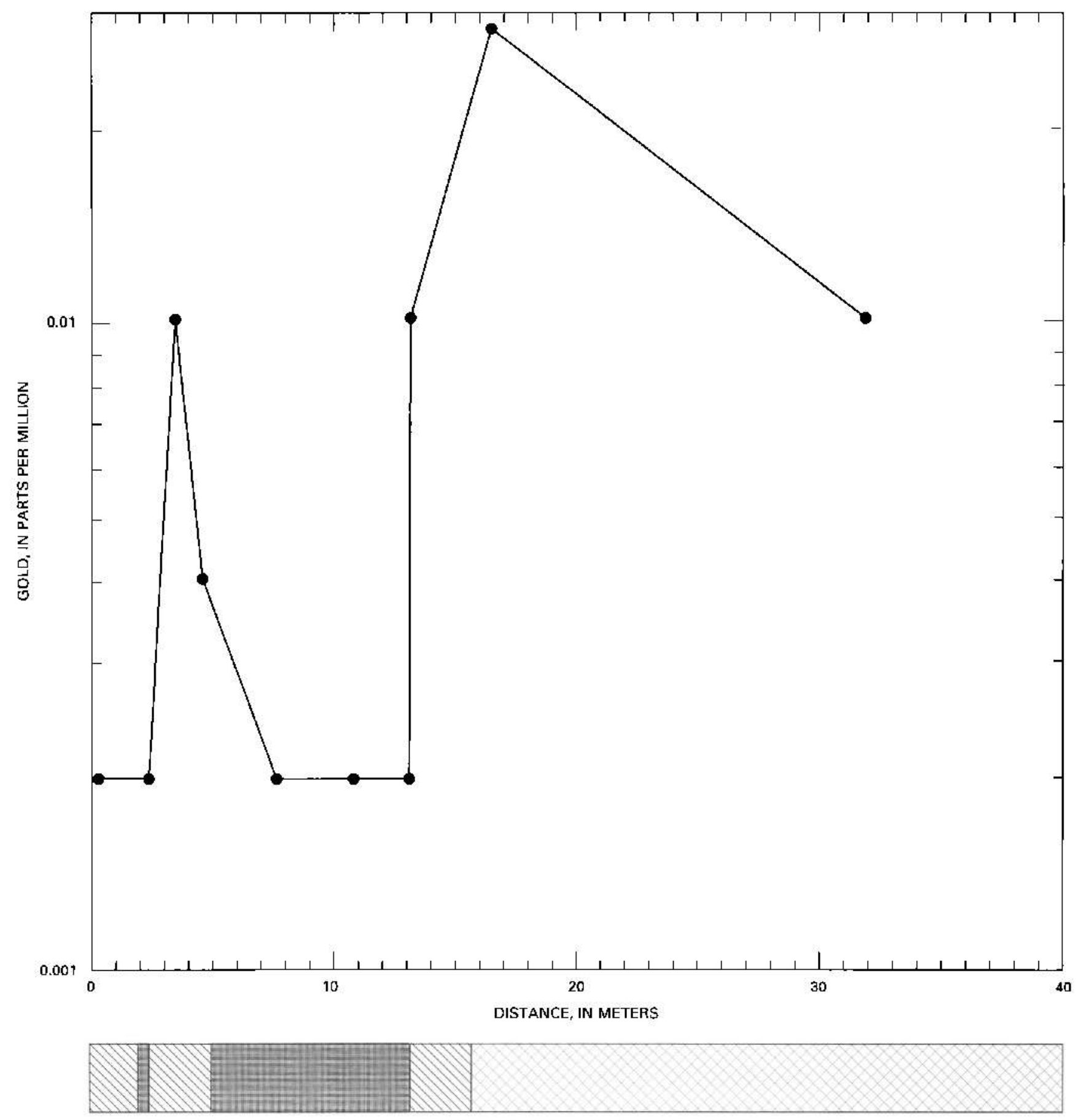

\section{EXPLANATION}

Quartz vein with tourmaline

Greenstone

Schist

Figure 17. Plot of gold values across the quartz veins exposed in a road cut approximatcly 500 m northeast of Bochinchita, Estado Bolívar, Venezuela. Generalized geologic section below the plot shows locations of quartz-carbonate-tourmaline veins. 
Table 20. Univariate statistics for host- and vein-rock samples from a road cut near Bochinche, Venezuela. [In parts per million unless otherwise noted. All analyses are by semiquantative spectrographic method except for $\mathrm{Cd}, \mathrm{Zn}, \mathrm{Hg}, \mathrm{Se}, \mathrm{Te}, \mathrm{T}$, and $\mathrm{Au}$, which were done by atomic absorption method. L, detected but below lower limit of determination; N, not detected at lower limit of determination; $\mathbf{G}$, greater than upper limit of determination]

\begin{tabular}{|c|c|c|c|c|c|c|c|c|c|c|}
\hline \multirow[b]{2}{*}{ Element } & \multicolumn{2}{|c|}{ Range } & \multicolumn{2}{|c|}{ Geometric } & \multicolumn{4}{|c|}{ Number of samples } & \multicolumn{2}{|c|}{ Cohen } \\
\hline & Minimum & Maximum & Mean & Deviation & Valid & $\mathrm{L}$ & $\mathrm{N}$ & $\mathrm{G}$ & Mean & Deviation \\
\hline $\mathrm{Ba}$ & 30 & 2,000 & 118 & 3.1 & 12 & 0 & 0 & 0 & 118 & 3.15 \\
\hline $\mathrm{Fe} \%$ & 0.5 & 7 & 2.8 & 2.9 & 12 & 0 & 0 & 0 & 2.83 & 2.89 \\
\hline $\mathrm{Mg} \%$ & 0.2 & 3 & 0.8 & 2.5 & 12 & 0 & 0 & 0 & 0.810 & 2.51 \\
\hline $\mathrm{Ca}$ & 0.05 & 10 & 0.2 & 6.4 & 7 & 5 & 0 & 0 & 0.159 & 6.42 \\
\hline $\mathrm{Ti} \%$ & 0.02 & 0.5 & 0.1 & 2.9 & 12 & 0 & 0 & 0 & -. & -- \\
\hline Mn & 70 & 1,500 & 451 & 2.6 & 11 & 0 & 0 & 1 & 574 & 3.39 \\
\hline B & 20 & 1,500 & 164 & 4.5 & 7 & 0 & 2 & 3 & -- & -- \\
\hline $\mathrm{Ni}$ & 5 & 200 & 42 & 4.0 & 11 & 1 & 0 & 0 & 33.3 & 4.75 \\
\hline $\mathrm{Be}$ & 1 & 2 & 1.4 & 1.4 & 5 & 6 & 1 & 0 & 0.873 & 1.73 \\
\hline Co & 15 & 500 & 49 & 3.0 & 11 & 1 & 0 & 0 & 40.8 & 3.35 \\
\hline $\mathrm{Cr}$ & 10 & 700 & 107 & 4.1 & 11 & 1 & 0 & 0 & 82.6 & 4.99 \\
\hline $\mathrm{Cu}$ & 7 & 500 & 49 & 4.0 & 12 & 0 & 0 & 0 & 48.6 & 3.98 \\
\hline $\mathrm{v}$ & 100 & 200 & 142 & 1.3 & 12 & 0 & 0 & 0 & 142 & 1.27 \\
\hline $\mathrm{Pb}$ & 10 & 20 & 14 & 1.3 & 12 & 0 & 0 & 0 & 14.1 & 1.32 \\
\hline Sc & 5 & 30 & 16 & 1.8 & 12 & 0 & 0 & 0 & 16.6 & 1.85 \\
\hline $\mathbf{Y}$ & 20 & 70 & 47 & 1.6 & 7 & 0 & 5 & 0 & 16.9 & 3.86 \\
\hline $\mathrm{Zn}$ & 200 & 700 & 402 & 1.7 & 5 & 2 & 5 & 0 & 167 & 2.52 \\
\hline $\mathrm{Zr}$ & 10 & 150 & 25 & 2.5 & 12 & 0 & 0 & 0 & 24.7 & 2.46 \\
\hline $\mathrm{Na} \%$ & 0.2 & 1.5 & 0.5 & 2.0 & 8 & 1 & 3 & 0 & 0.309 & 2.80 \\
\hline Ga & 5 & 30 & 14 & 1.9 & 9 & 1 & 2 & 0 & 9.63 & 2.49 \\
\hline Cd & 0.3 & 1.2 & 0.6 & 1.6 & 7 & 5 & 0 & 0 & 0.190 & 4.82 \\
\hline $\mathrm{Zn}$ & 6 & 970 & 64 & 7.5 & 12 & 0 & 0 & 0 & 64.5 & 7.52 \\
\hline $\mathrm{Hg}$ & 0.02 & 0.28 & 0.04 & 2.4 & 7 & 0 & 5 & 0 & 0.022 & 3.15 \\
\hline $\mathrm{Se}$ & 0.1 & 0.4 & 0.2 & 2.2 & 4 & 7 & 0 & 0 & 0.061 & 3.35 \\
\hline $\mathrm{Te}$ & 0.05 & 0.35 & 0.1 & 2.0 & 7 & 1 & 4 & 0 & 0.073 & 3.71 \\
\hline $\mathrm{T} 1$ & 0.05 & 0.1 & 0.08 & 1.5 & 3 & 1 & 8 & 0 & 0.029 & 2.20 \\
\hline $\mathrm{Au}$ & 0.002 & 0.03 & 0.004 & 2.5 & 11 & 1 & 0 & 0 & 0.004 & 2.65 \\
\hline
\end{tabular}

Table 21. Correlation coefficients for host- and vein-rock samples from a road cut near Bochinche, Venezuela. [Matrix shows significant correlations at or greater than the 95 percent confidence level. Number of sample pairs used to calculate the correlation is shown in parentheses]

\begin{tabular}{|c|c|c|c|c|c|c|c|c|c|c|}
\hline & $\mathrm{Ti}$ & $\mathrm{Mn}$ & $\mathrm{Nj}$ & $\mathrm{Co}$ & $\mathrm{Cr}_{\mathrm{r}}$ & $\mathrm{Cu}$ & $\mathrm{Sc}$ & $Z_{\boldsymbol{r}}$ & $\mathrm{Ga}$ & $\mathrm{Zn}$ \\
\hline$\overline{\text { Ba }}$ & & $0.6677(11)$ & $0.6623(11)$ & $0.9658(11)$ & & $0.9406(11)$ & & & & \\
\hline $\mathrm{Fe}$ & $0.9245(12)$ & $0.6775(11)$ & $0.7668(11)$ & & $0.7118(11)$ & & $0.7940(12)$ & $0.6284(12)$ & $0.7739(9)$ & \\
\hline $\mathrm{Mg}$ & $0.5829(12)$ & & $0.6505(11)$ & & & & $0.7225(\ 2)$ & & & \\
\hline Tì & & $0.7241(11)$ & $0.7897(11)$ & & $0.8780(11)$ & & $0.6678(12)$ & $0.8589(12)$ & $0.8322(9)$ & $0.8322(9)$ \\
\hline Mn & & & & & & $0.6089(11)$ & & & & \\
\hline $\mathrm{Ni}$ & & & & $0.6614(10)$ & & $0.7805(11)$ & $0.7465(11)$ & & $0.7777(9)$ & $0.9246(11)$ \\
\hline $\mathrm{Co}$ & & & & & & $0.9559(11)$ & & & & \\
\hline $\mathrm{Cr}$ & & & & & & & & $0.9195(11)$ & & \\
\hline $\mathrm{Cu}$ & & & & & & & & & $0.7003(9)$ & $0.7460(12)$ \\
\hline $\mathrm{V}$ & & & & & & & $0.7734(12)$ & & & \\
\hline $\mathrm{Zr}$ & & & & & & & & & $0.6924(9)$ & \\
\hline Ga & & & & & & & & & & $0.7882(9)$ \\
\hline $\mathrm{Cd}$ & & & & & & & & & & $0.8189(7)$ \\
\hline
\end{tabular}




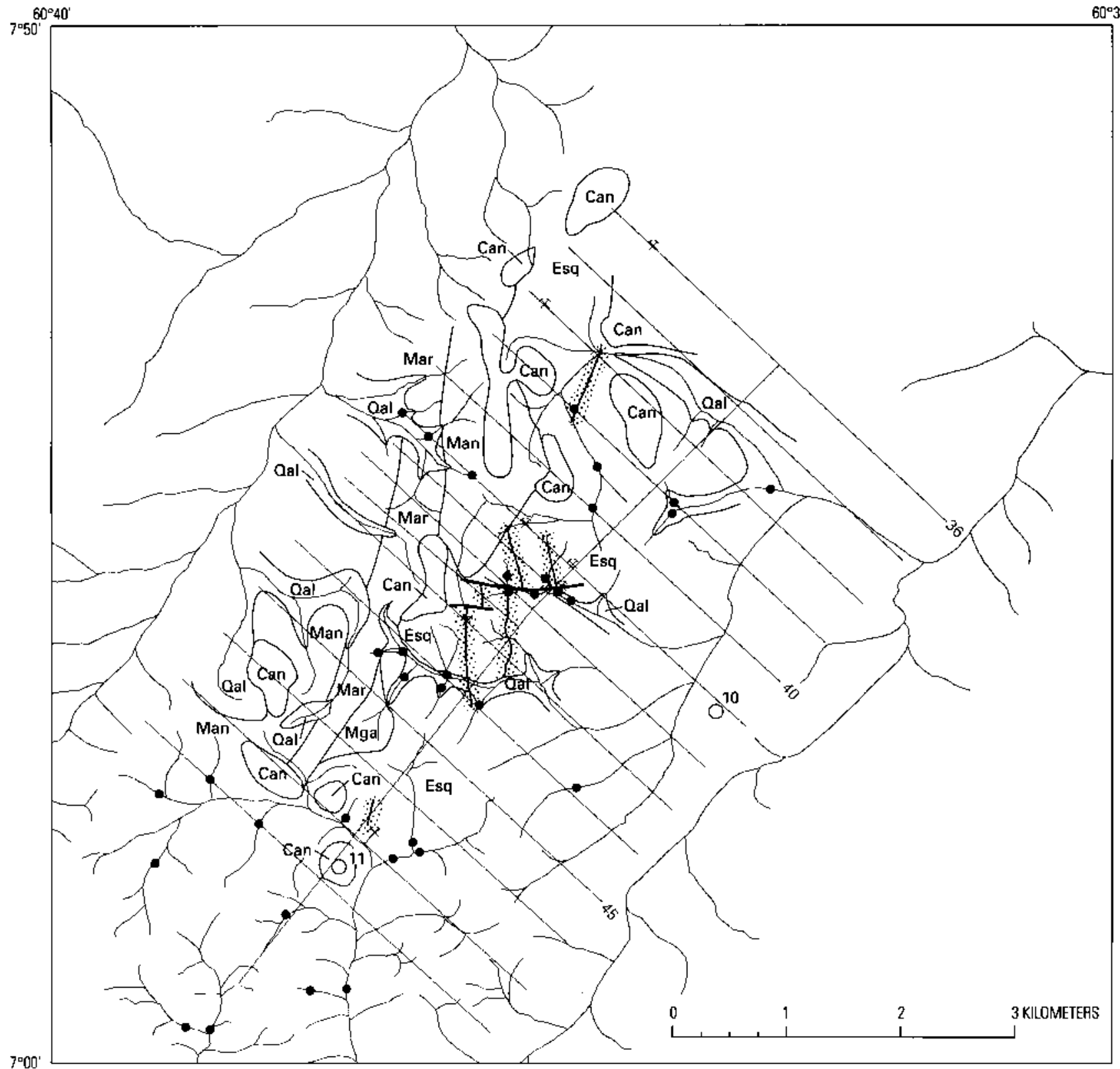

EXPLANATION

\begin{tabular}{|c|l}
\cline { 1 - 1 } Qal & Alluvium \\
\cline { 1 - 1 } Esq & Schist \\
\cline { 1 - 1 } Man & Meta-andesite \\
\cline { 1 - 1 } Mar & Meta-arenite \\
\cline { 1 - 1 } Mga & Metagabbro \\
\cline { 1 - 1 } Can & Canga \\
\hline
\end{tabular}

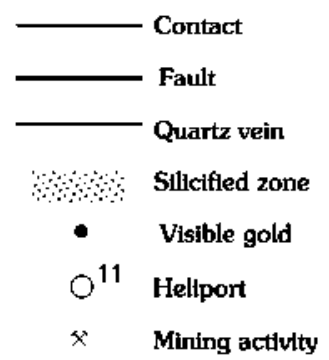

Figure 18. Schematic geologic map, zone 4, Marwani concession, Estado Bolívar, Venezuela. Gold bearing quartz-carbonate tourmaline veins, ejes (control lines cut through the jungle), picas (traverse lines cut through the jungle perpendicular to ejes at regular intervals), old mine locations, and helicopter landing sites are also shown. Modified from Jeffery Wynn (written commun., 1989). 


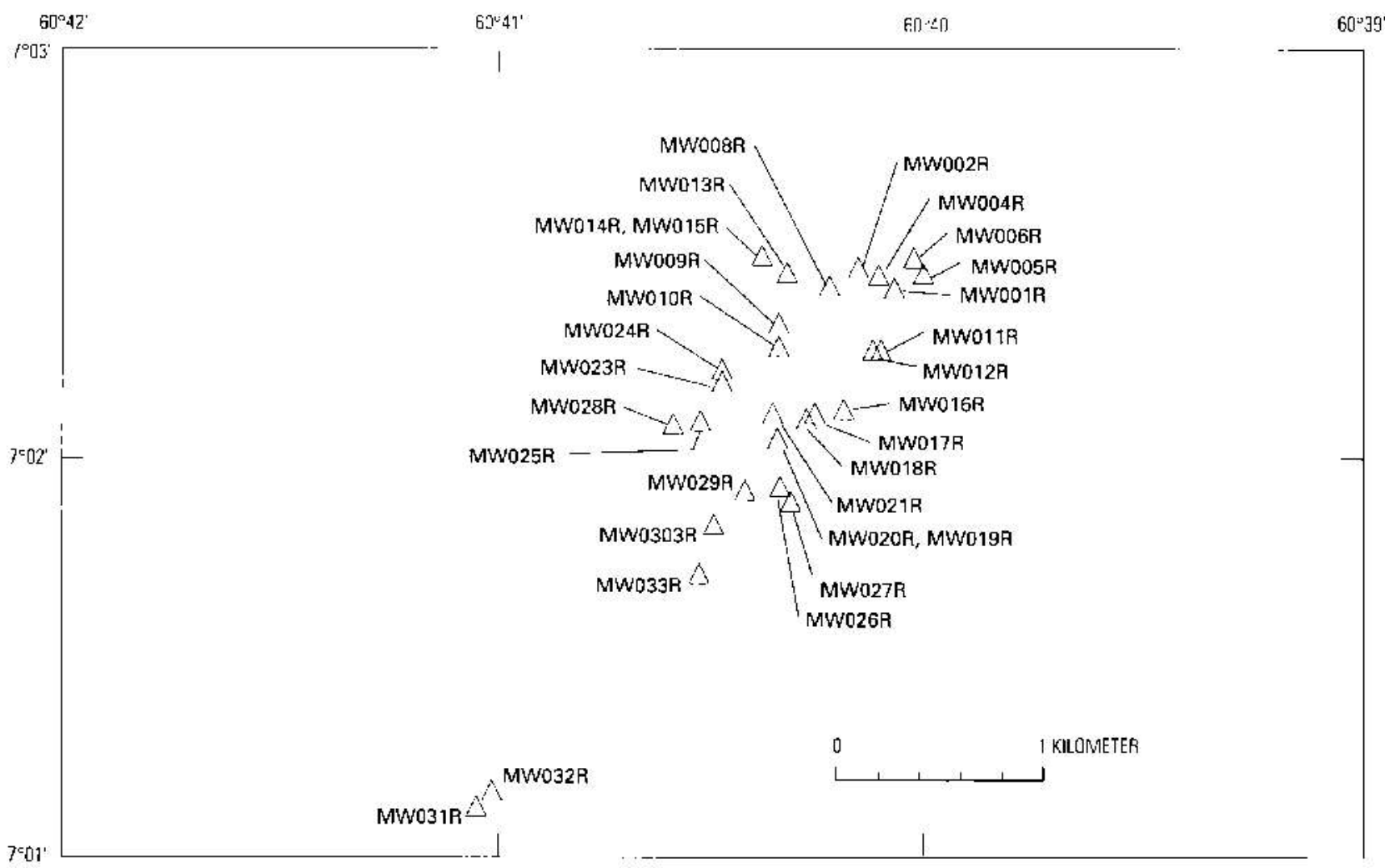

Figure 19. Map showing rock sample locations, zone 4, Marwani concession, Estado Bolívar, Venezuela. Sample numbers are plotted near triangles showing location; elemcntal concentrations for the samples are given in appendix table 6 .

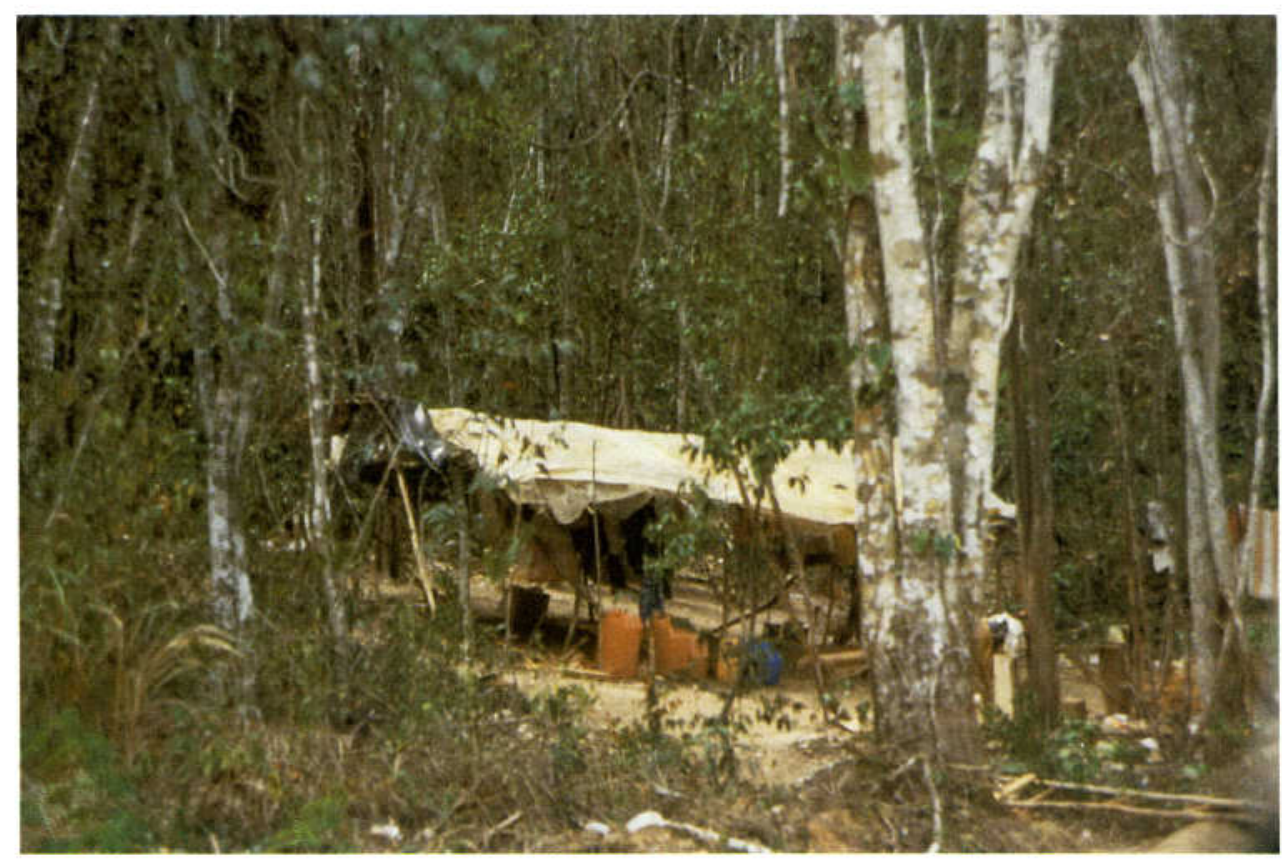

Figure 20. Typical geology field camp near Esperanza along the main road berween Tumeremo and Bochinche, Estado Bolfvar, Venezuela. 
Table 22. Univariate statistics for vein-rock samples from zone 4 of the Marwani concession, Venezuela.

[All values in parts per million unless otherwise noted. All analyses are by semiquantative spectrographic method except for $\mathrm{Cd}, \mathrm{Zn}, \mathrm{Hg}$. Te, and

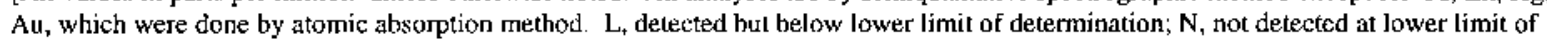
determination; G, greater than upper limit of determination]

\begin{tabular}{|c|c|c|c|c|c|c|c|c|c|c|}
\hline \multirow[b]{2}{*}{ Element } & \multicolumn{2}{|c|}{ Range } & \multicolumn{2}{|c|}{ Geometric } & \multicolumn{4}{|c|}{ Number of samples } & \multicolumn{2}{|c|}{ Cohen } \\
\hline & Minimum & Maximum & Mean & Deviation & Valid & $\mathrm{L}$ & $\mathrm{N}$ & $\mathrm{G}$ & Mean & Deviation \\
\hline $\bar{F}$ & 0.01 & 0.04 & 0.02 & $1 . \overline{8}$ & 6 & 28 & 0 & 0 & 0.003 & 3.35 \\
\hline $\mathrm{Ba}$ & 20 & 200 & 33 & 1.7 & 27 & 3 & 4 & 0 & 27.4 & 1.84 \\
\hline $\mathrm{Fe} \%$ & 0.15 & 20 & 1.8 & 3.7 & 34 & 0 & 0 & 0 & 1.77 & 3.67 \\
\hline $\mathrm{Mg} \%$ & 0.02 & 1.5 & 0.19 & 3.4 & 26 & 8 & 0 & 0 & 0.087 & 6.03 \\
\hline $\mathrm{Ti} \%$ & 0.002 & 0.3 & 0.03 & 4.5 & 29 & 5 & 0 & 0 & 0.016 & 6.80 \\
\hline Mn & 10 & 5,000 & 36 & 3.7 & 27 & 7 & 0 & 0 & 22.4 & 4.59 \\
\hline B & 10 & 2,000 & 164 & 6.1 & 20 & 3 & 3 & 8 & -- & - \\
\hline $\mathrm{Ni}$ & 5 & 50 & 14 & 2.1 & 18 & 15 & I & 0 & 5.48 & 0.44 \\
\hline Co & 10 & 100 & 16 & 2.3 & 7 & 9 & 18 & 0 & 3.42 & 3.37 \\
\hline $\mathrm{Cr}$ & 10 & 150 & 37 & 2.7 & 16 & 15 & 3 & 0 & 8.89 & 5.40 \\
\hline $\mathrm{Cu}$ & 5 & 50 & 16 & 2.1 & 17 & 8 & 9 & 0 & 5.27 & 3.90 \\
\hline V & 10 & 150 & 33 & 2.4 & 34 & 0 & 0 & 0 & 33.1 & 2.44 \\
\hline $\mathrm{Pb}$ & 10 & 20 & 12 & 1.3 & 16 & 17 & 1 & 0 & 9.25 & 1.46 \\
\hline Sc & 5 & 20 & 11 & 1.7 & 13 & 3 & 18 & 0 & 3.75 & 2.80 \\
\hline Y & 10 & 100 & 18 & 2.4 & 6 & 1 & 27 & 0 & 2.53 & 4.15 \\
\hline $\mathrm{Zr}_{\boldsymbol{r}}$ & 10 & 150 & 22 & 2.4 & 24 & 8 & 2 & 0 & 14.1 & 2.90 \\
\hline $\mathrm{Na} \%$ & 0.2 & 1.5 & 0.5 & 2.0 & 11 & 2 & 21 & 0 & 0.109 & 3.79 \\
\hline $\mathrm{Ga}$ & 5 & 70 & 13 & 2.8 & 13 & 14 & 7 & 0 & 2.91 & 4.78 \\
\hline $\mathrm{Cd}$ & 0.1 & 3.1 & 0.4 & 2.7 & 12 & 22 & 0 & 0 & 0.048 & 7.39 \\
\hline $\mathrm{Zn}$ & 2 & 270 & 9.6 & 5.3 & 17 & 17 & 0 & 0 & 1.66 & 10.6 \\
\hline $\mathrm{Hg}$ & 0.02 & 0.08 & 0.03 & 2.2 & 3 & 31 & 0 & 0 & 0.031 & 2.23 \\
\hline $\mathrm{Te}$ & 0.05 & 4.2 & 0.2 & 3.7 & 16 & 18 & 0 & 0 & 0.040 & 7.59 \\
\hline $\mathrm{Au}$ & 0.002 & 0.25 & 0.009 & 4.8 & 21 & 13 & 0 & 0 & 0.003 & 7.84 \\
\hline
\end{tabular}

Table 23. Correlation coefficients for vein-rock samples from zone 4 of the Marwani concession, Venezuela. [Matrix shows significant correlations at or greater than the 95 percent confidence level. Number of sample pairs used to calculate the correlation is shown in parentheses.]

\begin{tabular}{|c|c|c|c|c|c|c|c|c|c|}
\hline & $\mathrm{Ti}$ & Mn & $\mathrm{Ni}$ & $\mathrm{Pb}$ & $\mathrm{Sc}$ & $\mathrm{Zr}$ & Cd & $\mathrm{Te}$ & $\mathrm{Au}$ \\
\hline $\mathrm{Ba}$ & $0.6635(22)$ & $0.7894(21)$ & & & & & & & \\
\hline $\mathrm{Fe}$ & & & & $0.7400(12)$ & & $0.5926(24)$ & $0.9204(12)$ & & \\
\hline $\mathrm{Mg}$ & $0.5412(23)$ & & & & & $0.6430(21)$ & & & \\
\hline $\mathrm{Ti}$ & & $0.6473(25)$ & $0.8155(16)$ & & $0.7347(13)$ & & & & \\
\hline $\begin{array}{l}\mathrm{Ni} \\
\mathrm{Te}\end{array}$ & & & & & & & & $0.8192(9)$ & $0.6963(12)$ \\
\hline
\end{tabular}

\section{MINERALOGY}

All of the nonmagnetic fraction of each panned-concentrate sample was examined under a microscope for mineralogy. A total of 87 samples were taken, and 59 , or 68 percent, contained visible gold in amounts from 1 to 43 grains. In general, the grain size was less than $1 \mathrm{~mm}$. All samples also contained rutile, in some cases as much as 50 percent of the sample.

The rutile is in thin acicular crystals, many exhibiting the typical knee-shaped twinning. Other common minerals are zircon, apatite, tourmaline, and the zinc spinel ghanite.
All of the observed minerals, with the exception of the gold and tourmaline, probably reflect the metavolcanic host rocks.

The central part of zone 4 is in greenstone terrane that is permissive for the occurrence of low-sulfur gold-quartz veins. Results from our study indicate that this area contains (1) quartz-carbonate-tourmaline veins related to northeast-trending dislocations, (2) offsetting northwest-trending faults, (3) zones of silicification around the quartz-tourmaline veins, and (4) gold, commonly abundant, in small streams that drain the areas of quartz-tourmaline veins. On the basis of thesc results, there is a high probability of the occurrence of lode gold deposits similar to those in the greenstone belts at Lo Increíble, El Callao, and Bochinche. 


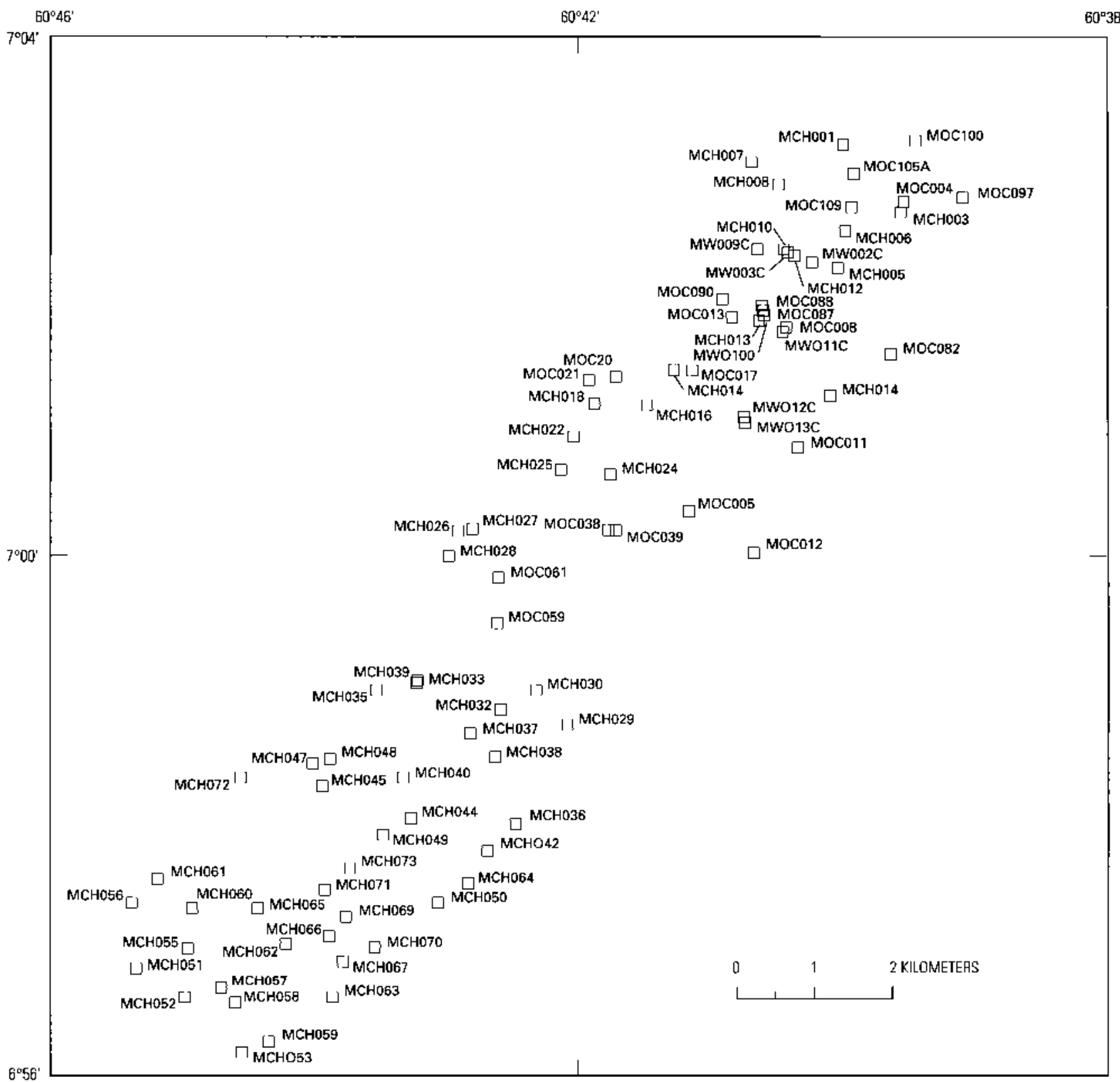

Figure 21. Map showing panned-concentrate sample locations, zone 4, Marwani concession, Estado Bolívar, Venezuela. Sample numbers are plotted near squares showing location; elemental concentrations for samples are given in appendix table 7. 


\section{GEOCHEMICAL AND GENETIC MODEL FOR GOLD-BEARING QUARTZ-CARBONATE-TOURMALINE VEINS IN VENEZUELA}

Work done by Colvine and others (1984) indicates that much of the world's gold has come from quartz veins in Archean greenstone belts similar to the greenstone belts in southeastern Venezuela. Gold in quartz veins in regionally metamorphosed metavolcanic rocks in the Precambrian greenstone belts in southeastem Venezuela is typical of the low-sulfide gold-quartz vein model (Berger, 1986; Bliss and Jones, 1988). Some Venezuelan gold-quartz veins contain tourmaline crystals, and the high boron content and associated tourmaline factor discussed in the R-mode factor analyses for Bochinche trench 2A support this observation. Many of veins contain measurable zinc and copper but generally in amounts only equal to or less than those in the analyzed host rocks. According to the model, amounts of lead and silver should be anomalous, but in the Venezuelan gold-bearing quartz-carbonate-tourmaline veins that we studied these elements are generally near or below the standard detection limits of the method used for analysis. Arsenic, considered the best pathfinder for this type of deposit, is present in samples collected underground at Mina Colombia at statistically significant levels and in the Mina San Pedro open pit at low levels, but it is present in only a few samples from the other locations studied. Many elements in the quartz-carbonate-tourmaline veins are depleted, and only gold and manganese and possibly boron are enriched. It may be that tropical weathering has leached away elements that could be used to target these deposits at the surface. This is likely because in this study the chemistry of the quartz-carbonate-tourmaline gold-bearing veins varies little between the surface, the near-surface, and depth ( $300 \mathrm{~m}$ or more) where the rocks are relatively fresh.

Bliss and Jones (1988) compiled reported mineralogical data from low-sulfide gold-quartz veins and ranked the frequency of occurrence reporting of sulfide minerals, which form less than 5 volume percent in this type of deposit. About 89 percent of the deposits contain pyrite; galena, arsenopyrite, and chalcopyrite are present in more than half of the deposits. Sphalerite, pyrrhotite, stibnite, tetrahedrite, and scheelite are present in $39,22,11,9$, and 7 percent of the deposits, respectively. These figures imply that for about half of the deposits the geochemical signature of the ore should contain iron, lead, arsenic, and copper and, less commonly, zinc, antimony, silver, and tungsten contained in sulfide minerals. Based on frequency of occurrence of the gangue minerals calcite ( 10 percent), ankerite $(6$ percent), mariposite ( 5 percent), sericite ( 4 percent), chlorite ( 4 percent), albite ( 3 percent), biotite, tourmaline, dolomite, rhodochrosite, and talc (a combined total of 2 percent), and ilmenite, barite, rutile, and siderite (a combined total of 1 percent), the geochemical elemental signatures could include elements such as manganese, boron, titanium, chromium, magnesium, and calcium. No one deposit includes a complete suite of either ore or gangue minerals, and thus the geochemical signature could be quite irregular.

In low-sulfide gold-quartz veins in Estado Bolívar, the base metals copper, lead, and zinc, iron, boron, and manganese are a consistent part of a geochemical signature. Thus, these veins meet much of the geochemical criteria for low-sulfide gold-quartz veins.

Based on grade and tonnage information compiled to 1974 (Rodríguez, 1986), low-sulfide gold-quartz veins in the Guayana Shield fit the tonnage and grade model presented by Bliss (1986) for this deposit type. Reported tonnages range from 1,666 metric tons at Carmen Rosa to 1,588,428 metric tons at Laguna, and average grades range from 32.7 gram per metric ton at Botanamo to 10.8 grams per metric ton at Union San Serfin. Reported production within $0.5 \mathrm{~km}$ of Mina Colombia is 429,442 metric tons (to 1974) at an average grade of 11.3 grams per metric ton, and production at Lo Increíble is 45,341 metric tons at 12.2 grams per metric ton. Thus, in the Bliss (1986) tonnage and grade model Mina Colombia is above the 80th percentile in tonnage and below the 40th percentile in grade, and Lo Increíble is above the 50 th percentile in tonnage and below the 50th percentile in grade.

\section{CONCLUSION}

Reconnaissance geochemical sampling of the gold bearing quartz-carbonate-tourmaline veins in Estado Bolívar, Venezuela, in surface, near-surface, and subsurface environments indicates that the chemistry of these veins does not vary significantly. Field observation, chemical analysis, and statistical analysis indicate that the veins are low sulfide and gold bearing. Statistical analysis of the chemical data defines a host-rock suite of elements, a base-metal suite of elements, and gold. The strong lack of correlation between gold and other elements indicates that gold is present as elemental gold. Only in two cases is the gold associated with tellurium, indicating a possibility of gold tellurides; these occurrences are in the surface and near-surface environments where alteration is the most pronounced. Carbonate minerals were observed only in samples from depth, either from mines or from drill core. Most commonly, the carbonate minerals have been weathered from the veins leaving irregular cavities containing particulate gold. Copper, lead, and zinc are present in the veins at very low levels and probably represent remobilization of these elements from the host metavolcanic rocks. The solutions forming the veins apparently did not carry base metals and were probably not chloride brines. The veins are depleted in most elements except gold and, in some cases, manganese and boron. The solutions forming the veins were probably carbonate bearing 
(calcium, magnesium, strontium, and barium) and contained gold, boron, and manganese. The manganese content of the veins is relatively constant except in the surface environment where weathering has removed most of the manganese.

As part of this study, several exploration techniques were used, and four were particularly useful. Before going into the dense jungle of zone 4 of the Marwani concession, aeromagnetic maps and side-looking airborne radar (SLAR) imagery were examined. From the SLAR imagery linear topographic features were identified that might indicate resistant quartz-vein systerns. Field checking of several of these features showed that this was a valid exploration approach, especially in the initial stages of exploration. Interpretation of aeromagnetic maps of the area prior to fieldwork identified faults and offsetting linear features. These faults were confirmed during field examination of zone 4 , and their location made mapping of the discontinuous and offset quartz veins much easier. Once in the field, the gold pan was the most effective tool for determining the extent of the gold-bearing quartz-carbonate-tourmaline veins. In the tropical weathering environment carbonate in the veins weathers, freeing particulate gold, which then accumulates at the clay-sediment interface in the streams draining the area. Because the areas examined are of generally low relief $(50-100 \mathrm{~m})$, the distribution of the gold in sediments is proximal to the quartz-carbonate-tourmaline veins. The very low frequency electromagnetic (VLF-EM) survey done along trench $2 \mathrm{~A}$ near Bochinche indicates that this technique may also be useful as an exploration tool. The quartz-carbonate-tourmaline veins were recorded as resistive highs as compared to background. An effective exploration procedure would be to select potential areas from interpretation of SLAR imagery and aeromagnetic maps, field check using VLF-EM and the gold pan, and then trench the most promising sites and collect rock samples for geochemistry. Very little of the greenstone terrane in the jungle-covered Guayana Shield has been explored, especially with modern techniques, and there is a high potential for the occurrence of more of these gold-bearing quartz-carbonate-tourmaline vein systems.

\section{REFERENCES CITED}

Acosta, J., 1987, Informe geologico, Zona Marwani: Informe Interno, PPGZF, 24 p.

Arbogast, B.F., ed., 1990, Quality assurance manual for the Branch of Geochemistry, U.S. Geological Survey; U.S. Geological Survey Open-File Repon 90-688, 184 p.

Benaim, Nesin, 1974, Geología de la región El Dorado-Anacoco-Botanamo, Estado Bolívar: Novena Conferencia Geológica Inter-Guayanas, Ciudad Guayana, Venezuela, 1972, Memoria, Publicación Especial 6, p. 198-206.
Berger, B.R., 1986, Descriptive model of low-sulfide Au-quartz veins, in Cox, D.P., and Singer, D.A., eds., Mineral deposit models: U.S. Geological Survey Bulletin I693, p. 239.

Bliss, J.D., 1986, Grade and tonnage model of low-sulfide Au-quartz veins, in Cox, D.P., and Singer, D.A., eds., Mineral deposit models: U.S. Geological Survey Bulletin 1693, p. 239-243.

Bliss, J.D., and Jones, G.M., 1988, Mineralogical and grade tonnage information on low-sulfide Au-quartz veins: U.S. Geological Survey Open-File Report 88-229, 99 p.

Colvine, A.C., Andrews, A.J., Cherry, M.E., Durocher, M.E., Fyon, A.J., Lavigne, Jr., M.J., Macdonaid, A.J., Maramont, Souissan, K.H., Poulsen, K.H., Springer, J.S., and Troop, D.G., 1984, An integrated model for the origin of Archean lode gold deposits: Ontario Geological Survey Open-File Report 5524, 98 p.

Crock, J.G., and Lichte, F.E., 1982, The determination of rare-earth elements in geological materials by inductively coupled argon plasma-optical emission spectroscopy: Aralytical Chemistry, v. 54 , p. $1329-1333$.

Crock, J.G., Lichte, F.E., and Briggs, P.E., 1983, Determination of elements in National Bureau of Standards geological reference materials SRM 278 obsidian and SRM 688 basalt by inductively coupled argon plasma-atomic emission spectroscopy: Geostandards Newsletter, v. 7, no. 2, p. 335-340.

Day, W.C., Martínez, L.F., and Quintana, Enot, 1989, Bedrock geology and geochemistry of the Alsacoco Sur II area, Bolívar State, Venezuela: U.S. Geological Survey Open-File Report 89-0305, $14 \mathrm{p}$.

Gibbs, A.K., 1980, Geology of the Barama-Mazaruni Supergroup of Guayana: Cambridge, Mass., Harvard University, Ph.D. dissertation, $385 \mathrm{p}$.

Gibbs, A.K., and Olszewski, W.J., Jr., 1982, Zircon U.Pb ages of Guayana greenstone-gneiss terraine: Precambrian Research, v. 17, p. 199-214.

Grimes, D.J., and Marranzino, A.P., 1968, Direct-current are and alternating current spark emission spectrographic field methods for the semiquantitative analysis of geologic materials: U.S. Geological Survey Circular 591, 6 p.

Gruau, G., Martin, H., Leveque, B., Capdevila, R., and Marot, A., 1985, Rb-Sr and Sm-Nd geochronology of Lower Proterozoic granite-greenstone terrains in French Guiana, South America: Precambrian Research, v. 30, p. 63-80.

Hopkins, D.M., 1977, An improved ion-selective electrode method for the rapid determination of fluorine in rocks and soils: U.S. Geological Survey Journal of Research, v. 5, p. 589-593.

Hubert, A.E., and Chao, T.T., 1985, Determination of gold, indium, tellurium, and thallium in the same sample digestion of geological materials by atomic-absorption spectroscopy and two-step solvent extraction: Talanta, v. 32, p.

Klar, Giampaolo, 1979, Geochronology of the El Manteco-Guri and Guasipati areas, Venezuelan Guiana Shield: Cleveland, Case Western Reserve University, Ph.D. dissertation, 163 p. [Dissertation Abstracts International, Sec. B, Sciences and Engineering, v. 39, p. 5284-B.]

Korol, Bohdan, 1965, Estratigrafía de la Serie Pastora, región Guasipati-El Dorado: Ministerio de Minas e Hidrocarburos, Boletín de Geología, v. 7, no. 13, p. 3-18.

Lichte, F.E., Meier, A.L., Crock, J.G., 1987, Determination of the rare-earth elements in geological materials by inductively 
coupled plasma mass spectrometry: Analytical Chemistry, April 15, 1987, p. 1150-1157.

Menéndez V. de V., Alfredo, 1968, Revisión de la estratigrafía de la Provincia de Pastora según el estudio de la región de Guasipatí, Guayana Venezolana: Ministerio de Minas e Hidrocarburos, Boletín de Geología, v. 10, no. 19, p. 309-338.

Motooka, J.M., and Grimes, D.J., 1976, Analytical precision of one-sixth order semiquantitative spectrographic analysis: U.S. Geological Survey Circular 738, 25 p.

O'Leary, R.M., and Meier, A.L., 1984, Analytical methods used in geochemical exploration: U.S. Geological Survey Circular 948,48 p.

Rodríguez M., S.E., 1986, Recursos minerales de Venezuela: Caracas, Ministerio de Energía y Minas, Dirección General Sectorial de Minas y Geología, Boletín de Geología, v. 15, no. $27,228 \mathrm{p}$.
Sanchez, H., 1986, Informe de advance trabajo de campo de Marwani: Informe Interno PPGZF.

1987, Planification trabajo de Campo-Zona de Marwani: Informe Interno PPGZF.

VanTrump, George, Jr., and Miesch, A.T., 1976: The U.S. Geological Survey RASS-STATPAC system for management and statistical reduction of geochemical data: Computers and Geosciences, v. 3, p. 475-488.

U.S. Geological Survey and Corporación Venezolana de Guayana, Técnica Minera, C.A., 1993, Geology and mineral resource assessment of the Venezuelan Guayana Shield: U.S. Geological Survey Bulletin 2062, 121 p.

Wilson, S.A., Kane, J.S., and Hatfield, D.B., 1988, Chemical methods of separation for optical emission, atomic absorption spectroscopy and colorimetry: U.S. Geological Survey Bulletin 1770, p. D1-D14. 



\section{APPENDIX DATA TABLES}

The designation $S$ on element headings indicates that analysis was done using semiquantitative cmission spectrography; the designation /p on element headings for $\mathrm{As}, \mathrm{Bi}, \mathrm{Cd}, \mathrm{Sb}$, and $\mathrm{Zn}$ indicates that analysis was done using inductively coupled plasma-atomic emission spectrometry (ICP-AES) following a partial sample digestion with hydrochloric acid/hydrogen peroxide and soivent extraction of the metals as tertiary amine-halide complexes. Te and $\mathrm{Tl}$ were analyzed by graphite furnace atomic absorption spectroscopy (AA); Hg was analyzed by continuous-flow cold-vapor atomic absorption spectrophotometry (CVAA); Au was analyzed by graphite furnace atomic absorption spectrophotometry (AA) following sample digestion with hydrobromic acid-bromine and solvent extraction; and $F^{-}$was analyzed using ion-selective electrode potentiometry, $N$ indicates that an element was looked for but not observed; $L$ indicates that an element was observed but was below the lowest reporting valuc, and the lower limit of determination is given; $G$ indicates that an element was observed but was above the upper reporting value, and the upper limit of determination is given; and $B$ indicates that no analysis was obtained. Values determined for the major elements $\mathrm{Ca}, \mathrm{F}, \mathrm{Fe}, \mathrm{Mg}, \mathrm{Na}, \mathrm{P}$, and $\mathrm{Ti}$ are given in weight percent; all other values are in parts per million (micrograms/gram). Detailed descriptions of analytical methods are given in Arbogast (1990). 
Appendix table 1. Rock samples collected from Mina Colombia, El Callao, Venezuela.

\begin{tabular}{|c|c|c|c|c|c|c|c|c|c|c|c|c|c|c|c|c|c|}
\hline & Latitude & Longitude & $\mathrm{Ca} \%-\mathrm{S}$ & $\mathbf{F} \%$ & $\mathrm{Fe} \%-\mathrm{S}$ & $\mathrm{Mg} \%-\mathrm{S}$ & $\mathrm{Na} \%-\mathrm{S}$ & $\mathrm{P} \%-\mathrm{S}$ & Ti\%-S & Ag-S & As-S & $\mathrm{Au}-\mathrm{S}$ & B-S & $\mathrm{Ba}-\mathrm{S}$ & $\mathrm{Be}-\mathrm{S}$ & $\mathrm{Bi}-\mathrm{S}$ & $\mathrm{Cd}-\mathrm{S}$ \\
\hline MC001R & $7^{\circ} 22^{\prime} 30^{\prime \prime}$ & $61^{\circ} 56^{\circ} 00^{\prime \prime}$ & 1.5 & $0.01 \mathrm{~L}$ & 0.7 & 0.5 & 0.2 & $0.2 \mathrm{~N}$ & 0.07 & $0.5 \mathrm{~N}$ & $200 \mathrm{~N}$ & $10 \mathrm{~N}$ & 100 & 20 & $1 \mathrm{~L}$ & $10 \mathrm{~N}$ & $20 \mathrm{~N}$ \\
\hline $\mathrm{MC} 002 \mathrm{R}$ & $7^{\circ} 22^{\prime} 30^{\prime \prime}$ & $61^{\circ} 56^{\prime} 00^{\prime \prime}$ & 3 & $0.01 \mathrm{~L}$ & 10 & 1 & 3 & $0.2 \mathrm{~N}$ & 0.7 & $0.5 \mathrm{~N}$ & $200 \mathrm{~N}$ & $10 \mathrm{~N}$ & $10 \mathrm{~N}$ & $20 \mathrm{~L}$ & $1 \mathrm{~N}$ & $10 \mathrm{~N}$ & $20 \mathrm{~N}$ \\
\hline MC003R & $7^{\circ} 22^{\prime} 30^{\prime \prime}$ & $61^{\circ} 56^{\circ} 00^{\prime \prime}$ & 5 & 0.03 & 7 & 1 & 3 & $0.2 \mathrm{~L}$ & 0.7 & 1.5 & $200 \mathrm{~N}$ & 15 & 30 & $20 \mathrm{~L}$ & IN & $10 \mathrm{~N}$ & $20 \mathrm{~N}$ \\
\hline $\mathrm{MC} 004 \mathrm{R}$ & $7^{\circ} 22^{\prime} 30^{\prime \prime}$ & $61^{\circ} 56^{\prime} 00^{\prime \prime}$ & 7 & $0.01 \mathrm{~L}$ & 10 & 1 & 5 & $0.2 \mathrm{~N}$ & 0.7 & $0.5 \mathrm{~N}$ & $200 \mathrm{~N}$ & $10 \mathrm{~N}$ & $10 \mathrm{~N}$ & $20 \mathrm{~L}$ & $1 \mathrm{~N}$ & $10 \mathrm{~N}$ & $20 \mathrm{~N}$ \\
\hline MC00SR & $7^{\circ} 22^{\prime} 30^{\prime \prime}$ & $61^{\circ} 56^{\prime} 00^{\prime \prime}$ & 7 & $0.01 \mathrm{~L}$ & 7 & 0.7 & 1 & $0.2 \mathrm{~N}$ & 0.7 & 1 & $200 \mathrm{~N}$ & 15 & 50 & 20 & $1 \mathrm{~N}$ & $10 \mathrm{~N}$ & $20 \mathrm{~N}$ \\
\hline $\mathrm{MC} 007 \mathrm{R}$ & $7^{\circ} 22^{\prime} 30^{\prime \prime}$ & $61^{\circ} 56^{\prime} 00^{\prime \prime}$ & 3 & $0.01 \mathrm{~L}$ & 10 & 1.5 & 3 & $0.2 \mathrm{~N}$ & 1 & 1.5 & $200 \mathrm{~L}$ & $10 \mathrm{~N}$ & 15 & 30 & $1 \mathrm{~N}$ & $10 \mathrm{~N}$ & $20 \mathrm{~N}$ \\
\hline MCOO8R & $7^{\circ} 22^{\prime} 30^{\prime \prime}$ & $61^{\circ} 56^{\prime} 00^{\prime \prime}$ & 0.1 & $0.01 \mathrm{~L}$ & 0.07 & 0.07 & $0.2 \mathrm{~N}$ & $0.2 \mathrm{~N}$ & 0.007 & $0.5 \mathrm{~N}$ & $200 \mathrm{~N}$ & $10 \mathrm{~N}$ & 10 & $20 \mathrm{~L}$ & $1 \mathrm{~N}$ & $10 \mathrm{~N}$ & $20 \mathrm{~N}$ \\
\hline $\mathrm{MC} 009 \mathrm{R}$ & $7^{\circ} 22^{\prime} 30^{\prime \prime}$ & $61^{\circ} 56^{\prime} 00^{\prime \prime}$ & 0.7 & $0.01 \mathrm{~L}$ & 0.3 & 0.3 & $0.2 \mathrm{~N}$ & $0.2 \mathrm{~N}$ & 0.03 & $0.5 \mathrm{~N}$ & $200 \mathrm{~N}$ & $10 \mathrm{~N}$ & 150 & 20 & $1 \mathrm{~N}$ & $10 \mathrm{~N}$ & $20 \mathrm{~N}$ \\
\hline MCOIOR & $7^{\circ} 22^{\prime} 30^{\prime \prime}$ & $61^{\circ} 56^{\prime} 00^{\prime \prime}$ & 7 & $0.01 \mathrm{~L}$ & 5 & 1.5 & 3 & $0.2 \mathrm{~N}$ & 0.5 & $0.5 \mathrm{~N}$ & $200 \mathrm{~N}$ & $10 \mathrm{~N}$ & $10 \mathrm{~N}$ & 20 & $1 \mathrm{~N}$ & $10 \mathrm{~N}$ & $20 \mathrm{~N}$ \\
\hline MC011R & $7^{\circ} 22^{\prime} 30^{\prime \prime}$ & $61^{\circ} 56^{\circ} 00^{\prime \prime}$ & 7 & 0.02 & 7 & 1 & 3 & $0.2 \mathrm{~L}$ & 0.5 & 7 & $200 \mathrm{~N}$ & 70 & 20 & 50 & $1 \mathrm{~L}$ & $10 \mathrm{~N}$ & $20 \mathrm{~N}$ \\
\hline MC012R & $7^{\circ} 22^{\prime} 30^{\prime \prime}$ & $61^{\circ} 56^{\prime} 00^{\prime \prime}$ & 7 & $0.01 \mathrm{~L}$ & 7 & 0.7 & 1.5 & $0.2 \mathrm{~N}$ & 0.5 & $0.5 \mathrm{~N}$ & $200 \mathrm{~N}$ & $10 \mathrm{~N}$ & 30 & 70 & $1 \mathrm{~L}$ & $10 \mathrm{~N}$ & $20 \mathrm{~N}$ \\
\hline MC013R & $7^{\circ} 22^{\prime} 30^{\prime \prime}$ & $61^{\circ} 56^{\prime} 00^{\prime \prime}$ & 3 & $0.01 \mathrm{~L}$ & 7 & 1 & 2 & $0.2 \mathrm{~N}$ & 1 & $0.5 \mathrm{~N}$ & $200 \mathrm{~N}$ & $10 \mathrm{~N}$ & $10 \mathrm{~N}$ & $20 \mathrm{~N}$ & $1 \mathrm{~N}$ & $10 \mathrm{~N}$ & $20 \mathrm{~N}$ \\
\hline & $\mathrm{Co}-\mathrm{S}$ & Cr $-S$ & $\mathrm{Cu}-\mathrm{S}$ & Ga-S & $\mathrm{Ge}-\mathrm{S}$ & La-S & $\mathrm{Mn}-\mathrm{S}$ & Mo-S & $\mathrm{Nb}-\mathrm{S}$ & $\mathrm{Ni}-\mathrm{S}$ & Pb-S & Sb-S & Sc-S & Sn-S & SI-S & Th-S & V-S \\
\hline MC001R & $10 \mathrm{~N}$ & 15 & $5 \mathrm{~L}$ & $5 \mathbf{L}$ & $10 \mathrm{~N}$ & $50 \mathrm{~N}$ & 300 & $5 \mathrm{~N}$ & $20 \mathrm{~N}$ & 7 & $10 \mathrm{~L}$ & $100 \mathrm{~N}$ & 7 & $10 \mathrm{~N}$ & $100 \mathrm{~N}$ & $100 \mathrm{~N}$ & 70 \\
\hline $\mathrm{MCO} 2 \mathrm{R}$ & 70 & $10 \mathrm{~L}$ & 100 & 50 & $10 \mathrm{~N}$ & $50 \mathrm{~N}$ & 1,000 & $5 \mathrm{~N}$ & $20 \mathrm{~N}$ & 10 & 10 & $100 \mathrm{~N}$ & 30 & $10 \mathrm{~N}$ & $100 \mathrm{~L}$ & $100 \mathrm{~N}$ & 300 \\
\hline MC003R & 100 & $10 \mathrm{~N}$ & 20 & 20 & $10 \mathrm{~N}$ & $50 \mathrm{~N}$ & 1,500 & $5 \mathrm{~N}$ & $20 \mathrm{~N}$ & $5 \mathbf{L}$ & 15 & $100 \mathrm{~N}$ & 30 & $10 \mathrm{~N}$ & 100 & $100 \mathrm{~N}$ & 150 \\
\hline MC004R & 70 & $10 \mathrm{~L}$ & 20 & 50 & $10 \mathrm{~N}$ & $50 \mathrm{~N}$ & 1,500 & $5 N$ & $20 \mathrm{~N}$ & $5 \mathrm{~L}$ & 15 & $100 \mathrm{~N}$ & 30 & $10 \mathrm{~N}$ & 100 & $100 \mathrm{~N}$ & 200 \\
\hline MCO0SR & 30 & $10 \mathrm{~L}$ & 30 & 15 & $10 \mathrm{~N}$ & $50 \mathrm{~N}$ & 1,000 & $5 \mathrm{~N}$ & $20 \mathrm{~N}$ & $\$ L$ & 10 & $100 \mathrm{~N}$ & 20 & $10 \mathrm{~N}$ & $100 \mathrm{~N}$ & $100 \mathrm{~N}$ & 200 \\
\hline MC007R & 100 & $10 \mathrm{~N}$ & 300 & 20 & $10 \mathrm{~N}$ & $50 \mathrm{~N}$ & 700 & $5 \mathrm{~N}$ & $20 \mathrm{~N}$ & 50 & 15 & $100 \mathrm{~N}$ & 30 & $10 \mathrm{~N}$ & $100 \mathrm{~N}$ & $100 \mathrm{~N}$ & 500 \\
\hline MC008R & $10 \mathrm{~N}$ & $10 \mathrm{~N}$ & $5 \mathrm{~N}$ & $5 \mathrm{~N}$ & $10 \mathrm{~N}$ & $50 \mathrm{~N}$ & 30 & $5 \mathrm{~N}$ & $20 \mathrm{~N}$ & $5 \mathrm{~N}$ & $10 \mathrm{~N}$ & $100 \mathrm{~N}$ & $5 \mathrm{~N}$ & $10 \mathrm{~N}$ & $100 \mathrm{~N}$ & $100 \mathrm{~N}$ & 10 \\
\hline $\mathrm{MCO} 09 \mathrm{R}$ & $10 \mathrm{~N}$ & IOL & $5 \mathrm{~N}$ & $5 \mathrm{~N}$ & $10 \mathrm{~N}$ & $50 \mathrm{~N}$ & 200 & $5 \mathrm{~N}$ & $20 \mathrm{~N}$ & $5 \mathrm{~N}$ & $10 \mathrm{~L}$ & $100 \mathrm{~N}$ & $5 \mathrm{~N}$ & $10 N$ & $100 \mathrm{~N}$ & $100 \mathrm{~N}$ & 50 \\
\hline MC010R & 30 & $10 \mathrm{~N}$ & 100 & 30 & $10 \mathrm{~N}$ & $50 \mathrm{~N}$ & 1,000 & $5 \mathrm{~N}$ & $20 \mathrm{~N}$ & 30 & 10 & $100 \mathrm{~N}$ & 30 & $10 \mathrm{~N}$ & $100 \mathrm{~N}$ & $100 \mathrm{~N}$ & 300 \\
\hline MC011R & 30 & $10 \mathrm{~N}$ & 50 & 30 & $10 \mathrm{~N}$ & $50 \mathrm{~N}$ & 1,000 & $5 \mathrm{~N}$ & $20 \mathrm{~N}$ & $5 \mathrm{~N}$ & 10 & $100 \mathrm{~N}$ & 20 & $10 \mathrm{~N}$ & $100 \mathrm{~N}$ & $100 \mathrm{~N}$ & 150 \\
\hline MC012R & 30 & $10 \mathrm{~L}$ & 20 & 50 & $10 \mathrm{~N}$ & $50 \mathrm{~N}$ & 1,000 & $5 \mathrm{~N}$ & $20 \mathrm{~N}$ & $5 \mathrm{~N}$ & 10 & $100 \mathrm{~N}$ & 20 & $10 \mathrm{~N}$ & $100 \mathrm{~N}$ & $100 \mathrm{~N}$ & 70 \\
\hline MC013R & 30 & $10 \mathrm{~L}$ & 10 & 30 & $10 \mathrm{~N}$ & $50 \mathrm{~N}$ & 700 & $5 \mathrm{~N}$ & $20 \mathrm{~N}$ & $5 \mathrm{~L}$ & 10 & $100 \mathrm{~N}$ & 30 & $10 \mathrm{~N}$ & 100 & $100 \mathrm{~N}$ & 300 \\
\hline & W.S & Y-S & $\mathrm{Zn}-\mathrm{S}$ & $\mathrm{Zr}-\mathrm{S}$ & $\mathrm{As} / \mathrm{p}$ & $\mathrm{Au}$ & $\mathrm{Bi} / \mathrm{p}$ & $\mathrm{Cd} / \mathrm{p}$ & $\mathrm{Hg}$ & $\mathrm{Sb} / \mathrm{p}$ & $\mathrm{Te}$ & T] & $\mathrm{Zn} / \mathrm{p}$ & \multicolumn{3}{|c|}{ Sample description } & \\
\hline MCOOIR & $20 \mathrm{~N}$ & $10 \mathrm{~N}$ & $200 \mathrm{~N}$ & $10 \mathrm{~L}$ & 12 & 1.4 & $2 \mathrm{~L}$ & $0.1 \mathrm{~L}$ & 0.02 & $2 \mathrm{~L}$ & $0.05 \mathrm{~L}$ & $0.05 \mathrm{~L}$ & 20 & \multicolumn{4}{|c|}{ Quartz from Americana vein. } \\
\hline MCO02R & $20 \mathrm{~N}$ & 20 & $200 \mathrm{~L}$ & 20 & $5 \mathrm{~L}$ & $0.002 \mathrm{~L}$ & $2 \mathrm{~L}$ & 0.6 & 0.02 & $2 \mathrm{~L}$ & $0.05 \mathrm{~L}$ & $0.05 \mathrm{~L}$ & 96 & \multicolumn{4}{|c|}{ Host rock. } \\
\hline MC003R & $20 \mathrm{~L}$ & 30 & $200 \mathrm{~N}$ & 50 & 34 & 7.8 & $2 \mathrm{~L}$ & 0.3 & $0.02 \mathrm{~N}$ & $2 \mathbf{L}$ & 0.55 & $0.05 \mathrm{~L}$ & 50 & \multicolumn{4}{|c|}{ Breccia zone. } \\
\hline MC004R & $20 \mathrm{~N}$ & 20 & $200 \mathrm{~L}$ & 30 & $5 \mathrm{~L}$ & 0.034 & $2 \mathrm{~L}$ & 1.3 & $0.02 \mathrm{~N}$ & $2 L$ & $0.05 \mathrm{~L}$ & $0.05 \mathrm{~L}$ & 110 & \multicolumn{4}{|c|}{ Silicified host rock. } \\
\hline MCO05R & $20 \mathrm{~L}$ & 30 & $200 \mathrm{~N}$ & 50 & 21 & 7.5 & $2 \mathrm{~L}$ & 0.4 & $0.02 \mathrm{~N}$ & $2 L$ & 0.25 & $0.05 \mathrm{~L}$ & 40 & \multicolumn{4}{|c|}{ Secondary vein. } \\
\hline MCO07R & 70 & 30 & 200 & 50 & 87 & 10 & $2 \mathrm{~L}$ & l & $0.02 \mathrm{~N}$ & $2 \mathbf{L}$ & 0.45 & $0.05 \mathrm{~L}$ & 100 & \multicolumn{4}{|c|}{ Quartz from main Colombia vein. } \\
\hline MC008R & $20 \mathrm{~N}$ & $10 \mathrm{~N}$ & $200 \mathrm{~N}$ & $10 \mathrm{~N}$ & $5 \mathbf{L}$ & 0.030 & $2 \mathrm{~L}$ & $0.1 \mathrm{~L}$ & $0.02 \mathrm{~N}$ & $2 \mathbf{L}$ & $0.05 \mathrm{~L}$ & $0.05 \mathrm{~L}$ & $2 \mathrm{~L}$ & \multicolumn{4}{|c|}{ Clear vein quartz. } \\
\hline MCOO9R & $20 \mathrm{~N}$ & $10 \mathrm{~N}$ & $200 \mathrm{~N}$ & $10 \mathrm{~L}$ & $5 \mathbf{L}$ & 0.048 & $2 \mathrm{~L}$ & $0.1 \mathrm{~L}$ & $0.02 \mathrm{~N}$ & $2 \mathrm{~L}$ & $0.05 \mathrm{~L}$ & $0.05 \mathrm{~L}$ & $2 \mathrm{~L}$ & \multicolumn{4}{|c|}{ Vein with pyrite. } \\
\hline MCO10R & $20 \mathrm{~N}$ & 20 & $200 \mathrm{~L}$ & 70 & 7 & $0.002 \mathrm{~L}$ & $2 \mathrm{~L}$ & 1.4 & $0.02 \mathrm{~N}$ & $2 \mathbf{L}$ & $0.05 \mathrm{~L}$ & $0.05 \mathrm{~L}$ & 91 & \multicolumn{4}{|c|}{ Hanging wall (host). } \\
\hline MC011R & $20 \mathrm{~N}$ & 30 & $200 \mathrm{~N}$ & 70 & 33 & 10 & $2 \mathrm{~L}$ & 1.3 & $0.02 \mathrm{~N}$ & $2 \mathrm{~L}$ & 0.8 & 0.1 & 110 & \multicolumn{4}{|c|}{ Main Colombia vein. } \\
\hline MC012R & $20 \mathrm{~N}$ & 30 & $200 \mathrm{~L}$ & 70 & 5 & 0.250 & $2 \mathrm{~L}$ & 1.8 & 0.04 & $2 L$ & $0.05 \mathrm{~L}$ & 0.1 & 110 & \multicolumn{4}{|c|}{ Host rock. } \\
\hline MC013R & $20 \mathrm{~N}$ & 30 & $200 \mathrm{~N}$ & 50 & $5 \mathrm{~L}$ & 0.03 & $2 \mathrm{~L}$ & 1.9 & $0.02 \mathrm{~N}$ & $2 \mathrm{~L}$ & $0.05 \mathrm{~L}$ & $0.05 \mathrm{~L}$ & 91 & \multicolumn{4}{|c|}{ Host rock (greenstone). } \\
\hline
\end{tabular}


Appendix table 2. Rock samples collected from Mina Sar Pedro, El Callao district, Venezuela.

\begin{tabular}{|c|c|c|c|c|c|c|c|c|c|c|c|c|c|c|c|c|c|}
\hline & Latitude & Longitude & $\mathrm{Ca} \%-\mathrm{S}$ & $\mathrm{F} \%$ & $\mathrm{Fe} \%-\mathrm{S}$ & $\mathrm{Mg} \%-\mathrm{S}$ & $\mathrm{Na} \%-\mathrm{S}$ & $\mathrm{P} \%-\mathrm{S}$ & $\mathrm{Ti} \%-\mathrm{S}$ & $\mathrm{Ag}-\mathrm{S}$ & As-S & $\mathrm{Au}-\mathrm{S}$ & B-S & $\mathrm{Ba}-\mathrm{S}$ & Be-S & $\mathrm{Bi}-\mathrm{S}$ & $\mathrm{Cd}-\mathrm{S}$ \\
\hline$\overline{L I} 006 \mathrm{R}$ & $7^{\circ} 25^{\prime} 00^{\prime \prime}$ & $61^{\circ} 48^{\prime} 00^{\prime \prime}$ & $0.05 \mathrm{~L}$ & 0.02 & 3 & 0.3 & 2 & $0.2 \mathrm{~N}$ & 0.7 & $0.5 \mathrm{~N}$ & $200 \mathrm{~N}$ & $10 \mathrm{~N}$ & 1,000 & 1,500 & 1 & $10 \mathrm{~N}$ & $20 \mathrm{~N}$ \\
\hline LI013R & $7^{\circ} 25^{\prime} 00^{\prime \prime}$ & $61^{\circ} 48^{\circ} 00^{\prime \prime}$ & $0.05 \mathrm{~L}$ & 0.02 & 3 & 1 & 0.7 & $0.2 \mathrm{~N}$ & 0.5 & $0.5 \mathrm{~N}$ & $200 \mathrm{~N}$ & $10 \mathrm{~L}$ & $2,000 \mathrm{G}$ & 150 & $1 \mathrm{~L}$ & $10 \mathrm{~N}$ & $20 \mathrm{~N}$ \\
\hline LIO14R & $7^{\circ} 25^{\prime} 00^{\prime \prime}$ & $61^{\circ} 48^{\circ} 00^{\prime \prime}$ & $0.05 \mathrm{~L}$ & 0.01 & $s$ & 0.7 & 1.5 & $0.2 \mathrm{~N}$ & 0.5 & $0.5 \mathrm{~N}$ & $200 \mathrm{~N}$ & $10 \mathrm{~N}$ & 2,000 & 700 & $1 \mathrm{~L}$ & $10 \mathrm{~N}$ & $20 \mathrm{~N}$ \\
\hline LIO2OR & $7^{\circ} 25^{\circ} 00^{\prime \prime}$ & $61^{\circ} 48^{\prime} 00^{\prime \prime}$ & $0.05 \mathrm{~N}$ & $0.01 \mathrm{~L}$ & 1.5 & 0.2 & $0.2 \mathrm{~N}$ & $0.2 \mathrm{~N}$ & 0.1 & $0.5 \mathrm{~L}$ & $200 \mathrm{~N}$ & 10 & 1,500 & 300 & $1 \mathrm{~N}$ & $10 \mathrm{~N}$ & $20 \mathrm{~N}$ \\
\hline L1027R & $7^{\circ} 25^{\prime} 00^{\prime \prime}$ & $61^{\circ} 48^{\prime} 00^{\prime \prime}$ & $0.05 \mathrm{~N}$ & 0.02 & 5 & 0.3 & 1.5 & $0.2 \mathrm{~N}$ & 0.5 & $0.5 \mathrm{~N}$ & $200 \mathrm{~N}$ & $10 \mathrm{~N}$ & 1,500 & 700 & 1 & $10 \mathrm{~N}$ & $20 \mathrm{~N}$ \\
\hline L1038R & $7^{\circ} 25^{\prime} 00^{\prime \prime}$ & $61^{\circ} 48^{\prime} 00^{\prime \prime}$ & $0.05 \mathrm{~L}$ & 0.02 & 3 & 0.3 & 2 & $0.2 \mathrm{~N}$ & 0.5 & $0.5 \mathrm{~N}$ & $200 \mathrm{~N}$ & $10 \mathrm{~N}$ & 2,000 & 1,000 & 1 & $10 \mathrm{~N}$ & $20 \mathrm{~N}$ \\
\hline LJ041R & $7^{\circ} 25^{\prime} 00^{\prime \prime}$ & $61^{\circ} 48^{\prime} 00^{\prime \prime}$ & $0.05 \mathrm{~L}$ & 0.02 & 2 & 0.7 & 1 & $0.2 \mathrm{~N}$ & 0.3 & $0.5 \mathrm{~N}$ & $200 \mathrm{~N}$ & $10 \mathrm{~N}$ & $2,000 \mathrm{G}$ & 300 & $\mathrm{tL}$ & $10 \mathrm{~N}$ & $20 \mathrm{~N}$ \\
\hline LI044R & $7^{\circ} 25^{\prime} 00^{\prime \prime}$ & $61^{\circ} 48^{\prime} 00^{\prime \prime}$ & $0.05 \mathrm{~L}$ & 0.02 & 3 & 0.1 & 1 & $0.2 \mathbf{L}$ & 0.3 & $0.5 \mathrm{~N}$ & $200 \mathrm{~N}$ & $10 \mathrm{~N}$ & 500 & 700 & 1 & $10 \mathrm{~N}$ & $20 \mathrm{~N}$ \\
\hline LlO60R & $7^{\circ} 25^{\prime} 00^{\prime \prime}$ & $61^{\circ} 48^{\prime} 00^{\prime \prime}$ & $0.05 \mathrm{~L}$ & 0.02 & 2 & 0.15 & 1.5 & $0.2 \mathrm{~L}$ & 0.3 & $0.5 \mathrm{~N}$ & $200 \mathrm{~N}$ & $10 \mathrm{~N}$ & 500 & 700 & 1 & $10 \mathrm{~N}$ & $20 \mathrm{~N}$ \\
\hline & Co-S & $\mathrm{Cr}-\mathrm{S}$ & $\mathrm{Cu}-\mathrm{S}$ & Ga-S & Ge-S & La-S & $\mathrm{Mn}-\mathrm{S}$ & Mo-S & $\mathrm{Nb}-\mathrm{S}$ & Ni-S & $\mathrm{Pb}-\mathrm{S}$ & Sb-S & Se-S & $\mathrm{Sn}-\mathrm{S}$ & Sr-S & Th-S & $\mathrm{V}-\mathrm{S}$ \\
\hline$\overline{L I 006 R}$ & $10 \mathrm{~N}$ & 70 & 30 & 50 & $10 \mathrm{~N}$ & 70 & 30 & $5 \mathrm{~N}$ & $20 \mathrm{~N}$ & 20 & 15 & $100 \mathrm{~N}$ & 7 & $10 \mathrm{~N}$ & 700 & $100 \mathrm{~N}$ & 150 \\
\hline LI013R & $10 \mathrm{~L}$ & 50 & 30 & 20 & $10 \mathrm{~N}$ & $50 \mathrm{~L}$ & 50 & $5 \mathrm{~N}$ & $20 \mathrm{~N}$ & 30 & 10 & $100 \mathrm{~N}$ & 7 & $10 \mathrm{~N}$ & 200 & $100 \mathrm{~N}$ & 150 \\
\hline LI014R & 10 & 50 & 30 & 30 & $10 \mathrm{~N}$ & 50 & 150 & $5 \mathrm{~N}$ & $20 \mathrm{~L}$ & 20 & 20 & $100 \mathrm{~N}$ & 7 & $10 N$ & 500 & $100 \mathrm{~N}$ & 100 \\
\hline LIO20R & $10 \mathrm{~N}$ & 10 & 7 & $5 \mathrm{~L}$ & $10 \mathrm{~N}$ & $50 \mathrm{~L}$ & 150 & $5 \mathrm{~N}$ & $20 \mathrm{~N}$ & 7 & $10 \mathrm{~L}$ & $100 \mathrm{~N}$ & $5 \mathrm{~L}$ & $10 \mathrm{~N}$ & $100 \mathrm{~N}$ & $100 \mathrm{~N}$ & 70 \\
\hline LI027R & 10 & 100 & 50 & 20 & $10 \mathrm{~N}$ & $50 \mathrm{~L}$ & 150 & $5 \mathrm{~N}$ & $20 \mathrm{~N}$ & 30 & 20 & $100 \mathrm{~N}$ & 10 & $10 \mathrm{~N}$ & 500 & $100 \mathrm{~N}$ & 100 \\
\hline LI038R & $10 \mathrm{~L}$ & 70 & 50 & 30 & $10 N$ & 50 & 200 & $5 \mathrm{~N}$ & $20 \mathrm{~N}$ & 20 & 20 & $100 \mathrm{~N}$ & 15 & $10 \mathrm{~N}$ & 500 & $100 \mathrm{~N}$ & 150 \\
\hline LI041R & $10 \mathrm{~N}$ & 30 & 20 & 15 & $10 \mathrm{~N}$ & $50 \mathrm{~L}$ & 30 & $5 \mathrm{~N}$ & $20 \mathrm{~N}$ & 15 & 10 & $100 \mathrm{~N}$ & 5 & $10 \mathrm{~N}$ & 200 & $100 \mathrm{~N}$ & 70 \\
\hline LIO44R & 20 & 30 & 50 & 20 & $10 \mathrm{~N}$ & 70 & 150 & $5 \mathrm{~N}$ & $20 \mathrm{~N}$ & 50 & 20 & $100 \mathrm{~N}$ & 7 & $10 \mathrm{~N}$ & 300 & $100 \mathrm{~N}$ & 50 \\
\hline$\underline{\mathrm{LIO60R}}$ & $10 \mathrm{~L}$ & 20 & 30 & 20 & $10 \mathrm{~N}$ & $50 \mathrm{~L}$ & 100 & $5 \mathrm{~N}$ & $20 \mathrm{~N}$ & 20 & 15 & $100 \mathrm{~N}$ & SL & $10 \mathrm{~N}$ & 500 & $100 \mathrm{~N}$ & 100 \\
\hline & W-S & $\mathrm{Y}-\mathrm{S}$ & $\mathrm{Zn}-\mathrm{S}$ & $\mathrm{Zr}-\mathrm{S}$ & As/p & $\mathrm{Au}$ & $\mathrm{Bi} / \mathrm{p}$ & $\mathrm{Cd} / \mathrm{p}$ & $\mathrm{Hg}$ & $\mathrm{Sb} / \mathrm{p}$ & $\mathrm{Te}$ & T] & $\mathrm{Zn} / \mathrm{p}$ & \multicolumn{3}{|c|}{ Sample description } & \\
\hline LI006R & $20 \mathrm{~N}$ & 20 & $200 \mathrm{~N}$ & 150 & 47 & 0.012 & $2 \mathrm{~L}$ & 0.3 & $0.02 \mathrm{~N}$ & $2 \mathrm{~L}$ & 0.05 & 0.1 & 12 & \multirow{2}{*}{\multicolumn{3}{|c|}{$\begin{array}{l}\text { Altered weathered schist. } \\
\text { Breccia zone. }\end{array}$}} & \\
\hline LIO13R & $20 \mathrm{~N}$ & 10 & $200 \mathrm{~N}$ & 100 & 31 & 8.3 & $2 \mathrm{~L}$ & 0.3 & $0.02 \mathrm{~N}$ & $2 L$ & 0.05 & $0.05 \mathrm{~L}$ & 11 & & & & \\
\hline LI014R & $20 \mathrm{~N}$ & 15 & $200 \mathrm{~N}$ & 150 & 76 & 0.044 & $2 \mathrm{~L}$ & 0.6 & 0.02 & $2 \mathbf{L}$ & 0.05 & 0.1 & 25 & \multicolumn{3}{|c|}{ Wallrock (schist?). } & \\
\hline LI020R & $20 \mathrm{~N}$ & $10 \mathrm{~L}$ & $200 \mathrm{~N}$ & 30 & 21 & 0.6 & $2 \mathrm{~L}$ & 0.2 & 0.04 & $2 \mathbf{L}$ & $0.05 \mathrm{~L}$ & $0.05 \mathrm{~L}$ & 6 & \multicolumn{3}{|c|}{ Quartz vein, breccia zone. } & \\
\hline LI027R & 20 & 20 & $200 \mathrm{~N}$ & 150 & 95 & 0.1 & $2 \mathrm{~L}$ & 0.7 & 0.04 & $2 \mathbf{L}$ & 0.1 & 0.15 & 28 & \multicolumn{3}{|c|}{ Schist with sericite. } & \\
\hline LI038R & 20 & 20 & $200 \mathrm{~N}$ & 200 & 69 & 0.014 & $2 \mathrm{~L}$ & 0.6 & 0.04 & $2 \mathbf{L}$ & 0.05 & 0.15 & 26 & \multicolumn{3}{|c|}{ Wallrock schist. } & \\
\hline LI041R & $20 \mathrm{~N}$ & $10 \mathrm{~L}$ & $200 \mathrm{~N}$ & 70 & 25 & 0.018 & $2 \mathrm{~L}$ & 0.2 & $0.02 \mathrm{~N}$ & $2 \mathbf{L}$ & 0.05 & 0.05 & 8 & \multicolumn{3}{|c|}{ Breccia zone, some quartz. } & \\
\hline LI044R & $20 \mathrm{~N}$ & 15 & $200 \mathrm{~N}$ & 150 & 82 & 0.016 & $2 \mathbf{L}$ & 2.4 & 0.04 & $2 \mathbf{L}$ & $0.05 \mathrm{~L}$ & 0.15 & 31 & \multirow{2}{*}{\multicolumn{3}{|c|}{ Wallirock. }} & \\
\hline LI060R & $20 \mathrm{~N}$ & $10 \mathrm{~L}$ & $200 \mathrm{~N}$ & 70 & 56 & 0.15 & $2 \mathrm{~L}$ & 0.4 & 0.04 & $2 \mathrm{~L}$ & 0.05 & 0.1 & 15 & & & & \\
\hline
\end{tabular}


Appendix table 3. Rock samples collected from trench T1, Bochinche area, Venezuela.

\begin{tabular}{|c|c|c|c|c|c|c|c|c|c|c|c|c|c|c|c|c|c|}
\hline & Latitude & Longitude & $\mathrm{Ca} \%-\mathrm{S}$ & $\mathrm{F} \%$ & Fe\%-S & $\mathrm{Mg} \%-\mathrm{S}$ & $\mathrm{Na} \%-\mathrm{S}$ & $\mathrm{P} \%-\mathrm{S}$ & $\mathrm{Ti} \% \cdot \mathrm{S}$ & Ag.S & As-S & Au-S & B-S & $\mathrm{Ba}-\mathrm{S}$ & $\mathrm{Be}-\mathrm{S}$ & $\mathrm{Bi}-\mathrm{S}$ & Cd-S \\
\hline$\overline{\mathrm{BCOOOR}}$ & $7^{\circ} 33^{\prime} 00^{\prime \prime}$ & $60^{\circ} 48^{\prime} 00^{\prime \prime}$ & $0.05 \mathrm{~N}$ & 0.02 & 7 & 0.3 & 2 & $0.2 \mathrm{~N}$ & 1 & $0.5 \mathrm{~N}$ & $200 \mathrm{~N}$ & $10 \mathrm{~N}$ & 500 & 1,000 & $\mathrm{IL}$ & $10 \mathrm{~N}$ & $20 \mathrm{~N}$ \\
\hline BCO14R & $7^{\circ} 33^{\prime} 00^{\prime \prime}$ & $60^{\circ} 48^{\prime} 00^{\prime \prime}$ & $0.05 \mathrm{~L}$ & $0.01 \mathrm{~L}$ & 1.5 & 0.05 & $0.2 \mathrm{~L}$ & $0.2 \mathrm{~N}$ & 0.3 & $0.5 \mathrm{~N}$ & $200 \mathrm{~N}$ & $10 \mathrm{~N}$ & 200 & 700 & IN & $10 \mathrm{~N}$ & $20 N$ \\
\hline BCO16R & $7^{\circ} 33^{\prime} 00^{\prime \prime}$ & $60^{\circ} 48^{\prime} 00^{\prime \prime}$ & $0.05 \mathrm{~L}$ & 0.01 & 7 & 0.1 & 1 & $0.2 \mathrm{~N}$ & 0.7 & $0.5 \mathrm{~N}$ & $200 \mathrm{~N}$ & $10 \mathrm{~N}$ & 20 & 700 & 1.5 & $10 \mathrm{~N}$ & $20 \mathrm{~N}$ \\
\hline $\mathrm{BCO} 27 \mathrm{R}$ & $7^{\circ} 33^{\prime} 00^{\prime \prime}$ & $60^{\circ} 48^{\prime} 00^{\prime \prime}$ & $0.05 \mathrm{~L}$ & $0.01 \mathrm{~L}$ & 3 & 0.07 & $0.2 \mathrm{~N}$ & $0.2 \mathrm{~N}$ & 0.1 & $0.5 \mathrm{~N}$ & $200 \mathrm{~N}$ & $10 \mathrm{~N}$ & 500 & 500 & נN & $10 \mathrm{~N}$ & $20 \mathrm{~N}$ \\
\hline $\mathrm{BCO} 28 \mathrm{R}$ & $7^{\circ} 33^{\prime} 00^{\prime \prime}$ & $60^{\circ} 48^{\prime} 00^{\prime \prime}$ & $0.05 \mathrm{~N}$ & 0.02 & 15 & 0.15 & 1.5 & $0.2 \mathrm{~N}$ & 0.7 & $0.5 \mathrm{~N}$ & $200 \mathrm{~N}$ & $10 \mathrm{~N}$ & 30 & 2,000 & 1 & $10 \mathrm{~N}$ & $20 \mathrm{~N}$ \\
\hline $\mathrm{BC} 048 \mathrm{R}$ & $7^{\circ} 33^{\prime} 00^{\prime \prime}$ & $60^{\circ} 48^{\prime} 00^{\prime \prime}$ & $0.05 \mathrm{~N}$ & $0.01 \mathrm{~L}$ & 7 & 0.07 & $0.2 \mathrm{~N}$ & $0.2 \mathrm{~N}$ & 0.7 & $0.5 \mathrm{~L}$ & $200 \mathrm{~N}$ & $10 \mathrm{~N}$ & $10 \mathrm{~N}$ & 150 & $1 \mathrm{~L}$ & $10 \mathrm{~N}$ & $20 \mathrm{~N}$ \\
\hline $\mathrm{BC} 063 \mathrm{R}$ & $7^{\circ} 33^{\prime} 00^{\prime \prime}$ & $60^{\circ} 48^{\prime} 00^{\prime \prime}$ & $0.05 \mathrm{~L}$ & $0.01 \mathrm{~L}$ & 7 & 0.1 & 0.2 & $0.2 \mathrm{~N}$ & 0.7 & $0.5 \mathrm{~N}$ & $200 \mathrm{~N}$ & $10 \mathrm{~N}$ & 100 & 1,500 & 1 & $10 \mathrm{~N}$ & $20 \mathrm{~N}$ \\
\hline $\mathrm{BCO} 2 \mathrm{R}$ & $7^{\circ} 33^{\prime} 00^{\prime \prime}$ & $60^{\circ} 48^{\prime} 00^{\prime \prime}$ & $0.05 \mathrm{~L}$ & $0.01 \mathrm{~L}$ & 7 & 0.15 & 0.5 & $0.2 \mathrm{~N}$ & 0.5 & $0.5 \mathrm{~N}$ & $200 \mathrm{~N}$ & $10 \mathrm{~N}$ & 200 & 1,000 & 1 & $10 \mathrm{~N}$ & $20 \mathrm{~N}$ \\
\hline $\mathrm{BC} 074 \mathrm{R}$ & $7^{\circ} 33^{\prime} 00^{\prime \prime}$ & $60^{\circ} 48^{\prime} 00^{\prime \prime}$ & $0.05 \mathrm{~N}$ & 0.02 & 7 & 0.15 & 0.7 & $0.2 \mathrm{~L}$ & 0.7 & $0.5 \mathrm{~N}$ & $200 \mathrm{~N}$ & $10 \mathrm{~N}$ & 30 & 700 & 1 & $10 N$ & $20 \mathrm{~N}$ \\
\hline $\mathrm{BCO} 0 \mathrm{R}$ & $7^{\circ} 33^{\prime} 00^{\prime \prime}$ & $60^{\circ} 48^{\prime} 00^{\prime \prime}$ & $0.05 \mathrm{~L}$ & $0.01 \mathrm{~L}$ & 3 & 0.15 & $0.2 \mathrm{~L}$ & $0.2 \mathrm{~N}$ & 0.2 & $0.5 \mathrm{~N}$ & $200 \mathrm{~N}$ & $10 \mathrm{~N}$ & 500 & 300 & $1 \mathrm{~L}$ & $10 N$ & $20 \mathrm{~N}$ \\
\hline $\mathrm{BCO} 22 \mathrm{R}$ & $7^{\circ} 33^{\prime} 00^{\prime \prime}$ & $60^{\circ} 48^{\prime} 00^{\prime \prime}$ & $0.05 \mathrm{~L}$ & 0.02 & 7 & 0.5 & 1.5 & $0.2 \mathrm{~N}$ & 1 & $0.5 \mathrm{~N}$ & $200 \mathrm{~N}$ & $10 \mathrm{~N}$ & 1,500 & 1,500 & 1.5 & $10 \mathrm{~N}$ & $20 \mathrm{~N}$ \\
\hline $\mathrm{BC} 090 \mathrm{R}$ & $7^{\circ} 33^{\prime} 00^{11}$ & $60^{\circ} 48^{\prime} 00^{\prime \prime}$ & $0.05 \mathrm{~L}$ & $0.01 \mathrm{~L}$ & 0.5 & 0.1 & $0.2 \mathrm{~N}$ & $0.2 \mathrm{~N}$ & 0.07 & $0.5 \mathrm{~N}$ & $200 \mathrm{~N}$ & $10 \mathrm{~N}$ & 500 & 150 & IN & $10 N$ & $20 \mathrm{~N}$ \\
\hline BC095R & $7^{\circ} 33^{\prime} 00^{\prime \prime}$ & $60^{\circ} 48^{\prime} 00^{\prime \prime}$ & $0.05 \mathrm{~L}$ & 0.01 & 10 & 0.07 & 0.2 & $0.2 \mathrm{~L}$ & 0.5 & $0.5 \mathrm{~N}$ & $200 \mathrm{~N}$ & $10 \mathrm{~N}$ & 30 & 700 & 1.5 & $10 \mathrm{~N}$ & $20 \mathrm{~N}$ \\
\hline $\mathrm{BCl} 100 \mathrm{R}$ & $7^{\circ} 33^{\prime} 00^{\mu}$ & $60^{\circ} 48^{\prime} 00^{\prime \prime}$ & $0.05 \mathrm{~L}$ & $0.01 \mathrm{~L}$ & 7 & 0.5 & 0.5 & $0.2 \mathrm{~N}$ & 0.3 & $0.5 \mathrm{~N}$ & $200 \mathrm{~N}$ & $10 \mathrm{~N}$ & $2,000 \mathrm{G}$ & 500 & 1 & $10 \mathrm{~N}$ & $20 \mathrm{~N}$ \\
\hline BC114R & $7^{\circ} 33^{\prime} 00^{n}$ & $60^{\circ} 48^{\prime} 00^{\prime \prime}$ & $0.05 \mathrm{~L}$ & $0.01 \mathbf{L}$ & 0.3 & 0.1 & $0.2 \mathrm{~N}$ & $0.2 \mathrm{~N}$ & 0.015 & $0.5 \mathrm{~N}$ & $200 \mathrm{~N}$ & $10 \mathrm{~N}$ & 500 & 50 & IN & $10 N$ & $20 \mathrm{~N}$ \\
\hline BC106R & $7^{\circ} 33^{\prime} 00^{\prime \prime}$ & $60^{\circ} 48^{\prime} 00^{\prime \prime}$ & $0.05 \mathrm{~L}$ & $0.01 \mathbf{L}$ & 0.5 & 0.07 & $0.2 \mathrm{~N}$ & $0.2 \mathrm{~N}$ & 0.020 & $0.5 \mathrm{~N}$ & $200 \mathrm{~N}$ & $10 \mathrm{~N}$ & 300 & 100 & IN & $10 \mathrm{~N}$ & $20 \mathrm{~N}$ \\
\hline BCl31R & $7^{\circ} 33^{\prime} 00^{\prime \prime}$ & $60^{\circ} 48^{\prime} 00^{\prime \prime}$ & $0.05 \mathrm{~L}$ & $0.01 \mathrm{~L}$ & 1.5 & 0.02 & $0.2 \mathrm{~N}$ & $0.2 \mathrm{~N}$ & 0.015 & $0.5 \mathrm{~N}$ & $200 \mathrm{~N}$ & $10 \mathrm{~N}$ & 70 & 200 & IN & $10 N$ & $20 \mathrm{~N}$ \\
\hline BC133R & $7^{\circ} 33^{\prime} 00^{\prime \prime}$ & $60^{\circ} 48^{\prime} 00^{\prime \prime}$ & $0.05 \mathrm{~N}$ & 0.01 & 7 & 0.2 & 2 & $0.2 \mathrm{~N}$ & 0.5 & $0.5 \mathrm{~N}$ & $200 \mathrm{~N}$ & $10 \mathrm{~N}$ & 300 & 1,500 & 1.5 & $10 \mathrm{~N}$ & $20 \mathrm{~N}$ \\
\hline BC141R & $7^{\circ} 33100^{n}$ & $60^{\circ} 48^{\prime} 00^{\prime \prime}$ & $0.05 \mathrm{~L}$ & 0.02 & 10 & 0.2 & 1 & $0.2 \mathrm{~L}$ & 0.3 & $0.5 \mathrm{~N}$ & $200 \mathrm{~N}$ & $10 \mathrm{~N}$ & 1,500 & 1,000 & 1.5 & $10 \mathrm{~N}$ & $20 \mathrm{~N}$ \\
\hline $\mathrm{BC} 156 \mathrm{R}$ & $7^{\circ} 33^{\prime} 00^{\prime \prime}$ & $60^{\circ} 48^{\prime} 00^{\prime \prime}$ & $0.05 \mathrm{~N}$ & 0.01 & 7 & 0.1 & 0.7 & $0.2 \mathrm{~L}$ & 0.7 & $0.5 \mathrm{~N}$ & $200 \mathrm{~N}$ & $10 \mathrm{~N}$ & 300 & 500 & 1 & $10 N$ & $20 \mathrm{~N}$ \\
\hline BC157R & $7^{\circ} 33^{\prime} 00^{\prime \prime}$ & $60^{\circ} 48^{\prime} 00^{\prime \prime}$ & $0.05 \mathrm{~L}$ & $0.01 \mathrm{~L}$ & 3 & 0.2 & 0.5 & $0.2 \mathrm{~L}$ & 0.7 & $0.5 \mathrm{~N}$ & $200 \mathrm{~N}$ & $10 \mathrm{~N}$ & 1,000 & 700 & $1 \mathrm{~L}$ & $10 \mathrm{~N}$ & $20 \mathrm{~N}$ \\
\hline BC164R & $7^{\circ} 33^{\prime} 00^{\prime \prime}$ & $60^{\circ} 48^{\prime} 00^{\prime \prime}$ & $0.05 \mathrm{~N}$ & $0.01 \mathbf{L}$ & 7 & 0.15 & 0.7 & $0.2 \mathrm{~N}$ & 0.7 & $0.5 \mathrm{~N}$ & $200 \mathrm{~N}$ & $10 \mathrm{~N}$ & 70 & 700 & 1 & $10 \mathrm{~N}$ & $20 \mathrm{~N}$ \\
\hline $\mathrm{BC} 189 \mathrm{R}$ & $7^{\circ} 33^{\prime} 00^{\prime \prime}$ & $60^{\circ} 48^{\prime} 00^{\prime \prime}$ & $0.05 \mathrm{~L}$ & 0.02 & 5 & 0.1 & 0.3 & $0.2 \mathrm{~N}$ & 0.3 & $0.5 \mathrm{~N}$ & $200 \mathrm{~N}$ & $10 \mathrm{~N}$ & 700 & 700 & 1.5 & $10 N$ & $20 \mathrm{~N}$ \\
\hline \multirow[t]{2}{*}{ BC135R } & $7^{\circ} 33^{\prime} 00^{\prime \prime}$ & $60^{\circ} 48^{\prime} 00^{\prime \prime}$ & $0.05 \mathrm{~L}$ & 0.02 & 5 & 0.3 & 0.7 & $0.2 \mathrm{~L}$ & 0.5 & $0.5 \mathrm{~N}$ & $200 \mathrm{~N}$ & $10 N$ & 1,500 & 1 & 0.5 & $10 \mathrm{~N}$ & $20 \mathrm{~N}$ \\
\hline & $\mathrm{Co}-\mathrm{S}$ & $\mathrm{C}_{\Gamma-\mathrm{S}}$ & $\mathrm{Cu}-\mathrm{S}$ & Ga-S & $\mathrm{Ge}-\mathrm{S}$ & $\mathrm{La}-\mathrm{S}$ & Mn-S & Mo-S & $\mathrm{Nb}-\mathrm{S}$ & $\mathrm{Ni}-\mathrm{S}$ & Pb-S & $\mathrm{Sb}-\mathrm{S}$ & $\mathrm{Sc}-\mathrm{S}$ & $S_{n-S}$ & $\mathrm{Sr}-\mathrm{S}$ & Th-S & V-S \\
\hline$\overline{\text { BCOOOR }}$ & 30 & 500 & 50 & 50 & $10 \mathrm{~N}$ & $50 \mathrm{~L}$ & 300 & $5 \bar{N}$ & $20 \mathrm{~L}$ & 70 & 20 & $100 \mathrm{~N}$ & 20 & $10 N$ & 200 & $100 \mathrm{~N}$ & 200 \\
\hline BCo14R & 70 & 20 & 30 & $5 \mathrm{~L}$ & $10 \mathrm{~N}$ & $50 \mathrm{~L}$ & 1,500 & $5 \mathrm{~N}$ & $20 \mathrm{~N}$ & 70 & $10 \mathrm{~L}$ & $100 \mathrm{~N}$ & 5 & $10 \mathrm{~N}$ & $100 \mathrm{~L}$ & $100 \mathrm{~N}$ & 70 \\
\hline $\mathrm{BC} 016 \mathrm{R}$ & 15 & 100 & 30 & 50 & $10 \mathrm{~N}$ & $50 \mathrm{~L}$ & 1,000 & $5 \mathrm{~N}$ & $20 \mathrm{~L}$ & 50 & 15 & $100 \mathrm{~N}$ & 15 & $10 \mathrm{~N}$ & 100 & $100 \mathrm{~N}$ & 150 \\
\hline $\mathrm{BC} 027 \mathrm{R}$ & 10 & 20 & 20 & $5 L$ & $10 \mathrm{~N}$ & $50 \mathrm{~N}$ & 1,500 & $S N$ & $20 \mathrm{~N}$ & 20 & $10 \mathrm{~L}$ & $100 \mathrm{~N}$ & $5 \mathrm{~L}$ & $10 \mathrm{~N}$ & $100 \mathrm{~N}$ & $100 \mathrm{~N}$ & 70 \\
\hline $\mathrm{BC} 028 \mathrm{R}$ & 50 & 50 & 50 & 50 & $10 \mathrm{~N}$ & $50 \mathrm{~N}$ & 5,000 & $5 \mathrm{~N}$ & $20 \mathrm{~L}$ & 70 & 15 & $100 \mathrm{~N}$ & 20 & ION & 300 & $100 \mathrm{~N}$ & 150 \\
\hline BC048R & 15 & 150 & 70 & 50 & $10 \mathrm{~N}$ & $50 \mathrm{~L}$ & 500 & $5 \mathrm{~N}$ & $20 \mathrm{~L}$ & 50 & 20 & $100 \mathrm{~N}$ & 10 & $10 N$ & $100 \mathrm{~N}$ & $100 \mathrm{~N}$ & 150 \\
\hline BC063R & 300 & 70 & 70 & 15 & $10 \mathrm{~N}$ & 70 & $5,000 \mathrm{G}$ & $5 \mathrm{~N}$ & $20 \mathrm{~L}$ & 150 & 10 & $100 \mathrm{~N}$ & 15 & $10 N$ & 200 & $100 \mathrm{~N}$ & 150 \\
\hline $\mathrm{BC} 072 \mathrm{R}$ & 100 & 100 & 50 & 20 & $10 \mathrm{~N}$ & 50 & 2,000 & $5 \mathrm{~N}$ & $20 \mathrm{~L}$ & 70 & 15 & $100 \mathrm{~N}$ & 15 & $10 \mathrm{~N}$ & 100 & $100 \mathrm{~N}$ & 150 \\
\hline $\mathrm{BC} 074 \mathrm{R}$ & 20 & 150 & 150 & 30 & $10 \mathrm{~N}$ & $50 \mathrm{~L}$ & 300 & $5 \mathrm{~N}$ & $20 \mathrm{~L}$ & 70 & 15 & $100 \mathrm{~N}$ & 20 & $10 \mathrm{~N}$ & 100 & $100 \mathrm{~N}$ & 150 \\
\hline $\mathrm{BC} 080 \mathrm{R}$ & 30 & 20 & 30 & 5 & $10 \mathrm{~N}$ & 50L & 700 & $5 \mathrm{~N}$ & $20 \mathrm{~N}$ & 70 & 10 & $100 \mathrm{~N}$ & 5 & $10 N$ & $100 \mathrm{~N}$ & $100 \mathrm{~N}$ & 70 \\
\hline $\mathrm{BC} 082 \mathrm{R}$ & 100 & 200 & 50 & 50 & $10 \mathrm{~N}$ & 100 & 1,500 & $5 \mathrm{~N}$ & $20 \mathrm{~L}$ & 100 & 20 & $100 \mathrm{~N}$ & 20 & $10 \mathrm{~N}$ & 300 & $100 \mathrm{~N}$ & 200 \\
\hline $\mathrm{BC} 090 \mathrm{R}$ & 30 & 15 & 20 & $5 \mathrm{~N}$ & $10 \mathrm{~N}$ & $50 \mathrm{~N}$ & 700 & $5 \mathrm{~N}$ & $20 \mathrm{~N}$ & 30 & $10 \mathrm{~L}$ & $100 \mathrm{~N}$ & $5 \mathrm{~N}$ & $10 \mathrm{~N}$ & $100 \mathrm{~N}$ & $100 \mathrm{~N}$ & 30 \\
\hline $\mathrm{BC} 095 \mathrm{R}$ & 100 & 500 & 70 & 20 & $10 \mathrm{~N}$ & 100 & 1,500 & $5 \mathrm{~N}$ & $20 \mathrm{~L}$ & 150 & 20 & $100 \mathrm{~N}$ & 15 & $10 \mathrm{~N}$ & 150 & $100 \mathrm{~N}$ & 100 \\
\hline BC $100 R$ & 70 & 200 & 50 & 15 & $10 \mathrm{~N}$ & $50 \mathrm{~L}$ & 1,500 & $5 \mathrm{~N}$ & $20 \mathrm{~N}$ & 50 & 10 & $100 \mathrm{~N}$ & 15 & $10 \mathrm{~N}$ & $100 \mathrm{~L}$ & $100 \mathrm{~N}$ & 100 \\
\hline BC114R & $10 \mathrm{~N}$ & 10 & 5 & $5 \mathrm{~N}$ & $10 \mathrm{~N}$ & $50 \mathrm{~N}$ & 50 & $5 \mathrm{~N}$ & $20 \mathrm{~N}$ & 5 & $10 \mathrm{~L}$ & $100 \mathrm{~N}$ & $5 \mathrm{~N}$ & ION & $100 \mathrm{~N}$ & $100 \mathrm{~N}$ & 30 \\
\hline BC106R & $10 \mathrm{~N}$ & 20 & 5 & $5 \mathrm{~N}$ & $10 \mathrm{~N}$ & $50 \mathrm{~N}$ & 700 & $5 \mathrm{~N}$ & $20 \mathrm{~N}$ & 10 & $10 \mathrm{~L}$ & $100 \mathrm{~N}$ & $5 \mathrm{~N}$ & ION & $100 \mathrm{~N}$ & $100 \mathrm{~N}$ & 20 \\
\hline BC13]R & 70 & 10 & 30 & $5 \mathrm{~N}$ & $10 \mathrm{~N}$ & $50 \mathrm{~N}$ & 1,000 & $5 \mathrm{~N}$ & $20 \mathrm{~N}$ & 30 & IOL & $100 \mathrm{~N}$ & $5 \mathrm{~N}$ & $10 \mathrm{~N}$ & $100 \mathrm{~N}$ & $100 \mathrm{~N}$ & 15 \\
\hline BC133R & 200 & 100 & 70 & 50 & $10 \mathrm{~N}$ & 50 & 200 & $5 \mathrm{~N}$ & $20 \mathrm{~L}$ & 70 & 20 & $100 \mathrm{~N}$ & 15 & $10 \mathrm{~N}$ & 200 & $100 \mathrm{~N}$ & 150 \\
\hline BC141R & 300 & 100 & 50 & 30 & $10 \mathrm{~N}$ & 50 & 1,500 & $5 \mathrm{~N}$ & $20 \mathrm{~N}$ & 100 & 20 & $100 \mathrm{~N}$ & 15 & $10 \mathrm{~N}$ & $100 \mathrm{~L}$ & $100 \mathrm{~N}$ & 100 \\
\hline $\mathrm{BC} 156 \mathrm{R}$ & 15 & 500 & 100 & 50 & $10 \mathrm{~N}$ & $50 \mathrm{~L}$ & 300 & $5 \mathrm{~N}$ & $20 \mathrm{~N}$ & 70 & 20 & $100 \mathrm{~N}$ & 20 & $10 \mathrm{~N}$ & $100 \mathrm{~N}$ & $100 \mathrm{~N}$ & 150 \\
\hline $\mathrm{BC} 157 \mathrm{R}$ & 70 & 200 & 50 & 20 & $10 \mathrm{~N}$ & $50 \mathrm{~L}$ & 1,000 & $5 \mathrm{~N}$ & $20 \mathrm{~N}$ & 50 & 15 & $100 \mathrm{~N}$ & 15 & $10 \mathrm{~N}$ & $100 \mathrm{~L}$ & $100 \mathrm{~N}$ & 150 \\
\hline $\mathrm{BC} 164 \mathrm{R}$ & 30 & 150 & 100 & 50 & $10 \mathrm{~N}$ & $50 \mathrm{~N}$ & 300 & $5 \mathrm{~N}$ & $20 \mathrm{~N}$ & 50 & 20 & $100 \mathrm{~N}$ & 15 & $10 \mathrm{~N}$ & $100 \mathrm{~N}$ & $100 \mathrm{~N}$ & 150 \\
\hline BC189R & $10 \mathrm{~L}$ & 150 & 50 & 30 & $10 \mathrm{~N}$ & $50 \mathrm{~L}$ & 300 & $5 \mathrm{~N}$ & $20 \mathrm{~N}$ & 30 & 20 & $100 \mathrm{~N}$ & 7 & $10 \mathrm{~N}$ & $100 \mathrm{~N}$ & $100 \mathrm{~N}$ & 70 \\
\hline & 200 & 100 & 70 & 50 & $10 \mathrm{~N}$ & 100 & 500 & $5 \mathrm{~N}$ & $20 \mathrm{~L}$ & ח & 15 & $100 \mathrm{~N}$ & 10 & 10 & 200 & & \\
\hline
\end{tabular}




\begin{tabular}{|c|c|c|c|c|c|c|c|c|c|c|c|c|c|c|}
\hline & W-S & $\mathrm{Y}-\mathrm{S}$ & $\mathrm{Zn}-\mathrm{S}$ & Zr-S & $\mathrm{As} / \mathrm{p}$ & $\mathrm{Au}$ & $\mathrm{Bi} / \mathrm{p}$ & $\mathrm{Cd} / \mathrm{p}$ & $\mathrm{Hg}$ & $\mathrm{Sb} / \mathrm{p}$ & $\mathrm{Te}$ & $\mathrm{T} !$ & $\mathrm{Zn} / \mathrm{p}$ & Sample description \\
\hline $\mathrm{BCO00R}$ & $20 \mathrm{~N}$ & 20 & $200 \mathrm{~N}$ & 200 & $5 \mathrm{~L}$ & 0.2 & $2 \mathrm{~L}$ & $0.1 \mathrm{~L}$ & $0.02 \mathrm{~L}$ & $2 \mathrm{~L}$ & 0.25 & 0.4 & 34 & Schist. \\
\hline $\mathrm{BC} 014 \mathrm{R}$ & $20 \mathrm{~N}$ & $10 \mathrm{~L}$ & $200 \mathrm{~N}$ & 70 & $5 \mathrm{~L}$ & 0.012 & $2 \mathrm{~L}$ & $0.1 \mathrm{~L}$ & $0.02 \mathrm{~L}$ & $2 \mathrm{~L}$ & $0.05 \mathrm{~L}$ & 0.1 & 17 & Quartz vein. \\
\hline BC016R & $20 \mathrm{~N}$ & 20 & $200 \mathrm{~N}$ & 200 & $5 \mathrm{~L}$ & 0.020 & $2 \mathrm{~L}$ & 0.1 & $0.02 \mathrm{~L}$ & $2 \mathrm{~L}$ & $0.05 \mathrm{~L}$ & 0.3 & 23 & Schist. \\
\hline $\mathrm{BC} 027 \mathrm{R}$ & $20 \mathrm{~N}$ & $10 \mathrm{~L}$ & $200 \mathrm{~N}$ & 30 & $5 \mathrm{~L}$ & 0.004 & $2 \mathrm{~L}$ & 0.1 & $0.02 \mathrm{~L}$ & $2 \mathrm{~L}$ & 0.05 & 0.05 & 14 & Quartz vein. \\
\hline BC028R & $20 \mathrm{~N}$ & 30 & $200 \mathrm{~N}$ & 150 & 5 & 0.028 & $2 \mathrm{~L}$ & 1.4 & $0.02 \mathrm{~L}$ & $2 \mathrm{~L}$ & 0.05 & 0.55 & 72 & Schist. \\
\hline BC048R & $20 \mathrm{~N}$ & 20 & $200 \mathrm{~N}$ & 150 & $5 \mathrm{~L}$ & 0.038 & $2 \mathrm{~L}$ & 0.4 & $0.02 \mathrm{~L}$ & $2 \mathrm{~L}$ & 0.05 & $0.05 \mathrm{~L}$ & 22 & Schist. \\
\hline BC063R & $20 \mathrm{~N}$ & 20 & $200 \mathrm{~N}$ & 150 & $5 \mathrm{~L}$ & 0.6 & $2 \mathrm{~L}$ & 0.5 & $0.02 \mathrm{~L}$ & $2 \mathrm{~L}$ & 0.65 & 0.45 & 73 & Quartz vein, MnO stained. \\
\hline $\mathrm{BC} 072 \mathrm{R}$ & $20 \mathrm{~N}$ & 20 & $200 \mathrm{~N}$ & 100 & $5 \mathrm{~L}$ & 0.150 & $2 \mathrm{~L}$ & 0.5 & $0.02 \mathrm{~L}$ & $2 \mathrm{~L}$ & 0.3 & 0.35 & 35 & Quartz vein. \\
\hline $\mathrm{BC} 074 \mathrm{R}$ & $20 \mathrm{~N}$ & 20 & $200 \mathrm{~N}$ & 150 & 5L & 0.1 & 2L & 0.2 & $0.02 \mathrm{~L}$ & $2 \mathrm{~L}$ & 0.05 & 0.45 & 51 & Schist. \\
\hline BC080R & $20 \mathrm{~N}$ & $10 \mathrm{~L}$ & $200 \mathrm{~N}$ & 50 & $5 \mathrm{~L}$ & 0.450 & 2L & 0.1 & $0.02 \mathrm{~L}$ & $2 \mathrm{~L}$ & 0.2 & 0.1 & 20 & Quartz vein. \\
\hline BC082R & $20 \mathrm{~N}$ & 50 & $200 \mathrm{~N}$ & 150 & 8 & 0.1 & $2 \mathrm{~L}$ & 0.6 & $0.02 \mathrm{~L}$ & $2 \mathrm{~L}$ & 1.1 & 0.7 & 48 & Silicified schist. \\
\hline BC090R & $20 \mathrm{~N}$ & $10 \mathrm{~N}$ & $200 \mathrm{~N}$ & 20 & $5 \mathrm{~L}$ & 0.1 & $2 \mathrm{~L}$ & $0.1 \mathrm{~L}$ & $0.02 \mathrm{~L}$ & $2 \mathrm{~L}$ & $0.05 \mathrm{~L}$ & $0.05 \mathrm{~L}$ & 10 & Quartz vein. \\
\hline BC095R & $20 N$ & 30 & $200 \mathrm{~N}$ & 200 & $5 \mathrm{~L}$ & 0.450 & $2 \mathrm{~L}$ & 0.5 & $0.02 \mathrm{~L}$ & $2 \mathrm{~L}$ & 0.1 & 0.2 & 100 & Quartz vein. \\
\hline BCIOOR & $20 \mathrm{~N}$ & 15 & $200 \mathrm{~N}$ & 50 & $5 \mathrm{~L}$ & 0.350 & $2 \mathrm{~L}$ & 0.5 & $0.02 \mathrm{~L}$ & $2 \mathrm{~L}$ & 0.45 & 0.1 & 42 & Tourmaline-quartz vein. \\
\hline $\mathrm{BC} 114 \mathrm{R}$ & $20 \mathrm{~N}$ & $10 N$ & $200 \mathrm{~N}$ & $10 \mathrm{~L}$ & $5 \mathrm{~L}$ & 0.1 & $2 \mathrm{~L}$ & $0.1 \mathrm{~L}$ & $0.02 \mathrm{~L}$ & $2 \mathrm{~L}$ & $0.05 \mathrm{~L}$ & $0.05 \mathrm{~L}$ & $2 \mathrm{~L}$ & Quart? vein. \\
\hline $\mathrm{BC} 106 \mathrm{R}$ & $20 \mathrm{~N}$ & $10 \mathrm{~N}$ & $200 \mathrm{~N}$ & 10 & $5 \mathrm{~L}$ & 0.1 & $2 \mathrm{~L}$ & $0.1 \mathrm{~L}$ & 0.020 & $2 \mathrm{~L}$ & 0.65 & $0.05 \mathrm{~L}$ & 3 & Quartz vein. \\
\hline BC131R & $20 \mathrm{~N}$ & $10 \mathrm{~N}$ & $200 \mathrm{~N}$ & $10 \mathrm{~L}$ & $5 \mathrm{~L}$ & 0.014 & $2 \mathrm{~L}$ & $0.1 \mathrm{~L}$ & $0.02 \mathrm{~L}$ & $2 \mathrm{~L}$ & $0.05 \mathrm{~L}$ & $0.05 \mathrm{~L}$ & 18 & Tourmaline-quartz vein. \\
\hline BC133R & $20 \mathrm{~N}$ & 20 & $200 \mathrm{~N}$ & 150 & $5 \mathrm{~L}$ & 0.020 & $2 \mathrm{~L}$ & 0.5 & $0.02 \mathrm{~L}$ & $2 \mathrm{~L}$ & 1 & 0.65 & 47 & Schist. \\
\hline $\mathrm{BCI} 41 \mathrm{R}$ & $20 \mathrm{~N}$ & 20 & $200 \mathrm{~N}$ & 100 & 7 & 1 & $2 \mathrm{~L}$ & 1.2 & $0.02 \mathrm{~L}$ & $2 \mathrm{~L}$ & 1.5 & 0.7 & 72 & Silicified schist. \\
\hline BCI56R & $20 \mathrm{~N}$ & 20 & $200 \mathrm{~N}$ & 100 & $5 \mathrm{~L}$ & 0.3 & $2 \mathrm{~L}$ & 0.3 & $0.02 \mathrm{~L}$ & $2 \mathrm{~L}$ & 0.05 & 0.4 & 65 & Schist. \\
\hline BC157R & $20 \mathrm{~N}$ & 15 & $200 \mathrm{~N}$ & 70 & $5 \mathrm{~L}$ & 0.1 & 2L & 0.3 & $0.02 \mathrm{~L}$ & $2 \mathrm{~L}$ & 0.65 & 0.35 & 18 & Schist. \\
\hline $\mathrm{BC} 164 \mathrm{R}$ & $20 \mathrm{~N}$ & 20 & $200 \mathrm{~N}$ & 100 & SL & 0.012 & $2 \mathrm{~L}$ & 0.5 & 0.020 & $2 \mathrm{~L}$ & $0.05 \mathrm{~L}$ & 0.4 & 64 & Quartz vein. \\
\hline $\mathrm{BCI89R}$ & $20 \mathrm{~N}$ & 15 & $200 \mathrm{~N}$ & 100 & 5L & 0.012 & $2 \mathrm{~L}$ & 0.2 & 0.020 & $2 \mathrm{~L}$ & $0.05 \mathrm{~L}$ & 0.1 & 18 & Schist. \\
\hline $\mathrm{BC} 135 \mathrm{R}$ & $20 \mathrm{~N}$ & 20 & $200 \mathrm{~N}$ & 150 & $5 \mathrm{~L}$ & 0.014 & $2 \mathrm{~L}$ & 0.3 & $0.02 \mathrm{~L}$ & $2 \mathrm{~L}$ & 0.7 & 0.4 & 35 & Schist. \\
\hline
\end{tabular}

Appendix table 4. Rock samples collected from trench T2, Bochinche area, Venezuela

\begin{tabular}{|c|c|c|c|c|c|c|c|c|c|c|c|c|c|c|c|c|c|}
\hline & Latitude & Longitude & $\mathrm{Ca} \%-\mathrm{S}$ & $\mathbf{F} \%$ & $\mathrm{Fe} \%-\mathrm{S}$ & $\mathrm{Mg} \%-\mathrm{S}$ & $\mathrm{Na \%}-\mathrm{S}$ & $\mathrm{P} \%-\mathrm{S}$ & $\mathrm{Ti} \%-\mathrm{S}$ & $\mathrm{Ag}-\mathrm{S}$ & As-S & $\mathrm{Au}-\mathrm{S}$ & B-S & $\mathrm{Ba}-\mathrm{S}$ & $\mathrm{Be}-\mathrm{S}$ & $\mathrm{Bi}-\mathrm{S}$ & $\mathrm{Cd}-\mathrm{S}$ \\
\hline $\mathrm{BC} 201 \mathrm{R}$ & $7^{\circ} 33^{\prime} 00^{\prime \prime}$ & $60^{\circ} 48^{\prime} 00^{\prime \prime}$ & $0.05 \mathrm{~L}$ & $0.01 \mathrm{~L}$ & 7 & 0.7 & 1 & $0.2 \mathrm{~N}$ & 0.5 & $0.5 \mathrm{~N}$ & $200 \mathrm{~N}$ & $10 \mathrm{~N}$ & 2,000 & 700 & 1 & $10 \mathrm{~N}$ & $20 \mathrm{~N}$ \\
\hline $\mathrm{BC} 202 \mathrm{R}$ & $7^{\circ} 33^{\prime} 00^{\prime \prime}$ & $60^{\circ} 48^{\prime} 00^{\prime \prime}$ & $0.05 \mathrm{~L}$ & 0.012 & 1.5 & 0.2 & $0.2 \mathrm{~L}$ & $0.2 \mathrm{~N}$ & 0.15 & $0.5 \mathrm{~N}$ & $200 \mathrm{~N}$ & ION & 1,500 & 50 & $1 \mathrm{~L}$ & $10 N$ & $20 \mathrm{~N}$ \\
\hline $\mathrm{BC} 203 \mathrm{R}$ & $7^{\circ} 33^{\prime} 00^{\prime \prime}$ & $60^{\circ} 48^{\prime} 00^{\prime \prime}$ & 0.05 & $0.01 \mathrm{~L}$ & 5 & I & 2 & $0.2 \mathrm{~N}$ & 0.5 & $0.5 \mathrm{~N}$ & $200 \mathrm{~N}$ & $10 \mathrm{~N}$ & 1,500 & 1,000 & $1 \mathrm{~L}$ & $10 \mathrm{~N}$ & $20 \mathrm{~N}$ \\
\hline $\mathrm{BC} 204 \mathrm{R}$ & $7^{\circ} 33^{\prime} 00^{\prime \prime}$ & $60^{\circ} 48^{\prime} 00^{\prime \prime}$ & 0.05 & 0.02 & 5 & 0.7 & 0.7 & $0.2 \mathrm{~N}$ & 0.7 & $0.5 \mathrm{~N}$ & $200 \mathrm{~N}$ & $10 \mathrm{~N}$ & $2,000 \mathrm{G}$ & 1,000 & 1.5 & $10 \mathrm{~N}$ & $20 \mathrm{~N}$ \\
\hline $\mathrm{BC} 205 \mathrm{R}$ & $7^{\circ} 33^{\prime} 00^{\prime \prime}$ & $60^{\circ} 48^{\prime} 00^{\prime \prime}$ & 1.00 & 0.01 & 7 & 0.7 & 1.5 & $0.2 \mathrm{~N}$ & 0.7 & $0.5 \mathrm{~N}$ & $200 \mathrm{~N}$ & $10 \mathrm{~N}$ & $2,000 \mathrm{G}$ & 1,000 & 1.5 & $10 \mathrm{~N}$ & $20 \mathrm{~N}$ \\
\hline $\mathrm{BC} 206 \mathrm{R}$ & $7^{\circ} 33^{\prime} 00^{\prime \prime}$ & $60^{\circ} 48^{\prime} 00^{\prime \prime}$ & $0.05 \mathrm{~L}$ & 0.012 & 1.5 & 0.2 & $0.2 \mathrm{~L}$ & $0.2 \mathrm{~N}$ & 0.07 & $0.5 \mathrm{~N}$ & $200 \mathrm{~N}$ & $10 \mathrm{~N}$ & 2,000 & 200 & IN & $10 \mathrm{~N}$ & $20 \mathrm{~N}$ \\
\hline $\mathrm{BC} 207 \mathrm{R}$ & $7^{\circ} 33^{\prime} 00^{\prime \prime}$ & $60^{\circ} 48^{\circ} 00^{\prime \prime}$ & 0.07 & 0.02 & 5 & 0.7 & 1 & $0.2 \mathrm{~N}$ & 0.5 & $0.5 \mathrm{~N}$ & $200 \mathrm{~N}$ & $10 \mathrm{~N}$ & $2,000 \mathrm{G}$ & 700 & 1.5 & $I 0 N$ & $20 \mathrm{~N}$ \\
\hline $\mathrm{BC} 208 \mathrm{R}$ & $7^{\circ} 33^{\prime} 00^{\prime \prime}$ & $60^{\circ} 4800^{\prime \prime}$ & $0.05 \mathrm{~L}$ & $0.01 \mathrm{~L}$ & 1.5 & 0.05 & $0.2 \mathrm{~L}$ & $0.2 \mathrm{~N}$ & 0.07 & $0.5 \mathrm{~N}$ & $200 \mathrm{~N}$ & $10 \mathrm{~N}$ & 200 & 1,000 & $1 \mathrm{~L}$ & $10 N$ & $20 \mathrm{~N}$ \\
\hline $\mathrm{BC} 209 \mathrm{R}$ & $7^{0} 33^{\prime} 00^{\prime \prime}$ & $60^{\circ} 48^{\circ} 00^{\prime \prime}$ & $0.05 \mathrm{~L}$ & 0.01 & 5 & 0.15 & 0.7 & $0.2 \mathrm{~N}$ & 0.5 & $0.5 \mathrm{~N}$ & $200 \mathrm{~N}$ & $10 \mathrm{~N}$ & 150 & 1,000 & 1 & $10 \mathrm{~N}$ & $20 \mathrm{~N}$ \\
\hline $\mathrm{BC} 210 \mathrm{R}$ & $7^{\circ} 33^{\prime} 00^{\prime \prime}$ & $60^{\circ} 48^{\prime} 00^{\prime \prime}$ & $0.05 \mathrm{~L}$ & 0.02 & 5 & 0.15 & 1 & $0.2 \mathrm{~N}$ & 0.5 & $0.5 \mathrm{~N}$ & $200 \mathrm{~N}$ & $10 \mathrm{~N}$ & 200 & 700 & 1.5 & $10 \mathrm{~N}$ & $20 \mathrm{~N}$ \\
\hline $\mathrm{BC} 211 \mathrm{R}$ & $7^{\circ} 33^{\prime} 00^{\prime \prime}$ & $60^{\circ} 48^{\prime} 00^{\prime \prime}$ & $0.05 \mathrm{~L}$ & $0.01 \mathrm{~L}$ & 1 & 0.02 & $0.2 \mathrm{~N}$ & $0.2 \mathrm{~N}$ & 0.1 & $0.5 \mathrm{~N}$ & $200 \mathrm{~N}$ & $10 \mathrm{~N}$ & 70 & 1,000 & $1 \mathrm{~L}$ & $10 \mathrm{~N}$ & $20 \mathrm{~N}$ \\
\hline $\mathrm{BC} 212 \mathrm{R}$ & $7^{\circ} 33^{\prime} 00^{\prime \prime}$ & $60^{\circ} 48^{\prime} 00^{\prime \prime}$ & 0.10 & 0.03 & 5 & 1.5 & 0.7 & $0.2 \mathrm{~N}$ & 0.5 & $0.5 \mathrm{~N}$ & $200 N$ & $10 \mathrm{~N}$ & $2,000 \mathrm{G}$ & 150 & 1.5 & $10 \mathrm{~N}$ & $20 \mathrm{~N}$ \\
\hline$B C 213 R$ & $7^{\circ} 33^{\prime} 00^{\prime \prime}$ & $60^{\circ} 48^{\prime} 00^{\prime \prime}$ & $0.05 \mathrm{~L}$ & 0.02 & 5 & 0.3 & 1 & $0.2 \mathrm{~N}$ & 0.5 & $0.5 \mathrm{~N}$ & $200 N$ & $10 \mathrm{~N}$ & 500 & 700 & 1.5 & $10 \mathrm{~N}$ & $20 \mathrm{~N}$ \\
\hline $\mathrm{BC} 214 \mathrm{R}$ & $7^{\circ} 33^{\prime} 00^{\prime \prime}$ & $60^{\circ} 48^{\prime} 00^{\prime \prime}$ & $0.05 \mathrm{~L}$ & 0.02 & 0.7 & 0.15 & $0.2 \mathrm{~N}$ & $0.2 \mathrm{~N}$ & $0.05 \mathrm{~L}$ & $0.5 \mathrm{~N}$ & $200 N$ & $10 \mathrm{~N}$ & 1,000 & 7,000 & 1.5 & $10 \mathrm{~N}$ & $20 \mathrm{~N}$ \\
\hline $\mathrm{BC} 215 \mathrm{R}$ & $7^{\circ} 33^{\prime} 00^{\prime \prime}$ & $60^{\circ} 48^{\prime} 00^{\prime \prime}$ & 0.07 & 0.01 & 3 & 0.2 & 0.7 & $0.2 \mathrm{~N}$ & 0.5 & $0.5 \mathrm{~N}$ & $200 \mathrm{~N}$ & $10 \mathrm{~N}$ & 1,000 & 700 & 1.5 & $10 \mathrm{~N}$ & $20 \mathrm{~N}$ \\
\hline $\mathrm{BC} 216 \mathrm{R}$ & $7^{\circ} 33^{\prime} 00^{\prime \prime}$ & $60^{\circ} 48^{\prime} 00^{\prime \prime}$ & 0.05 & 0.01 & 5 & 1 & 1.5 & $0.2 \mathrm{~N}$ & 0.5 & $0.5 \mathrm{~N}$ & $200 \mathrm{~N}$ & $10 N$ & $2,000 \mathrm{G}$ & 700 & 1.5 & $10 \mathrm{~N}$ & $20 \mathrm{~N}$ \\
\hline $\mathrm{BC} 217 \mathrm{R}$ & $7^{\circ} 33^{\prime} 00^{\prime \prime}$ & $60^{\circ} 48^{\prime} 00^{\prime \prime}$ & $0.05 \mathrm{~L}$ & $0.01 \mathrm{~L}$ & 0.7 & 0.07 & $0.2 \mathrm{~N}$ & $0.2 \mathrm{~N}$ & 0.05 & $0.5 \mathrm{~N}$ & $200 \mathrm{~N}$ & $10 N$ & 300 & 70 & $\mathrm{lL}$ & $10 N$ & $20 \mathrm{~N}$ \\
\hline $\mathrm{BC} 218 \mathrm{R}$ & $7^{\circ} 33^{\prime} 00^{\prime \prime}$ & $60^{\circ} 48^{\prime} 00^{\prime \prime}$ & $0.05 \mathrm{~L}$ & 0.01 & 5 & 0.2 & 1 & $0.2 \mathrm{~N}$ & 0.5 & $0.5 \mathrm{~N}$ & $200 \mathrm{~N}$ & $10 \mathrm{~N}$ & 300 & 700 & 1.5 & $10 N$ & $20 \mathrm{~N}$ \\
\hline $\mathrm{BC} 219 \mathrm{R}$ & $7^{\circ} 33^{\prime} 00^{\prime \prime}$ & $60^{\circ} 48^{\prime} 00^{\prime \prime}$ & 0.05 & 0.03 & 3 & 0.7 & 1 & $0.2 \mathrm{~N}$ & 0.5 & $0.5 \mathrm{~N}$ & $200 \mathrm{~N}$ & $10 \mathrm{~N}$ & $2,000 \mathrm{G}$ & 1,000 & 1.5 & $10 \mathrm{~N}$ & $20 \mathrm{~N}$ \\
\hline $\mathrm{BC} 220 \mathrm{R}$ & $7^{\circ} 33^{\prime} 00^{\prime \prime}$ & $60^{\circ} 48^{\prime} 00^{\prime \prime}$ & $0.05 \mathrm{~L}$ & $0.01 \mathrm{~L}$ & 1 & 0.1 & $0.2 \mathrm{~N}$ & $0.2 \mathrm{~N}$ & 0.03 & $0.5 \mathrm{~N}$ & $200 \mathrm{~N}$ & $10 \mathrm{~N}$ & 500 & 50 & $1 N$ & ION & $20 N$ \\
\hline BC221R & $7^{\circ} 33^{\prime} 00^{\prime \prime}$ & $60^{\circ} 48^{\prime} 00^{\prime \prime}$ & 0.07 & 0.01 & 7 & 1.5 & 1.5 & $0.2 \mathrm{~N}$ & 0.7 & $0.5 \mathrm{~N}$ & $200 \mathrm{~N}$ & $10 \mathrm{~N}$ & $2,000 \mathrm{G}$ & 300 & 1.5 & $10 \mathrm{~N}$ & $20 \mathrm{~N}$ \\
\hline
\end{tabular}


Appendix table 4. Rock samples collected from trench T2, Bochinche area, Venezuela - Continued

\begin{tabular}{|c|c|c|c|c|c|c|c|c|c|c|c|c|c|c|c|c|c|}
\hline & Latitude & Longitude & $\mathrm{Ca} \%-\mathrm{S}$ & $F \%$ & $\mathrm{Fe} \%-\mathrm{S}$ & $\mathrm{Mg} \%-\mathrm{S}$ & $\mathrm{Na} \%-\mathrm{S}$ & $\mathrm{P} \%-\mathrm{S}$ & $\mathrm{Ti} \%-\mathrm{S}$ & $\mathrm{Ag}_{\mathrm{g}}-\mathrm{S}$ & As-S & $\mathrm{Au}-\mathrm{S}$ & B-S & $\mathrm{Ba}-\mathrm{S}$ & Be-S & $\mathrm{Bi}-\mathrm{S}$ & $\mathrm{Cd}-\mathrm{S}$ \\
\hline BC222R & $7^{\circ} 33^{\prime} 00^{\prime \prime}$ & $60^{\circ} 48^{\circ} 00^{\prime \prime}$ & $0.05 \mathrm{~L}$ & 0.02 & 5 & 0.7 & 0.7 & $0.2 \mathrm{~N}$ & 0.5 & $0.5 \mathrm{~N}$ & $200 \mathrm{~N}$ & $10 \mathrm{~N}$ & $2,000 \mathrm{G}$ & 700 & 1 & $\overline{10 N}$ & $20 \mathrm{~N}$ \\
\hline BC223R & $7^{\circ} 33^{\prime} 00^{\prime \prime}$ & $60^{\circ} 48^{\circ} 00^{\prime \prime}$ & 0.05 & 0.02 & 5 & 0.7 & 1 & $0.2 \mathrm{~N}$ & 0.7 & $0.5 \mathrm{~N}$ & $200 \mathrm{~N}$ & $10 \mathrm{~N}$ & $2,000 \mathrm{G}$ & 500 & 1 & $10 \mathrm{~N}$ & $20 \mathrm{~N}$ \\
\hline BC224R & $7^{\circ} 33^{\prime} 00^{\prime \prime}$ & $60^{\circ} 48^{\prime} 00^{\prime \prime}$ & 0.15 & 0.01 & 2 & 0.7 & 0.5 & $0.2 \mathrm{~N}$ & 0.2 & 2 & $200 \mathrm{~N}$ & $10 \mathrm{~N}$ & $2,000 \mathrm{G}$ & 1,000 & 1.5 & $10 N$ & $20 \mathrm{~N}$ \\
\hline BC225R & $7^{\circ} 33^{\prime} 00^{\prime \prime}$ & $60^{\circ} 48^{\circ} 00^{\prime \prime}$ & $0.05 \mathrm{~L}$ & 0.01 & 5 & 0.3 & 0.5 & $0.2 \mathrm{~N}$ & 0.5 & $0.5 \mathrm{~N}$ & $200 \mathrm{~N}$ & $10 \mathrm{~N}$ & 700 & 500 & $1 \mathrm{~L}$ & ION & $20 \mathrm{~N}$ \\
\hline BC226R & $7^{\circ} 33^{\prime} 00^{\prime \prime}$ & $60^{\circ} 48^{\circ} 00^{\prime \prime}$ & 0.07 & $0.01 \mathrm{~L}$ & 1.5 & 0.15 & $0.2 \mathrm{~N}$ & $0.2 \mathrm{~N}$ & 0.07 & $0.5 \mathrm{~N}$ & $200 \mathrm{~N}$ & $10 \mathrm{~N}$ & 2,000 & 300 & IL & $10 N$ & $20 \mathrm{~N}$ \\
\hline $\mathrm{BC} 227 \mathrm{R}$ & $7^{\circ} 33^{\prime} 00^{\prime \prime}$ & $60^{\circ} 48^{\prime} 00^{\prime \prime}$ & $0.05 \mathrm{~L}$ & 0.02 & 5 & 0.7 & 0.7 & $0.2 \mathrm{~N}$ & 0.5 & $0.5 \mathrm{~N}$ & $200 \mathrm{~N}$ & $10 \mathrm{~N}$ & $2,000 \mathrm{G}$ & 1,000 & 1 & $10 \mathrm{~N}$ & $20 \mathrm{~N}$ \\
\hline $\mathrm{BC} 228 \mathrm{R}$ & $7^{\circ} 33^{\prime} 00^{\prime \prime}$ & $60^{\circ} 48^{\circ} 00^{\prime \prime}$ & $0.05 \mathrm{~L}$ & 0.01 & 7 & 0.07 & 0.5 & $0.2 \mathrm{~N}$ & 0.5 & $0.5 \mathrm{~N}$ & $200 \mathrm{~N}$ & $10 \mathrm{~N}$ & 20 & 500 & $1 \mathrm{~L}$ & $10 \mathrm{~N}$ & $20 \mathrm{~N}$ \\
\hline $\mathrm{BC} 228 \mathrm{RA}$ & $7^{\circ} 33^{\prime} 00^{\prime \prime}$ & $60^{\circ} 48^{\prime} 00^{\prime \prime}$ & 0.15 & 0.02 & 5 & 2 & 1 & $0.2 \mathrm{~N}$ & 0.3 & $0.5 \mathrm{~N}$ & $200 \mathrm{~N}$ & $10 \mathrm{~N}$ & $2,000 \mathrm{G}$ & 150 & 1 & ION & $20 \mathrm{~N}$ \\
\hline $\mathrm{BC} 229 \mathrm{R}$ & $7^{\circ} 33^{\prime} 00^{\prime \prime}$ & $60^{\circ} 48^{\prime} 00^{\prime \prime}$ & $0.05 \mathrm{~L}$ & $0.01 \mathrm{~L}$ & 1.5 & 0.5 & 0.2 & $0.2 \mathrm{~N}$ & 0.07 & $0.5 \mathrm{~N}$ & $200 \mathrm{~N}$ & $10 \mathrm{~N}$ & $2,000 \mathrm{G}$ & 30 & l & $10 N$ & $20 \mathrm{~N}$ \\
\hline $\mathrm{BC} 230 \mathrm{R}$ & $7^{\circ} 33^{\prime} 00^{\prime \prime}$ & $60^{\circ} 48^{\prime} 00^{\prime \prime}$ & $0.05 \mathrm{~L}$ & 0.01 & 7 & 0.3 & 0.7 & $0.2 \mathrm{~N}$ & 0.5 & $0.5 \mathrm{~N}$ & $200 \mathrm{~N}$ & $10 \mathrm{~N}$ & 1,500 & 1,000 & 1.5 & $10 \mathrm{~N}$ & $20 \mathrm{~N}$ \\
\hline BC231R & $7^{\circ} 33^{\prime} 00^{\prime \prime}$ & $60^{\circ} 48^{\prime} 00^{\prime \prime}$ & $0.05 \mathrm{~N}$ & 0.01 & 3 & 0.05 & 0.5 & $0.2 \mathrm{~N}$ & 0.3 & $0.5 \mathrm{~N}$ & $200 \mathrm{~N}$ & $10 N$ & 30 & 300 & $\mathrm{IL}$ & $10 \mathrm{~N}$ & $20 N$ \\
\hline BC232R & $7^{\circ} 33^{\prime} 00^{\prime \prime}$ & $60^{\circ} 48^{\prime} 00^{\prime \prime}$ & $0.05 \mathrm{~L}$ & $0.01 \mathrm{~L}$ & 7 & 0.2 & $0.2 \mathrm{~N}$ & $0.2 \mathrm{~N}$ & 0.1 & $0.5 \mathrm{~L}$ & $200 \mathrm{~N}$ & $10 \mathrm{~N}$ & 1,000 & 150 & $\mathrm{IL}$ & $10 \mathrm{~N}$ & $20 \mathrm{~N}$ \\
\hline $\mathrm{BC} 233 \mathrm{R}$ & $7^{\circ} 33^{\prime} 00^{\prime \prime}$ & $60^{\circ} 48^{\prime} 00^{\prime \prime}$ & $0.05 \mathrm{~L}$ & 0.02 & 3 & 0.3 & 1.5 & $0.2 \mathrm{~L}$ & 0.3 & $0.5 \mathrm{~N}$ & $200 \mathrm{~N}$ & $10 \mathrm{~N}$ & 500 & 1,000 & I & $10 \mathrm{~N}$ & $20 \mathrm{~N}$ \\
\hline $\mathrm{BC} 234 \mathrm{R}$ & $7^{\circ} 33^{\prime} 00^{\prime \prime}$ & $60^{\circ} 48^{\prime} 00^{\prime \prime}$ & 0.07 & 0.02 & 5 & 1.5 & 0.7 & $0.2 \mathrm{~N}$ & 0.5 & $0.5 \mathrm{~N}$ & $200 \mathrm{~N}$ & $10 \mathrm{~N}$ & $2,000 \mathrm{G}$ & 100 & 1.5 & ION & $20 \mathrm{~N}$ \\
\hline BC235R & $7^{\circ} 33^{\prime} 00^{\prime \prime}$ & $60^{\circ} 48^{\prime} 00^{\prime \prime}$ & $0.05 \mathrm{~L}$ & 0.01 & 7 & 0.3 & 1 & $0.2 \mathrm{~L}$ & 1 & $0.5 \mathrm{~N}$ & $200 \mathrm{~N}$ & $10 N$ & 1,000 & 700 & 1.5 & $10 \mathrm{~N}$ & $20 \mathrm{~N}$ \\
\hline $\mathrm{BC} 236 \mathrm{R}$ & $7^{\circ} 33^{\prime} 00^{\prime \prime}$ & $60^{\circ} 48^{\prime} 00^{\prime \prime}$ & $0.05 \mathrm{~L}$ & $0.01 \mathrm{~L}$ & 2 & 0.15 & $0.2 \mathrm{~L}$ & $0.2 \mathrm{~N}$ & 0.07 & $0.5 \mathrm{~N}$ & $200 \mathrm{~N}$ & $10 \mathrm{~N}$ & 700 & 70 & IL & 20 & $20 \mathrm{~N}$ \\
\hline $\mathrm{BC} 237 \mathrm{R}$ & $7^{\circ} 33^{\prime} 00^{\prime \prime}$ & $60^{\circ} 48^{\prime} 00^{\prime \prime}$ & 0.07 & 0.01 & 7 & 2 & 1 & $0.2 \mathrm{~N}$ & 0.7 & $0.5 \mathrm{~N}$ & $200 \mathrm{~N}$ & $10 \mathrm{~N}$ & $2,000 \mathrm{G}$ & 300 & 1 & ION & $20 \mathrm{~N}$ \\
\hline $\mathrm{BC} 238 \mathrm{R}$ & $7^{\circ} 33^{\prime} 00^{\prime \prime}$ & $60^{\circ} 48^{\prime} 00^{\prime \prime}$ & $0.05 \mathrm{~L}$ & $0.01 \mathrm{~L}$ & 1 & 0.07 & $0.2 \mathrm{~N}$ & $0.2 \mathrm{~N}$ & 0.07 & $0.5 \mathrm{~N}$ & $200 \mathrm{~N}$ & $10 \mathrm{~N}$ & 300 & 70 & $\mathrm{IL}$ & $10 \mathrm{~N}$ & $20 \mathrm{~N}$ \\
\hline BC239R & $7^{\circ} 33^{\prime} 00^{\prime \prime}$ & $60^{\circ} 48^{\prime} 00^{\prime \prime}$ & $0.05 \mathrm{~L}$ & 0.02 & 7 & 0.1 & 1 & $0.2 \mathrm{~N}$ & 0.7 & $0.5 \mathrm{~N}$ & $200 \mathrm{~N}$ & ION & 500 & 300 & I & $10 \mathrm{~N}$ & $20 \mathrm{~N}$ \\
\hline $\mathrm{BC} 240 \mathrm{R}$ & $7^{\circ} 33^{\prime} 00^{\prime \prime}$ & $60^{\circ} 48^{\prime} 00^{\prime \prime}$ & $0.05 \mathrm{~L}$ & 0.01 & 10 & 0.07 & 1 & $0.2 \mathrm{~L}$ & 0.7 & $0.5 \mathrm{~N}$ & $200 \mathrm{~N}$ & $10 \mathrm{~N}$ & 70 & 500 & 1.5 & ION & $20 \mathrm{~N}$ \\
\hline $\mathrm{BC} 241 \mathrm{R}$ & $7^{\circ} 33^{\prime} 00^{\prime \prime}$ & $60^{\circ} 48^{\prime} 00^{\prime \prime}$ & $0.05 \mathrm{~L}$ & $0.01 \mathrm{~L}$ & 2 & 0.3 & 0.2 & $0.2 \mathrm{~N}$ & 0.15 & $0.5 \mathrm{~N}$ & $200 \mathrm{~N}$ & $10 \mathrm{~N}$ & 2,000 & 1,000 & 1 & $10 \mathrm{~N}$ & $20 \mathrm{~N}$ \\
\hline $\mathrm{BC} 242 \mathrm{R}$ & $7^{\circ} 33^{\prime} 00^{\prime \prime}$ & $60^{\circ} 48^{\prime} 00^{\prime \prime}$ & 0.05 & $0.01 \mathrm{~L}$ & 2 & 0.3 & 0.2 & $0.2 \mathrm{~N}$ & 0.15 & $0.5 \mathrm{~N}$ & $200 \mathrm{~N}$ & $10 \mathrm{~N}$ & 2,000 & 1,000 & I & $10 \mathrm{~N}$ & $20 \mathrm{~N}$ \\
\hline BC243R & $7^{\circ} 33^{\prime} 00^{\prime \prime}$ & $60^{\circ} 48^{\prime} 00^{\prime \prime}$ & $0.05 \mathrm{~L}$ & $0.01 \mathrm{~L}$ & 1.5 & 0.1 & $0.2 \mathrm{~L}$ & $0.2 \mathrm{~N}$ & 0.07 & 3 & $200 \mathrm{~N}$ & $10 \mathrm{~N}$ & 700 & $5,000 \mathrm{G}$ & 1.5 & $10 \mathrm{~N}$ & $20 \mathrm{~N}$ \\
\hline BC244R & $7^{\circ} 33^{\circ} 00^{\prime \prime}$ & $60^{\circ} 48^{\prime} 00^{\prime \prime}$ & $0.05 \mathrm{~L}$ & 0.02 & 5 & 0.7 & 0.7 & $0.2 \mathrm{~N}$ & 0.5 & $0.5 \mathrm{~N}$ & $200 \mathrm{~N}$ & ION & 2,000 & 700 & 1.5 & $10 \mathrm{~N}$ & $20 \mathrm{~N}$ \\
\hline BC245R & $7^{\circ} 33^{\prime} 00^{\prime \prime}$ & $60^{\circ} 48^{\prime} 00^{\prime \prime}$ & $0.05 \mathrm{~L}$ & 0.02 & 5 & 0.3 & 1.5 & $0.2 \mathrm{~N}$ & 0.7 & $0.5 \mathrm{~N}$ & $200 \mathrm{~N}$ & $10 \mathrm{~N}$ & 700 & 1,000 & 1.5 & ION & $20 \mathrm{~N}$ \\
\hline $\mathrm{BC} 246 \mathrm{R}$ & $7^{\circ} 33^{\prime} 00^{\prime \prime}$ & $60^{\circ} 48^{\prime} 00^{\prime \prime}$ & $0.05 \mathrm{~L}$ & $0.01 \mathrm{~L}$ & 1 & 0.03 & $0.2 \mathrm{~N}$ & $0.2 \mathrm{~N}$ & 0.07 & $0.5 \mathrm{~N}$ & $200 \mathrm{~N}$ & $10 \mathrm{~N}$ & 100 & 200 & 12 & $10 \mathrm{~N}$ & $20 \mathrm{~N}$ \\
\hline $\mathrm{BC} 247 \mathrm{R}$ & $7^{\circ} 33^{\prime} 00^{\prime \prime}$ & $60^{\circ} 48^{\prime} 00^{\prime \prime}$ & $0.05 \mathrm{~L}$ & 0.01 & 5 & 0.7 & 2 & $0.2 \mathrm{~N}$ & 0.7 & $0.5 \mathrm{~N}$ & $200 \mathrm{~N}$ & $10 \mathrm{~N}$ & 2,0000 & 700 & 1.5 & $10 \mathrm{~N}$ & $20 \mathrm{~N}$ \\
\hline $\mathrm{BC} 248 \mathrm{R}$ & $7^{\circ} 33^{\prime} 00^{\prime \prime}$ & $60^{\circ} 48^{\prime} 00^{\prime \prime}$ & $0.05 \mathrm{~L}$ & 0.01 & 1.5 & 0.2 & $0.2 \mathrm{~L}$ & $0.2 \mathrm{~N}$ & 0.07 & $0.5 \mathrm{~N}$ & $200 \mathrm{~N}$ & $10 \mathrm{~N}$ & 1,500 & 100 & $1 \mathrm{~L}$ & $10 \mathrm{~N}$ & $20 \mathrm{~N}$ \\
\hline $\mathrm{BC} 249 \mathrm{R}$ & $7^{\circ} 33^{\prime} 00^{\prime \prime}$ & $60^{\circ} 48^{\prime} 00^{\prime \prime}$ & $0.05 \mathrm{~L}$ & 0.01 & 5 & 0.5 & 1.5 & $0.2 \mathrm{~L}$ & 0.5 & $0.5 \mathrm{~N}$ & $200 \mathrm{~N}$ & $10 \mathrm{~N}$ & 2,000 & 700 & 1.5 & $10 \mathrm{~N}$ & $20 \mathrm{~N}$ \\
\hline $\mathrm{BC} 250 \mathrm{R}$ & $7^{\circ} 33^{\prime} 00^{\prime \prime}$ & $60^{\circ} 48^{\prime} 00^{\prime \prime}$ & $0.05 \mathrm{~L}$ & 0.01 & 3 & 0.7 & 0.7 & $0.2 \mathrm{~L}$ & 0.3 & 3 & 300 & ION & $2,000 G$ & 500 & 1.5 & 30 & $20 \mathrm{~N}$ \\
\hline $\mathrm{BC} 267 \mathrm{R}$ & $7^{\circ} 33^{\prime} 00^{\prime \prime}$ & $60^{\circ} 48^{\prime} 00^{\prime \prime}$ & $0.05 \mathrm{~L}$ & $0.01 \mathrm{~L}$ & 1.5 & 0.3 & $0.2 \mathrm{~L}$ & $0.2 \mathrm{~N}$ & 0.07 & $0.5 \mathrm{~N}$ & $200 \mathrm{~N}$ & ION & 1,500 & 1,500 & IL & $10 \mathrm{~N}$ & $20 \mathrm{~N}$ \\
\hline$B C 268 R$ & $7^{\circ} 33^{\prime} 00^{\prime \prime}$ & $60^{\circ} 48^{\circ} 00^{\prime \prime}$ & 0.05 & 0.02 & 2 & 0.7 & 0.5 & $0.2 \mathrm{~N}$ & 0.15 & $0.5 \mathrm{~N}$ & $200 \mathrm{~N}$ & $10 \mathrm{~N}$ & $2,000 \mathrm{G}$ & 1,000 & $1 \mathrm{~L}$ & 10 & $20 \mathrm{~N}$ \\
\hline \multirow[t]{2}{*}{$\underline{\mathrm{BC}} 275 \mathrm{R}$} & $7^{\circ} 33^{\circ}\left(0^{\prime \prime}\right.$ & $60^{\circ} 48^{\prime} 00^{\prime \prime}$ & 0.05 & 0.02 & 3 & 0.5 & 0.5 & $0.2 \mathrm{~N}$ & 0.5 & $0.5 \mathrm{~N}$ & $200 \mathrm{~N}$ & $10 \mathrm{~N}$ & 1,500 & 1,000 & 1 & $10 \mathrm{~N}$ & $20 \mathrm{~N}$ \\
\hline & $\mathrm{Co}-\mathrm{S}$ & Cr-S & $\mathrm{Cu}-\mathrm{S}$ & Ga-S & $\mathrm{Ge}-\mathrm{S}$ & La-S & $\mathrm{Mn}-\mathrm{S}$ & Mo-S & $\mathrm{Nb}-\mathrm{S}$ & $\mathrm{Ni}-\mathrm{S}$ & $\mathrm{Pb}-\mathrm{S}$ & Sb-S & Sc-S & $\mathrm{Sn}-\mathrm{S}$ & Sr-S & Th-S & $\mathrm{V}-\mathrm{S}$ \\
\hline $\mathrm{BC} 201 \mathrm{R}$ & 30 & 100 & 150 & 50 & $10 \mathrm{~N}$ & 50 & 700 & $5 \mathrm{~N}$ & $20 \mathrm{~L}$ & $\overline{70}$ & 50 & $100 \mathrm{~N}$ & 20 & $10 \mathrm{~N}$ & 200 & $100 \mathrm{~N}$ & 100 \\
\hline BC202R & $10 \mathrm{~L}$ & 10 & 30 & $5 \mathrm{~L}$ & ION & $50 \mathrm{~N}$ & 150 & $5 \mathrm{~N}$ & $20 \mathrm{~N}$ & 10 & 102 & $100 N$ & 5 & $10 \mathrm{~N}$ & $100 \mathrm{~N}$ & $100 \mathrm{~N}$ & 50 \\
\hline BC203R & 30 & 70 & 70 & 30 & $10 \mathrm{~N}$ & 50 & 300 & $5 \mathrm{~N}$ & $20 \mathrm{~N}$ & 30 & 30 & $100 \mathrm{~N}$ & 20 & $10 \mathrm{~N}$ & 200 & $100 \mathrm{~N}$ & 100 \\
\hline BC204R & 50 & 70 & 50 & 30 & $10 \mathrm{~N}$ & $50 \mathrm{~L}$ & 1,000 & $5 \mathrm{~N}$ & $20 \mathrm{~L}$ & 50 & 30 & $100 \mathrm{~N}$ & 20 & $10 \mathrm{~N}$ & 300 & $100 \mathrm{~N}$ & 100 \\
\hline BC205R & 300 & 100 & 200 & 50 & $10 \mathrm{~N}$ & $50 \mathrm{~L}$ & $5,000 \mathrm{G}$ & $5 \mathrm{~N}$ & $20 \mathrm{~L}$ & 70 & 50 & $100 \mathrm{~N}$ & 20 & $10 \mathrm{~N}$ & 300 & $100 \mathrm{~N}$ & 100 \\
\hline $\mathrm{BC} 206 \mathrm{R}$ & 50 & 20 & 20 & $5 \mathrm{~N}$ & $10 \mathrm{~N}$ & $50 \mathrm{~N}$ & 1,000 & $5 \mathrm{~N}$ & $20 \mathrm{~N}$ & 15 & 15 & $100 \mathrm{~N}$ & $5 \mathrm{~L}$ & $10 N$ & $100 \mathrm{~N}$ & $100 \mathrm{~N}$ & 50 \\
\hline BC207R & 50 & 70 & 70 & 50 & $10 \mathrm{~N}$ & $50 \mathrm{~N}$ & 700 & $5 \mathrm{~N}$ & 20 & 30 & 30 & $100 \mathrm{~N}$ & 10 & $10 \mathrm{~N}$ & 300 & $100 \mathrm{~N}$ & 70 \\
\hline BC208R & 300 & 10 & 70 & $5 \mathrm{~L}$ & $10 N$ & $50 N$ & $5,000 \mathrm{G}$ & $5 \mathrm{~N}$ & $20 \mathrm{~N}$ & 30 & 30 & $100 \mathrm{~N}$ & 5 & $10 \mathrm{~N}$ & $100 \mathrm{~N}$ & $100 \mathrm{~N}$ & 30 \\
\hline BC209R & 50 & 100 & 50 & 30 & $10 \mathrm{~N}$ & $50 N$ & 1,000 & $5 \mathrm{~N}$ & $20 \mathrm{~L}$ & 70 & 20 & $100 \mathrm{~N}$ & 10 & $10 \mathrm{~N}$ & 300 & $100 \mathrm{~N}$ & 100 \\
\hline $\mathrm{BC} 210 \mathrm{R}$ & 15 & 150 & 50 & 50 & $10 \mathrm{~N}$ & $50 N$ & 700 & $5 \mathrm{~N}$ & $20 \mathrm{~L}$ & 30 & 50 & $100 \mathrm{~N}$ & 20 & $10 \mathrm{~N}$ & 300 & $100 \mathrm{~N}$ & 100 \\
\hline $\mathrm{BC} 211 \mathrm{R}$ & 20 & 10 & 30 & $5 \mathrm{~N}$ & $10 \mathrm{~N}$ & $50 \mathrm{~N}$ & $5,000 \mathrm{G}$ & $5 \mathrm{~N}$ & $20 \mathrm{~N}$ & 5 & 100 & $100 \mathrm{~N}$ & 5 & $10 \mathrm{~N}$ & $100 \mathrm{~N}$ & $100 \mathrm{~N}$ & 50 \\
\hline $\mathrm{BC} 212 \mathrm{R}$ & 30 & 100 & 70 & 20 & $10 \mathrm{~N}$ & $50 \mathrm{~L}$ & 200 & $5 \mathrm{~N}$ & $20 \mathrm{~L}$ & 30 & 20 & $100 \mathrm{~N}$ & 15 & $10 \mathrm{~N}$ & 300 & $100 \mathrm{~N}$ & 150 \\
\hline BC213R & 30 & 100 & 50 & 30 & $10 \mathrm{~N}$ & $50 \mathrm{~L}$ & 700 & $5 \mathrm{~N}$ & $20 \mathrm{~L}$ & 50 & 100 & $100 \mathrm{~N}$ & 20 & $10 \mathrm{~N}$ & 300 & $100 \mathrm{~N}$ & 100 \\
\hline BC214R & 150 & 15 & 20 & $5 \mathrm{~N}$ & $10 \mathrm{~N}$ & $50 \mathrm{~N}$ & 3000 & SL & $20 \mathrm{~N}$ & 7 & 100 & $100 \mathrm{~N}$ & $5 \mathrm{~L}$ & $10 \mathrm{~N}$ & $100 \mathrm{~N}$ & $100 \mathrm{~N}$ & 70 \\
\hline BC215R & 150 & 50 & 100 & 20 & ION & 200 & 3000 & 5 & $20 \mathrm{~N}$ & 100 & 30 & $100 \mathrm{~N}$ & 7 & $10 \mathrm{~N}$ & 300 & $100 \mathrm{~N}$ & 150 \\
\hline
\end{tabular}




\begin{tabular}{|c|c|c|c|c|c|c|c|c|c|c|c|c|c|c|c|c|c|}
\hline $\mathrm{BC} 216 \mathrm{R}$ & 20 & 100 & 70 & 50 & $10 \mathrm{~N}$ & $50 \mathrm{~L}$ & 1,000 & $5 \mathrm{~N}$ & $20 \mathrm{~L}$ & 30 & 30 & $100 \mathrm{~N}$ & 20 & $10 \mathrm{~N}$ & 300 & $100 \mathrm{~N}$ & 100 \\
\hline $\mathrm{BC} 217 \mathrm{R}$ & $10 \mathrm{~L}$ & 10 & 15 & $5 \mathrm{~N}$ & $10 \mathrm{~N}$ & $50 \mathrm{~N}$ & 300 & $5 \mathrm{~N}$ & $20 \mathrm{~N}$ & 5 & 10 & $100 \mathrm{~N}$ & $5 \mathrm{~L}$ & $10 \mathrm{~N}$ & $100 \mathrm{~N}$ & $100 \mathrm{~N}$ & 30 \\
\hline BC218R & 10 & 150 & 50 & 50 & $10 \mathrm{~N}$ & $50 \mathrm{~L}$ & 150 & $5 \mathrm{~N}$ & $20 \mathrm{~L}$ & 30 & 50 & $100 \mathrm{~N}$ & 20 & $10 N$ & 300 & $100 \mathrm{~N}$ & 150 \\
\hline BC219R & 10 & 100 & 50 & 50 & $10 \mathrm{~N}$ & $50 \mathrm{~L}$ & 200 & $5 \mathrm{~N}$ & $20 \mathrm{~L}$ & 20 & 70 & $100 \mathrm{~N}$ & 15 & $10 \mathrm{~N}$ & 300 & $100 \mathrm{~N}$ & 150 \\
\hline $\mathrm{BC} 220 \mathrm{R}$ & $10 \mathrm{~L}$ & 10 & 20 & $5 \mathrm{~N}$ & $10 \mathrm{~N}$ & $50 \mathrm{~N}$ & 200 & $5 \mathrm{~N}$ & $20 \mathrm{~N}$ & 5 & 30 & $100 \mathrm{~N}$ & $5 \mathrm{~L}$ & $10 \mathrm{~N}$ & $100 \mathrm{~N}$ & $100 \mathrm{~N}$ & 50 \\
\hline $\mathrm{BC} 22 \mathrm{IR}$ & 20 & 150 & 100 & 30 & $10 \mathrm{~N}$ & $50 \mathrm{~L}$ & 150 & $5 \mathrm{~N}$ & $20 \mathrm{~N}$ & 50 & 30 & $100 \mathrm{~N}$ & 20 & $10 \mathrm{~N}$ & 300 & $100 \mathrm{~N}$ & 200 \\
\hline $\mathrm{BC} 222 \mathrm{R}$ & 15 & 150 & 70 & 50 & $10 \mathrm{~N}$ & $50 \mathrm{~N}$ & 200 & $5 \mathrm{~N}$ & $20 \mathrm{~L}$ & 30 & 50 & $100 \mathrm{~N}$ & 20 & $10 \mathrm{~N}$ & 300 & $100 \mathrm{~N}$ & 100 \\
\hline $\mathrm{BC} 223 \mathrm{R}$ & 20 & 150 & 70 & 50 & $10 \mathrm{~N}$ & $50 \mathrm{~N}$ & 300 & $5 \mathrm{~N}$ & $20 \mathrm{~L}$ & 50 & 50 & $100 \mathrm{~N}$ & 20 & $10 \mathrm{~N}$ & 300 & $100 \mathrm{~N}$ & 150 \\
\hline $\mathrm{BC} 224 \mathrm{R}$ & 2,000 & 30 & 700 & 15 & $10 N$ & $50 \mathrm{~L}$ & $5,000 \mathrm{G}$ & $5 \mathrm{~N}$ & $20 \mathrm{~N}$ & 500 & 1,000 & $100 \mathrm{~N}$ & 15 & $10 \mathrm{~N}$ & 200 & $100 \mathrm{~N}$ & 150 \\
\hline $\mathrm{BC} 225 \mathrm{R}$ & 10 & 150 & 50 & 30 & $10 \mathrm{~N}$ & $50 \mathrm{~N}$ & 500 & $5 \mathrm{~N}$ & $20 \mathrm{~L}$ & 50 & 70 & $100 \mathrm{~N}$ & 20 & $10 \mathrm{~N}$ & 200 & $100 \mathrm{~N}$ & 150 \\
\hline $\mathrm{BC} 226 \mathrm{R}$ & 700 & 15 & 150 & $5 \mathrm{~L}$ & $10 \mathrm{~N}$ & $50 \mathrm{~N}$ & $5,000 \mathrm{G}$ & $5 \mathrm{~N}$ & $20 \mathrm{~N}$ & 70 & 150 & $100 \mathrm{~N}$ & 7 & $10 \mathrm{~N}$ & $100 \mathrm{~N}$ & $100 \mathrm{~N}$ & 70 \\
\hline $\mathrm{BC} 227 \mathrm{R}$ & 20 & 200 & 100 & 50 & $10 \mathrm{~N}$ & $50 \mathrm{~N}$ & 700 & $5 \mathrm{~N}$ & $20 \mathrm{~L}$ & 50 & 300 & $100 \mathrm{~N}$ & 20 & ION & 300 & $100 \mathrm{~N}$ & 150 \\
\hline BC228R & 15 & 200 & 50 & 30 & ION & $50 \mathrm{~N}$ & 300 & $5 \mathrm{~N}$ & $20 \mathrm{~N}$ & 50 & 50 & $100 \mathrm{~N}$ & 20 & $10 \mathrm{~N}$ & 300 & $100 \mathrm{~N}$ & 150 \\
\hline $\mathrm{BC} 228 \mathrm{RA}$ & 2,000 & 100 & 300 & 30 & $10 \mathrm{~N}$ & $50 \mathrm{~N}$ & 5,000 & $5 \mathrm{~N}$ & $20 \mathrm{~L}$ & 150 & 300 & $100 \mathrm{~N}$ & 20 & $10 \mathrm{~N}$ & 500 & $100 \mathrm{~N}$ & 200 \\
\hline $\mathrm{BC} 229 \mathrm{R}$ & 50 & 10 & 20 & 5 & $10 \mathrm{~N}$ & $50 \mathrm{~N}$ & 700 & $5 \mathrm{~N}$ & $20 \mathrm{~N}$ & 10 & 20 & 100 & 7 & $10 \mathrm{~N}$ & $100 \mathrm{~L}$ & $100 \mathrm{~N}$ & 100 \\
\hline $\mathrm{BC} 230 \mathrm{R}$ & 10 & 150 & 50 & 50 & $10 \mathrm{~N}$ & $50 \mathrm{~N}$ & 200 & $5 \mathrm{~N}$ & $20 \mathrm{~L}$ & 30 & 30 & $100 \mathrm{~N}$ & 20 & $10 N$ & 300 & $100 \mathrm{~N}$ & 150 \\
\hline BC23IR & $10 \mathrm{~N}$ & 70 & 30 & 30 & $10 \mathrm{~N}$ & $50 \mathrm{~N}$ & 200 & $5 \mathrm{~N}$ & $20 \mathrm{~N}$ & 15 & 30 & $100 \mathrm{~N}$ & 7 & $10 \mathrm{~N}$ & $100 \mathrm{~N}$ & $100 \mathrm{~N}$ & 100 \\
\hline $\mathrm{BC} 232 \mathrm{R}$ & 70 & 30 & 70 & 7 & $10 \mathrm{~N}$ & 70 & 1,000 & $5 \mathrm{~N}$ & $20 \mathrm{~N}$ & 20 & 50 & $100 \mathrm{~N}$ & 15 & $10 \mathrm{~N}$ & $100 \mathrm{~N}$ & $100 \mathrm{~N}$ & 50 \\
\hline $\mathrm{BC} 233 \mathrm{R}$ & $10 \mathrm{~L}$ & 150 & 100 & 50 & $10 \mathrm{~N}$ & $50 \mathrm{~L}$ & 150 & $5 \mathrm{~N}$ & $20 \mathrm{~N}$ & 30 & 70 & $100 \mathrm{~N}$ & 20 & $10 \mathrm{~N}$ & 150 & $100 \mathrm{~N}$ & 100 \\
\hline $\mathrm{BC} 234 \mathrm{R}$ & 30 & 150 & 50 & 30 & $10 N$ & $50 \mathrm{~N}$ & 300 & $5 \mathrm{~N}$ & $20 \mathrm{~L}$ & 50 & 30 & $100 \mathrm{~N}$ & 20 & $10 \mathrm{~N}$ & 300 & $100 \mathrm{~N}$ & 150 \\
\hline $\mathrm{BC} 235 \mathrm{R}$ & $10 \mathrm{~L}$ & 100 & 50 & 50 & $10 \mathrm{~N}$ & $50 \mathrm{~N}$ & 300 & $5 \mathrm{~N}$ & $20 \mathrm{~L}$ & 10 & 30 & $100 \mathrm{~N}$ & 15 & $10 \mathrm{~N}$ & 300 & $100 \mathrm{~N}$ & 150 \\
\hline $\mathrm{BC} 236 \mathrm{R}$ & 15 & 20 & 30 & $5 \mathrm{~L}$ & $10 \mathrm{~N}$ & $50 \mathrm{~N}$ & 700 & $5 \mathrm{~N}$ & $20 \mathrm{~N}$ & 5 & 300 & $100 \mathrm{~N}$ & $5 \mathrm{~L}$ & $10 N$ & $100 \mathrm{~N}$ & $100 \mathrm{~N}$ & 50 \\
\hline $\mathrm{BC} 237 \mathrm{R}$ & 30 & 100 & 50 & 50 & $10 \mathrm{~N}$ & $50 \mathrm{~N}$ & 300 & $5 \mathrm{~N}$ & $20 \mathrm{~L}$ & 50 & 30 & $100 \mathrm{~N}$ & 15 & $10 \mathrm{~N}$ & 300 & $100 \mathrm{~N}$ & 150 \\
\hline $\mathrm{BC} 238 \mathrm{R}$ & $10 \mathrm{~L}$ & 15 & 10 & $5 \mathrm{~N}$ & $10 \mathrm{~N}$ & $50 \mathrm{~N}$ & 300 & $5 \mathrm{~N}$ & $20 \mathrm{~N}$ & $5 \mathrm{~L}$ & 20 & $100 \mathrm{~N}$ & $5 \mathrm{~L}$ & $10 \mathrm{~N}$ & $100 \mathrm{~N}$ & $100 \mathrm{~N}$ & 50 \\
\hline $\mathrm{BC} 239 \mathrm{R}$ & 20 & 200 & 70 & 50 & $10 \mathrm{~N}$ & $50 \mathrm{~N}$ & 700 & $5 \mathrm{~N}$ & $20 \mathrm{~L}$ & 50 & 50 & $100 \mathrm{~N}$ & 20 & $10 \mathrm{~N}$ & 300 & $100 \mathrm{~N}$ & 200 \\
\hline BC240R & 15 & 200 & 150 & 50 & $10 \mathrm{~N}$ & $50 \mathrm{~N}$ & 2,000 & $5 \mathrm{~N}$ & $20 \mathrm{~L}$ & 30 & 100 & $100 \mathrm{~N}$ & 20 & $10 \mathrm{~N}$ & 200 & $100 \mathrm{~N}$ & 200 \\
\hline BC241R & 30 & 10 & 70 & 5 & $10 \mathrm{~N}$ & $50 \mathrm{~L}$ & $5,000 \mathrm{G}$ & $5 \mathrm{~N}$ & $20 \mathrm{~N}$ & 15 & 700 & $100 \mathrm{~N}$ & 10 & $10 \mathrm{~N}$ & 100 & $100 \mathrm{~N}$ & 100 \\
\hline $\mathrm{BC} 242 \mathrm{R}$ & 500 & 20 & 150 & $5 \mathrm{~L}$ & $10 \mathrm{~N}$ & $50 \mathrm{~L}$ & $5,000 \mathrm{G}$ & $5 \mathrm{~N}$ & $20 \mathrm{~N}$ & 30 & 50 & $100 \mathrm{~N}$ & 7 & $10 \mathrm{~N}$ & $100 \mathrm{~L}$ & $100 \mathrm{~N}$ & 100 \\
\hline BC243R & 700 & 15 & 700 & $5 \mathrm{~N}$ & $10 \mathrm{~N}$ & $50 \mathrm{~L}$ & $5,000 \mathrm{G}$ & $5 \mathrm{~N}$ & $20 \mathrm{~N}$ & 30 & 30 & $100 \mathrm{~N}$ & 5 & $10 \mathrm{~N}$ & 200 & $100 \mathrm{~N}$ & 100 \\
\hline BC244R & 100 & 70 & 100 & 20 & $10 \mathrm{~N}$ & 70 & 3000 & $5 \mathrm{~N}$ & $20 \mathrm{~L}$ & 50 & 30 & $100 \mathrm{~N}$ & 15 & $10 \mathrm{~N}$ & 300 & $100 \mathrm{~N}$ & 100 \\
\hline BC245R & 15 & 70 & 50 & 50 & $10 \mathrm{~N}$ & $50 \mathrm{~N}$ & 300 & $5 \mathrm{~N}$ & $20 \mathrm{~L}$ & 20 & 30 & $100 \mathrm{~N}$ & 15 & $10 \mathrm{~N}$ & 300 & $100 \mathrm{~N}$ & 150 \\
\hline $\mathrm{BC} 246 \mathrm{R}$ & 15 & 15 & 20 & $5 \mathrm{~L}$ & $10 \mathrm{~N}$ & $50 \mathrm{~N}$ & 700 & $5 \mathrm{~N}$ & $20 \mathrm{~N}$ & 5 & 10 & $100 \mathrm{~N}$ & SL & $10 \mathrm{~N}$ & $100 \mathrm{~N}$ & $100 \mathrm{~N}$ & 50 \\
\hline $\mathrm{BC} 247 \mathrm{R}$ & 15 & 100 & 50 & 50 & $10 \mathrm{~N}$ & $50 \mathrm{~N}$ & 300 & $5 \mathrm{~N}$ & $20 \mathrm{~L}$ & 20 & 50 & $100 \mathrm{~N}$ & 20 & $10 \mathrm{~N}$ & 300 & $100 \mathrm{~N}$ & 200 \\
\hline BC248R & 10 & $10 \mathrm{~L}$ & 20 & $5 \mathrm{~L}$ & $10 \mathrm{~N}$ & $50 \mathrm{~N}$ & 300 & $5 \mathrm{~N}$ & $20 \mathrm{~N}$ & 7 & 15 & $100 \mathrm{~N}$ & 5 & $10 \mathrm{~N}$ & IOON & $100 \mathrm{~N}$ & 70 \\
\hline BC249R & $10 \mathrm{~L}$ & 50 & 50 & 50 & $10 N$ & $50 \mathrm{~N}$ & 300 & $5 \mathrm{~N}$ & $20 \mathrm{~N}$ & 15 & 30 & $100 \mathrm{~N}$ & 15 & $10 \mathrm{~N}$ & 300 & $100 \mathrm{~N}$ & 150 \\
\hline $\mathrm{BC} 250 \mathrm{R}$ & $10 \mathrm{~L}$ & 30 & 30 & 20 & $10 \mathrm{~N}$ & $50 \mathrm{~L}$ & 150 & $5 \mathrm{~N}$ & $20 \mathrm{~L}$ & 7 & 700 & $100 \mathrm{~N}$ & 10 & $10 \mathrm{~N}$ & 300 & $100 \mathrm{~N}$ & 150 \\
\hline $\mathrm{BC} 267 \mathrm{R}$ & 70 & 15 & 50 & $5 \mathrm{~L}$ & $10 \mathrm{~N}$ & $50 \mathrm{~N}$ & $5,000 \mathrm{G}$ & $5 \mathrm{~N}$ & $20 \mathrm{~N}$ & 7 & 300 & $100 \mathrm{~N}$ & 7 & $10 N$ & $100 \mathrm{~N}$ & $100 \mathrm{~N}$ & 150 \\
\hline BC268R & 300 & 50 & 150 & 7 & $10 \mathrm{~N}$ & $50 \mathrm{~L}$ & $5,000 \mathrm{G}$ & $5 \mathrm{~N}$ & $20 \mathrm{~N}$ & 50 & 500 & $100 \mathrm{~N}$ & 10 & $10 \mathrm{~N}$ & 200 & $100 \mathrm{~N}$ & 150 \\
\hline BC275R & 100 & 70 & 100 & 15 & $10 N$ & $50 \mathrm{~L}$ & $5,000 \mathrm{G}$ & $5 \mathrm{~N}$ & $20 \mathrm{~L}$ & 20 & 300 & $100 \mathrm{~N}$ & 15 & $10 \mathrm{~N}$ & 200 & $100 \mathrm{~N}$ & 150 \\
\hline & W-S & Y.S & $\mathrm{Zn}-\mathrm{S}$ & $\mathrm{Zr}-\mathrm{S}$ & $\mathrm{As} / \mathrm{p}$ & $\mathrm{Au}$ & $\mathrm{Bj} / \mathrm{p}$ & $\mathrm{Cd} / \mathrm{p}$ & $\mathrm{Hg}$ & $\underline{s} / \mathrm{p}$ & $\mathrm{Te}$ & $\mathrm{Tl}$ & $\mathrm{Zn} / \mathrm{p}$ & \multicolumn{3}{|c|}{ Sample description } & \\
\hline BC201R & $20 \mathrm{~N}$ & 30 & $200 \mathrm{~L}$ & 150 & $5 \mathrm{~L}$ & 0.012 & $2 \mathrm{~L}$ & $0.1 \mathrm{~L}$ & 0.02 & $2 \mathrm{~L}$ & $0.05 \mathrm{~N}$ & 0.2 & 150 & \multicolumn{3}{|l|}{ Schist. } & \\
\hline $\mathrm{BC} 202 \mathrm{R}$ & $20 \mathrm{~N}$ & $10 \mathrm{~L}$ & $200 \mathrm{~N}$ & 50 & $5 \mathrm{~L}$ & 0.040 & $2 \mathrm{~L}$ & $0.1 \mathrm{~L}$ & 0.02 & $2 \mathrm{~L}$ & 0.55 & $0.05 \mathrm{~L}$ & 7 & \multicolumn{3}{|c|}{ Quartz-tourmaline vein. } & \\
\hline BC203R & $20 \mathrm{~N}$ & 50 & $200 \mathrm{~N}$ & 150 & $5 \mathrm{~L}$ & 0.004 & $2 \mathrm{~L}$ & $0.1 \mathrm{~L}$ & $0.02 \mathrm{~N}$ & $2 \mathrm{~L}$ & $0.05 \mathrm{~N}$ & 0.15 & 82 & \multicolumn{3}{|c|}{ Schist. } & \\
\hline BC204R & $20 \mathrm{~N}$ & 30 & $200 \mathrm{~L}$ & 150 & $5 \mathrm{~L}$ & 0.018 & $2 \mathrm{~L}$ & $0.1 \mathrm{~L}$ & $0.02 \mathrm{~N}$ & $2 \mathrm{~L}$ & $0.05 \mathrm{~N}$ & 0.2 & 53 & \multicolumn{3}{|c|}{ Silicified schist. } & \\
\hline BC205R & $20 \mathrm{~N}$ & 30 & $200 \mathrm{~L}$ & 150 & $5 \mathrm{~L}$ & 0.012 & $2 \mathrm{~L}$ & 0.3 & 0.04 & 2 & 0.15 & 0.15 & 69 & \multicolumn{3}{|c|}{ Silicified schist. } & \\
\hline BC206R & $20 \mathrm{~N}$ & $10 \mathrm{~N}$ & $200 \mathrm{~N}$ & 15 & $5 \mathrm{~L}$ & 0.1 & $2 \mathrm{~L}$ & 0.2 & 0.02 & $2 \mathrm{~L}$ & 1.45 & $0.05 \mathrm{~N}$ & 10 & \multicolumn{3}{|c|}{ Quartz vein. } & \\
\hline BC207R & $20 \mathrm{~N}$ & 30 & $200 \mathrm{~N}$ & 300 & $5 \mathrm{~L}$ & 0.038 & $2 \mathrm{~L}$ & $0.1 \mathrm{~L}$ & $0.02 \mathrm{~N}$ & $2 \mathrm{~L}$ & 0.2 & 0.15 & 19 & \multicolumn{3}{|c|}{ Silicified schist. } & \\
\hline BC208R & $20 N$ & $10 \mathrm{~L}$ & $200 \mathrm{~N}$ & 30 & SL & 0.014 & $2 \mathrm{~L}$ & 0.3 & $0.02 \mathrm{~N}$ & $2 \mathrm{~L}$ & $0.05 \mathrm{~N}$ & $0.05 \mathrm{~N}$ & 39 & \multicolumn{3}{|c|}{ Quartz-tourmaline vein. } & \\
\hline BC209R & $20 \mathrm{~N}$ & 20 & $200 \mathrm{~N}$ & 150 & $5 \mathrm{~L}$ & 0.002 & $2 \mathrm{~L}$ & $0.1 \mathrm{~L}$ & $0.02 \mathrm{~N}$ & $2 \mathrm{~L}$ & $0.05 \mathrm{~N}$ & 0.25 & 33 & \multicolumn{3}{|c|}{ Schist. } & \\
\hline BC210R & $20 \mathrm{~N}$ & 50 & $200 \mathrm{~N}$ & 150 & $5 \mathrm{~L}$ & 0.006 & $2 \mathrm{~L}$ & $0.1 \mathrm{~L}$ & $0.02 \mathrm{~N}$ & $2 \mathrm{~L}$ & $0.05 \mathrm{~N}$ & 0.25 & 49 & \multicolumn{3}{|c|}{ Schist. } & \\
\hline BC21IR & $20 \mathrm{~N}$ & $10 \mathrm{~L}$ & $200 \mathrm{~N}$ & 50 & SL & 0.008 & $2 \mathrm{~L}$ & 0.2 & $0.02 \mathrm{~N}$ & $2 \mathrm{~L}$ & $0.05 \mathrm{~N}$ & 0.05 & 12 & \multirow{2}{*}{\multicolumn{3}{|c|}{$\begin{array}{l}\text { Quartz vein. } \\
\text { Schist. }\end{array}$}} & \\
\hline BC212R & $20 \mathrm{~N}$ & 20 & $200 \mathrm{~N}$ & 200 & $5 \mathrm{~L}$ & 0.150 & $2 \mathrm{~L}$ & $0.1 \mathrm{~L}$ & $0.02 \mathrm{~N}$ & $2 L$ & 7 & $0.05 \mathrm{~N}$ & 29 & & & & \\
\hline
\end{tabular}


Appendix table 4. Rock samples collected from trench T2, Bochinche area, Venezuela - Continued.

\begin{tabular}{|c|c|c|c|c|c|c|c|c|c|c|c|c|c|c|}
\hline & W.S & $\mathrm{Y}-\mathrm{S}$ & $\mathrm{Zn}-\mathrm{S}$ & $\mathrm{ZI}-\mathrm{S}$ & $\mathrm{As} / \mathrm{p}$ & Au & $\mathrm{Bi} / \mathrm{p}$ & $\mathrm{Cd} / \mathrm{p}$ & $\mathrm{Hg}$ & Sb/p & $\mathrm{Te}$ & $\mathrm{T}]$ & $\mathrm{Zn} / \mathrm{p}$ & Sample description \\
\hline BC213R & $20 \mathrm{~N}$ & 20 & $200 \mathrm{~N}$ & 100 & $5 \mathrm{~L}$ & $0.002 \mathrm{~L}$ & $2 \mathrm{~L}$ & $0.1 \mathrm{~L}$ & $0.02 \mathrm{~N}$ & $2 \mathrm{~L}$ & $0.05 \mathrm{~N}$ & 0.2 & 43 & Schist. \\
\hline BC214R & $20 \mathrm{~N}$ & $10 \mathrm{~N}$ & $200 \mathrm{~N}$ & 30 & $5 \mathrm{~L}$ & 0.008 & $2 \mathrm{~L}$ & 0.1 & 0.02 & $2 \mathrm{~L}$ & 0.15 & $0.05 \mathrm{~N}$ & 9 & Quart vein. \\
\hline BC215R & $20 \mathrm{~N}$ & 70 & $200 \mathrm{~N}$ & 150 & $5 \mathrm{~L}$ & 0.008 & $2 \mathrm{~L}$ & 0.3 & $0.02 \mathrm{~N}$ & $2 \mathrm{~L}$ & $0.05 \mathrm{~N}$ & $0.05 \mathrm{~L}$ & 61 & Black siliceous zone. \\
\hline $\mathrm{BC} 2 \mathrm{I} 6 \mathrm{R}$ & $20 \mathrm{~N}$ & 20 & $200 \mathrm{~N}$ & 150 & $5 \mathrm{~L}$ & $0.002 \mathrm{~L}$ & $2 \mathrm{~L}$ & 0.1 & $0.02 \mathrm{~N}$ & $2 \mathrm{~L}$ & $0.05 \mathrm{~N}$ & 0.3 & 40 & Bleached schist. \\
\hline $\mathrm{BC} 217 \mathrm{R}$ & $20 \mathrm{~N}$ & $10 \mathrm{~N}$ & $200 \mathrm{~N}$ & 20 & $5 \mathrm{~L}$ & 0.010 & $2 \mathrm{~L}$ & $0.1 \mathrm{~L}$ & 0.02 & $2 \mathrm{~L}$ & 0.1 & $0.05 \mathrm{~L}$ & 6 & Quartz-tourmaline vein. \\
\hline $\mathrm{BC} 2 \mathrm{I} 8 \mathrm{R}$ & $20 \mathrm{~N}$ & 20 & $200 \mathrm{~L}$ & 150 & $5 \mathrm{~L}$ & 0.002 & $2 \mathrm{~L}$ & 0.2 & $0.02 \mathrm{~N}$ & $2 \mathrm{~L}$ & $0.05 \mathrm{~N}$ & 0.25 & 120 & Schist. \\
\hline $\mathrm{BC} 219 \mathrm{R}$ & $20 \mathrm{~L}$ & 20 & $200 \mathrm{~N}$ & 150 & $5 \mathrm{~L}$ & 0.002 & $2 \mathrm{~L}$ & 0.1 & $0.02 \mathrm{~N}$ & $2 \mathrm{~L}$ & $0.05 \mathrm{~N}$ & 0.25 & 56 & Siliceous host rock. \\
\hline $\mathrm{BC} 220 \mathrm{R}$ & $20 \mathrm{~L}$ & $10 \mathrm{~N}$ & $200 \mathrm{~N}$ & 15 & $5 \mathrm{~L}$ & 1 & 5 & 0.1 & 0.04 & $2 \mathrm{~L}$ & 1.8 & $0.05 \mathrm{~N}$ & 34 & Quartz vein. \\
\hline $\mathrm{BC} 221 \mathrm{R}$ & $20 \mathrm{~N}$ & 20 & $200 \mathrm{~L}$ & 200 & $5 \mathrm{~L}$ & 0.050 & $2 \mathrm{~L}$ & 0.2 & $0.02 \mathrm{~N}$ & 3 & 0.15 & 0.1 & 26 & Schist. \\
\hline $\mathrm{BC} 223 \mathrm{R}$ & $20 \mathrm{~N}$ & 30 & $200 \mathrm{~N}$ & 150 & $5 \mathrm{~L}$ & 0.004 & $2 \mathrm{~L}$ & $0.1 \mathrm{~L}$ & $0.02 \mathrm{~N}$ & $2 \mathrm{~L}$ & 0.05 & 0.15 & 50 & Schist. \\
\hline $\mathrm{BC} 224 \mathrm{R}$ & $20 \mathrm{~N}$ & 15 & 300 & 70 & $5 \mathrm{~L}$ & 0.1 & $2 \mathrm{~L}$ & 0.1 & 0.03 & 7 & 1.1 & 0.15 & 170 & Quartz yein. \\
\hline BC225R & $20 \mathrm{~N}$ & 20 & $200 \mathrm{~N}$ & 150 & $5 \mathrm{~L}$ & 0.002 & $2 \mathrm{~L}$ & $0.1 \mathrm{~L}$ & $0.02 \mathrm{~N}$ & $2 \mathrm{~L}$ & $0.05 \mathrm{~N}$ & 0.2 & 35 & Schist. \\
\hline $\mathrm{BC} 226 \mathrm{R}$ & $20 \mathrm{~N}$ & $10 \mathrm{~L}$ & $200 \mathrm{~N}$ & 30 & $5 \mathrm{~L}$ & 0.006 & 3 & $0.1 \mathrm{~L}$ & 0.04 & $2 \mathrm{~L}$ & $0.05 \mathrm{~N}$ & 0.2 & 71 & Quartz vein. \\
\hline $\mathrm{BC} 227 \mathrm{R}$ & $20 \mathrm{~N}$ & 20 & $200 \mathrm{~N}$ & 150 & $5 \mathrm{~L}$ & 0,006 & $2 \mathrm{~L}$ & 0.1 & $0.02 \mathrm{~N}$ & $2 \mathrm{~L}$ & 0.1 & 0.25 & 74 & Schist. \\
\hline $\mathrm{BC} 228 \mathrm{R}$ & $20 \mathrm{~N}$ & 30 & $200 \mathrm{~N}$ & 70 & 22 & 0.004 & $2 \mathrm{~L}$ & 0.5 & $0.02 \mathrm{~N}$ & $2 \mathrm{~L}$ & $0.05 \mathrm{~N}$ & 0.15 & 57 & Schist. \\
\hline $\mathrm{BC} 228 \mathrm{RA}$ & $20 \mathrm{~N}$ & 15 & $200 \mathrm{~L}$ & 200 & $5 \mathrm{~L}$ & 0.004 & $2 \mathrm{~L}$ & $0.1 \mathrm{~L}$ & $0.02 \mathrm{~N}$ & 3 & $0.05 \mathrm{~N}$ & $0.05 \mathrm{~N}$ & 37 & Siliceous host rock. \\
\hline $\mathrm{BC} 229 \mathrm{R}$ & $20 \mathrm{~N}$ & $10 \mathrm{~N}$ & $200 \mathrm{~N}$ & 20 & $5 \mathrm{~L}$ & 0.014 & $2 \mathrm{~L}$ & $0.1 \mathrm{~L}$ & $0.02 \mathrm{~N}$ & $2 \mathrm{~L}$ & 0.5 & 0.05 & 10 & Quartz-tourmaline vein. \\
\hline $\mathrm{BC} 230 \mathrm{R}$ & 30 & 30 & $200 \mathrm{~N}$ & 150 & $5 \mathrm{~L}$ & 0.004 & $2 \mathrm{~L}$ & 0.2 & $0.02 \mathrm{~N}$ & $2 \mathrm{~L}$ & $0.05 \mathrm{~N}$ & 0.25 & 55 & Schist. \\
\hline $\mathrm{BC} 231 \mathrm{R}$ & $20 \mathrm{~N}$ & 15 & $200 \mathrm{~N}$ & 100 & $5 \mathrm{~L}$ & 0.002 & $2 \mathrm{~L}$ & 0.1 & $0.02 \mathrm{~N}$ & $2 \mathrm{~L}$ & $0.05 \mathrm{~L}$ & 0.1 & 24 & Schist. \\
\hline BC233R & $20 \mathrm{~N}$ & 20 & $200 \mathrm{~N}$ & 100 & $5 \mathrm{~L}$ & 0.008 & $2 \mathrm{~L}$ & $0.1 \mathrm{~L}$ & $0.02 \mathrm{~N}$ & $2 \mathrm{~L}$ & $0.05 \mathrm{~N}$ & 0.35 & 45 & Schist. \\
\hline $\mathrm{BC} 234 \mathrm{R}$ & $20 \mathrm{~N}$ & 20 & $200 \mathrm{~N}$ & 150 & $5 \mathrm{~L}$ & 0.002 & $2 \mathrm{~L}$ & $0.1 \mathrm{~L}$ & $0.02 \mathrm{~N}$ & $2 \mathrm{~L}$ & $0.05 \mathrm{~N}$ & $0.05 \mathrm{~N}$ & 14 & Silicifred vein. \\
\hline $\mathrm{BC} 235 \mathrm{R}$ & $20 \mathrm{~N}$ & 50 & $200 \mathrm{~N}$ & 200 & $5 \mathrm{~L}$ & 0.004 & $2 \mathrm{~L}$ & 0.2 & $0.02 \mathrm{~N}$ & $2 \mathrm{~L}$ & $0.05 \mathrm{~N}$ & 0.25 & 26 & Schist. \\
\hline $\mathrm{BC} 236 \mathrm{R}$ & 70 & $10 \mathrm{~L}$ & $200 \mathrm{~N}$ & 30 & $5 \mathrm{~L}$ & 0.150 & 17 & 2.7 & $0.02 \mathrm{~N}$ & $2 \mathrm{~L}$ & 7 & $0.05 \mathrm{~N}$ & 60 & Quartz vein. \\
\hline $\mathrm{BC} 237 \mathrm{R}$ & $20 \mathrm{~N}$ & 15 & $200 \mathrm{~N}$ & 300 & $5 \mathrm{~L}$ & 0.002 & $2 \mathrm{~L}$ & 0.1 & $0.02 \mathrm{~N}$ & $2 \mathrm{~L}$ & 0.1 & 0.05 & 14 & Silicified host rock. \\
\hline BC238R & $20 \mathrm{~N}$ & $10 \mathrm{~N}$ & $200 \mathrm{~N}$ & 30 & 5L & 0.004 & $2 \mathrm{~L}$ & $0.1 \mathrm{~L}$ & $0.02 \mathrm{~N}$ & $2 \mathrm{~L}$ & 0.2 & $0.05 \mathrm{~L}$ & 8 & Quartz vein. \\
\hline $\mathrm{BC} 239 \mathrm{R}$ & $20 \mathrm{~N}$ & 20 & $200 \mathrm{~N}$ & 100 & 18 & 0.006 & $2 \mathrm{~L}$ & 0.7 & $0.02 \mathrm{~N}$ & $2 \mathrm{~L}$ & $0.05 \mathrm{~N}$ & $0 . I$ & 93 & Schist. \\
\hline $\mathrm{BC} 240 \mathrm{R}$ & $20 \mathrm{~N}$ & 20 & $200 \mathrm{~L}$ & 100 & 6 & 0.002 & 2 & 0.8 & $0.02 \mathrm{~N}$ & $2 \mathrm{~L}$ & $0.05 \mathrm{~N}$ & 0.1 & 100 & Schist. \\
\hline BC241R & $20 \mathrm{~N}$ & $10 \mathrm{~L}$ & $200 \mathrm{~N}$ & 50 & $5 \mathrm{~L}$ & 0.012 & 6 & 1.4 & 0.02 & $2 \mathrm{~L}$ & 7.2 & 0.1 & 43 & Quartz vein. \\
\hline BC242R & $20 \mathrm{~N}$ & 20 & $200 \mathrm{~N}$ & 70 & $5 \mathrm{~L}$ & 0.014 & $2 \mathrm{~L}$ & 1.3 & 0.02 & 3 & $0.05 \mathrm{~N}$ & 0.05 & 36 & Silicified host rock. \\
\hline BC243R & $20 \mathrm{~N}$ & 20 & $200 \mathrm{~N}$ & 50 & $5 \mathrm{~L}$ & 0.002 & $2 \mathrm{~L}$ & 6.8 & $0.02 \mathrm{~N}$ & 11 & $0.05 \mathrm{~N}$ & 0.15 & 62 & Silicified host rock. \\
\hline BC244R & $20 \mathrm{~N}$ & 50 & 200 & 150 & $5 \mathrm{~L}$ & 0.030 & $2 \mathrm{~L}$ & 1.2 & 0.02 & $2 \mathrm{~L}$ & 0.1 & 0.25 & 130 & Silicified host rock. \\
\hline BC245R & $20 \mathrm{~N}$ & 20 & $200 \mathrm{~N}$ & 200 & 5 & 0.004 & $2 \mathrm{~L}$ & 0.2 & $0.02 \mathrm{~N}$ & $2 \mathrm{~L}$ & $0.05 \mathrm{~N}$ & 0.25 & 29 & Silicified host rock. \\
\hline $\mathrm{BC} 246 \mathrm{R}$ & $20 \mathrm{~N}$ & $10 \mathrm{~N}$ & $200 \mathrm{~N}$ & 30 & $5 \mathrm{~L}$ & 0.002 & $2 \mathrm{~L}$ & $0.1 \mathrm{~L}$ & $0.02 \mathrm{~N}$ & $2 \mathrm{~L}$ & 0.1 & 0.05 & 18 & Quartz vein. \\
\hline $\mathrm{BC} 247 \mathrm{R}$ & $20 \mathrm{~N}$ & 20 & $200 \mathrm{~N}$ & 150 & $5 \mathrm{~L}$ & 0.004 & $2 \mathrm{~L}$ & 0.3 & $0.02 \mathrm{~N}$ & $2 \mathrm{~L}$ & 0.1 & 0.25 & 58 & Weathered schist. \\
\hline $\mathrm{BC} 248 \mathrm{R}$ & $20 \mathrm{~N}$ & $10 \mathrm{~L}$ & $200 \mathrm{~N}$ & 30 & $5 \mathrm{~L}$ & 0.008 & $2 \mathrm{~L}$ & 0.1 & $0.02 \mathrm{~N}$ & $2 \mathrm{~L}$ & 0.15 & $0.05 \mathrm{~L}$ & 21 & Quartz vein. \\
\hline BC249R & $20 \mathrm{~N}$ & 15 & $200 \mathrm{~N}$ & 150 & $5 \mathrm{~L}$ & 0.004 & $2 \mathrm{~L}$ & 0.2 & $0.02 \mathrm{~N}$ & $2 \mathrm{~L}$ & 0.05 & 0.2 & 50 & Schist. \\
\hline BC250R & $20 \mathrm{~N}$ & 20 & 500 & 150 & 260 & 2.6 & 15 & 1.2 & 0.02 & $2 \mathrm{~L}$ & 0.75 & 0.2 & 430 & Black schist. \\
\hline $\mathrm{BC} 267 \mathrm{R}$ & $20 \mathrm{~N}$ & $10 \mathrm{~L}$ & $200 \mathrm{~N}$ & 30 & $5 \mathrm{~L}$ & 0.004 & $2 \mathrm{~L}$ & 1.4 & $0.02 \mathrm{~N}$ & $2 \mathrm{~L}$ & 0.15 & 0.15 & 19 & Quartz vein. \\
\hline $\mathrm{BC} 268 \mathrm{R}$ & $20 \mathrm{~N}$ & 10 & $200 \mathrm{~L}$ & 150 & $5 \mathrm{~L}$ & 0.006 & 6 & 2.7 & $0.02 \mathrm{~N}$ & 3 & 3.85 & 0.1 & 55 & Quartz vein. \\
\hline BC275R & $20 \mathrm{~N}$ & 30 & 200 & 150 & 15 & 0.032 & $2 \mathrm{~L}$ & 4.6 & $0.02 \mathrm{~N}$ & 2 & 0.2 & 0.25 & 300 & Quartz-tourmaline vein. \\
\hline
\end{tabular}


Appendix table 5. Rock samples collected from the Bochinche road traverse area, Venezuela.

\begin{tabular}{|c|c|c|c|c|c|c|c|c|c|c|c|c|c|c|c|c|c|}
\hline & Latitude & Longitude & $\mathrm{Ca} \%-\mathrm{S}$ & $\mathrm{F} \%$ & $\mathrm{Fe} \%-\mathrm{S}$ & $\mathrm{Mg} \%-\mathrm{S}$ & $\mathrm{Na} \%-\mathrm{S}$ & $\mathrm{P} \%-\mathrm{S}$ & Ti\%-S & $\mathrm{Ag}-\mathrm{S}$ & As-S & Au-S & B-S & $\mathrm{Ba}-\mathrm{S}$ & $\mathrm{Be}-\mathrm{S}$ & Bi-S & $\mathrm{Cd}-\mathrm{S}$ \\
\hline BIOOI & $7^{\circ} 34^{\prime} 30^{\prime \prime}$ & $60^{\circ} 51^{\prime} 45^{\prime \prime}$ & 0.1 & $0.01 \mathrm{~L}$ & 7 & 2 & 1 & $0.2 \mathrm{~N}$ & 0.3 & $0.5 \mathrm{~N}$ & $200 \mathrm{~N}$ & $10 \mathrm{~N}$ & 20 & 150 & $1 \mathrm{~L}$ & $\overline{10 N}$ & $20 \mathrm{~N}$ \\
\hline BIOO2 & $7^{\circ} 34^{\prime} 30^{\prime \prime}$ & $60^{\circ} 51^{\prime} 45^{\prime \prime}$ & 0.07 & $0.01 \mathrm{~L}$ & 2 & 1 & 0.5 & $0.2 \mathrm{~N}$ & 0.07 & $0.5 \mathrm{~N}$ & $200 \mathrm{~N}$ & $10 \mathrm{~N}$ & $2,000 \mathrm{G}$ & 100 & $1 \mathrm{~L}$ & $10 \mathrm{~N}$ & $20 \mathrm{~N}$ \\
\hline BI003 & $7^{\circ} 34^{\prime} 30^{\prime \prime}$ & $60^{\circ} 51^{\prime} 45^{\prime \prime}$ & $0.05 \mathrm{~L}$ & 0.03 & 7 & 2 & $0.2 \mathrm{~N}$ & $0.2 \mathrm{~N}$ & 0.5 & $0.5 \mathrm{~N}$ & $200 \mathrm{~N}$ & $10 \mathrm{~N}$ & 50 & 200 & 2 & $10 \mathrm{~N}$ & $20 \mathrm{~N}$ \\
\hline BI004 & $7^{\circ} 34^{\prime} 30^{\prime \prime}$ & $60^{\circ} 51^{\prime} 45^{\prime \prime}$ & $0.05 \mathrm{~L}$ & $0.01 \mathrm{~L}$ & 7 & 0.5 & 0.2 & $0.2 \mathrm{~N}$ & 0.3 & $0.5 \mathrm{~N}$ & $200 \mathrm{~N}$ & $10 \mathrm{~N}$ & 300 & 150 & 1.5 & $10 \mathrm{~N}$ & $20 \mathrm{~N}$ \\
\hline BI005 & $7^{\circ} 34^{\prime} 30^{\prime \prime}$ & $60^{\circ} 51^{\prime} 45^{\prime \prime}$ & 0.07 & $0.01 \mathrm{~L}$ & 7 & 1.5 & 1.5 & $0.2 \mathrm{~N}$ & 0.3 & $0.5 \mathrm{~N}$ & $200 \mathrm{~N}$ & $10 \mathrm{~N}$ & 100 & 2,000 & 2 & $10 N$ & $20 \mathrm{~N}$ \\
\hline BI006 & $7^{\circ} 34^{\prime} 30^{\prime \prime}$ & $60^{\circ} 51^{\prime} 45^{\prime \prime}$ & $0.05 \mathrm{~L}$ & $0.01 \mathrm{~L}$ & 0.5 & 0.2 & $0.2 \mathrm{~N}$ & $0.2 \mathrm{~N}$ & 0.02 & $0.5 \mathrm{~N}$ & $200 \mathrm{~N}$ & $10 \mathrm{~N}$ & 700 & 100 & $\mathrm{lL}$ & $10 \mathrm{~N}$ & $20 \mathrm{~N}$ \\
\hline BI007 & $7^{\circ} 34^{\prime} 30^{\prime \prime}$ & $60^{\circ} 51^{\prime} 45^{\prime \prime}$ & 0.05 & $0.01 \mathrm{~L}$ & 0.7 & 0.7 & 0.2 & $0.2 \mathrm{~N}$ & 0.05 & $0.5 \mathrm{~N}$ & $200 \mathrm{~N}$ & $10 \mathrm{~N}$ & $2,000 \mathrm{G}$ & 30 & $1 \mathrm{~L}$ & $10 \mathrm{~N}$ & $20 \mathrm{~N}$ \\
\hline BI008 & $7^{\circ} 34^{\prime} 30^{\prime \prime}$ & $60^{\circ} 51^{\prime} 45^{\prime \prime}$ & $0.05 \mathrm{~L}$ & $0.01 \mathrm{~L}$ & 0.7 & 0.3 & $0.2 \mathrm{~L}$ & $0.2 \mathrm{~N}$ & 0.03 & $0.5 \mathrm{~L}$ & $200 \mathrm{~N}$ & $10 \mathrm{~N}$. & 1,500 & 30 & $1 \mathrm{~L}$ & $10 \mathrm{~N}$ & $20 \mathrm{~N}$ \\
\hline В1009 & $7^{\circ} 34^{\prime} 30^{\prime \prime}$ & $60^{\circ} 51^{\prime} 45^{\prime \prime}$ & 0.07 & $0.01 \mathrm{~L}$ & 1.5 & 0.7 & 0.7 & $0.2 \mathrm{~N}$ & 0.07 & $0.5 \mathrm{~N}$ & $200 \mathrm{~N}$ & $10 N^{\circ}$ & $2,000 \mathrm{G}$ & 30 & $1 \mathrm{~L}$ & $10 \mathrm{~N}$ & $20 \mathrm{~N}$ \\
\hline BI010 & $7^{\circ} 34^{\prime} 30^{\prime \prime}$ & $60^{\circ} 51^{\prime} 45^{\prime \prime}$ & $0.05 \mathrm{~L}$ & $0.01 \mathrm{~L}$ & 7 & 0.2 & $0.2 \mathrm{~N}$ & $0.2 \mathrm{~N}$ & 0.3 & $0.5 \mathrm{~N}$ & $200 \mathrm{~N}$ & $10 \mathrm{~N}$ & 100 & 100 & 1 & $10 \mathrm{~N}$ & $20 \mathrm{~N}$ \\
\hline BI011 & $7^{\circ} 34^{\prime} 30^{\prime \prime}$ & $60^{\circ} 51^{\prime} 45^{\prime \prime}$ & 0.15 & $0.01 \mathrm{~L}$ & 3 & 1.5 & 0.5 & $0.2 \mathrm{~N}$ & 0.2 & $0.5 \mathrm{~N}$ & $200 \mathrm{~N}$ & $10 \mathrm{~N}$ & $10 \mathrm{~N}$ & 200 & 1 & $10 \mathrm{~N}$ & $20 \mathrm{~N}$ \\
\hline BI012 & $7^{\circ} 34^{\prime} 30^{\prime \prime}$ & $60^{\circ} 51^{\prime} 45^{\prime \prime}$ & 10 & $0.01 \mathrm{~L}$ & 7 & 3 & 0.7 & $0.2 \mathrm{~N}$ & 0.3 & $0.5 \mathrm{~N}$ & $200 \mathrm{~N}$ & $10 \mathrm{~N}$ & $10 \mathrm{~N}$ & 150 & IN & $10 \mathrm{~N}$ & $20 \mathrm{~N}$ \\
\hline & Co-S & $\mathrm{Cr}_{-} \mathrm{S}$ & $\mathrm{Cu}-\mathrm{S}$ & Ga-S & $\mathrm{Ge}-\mathrm{S}$ & La-S & $\mathrm{Mn}-\mathrm{S}$ & Mo-S & $\mathrm{Nb}-\mathrm{S}$ & $\mathrm{Ni}-\mathrm{S}$ & $\mathrm{Pb}-\mathrm{S}$ & Sb-S & Sc-S & $\mathrm{Sn}-\mathrm{S}$ & St $-S$ & Th-S & V-S \\
\hline BIOOJ & 30 & 200 & 70 & 20 & $10 \mathrm{~N}$ & $50 \bar{N}$ & 700 & $5 \mathrm{~N}$ & $20 \mathrm{~N}$ & 150 & 20 & $100 \mathrm{~N}$ & 30 & $10 \mathrm{~N}$ & $100 \mathrm{~N}$ & $100 \mathrm{~N}$ & 150 \\
\hline B1002 & 15 & 30 & 10 & 7 & $10 \mathrm{~N}$ & $50 \mathrm{~N}$ & 700 & $5 \mathrm{~N}$ & $20 \mathrm{~N}$ & 20 & 20 & $100 \mathrm{~N}$ & 20 & $10 \mathrm{~N}$ & 200 & $100 \mathrm{~N}$ & 150 \\
\hline BI003 & 70 & 700 & 150 & 30 & $10 \mathrm{~N}$ & $50 \mathrm{~L}$ &, 500 & $5 \mathrm{~N}$ & $20 \mathrm{~L}$ & 150 & 20 & $100 \mathrm{~N}$ & 20 & $10 \mathrm{~N}$ & $100 \mathrm{~N}$ & $100 \mathrm{~N}$ & 150 \\
\hline B1004 & 150 & 150 & 150 & 20 & $10 \mathrm{~N}$ & $50 \mathrm{~N}$ & 500 & $5 \mathrm{~N}$ & $20 \mathrm{~N}$ & 70 & 15 & $100 \mathrm{~N}$ & 20 & $10 \mathrm{~N}$ & $100 \mathrm{~N}$ & $100 \mathrm{~N}$ & 150 \\
\hline BI005 & 500 & 200 & 500 & 30 & $10 \mathrm{~N}$ & 5OL &, $000 \mathrm{G}$ & $5 \mathrm{~N}$ & $20 \mathrm{~N}$ & 200 & 15 & $100 \mathrm{~N}$ & 30 & $10 \mathrm{~N}$ & $100 \mathrm{~N}$ & $100 \mathrm{~N}$ & 150 \\
\hline BI006 & 15 & $10 \mathrm{~L}$ & 15 & $5 \mathrm{~N}$ & $10 \mathrm{~N}$ & $50 \mathrm{~N}$ & 500 & $5 \mathrm{~N}$ & $20 \mathrm{~N}$ & 5 & 10 & $100 \mathrm{~N}$ & 5 & $10 \mathrm{~N}$ & $100 \mathrm{~N}$ & $100 \mathrm{~N}$ & 100 \\
\hline B1007 & $10 \mathrm{~L}$ & 15 & 7 & $5 \mathrm{~L}$ & $10 \mathrm{~N}$ & $50 \mathrm{~N}$ & 150 & $5 \mathrm{~N}$ & $20 \mathrm{~N}$ & 5 & 10 & $100 \mathrm{~N}$ & 7 & $10 \mathrm{~N}$ & $100 \mathrm{~N}$ & $100 \mathrm{~N}$ & 100 \\
\hline B1008 & 70 & 10 & 20 & $5 \mathrm{~N}$ & $10 \mathrm{~N}$ & $50 \mathrm{~N}$ & 300 & $5 \mathrm{~N}$ & $20 \mathrm{~N}$ & 5L & 10 & $100 \mathrm{~N}$ & 7 & $10 \mathrm{~N}$ & $100 \mathrm{~N}$ & $100 \mathrm{~N}$ & 100 \\
\hline BI009 & 15 & 50 & 10 & 5 & $10 \mathrm{~N}$ & $50 \mathrm{~N}$ & 70 & $5 \mathrm{~N}$ & $20 \mathrm{~N}$ & 10 & 15 & $100 \mathrm{~N}$ & 20 & $10 \mathrm{~N}$ & 200 & $100 \mathrm{~N}$ & 200 \\
\hline BIOI0 & 30 & 500 & 100 & 20 & $10 \mathrm{~N}$ & $50 \mathrm{~N}$ & 300 & $5 \mathrm{~N}$ & $20 \mathrm{~L}$ & 50 & 15 & $100 \mathrm{~N}$ & 20 & $10 \mathrm{~N}$ & $100 \mathrm{~N}$ & $100 \mathrm{~N}$ & 150 \\
\hline BI011 & 70 & 150 & 150 & 10 & $10 \mathrm{~N}$ & $50 \mathrm{~L}$ & 300 & $5 \mathrm{~N}$ & $20 \mathrm{~N}$ & 100 & 10 & $100 \mathrm{~N}$ & 20 & $10 \mathrm{~N}$ & $100 \mathrm{~N}$ & $100 \mathrm{~N}$ & 150 \\
\hline BI012 & 50 & 300 & 70 & 10 & $10 \mathrm{~N}$ & $50 \mathrm{~N}$ & 000 & $5 \mathrm{~N}$ & $20 \mathrm{~N}$ & 100 & 15 & $100 \mathrm{~N}$ & 30 & $10 \mathrm{~N}$ & 200 & $100 \mathrm{~N}$ & 200 \\
\hline & $W-S$ & Y-S & $\mathrm{Zn}-\mathrm{S}$ & $\mathrm{Z}_{\mathrm{I}-\mathrm{S}}$ & $\mathrm{As} / \mathrm{p}$ & $\mathrm{Au}$ & $\mathrm{Bi} / \mathrm{p}$ & $\mathrm{Cd} / \mathrm{p}$ & $\mathrm{Hg}$ & $\mathrm{Sb} / \mathrm{p}$ & $\mathrm{Te}$ & $\mathrm{Tl}$ & $\mathrm{Zn} / \mathrm{p}$ & \multicolumn{3}{|c|}{ Sample description } & \\
\hline BIO01 & $20 \mathrm{~N}$ & 50 & 700 & 30 & $5 \mathbf{L}$ & 0.0020 & $2 \mathrm{~L}$ & 1 & .02 & $2 \mathrm{~L}$ & $0.05 \mathrm{~N}$ & $0.05 \mathrm{~L}$ & 780 & \multicolumn{3}{|c|}{ Weathered schist. } & \\
\hline $\mathrm{B} 1002$ & $20 \mathrm{~N}$ & $10 \mathrm{~N}$ & $200 \mathrm{~N}$ & 10 & $5 L$ & 0.0020 & $2 \mathrm{~L}$ & $0.1 \mathrm{~L}$ & $.02 \mathrm{~N}$ & $2 \mathrm{~L}$ & 0.35 & $0.05 \mathrm{~N}$ & 16 & \multicolumn{3}{|c|}{ Quartz vein. } & \\
\hline $\mathrm{BI} 003$ & $20 \mathrm{~N}$ & 70 & 500 & 150 & $5 L$ & 0.0020 & $2 \mathrm{~L}$ & 1.2 & $.02 \mathrm{~N}$ & $2 \mathrm{~L}$ & $0.05 \mathrm{~L}$ & 0.10 & 790 & \multicolumn{3}{|c|}{ Weathered schist. } & \\
\hline BID04 & $20 \mathrm{~N}$ & 20 & 200 & 30 & $5 \mathrm{~L}$ & 0.0100 & $2 \mathrm{~L}$ & 0.4 & .04 & $2 \mathrm{~L}$ & 0.35 & 0.05 & 190 & \multicolumn{3}{|c|}{ Weathered schist. } & \\
\hline B1005 & $20 \mathrm{~N}$ & 70 & 500 & 50 & $5 \mathrm{~L}$ & 0.0040 & $2 \mathrm{~L}$ & 0.8 & .28 & $2 \mathrm{~L}$ & 0.35 & 0.10 & 970 & \multicolumn{3}{|c|}{ Weathered schist. } & \\
\hline BI006 & $20 \mathrm{~N}$ & $10 \mathrm{~N}$ & $200 \mathrm{~N}$ & 10 & $5 \mathrm{~L}$ & 0.0040 & $2 \mathrm{~L}$ & $0.1 \mathrm{~L}$ & $.02 \mathrm{~N}$ & $2 \mathrm{~L}$ & $0.05 \mathrm{~N}$ & $0.05 \mathrm{~N}$ & 13 & \multicolumn{3}{|c|}{ Quartz vein. } & \\
\hline BI007 & $20 \mathrm{~N}$ & $10 \mathrm{~N}$ & $200 \mathrm{~N}$ & 10 & $5 \mathrm{~L}$ & $0.0020 \mathrm{~L}$ & $2 \mathrm{~L}$ & $0.1 \mathrm{~L}$ & .02 & $2 \mathrm{~L}$ & $0.05 \mathrm{~N}$ & $0.05 \mathrm{~N}$ & 6 & \multicolumn{3}{|c|}{ Quartz vein. } & \\
\hline BID08 & $20 \mathrm{~N}$ & $10 N$ & $200 \mathrm{~N}$ & 10 & $5 \mathrm{~L}$ & 0.0020 & $2 \mathrm{~L}$ & $0.1 \mathrm{~L}$ & $.02 \mathrm{~N}$ & $2 \mathrm{~L}$ & 0.05 & $0.05 \mathrm{~N}$ & 7 & \multicolumn{3}{|c|}{ Quartz vein. } & \\
\hline BI009 & $20 \mathrm{~N}$ & $10 N$ & $200 \mathrm{~N}$ & 10 & $5 \mathrm{~L}$ & 0.0020 & $2 \mathrm{~L}$ & $0.1 \mathrm{~L}$ & $.02 \mathrm{~N}$ & $2 \mathrm{~L}$ & 0.15 & $0.05 \mathrm{~N}$ & 7 & \multicolumn{3}{|c|}{ Quartz vein. } & \\
\hline BI010 & $20 \mathrm{~N}$ & 30 & $200 \mathrm{~L}$ & 50 & $5 \mathrm{~L}$ & 0.0100 & $2 \mathrm{~L}$ & 0.6 & .04 & $2 \mathrm{~L}$ & 0.15 & $0.05 \mathrm{~N}$ & 53 & \multicolumn{3}{|c|}{ Weathered schist. } & \\
\hline BI011 & $20 \mathrm{~N}$ & 70 & 300 & 30 & $5 \mathrm{~L}$ & 0.0280 & $2 \mathrm{~L}$ & 0.6 & .04 & $2 \mathrm{~L}$ & 0.15 & $0.05 \mathrm{~N}$ & 400 & \multirow{2}{*}{\multicolumn{3}{|c|}{$\begin{array}{l}\text { Weathered greenstone. } \\
\text { Greenstone. }\end{array}$}} & \\
\hline BI012 & $20 \mathrm{~N}$ & 50 & $200 \mathrm{~L}$ & 50 & $5 \mathrm{~L}$ & 0.0100 & $2 \mathrm{~L}$ & 0.3 & .04 & $2 \mathrm{~L}$ & $0.05 \mathrm{~N}$ & $0.05 \mathrm{~N}$ & 35 & & & & \\
\hline
\end{tabular}


Appendix table 6. Rock samples collected from zone 4 of the Marwani concession, Venezuela.

\begin{tabular}{|c|c|c|c|c|c|c|c|c|c|c|c|c|c|c|c|c|c|}
\hline & Latitude & Longitude & $\mathrm{Ca} \%-\mathrm{S}$ & $\mathrm{F} \%$ & $\mathrm{Fe} \% \cdot \mathrm{S}$ & $\mathrm{Mg} \%-\mathrm{S}$ & $\mathrm{Na} \%-\mathrm{S}$ & $\mathrm{P} \%-\mathrm{S}$ & $\mathrm{Ti} \%-\mathrm{S}$ & $\mathrm{Ag}-\mathrm{S}$ & As-S & $\mathrm{Au}-\mathrm{S}$ & B-S & Ba-S & $\mathrm{Be}-\mathrm{S}$ & $\mathrm{Bi}-\mathrm{S}$ & Cd-S \\
\hline MW001R & $7^{\circ} 02^{\prime} 25^{\prime \prime}$ & $60^{\circ} 40^{\prime} 05^{\prime \prime}$ & $0.05 \mathrm{~L}$ & $0.01 \mathrm{~L}$ & 0.2 & 0.1 & $0.2 \mathrm{~N}$ & $0.2 \mathrm{~N}$ & 0.01 & $0.50 \mathrm{~N}$ & $200 \mathrm{~N}$ & $10 \mathrm{~N}$ & 300 & 30 & $1 \mathrm{~N}$ & $10 \mathrm{~N}$ & $20 \mathrm{~N}$ \\
\hline MW002R & $7^{\circ} 02 ' 27^{\prime \prime}$ & $60^{\circ} 40^{\prime} 07^{\prime \prime}$ & $0.05 \mathrm{~N}$ & 0.03 & 10 & 1 & $0.2 \mathrm{~N}$ & $0.2 \mathrm{~N}$ & 0.1 & $0.50 \mathrm{~N}$ & $200 \mathrm{~N}$ & $10 \mathrm{~N}$ & $10 \mathrm{~N}$ & 20 & $1 \mathrm{~N}$ & $10 \mathrm{~N}$ & $20 \mathrm{~N}$ \\
\hline MW003R & $7^{\circ} 02^{\prime} 28^{\prime \prime}$ & $60^{\circ} 40^{\prime} 10^{\prime \prime}$ & 0.05 & $0.01 \mathrm{~L}$ & 1 & 0.3 & 0.7 & $0.2 \mathrm{~N}$ & 0.015 & $0.50 \mathrm{~N}$ & $200 \mathrm{~N}$ & $10 \mathrm{~N}$ & 2,000 & 30 & $1 \mathrm{~N}$ & $10 \mathrm{~N}$ & $20 \mathrm{~N}$ \\
\hline MW004R & $7^{\circ} 02^{\prime} 30^{\prime \prime}$ & $60^{\circ} 40^{\prime} 02^{\prime \prime}$ & 0.05 & 0.04 & 1 & 0.5 & 0.3 & $0.2 \mathrm{~N}$ & 0.02 & $0.50 \mathrm{~N}$ & $200 \mathrm{~N}$ & $10 \mathrm{~N}$ & $2,000 \mathrm{G}$ & 20 & $1 N$ & $10 \mathrm{~N}$ & $20 \mathrm{~N}$ \\
\hline MW005R & $7^{\circ} 02^{\prime} 28^{\prime \prime}$ & $60^{\circ} 40^{\circ} 01^{\prime \prime}$ & $0.05 \mathrm{~L}$ & $0.01 \mathrm{~L}$ & 0.2 & 0.07 & $0.2 \mathrm{~N}$ & $0.2 \mathrm{~N}$ & $0.002 \mathrm{~L}$ & $0.50 \mathrm{~N}$ & $200 \mathrm{~N}$ & $10 \mathrm{~N}$ & 200 & 30 & IN & $10 \mathrm{~N}$ & $20 \mathrm{~N}$ \\
\hline MW006R & $7^{\circ} 0228^{\prime \prime}$ & $60^{\circ} 40^{\prime} 01^{\prime \prime}$ & 0.07 & 0.02 & 3 & 1.5 & 0.7 & $0.2 \mathrm{~N}$ & 0.15 & $0.50 \mathrm{~N}$ & $200 \mathrm{~N}$ & $10 \mathrm{~N}$ & $2,000 \mathrm{G}$ & $20 \mathrm{~N}$ & IN & $10 \mathrm{~N}$ & $20 \mathrm{~N}$ \\
\hline MW007R & $7^{\circ} 02^{\prime} 28^{\prime \prime}$ & $60^{\circ} 40^{\prime} 01^{\prime \prime}$ & $0.05 \mathrm{~L}$ & $0.01 \mathrm{~L}$ & 1 & 0.02 & $0.2 \mathrm{~N}$ & $0.2 \mathrm{~N}$ & 0.002 & $0.50 \mathrm{~N}$ & $200 \mathrm{~N}$ & $10 \mathrm{~N}$ & 70 & 30 & $1 \mathrm{~N}$ & $10 N$ & $20 \mathrm{~N}$ \\
\hline MW008R & $7^{\circ} 02^{\prime} 25^{\prime \prime}$ & $60^{\circ} 40^{\prime} 14^{\prime \prime}$ & $0.05 \mathrm{~L}$ & $0.01 \mathrm{~L}$ & 0.7 & 0.02 & $0.2 \mathrm{~N}$ & $0.2 \mathrm{~N}$ & $0.002 \mathrm{~L}$ & $0.50 \mathrm{~N}$ & $200 \mathrm{~N}$ & $10 \mathrm{~N}$ & 70 & 50 & IN & $10 \mathrm{~N}$ & $20 \mathrm{~N}$ \\
\hline MW009R & $7^{\circ} 0220^{\prime \prime}$ & $60^{\circ} 40^{\prime} 21^{\prime \prime}$ & $0.05 \mathrm{~L}$ & $0.01 \mathrm{~L}$ & 1.5 & 0.5 & 0.2 & $0.2 \mathrm{~N}$ & 0.07 & $0.50 \mathrm{~N}$ & $200 \mathrm{~N}$ & $10 \mathrm{~N}$ & $2,000 \mathrm{G}$ & 30 & $1 \mathrm{~N}$ & $10 \mathrm{~N}$ & $20 \mathrm{~N}$ \\
\hline MWOIOR & $7^{\circ} 02^{\prime} 17^{\prime \prime}$ & $60^{\circ} 40^{\prime} 21^{\prime \prime}$ & $0.05 \mathrm{~N}$ & $0.01 \mathrm{~L}$ & 0.5 & 0.03 & $0.2 \mathrm{~N}$ & $0.2 \mathrm{~N}$ & 0.002 & $0.50 \mathrm{~N}$ & $200 \mathrm{~N}$ & $10 \mathrm{~N}$ & 300 & 30 & $1 \mathrm{~N}$ & $10 \mathrm{~N}$ & $20 \mathrm{~N}$ \\
\hline MWOIIR & $7^{\circ} 02^{\prime} 16^{\prime \prime}$ & $60^{\circ} 40^{\prime} 07^{\prime \prime}$ & $0.05 \mathrm{~L}$ & $0.01 \mathrm{~L}$ & 0.7 & $0.02 \mathrm{~L}$ & $0.2 \mathrm{~N}$ & $0.2 \mathrm{~N}$ & $0.002 \mathrm{~L}$ & $0.50 \mathrm{~N}$ & $200 \mathrm{~N}$ & $10 \mathrm{~N}$ & $10 \mathrm{~L}$ & 30 & $1 \mathrm{~N}$ & $10 \mathrm{~N}$ & $20 \mathrm{~N}$ \\
\hline MWol2R & $7^{\circ} 02^{\prime} 16^{\prime \prime}$ & $60^{\circ} 40^{\prime} 08^{\prime \prime}$ & $0.05 \mathrm{~N}$ & $0.01 \mathrm{~L}$ & 3 & $0.02 \mathrm{~L}$ & $0.2 \mathrm{~N}$ & $0.2 \mathrm{~N}$ & 0.05 & $0.50 \mathrm{~N}$ & $200 \mathrm{~N}$ & $10 \mathrm{~N}$ & $10 \mathrm{~L}$ & $20 \mathrm{~N}$ & IN & $10 \mathrm{~N}$ & $20 \mathrm{~N}$ \\
\hline MW013R & $7^{\circ} 02^{\prime} 27^{\prime \prime}$ & $60^{\circ} 40^{\circ} 20^{\prime \prime}$ & $0.05 \mathrm{~L}$ & $0.01 \mathrm{~L}$ & 2 & 0.1 & $0.2 \mathrm{~L}$ & $0.2 \mathrm{~N}$ & 0.07 & $0.50 \mathrm{~N}$ & $200 \mathrm{~N}$ & $10 \mathrm{~N}$ & 700 & 30 & $1 N$ & $10 \mathrm{~N}$ & $20 \mathrm{~N}$ \\
\hline MW014R & $7^{\circ} 02 ' 27^{\prime \prime}$ & $60^{\circ} 40^{\prime} 20^{\prime \prime}$ & $0.05 \mathrm{~L}$ & $0.01 \mathrm{~L}$ & 0.15 & 0.07 & $0.2 \mathrm{~N}$ & $0.2 \mathrm{~N}$ & 0.002 & $0.50 \mathrm{~N}$ & $200 \mathrm{~N}$ & $10 \mathrm{~N}$ & 300 & 30 & $1 \mathrm{~N}$ & $10 \mathrm{~N}$ & $20 \mathrm{~N}$ \\
\hline MW015R & $7^{\circ} 02^{2} 30^{\prime \prime}$ & $60^{\circ} 40^{\prime} 23^{\prime \prime}$ & $0.05 \mathrm{~L}$ & $0.01 \mathrm{~L}$ & 0.3 & 0.15 & $0.2 \mathrm{~N}$ & $0.2 \mathrm{~N}$ & 0.015 & $0.50 \mathrm{~N}$ & $200 \mathrm{~N}$ & $10 \mathrm{~N}$ & 1,000 & 30 & $1 N$ & $10 \mathrm{~N}$ & $20 \mathrm{~N}$ \\
\hline MW016R & $7^{\circ} 02^{\prime} 08^{\prime \prime}$ & $60^{\circ} 40^{\prime} 12^{\prime \prime}$ & $0.05 \mathrm{~L}$ & $0.01 \mathrm{~L}$ & 3 & 0.3 & 0.7 & $0.2 \mathrm{~N}$ & 0.3 & $0.50 \mathrm{~N}$ & $200 \mathrm{~N}$ & $10 \mathrm{~N}$ & 30 & 200 & $1 N$ & $10 \mathrm{~N}$ & $20 \mathrm{~N}$ \\
\hline MW017R & $7^{\circ} 02^{\prime} 07^{\prime \prime}$ & $60^{\circ} 40^{\prime} 16^{\prime \prime}$ & $0.05 \mathrm{~L}$ & $0.01 \mathrm{~L}$ & 5 & $0.02 \mathrm{~L}$ & $0.2 \mathrm{~N}$ & $0.2 \mathrm{~N}$ & 0.02 & $0.50 \mathrm{~N}$ & $200 \mathrm{~N}$ & $10 \mathrm{~N}$ & $10 \mathrm{~L}$ & 30 & $1 N$ & $10 N$ & $20 \mathrm{~N}$ \\
\hline MW018R & $7^{\circ} 02^{\prime} 06^{\prime \prime}$ & $60^{\circ} 40^{\prime} 17^{\prime \prime}$ & $0.05 \mathrm{~L}$ & $0.01 \mathrm{~L}$ & 5 & $0.02 \mathrm{~L}$ & $0.2 \mathrm{~N}$ & $0.2 \mathrm{~N}$ & $0.002 \mathrm{~L}$ & $0.50 \mathrm{~N}$ & $200 \mathrm{~N}$ & $10 \mathrm{~N}$ & 20 & 20 & $1 \mathrm{~N}$ & $10 \mathrm{~N}$ & $20 \mathrm{~N}$ \\
\hline MW019R & $7^{\circ} 02^{\prime} 03^{\prime \prime}$ & $60^{\circ} 40^{\prime} 21^{\prime \prime}$ & $0.05 \mathrm{~L}$ & $0.01 \mathrm{~L}$ & 3 & $0.02 \mathrm{~L}$ & $0.2 \mathrm{~N}$ & $0.2 \mathrm{~N}$ & $0.002^{\prime}$ & $0.50 \mathrm{~N}$ & $200 \mathrm{~N}$ & $10 \mathrm{~N}$ & 20 & 30 & $1 \mathrm{~N}$ & $10 \mathrm{~N}$ & $20 \mathrm{~N}$ \\
\hline MW020R & $7^{\circ} 02^{\prime} 03^{\prime \prime}$ & $60^{\circ} 40^{\prime} 21^{\prime \prime}$ & $0.05 \mathrm{~L}$ & $0.01 \mathrm{~L}$ & 3 & 0.5 & 0.5 & $0.2 \mathrm{~N}$ & 0.07 & $0.50 \mathrm{~N}$ & $200 \mathrm{~N}$ & $10 \mathrm{~N}$ & $2,000 \mathrm{G}$ & 50 & $1 \mathrm{~L}$ & $10 \mathrm{~N}$ & $20 \mathrm{~N}$ \\
\hline MW021R & $7^{\circ} 02^{\prime} 07^{\prime \prime}$ & $60^{\circ} 40^{\prime} 22^{\prime \prime}$ & $0.05 \mathrm{~L}$ & $0.01 \mathrm{~L}$ & I & 0.15 & $0.2 \mathrm{~N}$ & $0.2 \mathrm{~N}$ & 0.07 & $0.50 \mathrm{~N}$ & $200 \mathrm{~N}$ & $10 \mathrm{~N}$ & 1,000 & 30 & $1 \mathrm{~L}$ & $10 \mathrm{~N}$ & $20 \mathrm{~N}$ \\
\hline MW022R & $7^{\circ} 02^{\prime} 12^{\prime \prime}$ & $60^{\circ} 40^{\prime} 29^{\prime \prime}$ & $0.05 \mathrm{~L}$ & $0.01 \mathrm{~L}$ & 1 & 0.3 & 0.2 & $0.2 \mathrm{~N}$ & 0.07 & $0.50 \mathrm{~N}$ & $200 \mathrm{~N}$ & $10 \mathrm{~N}$ & $2,000 \mathrm{G}$ & 30 & $\mathrm{IL}$ & ION & $20 \mathrm{~N}$ \\
\hline MW023R & $7^{\circ} 02^{\prime} 12^{\prime \prime}$ & $60^{\circ} 40^{\prime} 29^{\prime \prime}$ & 0.05 & 0.01 & 7 & 1.5 & 1.5 & $0.2 \mathrm{~N}$ & 0.2 & $0.50 \mathrm{~N}$ & $200 \mathrm{~N}$ & $10 \mathrm{~N}$ & $2,000 \mathrm{G}$ & $20 \mathrm{~L}$ & 1.5 & $10 \mathrm{~N}$ & $20 \mathrm{~N}$ \\
\hline MW024R & $7^{\circ} 02^{\prime} 14^{\prime \prime}$ & $60^{\circ} 40^{\prime} 29^{\prime \prime}$ & $0.05 \mathrm{~L}$ & 0.01 & 5 & 1 & 1 & $0.2 \mathrm{~N}$ & 0.1 & $0.50 \mathrm{~N}$ & $200 \mathrm{~N}$ & $10 \mathrm{~N}$ & $2,000 \mathrm{G}$ & $20 \mathrm{~N}$ & 1 & $10 N$ & $20 \mathrm{~N}$ \\
\hline MW025R & $7^{\circ} 02^{\prime} 06^{\prime \prime}$ & $60^{\circ} 40^{\prime} 32^{\prime \prime}$ & $0.05 \mathrm{~L}$ & $0.01 \mathrm{~L}$ & 0.7 & 0.2 & $0.2 \mathrm{~L}$ & $0.2 \mathrm{~N}$ & 0.05 & $0.50 \mathrm{~N}$ & $200 \mathrm{~N}$ & ION & 1,000 & 30 & $1 N$ & $10 \mathrm{~N}$ & $20 \mathrm{~N}$ \\
\hline MW026R & $7^{\circ} 01^{\prime} 56^{\prime \prime}$ & $60^{\circ} 40^{\prime} 21^{\prime \prime}$ & $0.05 \mathrm{~L}$ & $0.01 \mathrm{~L}$ & 1.5 & 0.2 & 0.2 & $0.2 \mathrm{~N}$ & 0.07 & $0.50 \mathrm{~N}$ & $200 \mathrm{~N}$ & $10 \mathrm{~N}$ & 2,000 & 30 & $1 \mathrm{~N}$ & $10 \mathrm{~N}$ & $20 \mathrm{~N}$ \\
\hline MW027R & $7^{\circ} 01^{\prime} 54^{\prime \prime}$ & $60^{\circ} 40^{\prime} 20^{\prime \prime}$ & $0.05 \mathrm{~L}$ & $0.01 \mathrm{~L}$ & 7 & $0.02 \mathrm{~L}$ & $0.2 \mathrm{~N}$ & $0.2 \mathrm{~N}$ & 0.005 & $0.50 \mathrm{~N}$ & $200 \mathrm{~N}$ & $10 \mathrm{~N}$ & 15 & $20 \mathrm{~L}$ & $1 \mathrm{~N}$ & $10 \mathrm{~N}$ & $20 \mathrm{~N}$ \\
\hline MW028R & $7^{\circ} 02^{\prime} 05^{\prime \prime}$ & $60^{\circ} 40^{\prime} 36^{\prime \prime}$ & $0.05 \mathrm{~N}$ & $0.01 \mathrm{~L}$ & 3 & 0.15 & $0.2 \mathrm{~N}$ & $0.2 \mathrm{~N}$ & 0.005 & $0.50 \mathrm{~N}$ & $200 \mathrm{~N}$ & $10 \mathrm{~N}$ & 10 & $20 \mathrm{~N}$ & IN & $10 \mathrm{~N}$ & $20 \mathrm{~N}$ \\
\hline MW029R & $7^{\circ} 01^{\prime} 55^{\prime \prime}$ & $60^{\circ} 40^{\prime} 26^{\prime \prime}$ & $0.05 \mathrm{~L}$ & 0.02 & 20 & 0.5 & 0.5 & 0.3 & 0.2 & $0.50 \mathrm{~N}$ & $200 \mathrm{~N}$ & $10 \mathrm{~N}$ & $2,000 \mathrm{G}$ & 30 & IL & $10 \mathrm{~N}$ & $20 \mathrm{~N}$ \\
\hline MW030R & $7^{\circ} 01^{\prime} 50^{\prime \prime}$ & $60^{\circ} 40^{\prime} 30^{\prime \prime}$ & $0.05 \mathrm{~L}$ & $0.01 \mathbf{L}$ & 0.7 & 0.1 & $0.2 \mathrm{~N}$ & $0.2 \mathrm{~L}$ & 0.007 & $0.50 \mathrm{~N}$ & $200 \mathrm{~N}$ & $10 \mathrm{~N}$ & 500 & 20 & $1 \mathrm{~N}$ & $10 \mathrm{~N}$ & $20 \mathrm{~N}$ \\
\hline MW031R & $7^{\circ} 01^{\prime} 11^{\prime \prime}$ & $60^{\circ} 4 \mathrm{I}^{\prime} 0 \mathrm{l}^{\prime \prime}$ & $0.05 \mathrm{~L}$ & $0.01 \mathrm{~L}$ & 0.3 & 0.07 & $0.2 \mathrm{~N}$ & $0.2 \mathrm{~L}$ & $0.002 \mathrm{~L}$ & $0.50 \mathrm{~N}$ & $200 \mathrm{~N}$ & $10 \mathrm{~N}$ & 300 & 30 & $i N$ & $10 \mathrm{~N}$ & $20 \mathrm{~N}$ \\
\hline MW032R & $7^{\circ} 0 l^{\prime} 09^{\prime \prime}$ & $60^{\circ} 4 \mathrm{~J}^{\prime} 03^{\prime \prime}$ & $0.05 \mathrm{~L}$ & $0.01 \mathrm{~L}$ & 7 & $0.02 \mathrm{~L}$ & $0.2 \mathrm{~N}$ & $0.2 \mathrm{~N}$ & 0.03 & $0.50 \mathrm{~N}$ & $200 \mathrm{~N}$ & $10 \mathrm{~N}$ & 10 & $20 \mathrm{~L}$ & IN & $10 \mathrm{~N}$ & $20 \mathrm{~N}$ \\
\hline MWO33R & $7^{\circ} 01^{\prime} 43^{\prime \prime}$ & $60^{\circ} 40^{\prime} 32^{\prime \prime}$ & $0.05 \mathrm{~L}$ & $0.01 \mathrm{~L}$ & 7 & $0.02 \mathrm{~L}$ & $0.2 \mathrm{~N}$ & $0.2 \mathrm{~N}$ & 0.03 & $0.50 \mathrm{~N}$ & $200 \mathrm{~N}$ & $10 \mathrm{~N}$ & $10 N$ & 20 & IN & $10 \mathrm{~N}$ & $20 \mathrm{~N}$ \\
\hline MW59650S & $6^{\circ} 55^{\prime \prime} 00^{\prime \prime}$ & $60^{\circ} 43^{\prime} 30^{\prime \prime}$ & $0.05 \mathrm{~N}$ & $0.01 \mathrm{~L}$ & 20 & 0.05 & $0.2 \mathrm{~N}$ & $0.2 \mathrm{~N}$ & 0.07 & $0.50 \mathrm{~N}$ & $200 \mathrm{~N}$ & $10 \mathrm{~N}$ & $10 \mathrm{~N}$ & 150 & 1 & $10 \mathrm{~N}$ & $20 \mathrm{~N}$ \\
\hline & $\mathrm{Co}-\mathrm{S}$ & $\mathrm{Cr}-\mathrm{S}$ & $\mathrm{Cu}-\mathrm{S}$ & Ga-S & Ge-S & La-S & $\mathrm{Mn}-\mathrm{S}$ & Mo-S & $\mathrm{Nb}-\mathrm{S}$ & $\mathrm{Ni}-\mathrm{S}$ & $\mathrm{Pb}-\mathrm{S}$ & Sb-S & Sc-S & Sn-S & $\mathrm{Sr}-\mathrm{S}$ & Th-S & $\mathrm{V}-\mathrm{S}$ \\
\hline MWOOIR & $10 \mathrm{~N}$ & $10 \mathrm{~L}$ & 5 & $5 \mathrm{~N}$ & $10 \mathrm{~N}$ & $50 \mathrm{~N}$ & 70 & $5 \mathrm{~N}$ & $20 \mathrm{~N}$ & 20 & 15 & $100 \mathrm{~N}$ & $5 \mathrm{~N}$ & $10 \mathrm{~N}$ & $100 \mathrm{~N}$ & $100 \mathrm{~N}$ & 20 \\
\hline MW002R & 10 & $10 \mathrm{~L}$ & 50 & 30 & $10 \mathrm{~N}$ & $50 \mathrm{~N}$ & 150 & $5 \mathrm{~N}$ & $20 \mathrm{~N}$ & $5 \mathrm{~L}$ & 15 & $100 \mathrm{~N}$ & 7 & $10 \mathrm{~N}$ & $100 \mathrm{~N}$ & $100 \mathrm{~N}$ & 50 \\
\hline MW003R & $10 \mathrm{~N}$ & $10 \mathrm{~L}$ & $5 \mathrm{~L}$ & 10 & $10 \mathrm{~N}$ & $50 \mathrm{~N}$ & 70 & $5 \mathrm{~N}$ & $20 \mathrm{~N}$ & $5 L$ & 15 & $100 \mathrm{~N}$ & $5 \mathrm{~N}$ & $10 \mathrm{~N}$ & $100 \mathrm{~N}$ & $100 \mathrm{~N}$ & 15 \\
\hline MW004R & $10 \mathrm{~N}$ & $10 \mathrm{~L}$ & $5 \mathrm{~L}$ & $5 \mathbf{L}$ & $10 \mathrm{~N}$ & $50 \mathrm{~N}$ & 100 & $5 \mathrm{~N}$ & $20 \mathrm{~N}$ & $5 \mathrm{~L}$ & 10 & $100 \mathrm{~N}$ & $5 \mathrm{~L}$ & $10 \mathrm{~N}$ & $100 \mathrm{~N}$ & $100 \mathrm{~N}$ & 10 \\
\hline MW00SR & $10 \mathrm{~N}$ & $10 \mathrm{~N}$ & $5 \mathrm{~L}$ & $5 \mathbf{L}$ & $10 \mathrm{~N}$ & $50 \mathrm{~N}$ & 100 & $5 \mathrm{~N}$ & $20 \mathrm{~N}$ & $5 L$ & $10 \mathrm{~L}$ & $100 \mathrm{~N}$ & $5 \mathrm{~N}$ & $10 \mathrm{~N}$ & $100 \mathrm{~N}$ & $100 \mathrm{~N}$ & 10 \\
\hline MW006R & $10 \mathrm{~N}$ & $10 \mathrm{~L}$ & $5 \mathrm{~N}$ & 20 & $10 \mathrm{~N}$ & $50 \mathrm{~N}$ & 100 & $5 \mathrm{~N}$ & $20 \mathrm{~N}$ & $5 \mathrm{~L}$ & 10 & $100 \mathrm{~N}$ & 15 & $10 \mathrm{~N}$ & $100 \mathrm{~L}$ & $100 \mathrm{~N}$ & 15 \\
\hline MW007R & $10 \mathrm{~N}$ & $10 \mathrm{~L}$ & $5 \mathrm{~L}$ & $5 \mathrm{~N}$ & $10 \mathrm{~N}$ & $50 \mathrm{~N}$ & $10 \mathrm{~L}$ & $5 \mathrm{~N}$ & $20 \mathrm{~N}$ & $5 \mathrm{~L}$ & $10 \mathrm{~L}$ & $100 \mathrm{~N}$ & $5 \mathrm{~N}$ & $10 \mathrm{~N}$ & $100 \mathrm{~N}$ & $100 \mathrm{~N}$ & 10 \\
\hline MW008R & $10 \mathrm{~N}$ & $10 \mathrm{~L}$ & $5 \mathrm{~N}$ & $5 \mathrm{~N}$ & $10 \mathrm{~N}$ & $50 \mathrm{~N}$ & 10 & $5 \mathrm{~N}$ & $20 \mathrm{~N}$ & $5 \mathrm{~L}$ & $10 \mathrm{~L}$ & $100 \mathrm{~N}$ & $5 \mathrm{~N}$ & $10 \mathrm{~N}$ & $100 \mathrm{~N}$ & $100 \mathrm{~N}$ & 15 \\
\hline MW009R & $10 \mathrm{~L}$ & 70 & $5 \mathrm{~L}$ & $5 L$ & $10 \mathrm{~N}$ & $50 \mathrm{~N}$ & 20 & $5 \mathrm{~N}$ & $20 N$ & 10 & 10 & $100 \mathrm{~N}$ & 15 & $10 \mathrm{~N}$ & $100 \mathrm{~L}$ & $100 \mathrm{~N}$ & 100 \\
\hline MWOIOR & $10 \mathrm{~N}$ & 20 & $5 \mathrm{~N}$ & $5 \mathrm{~L}$ & $10 \mathrm{~N}$ & $50 \mathrm{~N}$ & 30 & $5 \mathrm{~N}$ & $20 \mathrm{~N}$ & $5 \mathrm{~L}$ & $10 \mathrm{~L}$ & $100 \mathrm{~N}$ & $5 \mathrm{~N}$ & $10 \mathrm{~N}$ & $100 \mathrm{~N}$ & $100 \mathrm{~N}$ & 30 \\
\hline MW011R & $10 \mathrm{~N}$ & 10 & 7 & $5 \mathrm{~L}$ & $10 \mathrm{~N}$ & $50 \mathrm{~L}$ & $10 \mathrm{~L}$ & $5 \mathrm{~N}$ & $20 \mathrm{~N}$ & $5 \mathrm{~L}$ & 10 & $100 \mathrm{~N}$ & $5 \mathrm{~N}$ & $10 \mathrm{~N}$ & $100 \mathrm{~N}$ & $100 \mathrm{~N}$ & so \\
\hline MW012R & $10 \mathrm{~N}$ & $10 \mathrm{~L}$ & 15 & 5 & $10 \mathrm{~N}$ & $50 \mathrm{~N}$ & 10 & $5 \mathrm{~L}$ & $20 N$ & 5L & 10 & $100 \mathrm{~N}$ & $5 \mathrm{~N}$ & $10 \mathrm{~N}$ & $100 \mathrm{~N}$ & $100 \mathrm{~N}$ & 20 \\
\hline MW013R & $10 \mathrm{~L}$ & 100 & 10 & $5 L$ & $10 \mathrm{~N}$ & $50 \mathrm{~N}$ & 100 & $5 \mathrm{~N}$ & $20 N$ & 10 & $10 \mathrm{~L}$ & $100 \mathrm{~N}$ & 10 & $10 \mathrm{~N}$ & $100 \mathrm{~N}$ & $100 \mathrm{~N}$ & 70 \\
\hline
\end{tabular}




\begin{tabular}{|c|c|c|c|c|c|c|c|c|c|c|c|c|c|c|c|c|c|}
\hline MW015R & $10 \mathrm{~L}$ & 70 & $5 \mathrm{~L}$ & $5 \mathrm{~N}$ & $10 \mathrm{~N}$ & $50 \mathrm{~N}$ & 100 & $5 \mathrm{~N}$ & $20 \mathrm{~N}$ & 5 & 10 & $100 \mathrm{~N}$ & $5 L$ & $10 N$ & $100 \mathrm{~N}$ & $100 \mathrm{~N}$ & 50 \\
\hline MW016R & 100 & 150 & 30 & $5 \mathrm{~L}$ & $10 \mathrm{~N}$ & $50 \mathrm{~N}$ & 5,000 & $5 \mathrm{~N}$ & $20 \mathrm{~N}$ & 50 & $10 \mathrm{~L}$ & $100 \mathrm{~N}$ & 20 & $10 \mathrm{~N}$ & $100 \mathrm{~L}$ & $100 \mathrm{~N}$ & 100 \\
\hline MW017R & 10L & $10 \mathrm{~N}$ & 30 & 5 & $10 \mathrm{~N}$ & $50 \mathrm{~N}$ & 20 & $5 \mathrm{~N}$ & $2 \mathrm{ON}$ & 7 & 10 & $100 N$ & $5 \mathrm{~N}$ & $10 \mathrm{~N}$ & $100 \mathrm{~N}$ & $100 \mathrm{~N}$ & 15 \\
\hline MW018R & $10 \mathrm{~N}$ & $10 \mathrm{~N}$ & 10 & $5 \mathrm{~L}$ & $10 \mathrm{~N}$ & $50 \mathrm{~N}$ & $10 \mathrm{~L}$ & $5 \mathrm{~N}$ & $20 \mathrm{~N}$ & 5 & 10 & $100 \mathrm{~N}$ & $5 N$ & $10 \mathrm{~N}$ & $100 \mathrm{~N}$ & $100 \mathrm{~N}$ & 20 \\
\hline MW019R & $10 \mathrm{~N}$ & $10 \mathrm{~L}$ & 10 & $5 \mathrm{~L}$ & $10 \mathrm{~N}$ & $50 \mathrm{~N}$ & 10 & $5 \mathrm{~N}$ & $20 \mathrm{~N}$ & $5 \mathrm{~L}$ & $10 \mathrm{~L}$ & $100 \mathrm{~N}$ & $5 \mathrm{~N}$ & $10 \mathrm{~N}$ & $100 \mathrm{~N}$ & $100 \mathrm{~N}$ & 10 \\
\hline MW020R & 10 & 10 & $5 \mathrm{~L}$ & 5 & $10 \mathrm{~N}$ & $50 \mathrm{~N}$ & 10 & $5 \mathrm{~N}$ & $20 \mathrm{~N}$ & 7 & 10 & $100 \mathrm{~N}$ & 7 & $10 \mathrm{~N}$ & 100 & $100 \mathrm{~N}$ & 100 \\
\hline MW021R & $10 \mathrm{~N}$ & $10 \mathrm{~L}$ & $5 \mathrm{~N}$ & $5 \mathrm{~L}$ & $10 N$ & $50 \mathrm{~N}$ & 15 & $5 \mathrm{~N}$ & $20 \mathrm{~N}$ & $5 \mathrm{~N}$ & $10 \mathrm{~L}$ & $100 \mathrm{~N}$ & $5 \mathrm{~N}$ & $10 \mathrm{~N}$ & $100 \mathrm{~N}$ & $100 \mathrm{~N}$ & 15 \\
\hline MW022R & $10 \mathrm{~L}$ & 100 & $5 \mathrm{~N}$ & $5 \mathrm{~L}$ & $10 \mathrm{~N}$ & $50 \mathrm{~N}$ & 15 & $5 \mathrm{~N}$ & $20 \mathrm{~N}$ & 30 & $10 \mathrm{~L}$ & $100 \mathrm{~N}$ & 10 & $10 \mathrm{~N}$ & $100 \mathrm{~N}$ & $100 \mathrm{~N}$ & 100 \\
\hline MW023R & 15 & 10 & $5 \mathrm{~N}$ & 70 & $10 \mathrm{~N}$ & $50 \mathrm{~L}$ & 20 & $5 \mathrm{~N}$ & $20 \mathrm{~N}$ & 30 & 20 & $100 \mathrm{~N}$ & 20 & $10 \mathrm{~N}$ & 300 & $100 \mathrm{~N}$ & 100 \\
\hline MW024R & 10 & $10 \mathrm{~L}$ & 7 & 70 & $10 \mathrm{~N}$ & $50 \mathrm{~N}$ & 20 & 10 & $20 \mathrm{~N}$ & 30 & 10 & $100 \mathrm{~N}$ & 20 & $10 \mathrm{~N}$ & $100 \mathrm{~N}$ & $100 \mathrm{~N}$ & 150 \\
\hline MW025R & $10 \mathrm{~N}$ & $10 \mathrm{~L}$ & $5 \mathrm{~N}$ & $5 \mathrm{~L}$ & $10 \mathrm{~N}$ & $50 \mathrm{~N}$ & $10 \mathrm{~L}$ & $5 \mathrm{~N}$ & $20 \mathrm{~N}$ & SL & $10 \mathrm{~L}$ & $100 \mathrm{~N}$ & $5 \mathrm{~L}$ & ION & $100 \mathrm{~N}$ & $100 \mathrm{~N}$ & 15 \\
\hline MW026R & $10 \mathrm{~N}$ & 50 & 30 & $5 \mathrm{~L}$ & $10 N$ & $50 \mathrm{~N}$ & 30 & $5 \mathrm{~N}$ & $20 \mathrm{~N}$ & 15 & $10 \mathrm{~N}$ & $100 \mathrm{~N}$ & 5 & $10 \mathrm{~N}$ & $100 \mathrm{~N}$ & $100 \mathrm{~N}$ & 100 \\
\hline MW027R & $10 \mathrm{~L}$ & 30 & 15 & 5 & $10 \mathrm{~N}$ & $50 \mathrm{~N}$ & $10 \mathrm{~L}$ & $5 \mathrm{~N}$ & $20 N$ & 20 & $10 \mathrm{~L}$ & $100 N$ & $5 \mathrm{~N}$ & $10 N$ & $100 \mathrm{~N}$ & $100 \mathrm{~N}$ & 100 \\
\hline MW028R & $10 \mathrm{~L}$ & $10 \mathrm{~L}$ & 50 & $5 L$ & $10 \mathrm{~N}$ & $50 \mathrm{~N}$ & 30 & $5 \mathrm{~N}$ & $20 \mathrm{~N}$ & $5 \mathrm{~L}$ & $10 \mathrm{~L}$ & $100 \mathrm{~N}$ & $5 \mathrm{~N}$ & $10 \mathrm{~N}$ & $100 \mathrm{~N}$ & $100 \mathrm{~N}$ & 20 \\
\hline MW029R & 20 & 100 & 30 & 30 & $10 \mathrm{~N}$ & $50 \mathrm{~N}$ & 30 & $5 \mathrm{~N}$ & $20 \mathrm{~N}$ & 50 & 20 & $100 \mathrm{~N}$ & 15 & $10 \mathrm{~N}$ & $100 \mathrm{~N}$ & $100 \mathrm{~N}$ & 50 \\
\hline MW030R & $10 \mathrm{~N}$ & $10 \mathrm{~L}$ & $5 \mathrm{~N}$ & $5 \mathrm{~N}$ & $10 \mathrm{~N}$ & $50 \mathrm{~N}$ & 15 & $5 \mathrm{~N}$ & $20 \mathrm{~N}$ & $5 \mathrm{~L}$ & $10 \mathrm{~L}$ & $100 \mathrm{~N}$ & $5 \mathrm{~N}$ & $10 \mathrm{~N}$ & $100 \mathrm{~N}$ & $100 \mathrm{~N}$ & 15 \\
\hline MW031R & $10 \mathrm{~N}$ & 10 & $5 \mathrm{~L}$ & $5 \mathrm{~N}$ & $10 \mathrm{~N}$ & $50 \mathrm{~N}$ & $10 \mathrm{~L}$ & $5 \mathrm{~N}$ & $20 N$ & 5 & $10 \mathrm{~L}$ & $100 \mathrm{~N}$ & $5 \mathrm{~N}$ & $10 N$ & $100 \mathrm{~N}$ & $100 \mathrm{~N}$ & 20 \\
\hline MW032R & $10 \mathrm{~L}$ & 100 & 30 & 7 & $10 \mathrm{~N}$ & $50 \mathrm{~N}$ & 30 & $5 \mathrm{~N}$ & $20 \mathrm{~N}$ & 10 & $10 \mathrm{~L}$ & $100 \mathrm{~N}$ & 5 & $10 N$ & $100 \mathrm{~N}$ & $100 N$ & 150 \\
\hline MW033R & $10 \mathrm{~L}$ & 20 & 7 & 5 & $10 \mathrm{~N}$ & $50 \mathrm{~N}$ & $10 \mathrm{~L}$ & $5 \mathrm{~N}$ & $20 \mathrm{~N}$ & 15 & $10 \mathrm{~L}$ & $100 \mathrm{~N}$ & $5 \mathrm{~N}$ & $10 \mathrm{~N}$ & $100 \mathrm{~N}$ & $100 \mathrm{~N}$ & 30 \\
\hline MW59650S & 10 & 30 & 15 & 15 & $10 \mathrm{~N}$ & $50 \mathrm{~N}$ & 15 & $5 \mathrm{~N}$ & $20 \mathrm{~N}$ & 10 & 20 & $100 \mathrm{~N}$ & 7 & $10 \mathrm{~N}$ & $100 \mathrm{~N}$ & $100 \mathrm{~N}$ & 50 \\
\hline & W-S & $\mathrm{Y}-\mathrm{S}$ & $\mathrm{Zn}-\mathrm{S}$ & $\mathrm{Z}_{\mathrm{x}} \mathrm{S}$ & As/p & Aut & $\mathrm{Bi} / \mathrm{p}$ & $\mathrm{Cd} / \mathrm{p}$ & $\mathrm{Hg}$ & $\mathrm{Sb} / \mathrm{p}$ & $\mathrm{Te}$ & $\mathrm{Tl}$ & $\mathrm{Zn} / \mathrm{p}$ & \multicolumn{3}{|c|}{ Sample description } & \\
\hline MW001R & $20 \mathrm{~N}$ & $10 \mathrm{~N}$ & $200 \mathrm{~N}$ & 15 & $5 \mathrm{~L}$ & 0.004 & $2 \mathrm{~L}$ & $0.1 \mathrm{~L}$ & $0.02 \mathrm{~L}$ & $2 \mathrm{~L}$ & $0.05 \mathrm{~L}$ & $0.05 \mathrm{~L}$ & $2 \mathrm{~L}$ & \multicolumn{4}{|c|}{ Quartz-tourmaline vein. } \\
\hline MW002R & $20 \mathrm{~N}$ & 20 & $200 \mathrm{~L}$ & 150 & $5 \mathrm{~L}$ & 0.004 & $2 \mathrm{~L}$ & 0.7 & 0.02 & $2 \mathrm{~L}$ & 0.15 & $0.05 \mathrm{~L}$ & 92 & \multicolumn{4}{|c|}{ Phyllite. } \\
\hline MW003R & $20 \mathrm{~N}$ & $10 \mathrm{~N}$ & $200 \mathrm{~N}$ & 15 & $5 \mathrm{~L}$ & $0.002 \mathrm{~L}$ & $2 \mathrm{~L}$ & $0.1 \mathrm{~L}$ & $0.02 \mathrm{~L}$ & $2 \mathrm{~L}$ & $0.05 \mathrm{~L}$ & $0.05 \mathrm{~L}$ & $2 \mathrm{~L}$ & \multicolumn{4}{|c|}{ Quartz vein. } \\
\hline MW004R & $20 \mathrm{~N}$ & $10 \mathrm{~N}$ & $200 \mathrm{~N}$ & 15 & $5 \mathrm{~L}$ & $0.002 \mathrm{~L}$ & $2 \mathrm{~L}$ & $0.1 \mathrm{~L}$ & $0.02 \mathrm{~L}$ & $2 \mathrm{~L}$ & $0.05 \mathrm{~L}$ & $0.05 \mathrm{~L}$ & $2 \mathrm{~L}$ & \multicolumn{4}{|c|}{ Quartz vein. } \\
\hline MW005R & $20 \mathrm{~N}$ & $10 \mathrm{~N}$ & $200 \mathrm{~N}$ & 10 & $5 \mathrm{~L}$ & $0.002 \mathrm{~L}$ & $2 \mathrm{~L}$ & $0.1 \mathrm{~L}$ & $0.02 \mathrm{~L}$ & $2 \mathrm{~L}$ & $0.05 \mathrm{~L}$ & $0.05 \mathrm{~L}$ & $2 \mathrm{~L}$ & \multicolumn{4}{|c|}{ Quartz vein. } \\
\hline MW006R & $20 \mathrm{~N}$ & $10 \mathrm{~N}$ & $200 \mathrm{~N}$ & 100 & $5 \mathrm{~L}$ & $0.002 \mathrm{~L}$ & $2 \mathrm{~L}$ & 0.11 & $0.02 \mathrm{~L}$ & $2 \mathrm{~L}$ & $0.05 \mathrm{~L}$ & $0.05 \mathrm{~L}$ & $2 \mathrm{~L}$ & \multicolumn{4}{|c|}{ Quartz vein. } \\
\hline MW007R & $20 \mathrm{~N}$ & $10 \mathrm{~N}$ & $200 \mathrm{~N}$ & 10 & $5 \mathrm{~L}$ & 0.002 & $2 \mathrm{~L}$ & $0.1 \mathrm{~L}$ & $0.02 \mathrm{~L}$ & $2 \mathrm{~L}$ & $0.05 \mathrm{~L}$ & $0.05 \mathrm{~L}$ & $2 \mathrm{~L}$ & \multicolumn{4}{|c|}{ Host rock (quartzite?). } \\
\hline MW008R & $20 \mathrm{~N}$ & $10 \mathrm{~N}$ & $200 \mathrm{~N}$ & 10 & $5 \mathrm{~L}$ & $0.002 \mathrm{~L}$ & $2 \mathrm{~L}$ & $0.1 \mathrm{~L}$ & $0.02 \mathrm{~L}$ & $2 \mathrm{~L}$ & 0.1 & $0.05 \mathrm{~L}$ & $2 \mathrm{~L}$ & \multicolumn{4}{|c|}{ Quartz boulder. } \\
\hline MW009R & $20 \mathrm{~N}$ & $10 \mathrm{~N}$ & $200 \mathrm{~N}$ & 10 & $5 \mathrm{~L}$ & $0.002 \mathrm{~L}$ & $2 \mathrm{~L}$ & $0.1 \mathrm{~L}$ & $0.02 \mathrm{~L}$ & $2 \mathrm{~L}$ & $0.05 \mathrm{~L}$ & $0.05 \mathrm{~L}$ & $2 \mathrm{~L}$ & \multicolumn{4}{|c|}{ Quartz-tourmaline vein. } \\
\hline MWOIOR & $20 \mathrm{~N}$ & $10 \mathrm{~N}$ & $200 \mathrm{~N}$ & $10 \mathrm{~L}$ & $5 \mathrm{~L}$ & $0.002 \mathbf{L}$ & $2 \mathrm{~L}$ & $0.1 \mathrm{~L}$ & $0.02 \mathrm{~L}$ & $2 \mathrm{~L}$ & $0.05 \mathrm{~L}$ & $0.05 \mathrm{~L}$ & $2 \mathrm{~L}$ & \multicolumn{4}{|c|}{ Quartz-tourmaline veis. } \\
\hline MW011R & $20 \mathrm{~N}$ & $10 N$ & $200 \mathrm{~N}$ & 10 & $5 \mathrm{~L}$ & 0.048 & $2 \mathrm{~L}$ & $0.1 \mathrm{~L}$ & $0.02 \mathrm{~L}$ & $2 \mathbf{L}$ & $0.05 \mathrm{~L}$ & $0.05 \mathrm{~L}$ & $2 \mathrm{~L}$ & \multicolumn{4}{|c|}{ Quartz vein. } \\
\hline MW012R & $20 \mathrm{~N}$ & $10 \mathrm{~N}$ & $200 \mathrm{~N}$ & 15 & $5 \mathrm{~L}$ & 0.23 & $2 \mathrm{~L}$ & 0.3 & $0.02 \mathrm{~L}$ & $2 \mathrm{~L}$ & 0.45 & $0.05 \mathrm{~L}$ & 5 & \multicolumn{4}{|c|}{ Quartzite. } \\
\hline MW013R & $20 \mathrm{~N}$ & $10 \mathrm{~N}$ & $200 \mathrm{~N}$ & 15 & $5 \mathrm{~L}$ & $0.002 \mathrm{~L}$ & $2 \mathrm{~L}$ & $0.1 \mathrm{~L}$ & $0.02 \mathrm{~L}$ & $2 \mathrm{~L}$ & $0.05 \mathrm{~L}$ & $0.05 \mathrm{~L}$ & 9 & \multicolumn{4}{|c|}{ Quartz vein. } \\
\hline MW014R & $20 \mathrm{~N}$ & $10 \mathrm{~N}$ & $200 \mathrm{~N}$ & $10 \mathrm{~L}$ & $5 \mathrm{~L}$ & 0.002 & $2 \mathrm{~L}$ & $0.1 \mathrm{~L}$ & $0.02 \mathrm{~L}$ & $2 L$ & $0.05 \mathrm{~L}$ & $0.05 \mathrm{~L}$ & $2 \mathrm{~L}$ & Quartz & & & \\
\hline MW015R & $20 \mathrm{~N}$ & $10 \mathrm{~N}$ & $200 \mathrm{~N}$ & $10 N$ & $5 \mathrm{~L}$ & 0.002 & $2 \mathrm{~L}$ & $0.1 \mathrm{~L}$ & $0.02 \mathrm{~L}$ & $2 \mathbf{L}$ & $0.05 \mathrm{~L}$ & $0.05 \mathrm{~L}$ & $2 \mathrm{~L}$ & Quartz & urmaline & & \\
\hline MW016R & $20 \mathrm{~N}$ & 20 & $200 \mathrm{~L}$ & 30 & $5 \mathrm{~L}$ & 0.01 & $2 \mathrm{~L}$ & 0.6 & 0.02 & $2 \mathbf{L}$ & $0.05 \mathrm{~L}$ & $0.05 \mathrm{~L}$ & 120 & Quartz & & & \\
\hline MW017R & 50 & $10 \mathrm{~N}$ & $200 \mathrm{~N}$ & 10 & 8 & 0.008 & $2 \mathrm{~L}$ & 0.2 & $0.02 \mathrm{~L}$ & $2 L$ & 0.45 & $0.05 \mathrm{~L}$ & 15 & Quartz & with qus & veins. & \\
\hline MW018R & 30 & $10 \mathrm{~N}$ & $200 \mathrm{~N}$ & $10 \mathrm{~L}$ & $5 \mathrm{~L}$ & 0.002 & $2 \mathrm{~L}$ & 0.2 & $0.02 \mathrm{~L}$ & $2 \mathrm{~L}$ & 0.05 & $0.05 \mathrm{~L}$ & 5 & Quartz & & & \\
\hline MW019R & $20 \mathrm{~N}$ & $10 \mathrm{~N}$ & $200 \mathrm{~N}$ & $10 \mathrm{~L}$ & $5 \mathrm{~L}$ & 0.05 & $2 \mathrm{~L}$ & 0.1 & $0.02 \mathrm{~L}$ & $2 \mathbf{L}$ & 2 & $0.05 \mathrm{~L}$ & 3 & Quartz & urmaline & & \\
\hline MW020R & $20 \mathrm{~N}$ & $10 \mathrm{~N}$ & $200 \mathrm{~N}$ & 15 & $5 \mathrm{~L}$ & $0.002 \mathrm{~L}$ & $2 \mathrm{~L}$ & $0.1 \mathrm{~L}$ & $0.02 \mathrm{~L}$ & $2 \mathbf{L}$ & 0.4 & $0,05 \mathrm{~L}$ & $2 \mathrm{~L}$ & Quartz & urmaline & & \\
\hline $\mathrm{MW021R}$ & $20 \mathrm{~N}$ & $10 \mathrm{~N}$ & $200 \mathrm{~N}$ & 30 & $5 \mathrm{~L}$ & 0.01 & $2 \mathrm{~L}$ & $0.1 \mathrm{~L}$ & $0.02 \mathrm{~L}$ & $2 \mathbf{L}$ & 0.05 & $0.05 \mathrm{~L}$ & $2 \mathrm{~L}$ & Quartz & urmaline & & \\
\hline MW022R & $20 \mathrm{~N}$ & $10 \mathrm{~N}$ & $200 \mathrm{~N}$ & 10 & $5 \mathrm{~L}$ & 0.034 & $2 \mathrm{~L}$ & $0.1 \mathrm{~L}$ & $0.02 \mathrm{~L}$ & $2 \mathbf{L}$ & $0.05 \mathrm{~L}$ & $0.05 \mathrm{~L}$ & $2 \mathrm{~L}$ & Quartz & urmaline & & \\
\hline MW023R & $20 \mathrm{~N}$ & 10 & 300 & 50 & $5 \mathrm{~L}$ & $0.002 \mathrm{~L}$ & $2 \mathrm{~L}$ & $0.1 \mathrm{~L}$ & $0.02 \mathrm{~L}$ & $2 L$ & $0.05 \mathrm{~L}$ & $0.05 \mathrm{~L}$ & $2 \mathrm{~L}$ & Tourm & & & \\
\hline MW024R & $20 \mathrm{~N}$ & $10 \mathrm{~L}$ & 200 & 70 & $5 \mathrm{~L}$ & 0.002 & $2 \mathrm{~L}$ & $0.1 \mathrm{~L}$ & $0.02 \mathrm{~L}$ & $2 \mathrm{~L}$ & 0.2 & $0.05 \mathrm{~L}$ & 5 & Quartz & urmaline & & \\
\hline MW025R & $20 \mathrm{~N}$ & 100 & $200 \mathrm{~N}$ & 50 & $5 \mathrm{~L}$ & 0.01 & $2 \mathrm{~L}$ & $0.1 \mathrm{~L}$ & $0.02 \mathrm{~L}$ & $2 \mathrm{~L}$ & $0.05 \mathrm{~L}$ & $0.05 \mathrm{~L}$ & $2 \mathrm{~L}$ & Quartz & urmaline & & \\
\hline MW026R & $20 \mathrm{~N}$ & $10 \mathrm{~N}$ & $200 \mathrm{~N}$ & 15 & $5 \mathrm{~L}$ & 0.002 & $2 \mathrm{~L}$ & $0.1 \mathrm{~L}$ & $0.02 \mathrm{~L}$ & $2 \mathrm{~L}$ & $0.05 \mathrm{~L}$ & $0.05 \mathrm{~L}$ & 4 & Quartz & urmaline & & \\
\hline MW027R & $20 \mathrm{~N}$ & $10 \mathrm{~N}$ & $200 \mathrm{~N}$ & $10 \mathrm{~L}$ & $5 \mathrm{~L}$ & 0.014 & $2 \mathrm{~L}$ & 0.3 & $0.02 \mathrm{~L}$ & $2 \mathrm{~L}$ & 0.05 & $0.05 \mathrm{~L}$ & $2 \mathrm{~L}$ & Quartz & th magn & & \\
\hline MW028R & $20 \mathrm{~N}$ & $10 \mathrm{~N}$ & $200 \mathrm{~N}$ & 10 & $5 \mathrm{~L}$ & 0.04 & $2 \mathrm{~L}$ & 0.2 & $0.02 \mathrm{~L}$ & $2 \mathrm{~L}$ & 0.2 & $0.05 \mathrm{~L}$ & 7 & Quartz & th magn & & \\
\hline MW029R & $20 \mathrm{~N}$ & 10 & 300 & 1 & $5 \mathrm{~L}$ & 0.25 & $2 \mathrm{~L}$ & 3.1 & 0.08 & $2 \mathrm{~L}$ & 4.2 & $0.05 \mathrm{~L}$ & 270 & Quartz & urmaline & & \\
\hline MW030R & $20 \mathrm{~N}$ & $10 \mathrm{~N}$ & $200 \mathrm{~N}$ & $10 \mathrm{~L}$ & SL & 0.004 & $2 \mathrm{~L}$ & $0.1 \mathrm{~L}$ & $0.02 \mathrm{~L}$ & $2 \mathrm{~L}$ & 0.25 & $0.05 \mathrm{~L}$ & $2 \mathrm{~L}$ & Sugary & tartz-tou & Line vein. & \\
\hline MW031R & $20 \mathrm{~N}$ & $10 \mathrm{~N}$ & $200 \mathrm{~N}$ & $10 \mathrm{~N}$ & $5 \mathbf{L}$ & $0.002 \mathrm{~L}$ & $2 \mathrm{~L}$ & $0.1 \mathrm{~L}$ & $0.02 \mathrm{~L}$ & $2 \mathrm{~L}$ & $0.05 \mathrm{~L}$ & $0.05 \mathrm{~L}$ & $2 \mathrm{~L}$ & Quart2 & urmaline & & \\
\hline
\end{tabular}


Appendix table 6. Rock samples collected from zone 4 of the Marwani concession, Venezuela—Continued.

\begin{tabular}{|c|c|c|c|c|c|c|c|c|c|c|c|c|c|c|}
\hline & W-S & $\mathrm{Y}-\mathrm{S}$ & $\mathrm{Zn}-\mathrm{S}$ & $\mathrm{Zr}-\mathrm{S}$ & $\mathrm{As} / \mathrm{p}$ & $\mathrm{Au}$ & $\mathrm{Bi} / \mathrm{p}$ & $\mathrm{Cd} / \mathrm{p}$ & $\mathrm{Hg}$ & $\mathrm{Sb} / \mathrm{p}$ & $\mathrm{Te}$ & TI & $\mathrm{Zn} / \mathrm{p}$ & Sample description \\
\hline MW032R & $20 \mathrm{~N}$ & $10 \mathrm{~N}$ & $200 \mathrm{~N}$ & $10 \mathrm{~L}$ & 11 & $0.002 \mathrm{~L}$ & $2 \mathrm{~L}$ & 0.3 & $0.02 \mathrm{~L}$ & $2 \mathrm{~L}$ & 0.1 & $0.05 \mathrm{~L}$ & 5 & Quartzite with magnetite and quartz veins. \\
\hline MW033R & $20 \mathrm{~N}$ & $10 \mathrm{~N}$ & $200 \mathrm{~N}$ & $10 \mathrm{~L}$ & $5 \mathrm{~L}$ & $0.002 \mathrm{~L}$ & $2 L$ & 0.4 & $0.02 \mathrm{~L}$ & $2 \mathrm{~L}$ & 0.05 & $0.05 \mathrm{~L}$ & $2 \mathrm{~L}$ & Quartzite wiwth magnetite. \\
\hline MW59650S & $20 \mathrm{~N}$ & 10 & 200 & 50 & 5L & 0.002 & $2 L$ & 2 & $0.02 \mathrm{~L}$ & $2 \mathrm{~L}$ & 0.3 & 0.05 & 160 & \\
\hline
\end{tabular}

Appendix table 7. Heavy-mineral separates from stream concentrate samples, zone 4, Marwani concession, Venezuela.

\begin{tabular}{|c|c|c|c|c|c|c|c|c|c|c|c|c|c|c|c|c|c|}
\hline & Latitude & Longitude & $\mathrm{Ca} \%-\mathrm{S}$ & $\mathrm{Fe} \%-\mathrm{S}$ & Mg\%-S & $\mathrm{Na} \%-\mathrm{S}$ & $\mathrm{P} \%-\mathrm{S}$ & Ti\%-S & $\mathrm{Ag}-\mathrm{S}$ & As-S & $\mathrm{Au}-\mathrm{S}$ & B-S & $\mathrm{Ba}-\mathrm{S}$ & $\mathrm{Be}-\mathrm{S}$ & $\mathrm{Bi}-\mathrm{S}$ & $\mathrm{Cd} \cdot \mathrm{S}$ & $\mathrm{Co}-\mathrm{S}$ \\
\hline Moco0s & $7^{\circ} 00^{\prime} 21^{\prime \prime}$ & $60^{\circ} 41^{\prime} 13^{\prime \prime}$ & $0.1 \mathrm{~L}$ & 0.15 & 0.05 & $0.5 \mathrm{~N}$ & $0.5 \mathrm{~L}$ & $2 G$ & IN & $500 \mathrm{~N}$ & $20 \mathrm{~L}$ & 100 & 50 & $2 \mathrm{~N}$ & $20 \mathrm{~N}$ & $50 \mathrm{~N}$ & $20 \mathrm{~N}$ \\
\hline Mocoll & $7^{\circ} 00^{\prime} 49^{\prime \prime}$ & $60^{\circ} 40^{\prime} 24^{\prime \prime}$ & $0.1 \mathrm{~L}$ & 0.20 & $0.05 \mathrm{~L}$ & $0.5 \mathrm{~N}$ & $0.5 \mathrm{~L}$ & $2 G$ & $1 \mathrm{~N}$ & $500 \mathrm{~N}$ & $20 \mathrm{~N}$ & 50 & 50 & $2 \mathrm{~N}$ & $20 \mathrm{~N}$ & $50 \mathrm{~N}$ & $20 \mathrm{~N}$ \\
\hline $\mathrm{M} 0 \mathrm{C} 012$ & $\left.7^{\circ} 00^{\prime} 0\right]^{\prime \prime}$ & $60^{\circ} 40^{\prime} 44^{\prime \prime}$ & 0.15 & 0.30 & $0.05 \mathrm{~L}$ & $0.5 \mathrm{~N}$ & $0.5 \mathrm{~L}$ & $2 \mathrm{G}$ & IN & $500 \mathrm{~N}$ & 100 & 50 & 70 & $2 \mathrm{~N}$ & $20 N$ & $50 \mathrm{~N}$ & $20 \mathrm{~N}$ \\
\hline $\mathrm{MoC} 017$ & $7^{\circ} 01^{\prime} 25^{\prime \prime}$ & $60^{\circ} 41^{\prime} 11^{\prime \prime}$ & $0.1 \mathrm{~L}$ & 0.30 & $0.05 \mathrm{~L}$ & $0.5 \mathrm{~N}$ & $0.5 \mathrm{~L}$ & $2 \mathrm{G}$ & IN & $500 \mathrm{~N}$ & $20 \mathrm{~N}$ & 30 & 50 & $2 \mathrm{~N}$ & $20 \mathrm{~N}$ & $50 \mathrm{~N}$ & $20 \mathrm{~N}$ \\
\hline $\mathrm{M} 0 \mathrm{CO} 20$ & $7^{\circ} 01^{\prime 22}$ & $60^{\circ} 41^{\prime} 46^{\prime \prime}$ & $0.1 \mathrm{~L}$ & 0.30 & $0.05 \mathrm{~L}$ & $0.5 \mathrm{~N}$ & $0.5 \mathrm{~L}$ & $2 G$ & IN & $500 \mathrm{~N}$ & 50 & 70 & 50 & $2 \mathrm{~N}$ & $20 \mathrm{~N}$ & $50 \mathrm{~N}$ & $20 \mathrm{~N}$ \\
\hline MOC021 & $7^{\circ} 01221^{\prime \prime}$ & $60^{\circ} 41^{\prime} 59^{\prime \prime}$ & $0.1 \mathrm{~N}$ & 0.30 & $0.05 \mathrm{~L}$ & $0.5 \mathrm{~N}$ & $0.5 \mathrm{~N}$ & $2 G$ & IN & $500 \mathrm{~N}$ & 50 & 30 & $50 \mathrm{~L}$ & $2 \mathrm{~N}$ & $20 \mathrm{~N}$ & $50 \mathrm{~N}$ & $20 \mathrm{~N}$ \\
\hline MOC038 & $7^{\circ} 00^{\prime} 11^{\prime \prime}$ & $60^{\circ} 41^{\prime} 50^{\prime \prime}$ & $0.1 \mathrm{~L}$ & $0.1 \mathrm{~L}$ & 0.05 & $0.5 \mathrm{~N}$ & $0.5 \mathrm{~L}$ & $2 \mathrm{G}$ & IN & $500 \mathrm{~N}$ & $20 \mathrm{~N}$ & 200 & 70 & $2 \mathrm{~N}$ & $20 \mathrm{~N}$ & $50 \mathrm{~N}$ & $20 \mathrm{~N}$ \\
\hline $\mathrm{M} 0 \mathrm{C} 039$ & $7^{\circ} 00^{\prime} 11^{\prime \prime}$ & $60^{\circ} 41^{\prime} 46^{\prime \prime}$ & 0.12 & $0.1 \mathrm{~L}$ & 0.05 & $0.5 \mathrm{~N}$ & $0.5 \mathrm{~N}$ & $2 \mathrm{G}$ & $1 \mathrm{~N}$ & $500 \mathrm{~N}$ & $20 \mathrm{~N}$ & 50 & 50 & $2 \mathrm{~N}$ & $20 \mathrm{~N}$ & $50 \mathrm{~N}$ & $20 \mathrm{~N}$ \\
\hline M0C059 & $6^{\circ} 59^{\prime} 29^{\prime \prime}$ & $60^{\circ} 42^{\prime} 41^{\prime \prime}$ & $0.1 \mathrm{~N}$ & 0.30 & $0.05 \mathrm{~L}$ & $0.5 \mathrm{~N}$ & $0.5 \mathrm{~N}$ & $2 \mathrm{G}$ & $1 \mathrm{~N}$ & $500 \mathrm{~N}$ & 30 & $20 \mathrm{~L}$ & $50 \mathrm{~L}$ & $2 \mathrm{~L}$ & $20 \mathrm{~N}$ & $50 \mathrm{~N}$ & $20 \mathrm{~N}$ \\
\hline MoC06I & $6^{\circ} 59^{\prime} 49^{\prime \prime}$ & $60^{\circ} 42^{\prime} 41^{\prime \prime}$ & $0.1 \mathrm{~N}$ & 0.50 & 0.07 & $0.5 \mathrm{~N}$ & $0.5 \mathrm{~N}$ & $2 \mathrm{G}$ & 10 & $500 \mathrm{~N}$ & 700 & 70 & 50 & $2 \mathrm{~N}$ & $20 \mathrm{~N}$ & $50 \mathrm{~N}$ & $20 \mathrm{~N}$ \\
\hline MOC 082 & $7^{\circ} 01^{\prime} 30^{\prime \prime}$ & $60^{\circ} 39^{\circ} 41^{\prime \prime}$ & $0.1 \mathrm{~L}$ & 0.20 & 0.07 & $0.5 \mathrm{~N}$ & $0.5 \mathrm{~N}$ & $2 \mathrm{G}$ & IN & $500 \mathrm{~N}$ & $20 \mathrm{~N}$ & 200 & $50 \mathrm{~L}$ & $2 \mathrm{~N}$ & $20 \mathrm{~N}$ & $50 \mathrm{~N}$ & $20 \mathrm{~N}$ \\
\hline M0C086 & $7^{\circ} 01^{\prime} 43^{\prime \prime}$ & $60^{\circ} 40^{\prime} 28^{\prime \prime}$ & $0.1 \mathrm{~L}$ & 0.15 & 0.10 & $0.5 \mathrm{~N}$ & $0.5 \mathrm{~N}$ & $2 \mathrm{G}$ & IN & $500 \mathrm{~N}$ & $20 \mathrm{~N}$ & 100 & $50 \mathrm{~L}$ & $2 \mathrm{~N}$ & $20 \mathrm{~N}$ & $50 \mathrm{~N}$ & $20 \mathrm{~N}$ \\
\hline $\mathrm{M} 0 \mathrm{C} 087$ & $7^{\circ} 01^{\prime} 47^{\prime \prime}$ & $60^{\circ} 40^{\prime} 43^{\prime \prime}$ & $0.1 \mathrm{~L}$ & 0.20 & 0.05 & $0.5 \mathrm{~N}$ & $0.5 \mathrm{~N}$ & $2 \mathrm{G}$ & $1 \mathrm{~N}$ & $500 \mathrm{~N}$ & $20 N$ & 70 & $50 \mathrm{~L}$ & $2 \mathrm{~N}$ & $20 \mathrm{~N}$ & $50 \mathrm{~N}$ & $20 \mathrm{~N}$ \\
\hline MoC088 & $7^{\circ} 01^{\prime} 52^{\prime \prime}$ & $60^{\circ} 40^{\prime} 39^{\prime \prime}$ & $0.1 \mathrm{~N}$ & 0.10 & 0.05 & $0.5 \mathrm{~N}$ & $0.5 \mathrm{~L}$ & $2 \mathrm{G}$ & 20 & $500 \mathrm{~N}$ & 1,000 & 100 & 70 & 5 & $20 \mathrm{~N}$ & $50 \mathrm{~N}$ & $20 \mathrm{~N}$ \\
\hline MOC090 & $7^{\circ} 01^{\prime} 57^{\prime \prime}$ & $60^{\circ} 40^{\prime} 57^{\prime \prime}$ & $0.1 \mathrm{~L}$ & $0.1 \mathrm{~L}$ & 0.07 & $0.5 \mathrm{~N}$ & $0.5 \mathrm{~N}$ & $2 \mathrm{G}$ & $1 N$ & $500 \mathrm{~N}$ & $20 \mathrm{~L}$ & 70 & 70 & $2 \mathrm{~L}$ & $20 \mathrm{~N}$ & $50 \mathrm{~N}$ & $20 \mathrm{~N}$ \\
\hline M0C097 & $7^{\circ} 02^{\prime} 43^{\prime \prime}$ & $60^{\circ} 39^{\prime} 08^{\prime \prime}$ & $0.1 \mathrm{~N}$ & 0.12 & 0.10 & $0.5 \mathrm{~N}$ & $0.5 \mathrm{~N}$ & $2 \mathrm{G}$ & IN & $500 \mathrm{~N}$ & $20 \mathrm{~N}$ & 200 & $50 \mathrm{~L}$ & $2 \mathrm{~N}$ & $20 \mathrm{~N}$ & $50 \mathrm{~N}$ & $20 \mathrm{~N}$ \\
\hline MoC100 & $7^{\circ} 03^{\prime} 10^{\prime \prime}$ & $60^{\circ} 39^{\prime} 29^{\prime \prime}$ & $0.1 \mathrm{~N}$ & 0.10 & 0.05 & $0.5 \mathrm{~N}$ & $0.5 \mathrm{~N}$ & $2 \mathrm{G}$ & IN & $500 \mathrm{~N}$ & $20 \mathrm{~L}$ & 100 & 70 & $2 \mathrm{~N}$ & $20 \mathrm{~N}$ & $50 \mathrm{~N}$ & $20 \mathrm{~N}$ \\
\hline M0C105A & $7^{\circ} 02^{\prime} 55^{\prime \prime}$ & $60^{\circ} 39^{\prime} 58^{\prime \prime}$ & $0.1 \mathrm{~N}$ & 0.10 & 0.07 & $0.5 \mathrm{~N}$ & $0.5 \mathrm{~N}$ & $2 G$ & $1 \mathrm{~N}$ & $500 \mathrm{~N}$ & $20 \mathrm{~N}$ & 70 & 50 & $2 \mathrm{~N}$ & $20 \mathrm{~N}$ & $50 \mathrm{~N}$ & $20 \mathrm{~N}$ \\
\hline MoC109 & $7^{\circ} 02^{\prime} 39^{\prime \prime}$ & $60^{\circ} 39^{\prime} 58^{\prime \prime}$ & $0.1 \mathrm{~L}$ & 0.10 & 0.07 & $0.5 \mathrm{~N}$ & $0.5 \mathrm{~N}$ & $2 \mathrm{G}$ & $1 \mathrm{~N}$ & $500 \mathrm{~N}$ & $20 \mathrm{~N}$ & 70 & $50 \mathrm{~L}$ & $2 \mathrm{~N}$ & $20 \mathrm{~N}$ & $50 \mathrm{~N}$ & $20 \mathrm{~N}$ \\
\hline MCH001 & $7^{\circ} 03^{\prime} 08^{\prime \prime}$ & $60^{\circ} 40^{\prime} 03^{\prime \prime}$ & $0.1 \mathrm{~L}$ & 0.10 & 0.07 & $0.5 \mathrm{~N}$ & $0.5 \mathrm{~L}$ & $2 \mathrm{G}$ & $1 \mathrm{~N}$ & $500 \mathrm{~N}$ & $20 \mathrm{~N}$ & 30 & 50 & $2 \mathrm{~N}$ & $20 \mathrm{~N}$ & $50 \mathrm{~N}$ & $20 \mathrm{~N}$ \\
\hline MCH003 & $7^{\circ} 02^{\prime} 36^{\prime \prime}$ & $60^{\circ} 39^{\prime} 36^{\prime \prime}$ & $0.1 \mathrm{~N}$ & $0.1 \mathrm{~L}$ & 0.05 & $0.5 \mathrm{~N}$ & $0.5 \mathrm{~N}$ & $2 \mathrm{G}$ & IN & $500 \mathrm{~N}$ & $20 \mathrm{~N}$ & $20 \mathrm{~L}$ & 300 & $2 \mathrm{~N}$ & $20 \mathrm{~N}$ & $50 \mathrm{~N}$ & $20 \mathrm{~N}$ \\
\hline MCH004 & $7^{\circ} 02^{\prime} 40^{\prime \prime}$ & $60^{\circ} 39^{\prime} 34^{\prime \prime}$ & $0.1 \mathrm{~L}$ & $0.1 \mathrm{~L}$ & 0.05 & $0.5 \mathrm{~N}$ & $0.5 \mathrm{~N}$ & $2 \mathrm{G}$ & iN & $500 \mathrm{~N}$ & $20 \mathrm{~N}$ & $20 \mathrm{~L}$ & 500 & $2 \mathrm{~N}$ & $20 \mathrm{~N}$ & $50 \mathrm{~N}$ & $20 \mathrm{~N}$ \\
\hline $\mathrm{MCH} 005$ & $7^{\circ} 02^{\prime} 12^{\prime \prime}$ & $60^{\circ} 40^{\circ} 06^{\prime \prime}$ & $0.1 \mathrm{~L}$ & $0.1 \mathrm{~L}$ & 0.07 & $0.5 \mathrm{~N}$ & $0.5 \mathrm{~N}$ & $2 \mathrm{G}$ & 100 & $500 \mathrm{~N}$ & $1,000 \mathrm{G}$ & 150 & $50 \mathrm{~L}$ & $2 \mathrm{~N}$ & $20 \mathrm{~N}$ & $50 \mathrm{~N}$ & $20 \mathrm{~N}$ \\
\hline МСH006 & $7^{\circ} 02^{\prime} 28^{\prime \prime}$ & $60^{\circ} 40^{\circ} 02^{\prime \prime}$ & $0.1 \mathrm{~L}$ & $0.1 \mathrm{~L}$ & 0.07 & $0.5 \mathrm{~N}$ & $0.5 \mathrm{~N}$ & $2 G$ & $1 \mathrm{~N}$ & $500 \mathrm{~N}$ & $20 \mathrm{~N}$ & 150 & 50 & $2 \mathrm{~N}$ & $20 \mathrm{~N}$ & $50 \mathrm{~N}$ & $20 \mathrm{~N}$ \\
\hline MCH007 & $7^{\circ} 03^{\prime} 00^{\prime \prime}$ & $60^{\circ} 40^{\prime} 44^{\prime \prime}$ & $0.1 \mathrm{~L}$ & 0.10 & 0.07 & $0.5 \mathrm{~N}$ & $0.5 \mathrm{~L}$ & $2 \mathrm{G}$ & IN & $500 \mathrm{~N}$ & $20 \mathrm{~N}$ & 100 & 300 & $2 \mathrm{~L}$ & $20 N$ & $50 \mathrm{~N}$ & $20 \mathrm{~N}$ \\
\hline MCH008 & $7^{\circ} 02^{\prime} 50^{\prime \prime}$ & $60^{\circ} 40^{\prime} 32^{\prime \prime}$ & $0.1 N$ & $0.1 \mathrm{~L}$ & 0.05 & $0.5 \mathrm{~N}$ & $0.5 \mathrm{~N}$ & $2 G$ & $1 \mathrm{~N}$ & $500 \mathrm{~N}$ & $20 \mathrm{~N}$ & 150 & 70 & 3 & $20 \mathrm{~N}$ & $50 \mathrm{~N}$ & $20 \mathrm{~N}$ \\
\hline MCH010 & $7^{\circ} 02^{\prime} 20^{\prime \prime}$ & $60^{\circ} 40^{\prime} 28^{\prime \prime}$ & $0.1 \mathrm{~N}$ & 0.15 & 0.05 & $0.5 \mathrm{~N}$ & $0.5 \mathrm{~L}$ & $2 \mathrm{G}$ & $1 \mathrm{~N}$ & $500 \mathrm{~N}$ & $20 \mathrm{~N}$ & 70 & 70 & $2 \mathrm{~N}$ & $20 \mathrm{~N}$ & $50 \mathrm{~N}$ & $20 \mathrm{~N}$ \\
\hline MCH011 & $7^{\circ} 02^{\prime} 17^{\prime \prime}$ & $60^{\circ} 40^{\prime \prime} 26^{\prime \prime}$ & $0.1 \mathrm{~L}$ & 0.15 & 0.05 & $0.5 \mathrm{~N}$ & $0.5 \mathrm{~N}$ & $2 \mathrm{G}$ & $1 \mathrm{~N}$ & $500 \mathrm{~N}$ & 70 & $20 \mathrm{~L}$ & 70 & $2 \mathrm{~N}$ & $20 \mathrm{~N}$ & $50 \mathrm{~N}$ & $20 \mathrm{~N}$ \\
\hline MCH012 & $7^{\circ} 02^{\prime} 16^{\prime \prime}$ & $60^{\circ} 40^{\circ} 17^{\prime \prime}$ & $0.1 \mathrm{~L}$ & $0.1 \mathrm{~L}$ & $0.05 \mathrm{~L}$ & $0.5 \mathrm{~N}$ & $0.5 \mathrm{~L}$ & $2 \mathrm{G}$ & 10 & $500 \mathrm{~N}$ & 300 & 30 & 70 & $2 \mathrm{~L}$ & $20 \mathrm{~N}$ & $50 \mathrm{~N}$ & $20 \mathrm{~N}$ \\
\hline МCH013 & $7^{\circ} 01^{\prime} 48^{\prime \prime}$ & $60^{\circ} 40^{\prime} 53^{\prime \prime}$ & $0.1 \mathrm{~L}$ & $0.1 \mathrm{~L}$ & 0.05 & $0.5 \mathrm{~N}$ & $0.5 \mathrm{~L}$ & $2 \mathrm{G}$ & $1 N$ & $500 \mathrm{~N}$ & $20 \mathrm{~N}$ & 100 & 70 & $2 \mathrm{~N}$ & $20 \mathrm{~N}$ & $50 \mathrm{~N}$ & $20 \mathrm{~N}$ \\
\hline $\mathrm{MCH} 014$ & $7^{\circ} 01^{\prime} 12^{\prime \prime}$ & $60^{\circ} 40^{\prime} 08^{\prime \prime}$ & $0.1 \mathrm{~L}$ & $0.1 \mathrm{~L}$ & 0.05 & $0.5 \mathrm{~N}$ & $0.5 \mathrm{~L}$ & $2 \mathrm{G}$ & $1 \mathrm{~L}$ & $500 \mathrm{~N}$ & 50 & 100 & 100 & $2 \mathrm{~L}$ & $20 \mathrm{~N}$ & $50 \mathrm{~N}$ & $20 \mathrm{~N}$ \\
\hline $\mathrm{MCH} 015$ & $7^{\circ} 01^{\prime} 25^{\prime \prime}$ & $60^{\circ} 41^{\prime} 20^{\prime \prime}$ & $0.1 \mathrm{~L}$ & 0.50 & $0.05 \mathrm{~L}$ & $0.5 \mathrm{~N}$ & $0.5 \mathrm{~N}$ & $2 \mathrm{G}$ & $1 \mathrm{~N}$ & $500 \mathrm{~N}$ & 30 & $20 \mathrm{~N}$ & 300 & $2 \mathrm{~N}$ & $20 \mathrm{~N}$ & $50 \mathrm{~N}$ & 15 \\
\hline MCHO16 & $7^{\circ} 01^{\prime} 09^{\prime \prime}$ & $60^{\circ} 41^{\prime} 32^{\prime \prime}$ & $0.1 \mathrm{~L}$ & 0.15 & $0.05 \mathrm{~L}$ & $0.5 \mathrm{~N}$ & $0.5 \mathrm{~N}$ & $2 G$ & $1 \mathrm{~N}$ & $500 \mathrm{~N}$ & 20 & 20 & 200 & 5 & $20 \mathrm{~N}$ & $50 \mathrm{~N}$ & $20 \mathrm{~N}$ \\
\hline MCHOl8 & $7^{\circ} 01^{\prime} 09^{\prime \prime}$ & $60^{\circ} 41^{\prime} 56^{\prime \prime}$ & $0.1 \mathrm{~L}$ & $0.1 \mathrm{~L}$ & 0.05 & $0.5 \mathrm{~N}$ & $0.5 \mathrm{~L}$ & $2 \mathrm{G}$ & $1 \mathrm{~N}$ & $500 \mathrm{~N}$ & $20 \mathrm{~N}$ & 100 & 150 & $2 \mathrm{~L}$ & $20 \mathrm{~N}$ & $50 \mathrm{~N}$ & $20 \mathrm{~N}$ \\
\hline $\mathrm{MCHO} 22$ & $7^{\circ} 00^{\prime} 55^{\prime \prime}$ & $60^{\circ} 42^{\prime} 05^{\prime \prime}$ & $0.1 \mathrm{~N}$ & 0.30 & 0.05 & $0.5 \mathrm{~N}$ & $0.5 \mathrm{~N}$ & $2 \mathrm{G}$ & $1 \mathrm{~N}$ & $500 \mathrm{~N}$ & $20 \mathrm{~L}$ & 70 & 100 & $2 \mathrm{~L}$ & $20 \mathrm{~N}$ & $50 \mathrm{~N}$ & $20 \mathrm{~N}$ \\
\hline $\mathrm{MCHO} 24$ & $7^{\circ} 00^{\prime} 37^{\prime \prime}$ & $60^{\circ} 41^{\prime} 49^{\prime \prime}$ & $0.1 \mathrm{~L}$ & 0.70 & 0.05 & $0.5 \mathrm{~N}$ & $0.5 \mathrm{~N}$ & $2 \mathrm{G}$ & $1 \mathrm{~N}$ & $500 \mathrm{~N}$ & $20 \mathrm{~N}$ & 100 & 70 & $2 \mathrm{~N}$ & $20 \mathrm{~N}$ & $50 \mathrm{~N}$ & $20 \mathrm{~L}$ \\
\hline $\mathrm{MCHO} 25$ & $7^{\circ} 00^{\prime} 40^{\prime \prime}$ & $60^{\circ} 42^{\prime} 12^{\prime \prime}$ & $0.1 \mathrm{~N}$ & 0.70 & 0.05 & $0.5 \mathrm{~L}$ & $0.5 \mathrm{~N}$ & $2 \mathrm{G}$ & IN & $500 \mathrm{~N}$ & $20 \mathrm{~N}$ & 70 & 150 & 3 & $20 \mathrm{~N}$ & $50 \mathrm{~N}$ & $20 \mathrm{~L}$ \\
\hline MCHO26 & $7^{\circ} 00^{\prime} 11^{\prime \prime}$ & $60^{\circ} 42^{\prime} 58^{\prime \prime}$ & $0.1 \mathrm{~L}$ & 0.20 & 0.15 & $0.5 \mathrm{~N}$ & $0.5 \mathrm{~N}$ & $2 \mathrm{G}$ & IN & $500 \mathrm{~N}$ & $20 \mathrm{~L}$ & 700 & 150 & 5 & $20 \mathrm{~N}$ & $50 \mathrm{~N}$ & $20 \mathrm{~N}$ \\
\hline $\mathrm{MCH} 027$ & $7^{\circ} 00^{\prime} 13^{\prime \prime}$ & $60^{\circ} 42^{\prime} 51^{\prime \prime}$ & $0.1 \mathrm{~N}$ & 0.70 & $0.05 \mathrm{~L}$ & $0.5 \mathrm{~N}$ & $0.5 \mathrm{~N}$ & $2 \mathrm{G}$ & IN & $500 \mathrm{~N}$ & $20 \mathrm{~N}$ & 100 & 70 & $2 \mathrm{~N}$ & $20 N$ & $50 \mathrm{~N}$ & $20 N$ \\
\hline МCH028 & $7^{\circ} 00^{\prime} 01^{\prime \prime}$ & $60^{\circ} 43^{\prime} 03^{\prime \prime}$ & $0.1 \mathrm{~L}$ & 0.70 & 0.10 & $0.5 \mathrm{~N}$ & $0.5 \mathrm{~N}$ & $2 \mathrm{G}$ & $1 \mathrm{~N}$ & $500 \mathrm{~N}$ & 20 & 30 & 100 & 5 & $20 \mathrm{~N}$ & $50 \mathrm{~N}$ & $20 \mathrm{~N}$ \\
\hline
\end{tabular}




\begin{tabular}{|c|c|c|c|c|c|c|c|c|c|c|c|c|c|c|c|c|c|}
\hline МСH029 & $6^{\circ} 58^{\prime} 43^{\prime \prime}$ & $60^{\circ} 42^{\prime} 10^{\prime \prime}$ & $0.1 \mathrm{~L}$ & 0.50 & $0.05 \mathrm{~L}$ & 3 & $0.5 \mathrm{~N}$ & $2 \mathrm{G}$ & IN & $500 \mathrm{~N}$ & $20 \mathrm{~L}$ & 70 & 70 & 2 & $20 \mathrm{~N}$ & $50 \mathrm{~N}$ & $20 \mathrm{~N}$ \\
\hline MCH030 & $6^{\circ} 58^{\prime} 58^{\prime \prime}$ & $60^{\circ} 42^{\prime} 24^{\prime \prime}$ & $0.1 \mathrm{~N}$ & $0.1 \mathrm{~L}$ & 0.05 & $0.5 \mathrm{~N}$ & $0.5 \mathrm{~N}$ & $2 G$ & $1 \mathrm{~N}$ & $500 \mathrm{~N}$ & $20 \mathrm{~N}$ & 150 & 100 & 5 & $20 \mathrm{~N}$ & $50 \mathrm{~N}$ & $20 \mathrm{~N}$ \\
\hline МСH032 & $6^{\circ} 58^{\prime} 50^{\prime \prime}$ & $60^{\circ} 42^{\prime} 39^{\prime \prime}$ & $0.1 \mathrm{~L}$ & $0.1 \mathrm{~L}$ & $0.05 \mathrm{~L}$ & $0.5 \mathrm{~N}$ & $0.5 \mathrm{~N}$ & $2 G$ & IN & $500 \mathrm{~N}$ & $20 \mathrm{~N}$ & $20 \mathrm{~L}$ & 70 & 3 & $20 \mathrm{~N}$ & $50 \mathrm{~N}$ & $20 \mathrm{~N}$ \\
\hline MCH033 & $6^{\circ} 59^{\prime} 04^{\prime \prime}$ & $60^{\circ} 43^{\prime} 17^{\prime \prime}$ & $0.1 \mathrm{~N}$ & 0.30 & $0.05 \mathrm{~L}$ & $0.5 \mathrm{~N}$ & $0.5 \mathrm{~N}$ & $2 G$ & IN & $500 \mathrm{~N}$ & $20 \mathrm{~N}$ & 70 & 100 & 3 & $20 \mathrm{~N}$ & $50 \mathrm{~N}$ & $20 \mathrm{~N}$ \\
\hline MCH035 & $6^{\circ} 58^{\prime} 59^{\prime \prime}$ & $60^{\circ} 43^{\prime} 35^{\prime \prime}$ & $0.1 \mathrm{~N}$ & 0.70 & $0.05 \mathrm{~L}$ & $0.5 \mathrm{~N}$ & $0.5 \mathrm{~N}$ & $2 \mathrm{G}$ & 70 & $500 \mathrm{~N}$ & $1,000 \mathrm{G}$ & 50 & 70 & 5 & $20 \mathrm{~N}$ & $50 \mathrm{~N}$ & $20 \mathrm{~N}$ \\
\hline $\mathrm{MCH} 036$ & $6^{\circ} 57^{\prime} 56^{\prime \prime}$ & $60^{\circ} 42^{\prime} 33^{\prime \prime}$ & $0.1 \mathrm{~L}$ & 0.70 & 0.05 & $0.5 \mathrm{~N}$ & $0.5 \mathrm{~N}$ & $2 \mathrm{G}$ & $1 \mathrm{~N}$ & $500 \mathrm{~N}$ & 20 & 150 & 100 & 2 & $20 \mathrm{~N}$ & $50 \mathrm{~N}$ & $20 \mathrm{~N}$ \\
\hline $\mathrm{MCH} 037$ & $6^{\circ} 58^{\prime} 39^{\prime \prime}$ & $60^{\circ} 42^{\prime} 53^{\prime \prime}$ & $0.1 \mathrm{~N}$ & 0.20 & $0.05 \mathrm{~L}$ & $0.5 \mathrm{~N}$ & $0.5 \mathrm{~N}$ & $2 \mathrm{G}$ & $1 \mathrm{~N}$ & $500 \mathrm{~N}$ & $20 \mathrm{~L}$ & $20 \mathrm{~N}$ & 50 & $2 \mathrm{~L}$ & $20 \mathrm{~N}$ & $50 \mathrm{~N}$ & $20 \mathrm{~N}$ \\
\hline MCH038 & $6^{0} 58^{\prime 28 "}$ & $60^{\circ} 42^{\prime} 42^{\prime \prime}$ & $0.1 \mathrm{~L}$ & $0.1 \mathrm{~L}$ & $0.05 \mathrm{~L}$ & $0.5 \mathrm{~N}$ & $0.5 \mathrm{~L}$ & $2 \mathrm{G}$ & $1 \mathrm{~N}$ & $500 \mathrm{~N}$ & 50 & 70 & 700 & $2 \mathrm{~N}$ & $20 \mathrm{~N}$ & $50 \mathrm{~N}$ & $20 \mathrm{~N}$ \\
\hline MCH039 & $6^{\circ} 59^{\prime} 03^{\prime \prime}$ & $60^{\circ} 43^{\prime} 17^{n}$ & $0.1 \mathrm{~N}$ & 0.30 & 0.07 & $0.5 \mathrm{~N}$ & $0.5 \mathrm{~N}$ & $2 \mathrm{G}$ & $1 \mathrm{~N}$ & $500 \mathrm{~N}$ & $20 \mathrm{~N}$ & 150 & 70 & 2 & $20 \mathrm{~N}$ & $50 \mathrm{~N}$ & $20 \mathrm{~N}$ \\
\hline $\mathrm{MCH} 040$ & $6^{\circ} 58^{\prime} 20^{\prime \prime}$ & $60^{\circ} 43^{\prime} 24^{\prime \prime}$ & $0.1 \mathrm{~L}$ & 0.20 & 0.05 & $0.5 \mathrm{~N}$ & $0.5 \mathrm{~N}$ & $2 \mathrm{G}$ & $1 \mathrm{~N}$ & $500 \mathrm{~N}$ & $20 \mathrm{~L}$ & 20 & 50 & 3 & $20 \mathrm{~N}$ & $50 \mathrm{~N}$ & $20 \mathrm{~N}$ \\
\hline $\mathrm{MCH} 042$ & $6^{\circ} 57^{\prime} 44^{\prime \prime}$ & $60^{\circ} 42^{\prime} 46^{n}$ & $0.1 \mathrm{~N}$ & 0.10 & $0.05 \mathrm{~L}$ & $0.5 \mathrm{~N}$ & $0.5 \mathrm{~N}$ & $2 \mathrm{G}$ & IN & $500 \mathrm{~N}$ & $20 \mathrm{~N}$ & 70 & 50 & 3 & $20 \mathrm{~N}$ & $50 \mathrm{~N}$ & $20 \mathrm{~N}$ \\
\hline $\mathrm{MCH} 043$ & $6^{\circ} 58^{\prime} 31^{\prime \prime}$ & $60^{\circ} 4352^{n}$ & B & B & B & B & B & B & B & B & B & B & B & B & B & B & B \\
\hline МCH044 & $6^{\circ} 58^{\prime} 00^{\prime \prime}$ & $60^{\circ} 43^{\prime} 20^{n}$ & 0.1 & 0.30 & $0.05 \mathrm{~L}$ & $0.5 \mathrm{~N}$ & $0.5 \mathrm{~N}$ & $2 \mathrm{G}$ & $1 N$ & $500 \mathrm{~N}$ & $20 \mathrm{~L}$ & $20 \mathrm{~N}$ & $50 \mathrm{~L}$ & 3 & $20 \mathrm{~N}$ & $50 \mathrm{~N}$ & $20 \mathrm{~N}$ \\
\hline $\mathrm{MCH} 045$ & $6^{\circ} 58^{\prime} 15^{\prime \prime}$ & $60^{\circ} 44^{\prime} 00^{\prime \prime}$ & $0.1 \mathrm{~L}$ & 0.50 & 0.07 & $0.5 \mathrm{~N}$ & $0.5 \mathrm{~N}$ & $2 G$ & $1 \mathrm{~N}$ & $500 \mathrm{~N}$ & $20 \mathrm{~L}$ & $20 \mathrm{~N}$ & 50 & 3 & $20 N$ & $50 \mathrm{~N}$ & $20 \mathrm{~N}$ \\
\hline MCH047 & $6^{\circ} 58^{\prime} 26^{\prime \prime}$ & $60^{\circ} 44^{\prime} 05^{\mu}$ & $0.1 \mathrm{~N}$ & 0.70 & 0.07 & $0.5 \mathrm{~N}$ & $0.5 \mathrm{~N}$ & $2 \mathrm{G}$ & $1 \mathrm{~N}$ & $500 \mathrm{~N}$ & $20 \mathrm{~N}$ & 20 & 50 & 3 & $20 N$ & $50 \mathrm{~N}$ & $20 \mathrm{~N}$ \\
\hline МCH048 & $6^{\circ} 58^{\prime} 28 "$ & $60^{\circ} 43^{\prime} 58^{\prime \prime}$ & $0.1 \mathrm{~N}$ & 0.20 & $0.05 \mathrm{~L}$ & $0.5 \mathrm{~L}$ & $0.5 \mathrm{~N}$ & $2 \mathrm{G}$ & IN & $500 \mathrm{~N}$ & $20 \mathrm{~L}$ & $20 \mathrm{~L}$ & 100 & 5 & $20 N$ & $50 \mathrm{~N}$ & $20 \mathrm{~N}$ \\
\hline МСH049 & $6^{\circ} 57^{\prime} 52^{\prime \prime}$ & $60^{\circ} 43^{\prime} 33^{n}$ & $0.1 \mathrm{~L}$ & 0.15 & 0.05 & $0.5 \mathrm{~N}$ & $0.5 \mathrm{~L}$ & $2 G$ & IN & $500 \mathrm{~N}$ & 100 & 20 & 100 & 2 & $20 \mathrm{~N}$ & $50 \mathrm{~N}$ & $20 \mathrm{~N}$ \\
\hline MCH050 & $6^{\circ} 57^{\prime} 20^{\prime \prime}$ & $60^{\circ} 43^{\prime} 08^{\prime \prime}$ & $0.1 \mathrm{~N}$ & 0.30 & $0.05 \mathrm{~L}$ & $0.5 \mathrm{~N}$ & $0.5 \mathrm{~N}$ & $2 \mathrm{G}$ & $1 \mathrm{~N}$ & $500 \mathrm{~N}$ & $20 \mathrm{~L}$ & 500 & 70 & 3 & $20 \mathrm{~N}$ & $50 \mathrm{~N}$ & $20 \mathrm{~N}$ \\
\hline MCH051 & $6^{\circ} 56^{\prime} 50^{\prime \prime}$ & $60^{\circ} 45^{\prime} 26^{n}$ & $0.1 \mathrm{~L}$ & 1 & $0.05 \mathrm{~L}$ & $0.5 \mathrm{~N}$ & $0.5 \mathrm{~N}$ & $2 \mathrm{G}$ & IN & $500 \mathrm{~N}$ & $20 \mathrm{~L}$ & 70 & 100 & 3 & $20 \mathrm{~N}$ & $50 \mathrm{~N}$ & $20 \mathrm{~N}$ \\
\hline $\mathrm{MCH} 052$ & $6^{\circ} 56^{\prime} 38^{\prime \prime}$ & $60^{\circ} 45^{\prime} 04^{\prime \prime}$ & $0.1 \mathrm{~N}$ & 0.20 & 0.07 & $0.5 \mathrm{~N}$ & $0.5 \mathrm{~N}$ & $2 \mathrm{G}$ & $1 \mathrm{~N}$ & $500 \mathrm{~N}$ & $20 \mathrm{~N}$ & 1,000 & 150 & 2 & $20 \mathrm{~N}$ & $50 \mathrm{~N}$ & $20 \mathrm{~N}$ \\
\hline $\mathrm{MCH} 053$ & $6^{\circ} 56^{\prime} 12^{\prime \prime}$ & $60^{\circ} 44^{\prime} 38^{\prime \prime}$ & $0.1 \mathrm{~N}$ & 0.10 & 0.07 & $0.5 \mathrm{~N}$ & $0.5 \mathrm{~L}$ & $2 \mathrm{G}$ & 20 & $500 \mathrm{~N}$ & $1,000 \mathrm{G}$ & 500 & 100 & $2 \mathrm{~L}$ & $20 \mathrm{~N}$ & $50 \mathrm{~N}$ & $20 \mathrm{~N}$ \\
\hline MCH055 & $6^{\circ} 57^{\prime} 01^{\prime \prime}$ & $60^{\circ} 45^{\prime} 02^{M}$ & $0.1 \mathrm{~L}$ & 0.70 & $0.05 \mathrm{~L}$ & $0.5 \mathrm{~N}$ & $0.5 \mathrm{~N}$ & $2 \mathrm{G}$ & $1 \mathrm{~N}$ & $500 \mathrm{~N}$ & $20 \mathrm{~L}$ & 100 & 100 & 3 & $20 \mathrm{~N}$ & $50 \mathrm{~N}$ & $20 \mathrm{~N}$ \\
\hline MCH056 & $6^{\circ} 57 \times 22^{\prime \prime}$ & $60^{\circ} 45^{\prime} 28^{\prime \prime}$ & $0.1 \mathrm{~L}$ & 0.70 & $0.05 \mathrm{~L}$ & $0.5 \mathrm{~N}$ & $0.5 \mathrm{~N}$ & $2 \mathrm{G}$ & $1 N$ & $500 \mathrm{~N}$ & 30 & $20 \mathrm{~L}$ & 100 & 5 & $20 \mathrm{~N}$ & $50 \mathrm{~N}$ & $20 \mathrm{~N}$ \\
\hline $\mathrm{MCH} 057$ & $6^{\circ} 56^{\prime} 42^{\prime \prime}$ & $60^{\circ} 44^{\prime} 47^{n}$ & $0.1 \mathrm{~N}$ & 0.50 & 0.05 & $0.5 \mathrm{~N}$ & $0.5 \mathrm{~N}$ & $2 \mathrm{G}$ & 20 & $500 \mathrm{~N}$ & $1,000 \mathrm{G}$ & 500 & 150 & 3 & $20 \mathrm{~N}$ & $50 \mathrm{~N}$ & $20 \mathrm{~N}$ \\
\hline MCH058 & $6^{\circ} 56^{\prime} 35^{\prime \prime}$ & $60^{\circ} 44^{\prime} 41^{\mu}$ & $0.1 \mathrm{~N}$ & 0.20 & 0.05 & $0.5 \mathrm{~N}$ & $0.5 \mathrm{~N}$ & $2 \mathrm{G}$ & $1 \mathrm{~N}$ & $500 \mathrm{~N}$ & $20 \mathrm{~N}$ & 300 & 150 & $2 \mathrm{~N}$ & $20 \mathrm{~N}$ & $50 \mathrm{~N}$ & $20 \mathrm{~N}$ \\
\hline МСH059 & $6^{\circ} 56^{\prime} 16^{\prime \prime}$ & $60^{\circ} 44^{\prime} 26^{n}$ & $0.1 \mathrm{~N}$ & 0.10 & $0.05 \mathrm{~L}$ & $0.5 \mathrm{~N}$ & $0.5 \mathrm{~L}$ & $2 \mathrm{G}$ & IN & $500 \mathrm{~N}$ & 100 & 70 & 150 & $2 \mathrm{~L}$ & $20 \mathrm{~N}$ & $50 \mathrm{~N}$ & $20 \mathrm{~N}$ \\
\hline МCH060 & $6^{\circ} 5718^{\prime \prime}$ & $60^{\circ} 45^{\prime} 00^{\prime \prime}$ & $0.1 \mathrm{~L}$ & 0.20 & $0.05 \mathrm{~L}$ & $0.5 \mathrm{~N}$ & $0.5 \mathrm{~N}$ & $2 \mathrm{G}$ & IN & $500 \mathrm{~N}$ & $20 \mathrm{~L}$ & 200 & 70 & 3 & $20 \mathrm{~N}$ & $50 \mathrm{~N}$ & $20 \mathrm{~N}$ \\
\hline MCH061 & $6^{\circ} 57^{\prime} 33^{\prime \prime}$ & $60^{\circ} 45^{\prime} 16^{\prime \prime}$ & $0.1 \mathrm{~N}$ & 0.70 & 0.07 & $0.5 \mathrm{~N}$ & $0.5 \mathrm{~N}$ & $2 \mathrm{G}$ & $1 \mathrm{~N}$ & $500 \mathrm{~N}$ & $20 \mathrm{~N}$ & $20 \mathrm{~N}$ & $50 \mathrm{~L}$ & $2 \mathrm{~N}$ & $20 \mathrm{~N}$ & $50 \mathrm{~N}$ & $20 \mathrm{~N}$ \\
\hline МСH062 & $6^{\circ} 57^{\prime} 01^{\prime \prime}$ & $60^{\circ} 44^{\prime} 18^{\mu}$ & $0.1 \mathrm{~N}$ & 0.10 & 0.07 & $0.5 \mathrm{~N}$ & $0.5 \mathrm{~N}$ & $2 \mathrm{G}$ & $1 \mathrm{~N}$ & $500 \mathrm{~N}$ & $20 \mathrm{~N}$ & 700 & 70 & 3 & $20 \mathrm{~N}$ & $50 \mathrm{~N}$ & $20 \mathrm{~N}$ \\
\hline МCH063 & $6^{\circ} 56^{\prime} 37^{\prime \prime}$ & $60^{\circ} 4357^{\prime \prime}$ & $0.1 \mathrm{~N}$ & 0.15 & 0.05 & $0.5 \mathrm{~N}$ & $0.5 \mathrm{~L}$ & $2 \mathrm{G}$ & 20 & $500 \mathrm{~N}$ & 1,000 & 100 & 300 & 2 & $20 \mathrm{~N}$ & $50 \mathrm{~N}$ & $20 \mathrm{~N}$ \\
\hline MCH064 & $6^{\circ} 57^{\prime} 30^{\prime \prime}$ & $60^{\circ} 42^{\prime} 55^{\prime \prime}$ & $0.1 \mathrm{~L}$ & $0.1 \mathrm{~L}$ & $0.05 \mathrm{~L}$ & $0.5 \mathrm{~N}$ & $0.5 \mathrm{~N}$ & $2 \mathrm{G}$ & $1 \mathrm{~N}$ & $500 \mathrm{~N}$ & $20 \mathrm{~N}$ & 150 & 50 & 3 & $20 \mathrm{~N}$ & $50 \mathrm{~N}$ & $20 \mathrm{~N}$ \\
\hline МСH065 & $6^{\circ} 57^{\prime} 18^{\prime \prime}$ & $60^{\circ} 44^{\prime} 30^{\prime \prime}$ & $0.1 \mathrm{~L}$ & 1 & $0.05 \mathrm{~L}$ & $0.5 \mathrm{~N}$ & $0.5 \mathrm{~N}$ & $2 \mathrm{G}$ & 20 & $500 \mathrm{~N}$ & 1,000 & 70 & $50 \mathrm{~L}$ & $2 \mathrm{~L}$ & $20 \mathrm{~N}$ & $50 \mathrm{~N}$ & $20 \mathrm{~N}$ \\
\hline МСНО66 & $6^{\circ} 57^{\prime} 05^{\prime \prime}$ & $60^{\circ} 43^{\prime} 58^{\prime \prime}$ & $0.1 \mathrm{~L}$ & 5 & 0.05 & $0.5 \mathrm{~N}$ & $0.5 \mathrm{~N}$ & $2 \mathrm{G}$ & $1 N$ & $500 \mathrm{~N}$ & 20 & 200 & 50 & 3 & $20 \mathrm{~N}$ & $50 \mathrm{~N}$ & $20 \mathrm{~N}$ \\
\hline MCH067 & $6^{\circ} 56^{\prime} 53^{\prime \prime}$ & $60^{\circ} 43^{\prime} 52^{\prime \prime}$ & $0.1 \mathrm{~N}$ & 0.20 & 0.07 & $0.5 \mathrm{~N}$ & $0.5 \mathrm{~L}$ & $2 \mathrm{G}$ & 10 & $500 \mathrm{~N}$ & 1,000 & 300 & 200 & 2 & $20 \mathrm{~N}$ & $50 \mathrm{~N}$ & $20 \mathrm{~N}$ \\
\hline МСH069 & $6^{\circ} 57^{\prime} 14^{H}$ & $60^{\circ} 43^{\prime} 5 \mathrm{~J}^{\prime \prime}$ & $0.1 \mathrm{~N}$ & 0.10 & 0.10 & $0.5 \mathrm{~N}$ & $0.5 \mathrm{~N}$ & $2 \mathrm{G}$ & $1 \mathrm{~N}$ & $500 \mathrm{~N}$ & $20 \mathrm{~N}$ & 700 & 70 & $2 \mathrm{~L}$ & $20 \mathrm{~N}$ & $50 \mathrm{~N}$ & $20 \mathrm{~N}$ \\
\hline МCH070 & $6^{\circ} 57^{\prime} 00^{\mu}$ & $60^{\circ} 43^{\prime} 37^{\prime \prime}$ & $0.1 \mathrm{~N}$ & $0.1 \mathrm{~L}$ & 0.07 & $0.5 \mathrm{~N}$ & $0.5 \mathrm{~N}$ & $2 \mathrm{G}$ & $1 \mathrm{~N}$ & $500 \mathrm{~N}$ & 500 & 1,000 & $50 \mathrm{~L}$ & 2 & $20 \mathrm{~N}$ & $50 \mathrm{~N}$ & $20 \mathrm{~N}$ \\
\hline МСH071 & $6^{\circ} 57^{\prime} 27^{\mathrm{m}}$ & $60^{\circ} 44^{\prime} 00^{\prime \prime}$ & $0.1 \mathrm{~L}$ & 0.70 & 0.05 & $0.5 \mathrm{~N}$ & $0.5 \mathrm{~N}$ & $2 \mathrm{G}$ & IN & $500 \mathrm{~N}$ & 20 & 100 & 50 & 3 & $20 \mathrm{~N}$ & $50 \mathrm{~N}$ & $20 \mathrm{~N}$ \\
\hline МCH072 & $6^{\circ} 58^{\prime} 20^{n}$ & $60^{\circ} 44^{\prime} 38^{\prime \prime}$ & $0.1 \mathrm{~L}$ & 1 & $0.05 \mathrm{~L}$ & $0.5 \mathrm{~N}$ & $0.5 \mathrm{~N}$ & $2 \mathrm{G}$ & $1 N$ & $500 \mathrm{~N}$ & $20 \mathrm{~L}$ & $20 \mathrm{~N}$ & $50 \mathrm{~L}$ & $2 \mathrm{~N}$ & $20 \mathrm{~N}$ & $50 \mathrm{~N}$ & $20 \mathrm{~N}$ \\
\hline MCH073 & $6^{\circ} 57^{\prime} 38^{n}$ & $60^{\circ} 43^{\prime} 48^{\prime \prime}$ & $0.1 \mathrm{~L}$ & 0.10 & $0.05 \mathrm{~L}$ & $0.5 \mathrm{~N}$ & $0.5 \mathrm{~L}$ & $2 G$ & $1 N$ & $500 \mathrm{~N}$ & $20 \mathrm{~N}$ & 70 & 70 & 2 & $20 \mathrm{~N}$ & $50 \mathrm{~N}$ & $20 \mathrm{~N}$ \\
\hline MOC013 & $7^{\circ} 01^{\prime} 48^{\prime \prime}$ & $60^{\circ} 40^{\prime} 53^{\prime \prime}$ & $0.1 \mathrm{~N}$ & 0.50 & $0.05 \mathrm{~L}$ & $0.5 N$ & $0.5 \mathrm{~N}$ & $2 \mathrm{G}$ & 70 & $500 \mathrm{~N}$ & $1,000 \mathrm{G}$ & 70 & 70 & $2 \mathrm{~N}$ & $20 \mathrm{~N}$ & $50 \mathrm{~N}$ & $20 \mathrm{~N}$ \\
\hline MW002C & $7^{\circ} 02^{\prime} 18^{\prime \prime}$ & $60^{\circ} 40^{\prime} 24^{\prime \prime}$ & $0.1 \mathrm{~L}$ & 0.20 & 0.05 & $0.5 \mathrm{~N}$ & $0.5 \mathrm{~N}$ & $2 \mathrm{G}$ & $1 \mathrm{~N}$ & $500 \mathrm{~N}$ & $20 \mathrm{~N}$ & 100 & 70 & $2 \mathrm{~N}$ & $20 \mathrm{~N}$ & $50 \mathrm{~N}$ & $20 \mathrm{~N}$ \\
\hline MW003C & $7^{\circ} 02^{\prime} 19^{\prime \prime}$ & $60^{\circ} 40^{\prime} 24^{\prime \prime}$ & $0.1 \mathrm{~L}$ & 0.15 & 0.05 & $0.5 \mathrm{~N}$ & $0.5 \mathrm{~N}$ & $2 \mathrm{G}$ & $1 \mathrm{~N}$ & $500 \mathrm{~N}$ & $20 N$ & 150 & 70 & $2 \mathrm{~N}$ & $20 \mathrm{~N}$ & $50 \mathrm{~N}$ & $20 \mathrm{~N}$ \\
\hline MW009C & $7^{\circ} 02^{\prime} 20^{\prime \prime}$ & $60^{\circ} 40^{\prime} 41^{\prime \prime}$ & $0.1 \mathrm{~L}$ & $0.1 \mathrm{~L}$ & $0.05 \mathrm{~L}$ & $0.5 \mathrm{~N}$ & $0.5 \mathrm{~N}$ & $2 \mathrm{G}$ & IN & $500 \mathrm{~N}$ & $20 \mathrm{~N}$ & 150 & 70 & $2 \mathbf{L}$ & $20 \mathrm{~N}$ & $50 \mathrm{~N}$ & $20 \mathrm{~N}$ \\
\hline MW010C & $7^{\circ} 01^{\prime} 49^{\prime \prime}$ & $60^{\circ} 40^{\prime} 38^{\prime \prime}$ & $0.1 \mathrm{~L}$ & $0.1 \mathrm{~L}$ & $0.05 \mathrm{~L}$ & $0.5 \mathrm{~N}$ & $0.5 \mathrm{~N}$ & $2 G$ & IN & $500 \mathrm{~N}$ & $20 \mathrm{~N}$ & 30 & 50 & $2 \mathrm{~N}$ & $20 \mathrm{~N}$ & $50 \mathrm{~N}$ & $20 \mathrm{~N}$ \\
\hline MW01 IC & $7^{\circ} 01^{\prime} 41^{\prime \prime}$ & $60^{\circ} 40^{\prime} 29^{\prime \prime}$ & $0.1 \mathrm{~L}$ & $0.1 \mathrm{~L}$ & $0.05 \mathrm{~L}$ & $0.5 \mathrm{~N}$ & $0.5 \mathrm{~N}$ & $2 \mathrm{G}$ & $1 N$ & $500 \mathrm{~N}$ & $20 \mathrm{~L}$ & 30 & $50 \mathrm{~L}$ & $2 \mathrm{~N}$ & $20 \mathrm{~N}$ & $50 \mathrm{~N}$ & $20 \mathrm{~N}$ \\
\hline MW012C & $7^{\circ} 01^{\prime} 03^{\prime \prime}$ & $60^{\circ} 40^{\prime} 48^{\prime \prime}$ & $0.1 \mathrm{~L}$ & $0.1 \mathrm{~L}$ & 0.05 & $0.5 \mathrm{~N}$ & $0.5 \mathrm{~N}$ & $2 \mathrm{G}$ & $1 N$ & $500 \mathrm{~N}$ & $20 \mathrm{~L}$ & 20 & $50 \mathrm{~L}$ & $2 \mathrm{~N}$ & $20 \mathrm{~N}$ & $50 \mathrm{~N}$ & $20 \mathrm{~N}$ \\
\hline MW013C & $7^{\circ} 01^{\prime} 01^{\prime \prime}$ & $60^{\circ} 40^{\prime} 47^{n}$ & $0.1 \mathrm{~L}$ & $0.1 \mathrm{~N}$ & $0.05 \mathrm{~L}$ & $0.5 \mathrm{~N}$ & $0.5 \mathrm{~N}$ & $2 \mathrm{G}$ & $1 \mathrm{~N}$ & $500 \mathrm{~N}$ & $20 \mathrm{~N}$ & 30 & $50 \mathrm{~L}$ & $2 \mathrm{~N}$ & $20 \mathrm{~N}$ & $50 \mathrm{~N}$ & $20 \mathrm{~N}$ \\
\hline
\end{tabular}


Appendix table 7. Heavy-mineral separates from stream concentrate samples, zone 4, Marwani concession, Venezuela—Continued.

\begin{tabular}{|c|c|c|c|c|c|c|c|c|c|c|c|c|c|c|c|c|c|}
\hline & $\mathrm{Cr}-\mathrm{S}$ & $\mathrm{Cu}-\mathrm{S}$ & Ga-S & Ge-S & La-S & Mn-S & Mo-S & $\mathrm{Nb}-\mathrm{S}$ & Ni-S & $\mathrm{Pb}-\mathrm{S}$ & $\mathrm{PdS}$ & Pt-S & Sb-S & Sc-S & $\mathrm{Sn}-\mathrm{S}$ & Sr-S & Th-S \\
\hline MOCO0S & 300 & $10 \mathrm{~N}$ & $10 \mathrm{~N}$ & $20 \mathrm{~N}$ & $100 \mathrm{~N}$ & $20 \mathrm{~L}$ & $10 \mathrm{~N}$ & 70 & $10 \mathrm{~N}$ & 20 & $5 \mathrm{~N}$ & $20 \mathrm{~N}$ & $200 \mathrm{~N}$ & 70 & $20 \mathrm{~N}$ & $200 \mathrm{~N}$ & $200 \mathrm{~N}$ \\
\hline MoCol1 & 1,000 & $10 \mathrm{~N}$ & $10 \mathrm{~N}$ & $20 \mathrm{~N}$ & $100 \mathrm{~N}$ & 20 & $10 \mathrm{~N}$ & 50 & 50 & 20 & $5 \mathrm{~N}$ & $20 \mathrm{~N}$ & $200 \mathrm{~N}$ & 70 & $20 \mathrm{~N}$ & $200 \mathrm{~N}$ & $200 \mathrm{~N}$ \\
\hline MoC012 & 500 & $10 \mathrm{~N}$ & $10 \mathrm{~N}$ & $20 \mathrm{~N}$ & $100 \mathrm{~N}$ & $20 \mathrm{~L}$ & $10 \mathrm{~N}$ & 50 & $10 \mathrm{~N}$ & 20 & $5 \mathrm{~N}$ & $20 \mathrm{~N}$ & $200 \mathrm{~N}$ & 70 & $20 \mathrm{~N}$ & $200 \mathrm{~N}$ & $200 \mathrm{~N}$ \\
\hline $\mathrm{M} 0 \mathrm{C} 017$ & 100 & $10 \mathrm{~N}$ & $10 \mathrm{~N}$ & $20 \mathrm{~N}$ & $100 \mathrm{~N}$ & 30 & $10 \mathrm{~N}$ & 100 & $10 \mathrm{~N}$ & 30 & $5 \mathrm{~N}$ & $20 N$ & $200 \mathrm{~N}$ & 50 & $20 N$ & $200 \mathrm{~N}$ & $200 \mathrm{~N}$ \\
\hline $\mathrm{MOCO} 20$ & 200 & $10 \mathrm{~N}$ & $10 \mathrm{~N}$ & $20 \mathrm{~N}$ & $100 \mathrm{~N}$ & 150 & $10 \mathrm{~N}$ & $50 \mathrm{~N}$ & $10 \mathrm{~N}$ & 20 & $5 \mathrm{~N}$ & $20 \mathrm{~N}$ & $200 \mathrm{~N}$ & 100 & $20 \mathrm{~N}$ & $200 \mathrm{~N}$ & $200 \mathrm{~N}$ \\
\hline $\mathrm{MOCO} 21$ & 700 & $10 \mathrm{~N}$ & $10 \mathrm{~N}$ & $20 \mathrm{~N}$ & $100 \mathrm{~N}$ & 100 & $10 \mathrm{~N}$ & $50 \mathrm{~N}$ & 20 & 20 & $5 \mathrm{~N}$ & $20 \mathrm{~N}$ & $200 \mathrm{~N}$ & 70 & $20 \mathrm{~N}$ & $200 \mathrm{~N}$ & $200 \mathrm{~N}$ \\
\hline $\mathrm{MOC} 038$ & 700 & $10 \mathrm{~N}$ & $10 \mathrm{~N}$ & $20 \mathrm{~N}$ & $100 \mathrm{~N}$ & 20 & $10 \mathrm{~N}$ & 70 & $10 \mathrm{~N}$ & 30 & $5 \mathrm{~N}$ & $20 \mathrm{~N}$ & $200 \mathrm{~N}$ & 70 & $20 \mathrm{~N}$ & $200 \mathrm{~N}$ & $200 \mathrm{~N}$ \\
\hline MoC039 & 500 & $10 \mathrm{~N}$ & $10 \mathrm{~N}$ & $20 \mathrm{~N}$ & $100 \mathrm{~N}$ & 20 & $10 \mathrm{~N}$ & 70 & $10 \mathrm{~N}$ & 20 & $5 \mathrm{~N}$ & $20 \mathrm{~N}$ & $200 \mathrm{~N}$ & 70 & $20 \mathrm{~N}$ & $200 \mathrm{~N}$ & $200 \mathrm{~N}$ \\
\hline MoC059 & 500 & $10 \mathrm{~N}$ & $10 \mathrm{~N}$ & $20 \mathrm{~N}$ & $100 \mathrm{~N}$ & $20 \mathrm{~L}$ & $10 \mathrm{~N}$ & 70 & $10 \mathrm{~N}$ & so & $5 \mathrm{~N}$ & $20 \mathrm{~N}$ & $200 \mathrm{~N}$ & 70 & $20 \mathrm{~N}$ & $200 \mathrm{~N}$ & $200 \mathrm{~N}$ \\
\hline MoC061 & 1,500 & $10 \mathrm{~N}$ & $10 \mathrm{~N}$ & $20 \mathrm{~N}$ & $100 \mathrm{~N}$ & 20 & $10 \mathrm{~N}$ & 50 & 20 & 20 & $5 \mathrm{~N}$ & $20 \mathrm{~N}$ & $200 \mathrm{~N}$ & 70 & $20 \mathrm{~N}$ & $200 \mathrm{~N}$ & $200 \mathrm{~N}$ \\
\hline MoC082 & 500 & $10 \mathrm{~N}$ & $10 \mathrm{~N}$ & $20 \mathrm{~N}$ & $100 \mathrm{~N}$ & 100 & $10 \mathrm{~N}$ & 70 & 20 & 20 & $5 \mathrm{~N}$ & $20 \mathrm{~N}$ & $200 \mathrm{~N}$ & 50 & $20 \mathrm{~N}$ & $200 \mathrm{~N}$ & $200 \mathrm{~N}$ \\
\hline MoC086 & 500 & $10 \mathrm{~N}$ & $10 \mathrm{~N}$ & $20 \mathrm{~N}$ & $100 \mathrm{~N}$ & 20 & $10 \mathrm{~N}$ & 70 & $10 \mathrm{~N}$ & $20 \mathrm{~L}$ & $5 \mathrm{~N}$ & $20 \mathrm{~N}$ & $200 \mathrm{~N}$ & 70 & $20 \mathrm{~N}$ & $200 \mathrm{~N}$ & $200 \mathrm{~N}$ \\
\hline M0C087 & 500 & $10 \mathrm{~N}$ & $10 \mathrm{~N}$ & $20 \mathrm{~N}$ & $100 \mathrm{~N}$ & $20 \mathrm{~L}$ & $10 \mathrm{~N}$ & 100 & $10 \mathrm{~N}$ & 30 & $5 \mathrm{~N}$ & $20 \mathrm{~N}$ & $200 \mathrm{~N}$ & 30 & $20 \mathrm{~N}$ & $200 \mathrm{~N}$ & $200 \mathrm{~N}$ \\
\hline MoC088 & 200 & $10 \mathrm{~L}$ & $10 \mathrm{~N}$ & $20 \mathrm{~N}$ & $100 \mathrm{~N}$ & $20 \mathrm{~L}$ & $10 \mathrm{~N}$ & 100 & $10 \mathrm{~N}$ & 30 & $5 \mathrm{~N}$ & $20 \mathrm{~N}$ & $200 \mathrm{~N}$ & 70 & $20 \mathrm{~N}$ & $200 \mathrm{~N}$ & $200 \mathrm{~N}$ \\
\hline M0C090 & 200 & $10 \mathrm{~N}$ & $10 \mathrm{~N}$ & $20 \mathrm{~N}$ & $100 \mathrm{~N}$ & 30 & $10 \mathrm{~N}$ & 70 & $10 \mathrm{~N}$ & so & $5 \mathrm{~N}$ & $20 \mathrm{~N}$ & $200 \mathrm{~N}$ & 30 & $20 \mathrm{~N}$ & $200 \mathrm{~N}$ & $200 \mathrm{~N}$ \\
\hline MoC097 & 500 & $10 \mathrm{~N}$ & $10 \mathrm{~N}$ & $20 \mathrm{~N}$ & $100 \mathrm{~N}$ & $20 \mathrm{~L}$ & $10 \mathrm{~N}$ & 70 & $10 \mathrm{~N}$ & $20 \mathrm{~L}$ & $5 \mathrm{~N}$ & $20 \mathrm{~N}$ & $200 \mathrm{~N}$ & 70 & $20 N$ & $200 \mathrm{~N}$ & $200 \mathrm{~N}$ \\
\hline $\mathrm{M} 0 \mathrm{C} 100$ & 300 & $10 \mathrm{~N}$ & $10 \mathrm{~N}$ & $20 \mathrm{~N}$ & $100 \mathrm{~N}$ & $20 \mathrm{~L}$ & $10 N$ & 70 & $10 \mathrm{~N}$ & 50 & $5 \mathrm{~N}$ & $20 \mathrm{~N}$ & $200 \mathrm{~N}$ & 70 & $20 \mathrm{~N}$ & $200 \mathrm{~N}$ & $200 \mathrm{~N}$ \\
\hline M0C105A & 300 & $10 \mathrm{~N}$ & $10 N$ & $20 \mathrm{~N}$ & $100 \mathrm{~N}$ & $20 \mathrm{~L}$ & $10 \mathrm{~N}$ & 70 & $10 \mathrm{~N}$ & 50 & $5 \mathrm{~N}$ & $20 \mathrm{~N}$ & $200 \mathrm{~N}$ & 50 & $20 \mathrm{~N}$ & $200 \mathrm{~N}$ & $200 \mathrm{~N}$ \\
\hline M0C109 & 500 & $10 \mathrm{~N}$ & $10 \mathrm{~N}$ & $20 \mathrm{~N}$ & $100 \mathrm{~N}$ & 20 & $10 \mathrm{~N}$ & 50 & $10 \mathrm{~N}$ & $20 \mathrm{~L}$ & $5 \mathrm{~N}$ & $20 \mathrm{~N}$ & $200 \mathrm{~N}$ & 50 & $20 \mathrm{~N}$ & $200 \mathrm{~N}$ & $200 \mathrm{~N}$ \\
\hline MCHOOI & 200 & $10 \mathrm{~N}$ & $10 \mathrm{~N}$ & $20 \mathrm{~N}$ & $100 \mathrm{~N}$ & 20 & $10 \mathrm{~N}$ & 100 & $10 \mathrm{~N}$ & 30 & $5 \mathrm{~N}$ & $20 \mathrm{~N}$ & $200 \mathrm{~N}$ & 30 & $20 \mathrm{~N}$ & $200 \mathrm{~N}$ & $200 \mathrm{~N}$ \\
\hline MCHOO3 & 500 & $10 \mathrm{~N}$ & $10 \mathrm{~N}$ & $20 \mathrm{~N}$ & $100 \mathrm{~N}$ & $20 \mathrm{~L}$ & $10 \mathrm{~N}$ & 70 & $10 \mathrm{~N}$ & $20 \mathrm{~L}$ & $5 \mathrm{~N}$ & $20 \mathrm{~N}$ & $200 \mathrm{~N}$ & 50 & $20 \mathrm{~N}$ & $200 \mathrm{~N}$ & $200 \mathrm{~N}$ \\
\hline MCHOO4 & 500 & $10 \mathrm{~L}$ & $10 \mathrm{~N}$ & $20 \mathrm{~N}$ & $100 \mathrm{~N}$ & $20 \mathrm{~L}$ & $10 \mathrm{~N}$ & 70 & $10 \mathrm{~N}$ & $20 \mathrm{~L}$ & $5 \mathrm{~N}$ & $20 \mathrm{~N}$ & $200 \mathrm{~N}$ & 50 & $20 \mathrm{~N}$ & $200 \mathrm{~N}$ & $200 \mathrm{~N}$ \\
\hline MCH005 & 500 & $10 \mathrm{~N}$ & $10 \mathrm{~N}$ & $20 \mathrm{~N}$ & $100 \mathrm{~N}$ & $20 \mathrm{~L}$ & $10 \mathrm{~N}$ & 70 & $10 \mathrm{~N}$ & 20 & $5 \mathrm{~N}$ & $20 \mathrm{~N}$ & $200 \mathrm{~N}$ & 20 & $20 \mathrm{~L}$ & $200 \mathrm{~N}$ & $200 \mathrm{~N}$ \\
\hline MCH006 & 300 & $10 \mathrm{~N}$ & $10 \mathrm{~N}$ & $20 \mathrm{~N}$ & $100 \mathrm{~N}$ & 30 & $10 N$ & 50 & $10 \mathrm{~N}$ & 30 & $5 \mathrm{~N}$ & $20 \mathrm{~N}$ & $200 \mathrm{~N}$ & 50 & 200 & $200 \mathrm{~N}$ & $200 \mathrm{~N}$ \\
\hline $\mathrm{MCH} 007$ & 70 & $10 \mathrm{~N}$ & $10 \mathrm{~N}$ & $20 \mathrm{~N}$ & $100 \mathrm{~N}$ & 30 & $10 N$ & 70 & $10 \mathrm{~N}$ & 30 & $5 \mathrm{~N}$ & $20 \mathrm{~N}$ & $200 \mathrm{~N}$ & 30 & $20 \mathrm{~N}$ & $200 \mathrm{~N}$ & $200 \mathrm{~N}$ \\
\hline MCH008 & 100 & $10 \mathrm{~N}$ & $10 \mathrm{~N}$ & $20 \mathrm{~N}$ & $100 \mathrm{~N}$ & 30 & $10 \mathrm{~N}$ & 70 & $10 \mathrm{~N}$ & 50 & $5 \mathrm{~N}$ & $20 \mathrm{~N}$ & $200 \mathrm{~N}$ & 70 & 70 & $200 \mathrm{~N}$ & $200 \mathrm{~N}$ \\
\hline MCHOLO & 1,500 & $10 \mathrm{~N}$ & $10 \mathrm{~N}$ & $20 \mathrm{~N}$ & $100 \mathrm{~N}$ & 20 & $10 N$ & $50 \mathrm{~L}$ & 20 & 30 & $5 \mathrm{~N}$ & $20 \mathrm{~N}$ & $200 \mathrm{~N}$ & 70 & 30 & $200 \mathrm{~N}$ & $200 \mathrm{~N}$ \\
\hline MCH011 & 300 & $10 \mathrm{~N}$ & $10 \mathrm{~N}$ & $20 \mathrm{~N}$ & $100 \mathrm{~N}$ & 30 & $10 N$ & 100 & $10 \mathrm{~N}$ & 30 & $5 \mathrm{~N}$ & $20 \mathrm{~N}$ & $200 \mathrm{~N}$ & 50 & 50 & $200 \mathrm{~N}$ & $200 \mathrm{~N}$ \\
\hline $\mathrm{MCH} 012$ & 500 & $10 \mathrm{~L}$ & $10 N$ & $20 \mathrm{~N}$ & $100 \mathrm{~N}$ & 30 & $10 \mathrm{~N}$ & 70 & 20 & 30 & $5 \mathrm{~N}$ & $20 \mathrm{~N}$ & $200 \mathrm{~N}$ & 70 & 200 & $200 \mathrm{~N}$ & $200 \mathrm{~N}$ \\
\hline $\mathrm{MCH} 013$ & 200 & $10 \mathrm{~N}$ & $10 \mathrm{~N}$ & $20 \mathrm{~N}$ & $100 \mathrm{~N}$ & $20 \mathrm{~L}$ & $10 \mathrm{~N}$ & 100 & $10 \mathrm{~N}$ & 50 & $5 \mathrm{~N}$ & $20 \mathrm{~N}$ & $200 \mathrm{~N}$ & 30 & 100 & $200 \mathrm{~N}$ & $200 \mathrm{~N}$ \\
\hline $\mathrm{MCH} 014$ & 300 & 15 & $10 \mathrm{~N}$ & $20 \mathrm{~N}$ & $100 \mathrm{~N}$ & 50 & $10 \mathrm{~N}$ & 70 & $10 \mathrm{~L}$ & 70 & $5 \mathrm{~N}$ & $20 \mathrm{~N}$ & $200 \mathrm{~N}$ & 70 & 1,500 & $200 \mathrm{~N}$ & $200 \mathrm{~N}$ \\
\hline MCH015 & 500 & 20 & $10 \mathrm{~N}$ & $20 \mathrm{~N}$ & $100 \mathrm{~N}$ & 100 & $10 \mathrm{~N}$ & $50 \mathrm{~L}$ & 20 & $20 \mathrm{~L}$ & $5 \mathrm{~N}$ & $20 \mathrm{~N}$ & $200 \mathrm{~N}$ & 100 & 150 & $200 \mathrm{~N}$ & $200 \mathrm{~N}$ \\
\hline MCH016 & 200 & 15 & $10 \mathrm{~N}$ & $20 \mathrm{~N}$ & $100 \mathrm{~N}$ & $20 \mathrm{~L}$ & $10 \mathrm{~N}$ & 200 & $10 \mathrm{~N}$ & 20 & $5 \mathrm{~N}$ & $20 \mathrm{~N}$ & $200 \mathrm{~N}$ & 70 & 20 & $200 \mathrm{~N}$ & $200 \mathrm{~N}$ \\
\hline MCH018 & 300 & $10 \mathrm{~N}$ & $10 N$ & $20 \mathrm{~N}$ & $100 \mathrm{~N}$ & 30 & $10 N$ & 70 & $10 \mathrm{~N}$ & 20 & $5 \mathrm{~N}$ & $20 \mathrm{~N}$ & $200 \mathrm{~N}$ & 50 & $20 \mathrm{~N}$ & $200 \mathrm{~N}$ & $200 \mathrm{~N}$ \\
\hline $\mathrm{MCH} 022$ & 300 & 20 & $10 \mathrm{~N}$ & $20 \mathrm{~N}$ & $100 \mathrm{~N}$ & 20 & $10 \mathrm{~N}$ & 200 & 30 & $20 \mathrm{~L}$ & $5 \mathrm{~N}$ & $20 \mathrm{~N}$ & $200 \mathrm{~N}$ & 100 & $20 \mathrm{~L}$ & $200 \mathrm{~N}$ & $200 \mathrm{~N}$ \\
\hline $\mathrm{MCH} 024$ & 700 & 30 & $10 \mathrm{~N}$ & $20 \mathrm{~N}$ & $100 \mathrm{~N}$ & 50 & $10 \mathrm{~N}$ & 70 & 70 & 30 & $5 \mathrm{~N}$ & $20 \mathrm{~N}$ & $200 \mathrm{~N}$ & 70 & 700 & $200 \mathrm{~N}$ & $200 \mathrm{~N}$ \\
\hline $\mathrm{MCH} 025$ & 300 & 30 & IOL & $20 \mathrm{~N}$ & $100 \mathrm{~N}$ & 50 & $10 \mathrm{~N}$ & 150 & 50 & 50 & $5 \mathrm{~N}$ & $20 \mathrm{~N}$ & $200 \mathrm{~N}$ & 100 & 1,000 & $200 \mathrm{~N}$ & $200 \mathrm{~N}$ \\
\hline $\mathrm{MCH} 026$ & 300 & $10 N$ & $10 \mathrm{~N}$ & $20 \mathrm{~N}$ & $100 \mathrm{~N}$ & $20 \mathrm{~L}$ & $10 \mathrm{~N}$ & 150 & 50 & 30 & $5 \mathrm{~N}$ & $20 \mathrm{~N}$ & $200 \mathrm{~N}$ & 70 & 30 & $200 \mathrm{~N}$ & $200 \mathrm{~N}$ \\
\hline МCH027 & 1,000 & 15 & $10 \mathrm{~N}$ & $20 \mathrm{~N}$ & $100 \mathrm{~N}$ & 20 & $10 \mathrm{~N}$ & 100 & 50 & $20 \mathrm{~L}$ & $5 \mathrm{~N}$ & $20 \mathrm{~N}$ & $200 \mathrm{~N}$ & 70 & 70 & $200 \mathrm{~N}$ & $200 \mathrm{~N}$ \\
\hline MCH028 & 300 & $10 \mathrm{~N}$ & $10 \mathrm{~N}$ & $20 \mathrm{~N}$ & $100 \mathrm{~N}$ & So & $10 \mathrm{~N}$ & 300 & 10 & 30 & $5 \mathrm{~N}$ & $20 \mathrm{~N}$ & $200 \mathrm{~N}$ & 100 & 150 & $200 \mathrm{~N}$ & $200 \mathrm{~N}$ \\
\hline $\mathrm{MCH} 029$ & 300 & 15 & $10 \mathrm{~N}$ & $20 \mathrm{~N}$ & $100 \mathrm{~N}$ & 70 & $10 \mathrm{~N}$ & 70 & 10 & 30 & $5 \mathrm{~N}$ & $20 \mathrm{~N}$ & $200 \mathrm{~N}$ & 150 & 500 & $200 \mathrm{~N}$ & $200 \mathrm{~N}$ \\
\hline MCH030 & 700 & 15 & $10 \mathrm{~N}$ & $20 \mathrm{~N}$ & $100 \mathrm{~N}$ & $20 \mathrm{~L}$ & $10 \mathrm{~N}$ & 100 & 10 & 30 & $5 \mathrm{~N}$ & $20 \mathrm{~N}$ & $200 \mathrm{~N}$ & 100 & $20 \mathrm{~N}$ & $200 \mathrm{~N}$ & $200 \mathrm{~N}$ \\
\hline MCH032 & 500 & 15 & $10 \mathrm{~N}$ & $20 \mathrm{~N}$ & $100 \mathrm{~N}$ & $20 \mathrm{~L}$ & $10 \mathrm{~N}$ & 150 & ION & 30 & $5 \mathrm{~N}$ & $20 \mathrm{~N}$ & $200 \mathrm{~N}$ & 150 & 100 & $200 \mathrm{~N}$ & $200 \mathrm{~N}$ \\
\hline MCH033 & 500 & $10 \mathrm{~N}$ & $10 \mathrm{~N}$ & $20 \mathrm{~N}$ & $100 \mathrm{~N}$ & 20 & $10 \mathrm{~N}$ & 200 & 15 & 30 & $5 \mathrm{~N}$ & $20 \mathrm{~N}$ & $200 \mathrm{~N}$ & 100 & $20 \mathrm{~L}$ & $200 \mathrm{~N}$ & $200 \mathrm{~N}$ \\
\hline MCH035 & 300 & 15 & $10 \mathrm{~N}$ & $20 \mathrm{~N}$ & $100 \mathrm{~N}$ & 30 & $10 N$ & 100 & 10 & 30 & $5 \mathrm{~N}$ & $20 N$ & $200 \mathrm{~N}$ & 100 & 700 & $200 \mathrm{~N}$ & $200 \mathrm{~N}$ \\
\hline MCH036 & 700 & 10 & $10 \mathrm{~N}$ & $20 \mathrm{~N}$ & $100 \mathrm{~N}$ & 100 & $10 \mathrm{~N}$ & 100 & 15 & 30 & $5 \mathrm{~N}$ & $20 N$ & $200 \mathrm{~N}$ & 150 & $20 \mathrm{~N}$ & $200 \mathrm{~N}$ & $200 \mathrm{~N}$ \\
\hline MCH037 & 500 & ION & $10 \mathrm{~N}$ & $20 \mathrm{~N}$ & $100 \mathrm{~N}$ & $20 \mathrm{~L}$ & $10 \mathrm{~N}$ & 100 & $10 N$ & 20 & $5 \mathrm{~N}$ & $20 \mathrm{~N}$ & $200 \mathrm{~N}$ & 100 & 30 & $200 \mathrm{~N}$ & $200 \mathrm{~N}$ \\
\hline МCH038 & 300 & $10 \mathrm{~N}$ & $10 \mathrm{~N}$ & $20 \mathrm{~N}$ & $100 \mathrm{~N}$ & 20 & $10 \mathrm{~N}$ & $50 \mathrm{~L}$ & $10 N$ & 20 & $5 \mathrm{~N}$ & $20 \mathrm{~N}$ & $200 \mathrm{~N}$ & 100 & $20 \mathrm{~N}$ & $200 \mathrm{~N}$ & $200 \mathrm{~N}$ \\
\hline МCH039 & 2,000 & $10 \mathrm{~L}$ & $10 \mathrm{~N}$ & $20 \mathrm{~N}$ & $100 \mathrm{~N}$ & 20 & $10 \mathrm{~N}$ & 100 & 30 & $20 \mathrm{~L}$ & $5 \mathrm{~N}$ & $20 \mathrm{~N}$ & $200 \mathrm{~N}$ & 100 & 200 & $200 \mathrm{~N}$ & $200 \mathrm{~N}$ \\
\hline
\end{tabular}




\begin{tabular}{|c|c|c|c|c|c|c|c|c|c|c|c|c|c|c|c|c|c|}
\hline $\mathrm{MCH} 040$ & 2,000 & 10 & $10 \mathrm{~N}$ & $20 \mathrm{~N}$ & $100 \mathrm{~N}$ & 20 & $10 \mathrm{~N}$ & 150 & 20 & 20 & $5 \mathrm{~N}$ & $20 \mathrm{~N}$ & $200 \mathrm{~N}$ & 150 & 150 & $200 \mathrm{~N}$ & $200 \mathrm{~N}$ \\
\hline MCH042 & 500 & 10 & $10 \mathrm{~N}$ & $20 \mathrm{~N}$ & $100 \mathrm{~N}$ & 20 & $10 \mathrm{~N}$ & 70 & $10 \mathrm{~L}$ & 20 & $5 \mathrm{~N}$ & $20 \mathrm{~N}$ & $200 \mathrm{~N}$ & 200 & 150 & $200 \mathrm{~N}$ & $200 \mathrm{~N}$ \\
\hline $\mathrm{MCH043}$ & B & B & B & B & B & $\mathbf{B}$ & B & B & B & B & B & B & B & $\mathrm{B}$ & B & B & B \\
\hline МCH044 & 1,000 & $10 \mathrm{~N}$ & $10 \mathrm{~N}$ & $20 \mathrm{~N}$ & $100 \mathrm{~N}$ & 50 & $10 N$ & 100 & 15 & 20 & $5 \mathrm{~N}$ & $20 \mathrm{~N}$ & $200 \mathrm{~N}$ & 200 & 150 & $200 \mathrm{~N}$ & $200 \mathrm{~N}$ \\
\hline MCH045 & 1,500 & 10 & $10 \mathrm{~L}$ & $20 N$ & $100 \mathrm{~N}$ & 100 & $10 \mathrm{~N}$ & 150 & 30 & 50 & $5 \mathrm{~N}$ & $20 \mathrm{~N}$ & $200 \mathrm{~N}$ & 200 & 200 & $200 \mathrm{~N}$ & $200 \mathrm{~N}$ \\
\hline MCH047 & 700 & $10 \mathrm{~N}$ & $10 \mathrm{~N}$ & $20 N$ & $100 \mathrm{~N}$ & 500 & $10 \mathrm{~N}$ & 150 & 20 & 50 & $5 \mathrm{~N}$ & $20 N$ & $200 \mathrm{~N}$ & 200 & 300 & $200 \mathrm{~N}$ & $200 \mathrm{~N}$ \\
\hline MCH048 & 500 & 20 & $10 \mathrm{~N}$ & $20 \mathrm{~N}$ & $100 \mathrm{~N}$ & $20 \mathrm{~L}$ & $10 \mathrm{~N}$ & 100 & 10 & 50 & $5 \mathrm{~N}$ & $20 N$ & $200 \mathrm{~N}$ & 150 & 500 & $200 \mathrm{~N}$ & $200 \mathrm{~N}$ \\
\hline MCHO49 & 1,500 & $10 \mathrm{~N}$ & $10 \mathrm{~N}$ & $20 \mathrm{~N}$ & $100 \mathrm{~N}$ & 50 & $10 \mathrm{~N}$ & 70 & $10 \mathrm{~N}$ & 20 & $5 \mathrm{~N}$ & $20 \mathrm{~N}$ & $200 \mathrm{~N}$ & 100 & $20 \mathrm{~N}$ & $200 \mathrm{~N}$ & $200 \mathrm{~N}$ \\
\hline MCHOSO & 1,000 & 20 & $10 \mathrm{~N}$ & $20 \mathrm{~N}$ & $100 \mathrm{~N}$ & $20 \mathrm{~L}$ & $10 \mathrm{~N}$ & 150 & $10 \mathrm{~N}$ & $20 \mathrm{~L}$ & $5 \mathrm{~N}$ & $20 \mathrm{~N}$ & $200 \mathrm{~N}$ & 200 & 150 & $200 \mathrm{~N}$ & $200 \mathrm{~N}$ \\
\hline MCHOS1 & 700 & 15 & $10 \mathrm{~N}$ & $20 \mathrm{~N}$ & $100 \mathrm{~N}$ & 200 & $10 \mathrm{~N}$ & 150 & 15 & 15 & $5 \mathrm{~N}$ & $20 \mathrm{~N}$ & $200 \mathrm{~N}$ & 200 & 200 & $200 \mathrm{~N}$ & $200 \mathrm{~N}$ \\
\hline $\mathrm{MCH} 052$ & 1,000 & $10 \mathrm{~N}$ & $10 \mathrm{~N}$ & $20 \mathrm{~N}$ & $100 \mathrm{~N}$ & $20 \mathrm{~L}$ & $10 \mathrm{~N}$ & 100 & $10 \mathrm{~L}$ & 50 & $5 \mathrm{~N}$ & $20 \mathrm{~N}$ & $200 \mathrm{~N}$ & 100 & 70 & $200 \mathrm{~N}$ & $200 \mathrm{~N}$ \\
\hline $\mathrm{MCH} 053$ & 1,000 & $10 \mathrm{~N}$ & $10 \mathrm{~N}$ & $20 \mathrm{~N}$ & $100 \mathrm{~N}$ & 30 & $10 \mathrm{~N}$ & 50 & $10 \mathrm{~N}$ & 50 & $5 \mathrm{~N}$ & $20 \mathrm{~N}$ & $200 \mathrm{~N}$ & 100 & $20 \mathrm{~N}$ & $200 \mathrm{~N}$ & $200 \mathrm{~N}$ \\
\hline $\mathrm{MCH} 055$ & 700 & 50 & $10 \mathrm{~N}$ & $20 \mathrm{~N}$ & $100 \mathrm{~N}$ & 500 & $10 \mathrm{~N}$ & 100 & 15 & 50 & $5 \mathrm{~N}$ & $20 \mathrm{~N}$ & $200 \mathrm{~N}$ & 150 & 1,500 & $200 \mathrm{~N}$ & $200 \mathrm{~N}$ \\
\hline MCH056 & 500 & 30 & $10 \mathrm{~N}$ & $20 \mathrm{~N}$ & $100 \mathrm{~N}$ & 200 & $10 \mathrm{~N}$ & 150 & 20 & 50 & $5 \mathrm{~N}$ & $20 \mathrm{~N}$ & $200 \mathrm{~N}$ & 200 & 150 & $200 \mathrm{~N}$ & $200 \mathrm{~N}$ \\
\hline MCH057 & 700 & 20 & $10 \mathrm{~N}$ & $20 \mathrm{~N}$ & $100 \mathrm{~N}$ & $20 \mathrm{~L}$ & $10 \mathrm{~N}$ & 70 & 10 & 50 & $5 \mathrm{~N}$ & $20 \mathrm{~N}$ & $200 \mathrm{~N}$ & 100 & 100 & $200 \mathrm{~N}$ & $200 \mathrm{~N}$ \\
\hline MCH0S8 & 1,000 & $10 \mathrm{~L}$ & $10 \mathrm{~N}$ & $20 \mathrm{~N}$ & $100 \mathrm{~N}$ & $20 \mathrm{~L}$ & $10 \mathrm{~N}$ & 150 & 15 & 50 & $5 \mathrm{~N}$ & $20 \mathrm{~N}$ & $200 \mathrm{~N}$ & 70 & 150 & $200 \mathrm{~N}$ & $200 \mathrm{~N}$ \\
\hline MCH059 & 500 & $10 \mathrm{~N}$ & $10 \mathrm{~L}$ & $20 \mathrm{~N}$ & $100 \mathrm{~N}$ & $20 \mathrm{~L}$ & $10 N$ & 70 & $10 \mathrm{~N}$ & 50 & $5 \mathrm{~N}$ & $20 \mathrm{~N}$ & $200 \mathrm{~N}$ & 100 & $20 \mathrm{~N}$ & $200 \mathrm{~N}$ & $200 \mathrm{~N}$ \\
\hline MCH060 & 500 & $10 \mathrm{~N}$ & $10 \mathrm{~N}$ & $20 \mathrm{~N}$ & $100 \mathrm{~N}$ & 300 & $10 \mathrm{~N}$ & 200 & $10 \mathrm{~L}$ & 50 & $5 \mathrm{~N}$ & $20 \mathrm{~N}$ & $200 \mathrm{~N}$ & 150 & 300 & $200 \mathrm{~N}$ & $200 \mathrm{~N}$ \\
\hline MCH061 & 500 & $10 \mathrm{~L}$ & $10 \mathrm{~N}$ & $20 \mathrm{~N}$ & $100 \mathrm{~N}$ & 150 & $10 N$ & 150 & 20 & 30 & $5 \mathrm{~N}$ & $20 \mathrm{~N}$ & $200 \mathrm{~N}$ & 150 & 1,000 & $200 \mathrm{~N}$ & $200 \mathrm{~N}$ \\
\hline $\mathrm{MCH} 062$ & 700 & $10 \mathrm{~N}$ & $10 \mathrm{~N}$ & $20 \mathrm{~N}$ & $100 \mathrm{~N}$ & $20 \mathrm{~L}$ & $10 \mathrm{~N}$ & 150 & 15 & 50 & $5 \mathrm{~N}$ & $20 \mathrm{~N}$ & $200 \mathrm{~N}$ & 100 & 200 & $200 \mathrm{~N}$ & $200 \mathrm{~N}$ \\
\hline MCH063 & 500 & $10 \mathrm{~N}$ & $10 \mathrm{~N}$ & $20 \mathrm{~N}$ & $100 \mathrm{~N}$ & $20 \mathrm{~L}$ & $10 \mathrm{~N}$ & 70 & $10 N$ & 70 & $5 \mathrm{~N}$ & $20 \mathrm{~N}$ & $200 \mathrm{~N}$ & 70 & $20 \mathrm{~N}$ & $200 \mathrm{~N}$ & $200 \mathrm{~N}$ \\
\hline MCH064 & 500 & $10 \mathrm{~N}$ & $10 \mathrm{~N}$ & $20 \mathrm{~N}$ & $100 \mathrm{~N}$ & $20 \mathrm{~L}$ & $10 \mathrm{~N}$ & 150 & $10 \mathrm{~L}$ & 30 & $5 \mathrm{~N}$ & $20 \mathrm{~N}$ & $200 \mathrm{~N}$ & 200 & 700 & $200 \mathrm{~N}$ & $200 \mathrm{~N}$ \\
\hline MCH065 & 500 & $10 \mathrm{~L}$ & $10 \mathrm{~N}$ & $20 \mathrm{~N}$ & $100 \mathrm{~N}$ & 300 & $10 N$ & 100 & 20 & 50 & $5 \mathrm{~N}$ & $20 \mathrm{~N}$ & $200 \mathrm{~N}$ & 200 & 1,500 & $200 \mathrm{~N}$ & $200 \mathrm{~N}$ \\
\hline МСH066 & 700 & $10 \mathrm{~N}$ & $10 \mathrm{~N}$ & $20 \mathrm{~N}$ & $100 \mathrm{~N}$ & 70 & $10 \mathrm{~N}$ & 150 & 30 & 30 & $5 \mathrm{~N}$ & $20 \mathrm{~N}$ & $200 \mathrm{~N}$ & 200 & 300 & $200 \mathrm{~N}$ & $200 \mathrm{~N}$ \\
\hline МCH067 & 700 & $10 \mathrm{~L}$ & $10 \mathrm{~L}$ & $20 \mathrm{~N}$ & $100 \mathrm{~N}$ & 20 & $10 \mathrm{~N}$ & 50 & $10 \mathrm{~N}$ & 70 & $5 \mathrm{~N}$ & $20 \mathrm{~N}$ & $200 \mathrm{~N}$ & 100 & $20 \mathrm{~N}$ & $200 \mathrm{~N}$ & $200 \mathrm{~N}$ \\
\hline MCH069 & 1,000 & $10 \mathrm{~N}$ & $10 \mathrm{~N}$ & $20 \mathrm{~N}$ & $100 \mathrm{~N}$ & $20 \mathrm{~L}$ & $10 \mathrm{~N}$ & 70 & $10 N$ & 30 & $5 \mathrm{~N}$ & $20 \mathrm{~N}$ & $200 \mathrm{~N}$ & 100 & $20 \mathrm{~N}$ & $200 \mathrm{~N}$ & $200 \mathrm{~N}$ \\
\hline MCH070 & 1,000 & $10 \mathrm{~N}$ & $10 \mathrm{~N}$ & $20 \mathrm{~N}$ & $100 \mathrm{~N}$ & $20 \mathrm{~L}$ & $10 N$ & 150 & 10 & 50 & $5 \mathrm{~N}$ & $20 \mathrm{~N}$ & $200 \mathrm{~N}$ & 150 & 70 & $200 \mathrm{~N}$ & $200 \mathrm{~N}$ \\
\hline МCH071 & 500 & $10 \mathrm{~N}$ & $10 \mathrm{~N}$ & $20 \mathrm{~N}$ & $100 \mathrm{~N}$ & 150 & $10 \mathrm{~N}$ & 150 & 30 & 50 & $5 \mathrm{~N}$ & $20 \mathrm{~N}$ & $200 \mathrm{~N}$ & 200 & 150 & $200 \mathrm{~N}$ & $200 \mathrm{~N}$ \\
\hline MCH072 & 700 & 15 & $10 \mathrm{~N}$ & $20 N$ & $100 \mathrm{~N}$ & 300 & $10 \mathrm{~N}$ & 150 & 30 & 50 & $5 \mathrm{~N}$ & $20 \mathrm{~N}$ & $200 \mathrm{~N}$ & 150 & 1,500 & $200 \mathrm{~N}$ & $200 \mathrm{~N}$ \\
\hline MCH073 & 500 & $10 \mathrm{~N}$ & $10 \mathrm{~N}$ & $20 \mathrm{~N}$ & $100 \mathrm{~N}$ & 20 & $10 N$ & 70 & $10 \mathrm{~N}$ & 20 & $5 \mathrm{~N}$ & $20 \mathrm{~N}$ & $200 \mathrm{~N}$ & 200 & $20 \mathrm{~N}$ & $200 \mathrm{~N}$ & $200 \mathrm{~N}$ \\
\hline $\mathrm{MOC} 013$ & 500 & $10 \mathrm{~N}$ & $10 \mathrm{~N}$ & $20 \mathrm{~N}$ & $100 \mathrm{~N}$ & 30 & $10 N$ & 70 & 20 & 20 & $5 \mathrm{~N}$ & $20 \mathrm{~N}$ & $200 \mathrm{~N}$ & 100 & 30 & $200 \mathrm{~N}$ & $200 \mathrm{~N}$ \\
\hline MW002C & 50 & $10 \mathrm{~N}$ & $10 \mathrm{~N}$ & $20 \mathrm{~N}$ & $100 \mathrm{~N}$ & 70 & $10 N$ & 200 & 20 & 20 & $5 \mathrm{~N}$ & $20 \mathrm{~N}$ & $200 \mathrm{~N}$ & 70 & $20 \mathrm{~N}$ & $200 \mathrm{~N}$ & $200 \mathrm{~N}$ \\
\hline MW003C & 150 & $10 \mathrm{~N}$ & $10 \mathrm{~N}$ & $20 \mathrm{~N}$ & $100 \mathrm{~N}$ & 50 & $10 \mathrm{~N}$ & 150 & 30 & $20 \mathrm{~L}$ & $5 \mathrm{~N}$ & $20 \mathrm{~N}$ & $200 \mathrm{~N}$ & 70 & $20 \mathrm{~N}$ & $200 \mathrm{~N}$ & $200 \mathrm{~N}$ \\
\hline MW009C & 50 & $10 \mathrm{~N}$ & $10 \mathrm{~N}$ & $20 \mathrm{~N}$ & $100 \mathrm{~N}$ & $20 \mathrm{~L}$ & $10 N$ & 200 & $10 \mathrm{~N}$ & 30 & $5 \mathrm{~N}$ & $20 \mathrm{~N}$ & $200 \mathrm{~N}$ & 70 & $20 \mathrm{~N}$ & $200 \mathrm{~N}$ & $200 \mathrm{~N}$ \\
\hline MW010C & 500 & $10 \mathrm{~L}$ & $10 \mathrm{~N}$ & $20 \mathrm{~N}$ & $100 \mathrm{~N}$ & 20 & $10 N$ & 70 & $10 \mathrm{~N}$ & 30 & $5 \mathrm{~N}$ & $20 \mathrm{~N}$ & $200 \mathrm{~N}$ & 50 & $20 \mathrm{~N}$ & $200 \mathrm{~N}$ & $200 \mathrm{~N}$ \\
\hline MW011C & 300 & $10 \mathrm{~N}$ & $10 \mathrm{~N}$ & $20 \mathrm{~N}$ & $100 \mathrm{~N}$ & $20 \mathrm{~L}$ & $10 \mathrm{~N}$ & 100 & $10 \mathrm{~N}$ & $20 \mathrm{~L}$ & $5 \mathrm{~N}$ & $20 \mathrm{~N}$ & $200 \mathrm{~N}$ & 50 & $20 \mathrm{~N}$ & $200 \mathrm{~N}$ & $200 \mathrm{~N}$ \\
\hline MW012C & 500 & $10 \mathrm{~N}$ & $10 \mathrm{~N}$ & $20 \mathrm{~N}$ & $100 \mathrm{~N}$ & 20 & $10 \mathrm{~N}$ & 150 & $10 \mathrm{~N}$ & 20 & $5 \mathrm{~N}$ & $20 \mathrm{~N}$ & $200 \mathrm{~N}$ & 70 & $20 \mathrm{~N}$ & $200 \mathrm{~N}$ & $200 \mathrm{~N}$ \\
\hline MW013C & 300 & $10 \mathrm{~N}$ & $10 \mathrm{~N}$ & $20 \mathrm{~N}$ & $100 \mathrm{~N}$ & $20 \mathrm{~L}$ & $10 N$ & 70 & $10 \mathrm{~N}$ & 20 & $5 \mathrm{~N}$ & $20 \mathrm{~N}$ & $200 \mathrm{~N}$ & 70 & $20 \mathrm{~N}$ & $200 \mathrm{~N}$ & $200 \mathrm{~N}$ \\
\hline
\end{tabular}


Appendix table 7. Heavy-mineral separates from stream concentrate samples, zone 4, Marwani concession, Venezuela-Continued.

\begin{tabular}{|c|c|c|c|c|c|c|c|c|c|c|c|}
\hline & V-S & W-S & Y-S & $\mathrm{Zn}-\mathrm{S}$ & $\mathrm{ZI}-\mathrm{S}$ & & V-S & W-S & Y-S & $\mathrm{Zn}-\mathrm{S}$ & $\mathrm{Zr}-\mathrm{S}$ \\
\hline M0C005 & 200 & $50 \mathrm{~N}$ & 150 & $500 \mathrm{~N}$ & $2,000 \mathrm{G}$ & MCH035 & 300 & $50 \mathrm{~L}$ & 100 & $500 \mathrm{~N}$ & $2,000 \mathrm{G}$ \\
\hline MoC011 & 150 & $50 \mathrm{~N}$ & 500 & $500 \mathrm{~N}$ & $2,000 \mathrm{G}$ & МCH036 & 200 & $50 \mathrm{~N}$ & 100 & $500 \mathrm{~N}$ & $2,000 \mathrm{G}$ \\
\hline $\mathrm{M} 0 \mathrm{CO} 22$ & 200 & $50 \mathrm{~N}$ & 150 & $500 \mathrm{~N}$ & $2,000 \mathrm{G}$ & МCH037 & 300 & $50 \mathrm{~N}$ & 100 & $500 \mathrm{~N}$ & 2,000 \\
\hline M0C017 & 150 & $50 \mathrm{~N}$ & 200 & $500 \mathrm{~N}$ & $2,000 \mathrm{G}$ & МCH038 & 200 & $50 \mathrm{~N}$ & 150 & 500 & $2,000 \mathrm{G}$ \\
\hline M0C020 & 200 & $50 \mathrm{~N}$ & 1,500 & $500 \mathrm{~N}$ & $2,000 \mathrm{G}$ & МСH039 & 300 & $50 \mathrm{~N}$ & 100 & $500 \mathrm{~N}$ & $2,000 \mathrm{G}$ \\
\hline M0C021 & 200 & $50 \mathrm{~N}$ & 300 & $500 \mathrm{~N}$ & $2,000 \mathrm{G}$ & МСH040 & 300 & 70 & 150 & $500 \mathrm{~N}$ & $2,000 \mathrm{G}$ \\
\hline M0C038 & 300 & $50 \mathrm{~N}$ & 70 & $500 \mathrm{~N}$ & 2,000 & МСH 042 & 300 & $50 \mathrm{~N}$ & 150 & $500 \mathrm{~N}$ & $2,000 \mathrm{G}$ \\
\hline MoC039 & 200 & $50 \mathrm{~N}$ & 70 & $500 \mathrm{~N}$ & 1,500 & МСH 043 & B & B & B & B & B \\
\hline MoC059 & 300 & $50 \mathrm{~N}$ & 100 & $500 \mathrm{~N}$ & 2,000 & МCH044 & 300 & $50 \mathrm{~N}$ & 150 & $500 \mathrm{~N}$ & $2,000 \mathrm{G}$ \\
\hline M0C061 & 300 & $50 \mathrm{~N}$ & 150 & $500 \mathrm{~N}$ & $2,000 \mathrm{G}$ & MCH045 & 300 & 50 & 200 & $500 \mathrm{~N}$ & 2,000 \\
\hline MoCo82 & 300 & $50 \mathrm{~N}$ & 150 & $500 \mathrm{~N}$ & 2,000 & МСH047 & 300 & 200 & 200 & $500 \mathrm{~N}$ & $2,000 \mathrm{G}$ \\
\hline MoC086 & 200 & $50 \mathrm{~N}$ & 100 & $500 \mathrm{~N}$ & $2,000 \mathrm{G}$ & МCH048 & 300 & 70 & 100 & $500 \mathrm{~N}$ & 1,500 \\
\hline M0C087 & 300 & $50 \mathrm{~N}$ & 50 & $500 \mathrm{~N}$ & 2,000 & МСН049 & 200 & $50 \mathrm{~N}$ & 150 & $500 \mathrm{~N}$ & $2,000 \mathrm{G}$ \\
\hline M0C088 & 150 & $50 \mathrm{~N}$ & 500 & $500 \mathrm{~N}$ & $2,000 \mathrm{G}$ & МСH050 & 300 & $50 \mathrm{~L}$ & 100 & $500 \mathrm{~N}$ & $2,000 \mathrm{G}$ \\
\hline M0C090 & 150 & $50 \mathrm{~N}$ & 150 & $500 \mathrm{~N}$ & $2,000 \mathrm{G}$ & МCH051 & 300 & $50 \mathrm{~L}$ & 150 & $500 \mathrm{~N}$ & $2,000 \mathrm{G}$ \\
\hline M0C097 & 150 & $50 \mathrm{~N}$ & 100 & 500 & $2,000 \mathrm{G}$ & MCH052 & 300 & 50 & 70 & $500 \mathrm{~N}$ & $2,000 \mathrm{G}$ \\
\hline M0C100 & 200 & $50 \mathrm{~N}$ & 200 & 700 & $2,000 \mathrm{G}$ & MCHO53 & 300 & $50 \mathrm{~N}$ & 200 & $500 \mathrm{~N}$ & $2,000 \mathrm{G}$ \\
\hline M0Cl05A & 200 & $50 \mathrm{~N}$ & 150 & $500 \mathrm{~N}$ & 2,000 & MCH0S5 & 300 & $50 \mathrm{~N}$ & 150 & $500 \mathrm{~N}$ & $2,000 \mathrm{G}$ \\
\hline MoC109 & 200 & $50 \mathrm{~N}$ & 50 & $500 \mathrm{~N}$ & 700 & MCH056 & 300 & 70 & 200 & $500 \mathrm{~N}$ & 2,000 \\
\hline MCHOOI & 200 & $50 \mathrm{~N}$ & 150 & $500 \mathrm{~N}$ & 1,500 & $\mathrm{MCH} 057$ & 300 & 100 & 150 & $500 \mathrm{~N}$ & 2,000 \\
\hline MCH003 & 300 & $50 \mathrm{~N}$ & 70 & 500 & $2,000 \mathrm{G}$ & МCH058 & 500 & 100 & 100 & $500 \mathrm{~N}$ & $2,000 \mathrm{G}$ \\
\hline $\mathrm{MCH} 004$ & 300 & $50 \mathrm{~N}$ & 100 & 500 & $2,000 \mathrm{G}$ & MCH059 & 300 & $50 \mathrm{~N}$ & 200 & $500 \mathrm{~N}$ & $2,000 \mathrm{G}$ \\
\hline MCH005 & 200 & $50 \mathrm{~N}$ & 30 & $500 \mathrm{~N}$ & 300 & $\mathrm{MCH} 060$ & 300 & 50 & 500 & $500 \mathrm{~N}$ & $2,000 \mathrm{G}$ \\
\hline MCHOOS & 200 & $50 \mathrm{~N}$ & 150 & 500 & 1,000 & MCH061 & 300 & 100 & 100 & $500 \mathrm{~N}$ & 2,000 \\
\hline MCH007 & 70 & $50 \mathrm{~N}$ & 200 & 1,000 & $2,000 \mathrm{G}$ & MCH062 & 50 & 200 & 100 & $500 \mathrm{~N}$ & $2,000 \mathrm{G}$ \\
\hline MCH008 & 100 & $50 \mathrm{~N}$ & 500 & 1,000 & $2,000 \mathrm{G}$ & MCH063 & 200 & $50 \mathrm{~N}$ & 150 & $500 \mathrm{~N}$ & $2,000 \mathrm{G}$ \\
\hline MCH010 & 200 & $50 \mathrm{~N}$ & 300 & $500 \mathrm{~N}$ & 2,000 & MCH064 & 300 & 100 & 100 & $500 \mathrm{~N}$ & $2,000 \mathrm{G}$ \\
\hline MCH01I & 200 & $50 \mathrm{~N}$ & 200 & 500 & 2,000 & MCH065 & 300 & $50 \mathrm{~L}$ & 500 & $500 \mathrm{~N}$ & $2,000 \mathrm{G}$ \\
\hline $\mathrm{MCH} 012$ & 200 & $50 \mathrm{~N}$ & 300 & $500 \mathrm{~N}$ & 2,000 & МCH066 & 300 & 70 & 200 & $500 \mathrm{~N}$ & $2,000 \mathrm{G}$ \\
\hline MCH013 & 200 & $50 \mathrm{~N}$ & 150 & $500 \mathrm{~N}$ & 500 & МCH067 & 200 & $50 \mathrm{~N}$ & 300 & $500 \mathrm{~N}$ & $2,000 \mathrm{G}$ \\
\hline MCH014 & 200 & $50 \mathrm{~N}$ & 300 & $500 \mathrm{~N}$ & 2,000 & МСH069 & 300 & $50 \mathrm{~N}$ & 70 & $500 \mathrm{~N}$ & $2,000 \mathrm{G}$ \\
\hline MCH015 & 200 & $50 \mathrm{~N}$ & 700 & $500 \mathrm{~N}$ & $2,000 \mathrm{G}$ & МCH070 & 300 & 50 & 100 & $500 \mathrm{~N}$ & $2,000 \mathrm{G}$ \\
\hline MCH0l6 & 150 & $50 \mathrm{~L}$ & 300 & $500 \mathrm{~N}$ & $2,000 \mathrm{G}$ & $\mathrm{MCHO} 71$ & 300 & 70 & 150 & $500 \mathrm{~N}$ & 2,000 \\
\hline $\mathrm{MCH} 018$ & 200 & $50 \mathrm{~N}$ & 500 & 500 & $2,000 \mathrm{G}$ & $\mathrm{MCH} 072$ & 300 & 70 & 100 & $500 \mathrm{~N}$ & 2,000 \\
\hline $\mathrm{MCH} 022$ & 200 & $50 \mathrm{~L}$ & 300 & $500 \mathrm{~N}$ & $2,000 \mathrm{G}$ & MCH073 & 200 & $50 \mathrm{~N}$ & 150 & 700 & $2,000 \mathrm{G}$ \\
\hline $\mathrm{MCH} 024$ & 200 & $50 \mathrm{~N}$ & 150 & $500 \mathrm{~N}$ & $2,000 \mathrm{G}$ & $\mathrm{MOC} 013$ & 300 & 50 & 200 & $500 \mathrm{~N}$ & $2,000 \mathrm{G}$ \\
\hline $\mathrm{MCH} 025$ & 200 & 150 & 200 & $500 \mathrm{~N}$ & 2,000 & MW002C & 300 & 70 & 200 & $500 \mathrm{~N}$ & 2,000 \\
\hline MCH026 & 200 & $50 \mathrm{~L}$ & 500 & $500 \mathrm{~N}$ & $2,000 \mathrm{G}$ & MW003C & 500 & 70 & 200 & $500 \mathrm{~N}$ & 2,000 \\
\hline MCH027 & 300 & $50 \mathrm{~L}$ & 300 & $500 \mathrm{~N}$ & 2,000 & MW009C & 300 & 100 & 200 & $500 \mathrm{~N}$ & 2,000 \\
\hline MCH028 & 150 & 100 & 700 & $500 \mathrm{~N}$ & $2,000 \mathrm{G}$ & MW010C & 300 & $50 \mathrm{~N}$ & 200 & $500 \mathrm{~N}$ & $2,000 \mathrm{G}$ \\
\hline $\mathrm{MCH} 029$ & 200 & $50 \mathrm{~N}$ & 200 & $500 \mathrm{~L}$ & $2,000 \mathrm{G}$ & MW011C & 300 & $50 \mathrm{~L}$ & 30 & $500 \mathrm{~N}$ & $2,000 \mathrm{G}$ \\
\hline $\mathrm{MCH} 030$ & 300 & $50 \mathrm{~L}$ & 100 & $500 \mathrm{~N}$ & $2,000 \mathrm{G}$ & MW012C & 300 & 50 & 200 & $500 \mathrm{~N}$ & $2,000 \mathrm{G}$ \\
\hline $\mathrm{MCH} 032$ & 300 & $50 \mathrm{~L}$ & 150 & $500 \mathrm{~N}$ & $2,000 \mathrm{G}$ & MW013C & 300 & 50 & 100 & 500 & $2,000 \mathrm{G}$ \\
\hline $\mathrm{MCH} 033$ & 200 & $50 \mathrm{~L}$ & 500 & $500 \mathrm{~N}$ & 2,000 & & & & & & \\
\hline
\end{tabular}


Mineral Deposits of the Venezuelan Guayana Shield

By Gary B. Sidder

GEOLOGY AND MINERAL DEPOSITS OF THE VENEZUELAN GUAYANA SHIELD

U.S. GEOLOGICAL SURVEY BULLETIN 2124-O

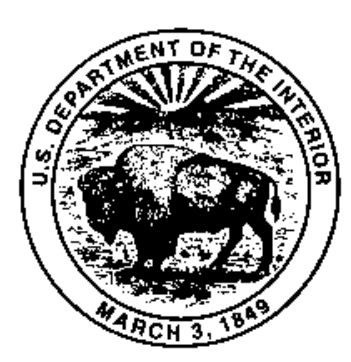

UNITED STATES GOVERNMENT PRINTING OFFICE, WASHINGTON : 1995 


\section{CONTENTS}

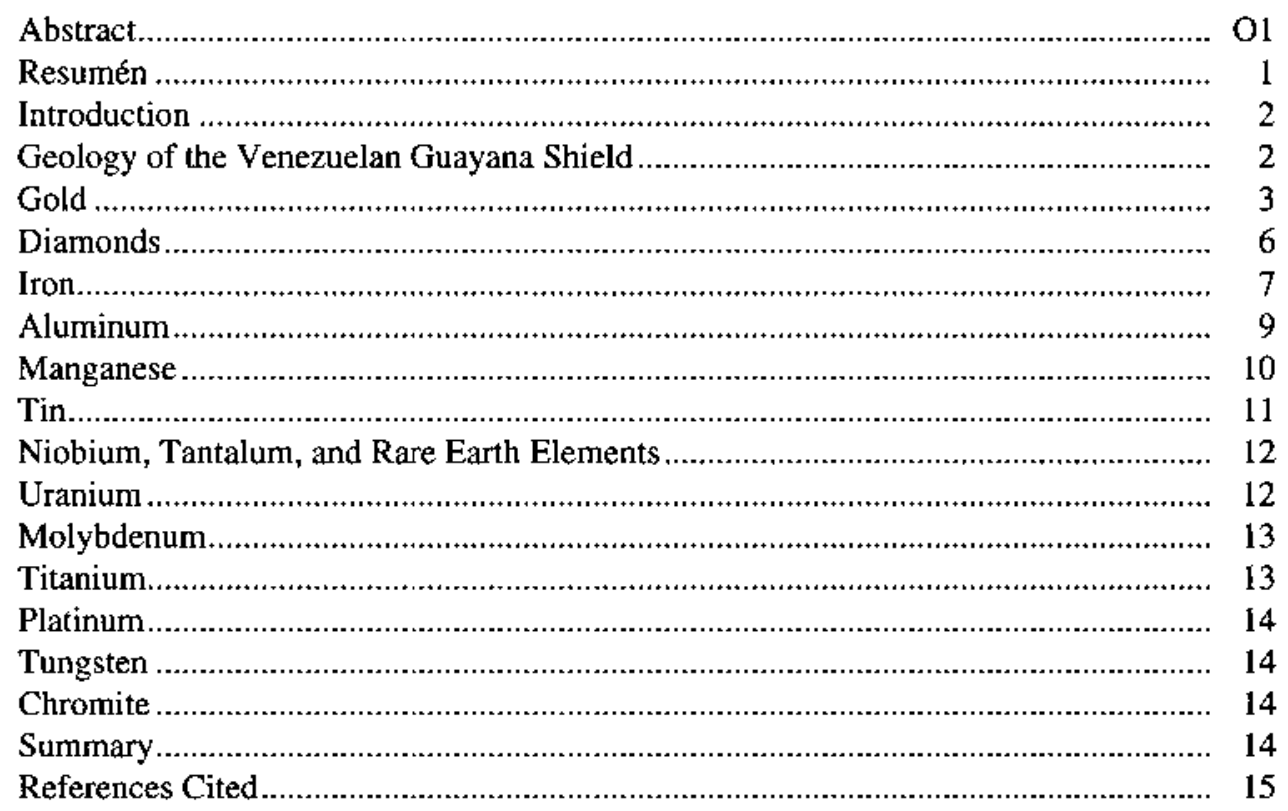

\section{PLATE}

[In pocket]

1. Mineral deposits of the Guayana Shield, Venezuela. 


\title{
Mineral Deposits of the Venezuelan Guayana Shield
}

\author{
By Gary B. Sidder ${ }^{1}$
}

\begin{abstract}
The Venezuelan Guayana Shield is a relatively unexplored area, and its jungle cover inhibits easy discovery. Gold, iron, aluminum from bauxite, and diamonds are the only commodities produced at present. Gold is commonly in low-sulfide gold-quartz vein-type deposits hosted by metavolcanic and metasedimentary rocks of the Early Proterozoic greenstone belts. The El Callao district, containing the underground Colombia mine, is historically the biggest gold producer in Venezuela and has total production of about 200 metric tons of gold. The Lo Increíble and Kilometer 88 districts are two other areas where mining activity is extensive. The Early Proterozoic Cuchivero Group has potential for gold deposits in epithermal veins, and the Early Proterozoic greenstone belts and possibly the banded iron formation of the Archean Imataca Complex have potential for gold in Homestake-type deposits. Superior-type deposits of enriched banded iron formation in the Imataca Complex, such as those at Cerro Bolívar, San Isidro, and Los Barran$\cos$, are among the largest in the world. The Los Pijiguaos bauxite deposit developed through intense tropical weathering of the Middle Proterozoic Parguaza Granite. Other prospects of bauxite and lateritic bauxite formed on felsic and mafic volcanic and plutonic rocks elsewhere in the shield. Placer diamond deposits are predominantly derived from paleoplacer conglomerate beds in the lower $600 \mathrm{~m}$ of the Early to Middle Proterozoic Roraima Group. Kimberlite has been identified only in the Quebrada Grande area, the richest diamond-producing area in Venezuela. Also favorable for exploration are prospects of other metals such as platinum, chromium, and manganese in the greenstone belts, tin in the Parguaza Granite and in rhyolite of the Early Proterozoic Caicara Formation, and rare earth elements in carbonatite such as at Cerro Impacto or associated with potential Olympic Dam-type iron-copper-uranium-gold-rare earth element deposits in the Cuchivero Group and the Parguaza Granite.
\end{abstract}

'U.S. Geological Survey, Denver Federal Center, MS905, Denver, Colorado 80225 .

\section{RESUMEN}

El Escudo de Guayana en Venezuela es un área relativamente poco explorada, además la densa selva inhibe los descubrimientos faciles. Los unicos minerales actualmente producidos son oro, hierro, aluminio a partir de bauxita y diamantes. El oro ocurre comunmente en vetas de cuarzo las cuales también llevan una baja proporción de sulfuros. Dichas vetas están encajadas en rocas metavolcánicas y metasedimentarias de los cinturones de rocas verdes de edad Proterozoico Temprano. Historicamente, El Callao, el cual contiene la mina subterranea Colombia, es el distrito que más oro produce en Venezuela, con una producción anual (total) de 200 toneladas métricas. Otras dos áreas donde la producción de oro es extensa son El Kilometro 88 y Lo Increíble. El Grupo Cuchivero tiene potencial para la existencia de depósitos de oro en vetas epitermales. Los cinturones de rocas verdes de edad Proterozoico Temprano y posiblemente las formaciones bandeadas de hierro de edad Arqueana tienen potencial para depósitos de oro del tipo Homestake. En el Complejo de Imataca, los depósitos de Cerro Bolívar, San Isidro y Los Barrancos, los cuales son formaciones bandeadas de hierro enriquecidas del tipo Superior, están entre los más granđes del mundo. El depósito de bauxita de Los Pijiguaos se desarrolló durante la intensa meteorización bajo clima tropical del granito de Parguaza. Otros prospectos de bauxita y bauxita laterítica se formaron en otros lugares del escudo sobre rocas volcánicas félsicas y máficas y sobre plutones. Las acumulaciones de diamantes en depósitos de tipo placer son predominantemente derivadas de paleoplaceres en capas conglomeráticas en los $600 \mathrm{~m}$ basales del Grupo Roraima el cual tiene una edad Proterozoico Temprano a Medio. Kimberlitas han sido identificadas solamente en el área de Quebrada Grande, la cual es el área más rica en diamantes en Venezuela. Otros metales, tales como platino, cromo y manganeso, son favorables para la prospección en los cinturones de rocas verdes. El granito de Parguaza y rocas riolíticas de la Formación Caicara de edad Proterozoico Temprano son favorables para depósitos de estaño. Elementos del grupo tierras raras son de interes prospectivo en la carbonatita del Cerro Impacto o en el granito de Parguaza y posiblemente las rocas del Grupo Cuchivero 
los cuales son favorables para acumulaciones de hierro-cobre-uranio-oro-elementos tierras raras del tipo Olympic Dam.

\section{INTRODUCTION}

Principal products of the Venezuelan mining sector currently are gold, iron, bauxite, and diamonds. Kaolin, sand and gravel, building stone, and other nonmetallic and industrial mineral commodities are also produced (Doan, 1994), but are not discussed herein. This paper describes known metallic mineral prospects and deposits in the Venezuelan Guayana Shield and suggests possible new, as yet undiscovered, types of deposits. The location and type of commodity for all known metallic mineral prospects, mines, and mining districts in the Venezuelan Guayana Shield are shown on plate 1. Information varies from a location and commodity symbol only (unnumbered on pl. 1) to a location, commodity symbol, and name (numbered prospects). Site-specific detailed geologic descriptions and, in some cases, reserve data on grade and tonnage are presented herein for some deposits. A list of prospects, mines, and mining districts, both those with production and those having potential for but without recorded production, is shown on plate 1 .

This paper is a companion to Sidder and Mendoza (this volume), in which a comprehensive review of the geology of the Venezuelan Guayana Shield and its relation to the entire Guayana Shield of northern South America and the West African craton is presented. A brief outline of the geology of the Venezuelan Guayana Shield is provided herein. The reader is referred to Sidder and Mendoza and other papers in this volume for detailed descriptions of the geology of the Venezuelan Guayana Shield. A geographic map of the Venezuelan Guayana Shield is given as plate 1 of Wynn, Sidder, and others (this volume).

\section{GEOLOGY OF THE VENEZUELAN GUAYANA SHIELD}

The Guayana Shield of Venezuela consists predominantly of Archean and Early to Middle Proterozoic rocks that are divisible into five lithotectonic provinces: (1) Archean Imataca amphibolite- to granulite-facies gneiss terrane, (2) Early Proterozoic greenstone-belt rocks and associated granite-gneiss terrane of the Supamo Complex, (3) Early Proterozoic unmetamorphosed volcano-plutonic complex of the Cuchivero Group, (4) Early to Middle Proterozoic continental sedimentary rocks of the Roraima Group, and (5) Middle Proterozoic anorogenic rapakivi-type Parguaza Granite. Early Proterozoic and possibly Archean rocks in Estado Amazonas of western Venezuela are undivided, and their relation to other rocks of the Venezuelan Guayana Shield is unclear. Early to Middle Proterozoic continental tholeiitic dikes, sills, and small irregular intrusive bodies and Mesozoic dikes emplaced during the opening of the Atlantic Ocean cut all of the lithotectonic provinces. Figure 2 in Sidder and Mendoza (this volume) is a simplified geologic province map, and table I in Sidder and Mendoza is a simplified stratigraphic explanation of the rock units and tectonic events of the Venezuelan Guayana Shield.

The Archean Imataca Complex (unit Ai, fig. 2, Sidder and Mendoza, this volume), the oldest unit of the Guayana Shield, consists predominantly of quartzofeldspathic gneiss and granulite and tesser amounts of internediate to mafic gneiss and granulite and minor dolomitic marble and banded iron formation. Large isoclinal folds, which have been refoided by relatively open folds, are common in the Imataca Complex. Metamorphic grade ranges from granulite facies in the northeastern part of the belt to amphibolite facies in the southwestern part. During the pre-Trans-Amazonian tectonomagmatic event, between about 2,800 and $2,700 \mathrm{Ma}$, granitic rocks intruded the Imataca Complex, and injection gneiss and migmatite were developed.

The Early Proterozoic greenstone belts (unit Xg, fig. 2, Sidder and Mendoza, this volume), which formed between about 2,250 and $2,100 \mathrm{Ma}$, consist of a submarine sequence of tholeiitic mafic volcanic rocks, a sequence of tholeiitic to calc-alkalic basalt to rhyolite, and a succession of turbiditic graywacke, volcaniclastic rocks, and chemical sedimentary rocks that characterize the basal, middle, and upper parts, respectively. Layered mafic-ultramafic complexes also are present in the greenstone belts. The greenstone-belt rocks are metamorphosed to the greenschist facies and locally to the amphibolite facies near granitic domes of the Supamo Complex (unit Xs, fig. 2, Sidder and Mendoza, this volume), which intruded the greenstone-belt rocks between about 2,230 and 2,050 Ma. Granite of the Supamo Complex divides the metasedimentary and meta-igneous greenstone-belt rocks into branching synclinoria between intrusive uplifts. The Trans-Amazonian orogeny was a period of continental collision and accretion between about 2,150 and $1,960 \mathrm{Ma}$ during which the Imataca Complex and the greenstone-granite terranes were deformed and metamorphosed.

Postcollisional, post-Trans-Amazonian magmatism between about 1,930 and 1,790 Ma produced volcanic, subvolcanic, and plutonic rocks of the Cuchivero Group (unit $X c$, fig. 2, Sidder and Mendoza, this volume) and its equivalents throughout the Guayana Shield. Silicic rocks (rhyolite and granite to granodiorite) are dominant, and associated intermediate to mafic dikes and lava flows are less abundant. Undivided Proterozoic and possibly Archean rocks in Estado Amazonas of westem Venezuela include granitic rocks, gneiss, and migmatite. Peak metamorphism and magmatism occurred between about 1,860 and 1,730 Ma.

Unmetumorphosed, posttectonic sedimentary rocks such as quartzarenite, conglomerate, arkose, siltstone, and shale of the Roraima Group (unit YXr, fig. 2, Sidder and 
Mendoza, this volume) were deposited in fluvial, deltaic, shallow coastal marine, and lacustrine or epicontinental environments. The Roraima Group is possibly as old as about $1,900 \mathrm{Ma}$ and as young as about $1,500 \mathrm{Ma}$.

Continental tholeiitic dikes, sills, and irregular intrusive bodies of the Avanavero Suite (unit Xa, fig. 2, Sidder and Mendoza, this volume) cut all older rocks of the Guayana Shield. These intrusive rocks are about 1,650 Ma in age, and possibly as old as about 1,850 Ma. Middle Proterozoic, about $1,545 \mathrm{Ma}$, undeformed granite having rapakivi texture (unit $Y p$, fig. 2, Sidder and Mendoza, this volume) is characteristic of the Parguaza province.

Continental collision in the westernmost part of the Guayana Shield during the Nickerie orogeny reset potassium-argon and rubidium-strontium mineral ages of Archean and Early Proterozoic rocks in the central and eastem parts of the shield to about 1,200 Ma. Tholeiitic diabase dikes (unit Mzd, fig. 2, Sidder and Mendoza, this volume) intruded the Guayana Shield during the opening of the Atlantic Ocean from about 210 to $200 \mathrm{Ma}$. Erosion of the Precambrian terranes and uplift during the Mesozoic and Cenozoic Eras produced at least six planar geomorphic surfaces in the Guayana Shield at distinct elevations between about 2,900 and $50 \mathrm{~m}$ above sea level.

\section{GOLD}

Venezuela has a long history of gold production, and recent changes in investment and tax laws in Venezuela have led to a mineral exploration boom in the past five years; gold is the primary metal of interest. Total reported gold production between 1829 and 1971 was 187 metric tons (Locher, 1974). Gold production between 1984 and 1991 totalled about 29.4 metric tons and was reportedly 7.6 metric tons in 1992 (Ensminger and others, 1990; Ensminger, 1992; U.S. Bureau of Mines, 1993; Doan, 1994). These numbers do not include production by unlicensed miners, and thus the actual level of production may be higher. In 1987, rudimentary sluices worked by mineros or garimpeiros (small-scale miners) produced an estimated 15 metric tons of gold (Engineering and Mining Journal, 1987; Hennius, 1988). Newspaper and unofficial reports imply that more than 10 metric tons of the mineros' production is smuggled out of the country each year. Indeed, as much as 10 metric tons of Brazil's annual reported gold production may have been obtained from mineros working in the Venezuelan Guayana Shield (Engineering and Mining Journal, 1987; Hennius, 1988). A total of more than 62 metric tons of gold is thought to have been removed by illegal immigrants from surface operations using primitive mining techniques (Doan, 1994).

Mendoza (1985) proposed that as much as 8,000 metric tons of gold had yet to be discovered in the Venezuelan Guayana Shield, and Newman (1989) reported that Venezuelan gold reserves are an estimated 358 metric tons. The similarity between the geology of the Precambrian Guayana Shield and the Precambrian shields in Canada, Australia, and West and South Africa, supported by information from regional reconnaissance exploration in Venezuela (Gibbs and Barron, 1983, 1993; Sidder and others, 1988; Sidder and Mendoza, this volume), indicates that potential for new discoveries of gold and other mineral deposits in Venezuela is high. Recent studies by the U.S. Geological Survey and the Corporación Venezolana de Guayana, Técnica Minera, C.A. (TECMIN) (a Venezuelan government-owned mineral exploration company) have estimated the number of undiscovered deposits for some deposit types such as low-sulfide gold-quartz veins, volcanogenic massive sulfide, and nickel-copper-platinum-group elements associated with mafic and ultramafic intrusive rocks (Wynn and Sidder, 1991; U.S. Geological Survey and Corporación Venezolana de Guayana, Técnica Minera, C.A., 1993).

Early Proterozoic greenstone-belt rocks have produced the most gold in Venezuela. The richest gold lodes mined to date are in the El Callao mining district (loc. 37, pl. 1), where more than 260 gold-bearing quartz veins are present. The El Callao mine was the most productive gold mine in the world during the latter part of the 19th century (Newhouse and Zuloaga, 1929; Knox, 1942). Cumulative production in the El Callao district between 1829 and 1990 was about 200 metric tons of gold (Bellizzia and others, 1981; Vicente Mendoza, Técnica Minera, C.A., written commun., 1991), and peak production was in 1885 when $8,194 \mathrm{~kg}$ was produced (Locher, 1974). Minería de Venezuela (MINERVEN) (a Venezuelan government-owned mining company) produced $1,820 \mathrm{~kg}$ of gold in 1990 from 188,800 metric tons of ore having an average grade of 9.64 grams of gold per metric ton from the underground Colombia mine in the El Callao district (Santaella, 1991). Reserves to a depth of $250 \mathrm{~m}$ at the Colombia mine are estimated to be about $14,300 \mathrm{~kg}$ from 1.55 million metric tons of ore having an average grade of 9.2 grams of gold per metric ton (Engineering and Mining Journal, 1988). Locher (1974) estimated that potential reserves in the El Callao district are about 84 metric tons of gold from 4.6 million metric tons of ore having an average grade of 18.33 grams of gold per metric ton. Tailings from old mines in the El Callao district have been dumped at Mocupia Gorge since 1928 (Engineering and Mining Journal, 1988). The tailings were initially estimated to contain 4.6 million metric tons that averages more than 1.34 grams of gold per metric ton (Ensminger, 1992); however, recent estimates indicate that less than 600,000 metric tons having about 1.5 grams of gold per metric ton are present (Paul A. Rose, Monarch Resources, 1993, oral commun.). Slightly less than 1 metric ton of gold was produced from the tailings in 1990 and 1991 (Ensminger, 1992; U.S. Bureau of Mines, 1993).

Veins in the El Callao district cut Early Proterozoic meta-igneous and metasedimentary rocks that are metamorphosed to the greenschist facies and locally to the 
amphibolite facies (Mentndez, 1968). The protoliths consisted of a submarine sequence of tholeiitic mafic volcanic rocks, a sequence of tholeitic to calc-alkalic basalt to rhyolite, and an interval of turbiditic graywacke, volcaniclastic rocks, and chemical sedimentary rocks in the basal, middle, and upper parts, respectively. Mafic metavolcanic rocks of the basal El Callao Fornation of the Pastora Supergroup (Sidder and Mendoza, this volume, table 1) are the most common ore host, and metavolcaniclastic and metasedimentary rocks in other parts of the greenstone-belt sequence less commonly host ore (Menendez, 1972). Faults and shear zones localized the mineralization. Quartz veins are typically from $2 \mathrm{~cm}$ to more than $10 \mathrm{~m}$ in thickness, and the quartz is milky white to gray and locally banded. Native gold and minor to trace amounts of pyrite, tetrahedrite, chalcopyrite, bomite, scheelite, molybdenite, galena, pyrrhotite, and sphalerite are present in the quartz veins. Carbonate minerals (commonly ankerite, siderite, and calcite) are also present, and carbonate flooding, as well as propylitization, sericitization, and silicification, has affected the wallrocks as much as several tens of meters away from the veins (Bundy, 1943; Banerjee and Moorhead, 1970; Menendez, 1974). Tourmaline and mariposite (chrome mica) are variably present in the veins and in the alteration assemblage (Macdonald, 1968).

The low-sulfide gold-quartz vein model (Berger, 1986a; Bliss and Jones, 1988; Klein and Day, 1994), also known as shear-zone-hosted, mesothermal, metamorphic, or orogenic gold, best characterizes mineral deposits in the $\mathrm{El}$ Callao district. Characteristics of alteration and mineralization in deposits at El Callao are similar to those of Archean vein-type deposits in the Superior province of the Canadian Shield (Card and others, 1989; Klein and Day, 1994) and lode-gold deposits of the Juneau gold belt in southeastern Alaska (Goldfarb and others, 1988, 1991). It is possible that the pinchout of metasedimentary and metavolcanic rocks of the Cicapra Formation and the fault contact between the Yuruari and El Callao Formations in the El Callao area represents a "break" (a terrane boundary or tectonically disturbed zone) similar to the Larder Lake "break" in the Abitibi greenstone belt of the Superior province (Hinse and others, 1986; Kerrich and Wyman, 1990). Low-sulfide gold-quartz vein deposits in the El Callao and other districts in Venezuela are also similar to gold deposits in the Early Proterozoic Birimian greenstone belts of the West African craton, such as the Syama deposit in Mali and deposits in Ghana (Leube and others, 1990; Milési and others, 1991, 1992; Eisenlohr, 1992; Olson and others, 1992; Dzigbodi-Adjimah, 1993; Oss, 1993a; Mumin and others, 1994). The deposits in Ghana, such as Ashanti, Prestea, and Bibiani, are also located in extensive shear zones and near breaks or transition zones between predominantly volcanic and predominantly sedimentary rocks (Leube and others, 1990; Appiah and others, 1991; Oberthür and others, 1991; Milési and others, 1992; Dzigbodi-Adjimah, 1993; Watkins and others, 1993). The transition zones are characterized by chemical sediments such as chert, iron-magnesium carbonate, and carbon-rich argillite and are the foci for the gold deposits (Leube and others, 1990; Milési and others, 1992). West Africa is also currently experiencing an exploration boom (Martineau, 1994). Gold, diamonds, and heavy minerals are the premier exploration and development targets, and nickel, copper, manganese, and graphite deposits are also being sought. Reported gold production in Ghana alone almost tripled between 1987 and 1993 from 10.2 to 26.3 metric tons (Oss, 1993a), and new discoveries have been made in several other countries including Mali, Ivory Coast, and Guinea (Oss, 1993b; Martineau, 1994).

The Kilometer 88 (locs. 99, 100, and 104, pl. 1) and the Lo Increible (loc. 38) districts were two other areas of extensive exploration and mining activity in 1992. Mines in the Lo Increible district exploit gold-quartz-tourmaline veins, similar to those in the El Callao district, in a shear zone (Ferrand and others, 1984; Day and others, this volume). Most of the recent exploration boom in Venezuela is centered on the Kilometer 88 district (Danielson, 1993; Doan, 1994). Rocks in the Kilometer 88 district are intensely weathered, and the geology is not well understood. Hydraulic methods are commonly used to mine the ore. Pedro Lira (Ministerio de Energía y Minas, oral commun., 1988) and Floyd Gray and others (U.S. Geological Survey, written commun., 1994) described the weathered host rocks as schist similar to that in the El Callao area and granitic rocks. Veins in the Kilometer 88 area contain native gold and pyrite, trace to minor amounts of chalcopyrite and molybdenite, and gangue of quartz, dolomite, hematite, tourmaline, and sericite. Wallrock alteration consists of propylitization, carbonatization, and argillization. Faults and shear zones localized mineralization. Gold production in 1987 at the Cristina 5 mine in the Kilometer 88 district was $1,700 \mathrm{~kg}$ from about 142,000 metric tons containing an average of 12 grams of gold per metric ton, 0.36 percent copper, and $50 \mathrm{ppm}$ lead (Pedro Lira, oral commun,, 1988). High-grade ore contains as much as 23 grams of gold per metric ton, 7.3 percent copper, 11.0 percent molybdenum, and 7.0 percent lead. An estimated 40 metric tons of gold has been mined using primitive techniques in the last decade in the Kilometer 88 district (The Mining Record, 1992). Recent drilling at Las Cristinas indicates reserves of about 8.6 million ounces at a grade of about 0.04 ounces per ton (The Northem Miner, 1994). Characteristics of alteration and mineralization in the Kilometer 88 district indicate that the prospects and deposits may be porphyry copper \pm molybdenum \pm gold or low-sulfide gold-quartz veins.

Técnica Minera, C.A., has explored several properties in eastern Venezuela. Bochinche (loc. 24, pl. 1), Marwani (locs. 26, 27), and Marwani-Los Caribes (loc. 31) are quartz-tourmaline vein prospects. The host rocks at Bochinche include a metamorphosed turbiditic sequence of graywacke, siltstone, and shale and mafic to intermediate tuff (Wynn and Sidder, 1991). Major faults and shear zones 
cut these rocks, and gold-bearing quartz veins both parallel with and at an angle to foliation cut the metasedimentary and metavolcanic rocks. Bochinche resembles some turbidite-hosted gold deposits such as Loulo in Mali and possibly Dorlin in Guyana (Boyle, 1986; Milési and others, 1989, 1992; Dommanget and others, 1993; Fouillac and others, 1993). Host rocks at Marwani consist of mafic to felsic volcanic and volcaniclastic rocks, siliceous chert, lean iron formation or ferruginous chert, and phyllite. Exhalative chemical sedimentary rocks associated with a quartz-tourmaline vent breccia at Marwani (loc. 26, pl. 1) (Sidder and others, 1988; Marsh and others, this volume) indicate that stratabound Algoma-type banded iron formation-hosted gold deposits may be present in the Marwani area. The prospect at Pistón de Uroy (loc. 98) contains quartz \pm carbonate-sulfide veins (without tournaline) that cut a mafic-ultramafic complex of cumulate rocks (Wynn and others, this volume). Gold has been mined from placers in streams that drain these areas.

Other lode gold prospects shown on plate 1 have little or no recorded production. La Camorra (loc. 91) reportedly contains as much as $11,000 \mathrm{~kg}$ of gold from 570,000 metric tons that grades from 9.1 to 24.4 grams of gold per metric ton and averages about 20 grams of gold per metric ton to $300 \mathrm{~m}$ depth (Engineeing and Mining Journal, 1988; Barnard, 1990). The gold is hosted in quartz-tourmaline veins that cut Early Proterozoic greenschist-facies rocks. Gold in a prospect near Cerro La Pinto (loc. 58) is in shear zones that cut a sequence of mafic metabasalt and metagabbro (Sidder and Mendoza, this volume). These deposits also may be representative of the low-sulfide gold-quartz vein model (Berger, 1986a; Bliss and Jones, 1988).

Vuelvan Caras (loc. 25, pl, 1) and Payapal (loc. 88) are the only known gold deposits in Venezuela hosted by granitic rocks, which are of probable Early Proterozoic age. The deposits are similar to deposits in Guyana, such as those at Omai, Peters' Mine, and Eagle Mountain, that are in stockwork veins within and at the periphery of granitic to dioritic plutons that formed from about 2,100 to $1,800 \mathrm{Ma}$, as dated by whole-rock rubidium-strontium isochrons (Macdonald, 1968; Barron, 1969; Carter and Fernandes, 1969; Elliot, 1986; Barnard, 1990; Bertoni and others, 1991; Gibbs and Barron, 1993). Several authors have suggested that gold deposits in greenstone-belt rocks in Guyana, Suriname, and French Guiana are spatially, if not genetically, related to granitic intrusions (Carter and Fernandes, 1969; Banerjee and Moorhead, 1970; Dahlberg, 1975; Blanc and others, 1980). In Venezuela, the association of granitic plutons and gold-bearing quartz veins is not well documented. Granitic rocks in the Early Proterozoic greenstone-granite terrane of the West African craton are estimated to contain only about 3 percent of the gold reserves (Milési and others, 1992).

Placer deposits of gold have been mined extensively in the Venezuelan Guayana Shield. Mining methods vary from panning and amalgamation with mercury to large dredges with a series of shaker tables, jigs, grizzlies, sorters, and mercury plates. Dohrenwend and others (this volume) identified three types of placer deposits in the southern Gran Sabana area of southeastemmost Venezuela: (1) diamond placers within modern channels of major rivers, (2) gold and diamond placers in colluvial-alluvial deposits of low-order drainages; and (3) gold and diamond paleoplacers associated with conglomeratic lenses and beds at several different levels within the lower part of the Roraima Group (lower $500-600 \mathrm{~m}$ of the Uairén Formation). Thus, the basal part of the Early to Middle Proterozoic Roraima Group is the source for modern placer gold and diamonds (Mendoza, 1985). Holocene paleoplacers (possibly about $8,000-10,000$ years old) have also been mined in some areas, such as at Chiricayen (loc. 134, pl. 1), and probably are the immediate source of gold in some modern alluvial placers.

Pre-Roraima Early Proterozoic metaquartzite and metaconglomerate such as rocks of the Los Caribes and Cinaruco Formations are also possible exploration targets for gold, diamonds, and perhaps uranium. These rocks are correlative with metasedimentary rocks such as the gold-bearing Orapu Formation in French Guiana and metamorphosed conglomerate, arkose, sandstone, and minor shale of the Tarkwaian Series in the West African craton (Black, 1980; Ghosh, 1985; Norman and Appiah, 1989; Vinchon, 1989; Leube and others, 1990; Ledru and others, 1991; Eisenlohr and Hirdes, 1992; Milési and others, 1992; Ledru and others, 1994). Deposits of the Tarkwa district in Ghana have produced about 165 metric tons of gold (Milési and others, 1992). Rocks of the Birimian greenstone belts are the source of the Tarkwaian sediments, and paleoplacer deposits in quartz-pebble conglomerate of the Tarkwaian Series in the Ashanti belt in Ghana were derived from the earliest shear-zone-hosted gold-quartz vein deposits in Birimian rocks (Vinchon, 1989; Milési and others, 1991, 1992; Eisenlohr, 1992; Eisenlohr and Hirdes, 1992; Davis and others, 1994).

A few gold placer deposits, such as La Planada (loc. 13, pl. 1), are within the area of outcrop of the Archean Imataca Complex or are near the Guri fault, which separates the Imataca Complex from the Early Proterozoic greenstone-belt rocks. The Imataca Complex contains deposits of enriched banded iron formation; however, the precious-metal content of these deposits is reportedly low (Engineering and Mining Journal, 1987). Hence, the source of the gold in placer deposits within the Imataca terrane is uncertain. Gold-bearing greenstone-belt rocks have been assumed to be the source of the gold because the placers are downstream from these rocks; however, it is possible that the Imataca Complex contains unknown, undiscovered gold resources.

Other types of gold-bearing deposits may also be present in the greenstone-belt rocks. Gold in a thin sequence of sheared rocks (finely laminated, rhythmically bedded exhalative metachert, graphitic metashale, and mafic 
metavolcanic rocks) at the Cerro La Pinto prospect is similar to Homestake-type gold deposits (Berger, 1986b; Sidder and others, 1991; Klein and Day, 1994). Homestake-type gold deposits may also be present in other areas within the greenstone belts such as Eldorado, Kaburi, and Honey Camp in Guyana (Gibbs and Barron, 1993).

Epithermal and bonanza-type precious-metal vein deposits are uncommon in Precambrian rocks (Hutchinson, 1987). Propylitic and potassic hydrothermal alteration in felsic to intermediate pyroclastic volcanic rocks in the Early Proterozoic Cuchivero terrane, geochemically anomalous amounts of silver $(\leq 3 \mathrm{ppm})$, bismuth $(\leq 1,000 \mathrm{ppm})$, and molybdenum ( $\leq 20 \mathrm{ppm}$ ) in quartz-sulfide veins such as at Merevari (loc. 151, pl. 1), and gold in panned concentrates imply, however, that epithermal deposits may be hosted by these rocks (Sidder and Martinez, 1990). Deposition of sedimentary rocks of the Early to Middle Proterozoic Roraima Group soon after the volcanic rocks, as evidenced by locally conformable contacts (Sidder and Mendoza, this volume), may have preserved deposits of this type in the Guayana Shield.

A potentially important type of gold deposit in tropical areas is saprolitic or lateritic gold. These eluvial deposits generally have higher grades of ore in the weathered zone than in underlying primary ore (Macdonald, 1968; Lecomte and Colin, 1989; Barnard, 1990; Smith and others, 1991; Minko and others, 1992; Olson and others, 1992; Wilhelm and Essono Biyogo, 1992). Deposits such as Omai, Akaiwong, and Tassawini in Guyana have been mined in the past, and additional reserves may be present (Macdonald, 1968; The Northern Miner, 1989; J.D. Bliss, U.S. Geological Survey, written commun., 1989). At Omai, the weathered zone (as deep as $3 \mathrm{~m}$ ) contains 1.5 million metric tons of ore that averages 3.19 grams of gold per metric ton; saprolitic material between 3 and $17 \mathrm{~m}$ below the surface contains about 10 million metric tons of ore that averages 1.44 grams of gold per metric ton; and the primary zone contains indicated and inferred reserves of 27 million metric tons of ore that averages 1.47 grams of gold per metric ton (Elliot, 1986; Ortslan, 1987). Barron (1973) described several other prospects in Guyana in which gold-enriched lateritic soils overlie lower grade, gold-bearing quartz veins in greenstone-belt or granitic rocks. S.D. Olmore (oral commun., 1991) noted that at some prospects in greenstone-belt rocks of Venezuela gold-enriched soils overlie lower grade mineralized rocks. Mines in the Kilometer 88 area may be representative of enriched ore in the weathered zone overlying mineralized greenstone-belt or granitic rocks. The Ity deposit in the Ivory Coast of West Africa is an open-pit, heap-leach mine in auriferous laterite; reserves are 500,000 metric tons grading 7 grams of gold per metric ton (Milési and others, 1992; Oss, 1993b). Recent investigations in West Africa (Danti and Brimhall, 1989; Davies and others, 1989; Minko and others, 1992; Beauvais and Colin, 1993; Bowell, 1993, Bowell and others, 1993; Colin and others, 1993; Costa, 1993) on the mineralogy and geochemistry of tropical rain forest soils and the mobility and distribution of gold in lateritic profjles are helpful guides to exploration for gold in the Guayana Shield. Secondarily enriched surface and near-surface gold deposits in the Guayana Shiejd are particularly attractive exploration targets because they can be mined by open-pit heap-leach methods.

The lithologic, petrologic, and tectonic characteristics of the greenstone belts are favorable for volcanogenic massive sulfide deposits; however, exploration throughout the Guayana Shield to the present has not identified any base-metal sulfide prospects in the greenstone belts of Venezuela or any massive sulfide deposits elsewhere in the shield (Gibbs and Barron, 1983). The Aremu airstrip prospect in Guyana is a possible massive sulfide deposit (Macdonald, 1968; Barron, 1973). There, a l.6-m-thick horizon containing disseminated pyrite and chalcopyrite averages 0.67 percent copper for a strike length of about $150 \mathrm{~m}$ (Barron, 1973). Mineralized rock pinches out in all directions. This horizon is conformable within a sequence of lava of intermediate composition, tuff, and minor carbonaceous sedimentary rocks (Barron, 1973). Groete Creek in Guyana is possibly a sediment-hosted massive sulfide deposit. Metamorphosed argillite, graywacke, and minor mafic volcanic rocks host a conformable zone of pyrite-chalcopyrite-gold-mineralized rock that has been traced along strike for more than 1,500 m (Macdonald, 1968; Barron, 1973; Fred Barnard, oral commun., 1991). Proven and indicated reserves are about 30 million metric tons having an average grade of about 0.29 percent copper and 0.5-1.0 grams of gold per metric ton (Barron, 1973; Gibbs and Barron, 1993). Vertically dipping, low-grade gold-bearing quartz veins and stringers containing disseminated chalcopyrite (Macdonald, 1968) may represent stockwork feeders below a massive sulfide deposit. Perkoa in Burkina Faso is the only known stratabound polymetallic massive sulfide deposit in Early Proterozoic rocks of West Africa. It contains about 4.5 million metric tons of ore at 17 percent zinc and about 60 grams of silver per metric ton (Milési and others, 1989, 1992). A lead-lead date on galena from the deposit yielded an age of $2,120 \pm 41 \mathrm{Ma}$ (Marcoux and others, 1988). Amphibolite-facies metasedimentary rocks that have been hydrothermally altered and intensely deformed host the two main ore bodies (Ratomaharo and others, 1988; Milési and others, 1989, 1992). The deposit formed in an intercontinental rift or a back-arc basin tectonic setting (Ratomaharo and others, 1988; Milési and others, 1992).

\section{DIAMONDS}

Diamonds are recovered from placer mining operations throughout the Venezuelan Guayana Shield. Production in 1991 totalled 213,557 carats, about 48 percent of which was gem quality and 52 percent industrial quality. Reported 
production in 1992 was 478,000 , about 63 of which percent was gem quality. These totals compare with peak production in 1974 of $1,248,979$ carats, and total production between 1913 and 1992 of 14,917,744 carats, about 27 percent of which was gem quality (Anez, 1985; Baptista and Parra, 1985; Newman, 1989; Ensminger and others, 1990; Ensminger, 1992; Doan, 1994). The Quebrada Grande area (loc. 66, pl. 1) and the San Salvador de Paúl mine (loc. 81) are the largest producers of diamonds. The former accounted for about $3,654,830$ carats between 1975 and 1980 , or 76 percent of all diamond production, whereas the latter totalled about 823,920 carats, or 17 percent of production (Anez, 1985). The majority of deposits are along the Río Caroni (for example, locs. $9,17,18,20,41,80,82,117,118,120,121$, 124, and 146) and along the Río Icabarú and on the south end of the Gran Sabana area (for example, locs. 125-130, 132, 133, and 135-145). All of the diamonds produced thus far have been recovered from placer deposits. Some placer deposits, particularly in the Gran Sabana area, have produced gold as well as diamonds.

Conglomerate in the lower part of the Roraima Group has been proposed as the source of diamonds by many investigators (Pollard and others, 1957; Briceño, 1984; Mendoza, 1985). Reid (1974a) suggested that kimberlite, possibly in Brazil or even West Africa, was the source for the paleoplacer deposits in the Roraina Group. Studies at San Salvador de Paúl (Briceño, 1984) and elsewhere along the Río Caroni and in the Gran Sabana area (Reid, 1974b; Reid and Bisque, 1975; J.C. Dohrenwend, U.S. Geological Survey, 1989, oral and written communs.) confirm that conglomerate of the Uairén Formation within the Early to Middle Proterozoic Roraima Group was the source of the alluvial diamonds. Briceño (1984) stated that conglomerates in the Uairén Formation are themselves paleoplacers and were the source for diamond-bearing gravels deposited about 8,000 years ago at San Salvador de Paúl. These Holocene paleoplacers are the source of diamonds in some deposits in currently mined drainages (Briceño, 1984).

Minerals indicative of kimberlite, such as chrome pyrope and magnesian ilmenite, were identified in the 1970's in stream sediments of the Quebrada Grande area (loc. 66, pl. 1) (Baptista and Svisero, 1978; Meyer and McCallum, 1993). More than a dozen diamond-bearing kimberlitic dikes and sills containing chrome pyrope, titanium-rich phlogopite, chromite, and yimengite $\left(\mathrm{K}(\mathrm{Cr}, \mathrm{Ti}, \mathrm{Fe}, \mathrm{Mg})_{12} \mathrm{O}_{19}\right)$, a rare alteration product of chromite previously recognized only in kimberlite from China, have also been discovered recently (Nixon, 1988; Nixon and Condliffe, 1989; Nixon and others, 1989; Meyer and McCallum, 1993). Leached whole-rock kimberlite samples from the Quebrada Grande area yielded a rubidium-strontium isochron date of about 1,732 $\pm 82 \mathrm{Ma}$ (Nixon and others, 1992). Although neither kimberlite nor its indicator minerals has been identified elsewhere in Venezuela, it is possible that diamond-bearing kimberlite was intruded along north-north- west-striking fractures that extend throughout the westem part of the Guayana Shield in Estado Bolívar, Estado Amazonas, and into Brazil. Sediments of the Roraima Group may have incorporated diamonds from the older Early Proterozoic kimberlite during transport and deposition. Alluvial diamonds mined in Ghana and elsewhere in West Africa are presumed to have a source in rocks of the Early Proterozoic Birimian greenstone belts (Kesse, 1985). Neither kimberlitic rocks nor kimberlitic indicator minerals have been identified; however, highly altered, metamorphosed, and deformed ultramafic rocks within the Birim diamond field in Ghana have major- and trace-element compositions, such as extreme light rare earth element enrichment and lanthanum to lutetium ratios greater than 30 , similar to those published for kimberlite elsewhere (Nixon and others, 1992; McKitrick and others, 1993).

\section{IRON}

Deposits of enriched banded iron formation in the Guayana Shield provide Venezuela with abundant resources of iron. Production of iron ore and concentrate in Venezuela between 1950 and 1992 totalled approximately 650 million metric tons (Suarez and others, 1981; Rodríguez, 1987; Newman, 1989; Ensminger and others, 1990; Ensminger, 1992; Doan, 1994). Four mines were in operation in 1992: Cerro Bolívar (loc. 52, pl. 1), San Isidro (loc. 51), Los Barrancos (loc. 53), and El Pao (loc. 16). Reserves at Cerro Bolívar, San Isidro, Los Barrancos, and the surrounding area are greater than 1,855 million metric tons and have a grade of about 63 percent iron. At a 55 percent cutoff grade, reserves total an additional 8,000-10,000 million metric tons (Rodríguez, 1986, 1987). Deposits containing more than 55 percent iron, such as Cerro Bolívar, Los Barancos, and San Isidro, are generally in hills between 400 and $700 \mathrm{~m}$ above sea level, an elevation that corresponds with the Imataca-Nuria planation surface that developed in the early Tertiary (Menendez and Sarmentero, 1985; Schubert and others, 1986; Briceño and Schubert, 1990). In contrast, deposits at elevations less than $400 \mathrm{~m}$ are small and have grades of less than 55 percent iron (Rodríguez, 1986; Marcano and others, 1989).

The beds of banded iron formation are associated with the Archean Imataca Complex. The complex consists of amphibolite- to granulite-facies metasedimentary and metaigneous rocks comprising more than 80 percent quartzofeldspathic gneiss and granulite, $10-15$ percent intermediate to mafic gneiss, granulite, and charnockite, 1 percent metamorphosed banded iron formation, and minor dolomitic marble and anorthosite (Dougan, 1976; Sidder and Mendoza, this volume). Protoliths of the Imataca Complex are possibly as old as 3,700-3,400 Ma (Montgomery and Hurley, 1978). The beds of banded iron formation vary in primary stratigraphic thickness from a few centimeters to 
$10 \mathrm{~m}$ and uncommonly to $200 \mathrm{~m}$. Folds and reverse faults have produced an apparent thickness of the banded iron formation of as much as $350 \mathrm{~m}$ (Ruckmick, 1963; Ferencic, 1969). Some individual beds extend for $20 \mathrm{krn}$ along strike, such as at Cеrro Bolívar. The entire stratigraphic sequence of the Imataca Complex has been isoclinally folded, and enriched banded iron formation ore generally occupies the limbs and centers of synclines (Ferencic, 1969). Oxide-facies banded iron formation is predominant; hematite and magnetite are the dominant iron minerals in the oxide facies (Ruckmick, 1963; Ferencic, 1969). The iron-rich beds are intimately interbedded with layers of silica, present as quartz, and iron-bearing silicate minerals such as greenalite, grunerite, cummingtonite, chlorite, and sericite. Enriched ore is composed predominantly of goethite and limonite and minor hydrohematite or turgite $\left(\mathrm{Fe}_{2} \mathrm{O}_{3} \cdot \mathrm{nH}_{2} \mathrm{O}\right)$ (Ferencic, 1969; Gruss, 1973; Ascanio, 1985; Moreno and Bertani, 1985a; Bertani and Moreno, 1989; Marcano and others, 1989).

Banded iron formation in the Imataca Complex is commonly compared to deposits of Superior-type banded iron formation (Cannon, 1986a), such as those in the Lake Superior region of the United States, at Minas Gerais in Brazil, and in the Hamersley Range of Australia (Ruckmick, 1963; Kalliokoski, 1965; Ferencic, 1969; Gruss, 1973; Sidder, 1991). Indeed, Superior-type banded iron formation and banded iron formation in the Imataca Complex have many similarities. For example, the primary stratigraphic thickness of banded iron formation at Cerro Bolívar and San Isidro is from less than 5 to $200 \mathrm{~m}$, minor horizons of banded iron formation about $2 \mathrm{~m}$ thick are interlayered with metasedimentary rocks, and the banded iron formation is thinly laminated and banded (Ruckmick, 1963; Ferencic, 1969). Differences with Superior-type banded iron formation and similarities to Algoma-type banded iron formation (Cannon, 1986b) are also present. For example, strike lengths of banded iron formation in the Imataca Complex are generally $20 \mathrm{~km}$ or less (Ferencic, 1969; Gruss, 1973), and, most importantly, banded iron formation at Cerro Bolivar is interpreted to be interbedded with metavolcanic rocks, not metasedimentary rocks (Dougan, 1977). In addition, laminated calc-silicate quartzite is associated with laminated quartz-magnetite and orthopyroxene-quartz-magnetite iron formation near Cerro Bolívar (Dougan, 1977). The calcareous rocks may represent carbonate-facies banded iron formation or carbonate alteration in banded iron formation. Algoma-type banded-iron-formation-hosted gold deposits are commonly associated with carbonate-facies rocks (Phillips and others, 1984); however, banded iron formation in the Imataca Complex is reportedly gold poor (Engineering and Mining Journal, 1987), and the metavolcanic rocks are subaerial, calc-alkaline, felsic continental arc rocks, not stbmarine mafic to felsic island arc or oceanic rocks (Dougan, 1977). Hence, banded iron formation in the Imataca Complex is predominantly Superior type, although some Algoma-type banded iron formation may be present. Both types of banded iron formation have been identified in Archean rocks correlative to the Imataca Complex in the Reguibat and Leo Shields of the West African craton (Rocci and others, 1991).

Ascanio (1985) divided iron ore deposits in the Imataca Complex into three groups on the basis of grain size of the banded iron formation: (1) coarse grained (>1 mm), (2) medium grained (about $1 \mathrm{~mm}$ ); and (3) fine grained $(<1$ $\mathrm{mm}$ ). Coarse-grained deposits include El Pao (loc. 16, pl. 1), Las Grullas (loc. 10), and Piacoa (loc. 7); Cerro Maria Luisa (loc. 19) is a medium-grained deposit; and Cerros Bolívar, San Isidro, Los Barrancos, El Trueno (loc. 59), Altamira (loc. 49), Redondo (loc. 47), Toribio (loc. 46), Arimagua (loc. 45), and others in the immediate area of Cerro Bolívar are fine-grained deposits. These three types of deposits are separated geographically; coarse-grained deposits are north of the El Pao fault toward the east, medium grained deposits are between the EI Pao and Río Carapo faults, and fine grained deposits toward the west are south of the Río Carapo fault. It is likely that the grade of metamorphism affected the grain size of the banded iron formation protore, and subsequently that of the enriched ore, because both grade and grain size decrease toward the west (Gruss, 1973). Alternatively, differential erosional stripping that resulted from Cenozoic block uplift may have exposed ore at different levels in the complex (Olmore and others, 1993). For example, fresh fault scarps along the El Pao fault near El Pao indicate that recent vertical movement took place along an older, reactivated fault (Short and Steenken, 1962).

Deposits of Algoma-type banded iron formation (Cannon, 1986b) may be present in the Early Proterozoic greenstone belts. Reports of "ferruginous quartzite," "hematitic-manganiferous siliceous shale," and "jasper" in volcano-sedimentary sequences of turbiditic graywacke and felsic to intermediate tuffs (Menendez, 1968; Aguilar, 1972; Lira and others, 1985) indicate that this deposit type may be present. Early Proterozoic banded iron formation is present in greenstone-belt rocks in Suriname, Guyana, and Brazil (Gibbs and Barron, 1993). Gold is commonly associated with this type of banded iron formation (Cannon, 1986b), as previously noted. Early Proterozoic banded iron formation within greenstone belts (Algoma type) in West Africa is the source of some alluvial and eluvial gold (Milési and others, 1992). Manganese-rich rocks and other chemical sediments are important exploration guides for gold deposits in the Early Proterozoic rocks of the greenstone belts in Ghana (Leube and others, 1990). The manganese deposits are on the flanks of the volcanic belts and in transition zones from volcanic rocks to basinal sediments. These transition zones, or breaks, are characterized by chemical sediments such as chert, iron-magnesium carbonate, and carbon-rich argillite and are the foci for the gold deposits (Leube and others, 1990; Milési and others, 1992). As in the Guayana Shield, however, the West African craton is poor in banded iron formation (Milési and others, 1992). 
Iron-rich deposits of Early and Middle Proterozoic age (1.89-1.45 Ma) such as Kiruna, Sweden, Pea Ridge and others in the St. Francois terrane, Missouri, and Olympic Dam, Australia, are associated with subalkalic to alkalic, metaluminous to peraluminous granite-rhyolite terranes (Meyer, 1988; Sims and others, 1987, 1988). Hematite, apatite, pyrite, barite, fluorite, quartz, sericite, monazite, actinolite, and chlorite are commonly intermixed in varying amounts with the magnetite ore, and $\mathrm{Au}, \mathrm{Ag}, \mathrm{Cu}, \mathrm{U}, \mathrm{Th}$, light rare earth elements, $\mathrm{P}, \mathrm{Ba}$, and $\mathrm{F}$ are typically enriched in anomalous to economic concentrations. These Olympic Dam-type iron-copper-uranium-gold-rare earth element magmatic-hydrothermal deposits are genetically related to magmas, especially those of intermediate to mafic composition, that formed the granite-rhyolite terrane (Sidder and Day, 1993; Sidder and others, 1993). The similarities in age, composition, and tectonic environment between the Early Proterozoic Cuchivero Group and Middle Proterozoic ( 1,545 Ma) Parguaza Granite in Venezuela and the granite-rhyolite terranes of the St. Francois Mountains and Olympic Dam area suggest that Olympic Dam-type deposits are a possible exploration target in the Venezuelan Guayana Shield. A highly magnetic area and a superimposed uranium anomaly detected in aeromagnetic and aeroradiometric data over the Parguaza Granite in Estado Bolívar (lat $5^{\circ} 10^{\prime} \mathrm{N}$., long 64 $20^{\prime}$ W.) (Wynn, 1993) is a good site to investigate.

\section{ALUMINUM}

The development of bauxite ore and processing of alumina in Venezuela currently represents the second largest source of foreign currency revenue after petroleum (Newman, 1988; Ensminger, 1992; Doan, 1994). The production of alumina totalled $1,295,000$ metric tons in 1991 and a reported 1,308,000 metric tons in 1992 (Doan, 1994); production of aluminum metal as unalloyed ingot totalled 600,544 metric tons and a reported 561,354 metric tons in 1991 and 1992, respectively, (Doan, 1994). Bauxite production has increased from 245,157 metric tons in 1987 to a reported 1,052,052 metric tons in 1992 (Ensminger, 1992; Doan, 1994). The principal deposits of bauxite are at Los Pijiguaos (loc. 64, pl. 1), Upata (loc. 15), Nuria (loc. 22), Los Guaicas (loc. 79), and in the Gran Sabana (loc. 105-107, 131).

Deposits of bauxite and aluminum-rich laterite are products of intense weathering of granitic, gabbroic, and diabasic rocks in the Guayana and West African Shields. The deposit of bauxite at Los Pijiguaos developed on the Middle Proterozoic Parguaza rapakivi granite (Moreno and Bertani, 1985b). The protolith granitic rocks contain from 65 to 73 percent $\mathrm{SiO}_{2}$ and from 13.5 to 15 percent $\mathrm{Al}_{2} \mathrm{O}_{3}$. Mining started at Los Pijiguaos in 1987, and Bauxita Venezolana, C.A., (BAUXIVEN) produced about 245,157 metric tons of ore. BAUXIVEN produced a reported 771,422 metric tons of bauxite in 1990 (Ensminger, 1992). Upgrade of the mine facilities has increased capacity to 6 million metric tons per year, and projected capacity is 8 million metric tons per year (Doan, 1994). Initial measured and indicated reserves of bauxite were 201.8 million metric tons averaging 48.7 percent $\mathrm{Al}_{2} \mathrm{O}_{3}$ and 10.9 percent $\mathrm{SiO}_{2}$. These reserves included 70.1 million metric tons averaging 51.8 percent $\mathrm{Al}_{2} \mathrm{O}_{3}$ and 6.4 percent $\mathrm{SiO}_{2}$ (Menendez and others, 1985). Newman (1989) reported that proven (200 million metric tons) and probable (500 million metric tons) reserves of 700 million metric tons are present in the Los Pijiguaos area. Three new bauxite deposits on the Parguaza Granite were discovered in 1989 between the Los Pijiguaos mine and Puerto Ayacucho ол the Río Orinoco (Ensminger, 1992). The average thickness of ore at Los Pijiguaos is about $7.5 \mathrm{~m}$, and overburden, where present, is less than $1 \mathrm{~m}$ thick. Gibbsite is the dominant ore mineral, and lesser amounts of kaolinite are present. The ratio of gibbsite to kaolinite decreases with depth.

The richest ore at Los Pijiguaos is at an erosional level known as the Imataca-Nuria erosion surface between 620 and $690 \mathrm{~m}$ above sea level that formed during an intense weathering cycle in the early Tertiary (Short and Steenken, 1962; Menendez and Sarmentero, 1985; Schubert and others, 1986). This weathering cycle corresponds to the cycle that formed the enriched iron ore at Cerro Bolívar, San Isidro, Cerro Altamira, and other deposits of enriched banded iron formation, as well as the bauxite deposits at Nuria, Upata, and Los Guaicas. It also correlates with a bauxite event elsewhere in South America, as well as in West Africa and India (Prasad, 1983). Structural and topographic features such as joints, fractures, and steepness of slope control the enrichment of $\mathrm{Al}_{2} \mathrm{O}_{3}$ and depletion of $\mathrm{SiO}_{2}$ in the granitic rocks (Moreno and Bertani, 1985b; Lo Monaco and Yanes, 1990). Those ore zones most enriched in alumina and depleted in silica correlate with zones of highest fracture density. A slope between $2^{\circ}$ and $10^{\circ}$ is most favorable for formation of ore because the thickness of ore and intensity of silica leaching are more affected by the slope than the degree of alumina enrichment (Moreno and Bertani, 19́85b).

The Upata district (loc. 15, pl. 1) contains 13 deposits of bauxite, 5 of which are possibly economic (Candiales, 1961). These include El Chorro, La Mesa de la Carata, El Baúl, Los Guamos, and Cerro Once. El Chorro has reserves of $1,259,250$ metric tons, and the other four have combined reserves of 2,904,666 metric tons. The grade varies from 39 to 67 percent $\mathrm{Al}_{2} \mathrm{O}_{3}$, from 3 to 29 percent $\mathrm{Fe}_{2} \mathrm{O}_{3}$, and from less than 1 to 23 percent $\mathrm{SiO}_{2}$. The ore is apparently a weathering product of gabbro or amphibolite (Candiales, 1961). A large-tonnage, low-grade bauxite deposit that has a high silica content recently has been discovered north of El Palmar on the Palsapa Plateau (Vicente Mendoza, written commun., 1992).

Nuria is a high plateau that forms an amphitheater and has a flat center and an elevated ringlike perimeter. The hills 
are between 600 and $700 \mathrm{~m}$ in altitude. Granitic gneiss comprises the central part of the structure, and diabase and gabbro forn the peripheral hills. Intense chemical weathering enriched the mafic rocks in alumina and formed a low-grade ore deposit. The total of measured, indicated, and inferred reserves is 50 million metric tons containing 37.5 percent $\mathrm{Al}_{2} \mathrm{O}_{3}, 28.9$ percent $\mathrm{Fe}_{2} \mathrm{O}_{3}$, and 8.7 percent $\mathrm{SiO}_{2}$ (Candiales, 1961; Bellizzia and others, 1981).

Deposits of aluminum-rich laterite and locally bauxite at Los Guaicas and in the Gran Sabana are weathering products of Proterozoic and possibly Mesozoic diabasic intrusive rocks (Bellizzia and others, 1981; Rodríguez, 1986). These deposits are relatively low in grade (about 35 percent $\mathrm{Al}_{2} \mathrm{O}_{3}$, 30-40 percent $\mathrm{Fe}_{2} \mathrm{O}_{3}$, and 3-9 percent $\mathrm{SiO}_{2}$ ) and generally small (much less than 100 million metric tons). The deposit at Los Guaicas contains 3.1 percent $\mathrm{TiO}_{2}$ (Bellizzia and others, 1981). The erosion surface in the Gran Sabana area, at altitudes between 900 and $1,200 \mathrm{~m}$, is called the Kamarata or Wonkén surface and is tentatively correlated with the Kanuku surface in Guyana, which developed during or prior to the Jurassic (Menendez and Sarmentero, 1985; Briceño and Schubert, 1990).

\section{MANGANESE}

Secondarily enriched deposits of manganese are associated with rocks of the Early Proterozoic greenstone belts and with banded iron formation of the Archean Imataca Complex. Deposits at San Cristobal (loc. 23, pl. 1) and La Esperanza (loc. 56) are in the area of outcrop of greenstone-belt rocks, and those at El Palmar (loc. 11), Guacuripia (loc. 12), El Manganeso (loc. 14), Upata (loc. 15), and El Pao (loc. 16) are within the Imataca Complex (Bellizzia and others, 1981).

Manganese deposits at San Cristobal are secondarily enriched residual accumulations (Aguilar, 1972). Metamorphosed manganiferous chert and siliceous manganiferous rocks of sedimentary-volcanogenic origin that have been correlated with the Caballape Formation of the Early Proterozoic Botanamo Group form the protore. These rocks are intercalated with beds of ferruginous quartzite, dark-gray phyllite, greenish chloritic phyllite, bluish-gray kaolinitic argillite, and siltstone. The beds of siliceous manganiferous rocks are from 0.2 to $2.0 \mathrm{~m}$ in thickness, and beds of metachert are as thick as $15 \mathrm{~cm}$. The protore consists of manganese silicate minerals, and enriched secondary ore contains psilomelane, pyrolusite, cryptomelane, wad (an impure, amorphous mixture of manganese oxide and oxides of other elements such as copper, cobalt, and silica), and spessartine. Samples of siliceous manganiferous protore and metachert contain 17.93 and 6.87 percent $\mathrm{MnO}$, respectively, whereas residual secondary ore contains about 50 percent $\mathrm{MnO}$. Aguilar (1972) determined that the poorly developed weathering profile and the thinness of the beds make these deposits subeconomic. Manganese prospects in the San Cristobal area are similar to and possibly a continuation of ore-bearing strata at Matthews Ridge in Guyana (Holtrop, 1965; Carter and Fernandes, 1969; Gibbs and Barron, 1993). Enriched spessartite-bearing ore at Matthews Ridge is interlayered with metachert, quartzite, and sericite or carbonaceous schist, (Holtrop, 1965). Braunite ore and manganite are also present at Matthews Ridge. Isoclinal folding and later crossfolds are the principal controls of the secondary ore at Matthews Ridge (Gibbs and Barron, 1993). Serra do Navio in Brazil is the largest manganese deposit in the Guayana Shield and has measured reserves of 15.7 million metric tons at 39.3 percent $\mathrm{MnO}_{2}$ and total reserves of 20.1 million metric tons (Nagell, 1962; Damasceno, 1982; Schobbenhaus and others, 1984). Amphibolite-facies quartz-biotite-garnet schist of the Vila Nova Group hosts the protore manganiferous carbonate and gondite. Graphite and iron and copper-iron sulfide minerals such as pyrite, pyrrhotite, chalcopyrite, and bornite are associated with the rhodochrosite and spessartite-bearing protore horizons. Enrichment of the protore by weathering and oxidation has formed secondary oxide ore containing pyrolusite and cryptomelane (Nagell, 1962; Holtrop, 1965; Damasceno, 1982; Gibbs and Barron, 1993). Manganiferous beds and manganese deposits such as Nsuta in Ghana, Tambao in Burkina Faso, and Ziémougoula in the Ivory Coast are present in the greenstone belts of the West African Shield (Milesi and others, 1992). Reserves at Nsuta are about 5 million metric tons of oxide ore at 48.9 percent manganese and about 28 million metric tons of carbonate ore at 15.3 percent manganese (Kesse, 1985; Milési and others, 1992). Manganiferous phyllite, schist, and carbonate are the host rocks at Nsuta, and nickeland cobalt-bearing sulfide minerals such as millerite, linnaeite, and pentlandite are associated with the manganese ore. The presence of tholeiitic volcanic rocks and siliceous beds in the Nsuta area suggests that the manganese ore is sedimentary-volcanogenic in origin (Sidder, 1991; Milési and others, 1992).

Beds of manganiferous rocks in the Upata-El Palmar-Guacuripia area are interstratified with rocks of the Imataca Complex. These beds crop out within a stratigraphic sequence that is less than $500 \mathrm{~m}$ thick, and they have strike lengths of about $20 \mathrm{~km}$ (Drovenik and others, 1967). Individual manganiferous beds are generally less than $10 \mathrm{~m}$ thick. Manganese protore, which contains from 11 to about 30 percent $\mathrm{MnO}$, is typical of gondite, a metamorphic rock containing spessartine and quartz that is derived from manganese-bearing rocks. The protore consists of spessartine garnet, quartz, and graphite and rhodonite-spessartine-rich rocks. These rocks are associated with quartzite, ferruginous quartzite, quartz-biotite schist, amphibole-bearing schist, and feldspathic gneiss that commonly contains cordierite and sillimanite. Dolomitic marble containing as much as 4 percent $\mathrm{MnO}$ also is present in the stratigraphic sequence and is commonly in direct contact with manganese-rich horizons as at Guacuripia (Drovenik and others, 
1967). Sulfide minerals such as pyrrhotite, pyrite, chalcopyrite, sphalerite, valeriite $\left(2(\mathrm{Fe}, \mathrm{Cu})_{2} \mathrm{~S}_{2} \cdot 3(\mathrm{Mg}, \mathrm{Al})(\mathrm{OH})_{2}\right)$, and millerite (NiS) make up as much as 2 modal percent in gondite as small grains from 0.001 to $0.15 \mathrm{~mm}$ in diameter. Beds of manganese protore in the Upata-El Palmar-Guacuripia area are not intimately associated with banded iron formation; however, banded iron formation deposits at El $\mathrm{Pao}$ and Los Barrancos are enriched in manganese and contain as much as 34 percent manganese and $4-16$ percent $\mathrm{MnO}_{2}$, respectively (Drovenik and others, 1967). Drovenik and others (1967) concluded that the sedimentary-nonvolcanogenic manganese deposit model best represents the protore manganese mineralization in the Imataca Complex; however, the lack of manganese carbonate ore minerals and the absence of metapelitic rocks suggest that some of the gneissic sequence may have an igneous protolith of felsic to intermediate volcanic rocks (Dougan, 1977), rather than a sedimentary protolith. Thus, the sedimentary-volcanogenic manganese model (Sidder, 1991) or the Cuban-type volcanogenic manganese model (Mosier and Page, 1988) may characterize some of the manganese deposits in the Imataca Complex.

Manganese orebodies in the Upata-El Palmar-Guacuripia area are secondarily enriched. Ore consists of manganese, iron oxide, and iron oxide and hydroxide minerals such as cryptomelane, psilomelane, pyrolusite, goethite, lithiophorite $\left[(\mathrm{Al}, \mathrm{Li}) \mathrm{MnO}_{2}(\mathrm{OH})_{2}\right]$, and nsutite (or gamma- $\mathrm{MnO}_{2}$ ) [ $\left.\left(\mathrm{Mn}_{1-\mathrm{x}}{ }^{+4} \mathrm{Mn}_{\mathrm{x}}{ }^{+2} \mathrm{O}_{2-2 \mathrm{x}}(\mathrm{OH})_{2 \mathrm{x}}\right)\right]$ (Drovenik and others, 1967). These minerals are associated with quartz and silicate minerals such as spessartine and mica and clay minerals. Minor amounts of hypogene minerals such as magnetite, mangano-magnetite, spessartine, rhodonite, braunite, hausmannite, and traces of rhodochrosite are also present. Four types of ore have been recognized: (1) earthy, (2) hard, (3) pisolitic; and 4) detrital. The first two types form beds that have relict protore textures, whereas the latter two are only present at the surface. Estimated total reserves in the area are 434,000 metric tons of earthy ore that averages 25 percent manganese, 25 percent iron, and 10 percent $\mathrm{SiO}_{2} ; 21,700$ metric tons of high-grade (46-48 percent manganese), hard metallurgical ore; 441,000 metric tons of pisolitic ore that averages 20.9 percent manganese, 17.8 percent iron, 12.41 percent $\mathrm{SiO}_{2}$, and 14.63 percent $\mathrm{Al}_{2} \mathrm{O}_{3}$; and 104,910 metric tons of detrital clastic ore that averages 27.96 percent manganese, 14.97 percent iron, and 13.49 percent $\mathrm{SiO}_{2}$ (Drovenik and others, 1967). These ores do not constitute a large resource. Some of these deposits have been mined in small quantities during the past 20 years.

The manganese prospects at La Esperanza are similar to those at San Cristobal. The protore in bedded manganiferous quartzite (apparently metachert of exhalative origin) has been secondarily enriched to form a residual deposit that contains reserves of about 40,000 metric tons of relatively low grade ore that averages about 20-30 percent $\mathrm{MnO}$ (Martin, 1976; Bellizzia and others, 1981).

\section{TIN}

Placer, eluvial, and lode prospects of cassiterite and tantalum-, niobium-, zirconium-, and titanium-bearing minerals have been identified in the extreme western part of Estado Bolivar and in Estado Amazonas. The best studied area is that surrounding Caño Aguamena (loc. 63, pl. 1), where a sequence of highly weathered complex pegmatite dikes, quartz veins, and aplite cuts the Middle Proterozoic (about $1.55 \mathrm{Ga}$ ) Parguaza Granite, near or along large regional north-northwest-striking faults (Gaudette and others, 1978; Rodríguez and Perez, 1982; Perez and others, 1985). The granite is massive, unmetamorphosed, coarsely crystalline, porphyritic with rapakivi (wiborgite-type) texture, and apparently anorogenic in origin. The Parguaza Granite correlates in age and composition with granite in the Surucucus area of northernmost Brazil and may correlate with granite in the Agua Boa batholith in northern Brazil (Dall'Agnol and others, 1994). The Surucucus granite has rapakivi texture, formed about $1.6-1.5 \mathrm{Ga}$, and has potential reserves of 20,000 metric tons of tin (Schobbenhaus and others, 1984; Jones and others, 1986; Dall'Agnol and others, 1994). Pitinga, one of the world's largest tin mines, is in the Agua Boa batholith and has measured placer reserves, as of 1984 , of about 60,000 metric tons of tin and measured lode reserves of 143,000 metric tons of tin; total measured, indicated, and inferred placer and lode reserves are 98,000 and 171,000 metric tons of tin, respectively (Schobbenhaus and others, 1984; Daoud and Antonietto, 1985, 1988; Damasceno, 1988; Thorman and Drew, 1988). Pegmatites and quartz veins in the Caño Aguamena area host the mineralized lode prospects identified thus far (Rodríguez and Perez, 1982; Perez and others, 1985), unlike the lode ore at Pitinga, which is hosted by greisenized granite (Daoud and Antonietto, 1985, 1988; Horbe and others, 1985, 1991; Gibbs and Barron, 1993). Neither hydrothermal alteration nor greisenization of granite have been detected in the Caño Aguamena area. Minerals in the pegmatites and quartz veins include cassiterite, tantalum-rich rutile or struverite, tantalum-niobium-iron-manganese-bearing rutile, tantalite-columbite, and stanniferous tantalite or ixiolite (Aarden and Davidson, 1977). In addition, hafnium-rich zircon, simpsonite $\left(\mathrm{Al}_{4}(\mathrm{Ta}, \mathrm{Nb})_{3}(\mathrm{O}, \mathrm{OH}, \mathrm{F})_{14}\right)$, and a uranium-bearing lead tantalate mineral are present as inclusions in rutile. Tungsten-bearing minerals and sulfide minerals have not been observed in any samples. Although resources of tin or other metals have not been defined to date, analyses of shallow drill holes in hills near Caño Aguamena indicate that 11-13 $\mathrm{kg}$ of heavy minerals per cubic meter are present and contain $0.01-0.77$ percent tin, 0.01-0.23 percent niobium, 1.8-29.0 percent titanium, and 0.5-11.1 percent zirconium (Perez and others, 1985). Exploration continues throughout Estado Amazonas and westem Estado Bolívar for secondary alluvial and eluvial deposits, as well as for primary pegmatite- or granite-hosted deposits (Rodríguez and Perez, 1982). 
At Alto Paragua (loc. 149, pl. 1), cassiterite is in peraluminous, high-silica rhyolite of the Early Proterozoic Caicara Formation of the Cuchivero Group and in panned concentrates. Cassiterite, barite, apatite, and copper-bearing pyrite are small (as much as $8 \mu \mathrm{m}$ by $4 \mu \mathrm{m}$ ) disseminated grains in rhyolitic tuff; several grains of cassiterite were present in heavy-mineral samples collected from creeks that drain into the Río Paragua (Sidder 1990). Geochemically anomalous concentrations of tin in panned-concentrate, stream-sediment, and whole-rock samples in the upper Río Paragua area (Sidder and others, 1991) are typical of rhyolite-hosted tin deposits (Duffield and others, 1990). Granitic rocks of the Uatumã magmatic event, such as the Mapuera and the Maloquinha suites in Brazil, host some tin prospects and deposits and are correlative with plutonic rocks of the Cuchivero Group in Venezuela (Damasceno, 1988).

\section{NIOBIUM, TANTALUM, AND RARE EARTH ELEMENTS}

Some prospects of niobium, tantalum, and rare earth elements are associated with complex pegmatites in the Parguaza Granite (pl. 1, loc. 63, prospect near Caño Aguamena), as discussed in the section on tin, and with pegmatites in the Imataca Complex (pl. 1, prospects near Ciudad Bolívar). The richest resource of rare earth elements, niobium, thorium, and barium in Venezuela is Cerro Impacto (loc. 67).

The Cerro Impacto prospect is interpreted to be a deeply weathered carbonatite (Aarden, Iturralde de Arozena, Navarro, and others, 1978). The carbonatite is associated with an oval ring structure about $10 \mathrm{~km}$ in diameter. A thick lateritic cover at Cerro Impacto that extends to at least $200 \mathrm{~m}$ depth does not retain any traces of the original rock (Garcia and Aarden, 1977). The laterite is enriched in iron (as much as 61 weight percent), manganese (as much as 35 weight percent), aluminum (as much as 25 weight percent), barium (as much as 58 weight percent), thorium (as much as 0.5 weight percent), niobium (as much as 1.5 weight percent), rare earth elements (as much as 7 weight percent cerium, 3 weight percent lanthanum, and 0.8 weight percent neodymium), titanium (as much as 7 weight percent), zinc (as much as 0.8 weight percent), lead (as much as 0.5 weight percent), and other elements. Rocks that crop out in the area immediately surrounding the enriched laterite are alkalic granite, monzonite, granodiorite, quartz diorite, tonalite, and gabbro, some of which are fenitized. Fragments from the bottom part of some drill holes consist of fenitized rock, barite, and quartz pseudomorphs after carbonate crystals. Other minerals and mineral fragments in the laterite include goethite, pyrolusite, wad, gibbsite, kaolinite, gorceixite $\left(\mathrm{BaAl}_{3}\left(\mathrm{PO}_{4}\right)_{2}(\mathrm{OH})_{5} \mathrm{H}_{2} \mathrm{O}\right)$, goyazite $\left(\mathrm{SrAl}_{3}\left(\mathrm{PO}_{4}\right)_{2}(\mathrm{OH})_{5} \mathrm{H}_{2} \mathrm{O}\right)$, florencite $\left(\mathrm{CeAl}_{3}\left(\mathrm{PO}_{4}\right)_{2}(\mathrm{OH})_{6}\right)$, bastnaesite $\left[(\mathrm{Ce}, \mathrm{La}) \mathrm{CO}_{3}(\mathrm{~F}, \mathrm{OH})\right]$, and monazite (Aarden,
Holm, and others, 1978; Aarden, Iturralde de Arozena, Moticska, and others, 1978). These characteristics suggest that an intensely weathered carbonatite is present at Cerro Impacto.

The Cerro Impacto complex is in proximity to large northwest-striking fractures. These fractures may be extensions of those along which kimberlite intruded in the Quebrada Grande area (loc. 66, pl. 1) northwest of Cerro Impacto, and they are parallel with large regional fractures that apparently controlled emplacement of pegmatitic dikes into the Parguaza Granite. These fractures extend throughout the western part of the Guayana Shield in Estado Bolivar, Estado Amazonas, and into Brazil.

The age of intrusion of Cerro Impacto is unknown. Mendoza and others (1977) suggested that the carbonatitic complex intruded plutonic rocks of the Cuchivero Group during the Mesozoic between 150 and $80 \mathrm{Ma}$; however, the date of about 1,732 $\pm 82 \mathrm{Ma}$ reported by Nixon and others (1992) for kimberlite in the Quebrada Grande area suggests that the carbonatite at Cerro Impacto may be much older than Mesozoic. Cerro Impacto may correspond in age with Early Proterozoic kimberlite.

\section{URANIUM}

Reconnaissance geologic and airborne geophysical investigations for uranium in the Guayana Shield have detected numerous areas that have anomalously high radiometric signatures (Pasquali, 1981). The most notable anomalies in Venezuela are associated with the Churuata ring structure in Estado Amazonas, with gneiss of the Imataca Complex, and with conglomerate of the Roraima Group. Two unnumbered prospects in Estado Amazonas (pl. 1) were identified from airborne radiometric anomalies and are possibly related to the Parguaza Granite or to rocks of the Cuchivero Group (U.S. Geological Survey and Corporación Venezolana de Guayana, Técnica Minera, C.A., 1993). Viable resources of uranium have not been identified to date elsewhere in the shield; the only identified occurrences in the West African Shield are associated with pegmatite (Kesse, 1985).

The Churuata ring structure (loc. 152) is an Early (?) to Middle (?) Proterozoic alkalic complex that intrudes sedimentary rocks of the Roraima Group (Soares, 1985). Plutonic rocks of the ring structure, which include syenite, quartz syenite, nepheline syenite, granite, and alaskite, are deeply weathered. Whole-rock rubidium-strontium isochrons for granite and syenite in the complex yielded dates of 1,318 $\pm 41 \mathrm{Ma}$ and 1,274 $\pm 34 \mathrm{Ma}$, respectively; potassium-argon analyses of amphibole and nepheline in syenite yielded dates of $1,288 \pm 40 \mathrm{Ma}$ and $1,230 \pm 40 \mathrm{Ma}$, respectively. These dates may be reset ages because many rubidium-strontium and potassium-argon analyses in the westem part of the shield yield dates of about $1,200 \pm 100 \mathrm{Ma}$ for 
Archean and Early Proterozoic rocks due to the Nickerie orogeny (Kroonenberg, 1982; Sidder and Mendoza, this volume). The concentration of uranium in whole-rock samples is from less than 1 to $165 \mathrm{ppm}$, and thorium is from 8 to 560 ppm. Uranium-bearing minerals have not been observed, but uranium is probably associated with refractory minerals such as zircon or monazite. Other elements such as tin, lanthanum, yttrium, arsenic, lead, zinc, tungsten, zirconium, titanium, rubidium, and niobium are enriched in eluvial and alluvial material (Soares, 1985).

Anomalous radioactivity related to gneiss of the Imataca Complex and conglomerate of the Roraima Group has been detected during ground reconnaissance surveys (Pasquali, 1981). For example, samarskite was observed in pegmatitic phases of granitic migmatite within the Imataca Complex (Dougan, 1975). Analysis of samarskite in pegmatitic veinlets that cut rocks of the Imataca Complex indicated 230 ppm equivalent uranium (Wyant and others, 1953). Chip samples of granitic gneiss contained 50 ppm equivalent uranium. Although these observations are of scientific interest, they have not led to the discovery of any uranium prospects. If, however, the Imataca Complex is slightly enriched in uranium, its rocks may have served as a source to as yet undiscovered deposits in younger sedimentary rocks within the Orinoco Ваsin or in small intracratonic basins on the Guayana Shield (Audemard, 1977).

Anomalous radioactivity has been measured in rocks of the Roraima Group at the southern end of the Gran Sabana between Santa Elena de Uairén and Icabarú (loc. 139, pl. 1) (Brooks and Nuñez, 1991). The apparent similarity between basal quartz-pebble conglomerate of the Roraima Group and gold-uranium-bearing quartz-pebble conglomerates of the Witwatersrand, South Africa, Jacobina, Brazil, and Blind River, Canada, and the reported presence of authigenic pyrite (Gallagher, 1976; Bellizzia and others, 198.1) led to the proposal that the basal conglomerate of the Roraima Group is a viable exploration target for gold and uranium deposits, as well as a possible source for younger alluvial deposits (Mendoza, 1985). Rocks of the Roraima Group are, however, significantly younger (about $1,900-1,500 \mathrm{Ma}$ ) than the Early Proterozoic and Archean (3,100-2,200 Ma) gold-uranium deposits and were deposited under a more oxygenated atmosphere. Uranium potential in the Roraima Group is low.

Although pre-Roraima metasedimentary rocks such as the Los Caribes and Cinaruco Formations are lithologically similar to those of the Roraima Group and may represent the same environments of deposition (Ghosh, 1985), the Los Caribes Formation is unexplored, and its mineral potential is unknown. Equivalent Early Proterozoic metasedimentary rocks of the Tarkwaian Series in the West African craton host gold-bearing paleoplacer deposits (Black, 1980; Norman and Appiah, 1989; Milési and others, 1991; Eisenlohr and Hirdes, 1992). Uranium has not been identified in the Tarkwa-type gold deposits. The Tarkwaian-hosted paleo- placer deposits were concentrated and subsequently deformed during the Ebumean orogeny; however, the source of the Tarkwaian-hosted gold deposits is unknown (Milési and others, 1991; Eisenlohr, 1992).

\section{MOLYBDENUM}

Molybdenite has rarely been reported in any descriptions of mineral prospects or deposits in the Venezuelan Guayana Shield. Molybdenum is uncommonly associated with tin in pegmatite within the Parguaza Granite and as a trace metal associated with vanadium, gallium, and tin at Cerro Impacto (Bellizzia and others, 1981). Molybdenite has recently been reported as an accessory ore mineral in the Kilometer 88 district, and molybdenum is present at ore grade together with gold, copper, and silver (The Mining Record, 1992). The molybdenum prospects shown on plate 1 are taken from the metallogenic maps of Venezuela (Rodríguez and others, 1976; Bellizzia and others, 1980) and are identified as minor isolated veins that cut Middle Proterozoic granitic rocks (probably of the Early Proterozoic Cuchivero Group or the Middle Proterozoic Parguaza Granite).

Mendoza and others (1977) reported that molybdenite is relatively common in contact zones between felsic volcanic rocks and biotite granite of the Cuchivero Group in Estado Amazonas, but did not identify locations of particular prospects. In northern Brazil, molybdenite is disseminated in biotite granite and in small quartz veins at faulted contacts between granite and volcanic rocks of the Surumu Formation (equivalent to the Caicara Formation) (Montalvao and others, 1975; Schobbenhaus and others, 1984). Field and geochemical evidence (Montalvao and others, 1975; Mendoza and others, 1977; Sidder, unpublished data, 1988) indicates that the shallow porphyritic granitic bodies that cut volcanic rocks of the Caicara Formation in westem Estado Bolívar and Estado Amazonas and their equivalents in Brazil are favorable for porphyry copper-molybdenum-type deposits.

\section{TITANIUM}

Ilmenite and rutile are abundant in heavy-mineral concentrates from numerous rivers in the Guayana Shield; however, commercial amounts of titanium have not been produced. Río Nichare (loc. 68, pl. 1) is an alluvial prospect that contains abundant ilmenite. Creeks that drain into the Río Marwani (loc. 28) contain high concentrations of rutile (Sherman Marsh, U.S. Geological Survey, oral commun., 1988). Exploration is continuing in other rivers for mineable deposits of titanium (Charles Connolly, consultant, oral commun., 1989). 


\section{PLATINUM}

Prospects of platinum-group elements are not well documented in Venezuela. Rodriguez (1987) reported that a newly discovered alluvial gold province in the area of the Río Guapuchi in central Estado Amazonas (pl. 1) contains high concentrations of palladium. Other alluvial gold and diamond deposits in the eastern and northern parts of the Venezuelan Guayana Shield are said to contain high concentrations of platinum-group elements (Charles Connolly, oral commun., 1989). Técnica Minera, C.A., and the U.S. Geological Survey recently discovered anomalous concentrations of platinum-group elements in the Pistón de Uroy area (Wynn and others, this volume) (loc. 98, pI. 1) and in the La Esmeralda area (Sidder and others, 1991). The presence of cumulate mafic-ultramafic rocks and concentrations of as much as about $300 \mathrm{ppb}$ platinum and $360 \mathrm{ppb}$ palladium in the Pistón de Uroy area (Wynn and others, this volume), in addition to placer prospects of platinum-group elements in French Guiana and Suriname (Choubert, 1974), indicate that platinum-group elements may be associated with deposits of nickel-copper sulfide minerals in these and similar rocks elsewhere in the Guayana Shield. Metabasalt and metagabbro in the Cerro La Pinto prospect (loc. 58) area near La Esmeralda may contain anomalous amounts of platinum-group elements (Sidder, 1990, 1994, unpublished data; Sidder, and others, 1991). Anomalous contents of platinum-group elements and rare platinoid minerals are present in several gold placers and associated with mafic and ultramafic rocks in Guyana and Suriname (Gibbs and Barron, 1993) and in the West African Shield (Kesse, 1985; Milési and others, 1992).

\section{TUNGSTEN}

Tungsten is associated with deposits or prospects of other metals in the Guayana Shield. For example, scheelite has been identified in trace amounts within gold-quartz veins in the El Callao (loc. 37, pl. 1) and Botanamo (loc. 33) districts, and minor elevated concentrations of tungsten have been detected in tin-niobium-tantalum-bearing veins in the Parguaza Granite (Korol, 1961; Bellizzia and others, 1981).

\section{CHROMITE}

Trace amounts of chromium (as much as 0.5 weight percent $\mathrm{Cr}_{2} \mathrm{O}_{3}$ ) are present in mafic and ultramafic rocks of the Imataca Complex and in the greenstone belts. Minor amounts of chromite are present in alluvium within the area of outcrop of the Imataca Complex (Vicente Mendoza, oral commun., 1988). Cumulate mafic-ultramafic rocks at Pistón de Uroy (loc. 98, pl. 1) may contain prospects for chromite
(Wynn and others, this volume). Small occurrences of alluvial and lode chromite are associated with ultramafic rocks in Suriname and Guyana (Gibbs and Barron, 1993) and in the West African Shield (Kesse, 1985; Milési and others, 1992).

\section{SUMMARY}

The Guayana Shield of Venezuela is a poorly explored, relatively unknown area. Gold, iron, diamonds, and bauxite are the only commodities currently mined. Gold is present in low-sulfide gold-quartz veins within Early Proterozoic greenstone-belt rocks cut by shear zones. Granite-hosted, lateritic, epithermal, and banded-iron-formation-associated gold prospects are also present. World-class deposits of enriched Superior-type, and possibly Algoma-type, banded iron formation are in the Archean Imataca Complex. The Los Pijiguaos bauxite deposit developed through intense tropical weathering of the Middle Proterozoic Parguaza Granite. Placer diamond deposits are predominantly derived from paleoplacer conglomerate beds in the lower $600 \mathrm{~m}$ of the Early to Middle Proterozoic Roraima Group. Kimberlite has been identified only in the Quebrada Grande area, where the richest placer diamond deposits in Venezuela are found. Also favorable for exploration are minor prospects of other metals such as platinum-group elements, chromium, and manganese in the greenstone belts, tin in the Parguaza Granite and in rhyolite of the Early Proterozoic Caicara Formation, and rare earth elements in carbonatite such as at Cerro Impacto or associated with Olympic Dam-type iron-copper-uranium-gold-rare earth element deposits in the Cuchivero Group and in the Parguaza Granite.

Descriptions of the deposits and prospects herein may provoke new thinking in mineral exploration of the Guayana Shield. For example, gold associated with banded iron formation might be present within the Imataca Complex in areas of carbonate \pm sulfide-facies rocks such as in the Upata-El Palmar-Guacuripia area and near Cerro Bolívar or in areas of ferruginous chert and other exhalative rocks associated with greenstone-belt rocks such as at Marwani, San Cristobal, La Esperanza, and Cerro La Pinto. Kuroko-type volcanogenic massive sulfide base- and precious-metal deposits may be hosted by the greenstone-belt rocks. Epithermal vein deposits of precious-metals may be present in felsic to intermediate volcanic rocks of the Cuchivero Group in the upper Río Caura area, and Olympic Dam-type deposits may be associated with the Cuchivero Group or with the Parguaza Granite and its coeval volcanic rocks. Cumulate mafic and ultramafic rocks in the Pistón de Uroy area may contain deposits of nickel-copper sulfide, platinum-group elements, and (or) chromium. Diamonds and rare metals may be associated with as yet undiscovered kimberlite and carbonatite that may intrude the Cuchivero Group in the western part of the shield. 


\section{REFERENCES CITED}

Aarden, H.M., and Davidson, M.T., 1977, Minerales de estaño, niobio, tantalo y titanio en la zona del Caño Aguamena, Estado Bolívar, analizades con microsonda de electrones: Congreso Geológico Venezolano, 5th, Caracas, 1977, Memoria, v. 3, p. 919-940.

Aarden, H.M., Holm, Victor, Iturralde de Arozena, J.M., Moticska, Peter, Navarro, Jorge, Pasquali Z., Jean, and Sifontes, R.S., 1978, Aspectos geoeconómicos del Cerro Impacto [abs.]; Segundo Congreso Latinoamericano de Geología, Caracas, 1973, Memoria, Publicación Especial 7, v. 5, p. 3901-3902.

Aarden, H.M., Iturralde de Arozena, J.M., Moticska, Peter, Navarro, Jorge, Pasquali Z., Jean, and Sifontes, R.S., 1978, Aspectos geoquímicos del prospecto del Cerro Impacto, Estado Bolívar [abs.]: Congreso Latinoamericano de Geología, 2nd, Caracas, 1973, Memoria, Publicación Especial 7, v. 5, p. 3899-3900.

Aarden, H.M., Iturralde de Arozena, J.M., Navarro, Jorge, Moticska, Peter, Pasquali Z., Jean, and Sifontes, R.S., 1978, Geología del área del Cerro Impacto [abs.]: Congreso Latinoamericano de Geología, 2nd, Caracas, 1973, Memoria, Publicación Especial 7, v. 5, p. $3897-3898$.

Aguilar R., Alfonso, 1972, Estudio preliminar de los yacimientos manganesíferos del Cerro San Cristobal, región cuenca norte del Róo Botanamo: Congreso Geológico Venezolano, 4th, Caracas, 1971, Memoria, Publicación Especial 5, v. 4, p. 2489-2495.

Anez, Guillermo, 1985, Exploración y evaluación de posibles depósitos diamantíferos en el Distrito Cedeño del Estado Bolívar: Simposium Amazonico, 1st, Caracas, 1985, Publicación Especial 10, p. 443-463.

Appiah, Henry, Norman, D.I., and Boadi, Isaac, 1991, The geology of the Prestea and Sahanti goldfields-A comparative study, in Ladeira, E.A., ed., Brazil gold'91-The economics, geology, geochemistry, and genesis of gold deposits: Rotterdam, A.A. Balkema, p. 247-255.

Ascanio T., Gustavo, 1985, Yacimientos de mineral de hierro del Precámbrico de Venezuela: Simposium Amazonico, 1st, Caracas, 1985, Publicación Especial 10, p. 464-473.

Audemard, F., 1977, Perspectivas geológicas favorables para mineralizaciones de uranio en la región norte de la Guayana Venezolana: Congreso Geológico Venezolano, 5th, Caracas, 1977, Memoria, v. 3, p. 1013-1022.

Banerjee, A.K., and Moorhead, G.A., 1970, Gold and sulphide mineralisation in Guiana Shield: Inter-Guiana Geological Conference, 8th, Georgetown, 1969, Proceedings, Paper 7, $24 \mathrm{p}$.

Baptista G., J., and Рапra, Acurcio, 1985, Contrihución al conocimiento de las áreas diamantíferas de la Guayana Venezolana: Simposium Amazonico, 1st, Caracas, 1985, Publicación Especial 10, p. 474-478.

Baptista G., J., and Svisero, D.P., 1978, Geología de los depósitos diamantíferos de la parte noroccidental de la Guayana Venezolana: Venezuela, Dirección de Geología, Boletín de Geología, v. 13, no. 24, p. 3-46.

Barnard, Fred, 1990, Gold rush arrives in Guiana Shield: Engineering and Mining Journal, v. 191, p. 57-63.

Barron, C.N., 1969, Notes on the stratigraphy of Guyana: Guiana Geological Conference, 7th, Paramaribo, Suriname, 1966,
Proceedings; Geological Survey of Guyana Records, v. 6 , paper 2-1, p. 1-28.

1973, A further guide to mineral exploration in Guyana forming a supplement to Bulletin 38: Geological Survey of Guyana Bulletin $38 \mathrm{a}, 39 \mathrm{p}$.

Beauvais, A., and Colin, Fabrice, 1993, Formation and transformation processes of iron duricrust systems in tropical humid environment: Chemical Geology, v. 106, p. 77-101.

Bellizzia G., Alirio, Pimentel de Bellizzia, Nelly, and Rodriguez, S., 1980, Mapa metalogenico de Venezuela: Caracas, Venezuela, Ministerio de Energía y Minas, Dirección de Geología, escala gráfica.

-1981, Recursos minerales de Venezuela y su relación a la metalogenesis: Caracas, Ministerio de Energía y Minas, Dirección de Geología, Boletín de Geología, Publicación Especial 8, p. 6-77.

Berger, B.R., 1986a, Descriptive model of low-sulfide Au-quartz veins, in Cox, D.P., and Singer, D.A., eds., Mineral deposit models: U.S. Geological Survey Bulletin 1693, p. 239.

- 1986b, Descriptive model of Homestake Au, in Cox, D.P., and Singer, D.A., eds., Mineral deposit models: U.S. Geological Survey Bulletin 1693, p. 244.

Bertani, César, and Moreno, Luis, 1989, Caracterización mineralogica del elemento fosforo en la protomena y menas del Cerro Bolívar y su aplicación en los procesos de concentración: Congreso Geológico Venezolano, 7th, Barquisimeto, Venezuela, 1989, v. 4, p. 1746-1767.

Bertoni, C.H., Shaw, R.P., Singh, R., Minamoto, Jorge, and Richards, J.M., 1991, Geology and gold mineralization of the Omai property, Guyana, in Ladeira, E.A., ed., Brazil gold'91-The economics, geology, geochemistry, and genesis of gold deposits: Rotterdam, A.A., Balkema, p. 767-771.

Black, Russell, 1980, Precambrian of West Africa: Episodes, v. 1980 , no. 4 , p. $3-8$.

Blanc, C., Mesnier, H.P., Plat, R., and Zeegers, H., 1980, Datos nuevos sobre los yacimientos de oro primario en Guyana Francesa y su prospección: Caribbean Geological Conference, 9th, Santo Domingo, Dominican Republic, 1980, Transactions, p. 273-276.

Bliss, J.D., and Jones, G.M., 1988, Mineralogical and grade-tonnage information on low-sulfide Au-quartz veins: U.S. Geological Survey Open-Fỉe Report 88-229, $99 \mathrm{p}$.

Bowell, R.J., 1993, Mineralogy and geochemistry of tropical rain forest soils-Ashanti, Ghana: Chemical Geology, v. 106, p. 345-358.

Bowell, R.J., Foster, R.P., and Gize, A.P., 1993, The mobility of gold in tropical rain forest soils: Economic Geology, v. 88 , p. 999-1016.

Boyle, R.W., 1986, Gold deposits in turbidite sequences-Their geology, geochemistry and history of the theories of their origin, in Keppie, J.D., Boyle, R.W., and Haynes, S.J., eds., Turbidite-hosted gold deposits: Geological Association of Canada Special Paper 32, p. 1-13.

Briceño M., H.O., 1984, Genesis de yacimientos minerales Venezolanos II-Placeres diamantíferos de San Salvador de Paúl: Acta Cientifica Venezolana, v. 36, p. 154-158.

Briceño M., H.O., and Schubert, Carlos, 1990, Geomorphology of the Gran Sabana, Guayana Shield, southeastern Venezuela: Geomorphology, v. 3, p. 125-141. 
Brooks, W.E., and Nuñez, Fernando, 1991, Road reconnaissance of anomalous radioactivity in the Early Proterozoic Roraima Group near Santa Elena de Uairén, Estado Bolivar, Venezuela: U.S. Geological Survey Open-File Report 9l-632, $10 \mathrm{p}$.

Bundy, P.A., 1943, Some gold lodes of Bolivar, Venezuela: Engineering and Mining Journal, v. 144, no. 1, p. 43-45.

Candiales, L_J., 1961, Descubrimiento y exploración de bauxita en Venezuela: Congreso Geológico Venezolano, 3rd, Caracas, 1959 , v. 4, p. $1661-1680$.

Cannon, W.F., 1986a, Descriptive model of Superior Fe, in Cox, D.P., and Singer, D.A., eds., Mineral deposit models: U.S. Geological Survey Bulletin 1693, p. 228.

1986b, Descriptive model of Algoma Fe, in Cox, D.P., and Singer, D.A., eds., Mineral deposit models: U.S. Geological Survey Bulletin 1693, p. 198.

Card, K.D., Poulsen, K.H., and Robert, Francois, 1989, The Archean Superior Province of the Canadian Shield and its lode gold deposits, in Keays, R.R., Ramsay, W.R.H., and Groves, D.I., eds., The geology of gold deposits-The perspective in 1988: Economic Geology Monograph 6, p. 19-36.

Carter, J.W., and Fernandes, L.L., 1969, The stratigraphical, lithological and structural controls to mineralization within the Barama-Mazanui assemblage: Geological Survey of Guyana, Records, v. 6, Paper 12-1, p. 12-1-12-22.

Choubert, B., 1974, Le Précambrien des Guyanes: Paris, Bureau de Recherches Geologiques et Minieres, Mémoires, no. 81, 213 p.

Colin, Fabrice, Vieillard, P., and Ambrosi, J.P., 1993, Quantitative approach to physical and chemical gold mobility in equatorial rainforest lateritic environment: Earth and Planetary Science Letters, v. 114, p. 269-285.

Costa, M.L. da, 1993, Gold distribution in lateritic profiles in South America, Africa, and Australia-Applications to geochemical exploration in tropical regions: Joumal of Geochemical Exploration, v. 47, p. 143-163.

Dahlberg, E.H., 1975, The metallogenic map of Suriname: Conferencia Geológica Interguianas, 10th, Belém, Brazil, 1975, Memoria, p. 706-714.

Dall'Agnol, Roberto, Lafon, J.-M., and Macambira, M.J.B., 1994, Proterozoic anorogenic magmatism in the Central Amazonian Province, Amazonian Craton-Geochronological, petrological and geochemical aspects: Mineralogy and Petrology, v. 50, p. 113-138.

Damasceno, E.C., 1982, Archean and Early Proterozoic mineral deposits in Brazil: Revista Brasileira de Geociencias, International Symposium on Archean and Early Proterozoic Geologic Evolution and Metallogenesis, Salvador, Bahia, Brazil, 1982, v. 12 , no. $1-3$, p. $426-436$.

1988, Geologia do estarho, in Schobbenhaus, Carios, and Coelho, C.E.S., coordinators, Principais depósitos minerais do Brasil: Brasilia, Departamento Nacional da Produção Mineral-Companhia Vale do Rio Doce, v. 3, Metais básicos não-ferrosos, ouro e alumínio, p. 181-199.

Danielson, Vivian, 1993, Venezuela a 'hot spot' for Canadian explorers: The Northem Miner, v. 79, no. 2, p. B1, B14.

Danti, K.J., and Brimhali, G.H., 1989, The distribution of gold in primary auriferous pyrite and two-stage oxidative gold enrichment in secondary iron-oxides from the Syama gold mine, Mali, West Africa: Geological Survey of America Abstracts with Programs, v. 21, no. 6, p. A294.
Daoud, W.E.K., and Antonjetto, A., Jr., 1985, Geología do granito estanífero Agua Boa-Pitinga: Simposio de Geologia da Amazonia, 2nd, Belém, 1985; Sociedade Brasileira de Geología, v. 3, p. 17-33.

1988, Mina de estanho de Pitinga, Amazonas, in Schobbenhaus, Carlos, and Coelho, C.E.S., coordinators, Principais depósitos minerais do Brasil: Brasília, Departamento Nacional da Produção Mineral, Companhia Vale do Rio Doce, v. 3, Metais básicos não-ferrosos, ouro e alumínio, p. 201-211.

Davies, T.C., Friedrich, G., and Wiechowski, A., 1989, Geochemistry and mineralogy of laterites in the Sula Mountains greenstone belt, Lake Sonfon gold district, Sierra Leone: Journal of Geochemical Exploration, v. 32, p. 75-98.

Davis, D.W., Hirdes, Wolfgang, Schaltegger, U., and Nunoo, E.A., 1994, U-Pb age constrainsts on deposition and provenance of Birimian and gold-bearing Tarkwaian sediments in Ghana, West Africa: Precambrian Research, v. 67, p. 89-107.

Doan, D.B., 1994, The mineral industry of Venezuela, in U.S. Department of the Interior, Bureau of Mines, Mineral industries of Latin America and Canada: Minerals Yearbook, 1992 International Review, v. 3, 9 p.

Dommanget, Alain, Milési, J.P., and Diallo, Mamadou, 1993, The Loulo gold and tourmaline-bearing deposit-A polymorph type in the Early Proterozoic of Mali (West Africa): Mineralium Deposita, v. 28, p. 253-263.

Dougan, T.W., 1975, A petrologic model for the Imataca Complex in an area near Cerro Bolívar, part I: Asociación Venezolana de Geología, Mineralogía y Petrología, Boletín Informativo, v. 18 , no. 2, p. 127-145.

1976, Origin of trondhjemitic biotite-quartz-oligoclase gneisses from the Venezuelan Guyana Shield: Precambrian Research, v. 3, no. 4, p. 317-342.

1977, The Imataca Complex near Cerro Bolívar, Venezuela-A calc-alkaline Archean protolith: Precambrian Research, v. 4, no. 3, p. $237-268$.

Drovenik, F., Knulc, Z., Tajder, M., and Talic, S., 1967, Menas manganesíferas de la región de Upata: Venezuela, Ministerio de Minas e Hidrocarburos, Boletín de Geología, v. 8, no. 17, p. $3-163$.

Duffield, W.A., Reed, B.L., and Richter, D.H., 1990, Origin of rhyolite-hosted tin mineralization-Evidence from the Taylor Creek Rhyolite, New Mexico: Economic Geology, v. 85, p. 392-398.

Dzigbodi-Adjimah, Komla, 1993, Geology and geochemical patterns of the Birimian gold deposits, Ghana, West Africa: Journal of Geochemical Exploration, v. 47, p. 305-320.

Eisenlobr, B.N., 1992, Conflicting evidence on the timing of mesothermal and paleoplacer gold mineralization in early Proterozoic rocks from southwest Ghana, West Africa: Mineralium Deposita, v. 27, p. 23-29.

Eisenlohr, B.N., and Hirdes, Wolfgang, 1992, The structural development of the early Proterozoic Birimian and Tarkwaian rocks of southwest Ghana, West Africa: Journal of African Earth Sciences, v, 14, p. 313-325.

Elliot, R.G., 1986, The nature and distribution of primary gold in the oxidized zone of the Omai and Kaburi goldfields, central Guyana: Newsletter of International Liaison Group on Gold Mineralization, October 1986, no. 3, p. 56-57.

Engineering and Mining Joumal, 1987, Gold could be a key to Venezuela's economic future: v. 118 , no. 10, p. 16G-16K. 
_. 1988, Monarch leads a gold consortium in Venezuela: v. 119 , no. 2, p. 16 .

Ensminger, H.R., 1992, Venezuela, in Bureau of Mines minerals yearbook, 1990 intemational review: Washington, U.S. Department of the Interior, v. 3, p. 313-324.

Ensminger, H.R., Gurmendi, A.C., and Machamer, J.F., 1990, The mineral industries of northem South America: U.S. Bureau of Mines Minerals Yearbook, 1988 International Review, 18 p.

Ferencic, A.J., 1969, Geology of the San Isidro iron ore deposit, Venezuela: Mineralium Deposita, v. 4, p. 283-297.

Ferrand, Allain, Vasquez, J.C., and Rodriguez, S.E., 1984 , Características litológicas y estructurales de los depósitos vetiformes de oro de la región de Lo Increíble, Estado Bolívar, Venezuela: Symposium Amazonico, 2nd, Manaus, Brazil, 1984, Anais, p. 327-338.

Fouillac, A.M., Dommanget, Alain, and Milési, J.P., 1993, A carbon, hydrogen and sulfur isotopic study of the gold mineralization at Loulo, Mali: Chemical Geology, v. 106, p. 47-62.

Gallagher, M.J., 1976, Recommendations for an initial five-year programme of uranium exploration in Venezuela: International Atomic Energy Agency/TA Report 1173, 30 p.

Garcia, V., and Aarden, H.M., 1977, Análisis preliminar de correlaciones y agrupaciones geoquímicas en lateritas de Cerro Impacto, Estado Bolívar: Congreso Geológico Venezolano, 5th, Caracas, 1977, Memoria, v, 3, p. 941-955.

Gaudette, H.E., Mendoza, Vicente., Hurley, P.M., and Fairbairn, H.W., 1978, Geology and age of the Parguaza rapakivi granite, Venezuela: Geological Society of America Bulletin, v. 89, no. 9 , p. $1335-1340$.

Ghosh, S.K., 1985, Geology of the Roraima Group and its implications: Simposium Amazonico, 1st, Caracas, 1981, Publicación Especial 10, p. 31-50.

Gibbs, A.K., and Barron, C.N., 1983, The Guiana Shield reviewed: Episodes, v. 1983, no. 2, p. 7-14.

1993, The geology of the Guiana Shield: New York, Oxford University Press, Oxford Monographs on Geology and Geophysics 22, 246 p.

Goldfarb, R.J., Leach, D.L., Pickthorn, W.J., and Paterson, C.J., 1988, Origin of lode-gold deposits of the Juneau gold belt, southeastern Alaska: Geology, v. 16, p. 440-443.

Goldfarb, R.J., Newberry, R.J., Pickthom, W.J., and Gent, C.A., 1991, Oxygen, hydrogen, and sulfur isotope studies in the Juneau gold belt, southeastem Alaska - Constraints on the origin of hydrothermal fluids: Economic Geology, v. 86, p. $66-80$.

Gruss, H., 1973, Itabirite iron ores of the Liberia and Guyana shields, in Genesis of Precambrian iron and manganese deposits, Proceedings of the Kiev Symposium, August 1970: Paris, UNESCO, Earth Sciences 9, p. 335-359.

Hennius, John, 1988, Search for gold and diamonds still big in Bolívar State: The Daily Journal, Caracas, Thursday, June 16, 1988 , p. 25.

Hinse, G.J., Hogg, G.M., and Robertson, D.S., 1986, On the origin of Archean vein-type gold deposits with reference to the Larder Lake 'break' of Ontario and Quebec: Mineralium Deposita, v. 21, p. $216-227$.

Holtrop, J.F., 1965, The manganese deposits of the Guiana Shield: Economic Geology, v. 60, p. 1185-1212.

Horbe, M.A., Hotbe, A.C., Costi, H.T., and Teixeira, J.T., 1991, Geochemical characteristics of cryolite-tin-bearing granites from the Pitinga Mine, northwestern Brazil-A review: Joumal of Geochemical Exploration, v. 40, p. 227-249.

Horbe, M.A., Horbe, A.C., Teixeira, J.T., and Costi, H.T., 1985 , Granito Madeira--Petrologia, petroquimica e mineralizaçöes: Simposio de Geologia da Amazonia, 2nd, Belém, 1985 , Sociedade Brasileira de Geología, v. 3, p. 284-320.

Hutchinson, R.W, 1987, Metallogeny of Precambrian gold deposits-Space and time relationships: Economic Geology, v. 82, p. 1993-2007.

Jones, J.P., Yamada, E.H., Marques, C.G.M., Yokoi, O.Y., and Yamamoto, M.F., 1986, Some aspects of the geology of the newly discovered tin deposits of Brazil: Mining Latin America/Minería Latinoamericana Conference, Santiago, Chile, 1986, Institution of Mining and Metallurgy, London, p. 165-182.

Kalliokoski, Joseph, 1965, Geology of north-central Guayana Shield, Venezuela: Geological Society of America Bulletin, v. 76 , p. $1027-1050$.

Kerrich, Robert, and Wyman, Derek, 1990, Geodynamic setting of mesothermal gold deposits-An association with accretionary tectonic regimes: Geology, v. 18, p. 882-885.

Kesse, G.O., 1985, The mineral and rock resources of Ghana: Boston, A.A. Balkema, 610 p.

Klein, T.L., and Day, W.C., 1994, Archean low-sulfide Au-quartz vein deposits: U.S. Geological Survey Open-File Report 94-250, $17 \mathrm{p}$.

Knox, N.B., 1942, Venezuelan gold from El Callao: Engineering and Mining Journal, v. 143, no. 3, p. 52-55.

Korol, Bohdan, 1961, Minerales de tungsteno de las minas Botanamo y El Callao: Congreso Geológico Venezolano, 3rd, Caracas, 1959, v. 4, p. 1889-1895.

Kroonenberg, S.B., 1982, A Grenvillian granulite belt in the Colombian Andes and its relation to the Guiana Shield: Geologie en Mijnbouw, v, 61, p. 325-333.

Lecomte, P., and Colin, Fabrice, 1989, Gold dispersion in a tropical rainforest weathering profile at Dondo Mobi, Gabon: Journal of Geochemical Exploration, v. 34, p. 285-301.

Ledru, Patrick, Johan, Véra, Milési, J.P., and Tegyey, Monique, 1994, Markers of the last stages of the Palaeoproterozoic collision-Evidence for a $2 \mathrm{Ga}$ continent involving circum-South Atlantic provinces: Precambrian Research, v. 69, p. 169-191.

Ledru, Patrick, Lassene, J.-L., Manier, Emmanuel, and Mercier, Daniel, 1991, Le Protérozoïque inférieur nord guyanais-Révision de la lithologie, tectonique transcurrente et dynamique des bassins sédimentaires: Bulletin de la Sociedad Géologica de France, v. 162, p. 627-636.

Leube, Alfred, Hirdes, Wolfgang, Mauer, Rudolf, and Kesse, G.O., 1990, The Early Protoerozoic Birimian Supergroup of Ghana and some aspects of its associated gold mineralization: Precambrian Research, v, 46, p. 139-165.

Lira, Pedro, Martinez, Jesús, Rodríguez, Baltazar, and Sosa, César, 1985, Reconocimiento geológico de la zona Botanamo-Akarabisí, Estado Bolívar: Congreso Geológico Venezolano, 6th, Caracas, 1985, Memoria, v. 3, p. 1758-1782.

Lo Monaco, S, and Yanes, C., 1990, Model for bauxite formation-Los Pijiguaos, Venezuela: Chemical Geology, v. 84 , p. $98-99$. 
Locher, Eugenio, 1974, Oro en Venezuela: Conferencia Geológica Inter-Guayanas, 9th, Ciudad Guayana, Venezuela, 1972, Memoria, Publicación Especial 6, p. 558-587.

Macdonald, J.R., 1968, A guide to mineral exploration in Guyana: Geological Survey of Guyana Bulletin 38, $91 \mathrm{p}$.

Marcano, Raysa, Bertani, César, Moreno, Luis, and Guilarte, Arturo, 1989, Geología del yacimiento Los Barrancos, Estado Bolívar: Congreso Geológico Venezolano, 7th, Barquisimeto, Venezuela, 1989, v. 4, p. 1860-1876.

Marcoux, Eric, Ouedraogo, M.-F., Feybesse, J.-L., Milési, J.-P., and Prost, André, 1988, Géochimie et géochronologie isotopiques âge $\mathrm{Pb} / \mathrm{Pb}$ à $2120 \pm 41 \mathrm{Ma}$ des corps sulfurés massifs à Zn-Ag de Perkoa (Burkina Faso): Comptes Rendus de l'Académie des Sciences, France, v. 306, série 2, p. 589-595.

Martin, Cecilia, 1976, Manganeso del Cerro de La Esperanza-Rio Aro, Edo. Bolívar: Congreso Geológico Venezolano, 4th, Caracas, 1971, Memoria, Publicación Especial 5, v. 5, p. 3439.

Martineau, Michael, 1994, Exploration review-Sub-Saharan Africa: Society of Economic Geologists Newsletter, no. 17, p. 21-25.

McKitrick, S.A., Norman, D.I, and Appiah, Henry, 1993, Proterozoic Ghanian metakimberlites [abs.]: EOS, Transactions, American Geophysical Union, v. 74, no. 43, p. 679.

Mendoza S., Vicente, 1985, Potencial aurífero de Guayana trabajo en progreso: Congreso Geológico Venezolano, 6th, Caracas, 1985, Memoria, v. 6, p. 4038-4068.

Mendoza, Vicente, Moreno, Luis, Barrios, Fernando, Rivas, Duggar, Martinez, Jesús, Lira, Pedro, Sardi, Gustavo, and Ghosh, Santosh, 1977, Geología de la parte norte del Territorio Federal Amazonas, Venezuela (informe en progreso): Congreso Geológico Venezolano, 5th, Caracas, 1977, Memoria, v. 1, p. $363-406$.

Menendez V. de V., Alfredo, 1968, Revisión de la estratigrafía de la Provincia de Pastora, según el estudio de la región de Guasipati, Guayana Venezolana: Caracas, Boletin de Geología, v. 10, p. 309-338.

1972, Geología de la región Guasipati, Guayana Venezolana: Congreso Geológico Venezolano, 4th, Caracas, 1971, Memoria, Publicación Especial 5, v. 4, p. 2001-2046.

_ 1974, Petrología y tectónica de la regíón de El Callao y su relación con la mineralización de] oro: Conferencia Geológica Inter-Guayanas, 9th, Ciudad Guayana, Venezuela, 1972 Memoria, Publicación Especial 6, p. 606.

Menendez, Alfredo, Rios, J.H., Weingarten, B., and Ticona, I., 1985. Características geológicas de la parte noreste del yacimiento de bauxita de "Los Pijiguaos," Estado Bolívar, Venezuela: Simposium Amazonico, 1st, Caracas, 1981, Publicación Especial 10, p. 548-570.

Menendez V. de V., Alfredo, and Sarmentero, Alberto, 1985 , Exploración de bauxita en la Guayana Venezolana con particular referencia a la Serranía de "Los Pijiguaos": Simposium Amazonico, Ist, Caracas, 1981, Publicación Especial 10 , p. $571-586$.

Meyer, Charles, 1988, Proterozoic ore-forming habitats-Tectonic and chemical transitions, in Kisvarsanyi, Geza, and Grant, S.K., eds., North American Conference on Tectonic Control of Ore Deposits and the Vertical and Horizontal Extent of Ore Systems: University of Missouri-Rolla, Proceedings, p. $217-235$.
Meyer, H.O.A., and McCallum, M.E., 1993, Diamonds and their sources in the Venezuelan portion of the Guyana Shield: Economic Geology, v. 88, p. 989-998.

Milési, J.-P., Feybesse, J.-L., Ledru, Patrick, Dommanget, Alain, Ouedraogo, M.F., Marcoux, Eric, Prost, André, Vinchon, Charlotte, Sylvain, J.-P., Johan, Vera, Tegyey, Monique, Calvez, J.-Y., and Lagny, Philippe, 1989, West African golddeposits in their Lower Proterozoic lithostructural setting: Chronique de la Recherche Minière, no. 497, p. 3-98.

Milési, J.P., Ledru, Patrick, Ankrah, P.T., Johan, V., Marcoux, Eric, and Vinchon, Ch., 1991, The metallogenic relationship between Birimian and Tarkwaian gold deposits in Ghana: Mineralium Deposita, v. 26, p. 228-238.

Milési, J.-P., Lednu, Patrick, Feybesse, J.-L., Dommanget, Alain, and Marcoux, Eric, 1992, Early Proterozoic ore deposits and tectonics of the Birimian orogenic belt, West Africa: Precambrian Research, v. 58 , p. $305-344$.

Minko, A.E., Colin, Fabrice, Trescases, J.-J., and Lecomte, P., 1992, Altération latéritique du gîte aurifêre d'Ovala (Gabon), et formation d'une anomalie superficielle de dispersion: Mineralium Deposita, v. 27, p. 90-100.

Montalvao, R.M.G. de, Muniz, M. de. B., Issler, R.S., Dall'Agnol, Roberto, Lima, M.I.C. de, Fernandes, P.E.C.A., and da Silva, G.G., 1975, Folha NA.20 Boa Vista e parte das Folhas NA.21 Tumucumaque, NB.20 Roraima e NB.21, Parte 1-Geologia: Rio de Janeiro, Levantamento de Recursos Naturais, Ministério das Minas e Energía, Departamento Nacional da Produção Mineral, Projecto RADAMBRASIL, v, 8, p. 13-136.

Montgomery, C.W., and Hurley, P.M., 1978, Total-rock U-Pb and Rb-Sr systematics in the Imataca Series, Guayana Shield, Venezuela: Earth and Planetary Science Letters, v. 39, no. 2, p. 281-290.

Moreno, L.A., and Bertani, César, 1985a, Mineralogía de algunas menas del Cerro San Isidro y sus implicaciones geneticas: Congreso Geológico Venezolano, 6th, Caracas, 1985, Memoria, v. 6, p. 4133-4156.

1985b, Caracterización química del yacimiento de bauxita de Los Pijiguaos e influencia de las estructuras y morfología en el enriquecimiento de las menas, con énfasis en el Bloque 3 de dicho yacimiento: Congreso Geológico Venezolano, 6th, Caracas, 1985, Memoria, v. 6, p. 4069-4132.

Mosier, D.L., and Page, N.J, 1988, Descriptive and grade-tonnage models of volcanogenic manganese deposits in oceanic environments-A modification: U.S. Geological Survey Bulletin $1811,28 \mathrm{p}$.

Mumin, A.H., Fleet, M.E., and Chryssoulis, S.L., 1994, Gold mineralization in As-rich mesothermal gold ores of the Bogosu-Prestea mining district of the Ashanti Gold Belt, Ghana-Remoblization of "invisible" gold: Mineralium Deposita, v. 29, p. $445-460$.

Nagell, R.H., 1962, Geology of the Serra do Navio manganese district, Brazil: Economic Geology, v. 57, p. 481-498.

Newhouse, W.H., and Zuloaga, Guillermo, 1929, Gold deposits of the Guayana Highlands, Venezuela: Economic Geology, v. 24, p. 797-810.

Newman, H.R., 1988, Venezuela, in Mineral industries of Latin America: U.S. Bureau of Mines, Mineral Perspectives, p. 123-129.

1989 , The mineral industry of Venezuela: U.S. Bureau of Mines Minerals Yearbook 1987, p. 945-951. 
Nixon, P.H., 1988, Diamond source rocks from Venezuela: Industrial Diamond Quarterly, no. 51, 1988/3, p. 23-29.

Nixon, P.H., and Condliffe, Eric, 1989, Yimengite of K-Tj metasomatic origin in kimberlitic rocks from Venezucla: Mineralogical Magazine, v. 53, p. 305-309.

Nixon, P.H., Davies, G.R., Condliffe, Eric, Baker, N.R., and Baxter Brown, R., 1989, Discovery of ancient source rocks of Venezuela diamonds: Intemational Geological Congress, 28th, Workshop on Diamonds, Washington, D.C., 1989, Extended Abstracts, p. 73-75.

Nixon, P.H., Davies, G.R, Rex, D.C., and Gray, Alan, 1992, Venezuela kimberlites: Journal of Volcanology and Geothermal Research, v. 50, p. 101-115.

Norman, D.I., and Appiah, Henry, 1989, The Tarkwa paleoplacer gold deposit, Ghana: Geological Survey of America Abstracts with Programs, v. 21, no. 6, p. A293-A294.

Oberthür, T., Vetter, U., Schwartz, M.O., Weiser, Th., Amanor, J., and Gyapong, W. 1991, Gold mineralization at the Ashanti mine, Obuasi, Ghana--Preliminary mineralogical and geochemical data, in Ladeira, E.A., ed., Brazil gold' 91-The economics, geology, geochemistry, and genesis of gold deposits: Rotterdam, A.A. Balkema, p. 533-537.

Olmore, S.D., García, Andrés, and Antonio, S.C., 1993, Cenozoic uplift of the northern margin of the Guayana Shield, Venezuela, and its influence on the distribution of mineral deposits [abs.]: American Association of Petroleum Geologists-Sociedad Venezolana de Geólogos, International Congress and Exhibition, Caracas, 1993, p. 61.

Olson, S.F., Diakite, Kassoum, Ott, Lawrence, Guindo, Ambogo, Ford, C.R.B., Winer, Nicholas, Hanssen, Eric, Lay, NiIda, Bradley, Robin, and Pohl, Demetrius, 1992, Regional setting, structure, and descriptive geology of the Middle Proterozoic Syama gold deposit, Mali, West Africa: Economic Geology, v. 87, p. $310-331$.

Ortslan, Terence, 1987, Golden Star, Placer, Giant probing for gold in Guyana: The Northern Miner, July 20, 1987, p. 21.

Oss, H.G. van, 1993a, The mineral industry of Ghana, in U.S. Department of the Interior, Bureau of Mines, Mineral industries of Africa: Minerals Yearbook, 1991 International Review, v. 3.p. 108-121.

1993b, The mineral industry of Côte d'Ivoire, in U.S. Department of the Interior, Bureau of Mines, Mineral industries of Africa: Minerals Yearbook, 199 I International Review, v. 3 , p. $76-80$.

Pasquali, Jean, 1981, Exploración de uranio en Venezuela-Situación a fines de 1978, in Uranium deposits in Latin America-Geology and exploration: International Atomic Energy Agency, Regional Advisory Group Meeting, Lima, Peru, 1978, Proceedings, p. 191-204.

Pérez, H.G., Salazar, Rolando, Peñaloza, Alberto, and Rodríguez, S.E., 1985, Evaluación preliminar geoeconómica de los aluviones presentando minerales de $\mathrm{Ti}, \mathrm{Sn}, \mathrm{Nb}$ y Ta del área de Boquerones y Aguamena, Distrito Cedeño, Estado Bolívar y Territorio Federal Amazonas: Simposium Amazonico, 1st, Caracas, 1981, Publicación Especial 10, p. 587-602.

Phillips, G.N., Groves, D.I., and Martyn, J.E., 1984, An epigenetic origin for Archean banded iron formation-hosted gold deposits: Economic Geology, v. 79, p. 162-171.
Pollard, E.R., Dixon, C.G., and Dujardin, R.A., 1957, Diamond resources of British Guiana: British Guiana Geological Survey Bulletin 28, 45 p.

Prasad, Gisela, 1983, A review of the early Tertiary bauxite event in South America, Africa, and India: Joumal of African Earth Sciences, v. 1, p. 305-313.

Ratomaharo, Sophie, Demange, Michel, Fonteilies, Michel, Joron, J.-L., and Treuil, Michel, 1988, La série birrimienne de Perkoa (Burkina Faso)-Géochimie et minéralogie-Interprétation lithostratigraphique-Conséquences sur l'interprétation géodynamique du Birrimien: Comptes Rendus de l'Académie des Sciences, France, v. 307, série 2, p. 2033-2040.

Reid, A.R., 1974a, Proposed origin for Gujanian diamonds: Geology, v. 2, no. 2, p. 67-68.

1974b, Stratigraphy of the type area of the Roraima Group, Venezuela: Conferencia Geológica Inter-Guayanas, 9th, Ciưad Guayana, Venezuela, 1972, Memoria, Publicación Especial 6, p. 343-353.

Reid, A.R., and Bisque, R.E., 1975, Stratigraphy of the diamond-bearing Roraima Group, Estado Bolívar, Venezuela: Quarterly Bulletin of the Colorado School of Mines, v. 70, no. 1, p. 61-82.

Rocci, G., Bronner, G., and Deschamps, M., 1991, Crystalline basement of the West African craton, in Dallmeyer, R.D., and Lécorché, J.P., eds., The West African orogens and circum-Atlantic correlatives: New York, Springer-Verlag, p. $29-61$.

Rodríguez M., S.E, 1986, Recursos minerales de Venezuela: Caracas, Ministerio de Energía y Minas, Dirección General Sectorial de Minas y Geología, Boletín de Geología, v, 15, no. $27,228 \mathrm{p}$.

1987, Venezuela: Mining International, August 1987, p. $165-167$.

Rodríguez, S.E., Moya, E., Baptista G., J., Vasquez, J.C., Martin F., C., Vasquez, E., Marcano, F., and Vogel, S., 1976, Mapa metalogenico de Venezuela: Caracas, Ministerio de Minas e Hidrocarburos, Dirección de Geología, presented at Congreso Latinoamericano de Geología (2nd, 1973), scale 1:1,000,000.

Rodríguez, S.E., and Perez, Herman, 1982, Nb, Ta, and Sn mineralization related to granitic magmatism in western Bolívar State, Venezuela: International Association on the Genesis of Ore Deposits, Symposium, 6th, Tbilisi, U.S.S.R., 10 p.

Ruckmick, J.C., 1963, The iron ores of Cerro Bolívar, Venezuela: Economic Geology, v. 58, p. 218-236.

Santaella, Teófilo, 1991, CVG-Minerven ganó 328 millones de bolívares: El Guayanes, Sunday, April 28, 1991, p. 7.

Schobbenhaus, Carlos, Campos, D. de A., Derze, G.R., and Asmus, H.E., coordinators, 1984, Geologia do Brasil-Texto explicativo do mapa geológico do Brasil e da área oceânica adjacente incluindo depósitos minerais, escala 1:2,500,000: Brasítia, Departamento Nacional da Produção Mineral, 419 p.

Schubert, Carlos, Briceño, H.O., and Fritz, Peter, 1986, Paleoenvironmental aspects of the Caroni-Paragua River basin (southeastern Venezuela): Interciencia, v. 11, p. 278-289.

Short, K.C., and Steenken, W.F., 1962, A reconnaissance of the Guayana Shield from Guasipati to the Río Aro, Venezuela: Asociación Venezolana de Geología, Minería y Petroleo, Boletín Informativo, v. 5, no. 7, p. 189-221. 
Sidder, G.B., 1990, Mineral occurrences of the Guiana Shield, Venezuela: U.S. Geological Survey Open-File Report 90-16, $28 \mathrm{p}$.

1991, Iron and manganese, in Gluskoter, H.J., Rice, D.D., and Taylor, R.B., eds., Economic geology, U.S.: Boulder, Colorado, Geological Society of America, The Geology of North America, v. P-2, p. 63-86.

Sidder, G.B., Acosta, Enrique, Brooks, W.E., Contreras, Gloria, Day, W.C., Earhart, R.L., Estanga, Yasmin, Franco, Luis, García, Andrés, Guerra, Acenk, Ludington, Stephen, Marcano, Iris, Marsh, S.P., Martinez, Félix, Nuñez, Fernando, Page, N.J, Quintana, Enot, Rivero, Ibel, Sanchez, Henry, and Wynn, J.C., 1988, Preliminary mineral resource evaluation of the Guayana Shield, Bolivar State, Venezuela: Geological Society of America Annual Meeting, Abstracts with Programs, v. 20, no. 7 , p. A277-A278.

Sidder, G.B., Brooks, W.E., Estanga, Yasmin, Nuñez, Femando, and Garcia, Andres, 1991, Early to Middle Proterozoic supracrustal rocks and mineralization of the southern Guayana Shield, Venezuela, in Good, E.E., Slack, J.F., and Kotra, R.K., eds., USGS research on mineral resources-1991 program and abstracts: U.S. Geological Survey Circular 1062, p. 69.

Sidder, G.B., and Day, W.C., 1993, Fe-Cu-REE deposits in Middle Proterozoic rocks of the Midcontinent region of the United States-Are they Olympic Dam-type deposits: The Gangue, Geological Association of Canada, Mineral Deposits Division Newsletter, issue 42, p. 1-5.

Sidder, G.B., Day, W.C., Nuelle, L.M., Seeger, C.M., and Kisvarsanyi, E.B., 1993, Mineralogic and fluid-inclusion studies of the Pea Ridge iron-rare-earth-element deposit, southeast Missouri, in Scott, R.W., Jr., Detra, P.S., and Berger, B.R., eds., Advances related to United States and international mineral resources-Developing frameworks and exploration technologies: U.S. Geological Survey Bulletin 2039, p. 205-216.

Sidder, G.B., Day, W.C., Tosdal, R.M., Olmore, S.D., Guzman, Luis, and Prieto, Freddy, 1991, Evolution of an Early Proterozoic rift basin in the La Esmeralda area, Guayana Shield, Venezuela, in Good, E.E., Slack, J.F., and Kotra, R.K., eds., USGS research on mineral resources-1991 program and abstracts: U.S. Geological Survey Circular 1062, p. 69-70.

Sidder, G.B., and Martínez, Félix, 1990, Geology, geochemistry, and mineral resources of the upper Caura River area, Bolívar State, Venezuela: U.S. Geological Survey Open-File Report 90-231, $29 \mathrm{p}$.

Sims, P.K., Kisvarsanyi, E.B., and Morey, G.B., 1987, Geology and metallogeny of Archean and Proterozoic basement terranes in the northem midcontinent, U.S.A.-An overview; U.S. Geological Survey Bulletin 1815, 51 p.

1988, The Precambrian basement of the northern midcontinent, U.S.A.-A major frontier for mineral exploration, in Kisvarsanyi, Geza, and Grant, S.K., eds., North American Conference on Tectonic Control of Ore Deposits and the Vertical and Horizontal Extent of Ore Systems: University of Missouri-Rolla, Proceedings, p. 236-244.

Smith, R.E., Zeegers, Hubert, and Oliveira, S.M.B., 1991, Workshop report-Geochemistry of precious metals in laterite: Joumal of Geochemical Exploration, v. 41, p. 233-244.
Soares, M.A., 1985, Estudio petrógrafico de la estructura alcalina La Churuata, Territorio Federal Amazonas: Congreso Geologico Venezolano, 6th, Caracas, 1985, v. 4, p. 2117-2158.

Suarez de Moreno, Concepción, Liccioni, J.R., and Guzmán, J.F., 1981, Aspectos económicos y planificación de la industria minera en Venezuela: Caracas, Ministerio de Energía y Minas, Dirección de Geología, Boletín de Geología, Publicación Especial 8, p. 78-106.

The Mining Record, 1992, Gold Reserve's Venezuelan subsidiary announces acquisition of gold property: September 18, 1992, p. 5 .

The Northern Miner, 1989, Golden Star optimistic as Placer tables Omai results: v. 75, no. 5, April 10, 1989, p. 14.

The Northern Miner, 1994, Las Cristinas gold resource on the rise: v. 80 , no. 31, October 3, 1994, p. 1 .

Thorman, C.H., and Drew, L.J., 1988, A report on site visits to some of the largest tin deposits in Brazil, March 11-25, 1988: U.S. Geological Survey Open-File Report 88-0594, 19 p.

U.S. Bureau of Mines, 1993, The mineral industry of Venezuela, in U.S. Department of the Interior, Bureau of Mines, Mineral industries of Latin America and Canada: Minerals Yearbook, 1991 Intemational Review, v. 3, p. 410-427.

U.S. Geological Survey and Corporación Venezolana de Guayana, Técnica Minera, C.A., 1993, Geology and mineral resource assessment of the Venezuelan Guayana Shield: U.S. Geological Survey Bulletin 2062, $121 \mathrm{p}$.

Vinchon, Charlotte, 1989, Nouvelles hypothèses sur les contrôles sédimentologiques des gîtes auriferes dans les séries gréso-conglomératiques du Witwatersrand (Afrique du Sud), du Tarkwaïen (Afrique el l'Ouest) et de l'Orapu (Guyane française): Chronique de ta Recherche Minière, no. 497, p. 115-129.

Watkins, A.P., Iliffe, J.E., and Sharp, W.E., 1993, The effects of extensional and transpressional tectonics upon the development of Birimian sedimentary facies in Ghana, W. Africa-Evidence from the Bomfa/Beposo District, near Konongo: Journal of African Earth Sciences, v. 17, p. $457-478$

Wilhelm, E., and Essono Biyogo, J.P., 1992, Lode gold exploration in the iron-rich surficial environment of Gabon: Joumal of Geochemical Exploration, v. 43, p. 167-186.

Wyant, D.G., Sharp, W.N., and Rodríguez, C.P., 1953, Radioactive source materials in Los Estados Unidos de Venezuela; U.S. Geological Survey Trace Elements Investigations Report 222, $113 \mathrm{p}$.

Wyлn, J.C., 1993, Gcophysics of the Venezuelan Guayana Shield, in U.S. Geological Survey and Corporación Venezolana de Guayana, Técnica Minera, C.A., Geology and mineral resource assessment of the Venezuelan Guayana Shield: U.S. Geological Survey Bulletin 2062, p. 17-27.

Wynn, J.C., and Sidder, G.B., 1991, Mineral resource potential of the NB-20-4 quadrangle, eastem Guayana Shield, Bolívar State, Venezuela: U.S. Geological Survey Bulletin 1960, 16 p. 


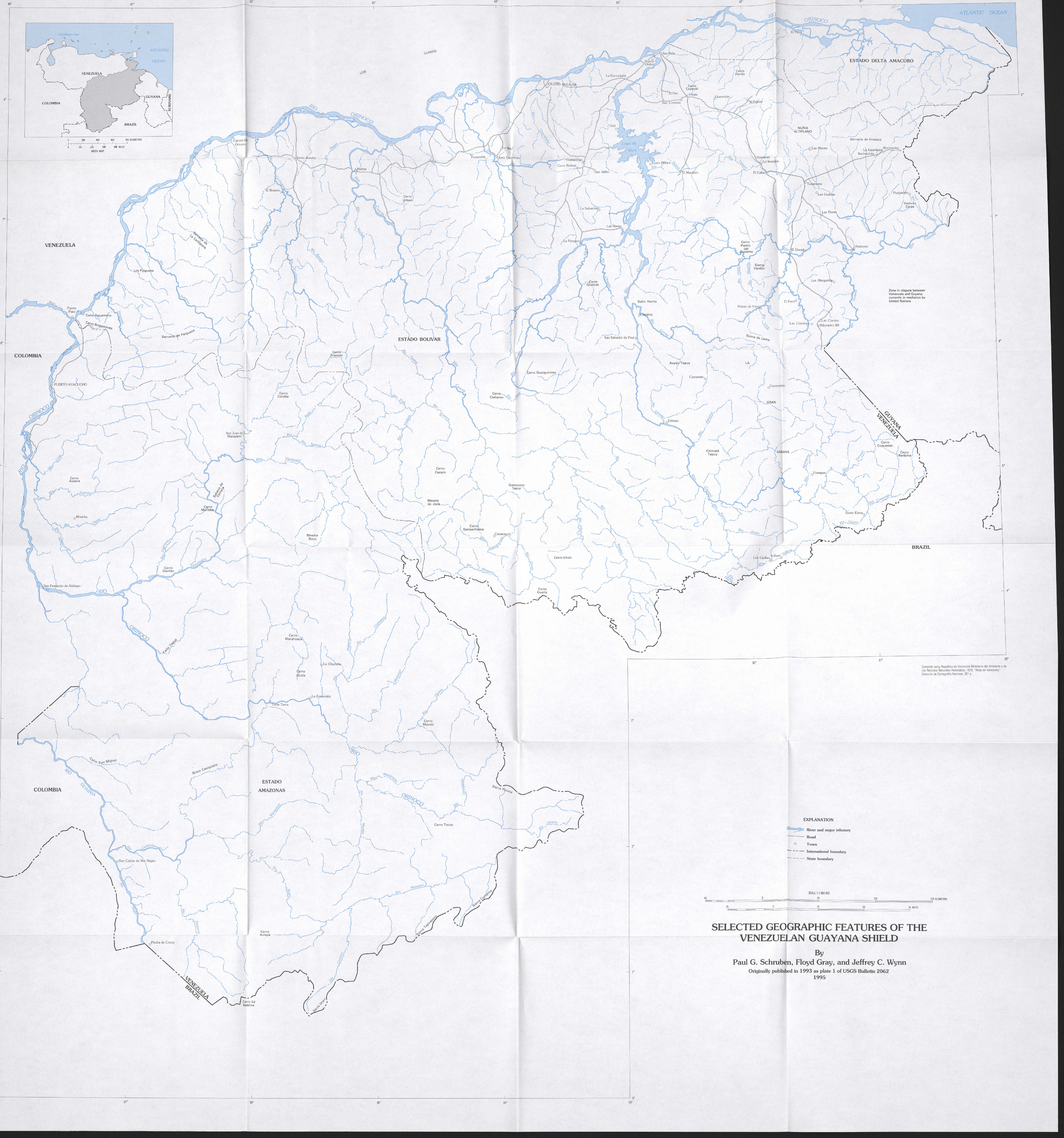




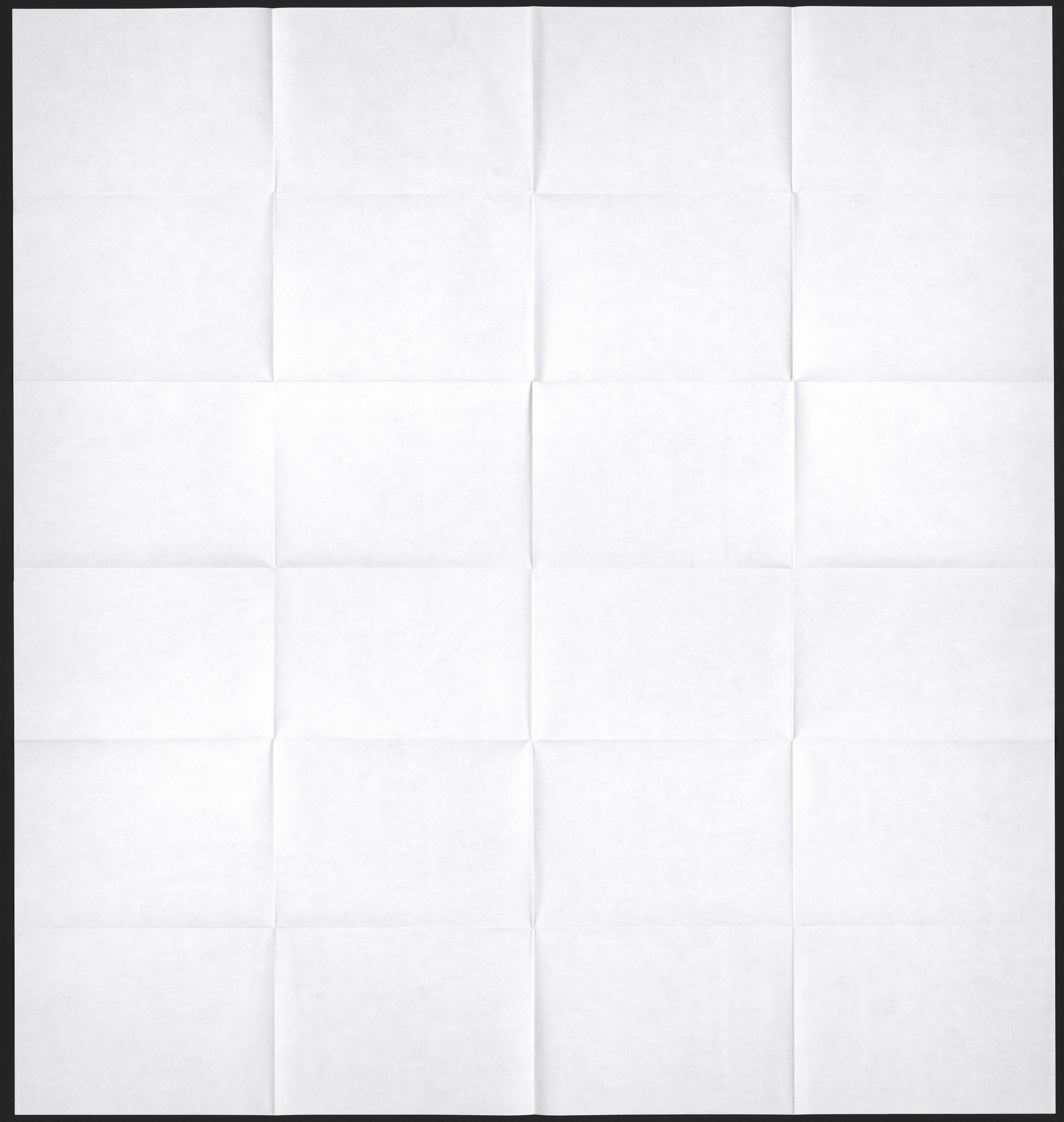




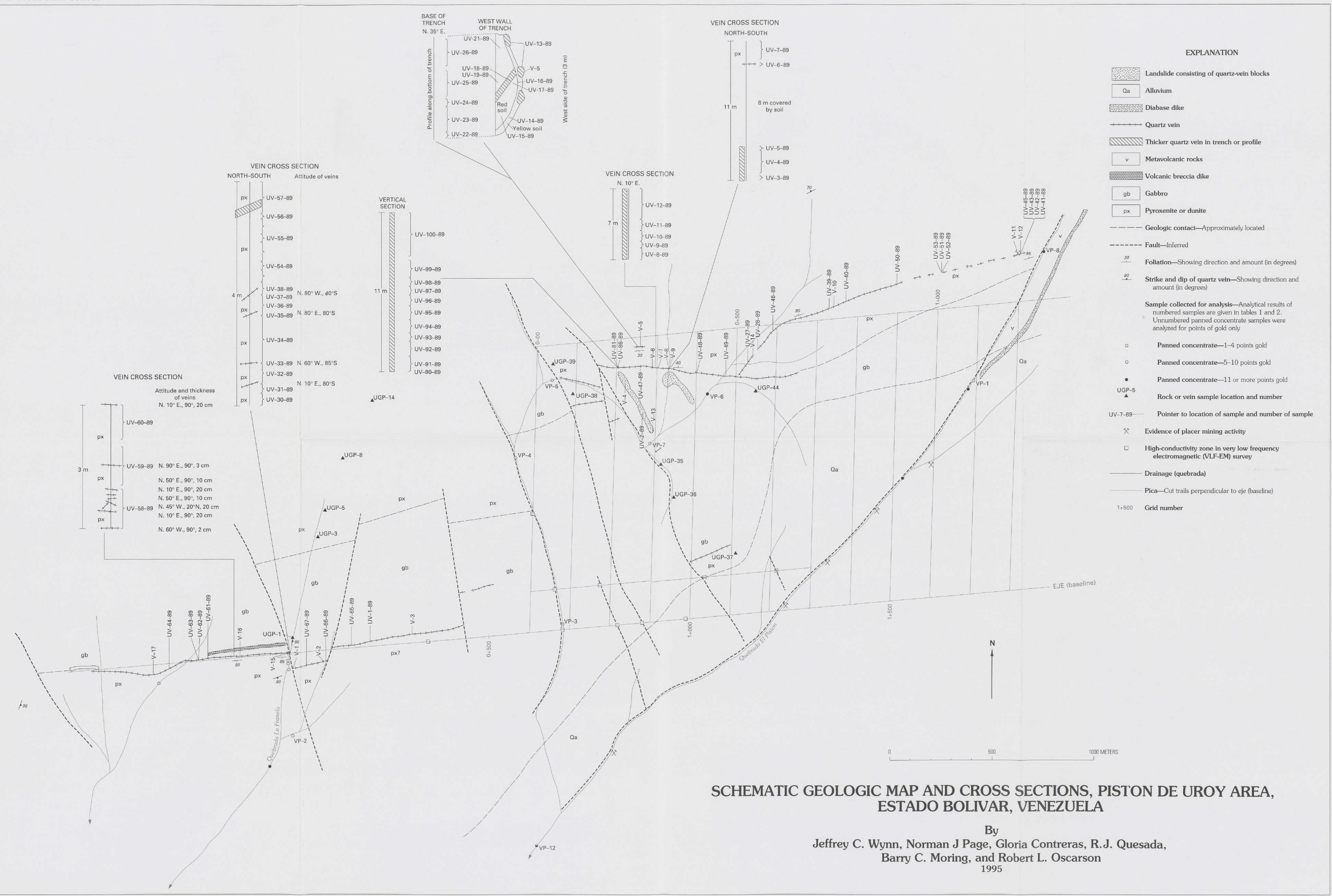




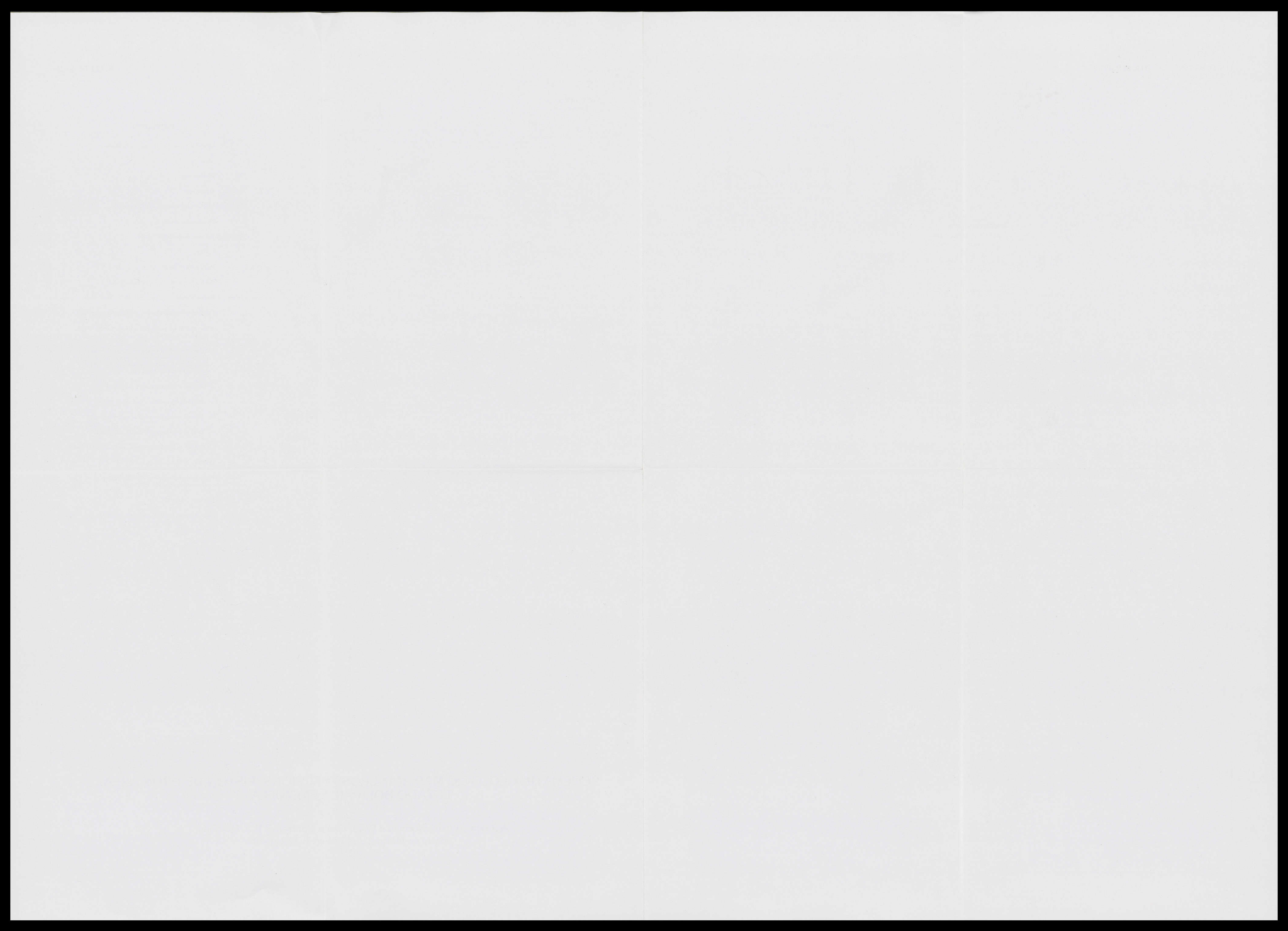




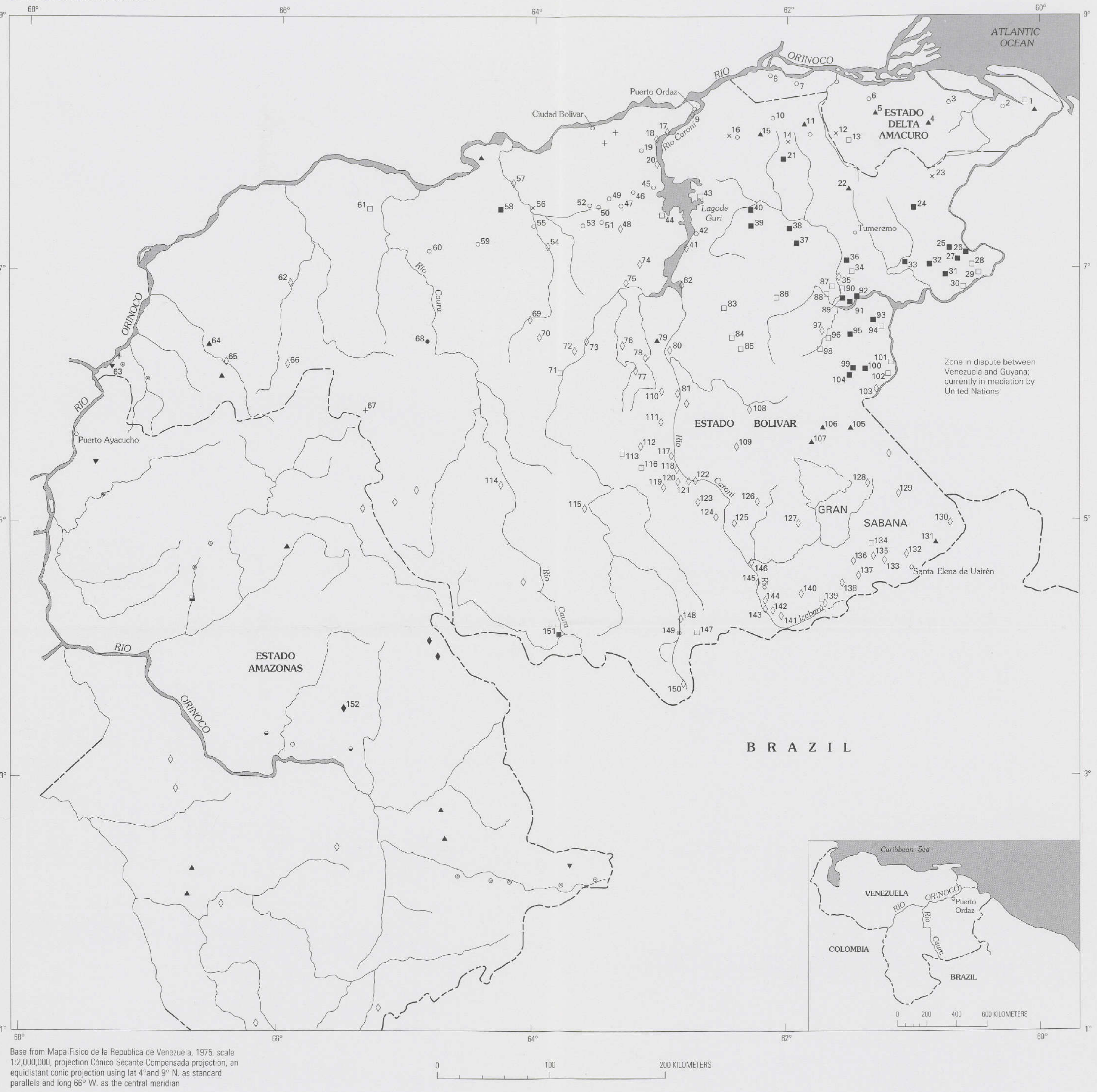

MINERAL DEPOSITS OF THE GUAYANA SHIELD, VENEZUELA

$\checkmark$ Lode tin

$\times$ Manganese

- Uranium

- Titanium

Niobium, tantalum, and rese cht dist

- Molybdenum

- Platinum-group elen
34 Deposit number

Principal mining districts, mines, and prospects in the Guayana Shield, Venezuel.

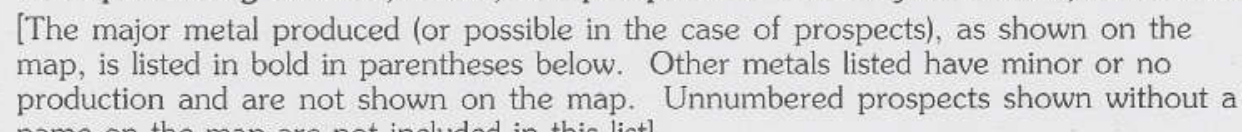
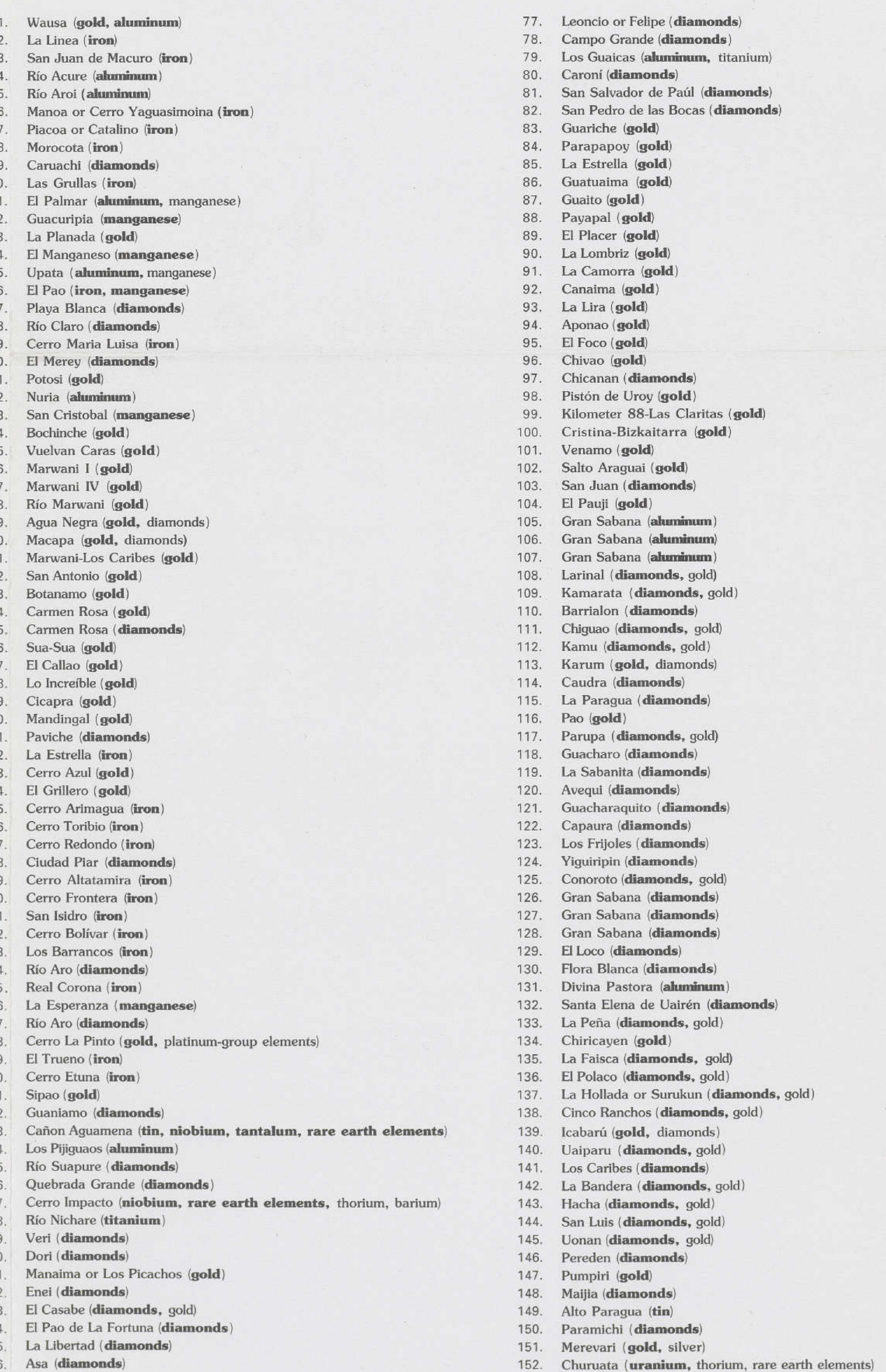

WENT OF

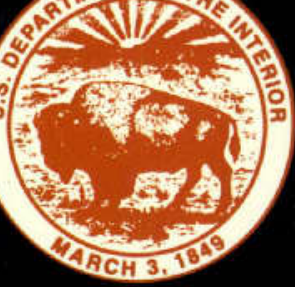

